ARTHUR ROBERTO CAPELLA GIANNATTASIO

\title{
A INTEGRAÇÃO COMO FENÔMENO JURÍDICO-POLÍTICO: Uma Leitura sobre a Construção Histórica da CECA
}

\author{
Tese de Doutorado
}

Orientador: Professor Titular Paulo Borba Casella

Universidade de São Paulo

Faculdade de Direito - Largo São Francisco

São Paulo

2013 
ARTHUR ROBERTO CAPELLA GIANNATTASIO

\section{A INTEGRAÇÃO COMO FENÔMENO JURÍDICO-POLÍTICO: Uma Leitura sobre a Construção Histórica da CECA}

Tese de Doutorado apresentada ao Departamento de Direito Internacional e Comparado da FACULDADE DE DIREITO DA UNIVERSIDADE DE SÃo PAUlO - LARGo SÃo Francisco, como exigência parcial para a obtenção do título de Doutor em Direito, sob orientação do Professor Titular PAUlo BORBA CASELla.

Universidade de São Paulo

Faculdade de Direito - Largo São Francisco

São Paulo

2013 
Nome: GIANNATTASIO, Arthur Roberto Capella

Título: A Integração como Fenômeno Jurídico-Político: Uma Leitura sobre a Construção Histórica da CECA

Tese de Doutorado apresentada ao Departamento de Direito Internacional e Comparado da FACULDADE DE DIREITO DA UNIVERSIDADE DE SÃo PAUlo - LARGo SÃo Francisco, como exigência parcial para a obtenção do título de Doutor em Direito.

Banca Examinadora:

Prof. Dr. Instituição:

Julgamento: Assinatura:

Prof. Dr. Instituição:

Julgamento: Assinatura:

Prof. Dr. Instituição:

Julgamento: Assinatura:

Prof. Dr. Instituição:

Julgamento: Assinatura:

Prof. Dr. Instituição:

Julgamento: Assinatura: 
Ao mundo peripatético. $:<>$ : 


\section{AGRADECIMENTOS}

Ao meu Orientador, Professor Paulo Borba Casella, pela fonte de inspiração e admiração que o exemplo produz naqueles que procuram traçar o mesmo percurso de sério engajamento intelectual fora da Caverna.

À Professora Catherine Kessedjian e ao Professor Olivier Descamps, pelo caloroso, cordial e cuidadoso acolhimento na Université Panthéon-Assas (Paris II). Mentores fundamentais de minha Pesquisa, patronos e verdadeiros pais no além-mar durante minha estadia acadêmica em Paris, sempre me encorajaram abertamente a seguir meus impulsos acadêmicos. Je vous remercie infiniment.

Ao Professor Sérgio Cardoso, não apenas pelos diálogos críticos e pelos esclarecimentos contínuos, mas por ter trazido do Monte a necessária luz para provocar minha formação humanística e Política. O espanto investigativo não deve ser temido quando tem em mente a imitação do exemplo excelente.

À Coordenação de Aperfeiçoamento de Pessoal de Nível Superior (CAPES), pelo financiamento de meu período de Pesquisador Visitante de Doutorado (DoutoradoSanduíche) junto à Université Panthéon-Assas (Paris II), sem o qual teria sido impossível ter acesso ao material histórico e historiográfico desta Tese.

Ao Ryoichi Sasakawa Young Leaders Fellowship Fund (SYLFF), pelo financiamento do último ano de Pesquisas da Tese de Doutorado. Especial atenção deve ser dada às valiosas contribuições trazidas pelas reuniões com os Professores do Comitê Gestor do Fundo Sasakawa, junto à Faculdade de Economia, Administração e Contabilidade da Universidade de São Paulo (FEA/USP): Professores Adalberto Américo Fischmann, Carlos Roberto Azzoni e Pedro Bohomoletz de Abreu Dallari.

Ao Curso de Pós-Graduação em Direito da Faculdade de Direito da Universidade de São Paulo - Largo São Francisco. A Velha e Sempre Nova Academia de Direito, responsável por ter suscitado a centelha crítica necessária para se estar aberto a pensamentos novos, sem desconsiderar o ensinamento da tradição. Dentre tantas, foram profícuas as discussões sobre questões jurídicas fundamentais desenvolvidas com: Camila Villard Duran, Elisa Pires da Cruz, Luís Fernando Baracho, Mariana Chaimovich, Mariana Pimentel Fischer, Olavo Bittencourt Neto e Vitor Blotta.

À Escola de Direito de São Paulo da Fundação Getulio Vargas - DIREITO GV, que, em três oportunidades, me aceitou dentro de seu corpo de Pesquisadores. Não 
apenas me ensinou reiteradamente a importância do rigor metodológico para a condução de uma séria Pesquisa em Direito, como também contribuiu para minha formação no pensamento crítico da relação entre Direito e Instituições. Especal atenção deve ser dada aos diálogos férteis com: Daniela Monteiro Gabbay, Fabia Fernandes Carvalho Veçoso, Luciana Gross Cunha, Paulo Eduardo Alves da Silva, Adriane Sanctis de Brito, Camila Perruso, Clarissa Piterman Gross, Fabiana Luci Oliveira, Handemba Mutana Poli dos Santos, Juliana Palma, Luciana de Oliveira Ramos, Maria Cecília de Araújo Asperti, Marina Feferbaum e Yonara Dantas de Oliveira.

Ao Institut d'Histoire du Droit (IHD) e ao Institut de Droit Comparé (IDC), ambos da Université Panthéon-Assas (Paris II), em Paris, que, além de terem me acolhido academicamente durante meu período de Pesquisas, permitiram acesso integral a seus preciosos acervos bibliográficos, sem o que a pesquisa documental de fontes primárias e secundárias para este trabalho não teria sido possível. Nos dois Institutos tive encontrei a coridal abertura para acompanhar como ouvinte disciplinas do Master II Droit de l'Union Européenne (finalité Recherche) e do Master II - Histoire du Droit (finalité Recherche), onde pude dialogar intensamente com os Professores Catherine Kessedjian (Marché Intérieur) e Olivier Descamps (Histoire de la Construction Européenne) sobre temas diretamente relacionados à minha Pesquisa, e também com o Professor Guillaume Leyte (Histoire Constitutionelle Comparée), sobre temas históricos indiretamente relacionados à minha Pesquisa.

Ao menos duas outras instituições contribuíram fundamentalmente para a profunda formação acadêmica necessária para a execução deste trabalho. Em primeiro lugar, o European University Institute (EUI) - e particularmente seu Robert Schuman Centre for Advanced Studies (RSCAS), em Florença, por meio de seus Cursos do Global Governance Programme, onde tive oportunidade de entrar em contato com Pesquisas de ponta sobre a História Contemporânea da Europa e sobre as instituições da CECA e da UE, e onde pude travar debates imprescindíveis com os Professores Carlos Closa, Félix Peña, Nuno Severiano Teixeira e Phillip Bobbitt. Também pude discutir calorosamente temas relacionados à presente Pesquisa com colegas dos Cursos, alunos de Pós-Graduação do EUI ou de outros centros europeus de Pesquisa: Beatriu Domenech, Cristina Blanco SioLopez, Pedro da Silva e Tatiana Couto. Em segundo lugar, a Universidad de Alcalá de Henares, em Madri, em cujo Curso pude também debater temas atuais relevantes da UE com os Professores Carlos Molina del Pozo, Calogero Pizzolo e Teresa Molina Schmidt. 
Aos meus pais, Fátima Capella e Francisco Giannattasio, pelo apoio incondicional de sempre, bem como pela profunda e paciente compreensão dos caminhos tortuosos que um obstinado filho acadêmico poderia ter escolhido. A vocês dois, com toda sinceridade, não tenho como não agradecer profundamente pela educação pessoal de perseverança, confiança, resolução, autocrítica e consciência. Muito obrigado por tudo.

Aos meus irmãos, Thiago, Vitor, Bruno e Raphael, pelo fiel companheirismo, pela inestimável confiança e pelo sempre pronto e bem-humorado suporte pessoal e familiar.

À família Khoury, que tão bem e abertamente me recebeu em seus braços e que prontamente me honrou com o privilégio de sua confiança e de seu apoio e, sobretudo, de seu especial carinho.

E, certamente, se uma Tese de Doutorado nunca é escrita sozinha, não poderia jamais deixar de dirigir minha eterna e sincera gratidão à pessoa extraordinária que acompanhou de perto a criação, a gestação e a modificação de cada um dos passos acadêmicos e pessoais seguidos pelo presente trabalho. Quem esteve sempre pronta para ouvir e discutir ativamente minhas dúvidas acadêmicas e angústias pessoais e existenciais, quem sempre esteve presente e me trouxe a calma e a tranquilidade de espírito necessárias para seguir este trabalho - aceitando conversar madrugadas inteiras, e até mesmo cruzar um Oceano inteiro por quatro vezes, apenas para me lembrar da clareza e da certeza do caminho pessoal, profissional e acadêmico escolhido. Sem encontrar palavras para expressar meu mais profundo e terno reconhecimento, bem como minhas mais sinceras admiração e gratidão, apenas posso dizer que, por tudo isso, esta Tese também é sua, Aline Khoury. 
O Ateniense - Sendo assim, caros amigos, como se explica que houvesse corrido tão mal entre eles a fundação da cidade e sua legislação?

Megilo - Que tens a objetar-lhes, para falares desse modo?

O Ateniense - É que, das três colônias então fundadas, em duas logo a forma de governo e as leis degeneraram, só se conservando uma delas, precisamente a de nossa cidade.

Megilo - Eis uma pergunta nada fácil de responder.

O Ateniense - Mas não podemos desprezá-la, uma vez que nos ocupamos com essa questão e estudamos leis neste entretenimento condizente com nossa idade. Será a maneira mais agradável de vencermos o caminho, conforme nos propusemos de início.

Megilo - Como não? Teremos de fazer isso mesmo.

O Ateniense - E que mais belas reflexões poderíamos excogitar do que o estudo das leis que organizaram essas cidades? Haverá cidades maiores ou mais importantes, cuja fundação nos ofereça tão feliz tema para meditação?

Megilo - Não será fácil mencionar outra. (PLATÃO, 1980, p. 90).

Os homens facilmente se corrompem pela prosperidade, pois nem todos são capazes de suportá-la. Portanto, trata-se de uma regra geral para todo governo, democrático, oligárquico, monárquico ou outro, não valorizar demais quem quer que seja e não distribuir nenhuma honra excessiva, mesmo que breve. Se se acumulam muitos cargos em uma só pessoa, tais cargos devem ser-lhes retirados aos poucos, e não todos de uma vez. Será sobretudo conveniente estabelecer através das leis que ninguém possa adquirir poder, crédito ou riqueza demais, ou que sejam afastados os que tiverem demais. (ARISTÓTELES, 1998, p. 235).

5. Lire les textes existants, afin d'être au courant des opinions des anciens, des idées qu'ils se faisaient de telle ou telle contrée, de tel ou tel peuple, de leurs institutions et de leur histoire, afin aussi de prendre une vue d'ensemble sur les crises et les vicissitudes que les uns et les autres ont connues dans le passé, cela est chose utile. 6. En effet, la connaissance du passé est bien faite pour mettre notre esprit en éveil en ce qui concerne l'avenir, à condition que, sur chacun des faits qui ont marqué ces temps révolus, on se livre à une étude sérieuse. (POLYBE, 2003, p. 824).

O tratamento do passado é patrimônio da criatividade humana e, como tal, apátrida. (SEBASTIANI, 2006a, p. 76).

[L]a Communauté européenne du charbon et de l'acier est un succès. Ce n'est pas mon succès, croyez-le bien. Les résultats qui ont été obtenus l'ont été non pas par une personne ou grâce à un homme, mais par des institutions [...]. (MONNET, 2001b, p. 179). 


\section{RESUMO}

Pretendendo evidenciar uma leitura jurídico-política sobre o começo da integração europeia - iniciada por meio da fundação jurídica da CECA, esta Tese visa a responder à pergunta: quando, como e por meio de quais instituições, países europeus tradicionalmente opostos em termos militares estabeleceram entre si, após o término da Segunda Guerra Mundial, de maneira inédita e inaudita em sua História, um novo modo de relações responsável por tornar impossível e impensável a deflagração de nova Guerra regional?

Para responder a essa pergunta, o presente trabalho assume a perspectiva de uma Pesquisa interdisciplinar em Direito, recorrendo não apenas ao Direito Positivo, mas também a outras áreas do conhecimento, tais como a Filosofia Política Antiga e Contemporânea e a História Contemporânea da Europa. O objetivo consiste em formular um aparato discursivo racional conceitual a partir de matriz de leitura fornecida pela Filosofia Política Antiga e Contemporânea para, em seguida, aplicá-lo sobre elementos da experiência histórica e jurídico-normativa positiva da CECA.

A chave de leitura conceitual formada a partir de contribuições da Filosofia Política tem sua origem principalmente na aproximação das reflexões de POLÍBIO e de Claude LEFORT. O trabalho evidencia a importância de normas jurídicas institucionalmente previstas para lidar com oposições escalares na construção e na manutenção de um sistema de relações jurídico-Politicamente organizado, de maneira a que tensões entre distintas dimensões existenciais - institucionalmente absorvidas e encaminhadas - não possam significar a ruptura violenta desse sistema.

Este aparato racional conceitual pode ser aplicado sobre os elementos da experiência histórica e normativa originária (Tratado de Paris de 1951) da CECA, o que permite diferenciar histórica e institucionalmente esta iniciativa em particular dos demais Projetos de Europa Unida do imediato pós-Segunda Guerra Mundial.

Para os fundadores da CECA (Konrad ADENAUER, Jean MONNET e Robert SCHUMAN), um regime juridicamente regulado de simples cooperação política (Unionismo Europeu) não era considerado como suficiente para instaurar um novo modo de relações na Europa. Ao mesmo tempo, eles não visavam à construção jurídica de uma Unificação Política da Europa em torno de um Estado Federal Europeu (Federalismo Europeu). 
Nesse sentido, a CECA pode ser entendida como exemplo histórico singular de organização jurídico-Política de países europeus. Foram criados pelo Tratado da CECA órgãos comunitários supranacionais e intergovernamentais voltados a compartilhar com os Estados-Membros e com os respectivos povos europeus a formação do sentido normativo que deveria ser impresso sobre questões concretas sensíveis tornadas comuns. A nenhum deles foi atribuída uma posição central na nomogênese comunitária.

A leitura jurídico-política da integração europeia iniciada com a CECA se mostra possível assim a partir da constatação de que a arquitetura das instituições do Tratado desta Organização Internacional - mesmo das instituições que se referiam a normas jurídicoeconômicas - foi responsável pela afirmação e pela conservação de um novo modo de relações entre os países europeus. Buscava-se, não um Estado Europeu, nem uma singela cooperação intergovernamental institucionalizada, mas um meio termo de organização jurídico-Política: um sistema de relações estruturado por um engenhoso mecanismo institucional orientado para promover, por meio de freios e contrapesos, de forma ininterrupta, oposições entre os participantes da vida comunitária.

Palavras-chave: Comunidade Europeia do Carvão e do Aço; CECA; Federalismo Europeu; Unionismo Europeu; Funcionalismo; integração; integração europeia; integração política; integração política europeia; União Política da Europa; Leis; direitificação; Direito Comunitário; POLÍBIO; Claude LEFORT; Konrad ADENAUER; Jean MONNET; Robert SCHUMAN; Tratado de Paris de 1951. 


\section{RÉSUMÉ}

En cherchant à dévoiler une lecture juridico-politique du début de l'intégration européenne - démarrée par le fondement juridique de la CECA, cette Thèse se propose à répondre la question: quand, comment et grâce à quelles institutions, des pays européens traditionnellement opposés militairement ont été capables d'établir entre eux, après la fin de la Seconde Guerre mondiale - sans précédent et sans équivalent dans leur Histoire, un nouveau type de relation, lequel était responsable pour faire devenir impossible et impensable le déclenchement d'une nouvelle guerre régionale?

Afin de répondre à cette question, cet étude suit le chemin d'une Recherche interdisciplinaire en Droit : il recourt, pas seulement au Droit Positif, mais aussi à d'autres domaines de la connaissance, comme la Philosophie Politique Antique et Contemporaine et l'Histoire Contemporaine de l'Europe. L'objectif est lire les éléments d'expérience donnés par l'Histoire et par les règles juridiques positives de la CECA à travers d'une lentille formée selon un appareil conceptuel rationnel fondé sur la Philosophie Politique Antique et Contemporaine.

La clé herméneutique fondée sur la Philosophie Politique a ses principales origines dans la discussion conjointe de la pensée de POLYBE et des contributions de Claude LEFORT. Ce travail met en évidence l'importance des institutions juridiques pour faire face aux oppositions des échelles d'existence dans la construction et la maintenance d'un système de relations organisé juridico-politiquement, de sorte que les tensions institutionnellement absorbées et adressées - parmi les différentes dimensions existentielles ne brise pas violemment ce système.

Cet appareil conceptuel peut être appliqué pour comprendre l'expérience historique et normative (Traité de Paris, 1951) de la CECA et contribue à différencier - dans une perspective en même temps historique et institutionnelle - cette initiative en particulier des Projets alternatifs d'Union Européenne proposés juste après la fin de la Seconde Guerre mondiale.

Pour les pères fondateurs de la CECA (Konrad ADENAUER, Jean MONNET et Robert SCHUMAN), un simple régime juridique de coopération politique (Unionisme Européen) n'a pas été considéré comme suffisamment capable de créer un nouveau type de relations en Europe. Au même temps, ils n'ont pas non plus poursuivi une Unification 
Politique de l'Europe par règles juridiques au sein d'un État Fédéral Européen (Fédéralisme Européen).

En ce sens, la CECA peut être vue comme un exemple historique unique d'organisation juridico-politique des pays européens. Organismes communautaires supranationales et intergouvernementales ont été créés par le Traité de la CECA, afin de partager avec leurs propres Etats-membres et leurs respectifs peuples la construction du sens normatif des questions concernant des problèmes communs sensibles. Aucun d'entre eux a reçu un poste central dans le processus normatif de la Communauté.

Une lecture juridico-politique de l'intégration européenne - commencé par la CECA - semble possible parce que le cadre institutionnel de son Traité - même si reporté à des règles juridico-économiques - était responsable par l'affirmation et par la préservation d'un nouveau type de relations parmi les pays européens. On a envisagé, ni un État Européen, ni une simple coopération intergouvernementale institutionnalisée, mais une voie médiane d'organisation juridico-Politique: un système de relation structuré selon un ingénieux mécanisme institutionnel conçu pour promouvoir - par contrôles et contrepoids oppositions ininterrompues parmi les participants de la vie communautaire.

Mots-clés: Communauté Européenne du Charbon et de l'Acier; CECA; le Fédéralisme Européen; l'Unionisme Européen; le Fonctionnalisme; l'intégration; l'intégration européenne; l'intégration politique; l'intégration politique européenne; l'Union Politique de l'Europe; Lois; légalisation; Droit Communautaire; POLYBE; Claude LEFORT; Konrad ADENAUER; Jean MONNET; Robert SCHUMAN; Traité de Paris, 1951. 


\begin{abstract}
Aiming to unveil a legal-political reading of the beginning of European integration - initiated by the legal foundation of the ECSC, this Thesis intends to answer the question: when, how and through which institutions, European countries traditionally opposed militarily established between themselves, after the end of the Second World War unprecedentedly and unparalleled in their history, a new kind of relationship, which was responsible for making impossible and unthinkable the outbreak of new regional war?

In order to answer this question, this study follows the path of an interdisciplinary Research in Law, resorting not only to Positive Law, but also to other fields of knowledge, such as Ancient and Contemporary Political Philosophy and Contemporary History of Europe. The objective is to read experience elements given by ECSC's History and positive legal rules through lens framed according to a rational conceptual apparatus grounded on Ancient and Contemporary Political Philosophy.

The hermeneutical key framed according to Political Philosophy has its main origins in the conjoint discussion of POLYBIUS' thought and Claude LEFORT's contributions. This work highlights the importance of legal institutions dealing with dimensional oppositions within the construction and maintenance of a legal-Politically organized relationships system, by which tensions - institutionally absorbed and addressed - between different existential dimensions do not disrupte violently this system.

This conceptual apparatus can be applied to understand ECSC's historical and and normative (Treaty of Paris, 1951) experience and helps differentiating - from both a historical and institutional perspective - this peculiar initiative from alternative European Union Projects immeadiately proposed after the Second World War.

For ECSC founding fathers (Konrad ADENAUER, Jean MONNET and Robert SCHUMAN), a mere legal regime of political cooperation (European Unionism) was not regarded as sufficiently capable of creating a new kind of relationship in Europe. At the same time, they did not pursue a legal Political Unification of Europe within a European Federal State (European Federalism).

In this sense, the ECSC can be seen as an unique historic example of a legalPolitical organization of European countries. Supranational and intergovernmental community bodies were created by ECSC's Treaty in order to share with its own memberStates and their respective peoples the construction of the normative sense which would
\end{abstract}


conduct issues concerning sensitive common problems. To none of them was assigned a central position in Community's normative process.

A legal-political reading of European integration - started with the ECSC - seems possible because the institutional framework whithin its Treaty - even when referred to legal and economic rules - was responsible for the affirmation and preservation of a new kind of relationship between European countries. It was envisaged, neither a European State, nor an institutionalized intergovernmental cooperation, but a middle-way legalPolitical organization: a relationship system erecte by an ingenious institutional mechanism conceived to promote - through checks and balances - nonstop oppositions between participants of Community's life.

Keywords: European Coal and Steel Community; ECSC; European Federalism; European Unionism; Functionalism; integration; European integration; political integration; European political integration; Political Union of Europe; Laws; juridification; Community Law; POLYBIUS; Claude LEFORT; Konrad ADENAUER, Jean MONNET; Robert SCHUMAN; Treaty of Paris, 1951. 


\section{SUMÁRIO}

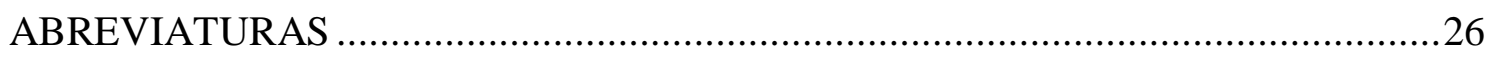

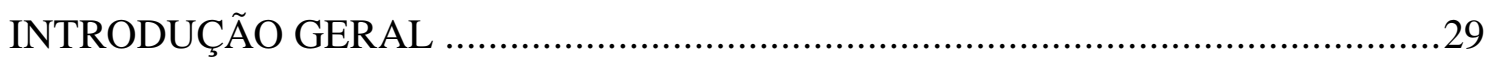

PARTE I: O ARCO DO CONHECIMENTO JURÍDICO APLICADO À TESE: SUA SITUAÇÃO TEMPORAL ESPACIAL, TEMÁTICA E METODOLÓGICA ...............39

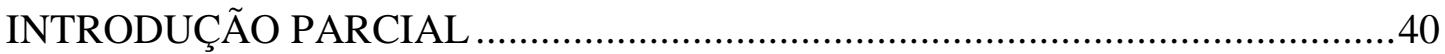

PRIMEIRO CAPÍTULO - DELIMITAÇÃO ESPÁCIO-TEMPORAL: A CECA COMO EXPERIÊNCIA SINGULAR NO PÓS-SEGUNDA GUERRA MUNDIAL ............56

1.1. Demarcações de Caráter Temporal do Objeto de Estudo ..............................58

1.2. Demarcações de Caráter Espacial do Objeto de Estudo ................................67

1.3. Demarcações de Caráter Temático do Objeto de Estudo - I: O Direito ...........71

1.4. Demarcações de Caráter Temático do Objeto de Estudo - II: As Leis ............83

1.4.1. As Leis e o Direito: Distinções Fundamentais.........................................88

1.4.2. As Leis Percebidas sob uma Perspectiva Formal ..................................94

1.4.3. As Leis Percebidas sob uma Perspectiva Material .............................. 103

1.5. Convergência das Demarcações Temporais, Espaciais e Temáticas ..............116 SEGUNDO CAPÍTULO - DELIMITAÇÃO METODOLÓGICA: O CAMPO DE LEITURA PROPOSTO PELO PRESENTE ESTUDO ........................................ 122

2.1. Direito Comunitário como Direitificação da Convivência ........................... 124

2.1.1. A Inserção da Política nos Cosmos Jurídico Direitificado ..................... 125

2.1.2. A CECA como Instrumento Jurídico-Político de Convivência ...............133

2.2. A Inter-relação Necessária entre Dogmática e Zetética Jurídicas .................. 161

2.2.1. Noções Fundamentais da Fenomenologia de Edmund HUSSERL ........ 163

2.2.2. O Estilhaçamento do Absoluto Interpretativo: A CECA como Suporte Significativo Vazio Uno e Múltiplo ......................................................... 173

2.2.3. Inter-Relações Fenomenológicas entre Dogmática e Zetética Jurídicas 176 2.2.4. Posicionamento Intencional deste Trabalho: A Dupla Orientação DogmáticoZetética Jurídica.

TERCEIRO CAPÍTULO - A ANÁLISE JURÍDICA COMO ANÁLISE INSTITUCIONAL: DEFINIÇÃO E MATRIZ DE LEITURA

3.1. A Significação Jurídico-Política em torno das Normas de Direito Econômico da CECA. 195

3.2. Análise Institucional: Mapeamento e Crítica do Direito Positivo 202 
3.3. Individuação dos Critérios Componentes da Análise Institucional ...............209

3.3.1. Empréstimos Conceituais e Conhecimento .........................................2212

3.3.2. Percepções sobre a Natureza Jurídica da Europa Unida da CECA.........219

3.3.3. POLÍBIO e as Normas Jurídicas de Oposições Escalares......................2224

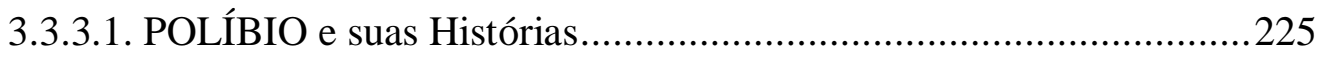

3.3.3.2. A Análise Polibiana das Instituições Romanas no Livro VI ...........232

3.3.3.2.1. As Razões e a Estrutura do Livro VI ....................................233

3.3.3.2.2. A Anaciclose entre os Oito Regimes Políticos.......................237

3.3.3.2.3. A Análise das Instituições Romanas da Segunda Guerra Púnica243

3.3.3.2.4. A Comparação das Instituições Romanas com as de Cartago ..253

3.3.3.3. Apropriação da Reflexão Polibiana: Seleção de Normas Jurídico-

Positivas de Oposições Escalares Institucionalizadas do Tratado da CECA 254

3.4. Duas Possíveis Qualidades das Leis: A Oposição entre a Organização JurídicoPolítica e a Jurídico-Teológico-Política........................................................220

3.4.1. O Problema da Definição do Político no Tratado da CECA ..................2270

3.4.2. Claude LEFORT e a Política .............................................................227

3.4.3. A Distinção entre o Político e o Teológico-Político ..............................285

3.4.4. Apropriação da Reflexão Lefortiana: As Leis Materiais da Europa Unida da CECA como Leis de Organização Jurídico-Política .......................................294

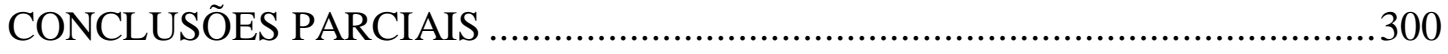

PARTE II: A HISTÓRIA E O TRATADO DA CECA: OS ANTECEDENTES E A AFIRMAÇÃO DE UMA ORGANIZAÇÃO JURÍDICO-POLÍTICA DA EUROPA . 304

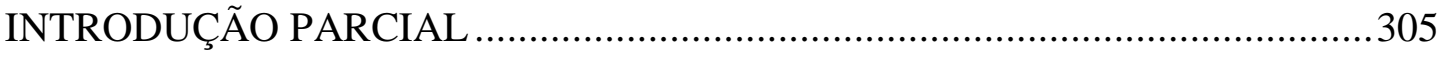

QUARTO CAPÍTULO - DO FINAL DA SEGUNDA GUERRA MUNDIAL AO

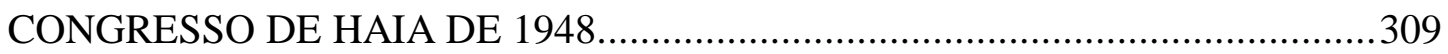

4.1. O Saldo da Segunda Guerra Mundial: A Europa Ano Zero..........................317

4.2. Relações Transatlânticas e suas Repercussões Institucionais na Europa........321

4.2.1. O Plano Marshall e a Cooperação Econômica da OECE ........................ 324

4.2.2. A Cooperação Militar do Pacto de Bruxelas ..........................................338

4.3. OECE e Pacto de Bruxelas: Reconhecimento Institucional contra Leis Externas à Europa

QUINTO CAPÍTULO - O CONGRESSO DE HAIA E SUAS REPERCUSSÕES

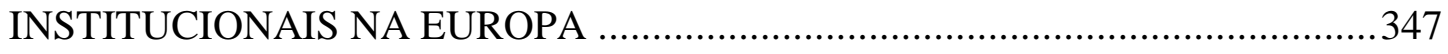

5.1. Origens do Congresso de Haia de 1948 ...................................................349 
5.2. Principais Movimentos Europeístas Participantes do Congresso de Haia ......351

5.2.1. Unionismo Europeu: Cooperação Política Intergovernamental e Intangibilidade das Soberanias . 352

5.2.2. Federalismo Europeu: a Unidade Cultural e o Estado Federal Europeu da Civilização Europeia 354

5.2.2.1. As Novas Equipes Internacionais (NEI). 358

5.2.2.1.1. Origens das NEI 358

5.2.2.1.2. O Projeto Europeu das NEI: Diálogos com o Teológico-Político358

5.2.2.2. A União Europeia dos Federalistas (UEF) 362

5.2.2.2.1. Origens da UEF 362

5.2.2.2.2. O Projeto Europeu da UEF: Diálogos com o Teológico-Político363

5.2.2.2.2. A Catequese do Credo Federalista 363

5.2.2.2.2.2. "Unidade na Diversidade" I: A Substituição da Diversidade Estatal-nacional pela Unidade Supranacional Federal Europeia 365

5.2.2.2.2.3. "Unidade na Diversidade" II: A Diversidade Cultural Europeia enquanto Unidade Escalar Civilizada ditada pelos Direitos Humanos e pela Democracia 369

5.2.2.2.2.4. "Unidade na Diversidade" III: Da Paz do Estado Federal Europeu à Paz do Estado Federal Mundial. 374

5.2.2.2.2.5. A Diversidade na Unidade: Elementos Teológico-Políticos do Evangelho Federalista Europeu 379

5.3. As Comissões Especializadas do Congresso de Haia: O Vetor Teológico-Político de suas Resoluções Finais 382

5.4. Repercussões Institucionais do Congresso de Haia e a Contenção Parcial do Teológico-Político 387

5.4.1. O Centro Europeu de Cultura e o Colégio Europeu de Bruges 389

5.4.2. O Tratado de Londres de 1949 e o Conselho da Europa (CdE) .... 393

5.4.2.1. Origens do CdE 393

5.4.2.2. A Controvérsia da Realização Institucional da Assembleia Europeia: Unionismo versus Federalismo 395

5.4.2.3. A Realização Institucional do CdE: Persistência da Tensão entre Unionismo e Federalismo 399

5.4.2.4. A Primeira Reunião do CdE: Uma Tentativa Frustrada de Reveter as Instituições em prol de uma Federação Europeia 400 
5.4.2.5. CdE: Uma Cooperação Intergovernamental Institucionalizada contra

Leis Teológico-Políticas na Europa. 404

SEXTO CAPÍTULO - A DECLARAÇÃO DE ROBERT SCHUMAN DE 1950: FUNCIONALISMO E IMANÊNCIA.

6.1. Antecedentes da Declaração Schuman: As Reflexões de Winston CHURCHILL, Konrad ADENAUER e Jean MONNET

6.1.1. As Reflexões de Winston CHURCHILL: Leis na Europa Continental ..412

6.1.2. O Interstício Europeu (1946-1950): A Percepção da Importância da Fundação de Leis Políticas entre Alemanha e França

6.1.3. As Reflexões de Konrad ADENAUER: Paridade de Condições e Compartilhamento de Deveres entre Alemanha e França na Construção Comum420 6.1.4. As Reflexões de Jean MONNET: Ponto de Partida Concreto para uma União Política entre Alemanha e França 423

6.2. A Declaração de Robert SCHUMAN de 1950: A Via Funcionalista e a Opção pela Imanência.

6.2.1. Origens da Declaração Schuman de 1950 427

6.2.2. O Sentido Jurídico-Político da Declaração Schuman de 1950 429

6.2.2.1. Aspectos Gerais da Declaração Schuman de 1950 429

6.2.2.2. Elementos para uma Organização Jurídico-Política das Relações FrancoAlemãs: Nem Coexistência, Nem Cooperação, Nem Federação, mas Direitificação da Convivência 431

6.2.2.2.1. Reconhecimento e Permanência da Tensão Escalar Fundamental: Rejeição da Guerra e da Paz 431

6.2.2.2.2. Solidariedade de Fato e Pluriescalaridade: Confiança, Reconciliação e Preservação de Igualdade de Condições entre Escalas de Existência ....435 6.2.2.3. Desdobramentos da Direitificação I: A Oposição Escalar e o Vazio de Poder Subjacentes à Produção Comum das Normas sobre o Carvão e o Aço438 6.2.2.4. Desdobramentos da Direitificação II: Rejeição da Transcendência do Federalismo Europeu por meio do Vazio de Poder 440

6.2.2.5. Desdobramentos da Direitificação III: Funcionalismo como Técnica Jurídico-Política Institucional de Preservação da Imanência 443

6.2.2.6. A Declaração Schuman de 1950: Fundação de Leis Políticas na Europa 
6.3.1. Vetores Jurídico-Políticos do Futuro Sistema Institucional da CECA ...455 6.3.1.1. Organizar Leis Políticas I: Fundação contra Questões Externas à Europa 455

6.3.1.2. Organizar Leis Políticas II: Fundação contra a Uniescalaridade .....456 6.3.1.3 Organizar Leis Políticas III: Fundação contra o Preenchimento Total e Pacificador do Lugar do Direito e do Poder. 458

6.3.2. A Rejeição de Leis Políticas pelo Reino Unido. 459

6.3.3. A Instrumentalização Prática das Leis Políticas: Um Método Pluriescalar para Instituições Multidimensionais 462

6.3.3.1. Abertura das Discussões em torno do Futuro Tratado: Produção Pluriescalar de Centro Normativo Comum Vazio e Descentralizado. 462

6.3.3.2. A Intuição Jurídico-Política dos Países-Membros do BENELUX: O Último Nicho de Resistência do Teológico-Político na Futura Vida Comum466 6.3.4. A Assinatura do Tratado de Paris de 1951 e a Escolha da Sede da CECA469 SÉTIMO CAPÍTULO - ANÁLISE JURÍDICA DO TRATADO DA CECA: INSTITUIÇÕES PRÁTICAS DE LEIS JURÍDICO-POLÍTICAS.

7.1. Conservação da Imanência por Vertente Negativa: Rejeição Normativa da Transcendência 482

7.1.1. A Rejeição Normativa da Transcendência Externa à Europa. 483

7.1.2. A Rejeição Normativa da Transcendência Interna à Europa. 486

7.1.2.1. Observações Gerais acerca do Protocolo 486

7.1.2.2. A Chave de Compreensão: Paridade e Independência 488

7.1.2.3. Derivações Interpretativas: Explicitação Normativa da NãoSubordinação da CECA ao CdE 490

7.1.2.3.1. Informação e Declaração da Independência Jurídico-Política da CECA 491

7.1.2.3.2. A Alta Autoridade perante o CdE: Deveres de Mera Comunicação 493

7.1.2.3.3. A Interação entre Assembleias: Um Diálogo Inofensivo 497

7.1.2.4. O Significado Jurídico-Político do Protocolo: Não-Subordinação da CECA como Recusa da Transcendência Federalista Europeia do CdE. 502

7.2. Instauração e Conservação da Imanência por Vertente Positiva: Afirmação e Preservação Normativas da Horizontalidade na Solução de Conflitos 504 
7.2.1. A Chave de Compreensão dos Dispositivos sobre Solução das Oposições Escalares: Opção Reiterada pelo Uso das Vias Institucionais previstas pelo Tratado 510

7.2.2. A Significação Jurídico-Política do Sistema de Solução de Controvérsias da CECA: A Resolução Judicial de Conflitos Escalares por meio de Normas de Oposições Escalares. 513

7.2.2.1. O Artigo 33 do Tratado da CECA: Anulação de Decisões e de Recomendações da Alta Autoridade como Recusa da Estrutura MandoObediência entre as Escalas de Existência 513

7.2.2.1.1. Observações Gerais sobre o Artigo 33 513

7.2.2.1.2. Resistência da Estatalidade a Investidas da Supranacionalidade sobre o Lugar do Direito e do Poder 514

7.2.2.1.3. A Limitação da Resistência: Autocontenção do Contra-Poder.516

7.2.2.1.3.1. O Significado Jurídico-Político da Limitação Jurídicoprocessual Temporal: Risco de Unidimensionalização Supranacional e Tarefa Política das Estatalidades 517

7.2.2.1.3.2. O Significado Jurídico-Político da Limitação Jurídicoinstitucional Política: Explicitação da Divisão e Convite à Oposição Pluriescalar 519

7.2.2.1.4. A Complexa Rede de Oposições Escalares do Dispositivo ......521

7.2.2.1.4.1. A Contenção do Controle da Corte de Justiça da CECA ...522

7.2.2.1.4.2. A Institucionalização de Oposições Escalares: O Controle de Anulação da Corte como Nicho de Resistência à Unidimensionalização da Supranacionalidade da Alta Autoridade. 527

7.2.2.2.: O Artigo 34 e o Significado Jurídico-Político das Consequências da Anulação do Ato Normativo pela Corte. 529

7.2.2.2.1. Observações Gerais sobre o Artigo 34 529

7.2.2.2.2. A Circunscrição da Anulação como Constrição Constrita da Alta Autoridade 530

7.2.2.2.2.1. A Armadilha da Anulação I: Repulsa Mútua à Supranacionalidade 531

7.2.2.2.2. A Armadilha da Anulação II: O Poder "sem Poder" da Corte533 7.2.2.2.2.3. A Armadilha da Anulação III: Novos Freios e Contrapesos entre Alta Autoridade e Corte. 534 
7.2.2.2.2.4. A Armadilha da Anulação IV: O Significado Jurídico-Político do Constrangimento Econômico 538

7.2.2.3. O Artigo 35 do Tratado da CECA: O Controle da Inação da Alta Autoridade e seu Significado Jurídico-Político 540

7.2.2.3.1. A Inação Participativa como Ameaça à Horizontalidade Relacional 541

7.2.2.3.2. A Contenção da Inação da Alta Autoridade: Limites e Possibilidades 543

7.2.2.4. O Artigo 37 do Tratado da CECA: O Trabalho Multiescalar no Controle Judicial das Repercussões Econômicas de Ação ou Inação da Alta Autoridade 547

7.2.2.4.1. Observações Gerais sobre o Artigo 37 547

7.2.2.4.2. Oposições Escalares em torno da Economia: Orientação JurídicoPolítica Multiescalar de Questões Econômicas 548

7.2.2.4.3. Significado Jurídico-Político do Controle Judicial das Repercussões Econômicas de Ação ou Inação da Alta Autoridade. 554

7.2.2.5. O Artigo 38 do Tratado da CECA: A Anulação Multiescalar de Ato da Assembleia ou do Conselho 555

7.2.2.5.1. Observações Gerais sobre o Artigo 38 555

7.2.2.5.2. Detalhamento da Intrincada Rede de Oposições Escalares do Artigo e seu Significado Jurídico-Político 557

7.2.2.5.3. As Limitações do Controle Judicial-Multiescalar dos Atos do Conselho: A Reiteração da Constrição Contida 559

7.2.2.5.3.1. O Significado Jurídico-Político da Limitação JurídicoProcessual Temporal: Risco de Unidimensionalização da Intergovernamentalidade e Tarefas da Supranacionalidade da Alta Autoridade e das Estatalidades Isoladas 560

7.2.2.5.3.2. O Significado Jurídico-Político da Limitação JurídicoInstitucional Política: Delimitação de um Círculo Multiescalar de Liberdade e de Resistência . 562

7.2.2.6. O Artigo 41 do Tratado da CECA: O Exame Prejudicial Jurisdicional da Validade de Deliberações e seu Significado Jurídico-Político..... 566

7.2.2.6.1. Observações Gerais sobre o Artigo 41 566

7.2.2.6.2. A Rede de Oposições Escalares do Artigo 41 567 
7.2.2.6.3. As Limitações do Exame Prejudicial da Corte: Freios e Contrapesos da Comunidade Política da CECA. 570

7.2.3. O Cumprimento Estatal de Decisões dos Órgãos Comunitários: A Sujeição Compartilhada a Deveres Comuns e à Preservação da Horizontalidade .571

7.2.3.1. Fiscalização do Estado-Membro pela Alta Autoridade: Limites do Controle entre Pares Comunitários 573

7.2.3.1.1. Apresentação Geral do Artigo 86 do Tratado da CECA .573

7.2.3.1.2. Observância do Direito Comunitário: Submissão da Estatalidade Isolada à Supranacionalidade?..... 575

7.2.3.1.3. Fiscalização dos Estados-Membros pela Alta Autoridade: Instauração de Oposição Escalar 577

7.2.3.1.4. Limites à Fiscalização pela Alta Autoridade: Restrição e Esvaziamento do Poder e Preservação da Paridade Comunitária..... 580

7.2.3.1.4.1. Notificação Prévia ao Estado-Membro e Acompanhamento da Fiscalização por Agentes Nacionais 581

7.2.3.1.4.2. Agentes de Fiscalização da Alta Autoridade: Independentes, Autônomos e Iguais 584

7.2.3.2. Inadimplemento Estatal e Possíveis Respostas da Alta Autoridade: Indícios de um Controle a serviço da Horizontalidade 589

7.2.3.2.1. Apresentação Geral do Artigo 88 do Tratado da CECA 589

7.2.3.2.2. Controle Contido I: Necessidade de Confirmação do Resultado da Fiscalização 590

7.2.3.2.3. Controle Contido II: Possibilidade de Questionamento Judicial A593

7.2.3.2.4. Controle Contido III: Limitação das Principais Consequências ao Inadimplemento Estatal 596

7.2.3.2.5. Controle Contido IV: Possibilidade de Questionamento Judicial B 606

7.2.3.2.6. Controle Contido V: A Última Consequência Limitada ao Inadimplemento Estatal como Atestado da Não-Sujeição do Estado aos Órgãos Comunitários 608

7.2.4. Execução de Decisões da Corte (e também da Alta Autoridade): Preservação da Imanência e Recusa à Formação de um Estado Europeu .

7.2.4.1. O Artigo 92 do Tratado da CECA: O Dado Jurídico-Normativo Positivo e o Não-Dado Jurídico-Político Institucional 613 
7.2.4.1.1. Observações Gerais sobre o Artigo 92 613

7.2.4.1.2. Equivalência do Tratamento Jurídico da Execução das Decisões da Corte e da Alta Autoridade e Horizontalidade Relacional 614

7.2.4.1.3. Limitações à Execução das Decisões da Corte e da Alta Autoridade: Marcas de uma Organização Jurídico-Política da Europa contra um Estado Europeu 619

7.2.4.1.4. Suspensão da Execução de Decisão da Corte e da Alta Autoridade: Contenção e Horizontalidade Multiescalares 625

7.2.4.2. O Significado Jurídico-Político da Execução de Decisões da Corte e da Alta Autoridade: A Opção por uma Horizontalidade Relacional marcada pela Ausência de Coerção. 628

7.3. Instauração e Conservação do Vazio no Lugar do Direito e do Poder na Comunidade: A Europa Politicamente Unida da CECA e a Multiescalaridade na Formação do Sentido Normativo Comum

7.3.1. A Camada Jurídico-Política das Regras Jurídico-Econômicas da CECA: O Sentido Normativo Econômico e o Não-Sentido Jurídico-Político

7.3.1.1. Os Capítulos IV e V do Título Terceiro do Tratado da CECA: A Disciplina Jurídico-Política da Produção e do Consumo do Carvão e do Aço na Comunidade 634

7.3.1.1.1. A Chave de Compreensão da Disciplina da Produção e do Consumo do Carvão e do Aço: O Artigo 57 do Tratado da CECA. 635 7.3.1.1.2. A Nomogênese Multiescalar nas Crises de Produção e de Consumo de Carvão e de Aço na Comunidade nos Artigos 58 e 59 do Tratado da CECA 640

7.3.1.1.2.1. Observações Gerais Comuns aos Artigos 58 e 59 640

7.3.1.1.2.2. O Artigo 58 do Tratado da CECA e a Tutela Jurídico-Política da Superprodução de Carvão e de Aço 642

7.3.1.1.2.2.1. A Contenção Recíproca entre Supranacionalidade da Alta Autoridade e Estatalidades. 642

7.3.1.1.2.2.2. Outros Aspectos Institucionais caracterizadores da Organização Jurídico-Política da Europa Unida da CECA: Opção Normativa pela Recusa ao Uso Centralizado da Força 651

7.3.1.1.2.3. O Artigo 59 do Tratado da CECA e a Tutela Jurídico-Política da Sub-produção de Carvão e de Aço 653 
7.3.1.1.2.3.1. A Contenção Recíproca entre Supranacionalidade da Alta Autoridade e Estatalidades. 653

7.3.1.1.2.3.2. Outros Aspectos Institucionais caracterizadores da Organização Jurídico-Política da Europa Unida da CECA: Opção Normativa pela Recusa ao Uso Centralizado da Força 679

7.3.1.1.3. Artigos 60 a 64 do Tratado da CECA: A Organização JurídicoPolítica das Soluções Normativas Comunitárias para Condutas de Afecção Direta na Formação dos Preços de Carvão e Aço na CECA 680

7.3.1.1.3.1 O Artigo 60 e as Condutas Desleais e Discriminatórias na CECA 682

7.3.1.1.3.2. O Artigo 61 e os Preços Máximos e Mínimos dos Produtos690

7.3.1.1.3.3. O Artigo 63 e a Discriminação Motivada por Regulação Jurídico-Econômica Nacional. 699

7.3.1.1.3.4. O Artigo 64 e o não-Estado Europeu da CECA: Breve Apontamento da Reiteração da Recusa ao Uso da Força pela Alta Autoridade .708

7.3.1.2. Os Capítulos VI e VII do Título Terceiro do Tratado da CECA: A Disciplina Jurídico-Política da Concorrência na Comunidade 710

7.3.1.2.1. O Artigo 65 do Tratado da CECA e os Acordos entre Empresas: O Significado Jurídico-Político do Controle Concorrencial de Condutas na CECA 716

7.3.1.2.2. O Artigo 66 do Tratado da CECA e os Atos de Concentração: O Significado Jurídico-Político do Controle Concorrencial das Estruturas na CECA 727

7.3.1.2.2.1. Os Parágrafos Primeiro, Terceiro e Quarto do Artigo 66: Concentração das Estruturas e Condicionamento da Tutela da Alta Autoridade 730

7.3.1.2.2.2. O Parágrafo Segundo do Artigo 66: As Condições à Autorização de Atos de Concentração pela Alta Autoridade 740

7.3.1.2.2.3. O Parágrafo Quinto do Artigo 66: A Disciplina Limitadora e Multiescalar do Controle Repressivo de Atos de Concentração pela Alta Autoridade 744

7.3.1.2.2.4. O Parágrafo Sétimo do Artigo 66: Condições para o Controle de Concentração Inesperada pela Alta Autoridade 761 
7.3.1.2.2.5. O Parágrafo Sexto do Artigo 66: Imposição de Multas pela Alta Autoridade e Controle pela Corte - Multiescalaridade e Recusa ao Uso da Força 774

7.3.1.2.3. O Artigo 67 e as Violações das Condições de Concorrência pelos Estados-Membros: O Significado Jurídico-Político do Controle da Intervenção dos Estados sobre o Ambiente Concorrencial 780

7.3.2. O Papel Fundante da Populidade 788

7.3.2.1. Aprovação de Modificações Jurídico-Normativas do Tratado da CECA 789

7.3.2.2. Aprovação da União Política da Europa Constituída pelo Tratado de Paris de 1951 799

7.3.2.3. O Significado Jurídico-Político da Populidade: Fundação e Refundação da Comunidade Política da Europa Unida pela CECA. 802

CONCLUSÕES PARCIAIS 806

CONCLUSÕES GERAIS 825

REFERÊNCIAS 831

Fontes Primárias 831

Fontes Secundárias 838

ANEXO I - Artigos do Tratado da CECA Comentados por este Trabalho 868 ANEXO II - Artigos do Protocolo sobre as Relações da CECA com o CdE Comentados por este Trabalho 885 


\section{ABREVIATURAS}

AELC Associação Europeia de Livre Comércio

ANPOF Associaçãon Nacional de Pós-Graduação em Filosofia

AUE

Ato Único Europeu

BCE Banco Central Europeu / Banque Centrale Européenne

BENELUX Bélgica, Países Baixos, Luxemburgo (Tratado de Londres, de 1944)

CCEE Conferência de Cooperação Econômica Europeia

CdE Conselho da Europa

$\mathrm{CDH}$ Convenção Europeia dos Direitos do Homem

CE Comunidade Europeia

CEB Colégio Europeu de Bruges

CEBRAP Centro Brasileiro de Análise e Planejamento

CEC Centro Europeu de Cultura

CECA Comunidade Europeia do Carvão e do Aço / Communauté Européene du

Charbon et de l'Acier / Comunità Europea del Carbone e dell'Acciaio

CED Comunidade Europeia de Defesa

CEDH Corte Europeia de Direitos Humanos

CEDIN Centro de Direito Internacional

CEE Comunidade Econômica Europeia

CEEA Comunidade Europeia de Energia Atômica

CEU Conselho Europeu

CFUE Conselho Francês pela Europa Unida

CGH Congresso de Haia

CNED Centre National d'Enseignement à Distance

CONPEDI Conselho Nacional de Pesquisa e Pós-Graduação em Direito

CPE Comunidade Política Europeia

CVCE Centre Virtuel de la Connaissance sur l'Europe

DIDH Direito Internacional dos Direitos Humanos

ECSC European Coal and Steel Community

EEE Espaço Econômico Europeu

EHESS École des Hautes Études en Sciences Sociales

EJIL European Journal of International Law 


\begin{tabular}{|c|c|}
\hline EUA & Estados Unidos da América \\
\hline EUI & European University Institute \\
\hline FADUSP & Faculdade de Direito da Universidade de São Paulo - Largo São Francisco \\
\hline FFLCH/USP & $\begin{array}{l}\text { Faculdade de Filosofia, Letras e Ciências Humanas da Universidade de São } \\
\text { Paulo }\end{array}$ \\
\hline FUNAG & Fundação Alexandre de Gusmão \\
\hline GATT & Acordo Geral de Tarifas e Comércio / General Agreement on Tariffs and Trade \\
\hline IDC & Institut de Droit Comparé - Université Panthéon-Assas (Paris II) \\
\hline IHD & Institut d'Histoire du Droit - Université Panthéon-Assas (Paris II) \\
\hline MANCEPT & Manchester Centre for Political Theory \\
\hline ME & Movimento Europeu / Mouvement Européen \\
\hline MERCOSUL & Mercado Comum do Sul \\
\hline NATO & North Atlantic Treaty Organization \\
\hline NEI & Novas Equipes Internacionais \\
\hline OCDE & Organização de Cooperação e de Desenvolvimento Econômicos \\
\hline OECE & Organização Europeia de Cooperação Econômica \\
\hline OEEC & Organisation for European Economic Cooperation \\
\hline OMC & Organização Mundial do Comércio \\
\hline ONU & Organização das Nações Unidas \\
\hline OTAN & Organização do Tratado do Atlântico Norte \\
\hline PUC-Rio & Pontifícia Universidade Católica do Rio de Janeiro \\
\hline RDA & República Democrática da Alemanha \\
\hline RDUE & Revue du Droit de l'Union Européenne \\
\hline RFA & República Federal da Alemanha \\
\hline RHIE & Revue d'Histoire de l'Intégration Européenne \\
\hline RSCAS & Robert Schuman Centre for Advanced Studies \\
\hline SciencesPo & Institut d'Études Politiques de Paris \\
\hline SEDEIS & Société d'Études et de Documentation Économiques, Industrielles et Sociales \\
\hline SFIO & Seção Francesa da Internacional Operária \\
\hline TFUE & Tratado sobre o Funcionamento da União Europeia \\
\hline TUE & Tratado da União Europeia \\
\hline UDSR & União Democrática e Socialista da Resistência \\
\hline $\mathrm{UE}$ & União Europeia / Unión Europea \\
\hline
\end{tabular}


UEF União Europeia dos Federalistas / Union Européenne des Fédéralistes

UEM Movimento pela Europa Unida / United Europe Movement

União da Europa Ocidental / Union de l'Europe Occidentale / Unione Europea

Occidentale

UK United Kingdom

URSS União das Repúblicas Socialistas Soviéticas

US United States

USA United States of America

USP Universidade de São Paulo

USSR Union of Soviet Socialist Republics 


\section{INTRODUÇÃO GERAL}

Se vier a encontrar dificuldade e aborrecimentos, espero colher também recompensa na aprovação dos que lançarem um olhar benevolente aos objetivos deste esforço. E se a tentativa for falha e de escassa utilidade, devido à pobreza do [...] meu espírito, à insuficiente experiência das coisas de hoje ou ao pouco conhecimento do passado, terá ao menos o mérito de abrir caminho a quem, dotado de maior vigor, eloquiência e discernimento, possa alcançar a meta. (MAQUIAVEL, 2008, p. 17).

Ao trazer à memória a descrição de uma gravura japonesa sobre um elefante rodeado de cegos, Maurice MERLEAU-PONTY (2004, p. 39-40) lembra algumas observações do poeta e diplomata francês Paul CLAUDEL:

[é] uma comissão encarregada de identificar essa intervenção monumental nos assuntos humanos. O primeiro abraça uma das patas e diz: "É uma árvore". "É verdade", diz o segundo, que descobre as orelhas, "Aqui estão as folhas". "De jeito nenhum", diz o terceiro, que passa sua mão pelo flanco, “é um muro!" "É uma corda", exclama o quarto, que pega a cauda. "É um cano", replica o quinto que pega a tromba...

Utilizada como um discurso metafórico, essa imagem suscita a pluralidade de leituras possíveis em torno de um e mesmo objeto de indagação: há diferentes modos de interpretar fenômenos que se colocam à investigação humana, sendo que nenhum deles é suficiente para esgotar definitivamente as significações. Qualquer explicação geral sobre algo jamais pode repousar sobre uma única fonte interpretativa, pois nenhuma delas é completamente certa, nem completamente errada - uma e outra apenas evidenciam aspectos determinados do mesmo fenômeno, a partir de uma determinada perspectiva assumida com relação a ela.

Quando se estuda particularmente a História de Projetos de Europa Unida, essa pluralidade interpretativa se revela ainda mais evidente. Essa fonte multicêntrica das interpretações sobre a origem da Europa Unida não apenas se refere aos estudos contemporâneos sobre o sentido do atual processo de integração europeu. Ela surge ao menos desde as descrições míticas sobre uma unidade cultural da Europa: (i) o mito grego da Princesa fenícia Europé; e (ii) o mito medieval do parentesco dos príncipes e dos povos, fundante da cultura política europeia em torno do cristianismo e de uma visão nacionalista dos ancestrais. Cada um deles operou arsenal lingüístico transmitido imemorialmente entre gerações com o objetivo de reunir série de imagens largamente disseminadas e conhecidas, 
relacionadas ao irracional e ao sagrado, para conferir uma perspectiva de "unidade e de coesão grupais" na Europa (CARBONELL et alli, 1999a, p. 31-2).

Apesar de se tratar de um tema interessante, um estudo exaustivo de cada um dos mitos mencionados a seguir, e de cada uma de suas versões conhecidas, não será empreendido pelo presente texto, pois ultrapassaria a clareza na definição de seus objetivos. Não se tratando do objeto de investigação científica principal deste texto, os mitos serão brevemente mencionados com o único escopo de difundir dentre a comunidade jurídica brasileira delineamentos gerais sobre eles.

O mito grego sobre a Europa revelava (i) a origem etimológica de seu nome; (ii) as raízes culturais tipicamente asiáticas assírio-hebraicas - a Fenícia-Palestina (a Terra de Canaã da Bíblia), o Egito, Creta, Cartago, Sicília, Bósforo, Thasos, Béotie, Tebas - da civilização grega arcaica, do helenismo e da Europa - dado seu descobrimento e seu povoamento inicial pelos fenícios (ROUGEMONT, 1961, p. 10-2, 18, 22, 27 e 34), usualmente esquecido pelas manifestações contemporâneas intolerantes centradas no binômio conflitivo Ocidente-Oriente; e (iii) o imaginário de ser possível atribuir aos povos europeus a ideia de que viveram em conjunto no mesmo espaço série de aventuras afortunadas comuns a partir de diferentes influências civilizatórias às margens do continente (CARBONELL et alli, 1999a, p. 33-6 e 38).

A versão mais completa e disseminada deste mito consiste no Diálogo dos Deuses, de Lúcio de SAMOSATO, do século II. Ele remonta à história da jovem princesa fenícia, Europé, filha ainda virgem de Agenor, rei de Tyr e de Sidon, raptada por Zeus e, desde então, procurada por seus irmãos. Seu rapto fora anunciado à princesa por meio de um sonho, que remonta ao poema do século II a. C. de Moschos de Siracusa, Idília. No sonho, alertada sobre seu seqüestro, a princesa teria visto duas terras, a saber, a Ásia e a terra a sua frente (a Europa), sendo que esta última a teria ameaçado pela força a reconhecer que pertencia a Zeus (CARBONELL et alli, 1999a, p. 33; ROUGEMONT, 1961, p. 12-3).

No dia seguinte ao sonho, enquanto se distraía com as demais virgens de sua idade, Europé teria encontrado um touro magnífico, dourado, de ares divinos, bastante calmo, doce e amoroso. Tratava-se de Zeus, que se transformara em touro para evitar a ira da ciumenta Hera. Este lhe teria revelado seu dorso amigavelmente, convidando-a a subir - o que fizera esperando ser acompanhada pelas demais virgens. No momento em que montara no animal, este teria se levantado subitamente e corrido em direção ao mar, carregando Europé em seu flanco para longe de sua terra natal. O destino de ambos teria sido a ilha de Creta, sobre a qual ela deveria reinar. Nesta ilha teriam nascido da união dos dois: Minos, 
Radamante e Sarpédon, reis da dinastia Minos. A briga entre estes teria motivado Europé a sair de Creta e a se estabelecer na Ásia Menor (CARBONELL et alli, 1999a, p. 33; ROUGEMONT, 1961, p. 12-6).

Apesar de ter sido intensamente procurada por seus cinco irmãos na "busca pela Europa" - levados aos limites do mundo conhecido pelos fenícios, a saber, Fênix até Cartago (batizada, em sua homenagem, de Fenícia, ou Punici), Cilix à Sicília, Phineu ao Bósforo de Dardanelos, Thasos até a ilha de Thasos, passando por Olympia, e Cadmos até Béotie, onde fundara a cidade de Tebas, passando por Rodes, pela Trácia e por Delfos. Mas Europé nunca mais teria sido encontrada (CARBONELL et alli, 1999a, p. 33-4; ROUGEMONT, 1961, p. 26). E, deste modo, com a ajuda de Zeus e por meio da força, a "terra não-civilizada" diante da Ásia teria recebido o nome de Europa (ROUGEMONT, 1961, p. 16-8).

O mito medieval sobre a ancestralidade comum é um conjunto de imagens e histórias que se sucederam, se superpuseram, se reescreveram e/ou que se influenciaram no tempo, durante toda a Idade Média, voltados a afirmar a irmandade cristã entre seus povos. Eles parecem buscar retratar, em conjunto, o reconhecimento de um patrimônio histórico comum que ligaria os povos a uma mesma linhagem familiar que, por sua vez, também os apresentaria como mútuos rivais (CARBONELL et alli, 1999a, p. 38-43).

O discurso do ancestral comum europeu que remontaria a Roma se afirma conjunta e contraditoriamente com a origem unitária das diferentes nações e das diversas dinastias legitimadas pelo sangue. Estas últimas seriam reforçadas pela concessão a cada povo de uma identidade própria derivada do nome de um pretenso heroi-fundador particular: Francus, Brito, Alamanus, Romanus, Gothus, Saxo (CARBONELL et alli, 1999a, p. 3843). Ademais, nos mitos do medievo há uma tendência dupla a afirmar uma unidade continental concomitante a um discurso religioso cristão independente da Grécia: eles teriam permitido manter uma visão da Europa como um continente distinto dos demais (ROUGEMONT, 1961, p. 23).

Um destes mitos - mais difundido - surgiu no século IV e não foi muito contestado até mais ou menos o início do século XIX: trata-se daquele que afirma a origem jafetiana da Europa. A extrema popularidade desse mito motivou determinados autores a sugerir a substituição do nome do continente de Europa para Jafétia, como fizera Guillaume POSTEL, no século XVI (ROUGEMONT, 1961, p. 25-6).

Essa concepção parte da leitura do Primeiro Livro da Bíblia (Genesis), referente à história da humanidade após o Dilúvio. Noé teria designado seus três filhos para que 
povoassem toda a Terra: CHAM teria por objetivo o povoamento da África; por sua vez, SEM, o de povoar a Ásia; e, por fim, JAFET teria de cuidar da Europa. Essa tripartição mítica sobre a terra orientou a concepção geográfica de toda a Idade Média, bem como as leituras da origem genealógica de todos os povos europeus: todos eles seriam supostos descendentes diretos de JAFET (ROUGEMONT, 1961, p. 23-6).

Dentre as genealogias das quais se tem registro, a mais conhecida é a obra Anônima de 700, a Historia Britonum, na qual se apresentam os quatro irmãos Francus, Alamanus, Romanus e Brito (herois-fundadores de uma unidade francesa, alemã, romana e britânica), todos eles (i) primos de Gothus e Saxo e (ii) descendentes de JAFET na décima-quinta geração. Há ainda a Historia Francorum, um mito constituído no século VII. Este afirmaria que, após a queda de Troia, Francion, sobrinho de Eneida, em conjunto com outros troianos, teria fundado a cidade de Sicambria e, em nome de sua coragem teriam recebido o nome de Francos - ferozes - e o direito de conquistar e ocupar a Gália, de modo a que um dos seus - Clóvis - pudesse se tornar rei em 496 (CARBONNEL et alli, 1999a, p. 39-41; ROUGEMONT, 1961, p. 25).

Apesar de serem povos potencialmente conflitantes entre si, a ancestralidade justificaria uma irmandade no sentido de dilatar geográfica e culturalmente sobre o mundo a perspectiva eurocêntrica: descendentes de JAFET (ou Yepheth: dilatar-se, expandir-se), os povos europeu deveriam se difundir em bloco sobre toda a terra portando pedagogicamente seus valores cristãos (ROUGEMONT, 1961, p. 24-5).

São inúmeras as tentativas de explicar a construção histórica de uma União na Europa. E a pluralidade interpretativa sobre as origens da Europa se manifesta também na contemporaneidade, quando se busca compreender a construção histórica do atual processo de integração europeu iniciado com a fundação jurídica da Comunidade Europeia do Carvão e do Aço (CECA). E, a partir de uma perspectiva alternativa sobre a História da CECA, esta Tese faz expressa referência a uma parte do quebra-cabeça derivado da multiplicidade de leituras possíveis sobre este extraordinário acontecimento da História Contemporânea que, em menos de 6 (seis) anos após o término da Segunda Guerra Mundial, em caráter inédito, tornou impossível e impensável o surgimento de outra Guerra regional europeia.

Este trabalho não visa a repetir as perspectivas gerais já conhecidas sobre a História da CECA: pretende antes precisamente testar uma fonte alternativa de explicações sobre a origem da CECA e sobre seu sucesso jurídico-institucional no início do processo de integração europeu. Este estudo não propõe uma revisão da História da 
CECA, mas uma perturbação discursiva do conhecimento existente, mediante a aposição de uma forma outra de ler este mesmo fenômeno: teria havido uma escolha institucional racional de composição das estruturas jurídicas da CECA, no interior de um movimento histórico específico preocupado com a reconstrução da forma do relacionamento entre os países europeus. Estabelecer o novo (Direito Internacional Comunitário), a partir da tradição (Direito Internacional Público).

A literatura jurídica brasileira e estrangeira sobre a História da CECA segue a tradição de se pautar automaticamente pelo argumento de que a integração europeia teria se iniciado a partir de uma conjunção racional de interesses econômicos, vale dizer, que

\begin{abstract}
economic interests remained primary. Pressures from economic interest groups generally imposed tighter constraints on policy than did security concerns and the ideological visions of politicians and public opinion. When one factor had to give way, it tended do be geopolitics. Economic interests, moreover, determined the circumstances under which geopolitical ideology could influence policy. Only when economic interests were weak, diffuse, or indeterminate could national politicians indulge the temptation to consider geopolitical goals. Political economic interests predominated even where we would least expect them to. (MORAVCSIK, 2005, p. 6-7, grifos nossos).
\end{abstract}

Em outras palavras, há uma extensa literatura jurídica brasileira e estrangeira que percebe a atual UE como tendo sido deflagrada por razões estritamente econômicas, isto é, há ampla literatura que tradicionalmente segue uma perspectiva fundada em uma leitura jurídico-econômica sobre a CECA.

Percebida como "Bloco Econômico" (BASSO, 1997, p. 21, 1998a, p. 81, 1998b, p. 34; CELLI JR., 1990, p. 16-9, 2006, p. 21; COSTA, 2001, p. 44; CUNHA, 2000; CURRO, 2009; FLORIO, 2002; MENEZES, 2000a, p. 53-5, 64-9 e 71-2; OLIVEIRA, 2006; RAMOS, 2005, p. 23-5, 49 e 58; SCHOUERI, 2007), a CECA é entendida como (i) resquício do movimento de liberalização multilateral do comércio internacional inaugurado pela Conferência de Bretton Woods (1944); e, por isso mesmo, (ii) inserta na lógica geral do Acordo Geral de Tarifas e Comércio (GATT, sigla em inglês); ou mesmo, (iii) motor de promoção de Desenvolvimento Econômico regional (ACCIOLY, 2003, p. 46; BASSO, 2008, p. 90; BERL, 1961, p. 3 e 5; BOBBITT, 2011; CELLI JR., 1990, p. 28-37; DELMASMARTY, 2004, p. 47 e 236; FRIEDMANN, 1964, p. 62-3; JAMET, 2011, p. 44-5; LAFER, 1997, p. 86, 1998, p. 49; MAGALHÃES, 2005, p. 106; MENEZES, 2000a, p. 58; NASCIMENTO E SILVA; ACCIOLY, 2002, p. 247; RÉAU, 2008, p. 79; REFALO, 1980, p. 67; VASCONCELOS, 2010; VIEIRA, 1999, p. 74-8). 
Isso justifica a série de estudos em Direito que avaliam a estrutura institucional de seu Tratado como portadora exclusivamente de normas de Direito Econômico Internacional voltadas simplesmente ao estabelecimento de um mercado comum, ou ainda, preocupadas precipuamente com a realização primária de fins econômicos (ACCIOLY; NASCIMENTO E SILVA; CASELLA, 2009, p. 9 e 427; BASSO, 1998a, p. 81, 1998b, p. 34; BOBBITT, 2011; CASELLA, 1994c, p. 247; CELLI JR., 1990, p. 16-9 e 87; CLERGERIE; GRUBER; RAMBAUD, 2010, p. 45; FRIEDMANN, 1964, p. 63 e 68; GLAESNER, 1991，p. 288; JAMET, 2011; MACEK, 2011; MORAVCSIK, 2005; RAMOS, 1996, p. 648, 2005, p. 49; REFALO, 1980, p. 67; REUTER, 1965, p. 173-4 e 197; VEÇOSO, 2006, p. 27, 32 e 249; VIEIRA, 1999, p. 125 e 169-79).

Segundo esta literatura tradicional, a integração promovida na Europa seria o exemplo perfeito da sucessão entre fases necessárias de integração econômica: (i) Zona de Livre Comércio, isto é, livre circulação de mercadorias entre países em virtude de ausência de barreiras ou restrições quantitativas ou aduaneiras; (ii) União Aduaneira, ou seja, além da livre circulação de mercadorias, adoção de tarifa externa comum e de uma pauta aduaneira comum entre determinados países com relação a mercadorias oriundas de países terceiros; (iii) Mercado Comum, vale dizer, livre circulação de mercadorias, de serviços, de pessoas e de capitais, implicando também livre estabelecimento e livre investimento; (iv) União simplesmente Econômica, implicando a harmonização das Políticas Econômicas nacionais (metas comuns de controle da inflação, de crescimento do Produto Interno Bruto, de controle do déficit orçamentário); (v) União Econômica e Monetária, ou seja, a harmonização das Políticas Econômicas e das Políticas Monetárias nacionais, inclusive pela adoção de uma moeda únida, sendo, assim, apenas uma eventualidade a (vi) União Política, verificada, segundo esta leitura, pela criação de cidadania comum aos países e pela construção de um novo Estado a partir dos países inicialmente integrados em torno de aspectos econômicos (ACCIOLY, 2003, p. 26-44; CASELLA, 1994a, p. 212; CELLI JR., 1990, p. 48-67, 2006; MENEZES, 2000a, 59-63). Em outras palavras, para esta leitura, a integração política da Europa apenas teria advindo após o sucesso da integração econômica (BERL, 1961, p. 4; CASELLA, 1994a, p. 212; HABERMAS, 2011a; POZO, 2011a, p. 63; QUADROS, 1984, p. 121-4; RAMOS, 2005, p. 648-9 e 657; VEÇOSO, 2006, p. 32-3).

Apesar de essa leitura ser relevante e ser acadêmicamente profícua, é importante observar que "[c]ette prééminence de l'économie dans la conception de l'unité européenne est source d'équivoques dans la mesure où la construction de l'unité est rapportée aux 
besoins de l'économie plus qu'à l'Europe elle-même." (ROLLAND, 2006, p. 8). Dito de outro modo, apesar de ser capaz de explicar coerentemente alguns aspectos do início da União Europeia (UE), essa leitura jurídico-econômica deposita imoderamente em uma perspectiva estritamente pautada por mandamentos econômicos a capacidade de interpretar o um e mesmo fenômeno da CECA. E, como ressalta a metáfora do elefante acima lembrada, há que se notar ser possível apresentar uma outra raiz explicativa que, se não é exclusiva, pode ao menos contribuir ao conhecimento jurídico brasileiro em Direito Internacional por meio da explicitação de aspectos até então não adequadamente compreendidos pela literatura jurídica tradicional.

Deste modo, sem ignorar ou invalidar a leitura jurídico-econômica tradicionalmente dada pelas literaturas jurídicas brasileira e estrangeira, o trabalho visa a fornecer outra fonte explicativa deste fenômeno, a partir da ênfase na igual possibilidade de se desenvolver uma leitura jurídico-política da integração europeia. Assim, por meio da suspensão da leitura jurídico-econômica, este trabalho pretende ampliar os termos de interpretação do início da construção da Europa Unida de hoje e com isso alargar as vias de compreensão de seu atual encaminhamento. Toda leitura diz algo, mas não diz tudo - ou melhor, não diz tudo, mas diz algo.

Assim, o objetivo geral desta pesquisa é apresentar uma forma de compreensão alternativa do momento inicial da integração europeia - a CECA, a partir de uma chave explicativa de fundamento jurídico-político de sua História - deixando de lado, sem pretender invalidar, desprezar, desmentir ou simplesmente "superar", a corrente interpretação jurídico-econômica. Busca-se apenas apontar outras camadas do fenômeno da CECA e, a partir delas, desenvolver uma nova via de leitura.

Sob uma perspectiva geral, este trabalho pretende contribuir para ampliar o campo de questões que podem auxiliar a esclarecer os primeiros passos da integração europeia. Tais questões poderão fornecer uma nova medida comparativa histórica que, em trabalhos futuros permitirá avaliar criticamente as condições segundo as quais a integração europeia se apresenta hoje (isto é, onde teria ocorrido um suposto "desvio de rota"). Neste trabalho objetiva-se compreender conceitualmente o passado, para, a partir dele, tratar do tempo atual em uma pesquisa posterior, de modo a abrir uma Nova Agenda de Pesquisas em Direito.

A pesquisa possui como objetivo específico analisar o texto de Direito Positivo do Tratado da CECA e nele identificar uma preocupação em estabelecer uma racionalidade arquitetônica bastante peculiar no desenho institucional da Comunidade. Não teria se 
tratado de uma neutra e leviana divisão de funções, mas de verdadeiro arranjo técnico jurídico voltado a construir uma vida comum em torno de um regime de contraposição contínua entre diferentes para decidir em conjunto sobre o sentido normativo a ser dado a questões concretas sensíveis comuns.

A hipótese que se pretende demonstrar é que a História e o Tratado da CECA podem ser entendidos de acordo com uma perspectiva jurídico-política. Esta evidenciará uma preocupação histórica em construir institucionalmente uma organização jurídicopolítica toda especial das relações entre os países europeus participantes da CECA, na qual e pel qual, mediante mútuas contraposições institucionalmente previstas no Tratado da CECA, fosse tornada impossível a deflagração de nova Guerra regional.

Para tanto, este trabalho procurará responder à seguinte pergunta: quando, como, e por meio de quais instituições, povos europeus tradicionalmente opostos em termos militares (Bélgica, França, Itália, Luxemburgo, Países Baixos e República Federal da Alemanha) conseguiram estabelecer entre si, após o término da Segunda Guerra Mundial, de maneira inédita e inaudita em sua História, um novo modo de relações, o qual foi responsável pela construção de um sistema de convivência permanentemente conflitivo, porém não belicoso?

Deste modo, entenda-se que, visando à originalidade da contribuição para o pensamento jurídico brasileiro em Direito Internacional sobre a CECA, o impulso básico desta Tese de Doutorado é ser contrário à literatura tradicional sobre a História da CECA. Mediante a suspensão da leitura jurídico-econômica e por meio da introdução de uma específica forma jurídico-política de se compreender este início da integração europeia, quer-se dizer algo novo sobre a História da CECA - isto é, sobre o início da atual UE. E, dessa forma, poderia o leitor se questionar porque deveria aceitar esse novo conjunto interpretativo sobre a História da CECA e sobre seu respectivo arranjo institucional positivado nas normas jurídicas de seu Tratado Constitutivo.

A resposta mais fundamental é epistemológica: pretende-se fazer conjugar, a partir de metodologia rigorosamente conduzida, um discurso racional conceitualmente novo com elementos da experiência histórica da CECA ainda não conhecidos (fontes históricas primárias e algumas fontes históricas secundárias recentes), ou com elementos da experiência histórica e normativa da CECA que, apesar de conhecidos (outras fontes históricas secundárias e o Tratado da CECA), sofrerão um processo de ressignificação derivado da nova raiz explicativa. Se o conhecimento se produz a partir da conjunção entre razão e experiência (KANT, 2012, p. 96-7), acredita-se que se poderá construir um 
conhecimento jurídico novo a partir da conjunção entre discurso racional conceitualmente novo e experiência nova, ou entre aquele e uma experiência já conhecida, mas trabalhada de maneira significativamente inovadora.

Para tanto, este trabalho foi dividio em duas Partes. A Parte Primeira é responsável pela delimitação e pela construção do aparato conceitual novo a ser empregado por esta Tese. A Parte Segunda se ocupa com a apresentação dos elementos da experiência histórica e normativa da CECA, em um misto de narrativa e de interpretação segundo a chave de leitura conceitual, a fim de facilitar o acompanhamento contínuo da construção intelectual dos elos entre razão e experiência por parte do leitor. Em outras palavras, a Parte Primeira erige o edifício conceitual, enquanto a Parte Segunda revela os elementos da experiência de acordo com a chave de leitura fornecida na Parte Primeira.

A Parte Primeira é divida em três Capítulos. O Primeiro Capítulo tem por objetivo precisar de maneira circunstanciada os limites metodológicos impostos pela pergunta norteadora da reflexão deste trabalho. O Segundo Capítulo apresenta a justificativa da localização desta Pesquisa interdisciplinar em Direito Internacional - que congrega contribuições de História Contemporânea da Europa e de Filosofia Política Antiga e Contemporânea - no interior do campo de preocupações em Direito. O Terceiro Capítulo se ocupa principalmente da construção da chave de leitura jurídico-política que orientará a interpretação dos elementos da experiência histórica e da experiência normativa.

A Parte Segunda é dividida em quatro Capítulos. O Quarto Capítulo apresenta a situação da Europa no imediato pós-Segunda Guerra Mundial (1945) e, em seguida, se ocupa brevemente da história da construção da Organização Europeia de Cooperação Econômica (OECE) (1948) e do Pacto de Bruxelas (1948), estabelecendo um elo entre estas e as pressões estadunidenses de cooperação econômica e militar na Europa. O Quinto Capítulo desenvolve aspectos históricos relacionados à criação do Conselho da Europa (CdE) (1949), vinculando-o a um Projeto Federal de Unificação Política da Europa em um Estado Europeu fundado nos Direitos Humanos e na Democracia. O Sexto Capítulo revela o processo de constituição histórica e institucional da CECA (1951) como um movimento distinto daquele expresso nos dois Capítulos anteriores, por não ser nem um Projeto de simples cooperação entre países europeus, nem um Projeto de Unificação Política da Europa em um Estado Europeu. O Sétimo Capítulo interpreta minuciosamente determinadas normas jurídicas positivas do Tratado da CECA, com o objetivo de evidenciar em sua composição uma complexa engenharia institucional voltada a promover um modo de vida comum entre os países componentes da Comunidade. 
Michel de MONTAIGNE (1980, p. 9), no título do Capítulo I, do Livro I, de seus Ensaios, afirmava que “[p]or diversos meios chega-se ao mesmo fim", ressaltando que

\begin{abstract}
a maneira mais comum de amolecer o coração dos que nos ofendem, quando, vingança em mãos, eles nos têm a sua mercê, é comovê-los pela nossa submissão, inspirando-lhes comiseração e piedade. Entretanto, a bravura, a tenacidade e a resolução, meios inteiramente opostos, alcançam às vezes idêntico resultado. [...].

Scanderberg, Príncipe do Egito, perseguia um de seus soldados com a intenção de matá-lo. Este, depois de ter tentado em vão acalmá-lo com protestos de toda espécie e as mais humildes súplicas, resolveu, em desespero de causa, esperá-lo de espada na mão. $O$ gesto resoluto freou instantaneamente a exasperação do senhor, o qual, ao ver tão honrosa atitude, outorgou mercê ao perseguido. O exemplo é suscetível de ser interpretado de outra maneira, mas tão-somente por quem ignore a força prodigiosa e a valentia desse príncipe.
\end{abstract}

Entre submissão e resolução de espírito, ao recusar seguir a esteira das leituras tradicionais sobre a História da CECA e sobre as instituições de seu Tratado, este trabalho optou pela segunda perspectiva. A ousadia do empreendimento acadêmico original é sempre problemática, pois suscita o temor no autor de um trabalho que tem por objetivo ser original - afinal, ele está sujeito, agindo deste modo necessariamente irreverente, tanto a uma boa, quanto a uma má recepção do trabalho por parte da Comunidade acadêmica.

Se por diferentes meios se chega ao mesmo fim, talvez por meios iguais se chegue a fins diferentes. E, para se defender de um fim indesejado, o autor se cerca decididamente aqui do maior número possível de instrumentos de defesa racionais conceituais e da experiência encontrados durante a Pesquisa, a fim de os apresentar à comunidade epistêmica jurídica brasileira, para que, em conjunto com ela, se possa propor e pensar o novo a partir do consciente, sério, honesto e cordial conflito acadêmico. 
PARTE I: O ARCO DO CONHECIMENTO JURÍDICO APLICADO À TESE: SUA SITUAÇÃO TEMPORAL ESPACIAL, TEMÁTICA E METODOLÓGICA 


\section{INTRODUÇÃO PARCIAL}

[C]aberá a cada um encontrar e aperfeiçoar a sua própria receita de metodologia e de pesquisa. [...]

Encontrar o ponto certo, de combinação entre originalidade, sem deixar de ter consciência de se estar inserto, em tradição intelectual e histórica, também cabe a cada um determinar: se se perde a espontaneidade, a alegria, e o dado pessoal, a obra será mera cópia, será falsa perfeição. Mas, também, se tem de levar em conta, nada pode ser mais ridículo do que pretender reinventar a roda, a cada empreitada intelectual que se encete. Se não se leva em conta o que disseram os que nos precederam pode acontecer que as melhores intenções não levem a nada. (CASELLA, 2009a, p. 174 e 176, grifos do autor).

O domínio do trabalho científico não tem por base as conexões "objetivas" entre as "coisas", mas as conexões conceituais entre os problemas. Só quando se estuda um novo problema com o auxílio de um método novo e se descobrem verdades que abrem novas e importantes perspectivas é que nasce uma nova "ciência". (WEBER, 2006, p. 37, grifos do autor).

O tema desta Tese de Doutorado consiste em apresentar uma leitura jurídicopolítica da CECA, sendo o problema que norteia a presente investigação buscar compreender quando, como, e por meio de quais instituições países europeus tradicionalmente opostos em termos militares (Bélgica, França, Itália, Luxemburgo, Países Baixos e República Federal da Alemanha) conseguiram estabelecer entre si após o término da Segunda Guerra Mundial, de maneira inédita e inaudita em sua História, um novo modo de relações que tornou impensável o cometimento de novas Guerras.

Esta nova forma histórica de articulação das relações destes países se instaurou juridicamente por meio do Tratado da CECA e se revela como merecedora de especial atenção. Com efeito, ela viabilizou, pelo abandono da tradicional perspectiva da negociação diplomática, a impossibilidade mesmo de se pensar a realização de uma Guerra entre os Estados-nacionais que compunham a referida Organização Internacional ${ }^{1}$.

Com efeito, por meio de específica engenharia institucional, a Europa Unida da CECA permitiu estabelecer um novo patamar jurídico de relações que instaurara a possibilidade - ou melhor, a obrigatoriedade - de solucionar os persistentes conflitos que

\footnotetext{
${ }^{1}$ Organizações Internacionais são “[a]ssociações voluntárias de sujeitos de direito internacional (Estados ou outras organizações internacionais), dotadas de personalidade jurídica [distinta da de seus membros] e órgãos próprios, constituídas através de um tratado, com a finalidade de alcançar os objetivos comuns por meio da cooperação institucionalizada e permanente entre seus membros.” (RAMOS, 2007, p. 253). Em seguida, o mesmo autor aponta para o fato de que as Organizações Internacionais podem deter um caráter mais profundo do que o de uma simples cooperação entre seus Estados-Membros, adquirindo contornos de Organizações Internacionais supranacionais: “órgão ou órgãos compostos por pessoas com independência e comprometidas com os objetivos da organização, votação em alguns temas por maioria (dispensada a unanimidade), controle da interpretação e aplicação das normas por meio de um mecanismo externo vinculante aos Estados.” (RAMOS, 2007, p. 253-4).
} 
surgissem entre seus Estados-Membros no interior de suas instituições. Não mais um país mobilizaria suas forças armadas sem que os demais tivessem conhecimento, dissipando assim a desconfiança e a tensão bélica existentes entre seus países-membros depois da Segunda Guerra Mundial.

Diante da novidade desta nova dinâmica relacional, pautada não mais pela fragilidade da conveniência das barganhas políticas entre interesses de Estado, mas pela presença de arquitetura institucional juridicamente posta para efetuar uma resolução jurídica de conflitos $^{2}$, este estudo se propõe simplesmente a realizar nada mais do que a

${ }^{2}$ Na literatura jurídica brasileira, autores como Paulo Borba CASELLA (2007b, p. 17, 2008, p. 228), Lucia Baungartner LAMBERTI (1991) e Geraldo MINIUCI (2012) denominam essa inventividade realizada na primeira metade do século XX como a transição do Direito Internacional do paradigma da coexistência para o da cooperação.

A coexistência seria caracterizada pela persistência de um discurso de Direito Internacional exclusivamente moldado para e pelos os Estados, à imagem e semelhança deles, razão pela qual sua lógica poderia ser igualmente conhecida como sendo a do bilateralismo, da coordenação ou de uma sociedade relacional. A cooperação constituiria, por sua vez, um novo paradigma de estrutura para o Direito Internacional, pois partiria de sujeitos de Direito Internacional adicionais, como as Organizações Internacionais, dentro das quais os Estados seriam convidados a se concertar organizada e ativamente, o que qualificaria sua racionalidade como sendo a do multilateralismo ou a da sociedade institucional (ACCIOLY; NASCIMENTO E SILVA; CASELLA, 2009, p. 388-91; CASELLA, 2008, p. 189, 228-9, 250 e 259; MINIUCI, 2012).

"A partir de um corpo de normas (negativas) de abstenção, que estabelecem condições de independência para que os Estados coexistam, o Direito Internacional vem desenvolvendo-se em um corpo de normas (positivas) de cooperação, que buscam administrar a interdependência e as disparidades econômicas entre os Estados." (LAMBERTI, 1991, p. 108).

A coexistência teria sido o fundamento do Direito Internacional em suas origens (séculos XVI e XVII). Este entendia a relação entre países como relações entre entidades políticas independentes, centros de poder incondicionados não subordinados a uma autoridade superior, salvo mediante consentimento, usualmente expresso por meio de Tratados Internacionais (CARRILLO SALCEDO, 1985, p. 183; LAMBERTI, 1991, p. 16 e 28-9). Em palavras mais simples, o Direito Internacional inserto em paradigma de coexistência se tratava de uma "matter of diplomatic interstate relations" (FRIEDMANN, 1964, p. 60).

"El orden internacional expresado en la Paz de Westfalia hace del Estado soberano territorial el centro de gravedad del sistema de regulación de las relaciones internacionales: las normas de Derecho internacional son creadas por la voluntad de los Estados, bien sea de modo expreso (tratados) o de modo tácito (costumbres), y los principios fundamentales del sistema serán el resto de los límites territoriales de los Estados; la jurisdicción territorial de los Estados; la igualdad soberana de los Estados." (CARRILO SALCEDO, 1985, p. 183).

É no interior dessa ordem internacional de coexistência que se mostra possível compreender entendimentos semelhantes ao esposado exemplificativamente por Dionisio ANZILOTTI (1923, p. 39-40). Para este autor, seriam fontes do Direito Internacional Público os acordos das vontades manifestadas pelos Estados, de modo expresso (Tratados Internacionais) ou tácito (costume), mas sempre o acordo entre as vontades estatais (pacta sunt servanda). Pois, afinal, a coexistência seria um sistema de relações diplomáticas interestatais (LAMBERTI, 1991, p. 16 e 24).

O objetivo do Direito Internacional de Coexistência consistia em regular as condições de intercursos diplomáticos mútuos, abrangendo o respeito recíproco pela igual soberania internacional, independentemente da estrutura econômica e social de cada Estado. Nesse sentido, há que se perceber que as normas jurídicas deste Direito Internacional são normas de obrigação negativa, ou ainda, normas de mútua abstenção (FRIEDMANN, 1964, p. 60 e 62), "definidas pela proposição não faça” (LAMBERTI, 1991, p. 47, grifos da autora). Fausto de QUADROS (1984, p. 386) designa este Direito Internacional como um Direito Internacional clássico, tradicional, de coordenação da coexistência passiva e pacífica de entidades soberanas.

Por seu turno, a cooperação estaria vinculada à ideia de introduzir normas jurídicas para a satisfação de interesses e necessidades comuns por meio de instituições comuns. Nesse sentido, a cooperação sempre 
seria manifestada por meio de instituições (cooperação institucionalizada) (CARRILLO SALCEDO, 1985, p. 185 e 188). Abandona-se com isso a restrição de as relações entre Estados estarem pautadas apenas pelas relações diplomáticas (FRIEDMANN, 1964, p. 61), a fim de regulamentar internacionalmente problemas transfronteiriços, tais como os Direitos Humanos e o Direito Ambiental (LAMBERTI, 1991, p. 16, 24, 51, 53 e 81).

O Direito Internacional de Cooperação teria surgido com modificações dramáticas da estrutura da sociedade internacional, as quais teriam imposto uma crescente interdependência entre os Estados (LAMBERTI, 1991, p. 23 e 26). Ele seria caracterizado por sua exigência de atuação positiva (intervenção ativa) pelos Estados no sentido de cooperarem em diferentes áreas transnacionalmente interconectadas.

Esse direcionamento seria dado por meio de Tratados Internacionais e Organizações Internacionais permanentes, isto é, por meio de normas jurídicas internacionais caracterizadas pelo fato de serem normas de obrigação positiva (FRIEDMANN, 1964, p. 60-2), "definidas pela proposição faça" (LAMBERTI, 1991, p. 48, grifos da autora), as quais vinculariam os Estados para o atingimento de objetivos comuns (interdependentes, interconectados). Fausto de QUADROS (1984, p. 386) designa este Direito Internacional como um Direito Internacional novo, de solidariedade internacional.

Frise-se que para Wolfgang FRIEDMANN (1964, p. 60-2) a cooperação se desenvolveria principalmente nas áreas econômica e social, ao passo que, para Lucia Baungartner LAMBERTI (1991, p. 41), com base na Carta da ONU, a cooperação se dirigiria para solucionar problemas econômicos, sociais, culturais ou humanitários.

Como se poderá ver reiteradamente nas linhas a seguir, a partir da suspensão da leitura econômica indicada na Introdução Geral deste trabalho, o presente texto não pode concordar com a afirmação de a alteração do paradigma das relações entre Estados se mover supostamente com maior ênfase em um patamar econômico. De todo modo, "[t]his move of international society, from essentially negative code of rules of abstention to positive rules of co-operation, however fragmentary in the present state of world politics, is an evolution of immense significance for the principles and structure of international law." (FRIEDMANN, 1964, p. 62).

Independentemente de se preocupar com a questão de se filiar ou não a esta diferenciação terminológica - ou, o que é o mesmo, a essa chave de classificação, o presente estudo procurará compreender a engenharia institucional do Tratado da CECA nela mesma. Seu objetivo consiste em identificar a qualidade específica deste desenho institucional em particular, de maneira a averiguar a racionalidade subjacente a cada uma das normas jurídicas deste Tratado. Não se trata tanto de discutir a classificação do Direito Internacional que pautava a construção da CECA, mas sim de a compreender nela mesma. A distinção apenas tangencia as discussões principais deste trabalho. De todo modo, note-se que tais objetivos ficarão mais claros à medida que este trabalho desenvolver seus pontos de partida metodológicos e hermenêuticos.

Perceba-se, ainda, que essa distinção tradicional entre coexistência e cooperação não teria diagnosticado uma ruptura absoluta entre as duas situações. Com efeito, a antiga ordem vigente até meados do século XX não teria sido superada de modo integral pela nova ordem (CARRILLO SALCEDO, 1985, p. 188-9; FRIEDMANN, 1964, p. 62; LAMBERTI, 1991, p. 32, 46, 49, 52, 81 e 108-9; MINIUCI, 2012): “[o]s dois princípios coexistem num relacionamento dialético e quase sempre tenso" (LAMBERTI, 1991, p. 49).

Lembre-se, aqui, sutil crítica apontada por Paulo Borba CASELLA (2008, p. 259): "Multiplicam-se em número e relevância, os demais co-atores da cena mundial - com papel e atuação crescentes para as organizações internacionais, as quais, todavia, enquanto colegiados de estados, conservam, em boa medida, a mesma lógica de atuação, embora com meios e fins nem sempre coincidentes.". Pois, afinal, entre coexistência e cooperação, "aquélla no ha quedado desplazada por ésta, aunque sí erosionada y alterada." (CARRILlO SALCEDO, 1985, p. 188). No mesmo sentido, Wolfgang FRIEDMANN (1964, p. 64): "International law is now developing on several levels, one continuing the traditional international law of diplomatic coexistence, and [...] implementing the quest for both universal and regional international cooperation and organization.".

A discussão em torno do embate entre coexistência e cooperação não chegou a termo, pois depende da perspectiva assumida por cada um que pretende investigar os processos de integração: "Las teorías de la integración se han caracterizado desde su surgimiento por la problematización de su objeto de estudio, esto es, el próprio concepto de integración. Qué es la integración y cómo ocurre han sido las preguntas centrales para los teóricos sobre las que ha sido imposible establecer un consenso científico. [...] La teorización sobre la integración refleja el sucesivo predominio de paradigmas [...].” (CLOSA, 1994, p. 339).

Relevante esta informação. Deverá ser guardada para futuras considerações, especialmente no que se refere aos próximos itens, 1.4., infra, e aos Segundo e Sétimo Capítulos desta Tese: as Organizações Internacionais - tais como o Pacto de Bruxelas, a OECE, o CdE, a CECA, a Comunidade Europeia de Defesa (CED) e a Comunidade Política Europeia (CPE) - não necessariamente estariam voltadas igual e uniformemente a operar segundo uma lógica supranacional ou estatal intergovernamental, vale dizer, não 
compreensão histórica da invenção institucional deste instrumento jurídico internacional do pós-Segunda Guerra Mundial.

Trata-se de fundamental importância compreender o Direito Internacional contemporâneo e suas manifestações institucionais no interior da própria situação histórico-contextual e cultural que o constituiu. É por meio desse exame acurado que se torna possível depreender dele uma interpretação sobre sua qualidade a partir do conhecimento de suas fundações e seu enraizamento na vida em sociedade (CASELLA, 2008, p. 189, 2009a, p. 67-8).

Não apenas é fundamental relembrar a historicidade deste arcabouço institucional ${ }^{3}$, nem mesmo somente explicitar de maneira detalhada cada uma das articulações entre os dispositivos constantes do Tratado. Além disso, também é indispensável compreender este novo modo de relações de acordo com uma chave de leitura específica que permitirá produzir interpretações em torno do próprio móvel histórico informador das instituições jurídico-positivas do Tratado da CECA (os elementos que conectam o fenômeno jurídico estudado com a vida em sociedade).

A proposição de chave hermenêutica diversa é relevante para a produção de conhecimento científico diferenciado (CASELLA, 2007a, p. 17; HUSSERL, 2006, p. 85; WEBER, 2006, p. 37). Introduzir um objeto de estudo tradicional em um novo campo significativo fora da chave de compreensão tradicional permite dele extrair novas respostas e, mais do que isso, apresentar a este objeto novas perguntas. Este florescer de novas perguntas e de novas respostas deriva precisamente deste deslocamento de sentido produzido por meio desta inserção em novo feixe de leituras.

seriam apenas motoras de um processo de integração/convivência (união política) ou de um processo de cooperação. Tudo dependeria da maneira segundo a qual sua instituição fora operada, bem como dos pontos de partida da maneira como se pretende compreender esta arquitetura institucional.

Se nas próximas páginas se pretende ensaiar ligeira e sutilmente, ou ainda, esboçar simplesmente, uma outra forma possível de compreender a integração europeia da CECA (não coexistência, nem cooperação, mas convivência), perceba-se que esta discussão de nomenclatura final tem fundamento no ponto de partida reflexivo assumido por este estudo (a restar mais claro nos itens 1.2. e seguintes, infra).

Não é própria e precisamente o objetivo deste trabalho querer propor um termo supostamente melhor para designar a integração da Europa Unida da CECA, ou mesmo querer resolver o debate em torno desta distinção entre cooperação ou coexistência. Antes, o objetivo deste texto é compreender a engenharia institucional arquitetada por meio de normas jurídicas positivas constantes do Tratado de Paris de 1951, o qual instituiu a CECA.

Assim, mais do que querer classificar a Europa Unida da CECA dentro de uma ou de outra corrente (coexistência, cooperação ou convivência), este trabalho pretende compreender seu inaudito arranjo institucional em si mesmo, conforme se poderá ver nas linhas a seguir.

${ }^{3}$ Isto é, reinstaurar a percepção desse construído jurídico em sua História, a fím de não ignorar o elo vital entre estudo em Direito e o Direito como elemento fundamental da vida em sociedade, como enfatiza Paulo Borba CASELLA (2009a, p. 67-74 e 113-20). O uso do conhecimento histórico neste trabalho será mais bem compreendido nos três primeiros Capítulos da Parte Segunda, infra, onde se tematiza a História da CECA. 
Isso significa que o objeto da ciência não é uma coisa em si, mas um modo de encarar o objeto material pelo sujeito, uma maneira de abordá-lo. De certo modo, o método é o procedimento que faz parte da construção do objeto e que, até certo ponto, o determina também. (ALVES, 2003, p. 298, grifos do autor).

Deste modo, por meio do diálogo com as formas tradicionais de compreensão deste fenômeno jurídico específico ${ }^{4}$, sem deixar de sublinhar a existência de alternativas de interpretação deste objeto de estudo, este trabalho procurará responder a sua tríplice indagação: (i) quando, (ii) por meio de, e (iii) como. Estes três polos inquisitivos remetem respectivamente a questões de (iv) ordem histórico-temporal, espacial e temática $(\text { Primeiro Capítulo })^{5}$, (v) estabelecimento de critérios de análise de instituições manifestas por meio do Direito Positivo (Terceiro Capítulo) ${ }^{6}$, e (vi) aferição da qualidade do modo como foram articuladas tais normas jurídicas que estabeleceram este novo tipo de relações entre os países formadores da CECA, o que necessariamente exigirá o concurso de uma nova perspectiva analítica, marcada por vocação interdisciplinar (Segundo Capítulo).

Em razão da amplitude do alcance deste estudo, é fundamental a presença desta primeira parte metodológica, destinada ao esclarecimento e à precisão dos termos destinados a guiar a análise empreendida por este trabalho. Mostra-se indispensável uma rápida apresentação do arco de conhecimento jurídico aplicado à Tese, para que haja a adequada compreensão segura e certa de cada um dos passos lógicos efetuados em cada degrau de construção das conclusões deste texto.

É importante notar neste ponto que se efetua referência consciente à imagem sugerida por David OLDROYD (1986, p. 26-8) para sinalizar imageticamente o método científico indutivo-dedutivo (em "vai-e-vem”) desenvolvido por ARISTÓTELES em seus Analíticos Posteriores (2005).

Segundo o filósofo grego, haveria no processo de conhecimento científico um movimento duplo ascendente-descendente. O conhecimento iniciaria pela apreensão de dados sensíveis particulares que possibilitaria a formulação de um princípio explicativo geral sobre os mesmos (indução), ao mesmo tempo em que seria finalizado por um retorno

\footnotetext{
${ }^{4}$ Vale dizer, sem desconsiderar o conhecimento interpretativo dado pelo discurso vigente nas literaturas jurídicas nacional e estrangeira.

${ }_{5}$ A vinculação necessária de uma compreensão conjunta entre espaço e tempo no Direito Internacional tem como um dos principais nomes no pensamento jurídico nacional Paulo Borba CASELLA, em seu Direito Internacional dos Espaços (2009b) e em seu Direito Internacional no Tempo Antigo (2012).

${ }^{6}$ No caso específico deste trabalho, exclusivamente o Tratado que Institui a CECA, como será mais bem explicitado nos dois próximos Capítulos.
} 
à interpretação de dados particulares a partir dessa formulação generalizável (dedução) (ARISTÓTELES, 2005, p. 253-4, 276-8, 312 e 344-5). Por meio deste método, seria possível distinguir o falso conhecimento (não metódico) do verdadeiro conhecimento (metódico) (BITTAR, 2003, p. 263-4).

Não se trata de recorrer aqui ao método científico tal qual formulado por ARISTÓTELES para nortear a pesquisa deste trabalho ${ }^{7}$, principalmente porque a questão em torno do caráter indutivista ou dedutivista do conhecimento jurídico não mais faz sentido hoje nos estudos e nas Pesquisas em Direito (REALE, 2001, p. 84) ${ }^{8}$. Antes, a menção a ARISTÓTELES aqui visa apenas a recorrer argumentativamente a um simples auxílio imagético sugerido por David OLDROYD (1986, p. 26-8).

Mais simplesmente, socorre-se do didático recurso em que consiste a noção de imagem de "arco do conhecimento jurídico". Utiliza-se topicamente ${ }^{9}$ esta imagem circular ascendente e descendente de construção do conhecimento em Direito para sinalizar o percurso reflexivo empreendido durante as Pesquisas para este trabalho. Esse rastro circular é o preciso movimento intelectual descrito por este trabalho.

Assim, imageticamente, o procedimento de construção de um conhecimento jurídico-científico seguro neste trabalho parte de um dado jurídico particular da experiência histórica. Este será posteriormente examinado de acordo com princípios explicativos conceituais interdisciplinarmente construídos, os quais direcionariam em seguida o raciocínio para o mesmo dado particular, mas de maneira modificada: estaria neste movimento descendente de posse de polos significativos adicionais voltados a

\footnotetext{
${ }^{7}$ A literatura explicativa do método científico em ARISTÓTELES é demasiado ampla para ser exaurida em qualquer nota de rodapé; restringe-se a mencionar exemplificativamente obra de Eduardo Carlos Bianca BITTAR (2003), onde o filósofo do Direito brasileiro empreendera um esforço explicativo de todo o pensamento da Filosofia Aristotélica. Por se preocupar com uma compreensão holística do pensamento deste autor, o comentário daquele autor nacional pode ser bastante interessante para entrar em contato com o pensamento de ARISTÓTELES.

Inúmeras obras adicionais poderiam ser mencionadas, mas se evita que a menção de outras extrapole os limites e os objetivos deste trabalho, haja vista que o esclarecimento completo das questões de método científico em ARISTÓTELES foge aos escopos deste texto. Qualquer enumeração de textos ignoraria tantos outros igualmente relevantes, ou seja, qualquer enumeração de comentadores restaria imprecisa e imperfeita, razão pela qual não se ousa aqui sequer indicar literatura especializada.

${ }^{8}$ Segundo Miguel REALE (2001, p. 84), isso se justificaria pelo fato de hoje se admitir o pluralismo metodológico nas Pesquisas em cada ramo do conhecimento humano, e mesmo no interior de cada um deles. Essa condição pluralista de metodologias é assumida por este trabalho e por ele incorporada. Restará mais bem compreendida a maneira pela qual foi adotada neste estudo nas linhas a seguir, razão pela qual se deixa de tecer aqui considerações sobre a mesma.

${ }^{9}$ Topicamente no sentido de topos, isto é, de lugar comum no processo argumentativo; sobre esta questão, sugerimos a leitura da Tópica e Jurisprudência, de Theodor VIEHWEG (2008), obra inauguradora desta temática no conhecimento jurídico. O que não implica afirmar que se corrobora e que se incorpora de maneira integral todo o pensamento jurídico e de metodologia jurídica deste autor neste trabalho. Recorre-se apenas argumentativamente ao espaço significativo trazido pelo termo topos.
} 
interpretá-lo de maneira distinta da inicial. Esta imagem formal de arco é o caminho a ser seguido neste estudo para produzir um conhecimento jurídico novo a partir da conjunção entre conceito racional e experiência.

Será estabelecido temporal, espacial e tematicamente o objeto de estudo (Primeiro Capítulo), o qual terá sua perspectiva histórica mais bem divulgada à comunidade epistêmica jurídica nacional à luz do exame de documentos originais relacionados à construção da CECA (fonte primária) e do de literatura estrangeira (fonte secundária) recente sobre a história da construção da Europa Unida (Quarto, Quinto e Sexto Capítulos). Em seguida, serão determinados os critérios componentes da chave de leitura interdisciplinar (Segundo e Terceiro Capítulos), a qual regerá conceitualmente a interpretação minuciosa da experiência histórica e normativa da CECA (Sétimo Capítulo).

A conjunção das conclusões dos dois exames anteriores permitirá descrever sobre o objeto singularmente selecionado - a CECA - determinadas conclusões (Conclusões Parciais da Parte Segunda). Tais conclusões, por explicitarem novas leituras, poderão entreabrir Nova Agenda de Pesquisas sobre a construção histórica da Europa Unida até os dias de hoje, conforme ponto de partida diferenciado.

É neste momento que se revela a importância desta primeira parcela deste estudo: ela tem por objetivo elucidar conceitualmente o método utilizado para desenvolver a presente investigação - que, para ser científica, exige que se percorra um caminho certo e seguro (REALE, 2001, p. 9-10) ${ }^{10}$.

O conhecimento científico é um conhecimento metódico. Por meio de um Método, ela procura estabelecer a certeza sobre as certezas, ou ainda, a "segurança quanto àquilo que [se] afirma”, sendo "inútil percorrermos o mundo jurídico buscando sua visão unitária sem dispormos dos métodos adequados para conhecê-lo" (REALE, 2001, p. 10).

\footnotetext{
${ }^{10}$ Afinal, o problema fundamental do conhecimento científico reside em buscar fundações seguras para sua sustentação argumentativa.

Nesse sentido, é interessante lembrar a tríplice definição de conhecimento científico (epistheme) dada por PLATÃO, por oposição à mera opinião (doxa): conhecimento seria opinião verdadeira justificada: "a opinião verdadeira acompanhada de razão é conhecimento[; ...] desprovida de razão, a opinião está fora do conhecimento" (PLATÃO, 19??a, p. 159). Em outros termos, segundo este autor, não se deveria reconhecer no não-racional a possibilidade de adequada produção do conhecimento verdadeiro, precisamente por não ter sido fruto de um encadeamento racional (PLATÃO, 19??b, p. 72).

Note-se que "a ciência se distingu[iria] da opinião certa por seu encadeamento racional" (PLATÃO, 19??, p. 72), isto é, por ser um conhecimento seguro, assegurado por uma via certa, isto é, por um método (REALE, 2001, p. 9-10). Pode-se identificar ser essa a constante preocupação fundamental de René DESCARTES em seu célebre Discurso do Método (2001), mais especificada em suas menos conhecidas Regras para a Direção do Espírito (1985): a busca por critérios certos, seguros, definidos, claros e distintos que permitissem estabelecer um conhecimento seguro.
} 
A existência e a aplicação de um Método claro e distinto é, por esse motivo, indispensável para construir um conhecimento científico. É o Método o elemento ordenador da inteligência do investigador em direção à obtenção de um resultado dotado de relativa certeza (REALE, 2001, p. 81).

Perceba-se, assim, que a determinação precisa de um método viabiliza o manejo adequado de instrumentos analíticos conceituais que permitem produzir um resultado conclusivo, a ser comunicado (CASELLA, 2009a, p. 173). É impossível determinar a existência de um único método uniforme, qualquer que seja o ramo do conhecimento humano (ALVES, 2003, p. 298-9; CASELLA, 2009a, p. 173-5), quer sejam ciências exatas ou biológicas, quer sejam ciências humanas (REALE, 2001, p. 10 e 82; SANTOS, 1988).

Vige nesse sentido um quadro de pluralismo metodológico (REALE, 2001, p. 84), onde se deve perceber não haver unidade metodológica nem entre os ramos do conhecimento humano (REALE, 2001, p. 10 e 82; SANTOS, 1988), nem mesmo no interior de um único deles (CASELLA, 2009a, p. 174-5; SANTOS, 1988). Nesse sentido, ainda que não lide com categorias como causalidade, a condição de Ciência Humana Aplicada que caracteriza o conhecimento jurídico impede de sua caracterização como nãocientífico: "no quadro de um pluralismo metodológico, o Direito é uma ciência tão legítima como as demais." (REALE, 2001, p. 88) ${ }^{11}$.

A característica de todo conhecimento científico consiste simplesmente em buscar um fundamento seguro e certo para a produção de suas conclusões, o que implica reconhecer que basta estabelecer coerentemente vetores analíticos conceituais fundamentais de uma investigação em cadeia racional para que esta seja reputada com científica (ALVES, 2003, p. 298-9; REALE, 2001, p. 10 e 82).

Todavia, o conhecimento científico existe para ser transmitido e compreendido. Por esse motivo, a metodologia empregada não vale por si mesma ou pela autoridade de quem a constrói, a afirma e a aplica. Com efeito, não se pode ignorar que "poucas questões suscitam tanto interesse e tantos desencontros no meio acadêmico como a questão da metodologia e da pesquisa. Muito se fala a respeito, muitas técnicas e expedientes variados são referidos, mas pouco se aproveita de tudo isso." (CASELLA, 2009a, p. 171).

Precisões terminológicas e premissas metodológicas são de fundamental importância, não apenas por auxiliarem a elaboração do trabalho. Antes, são elas quem viabilizam a

${ }^{11}$ É interessante lembrar Boaventura de Sousa SANTOS (1988), para quem, com o ingresso da Ciência em condição Pós-Moderna, nem mesmo nas ciências exatas seria possível argumentar por uma certeza absoluta fundada na causalidade. 
compreensão do trabalho pelos leitores, na medida em que criam um consenso sobre os campos significativos dos vocábulos empregados. Ademais, trata-se de um ato de humildade e de sinceridade acadêmicas, pois promove a abertura a críticas relevantes e pertinentes por visões distintas sobre exata e precisamente o mesmo objeto de pesquisa (CASELLA, 2008, p. 181).

Em outros termos, a preocupação metodológica não é fim em si mesmo. Ela deve viabilizar o estabelecimento de patamar linguístico e significativo comum com o público de leitores de um trabalho que se pretende científico. Por este mecanismo se assegura que este poderá receber uma certificação adequada pelos pares de seu autor. Por essa razão, o método utilizado em uma Pesquisa deve também ter seus pontos de partida reconhecidos pelos fruidores do trabalho, para que com eles se estabeleça um diálogo compreensível (CASELLA, 2009, p. 171-3).

Não basta haver, assim, a condução metódica de uma investigação para que o resultado produzido seja considerado seguro, fundamental, certo - ou seja, científico. Tão importante quanto definir um método de Pesquisa e o aplicar, deve o investigador se preocupar com a explicitação deste método a seus leitores. Apenas desta maneira se mostrará possível ao público receptor atribuir seu consentimento prévio às linhas gerais de condução da reflexão em torno de determinado objeto que foram estabelecidas pelo Pesquisador. Isso estabelece uma base de legitimidade ao discurso formulado segundo o método determinado.

Por isso, para permitir a adequada compreensão de cada etapa lógica seguida por este trabalho, surge esta Parte Primeira. Esta se destina à precisão metodológica e terminológica deste texto. Enquanto proêmio ${ }^{12}$, visa a convencer com clareza e distinção seus interlocutores do caráter certo e seguro de seu método inovador - e, portanto, do conhecimento jurídico produzido a partir dele.

Ao dizer isso, acredito perceber no rosto do leitor, diante de tão pretensiosas e imodestas afirmações, um semblante que mistura desprezo e contrariedade; e no entanto elas são incomparavelmente mais modestas do que as de qualquer autor do programa mais usual [...]. (KANT, 2012, p. 20).

\footnotetext{
12 Já sinalizava PLATÃO (1980, p. 135), no Livro IV de suas Leis, para a importância democrática da aposição de preâmbulos suficientemente claros e persuasivos para assegurar o respeito a norma jurídica nova por parte de seus destinatários. O respeito derivaria do consentimento, em substituição à obrigação de obediência pela força da autoridade. Toda preocupação com precisões metodológicas e terminológicas, como esta, opera em certa medida como um proêmio.
} 
O caráter inovador do método de Pesquisa determinado do trabalho não deriva de qualquer inadvertida pretensão de genialidade própria a este texto ou a ele subjacente. Antes, decorre da singular e inafastável condição de que inexiste um único método. Cada nova Pesquisa iniciada exige o estabelecimento de uma nova forma de abordagem do objeto de estudo, de tal modo que "em toda pesquisa [...] somente cada um pode determinar como construir e como fazer avançar." (CASELLA, 2009a, p. 175).

Cada autor e cada processo investigativo requer o estabelecimento criativo de sua própria linguagem para que sejam entendidos pela comunidade epistêmica receptora. Toda atividade efetivamente acadêmica pressupõe e estabelece uma proposta de inovação metodológica $^{13}$ a ser coerentemente estabelecida e aplicada por seu executor. Esta inovação deve ao mesmo tempo se esforçar para ser devidamente compreendida por seu receptor (CASELLA, 2009a, p. 175).

\begin{abstract}
O domínio do trabalho científico não tem por base conexões "objetivas" entre as "coisas", mas as conexões conceituais entre os problemas. Só quando se estuda um novo problema com o auxílio de um método novo e se descobrem verdades que abrem novas e importantes perspectivas é que nasce uma nova "ciência". (WEBER, 2006, p. 37, grifos do autor).
\end{abstract}

O Método estipulado para ser utilizado é individual, o que não significa que se trata de algo pessoal. É, antes, elemento de fundação discursiva individuado, porquanto é instrumental escolhido para o estudo de tema especificamente delimitado no tempo e no espaço.

A escolha desse instrumental é certamente influenciada por convicções e referenciais sobre os arredores, sobre os outros homens e sobre si mesmo que acompanham o fazer humano (CASELLA, 2009a, p. 316; WEBER, 2006, p. 43). Busca-se eleger pontos de partida os mais objetivos possíveis, mas não se deve ignorar que "elementos mais íntimos da 'personalidade', os juízos de valor mais elevados e finais que determinam nossa ação e dão sentido e importância à nossa vida, são percebidos por nós como algo 'objetivamente' valioso.” (WEBER, 2006, p. 18).

A sinceridade e a honestidade intelectuais exigem que se fixe "sua crença fundamental, a decisiva, a que leva, e vivifica todas as demais." (CASELLA, 2009a, p.

\footnotetext{
${ }^{13}$ Ainda que simplesmente trabalhe sobre um determinado objeto de estudo tradicionalmente abordado pelo conhecimento científico vigente em dada condição espacial e temporal. É precisamente essa presença de uma nova perspectiva segundo a qual se aproxima de um objeto de estudo que assegura a originalidade das investigações e a ampliação do campo do conhecimento científico tradicional (HUSSERL, 2006, p. 85 e passim; WEBER, 2006, p. 37). Afinal, "para que se progrida, é preciso estar no presente, mas, sem deixar de ter consciência do que passou, ao mesmo tempo, em que se contemple o futuro.” (CASELLA, 2009a, p. 315).
} 
317). Apenas deste modo o interlocutor saberá com precisão o ponto a partir do qual se discursa. Trata-se "sem dúvida [de] uma das tarefas mais essenciais de qualquer ciência da vida cultural humana[, pois] abr[e] à compreensão intelectual essas 'idéias' pelas quais real e supostamente se lutou e se luta." (WEBER, 2006, p. 16).

São assim pontos de partida de ordem subjetiva que estabelecem os termos segundo os quais será constituída a objetividade do conhecimento na ciência. Ainda que não haja concordância universal com relação a cada um deles, não podem ser contestados se se verificar sua aptidão para constituir um fundamento sólido e rigoroso do conhecimento.

Se “carência de convicções e 'objetividade' científica não tem nenhuma afinidade interna" (WEBER, 2006, p. 25, grifos do autor), a escolha, seguida da explicitação, dos critérios orientadores do método de Pesquisa, precisamente por não afetar, macular ou contaminar um suposto caráter sagrado de uma pretensa "objetividade" não pode ser contestada no plano científico com base em divergência de concepções de mundo ${ }^{14}$.

Há que se lembrar de que o embate eclipsado entre concepções de mundo, "tão sagrad[a]s para outros quanto [a]s noss[a]s são para nós" (WEBER, 2006, p. 21) marca não apenas as Ciências Humanas como um todo, mas também a especificidade do conhecimento jurídico.

Com efeito, não apenas o Direito detém uma origem "profana"15, vale dizer, é resultante de uma política entre interesses e ideologias conflitantes de uma sociedade real (UNGER, s.d., p. 10). A própria compreensão deste fenômeno é ela própria parcial, profana, objeto de lutas e disputas entre formas de habitar e de experienciar o mundo. A arena de batalhas infindáveis entre concepções de mundo não reside apenas na formação do Direito, mas também reside subliminarmente ao próprio processo de construção e de disseminação do conhecimento jurídico ${ }^{16}$.

\footnotetext{
${ }^{14} \mathrm{Ou}$ ainda, trata-se antes de ser, não só "inofensivo para o interesse puramente científico[, mas também] diretamente útil e até devido" (WEBER, 2006, p. 24). Por isso, as linhas a seguir vão explicitar os pontos de partida deste trabalho.

${ }^{15}$ A qualificação é dada por Roberto Mangabeira UNGER (s.d., p. 10), a ser utilizada somente enquanto for o pensamento deste autor a referência para sustentar nossa argumentação.

${ }^{16}$ É importante guardar para este trabalho a noção de que o Direito é fruto de embate entre diferentes concepções de mundo e de o habitar, sendo produzido em uma arena de batalhas infindáveis. Isso restará ainda mais claro quando da leitura do Terceiro e do Sétimo Capítulos, bem como das Conclusões Parciais da Parte Segunda.

De todo modo, sugerimos a leitura de nosso Problemas sobre a Pesquisa em Direito no Brasil: Uma Perspectiva (2010), trabalho apresentado no XIX Congresso Nacional do Conselho Nacional de Pesquisa em Direito (CONPEDI), onde se apontaram traços deficientes da opção po uma excessiva econometrização da produção do conhecimento jurídico brasileiro. A arena de batalhas infindáveis na Academia jurídica brasileira teria quase selecionado uma perspectiva econômica para ocupdar um lugar privilegiado na produção do Saber em Direito.
} 
A condição permanente do Direito e da produção do conhecimento jurídico é a de ser objeto de luta política subjacente, em que se escolhem critérios, seja para formar o arcabouço jurídico, seja para constituir conhecimento científico sobre tal estrutura (UNGER, s.d., p. 7 e 10-1). Uma vez explicitados com sinceridade os princípios constitutivos da investigação científica sobre o Direito, entreabre-se um campo específico de discussão das conclusões produzidas: a Ciência.

Deste modo, não se contestam os fundamentos em virtude de desacordo com relação a concepções de mundo, mas apenas e tão somente com base em preocupação de caráter científico: as premissas de leitura foram solidamente instituídas? Estão elas aptas a formar rigorosamente um conhecimento seguro e certo (científico)? As premissas foram coerentemente aplicadas para a formação da conclusão? Esta fora produzida de acordo com as bases metodológicas estipuladas?

A explicitação dos vetores fundantes escolhidos deve ser estimulada e elogiada ${ }^{17} \mathrm{e}$ sua aplicação rigorosa verificada. Porém, sob uma perspectiva científica estrita, não se pode criticar a mera eleição de um ideal - em detrimento de outro - com base em critérios outros que não a preocupação científica.

\begin{abstract}
A "linha do meio" não é nem minimamente mais verdade científica do que os ideais partidários da direita e da esquerda. Em lugar algum o interesse da ciência está menos protegido do que naquele em que não se quer enxergar fatos desconfortáveis e as realidades da vida. (WEBER, 2006, p. 22, grifos do autor).
\end{abstract}

Sublinhe-se que não pode haver, assim, discussão sobre a conveniência ou sobre a predileção por um ou outro fundamento da reflexão científica (escolha por determinado autor, por determinada linha teórica, por determinada matriz filosófica, por rejeiçã de determinado perfil de explicações, ...). Esse questionamento sobre tais fundamentos não é, ele mesmo, científico, pois opera no interior do plano da crença (WEBER, 2006, p. 16 e 18-9), devendo ser excluído de um debate acadêmico sério. Todavia, isso também não exime o autor da tarefa de construir bases consensuais para a fundamentação do raciocínio. É fundamental que ele procure estabelecer o consenso

\footnotetext{
${ }^{17}$ Nesse sentido, destaca Max WEBER (2006, p. 24, grifos do autor) que se trata de uma obrigação "em cada momento trazer claramente à consciência do leitor e à própria quais os critérios segundo os quais a realidade é medida e o juízo de valor é derivado, em vez de fazer o costumeiro, ao introduzir uma mescla imprecisa de valores de toda espécie que mascaram os conflitos entre os ideais e levam a buscar oferecer 'a cada um o seu"'. O que se pretende fazer aqui é precisamente tomar uma posição determinada, de maneira clara e precisa, e apresentar de maneira distinta os critérios de análise do objeto a ser lido, que serão a base das conclusões deste trabalho.
} 
científico em torno do método escolhido, comprovando sua coerência e sua certeza perante seu auditório de leitores.

É estritamente no plano da preocupação científica com a construção de um conhecimento rigoroso que se devem desenvolver as críticas a toda e qualquer atividade acadêmica. Explicitadas as premissas metodológicas e feitas as precisões terminológicas apesar de poderem ser criticadas para além do texto de registro da pesquisa, para que haja a adequada compreensão de determinado estudo, devem ser entendidas no con-texto significativo apresentado pelo autor.

Compreender desta maneira possibilita acompanhar o desenvolvimento do raciocínio, nos exatos termos propostos. Com isso, devem ser deixadas de lado eventuais tentações de questionamento dos pontos de partida por discordância com relação às concepções de mundo que fundam todo e qualquer trabalho. Contestações científicas apenas devem considerar o reduzido plano do sincero embate e do cordial contraditório acadêmico. Com efeito, em uma séria atividade científica,

\begin{abstract}
ninguém [...] está protegido contra a mais dura crítica de caráter objetivo e científico. Quem não suporta isso, ou quem não está disposto a colaborar a serviço do conhecimento científico com pessoas que sustentam ideais diferentes dos seus, deve afastar-se dela. (WEBER, 2006, p. 26, grifos nossos).
\end{abstract}

Por isso, antes mesmo de iniciar a direta exposição detalhada de cada uma das informações extraídas do objeto de conhecimento selecionado para este estudo ${ }^{18}$, preocupou-se com o esclarecimento dos pontos de partida da presente investigação. Isso permitirá a sedimentação do solo sobre o qual o pensamento conjuntamente se deslocará. Haverá com esta Parte Primeira a organização do repertório linguístico comum que tornará viável a necessária empatia entre autor, obra e leitores, que "estabeleça a comunicação, o diálogo e a transmissão do conhecimento." (CASELLA, 2009a, p. 173, grifos do autor).

Há que se apreender a função comunicativa exercida por esta Parte Primeira. Seu objetivo consiste em assegurar que esta abordagem original de um objeto de estudo tradicionalmente investigado seja recebida com as indispensáveis civilidade, cordialidade e abertura acadêmicas, ainda que constitua uma proposta alternativa de análise daquele mesmo objeto. Disto deriva a importância de definir o sentido e o alcance de determinados termos empregados por este texto.

${ }^{18}$ O que é realizado na Parte Segunda deste trabalho. 
Termos de uso corrente e sentidos variados são propícios a ensejar desentendimentos, mesmo prevalecendo a boa-fé dos participantes do debate. Caracterizar o sentido, no qual serão empregados os termos, pode facilitar a comunicação de sentidos, e evitar controvérsias formais. (CASELLA, 2008, p. 226).

Toda atividade humana que pretende fomentar mútua compreensão "pressupõe que se possa captar o que os outros exprimem e que possamos nos fazer compreender pelos demais" (CASELLA, 2009a, p. 159), ainda que não haja concordância imediata com relação a todos os pontos. É por esse motivo que esta Parte Primeira se dedica à explicitação das perspectivas e dos mecanismos de condução do pensamento, a fim de que sejam compreendidos por seus leitores no interior da precisa racionalidade que é própria a este trabalho.

Essa camada de linguagem compartilhada poderá instaurar intersubjetivamente um diálogo acertado por meio de vocabulário comum, tornando desnecessárias digressões posteriores que visem a problematizar o campo significativo estabelecido e seguido. Mais simplesmente, a existência desta Parte com relação a este trabalho se justifica por ela se mostrar necessária "para se fazer compreender" (CASELLA, 2009a, p. 160) a partir do estabelecimento de conjuntos de referenciais comuns que permitirão estabelecer a comunicação.

\footnotetext{
Precisões terminológicas e valorativas servem para encurtar o caminho para as possíveis digressões externas ao trabalho, que somente poderiam ensejar discussões estranhas ao objeto deste. Não se colocam como fins em si mesmas, mas como indicadores de bases conceituais e operacionais aqui adotadas [...]. Servem para mapear o terreno, e esse mapeamento pode ser vital, em relação a conceitos de uso corrente, porém não unívocos. (CASELLA, 2008, p. 181).
}

De caráter metodológico, a primeira virada lógica apresentada por este trabalho servirá para ilustrar o percurso a ser seguido até a produção da Conclusão. Ela existe para dissipar dúvidas sobre o algo que será dito e principalmente para afastar obscuridades e estéreis incompreensões vazias sobre como aquele algo será dito. Ao indicar o caminho a ser trilhado, visa a treinar o leitor para compreender as "legendas" que o acompanharão neste deslocamento reflexivo. Prepara-o para a leitura do caminho: "baliza os rumos do que se pode e se deve esperar, a partir de tais premissas” (CASELLA, 2008, p. 181).

Nada mais se pretende do que garantir a tranquilidade da tradição do conhecimento jurídico. Sem almejar "reinventar a roda", este trabalho simplesmente visa ao avanço do conhecimento jurídico-científico sobre determinado objeto de estudo a partir de outros pontos de partida. Para a construção do novo, certamente há sucessão histórica 


\title{
direta de conceitos e pensamentos de outros autores. Mas tais empréstimos jamais ocorrem sem uma inserção destes em nova teia de significações que transforma seus sentidos.
}

Busca-se com esta Parte Primeira apontar que os novos pontos de partida devem ser compreendidos como fundamentos investigativos igualmente seguros, isto é, como aptos a produzir conhecimento novo sem ignorar a tradição, apesar de não a endossar automaticamente. Trata-se do típico desafio a todo e qualquer trabalho acadêmico de originalidade consciente (CASELLA, 2009a, p. 176), duplo aspecto exigido ainda mais fortemente de toda e qualquer Tese de Doutorado.

\begin{abstract}
[T] emos diante de nós, todo um mundo a descobrir. Qualquer viajante ou turista que vai percorrer terras desconhecidas, procura um guia que lhe diga onde poderá tomar um trem, um navio, um avião; onde terá um hotel para pernoitar, museus, bibliotecas e curiosidades que de preferência deva conhecer. (REALE, 2001, p. 10).
\end{abstract}

Deste modo, esta Parte Primeira estabelecerá de maneira clara e distinta a comunhão de linguagem necessária para a compreensão adequada dos percursos analíticos sugeridos por este "guia da leitura alternativa" do processo histórico de construção da CECA.

Nestes caminhos não será vista coisa alguma nova: a paisagem será marcada por elementos históricos e jurídico-positivos em geral já conhecidos em torno da CECA. Como se poderá perceber, o principal diferencial residirá na escolha de caminhos alternativos para desbravar este objeto, de maneira a reorganizar em termos significativos distintos isto é, conforme diferentes critérios de interpretação - a maior parte das informações já conhecidas $^{19}$. Ao lado destas, surgirá pontualmente um ou outro elemento novo, dado por

\footnotetext{
${ }^{19}$ Há que se notar que este procedimento de reorganização interpretativa de conhecimentos jurídico-teóricos e jurídico-históricos detidos pelo leitor/ouvinte não é novidade nos estudos jurídicos brasileiro e estrangeiro.

Nesse sentido, mencione-se a título exemplificativo no pensamento jurídico nacional a dinâmica reflexiva e a metodologia aplicadas por José Eduardo FARIA em suas aulas da Pós-Graduação na Faculdade de Direito da Universidade de São Paulo - Largo São Francisco (FADUSP), na disciplina Metodologia do Ensino Jurídico ministrada no Segundo Semestre de 2009, à luz de contribuições teóricas desenvolvidas em sua obra O Direito na Economia Globalizada (1999).

Entre autores estrangeiros, no que se refere especificamente ao estudo histórico da construção da Europa Unida, a mesma advertência foi dada por Philip BOBBITT em recente curso ministrado no Robert Schuman Centre for Advanced Studies (RSCAS) do European University Institute (EUI), em Florença, no Segundo Semestre de 2011, sobre The Idea of War on Terror, oportunidade em que efetuou um paralelo entre a História da União Europeia e a sucessão de formas de Estado em sua obra The Shield of Achilles (2003).

Essa característica de reorganização reinterpretativa de informações históricas ao lado de campos teóricos significativos alternativos é típica de todo conhecimento histórico que busca propor novos campos de significação de fenômenos estudados. A ressignificação é estabelecida por chave hermenêutica distinta,
} 
fonte primária nova, encontrada precisamente por se ter seguido uma rota alternativa de leitura.

Uma vez equalizadas a linguagem e sua utilização perante a comunidade epistêmica, espera-se restarem esclarecidas as vias analíticas propostas pelo guia hermenêutico oferecido por este trabalho. Este aparelhamento da linguagem comungada poderá tornar esta leitura, como toda e qualquer viagem previamente planejada de maneira certa e segura, a mais agradável e útil ao leitor atento e sem medo (CASELLA, 2008, p. 271, 2009a, p. 14 e 161).

estabelecida de maneira clara por aquele que narra a História. Trata-se de fazer com que a Teoria interprete a conjuntura passada ou presente.

No caso de FARIA (2009), o autor pretende apontar para a sucessão de modelos de sistema legal no tempo, em virtude da inserção do Direito em uma Economia Globalizada; no caso de BOBBITT (2011), este busca identificar a construção da Europa Unida com a afirmação de um Estado-mercado Europeu - tese que propõe uma leitura econômica da construção da União Europeia, a qual escapa ao arco de questões postas para este trabalho (interpretação jurídico-política alternativa do princípio da Europa Unida), conforme ressaltado na Introdução Geral, supra.

Trata-se de um teatro de disputas infindáveis em torno de formas de leitura que é típico e inafastável dos estudos em História - bastando mencionar exemplificativamente POLÍBIO (POLYBE, 2003) e Nicolau MAQUIAVEL (2008) - da qual a História do Direito não pode se esquivar. Essa condição de arena de irresolvíveis batalhas significativas será mais bem compreendida adiante, nos três primeiros Capítulos da Parte Segunda, infra, onde se debruça especificamente sobre a questão da construção histórica da CECA. 


\title{
PRIMEIRO CAPÍTULO - DELIMITAÇÃO ESPÁCIO-TEMPORAL: A CECA COMO EXPERIÊNCIA SINGULAR NO PÓS-SEGUNDA GUERRA MUNDIAL
}

\begin{abstract}
A razão humana tem o peculiar destino, em um dos gêneros de seus conhecimentos, de ser atormentada por perguntas que não pode recusar, posto que lhe são dadas pelas natureza própria da razão, mas que também não pode responder, posto ultrapassarem todas as faculdades da razão humana.

Ela não tem culpa por cair nesse embaraço. Ela começa por princípios cujo uso, inevitável no curso da experiência, é também suficientemente confirmado por esta. Com eles, ela sobe então (como também é próprio de sua natureza), cada vez mais alto, a condições mais longínquas. Como, no entanto, ela se torna consciente de que desse modo, visto que as perguntas nunca cessam, seu trabalho teria de permanecer inacabado, ela se vê então forçada a buscar refúgio em princípios que ultrapassam todo uso possível da experiência e, ao mesmo tempo, parecem tão insuspeitos que mesmo a razão humana comum está de acordo com eles. Com isso, porém, ela se lança na escuridão e em contradições que pode até dirimir, supondo que alguns erros estejam ocultos em seu fundamento, mas não consegue descobrilos porque os princípios de que se serve, na medida em que extrapolam todos os limites da experiência, já não reconhecem nesta qualquer pedra de toque. (KANT, 2012, p. 17).
\end{abstract}

A preocupação em estudar a construção histórica da CECA no interior de uma Pesquisa em Direito se baseia na singular condição de que o fenômeno jurídico deve ser percebido como um dado da vida em sociedade (CASELLA, 2009a, p. 67). Isso implica reconhecer que um estudo em Direito não pode esquecer como a institucionalização jurídica das relações entre determinados povos europeus no pós-Segunda Guerra Mundial surgiu para cumprir objetivos singulares por meios novos.

Trata-se esta de típica preocupação afinada a uma dimensão humana do estudo do fenômeno jurídico - a qual deve ser ignorada pelos estudos em Direito, a fim de que se compreenda "quem o faz e para que o faz" (CASELLA, 2009a, p. 67) - ou seja, para que sejam apreensíveis as origens humanas às quais respondeu a criação desta instituição.

Os objetos a serem analisados por este trabalho são a História da CECA e o texto jurídico-normativo positivo do Tratado de Paris, de 1951 - o Tratado que instituiu juridicamente a CECA. Este Tratado Internacional foi assinado entre Bélgica, França, Itália, Luxemburgo, Países Baixos e República Federal da Alemanha em 18.4.1951. Seu regime jurídico entrou em vigor em 23.7.1952, tendo permanecido em vigência por exatos cinquenta anos (conforme determinado por seu artigo 97), atingindo seu termo final em 23.7.2002 21 . E, é importante indicar neste Capítulo as razões pelas quais se delimitou

20 À medida que novos Estados-Membros ingressaram na CECA, seu texto fundamental foi progressivamente alterado: em 1973, Dinamarca, Irlanda e Reino Unido; em 1981, a Grécia; em 1986, Espanha e Portugal; e, em 1995, Áustria, Finlândia e Suécia. Posteriormente, quando não mais estava em vigor o Tratado da CECA, integraram as Comunidades Europeias, em 2004, República Checa, Chipre, Eslováquia, Eslovênia, Estônia, 
temporal, espacial e tematicamente a investigação da presente Tese a esta experiência jurídica Internacional isolada.

Como em todo trabalho de caráter científico, operou-se uma escolha com a determinação deste ponto de partida escolhido. E a eleição desta Organização Internacional em particular implicou certamente também série de renúncias. Por isso, fundamental se mostra aqui delimitar não apenas o enquadramento teórico e conceitual segundo o qual o fenômeno será analisado, nem mesmo somente o situar temporal e espacialmente, mas também explicitar as origens temáticas de tal seleção.

\begin{abstract}
Oferecemos [...] ao agente a possibilidade de ponderar as consequiências esperadas contra as não esperadas do seu agir e assim a resposta à pergunta: qual é o "custo" de atingir-se o fim esperado, do previsível dano a outros valores? Posto que na grande maioria das vezes todo fim almejado "custa" algo nesse sentido ou ao menos pode custar, nenhum ser humano que aja de modo responsável pode furtar-se à ponderação do fim e das consequiências da ação [...]. [L]evar essa ponderação à decisão certamente não é uma tarefa possível da ciência, mas do homem dotado de vontade: ele sopesa e escolhe entre os valores envolvidos conforme sua consciência e sua concepção de mundo. A ciência pode ajudá-lo a tornar-se consciente de que todo agir, e naturalmente também o nãoagir, significa nas suas conseqüências assumir posição em favor de determinados valores e, assim, regularmente contra outros - o que hoje tanto se aprecia ignorar. A ele cabe a escolha. (WEBER, 2006, p. 16, grifos do autor).
\end{abstract}

Esse breve esclarecimento inicial do percurso de escolha deste objeto específico permitirá compreender as razões pelas quais se optou pela análise da História da construção CECA a partir das fontes primárias e secundárias pesquisadas (Quarto, Quinto e Sexto Capítulos), seguida pela interpretação minuciosa das instituições componentes daquela Organização Internacional (Sétimo Capítulo).

Ressalte-se que se está consciente quanto às consequências da escolha metodológica efetuada. A eleição de se dedicar exclusivamente à compreensão do processo histórico de construção da CECA e à análise detalhada de seu corpo institucional jurídico-

Hungria, Letônia, Lituânia, Malta e Polônia e, em 2007, Bulgária e Romênia. Em 1.7.2013, a Croácia ingressou na União Europeia, conforme o artigo $3^{\circ}$ de seu Tratado de Adesão à UE, assinado em 9.12.2011, e publicado no Jornal Oficial da União Europeia em 24.4.2012.

De todo modo, como será especificado mais adiante, no Segundo e no Sétimo Capítulos, ambos infra, o instrumento normativo a ser detalhadamente analisado será apenas e tão-somente o Tratado que Institui a CECA, em sua versão original, em francês, antes de qualquer alteração, ou ainda, da maneira como fora publicado quando de sua assinatura.

${ }^{21}$ Não se pode deixar de mencionar que, após o fim da vigência do Tratado da CECA, entrou em vigor em 1.2.2003, o Tratado de Nice (o Tratado que Instituiu a Comunidade Europeia, assinado em 26.2.2001), de duração ilimitada, conforme os termos de seu artigo $11^{\circ}$, havendo a transferência de todos os ativos da CECA à Comunidade Europeia, nos termos do respectivo Protocolo relativo às Conseqüências Financeiras do termo de vigência do Tratado CECA e ao Fundo de Investigação do Carvão e do Aço. Uma explicação mais detalhada e mais bem organizada sobre as sucessões entre os Tratados será feita mais adiante, razão pela qual se evita efetuar maiores precisões sobre o tema nesta rápida nota de rodapé. 
normativo fundamental implica o necessário do interior do campo investigativo de outras experiências históricas propostas - adotadas ou rejeitadas - durante o mesmo período na Europa $^{22}$.

Nestes termos, haveria que se indicar de maneira precisa os motivos que justificaram a seleção da CECA como objeto de estudo por excelência deste trabalho em detrimento das demais formas de aproximação de países europeus durante os primeiros anos subsequentes à Segunda Guerra Mundial. Qual seria, a final, a especificidade da CECA? O que a destacaria como especial com relação às demais, autorizando a desconsideração destas em prol daquela?

\subsection{Demarcações de Caráter Temporal do Objeto de Estudo}

J'étais loin de soupçonner l'ampleur et la complexité de la matière lorsque j'entrepris cet ouvrage. Je suis allé de découverte en découverte, et mon espoir est que le lecteur participe au plaisir que j'y ai pris. (ROUGEMONT, 1961, p. 8).

Antes de tudo, a escolha pelo estudo desta Organização Internacional específica se justifica em virtude da pergunta proposta e do objetivo buscado com a análise histórica iniciada por esta Tese de Doutorado. Relembrando em termos mais gerais a dúvida suscitada ao início do trabalho, busca-se compreender como, quando e graças a quais instituições determinados países europeus no pós-Segunda Guerra Mundial conseguiram estabelecer, de maneira inédita e inesperada, um novo modo de relações entre si, que tornou impossível e impensável a deflagração de nova Guerra regional na Europa - o que constitui um fato sem precedentes em sua História.

Em uma análise inicial, haveria que se perceber a primeira delimitação do fenômeno a ser estudado neste trabalho opera no registro da ordem temporal. Nesse sentido, frise-se a pretensão radicalmente modesta deste estudo: trata-se de buscar retraçar

${ }^{22}$ Como se poderá ver mais adiante, tais experiências não analisadas minuciosamente por este trabalho são precisamente o Pacto de Bruxelas, a OECE, o CdE, a CED e a CPE. No entanto, o fato de tais Organizações Internacionais não serem o objeto de investigação deste trabalho não significa que elas não serão mencionadas durante a narrativa histórica do processo de construção da CECA.

Com efeito, não se pode ignorar que a adoção de tais Organizações Internacionais ocorre de maneira paralela à instituição da CECA no pós-Segunda Guerra Mundial. Por isso, será fundamental em determinados momentos mencionar tais opções institucionais distintas da CECA - sob pena de indevido ocultamento de fatos históricos igualmente relacionados, os quais foram determinantes para a instituição da CECA.

Contudo, frise-se que, em virtude da exclusão operada por força desta opção metodológica, a menção a essas outras experiências será efetuada na medida estritamente necessária para auxiliar na compreensão do processo de construção histórica da CECA. Essa sistemática de abordagem histórica não é incomum nos estudos de História, o que será mais facilmente compreendido a partir da leitura do conteúdo da Introfução Parcial da Parte Segunda, e dos Quarto, Quinto e Sexto Capítulos desta Tese, todos infra. 
de maneira exclusiva e mais profunda a história da construção de uma aproximação de qualidade distinta entre determinados Estados europeus nos anos subsequentes ao término da Segunda Guerra Mundial.

O primeiro movimento analítico da Pesquisa relacionada a este trabalho se dirigiu no sentido de mapear e captar o surgimento da primeira forma de organização qualitativamente distinta das relações entre alguns países europeus no pós-Segunda Guerra Mundial dentro do prazo aleatoriamente estipulado de dez anos.

Perceba-se que o primeiro movimento reflexivo anterior a este trabalho visou assim a penetrar na História Contemporânea da Europa a partir de 8 de Maio de 1945 e, em um corte temporal de até dez anos após esta precisa data (8 de Maio de 1954), identificar qual foi a primeira forma detentora de um caráter distinto de organização das relações entre alguns dos Estados europeus.

A partir do reconhecimento desta nova maneira de organização - identificada poteriormente na CECA, este movimento de busca histórica foi contido para avaliar de maneira exclusiva e verticalizante os principais atributos jurídico-institucionais de Direito Internacional desta Organização. Isso permitiria eliminar mal-entendidos em torno das explicações históricas sobre o princípio da construção daquilo que hoje se denomina $\mathrm{UE}^{23}$.

É importante salientar desde já que a questão da terminologia destinada a designar a União Europeia é apenas compreensível adequadamente no tempo, a partir da consideração conjunta da sucessão dos Tratados que progressivamente ampliaram este processo de integração por diferentes instrumentos e conceitos jurídicos que conferiram personalidade jurídica $^{24}$ a distintas Organizações Internacionais.

${ }^{23}$ Bastando lembrar que é a UE de hoje, como eram as Comunidades Europeias, mera "extrapolação da CECA" (CASELLA, 1994a, p. 77) - ainda que o autor citado faça referência estritamente "aos intercâmbios comerciais, [à] estrutura das instituições e [a]o instrumental jurídico”. A CECA é precisamente vista hoje como o início daquilo que se denomina hoje integração europeia (BASSO, 1998a, p. 81, 1998b, p. 34; DEHOUSSE, 2011, p. 3).

Há uma indubitável linha de continuidade entre a Organização Internacional de 1951 examinada com exclusividade por este trabalho e as subsequentes Organizações Internacionais - Comunidade Europeia de Energia Atômica (CEEA) e Comunidade Econômica Europeia (CEE), bem como entre estas e a progressiva reunião das três naquilo que hoje se denomina União Europeia.

É por essa razão que se mostra possível reconstituir o conhecimento sobre o início da História da UE pelo reenvio do exame científico ao estudo de sua Organização Internacional originária, a CECA. Uma adequada compreensão da construção histórica desta permitirá dissipar dúvidas com relação ao movimento inicial de orientação jurídico-institucional daquele processo de integração, ainda que ele tenha sido modificado no tempo até os presentes dias. O estabelecimento desta medida comparativa histórica ficará mais claro quando da leitura da Introdução Parcial da Parte Segunda, do início do Capítulo Quarto, das Conclusões Parciais da Parte Segunda e da Conclusão Geral deste trabalho, todos infra.

${ }^{24} \mathrm{E}$ que, como poderá ser visto adiante, teriam também conferido no tempo distintas formas de natureza jurídica a tal processo de integração. Uma discussão pormenorizada sobre problemas relacionados à natureza jurídica da CECA será feita no item 3.3.2., infra. 
Três Organizações Internacionais dotadas de personalidades jurídicas distintas foram instituídas durante a década de 1950 na Europa: (i) a Comunidade Europeia do Carvão e do Aço (CECA), por meio do Tratado de Paris de 1951; (ii) a Comunidade Europeia de Energia Atômica (CEEA), por meio do Tratado de Roma de 1957; e (iii) a Comunidade Econômica Europeia (CEE), por outro Tratado de Roma, também de $1957^{25}$.

Tratavam-se no início de três distintas Comunidades Europeias. Cada uma delas era dotada de personalidade jurídica própria, o que justificava o uso da expressão no plural para as designar. Segundo Paul REUTER (1965, p. 176), a decisão tomada em 1957 de manter separadas as personalidades jurídicas das três Comunidades visava a lhes dar "plus de souplesse et [...] diviser le risques".

Após a instituição destas três Organizações Internacionais, houve duas tentativas históricas buscando facilitar a nomeação de todas elas a partir de uma única expressão linguística que designasse de uma vez o conjunto.

A primeira consistiu na instituição de um Conselho Único e de uma Comissão Única às três Comunidades Europeias por meio do Tratado de Bruxelas de $1965^{26}$, que visava à unidade europeia e à unificação das três Comunidades por intermédio de instituições comunitárias comuns. A segunda consistiu na sugestão dada por Resolução do Parlamento Europeu de 16.2.1978 (PARLEMENT EUROPÉEN, 1978, p. 36), segundo a qual se afirmara a preferência pelo uso da expressão no singular "Comunidade Europeia" pelos documentos oficiais, pelas outras instituições da Comunidade, pelos EstadosMembros, pelos grupos sócio-profissionais e pelos meios de comunicação.

A despeito dessas iniciativas, há que se perceber que elas não alteraram a condição de co-presença de três Organizações Internacionais juridicamente distintas. Por esse motivo, apesar do possível uso do termo no singular, o rigor jurídico exigia ainda a perpetuidade do uso da expressão no plural ${ }^{27}$.

${ }^{25}$ O Tratado da CECA, assinado em 18.4.1951, entrou em vigor em 23.7.1952, e manteve-se em vigência por exatos 50 (cinquenta) anos, vale dizer, até 23.7.2002. Os Tratados da CEEA e da CEE, assinados ambos em 25.3.1957, entraram em vigor igualmente em 1.1.1958, detendo vigência ilimitada.

${ }^{26}$ Também conhecido como Tratado de Fusão, foi assinado em 8.4.1965 e entrou em vigor em 1.1.1967.

${ }^{27}$ Não se menciona aqui o Ato Único Europeu (AUE), documento assinado em Luxemburgo, em 17.2.1986, e em Haia, em 28.2.1986, e que entrou em vigor em 1.7.1987. Ele foi revogado pelo artigo $50^{\circ}$ do Tratado de Amsterdam, de 1997.

"La signature à Luxembourg de l'Acte unique par les Douze se fait en deux étapes. Les ministres des Affaires étrangères d'Allemagne, de Belgique, d'Espagne, de France, du Luxembourg, d'Irlande, de Grande-Bretagne, des Pays-Bas et du Portugal signèrent le 17 février 1986. Le gouvernement danois, qui avait dû organiser un référendum pour passer outre à la résistance de son Parlement, ne peut signer que le 28 février, suivi par l'Italie et la Grèce qui, insatisfaites du Traité pour des raisons opposées, ont voulu attendre un éventuel refus danois. Les ratifications ne posent pas de problème, sauf en Irlande où un référendum 
Apenas com a instituição da União Europeia por meio do Tratado de Maastricht em $1992^{28}$ é que a expressão "União Europeia" poderia designar de maneira substitutiva nos documentos oficiais o conjunto das Comunidades, pois a União se fundava nas Comunidades Europeias (artigo A, parágrafo terceiro, do referido Tratado). Todavia, a personalidade jurídica ainda não era atribuída de maneira distinta à União Europeia, pois ela permaneceria residindo em cada uma das três Comunidades.

Ainda que tenha havido ainda uma vez a denotação da preferência pelo uso de uma expressão única e no singular - "União Europeia", e por mais que tenha havido a instituição de quadro institucional único (artigo $\mathrm{C}$ do mesmo Tratado de Maastricht), o refinamento jurídico exigia a necessidade de se frisar esta diferença entre o uso nos documentos oficiais e a precisão na denominação da entidade jurídica a que se referia (isto é, a exatidão na designação do ente revestido de personalidade jurídica) ${ }^{29}$.

É por meio do Tratado de Lisboa, de $2007^{30}$, que se estabelece a "União Europeia" como um ente dotado de personalidade jurídica própria que se substitui àquelas das distintas Comunidades ${ }^{31}$. A partir deste momento seria admissível no âmbito do discurso jurídico afirmar - com exatidão e rigor - existir uma União Europeia enquanto entidade dotada de personalidade jurídica própria, distinta e definitivamente substitutiva, para além de singelas recomendações estilísticas ou conveniências discursivas. Não mais haveria uma

s'avère nécessaire. Le résultat est très favorable, mais l'entrée en vigueur de l'Acte unique, prévue pour le $1^{\text {er }}$ janvier 1987, s'en trouve retardée au $1^{\text {er }}$ juillet." (GERBET, 2009a, p. 19).

Apesar de sua importância institucional para as Comunidades - na medida em que efetuou reformas institucionais para a entrada da Espanha e de Portugal e por ter visado a acelerar o processo de instauração do Mercado Único, não apresentou modificações no que se refere à designação das Comunidades Europeias.

${ }^{28}$ Também conhecido como Tratado sobre a União Europeia, foi assinado em 7.2.1992, e entrou em vigor em 1.11.1993.

${ }^{29}$ Perceba-se que não são mencionados aqui o Tratado de Amsterdam, assinado em 2.10.1997, e que entrou em vigor em 1.5.1999, e o Tratado de Nice, assinado em 26.2.2001, e que entrou em vigor em 1.2.2003, o qual institui a Comunidade Europeia. A despeito de ambos serem relevantes para as Comunidades - por se tratarem de iniciativas de reforma institucional voltadas à preparação da União europeia para a adesão de novos países-membros, de maneira a tornar seu funcionamento mais eficaz, não se referiram de modo relevante à modificação do modo de designação das Comunidades.

Também não se faz referência ao Tratado que pretendeu estabelecer uma Constituição para a Europa, assinado em Roma, em 29.10.2004. A justificativa para não o mencionar deriva da singela condição de que, apesar de assinado, este documento jurídico-normativo internacional não foi ratificado. Nesse sentido, não tendo entrado ele mesmo em vigor, suas disposições não adquiriram juridicidade, razão pela qual não interessam de forma alguma a um estudo em Direito. Afinal, toda Pesquisa em Direito deve sempre partir de um exame do Direito Positivo, isto é, de um Direito que em algum momento foi vigente (REALE, 2001, p. 17). Sobre esse último tema, remetemos à leitura dos itens 1.3. e 2.2., infra.

${ }^{30} \mathrm{O}$ Tratado de Lisboa, assinado em 13.12.2007, entrou em vigor em 1.12.2009, composto por dois Tratados Internacionais, a saber: o Tratado da União Europeia (TUE) e o Tratado sobre o Funcionamento da União Europeia (TFUE). O TUE é o próprio Tratado de Maastricht, sucessivamente alterado; o TFUE é nova denominação dada ao Tratado que institui a Comunidade Europeia - o Tratado de Nice.

${ }^{31}$ Artigo $46^{\circ}$-A, introduzido no TUE, por meio do artigo $1^{\circ}$, alínea 55, do Tratado de Lisboa, conjugado com o artigo $1^{\circ}$, parágrafo terceiro, do TUE, com redação alterada pelo mesmo Tratado de Lisboa, no artigo $1^{\circ}$, alínea 2. 
oposição entre precisão de terminologia jurídica e a designação dada por uso corrente a uma entidade ${ }^{32}$.

Feitas tais precisões sobre as designações da atual UE no tempo, há que se voltar à reflexão propriamente dita deste Capítulo.

O supramencionado procedimento intelectual de varredura em busca daquela nova forma de organização de relações entre alguns Estados da Europa foi efetuado apenas até a descoberta desta. Uma vez identificada a primeira manifestação deste novo modo de organização qualitativamente diferente dos anteriores, a investigação histórica se deteve para compreender profundamente apenas e tão-somente esta singular expressão original e originária de um sistema distinto de interação entre alguns dos países europeus. Dentro daquele período de dez anos, uma vez identificado o advento de tal encontro bemsucedido, a análise histórica não seguiu adiante no tempo.

A estreiteza do lapso temporal escolhido para realizar a busca determina, assim, um duplo movimento de exclusão. Desconsideram-se neste trabalho imediata e simultaneamente inúmeras propostas históricas de tentativas de aproximação entre povos europeus: as apresentadas antes de 1945, e as sugestões adotadas ou rejeitadas após 1954.

Deste modo, este trabalho não analisa as pretensas Europas imaginadas, propostas e/ou tentadas durante o período da (i) Idade Antiga, (ii) Idade Média ou (iii) Idade Moderna. Ademais, ao longo da (iv) Idade Contemporânea, todas as propostas sugeridas ou intentadas até 1945 são sumariamente desconsideradas por este estudo.

32 Por enquanto, não convém adentrar ainda mais neste trabalho nas minúcias jurídicas que explicam a sucessão no tempo de cada um dos termos utilizados em função da personalidade jurídica e sua correspondente natureza jurídica. Como se poderá ver mais a seguir, este questionamento não encontra ressonância no interior do arco metodológico de questões a serem examinadas pelo presente estudo. V., nesse sentido, o item 3.3.2., infra.

De todo modo, a despeito da precisão terminológica acima efetuada de maneira bastante breve, há que se notar que, nos momentos em que neste trabalho se fizer referência à CECA em si mesma, se utilizarão neste texto, além da própria sigla CECA, as seguintes expressões, indistintamente: Europa Unida, União Europeia, Comunidade Europeia, Comunidade, União da Europa, União dos povos europeus, povos europeus unidos, e demais variações possíveis entre tais significantes. Isso deriva precisamente do fato de que, em virtude do corte metodológico temporal e hermenêutico a ser explicitado infra, o questionamento sobre a relação terminologia-personalidade jurídica-natureza jurídica não fará qualquer sentido para o trabalho, condição que o desincumbe desta preocupação por um dito preciosismo jurídico.

Por fim, cumpre salientar que a expressão "União Europeia" não é uma inovação, nem do Tratado de Maastricht, de 1992, nem do Tratado de Lisboa, de 2007. Lembre-se nesse sentido o período entre guerras: o termo "União Europeia" foi utilizado pela primeira vez - segundo os registros disponíveis, encontrados e consultados - por Aristide BRIAND (2000) em seu Discurso por uma União Europeia perante a Sociedade das Nações, proferido em 1929. A expressão foi reutilizada no Memorandum de 1930, de Aristide BRIAND e de Alexis LÉGER (1998), sobre a organização de um Regime Federal Europeu. Apenas um inadmissível anacronismo contrário ao método histórico adotado pelo presente trabalho não permitiria o uso intercambiável dos termos acima mencionados. 
Esquiva-se assim da pretensão de examinar a completude da história daquilo que Denis de ROUGEMONT (1961) denominou de Vinte e Oito Séculos de Europa. Autores como Emmanuel BERL (1961), Alexander Freiherr von CAMPENHAUSEN (2010), Charles-Olivier CARBONELL (1996a, 1996b, 1996c), Charles-Olivier CARBONELL et alii (1999a, 1999b), Paulo Borba CASELLA (1994a, p. 58-90, 2000a), Jean-Louis CLERGERIE, Annie GRUBER e Patrick RAMBAUD (2010, p. 1-42), Olivier DESCAMPS (2011a, 2011b, 2011c, 2011d, 2011e, 2011f), Élisabeth du RÉAU (2008, p. 13-140), Denis de ROUGEMONT (1961), Charles SEIGNOBOS (1934, 1947), José Luiz Conrado VIEIRA (1999, p. 30-79), Heirich August WINKLER (2011), Charles ZORGBIBE (1997, p. 1-7), entre outros, são apenas exemplos daqueles que pretenderam reconstituir de maneira mais ou menos extensa este percurso intelectual - ainda que a partir de questões distintas, de perspectivas diferentes, bem como de orientações e de preocupações históricas particulares e próprias ${ }^{33}$.

Nesse sentido, estão sumariamente excluídos deste trabalho ${ }^{34}$ : (i) o Reino Romano do Império Carolíngio (768-843); (ii) a República Cristã - ou a Confederação da Sociedade Cristã - de Pierre DU BOIS (1306); (iii) a Monarquia Única da Sociedade Universal dos Estados do De Monarchia de Dante ALIGHIERI (1308); (iv) o Tratado de Aliança e Confederação entre o Rei Louis XI, Georges, Rei da Bohemia, e a Senhoria de Veneza, para Resistir aos Turcos, apresentado pelo Rei Georges PODIEBRAD $(1463)^{36}$; (v) a Europa Cristã do Papa Pio II - Aeneas Silvius PICCOLOMINI - (1464); ou mesmo (vi) as propostas de Europa unida contra a ameaça turca desenvolvidas na

${ }^{33}$ Gerard DELANTY (2010, p. 11-8) aponta que atualmente há quatro maneiras de compreender a História da Europa, com base na noção de herança: a Europa poderia ser algo uno (i) por força de tradição política comum herdada; (ii) por força da operação da lógica da unidade na diversidade, isto é, de multiplicidade de tradições; (iii) por força de comunhão de traumas ou de memórias coletivas; ou (iv) por força de uma suposta herança cosmopolita.

Apesar de se tratar de tema relevante, a discussão sobre as diferentes formas de compreender historicamente a integralidade da construção da Europa não é objeto do presente trabalho. Mais modestamente, este estudo mais busca (i) formar apenas uma leitura, dentre inúmeras possíveis, de (ii) tãosomente uma entre as inúmeras experiências de construção de uma união na Europa durante o século XX: a CECA. Os limites analíticos deste trabalho estabelecem contenções e condições conscientes a qualquer inadvertida presunção de se aventurar em terrenos historiográficos e históricos localizados para além deste recorte temporal e temático de estudo. Não há aqui, deste modo, qualquer incorporação da chave de leitura proposta por Gerard DELANTY (2010), acima mencionada.

${ }^{34}$ Excluídos os mitos sobre as origens da Europa já mencionados brevemente na Introdução Geral deste trabalho: o da princesa fenícia do Diálogo dos Deuses, de Lúcio de SAMOSATO e o do parentesco dos príncipes e dos povos, gestado no período medieval. Sobre cada um deles, v. a bibliografia indicada quando do desenvolvimento destas considerações na Introdução Geral.

${ }^{35}$ Para uma interessante introdução ao estudo de cada um desses Projetos, indicamos a leitura de Denis de ROUGEMONT (1961, p. 48-87), além de cada um dos demais textos mencionados no parágrafo anterior sobre este período.

${ }^{36}$ Importante lembrar que os turcos acabavam de conquistar Bizâncio, após a Queda do Império Romano do Oriente, em 1453. 
segunda metade do século XVI, tais como (a) De Europae Dissidiis et Bello Turcico Dialogus, de Jean-Louis VIVES; (b) a República Cristã Luterana, de Gaspard PEUCEUR, uma Confederação Anti-Papal e Anti-Império pela conjunção de Alemanha, França e Itália; (c) da Confederação dos Príncipes Cristãos sob a presidência do Imperador, proposta pelo huguenote François de LA NOUE; ou (d) a Monarquia Universal Cosmopolita de Guillaume POSTEL, a qual unificaria a todos, inclusive os turcos por conversão racional.

Do mesmo modo, igualmente estão localizadas fora do objeto de estudo deste trabalho: (vii) o Novo Cineu, ou Discurso sobre a Ocasião e os Meios para Estabelecer uma Paz Geral e a Liberdade do Comércio por todo o Mundo, de Émeric CRUCÉ (1623); (viii) o Grande Desenho de Henri IV, de Maximilien de BÉTHUNE, duque de Sully (1638); (ix) o Ensaio sobre a Paz Presente e Futura da Europa, de Willian PENN (1693); (x) o Projeto para Conceder a Paz Perpétua na Europa, do Abade SAINTPIERRE (1713); (xi) o Julgamento sobre a Paz Perpétua, de Jean-Jacques ROUSSEAU (1760); (xii) o Plano para uma Paz Universal e Perpétua, de Jeremy BENTHAM (1789); (xiii) o Projeto de Paz Perpétua, de Immanuel KANT (1795); (xiv) a Reorganização da Sociedade Europeia, ou da Necessidade e dos Meios de Unir os Povos da Europa em um Único Corpo Político, conservando a cada um sua Independência Nacional, de SAINT-SIMON (1814); (xv) a Europa Cristã e Socialista, de Philippe BUCHEZ (1831); (xvi) o Manifesto da Jovem Europa, de Giuseppe MAZZINI (1834); (xvii) os Congressos Europeus, de Victor CONSIDERANT (1839); (xviii) a Federação Europeia, de Auguste OTT (1840); (xix) a Da Paz, de seu Princípio e de sua Realização, de Constantin PECQUEUR (1842); (xx) a Federação Europeia, de Henry FEUGUERAY (1848); (xxi) o Discurso de Abertura do Congresso da Paz, de Victor HUGO (1849); (xxii) o Princípio Federativo, de Pierre-Joseph PROUDHON (1863); (xxiii) os Estados Unidos da Europa, de Mikhail BAKUNIN (1867); (xxiv) a Confederação Europeia, de Ernest RENAN (1871); (xxv) os Estados Unidos da Europa, de Charles LEMONNIER (1872); (xxvi) a Organização de uma Sociedade de Estados Europeus, de J. C. BLÜNTSCHLI (1878); (xxvii) os Estados Unidos da Europa, conforme indicado pelo Relatório do Congresso de Ciências Políticas organizado pela Escola Livre de Ciências Políticas de Paris (1900); (xxviii) a Federação da Europa, de Jacques NOVICOW (1901); (xxix) o Pan-Europa, de Richard de COUDENHOVEKALERGI (1923); (xxx) o Unir-se, ou Morrer, de Gaston RIOU (1929); (xxxi) o Projeto de União Aduaneira Europeia, de Yves LE TROCQUER (1929); (xxxii) o Discurso à 
Sociedade das Nações, de Aristide BRIAND (1929); (xxxiii) o Memorandum sobre a Organização de um Regime de União Federal Europeia, de Aristide BRIAND e de Alexis LÉGER (1930); (xxxiv) o Manifesto de Ventotene, de Ernesto ROSSI e Altiero SPINELLI (1942); (xxxv) as Teses do Movimento Italiano pela Federação Europeia (1943); (xxxvi) a Declaração do Comitê Francês pela Federação Europeia (1944); e (xxxvii) o Projeto de Declaração Federalista dos Movimentos de Resistência (1944).

Essa primeira delimitação temporal do trabalho, em sentido retroativo, surge porque não apenas escaparia à capacidade de o autor trabalhar a completude da historiografia sobre a União Europeia ou sobre a ideia de Europa ${ }^{37}$, ou porque fugiria tal empreendimento do campo de conhecimento histórico por ele detido. Rejeita-se também esta proposta de retomar as origens históricas mais remotas da ideia de Europa principalmente porque esta investigação extrapolaria os limites materiais deste trabalho e sua respectiva circunscrição metodológica temporal ${ }^{38}$.

Do mesmo modo, há que se notar que a delimitação em caráter prospectivo também deve ser levada em consideração a partir do momento em que se verifica ser o período de interesse inicial da Pesquisa relacionada a este trabalho aquele compreendido entre 1945 e 1954. Não será objeto de investigação deste trabalho qualquer Projeto de aproximação entre países europeus que, após 1954, fora proposto e adotado - ou mesmo rejeitado.

Por esse motivo, também foram imediatamente afastados deste trabalho: (i) a Comunidade Europeia de Energia Atômica (CEEA), instituída pelo Tratado de Roma, entre os seis países componentes da CECA (1957); (ii) a Comunidade Econômica Europeia (CEE), instituída por outro Tratado de Roma, também entre os mesmos seis países componentes da CECA (1957); (iii) a Associação Europeia de Livre Comércio (AELC), a qual foi estabelecida entre sete países europeus não-participantes da CECA, da

${ }^{37}$ Cumpre salientar que a lista apresentada acima de maneira cronológica é meramente exemplificativa, não exaurindo jamais o rol completo de textos na História que propuseram alguma aproximação entre os povos europeus. Nesse sentido, é importante relembrar a observação de Denis de ROUGEMONT (1961, p. 7) de que nenhuma análise sobre este tema poderá ser exaustiva, pois no lapso temporal de quase 3.000 (três mil) anos de Europa, seriam facilmente mencionáveis cerca de 2.000 (dois mil) nomes de autores preocupados com o tema.

${ }^{38}$ A singela menção dos demais Projetos de aproximação de países europeus ao longo de toda a História da Europa anterior a 1945 evidencia a existência de bastante amplo e fértil campo para futuras investigações jurídico-históricas sobre o tema, o qual ainda não foi completamente explorado, nem pela literatura jurídica estrangeira, nem pela literatura jurídica nacional.

Este simples mapeamento aponta para amplas possibilidades de objetos a serem examinados posteriormente por uma Nova Agenda de Pesquisa em Direito, preocupada com uma compreensão mais completa do fenômeno da Europa Unida. Apesar de se restringir o presente trabalho à análise histórica da CECA e de suas normas jurídicas positivas, fica registrado aqui o convite para futuras reflexões conjuntas sobre o tema. 
CEEA e da CEE, a saber, Áustria, Dinamarca, Noruega, Portugal, Reino Unido, Suécia e Suíça $^{39}$ (1960); (iv) a Organização de Cooperação e de Desenvolvimento Econômicos (OCDE), instituída pelo Tratado de Paris (1960); (v) o Pela Europa, de Robert SCHUMAN (1963); (vi) o Tratado de Fusão dos Executivos da CECA, da CEEA e da CEE (1965); (vii) o Ato Único Europeu (1986); (viii) a União Europeia, instituída pelo Tratado de Maastricht (1992); (ix) o Tratado de Amsterdã (1997); (x) o Tratado de Nice (2001); e (xi) o Tratado de Lisboa (2007).

Perceba-se assim o espírito de modéstia que acompanha este trabalho. Examinou-se na Pesquisa relacionada a este trabalho primeiramente o período localizado entre 1945 e 1954, a fim de compreender o processo de construção histórica de um novo modo de relações entre países europeus inicialmente neste período de dez anos. Literal e temporalmente, não foi objeto de atenção neste texto nada aquém deste lapso temporal, nem nada localizado para além dele. Foi exclusivamente sobre esses dez anos subsequentes à Segunda Guerra Mundial - campo fértil de adoção de instituições jurídicas completamente novas - que se debruçou.

É neste intervalo de dez anos que se buscou a primeira manifestação de alguma iniciativa pioneira de instauração de novo modo de relações. Nestes dez anos, dentre as diferentes ações institucionais intentadas, identificara-se ter sido a CECA a iniciativa singular apresentada e instaurada em menos de seis anos. Mas, para compreender este recorte preferencial pela CECA, mais precisões são necessárias.

Ainda que tenham sido estabelecidas as linhas gerais de demarcação da fronteira temporal de análise, haveria que se preocupar igualmente com a localização do objeto de estudo desta Tese de Doutorado no interior da dimensão espacial e temático. O próximo item (1.2.) determinará sobre quais países europeus que buscaram se unir naquele período este trabalho pretende discursar, a fim de se manter distante do arco metodológico deste trabalho manifestações não insertas no campo de preocupações estabelecido no início deste estudo.

${ }^{39}$ Em 1970, a Islândia se torna seu membro; em 1973, o Reino Unido e a Dinamarca deixam de integrar a AELC para compor a CEE; em 1986, a Finlândia adentra a AELC; no mesmo ano, Portugal deixa de participar da AELC para compor a CEE. Em 1991, Liechtenstein passa a compor a AELC; em 1995, Áustria, Finlândia e Suécia optam pela CE, restando hoje apenas quatro membros desta Organização: Islândia, Liechtenstein, Noruega e Suíça. Em 1992, o Espaço Econômico Europeu (EEE) é estabelecido pelo Tratado de Porto, entre a CE e os países membros da AELC; o objetivo deste Tratado em especial consistia em pôr fim à divisão da Europa em dois grandes grupos econômicos. 
Por esse motivo, as reflexões a seguir esclarecerão de maneira mais exata as razões pelas quais se elegeu a CECA e suas instituições jurídico-positivas como os objetos privilegiados e exclusivos deste trabalho.

\title{
1.2. Demarcações de Caráter Espacial do Objeto de Estudo
}

\begin{abstract}
Dès ces débuts fabuleux, il parait difficile de "retrouver Europe"! C'est la poursuite de son image mythique qui fait découvrir [...] sa réalité géographique [...]. Rechercher l'Europe c'est la faire! En d'autres termes: c'est la recherche qui la crée. (ROUGEMONT, 1961, p. 27, grifos do autor).
\end{abstract}

A exclusão sumária de Projetos de União de Europa acima mencionada em função de delimitações metodológicas de caráter temporal não é suficiente para justificar a escolha por um estudo aprofundado e exclusivo apenas da CECA.

A simples circunscrição no tempo do objeto desta Tese não basta para elucidar esta escolha, ainda que tenha permitido apontar com clareza, distinção e precisão, em um primeiro momento, quais os Projetos de Europa Unida manifestos na História não seriam examinados. Os dez anos subsequentes ao final da Segunda Guerra Mundial consistiram em momento histórico efetivamente fértil, na medida em que sucessivas experiências foram propostas e adotadas, ou, se rejeitadas, ao menos foram objeto de intensos debates no período (CASELLA, 2008, p. 189) ${ }^{40}$.

Com efeito, durante os anos 1945 a 1954, além da CECA, foram suscitadas outras iniciativas de promoção da aproximação entre países europeus, a saber: (i) a Organização Europeia de Cooperação Econômica (OECE), derivada da assinatura do Tratado de Paris, em 1948; (ii) a Organização militar instituída pelo Pacto de Bruxelas, em 1948; (iii) o Conselho da Europa (CdE), adotado após o Congresso de Haia de 1948, por força da assinatura do Tratado de Londres, em 1949; (iv) a Comunidade Europeia de Defesa (CED), proposta em 1950, cujo Tratado fora assinado em Paris, no ano de 1952; e (v) a Comunidade Política Europeia (CPE), proposta em 1952, cuja versão final Projeto de Tratado fora elaborada em 1953.

Enquanto as três primeiras receberam formatação institucional após a assinatura de seus respectivos Tratados e, em seguida, tiveram iniciados seus respectivos períodos de vigência, as duas últimas não tiveram a oportunidade de se organizar institucionalmente. A

${ }^{40}$ Mostra a obra L'Unité Politique de l'Europe - Histoire d'une Idée, de Patrice ROLLAND (2006, p. 447-595), inclusive com excertos de textos do período - artigos, discursos, panfletos ou manifestos, o quão fértil se revelara o período em Projetos de Europa Unida no dez anos subsequentes à Segunda Guerra Mundial. 
ausência de institucionalização destas duas Organizações Internacionais decorre da rejeição do Tratado da CED pela Assembleia Nacional da França ${ }^{41}$.

De todo modo, haveria que se compreender a razão pela qual, dentre as seis experiências históricas de aproximação entre países europeus iniciadas entre 1945 e 1954, cinco delas foram rejeitadas do arco de questões proposto para esta Tese de Doutorado. As razões se revelam bastante simples, principalmente quando se examina de maneira mais detida a pergunta inicial que confere o ritmo e o tom do presente estudo. Retome-se assim a pergunta formulada em termos mais gerais: como, quando e por meio de quais instituições países europeus tradicionalmente opostos conseguiram estabelecer entre si após o término da Segunda Guerra Mundial, de maneira inédita e inaudita em sua História, um novo modo de relações.

Antes de tudo, há que se perceber que este problema reside sobre uma dimensão espacial do problema de delimitação do objeto de estudo, pois haveria que se determinar de modo ainda mais preciso sobre quais países europeus se estaria debruçando ${ }^{42}$.

Nesse sentido, lembre-se aqui da dificuldade de se definir mesmo a própria noção de Europa em termos espaciais e culturais. Se se está preocupado em apontar as razões de escolha de um Projeto de Europa Unida em detrimento de tantos outros, não se poderia ignorar a necessidade de se mencionar a própria dificuldade de se estabelecer com precisão o que se designa por Europa (BAUMAN, 2006, p. 10-2; ROLLAND 2006, p. 4; ROUGEMONT, 1961, p. 8 e 27).

\begin{abstract}
Quando ouvimos alguém pronunciar a palavra "Europa", não fica imediatamente claro se esta se refere a uma realidade territorial delimitada, presa ao solo, dentro das fronteiras estabelecidas e meticulosamente desenhadas por tratados políticos e documentos jurídicos ainda não revogados, ou a uma essência livremente flutuante que não conhece divisões territoriais e que desafia todos os vínculos e limites espaciais. E é essa dificuldade, quase impossibilidade, de falar da Europa estabelecendo uma separação clara e nítida entre a questão da essência e os fatos da realidade que distingue o debate sobrea Europa da maioria das discussões a respeito de entidades dotadas de referências geográficas. (BAUMAN, 2006, p. 12).
\end{abstract}

Não se trata obviamente de tomar parte de forma definitiva no interior do inesgotável debate em torno do que seja a Europa enquanto civilização marcada por uma herança comum ou por modos de vida convergentes (DELANTY, 2010) - tema ilimitado,

\footnotetext{
${ }^{41}$ Para um breve relato histórico dessas cinco Organizações Internacionais, v. considerações nas linhas a seguir: no item 1.3., sobre a CED e a CPE; no item 1.4. e nos Quarto e Quinto Capítulos desta Tese, sobre a OECE, o Pacto de Bruxelas e o CdE.

${ }^{42}$ Isto é, quais países teriam se aproximado neste período de maneira qualitativamente distinta, a tal ponto de atrair tão fortemente a atenção exclusiva do investigador?
} 
inexaurível, dada a impossibilidade de encerrar analiticamente seu objeto (BAUMAN, 2006, p. 7-12; ROLLAND, 2006, p. 2; ROUGEMONT, 1961, p. 8). Também não se busca reconstituir inteiramente o debate, pois esse empreendimento escaparia aos objetivos metodológicos do presente estudo e ultrapassaria os limites materiais do mesmo.

Há na verdade inúmeras obras preciosíssimas sobre o tema, às quais remetemos o leitor $^{43}$. Nunca se poderia esperar igualar os esforços reflexivos desta obra nãoespecializada em História aos empreendimentos por diversas vezes tentados pela historiografia remota e recente sobre a Europa. Pretende-se aqui apresentar apenas e tãosomente a racionalidade subjacente à preferência pelo estudo de apenas um Projeto de Europa Unida - a CECA, sem pretender efetuar - frise-se - uma definição que pretenda em vão resolver absolutamente a questão em torno da noção espacial de Europa.

A tradição do pensamento sobre a Europa a compreende como uma civilização detentora de uma unidade cultural espacialmente localizada desde os tempos homéricos. Esta persistiria até o tempo presente em virtude da permanência do legado jurídico-político e filosófico helênico, romano e bíblico (BAUMAN, 2006, p. 7-9; VALÉRY, 1924). Essa condição lhe teria dotado de uma vocação pedagógica universal e universalizante de assegurar a unidade do gênero humano (ROUGEMONT, 1961, p. 7 e 35) por meio da difusão da Filosofia, do pensamento crítico, da Ciência, da Democracia, dos Direitos Humanos e do Desenvolvimento Econômico (ROLLAND, 2006, p. 2-3).

Segundo essa percepção tradicional, dada a origem grega, romana e cristã da Europa (CARBONELL et alii, 1999a, p. 51-87, 110, 121-5 e 130-9), nada the seria mais característico do que a perspectiva universalizante (ROUGEMONT, 1961, p. 35). Todavia,

[q]uel est le poids des déterminations naturelles et historiques qui pèsent sur l'Europe? Ni la géographie, ni les langues, ni la race, ni même l'héritage culturel ou spirituel sont déterminants. Elles ne jouent, en fin de compte, un rôle que comme les conditions d'une communauté politique, mais non comme la volonté d'en former une. (ROLLAND, 2006, p. 4).

O caráter irritantemente etéreo e a obstinada extraterritorialidade da "essência [europeia]" solapam e corroem a territorialidade sólida das realidades européias. A Europa geográfica nunca teve fronteiras fixas e é improvável que venha a adquiri-las enquanto a "essência" continuar existindo, já que até agora ela tem "flutuado livremente", apenas frouxamente atada, se é que chega a isso, a algum local determinado. (BAUMAN, 2006, p. 12).

43 A título exemplificativo, mencionem-se dentre inúmeros outros Zygmunt BAUMAN (2006); Emmanuel BERL (1961); Alexander Freiherr von CAMPENHAUSEN (2010); Olivier CARBONELL et alii (1999a, 1999b); Alfonso MATTERA (2002); Patrice ROLLAND (2006, p. 1-11); Denis de ROUGEMONT (1961); Oswald SPENGLER (1976a, 1976b); Paul VALÉRY (1924). 
Perceba-se que o espaço geográfico europeu teve ao longo de sua História fronteiras fluidas e indeterminadas em virtude da presença ou da ausência da operação de um determinado tipo de construção jurídico-política civilizacional comum (CARBONELL et alii, 1999a, p. 89). Nem a diferença religiosa, nem a diversidade cultural, nem mesmo todos os conflitos que marcaram no tempo a Europa foram capazes de impedir o constante retorno da questão de se buscar uma união entre alguns dos tão diversos povos habitantes da península euroasiática situada a Oeste dos Urais $^{44}$.

Perceba-se que o critério geográfico não é suficiente por si só para delimitar a Europa sem a presença de um critério identificador afeito ao político (ROLLAND, 2006, p. 2-3 $)^{45}$. O tamanho geográfico da Europa variou enquanto civilização. Ele se modificou fisicamente em função da variabilidade dos povos europeus que, por condições históricas específicas as mais diversas, buscaram promover (com ou sem sucesso) uma união que estabelecesse entre si um novo modo de relações por meio de instituições jurídico-positivas ${ }^{46}$.

44 Mesmo a demarcação da Europa como estando a Oeste dos Urais é problemática. Esta delimitação excluiria a Rússia, cujo pertencimento a uma civilização europeia é ao mesmo tempo defensável e nãodefensável. A título meramente exemplificativo, Oswald SPENGLER (1976a) a coloca, ao lado dos EUA, como compondo o Ocidente em declínio com a Europa.

Também exemplificativamente, pode-se indicar a reflexão de Heinrich August WINKLER (2011). Apesar de este indicar ao lado da Europa e dos EUA, também o Canadá, a Austrália, a Nova Zelândia e Israel como componentes do Ocidente, parece não incluir a dentre estes a Rússia (ao menos enquanto esta compunha a União Soviética). Segundo o mesmo autor, a separação entre Ocidente e Oriente na Europa teria se iniciado com a divisão do cristianismo entre a Igreja Católica Apostólica Romana e a Igreja Católica Ortodoxa (WINKLER, 2011, p. 4).

De todo modo, sobre esta discussão, é interessante lembrar que, no pós-Segunda Guerra Mundial, a União Soviética fora convidada para pensar em conjunto com a França e com o Reino Unido (as potências europeias vencedoras e ocupantes da Alemanha) uma aproximação entre povos europeus nas Conferências de Paris, as quais foram realizadas em junho-julho de 1947.

Tendo inicialmente participado das atividades com surpreendentes 90 membros de seu corpo diplomático, a União Soviética se auto-excluíra dos debates, sob a justificativa de não concordar com a iniciativa de aproximação que significasse uma ingerência estadunidense na Soberania e na independência econômica dos países europeus via Plano Marshall - isto é, que pudesse significar a separação da Europa em dois grandes grupos (RÉAU, 2008, p. 151-7).

${ }^{45}$ Note-se que, apesar de se concordar com Patrice ROLLAND (2006, p. 3-4) que o critério que define a Europa como unida não é geográfico, nem o natural, nem mesmo o histórico, mas o político, os limites metodológicos assumidos por este trabalho no item 3.4., infra, não permitem que se concorde com a perspectiva universalista-universalizante de Europa à qual o autor parece ao menos em parte assentir (ROLLAND, 2006, p. 4), nem com a ideia de que a política seja uma singela vontade barganhada de união. Parte-se neste estudo de outra forma de se pensar o Político, a qual não se conforma ao paradigma Moderno da vontade ou da barganha entre interesses opostos, mas ao de Política como convivência necessária entre diferentes; nesse sentido, v. item 3.4., infra

${ }^{46}$ Nesse sentido, ainda que não tenham sido analisados neste estudo, basta tomar contato com os títulos dos Projetos Europeus propostos na História antes de 1945 e após esta data, e se poderá perceber a variação do espaço geográfico ocupado por uma entidade denominada Europa. Não há como se estabelecer uma Europa, pois esta noção é fluida e varia seu preenchimento no vazio, ao sabor dos tempos; nos dizeres de Mireille DELMAS-MARTY (2004, p. 47, grifos da autora), não há "sequer uma visão única e preestabelecida da 
Ainda que o lapso temporal escolhido tenha sido precisamente definido (1945 a 1954), haveria que se estabelecer um critério adicional para auxiliar na justificação da escolha por um objeto de estudo em especial. A variação da extensão espacial daquilo que se denomina Europa - em função da modificação no tempo de propostas jurídico-políticas de aproximação entre países que se percebem como europeus - instaura neste momento do trabalho uma dificuldade de definição do objeto de estudo.

A supramencionada dificuldade se revela apenas inicialmente. Sua resolução se encontra fora de um campo significativo estritamente espacial. Neste momento, busca-se fazer inserir o objeto de estudo em uma rede de significações distinta daquela que até o presente momento pautou as presentes considerações. Em vez de procurar delimitar a esfera espacial do objeto de estudo a partir de considerações culturais ou geográficas incertas (porque variáveis e não confiáveis para este conhecimento científico), opta-se por se socorrer de elemento temático oriundo de outros ramos do conhecimento humano: o Direito e a Filosofia Política.

Como mostra a dificuldade histórica de definir espacialmente a Europa, apenas a partir da definição dos critérios jurídico-políticos que pautam institucionalmente o Projeto de Europa Unida visado por este estudo, o espaço da Europa Unida a que se pretende se tornará mais preciso. São necessárias, assim, demarcações temáticas (itens 1.3. e 1.4.) para se delimitar a demarcação espacial incompleta neste item. As convergências entre tempo, espaço e tema restam mais claras ao final, em que se propõe visão de conjunto dos critérios delimitados (item 1.5.).

\subsection{Demarcações de Caráter Temático do Objeto de Estudo - I: O Direito}

\footnotetext{
Il y a un désir de substituer à la régulation politique des sociétés une régulation par le droit ou par les techniques d'organisation sociale. Il y a une filiation saintsimonienne dans l'idéologie européenne, celle qui rêve de remplacer le gouvernement des hommes par \administration des choses. (ROLLAND, 2006, p. 7).
}

A inserção deste fenômeno no interior de um cosmos significativo produzido pelo conhecimento jurídico pode fornecer elemento adicional para estreitar a concepção de Europa, de modo a auxiliar na determinação espacial deste fenômeno. Ademais, por este estudo se desenvolver no interior de um campo de preocupações jurídicas, não pode ele 
descuidar da compreensão desta aposição de elementos do Direito que procuraram viabilizar a aproximação juridicamente mediada de países europeus.

Todo estudo em Direito se compromete a produzir um conhecimento a partir de um discurso em torno do Direito Positivo (FERRAZ JR., 2001, p. 48; REALE, 2001, p. 17) ${ }^{47}$. Por essa razão, este trabalho jamais poderia deixar de se preocupar com esta especificidade da perspectiva jurídica, ou seja, sua investigação deve se debruçar apenas e tão-somente sobre aquelas manifestações fenomênicas que encontraram ressonância no interior de uma compreensão jurídica.

Dentro do lapso de tempo selecionado (1945 a 1954), diante de seu compromisso com uma reflexão jurídica, esta Tese de Doutorado em Direito não poderia se voltar à compreensão de fenômenos que não encontraram condições para serem juridicamente instituídos. Diante rejeição pela Assembleia Nacional da França da CED e da CPE em 1954, estes Projetos de aproximação de povos europeus não puderam ver a luz do dia vale dizer, as instituições previstas em seus respectivos Tratados não puderam nem mesmo ter sua vigência iniciada. Não tendo assim constituído Direito Positivo em momento algum, estas duas Organizações devem ser sumariamente afastadas do campo de preocupações deste trabalho jurídico.

A História da proposição dessas duas últimas Organizações Internacionais é interessante, principalmente porque poderia causar uma perplexidade diante da aparente contradição de ter sido a CED - e consequentemente a CPE, cujo destino fora vinculado à decisão sobre a instauração da CED - rejeitada precisamente por aquele país que propusera sua criação. Esta suposta ausência de lógica da postura da França pode ser explicada se os relatos disponibilizados forem lidos com maior cuidado ${ }^{48}$.

A origem da CED está vinculada ao objetivo de ampliar a segurança no território europeu no contexto da Guerra Fria. Ela visava a integrar militarmente a República Federal da Alemanha à Bélgica, à França, à Itália, a Luxemburgo, aos Países Baixos, à imagem e semelhança do que ocorrera com a CECA (RÉAU, 2008, p. 203 e 210; REUTER, 1991).

\footnotetext{
${ }^{47}$ Isto é, em torno do Direito que, "em algum momento histórico, entrou em vigor, teve ou continua tendo eficácia. A positividade do Direito pode ser vista como uma relação entre vigência e eficácia" (REALE, 2001, p. 17).

${ }^{48}$ Considerando que o objetivo desta Tese não consiste em examinar em exaustão a História dessas duas Organizações Internacionais recusadas, será feita aqui uma breve narrativa sobre o percurso histórico delas. Isso permitirá não apenas esclarecer essa peculiar situação, como também reforçar a justificativa da exclusão da CED e da CPE do foco de atenção deste estudo.

Apresentam-se assim neste Capítulo apenas algumas informações reunidas, sem qualquer pretensão de apresentar uma história completa da CED e da CPE, com o simples objetivo de elucidar essas duas iniciativas posteriores à instituição da CECA.
} 
Aponta-se como elemento deflagrador da CED a frase de Dean ACHESON, Secretário de Defesa dos EUA, em discurso proferido em setembro de 1950: “Gostaria de ver alemães em uniforme no outono de 1951" (OLIVI; GIACONE, 2007, p. 37).

\begin{abstract}
In n'était pas envisagé à l'époque de reconstituer un système militaire allemand complet, mais «seulement » de constituer des divisions d'infanterie formées de contingents allemands, sans doter ces troupes des armes, des moyens logistiques et du haut commandement qui leur auraient permis de mener une action stratégique autonome; il ne devait y avoir ni aviation, ni marine allemandes. (REUTER, 1991, p. 242).
\end{abstract}

A Declaração do Secretário de Defesa dos EUA fora motivada pelo ataque à Coreia pela Coreia do Norte, efetuado em 25.6.1950. Dean ACHESON tinha em mente a participação da República Federal da Alemanha na contribuição militar para a segurança na Europa, pois os contingentes americanos não eram suficientes para proteger todo o continente europeu (REUTER, 1991, p. 241-2).

É nesse sentido que, em sua sessão de 15-18.9.1950, o Conselho da Organização do Tratado do Atlântico Norte (OTAN) ${ }^{49} 50$ declarara ser fundamental haver mais uma vez a presença de tropas alemãs em solo europeu continental, ainda que de maneira limitada: deveria estar desprovida de Estado-Maior, de logística, de aviação e de marinha, ou seja, consistiria em uma simples infantaria (REUTER, 1965, p. 44).

Essa situação preocupava o Governo francês e a opinião pública francesa. A reinserção alemã na construção da Europa pela via militar poderia colocar em risco, não apenas a implementação do Plano Schuman $^{51}$ de colocar em comum a produção francoalemã de carvão e aço por meio da CECA, como também poderia desequilibrar mais uma vez as relações no continente europeu ${ }^{52}$ (REUTER, 1965, p. 44). O fantasma do

${ }^{49}$ Com exceção da França.

${ }^{50}$ Em 4.4.1949, foi assinado o Tratado de Washington que institui a OTAN entre Canadá, EUA, Bélgica, Dinamarca, França, Islândia, Itália, Luxemburgo, Noruega, Países Baixos, Portugal e Reino Unido. A OTAN também não será objeto de estudo por parte deste trabalho, apesar de dever ser mencionada em determinados momentos da narrativa histórica desta Tese, na estrita medida necessária para esclarecer o processo histórico de constituição da CECA.

Preocupada com a segurança da região do Atlântico Norte, esta cooperação militar entre países Ocidentais não era uma iniciativa propriamente europeia, mas estadunidense - apesar de envolver necessariamente os países europeus que dela participavam. Por não envolver apenas países do continente europeu, não se trata de uma integração europeia, nos termos assumidos por este trabalho (nesse sentido, v. item 1.4., infra.), razão pela qual não será a OTAN analisada.

Assim, a necessidade de se manter o rigor e a coerência metodológicos neste trabalho justifica a ausência de qualquer preocupação em compreender mais profundamente a OTAN e suas relações com o processo de integração na Europa. Fica aqui registrado o convite para futuras investigações sobre o tema.

${ }^{51}$ A ser examinado mais detidamente no Sexto Capítulo desta Tese.

${ }^{52}$ Frise-se aqui a consciência de se ter referido ao continente europeu, e não à Europa. O Governo francês julgava terem os britânicos aprovado o rearmamento militar parcial dos alemães pelo fato de que a ilha do 
rearmamento alemão, sob todas as formas, era fortemente hostilizado pela França (REUTER, 1991, p. 242 e 245).

Ces sentiments reflétaient une opinion solidement assise dans la population [française]; mais elle était loin d'être partagée par l'ensemble des gouvernements alliés membres du système atlantique ; ceux-ci ou bien acceptaient avec moins de réserves de fonder leur sécurité sur les forces d'autres pays, ou bien avaient moins souffert d'une occupation étrangère. (REUTER, 1991, p. 242).

É nesse sentido que a França se preocupara em apresentar uma proposta nova para assegurar a segurança na Europa. Segundo esse Projeto alternativo, dever-se-ia pensar na formação de um exército europeu vinculado a instituições políticas de uma Europa Unida - ainda que essa autoridade política europeia ainda não existisse ${ }^{53}$. Todavia, essa proposta não fora bem recebida no interior da OTAN, nem mesmo entre todos os seis partícipes da CECA (REUTER, 1991, p. 244).

Enquanto os EUA perceberam a CED como medida dilatória, por outro lado, os Países Baixos se manifestaram contra ela. Não apenas os EUA procuraram uma solução direta com a República Federal da Alemanha ${ }^{54}$, como, entre países europeus, as discussões sobre forças armadas europeias se iniciaram entre os cinco outros países participantes da CECA $^{55} 56$ (REUTER, 1965, p. 45).

Reino Unido não estaria geograficamente ameaçada por eventual ataque de uma infantaria alemã. Nesse sentido, mencione-se observação feita por Jean MONNET, em outubro de 1950, relatada por Paul REUTER (1991, p. 243, grifos do autor), sobre o apoio britânico à proposta estadunidense: "Ils sont tout de même extraordinaire nos amis britanniques... du moment que la République fédérale ne possèdera ni navy ni air force ils ne voient que des avantages à la reconstitution de divisions d'infanterie composées de contingents allemands.".

53 O que explica a aposição do artigo 38 no Tratado da CED, a ser referido nas linhas a seguir: "la constitution d'une armée européenne supposait la constitution d'une autorité politique européenne qui dispose de cette armée. L'article 38 du traité instituant la C.E.D. prévoyait que la mise en vigueur de ce projet par la ratification des parties serait suivi par l'élaboration par l'Assemblée parlementaire européenne de la C.E.D. d'un projet de traité prévoyant une autorité politique de forme confédérale ou fédérale." (REUTER, 1991, p. 246-7).

${ }^{54}$ Posteriormente, os EUA aceitaram a criação da CED na Conferência de Ottawa, de setembro de 1951, diante da constatação de que os alemães (i) não pretendiam fornecer contingentes armados para um exército estrangeiro; e (ii) almejavam a aquisição de igualdade de direitos com relação aos demais membros da OTAN (REUTER, 1965, p. 45, 1991, p. 245-6); "le Gouvernement de Bonn [...] demanderait et obtiendrait des conditions beaucoup plus favorables, même s'il ne pouvait prétendre obtenir, à raison des accords entre les vainqueurs de la Deuxième Guerre mondiale, une souveraineté militaire égale à celle de ces derniers." (REUTER, 1991, p. 243).

${ }_{55}$ As negociações com os Países Baixos foram retomadas a partir de 3.10.1951 (REUTER, 1965, p. 45).

${ }^{56} \mathrm{O}$ que permite sinalizar, aliás, conforme indicado nas notas de rodapé 63 e 65 , infra, não ser de todo acertado imputar isoladamente à França as razões do fracasso do CED; na verdade, não se deve deixar de notar que mesmo entre os países europeus, a criação da CED e de sua correlata política CPE não era pacificamente aceita. Como restará mais claro a seguir. 
A CED fora resultado de trabalhos de uma pequena comissão Federalista ${ }^{57}$ reunida em torno de Jean MONNET ${ }^{58}$, futuro primeiro Presidente da Alta Autoridade da CECA ${ }^{59}$. Tal resultado foi apresentado em um Contra-Projeto de Tratado por René PLEVEN ${ }^{60}$, Presidente do Conselho de Ministros da França, em 24.10.1950, perante a Assembleia Nacional da França.

O objetivo desta proposta consistia em conferir a seus países-membros forças armadas europeias vinculadas às instituições políticas da Europa Unida; estas seriam integradas e postas sob um comando militar único comum. Haveria a designação de um Ministro Europeu da Defesa, o qual seria responsável perante uma Assembleia Europeia. A proposta do Plano PLEVEN (como ficara conhecido) foi acolhida pelo Reino Unido com bons olhos, apesar de este não pretender fazer parte da futura Organização Internacional (CANSACCHI, 1973, p. 1013; OLIVI; GIACONE, 2007, p. 37; RÉAU, 2008, p. 203-13; VEÇOSO, 2006, p. 37).

Após longas negociações entre os seis futuros Estados-Membros, assinou-se o Tratado de Paris, em 27.5.1952, o qual instituía a CED. Este documento deveria ser ratificado pelos Parlamentos de seus países signatários. Se o Reino Unido dele não faria parte, ao menos assinara posteriormente, em 13.4.1954, uma Convenção de Cooperação com a CED, segundo a qual a conveniência sobre a presença de tropas armadas britânicas no continente seria avaliada pelo Governo britânico (RÉAU, 2008, p. 211-3).

É neste momento que se mostra relevante mencionar também a proposta de criação da CPE. A iniciativa de instituição de uma Comunidade Política Europeia - pensada igualmente sob forte influência Federalista - fora proposta durante o período de ratificação da CED. O destino da CPE fora vinculado intimamente ao da CED (OLIVI; GIACONE, 2007 , p. 40), pois, parafraseando a curta, porém significativa, expressão de Fausto de QUADROS (1984, p. 125), a CED era pressuposto da CPE.

\footnotetext{
${ }^{57}$ Sobre o caráter federalista da proposta da CED associada à da CPE, lembramos a observação acurada de Paul REUTER (1965, p. 47, grifos nossos): "Il était nettement fédéral avec un Parlement composé d'une Chambre élue au suffrage universel et d une Chambre élue par les Parlements nationaux, un Conseil exécutif élu par le Parlement de la Communauté et un Conseil formé de ministres nationaux.". Sobre o Federalismo Europeu, v. o item 1.4.3., infra, e principalmente o Quinto Capítulo desta Tese.

${ }_{59}^{58}$ Com especial destaque a Paul REUTER (REUTER, 1991).

${ }^{59} \mathrm{O}$ famoso órgão supranacional da CECA; sobre ele, v. o Sétimo Capítulo e as Conclusões Parciais da Parte Segunda desta Tese.

60 "Finalement, avec le secours de quelques sandwiches qui nous tinrent lieu de déjeuner nous travaillâmes sans arrêt et le texte était présenté au propre pour 18 heures à Jean Monnet. Celui-ci le lut, y apporta quelques corrections. Restait à lui trouver un père. Sans perdre de temps, il donna en ma présence un long coup de téléphone à M. Pleven, ministre responsable de la Défense ; celui-ci avait été un collaborateur personnel de Jean Monnet dans ses affaires familiales et était un ami de vieille date ; il fut rapidement conquis à la solution proposée.”. (REUTER, 1991, p. 244-5).
} 
Lembre-se de que a CED detinha caráter provisório. Incompetente para dispor sobre política estrangeira, a CED deveria ser substituída e incorporada por um sistema de unificação política Confederal ou Federal, de maneira a atuar em conjunto com a OTAN (REUTER, 1965, p. 46). Por essa razão se justificava a importância de instituir uma terceira Comunidade - de caráter político - para coordenar a ação da CED (REUTER, 1965, p. 46).

A proposta da CPE tem origem em declaração feita por Anthony EDEN, Secretário de Estado do Ministério das Relações Exteriores do Reino Unido, perante o Comitê de Ministros do CdE. A proposta britânica consistia em estabelecer uma relação orgânica entre o CdE, a CECA e a CED em gestação, de maneira a coordenar a atuação dos seis membros da CECA e da CED sob a autoridade política do CdE - cujos poderes seriam aumentados $^{61}$. Tratava-se de uma maneira de introduzir por vias transversas a influência do Reino Unido sobre os processos de união entre países que se disseminavam no continente europeu (RÉAU, 2008, p. 216).

$\mathrm{O}$ artigo 38 do Tratado da CED previa a possibilidade de se instaurar uma estrutura Federal ou Confederal entre seus países-membros por meio de sua futura Assembleia Parlamentar. O italiano Altiero SPINELLI, delegado geral da União Europeia dos Federalistas, consegue que a proposta suscitada por Anthony EDEN fosse entendida como correspondendo ao anseio veiculado por aquele dispositivo.

Os Federalistas - dentre os quais devem ser destacados Alcide de GASPERI e PaulHenri SPAAK - entenderam que seria mais interessante fazer coincidir a unificação política (CPE) com a integração militar (CED) (QUADROS, 1984, p. 124). Sem aguardar a ratificação do Tratado da CED, instituiu-se uma Assembleia ad hoc de caráter misto, composta pelos seis Ministros da CECA e por oito parlamentares da Assembleia Consultiva do CdE (REUTER, 1991, p. 247). ${ }^{62}$

\footnotetext{
${ }^{61}$ Pode ser esta entendida como uma das maneiras encontradas para tentar contornar a carência da capacidade de atuação com a qual restara o CdE logo após sua criação, como indicado no item 1.4.3., e no Quinto Capítulo, ambos infra. Suas pretensões iniciais de introduzir um Estado Federal Europeu foram consecutivamente bloqueadas, mas foram tentadas na História Contemporânea Europa oportunidades como esta, com o objetivo de reinserir tal ideia recusada.

Este tema particularmente interessante tangencia este trabalho, mas não se encontra exatamente dentro do arco de questões selecionado para este texto. Por essa razão, não mais serão desenvolvidas considerações a respeito dele. Todavia, registrado está o convite para futuras investigações conjuntas sobre o mesmo.

${ }^{62}$ A estratégia era bastante inteligente: assinado o Tratado da CED, bastaria aguardar sua ratificação. Uma vez instituídos seus órgãos, restaria apenas à Assembleia da futura CED aprovar, com base no artigo 38, a proposta finalizada da CPE (OLIVI; GIACONE, 2007, p. 39-40; RÉAU, 2008, p. 216-7) elaborada em conjunto pela Assembleia ad hoc (CECA e CdE) para, assim, introduzir de inopino o Federalismo na Europa.
} 
A referida Assembleia elaborou o Projeto da CPE, cuja versão final fora aprovada em 10.3.1953. A CPE “consagrava o «Pacto federal» [...] e deveria absorver a CECA e a CED, criar um mercado comum e coordenar a política externa dos Estados membros" (QUADROS, 1984, p. 125). Seu Projeto fora enviado ao Presidente em exercício do Conselho de Ministros da CECA, Georges BIDAULT - o Ministro das Relações Exteriores francês da época, e não foi recebido de maneira muito positiva (REUTER, 1965, p. 47, 1991, p. 247).

Apesar do grande apoio de origem Federalista aos dois Projetos, havia uma forte opinião contrária por parte de não-Federalistas, podendo-se mencionar a visão negativa sobre ambos, não apenas de Georges BIDAULT, mas também de Paul van ZEELAND, Ministro das Relações Exteriores belga da época (RÉAU, 2008, p. 219). Tais documentos, escritos, assinados e aprovados quase que apenas por partidários de uma única perspectiva sobre a Europa - a perspectiva Federalista, encontraram resistências não-Federalistas em diferentes graus em cada um de seus países signatários ${ }^{63}$.

O Tratado da CED foi ratificado pela República Federal da Alemanha em março de 1953; pelos Países Baixos, em janeiro de 1954; pela Bélgica, em março de 1954; e por Luxemburgo, em abril de 1954. Na Itália, os anti-Federalistas comunistas, socialistas, neofascistas e monarquistas conseguiram se unir para impedir a aprovação do texto do Tratado, mantendo a decisão em suspenso (RÉAU, 2008, p. 213).

Na França, o Projeto da CED fora submetido a uma avaliação definitiva em agosto 1954 pela Assembleia Nacional francesa durante o Governo de Pierre Mendès FRANCE. Não houve uma discussão sobre o mérito do Projeto. De maneira igualmente astuciosa, foi suscitada uma moção formal prévia com o objetivo de evitar que o Projeto fosse encaminhado a uma votação definitiva. Com a aprovação dessa engenhosa moção, por 319 votos contra 264, a Assembleia Nacional da França pôde decidir que não estaria obrigada a deliberar sobre a ordem do dia a ela submetida - portanto, que não deliberaria sobre o Tratado da CED a ela submetido ${ }^{64}$.

Por meio deste ardiloso artifício, a perspectiva Federalista da Europa pretendeu inserir e disseminar universal e sub-repticiamente de cima a baixo seu próprio e exclusivo modo de compreender a aproximação dos povos europeus.

${ }^{63}$ Mais uma vez, relembramos ao leitor que este fato reforça a impossibilidade de se atribuir somente à França uma suposta responsabilidade exclusiva pelo fracasso da CED e de sua correlata CPE. Mais do que uma simples manifestação de pretenso interesse nacional momentâneo, esta se tratou de uma das diferentes explicitações nacionais do descontentamento europeu com relação a uma proposta de uma união da Europa que pudesse significar desautorizada e inadvertidamente a realização de uma unificação política europeia em um Estado Federal.

${ }^{64}$ A fim de complementar a informação histórica acima brevemente trazida a esta Tese, é importante lembrar que, após o fracasso da CED e da CPE, a solução encontrada para integrar militarmente a República Federal 
A aprovação da moção formal prévia fora sustentada pelos anti-Federalistas (também conhecidos como anti-cedistas), reunidos entre diversos partidos nacionais, a saber: comunistas, republicanos sociais gaullistas, membros da Seção Francesa da Internacional Operária (SFIO), membros do Partido Radical e membros da União Democrática e Socialista da Resistência (UDSR) (RÉAU, 2008, p. 215).

Há que se notar que a suspensão do processo de ratificação do Tratado da CED na Itália permite abrandar a suposta responsabilidade imputada exclusivamente à França pelo duplo fracasso da CED e da CPE - como usualmente tende a apontar o discurso sobre a História Contemporânea da Unida ${ }^{65}$. A França não se encontrava sozinha em dispor de forte oposição interna aos desígnios unificadores Federalistas ${ }^{66}$, e a suspensão da votação na Itália lançou a sombra da indeterminação sobre tal Projeto também a partir de Roma ${ }^{67}$.

Exatamente por essa razão também não se pode julgar apressadamente como confusa ou esquizofrênica a postura da França com relação à CED, nem mesmo perceber

da Alemanha à Europa Ocidental consistiu em fazê-la aderir por meio dos Acordos de Paris de 1954, em conjunto com a Itália, ao Pacto de Bruxelas de 1948, instituindo assim a União da Europa Ocidental (UEO).

Assim, o inevitável rearmamento alemão fora realizado no interior do quadro burocrático do pacto de Bruxelas, por meio de um Tratado Internacional o qual (i) conferira um novo estatuto à República Federal da Alemanha, (ii) determinara o término do regime de ocupação na Alemanha Ocidental; e (iii) previu um estatuto europeu à região do Sarre (REUTER, 1965, p. 49).

"Le réarmement de l'Allemagne devait s'opérer dans des conditions peu faites pour flaire à des larges fractions de l’opinion française; pour essayer de diminuer les inconvénients de la situation ou de les masquer, il fallait faire preuve d'ingéniosité, d'autant plus que l'Allemagne était habilité à faire valoir les mérites de son attitude. On tira du sommeil où il était tombé le traité de Bruxelles de 1948; on en fit disparaître les mentions blessantes pour l'Allemagne; on créa divers organes nouveaux, notamment une Assemblé pour y mettre selon les déclarations du président du Conseil français «un peu supranational» [...]. A l'Union européenne occidentale ainsi crée adhéraient l'Allemagne et l'Italie. Cette Europe à sept en organisant un contrôle des armements permettait de maintenir les limitations que l'Allemagne avait acceptés dans la CED [...].” (REUTER, 1965, p. 48).

Deste modo, a República Federal da Alemanha teria reconhecida a partir de 1955 sua autonomia militar - com exceção ao domínio dos armamentos nucleares -, desde que aderisse plenamente à OTAN. O modelo atlântico se revelou assim como a solução encontrada para o problema de segurança na Europa Ocidental (OLIVI; GIACONE, 2007, p. 41-2; RÉAU, 2008, p. 221).

${ }^{65}$ Como faz grande parte dos autores, mencionando-se exemplificativamente Giorgio CANSACCHI (1973, p. 1013), Olivier DESCAMPS (2011j, 2011k), Riccardo MONACO (1961a, p. 320), Bino OLIVI; Alessandro GIACONE (2007, p. 41-2), André de Carvalho RAMOS (1996, p. 649, 2005, p. 58) e Élisabeth du RÉAU (2008, p. 215 e 220).

${ }^{66}$ Fausto de QUADROS (1984, p. 125) parece concordar com o presente argumento de não se poder atribuir apenas à França a responsabilidade pela rejeição do Tratado da CED e de seu correlato, o Projeto da CPE ou seja, pelo "mais importante revés dos federalistas.".

Não somente a França, mas a Europa se mostrava não integralmente concordante com o profundo enraizamento de princípios comunitários federalistas entre os povos europeus (QUADROS, 1984, p. 379-80). Diferentemente do que o federalismo supunha, não havia um amplo contentamento com a proposta de plena "satisfação ao ímpeto das concepções supranacionais em que, poucos anos antes, políticos, juristas e economistas haviam posto as mais fagueiras esperanças e o mais vivo entusiasmo.”. (QUADROS, 1984, p. 266).

${ }^{67}$ Também não se pode ignorar que as hostilidades na Coreia se acalmaram anos depois, principalmente após a assinatura do armistício de Pan Mun Jom, de 27.7.1953. Esse fato diminuiu a percepção de ser urgente promover o rearmamento militar alemão (REUTER, 1965, p. 45 e 47). 
com perplexidade a rejeição deste Projeto - em conjunto com o da CPE - por parte da Assembleia Nacional da França ${ }^{68}$.

Iniciado por proposta Federalista francesa, e reforçado internacionalmente quase que exclusivamente por partidários europeus dessa perspectiva, apenas na França um antiFederalismo Europeu de caráter nacional reuniu forças suficientes ${ }^{69}$ para afirmar vigorosa e corajosamente uma forte posição contra a CED e sua furtiva CPE na Europa. Em outras palavras, na França se encontrou a possibilidade de vocalizar veementemente que nem todos na Europa almejavam um Estado Federal Europeu - ou, o que é o mesmo, que parcela Europa não se queria Federal ${ }^{70}$.

Compreende-se por isso porque a análise da CED e da CPE foi excluída do presente estudo: não puderam suas instituições adentrar o cosmos jurídico, o que metodologicamente impediria o estudo dessas Organizações Internacionais por uma investigação em Direito. Se o discurso jurídico deve sempre partir de um Direito Positivo, não deve a presente Tese se debruçar mais detidamente sobre esses fenômenos, pois suas normas jurídico-institucionais jamais se positivaram - nunca entraram em vigência, isto é, nunca foram aplicáveis espacial e temporalmente ${ }^{71}$.

Não é o simples fato de ter havido a rejeição dessas duas Organizações Internacionais que justifica o afastamento de ambas do arco metodológico deste trabalho. A justificativa é mais sutil, pois deriva da ausência de repercussão jurídico-positiva de suas instituições. Nenhum estudo em Direito pode deixar de partir de um Direito Positivo. Mas também há que se perceber: de determinado tipo de Direito Positivo, pois é sempre uma qualidade de regulamentação jurídica positivada que interessa o investigador em Direito.

\footnotetext{
${ }^{68}$ Mesmo em âmbito ministerial, o Governo francês encontrava-se dividido entre Federalistas e anti-cedistas: "Je rencontrai également à cette occasion quelques très hauts et haut fonctionnaires du Département. Les très hauts fonctionnaires étaient atterrés de ce qui prenait pour eux figure de cataclysme; les hauts fonctionnaires, déjà mécontents de ce que le Plan Schuman ait été élaboré sans eux, étaient irrités de ce nouveau dédain et ne sympathisaient pas avec un projet qui prenait le contre-pied de toute la politique antérieure. " (REUTER, 1991, p. 245).

${ }^{69}$ Como visto acima, dentre as mais diferentes segmentações políticas internas. O mesmo ocorrera na Itália, mas com menos vigor, pois foi possível apenas suspender a aprovação.

70 A aprovação do Tratado nos demais países signatários da CED também não ocorrera sem oposição: na República Federal Alemanha, houve resistência por parte dos socialistas alemães (DESCAMPS, 2011j, 2011k); nos Países Baixos, foi aprovado no Senado por 36 votos contra 4; em Luxemburgo, foi aprovado na Câmara por 46 votos contra 4; e, na Bélgica, foi aprovado, em novembro de 1953, na Câmara, por 148 votos contra 49 (socialistas e comunistas), e, no Senado, por 125 votos contra 40 (socialistas e comunistas) (RÉAU, 2008, p. 213).

${ }^{71}$ Lembrando que o Direito Positivo é precisamente aquele Direito que deteve vigência em determinado período de tempo, sobre determinada localização espacial (REALE, 2001, p. 17). É isso que autoriza, por outro lado, o estudo em História do Direito de normas jurídicas positivas, ainda que não mais vigentes: "A Ciência do Direito é sempre ciência de um Direito positivo, isto é, positivado no espaço e no tempo, como experiência efetiva, passada ou atual. Assim é que o Direito dos gregos antigos pode ser objeto de ciência, tanto como o da Grécia de nossos dias.” (REALE, 2001, p. 17, grifos do autor).
} 
As próximas especificações não apenas permitirão reforçar os motivos pelos quais CED e CPE foram colocadas fora do campo de investigação desta Tese de Doutorado, como também permitirão elucidar as razões pelas quais também foram excluídas desta análise a OECE, o Pacto de Bruxelas e o CdE.

Para tanto, são necessárias ainda mais precisões em torno da pergunta inicialmente formulada. A simples estipulação de um critério jurídico-positivo é insuficiente para permitir a compreensão das razões de escolha da CECA. Esta, a OECE, a Pacto de Bruxelas e o CdE foram tentativas de promover a aproximação de países europeus no pósSegunda Guerra Mundial que se revestiram de juridicidade positivada.

A princípio, segundo o critério até então apresentado ${ }^{72}$, as quatro iniciativas seriam igualmente passíveis de análise por este trabalho, pois cada uma delas se constituiu institucionalmente em Organizações Internacionais próprias por meio de normas jurídicas positivadas. Mas este estudo se dirige ao exame preciso das instituições da Organização Internacional que permitiu estabelecer um novo modo de relações entre alguns dos povos europeus.

“[N]ão existe uma entidade jurídica nomeada Europa [...]. A Europa é feita de instituições jurídicas diversas. Cada uma delas se construiu segundo suas próprias regras e vive como uma entidade autônoma.” (DELMAS-MARTY, 2004, p. 47, grifos da autora). Cada uma das iniciativas demandou a elaboração de estruturas jurídicas próprias para viabilizar seu próprio sistema de relações, o que engendrou um pluralismo jurídico na Europa. Formou-se uma polissemia jurídica derivada da simultaneidade de distintos regimes jurídicos igualmente aplicáveis sobre o espaço europeu ${ }^{73}$.

${ }_{73}^{72}$ Ausência ou presença de ordem jurídica-institucional.

${ }^{73}$ Apesar de se ter mencionado neste momento do texto parcela das reflexões de Mireille DELMASMARTY, isso não significa que serão incorporadas neste trabalho suas conclusões sobre a necessidade de harmonizar essa complexidade jurídico-significativa por meio de "duplo jogo de chaves".

Segundo a perspectiva da autora mencionada, esse duplo jogo deveria ser compreendido como consistindo na operação interpretativa orientada concomitantemente por "princípios diretores" desprovidos de prévia hierarquia entre si e pelo discurso de "legitimação impost[o] pela primazia ética dos direitos do homem." (DELMAS-MARTY, 2004, p. 260 e 266). Deste modo, segundo Mireille DELMAS-MARTY (2004, p. 256), seria possível pôr em ordem a complexidade de fontes normativas europeias sem eliminar a polissemia dada pela pluralidade nomogenética - isto é, sem que a harmonização implicasse unificação da Europa.

Ao propor uma solução pautada por esta dupla chave interpretativa, a autora parece se contrapor a determinados discursos que temerariamente imporiam uma ordem hierárquica piramidal na Europa, segundo a qual os Estados se subordinariam à ordem jurídica comunitária (CECA, CEEA e CEE), ao passo que esta estaria indelevelmente de acordo com um vé(ó)rtice superior dos direitos do homem - CdE e sua Corte Europeia de Direitos Humanos (CEDH). Nesse sentido, valeria frisar que Mireille DELMAS-MARTY (2004, p. 268) mencionaria a necessidade de operação conjunta de princípios diretores (como a proporcionalidade) e do princípio ético da primazia dos direitos do homem.

Como se poderá verificar mais adiante, no Sétimo Capítulo desta Tese de Doutorado - dedicado à análise institucional do Tratado da CECA, é importante destacar que o Terceiro Protocolo ao Tratado da 
CECA - referente às relações desta Organização com o CdE, analisado no item 7.1.2., infra - não indica haver qualquer relação hierárquica entre CdE e CECA, mas apenas uma relação de cooperação. Por esse motivo, esse discurso de pretensa subordinação da CECA ao CdE não teria encontrado - ao menos quando da assinatura do Tratado da CECA - qualquer respaldo no regime jurídico vigente no período - isto é, no Direito Positivo da época.

Todavia, não se pode ignorar a proposta britânica, de 1952, diante do CdE, de estabelecer uma relação orgânica entre este, a CECA e a CED em gestação, por meio da CPE, a fim de que os ingleses obtivessem influência sobre o continente europeu sem participar do processo comunitário. Como visto, a CPE previa a ampliação destacada do CdE com relação às demais Organizações Internacionais, revestindo-se de autoridade política central na Europa - um discurso que agradava aos Federalistas. Lembre-se de que tanto a CED como a CPE não foram instauradas, em virtude de rejeição da primeira pela Assembleia Nacional da França, em 1954.

A busca de tornar os Direitos Humanos do CdE e de sua CEDH o ponto de convergência interpretativa e harmonizante do pluralismo jurídico europeu se trataria talvez de uma revitalização do discurso Federalista que informou a constituição da CdE e que, por sua vez, fora ignorado quando da instituição da CECA - pautada pela orientação tradicionalmente conhecida como funcional (CLOSA, 1994, p. 340). Sobre o caráter Federalista do CdE, remetemos o leitor à leitura do Quinto Capítulo desta Tese de Doutorado; sobre o caráter Funcionalista da CECA, remete-se o leitor ao Sétimo Capítulo deste estudo.

De todo modo, em primeiro lugar, há que se lembrar de que se aceita geralmente que o Funcionalismo foi a Teoria adotada estrategicamente na prática para realizar instrumentalmente a integração na Europa (CLOSA, 1994, p. 340). Para Fausto de QUADROS, a assunção do Funcionalismo consistiu em uma forma histórica de recusar a introdução do Federalismo na Europa para este específico Projeto de construção da Europa Unida da CECA (QUADROS, 1984, p. 121).

Todavia, este autor indica que após a instauração da CECA, o Federalismo retornara com força ainda maior, o que teria sido demonstrado pelo desenrolar do processo histórico posterior (QUADROS, 1984, p. 122-4 e 126-9). É importante lembrar, neste particular, que a circunscrição metodológica assumida pelo presente estudo (itens 1.1. a 1.5.) impede que sejam analisados os movimentos históricos posteriores a 1951 o ano da assinatura do Tratado de Paris de 1951, uma vez que a CED e a CPE, posteriores à CECA, foram deixadas de lado por este trabalho.

Nesse sentido, como reiterado por diversas vezes ao longo do presente estudo, o que interessa ao arco de questões metodologicamente traçado para o presente estudo é compreender a constituição histórica da CECA até a assinatura de seu Tratado, bem como o fornecimento de uma leitura sobre seu arranjo institucional. Nos Sexto e Sétimo Capítulos desta Tese, restará claramente evidente - como rapidamente sinalizado por Fausto de QUADROS (1984, p. 121) - poder se compreender que, até 1951, a CECA não se instituíra como uma Organização Internacional proto-federativa (ou ainda, como uma "Federação em potencial", em "incubação", ou em "estado letárgico").

Todavia, se, após 1951, sucessivas reformas institucionais (como o Ato de Unificação de 1965) e/ou constituições de outras Organizações Internacionais (tais como CEEA e CEE) detiveram ou não o condão de alterar a orientação do processo de construção de Europa Unida da CECA no sentido de formar uma Federação, este problema não interessa ao presente estudo, por se localizar fora da dimensão temporal do campo de questões assinaladas para esta Tese.

Dessa forma, a exigência de manter uma rigorosa coerência metodológica no interior deste trabalho permite apenas que, após rápida menção a essa discussão, se registre o convite para futuras reflexões conjuntas sobre o referido tema.

Ademais, é importante destacar que a discussão sobre as diversas teorias que buscam explicar a construção da Europa Unida (da CECA e das experiências posteriores) não serão examinadas no presente estudo. O conjunto e as diferenças entre elas foram organizados e sistematizados em Carlos CLOSA (1994), texto para o qual remetemos o leitor.

Este último texto mencionado apresenta um percurso histórico de avaliação de ascensão, queda e ressurgimento de cada uma das teses explicativas, ressaltando que cada uma delas teria adquirido importância em diferentes momentos da história da construção da União Europeia de hoje. Em outras palavras, a presença de uma ou de outra lente teórica explicativa deste fenômeno teria como fundamento empírico as Reformas Institucionais trazidas pela CEEA, pela CEE, pelo AUE e pelo Tratado da Maastricht, isto é, a própria evolução da Comunidade (CLOSA, 1994, p. 346).

Em outras palavras, a reaquisição de vigor de um ou de outro corpo teórico teria como princípio justificador um cronológico "nuevo corpus de evidencia empírica" (CLOSA, 1994, p. 349). Afinal seriam tentativas de construção teórica vinculadas contemporaneamente à cronologia da Europa que examinavam.

Cumpre salientar que este trabalho não tem por objetivo discutir as teorias que tentaram explicar a integração da Europa Unida no tempo, porquanto este não consiste em uma História das Ideias construídas 
sobre a Europa Unida. Antes, ele procura propor uma leitura específica sobre uma experiência de integração temporal, espacial e tematicamente circunscrita: a CECA. Em outros termos, este trabalho está cronologicamente restrito ao exame de uma experiência determinada, a saber, aquela dada pela CECA, e não pelas evoluções históricas que a ela se seguiram.

Por esse motivo, apesar de se tratar de temática interessante, ela não será abordada neste estudo. Fica registrado aqui o convite para futuras investigações conjuntas sobre esta questão. Para leitores eventualmente interessados nesta discussão, remetemos à leitura do texto supramencionado de Carlos CLOSA (1994).

Em segundo lugar, é importante notar ainda que alguns autores estrangeiros (MEZZETTI, 2012; PIZZOLO, 2012a) e nacionais (ACCIOLY; NASCIMENTO E SILVA; CASELLA, 2009, p. 451; BITTAR; ALMEIDA, 2006, p. 530-64; CASELLA, 2007b, 2008, 2009a, 2009c, 2009d; CONCI, 2012; FIGUEIREDO, 2012; MIRAGEM, 2005; PIOVESAN, 2003, p. 59-72, 2007, p. 7-16; VIEIRA, 2010) parecem se aproximar da tendência de buscar um fundamento absoluto e último do Direito Internacional - e, dessa forma, também do Direito Comunitário - naquilo que se convencionou denominar Direito Internacional dos Direitos Humanos (DIDH), aparentemente em linha diversa da proposta por Mireille DELMAS-MARTY (2004).

A referida discussão entreabre temática bastante relevante e interessante, à qual se deveria dar atenção com maior cuidado. Principalmente a partir da verificação de que desde a entrada em vigor do Tratado de Lisboa, a União Europeia dispõe de sua própria Carta de Direitos Fundamentais como um documento anexo ao Tratado.

As normas jurídicas da Carta de Direitos Fundamentais da União Europeia detêm iguais qualidade e validade se comparadas com as demais que compõem o TUE e o TFUE, conforme determina o artigo $6^{\circ}$, parágrafo primeiro, do TUE, após alteração da redação dada pelo Tratado de Lisboa: “A União reconhece os direitos, as liberdades e os princípios enunciados na Carta dos Direitos Fundamentais da União Europeia, de 7 de Dezembro de 2000, com as adaptações que lhe foram introduzidas em 12 de Dezembro de 2007, em Estrasburgo, e que tem o mesmo valor jurídico que os Tratados.".

Também não se pode ignorar que o mesmo artigo $6^{\circ}$, em seus parágrafos segundo e terceiro, determina que a UE adere à Convenção Europeia para a Proteção dos Direitos do Homem (CDH): "2. A União adere à Convenção Europeia para a Protecção dos Direitos do Homem e das Liberdades Fundamentais. Essa adesão não altera as competências da União, tal como definidas nos Tratados" e "3. Do direito da União fazem parte, enquanto princípios gerais, os direitos fundamentais tal como os garante a Convenção Europeia para a Protecção dos Direitos do Homem e das Liberdades Fundamentais e tal como resultam das tradições constitucionais comuns aos Estados-Membros.”.

Há deste modo a afirmação de uma ordem jurídica comunitária protetora de Direitos Humanos na Europa, a qual é distinta da dada pela CEDH do CdE, apesar de restar complementada pela CDH. Todavia, as discussões sobre a posição da tutela dos Direitos Humanos na Europa Unida de hoje ainda não se esgotaram. Nesse sentido, mencionem-se Conferências inteiras realizadas durante todo o Segundo Semestre de 2011 em Paris, sob os auspícios da Corte de Cassação (FRANCE. Cour de Cassation, 2011a, 2011b, 2011c), sob a coordenação acadêmica da Professora Catherine KESSEDJIAN, da Université Panthón-Assas (Paris II) e do Collège Européen de Paris.

Tal temática foi também objeto de estudo no Seminario Internacional - Derecho Constitucional Transnacional, realizado em Madri, na Faculdade de Direito da Universidad de Alcalá de Henares, em 22.2.2012, bem como no II Curso de Actualización en Teoría y Práctica de la Integración Regional, realizado na mesma Universidade entre os dias 6-28 de fevereiro de 2012, principalmente nos discursos de Luca MEZZETTI (2012), Calogero PIZZOLO (2012a), Luiz Guilherme Arcaro CONCI (2012) e Marcelo FIGUEIREDO (2012).

Em artigo recente, Giuseppe MARTINICO (2012, p. 423-4) conclui que, até o presente momento a $\mathrm{CDH}$ ainda não detém uma primazia ilimitada, apesar de alguns juízes nacionais estenderem os princípios estruturais do Direito da UE (primazia e efeito direto) à CDH. Todavia, segundo a análise do mesmo autor, isso não impede que dispositivos constitucionais dos Estados-Membros obstem a superioridade da CDH sobre o ordenamento jurídico interno por meio de interpretação, apesar de a primazia da CDH ser algo que se encontra além do controle exercido por dispositivos constitucionais nacionais. Em razão da incapacidade de se formular juízos definitivos sobre o tema, o autor conclui (MARTINICO, 2012, p. 424): "there cannot be obvious conclusions in this area, as is often the case in the fascinating 'journey to an unknown destination' of European integration.”.

Esse debate, apesar de interessante e relevante, não se encontra dentro do recorte metodológico temporal, espacial e temático estipulado para o presente estudo, razão pela qual se deixa de tecer comentários próprios sobre o mesmo. Em outras oportunidades discorremos sobre temática relacionada (o fundamento último da ordem jurídica internacional no DIDH), reflexões para as quais remetemos o leitor, caso se interesse (GIANNATTASIO, 2010b, 2011a, 2011b). 
Diante dessa complexidade normativa, não basta simplesmente determinar a existência de normas jurídicas positivas como o critério de recorte em prol de uma Organização Internacional, em detrimento das outras.

Com efeito, apesar de permitir determinados cortes metodológicos ${ }^{74}$, ele não está suficientemente apto para justificar por si só a escolha da CECA como o objeto de estudo privilegiado deste trabalho diante das outras quatro iniciativas. Afinal, ainda que cada uma delas tenha sido arquitetada de maneiras qualitativamente distintas, todas as supramencionadas Organizações Internacionais europeias propostas entre 1945 e $1951^{75}$ encontraram revestimento jurídico específico para suas instituições articuladas normativamente.

Por esse motivo, critério adicional deve ser eleito para justificar a seleção da CECA como o fenômeno jurídico-Político por excelência a ser investigado por este trabalho. Não apenas tal critério reforçará as razões pelas quais se excluíra da análise a CED e a CPE, como também explicará o afastamento da OECE, do Pacto de Bruxelas e do CdE com relação ao círculo de preocupações desta investigação. Para tanto, é fundamental recorrer mais uma vez à pergunta formulada no início deste texto.

\title{
1.4. Demarcações de Caráter Temático do Objeto de Estudo - II: As Leis
}

\begin{abstract}
[D]iriam talvez as Leis: [...] Nós que te geramos, te criamos, te educamos, te admitimos à participação de todos os benefícios que podemos proporcionar a ti e a todos [... Q] Quem dentre vós aqui permanece, vendo a maneira pela qual distribuímos justiça e desempenhamos as outras atribuições do Estado, passamos a dizer que convencionou conosco de fato cumprir nossas determinações; desobedecendo-nos, é réu tresdobradamente. (PLATÃO, 2006, p. 130).
\end{abstract}

Como por diversas vezes afirmado anteriormente, pretende-se investigar neste estudo quando, como, e por meio de quais instituições países tradicionalmente opostos em termos bélicos foram capazes de estabelecer entre si, de maneira inaudita em sua História, um novo modo de relações. Esta nova maneira de empreender as relações é relevante e instigante para uma investigação jurídico-científica, pois o Direito pudera ser moldado positivamente no sentido de afastar o retorno de uma lógica de resolução de conflitos entre esses países baseada na Guerra.

${ }^{74} \mathrm{O}$ qual permitiu descartar da presente análise, como visto acima, a CED e a CPE.

75 Ano da assinatura do Tratado da CECA. Perceba-se que a partir deste momento, passa-se a desconsiderar definitivamente a CED e a CPE como possíveis objetos de estudo - ainda que comentários posteriores neste mesmo Capítulo venham a reforçar essa exclusão. Nesse sentido, não 1954, mas 1951, é o marco temporal final do período de estudo a ser investigado neste trabalho, a partir de 1945. 
Perceba-se que as quatro Organizações Internacionais dispõem igualmente de uma ordem jurídica institucional voltada à consecução de seus objetivos específicos ${ }^{76}$. Cada uma delas constituiu para si um aparato institucional expresso por meio de normas jurídicas trazidas por seus respectivos Tratados Internacionais.

O Direito Positivo é um elemento passível de ser encontrado igualmente em cada uma delas, mas não lhes é comum o mesmo modo de articular o arcabouço jurídicopositivo. Em outras palavras, o que as diferencia entre si - e o que legitima a preferência da escolha por uma delas, em detrimento das demais - não é presença ou a ausência de normas jurídicas institucionais positivadas, mas precisamente a qualidade dessa articulação normativa jurídico-institucional.

Cada uma das Organizações Internacionais fora concebida para um fim específico de promoção de uma União entre países da Europa, vale dizer, cada uma delas representa Projetos diferentes de aproximação entre determinados povos europeus ${ }^{77}$.

Se todas possuíam igualmente Direito Positivo voltado a permitir institucionalmente a operação de seus próprios Projetos de Europa Unida, há que se perceber a presença de uma distinção da qualidade jurídico-institucional (isto é, da forma segundo a qual as instituições foram articuladas). Esta diferença decorre do fato de que cada Organização Internacional fora instituída para atingir um fim específico: uma não partilha do mesmo Projeto de Europa Unida da outra ${ }^{78}$.

Entenda-se aqui a especificidade da pergunta proposta: não se pretende analisar apenas e tão-somente o aspecto institucional de aproximação de alguns países europeus. Essa dimensão seria uma resposta parcial, pois passaria diretamente à

\footnotetext{
${ }^{76}$ Tais objetivos serão mais bem detalhados nas linhas a seguir e serão rapidamente relembrados nos Quarto, Quinto e Sexto Capítulos desta Tese, de acordo com as limitações postas pelas reflexões deste item.

${ }^{77} \mathrm{O}$ que será mais facilmente perceptível a partir da leitura das linhas a seguir, mas, principalmente, dos Capítulos Quarto, Quinto e Sexto deste trabalho.

${ }^{78}$ Com efeito, não se pode confundir as razões de instituição da OECE, do Pacto de Bruxelas, do CdE com a da CECA, sob pena de considerar cada uma das iniciativas como um único e mesmo processo capitaneado por diferentes Organizações.

Não se trata de um mesmo e único Projeto de Europa Unida, mas de quatro iniciativas distintas. Ou ainda, tratam-se antes de formas institucionais representativas de posições de batalha de concepções de mundo distintas que se contrapunham no pós-Segunda Guerra Mundial. Encontra-se aqui mais uma manifestação do problema de uma origem profana do Direito, referida no início deste Primeiro Capítulo, tal qual indicada por Roberto Mangabeira UNGER (s.d., p. 10).

Em outras palavras, as disputas infindáveis no cosmos jurídico em torno de diferentes concepções de mundo também teriam encontrado lugar no pós-Segunda Guerra Mundial na discussão sobre o problema das instituições jurídicas preocupadas com a união da Europa. Teriam sido suscitadas neste momento original diferentes iniciativas independentes de conformação de uma Europa Unida: em torno da Economia (OECE), da Segurança (Pacto de Bruxelas), em torno de valores ocidentais europeus Modernos pretensamente universais $(\mathrm{CdE})$, ou em torno da Política (CECA)...
} 
camada singela do quesito "por meio de quais instituições" e deixaria de lado a perquirição em torno do "como".

\begin{abstract}
Os homens tampouco se reuniram para formar uma sociedade militar e se precaver contra as agressões, nem para estabelecer contratos e fazer trocas de coisas ou outros serviços. Caso contrário, os tirrenianos e os cartagineses e todos os outros povos que comerciam uns com os outros seriam membros de uma mesma Cidade. Eles possuem tratados redigidos por escrito, com base nos quais importam e exportam suas mercadorias, garantem-nas uns aos outros, prometendo defendê-las a mão armada. [...] Sua lei não é senão uma simples convenção de garantia [...]. (ARISTÓTELES, 1998, p. 54, grifos nossos).
\end{abstract}

É fundamental perceber que este trabalho supõe e estabelece uma distinção entre o perguntar pelas instituições e o inquirir em torno do modo foram elas instituídas. Ao perguntar "por meio de quais instituições" e "como", este estudo compreende que estes quesitos se referem a indagações próximas, mas de qualidades distintas, ou ainda, que elas apontam para um leque de perguntas relacionadas, porém não idênticas.

Nesse sentido, se se reduzisse a análise desta Tese de Doutorado à dimensão do "por meio de quais instituições", careceria este texto de originalidade metodológica. Bastaria detalhar as disposições normativas da CECA por meio de uma narrativa comentadora em prosa, seguindo método por outros já aplicado com maior ou menor grau de delimitação temática ou de investigação interdisciplinar sobre as instituições europeias posteriores à $\mathrm{CECA}^{79}$.

No entanto, ao dirigir seu arsenal reflexivo para tentar responder à pergunta de "como" foi possível o estabelecimento de uma aproximação inovadora entre determinados povos europeus no imediato pós-Segunda Guerra Mundial, e não depois deste período, esta investigação ganha outros contornos. Seu interesse detém marcante orientação histórica ${ }^{80}$.

79 Mencionem-se exemplificativamente tantos outros trabalhos, nacionais e estrangeiros: Elizabeth ACCIOLY (2003), Ricardo Thomazinho da CUNHA (2000), Líbia Cristiane Corrêa de Andrade e FLORIO (2002), Fredric JAMET (2011), Lukáš MACEK (2011), Paulo de PITTA E CUNHA (2004), Carlos Molina del POZO (2002, 2004, 2009, 2011a, 2012), André de Carvalho RAMOS (2005), José Blanes SALA (2002). A lista é de alcance interminável, e jamais passível de ser esgotada em uma singela nota de rodapé.

Destaque-se Paulo Borba CASELLA (1994a, 2002), quem analisara com grande profundidade, com especial atenção a dados históricos afeitos às instituições, os textos normativos das Comunidades Europeias e, posteriormente, da União Europeia. Mas não da CECA, em exclusividade.

${ }^{80} \mathrm{O}$ que diferencia este estudo pelo fato de eleger um fenômeno jurídico não mais atual como seu objeto exclusivo de interesse. Trata-se de buscar conferir dignidade histórica a um objeto de interesse jurídico, o que pretende evitar que sua menção se restrinja a uma impensada narrativa automática - o famigerado "rito de passagem" de uma suposta e leviana "visão histórica" em uma Pesquisa em Direito que, em poucas linhas, percorre apressadamente cinquenta ou sessenta anos -. Em outros termos, a História não se reduz a uma reprodução narrada de galeria sucessiva de fatos curiosos e de anedotas, posição esta que poderá ser mais bem compreendida quando da leitura do início do Quarto Capítulo desta Tese.

Ademais, os fatos que circundam a construção de qualquer objeto que detenha historicidade não podem ser tidos como se fossem plenamente conhecidos por todos. Não se está autorizado jamais a pensar de 
Não se trata apenas e tão-somente de buscar compreender de maneira minuciosa o texto jurídico-normativo do Tratado da CECA. Antes, trata-se de buscar ir além deste tecido normativo, para aferir sua qualidade. Esse traspassamento se mostra possível apenas mediante a aplicação de um específico método de análise institucional interpretativa associado a uma reflexão que reinsere este objeto em uma perspectiva histórica. Essa conjunção específica de pontos de partida viabiliza compreender esse complexo da experiência histórica e normativa da CECA conforme teia significativa original $^{81}$.

Para compreender a seleção da CECA como fenômeno privilegiado deste trabalho, há que se compreender a especificidade da pergunta inicial. É a precisa busca pela resposta a este "como" que exprime a razão da escolha desta Organização Internacional em detrimento das demais. A preocupação deste texto não reside simplesmente na compreensão das instituições desta Organização ("por meio de"), mas na compreensão conjunta dessas instituições com um elemento qualitativo distinto, a saber, o modo como foram tais instituições constituídas ${ }^{82} 83$.

Retoma-se ainda uma vez, de maneira resumida, a pergunta inicial deste trabalho: como e por meio de quais instituições países tradicionalmente opostos em termos bélicos foram capazes de estabelecer entre si, de maneira inaudita em sua História, um novo modo de relações. Há ainda um termo não esclarecido neste conjunto da pergunta, termo este que permitirá compreender de maneira mais precisa a preocupação portada pelo trabalho lado a lado com o "como": a indicação de ter havido a instauração de um "novo modo de relações".

Este estudo procura compreender como foi possível estabelecer por meio de instituições jurídicas um novo modo de relações entre determinados povos europeus. Mas o que seria precisamente este "novo modo de relações"?

antemão que as possibilidades de conhecimento em torno dele teriam se esgotado por completo, pois nunca se diz completamente algo sobre um fenômeno. Essa postura será mais compreendida nas linhas a seguir, principalmente nos itens 2.2.1. e 2.2.2., infra, onde se precisarão mais adequadamente os contornos dessa ideia de fenômeno assumida por este trabalho.

${ }^{81}$ Sobre o método de leitura assumido por este trabalho, remetemos o leitor ao Segundo e ao Terceiro Capítulos, infra. É pela inserção de um objeto de estudo em uma nova cadeia de fontes de perguntas que se pode encontrar a originalidade em qualquer investigação de caráter científico (WEBER, 2006, p. 37).

${ }^{82}$ Isto é, "como" e "por meio de" são perguntas que devem ser respondidas conjuntamente neste trabalho, ainda que se refiram a questões distintas.

${ }^{83}$ Tais colocações serão mais bem compreendidas quando da explicitação do método de leitura adotado por esta Tese no Segundo e no Terceiro Capítulos, infra, bem como quando de sua aplicação, no Sétimo Capítulo deste trabalho, também infra. 
É neste específico aspecto que se insere a preocupação deste trabalho: pretendeu-se investigar exclusivamente a construção histórica daquela Organização Internacional que, na primeira década subsequente ao término da Segunda Guerra Mundial, deteve a aptidão de instaurar um novo modo de relações entre determinados povos europeus. Encontrada esta Organização Internacional, a varredura analítica cessou seu movimento cronológico, e todo esforço investigativo foi dirigido para compreender verticalmente esta Organização Internacional. As demais foram mencionadas aqui na medida estritamente necessária para constituir o panorama histórico anterior à construção da CECA, ao passo que as posteriores não foram sequer examinadas de maneira mais profunda neste trabalho ${ }^{84}$.

A partir deste momento, torna-se mais fácil a compreensão do recorte metodológico efetuado neste trabalho: o "como" se refere a este "novo modo de relações", e este “novo modo de relações" guarda aqui um sentido bastante específico. Não se tratava simplesmente do condão de afastar a Guerra, mas de buscar fomentar, constituir e disseminar um sentimento de dependência entre cada um dos países europeus com relação a uma só e mesma comunidade - ou ainda, o sentimento de uma vida pública, comum, entre países europeus tradicionalmente opostos violentamente.

O modo "como" as instituições jurídico-normativas positivas são construídas tendo em vista o fim de instaurar uma vida comum é a "misteriosa virtude" pela qual se interessa este estudo. Elas teriam permitido a convivência de determinados países europeus culturalmente distintos e tradicionalmente opostos em termos bélicos dentro de um mesmo espaço comum. Neste novo modo de relações, todos teriam passado a participar do processo de formação de decisões e de normas jurídicas comuns, sem qualquer destaque de uma figura central e única sobre as demais ${ }^{85}$.

\footnotetext{
${ }^{84}$ Como se poderá ver a seguir, em virtude de se ter compreendido que apenas a CECA detivera a capacidade de instaurar este "novo modo de relações", nada mais além dela dentro do período de dez anos estipulado inicialmente foi ser analisado.

Nesse sentido, se a apresentação da OECE, do Pacto de Bruxelas e do CdE será efetuada durante a narrativa da construção histórica da CECA na Parte Segunda desta Tese de Doutorado - a fim de complementar o leque de informações laterais sobre a história da gênese da CECA, o mesmo não ocorrerá com a CED e com a CPE - tendo em vista terem sido propostas posteriormente à instituição da CECA. Afinal, o compromisso deste trabalho reside precisamente em compreender a primeira Organização Internacional apta a introduzir este "novo modo de relações" - o que só ocorreu seis anos após o fim da Segunda Guerra Mundial.

Tendo sido identificada a CECA como a Organização que desempenhara esta função, nada após ela será investigado - apesar do grande interesse histórico em torno da CED e da CPE, razão pela qual o marco temporal final do trabalho é precisamente 1951. Por esse motivo, fica aqui registrado o convite para futuras Pesquisas conjuntas sobre o período posterior à CECA.

${ }^{85}$ Perceba-se que, longe de pretender unificar os partícipes, a arquitetura jurídico-institucional do "novo modo de relações" que interessa a este trabalho fora desenhada conforme uma perspectiva voltada a promover a diversidade, a mantê-la em contato constante e a sua conservação por delimitações recíprocas. Uma ordem jurídico-Política poderia surgir deste conflito e dessa oposição, desde que por meio de normas
} 
O objeto desta investigação não é assim toda e qualquer ordem jurídica positiva que, expressa em instituições, instaurara uma Organização Internacional entre determinados países europeus.

O foco privilegiado deste estudo é precisamente aquela Organização Internacional que primeiramente no imediato pós-Segunda Guerra Mundial se expressou institucionalmente em normas jurídico-positivas orientadas para um novo modo de relações sustentado em uma nova maneira de se conceber o fundamento do Direito e do Poder $^{86}$. Ou ainda, este estudo se ocupa da Organização Internacional cujas instituições expressas em normas jurídicas positivas foram responsáveis - isto é, importaram - para construir uma ordem de convivência pública/comum entre diferentes - ou seja, para constituir uma organização jurídico-política das relações.

Mais simplesmente, quer-se compreender a construção histórica da primeira Organização Internacional europeia do pós-Segunda Guerra Mundial cuja ordem jurídicopositiva institucional fora concebida como fundada em Leis - pois o Direito positivo, por meio de suas normas, foi considerado como variável importante para o desenvolvimento de uma vida política entre diferentes usualmente opostos entre si. Afinal, o Direito pode apresentar mecanismos institucionais que favoreçam a construção de uma vida pública entre diferentes, na medida em que estabeleça diretrizes para a interação permanente entre tais diferentes continuamente opostos entre si.

Precisões adicionais são necessárias, a fim de compreender a última asserção.

\subsubsection{As Leis e o Direito: Distinções Fundamentais}

As Leis - determinantes do modo de organização jurídico-política do social - não se confundem neste trabalho com o Direito Positivo. A ordem estabelecida pelas Leis deve ser adequadamente diferenciada aqui da ordem jurídico-normativa positiva. As Leis consistem em regras, as quais detêm qualidade e finalidade distintas se comparadas com as do Direito, pois se voltam para fundamentar a racionalidade de articulação das normas

jurídicas de qualidade específica. Isso será mais compreendido a partir da leitura dos itens 1.4.3., 3.3.3.3, 3.4., bem como do Sétimo Capítulo deste trabalho, todos infra.

${ }^{86}$ Essa nova concepção sobre o fundamento do Direito e do Poder será melhor compreendida ao longo do presente texto, principalmente no item 3.4., infra, e no Sétimo Capítulo. No primeiro, será apresentada a chave hermenêutica adotada por este trabalho, ao passo que, no último, tal chave interpretativa será aplicada exaustivamente para compreender o Tratado da CECA. 
jurídicas positivadas - sejam elas normas de organização, ou normas de conduta ${ }^{87}$. É a presença de Leis que determina o conjunto de limites e de condições à definição do sentido do Direito e do Poder, ou ainda, que estabelece a estrutura e o funcionamento do Direito Positivo que determinada o entrelaçamento dos Poderes que interagem em conjunto para formar o sentido normativo destinado a reger a vida em comum.

Fundadas em uma determinada concepção sobre o fundamento do Direito e do $\operatorname{Poder}^{88}$, as Leis são elementos ordenadores que se diferenciam do Direito, mas que o estruturam de acordo com uma específica forma de compreender o mundo. Mais simplesmente: as Leis não são o Direito, com ele não se confundem, apesar de por meio dele parcialmente se expressarem.

Frise-se o seguinte aspecto: não sendo idênticas ao Direito, as Leis se manifestam por meio das normas jurídicas-positivadas e simultaneamente por meio do modo como são tais normas jurídicas articuladas.

Este modo particular de ordenação das normas jurídicas positivadas é dado por meio de regras que estruturam as relações entre os elementos normativos positivados, ou ainda, por meio de disposições não-ditas constitutivas de um sentido holístico do Direito Positivo. Tais disposições não-dadas imediatamente atribuem ao Direito Positivo uma qualidade específica, a qual apenas é compreensível mediante a consideração conjunta das normas jurídicas positivadas e dos modos de relações entre tais normas - isto é, mediante a compreensão conjunta do Direito Positivo e de suas respectivas Leis.

\footnotetext{
Note bem a diferença: uma sala de aula é um conjunto de elementos, as carteiras, a mesa do professor, o quadro-negro, o giz, o apagador, a porta etc.; todavia, esses elementos, todos juntos, não formam uma sala de aula, pois pode tratar-se de um depósito da escola; é a disposição deles, uns em relação aos outros, que nos permite identificar a sala de aula; essa disposição depende de regras de
}

\footnotetext{
${ }^{87}$ A distinção de normas jurídicas entre normas de organização e normas de conduta à qual se refere é a apresentada por Miguel REALE (2001, p. 96-7, grifos do autor), para quem as normas de conduta são aquelas "cujo objetivo imediato é disciplinar o comportamento dos indivíduos, ou as atividades dos grupos e entidades sociais", ao passo que as normas de organização são precisamente as que "possuem um caráter instrumental, visando à estrutura e funcionamento de órgãos, ou à disciplina de processos técnicos de identificação e aplicação de normas, a fim de assegurar uma convivência juridicamente ordenada.”.

Nenhuma distinção entre tipos de normas jurídicas é rigorosa, porquanto deriva de classificação que visa a determinado fim explicativo. Assim, qualquer classificação não encerra em si mesma a verdade ou a falsidade. Apenas indica um ou outro aspecto que determinado autor pretende enfatizar ou ressaltar sobre o fenômeno da norma jurídica.

Variam assim as classificações, conforme a perspectiva adotada por cada autor, sendo desnecessário pretender desenvolver ou detalhar qualquer classificação normativa quando este não é o objeto principal de uma investigação - como bem sinalizam Tercio Sampaio FERRAZ JR. (2001, p. 122) e Miguel REALE (2001, p. 97-9). Por esse motivo, apesar de se tratar de tema interessante, não será ele objeto deste estudo; do contrário, seria extrapolado o campo metodológico estabelecido para ele.

${ }^{88}$ Como poderá ser mais bem compreendido no item 3.4., infra.
} 
relacionamento; o conjunto dessas regras e das relações por elas estabelecidas é a estrutura. (FERRAZ JR., 2001, p. 172, grifos do autor).

As Leis existem em uma determinada sociedade como estrutura ordenadora de suas normas jurídico-positivas, ou ainda, as Leis são a dimensão de uma cultura jurídicopolítica específica que informa não apenas a positivação jurídico-normativa, mas o modo como tal positivação seria feita - sua lógica específica para a constituição de uma vida em comum.

As Leis não significam desta forma uma mera ordenação racional e sistêmica de um conjunto de normas jurídicas em um ordenamento (as Leis não são o Direito organizado em forma sistêmica) ${ }^{89}$. Elas fundam o ordenamento jurídico positivo e a organização de um modo de relação das normas deste, vale dizer, por meio de tais normas e por meio de tal modo de organização se expressam, mas não se confundem com eles. Ou se tem Leis, ou não se tem Leis - mas, nos dois casos, há o Direito Positivo. Quando as Leis estão presentes, o Direito Positivo tem suas normas jurídicas positivadas de um modo particular, distinto de quando não existem Leis: as normas jurídicas positivas

${ }^{89}$ Como se poderia inicialmente suspeitar de maneira equivocada, diante da sucinta referência feita acima a Tercio Sampaio FERRAZ JR. (2001, p. 172). Nesta passagem, o autor procura apresentar a ideia de que o Direito seria um ordenamento jurídico, um sistema. Por outro lado, o presente trabalho aponta para um elemento conceitual distinto, apesar de perpassar essa temática: as Leis fundam o ordenamento jurídico positivo e sua organização sistêmica, por meio deles se expressam, mas não se confundem com eles, e nem devem ser entendidas como sistema.

Com efeito, há que se lembrar de que a ideia de sistema aponta não apenas para a ideia de racionalidade, mas também para outros elementos que não são supostos na ideia de Leis. Para que uma ordenação racional seja denominada sistema, ela deve estar caracterizada por três elementos: (i) identidade; (ii) totalidade; e (iii) singularidade. A identidade é a ausência de contradição, a suposição de que há uma conexão do todo do sistema em caráter não contraditório; a totalidade corresponde, por sua vez, à ideia de que o sistema único e global deve ter capacidade total de explicação dos fenômenos singulares; e, por fim, a singularidade significa a aplicabilidade fecunda do sistema a casos concretos, conforme a coerência identitária suposta em todo sistema (FERRAZ JR., 1976, p. 161-2). Remetemos o leitor a esta última obra, caso se interesse pela temática da aplicação da ideia de sistema no Direito, sem pretender significar que, com isso, se incorporam neste trabalho as ideias daquele texto.

Como se poderá ver mais adiante, apesar de se compreender que as Leis introduzem uma organização coerente e ordenada das articulações jurídico-normativas positivas, é importante notar que não se trata de uma simples ordenação por racionalidade lógica conforme um sistema - pois as Leis não se confundem com o conceito de sistema do Direito.

Tratam-se as Leis precisamente de determinado modo de organização das normas jurídicas, o qual é manifesto por meio de regras não-ditas. Não são as Leis o simples conjunto das normas jurídicas positivadas ordenado racionalmente como se fosse um sistema coeso, coerente, racional, identitário, total e aplicável à singularidade. Pois, como dito acima, as Leis não se confundem com o Direito, ao passo que o sistema do Direito é, enfim, a rigor, Direito - mas um Direito organizado sistêmicamente. Na citação efetuada supra, empresta-se para este trabalho de Tercio Sampaio FERRAZ JR. (2001, p. 172), não a ideia de sistema, mas a de regras de relacionamento não-ditas entre as normas jurídicas positivas, ou ainda, simplesmente, a noção de estrutura.

Sabe-se que a distinção não é de todo clara, e nem tão simples, demandando sutilezas mentais e especificações posteriores. Não é objetivo deste trabalho detalhar a discussão de diferenciação entre sistema e Leis, razão pela qual se registra aqui o convite para futuras investigações em torno da temática. O texto principal da Tese pretende fornecer um pouco mais de indícios do sentido de Leis. 
estão dispostas, diante de Leis, para estruturar as regras fundamentais da vivência pública de diferentes, ou seja, para estabelecer as regras que constituam e mantenham uma vida comum entre eles.

Perceba-se que o termo "Leis" detém neste trabalho um campo de significação bastante especial. Não consiste em uma forma nova de nomear a ideia genérica de uma "racionalidade" informadora do ordenamento jurídico. Do contrário, em nada se inovaria no conhecimento sobre o Direito se se simplesmente apusesse um termo sinônimo desprovido de potencial interpretativo distinto.

Ao afirmar que este estudo se importa somente com a Organização Internacional que se expressou por meio de ordem jurídico-positiva institucional forjada de acordo com Leis, quer-se dizer que se preocupa aqui com uma forma determinada de estruturação das relações normativas estipulada pelo Tratado Internacional daquela Organização: uma estruturação responsável por uma organização jurídico-política das relações, isto é, responsável pela organização de uma vida comum e dos modos de se decidir normativamente sobre o destino desta - organização, instauração ou invenção e manutenção do político entre diferentes, a qual foi feita por meio de instituições jurídiconormativas positivadas.

Em outras palavras, o esforço investigativo deste trabalho se direcionará para compreender as normas jurídicas positivadas ${ }^{90}$ daquela experiência de aproximação entre países europeus que assumiu um contorno específico ${ }^{91}$ - contorno esse derivado do fato de esta organização ter se regido estruturalmente por Leis, isto é, por ter se orientado a construir uma vida comum.

É necessário precisar aqui o sentido que se atribui à noção de Leis.

Como afirmado supra, as Leis não são simplesmente uma racionalidade de organização de normas jurídicas: elas cumprem uma função ordenadora, mas a realizam de acordo com determinadas premissas. Isso quer dizer que as Leis não apenas se expressam por normas jurídicas positivas, mas também (i) determinam regras de estruturação de normas jurídicas positivadas, e (ii) orientam tal estruturação para que ocorra de determinado modo, isto é, conforme determinada concepção de mundo. As Leis detêm assim uma dupla significação.

\footnotetext{
${ }^{90}$ De maneira a compreender o "por meio de quais instituições".

${ }^{91}$ De maneira a compreender o "como".
} 
Quando se fala em Leis neste trabalho, há que se efetuar uma distinção entre dois registros reflexivos ${ }^{92}$, a saber, (i) Leis em sentido formal, vale dizer, o que se pretende designar puramente com a noção de Leis ${ }^{93}$, e (ii) Leis em sentido material, ou melhor, qual qualidade ou espécie de Leis se está enfatizando ${ }^{94}$. Tratam-se de perfis distintos, porém intimamente relacionados, do mesmo fenômeno "Leis". São partes distintas, mas

92 Ressalte-se desde já que a distinção é meramente didática, a fim de permitir a compreensão de dois planos reflexivos distintos, porém simultâneos, referentes à noção de Leis. Nesse sentido, v. considerações mais adiante.

93 Isto é, a noção de Leis desprovida de qualquer conteúdo que as qualifique em um sentido ou em outro.

${ }^{94}$ Frise-se que esta distinção entre Leis em sentido formal e Leis em sentido material em nada guarda relação com a tradicional distinção do senso comum jurídico brasileiro entre lei em sentido formal (meio introdutor de normas jurídicas derivado de órgão competente para realizar o processo legislativo) e lei em sentido material (temática regulamentada que deteria supostamente essência de lei) - o que explica e justifica a preferência em utilizar o termo Leis no plural, e com um "L" maiúsculo.

"Resumidamente, podemos distinguir, então, entre leis materiais, isto é, leis caracterizadas por sua natureza (produção solene e institucionalizada de normas gerais) e leis formais ou caracterizadas pela forma (conteúdos que adquirem o caráter de lei porque obedecem a sua forma de produção). Essa distinção entre lei material e lei formal, porém, não é uniformemente usada pela doutrina. [...] Segundo Limongi França [...] ao que parece, essa distinção, que perdura na linguagem do senso comum jurídico, foi definida por Bartolo, chefe-escola dos pós-glosadores.” (FERRAZ JR., 2001, p. 231).

Com a distinção supramencionada, este trabalho quer apenas enfatizar perfis distintos segundo os quais se pode perceber o mesmo fenômeno jurídico-político das Leis. Não se refere este estudo a quaisquer dos objetos que possam ser encontrados nas duas classes de lei (formal ou material) apontadas pela literatura jurídica brasileira. Afinal, como afirmado supra, as Leis não se confundem com o Direito Positivo - e a distinção entre lei material e lei formal se baseia em uma concepção de ordem jurídico-normativa posta.

O termo "Leis" utilizado por este trabalho recebe significação distinta. O recurso a este vocábulo deriva de remissão expressa e consciente à obra homônima de PLATÃO (1980), onde o autor trata do tema da melhor Cidade possível em um mundo humano - diferentemente do que visa o autor em sua República (2006), onde trata da Cidade ideal, Governada pelo rei-filósofo -. A noção de Leis adotada por este estudo está fundamentalmente ancorada na tradição do pensamento da Filosofia Política Antiga de PLATÃO e ARISTÓTELES: Leis como normas da vida social - e, portanto, não apenas normas jurídicas positivas - que pretendem instaurar a vida Pública e garantir a permanência dela (BITAR, 1980, p. 14).

Não se pretende afirmar com isso que os autores clássicos da Filosofia Política Antiga efetuaram de maneira expressa uma distinção conceitual entre Leis em sentido formal e Leis em sentido material. Há aqui a apresentação de uma leitura que busca construir a partir das palavras destes autores - os quais pensaram o tema das Leis e o da relação destas com o melhor Governo - tal distinção. Trata-se de uma reflexão sintética sobre o pensamento desenvolvido por tais autores, e não uma impensada incorporação analítica de suas contribuições ao presente trabalho.

De todo modo, a assunção dessa perspectiva aponta para (i) a desvinculação do campo significativo atribuído ao termo Leis (em sentido formal e em sentido material) com relação à diferenciação tradicional desenvolvida no interior do senso comum da literatura jurídica brasileira entre lei em sentido formal e lei em sentido material (como apontado acima); (ii) a necessidade de precisar o campo significativo segundo o qual se utiliza o termo Leis (a ser feito nos próximos dois itens, 1.4.2. e 1.4.3.); e (iii) a necessidade de esclarecimento dos aspectos metodológicos da interdisciplinaridade assumida por esta Tese de Doutorado, o que será desenvolvido nos itens 2.2., infra.

Aliás, por derradeiro, é importante lembrar que a tentativa de compreender jurídico-politicamente o processo de integração da Europa a partir das contribuições da Filosofia Política Antiga não é exclusividade deste estudo. Com efeito, ainda que voltada a compreender a questão da cidadania europeia no interior da UE de hoje, é relevante mencionar a iniciativa teórica de Thomas RICHTER; Rainer SCHMIDT (2011), em sua Introdução à obra coletiva por eles organizada sobre temas relacionados à Integração e Cidadania Europeia. Em seu texto, os autores desenvolvem reflexão jurídico-política em torno da noção de cidadania na Europa a partir do pensamento antigo sobre a cidadania. Temática que, interessante, extrapola os limites metodológicos deste texto, haja vista que a cidadania europeia não era prevista no Tratado da CECA. De todo modo, fica aqui mencionada aplausibilidade acadêmica já intentada por outros de pensar questões contemporâneas da Europa a partir de referencias da Filosofia Política Antiga. 
que estão internamente referidas, uma remetendo imediatamente à outra, sem que uma por si só esgote por completo o sentido de "Leis".

Evidencie-se que apenas se pode falar em Leis em sentido material (qualidade) se houver antes Leis em sentido formal a serem qualificadas (materialmente). E vice-versa. Em outras palavras, ou não existem Leis (e existe apenas o Direito Positivo), ou existem Leis (isto é, existe o Direito Positivo, sendo este Direito Positivo organizado de determinado modo, a fim de instaurar uma vida Pública comum entre diferentes ${ }^{95}$. E, na hipótese de haver Leis, elas sempre deterão uma qualidade em especial, vale dizer, elas sempre terão sido instituídas de determinado modo.

As Leis sempre serão formais e materiais simultaneamente. A distinção aqui detém finalidades meramente didáticas, pois forma e matéria são apenas perfis complementares segundo os quais se pode compreender o termo "Leis", pois é impossível falar em Leis sem que sejam uma forma provida de uma qualidade.

Não se tratam assim de entidades distintas e passíveis de separação: as Leis se manifestam sempre simultaneamente em termos formais e materiais, não havendo Leis formais que não detenham uma substância que as qualifique. Somente não se poderá falar sobre Leis em sentido material se não houver Leis em sentido formal - isto é, se não houver em absoluto quaisquer Leis. Como todo corpo extenso, que detém cor, tamanho, formato.

Perceba-se que se trata apenas de uma alteração da posição reflexiva para compreender as Leis. A oscilação entre Leis em sentido formal e Leis em sentido material deriva assim apenas do modo como são elas percebidas, ou ainda, da intencionalidade segundo a qual se dirige a reflexão sobre as Leis. Em vez de se analisar as Leis apenas sob uma relação meramente formal, procura-se examiná-las também sob outra perspectiva ${ }^{96}$, a saber, uma perspectiva material.

As Leis são assim uma e mesma coisa, ainda que possam ser olhadas a partir de diferentes perspectivas e explicitadas em termos de um perfil formal ou de um perfil material. Não há Leis que não sejam formais e materiais simultaneamente. $O$ que varia é simplesmente a lente de análise sobre este fenômeno ${ }^{97} 98$. São partes que se

\footnotetext{
95 Isto é, ou há uma relação de união política de convivência entre diferentes - institucionalmente estabelecida por normas jurídicas positivas (organização jurídico-política do social/Leis), ou não há tal predisposição institucional (coexistência ou cooperação) - instituições jurídico-normativas positivas não preocupadas com a organização de uma vida Pública (não existe organização jurídico-política do social/não existem Leis). Essa asserção restará mais clara a partir das considerações do item 1.4.2., infra.

${ }^{96}$ A qual não anula a anterior, mas a complementa.

${ }^{97}$ Sobre fenômeno, v., nesse sentido, as considerações desenvolvidas no item 2.2., infra.
} 
referem intimamente entre si e ao mesmo tempo ao todo, da mesma maneira que a elas se refere o todo, simultaneamente.

Quando se fala em Leis, fala-se concomitantemente em uma organização da vida pública entre aqueles que a ela se sujeitam (sentido formal) e em uma tal organização de determinada qualidade (sentido material). Tudo depende da maneira como se preenche o conteúdo dessas Leis; todavia, uma vez presentes as Leis, necessariamente haverá estruturação institucional de normas jurídico-positivas voltadas a instaurar uma vida Pública.

\subsubsection{As Leis Percebidas sob uma Perspectiva Formal}

Compreender as Leis em sentido formal é compreendê-las sob uma perspectiva pura, isto é, trata-se de entender as Leis sem qualquer qualidade de conteúdo em especial. As Leis seriam simplesmente uma estruturação jurídico-política das relações conforme uma determinada concepção sobre o fundamento do Direito e do Poder - ainda que esta concepção não tenha sido materialmente individuada. Sua preocupação é apenas a de instaurar formalmente um centro nomogenético minimamente compartilhado para determinar o sentido normativo da vida em comum.

As Leis puramente consideradas são aquilo que atribui uma forma jurídico-política a uma sociedade ${ }^{99}$, pois elas estabelecem simplesmente que seus participantes devem conviver entre si em um espaço comum e que de alguma forma definam o sentido normativo destinado a reger tal vida comum. Estes não são convidados a dele participar; antes, são institucionalmente postos, forçados por normas jurídicas positivadas a manter relações neste ambiente compartilhado. Se não houver Leis, não haverá instituição por meio de normas jurídico-positivas de uma vida comum.

\footnotetext{
${ }^{98}$ Essa inseparabilidade de Leis percebidas em sentido formal e Leis percebidas em sentido material explica porque, nos itens a seguir, em alguns momentos se mencionam as Leis em sentido material quando se aborda o tema das Leis em sentido formal, da mesma maneira que se mencionam as Leis em sentido formal, quando se versa sobre as Leis em sentido material.

A preocupação consistiu em tentar determinar esses dois perfis de maneira didaticamente distinta, apesar de estarem íntima e inevitavelmente imbricados esses dois modos de se posicionar com relação ao fenômeno das Leis. A divisão das Leis nesses dois perfis permite, todavia, que haja o afastamento do interior do campo de análise deste estudo, tanto da OECE e do Pacto de Bruxelas, como do CdE. Como será mais bem compreendido nas linhas a seguir.

${ }^{99}$ Frise-se que essa característica sempre se apresenta quando se tem Leis, ainda que não tenha sido definido seu conteúdo material.
} 
Do fato de as pessoas habitarem o mesmo lugar não se segue que se trata de uma única e mesma Cidade. Os muros não podem servir de critério, pois todo o Peloponeso poderia ser cercado por uma mesma muralha. Não seria a primeira vez que vastos espaços seriam assim fechados. (ARISTÓTELES, 1998, p. 199, grifos nossos).

As Leis em sentido formal instauram normas para uma vida social comum e pretendem garantir por meio de instituições jurídicas positivas a permanência desta vida Pública a partir de determinada concepção sobre o fundamento do Direito e do Poder. De acordo com a maneira que se concebe tal fundamento, despeja, enquanto fonte, regras nãoditas que articulam instituições jurídico-normativas positivas, de maneira a estabelecer uma organização jurídico-política das relações (LEFORT, 1991).

Perceba-se que são as Leis que promovem a aproximação de povos distintos. Elas permitem que estes possam se identificar consigo enquanto partícipes de um mesmo sistema de convivência jurídico-político. É a precisa presença de diferentes escalas de existência e de valores costumeiramente constituídas e a exata potencialidade de conflitos sangrentos e mutuamente destrutivos entre tais escalas que justifica "o começo da legislação" (PLATÃO, 1980, p. 85).

É a precisa coexistência de diferentes escalas de existência e a incontornável necessidade constatada de convivência entre elas que clamam pela necessidade de Leis: afinal há a possibilidade de as tensões escalares significarem exponencial e interminável carnificina - o que justifica o estabelecimento de regras de ordenação das relações que permitam instaurar um modo de vida comum entre tais diferentes formas de habitar o mundo. É a presença de Leis que atesta a existência de uma comunidade política - de uma polis, detendo a capacidade de

\footnotetext{
mudar, por assim dizer, a natureza humana; de transformar cada indivíduo, que por si só é um todo perfeito e solitário, em parte de um todo maior do qual esse indivíduo recebe de alguma maneira sua vida e seu ser; de alterar a constituição do homem a fim de reforçá-la; de substituir por uma existência parcial e moral a existência física e independente que todos nós recebemos da natureza. É mister, numa palavra, que [elas] subtraia[m] do homem suas próprias forças para lhe dar forças que lhe são estranhas e das quais não pode fazer uso sem o auxílio de outrem. (ROUSSEAU, 2000, p. 60, grifos nossos). ${ }^{100}$
}

100 A citação de Jean-Jacques ROUSSEAU (2000) pode figurar estranha em um primeiro momento, na medida em que na nota de rodapé 94, supra, afirmara-se que a reflexão sobre as Leis neste trabalho partiria da tradição da reflexão da Filosofia Política Antiga de PLATÃo e ARISTÓTELES.

Todavia, a citação é justificada. Não apenas ela opera linguisticamente como veículo de discurso que quase perfeitamente se adequa ao que se pretende aqui dizer sobre as Leis percebidas sob um sentido formal. Antes, não se pode ignorar existir um diálogo intenso entre a reflexão política proposta pelo autor francês e a desenvolvida no interior do pensamento filosófico da Antiguidade, como bem sinaliza Sérgio CARDOSO (2004, p. 50): "Rousseau repõe e renova [...] os traços fundamentais da antiga politeia". 
Em outras palavras, são as Leis as responsáveis pelas regras que estruturam a Cidade como tal ${ }^{101}$, ou seja, são elas que tornam admissível e possível o encenar de uma vida Pública entre povos tradicionalmente opostos entre si em termos culturais e potencialmente em constante conflito armado. A presença de Leis permite que haja uma estabilidade $^{102}$ na Cidade, pois informam instituições voltadas a modificar o modo de relações entre os Homens em um mesmo espaço para que comunguem socialmente condições jurídico-políticas - isto é, para que se unam politicamente ${ }^{103}$.

Com efeito, sem necessariamente os unificar, as Leis estipulam regras de articulação das normas jurídico-positivas com o objetivo de estabelecer institucionalmente um sistema de convivência comum que una os diferentes conforme uma determinada concepção de organização jurídico-política. As Leis estabelecem uma ordem que torna possível um determinado modo de viver público na Cidade - viver este traduzido por meio de instituições jurídicas desenhadas conforme as Leis ${ }^{104}$.

As Leis organizam a polis, elas "modelam as almas" de seus participantes (PLATÃO, 1980, p. 73-4 e 118) para que estabeleçam entre si relações distintas da de um mero agrupamento de seres humanos auto-interessados. Em outras palavras, as Leis são informadas por uma virtude política e estruturam as instituições jurídico-normativas segundo esta orientação virtuosa, de maneira a conservar nesse agrupamento humano tal virtude - de fazer conviver os diferentes em torno de destino comum - o tanto quanto possível (PLATÃO, 1980, p. 155). As Leis existem não apenas para instituir a polis, mas também para a conservar enquanto regime de vivência pública entre diferentes (ARISTÓTELES, 1998, p. 231 e 241).

Note-se que é a presença ou a ausência de Leis que permite atestar a existência ou a ausência de um modo de relações político fundante de uma estrutura jurídico-normativa institucional promotora da convivência constante entre seus partícipes. Isso deriva do fato de serem as Leis precisamente aquilo que confere uma forma unida a Homens distintos,

\footnotetext{
${ }^{101}$ Como união jurídico-política de povos distintos; unidos, mas não necessariamente unos ou unificados.

102 Ainda que tal estabilidade possa ser conflituosa, como será mais facilmente perceptível a partir da leitura do item 3.4., infra, onde se desenvolvem considerações em torno da chave hermenêutica deste estudo.

103 Ainda que união não signifique unificação do corpo social: unidos, mas não necessariamente unos ou unificados. Isso depende de como as Leis são materialmente qualificadas em cada situação específica. Nesse sentido, v. o item a seguir, sobre as Leis percebidas em sentido material.

${ }^{104}$ Este determinado modo de viver na Cidade é determinado por uma escolha sobre o conteúdo que preencherá materialmente as Leis. Isso será mais bem compreendido a partir da leitura das linhas a seguir, quando tratarmos das Leis em sentido material.
} 
pois elas conferem formalmente uma figura de união jurídico-política entre os elementos associados (ARISTÓTELES, 1998, p. 168).

Em outras palavras, são as Leis o elemento fundamental instituidor de uma politeia, isto é, de uma organização social, por meio de normas jurídicas positivas voltadas a uma vida em comum, ou simplesmente, direcionadas a um regime político (CARDOSO, 2002, p. 31 ${ }^{105}$. São elas que promovem uma união política entre diferentes ${ }^{106}$.

${ }^{105}$ Lembre-se, nesse sentido, que há uma confusão inicial quando se refere ao termo "político", uma vez que, derivado do grego politeia, indica simultaneamente não apenas "o gênero dos regimes políticos[, mas também] uma de suas formas específicas, aquela, justamente, cuja disposição excelente para a realização de sua natureza política, permite assinalá-la com a denominação do gênero." (CARDOSO, 2002, p. 31).

Essa confusão deriva da dificuldade de traduzir para a atualidade e para idiomas Ocidentais Modernos as expressões do grego clássico - as quais são imprescindíveis e devem ser utilizadas sempre que se pretende falar de política. Afinal, “[j]á se conseguiu dizer que a filosofia fala grego. É possível. Em todo caso, é certo que a política, sim, fala grego. Não se pode, com efeito, falar de política sem a língua grega: 'tirania', 'monarquia', 'oligarquia', 'aristocracia, 'plutocracia', 'democracia'... todo o nosso vocabulário político saiu dela. E, em primeiro lugar, a própria palavra política. A palavra tanto quanto a coisa. [...]. A política é a prática da polis que se tornou consciente de si própria, ou, inversamente, a investigação sistemática aplicada à polis. É, numa palavra, o livre pensamento de uma vida livre." (WOLFF, 1999, p. 7 , grifos do autor).

O cuidado desta nota de rodapé é, todavia, redobrado. Afinal, as precisões terminológicas são ainda mais necessárias quando um trabalho - como o presente - tem pretensões interdisciplinares. Com efeito, mostra-se ainda mais fundamental buscar demarcar um campo de significações dos termos empregados, a fim de limitar potenciais mal-entendidos e discussões estéreis que poderiam atrapalhar a discussão da proposta por este texto. Neste sentido, sobre a importância de precisões terminológicas, remetemos à leitura da Introdução Parcial desta Parte Primeira, supra.

De todo modo, note-se que se preocupa aqui em indicar que a existência de Leis instaura politeia, ou seja, que não há um regime de convivência entre Homens diferentes que possa ser qualificado de político se não houver Leis; isso implica reconhecer que, neste momento do trabalho, utiliza-se o termo "político", Cidade ou politeia, em seu significado mais genérico, a saber, o de um tipo de regime (o regime político) (CARDOSO, 2002, p. 31).

Mais adiante, no item 3.4., infra, referir-se-á ao Político, em oposição ao Teológico-Político, conforme distinção teórica estabelecida por Claude LEFORT (1991). As especificações terminológicas necessárias serão feitas oportunamente. Quando do item 3.4., restará mais claro que a noção de Política à qual se recorre será distinta desta de regime político. Politeia designará o gênero de regimes políticos, isto é, de um sistema de convivência entre diferentes (presença de Leis em sentido formal), ao passo que a noção de Política se referirá à espécie de regime político cuja disposição de maneira mais perfeita realiza a "politicidade", ou melhor, este regime de convivência em comum entre diferentes (uma específica designação material qualificativa das Leis).

Nesse sentido, saliente-se desde já que, neste trabalho, quando se referiu e se refere ao regime político em sua generalidade, utilizaram-se e utilizam-se os termos politeia, "político" (com "p" minúsculo) e Cidade, ao passo que, ao se referir a uma qualidade específica de regime político de convivência plural permanente (como será compreendido melhor a partir da leitura do item 3.4., infra), utilizara-se e utiliza-se o termo "Político" (com "P" maiúsculo), em oposição ao "Teológico-Político" (convivência plural unificadora).

Isso permitirá concluir, como se poderá perceber quando da leitura da chave hermenêutica deste trabalho, que todo regime jurídico-Político ou jurídico-Teológico-Político é um regime jurídico-político (é politeia), mas que nem todo regime jurídico-político (politeia), é um regime jurídico-Político - pois pode ser jurídico-Teológico-Político.

Aqui opera a distinção entre Leis percebidas em sentido formal e Leis percebidas em sentido material: uma organização jurídico-política do social é uma politeia (há Leis em sentido formal), mas ela detém uma determinada qualidade (Política ou Teológico-Política), conforme seu regime jurídicopolítico seja qualificado materialmente por suas Leis como voltado, ou não, a uma convivência plural permanente. 
As Leis são a condição formal de instauração de um sistema de convivência entre diferentes organizado institucionalmente por meio de normas jurídico-positivas. Elas criam um sentimento de dependência com relação a uma mesma coisa, a qual é entre todos igualmente compartilhada. As Leis percebidas em seu sentido formal constituem o "terreno político", o campo do "comum", isto é, fundam o conjunto das "“atividades e práticas que devem ser partilhadas, isto é, que não devem ser o privilégio exclusivo de ninguém.'” (WOLFF, 1999, p. 10-1, grifos do autor).

As Leis estabelecem uma disciplina comum, regras que orientam as instituições jurídico-normativas positivadas para fundar e conservar uma vida em comum equilibrada e harmoniosa entre diferentes, para que se mantenha uma coesão de grupo jurídicopoliticamente unido. Sem Leis, não há como haver politeia, isto é, não há como instaurar uma união política, ou seja, uma união promovida por meio de instituições jurídicas

Por derradeiro, observe-se que nem o jurídico-Político, nem o jurídico-Teológico-Político, são desprovidos de politicidade (de politeia), na medida em que são espécies do gênero de regimes políticos (são, em termos mais simples, políticos), ainda que com contornos distintos dados por suas Leis, na estruturação de suas respectivas ordens jurídico-normativas positivadas.

Essas considerações restarão mais claras quando da leitura do item 3.4., infra; mostra-se importante apenas reter por ora essa distinção, pois facilitará a compreensão dos próximos passos da reflexão deste texto - os quais não apenas viabilizarão o destacamento da CECA com relação às demais Organizações Internacionais (OECE, Pacto de Bruxelas e $\mathrm{CdE}$ ), como também facilitarão a compreensão da chave hermenêutica do item 3.4., infra.

106 Compreender a CECA como uma Organização Internacional cujo ordenamento jurídico positivo fora instituído por Leis, isto é, no sentido de promover uma união política de seus participantes, entreabre a possibilidade de atribuir a esse processo de integração um significado jurídico dotado também de contornos políticos. A CECA poderia portar consigo também um profundo significado de integração jurídico-política, e não apenas econômica.

Ainda que essa asserção reste mais bem esclarecida a partir da leitura dos itens 2.1. e 2.2. e do Terceiro Capítulo, infra, é importante mencionar que a proposta de leitura política da CECA desenvolvida por este trabalho é ligeiramente diversa daquela segundo a qual se pauta a tradição do pensamento jurídico brasileiro. Lembre-se aqui da existência, na literatura jurídica brasileira, de estudo mencionando a preocupação em compreender a integração política europeia (RAMOS, 1996).

Essa concepção de político difere daquela adotada pelo presente trabalho: naquele estudo, restringese a dimensão da integração política da Europa a aspectos de política externa e de segurança comum, procurando compreender historicamente as propostas de integração de estratégias de defesa em nome de uma mais ou menos profunda cooperação militar (RAMOS, 1996, p. 646-8), tais como o Pacto de Bruxelas, a OTAN, a CED e a UEO.

Também se deve frisar que igualmente longe se encontra o uso do termo "político" por este trabalho da noção singela de que "todo acordo entre Estados envolve um forte componente político" (RAMOS, 1996, p. 647), isto é, de que todo acordo entre Estados é político por ser produto de barganha diplomática. A noção de político aqui também se afasta da ideia de que seria política CECA por simplemente haver o comprometimento das soberanias originais de seus membros por força de compromissos internacionalmente assumidos (COSTA, 2001, p. 44).

O político, aqui, não se refere a este aspecto de negociação como política (ou vulga "politicagem”) diplomática, típico do paradigma do Direito Internacional de coexistência (v., nesse sentido, a nota de rodapé 2, supra). Nesta Tese, indica-se o político como o modo de fazer conviver diferentes escalas de existência (CARDOSO, 2004, p. 50; VERNANT, 1981, p. 71-2). Sobre as concepções de político e de Político adotadas pelo presente estudo, indicamos a leitura da nota de rodapé 105, supra, bem como da integralidade do item 3.4., infra. 
positivas em uma vida em comum - em uma polis (ARISTÓTELES, 1998, p. 41, 53-6, 105, 126, 164 e 199-200).

Nesse sentido, Homens sob a regência de mesmas Leis são Homens jurídicopoliticamente unidos, isto é, são Homens sujeitos a um mesmo sistema de convivência entre diferentes (Homens que vivem em uma mesma Cidade, ou ainda, em uma mesma polis). Essa união não necessariamente unificadora ${ }^{107}$ estabelece uma convivência que se manifesta por normas jurídicas positivas, as quais determinam a própria necessidade deste conviver $^{108}$.

Estar sob as mesmas Leis não significa simplesmente estar sob o mesmo Direito Positivo. A vida comum em uma união política não deriva do simples fato de se estar sujeito a um mesmo conjunto de normas jurídicas positivadas. É possível haver a previsão de instituições comuns por meio de normas jurídicas positivas; todavia, tais normas podem não estabelecer uma forma de organização jurídico-política das relações entre seus partícipes.

Se é necessário que as Leis se expressem por meio de normas jurídicas, a reunião política de uma multidão de diferentes por meio do Direito Positivo apenas ocorre quando

${ }^{107}$ A tendência à unificação ou não depende da maneira segundo a qual se estabelece um conteúdo destinado a preencher as Leis em sentido formal, como se poderá perceber mais adiante.

${ }^{108}$ Perceba-se a sutileza dessa afirmação: o espaço comum no interior do qual convivem diferentes é constituído institucionalmente por meio das normas jurídico-positivas, não existindo antes desse momento fundador. A necessidade de convivência entre diferentes (sempre de determinado modo) é assim determinada pelas instituições jurídico-normativas positivas, não preexistindo a essa fundação jurídico-positiva do comum. É por isso que, inclusive, se diz neste trabalho ser a fundação jurídica da CECA o marco de estabelecimento de um novo modo de relações entre países europeus, o qual é passível de uma leitura jurídico-política.

Apesar de parecer uma observação de caráter exclusivamente teórica, essa distinção produz consequências interessantes para compreender o fenômeno estudado por esta Tese. Recusa-se com isso a fácil atribuição da formação de uma Comunidade politicamente unida a entidade terceira, externa e estranha a ela (à "necessidade"), ou em nome da qual ela teria se formado (à "Paz", à "Segurança", à "Economia", à "civilização").

No pensamento jurídico brasileiro, usualmente se aponta a obediência servil por parte dos povos europeus a uma imaginada necessidade como a "causa" originária da CECA e das demais Comunidades Europeias, ou mesmo a Paz, a Segurança ou a Economia (MENEZES, 2000a, p. 54, 2000b, p. 734; RAMOS, 1996, p. 648, 2005, p. 49; VEÇOSO, 2006, p. 32). Afinal, “o carvão e o aço naquela época eram setores fundamentais para qualquer indústria bélica” (RAMOS, 1996, p. 648).

Todavia, pretende-se apontar neste estudo para a possibilidade de compreender a alteração do modo de relações entre países europeus promovida pela CECA (coexistência para convivência) diante de uma modificação da maneira segundo a qual cada um dos partícipes do processo de integração se autocompreendeu politicamente implicado com o outro. As instituições teriam sido o produto dessa reformulação comum da consciência de cada um dos seis países-membros da CECA sobre a maneira como deveriam se posicionar entre si perante questões concretas sensíveis comuns. Teria sido produto de convicção residente entre tais povos europeus que procuraram se unir, vale dizer, de elemento a eles interno.

Apesar de esta construção permanecer nebulosa, ela fará mais sentido à medida que avançar a leitura do presente texto. Para compreender as instituições como instrumentalização prática de fins socialmente relevantes, remetemos o leitor ao item 3.2., infra. A importância dessa distinção entre um fundamento interno e um fundamento externo da união política promovida entre diferentes restará mais clara a partir da leitura da chave hermenêutica delineada no item 3.4., infra. 
este unir é realizado conforme regras que permitam instaurar e conservar uma vida comum entre tais diferentes anteriormente em conflito - isto é, a união não necessariamente unificadora se revela como sendo política quando este unir por meio do Direito Positivo se dá conforme Leis.

As Leis efetuam dessa forma uma organização pública das relações entre diferentes. Elas instauram uma vida comum entre seus partícipes, todos e cada um deles convivendo com o outro para atuar em vistas da preservação do todo politicamente unido - pois, afinal, sem estas Leis, a relação entre diferentes poderia se pautar apenas por uma lógica de solução armada de conflitos. Esta é a misteriosa virtude e o grande desafio - de uma união política entre diferentes:

como a ordem pode nascer do conflito entre grupos rivais, do choque das prerrogativas e das funções opostas? Como uma vida comum pode apoiar-se em elementos discordantes? Ou - para retomar a própria fórmula dos Órficos como, no plano social, o uno pode sair do múltiplo e o múltiplo do uno? (VERNANT, 1981, p. 31).

Perceba-se que a união política orientada por Leis não elimina o conflito, mas o traduz em termos institucionais - pois os polos são absorvidos pelas instituições. Persistindo a oposição, os conflitos são desenvolvidos em tensões a serem solucionadas por meio das instituições da polis - as instituições políticas. Afinal, é a política que se revela como o lugar em que se decide o Poder (WOLFF, 1999, p. 12): não se instaura a Paz, mas a solução de conflitos e tensões permanentes por meio da estabilidade harmoniosa das instituições, constituída e conservada por normas jurídicas positivas.

Perceba-se que essa integração de cada um dos oponentes em uma vida pública comum ocorre a partir de determinada concepção sobre o fundamento do Direito e do Poder - a qual qualifica materialmente as Leis em um sentido ou em outro.

Diante dessas considerações, é possível compreender a primeira razão em virtude da qual a OECE e o Pacto de Bruxelas foram excluídos da análise deste trabalho. Com efeito, dentre as quatro iniciativas desencadeadas no período, apenas as ordens jurídicas dessas duas se revelavam como tendo sido forjadas desprovidas de um fundamento em Leis $^{109}$.

\footnotetext{
109 Perceba-se, nesse sentido, que a partir dessa consideração, ainda não se mostra possível justificar a retirada do $\mathrm{CdE}$ do arco de questões deste trabalho. $\mathrm{O}$ afastamento desta última Organização Internacional restará mais claro a partir da leitura do próximo movimento lógico do texto: se o CdE - como a CECA apresentava deter Leis, não seriam as do CdE caracterizadoras de um modo de relações Político (aqui, com "P” maiúsculo) entre alguns países europeus. Esse qualificativo restará mais claro a partir da leitura do item
} 
Antes de tudo, é fundamental reconhecer que a OECE e o Pacto de Bruxelas representaram inegável mutação da qualidade das relações entre seus países-membros por meio de suas respectivas instituições jurídicas ${ }^{110}$. A OECE e o Pacto de Bruxelas expressariam a assunção de uma perspectiva de cooperação entre seus países membros, vale dizer, seriam representantes do abandono da antiga lógica de coexistência ${ }^{111}$ : a primeira sob uma perspectiva econômica ${ }^{112}$, a segunda, sob uma perspectiva militar $^{113}$ (VEÇOSO, 2006, p. 29 e 31).

Note-se, desde já, que tanto a OECE como o Pacto de Bruxelas se trataram de exigências forjadas no interior de uma dinâmica internacional advinda da exterioridade da Europa. Ambas eram soluções da estratégia geopolítica estadunidense de contenção de uma possível influência da União das Repúblicas Socialistas Soviéticas (URSS) sobre a Europa Ocidental - a primeira seria uma solução econômica, ao passo que a segunda operaria como solução militar. De origem externa à Europa, não poderiam jamais ter se orientado no sentido de constituir Leis ${ }^{114}$.

A Organização Europeia de Cooperação Econômica (OECE) tem origens em proposta estadunidense formulada a partir do discurso do Presidente estadunidense Harry TRUMAN, proferido em março de 1947 diante do Congresso dos EUA. Seu objetivo era condicionar o recebimento do auxílio econômico pelos países da Europa sob a égide do Plano Marshall à instituição da referida Organização Internacional.

A OECE fora instituída por meio do Tratado de Paris, de 16 de abril de 1948, assinado por Áustria, Bélgica, Dinamarca, França, Grécia, Irlanda, Islândia, Itália, Luxemburgo, Noruega, Países-Baixos, Portugal, Reino Unido, Suécia, Suíça e Turquia. Esta cooperação econômica fora inaugurada para pôr em prática o Plano Marshall e para repartir entre seus dezesseis países-membros a respectiva ajuda econômica estadunidense (RÉAU, 2008, p. 141-96).

3.4., infra, onde se apresenta a chave hermenêutica adotada por este trabalho. Por enquanto, mostra-se suficiente remeter à nota de rodapé 105 , supra.

${ }^{110}$ A breve menção da História destas duas Organizações Internacionais feita nas linhas a seguir e no Quarto Capítulo deste trabalho permitirá reforçar as conclusões que seguem.

${ }^{111}$ Para a distinção coexistência e cooperação, v. a nota de rodapé 2 , supra.

${ }^{112}$ Condição sinalizada ainda mais fortemente pelo próprio nome da Organização Internacional: Organização Europeia de Cooperação Econômica.

${ }^{113}$ Organização Internacional europeia de cooperação na área militar, sob regência dos EUA, associada à ideia da necessidade proteção do Atlântico Norte, constituída para afastar a ameaça de potencial invasão da Europa Ocidental pela União Soviética durante a Guerra Fria.

${ }^{114}$ Essa constatação baseada na dicotomia exterioridade/interioridade de fundamento permanecerá mais clara quando da leitura do item 3.4., infra, onde serão aduzidas considerações em torno da chave hermenêutica assumida por este trabalho. Também remetemos o leitor ao Quarto Capítulo, onde mais informações sobre essas duas Organizações Internacionais serão apresentadas de maneira breve. 
Em 14.12.1960, a OECE foi extinta, tendo sido substituída pela Organização de Cooperação e de Desenvolvimento Econômicos (OCDE). Esta nova Organização Internacional não detinha uma missão propriamente europeia, por abarcar já naquele momento, também os EUA e o Canadá e, posteriormente, outros países, como o Japão.

O Pacto de Bruxelas instituiu, em 17.3.1948, entre Bélgica, França, Luxemburgo, Países Baixos e Reino Unido, uma Organização militar por força de pressões estadunidenses. Uma vez instituída, prontamente foi considerada como o polo europeu de defesa da região do Atlântico Norte.

De fato, em pouco mais de um ano, em 4.4.1949, foi assinado o Tratado de Washington que instituiu a Organização do Tratado do Atlântico Norte (OTAN) entre o Canadá, os EUA, os cinco membros do Pacto de Bruxelas, Dinamarca, Islândia, Itália, Noruega e Portugal. Rapidamente, toda a estrutura do Pacto de Bruxelas foi imediatamente estabelecida sob o comando da OTAN (RÉAU, 2008, p. 203-7).

Perceba-se que, apesar de tais Organizações Internacionais terem detido um aparato jurídico-institucional específico ${ }^{115}$, não teriam sido constituídas conforme Leis. Se suas normas jurídicas abandonaram a perspectiva da coexistência, assumiram apenas e tãosomente uma orientação de cooperação. A lógica de convivência (segundo Leis) não parece ter estado presente quando de sua instauração.

Em outros termos, apesar de ser uma mudança considerável e louvável para o período $^{116}$, há que se notar não consistir essa nova racionalidade multilateral da OECE e do Pacto de Bruxelas no "novo modo de relações" especificamente sinalizado e investigado por este trabalho. Suas instituições seriam apenas instituições de cooperação, isto é, não teriam sido estabelecidas conforme regras estruturais voltadas à constituição de uma convivência pública entre os diferentes países europeus que por elas se associaram.

Assim, por suas instituições terem restado no meio do caminho entre coexistência e convivência, isto é, por tais Organizações Internacionais terem se caracterizado juridicamente pela cooperação, é possível compreender o porquê do afastamento delas da presente análise. Dotadas de ordem jurídico-normativa positiva, mas desprovidas de Leis, o Pacto de Bruxelas e a OECE não poderiam ser objeto de interesse metodológico por parte deste estudo ${ }^{117}$.

\footnotetext{
${ }^{115}$ Isto é, terem produzido uma expressão normativa jurídico-positiva.

${ }^{116}$ Implicando na alteração de parte do paradigma fundante do Direito Internacional, como mencionado na nota de rodapé 2 , supra.

${ }^{117} \mathrm{Na}$ medida em que a pergunta formulada inicialmente neste trabalho exigia que se analisassem, em primeiro lugar, apenas as Organizações Internacionais do período determinado, cujas normas jurídicas
} 
A Cidade, portanto, não é precisamente uma comunidade de lugar, nem foi instituída simplesmente para se defender contra as injustiças de outrem ou para estabelecer comércio. (ARISTÓTELES, 1998, p. 55).

Quando percebidas apenas por seu perfil formal, as Leis efetuam apenas a instauração de uma comunidade jurídico-política; todavia, há que se notar que existem diferentes espécies de união jurídico-política, o que é dado por meio da específica qualificação material que se atribui às Leis ${ }^{118}$. Portanto, é necessário um deslocamento posicional com relação ao termo Leis, de maneira a que se assuma uma perspectiva outra, voltada a perceber as Leis sob uma perspectiva material.

\subsubsection{As Leis Percebidas sob uma Perspectiva Material}

Compreender as Leis sob uma perspectiva material significa atribuir um conteúdo à determinação da vida pública instaurada. Se as Leis estabelecem "ritmo, harmonia e melodia” (BITAR, 1980, p. 11) públicos nesta convivência, pensar materialmente as Leis é pensar e reconhecer que existem diferentes qualidades ou modos para estabelecer esta convivência obrigatória em uma vida comum. Ou ainda, é pensar e reconhecer que existem diferentes maneiras de instituir "ritmo, harmonia e melodia" na Cidade, cada um deles estabelecido por diferentes modos de se conceber o fundamento do sentido normativo do Direito e do Poder.

Lembre-se de que apenas se pode falar em Leis em sentido material se houver antes Leis em sentido formal a serem qualificadas. Em outras palavras, ou não existem Leis, ou existem Leis ${ }^{119}$; na hipótese de haver Leis, elas sempre deterão uma qualidade em especial, vale dizer, elas sempre terão sido instituídas de determinado modo.

É impossível falar de Leis sem que elas estejam providas de uma qualidade. Elas serão concomitantemente uma organização da vida pública entre aqueles que a ela se sujeitam (sentido formal) e uma organização de tal vida de determinada qualidade (sentido material). Tudo depende da maneira como se preenche o conteúdo dessas Leis; todavia,

tivessem sido articuladas para instaurar um novo modo de relações (relações desenvolvidas conforme Leis). A percepção das Leis conforme um perfil formal se trata de uma parcela da resposta à pergunta "como". A outra parcela de resposta será esclarecida nas linhas a seguir, quando serão elucidadas as questões sobre a percepção das Leis sob uma perspectiva material.

${ }_{118}^{11}$ Isto é, o que é determinado por específica qualidade material das Leis.

119 Isto é, ou há uma relação de união política (conviência entre diferentes), ou não há união política (coexistência ou cooperação). 
uma vez presentes as Leis, necessariamente haverá regras institucionais de estruturação jurídico-normativa positiva da vida comum.

O conteúdo material das Leis é dado pelos termos segundo os quais a vida em comum fora estabelecida. A qualificação de Leis remete a uma escolha específica sobre a concepção em torno do fundamento do Direito e do Poder. Por isso, a obrigatoriedade de convivência de diferentes dentro de um espaço comum é determinada de maneira variável por contornos qualificativos dados por uma perspectiva (ou ainda, por um modo) de como se deveria conceber a relação entre seus componentes no processo de produção de um sentido normativo e decisório comum.

Nesse sentido, se são as Leis (percebidas sob uma perspectiva formal) aquilo que permite assegurar uma vida pública em comum, é sobre a qualidade das Leis (percebidas sob uma perspectiva material) que reside a aptidão para preservar ou fazer desaparecer o regime de convivência entre diferentes (PLATÃO, 1980, p. 88). É a presença nas Leis de determinados elementos que permite identificar nelas um semblante, um índice que aponta a existência de uma opção por específico sentido mais ou menos durável de instaurar, de encaminhar e de conservar a vida pública.

É esse sentido escolhido que articula as instituições jurídico-positivas de um modo singular, o qual "preserva grandes e florentes cidades, ou que, o contrário disso, as arruínam de todo" (PLATÃO, 1980, p. 91). Em outros termos, é esta maneira qualitativa de articulação da vida dos participantes da vida em comum que determina se a politeia constituída poderá perdurar como uma união política (PLATÃO, 1980, p. 99).

\footnotetext{
[D]esse particular depende a salvação ou a ruína da cidade. As cidades em que a lei é dependente e fraca, vejo-as perto da destruição; e o contrário disso: onde é senhora dos dirigentes, e estes, servos da lei, uma cidade nessas condições se conserva (PLATÃO, 1980, p. 126).
}

Compreender as Leis sob uma perspectiva material demanda que se preste atenção nos elementos que indicam a maneira segundo a qual se concebe o fundamento do Direito e do Poder na sociedade.

A definição do modo de organizar institucionalmente as relações entre os participantes dessa vida pública - no que se refere à formação do sentido decisório jurídiconormativo e do Poder - é o que determina a qualidade das Leis. Essa qualidade é dada precisamente por meio da ordem de distribuição dos poderes decisórios fundamentais de 
uma organização jurídico-política entre seus participantes (ARISTÓTELES, 1998, p. 42 e 149).

Haveria duas maneiras básicas de se arquitetar institucionalmente o jogo das relações entre os diferentes participantes da vida em comum, conforme regras dadas pelas Leis, a saber, uma orientação voltada a privilegiar (i) a vantagem de alguns poucos no interior desta união política entre diferentes (unidimensionalidade na distribuição dos poderes decisórios); ou (ii) o interesse mesmo da comunidade em se preservar como tal, enquanto uma união política entre diferentes constituída para os interesses comuns (PLATÃO, 1980, p. 126) (pluridimensionalidade na distribuição dos poderes decisórios) $^{120}$.

Em outros termos, a distinção fundamental das qualidades possíveis das Leis reside precisamente na possibilidade de elas orientarem a constituição de instituições jurídiconormativas que privilegiem

(i) uma única maneira de decidir sobre o sentido último do Direito e do Poder (dada conforme uma única escala de existência, e no interesse dela); ou

(ii) a pluralidade de formas de se decidir sobre o sentido último do Direito e do Poder (dada pela co-presença forçada entre as diferentes escalas de existência).

Mais simplesmente, ou as Leis motivam instituições que facilitem a supremacia de uma única fonte de autoridade decisória sobre as demais (sobejo), ou elas fomentam instituições que estimulem o concurso de todas as fontes de autoridade decisórias possíveis (moderação), refreando cada uma delas mutuamente a ascensão de uma única fonte decisória.

As Leis que instituam "autoridade muito grande [não temperada]" (PLATÃO, 1980, p. 100) produzem instituições que estimulam no tempo a expansão ilimitada e incontida de uma única forma de preencher o sentido normativo a ser dado a questões atinentes à vida comum. Tais Leis caracterizadas pelo sobejo são precisamente as que produzem o excesso pernicioso para a permanência de uma união política como tal - pois afasta a possibilidade de instaurar e de preservar uma situação de equilíbrio entre os diferentes que compõem a vida em comum (PLATÃO, 1980, p. 100-10).

\footnotetext{
${ }^{120}$ Sobre a distinção entre pluridimensionalidade e unidimensionalidade, v. considerações no item 3.4., infra, onde se desenvolvem os principais aspectos da chave hermenêutica deste trabalho.
} 
Por outro lado, as Leis cujas regras imponham uma articulação institucional que instaure uma relação de horizontalidade entre as diferentes concepções de mundo permitem a produção de condição diversa. A garantia desta horizontalidade no concurso das diferentes formas de compreender qual deveria ser o sentido normativo último em determinada organização jurídico-política é o mecanismo preciso das Leis preocupadas com a necessária moderação da justa medida - condição que viabiliza a perduração da vida política (PLATÃO, 1980, p. 98).

Instituições voltadas ao abandono de uma perspectiva moderada seria o princípio da desestruturação de uma vida pública. Por sua vez, se as Leis detiverem a aptidão para constituir instituições aptas a impedir a posse do centro de definição do sentido último do Direito e do Poder por uma única forma de experienciar e de decidir sobre o mundo, poderse-ia retardar com maior segurança o processo de degeneração.

A qualidade das Leis residiria assim na capacidade de impedir ou não a nociva supremacia de um estrato sobre outro. Mais genericamente, ela seria derivada da aptidão de suas instituições afastarem ou não a possibilidade de uma única maneira de conceber o mundo se sobressair dentre as demais e sobre elas se impor mediante suas próprias medidas normativas de dever-ser ${ }^{121}$.

Em termos mais simples, a qualidade das Leis é aferível conforme elas se mostrem capazes de assegurar por meio de suas instituições o múltiplo (unidade-diferenciação) ou o Um (unidade-unificação) ${ }^{122}$ - ou ainda, uma união política entre diferentes que conserve ou não a diferença entre seus participantes.

É neste momento preciso da exposição que se permite compreender o último movimento do recorte metodológico deste trabalho. Com as informações apresentadas, é possível afirmar com mais precisão o "novo modo de relações" ao qual se refere como apto a responder à pergunta inicialmente formulada para este estudo.

Sob uma percepção material, esta Tese se debruça sobre as Leis vigentes entre países europeus unidos no imediato pós-Segunda Guerra Mundial cujas instituições se mostraram voltadas a promover uma união política sem que houvesse uma ameaça tendendo à unificação. Em outras palavras, é sobre a Organização Internacional que instaurara instituições conforme Leis de unidade-diferenciação (preservação do múltiplo)

\footnotetext{
${ }^{121}$ Sobretudo, o Direito e o Poder.

122 Sobre o múltiplo e o Um, v. Etienne de LA BOÉTIE (1999) e Claude LEFORT (1999). Algumas explicações sobre essa diferenciação serão desenvolvidas no item 3.4., infra, onde essa terminologia será retomada no contexto da chave hermenêutica desta Tese.
} 
que se dedica este trabalho, sendo este o específico novo modo de relações ao qual se refere na pergunta inicialmente formulada.

Entende-se aqui que a recusa de uma unidimensionalidade na definição do Direito e do Poder comuns teria sido o móvel orientador das Leis que formaram o início da Europa Unida inaugurada pela $\mathrm{CECA}^{123}$ : nenhum de seus participantes teria aberto mão de suas especificidades para dela participar e para promover entre si o comum (HABERMAS, 2011a). É esta ênfase na convivência equilibrada entre distintos polos a condição que caracterizou as Leis e as instituições da Europa Unida da CECA no pós-Segunda Guerra Mundial. A rejeição do excesso, o destaque da ponderação e a ênfase na pluridimensionalidade seriam as condições que teriam marcado o supramencionado "novo modo de relações".

É por esse motivo que haverá a preocupação em compreender a construção histórica da CECA: acredita-se ser possível identificar na narrativa do período entre 1945 e 1951 o desenvolvimento da percepção da necessidade de apostar na virtude Política deste justo meio (ARISTÓTELES, 1998, p. 187; VERNANT, 1981, p. 60), a fim de evitar qualquer monopólio da produção do sentido normativo último por quaisquer unidimensionalidades. Afinal, na construção do comum, o objetivo seguido por suas instituições teria suposto, instaurado, preservado e promovido o equilíbrio tenso que é típico da pluridimensionalidade.

Busca-se entender como historicamente foi possível gestar Leis que apostaram no equilíbrio e na igualdade dos polos participantes de uma Europa Politicamente Unida por meio das instituições da CECA ("como"). Em seguida, serão desenvolvidas análises que procurarão mostrar as características de tais instituições inovadoras ("por meio de").

Nada mais coerente a pretensão deste trabalho. Procura-se compreender a constituição histórica das Leis e de suas respectivas instituições, de maneira a que elas pudessem atender ao tão caro e zeloso mote europeu da unidade na diversidade (HABERMAS, 2011a) ${ }^{124}$, ou ainda, que pudessem ter dito, como SÓLON:

\footnotetext{
${ }^{123}$ Apesar de esta conclusão restar nebulosa, ela restará mais bem esclarecida a partir da leitura do Sexto e do Sétimo Capítulos desta Tese, ambos infra.

${ }_{124}$ Segundo Armin von BOGDANDY (2008, p. 242), este mote seria o próprio autorretrato da Comunidade e, hoje, da União Europeia.

Para uma rápida informação sobre o desenvolvimento da noção de diversidade cultural no Direito Internacional, indicamos a leitura de Armin von BOGDANDY (2008, p. 244-7), lembrando que, para este autor, diversidade se revela como podendo significar tanto distinção cultural, como pluralismo cultural, ou mesmo universalização - cada um deles podendo implicar diferentes consequências jurídico-normativas.

Sobre o debate em torno da noção de diversidade cultural na Europa Unida, indicamos o mesmo artigo (BOGDANDY, 2008, p. 247-50). Apesar de ser temática interessante, é importante frisar que ela não será analisada pelo presente trabalho, razão pela qual se deixa de tecer comentários sobre ela.
} 
J'ai donné au peuple autant de part d'honneur qu'il suffit, ne lui enlevant ni ajoutant d'honneur; pour ceux qui avaient la force et que leurs richesses rendaient considérables, pour eux aussi j'ai fait attention qu'ils n'éprouvent rien d'inconvenant. Je me suis tenu droit, tendant mon fort bouclier face à chacun des deux camps, sans permettre à chacun des deux de vaincre dans l'injustice. (SÓLON apud ARISTOTE, 2006, p. 76, grifos nossos) ${ }^{125}$.

É por esse motivo que se pode compreender porque, em último lugar, o $\mathrm{CdE}$ foi retirado do campo de preocupações deste trabalho. Se até o presente momento ele compartilhava das características da CECA - Direito Positivo e Leis, de tal modo que se poderia autorizadamente concluir que com ela concorria pelo espaço de objeto de atenção deste trabalho, não restam dúvidas sobre a legitimidade da exclusão do $\mathrm{CdE}$ do campo investigativo deste estudo. Materialmente consideradas, as Leis do CdE eram distintas das da CECA: o regime de convivência do primeiro visava à unificação dos diferentes unidos, ao passo que o da última visava à conservação dos diferentes unidos.

Com efeito, como afirmado diversas vezes acima, esta Tese de Doutorado não apenas se preocupa em compreender os Projetos de Europa Unida propostos e adotados no imediato pós-Segunda Guerra Mundial. Se entendida a localização temporal das preocupações investigativas entre 1945 e 1954, haveria que se compreender que em termos espaciais e temáticos o objeto seria ainda mais restrito - do contrário, OECE, Pacto de Bruxelas, CdE, CED e CPE seriam igualmente passíveis de serem estudados por este trabalho.

Por meio da situação deste estudo no interior do conhecimento jurídico, foi possível afastar a CED e a CPE, na medida em que as preocupações deste se deslocam no interior de um campo analítico que exige a presença de instituições jurídico-normativas positivadas. Não tendo suas normas jurídicas entrado em vigor, não faria sentido examinar tais Organizações no presente trabalho.

Também não foi admitida como objeto deste estudo toda e qualquer Organização Internacional dotada de Direito Positivo, mas apenas aquelas que se configuraram segundo Leis, isto é, que se articularam para promover uma vida pública entre seus EstadosMembros (Leis em sentido formal). Com esse raciocínio, foi possível afastar deste estudo a

\footnotetext{
${ }^{125}$ Trata-se de conhecido fragmento de poema escrito por SÓLON - relatado pela Constituição de Atenas, de ARISTÓTELES (ARISTOTE, 2006), referente às reformas legislativas por ele promovidas para estabelecer o equilíbrio e a moderação em Atenas. O objetivo de suas Leis consistia em impedir a continuidade da profunda luta civil que dividia a Cidade. SÓLON foi o arconte e mediador do conflito escolhido em comum acordo pelas duas partes opostas da Cidade, em 594-593 a.C. (ARISTOTE, 2006, p. 68; VERNANT, 1981, p. 58-69).
} 
OECE e o Pacto de Bruxelas, duas Organizações Internacionais de cooperação, mas não de convivência.

Ao lado da CECA, teria restado apenas o CdE como objeto de estudo em potencial; como a CECA, o CdE deteria instituições moldadas segundo regras dadas por Leis preocupadas com a viabilização de uma vida pública entre seus Estados-Membros.

Entretanto, a qualidade das Leis que orientaram a arquitetura institucional do $\mathrm{CdE}$ autorizaria a exclusão desta Organização Internacional do interior do campo de preocupações deste estudo. Afinal, para responder adequadamente à pergunta formulada inicialmente $^{126}$, não seriam cabíveis todas e quaisquer Leis. Não bastaria haver a singela presença de uma preocupação com a organização jurídico-política das relações entre países europeus. As Leis pelas quais se interessa este estudo detêm uma qualidade específica, um conteúdo material especial.

O "novo modo de relações" entre alguns países europeus buscado por este trabalho consiste precisamente neste fazer conviver diferentes (unidadediferenciação), de maneira a que estes se conservem em sua diferença. As Leis às quais esta Tese se refere são especificamente aquelas que permitiram constituir uma vida pública entre diferentes (Leis em sentido formal), conservando essa diferença (Leis em sentido material).

Tratam-se de Leis que promoveram uma união política sem que isso significasse unidade cultural ou unificação dos modos de existência. Essa específica qualidade de promover o refreamento da totalização de uma medida de existência em detrimento das demais - recusa da unidimensionalidade, ou ainda, afirmação de convivência plural permanente - é a das Leis escolhidas para serem examinadas pelo presente estudo.

Ora, as Leis orientadoras da construção histórica do CdE não se enquadram nesta perspectiva. Elas não se constituíram segundo a qualidade buscada por este estudo. Sua organização jurídico-política do social, apesar de instituir uma convivência entre diferentes, não visaria à preservação deles como tais ${ }^{127}$.

O CdE fora instituído por meio do Tratado de Londres, em 5.5.1949, assinado por dez Estados-Membros, a saber, Bélgica, Dinamarca, França, Irlanda, Itália, Luxemburgo,

\footnotetext{
${ }^{126}$ Ponto de fuga desta Tese, ao qual reiteradamente se busca remeter e relembrar, de maneira a assegurar sua fixação pelos leitores.

${ }^{127} \mathrm{O}$ breve relato da História do CdE a ser feito nas linhas a seguir e no Quinto Capítulo desta Tese permitirá compreender mais detalhadamente as razões dessa exclusão. Esta ainda fará mais sentido a partir da leitura do item 3.4., infra, sobre a chave hermenêutica adotada pelo trabalho.
} 
Noruega, Países-Baixos, Reino Unido e Suécia ${ }^{128}$. Sua constituição é fortemente influenciada pela Comissão da Cultura do Congresso de Haia de 1948, a qual era profundamente caracterizada por uma orientação cultural de caráter Federalista (REFALO, 1980, p. 72) ${ }^{129}$.

Em 4.11.1950, o CdE estabeleceu uma Convenção de Salvaguarda de Direitos Humanos na Europa, a Convenção Europeia dos Direitos do Homem (CDH). O dispositivo institucional voltado à tutela dos Direitos Humanos no interior do CdE é a Corte Europeia de Direitos Humanos (CEDH), instituída em Estrasburgo em $1959^{130}$.

As informações sucintamente referidas linhas acima são fundamentais para esclarecer as razões pelas quais o CdE não é estudado pela presente Tese de Doutorado. Como se pode depreender rapidamente do que foi dito, a principal preocupação do $\mathrm{CdE}$ consistia em promover e proteger os Direitos Humanos na Europa, bem como assegurar a preservação das liberdades fundamentais e dos princípios democráticos, além de garantir a defesa da Paz entre seus Estados-Membros (RÉAU, 2008, p. 184).

É importante lembrar a informação já supramencionada de que o CdE é profundamente marcado por uma orientação Federalista, tal qual manifesta no Congresso de Haia de 1948. O objetivo desta é duplamente ambicioso: não apenas almeja constituir um Estado Federal Europeu, mas também porta consigo um Projeto civilizatório europeu salvaguardar os valores fundamentais da civilização europeia, e, sobretudo, disseminar a "Boa Nova Europeia" (ROLLAND, 2006, p. 557).

Por mais que sua Assembleia fosse meramente consultiva, o CdE detinha por compromisso institucional difundir a forma de existência típica dos Direitos Humanos, da Democracia e da Paz por toda a Europa Ocidental e para além dela. Desprovido de pujante capacidade de atuação, seu poder unificador seria pouco a pouco construído culturalmente, de modo a progressivamente viabilizar a unificação política da Europa por meio de cultura una. A limitação de seu principal órgão institucional - a

\footnotetext{
${ }^{128}$ Hoje essa Organização Internacional é composta por 47 (quarenta e sete) países, dentro os quais se pode mencionar a título de curiosidade a Rússia e a Turquia, países cujo pertencimento a uma Europa Unida é até hoje alvo de questionamentos.

${ }^{129}$ Como será possível explicitar com maiores detalhes no Quinto Capítulo desta Tese de Doutorado. A referência ao CdE e ao Congresso de Haia de 1948 neste momento do discurso surge apenas e tão-somente para esclarecer as razões pelas quais se entende estar o $\mathrm{CdE}$ fora do objeto de estudos deste trabalho.

${ }^{130}$ Uma análise mais completa do histórico e do Estatuto do CdE, bem como de sua CEDH, não é o objetivo deste trabalho. Na literatura brasileira remetemos exemplificativamente à leitura de Elizabeth de Almeida Meirelles REFALO (1980, p. 74-82) e, de maneira mais atual, à Tese de Livre-Docência de André de Carvalho RAMOS (2005) e à Dissertação de Mestrado de Fabia Fernandes Carvalho VEÇOSO (2006).
} 
Assembleia de Estrasburgo - deveria ser superada aos poucos no futuro (RÉAU, 2008, p. $177,184$ e 187$)^{131}$.

Perceba-se aqui a presença de elemento bastante particular: o CdE não visaria apenas e tão-somente efetuar uma união política da Europa - uma simples organização jurídico-política das relações entre seus Estados-Membros (RÉAU, 2008, p. 187). Suas Leis apontavam para a preocupação de aproximar seus países-membros (atuais e futuros) a partir de um discurso culturalmente unificador. Em outras palavras, seu objetivo era fomentar uma união de países europeus a partir de uma imaginada e imposta unificação cultural da Europa - inclusive, por meio de um Estado Federal Europeu! ${ }^{132}$.

A concepção sobre o fundamento do Direito e do Poder das Leis do CdE era bastante precisa: organizar-se em torno do paradigma cultural da civilização europeia do Ocidente $^{133}$. Seria este o elemento fundador e orientador de toda e qualquer relação a ser estabelecida entre os diferentes politicamente unidos - sem que nada pudesse ser definido sem levar em consideração esse polo axiológico absoluto.

Em outros termos, a estruturação de uma vida pública entre os EstadosMembros do CdE apontava para um fazer conviver diferentes, sem buscar preservar, todavia, os diferentes enquanto tais. Suas Leis detinham uma qualidade distinta daquela que este trabalho visa a examinar, pois não se trata do "novo modo de relações"

${ }^{131}$ Lembre-se, assim, que a CED e a CPE se trataram de tentativas frustradas de reinserção do Federalismo na Europa unida (QUADROS, 1984, p. 124-5).

${ }^{132}$ Como se poderá perceber mais detalhadamente, durante a narrativa histórica do Quinto Capítulo desta Tese, infra.

${ }^{133}$ É importante frisar que este texto não supõe uma cultura una de Europa Ocidental, tal qual afirmada pelo CdE e pela vertente Federalista. Há aqui uma singela preocupação histórica de indicar os termos gerais segundo os quais se apresentavam a si próprios os partidários de uma Europa Federal - ou dos Estados Unidos da Europa. Eles serão mais bem compreendidos quando da leitura do Quinto Capítulo desta Tese, infra.

Há que se lembrar, de todo modo, de que o discurso sobre uma pretensa homogeneidade cultural nada mais se mostra tradicionalmente do que um artifício usualmente encontrado para promover, a partir de narrativas biográficas e históricas imaginadas sobre um tronco cultural supostamente comum, a construção de uma fictícia organização jurídico-política do social ilusoriamente pura e idêntica a si mesma em um todo coerente e unitário.

Deste processo de forja de uma não-natural unidade cultural e política, são exemplos a invenção dos Estados-nacionais, sustentados por uma dissimulação da unidade e da uniformidade culturais de seus povos (ANDERSON, 2009, p. 32-3; FERRAJOLI, 2006, p. 50 e 58; HALL, 2006, p. 13; KYMLICKA, 2007, p. 614). Indica-se aqui que no mesmo sentido parecerem operar as propostas dos Federalistas Europeus.

De todo modo, seria interessante lembrar haver iniciativas investigativas estrangeiras que buscam compreender a Europa Unida de hoje como uma comunidade imaginada (HOBOLTH, 2011), o que, para tais estudos, permitiria explicar o sucesso de determinadas regulamentações comunitárias atuais. No caso deste estudo em especial, argumenta-se que seria possível explicar a adição de padrões de políticas comuns de vistos na União Europeia de hoje pois teria havido a formação de comunidades imaginadas regionais na Europa (ao Norte, ao Sul, ao Leste e no BENELUX). Esta discussão, apesar de interessante, foge aos escopos desta investigação. 
sobre o qual se debruça com este estudo (união política sem unificação). Por isso, o estudo do CdE não conferirá uma resposta adequada à pergunta inicial deste trabalho ${ }^{134}$.

Deste modo, por o CdE não partilhar de Projeto de Europa Unida da mesma qualidade daquele inaugurado sob os auspícios da $\mathrm{CECA}^{135}$, isto é, por suas instituições

${ }^{134}$ Fabia Fernandes Carvalho VEÇOSO (2006, p. 30, grifos da autora) indica enfaticamente que o CdE é um “movimento de cooperação política entre os Estados europeus, de caráter intergovernamental". Concordamos com a posição da autora, como se pode ver mais adiante neste Primeiro Capítulo. Isso restará mais claro quando da leitura da Parte Segunda desta Tese.

Todavia, é importante relembrar a observação constante da nota de rodapé 2 deste trabalho, onde não apenas se menciona a distinção entre cooperação e coexistência, como também se afirma que esta Tese não pretende utilizar essa classificação tradicional para compreender os Projetos de união da Europa propostos nos dez primeiros anos subsequentes ao final da Segunda Guerra Mundial (Pacto de Bruxelas, OECE, CdE, CECA, CED e CPE).

Como se pôde perceber à medida que se desenvolveu a leitura deste texto, os critérios distintivos deste trabalho são outros, não preocupados em compreender tais Organizações Internacionais no interior do esquema tradicional coexistência versus cooperação. Se a classificação tradicional permite compreender a OECE, o Pacto de Bruxelas e o CdE como experiências de cooperação, neste texto, a chave de leitura é qualitativamente distinta - o que certamente produz como resultado uma classificação diferente.

Nesse sentido, perceba-se que se preocupa com a existência ou não de Leis entre os processos de união da Europa no pós-Segunda Guerra Mundial. Segundo essa perspectiva, não bastaria a existência de um corpo jurídico-institucional comum: haveria que se verificar se este corpo normativo estaria fundado em Leis, isto é, em uma orientação (formal) no sentido de promover uma união política entre seus participantes (qualquer que seja a finalidade desta união política, como a tendência ou não de promover uma unificação política).

O CdE seria compreendido a partir de outra lente interpretativa - isto é, como uma tentativa de promover uma união política caracterizada pela tendência à unificação, que permitiria a aproximar (apenas formalmente, frise-se, como visto acima neste Primeiro Capítulo) da CECA.

A classificação nova é distinta e permite conferir contornos significativos novos ao CdE: afinal, não seria mera cooperação política, mas um Projeto de união política voltado à unificação (Federal). Sua distinção com relação à CECA residiria no fato de ser um regime de convivência (união política) dotado de Leis materialmente diferentes.

Em outras palavras, em comparação com a OECE e o Pacto de Bruxelas, o Projeto do CdE deteria um caráter integrativo qualitativamente mais profundo, não podendo ser a eles equiparado como simples cooperação. É por essa razão que, em relação a estes dois, poderia ser entendido como proposta de convivência entre diferentes (presença formal de Leis), e não como uma simples cooperação clássica. Por outro lado, em comparação com a CECA, o CdE se diferenciaria por se tratar de um regime de convivência marcado pela tendência unificadora (diferença material de suas Leis). Essa questão ficará mais precisa quando da leitura dos Capítulos Terceiro e Sexo, ambos infra.

Deste modo, apesar de apresentar uma distinção classificatória mais sutil e mais específica (coexistência, cooperação ou convivência; convivência plural unificadora ou convivência plural permanente), não se afasta este trabalho da percepção da tradição do pensamento jurídico brasileiro sobre o um e mesmo dado de que "o Conselho da Europa é um órgão político, que tem como objetivo a criação de uma união mais estreita entre seus membros" (VEÇOSO, 2006, p. 30). Apenas se pretendeu reorganizar significativamente o mesmo leque de informações outrora detidos pelo conhecimento jurídico vigente. Sobre essa intenção deste estudo, remetemos o leitor à nota de rodapé 19, supra.

Não se está tão longe, assim, da tradição do pensamento jurídico brasileiro, pois se examina precisamente um e mesmo fenômeno. Apenas se propõe uma maneira alternativa de o compreender. Sobre a proposta fenomenológica deste trabalho, indicamos a leitura do item 2.2., infra.

${ }^{135}$ Cabe ressaltar que o Tratado da CECA não contém em suas disposições normativas qualquer cláusula afirmando a necessidade de se preservar os Direitos Humanos e a Democracia, como se poderá perceber quando da leitura da interpretação constituída sobre o Tratado da CECA, no Sétimo Capítulo desta Tese.

Para Fabia Fernandes Carvalho VEÇOSO (2006, p. 249), a ausência de regulamentação de Direitos Humanos no Tratado que instituía a CECA derivava do fato de esta Organização Internacional se cingir a questões meramente econômicas, enquanto primeira etapa para a construção de uma Federação Europeia. André de Carvalho RAMOS (2005, p. 58-61) apresenta rápido resumo das razões pelas quais os Direitos 
não terem sido construídas conforme um mandamento de Leis de convivência plural permanente, mostra-se admissível retirar o CdE do interior do arco de questões deste trabalho, por força de uma justificativa metodológica. Apenas a CECA teria conseguido demonstrar deter a aptidão para responder de maneira integral à tripla conjugação do

Humanos não foram incluídos no Tratado da CECA, tais como: (i) pré-existência da CEDH do CdE; (ii) temor com relação à usurpação de competências dos Estados-nacionais; (iii) impossibilidade de se pensar em Direitos Humanos Econômicos e Sociais naquele momento, haja vista que estes ainda estavam presos ao paradigma de uma concepção de Estado liberal (lembre-se de que o Pacto Internacional de Direito Sociais, Econômicos e Culturais é de 1966), entre outros.

De todo modo, tanto André de Carvalho RAMOS (2005), como Fabia Fernandes Carvalho VEÇOSO (2006) parecem concordar com a explicação de que a CECA teria recaído em uma "ilusão economicista", segundo a qual "temas de integração regional eram estranhos à proteção de direitos humanos" (RAMOS, 2005, p. 60). Em outras palavras, precisamente porque detinha a CECA objetivos de promover uma regulamentação jurídica exclusiva e unicamente econômica (por ser uma integração econômica) seria explicada e justificada a ausência de regulamentação dos Direitos Humanos.

Além do fato histórico de ter sido a CEDH fundada apenas em 1959, isto é, oito anos após a fundação jurídica da CECA, o que ao menos fraqueja a razão (ii) do argumento de André de Carvalho RAMOS (2005, p. 58-61) acima mencionado, cumpre salientar que, conforme indicado na nota de rodapé 73, supra, este trabalho não concorda com esta posição. Segundo a leitura proposta por este estudo, a ausência de previsão de Direitos Humanos poderia ser justificada precisamente pelo fato de a CECA repudiar qualquer tentativa de promoção de unificação política por meio de instrumentos civilizadores - como os Direitos Humanos anunciados total e totalizantemente pelos Federalistas europeus no CdE e por sua CEDH. Curiosamente, apenas após a extinção da CECA, em 2002, é que os Direitos Humanos foram oficialmente introduzidos por meio de norma jurídica na UE de hoje - isto é, precisamente quando parecem ter sido assumidos contornos que permitem poderiam confundir a natureza jurídica da UE com a de um Estado Federal (BOBBITT, 2011, POZO, 2011a; SERRANO, 2011; WEILER, 2011). Lembre-se, contudo, de que não esta Tese não versará sobre a atual UE, mas apenas e tão-somente sobre a CECA. Ademais, sobre a discussão da natureza jurídica da CECA, v. item 3.3.2., infra.

De todo modo, a tendência unificadora não apenas era verificável nas propostas de união política Federal da CdE, mas também na própria condição universalizante dos Direitos Humanos. Remetemos, sobre este último aspecto, a trabalhos anteriores de nossa autoria (GIANNATTASIO, 2010b, 2011a, 2011b), onde nossa perspectiva particular se revela com maiores especificações. Também restará mais clara a afirmação sobre a pretensão universalista dos Federalistas a partir da leitura do Quinto Capítulo desta Tese, infra.

Frise-se, entretanto, como indicado também na nota de rodapé 73, supra, que o tema da regulação europeia dos Direitos Humanos não é objeto de atenção por parte deste estudo, razão pela qual não se continuará a tecer considerações sobre esta temática, apesar de ser interessante tema a ser debatido. Apenas se procurou posicionar sobre este tema nesta nota de rodapé, a fim de indicar os possíveis caminhos alternativos de interpretação passíveis de serem derivados da leitura proposta por este estudo. Registra-se aqui, deste modo, o convite para futuras investigações conjuntos sobre este tema.

Haveria que se lembrar, de todo modo, de que um dos mais proeminentes federalistas atuais, Joseph H. H. WEILER (2011), entende que esta constatação de ausência de previsão de Direitos Humanos no Tratado da CECA é no mínimo desconcertante - e muitas vezes consciente ou inconscientemente esquecida por um discurso Federalista atual que procura - e não consegue encontrar - raízes pretensamente legitimadoras nos próprios documentos fundacionais do início da integração europeia, seja no Tratado da CECA, seja no Tratado da CEEA, ou mesmo no da CEE.

Com isso, pode-se perceber desde já uma orientação distinta na CECA daquela perseguida pelo $\mathrm{CdE}$, a qual pode ser justificada pela diferença das Leis que constituíram o arcabouço institucional jurídiconormativo positivo de cada uma das Organizações Internacionais: CdE e CECA não partilhariam do mesmo Projeto de construção de uma Europa (politicamente) Unida, o que seria facilmente sinalizável pela preocupação da primeira em promover universalmente o Direitos Humanos, diferente da via seguida pela CECA, caracterizada pela convivência plural permanente.

Este trabalho se preocupa assim com aquele Projeto que fora inaugurado pela CECA e que posteriormente foi acompanhado por outros (CEEA e CEE) - ainda que se possa cogitar que, em algum momento, houvera um desvio de rota. Como ressaltado anteriormente, não se buscará tecer considerações em torno das condições das Leis que orientam a atual UE, pois o recorte temporal metodológico definiu como o intervalo de interesse deste estudo o período localizado entre 1945 e 1951. 


\author{
"quando", "como" e "por meio de quais instituições". O que será mais bem demonstrado \\ ao longo da leitura integral deste trabalho ${ }^{136}$.
}

136 É importante frisar que o presente texto de Doutorado consiste apenas em um registro logicamente articulado da Pesquisa efetuada ao longo dos últimos anos sobre seu tema, e não em um relato da cronologia seguida para o exame das questões relacionadas ao objeto de estudo.

Não se iluda por isso o leitor pela divisão lógica do texto. À medida que avança a leitura, não se está efetuando simultaneamente a investigação realizada pelo autor como um companheiro (crítico, é verdade) das atividades da Pesquisa realizada.

A Pesquisa já fora desenvolvida e finalizada integralmente pelo autor, quem se preocupa apenas em efetuar de forma mais ou menos ordenada neste texto a exposição mais organizada e coerente possível dos resultados obtidos. Sua apresentação em registro documental apenas produz essa ilusão imagética de que o leitor acompanha o passo a passo da Pesquisa. Quando, na verdade, ele apenas lê o registro da Pesquisa por meio de um relato metodologicamente consistente de um pensamento único formado após a extração integral das conclusões da atividade investigativa.

Isso significa que o presente texto é apenas um veículo formal de relato da Pesquisa. Sua apresentação orgânica mais ou menos logicamente articulada foi preparada com o objetivo de facilitar o entendimento ordenado por parte do leitor das conclusões produzidas pelo autor no curso de investigação.

Aqui operam facilmente duas metáforas que permitem compreender o significado da Tese de Doutorado: toda construção de edifício pressupõe a existência e o suporte de andaimes que auxiliem na edificação do prédio; todavia, uma vez finalizado o empreendimento, deixa-se apenas o edifício pronto, sem que se vejam os andaimes. A Tese escrita seria este edifício finalizado, o qual depende do apoio dado pela Pesquisa da Tese, mas que supõe apenas a apresentação daquilo que é fundamental para tornar o texto escrito coerente e consistente.

Apenas se indicam assim seus pilares fundantes - mesmo que se ignorem percursos reflexivos laterais, acabados ou não, que auxiliaram na formação do resultado da Pesquisa, pois impertinentes para uma exposição coerente do objeto de estudo. Ou ainda, mais simplesmente, o provérbio acadêmico francês "De la plus grande montagne, le plus petit souris.": a Tese de Doutorado não é nada mais que um pequeno texto (rato) se comparado à grande quantidade de leituras e reflexões feitas (montanha) em torno do tema escolhido.

É importante perceber que antes mesmo de o presente texto ter sido escrito, a Pesquisa fora realizada em etapas cronológicas sucessivas que, todavia, não acompanham a ordem de exposição do presente texto. A conveniência de disposição de determinados temas neste trabalho antes de outros foi fruto de mera decisão prática voltada a construir (com maior ou menor sucesso) a maneira mais didática possível para apresentar ao leitor a significação pretendida pelo autor.

Nesse sentido, frise-se que, pelo fato de a Pesquisa ter sido concluída antes mesmo de este trabalho iniciar seu processo de escrita, este texto constitui apenas um mero registro resumido de todo o empreendimento investigativo seguido. Ele busca relatar discursivamente o produto da contemplação investigativa que formara um pensamento único.

Deste modo, sua ordem de apresentação, por sua vez, é lógica, e não cronológica, a despeito da disposição material que ela deve seguir (Introdução, Desenvolvimento em Capítulos, Conclusão) - afinal, o 1 deve vir antes do 2!. Lógica, a final, pois o trabalho é um todo único cujas partes mantêm uma relação de íntima interdependência e comunicação umas com as outras e com o todo, de tal modo que, sem elas, nem o todo, nem as partes individualizadas, fariam sentido completo.

É precisamente essa relação mútua e recíproca entre as partes e entre as partes e o todo que revela o presente texto como um bloco único, no interior do qual necessariamente uma parte se comunica com a outra, cada uma se influenciando com relação às outras (daí deriva a necessidade de constantes referências e remissões cruzadas no interior desta Parte Primeira, e desta com relação à próxima, e vice-versa). Apesar do cuidado em segmentar tematicamente parcelas do texto deste Doutorado, não há como evitar que conclusões de determinadas partes do texto tenham operado significativamente nas entrelinhas da escrita de outras (o que constantemente se faz por meio de referência e remissões em sucessivas notas de rodapé, como se pôde e como se poderá perceber ao longo deste trabalho).

Não há como evitar, na transcrição e no registro (do pensamento) dos resultados finais da Pesquisa, a influência das conclusões obtidas no processo de construção do texto; obviamente, cada parte ou Capítulo detém sua especificidade temática e seu objeto próprio de preocupações. No entanto, apesar de a investigação ter sido de fato operada em separado, na redação da versão final deste texto - que consolida o exaustivo procedimento de Pesquisa - há evidentemente em cada uma de suas partes o concurso do conjunto das conclusões das outras partes do texto, bem como do todo por ele veiculado. 
"Visto que, como já dito, toda esta obra é apenas o desdobramento de um pensamento único, seguese que todas as suas partes não apenas têm a mais íntima ligação entre si - e não meramente cada uma delas está numa relação necessária com as imediatamente anteriores, e, desta forma, apenas estas são supostas na memória do leitor [....] -, mas também cada parte de minha obra é aparentada às outras e as pressupõe. Por esse motivo, é requerida a lembrança do leitor não apenas das coisas há pouco ditas, como também das precedentes, para poder conectá-las com o lido a todo momento, por mais que já tenha sido dito de outro modo. Exigência esta também feita por Platão aos seus leitores nas digressões complexas e tortuosas de seus diálogos, os quais só depois de longos episódios retomam o pensamento principal; contudo, exatamente por isso, o pensamento se torna mais claro. Conosco, tal exigência era sem dúvida necessária, pois a análise de nosso pensamento único em várias considerações era o único meio para sua comunicação, apesar de semelhante forma não lhe ser essencial, mas artificial. [...] O conteúdo dos temas, todavia, de forma alguma admite um progresso em linha reta [...]. Daqui a necessidade de um estudo repetido do livro, unicamente por meio do qual a conexão de todas as suas partes se torna distinta; só assim elas se elucidam reciprocamente, tornando-se perfeitamente claras." (SCHOPENHAUER, 2005, p. 370-1).

Essa condição é na verdade inevitável, pois deriva do estado mental de turbulência que decorre das necessárias reformulação e ressignificação das premissas por força das conclusões, um movimento típico do arco do conhecimento. Todo procedimento científico rigoroso exige que, durante a Pesquisa, haja a separação precisa das premissas e conjunção destas para a produção dedutiva das conclusões; contudo, após a produção das conclusões, elas devem retornar para restabelecer as premissas adequadamente ao resultado produzido.

O presente texto do Doutorado é assim um registro posterior à Pesquisa, e não um movimento concomitante à investigação realizada e já finalizada. Nesse sentido, foi produzido este texto no exato momento do processo de retrocessão das conclusões às premissas, vale dizer, ele consubstancia a transcrição da reformulação das premissas à luz das conclusões obtidas. O que permite compreender a unicidade do texto e o intenso diálogo entre diversas de suas partes, e destas com o todo.

Esta condição, inclusive, mostrou-se fundamental para a compleição material desta obra, bem como para facilitar sua legibilidade. Com efeito, para evitar que este registro racionalmente ordenado e estruturalmente articulado da Pesquisa se demorasse na descrição de aspectos inúteis, impertinentes ou inconvenientes para a compreensão do objeto de estudo, a fim de não aborrecer os leitores, manteve-se apenas o fundamental, tendo-se eliminado qualquer aspecto secundário, irrelevante ou suporte conclusivo intermediário.

Por isso, por exemplo, toda a análise dos Projetos de Europa Unida anteriores ou posteriores à CECA foi transcrita resumidamente em uma apresentação sucinta das iniciativas que não serão analisadas. Essa exclusão registrada neste texto deriva da conclusão a que se chegou ao final da Pesquisa (não transcrita), ou seja, após o estudo dos documentos consultados e depois da produção da chave hermenêutica jurídicoPolítica (item 3.4., infra).

Concluiu-se que apenas a CECA fora capaz de promover por meio de suas instituições uma União de caráter Politico da Europa no imediato pós-Segunda Guerra Mundial, pois teria sido a única Organização Internacional movida por Leis dotadas de sentido material de convivência permanente de pluralidades. Apenas a CECA deteria Leis, e Leis em determinado sentido (Leis Políticas).

É essa conclusão final que ressignificou todas as premissas do trabalho e que, por se mostrar como a hipótese conclusiva a ser apresentada em texto, nesta Tese de Doutorado, determinou a confecção estrutural desta obra. Se inúmeros foram os motivos que determinaram a exclusão da análise dos demais Projetos de Europa Unida (antes e depois da CECA, inclusive a OECE, o Pacto de Bruxelas, o CdE, a CED e a CPE), os que são apresentados aqui são apenas e tão-somente aqueles capazes de se sustentar a partir de uma preocupação de coerência metodológica.

Afinal, neste texto de Tese de Doutorado se revela logicamente (e não cronologicamente) o resultado da Pesquisa de Doutorado, o qual deve ser apresentado de acordo com um rigor de absoluta coerência metodológica. Escrevera-se neste texto apenas aquilo que poderia ser mencionado a partir de opções metodológicas realizadas para explicar e justificar as conclusões alcançadas. Mais simplesmente: são ditas neste texto apenas algumas das conclusões encontradas durante todo o percurso de investigação, vale dizer, apenas aquelas que estavam metodologicamente autorizadas para serem ditas. As restantes foram afastadas, para evitar confusões quando da leitura deste texto por aqueles que não efetuaram a investigação em conjunto com seu autor.

Se a História de todos os Projetos de Europa Unida nos primeiros dez anos subsequentes ao final da Segunda Guerra Mundial foi estudada, em virtude da identificação da CECA como aquela Organização Internacional mais apta a responder a pergunta formulada no início do trabalho, todos os demais foram excluídos da presente análise. Reduzida será assim a menção destes neste texto, a ser efetuada nos estritos limites necessários para complementar o relato da construção histórica da CECA. 


\subsection{Convergência das Demarcações Temporais, Espaciais e Temáticas}

A partir da explicitação dos termos segundo os quais as escolhas metodológicas foram realizadas, é possível agora compreender plenamente as razões pelas quais foram desconsideradas como potenciais objetos deste estudo iniciativas institucionais jurídiconormativamente positivadas, que, a partir de uma compreensão estritamente epidérmica do tema de investigação proposto, poderiam parecer dialogar com ele.

Estão assim fora do arco metodológico do presente trabalho as experiências (i) não localizadas entre 1945 e 1951, (ii) que, entre o Oceano Atlântico e os Montes Urais, detiveram uma concepção geográfica estreita e hermética sobre a Europa, (iii) que não encontraram expressão institucional jurídico-normativa positiva, e (iv) cujas normas jurídicas não sinalizaram (a) terem sido forjadas conforme Leis (ausência de Leis em absoluto, isto é, de Leis em sentido formal), ou ainda, (b) terem sido constituídas conforme Leis de convivência plural permanente entre diferentes (presença de Leis em sentido formal, mas ausência de Leis em um sentido material específico).

Este trabalho se preocupa deste modo com a compreensão da construção histórica da Organização Internacional europeia cujas normas jurídico-positivas foram constituídas segundo uma estrutura dada por Leis. Foram assim desconsideradas tanto as iniciativas de promoção de uma Europa Unida desprovidas de Leis em sentido formal, como aquelas que não se constituíram de acordo com uma concepção determinada de Leis em sentido material escolhida por este trabalho: Leis materiais de convivência plural permanente ${ }^{137}$.

Nesse sentido, por estarem suas instituições desprovidas de quaisquer Leis, este trabalho excluiu de seu campo analítico a análise das instituições e da História da OECE e do Pacto de Bruxelas. Da mesma forma, por as instituições do CdE terem sido forjadas

Isso garantirá uma unidade para a apresentação deste trabalho a seu público leitor: foram incluídas aqui apenas as razões que, metodologicamente consistentes, podem assegurar um adequado entendimento pelo leitor das conclusões formuladas - uma vez que não deteve a oportunidade de acompanhar a formação passo a passo de cada elo da cadeia de razões construída durante a Pesquisa.

Deste modo, em nome da facilitação da compreensão da Tese conclusiva obtida pela Pesquisa, é somente a preocupação com o entendimento da conclusão encontrada que determinou (i) a redução da quantidade do material a ser aqui exposto e (ii) a diminuição da complexidade das inúmeras conclusões parciais a que se chegou, bem como (iii) a eliminação de outras observações secundárias não pertinentes para a demonstração da Tese - ainda que tenham sido suscitadas durante o período de Pesquisas e que tenham auxiliado inferências, induções e deduções que permitiram chegar à conclusão.

Por isso mesmo, este texto se apresenta apenas como a síntese transcrita de um longo, complexo e tortuoso percurso de Pesquisa que, para efeitos de formalização material e de facilitação de compreensão, demandou um registro escrito o mais coerentemente ordenado possível, no qual cada parte dialoga explícita ou implicitamente com a outra. É nesse sentido preciso que se deve compreender este texto como um registro lógico, e não cronológico, da conclusão produzida e da Pesquisa desenvolvida.

${ }^{137} \mathrm{O}$ sentido material das Leis que foi assumido por este trabalho restará mais claro quando da leitura do item 3.4., infra, onde se explicita a chave hermenêutica adotada por este estudo. 
segundo Leis que conferiram uma determinada organização jurídico-política entre seus Estados-Membros diversa da buscada pela pergunta inicial deste trabalho, foi igualmente eliminada a análise das instituições e da História do CdE.

Ademais, em virtude de a CED e a CPE terem sido propostas de aproximação entre países europeus forjadas no interior de uma óptica Federalista diretamente derivada da que constituiu o $\mathrm{CdE}^{138}$, há que se compreender que mais uma vez se justifica a exclusão dessas duas Organizações Internacionais do interior do presente estudo ${ }^{139}$. Ao partilhar de um Projeto de Europa Unida que não interessa ao presente trabalho - o Projeto de Europa Unida da vertente Federalista, da mesma maneira que o CdE foi mantido à distância do foco de investigação deste texto, foram afastadas igualmente a CED e a CPE.

Entende-se assim se ter considerado que apenas a CECA teria detido a aptidão para instituir um novo modo de relações entre determinados países europeus no imediato pósSegunda Guerra Mundial. Aliás, uma vez identificada a CECA como a primeira Organização Internacional do pós-Segunda Guerra Mundial detentora da aptidão de instituir jurídico-normativamente um sistema institucional de convivência plural permanente fundado em Leis ${ }^{140}$, seria desnecessário prosseguir a procura por outras iniciativas propostas no período.

Dessa forma, reforça-se o afastamento metodologicamente justificado da necessidade de analisar aqui a CED e a CPE.

Espera-se assim que tenham restado plenamente esclarecidas as razões de escolha da CECA como o objeto de atenção privilegiado e exclusivo deste estudo. Por ser a única Organização Internacional do imediato pós-Segunda Guerra Mundial apta a responder à

\footnotetext{
${ }^{138}$ Conforme relato histórico brevemente efetuado no item 1.3., supra.

139 Além do fato de não terem suas normas ingressado no cosmos jurídico, diante a rejeição das duas Organizações pela Assembleia Nacional francesa, em 1954, como afirmado no item 1.3., supra.

Nesse sentido, este trabalho rejeita a análise da CED e da CPE por três motivos principais:

(i) porque não são objeto de estudo capaz de suscitar interesse no interior de um campo de estudos em Direito, na medida em que não detiveram normas de Direito Positivo para ser o ponto de partida de um discurso jurídico (neste particular, v. também o item 2.2., infra, onde se apresenta a posição deste trabalho no interior da oposição entre Dogmática e Zetética Jurídicas);

(ii) porque, caso tivessem obtido sucesso, seriam manifestações de intento Federalista Europeu, o qual, como sinalizado acima, estava orientado para promover uma União política unificadora na Europa (ou simplesmente, porque suas Leis teriam sido distintas das com as quais este estudo se preocupa); e

(iii) porque se tratariam de Organizações Internacionais localizadas fora do recorte metodológico efetuado pela conjunção do lapso temporal com as delimitações temáticas: em 1951, a CECA teria sido instituída; com isso, seria desnecessário prosseguir na procura de outras Organizações Internacionais posteriores à CECA que eventualmente visassem à constituição de uma união política de convivência plural permanente; considerando que a CED e a CPE foram propostas posteriormente, não faria assim sentido aos limites deste estudo investigar algo temporalmente localizado após 1951.

${ }^{140}$ Um novo modo de relações entre países europeus.
} 
pergunta formulada no início deste trabalho, sua construção histórica e suas normas jurídicas positivas foram detalhadamente analisadas.

Frise-se deste modo que essa análise privilegiada se fará em detrimento das demais experiências (OECE, Pacto de Bruxelas, CdE, CED e CPE) tendo em vista que estas não partilham do mesmo Projeto de Europa Unida proposto pela CECA. Afinal. desprovidas de Leis que pudessem estabelecer um novo modo de relações entre países europeus tradicionalmente opostos em termos bélicos, seriam tais experiências incapazes de sustentar uma reflexão suficientemente digna para responder à pergunta do início deste trabalho.

Sem Direito, sem Leis, ou sem Leis materiais de convivência plural permanente, não teriam a CED, a CPE, a OECE, o Pacto de Bruxelas e o CdE inaugurado de maneira inaudita na História da Europa uma maneira qualitativamente renovada de aproximação de alguns países europeus. Apenas a CECA teria detido a aptidão de os forçar a conviver pressupondo, preservando e promovendo as diferenças entre seus Estados-Membros. Apenas ela teria sido a primeira experiência jurídico-normativamente estruturada para lhes impor institucionalmente uma união Política - uma união descompromissada com uma tendência potencialmente unificadora.

Assim, a análise histórica a ser empreendida por este estudo se desenvolverá entre os anos de 1945 a $1951^{141}$, de maneira a elucidar o percurso histórico de construção da $\mathrm{CECA}^{142}$ antes da análise institucional propriamente dita ${ }^{143}$. Afinal, é neste período que alguns países europeus souberam e puderam estabelecer entre si um novo modo de relações ${ }^{144}$. A resposta ao aspecto temporal "quando" da pergunta encontra suas balizas nessa primeira reflexão, de caráter metodológico: "quando" foi possível o novo modo de relações? A resposta é simples: a partir de 1945, com sua manifestação normativa jurídicopositiva em 1951: a CECA.

Por fim, note-se que se a instituição da OECE, do Pacto de Bruxelas e do CdE não será objeto de preocupação deste estudo ${ }^{145}$. Em virtude do fato de tais Organizações Internacionais terem sido gestadas e criadas no interior do período analisado (1945-1951), não será possível as excluir integralmente desta Tese. Será fundamental as mencionar na

\footnotetext{
${ }^{141}$ Tendo em vista que foi sumariamente excluída deste trabalho a análise da História da CED e da CPE.

${ }^{142}$ Nos três primeiros Capítulos da Parte Segunda desta Tese de Doutorado.

${ }^{143}$ A ser realizada no Sétimo Capítulo desta Tese de Doutorado, conforme a chave hermenêutica e o método de Pesquisa a serem especificados nos Segundo e Terceiro Capítulos, infra.

${ }^{144}$ Relações estruturadas por organização jurídico-política dada por Leis materiais de convivência plural permanente (unidade-diferenciação).

${ }^{145}$ Haja vista que tais Projetos de Europa Unida foram apartados metodologicamente das preocupações principais deste trabalho.
} 
narrativa da época selecionada, sob pena de falseamento de elementos que concorreram na construção da CECA.

Deste modo, apesar de não partilharem do mesmo Projeto de Europa Unida proposto pela CECA, há que se perceber que a OECE, o Pacto de Bruxelas e o CdE serão indicados no presente texto à medida que se mostrarem estritamente necessários para elucidar questões que disserem respeito à CECA. Não se estranhe assim que a exclusão da análise de tais iniciativas não significou neste trabalho a aposição de absoluto e completo silêncio com relação a tais Organizações Internacionais. A narrativa histórica destas cumprirá os desígnios de uma exposição séria e mais completa possível da História da CECA - pois, além das próprias afirmações a serem feitas sobre a CECA individualmente considerada, também se pode saber mais sobre esta ao se conhecer precisamente aquilo que ela não era.

Uma vez localizado metodologicamente o objeto de estudo por meio do esclarecimento dos limites estabelecidos por um critério temporal definido (1945 a 1951), e diante de uma delimitação espacial vinculada a um rápido detalhamento de um critério temático $^{146}{ }^{147}$, julga-se terem sido esgotadas todas as possibilidades de justificação do recorte metodológico que permitiu escolher a CECA como o fenômeno a ser estudado por este trabalho.

Fique assim claro que o estudo da história a ser empreendido neste estudo será desenvolvido

146 Fenômeno a ser analisado: a História da CECA e as instituições jurídico-normativas positivadas desta. Motivo: por terem estabelecido um novo modo de relações entre alguns países europeus conforme uma Lei de convivência plural permanente (na produção do sentido normativo último sobre questões relacionadas à vida comum).

${ }^{147}$ Ainda que as razões de recorte temático se revelem de maneira mais plena a partir do exame dos itens a seguir e dos próximos Capítulos. Mostrou-se necessário mencionar as questões de caráter temático neste momento do discurso, haja vista que tais considerações auxiliariam na compreensão mais adequada das exclusões metodológicas efetuadas neste trabalho. Relembre-se aqui a distinção entre o registro textual da Pesquisa nesta Tese e a realização da Pesquisa fora desta Tese, mencionada na nota de rodapé 136, supra.

Note-se que sem a inserção parcial destas considerações, restaria ainda bastante ampla e aparentemente injustificada a opção pelo estudo exclusivo e vertical da história da construção da CECA pois, efetivamente, os critérios temporal e espacial por si só não seriam suficientes para justificar a predileção pela CECA, em detrimento da OECE, do Pacto de Bruxelas, do CdE, da CED e da CPE. Tempo e espaço não sustentariam por si só a restrição da preocupação investigativa deste trabalho à CECA.

Deste modo, a fim de afastar discussões infindáveis em torno das razões da exclusão daquelas Organizações Internacionais, mostrou-se fundamental efetuar uma rápida associação de um raciocínio temático-espacial de demarcação metodológica ao de delimitação metodológica com base em critérios temporais. Com isso, esgota-se o detalhamento do tema e do problema de Pesquisa e do objeto a ser estudado. Será feita a partir de agora a exposição do Método de abordagem deste objeto para responder à pergunta. 
(i) com base em relatos históricos antigos e recentes sobre a História da CECA (fontes secundárias), conhecidos ou não pela literatura jurídica brasileira; bem como

(ii) a partir de documentos que reproduziram hoje a integralidade de originais da época, tais como rascunhos, manuscritos, cartas, atas de reuniões ou de Congressos, transcrição de discursos, entrevistas, entre outros (fontes primárias), não consultados de maneira usual pela produção jurídica brasileira preocupada em compreender o processo de construção da Europa Unida ${ }^{148}$.

Desenhado o campo metodológico estabelecido pela busca de uma resposta ao aspecto temporal ("quando") da pergunta formulada ao início deste trabalho, parte-se para o delineamento mais preciso do arco de questões metodológicas a serem postas ao fenômeno da CECA e a suas respectivas instituições ("como" e "por meio de").

Os próximos Capítulos se preocuparão em definir a maneira pela qual a experiência histórica e normativa da CECA será abordada conceitualmente, a fim de que se abra a possibilidade de uma leitura alternativa sobre esta aproximação entre países europeus por meio do filtro significativo aposto por um dicurso racional conceitual diferente ${ }^{149}$. Com efeito, há sempre um

\footnotetext{
${ }^{148}$ Uma das consequências, aliás, de tratar historicamente a CECA como um elemento singular a ser estudado, muito diferente de a simplsmente a incuir entre os muitos componentes daquela automática e impensada sucessão de fatos narrados para evidenciar uma superficial "visão histórica" da UE atual, tal qual criticada na nota de rodapé 80 , supra.

Como afirmado anteriormente, recusa-se que se considere a apresentação da construção histórica da CECA como ato destinado a cumprir um simples "rito de passagem" exigido para adentrar especificamente no tema Pesquisado - postura que será mais bem compreendida a partir da leitura do início da Parte Segunda desta Tese de Doutorado. Apreende-se conceitualmente o passado para dele extrair um ensinamento para o tempo presente.

Trata-se inclusive da virtude de se escolher um objeto de estudo único e exclusivo para uma investigação: mostra-se possível aprofundar o conhecimento em torno do mesmo, inclusive por meio do esforço em encontrar elementos que possam fornecer informações adicionais e novas em comparação com aquelas que rápida e usualmente são apresentadas como já amplamente conhecidas pela tradição vigente do conhecimento jurídico sobre a atual UE.

Deixa-se assim de considerar o objeto de estudo (CECA) como desprovido de qualquer ênfase ou privilégio, isto é, não mais se o considera como apenas mais um elemento a ser rapidamente mencionado - e, em seguida, esquecido - na teia discursiva da investigação. Busca-se lhe conferir a necessária dignidade investigativa apta a dele extrair novas e mais profundas conclusões.

A verticalização do conhecimento assegura aqui uma ênfase produtora de significações adicionais sobre a CECA. Isso permite produzir conhecimento novo, na medida em que se passa a dar a devida atenção aos mais precisos e preciosos detalhes relacionados à produção do fenômeno jurídico-político escolhido. Diferentemente do que faz o tradicional relato em varredura das distintas Organizações Internacionais que historicamente foram criadas e progressivamente unidas para formar aquilo que hoje se denomina UE.

${ }^{149}$ Mais uma vez, como mencionado na nota de rodapé 19, supra, uma Teoria visa a interpretar uma conjuntura passada, procedimento que jamais perde sua normalidade em estudos dotados de seriedade acadêmica.
} 
salutary effect of applying theory to historical empirical work. Theory generally teaches us to pose the right questions and often helps us to reinforce the analytical value of academic research. Historians should continue to do what they are good at, but openness towards other disciplines will lead to a better understanding of what the intricate field of European integration is all about. (HARST, 2008, p. 8).

Se este estudo se desloca no interior de um arco de preocupações jurídicas, há que se compreender com precisão a partir de qual perspectiva em Direito o fenômeno da CECA é percebido no interior deste trabalho - haja vista que ele não parece se reduzir a uma apreensão estrita de Direito Positivo. De fato, ao se preocupar, não apenas com o ordenamento jurídico-normativo positivo da CECA, mas também com sua História constitutiva, com as Leis desta Comunidade e com sua questão correlata sobre a concepção em torno do fundamento do Direito e do Poder, este estudo acena flertar com um conhecimento interdisciplinar ${ }^{150}$.

Realiza-se nos itens a seguir a necessária elucidação posicional deste trabalho no conhecimento jurídico. Este posicionamento metodológico é ainda tão fundamental quanto o até então revelado, na medida em que permitirá compreender o modo como se pretendeu deslizar conceitualmente o empreendimento reflexivo em torno do fenômeno jurídicopolítico apontado neste Capítulo como o destino e o ponto de partida exclusivo deste estudo.

${ }^{150}$ Como fora sinalizado por meio da nota de rodapé 94, supra. 


\title{
SEGUNDO CAPÍTULO - DELIMITAÇÃO METODOLÓGICA: O CAMPO DE LEITURA PROPOSTO PELO PRESENTE ESTUDO
}

\begin{abstract}
[É] um estímulo à razão para que assuma novamente o mais árduo de seus trabalhos, qual seja o do autoconhecimento, e instaure um tribunal capaz tanto de assegurá-la em suas pretensões legítimas como, por outro lado, de ajudá-la a livrarse de todas as suposições infundadas [...]. (KANT, 2012, p. 19).
\end{abstract}

Uma vez tendo sido delimitado temporal, espacial e tematicamente o objeto deste estudo, é fundamental que sejam feitas maiores precisões de caráter jurídico sobre o mesmo. Por este estudo se situar no interior de um campo de conhecimento jurídico científico, é importante compreender de que maneira o Direito percebe o fenômeno a ser investigado. Trata-se de tentar esclarecer os parâmetros gerais de inserção da CECA e de sua respectiva ordem institucional no cosmos jurídico.

Como afirmado outrora ${ }^{151}$, recorre-se neste texto à imagem do arco do conhecimento jurídico. Ela delineia o percurso de investigação a ser traçado por este estudo em Direito. Se até o presente momento as reflexões metodológicas permitiram precisar os contornos do fenômeno estudado, é importante que se preocupe em definir o modo como ocorre seu ingresso na teia significativa dada pelo conhecimento jurídico.

Definido o ponto de partida (o que será investigado), é preciso entender como ele recebe dignidade jurídica, ou melhor, como o pensamento em Direito admite e absorve este fenômeno dentro de seus domínios, a fim de que ele sofra a incidência de uma reflexão informada por uma racionalidade jurídica própria. Mais simplesmente, uma vez recortado do fenômeno social no tempo, no espaço e tematicamente, mostra-se necessário precisar os termos da tradição em Direito segundo os quais é este traduzido para ser objeto de questionamentos próprios do campo do conhecimento jurídico (o modo como ele será investigado).

Relembre-se aqui a advertência formulada nos itens anteriores ${ }^{152}$ de que todo discurso jurídico tem por aspecto singular o fato de principia sua reflexão no Direito Positivo, isto é, em um Direito que tenha sido vigente e eficaz, ou que ainda está vigente e eficaz (FERRAZ JR., 2001, p. 42; REALE, 2001, p. 17).

Isso significa que o fenômeno CECA se torna suscetível a uma reflexão jurídica a partir do momento em que assumiu uma roupagem linguística que lhe conferiu a aptidão para ser objeto de investigações jurídicas. Ou ainda, a partir do momento em que passou a

\footnotetext{
${ }^{151}$ Início da Introdução Parcial a esta Parte Primeira, supra.

${ }^{152}$ Principalmente nos itens 1.3. e 1.4., supra.
} 
se expressar em termos compreensíveis pelo conhecimento jurídico, a saber, quando ela foi estruturada em Direito Positivo ${ }^{153}$.

Todavia, é insuficiente dizer que o ponto de partida desta investigação em Direito é a ordem jurídica positiva da CECA, na medida em que essa afirmação resta ainda demasiado ampla. Com efeito, o arcabouço jurídico-normativo positivo da CECA detém uma amplitude singular: seu Direito Positivo não se reduz a seu respectivo Tratado Constitutivo, abrangendo também, dentre outros, as Decisões e as Recomendações de suas entidades comunitárias (artigo 14 do Tratado da CECA) ${ }^{154}$.

Nesse sentido, poder-se-ia pensar que o objetivo desta Tese consistiria em analisar exaustivamente toda a constelação jurídico-normativa positivada da CECA, o que exigiria uma preocupação detalhada não apenas do Tratado da CECA, mas também de cada uma das Decisões e Recomendações proferidas por seus órgãos comunitários ${ }^{155}$.

Nada mais incoerente com a proposta deste estudo. Isso romperia com o recorte metodológico triplo feito no Capítulo anterior e acenaria para uma pretensão imodesta de tentar compreender holisticamente todo o arcabouço de Direito Positivo dessa Organização Internacional $^{156}$.

Lembre-se de que este estudo se restringe temporalmente aos anos de 1945 e 1951, vale dizer, até o momento em que foi assinado o Tratado da CECA. Não teria nem mesmo havido decurso de tempo suficiente para a produção de atos normativos derivados do Tratado. Essa condição justificaria por si só a designação do Tratado que instituíra a CECA

\footnotetext{
${ }^{153} \mathrm{O}$ qual, como reiterado longamente nas partes 1.4. e 1.5., supra, revelou-se como tendo sido articulado segundo Leis, de maneira a estabelecer um novo modo de relações entre os povos europeus em um sistema de convivência plural permanente.

154 Segundo este dispositivo, a Alta Autoridade da CECA poderia atuar normativamente mediante (i) decisões as quais eram obrigatórias em todos seus elementos; ou (ii) recomendações, as quais eram obrigatórias quanto aos fins visados, mas deixaram aos destinatários a escolha dos meios para o atingimento deles. $\mathrm{O}$ mesmo artigo 14 ressaltava ainda a existência de (iii) pareceres, que não eram espécie normativa, pois não eram juridicamente vinculantes. Por fim, mencione-se que a parcela final do mesmo dispositivo seguia a lógica de "quem pode o mais, pode o menos", na medida em que facultava à Alta Autoridade proferir uma recomendação quando ela tivesse recebido competência para proferir uma decisão. Este artigo não será objeto de considerações no Sétimo Capítulo desta Tese de Doutorado, razão pela qual os comentários acima foram julgados pertinentes apenas para evitar lacunas no fornecimento ao leitor de informações laterais, voltadas à elucidação de raciocínios constantes de passagens principais.

${ }_{156}^{155}$ Abrangeria inclusive os julgamentos da Corte da CECA.

${ }^{156} \mathrm{O}$ que não impede que, em alguns momentos, quando conveniente, sejam mencionados alguns atos proferidos pelas entidades comunitárias. Essa preocupação aparecerá principalmente nas situações em que a apresentação exemplificativa de uma ou de outra disposição normativa tomada em concreto facilitar a compreensão do texto do Tratado da CECA.

Essa ressalva restará mais clara quando da leitura do Sétimo Capítulo deste trabalho: tratar-se-ão de situações esporádicas, pontuais, em que o recurso explicativo a um ou outro ato normativo mais específico será feito apenas para facilitar a compreensão do regime normativo introduzido pelo Tratado - e não daquele positivado pelo ato normativo derivado.
} 
como o Direito Positivo produzido no microcosmo desta Organização Internacional a ser analisado com exclusividade por este trabalho.

Todavia, mais do que isso, há que se notar que o próprio delineamento temático deste trabalho aponta para a necessidade de se considerar apenas e tão-somente o Tratado da CECA como o documento jurídico-normativo positivo a ser considerado o ponto de partida fundamental desta Tese. Afinal, se se pretende compreender como e por meio de quais instituições os países que compunham a CECA detiveram a capacidade de instaurar um regime de convivência que preservava a diferença entre cada um deles, há que se considerar apenas as disposições jurídico-normativas positivadas que estruturariam tais relações. Mas há que se compreender teoricamente essa ideia de orientação institucional pelas Leis, por meio de chave explicativa dada por conhecimento jurídico-teórico.

\subsection{Direito Comunitário como Direitificação da Convivência}

O Direito é especificamente uma forma de organizar a vida de uma sociedade em instituições (UNGER, 2001, p. 6). Toda construção jurídico-normativa positiva institucional resulta de acidentes e arbitrariedades típicos da condição profana originária do Direito. Produto de lutas políticas entre diferentes concepções de mundo, suas normas portariam não-explicitamente as marcas dessas escolhas entre inúmeras opções e ideologias conflitantes. Haveria uma arena de disputas infindáveis entre as mais diferentes vertentes opositoras, condição que caracterizaria o fenômeno jurídico. As batalhas entre tais concepções moldariam as opções de arquitetura institucional (UNGER, s.d., p. 11 e $15)^{157}$.

A despeito da existência dessa contraposição entre modos de conceber o Direito e o mundo, haveria uma decisão (ainda que historicamente determinada e limitada) sobre como estabelecer parâmetros jurídico-normativos positivos (UNGER, s.d., p. 7). Neste momento, dir-se-ia que relações conflituosas teriam sido incorporadas pelo cosmos do Direito, vale dizer, que elas teriam sido “juridificadas". A partir deste instante de “direitificação”, as relações teriam recebido densidade jurídica, isto é, elas passariam a ser regidas pelo Direito.

157 Por esse motivo, inclusive, segundo Roberto Mangabeira UNGER (s.d., p. 7), seria necessário desnaturalizar as instituições com as quais se tem contato, na medida em que apenas por meio de desmistificações se poderia lembrar que as instituições não são nem historicamente necessárias, nem permanentes. 
Ao se falar de "juridificação" ou ainda, de "direitificação" neste texto, há que se salientar que se parte conscientemente da expressão alemã Verrechtlichung, cuja origem a tradição jurídica brasileira remonta a Gunther TEUBNER (1984). Este termo é normalmente traduzido para o português por "hiperjuridização", "sobrejuridificação", “explosão normativa”, ou simplesmente “juridização” (FARIA, 2008, p. 45-7, 2009).

Todavia, para evitar mal-entendidos e discussões estéreis fora do campo de investigação deste trabalho, há que se registrar desde o presente momento que este texto não pretende atribuir ao termo "juridificação" ou "direitificação" de maneira integral e exatamente idêntica o mesmo campo significativo ao qual usualmente se associa signicamente essa expressão no pensamento jurídico brasileiro. São necessárias assim mais precisões sobre o uso desta noção por este trabalho.

\subsubsection{A Inserção da Política nos Cosmos Jurídico Direitificado}

Normalmente se compreende Verrechtlichung no interior de uma teia de significações mais particular e parcial, a saber, a que aponta para a noção de inflação legislativa (FARIA, 1994, 1996, 1999, 2008, 2009; TEUBNER, 1984, p. 294-6).

Segundo essa perspectiva, um Estado de Bem-Estar social inserto em uma Economia Globalizada visa a construir normativamente sua legitimidade a partir de desenfreada edição de normas jurídicas particulares voltadas a controlar os novos conflitos e situações derivados da crescente complexidade do mundo contemporâneo.

Movido pela ideia de que deve dar uma resposta formal e padrão à crescente diversificação singular de conflitos, desenvolvidos em contextos "marcados por mudanças muito rápidas e, por vezes radicais", o Estado tenderia a "abusar dos dispositivos legais de caráter programático e multiplicar o número de normas com textura e tipologia abertas" (FARIA, 2008, p. 45).

No contexto de inflação legislativa, juridificação indicaria esse movimento de aposição de regras circunstanciadas e circunstanciais para questões pontuais e imediatas. Isso culminaria na ampliação confusa e cada vez menos sistemática do Direito Positivo, mais e mais contraditório, desordenado e desprovido de racionalidade lógica. Essa condição retiraria do Direito sua organicidade, sua racionalidade e sua capacidade de orientar decisões e condutas (FARIA, 2008, p. 46-7).

Todavia, a noção de Verrechtlichung ultrapassa essa simples caracterização de inflação legislativa, apontando para outras possíveis significações (TEUBNER, 1984, 
1993). Haveria, na verdade, uma variação de significações em função do contexto em que o termo é utilizado, bem como em virtude daquilo sobre o qual o autor pretende discorrer ou enfatizar.

Este termo é usado por Gunther TEUBNER para desenvolver suas considerações em torno da ideia de Direito como controlador de processos de auto-regulação (1984, p. 334-44) ${ }^{158}$. Entretanto, este autor fundamenta suas reflexões a partir das contribuições do pensamento desenvolvido por Otto KIRCHHEIMER no interior do campo da Sociologia do Direito (TEUBNER, 1984, 1993), quem, por sua vez, também parece não deter a "paternidade legítima" do termo (TEUBNER, 1993, p. 505).

A origem da expressão parece residir na obra de Hugo SINZHEIMER, Die Zukunft der Arbeiterräte, publicada em 1919. Nesta obra, Verrechtlichung indicaria a tendência de transformação qualitativa da luta política promovida pelas organizações sociais de trabalhadores em lutas realizadas pelas vias das instituições jurídicas - isto é, por meio de um caminho dado pelo Direito - (TEUBNER, 1993, p. 505) ${ }^{159}$ :

Der Kampf, den sie führen, spielt sich immer mehr ab in der Form einer „Verrechtlichung“ des Kampfes in den geordneten Bahnen eines besonderen Rechtsgangs; man denke an Tarifabschlüsse und Schlichtungsorgane. (SINZHEIMER apud TEUBNER, 1993, p. 505).

Otto KIRCHHEIMER teria incorporado o termo em seu discurso investigativo a partir de 1928, após a apresentação de sua Tese Zur Staatlehre des Sozialismus und Bolschewismus. Se a paternidade do termo não era sua, Otto KIRCHHEIMER absorvera e desenvolvera com tamanho refinamento a noção de Verrechtlichung que pudera receber historicamente o reconhecimento de ter moldado o conceito de maneira ainda mais sofisticada (TEUBNER, 1993, p. 506), praticamente ofuscando a contribuição original de Hugo SINZHEIMER.

Antes de tudo, Otto KIRCHHEIMER foi responsável pela ampliação do campo significativo de Verrechtlichung. Comumente se indica (TEUBNER, 1984, p. 298) que Otto KIRCHHEIMER também teria usado o termo Verrechtlichung como uma maneira

\footnotetext{
${ }^{158}$ Conceito a ser rapidamente explicado nas linhas a seguir, nos estritos limites da necessidade de esclarecer a maneira como se aplica a noção de Verrechtlichung no presente texto.

159 Mencione-se a título de curiosidade que, a partir de repertório hermenêutico fundado na Semiótica, fizemos uma leitura parecida com relação à incorporação histórica da liberdade sindical no ordenamento jurídico brasileiro, em nossa A Função Simbólica da Liberdade Sindical: Uma Visão Apocalíptica da Dogmática Jurídica Sindical Brasileira.

Trata-se de monografia apresentada, em 2009, perante o Departamento de Direito do Trabalho e Seguridade Social da Faculdade de Direito da Universidade de São Paulo - Largo São Francisco (FADUSP), no interior do Programa de Especialização em Direito do Trabalho e Seguridade Social desta Faculdade.
} 
de designar a formalização legal das relações de trabalho. Segundo esta visão comum, com este termo, o autor teria denunciado o objetivo de neutralizar um conflito de classes genuinamente político, ou ainda, o mecanismo encontrado para petrificar a dinâmica da política (instrumento de despolitização das relações).

Todavia, para Otto KIRCHHEIMER, Verrechtlichung não era um simples "conceito de luta" com o qual poderia combater discursivamente no conhecimento jurídico aqueles que pretendiam neutralizar por meio do Direito o caráter político das relações sociais nas discussões em torno da Constituição da República de Weimar. Essa forma de compreender seria uma leitura superficial de Otto KIRCHHEIMER (TEUBNER, 1993, p. 506-7), principalmente porque teria eleito como preocupações centrais de Otto KIRCHHEIMER aquelas relacionadas exclusivamente ao Direito do Trabalho, o que reduziria em muito o campo significativo da expressão e suas potencialidades no pensamento jurídico (TEUBNER, 1984, p. 299-300).

Com a noção de Verrechtlichung, Otto KIRCHHEIMER teria tentado compreender as novas maneiras de inter-relação entre Direito, política e economia. E, para isso, congregaria parcelas das contribuições reflexivas dadas pelos principais pensadores de seu tempo, tais como Max WEBER, Vilfredo PARETO, Georges SOREL e, sobretudo, Karl MARX e Carl SCHMITT (TEUBNER, 1993, p. 507). A partir da apropriação parcial e crítica das teorias desses autores, teria conseguido apontar por meio deste termo específico para um novo modo de relacionamento entre Direito, política e economia.

Em linhas gerais ${ }^{160}$, Otto KIRCHHEIMER teria se preocupado em indicar com Verrechtlichung a mutação da função do Estado de Direito a partir da introdução da ideia

\footnotetext{
160 Não serão aqui discutidas todas as peculiaridades de construção do conceito de Verrechtlihung no pensamento de Otto KIRCHHEIMER, tendo em vista que este trabalho não consiste em uma investigação sobre o surgimento e a mutação significativa na História deste conceito. Sobre essa temática, indicamos a leitura de Gunther TEUBNER (1984, 1993).

Aqui serão mencionados apenas os pontos principais sobre este termo, a fim de (i) especificar e justificar o uso da ideia de direitificação - como um dos desdobramentos possíveis da ideia de Verrechtlichung - para designar teoricamente o arcabouço jurídico originário da CECA; e (ii) diferenciar o uso efetuado neste trabalho com relação à recepção deste conceito na literatura jurídica brasileira sob o termo juridificação - esta entendida como inflação normativa.

Não serão exploradas aqui, por esse motivo, as consequências tradicionalmente atribuídas à juridificação, tais como (i) alteração da função do Direito (intervenção estatal na Economia); (ii) alteração da legitimação do Direito (por resultado); (iii) alteração da estrutura do Direito (particularizada); e (iv) o trilema regulatório: (a) indiferença recíproca entre Direito e sociedade; (b) desintegração da sociedade por meio do Direito; ou (c) desintegração do Direito pela sociedade (TEUBNER, 1984, p. 304-25).

Essa discussão não se comunica com os objetivos investigativos deste trabalho. Remetemos o leitor mais uma vez ao texto de Gunther TEUBNER (1984), bem como aos de José Eduardo FARIA (1999, 2008), para uma compreensão mais completa sobre essa discussão.

Conceito de apoio para a reflexão desenvolvida neste trabalho, não haveria razão para se deter demasiadamente em torno da historicidade de Verrechtlichung. Esta é ideia que apenas fornece roupagem
} 
de segurança jurídica. O Direito teria se tornado independente dos diferentes grupos políticos, de maneira a constituir um maquinário jurídico instrumental dotado de função específica: impedir a totalização do mundo vivido por uma única dimensão de existência a dada pela economia - por meio da direitificação da política (TEUBNER, 1993, p. 507-8). O Direito seria instrumento institucional de refreamento do potencial totalizante e unidimensional da Economia sobre o corpo social.

Por meio da noção de Verrechtlichung, Otto KIRCHHEIMER teria identificado a tendência de canalizar os conflitos políticos de seu período por meio do Direito - técnica social de intermediação das relações entre política e economia, a fim de impedir a difusão total no mundo vivido de uma única forma de compreender as relações sociais: a forma Econômica (TEUBNER, 1993, p. 509-10).

Com essa perspectiva, o autor também teria procurado criticar a ideia da imparcialidade pretensamente neutra do Direito enquanto técnica - sob pena de haver uma equivalente disseminação total da forma do Direito sobre a sociedade (TEUBNER, 1993, p. 509). O Direito deteria um caráter efetivamente político: seria o meio de promover o encontro de diferentes segmentos políticos, para impedir que apenas a forma da economia (burguesa) pudesse pautar normativamente os termos da sociedade (TEUBNER, 1993, p. 509-10). O Direito reviveria por meio de suas normas jurídicas positivas as tensões políticas fundamentais e impediria que a expressão econômica de

linguística auxiliar para a construção do argumento central deste trabalho. Há que se priorizar o avanço da reflexão centrada propriamente no tema desta Pesquisa.

Mais do que se preocupar em se deter em aspectos e anedotas pontuais em torno do conceito, pretende-se assegurar o quanto antes a passagem ao desenvolvimento da reflexão propriamente dita deste trabalho, na Parte Segunda desta Tese. Centrar-se em demasia nesta discussão apenas prolongaria ainda mais a extensão material deste estudo em aspectos que, apesar de interessantes, pouco poderiam contribuir para este trabalho.

Bastará efetuar, deste modo, uma rápida menção de como se deve compreender a ideia de Verrechtlichung de acordo com as preocupações investigativas deste trabalho (e a correlata preferência pelo uso do termo "direitificação" em detrimento de "juridificação"), em comparação com outras formas que o pensamento jurídico pretendeu compreender este conceito.

Adiante-se que nem a presente significação, nem as demais, são capazes de esgotar as possibilidades de preenchimento do campo significativo produzido a partir da ideia de Verrechtlichung. Este sucinto mapeamento comparativo de modos de compreender essa noção não tem a pretensão, nem de esgotar o tema, nem de encontrar uma resposta definitiva sobre o problema. Afinal, nenhuma tentativa de exaurir as possibilidades de preenchimento de um conceito permanece na História, sendo assim variável no tempo, conforme aquilo que se pretende fazer ressaltar por meio dele. Nem mesmo uma única tentativa de delimitar o conceito pode ser vista como a melhor e apta a excluir as demais como inadequadas.

Sobre essa inesgotabilidade das possibilidades de leitura de um e mesmo fenômeno em virtude de determinada posição histórica e contextual assumida com relação a ele, indicamos a leitura do item 2.2., infra, onde se aponta a Fenomenologia como constituinte metodológica parcial do presente texto e informadora de seus principais enlaces e encadeamentos lógicos e intelectuais. Remetemos ainda à leitura do item 3.3.1., infra, onde se disserta sobre a normalidade de empréstimos conceituais parciais e a necessidade de inserir conceitos fora de seu lugar para a construção de conhecimento novo. 
apenas um dos participantes da vida comum disseminasse seus padrões normativos com exclusividade sobre os demais.

Otto KIRCHHEIMER teria identificado ter havido assim uma direitificação dos conflitos políticos, sem pretender indicar com isso ter havido uma despolitização dessas tensões por meio de formas jurídicas supostamente neutras. A ideia de direitificação indicava que o estabelecimento de uma via jurídica para tratar dos conflitos políticos era uma via igualmente política de os encaminhar. A direitificação não buscaria desfazer as implicações políticas dos confrontos por meio do Direito, mas os transformar em conflitos políticos desenvolvidos dentro do Direito (TEUBNER, 1993, p. 510).

Otto KIRCHHEIMER teria evidenciado (i) a importância de não se esquecer dos pré-requisitos e do valor políticos do Direito; (ii) o Direito dever ser entendido, assim, como técnica social de aproximação e de convivência de diferentes; e (iii) a relevância de considerar na análise jurídica desta técnica social formal a perpetuidade desses prérequisitos e do valor políticos.

Em outras palavras, direitificação seria a indicação de que se mostraria indispensável perceber o conteúdo político usualmente não-dito que permeia as formas jurídicas institucionais positivadas do aparato do Direito. Trata-se de uma sinalização da importância de se relembrar continuamente a presença da política no interior dessa técnica - ou, simplesmente, de assumir uma posição de leitura que não deixe de efetuar a repolitização dos conflitos políticos direitificados/submetidos a uma forma do Direito (TEUBNER, 1993, p. 510-1) ${ }^{161}$.

\footnotetext{
Diese vier Elemente des Verrechtlichungsbegriffs - Verselbständigung der Rechtsmaschinerie, Kolonialisierung der Gesellschaft durch die Rechtsform, Repolitisierung der Verrechtlichung der Politik, Verwandlung des Rechts in einen politischen Mechanismus - dürften deutlich machen, wie wenig angemessen es ist, ihn als bloßen „Kampfbegriff“ gegen die Entpolitisierung des Klassenkonfliktes zu interpretieren. (TEUBNER, 1993, p. 511).
}

Todavia, é importante observar que a noção de Verrechtlichung no pós-Segunda Guerra Mundial foi retomada de diferentes maneiras parciais por inúmeros autores, cada uma delas evidenciando modos e qualidades distintos desse conceito (TEUBNER, 1993, p.

\footnotetext{
${ }^{161}$ Perceba-se aqui a comunhão das pretensões do presente trabalho com relação ao Tratado da CECA com as de Otto KIRCHHEIMER com relação à República de Weimar. Essa perspectiva de repolitização de uma aparentemente neutra e exclusiva técnica jurídico-normativa positiva restará mais clara a partir da leitura do item 2.1., infra. Pois, afinal, indica-se aqui que o Direito Comunitário da CECA nada mais seria do que uma direitificação (Verrechtlichung): convivência, ou ainda, união política, por meio de técnica, a qual reintroduzira institucionalmente tensões entre diferentes formas de habitar o mundo.
} 
$512)^{162}$. Serão rapidamente apontadas abaixo as cinco principais abordagens desse conceito. Isso permitirá apresentar a ideia de que a direitificação adotada por este trabalho se diferencia das demais apenas como um $^{163}$ dentre os inúmeros modos de se compreender Verrechtlichung.

A primeira forma recente de compreender Verrechtlichung consiste na retomada do supramencionado argumento superficial de despolitizaçãa das relações (Entpolitisierung). A juridificação produziria uma formalização das relações de trabalho, de tal modo que os conflitos de classe, genuinamente políticos, se neutralizariam ${ }^{164}$. A resposta a esse problema consistiria precisamente na reversão do processo de juridificação por meio de representação autônoma de interesses, de maneira a repolitizar os conflitos da relação de trabalho para além da luta política promovida pelas organizações de trabalhadores. Como mencionado acima, esta seria uma simplificação do conceito de Verrechtlichung, pois o reduziria a problemas desenvolvidos no interior do Direito do Trabalho (TEUBNER, 1984, p. 298-300).

Uma segunda maneira de compreender juridificação é qualificá-la como uma forma que efetua uma expropriação de conflitos (Konfliktenteignung). Segundo essa perspectiva, os conflitos humanos seriam deturpados por meio da formalização de seu caráter vivido, em virtude de sua sujeição a procedimentos e a processos legais. Deste modo, o Direito não resolveria o conflito social, apenas o reduziria a mais um caso legal, alienando os homens dos meios de sua solução ${ }^{165}$. A solução para esse problema seria reintroduzir a resolução dos conflitos na dimensão social, não mais na abstração conceitual - o retorno para um trabalho alternativo dos conflitos mediante uma "expropriação dos expropriadores" (TEUBNER, 1984, p. 296-8).

Um terceiro modo de conceber a juridificação é a supramencionada ideia de inundação legislativa (Normenflut), ou ainda, a famigerada explosão legislativa.

\footnotetext{
162 Gunther TEUBNER (1993, p. 515) indica, por exemplo, que Jürgen HABERMAS teria emprestado da noção de Verrechtlichung de Otto KIRCHHEIMER a ideia de que o Direito deteria a tendência de se expandir sobre a política, permitindo-lhe argumentar que a juridificação das relações sociais implicaria a colonização do mundo da vida. A título exemplificativo, mencionem-se três estudos produzidos nesta Faculdade que se preocuparam em trabalhar essa noção de juridificação habermasiana no pensamento jurídico brasileiro: Luis Fabiano de ASSIS (2011), Liliane BENETTI (2002) e Vitor Souza Lima BLOTTA (2012).

${ }^{163}$ Nem melhor, nem pior, mas apenas especialmente direcionado à temática deste estudo.

164 "Verrechtlichung unterstützt »kooperative« Gewerkschaftspolitik, ebenso wie sie von dieser abgestürtzt wird. Dieses Wechselspiel geht freilich zulasten »konfliktorischer« Gewerkschaftspolitik.” (TEUBNER, 1984, p. 299).

165 "Danach löst Verrechtlichung nicht Konflikte, sondern sie entfremdet sie. Sie verstümmelt den sozialen Streit zum Rechtsfall, womit eine adäquate zukunftsgerichtete Lösung des Konflikts ausgeschlossen ist." (TEUBNER, 1984, p. 296).
} 
Segundo essa perspectiva, Verrechtlichung designaria a incontrolável avalanche de normas jurídicas estatais - especialmente em Direito Tributário, Direito Concorrencial e Direito da Seguridade Social - produzidas incessantemente. Isso engendraria uma incoerência entre o grande número de normas produzidas para responder a situações particulares, o que enfraqueceria a capacidade de o Direito se fazer cumprir ${ }^{166}$. A solução desse procedimento seria a desregulamentação pela simplificação do Direito Positivo, ou ainda, permitir que ele crescesse para além de um ponto ótimo, para exterminar o conjunto normativo positivado (TEUBNER, 1984, p. 294-6).

A quarta maneira de se compreender a juridificação é relacioná-la à ideia de materialização de direito formal (Materialisierung), a qual seria típica, mas não exclusiva, de um Estado de Bem-Estar Social - com expressão característica no Direito do Trabalho, no Direito da Concorrência e no Direito da Seguridade Social. A materialização residiria na complexificação da malha normativa positivada com o objetivo de introduzir conteúdos de proteção social, ampliando a intervenção do Estado sobre a Economia por meio do Direito. A solução para a juridificação seria a ilusória argumentação pela desregulamentação, de maneira reverter o excesso normativo material (TEUBNER, 1984, p. $300-4)^{167}$.

A quinta maneira de entender a juridificação é precisamente associar ao Direito a função de controlador de processos de auto-regulação (Steuerung von Selbstregulierung). Segundo essa perspectiva, o Direito Positivo estatal estabeleceria um ornamento jurídico-estrutural no interior do qual agentes privados estariam livres para atuar segundo os procedimentos próprios de auto-regulação. A ideia é estimular a conduta das entidades privadas por meio de sanções legais (ainda que se trate de mera ameaça que jamais se materialize), as quais incentivariam a produção de soluções sob a sombra do Direito $^{168}$. Haveria assim a estruturação de um sistema jurídico-positivo de livre negociação entre agentes privados, por meio de um Direito estritamente procedural (TEUBNER, 1984, p. 334-44) ${ }^{169}$.

\footnotetext{
166 "Die Rechtsdurchsetzung nimmt Schaden, die Glaubwürdigkeit leidet und an eine anspruchsvolle dogmatische Durcharbeitung ist nicht mehr zu denken.” (TEUBNER, 1984, p. 294).

167 Importante frisar que, para Gunther TEUBNER (1984, p. 303), a desregulamentação não pode ser entendida como uma solução para a crescente materialização de Direito formal. Para responder a esse problema de materialização no Estado de Bem-Estar Social, o autor aponta como possível o recurso a outra forma de compreender Verrechtlichug, a qual será igualmente referida nas linhas a seguir.

168 "Die Vorteile liegen auf der Hand: Gegenüber einer starken, pauschalierenden autoritativen Lösung sind auf dem Verhandlungsweg flexible, situationsgerechte und kooperative Lösungen zu erwarten.” (TEUBNER, 1984, p. 336).

${ }^{169}$ Indicamos ao leitor interessado sobre o tema desta nova forma de conceber o Direito os textos de José Eduardo FARIA (1999) e Gunther TEUBNER (1983; 1984), onde se desgina este novo modelo de sistema
} 
Apesar de estas serem as principais formas atuais de compreender a ideia de Verrechtlichung, é importante notar que o recurso à expressão "direitificação" neste texto tem pretensões muito mais modestas e diferenciadas. Direitificação significa aqui algo distinto daquilo até então apontado, pois adquire especificidades diante da temática examinada pelo presente estudo.

As leituras acima mencionadas de Verrechtlichung não esgotam a multiplicidade de potencialidades críticas aportadas pelo pensamento refinado de Otto KIRCHHEIMER (TEUBNER, 1993, p. 514-5). O uso do termo variou de acordo com cada um dos temas individualmente apontados acima: o campo de possibilidades de significação em torno da expressão Verrechtlichung foi preenchido de diferentes maneiras ao longo do tempo, conforme a especificidade dos temas examinados.

Nesse sentido, como apontado acima, com a expressão Verrechtlichung, Hugo SINZHEIMER analisara as organizações de trabalhadores em 1919, ao passo que Otto KIRCHHEIMER pretendeu compreender o modo de relações entre política, Direito e economia na República de Weimar. A partir deste último, Gunther TEUBNER examina a intervenção estatal na economia por meio do Direito, diante da ascensão do Estado de Bem-Estar Social. No Brasil, José Eduardo FARIA herda de Gunther TEUBNER a discussão sobre juridificação e direciona este instrumental analítico para investigar o Brasil após a redemocratização e sua abertura para uma Economia Globalizada.

Neste breve apanhado histórico sobre as significações de Verrechtlichung, percebe-se a existência de inúmeras possibilidades de continuar a sofisticada tese de Otto KIRCHHEIMER. Ela se mostra como fonte de potenciais frutos reflexivos críticos mais e mais inovadores. Inúmeros aspectos parciais desta ideia podem ser voltados para as mais diferentes direções, não sendo admissível pretender haver um monopólio do saber, isto é, uma exclusividade sobre um suposto sentido único e imutável de Verrechtlichung, pois ele designa diferentes maneiras de conceber o fenômeno jurídico.

Por essa razão, é necessário romper com um indesejado - porém sempre em potencial - estreitamento do pensamento desenvolvido por Otto KIRCHHEIMER, pois apenas deste modo se poderá compreender os variados mecanismos de alteração qualitativa de conflitos promovida pelo Direito. Isso apenas é possível por meio da reinserção social da ideia de Otto KIRCHHEIMER, o que permite a transformar e a re-tematizar da maneira

legal como direito reflexivo. Apesar de se tratar de discussão interessante, deixa-se de desenvolver considerações sobre o tema, por se situar fora do arco de questões metodológicas estabelecidas para este trabalho. 
adequada e necessária para a continuação mais atual e mais específica de seu pensamento, pois há que se tentar buscar compreender continuamente os atuais processos de Verrechtlichung (TEUBNER, 1993, p. 513 e 516).

\subsubsection{A CECA como Instrumento Jurídico-Político de Convivência}

Não há com isso a pretensão de incorporar neste trabalho toda essa tradição do pensamento jurídico nacional e estrangeiro de Verrechtlichung. Esse campo de significações pouco guarda relação com o arco de questões metodologicamente desenhado para esta investigação.

Tratam-se de situações díspares (i) lá, características de um Estado nacional, referidas a sua produção jurídico-normativa interna (despolitização, expropriação, inundação normativa, materialização, controle de auto-regulação), com relação a agentes privados; e (ii) aqui, a descrição de movimento de nova qualidade de regulamentação jurídico-internacional das relações entre países europeus no pós-Segunda Guerra Mundial, mediante Organização Internacional que instaurara entre eles um sistema de convivência, em detrimento do de coexistência e do de cooperação.

Trata-se da mera necessidade de se socorrer de uma expressão - por incapacidade de encontrar outra melhor, com o singular objetivo de nomear juridicamente o processo de construção institucional de uma Europa Unida no pós-Segunda Guerra Mundial. No interior deste movimento, houve a criação e a multiplicação de instituições internacionais regionais que efetuaram a tradução dos conflitos político-diplomáticos em termos jurídicopolíticos institucionais. O recurso à expressão "direitificação" testemunha a busca por uma roupagem linguística que permita dizer ter havido a substituição do paradigma de coexistência por outro $^{170}$.

Trata-se assim de situação completamente distinta da abordada pela tradição. Normalmente Verrechtlichung se refere à produção normativa dada por um Estado. Neste texto, o mesmo termo se refere à fundação jurídica de uma entidade comunitária, vale dizer, a uma Organização Internacional - um ente dotado de personalidade jurídica de Direito Internacional Público distinta da de um Estado e das dos Estados-Membros que a compõem ${ }^{171}$.

\footnotetext{
${ }^{170}$ Como bem sinalizara Wolfgang FRIEDMANN (1964, p. 60), o Direito Internacional compreendido no interior de um paradigma de coexistência reduzia-se à posição de "a matter of diplomatic interstate relations".

${ }^{171}$ Sobre o conceito jurídico de Organização Internacional, v. nota de rodapé 1, supra.
} 
Recorrer à ideia de Verrechtlichung para caracterizar a relação de integração entre países por meio da CECA tem um sentido preciso: indicar que, com o final da Segunda Guerra Mundial, houve uma tendência a modificar a qualidade das relações entre tais Estados, os quais optaram por uma via dada pelo Direito constituído segundo Leis - o que não teria significado a despolitização de suas relações, mas o desenvolvimento de tais relações politicamente tensas entre eles por meio de via normativo-jurídica positiva própria;

Se tradicionalmente as relações entre os seis países da CECA foram marcadas e orientadas pela habitual política diplomática ${ }^{172}$, com o final da Segunda Guerra Mundial tais relações foram direitificadas e, com isso, qualitativamente reorientadas ${ }^{173}$ para o interior de instituições jurídico-normativas positivas, dentro das quais os conflitos políticos encontrariam plenas condições para continuar a surgir, se desenvolver e a se encaminhar.

Deste modo, ao se recorrer ao termo Verrechtlichung, pretende-se apenas indicar que houve a substituição qualitativa de um paradigma relacional por outro, havendo uma migração da orientação político-diplomática para outra, de caráter jurídico-político (FRIEDMANN, 1964, p. 61). Em outras palavras, essa nova maneira de se relacionar trazida pela CECA teria determinado que os conflitos políticos entre diferentes se desenvolveriam a partir de então dentro do Direito Positivo estabelecido em comum $^{174}$, o qual fora constituído por meio de Leis.

Não se trataria a CECA, assim, de uma simples migração de um sistema de relações políticas diplomáticas (Direito Internacional de Coexistência) para um sistema de relações jurídico-econômico-técnicas (Direito Internacional de Cooperação) para formar um mercado comum de carvão e de aço. Antes, a transição teria partido de um sistema de relações políticas diplomáticas (Direito Internacional de Coexistência) para um sistema de relações jurídico-políticas institucionalizadas normativamente (Direito Internacional de

172 “A diplomacia internacional, traduzida em normas de Direito, preocupava-se com a demarcação dos territórios, o status jurídico do alto-mar, as imunidades diplomáticas e jurisdicionais dos Estados, de chefes de Estados e de representantes diplomáticos, a proteção de sujeitos de um Estado no território de outro, e a regulamentação da guerra e da neutralidade.” (LAMBERTI, 1991, p. 27, grifos da autora).

Perceba-se que, em ambiente europeu, o recurso à maneira diplomática de estruturação do Direito Internacional resultara sempre, nos últimos seiscentos anos (CASELLA, 2004, p. 537), na opção pela Guerra; com efeito, "[t]he history of Europe along centuries remains a series of wars being waged while peace is being first threatened subsequently attempted to be restored." (CASELLA, 2000a, p. 81).

${ }^{173}$ Com efeito, "[w] hat complicates the working of the rules of coexistence far more is the proliferation of sovereignties and the consequent multiplication of clashing national interests." (FRIEDMANN, 1964, p. 61).

${ }^{174}$ Ainda que se refira mais diretamente ao paradigma clássico de cooperação, é bastante pertinente a observação de Wolfgang FRIEDMANN (1964, p. 62) sobre essa modificação qualitativa das relações entre os países no pós-Segunda Guerra Mundial: "This move of international society, from essentially negative code of rules of abstention to positive rules of co-operation, however fragmentary in the present state of world politics, is an evolution of immense significance for the principles and structure of international law.". 
Convivência), sistema este efetivamente bastante particular: convivência plural permanente.

Entende-se assim que o Direito Comunitário da CECA teria sido o meio encontrado para efetuar uma Verrechtlichung (direitificação) das relações entre seus países-membros. A estrutura institucional fora constituída para estabelecer entre eles um aprofundamento das relações por meio do Direito Positivo Internacional, mas de maneira qualitativamente distinta da de uma simples cooperação. Não houve qualquer necessidade causalmente préestabelecida por qualquer interdependência transfronteiriça "naturalmente" suposta (Direitos Humanos, Direito Ambiental, ...) ${ }^{175}$. A CECA teria sido produto de uma convicção jurídico-política de ser necessário fazer conviver diferentes, mantendo entre estes a diferença.

É por essa razão que as relações sociais de caráter político entre os seis paísesmembros da CECA teriam sido assim formalizadas pelo Direito (Verrechtlichung), sem consubstanciar as hipóteses de "inflação legislativa", "materialização", "expropriação de conflitos", "despolitização" ou "controle de auto-regulação".

Isso porque, em primeiro lugar, essas associações tradicionalmente designam problemas que se desenvolvem dentro do Direito Positivo constituído no interior de um Estado. Por se situar em uma ordem de preocupações de Direito Internacional Público produzido por Estados para constituir uma Organização Internacional, não haveria como associar esta forma de Verrechtlichung à tradicionalmente designada.

Ademais, lembre-se de que mesmo a ideia de controle de processos de autoregulação foge à situação examinada pelo presente estudo. O controle de auto-regulação se aplica a agentes privados, enquanto que o Direito Comunitário a ser examinado pelo presente trabalho se dirige a relações entre entidades comunitárias, e entre estas e EstadosMembros. Os destinatários de cada uma das formas de Direito são qualitativamente distintos, não se podendo equiparar a situação examinada aqui com a designada pela forma de relação jurídica apresentada por Gunther TEUBNER (1984) ${ }^{176}$.

\footnotetext{
${ }^{175}$ Nesse sentido, v. observações na nota de rodapé 2, supra, principalmente no que se refere à menção a Wolfgang FRIEDMANN (1964) e a Lucia Baungartner LAMBERTI (1991).

176 Como se poderá notar a partir da leitura do Sétimo Capítulo desta Tese, não há previsão de livre negociação entre agentes privados no interior da dinâmica Política instituída e promovida pelo Tratado da CECA; antes, suas instituições jurídicas exigem e determinam uma constante relação entre cinco formas de habitar o mundo: (i) "estatalidade isolada" (Estados), (ii) "estatalidade intergovernamental" (Conselho), (iii) supranacionalidade da Alta Autoridade, (iv) supranacionalidade da Corte, e (v) "populidade" (povos europeus politicamente unidos). Isso será examinado adiante, no item 3.3.3.3., infra, quando tais noções restarão mais bem explicadas.
} 
Mais do que isso, é importante notar que a específica Verrechtlichung promovida pelo Direito Comunitário da CECA adquire contornos ainda mais distintos. Por meio da direitificação de um espaço comum entre seus seis Estados-Membros, teria havido uma direitificação dos conflitos políticos de caráter diplomático que, todavia, não os teria despolitizado por "formas jurídicas neutras". Este Direito comum produzido entre os Estados constituintes da CECA, apesar de ser instrumento, não era neutro, pois fora arquitetado conforme uma opção, a saber, a de ser técnica social voltada a viabilizar a convivência entre diferentes, mantendo a pluralidade ${ }^{177}$.

Nesse sentido, os conflitos tradicionais da diplomacia de coexistência foram transformados e encaminhados para serem desenvolvidos no interior de uma via dada por estruturas institucionais jurídico-políticas positivadas ${ }^{178}$. A direitificação teria assim promovido uma união política entre diferentes, na medida em que as tensões entre as diferentes formas de habitar o mundo foram mantidas e incitadas a se desenvolver continuamente no interior e por meio do Direito Positivo constante do Tratado da CECA. Tais conflitos não deixariam de eclodir e de se realizar: eles apenas teriam encontrado instrumentos jurídicos positivos que puderam dar institucionalmente condições suficientes para que se desenvolvessem sem implicar a disrupção do sistema de convivência.

Não há com isso qualquer expropriação de meios de resolução de conflitos por meio da formalização jurídica das relações. Por um lado, houve a aposição de instituições jurídico-normativas positivas por meio do Direito Comunitário da CECA, com o fim de eliminar a possibilidade de solucionar conflitos por meio da opção pela Guerra. Por outro lado, não se pretendeu pacificar as relações entre seus partícipes, pois, como se poderá ver mais adiante ${ }^{179}$, as relações conflitivas foram traduzidas em termos jurídicos, para continuar a se desenvolver politicamente dentro do Direito (dentro das instituições jurídico-políticas, isto é, da polis).

Para tanto, cada um dos partícipes recebera série de Poderes para, no interior de um espaço comum, desenvolver juridicamente seus conflitos políticos mediante a apresentação de suas específicas formas de habitar o mundo diante das demais. Os conflitos não desapareceram - não se instaurou a Paz, como tranquilidade absoluta das relações: eles

\footnotetext{
${ }^{177}$ Conforme visto nos itens 1.4. e 1.5., supra.

${ }^{178}$ Como se poderá perceber mais claramente, a partir da leitura do Sétimo Capítulo desta Tese.

${ }^{179}$ No Sétimo Capítulo da Tese.
} 
foram apenas deslocados para o interior do Direito Comunitário, por meio das instituições da Comunidade ${ }^{180}$.

Assim, neste novo ambiente de relações, direitificadas, os participantes permaneceram detendo a possibilidade de resolver os conflitos - por meio de instrumentos jurídicos comuns, dos quais não se podia lançar mão sem implicar o correlato e imediato desencadeamento de série de oposições entre os participantes, as quais foram institucionalmente previstas e promovidas pelas normas do Tratado da CECA. O Direito, como técnica social de promoção de convivência, era o meio voltado a impedir a unidimensionalização totalizante de uma ou de outra forma da habitar o mundo na Europa Unida da CECA.

Os partícipes da vida em comum nada teriam perdido perante a Comunidade, pois não teriam sido alienados. Muito pelo contrário, eles teriam ganhado a possibilidade e o dever de desempenhar inúmeras tarefas no interior da Comunidade, envolvendo-se cada um de maneira mais e mais intensa. Parafraseando aqui célebre frase de Jean-Jacques ROUSSEAU (2000, p. 60), a vida em comum subtraíra de seus partícipes suas próprias forças, para lhes dar forças que lhes eram estranhas, e das quais não poderiam lançar mão sem o auxílio - e a contenção - de cada um dos demais.

Assim, diante da necessidade de convivência, estabeleceu-se o necessário concurso - não mais unilateral, mas em conjunto - das diferentes posições - o que preservava e promovia a tensão conflitiva entre todos partícipes da Comunidade - para realizar a vocação de união política detida pela CECA. Isso retira a possibilidade de compreendê-la também como uma forma de despolitização das relações entre seus componentes - pois a política passara a se realizar dentro das instituições jurídicas comuns, haja vista a permanência irresolvível das tensões ${ }^{181}$.

O presente trabalho concede assim uma ênfase diferenciada ao conceito de Verrechtlichung em comparação com as cinco vertentes acima mencionadas. Evidencia aspectos que, contidos na ideia de Verrechtlichung, não são ressaltados pelas cinco maneiras tradicionais de o nomear.

Com o objetivo de resguardar a exclusividade do campo de estudos da tradição da literatura jurídica contemporânea - que compreende Verrechtlichung como "inflação legislativa", "materialização", "expropriação de conflitos”, "despolitização" ou "controle

\footnotetext{
${ }^{180}$ Remete-se, aqui, às observações constantes da nota de rodapé 108, supra, e das notas de rodapé 203 e 204, infra.

${ }^{181}$ Essa conclusão fará mais sentido a partir da leitura do item 3.4., e do Sétimo Capítulo, ambos infra.
} 
de auto-regulação", prefere-se neste trabalho não utilizar o termo "juridificação", tradicionalmente associado aos cinco modos supramencionados de entender Verrechtlichung. Opta-se aqui, com toda precaução, pelo termo menos usual, "diretificação".

A direitificação deve ser entendida neste trabalho como a estipulação de um reto caminho institucionalmente pavimentado pelo Direito Positivo para viabilizar determinada escolha - formulada profanamente no interior da arena de disputas infindáveis - sobre a maneira de se organizar jurídico-politicamente as relações ${ }^{182}$. Nesse sentido, não se pode ignorar que a direitificação nada mais consiste do que na estipulação formal de instrumentos jurídico-normativos positivos para estabelecer relações institucionalizadas entre aqueles que deles se socorrem.

A direitificação é uma fôrma jurídica que opera no sentido de organizar juridicamente diferentes tipos de relações e que, com isso, pode servir a diferentes desígnios. Quando se entende a direitificação sob uma perspectiva jurídico-política ${ }^{183}$, se pensa o arranjo institucional a ser desenhado como visando a conferir instrumentalmente uma resposta jurídico-positiva a um problema em torno da definição do modo como se fundamenta o Direito e o Poder ${ }^{184}$.

Em outros termos, uma direitificação jurídico-política se trata de uma maneira de enfatizar que as instituições do Direito teriam sido concebidas e articuladas para conferir suporte a um modelo de relações entre diferentes, conforme um padrão dado por uma determinada concepção sobre como definir o sentido das decisões últimas sobre o sentido normativo a ser impresso sobre questões sensíveis tornadas comuns ${ }^{185}$.

\footnotetext{
${ }^{182}$ Ou simplesmente, como inserção do Direito entre todos, a fim de que este opere como uma técnica social de realização de fins determinados pela política (CASELLA, 2009a, p. 69).

${ }^{183}$ Como ressaltado na Introdução Geral deste trabalho, colocou-se entre parênteses uma leitura econômica da CECA para tentar revelar a possibilidade de uma leitura - dentre tantas outras - de caráter jurídico-político. Por esse motivo, não se pretende efetuar aqui reflexões em torno da noção da institucionalização jurídica de relações que detenham qualidade econômica. Deste modo, deixa-se de tentar esclarecer neste ponto o que seria propriamente uma organização jurídico-econômica do social.

Indicamos exemplificativamente a leitura de Mario Gomes SCHAPIRO (2011), obra que recentemente na literatura jurídica brasileira se preocupou com o tema da análise de instituições jurídicas de organização das condições econômicas de determinada sociedade. Segundo este trabalho, haveria a necessidade de se pensar em estruturas jurídico-institucionais bem ordenadas para promover o desenvolvimento econômico.

${ }^{184}$ Questão que restará mais clara a partir da leitura do item 3.4., infra.

185 É nesse sentido que se revela parcela do caráter original do interesse deste trabalho. Não se pretende compreender apenas as instituições jurídico-normativas positivadas da CECA de maneira detalhada, mas aferir a qualidade desta articulação institucional moldada a partir dessa concepção sobre o modo de organizar jurídico-politicamente as relações entre seus seis países-membros.

A avaliação dessa qualidade é feita no Sétimo Capítulo a partir da aplicação da chave hermenêutica proposta em torno dos dois tipos possíveis de Leis (item 3.4., infra), ao mesmo tempo em que se desenvolve
} 
Perceba-se nesse sentido que o arranjo institucional a ser desenhado para efetuar uma organização jurídico-política das relações entre diferentes pode ser realizado de diferentes maneiras, variando de acordo com as condições históricas e sociais daqueles que recorrem ao Direito como forma de instaurar um patamar de juridicidade comum.

Não haveria assim um padrão único e universalizável das maneiras de orientar a organização institucional daquele que será o centro nomogenético de um sistema de convivência. As respostas institucionais variam espacial e temporalmente como maneiras individuadas de reação jurídico-positiva a condições sociais específicas (UNGER, 2004, p. $53)^{186}$.

Assim, o desenho institucional voltado a organizar o espaço nomogenético visa a responder a condições, dificuldades e necessidades particulares de cada aproximação entre diferentes que almejam conviver. Nesse sentido, as instituições têm sempre suas tarefas customizadas, na medida em que sempre procuram atender a objetivos que se apresentam em cada contexto particular, devendo-se prestar atenção a essa singularidade para avaliar o desenho de marcos institucionais (SCHAPIRO, 2011, p. 343).

O processo de integração europeu do imediato pós-Segunda Guerra Mundial que constituíra a CECA pode ser entendido como uma forma de direitificar as relações entre seus seis países fundadores ${ }^{187}$ por meio de técnicas jurídico-regulatórias voltadas para

a análise institucional deste Tratado por meio do exame dos critérios fundamentais enumerados no item 3.3.3., infra.

${ }^{186}$ Faz-se aqui também referência implícita à afirmação de Mario Gomes SCHAPIRO (2011, p. 343), sobre organização institucional contextualmente adaptada.

Frise-se que não há um compromisso aqui em seguir o discurso deste autor no que se refere ao pensar instituições jurídicas para promover o desenvolvimento econômico. Quer-se apenas e tão-somente nele buscar a Linguagem adequada para formular as reflexões sobre instituições que ora se desenvolvem. A referência a este autor se faz estritamente no que diz respeito à necessidade de encontrar vocabulário, palavras para dizer algo - ainda que seja algo distinto o dito resultante do uso desse arcabouço linguístico.

Nesse sentido, lembre-se de que, como ressaltado na Introdução Geral deste trabalho, colocou-se entre parênteses uma leitura econômica da CECA para tentar revelar a possibilidade de uma leitura - dentre tantas outras - de caráter jurídico-político. Por isso, não se poderia pensar a institucionalização jurídica de relações a partir de paradigma de Direito Econômico.

Todavia, é importante notar que, sob uma perspectiva mais generalizada, a reflexão de Mario Gomes SCHAPIRO (2011) permite pensar o problema da necessidade de se pensar arranjos jurídico-institucionais para o atingimento de fins determinados especificamente para e por cada realidade espacial e temporalmente localizada.

Por esse motivo é que neste ponto o presente trabalho se socorre implicitamente desta literatura: ao menos, ela fornece condições e roupagem linguística para que se possa pensar e dizer o que pensa sobre a temática. Nesse sentido, o recurso a Mario Gomes SCHAPIRO (2011) neste texto ocorre com o simples objetivo de encontrar as palavras necessárias para pensar este tema - não havendo qualquer preocupação ou compromisso em associar a presente investigação com seus pressupostos de Direito Econômico do Desenvolvimento, nem em endossar a integralidade de sua maneira de interpretar o Direito.

${ }^{187}$ Consubstanciando precisamente aquilo que a literatura jurídica tradicional sobre processos de integração denomina ser a vertente/dimensão jurídica de processos de integração em geral (ACCIOLY, 2003, p. 25-6 e 
estabelecer a vida em comum (CASELLA, 2011, p. 17) entre diferentes tradicionalmente opostos em termos militares. E, como toda direitificação, enquanto "incremento da regulação da vida jurídica internacional” (CASELLA, 2010, p. 173), teria manufaturado seu arranjo institucional de acordo com as vicissitudes específicas deste processo de integração, de tal modo que as tensões entre tais países se mantivessem e se desenvolvessem no interior do aparato jurídico-normativo positivo comunitário ${ }^{188}$.

O método de construção da Comunidade (ou simplesmente, método comunitário da CECA) ${ }^{189}$ revelaria ter se preocupado com o afastamento da possibilidade de cometimento de novas Guerras entre seus países-membros (ROLLAND, 2006, p. 1, 5 e 7).

Para tanto, teria sido necessário introduzir entre eles um patamar de juridicidade compartilhado em torno do centro de formação do sentido normativo comum sobre questões que foram tornadas comuns ${ }^{190}$.

161-2; CASELLA, 1994a, p. 206, 1994b, 1996a, p. 33, passim, 2000b, p. 51-2, 95-6 e 122, 2005, p. 108-9, 2010, p. 172-3; CELLI JR., 2006; PITTA E CUNHA, 2004).

Segundo essa perspectiva, a integração encontraria uma expressão também por meio de instituições positivadas de Direito Internacional Público. Estas seriam instrumentos que viabilizariam sua realização e sua manutenção. No caso da CECA, esta seria o princípio de uma forma de promover a "convivência institucionalizada entre quase todos os povos europeus, do Atlântico até a fronteira russa." (CASELLA, 2005, p. 109).

Todavia, haveria que se frisar o fato de que alguns autores enfatizam deter a integração "conteúdo essencialmente econômico" (CASELLA, 2000b, p. 52 e 95), leitura a qual colocamos entre parênteses para desenvolver este trabalho - como afirmado na Introdução Geral deste texto, com o objetivo de fornecer uma leitura jurídico-política distinta sobre a História e as instituições da CECA.

${ }^{188}$ A necessidade de se pensar e se compreender as instituições de cada processo de integração entre países da maneira como se apresentam, sem lamentos ou frustrações desamparados, de maneira a os entender como diferentes respostas institucionais a condições históricas particulares, é temática atual do Direito da Integração no pensamento jurídico brasileiro e estrangeiro.

Mencione-se nesse sentido edição inteira do periódico Droit et Société, n. 59, 2005, dedicada à compreensão comparativa entre a UE e o Mercosul, afirmando a necessidade de enfatizar a especificidade da integração mercosulina com relação à da UE. Destaquem-se a apresentação de André ARNAUD e os artigos de François D'ARCY, Luis Alejandro ESTOUP, Roberto FALCHETTI e Deisy VENTURA.

Especial atenção deve ser dada ainda a Curso inteiro realizado em Florença, em Outubro de 2011, no EUI, organizado pelo RSCAS, sob o nome Comparing Models of Regional Integration: Experiences from the Latin America Region. Este evento acadêmico conferiu especial enfoque aos processos integração latino-americanos e à relação de protagonismo do Brasil em cada um deles. A conclusão geral deste Curso poderia ser resumida no seguinte mote: "cada processo de integração deve buscar seu próprio método de aproximação, sem pretender copiar os passos desenhados outrora pela União Europeia.", frase enunciada no início do Curso por um de seus professores, Félix PEÑA, e reproduzida ao final do mesmo, pelo coordenador do evento, Carlos CLOSA.

Sobre o tema da integração regional na América do Sul, há ainda obra recente (BRASIL. Ministério das Relações Exteriores, 2010), em que se discutem temas em torno da necessidade de se reinterpretar a integração neste continente. Deve-se dar especial destaque à contribuição de Paulo Borba CASELLA (2010, p. 174), onde o autor propõe repensar a integração regional sul-americana à luz dos interesses brasileiros atuais e do diagnóstico de esgotamento dos projetos regionais. Tal obra coletiva é compilação de série de palestras proferidas por diplomatas e acadêmicos no Palácio Itamaraty, em 23.7.2009, no Rio de Janeiro, voltadas a apreciar a situação atual dessa integração regional.

${ }^{189}$ Sobre método comunitário, v. a nota de rodapé 202, infra.

190 O Direito como dado da vida social (CASELLA, 2009a, p. 67-74), ou ainda, como viabilizador regulatório de uma vida em sociedade (CASELLA, 2011, p. 13), ou simplesmente, como meio de organização jurídica das relações entre diferentes (pessoas, povos e países). 
Dans le contexte de la période qui suit la Seconde Guerre mondiale chacun comprend aisément qu'il s'agit d'évoquer par ces termes une Europe unie par des liens institutionnels et politiques plus forts que ceux qui résultent du seul jeux des rapports internationaux traditionnels. (ROLLAND, 2006, p. 1).

[P]ara que ocorra a integração, necessita-se de firme engajamento político e institucional, que permita construir grau de solidariedade, entre os participantes, e esta acompanhada da clara percepção, e não menos firme engajamento, no sentido de construir esse projeto comum, entre os estados insertos no processo. $\mathrm{O}$ que não é pouco, nem facilmente se mantém, ao sabor do jogo entre mudanças políticas internas e do contexto internacional. (CASELLA, 2010, p. 172).

O desenvolvimento de tais estruturas jurídicas comuns anunciava por si só o aspecto jurídico qualitativamente distinto desta iniciativa: não se trataria de uma singela coexistência entre Estados, como foram os Tratados Internacionais clássicos celebrados até meados do século XX, nem de uma cooperação clássica (CASELLA, 1994a, p. 248; MINIUCI, 2012, p. 1; ROLLAND, 2006, p. 1; VEÇOSO, 2006, p. 28-9 e 32-4). Tratou-se de buscar construir o comum, mas um comum bastante específico: um comum estrategicamente disposto por arcabouço jurídico-normativo institucional fundado em Leis, isto é, voltado a estruturar o modo de encenar o público e a convivência entre diferentes ${ }^{191}$. Lembre-se de que o Projeto da Europa Unida da CECA detinha contornos específicos ${ }^{192}$, na medida em que a edificação de suas instituições se regeria inteiramente por Leis. Por isso, a opção de seu desenho institucional seria orientada por uma determinada concepção sobre o fundamento do Direito e do Poder, a qual conferira determinada qualidade ao patamar de juridicidade erigido entre os países-membros.

Perceba-se que essa condição confere ao Direito igualmente caráter político. Quando da direitificação das relações, há a inserção dessa técnica como meio de realização alternativa da política segundo a qual, os conflitos permanecem ardentes no interior da via jurídica. Essa condição de politização do Direito técnico já fora sinalizada por Otto KIRCHHEIMER, por meio das reflexões desenvolvidas a partir da noção de Verrechtlichung (TEUBNER, 1993, p. 510). Afinal, a engenharia para estabelecer institucionalmente este conviver entre diferentes é o preciso desafio e mistério virtuoso do político (CARDOSO, 2004, p. 50; VERNANT, 1981, p. 71-2).

Frise-se que aqui se revela parcialmente como este texto mostra tender a se diferenciar das leituras jurídico-políticas usuais sobre a CECA, como indicadas rapidamente na nota de rodapé 106, supra: não se trata de um processo de integração jurídico-política, por exemplo, porque (i) almejaria uma unificação política em um Estado Federal; (ii) teria sido objeto de negociação diplomática; ou (iii) por ter sido eventualmente ratificado por cidadãos de seus Estados-Membros. A noção de Político, aqui, deteria outro significado. Essa diferença restará mais evidente no item 3.4. e nas Conclusões Parciais da Parte Segunda, ambos infra.

${ }^{191} \mathrm{Na}$ medida em que a constituição das instituições atingiu as formas de decisão na Europa Unida em torno do sentido normativo sobre temas comuns - o que revela a possibilidade de pensar politicamente essa união entre diferentes. Qual a qualidade dessas instituições e de que forma elas desenharam o modo de cada um dos partícipes se relacionar com a formação do Direito e do Poder agora colocados entre todos, no meio, ou seja, determinados como sendo comuns?

${ }^{192}$ Como visto nas discussões desenvolvidas acima, nos itens 1.4. e 1.5. 
Abandonara-se a perspectiva da coexistência para se dar margem ao exercício de necessária imaginação institucional diante dos institutos clássicos do Direito Internacional. Por meio do "esforço para ampliar [...] por extensão analógica ou por recombinação dos elementos disponíveis, o repertório institucional existente" (UNGER, 2001, p. 27), foi-lhes possível apostar em algo localizado além mesmo da tradicional cooperação - na vida em comum, na comunidade de formação do Direito e do Poder comuns na Europa ${ }^{193}$.

[L]es premières pensées de l'unité politique de l'Europe, ont été des réponses à ses problèmes intérieurs: si vagues soient-elles, elles se voulaient une réponse alternative au mécanisme de l'équilibre européen clairement établi et consacré lors de la paix de Westphalie. Elles se veulent la solution aux échecs répétés de cet équilibre qui conduisait régulièrement au retour de la guerre comme moyen de régulation des rapports de force entre États. (ROLLAND, 2006, p. 5).

O afastamento da Guerra não seria bem sucedido enquanto não houvesse um bloqueio jurídico-institucional comum a qualquer manifestação de surgimento da pretensão de conformar unilateralmente as normas jurídicas e as decisões entre os países europeus que compunham a $\mathrm{CECA}^{194}$ - dando-se evidente destaque à conciliação do casal francoalemão $^{195}$ (ROLLAND, 2006, p. 5).

${ }^{193}$ Lembrando aqui Roberto Mangabeira UNGER (2001, p. 7), poder-se-ia cogitar ter se tratado de momento bastante sensível, em que se percebeu ser fundamental alterar o repertório de instituições responsáveis pelo estabelecimento de diferentes modos de relações entre países europeus; afinal, "[m]uda-se o mundo ampliando o repertório: acrescentando a ele uma possibilidade institucional que não existia antes.”.

${ }^{194}$ Diferentemente da situação do período entre Guerras, quando o regime jurídico vigente da instituição da Paz pelo Direito consistiu simplesmente na ordenação jurídica imposta pelos vencedores da Primeira Guerra Mundial (CASELLA, 2007b).

Note-se que naquele período se buscou estabelecer um sistema institucional de coexistência (sobre coexistência, v. nota de rodapé 2, supra) na Europa não preocupado com a formatação de um modo Político de relações, mas com a manutenção de uma única ordem fundada no Direito - enquanto arcabouço jurídico unidimensional revanchista imposto pelos vencedores - como início e fim absoluto das relações entre os povos europeus. Institucionalização jurídica perniciosa, pois não era senão uma espécie de "trégua de duração indeterminada" (VALÉRY, 1934, p. IX).

Com efeito, a regulamentação parcial dada pelo Tratado de Versalhes se mostrou como efetivo exemplo histórico sobre "o que se pode e o que não se pode pretender impor a outros estados, sob pena de preparar efeitos tão devastadores como os que resultaram da implantação do regime hitlerista, na derrocada da Alemanha de Weimar. As lições da história podem ser difíceis, mas nem por isso são menos necessárias." (CASELLA, 2007b, p. 60).

${ }_{195}$ A designação das relações entre Alemanha e França nos termos de um casal não é nova, e tem por objetivo argumentativo sinalizar a necessidade de um enraizamento de relações difíceis, porém necessárias, entre dois elementos que pretendem se destacar sobre o outro.

Ao designar Alemanha e França como componentes de um casal, quer-se indicar que ambos deveriam manter entre si uma relação de igualdade, sem que qualquer um deles visasse à aquisição de posição dominante sobre o outro e sobre os demais a sua volta. A lógica da relação deveria ser a de parceria e amizade (HUDEMANN, 2008, p. 94): uma concomitante recusa de servir e de dominar.

Para uma perspectiva histórica sucinta sobre as relações do casal franco-alemão, remete-se o leitor ao verbete Couple Franco-Allemand, de Rainer HUDEMANN (2008). 
O estudo das variações institucionais existentes leva, naturalmente, à investigação das alternativas institucionais. Em vez de serem concebidas como sistemas prontos e indivisíveis, as alternativas passam a ser vistas como construções com os materiais existentes, como "bricolage". O que transforma a "bricolage" em projeto, como sentido exemplar para a humanidade, é seu casamento com uma visão transformadora. (UNGER, 2001, p. 27, grifos nossos).

$\mathrm{Na}$ CECA, nada nem ninguém poderia se afirmar ou pretender se afirmar como detentor da possibilidade de definir o sentido último da decisão nomogenética destinada a reger os países que, sob ela, pretenderam se unir. Este seria o tom que regeria o processo de construção da CECA e de suas instituições ${ }^{196}$. A integração - percebida como direitificação das relações ${ }^{197}$ - viabilizaria a construção de um sistema de vivência pública que bloquearia pretensões imoderadas de inserção exclusiva ou de exclusão de qualquer um do centro de definição do Direito e do Poder nesta Comunidade.

Por essa razão, a CECA teria disponibilizado série de estruturas compartilhadas que constantemente convidariam cada um dos envolvidos nesta vida em comum a participar a todo momento da formação do sentido normativo último o interior da Comunidade. $\mathrm{O}$ conjunto da produção franco-alemã de carvão e de aço fora submetido pelo aparato jurídico-institucional comum a um Poder decisório compartilhado por todos aqueles que da Comunidade participavam ${ }^{198}$.

Essa integração se tratou de efetiva intensificação das relações entre os diferentes partícipes da vida em comum por meio do Direito ${ }^{199}$. No interior dos caminhos estabelecidos pelas instituições, promovera-se a integração não-unificadora e conflitiva de pluralidades, operando-se assim uma união política juridicamente encaminhada entre diferentes continuamente em oposição.

Por meio da comunitarização tensiva da construção dos sentidos normativos sobre questões concretas sensíveis, mostrou-se possível afastar a Guerra sem eliminar o conflito: as tensões entre os diferentes puderam permanecer eclodindo para formular o sentido normativo comum - mas, agora, passariam a se desenvolver no interior dos limites

\footnotetext{
${ }^{196}$ O que restará mais claro quando da leitura dos Sexto e Sétimo Capítulos desta Tese. V. a indicação feita sobre as relações entre o casal franco-alemão, na nota de rodapé 195, supra.

197 Direitificação como migração dos conflitos políticos de fora do Direito para dentro deste. Como mencionado acima, a integração fora viabilizada institucionalmente por meio de Direito Positivo, o qual passou a resolver conflitos entre diferentes por meios de instituições comuns. Estas retamente impediam uma pulsão unilateral na definição do sentido do Direito e do Poder - pois estes estariam no meio, entre todos, mas seriam de propriedade de ninguém. Não apenas essa constatação se esclarecerá a partir da leitura do item 3.4., infra, como também a partir da leitura do Sétimo Capítulo desta Tese, também infra.

${ }^{198}$ Essa asserção ficará mais clara quando da leitura do Sétimo Capítulo desta Tese.

${ }^{199}$ Ou ainda, por meio de dispositivos institucionais jurídico-normativos positivados.
} 
institucionais estabelecidos pelo aparato jurídico-normativo positivo comunitário estabelecido pelo Direito Internacional.

\begin{abstract}
Il y a un désir de substituer à la régulation politique des sociétés une régulation par le droit ou par les techniques d'organisation sociale. Il y a une filiation saintsimonienne dans l'idéologie européenne, celle qui rêve de remplacer le gouvernement des hommes par l'administration des choses. (ROLLAND, 2006, p. 7).
\end{abstract}

Esse adensamento jurídico das relações por meio de instrumentos jurídiconormativos positivados deteria uma inteligência constitutiva precisa: constranger institucionalmente à contínua co-presença de todos os envolvidos na vivência pública da Comunidade $^{200}$. Jamais o sentido Direito e o Poder sobre questões concretas comuns seriam determinados unilateral e unidimensionalmente por um dos institucionalmente implicados na vida em comum ${ }^{201}$, pois eles estariam no meio, entre todos, e seriam de propriedade de nenhum deles ${ }^{202}$.

${ }^{200}$ Seguindo a impulsão das Leis de obrigar a interação entre os diferentes, de forma a que nenhum deles pudesse pretender sobre os outros se destacar.

${ }^{201}$ Como se poderá perceber na leitura do Sétimo Capítulo desta Tese.

${ }^{202}$ Apesar de ser corrente na literatura jurídica nacional e estrangeira apontar que a CECA seria comunidade centrada na Alta Autoridade, a qual teria recebido parcela da Soberania dos Estados-Membros. R. DEHOUSSE (2011) denomina esse modo de construir a CECA como método comunitário. Segundo este método, haveria não apenas a preponderância das instituições da Comunidade sobre os Estados, mas também a predominância da Alta Autoridade sobre os demais órgãos comunitários.

A título exemplificativo, mencionem-se Mireille DELMAS-MARTY (2004, p. 236), Olivier DESCAMPS (2011j), Syméon KARAGIANNIS (2000, p. 351), Alfonso MATTERA (2002, p. 9), Geraldo Eulálio do NASCIMENTO E SILVA; Hildebrando ACCIOLY (2002, p. 248), Fausto de QUADROS (1984, p. 263-4), Elizabeth de Almeida Meirelles REFALO (1980, p. 67), Paul REUTER (1965, p. 174) e Fabia Fernandes Carvalhos VEÇOSO (2006, p. 27 e 35). Estes parecem compreender da mesma maneira a organização institucional da CECA: partícipes comunitários em torno da Alta Autoridade, a quem caberia a missão exclusiva de gerir os interesses comuns, em nome do interesse comum, sobre os Estados-Membros e sobre as demais entidades comunitárias.

"Com relação ao quadro institucional e a tomada de decisões para o governo da CECA nesses primeiros anos, pode-se falar que a Alta Autoridade possuía maior relevância no comando da comunidade [...]." (VEÇOSO, 2006, p. 36, grifos nossos). No mesmo sentido, Fausto de QUADROS (1984, p. 263-4) chega a afirmar, inclusive, ser a Alta Autoridade "o órgão motor da integração na CECA", indicando que "o equilíbrio institucional na CECA foi obtido em torno da Alta Autoridade". Ainda segundo o mesmo autor, se "abstrairmos do poder judicial, que foi conferido pelo T[ratado da] CECA ao Tribunal, e do poder de fiscalização política, que o art. $24^{\circ}$ conferiu à Assembleia, podemos dizer que todos os demais poderes ficaram concentrados pelo Tratado na Alta Autoridade". (QUADROS, 1984, p. 264-5, grifos do autor).

Todavia, a presente Tese de Doutorado não concorda com esta asserção de que "à Alta Autoridade foi atribuída vastíssima competência", visando a conceder um predomínio "à componente supranacional do processo de integração" (QUADROS, 1984, p. 265-6 e 379).

De fato, a leitura do Sétimo Capítulo da presente obra indicará haver uma correlata e concomitante preocupação de esvaziar os Poderes atribuídos à Alta Autoridade por meio da concessão de contrapesos aos demais partícipes da Comunidade - entidades comunitárias e/ou Estados-Membros -. Essa constatação desautorizará concluir que a CECA dera preferência a priori a qualquer das escalas de existência que a compunham - nem mesmo à supranacionalidade. Sobre as formas de experienciar o mundo que participavam do empreendimento da Europa Unida de CECA, v. o item 3.3.3., infra. 
Assim, mais do que uma singela cooperação entre países em um setor econômico específico (carvão e aço), a CECA teria introduzido uma nova lógica de interação entre diferentes na Europa (CASELLA, 2008, p. 212). Os Estados não estariam simplesmente conectados por normas jurídicas internacionais determinantes de direitos e de deveres; antes, estariam comprometidos internacionalmente a conviver um com o outro de maneira ativa e integrada, sem que esta união política viabilizada pelo Direito (jurídico-política) pudesse significar unificação ${ }^{203}$.

Esse tema será retomado com maior profundidade quando das Conclusões Parciais da Parte Segunda deste trabalho, infra. Aqui apenas se aponta rapidamente um dos deslocamentos significativos produzido pela chave hermenêutica adotada por este texto com relação ao pensamento jurídico tradicional sobre a construção histórica da CECA.

O método comunitário não se tratara de singela transferência de parcela de Soberanias estatais para uma autoridade supranacional localizada acima de todos, a qual disporia de um Poder incondicionado e indeterminável pelos demais partícipes da Comunidade. Nem a letra, nem o espírito do Tratado permitem assim concluir. Todavia, esse debate será mais bem compreendido adiante, oportunidade em que será retomado.

${ }^{203}$ Paulo Borba CASELLA (1994a, p. 251, 1996a, p. 34) apontou para uma tendência à unificação de tais países. No mesmo sentido, mencionem-se Elizabeth de Almeida Meirelles REFALO (1980, p. 47 e 84 ) e Paul REUTER (1965, p. 3, 7-9 e 173, 1991, p. 243), para quem as Comunidades Europeias (CECA, CEEA e CEE) tenderiam a uma unificação entre os países europeus - uma unificação esta de caráter econômico. A singularidade da CECA consistiria precisamente no fato de ter almejado unificação econômica em um âmbito setorialmente reduzido: o específico mercado comum do carvão e do aço (REFALO, 1980, p. 67; REUTER, 1965, p. 173-4). Em texto posterior, todavia, Paul REUTER (1991, p. 243) enfatiza que a CECA detinha profunda vocação para promover uma unificação política.

Inclusive, não se pode ignorar a existência de autores que insistem em afirmar que a Comunidade teria sido estruturada para direcionar a maior parte de seu empenho para promover uma integração econômica. Esta seria realizada por meio de uma ordem jurídica de mercado estruturada pelo Direito da Concorrência e fundada na estrita lógica da estrutura liberal do Comércio Internacional no pós-Segunda Guerra Mundial (ACCIOLY, 2003, p. 46; BASSO, 2008, p. 90; BERL, 1961, p. 3 e 5; BOBBIT, 2011; CELLI JR., 1990, p. 28-37; DELMAS-MARTY, 2004, p. 47 e 236; FRIEDMANN, 1964, p. 62-3; JAMET, 2011, p. 44-5; LAFER, 1997, p. 86, 1998, p. 49; MAGALHÃES, 2005, p. 106; RÉAU, 2008, p. 79; REFALO, 1980, p. 67; VASCONCELOS, 2010; VIEIRA, 1999, p. 74-8). Para esta perspectiva, seu fundamento seria precisamente este sistema multilateral de Comércio Internacional.

Diferentemente destes, ainda na discussão sobre a relação entre a CECA e o sistema de Comércio Internacional do pós-Segunda Guerra Mundial - fundado após a Conferência de Bretton Woods, de 1944, Paul REUTER (1965, p. 418) indica não ser este novo sistema de Comércio Internacional o fundamento jurídico (absoluto e determinante) da CECA. Todavia, ainda segundo o mesmo autor, esta união dos países europeus era um exemplo de aproximação entre Estados não contrária aos compromissos - assumidos internacionalmente pelos países-membros da CECA - de contribuir progressivamente à liberalização do Comércio Internacional por meio do multilateralismo.

Frise-se que o exame do surgimento da estrutura liberal do Comércio Internacional no pós-Segunda Guerra Mundial em Bretton Woods, em 1944, não será realizado pelo presente trabalho. A ausência de menção a este momento deriva da precisa necessidade de se manter rigorosamente uma coerência metodológica neste trabalho.

Com efeito, a exclusão deste evento do interior desta Tese se justifica por razões (i) de caráter temporal, tendo em vista que o marco temporal inicial deste estudo é exatamente o final da Segunda Guerra Mundial (1945), não sendo admissível incluir o exame exaustivo de fatos anteriores a essa data (Bretton Woods foi organizado em 1944); e (ii) de caráter temático, pois, por diversas vezes se reiterou neste texto, desde sua Introdução Geral, que o exame de uma leitura econômica da CECA seria deixado em suspenso durante o desenvolvimento deste trabalho. Sobre a oposição entre multilateralismo e regionalismo, sugerimos exemplificativamente a leitura de Celso LAFER (1997, 1998), de Maria Lúcia M. Pádua LIMA et alii (2005) e de Rodrigo Luís PUPO (2006).

De todo modo, a perspectiva que aponta como fundamento do processo de integração (econômica) da CECA o sistema de Comércio Internacional do pós-Segunda Guerra Mundial reconhece tal Comunidade 
como o princípio de uma integração econômica em direção à constituição de um Bloco Econômico regional. Este teria atingido recentemente o status de integração econômica perfeita por meio de coordenação de políticas macroeconômicas (BASSO, 1997, p. 21, 1998a, p. 81, 1998b, p. 34; COSTA, 2001, p. 44; MENEZES, 2000a, p. 53-5, 64-9 e 71-2; RAMOS, 2005, p. 23-5, 49 e 58). Para Umberto CELLI JR. (1990, 28-37), dever-se-ia mesmo compreender que a integração econômica promovida pela CECA teria como antecedente histórico a instituição do sistema de Comércio Internacional liberal do pós-Segunda Guerra Mundial.

"No que tange à tendência mundial de regionalização de blocos econômicos, que coexiste com o processo de globalização, os países da Europa foram os precursores desse tipo de integração econômica, e que, dado os bons índices alcançados, fez com que outros Estados, das mais diferentes regiões do mundo, buscassem os mesmos caminhos para fortalecer sua economia e imprimir maior competitividade mundial no comércio." (MENEZES, 2000a, p. 53).

Ainda no interior dessa linha de compreensão econômica da construção da Europa Unida, Umberto CELLI JR. (1990, p. 16-9, 2006, p. 21) critica a excessiva ênfase na visão econômica de mercado. Segundo este autor, seria necessário pensar a integração - em termos econômicos, sem dúvida - enquanto instrumento de promoção de Desenvolvimento Econômico, para além das simples regras de mercado. Nessa direção também parece seguir Wagner MENEZES (2000a, p. 58 e 71), para quem a integração regional seria ao mesmo tempo integração econômica, comercial e social, voltada, assim, ao desenvolvimento econômico - sem indicar seu caráter político. No mesmo sentido, a proposta de toda a Dissertação de Larissa BASSO (2008), apesar de centrar seu estudo na América Latina. Wolfgang FRIEDMANN (1964, p. 63 e 68) também acena para o fato de que a integração econômica da CECA seguida pela CEEA e pela CEE - se orientaria no sentido de assegurar um bem-estar internacional pela promoção de maneiras mais elevadas de vida em termos econômicos e sociais (em outras palavras, o desenvolvimento econômico).

"O que se busca agora é o desenvolvimento dos mercados consumidores e o fortalecimento dos índices econômicos através, não mais da cooperação entre Estados, mas, de uma integração mais aprofundada e com elementos reguladores. [...] Poderíamos também definir este processo de integração regional econômica como sendo aquele pelo qual os Estados se unem para atingir um desenvolvimento econômico maior e para se inserirem na competitividade mundial, por meio de mecanismos de aproximação e harmonização legislativa e de concessões mútuas, visando criar um único espaço de desenvolvimento econômico." (MENEZES, 2000a, p. 58, grifos nossos).

Sobre esta temática, é importante mencionar observação de Gustavo Ferraz de Campos MONACO (2004, p. 212) de que o objetivo de Desenvolvimento Econômico não constava do Tratado constitutivo da CECA, pois as diferenças de desenvolvimento econômico e social entre seus seis países membros não eram marcantes. Essa condição explicaria a "falta de configuração e delineamento de uma política regional para tornar equânime a distribuição de renda e meios de produção.”. E, mais do que isso, permite perceber que nem todo processo de integração teria como objetivo a promoção do desenvolvimento econômico e de uma coesão econômico-social de seus partícipes.

De todo modo, lembre-se de que, apesar de ser interessante, essa discussão se encontra fora do campo de questões desenhado para esta Tese, razão pela qual se deixa de tecer comentários sobre ela. Para um breve histórico da Política Regional da atual União Europeia, indicamos exemplificativamente a leitura do texto de Gustavo Ferraz de Campos MONACO (2004).

Paulo Borba CASELLA (2000a, p. 81-4 e 87) enfatiza a necessidade de se compreender a integração europeia como tendo surgido para superar antagonismos políticos antigos. Essa superação teria sido bem sucedida uma vez que não teria sido instaurada por mecanismos militares, mas sim mediante instrumentos jurídico-econômicos. Estes teriam instaurado entre seus países vínculos estáveis de caráter econômico. Para o mesmo autor, isso permitiria compreender a Europa como um processo de integração não apenas econômico, mas economicamente orientado para - por meio de uma "joint economic venture" (CASELLA, 2000a, p. 84, grifos nossos) - tornar não mais possível a realização de uma Guerra entre tais parceiros econômicos:

"where other devices seem to have failed, business can be a driving force strong enough to hold things together, in a considerably more stable and more effective way than armies ever did, as paradigmatically illustrated by the European integration process: a war has become operationally impossible among national economies so deeply intermingled as to render same interconnected to a level that severing ties would be unbearable." (CASELLA, 2000a, p. 86, grifos nossos).

No interior desse raciocínio, Jürgen HABERMAS (2011a) e Fabia Fernandes Carvalho VEÇOSO (2006, p. 27, 32-3 e 249) argumentam que a CECA seria uma etapa inicial para uma Federação: "a federação européia [...] seria o objetivo final do processo de integração, uma consequiência natural da união econômica 
que deveria ser empreendida.” (VEÇOSO, 2006, p. 32). Sem a presença deste elemento econômico, os países europeus não poderiam ser considerados como estando preparados para ensejar uma união política.

Para esta forma de compreender o princípio do processo de integração europeu deflagrado pela CECA, a integração política teria sido iniciada pela integração econômica: "[r]esumidamente: o objetivo de constituir uma Europa federal (união política) teria como meio a constituição de uma autoridade européia para reger determinado setor econômico, utilizando-se o método de ação comunitária, através do qual seriam reunidos setores econômicos específicos dos países signatários. Vale frisar que esse esquema permeou todo o processo de integração, ademais, o mesmo foi responsável pelo início concreto da integração européia, de forma a superar o impasse então existente." (VEÇOSO, 2006, p. 33).

No mesmo sentido, mas com alguns matizes reflexivos, pondera Fausto de QUADROS (1984, p. 121-4). Para este autor, a CECA em si mesma não teria adotado uma estrutura Federal, por ter se pautado por uma vertente funcional, vale dizer, por ter se restringido a colocar em comum a produção do carvão e do aço da Alemanha e da França. Teria sido, segundo o autor, uma opção pragmática, para evitar a continuidade da explicitação geral dos revezes dos Federalistas. Todavia, uma vez bem sucedida a aproximação por meio da CECA, seria possível retomar posteriormente o Projeto de unificação política Federal da Europa - segundo o mesmo autor, o objetivo último dos "pais" da CECA, jamais esquecido ou descartado por eles -: "Por duas vezes se tentou, antes da criação da CECA, promover a integração europeia pelo método federal. Foi porque se não conseguiu aí um consenso que se instituiu a CECA à luz do funcionalismo. O caráter transitório do método então adoptado ficou bem claro [...] na definição da CECA como o primeiro passo rumo à Federação europeia [...]." (QUADROS, 1984, p. 127, grifos nossos).

Da mesma maneira, André de Carvalho RAMOS (2005, p. 648-9 e 657) argumenta que a CECA teria sido uma integração econômica em si mesma, a qual consistia apenas em um primeiro passo para criar os vínculos necessários para uma futura integração política entre seus países-membros. Para ele, a integração econômica necessariamente procederia a integração política, pois os países que compunham a CECA ainda não estariam preparados para uma união política.

Em termos mais simples, enunciados criticamente pelo Federalista Emmanuel BERL (1961, p. 4): "les personnes et les organismes qui travaillent à édifier l'Europe [...] ont pensé: 'Créons une Europe économique, l'Europe politique suivre'.”. A crítica deste autor se funda na percepção de a CECA ter sido a opção de união de países europeus, em detrimento da opção da unificação política Federal, por ser a opção mais simples. Com efeito, na perspectiva de Emmanuel BERL (1961, p. 5), os construtores da Europa Unida da CECA teriam se adstrito apenas e tão-somente a aspectos técnicos e econômicos, inadequados para promover a unificação política Federal.

É importante salientar que o presente trabalho procura se afastar dessa compreensão, como ressaltado em sua Introdução Geral: houve a suspensão da chave explicativa econômica. A partir dessa parentetização da leitura econômica, poder-se-ia compreender o princípio da integração europeia promovido pela CECA, não como uma integração econômica promovida no sentido de promover uma união política de caráter Federal.

Antes, para esta Tese, a CECA ela própria seria uma união política executada por meio de instrumentos jurídico-normativos - de conteúdo econômico, ou não - que regulamentaram a produção do sentido normativo a ser impresso sobre questões concretas sensíveis - relacionadas ao carvão e ao aço - tornadas institucionalmente comuns (nesse sentido, remetemos à leitura do Terceiro Capítulo e, especialmente, do item 3.1, infra). Em outros termos, a CECA teria se recusado simultaneamente (i) a postergar a realização de uma União política estatal; e (ii) a ser e a engendrar futuramente uma unificação política Federal. Isso permite afastar compreensões segundo as quais a Europa "não estaria ainda preparada" para uma união política no pós-Segunda Guerra Mundial. A presente proposta de interpretação restará mais clara a partir da leitura da Parte Segunda desta Tese, especialmente dos Capítulos Sexto e Sétimo, infra.

De todo modo, lembre-se de que, como salientado no recorte metodológico temático, a Europa Unida não pareceria ter se orientado em favor de uma unificação política nos primeiros dez anos subsequentes ao final da Segunda Guerra Mundial - bastando notar a rejeição da proposta de um Estado Federal Europeu com a aprovação de um CdE provido de capacidade reduzida de atuação efetiva e com a rejeição da CED e da CPE, anos depois (como visto nos itens 1.4.1., 1.4.2. e 1.4.3., supra). Esse aspecto ficará mais claro na narrativa da construção da CECA, no Sexto Capítulo deste trabalho.

Ademais, como referido na Introdução Geral desta Tese, não se preocupará em discutir os limites e as possibilidades de uma leitura econômica da Europa Unida, haja vista que ela fora deixada em suspenso para o desenvolvimento deste estudo preocupado com uma explicação jurídico-Política deste fenômeno.

Por fim, como se poderá ver mais adiante, na nota de rodapé 204 , e, principalmente, no Sétimo Capítulo deste trabalho, o fato de querer superar os antagonismos políticos que culminavam em Guerras não permite concluir imediatamente que a CECA almejara instituir a Paz pela eliminação do conflito. Com efeito, 
A diretificação das relações entre tais países tinha por objetivo, assim, estabelecer mecanismos regulatórios jurídico-normativos capazes de construir uma vida em comum entre diferentes (um arcabouço normativo fundado em Leis).

[H]á um momento quente, um momento da refundação: a crise, em geral provocada por guerra ou colapso econômico, que no Atlântico Norte foi o período da depressão e da guerra em meados do século XX. Aí, a sociedade é reimaginada, é reorganizada, sob pressão. [... O O]s juristas atuam nesse momento de refundação [...]. (UNGER, s.d., p. 5, grifos nossos).

Tratou-se a CECA de uma maneira de simplesmente pretender afastar o cometimento de Guerra por meio do Direito. Mas há que se perceber que este recurso ao Direito Internacional no sentido de criar a CECA foi orientado a partir de uma perspectiva distinta $^{204}$ : as normas jurídicas internacionais positivas buscariam instaurar uma vida comum (Direito Comunitário), a qual seria aberta institucionalmente à periódica, renovada e ininterrupta deflagração de conflitos limitados às previsões dadas pelo Direito.

O Tratado Internacional que instituíra a CECA teria organizado uma estrutura institucional comum dotada de características particulares. Esta existiria para efetuar a mediação jurídica de oposições entre cada um dos Estados-Membros, no interior de um

muito pelo contrário, a disposição institucional da CECA traduzia os conflitos políticos para serem tratados juridicamente (por meio do Direito) - tal qual aponta a noção de Verrechtlichung assumida por este estudo: eles se transformaram em conflitos políticos desenvolvidos de acordo com os limites dados pelo Direito Positivo (ou simplesmente, transformaram-se em conflitos jurídico-políticos).

Nesse sentido, as normas jurídicas positivas da CECA poderiam até deter conteúdo econômico, mas sua regulamentação tinha por orientação arquitetônica geral preocupações voltadas a definir o problema do fundamento do Direito e do Poder na Comunidade - por ser conjunto de Direito Positivo arquitetado segundo Leis, como sugerido no item 1.4., supra. Nesse sentido, v. o Terceiro Capítulo e, principalmente, seu item 3.1., infra, bem como o Sétimo Capítulo, igualmente infra.

Perceba-se assim essa sutil diferença salientada por este trabalho, com relação aos demais estudos acima mencionados: o vínculo sem dúvida alguma fora estabelecido por meio de normas jurídicopositivas; todavia, o vínculo instaurado fora, ele mesmo, jurídico-político. Para tanto, não apenas remetemos o leitor ao Sétimo Capítulo desta Tese - onde essa preocupação resta mais bem esclarecida, como também ao Terceiro Capítulo e ao item 3.1., infra, onde se aponta para a discussão da possibilidade de compreender jurídico-politicamente a regulamentação estabelecida por normas de Direito Econômico constantes do Tratado de Paris de 1951.

${ }^{204}$ Perceba-se que este trabalho de forma alguma pretende afirmar que a CECA buscou instituir a Paz ou a Segurança entre seus Estados-Membros, objetivos ditos políticos usualmente apontados pelo pensamento tradicional (MENEZES, 2000a, p. 54; RAMOS, 1996, p. 648, 2005, p. 49; VEÇOSO, 2006, p. 32). É por essa razão que ele se restringe tão-somente a dizer que buscara afastar a Guerra entre os participantes da Comunidade (CASELLA, 2000a, p. 84).

Como se poderá compreender a partir da leitura do item 3.4., infra, onde são desenvolvidas considerações sobre a chave hermenêutica desta Tese, visar a uma união Política entre diferentes com o objetivo de afastar a possibilidade de cometimento de Guerra deve ser diferenciada de uma vulgar ideia de Paz ou de Segurança como pacificação das relações. Em uma união Política, os conflitos entre os partícipes não deixam de existir, são apenas traduzidos para serem mediados pelas instituições jurídicas da polis (direitificação ou simplesmente, Verrechtlichung). A rejeição da Guerra por meio do Direito é algo bastante diferente de almejar a instauração da ordem única da Paz ou a da Segurança. Essas considerações restarão mais claras também quando da leitura das Conclusões Parciais da Parte Segunda deste trabalho. 
Conselho e fora dele. Ao mesmo tempo, teria instituído um novo tipo de entidade, de caráter supranacional e independente em relação aos Estados: a Alta Autoridade e a Corte. Estas não apenas se oporiam entre si, como também se oporiam aos Estados ${ }^{205}$.

De todo modo, há que se reter neste ponto o aspecto fundamental: o Direito Internacional fora utilizado aqui como uma forma de construir um mecanismo de convivência entre diferentes por meio de especial técnica de engenharia social de uma vida em comum institucionalizada permanentemente tensa (Direito Comunitário Originário como direitificação). Suas normas jurídicas seriam técnicas promotoras de conflitos políticos, isto é, de instauração continuada de tensões institucionalmente encaminhadas entre formas de habitar o mundo distintas que passaram a viver em um espaço comum. Impossível prever uma automático apaziguamento das relações entre tais diferentes.

A alternativa ao desencadeamento de Guerra fora delineada para operar no interior de uma dinâmica jurídico-institucional positivada - em suma, no interior de uma racionalidade própria do Direito Positivo. A CECA se mostrara como instrumento de instituição de uma vida em sociedade caracterizada por forçar o estabelecimento de uma convivência contínua e conflitiva entre portadores de escalas de existência distintas (CASELLA, 2008, p. 228-9, 2009, p. 69).

A CECA se revelara como um inteligente mecanismo do pós-Segunda Guerra Mundial voltado a regular a vida em sociedade em âmbito internacional, por meio de um instrumento típico do Direito Internacional: o Tratado Internacional (CASELLA, 1994a, p. 248, 2000a, p. 88, 2008, p. 215, 259 e 294-5, 2009, p. 71) ${ }^{206}$. Este instaurara um novo tipo de Direito: o Direito Comunitário, o qual pode ser entendido como tendo institucionalmente previsto uma autoridade internacional compartilhadamente exercida entre Estados-Membros e entidades comunitárias. Esta autoridade internacional comum entre tantos diferentes foi viabilizada jurídico-normativamente por meio da delimitaçção de

205 O modo como essa oposição era desenvolvida será mais bem esclarecido quando do detalhamento do regime jurídico da CECA no Sétimo Capítulo deste trabalho. Por enquanto a construção acima resta parcialmente nebulosa, o que deriva do fato de o leitor ainda não ter confrontado as considerações dos itens finais desta Tese. Solicita-se assim paciência e a manutenção da empatia, pois a explicação restará mais clara posteriormente.

Lembre-se nesse sentido a distinção mencionada na nota de rodapé 136, supra, sobre a Pesquisa de Doutorado e o registro da mesma neste texto da Tese. Enquanto esta obra é fruto de pensamento único que pretende se ordenar logicamente, o contato com este texto é feito em etapas sucessivas que necessariamente dialogam entre si: pois as conclusões de um resultado científico sempre retornam e reescrevem suas premissas.

206 "Si tratta di un complesso di norme che, quando inserite in trattati che creano diritti ed obblighi reciproci tra gli Stati contraenti, non possono non appartenere al diritto internazionale e che solo nell'ordinamento internazionale sono suscettibili di trovare idonea collocazione e valutazione." (POCAR, 2006, p. 2). 
série de competência intercruzadas voltadas à viabilização de uma vida em sociedade entre seus participantes ${ }^{207}$.

É importante frisar que o artigo $6^{\circ}$ do Tratado da CECA atribuíra personalidade jurídica própria à Comunidade formada pela CECA, isto é, a todo o sistema de convivência pública estipulada institucionalmente pelas normas jurídicas deste Tratado. Ela abrange a posição ativa dos Estados considerados em si mesmos, cada um deles dotado de sua própria perspectiva estatal isoladamente considerada; a posição ativa dos Estados considerados conjuntamente, enquanto partícipes de um órgão comum, o Conselho; a posição ativa da Alta Autoridade, independente de cada um dos Estados e dos demais órgãos comunitários; a Corte, quando convidada a atuar pelo texto do Tratado. E todos em conjunto $^{208}$.

É a precisa dinâmica entre estes participantes da Comunidade que passaria a produzir na Europa um sentido normativo último do Direito e do Poder, ao mesmo tempo pressupondo e efetuando limitações recíprocas entre cada dos partícipes - o que impediria que qualquer decisão sobre temas comuns fosse proferida isolada e unilateralmente.

Para instituir o afastamento da Guerra, passa-se a construir por meio do clássico instrumento do Direito Internacional Público - o Tratado Internacional ${ }^{209}$ - estruturas jurídicas positivas (CASELLA, 1994a, p. 248, 2008, p. 189, 2012, p. 173) ${ }^{210}$, as quais permitiram o surgimento de uma nova forma de organização das relações entre os $\operatorname{Estados}^{211}$ (FRIEDMANN, 1964, p. 60-2).

\footnotetext{
${ }^{207}$ Não se refere aqui à autoridade da supranacionalidade Alta Autoridade, mas à autoridade formada pela conjunção desta e dos demais partícipes desta integração entendida como sistema de convivência. Como ficará mais claro quando da leitura do Sétimo Capítulo desta Tese.

${ }^{208}$ Perceba-se a sutileza dessa afirmação: a personalidade jurídica constituída pelo Tratado da CECA é aquela conferia à CECA, não se referindo a seus órgãos comunitários individualmente considerados. Nesse sentido, é a Comunidade de convivência entre seus órgãos comunitários e os Estados-Membros que recebe a personalidade jurídica distinta da simples congregação de interesses auto-interessados multilaterais e multifacetados. Ela restará mais clara quando da leitura do Sétimo Capítulo desta Tese.

209 "Il tratatto istitutivo della UE, al pari di quelli che riguardano la CE, la CECA e la CEEA, sono [...] tratatti internazionali non dissimili da qualsiasi altro, e altro non fanno che creare uma serie di diritti e di obblighi tra gli Stati contraenti; e in ciò esauriscono la loro portata dal punto di vista de diritto internazionale." (POCAR, 2006, p. 3); afinal, a origem do Direito Comunitário seria inegavelmente um instrumento clássico do Direito Internacional, o Tratado Internacional (MENEZES, 2000a, p. 59), ainda que com relação a ele se autonomizasse (REUTER, 1965, p. 200-1 e 245).

${ }^{210} \mathrm{Ou}$, nos termos de André de Carvalho RAMOS (2005, p. 54), o Direito Comunitário Originário - isto é, constante do Tratado Originário que instituiu a CECA - "paga seu tributo ao Direito Internacional tradicional.".

${ }^{211}$ A qual, como bem ressaltam Juan António CARRILLO SALCEDO (1985, p. 188-9), Paulo Borba CASELLA (2008, p. 259, 2010, p. 172-3), Wolfgang FRIEDMANN (1964, p. 62) e Geraldo MINIUCI (2012, p. 2), não eliminara o paradigma clássico, subsistindo até hoje um sistema misto. Sobre este tema, remetemos o leitor à nota de rodapé 2.
} 
Não apenas uma coexistência ou uma simples cooperação entre Estados por meio do Direito, mas uma integração institucionalmente promovida por meio de complexa trama jurídico-normativa positiva voltada a instaurar uma união Política entre diferentes pelo Direito (Verrechtlichung) - ou simplesmente, uma "convivência organizada entre os estados" (CASELLA, 2008, p. 228-9, grifos nossos) ${ }^{212}$.

A importância da conclusão anterior resta eclipsada pela simplicidade das palavras, mas sua complexidade será mais bem compreendida a partir da leitura das próximas partes deste trabalho ${ }^{213}$.

No entanto, é relevante suscitar apenas a parcela que diz respeito a esta Parte Primeira, de precisões metodológicas: o Direito Internacional Público se individuara com a iniciativa do Tratado Internacional que Instituiu a CECA no sentido de constituir um efetivo Direito Comunitário (CASELLA, 1994a, p. 260-6) (14 $^{214}$ a ordem jurídica de um

212 Maristela BASSO (1998a, p. 74, 1998b, p. 23) Paulo Borba CASELLA (1994a, p. 248, 2010, p. 172), Umberto CELLI JR. (1990, p. 39, 2006, p. 19 e 22-4) e Fabia Fernandes Carvalho VEÇOSO (2006, p. 28-9 e 32-4) destacam que a integração promovida no interior do Projeto de Europa Unida da CECA deve ser entendida como distinta da de uma cooperação clássica. Essa distinção derivaria do aprofundamento qualitativo das relações entre os países participantes, se em comparação com a cooperação em termos tradicionais: a qualidade, a complexidade, a intensidade e os objetivos das normas jurídicas que compõem os processos de integração seriam um índice desse grau mais profundo.

Saliente-se, contudo, que Maristela BASSO (1998a, 1998b) e Umberto CELLI JR. (2006) efetuam essa análise a partir de uma abordagem econômica dos processos de integração - perspectiva colocada entre parênteses já na Introdução Geral deste texto.

Entretanto, como ressaltado nos itens 1.4. e 1.5., supra, também se mostra possível compreender a direitificação entre os países constituintes da CECA a partir de uma perspectiva jurídico-política e, com isso, apontar para uma diferença com relação às simples experiências de cooperação entre países a partir da mera constatação de presença de Leis.

${ }^{213}$ Principalmente do Sétimo Capítulo desta Tese.

${ }^{214}$ É importante destacar que Calogero PIZZOLO (2012b) procura diferenciar o Direito Internacional de um Direito Supranacional.

Para este autor, o Direito Internacional seria o clássico Direito de coordenação entre pares Soberanos, o qual não admitiria quaisquer submissão e verticalização - salvo no que se referisse ao jus cogens, nem Organizações Internacionais ou instituições similares às gestadas pela União Europeia. Toda e qualquer limitação derivaria apenas e tão-somente de consentimento explícito dos Estados.

Por outro lado, ainda segundo o mesmo autor, o Direito Supranacional não seria parte do Direito Internacional, apesar de ser o produto de uma Convenção celebrada de acordo com a matriz do Direito Internacional - a Convenção de Viena de Direito dos Tratados (1969). Essa independência derivaria do fato de o Direito Supranacional deter uma variável normativa diversa, fruto de uma autonomização de seu desenvolvimento normativo.

O Direito Supranacional seria caracterizado pela submissão vertical de entidades outrora Soberanas a uma autoridade comum, não mais dependendo as limitações à atuação dos Estados qualquer manifestação de consenso destes.

Para o mesmo autor, suas normas deteriam as características daquelas que compõem o ramo do Direito tradicionalmente designado por Direito Comunitário: (i) primazia, ou ainda, a prevalência sobre qualquer disposição interna de Estados, inclusive sobre as disposições Constitucionais destes, desde que dentro da esfera de competência da entidade supranacional - posição hierárquica superior; (ii) efeito direto, vale dizer, a possibilidade de invocação perante instituições e chefes nacionais para beneficiar aquele que dela se socorre (invocabilidade); (iii) aplicabilidade imediata, o que implica reconhecer a independência de qualquer mecanismo nacional de internalização de tais normas para poderem ser aplicadas no território dos Estados; e (iv) possibilidade de alegação, isto é, tais normas seriam passíveis de serem alegadas perante jurisdições nacionais como argumento processual. 
Perceba-se que se trata de maneira distinta de conceber a ordem jurídica comunitária: ela seria ou não produto do Direito Internacional? Segundo Christian JOERGERS (2010, p. 11-2), Hans Peter IPSEN teria inaugurado, em 1970, essa tendência de diferenciar o Direito Comunitário do Direito nacional e do Direito Internacional, identificando-o como um termo médio, na medida em que suas normas deteriam objetivos fundamentalmente diferentes.

Paul REUTER (1965, p. 200-1 e 245) argumenta que o Direito Comunitário seria autônomo com relação do Direito Internacional, apesar de nele se fundamentar e com ele guardar algumas relações de semelhança; essa distinção permitiria concluir pela impossibilidade de se aplicar ao Direito Comunitário determinados princípios do Direito Internacional clássico.

No Brasil, alguns autores concordam com o argumento do caráter sui generis do Direito Comunitário, distinto do Direito Internacional e do direito interno, tais como Wagner MENEZES (2000a, p. 53-4, 2000b, p. 735, 738-40 e 741-3), André de Carvalho RAMOS (2005, p. 52-5) e José Luiz Conrado VIEIRA (1999, p. 159-60).

A existência dessa perspectiva tendendo a facilmente fundamentar fora do Direito Internacional o Direito Comunitário - por o considerar um tertium genus - já havia sido anteriormente constatada e criticada por Paulo Borba CASELLA (1994a, p. 147) e por Fausto POCAR (2006, p. 1-4). Essa questão parece ser interessante, mas não é discutir o caráter sui generis ou não do Direito Comunitário o objetivo deste trabalho. Apenas se mencionou brevemente a existência dessa discussão para apontar a leitores eventualmente interessados na temática caminhos possíveis de interpretação.

De todo modo, ainda haveria que se notar que, anteriormente, esse modo de conceber parecia se restringir ao Direito Comunitário. Hoje, o argumento da autonomização exponencializa sua própria autonomia e se dirige para além dessas limitações, buscando legitimar até mesmo o surgimento de um ramo do Direito até então desconhecido: o do Direito Supranacional!

Este novo ramo abrangeria, segundo alguns de seus fautores - tais como Luiz Guilherme Arcaro CONCI (2012), Marcelo FIGUEIREDO (2012) e Calogero PIZZOLO (2012a, 2012b), não apenas o Direito Comunitário, mas também aquilo que usualmente se denomina Direito Internacional dos Direitos Humanos (DIDH). A construção deste novo ramo do Direito exigiria inclusive a modificação do nome do DIDH para Direito Constitucional Transnacional Descendente, denominação derivada do movimento de imposição absoluta e incondicionada das normas de Direitos Humanos sobre as ordens jurídicas nacionais (de cima, a baixo) (PIZZOLO, 2012).

A discussão é interessante, principalmente quando se percebe que é possível cogitar por fundamento não Internacional do Direito Comunitário - o que pode ser uma solução fácil apressadamente tomada para evitar o necessário esforço intelectual de sistematização (CASELLA, 1994a, p. 147).

Para Paulo Borba CASELLA (1994a, p. 260-6), Geraldo MINIUCI (2012, p. 1-2) e Fausto POCAR (2006, p. 3), o Direito Comunitário este seria uma individuação do Direito Internacional, o qual teria sofrido uma parcial mutação paradigmática no transcurso da História do século XX: teria sido uma alteração do paradigma de coexistência para o de cooperação e, posteriormente, para o de integração. Ou mais simplesmente, a integração seria "dimensão para o perfazimento de novos planos de realização do direito internacional.” (CASELLA, 2010, p. 171).

Por sua vez, parecendo não distinguir conforme a tradição jurídica brasileira e estrangeira entre um Direito Internacional de Coexistência e um Direito Internacional de Cooperação e, dentro desta última, de Cooperação mais profunda (sobre essas distinções, v. nota de rodapé 2, supra, bem como para as menções feitas a essa distinção, neste mesmo item 2.1.2.), Wagner MENEZES (2000b, p. 738-9) afirma que o Direito Comunitário se diferenciaria do Direito Internacional porque este apenas poderia no máximo estabelecer uma relação de cooperação e de respeito entre Estados autônomos, independentes e soberanos.

Se o debate terminológico é interessante e relevante, ele extrapola os objetivos deste trabalho e os limites metodológicos estabelecidos para ele, razão pela qual se recusa a desenvolver considerações adicionais sobre essa temática neste texto.

Por esse motivo, assume-se simplesmente neste trabalho que o Direito Comunitário é individuação do Direito Internacional Público, uma especificação do Direito da Integração (CASELLA, 1994a, p. 248; GAUTRON, 2000, p. 25) voltada ao estabelecimento de convivência pública entre os participantes da Comunidade (CASELLA, 2008, p. 228-9) (nem coexistência, nem cooperação).

Como dito acima, assume-se ser o Direito da Integração - e sua individuação, o Direito Comunitário - uma das múltiplas formas de realização do Direito Internacional (CASELLA, 2010, p. 171), ainda que detenha algumas especificidades. Nesse sentido, lembre-se de Fausto POCAR (2006, p. 35), para quem a origem internacional do Direito Comunitário não pretende negar a este sua autonomia e sua individualidade com relação ao Direito Internacional Público (POCAR, 2006, p. 3-5).

Note-se que Wagner MENEZES (2000a, p. 53-4 e 64-72, 2000b, 735, 738-40 e 741-3) também aponta para a percepção de o Direito Comunitário ser individuação do Direito da Integração, mas de acordo 
com perspectiva diferentemente matizada: tendo uma origem no Direito Internacional, posteriormente teria adquirido uma independência. Em outras palavras, com o tempo, diferenciara-se essencialmente do Direito Internacional e do direito interno, voltando-se à promoção de uma integração regional econômica.

No mesmo sentido parece compreender André de Carvalho RAMOS (2005). Este compreende o Direito Comunitário como um ramo do Direito Internacional (RAMOS, 2005, p. 51), ao mesmo tempo em que afirma ter se formado por meio de via jurisprudencial um Direito Comunitário passível de ser entendido como ramo de Direito autônomo e independente, ou ainda, como uma ordem jurídica sui generis (RAMOS, 2005, p. 52-5).

Interessante mencionar a posição de José Luiz Conrado VIEIRA (1999, p. 25 e 161-2), quem também argumenta no sentido de ser o Direito Comunitário uma individuação do Direito da Integração -e, portanto, do Direito Internacional. Contudo, não concordamos com a conclusão deste mesmo autor (1999, p. 25, 125 e 169-78) de que seriam ambos expressões jurídicas essencialmente de Direito Econômico. Para essa discussão específica em torno de uma suposta essência do Direito Comunitário, remetemos o leitor ao Terceiro Capítulo e ao item 3.1., infra.

Por sua vez, Maristela BASSO (1997, p. 21, 1998a, p.74, 1998b, p. 23) parece não diferenciar o Direito Comunitário do Direito da Integração, apesar de compreender o Direito Comunitário como um ramo do Direito Internacional. Não do Direito Internacional clássico, mas de um novo Direito Internacional. Em texto anterior, a mesma autora declarara ser o Direito Comunitário um ramo autônomo próprio, distinto do Direito Internacional (BASSO, 1997, p. 21). Talvez estivesse se referindo aqui ao Direito Internacional clássico, e não a um suposto ramo do Direito sui generis.

Neste particular, não se pode deixar de mencionar a posição marcadamente incisiva de Fausto de QUADROS (1984). Para este autor, o Direito Comunitário não pode ser entendido como (i) um Direito estatal, pois as Comunidades não detinham um caráter estatal - isto é, não eram um Estado - (QUADROS, 1984, p. 99-100); (ii) um Direito Federal, tendo em vista que as Comunidades não seriam um Estado Federal, precisamente por não serem nem mesmo um Estado (QUADROS, 1984, p. 106); (iii) um Direito supranacional, visto que não seria produzido por um poder político superior ao dos Estados, na medida em que ainda seria a expressão predominante dos interesses estatais e o produto de vontade Soberana destes (QUADROS, 1984, p. 169 e 386); (iv) um Direito sui generis, pois apesar de ser específico das Comunidades, não ensejaria a produção de um ramo distinto do Direito que em nada remetesse ao Direito Internacional ou ao Direito nacional (QUADROS, 1984, p. 170); e (v) um Direito passível de ser igualado ao Direito Internacional Público clássico, precisamente porque ele não opera de acordo com o esquema de inter-relação coordenada de Soberanias estatais, não sendo apto para explicar a "transferência de poderes soberanos dos Estados para as Comunidades" (QUADROS, 1984, p. 174).

Para o mesmo autor, o Direito Comunitário seria um "estádio superior da evolução do Direito Internacional Público" (QUADROS, 1984, p. 179), vale dizer, seria o produto de um Direito Internacional novo, de cooperação, de interdependência e de solidariedade entre os povos, isto é, não mais fundamentado em um Direito Internacional pautado pela coordenação da coexistência pacifica de Soberanias estatais (QUADROS, 1984, p. 386).

Essa qualificação remete necessariamente ao embate entre o Direito Internacional de Coexistência e o Direito Internacional de Cooperação, tal qual evidenciado na nota de rodapé 2 desta Tese. Frise-se não ser possível este trabalho concordar com a asserção de que o Direito Comunitário seria a expressão predominante dos interesses estatais e o produto de vontade Soberana destes (QUADROS, 1984, p. 169 e 386), o que fora já parcialmente indicado na nota de rodapé 106, supra, e que restará mais bem explicado no Sétimo Capítulo desta Tese.

Mais uma vez, como afirmado supra, trata-se efetivamente de um debate interessante, mas que escapa aos objetivos deste trabalho, razão pela qual se registra aqui o convite para futuras investigações conjuntas sobre o tema.

Por fim, haveria que se lembrar de que o debate sobre o tema da autonomia do Direito Comunitário surge apenas a partir da década de 1960, após julgados proferidos pela Corte de Justiça das Comunidades Europeias que progressivamente afirmaram a autonomia do Direito Comunitário com relação ao Direito nacional, tendência reforçada posteriormente pela afirmação de sua primazia e de seu efeito direto (GAUTRON, 2000, p. 26; PITTA E CUNHA, 2004, p. 45-54; POCAR, 2006, p. 2).

Apesar de essa discussão ser relevante para compreender a evolução do Direito Comunitário e os fundamentos que este estabelecera para a formação do atual Direito da União Europeia, há que se lembrar de que ela se encontra fora dos limites metodológicos de caráter temporal que foram estabelecidos para este trabalho (1945 a 1951), ao mesmo tempo em que se encontra fora do arco metodológico de questões formuladas.

Por esse motivo, não apenas se deixará de tecer comentários sobre essa temática nesta nota de rodapé, como também esse tema não será novamente mencionado posteriormente neste trabalho, em nome da 
sistema de convivência comum, permanentemente mantido em um equilíbrio tenso, estabelecido entre diferentes países.

O aparato jurídico instituído pelo Tratado da CECA se orientara para regular uma vida em comum entre diferentes formas de interagir em uma Comunidade, isto é, para instituir uma forma de convivência em que todos os implicados deveriam interagir compartilhadamente na construção do sentido das decisões normativas sobre questões comuns. Suas normas jurídicas positivadas institucionalizaram a construção de uma exigente consciência comunitária, ou melhor, de um sentimento entre todos e cada um de que estavam coletivamente comprometidos.

Anteriormente opostos militarmente, estes diferentes não mais desenvolveriam seus conflitos fora de uma preocupação comum estabelecida por normas jurídicas responsáveis pela direitificação de suas oposições, ou ainda, responsáveis pelo reenvio de tais conflitos políticos para o interior de instituições estruturadas por normas jurídicas positivas. Seus conflitos não foram eliminados, mas simplesmente redirecionados para o interior de instituições que passaram a os apresentar como questões a serem pensadas conjuntamente por todos os implicados na vida comum - por serem, a partir de então, questões comuns.

Não mais coexistência, nem somente uma cooperação, mas uma convivência entre diferentes marcada por conflitos. Ou ainda, não mais normas de abstenção, nem apenas normas de ação, mas normas de oposição.

\footnotetext{
A ordem social [...] já não está ligada ao poder criador de um personagem excepcional, à sua atividade de ordenador. É a ordem, ao contrário, que regula o poder de todos [...], que impõe um limite à sua vontade de expansão. A ordem é primeira em relação ao poder. A arché pertence na realidade exclusivamente à lei. [... T] oda facção que pretende assegurar-se o monopólio da arché ameaça, por esse golpe contra o equilíbrio das outas forças, a homónoia do corpo social e põe em risco, com isso, a própria existência da cidade. (VERNANT, 1981, p. 47, grifos nossos). ${ }^{215}$
}

coerência e do rigor metodológicos assumidos. Há ampla literatura sobre este tema em âmbito nacional e internacional, mencionando-se apenas exemplificativamente os seguintes textos para eventuais leitores interessados: Paulo Borba CASELLA (1994a), Jean-Claude GAUTRON (2000), Robert LECOURT (1991) e Paulo de PITTA E CUNHA (2004).

215 "Homónoia: Palavra composta de homó-, que vem de hómoios (semelhante, igual, de mesma natureza, o mesmo, a mesma, que concerne igualmente a todos, comum a todos, que convém à natureza de, igual a, de mesma força, de mesmo valor), e noia, que vem de noéo (ter no espírito, ter no pensamento). Homónoia: conformidade ou comunidade de pensamentos e sentimentos, unanimidade, concórdia, união. Refere-se ao ideal da unidade pan-helênica ou à união de todos os gregos." (CHAUÍ, 2008, p. 502, grifos da autora). 
Note-se que a forma jurídico-institucional assumida pela CECA não era necessária ${ }^{216}$. Não havia um suposto "espírito do tempo" que guiaria todas as iniciativas em comum para um mesmo sentido de articulação institucional, mas uma divergência entre concepções de mundo que, em cada uma das Organizações Internacionais encontrou condições propícias para se desenvolver.

A especificidade da CECA reside no fato de ser singular forma de organização jurídico-política institucional da vida comum entre os seis países europeus que a fundaram. Em outras palavras, o aspecto singular da CECA deriva pontualmente do fato de ter suas instituições constituídas conforme Leis de convivência plural permanente entre diferentes $^{217}$. Ou ainda, decorre precisamente do fato de suas normas jurídicas terem se preocupado com a constituição de uma Comunidade entre diferentes, sem pretender com isso apaziguar os conflitos usualmente desenvolvidos entre eles: estes apenas passam a ser tratados em conjunto, no interior de instituições estruturadas a partor de normas jurídicopositivas forjadas segundo Leis.

Deste modo, os conflitos entre diferentes formas de habitar o mundo permanecem (conflitos políticos), mas estes passam a ser encaminhados para ser desenvolvidos sempre e tão-somente de acordo com os limites dados pelo Direito Positivo (conflito político se torna, assim, conflito jurídico-político) e, por isso, o Direito Comunitário da CECA pode ser entendido como expressão no Direito Internacional de direitifcação (Verrechtlichung).

Nesse sentido, é ainda necessário especificar quais serão as normas jurídicas analisadas pelo presente trabalho de acordo com a classificação tradicional de normas de Direito Comunitário $^{218}$. Isso permitirá estabelecer com o leitor um diálogo a partir de

${ }^{216}$ Como mostram as experiências de União da Europa excluídas da análise deste trabalho, mencionadas conjuntamente nos itens 1.4. e 1.5., supra.

${ }^{217}$ Nesse sentido, v. considerações dos itens 1.4. e 1.5., supra.

${ }^{218}$ Ainda com relação ao aspecto terminológico, é importante destacar que o termo Direito Comunitário é aplicado apenas para a ordem jurídico-normativa positivada que constitui uma Comunidade e as quais são no interior dela desenvolvidas - como as das Comunidades Europeias (CECA, CEEA e CEE) (MENEZES, 2000a, p. 53, 2000b, p. 735). Ainda que se expressem por meio de vias distintas, são aquelas normas jurídicas atinentes ao fenômeno comunitário; mais simplesmente, é o Direito Comunitário o Direito de uma Comunidade de países em processo de integração (CELLI JR., 1990, p. 79; RAMOS, 2005, p. 51; VIEIRA, 1999 , p. 25 e $161-2)$.

Em maneira mais específica, pode-se dizer que se tratam das normas relativas à Comunidade Europeia, isto é, das que interessam a esta Comunidade (POCAR, 2006, p. 2-5): "[r]ientrano nella nozione di diritto comunitario tutte quelle norme che riguardano, a vario titolo, le Comunità europee nonché le norme che sono state poste in essere dalle Comunità stesse nell'esercizio delle competenze normative loro spettanti." (DANIELE, 1991, p. 1, grifos do autor).

Nesse sentido, a mero título de esclarecimento, mencione-se que instituições comuns de uma ordem jurídico-positiva que não correspondam a uma Comunidade não podem ser designadas em seu conjunto pela expressão Direito Comunitário, mas apenas e tão-somente como normas jurídicas de Direito da Integração. Essa última condição é verificável, por exemplo, no Mercado Comum do Sul (MERCOSUL), o qual revela ser uma simples integração lato sensu (CELLI JR., 2006, p. 22). No caso específico deste, suas normas 
repertório linguístico comum formado a partir da tradição da literatura jurídica comunitária. Deste modo, será possível mostrar mais diretamente sobre quais normas comunitárias este estudo se debruçará especificamente, como também compreender as razões pelas quais um determinado tipo foi escolhido em detrimento do outro.

O Direito Comunitário é composto globalmente por normas de Direito Originário e normas de Direito Derivado 21920.

devem ser consideradas como constituindo um corpo jurídico de Direito da Integração (CASELLA, 1996a, p. $53)$.

Lembre-se neste ponto que o compromisso deste trabalho não consiste em analisar o MERCOSUL, mas apenas e tão-somente a CECA, razão pela qual se deixa de tecer considerações mais específicas sobre esse processo de integração regional entre Argentina, Brasil, Paraguai, Uruguai e Venezuela. Ele foi mencionado aqui apenas a título de exemplo voltado a elucidar a terminologia enunciada nesta nota de rodapé.

No que se refere ao ambiente europeu, após a substituição da CECA, da CEEA e da CEE pela UE, deixou de fazer sentido designar tal constelação jurídico-positiva como Direito Comunitário, sendo mais acertado a denominar "Direito Europeu". Sobre a cronologia de progressiva substituição da CECA, da CEEA e da CEE pela União Europeia, remetemos o leitor à breve discussão efetuada no item 1.1., supra.

De todo modo, é sintomático notar a modificação de títulos de obras que se dedicavam ao estudo das Comunidades Europeias, para se referirem ao estudo da União Europeia. Exemplificativamente mencionamos Paulo Borba CASELLA, cuja obra Comunidades Européias e seu Ordenamento Jurídico (1994a) passou a se denominar União Europeia: seus Ordenamento e suas Instituições (2002), da mesma maneira que ocorrera com Carlos Molina del POZO, cuja obra Derecho Comunitario (2004) passara a se denominar Derecho de la Unión Europea (2011a).

Por fim, por este trabalho se cingir ao estudo das normas jurídicas positivadas pelo Tratado da CECA, autoriza-se - antes, mostra-se ser rigorosamente necessário em termos jurídicos - denominar esse aparato jurídico-normativo positivo como Direito Comunitário, porquanto se refere ao estudo das normas jurídicas de uma Comunidade: a CECA.

${ }^{219}$ Como ressalta Tercio Sampaio FERRAZ JR. (2001, p. 122), toda tentativa de classificar normas jurídicas não pode pretender ser definitiva, pois corresponde a desígnios específicos de campos significativos distintos de cada autor.

Todavia, parece que a distinção entre Direito Originário e Direito Derivado não parece produzir maiores dificuldades ou problemas conceituais, salvo no que se refere à discussão mencionada por JeanClaude GAUTRON (2000, p. 43) sobre o transformismo. Este termo designaria a dinâmica de reelaboração do Direito Originário por meio da qual poderiam ser consideradas partes integrantes de Direito Originário normas jurídicas de natureza diversa (tais como Acordos Internacionais celebrados pela Comunidade), as quais não teriam figurado originariamente entre os documentos típicos de Direito Originário. Temática que, apesar de ser interessante, foge ao escopo investigativo do presente estudo, razão pela qual não serão tecidas considerações adicionais sobre ela.

${ }^{220}$ Haveria ainda outras denominações intercruzadas de normas jurídicas comunitárias possíveis; podem ser assim distinguidos: (i) o direito público comunitário, ou ainda, direito institucional comunitário (CASELLA, 1994a, p. 252; DANIELE, 1991, p. 3), o qual prevê e organiza as instituições componentes das Comunidades, determina suas formas e seus procedimentos de funcionamento e divide entre elas as competências e os poderes, e (ii) o direito privado, ou ainda, o direito material (CASELLA, 1994a, p. 252; DANIELE, 1991, p. 3), cujas normas estabelecem a disciplina da Comunidade nas atividades insertas no âmbito de suas competências.

Esta última categoria abrange tanto normas de Direito Originário como de Direito Derivado, pois por meio dessas categorias a Comunidade poderia atuar dentro de seu âmbito de competência: o binômio Direito Originário/Direito Derivado se comunica o outro par distintivo direito institucional/direito material (CASELLA, 1994a, p. 252; DANIELE, 1991, p. 3).

A discussão em torno das distinções entre normas comunitárias e das diferenças entre elas não interessa aos objetivos do presente estudo. Por esse motivo, não será mais mencionada palavra adicional sobre tal classificação, nem aqui, nem ao longo da produção do presente texto. Este trabalho não consiste em discutir a classificação tradicional das normas jurídicas comunitárias: antes, apenas se pretende indicar qual espécie de normas será analisada por esse trabalho, conforme a terminologia dada pela tradição. 
As normas jurídicas de Direito Originário, ou ainda, de Direito Primário, de Direito Comunitário estão positivadas nos Tratados Internacionais Constitutivos, nos Tratados Modificativos, em seus Protocolos Anexos, e nos Tratados e Atos relativos às Adesões. Em outras palavras, são as normas mais relevantes - ainda que em menor número, pois constam de todo e qualquer ato convencional celebrado entre os EstadosMembros da Comunidade (CASELlA, 1994a, p. 252; DANIELE, 1991, p. 1-2; GAUTRON, 2000, p. 43; PITTA E CUNHA, 2004, p. 40; POCAR, 2006, p. 2; POZO, 2012; RAMOS, 2005, p. 51; REUTER, 1965, p. 246).

Por outro lado, as normas jurídicas de Direito Derivado, ou também, de Direito Secundário, constam dos atos jurídicos produzidos pelas instituições da Comunidade. Mais numerosos, tais atos derivam de competência normativa atribuída às entidades comunitárias pelo próprio Direito Originário (CASELLA, 1994a, p. 252; DANIELE, 1991, p. 2; GAUTRON, 2000, passim; PITTA E CUNHA, 2004, p. 40; POCAR, 2006, p. 4; POZO, 2012; RAMOS, 2005, p. 54; REUTER, 1965, p. 246).

Por o Direito Originário estabelecer as condições formais de produção das normas de Direito Derivado, afirma-se que o primeiro é o fundamento das últimas e, por isso, as normas de Direito Originário se colocariam em posição hierarquicamente superior às de Direito Derivado (DANIELE, 1991, p. 2; GAUTRON, 2000, p. 26; POZO, 2012).

O artigo 14 do Tratado da CECA apresenta duas espécies normativas, a saber, as Decisões e as Recomendações ${ }^{221}$. Nos termos do próprio artigo 14 do Tratado da CECA, as Decisões seriam obrigatórias em todos os seus termos, ao passo que as Recomendações vinculariam quanto a seus fins, deixando a seus destinatários a livre escolha dos meios para produzir tais fins ${ }^{222} 223$.

Todavia, apesar de essa preocupação terminológica mais específica estar localizada fora do campo de questões metodologicamente determinadas para o presente estudo, julgou-se ser ao menos interessante indicar brevemente nota de rodapé essa outra distinção. Isso permitirá ver a complexidade normativa que compunha a CECA e as demais Comunidades Europeias, bem como a atual UE.

${ }^{221}$ Também são previstos pareceres; todavia, diante de disposição expressa do Tratado que lhes retira força vinculante, não devem ser entendidos como compondo o corpo normativo, uma vez que seu conteúdo não poderia pretender veicular normas revestidas de juridicidade.

${ }^{222} \mathrm{~V}$. nota de rodapé 154 , supra.

223 Paulo Borba CASELLA (1994a, p. 252), mencionando obra de Gérard DRUESNE, Droit Matériel et Politiques de la Communauté Européenne (1986), lembra haver discussão quanto a uma flutuação terminológica na especificação de atos jurídico-normativos derivados, diante de variação de denominação dada pelo texto de cada Tratado das Comunidades Europeias.

Este problema de multiplicidade de signos nomeadores dos atos de Direito Derivado da Comunidade não encontra condições para ressoar neste estudo. Com efeito, dedica-se aqui apenas e tão-somente ao Tratado da CECA, não havendo qualquer dificuldade com relação à nomenclatura destes atos. Note-se que o artigo 14 do Tratado da CECA expressamente apresenta apenas duas únicas possibilidades de espécies normativas (ou as Decisões, ou as Recomendações). V. a nota de rodapé 154, supra. 
Diante da classificação brevemente exposta linhas acima, é importante compreender que este trabalho se deterá apenas sobre uma espécie normativa. Esta deverá ser a que melhor puder satisfazer a pretensão de compreender "como" e "por meio de quais instituições" os seis países europeus conseguiram estabelecer por meio da CECA um novo modo de relações entre si para, com isso, constituir uma comunidade entre diferentes, preservando essa diferença.

Não é assim todo o complexo ordenamento jurídico-positivo comunitário que interessa este estudo ${ }^{224}$, mas apenas e tão-somente aquele que esteja apto a responder à indagação inicial.

Perceba-se que são as normas jurídicas positivadas nos instrumentos de Direito Originário que estabelecem as modalidades institucionais de interação entre os diversos componentes e partícipes da Comunidade. Não apenas estabelecem as condições de produção do Direito Derivado, como também efetuam as divisões de competência necessárias para viabilizar a convivência conflitiva entre Estados-Membros - unidos ou não perante um Conselho intergovernamental, e destes com a Alta Autoridade e com a Corte. Por meio das normas jurídicas positivas de Direito Comunitário Originário, cada um deles encontrava plenas condições para apresentar perante os demais suas específicas formas de habitar o mundo. Por meio dessa direitificação (Verrechtlichung) de suas relações de oposição - dada por instituições de Direito Comunitário Originário, cada uma dessas maneiras de perceber o mundo encontrava condições para contribuir na formação do sentido normativo a ser dado sobre questões comuns.

Em outras palavras, são as normas jurídicas de Direito Originário que instrumentalizaram institucionalmente o sistema de convivência pública instaurado pelo Tratado da CECA. São elas que regulamentaram e condicionaram a atuação normativa e decisória de cada uma das entidades comunitárias e dos EstadosMembros no interior da Comunidade ${ }^{225}$ no processo de formação do sentido normativo

De todo modo, apesar de as discussões em torno das diferentes possibilidades de nomeação de tais atos normativos serem interessantes e relevantes, elas dizem respeito apenas e tão-somente à pluralidade de regimes jurídicos na Europa resultante da criação da CEEA, da CEE e, posteriormente, da UE. Ademais, tais discussões dizem respeito às normas jurídicas de Direito Derivado, as quais, como se verá linhas a seguir, não serão analisadas pelo presente estudo.

Por essa razão, há que se perceber que este problema não é pertinente nem temática, nem temporalmente, ao objeto de estudo desta Tese. Por esse motivo, não serão desenvolvidas considerações adicionais sobre esse tema, nem nesta nota de rodapé, nem nesta Tese de Doutorado.

${ }^{224}$ Como lembra Luigi DANIELE (1991, p. 1): "Va subito precisato che si tratta di un complesso di norme estremamante vasto e, per altro verso, variegato, al punto che non sarebbe errato concludere che il diritto comunitario manca di omogeneità.".

${ }^{225}$ Como restará mais claro quando da leitura do Sétimo Capítulo desta Tese de Doutorado. 
último para encaminhar, a partir de perspectiva conflitivamente múltipla, a formulação de uma solução compartilhadamente gestada para questões comuns. O múltiplo no uno era garantido precisamente por meio de normas jurídicas positivadas que introduziram e mantiveram no interior da vida comum a constante oposição entre as distintas formas de habitar o mundo.

Lembre-se de que este trabalho visa a compreender e qualificar especificamente o modo como este arranjo institucional entre órgãos comunitários e Estados-Membros viabilizou a instauração daquele novo modo de relações segundo o qual não haveria a primazia de qualquer um dos partícipes sobre os demais ${ }^{226}$. Este pressupusera e preservara a diferença entre cada um de seus participantes, além de ter mantido afastada a unidimensionalização da determinação do sentido último das normas jurídicas e das decisões na CECA.

É esta precisa forma de articulação normativa das instituições da CECA - inclusive em torno de normas de competência, que interessa ao presente estudo. Por esse motivo, o texto jurídico-normativo positivo a ser analisado por este trabalho é especificamente o conjunto das normas que constam do Direito Originário da CECA - isto é, do Tratado de Paris, de 1951, pois foram elas as responsáveis pela instrumentalização jurídico-normativa positiva deste sistema de convivência entre diferentes formas de habitar o mundo.

Nesse sentido, a análise institucional deste trabalho interpretará o texto do Tratado da CECA e o conjunto de seus Protocolos e Anexos. Isso permitirá deles depreender as disposições normativas que instauraram o modo de convivência público entre alguns países europeus.

Restam excluídas deste modo as normas jurídicas de Direito Derivado. Sobre elas não se falará neste texto, salvo em hipóteses específicas e incidentais, em caráter de curiosidade, que permitam evidenciar um pouco melhor o sentido do Direito Originário ${ }^{227}$. Pois, afinal, o fenômeno jurídico-normativo positivo a ser analisado é precisamente o Direito Originário da CECA.

A partir desse movimento reflexivo preliminar, mostrou-se possível delimitar com precisão o objeto jurídico-normativo positivo deste trabalho. Situado no interior de preocupações de uma Pesquisa em Direito, este estudo produzirá seu conhecimento a partir

\footnotetext{
226 Tendência normativamente mantida.

${ }^{227}$ O recurso pontual a normas de Direito Derivado será em função da pretensão de compreender melhor o Direito Comunitário Originário, e não o Direito Comunitário Derivado em si mesmo.
} 
da conjunção de aparato conceitual também com elementos da experiência normativa dada pelo Direito Originário da CECA, da maneira como ele se mostrara quando fora assinado em Paris, em 1951.

Apontado com precisão, nos termos da tradição de Direito Comunitário, quais as instituições jurídico-normativas positivadas a serem examinadas pelo presente trabalho, resta delimitar o modo como o percurso analítico será desenvolvido. Restando por enquanto claro e evidente que, conforme uma preocupação típica de uma Pesquisa em Direito, serão o Tratado da CECA e seus Protocolos e Anexos o ponto de partida do discurso jurídico deste trabalho, não se mostrou ainda de maneira precisa o modo como se aproximará desta experiência expressa em um texto jurídico-normativo positivo.

Não é suficiente afirmar pura e simplesmente que será efetuada uma análise institucional de tais normas jurídicas positivadas. Há diferentes maneiras de guiar metodologicamente o desenvolvimento de uma leitura do texto do Tratado da CECA ainda que todas elas sejam possibilidades de leitura que, por serem jurídicas, tenham em comum a preocupação em revelar aspectos sensíveis ao conhecimento jurídico.

Trata-se aqui de buscar efetuar mais uma precisão de escolha metodológica, na medida em que o desenho do arco do conhecimento jurídico a ser efetuado por este estudo - como em qualquer estudo - deriva de opções concernentes a pontos de partida conceituais norteadores da atividade de interpretação.

Mais uma vez entram em choque aqui as oposições sobre diferentes concepções de mundo, explicitando-se ainda uma vez a origem profana do conhecimento jurídico. Afinal, a maneira de interpretar um fenômeno se revela também como uma forma de oposição de discursos e de modos de habitar o mundo - isto é, trata-se igualmente de uma atividade Política (LEFORT, 1986, p. 306-9) ${ }^{228}$ de encontro e embate ininterrupto de multiplicidade de dimensões explicativas de um e mesmo fenômeno.

\footnotetext{
Car la littérature ne décrit pas seulement le réel. Elle l'interroge. Et, s'il est vrai que le réel n'est pas une fois pour toutes constitué, mais qu'il se fait, cette interrogation est une action. Une action qui décide, à chaque fois, de la puissance ou de l'impuissance. Quand elle nous présente son vrai visage, la littérature n'est plus une expression : elle est l'homme même. (LEFORT, 2007a, p. 126).
}

O próximo item se dedicará a explicitar alguns dos termos conceituais de orientação da leitura da História da CECA e das instituições jurídico-normativas

228 O caráter de "Político", sucintamente mencionado na nota de rodapé 105, supra, será mais bem explicitado no item 3.4., infra, onde são apresentados os elementos fundamentais da chave hermenêutica adotada por este trabalho. 
positivadas no Tratado Constitutivo da Comunidade. Isso permitirá esclarecer o caminho a ser percorrido pelo arco de conhecimento jurídico proposto por esta Tese de Doutorado. $\mathrm{O}$ campo é composto mais uma vez de escolhas e de renúncias conscientes, as quais caracterizam todo e qualquer conhecimento científico (WEBER, 2006, p. 16 e 18-9).

[L]'écrivain signifie qu'il abandonne la position d'un observateur absolu et qu'il se situe au cœur du monde, comme un homme parmi les hommes plutôt spectateur ou lecteur du réel, que créateur. (LEFORT, 2007a, p. 125).

Tratam-se de escolhas originadas da condição subjetiva do investigador, as quais não deslegitimam ou reduzem qualquer objetividade do conhecimento produzido. Por essa razão, estas não devem ser lamentadas ou repudiadas, mas entendidas em seus próprios termos - tendo sido coerente e rigorosamente fundamentadas, poderão produzir conhecimento certo e seguro (científico) (ALVES, 2003, p. 298-9; CASELLA, 2009a, p. 174; REALE, 2001, p. 10 e 82; WEBER, 2006, p. 24) $)^{229}$.

É a partir dos elementos a seguir que serão questionados a História da CECA e seu respectivo arcabouço institucional, constante de seu Direito Originário, da maneira como ele se apresentou imediatamente após sua assinatura.

\subsection{A Inter-relação Necessária entre Dogmática e Zetética Jurídicas}

O jurista, em geral, ocupa-se complementarmente d[as Disciplinas da zetética jurídica]. Elas são tidas como auxiliares da ciência jurídica stricto sensu. Esta última, nos últimos 150 anos, tem-se configurado como um saber dogmático. É óbvio que o estudo do direito pelo jurista não se reduz a esse saber. Assim, embora ele seja um especialista em questões dogmáticas, é também, em certa medida, um especialista nas zetéticas. (FERRAZ JR., 2001. p. 47, grifos do autor).

Se hoje os cientistas não têm mais necessidade nenhuma dos filósofos, nem sobretudo, de se fazer filósofos, é na medida em que seus métodos estão em ordem, seus conceitos são universalmente admitidos e as querelas científicas rareiam. Que apareçam contradições (crise na teoria dos conjuntos, em matemática, no começo do século), que nasçam controvérsias (problemas da hereditariedade do adquirido, em biologia), e bem depressa o cientista volta a tornar-se filósofo. (LEBRUN, 1993, p. 25).

Até o presente momento, este trabalho indicou pretender examinar o fenômeno jurídico-político da CECA, tendo como ponto de partida a História e o documento jurídico-normativo positivado desta Organização Internacional - o Tratado de Paris, de

\footnotetext{
${ }^{229}$ Remetemos o leitor, nesse sentido, mais uma vez à Introdução Parcial desta Parte Primeira, supra.
} 
1951, que instituiu originariamente a CECA. No entanto, o presente estudo deve ainda buscar se fazer compreender especificamente pelo leitor, pois o uso do termo "fenômeno" neste trabalho não é ingênuo, nem descompromissado.

Com efeito, é importante notar que a noção de fenômeno à qual se recorre neste estudo possui um significado bastante particular - o que deve ser adequadamente precisado perante o público leitor, a fim de evitar mal-entendidos. Inclusive, há que se notar que, precisamente em virtude de se tomar a CECA, sua História e seu Direito Originário como fenômenos $^{230}$, é que se autoriza o desenvolvimento de uma pluralidade infindável de leituras em torno da construção histórica da fundação jurídica da $\mathrm{CECA}^{231}$.

Não se usa neste texto de forma leviana e livre a noção de fenômeno. Retirada da Fenomenolodia de Edmund HUSSERL, ela é um dos elementos fundantes da matriz metalinguística informadora do discurso que estrutura o presente estudo ${ }^{232}$. Não apenas se

${ }^{230}$ Posteriormente precisados como fenômenos jurídico-políticos; neste sentido, v. as considerações a seguir,
neste mesmo item.
${ }^{231}$ Dentre as quais esta se revela como sendo uma a mais, nem a melhor, nem a pior, mas simplesmente uma
compreensão adicional.
${ }^{232}$ É importante notar que a introdução da Fenomenologia nos estudos e na Pesquisa em Direito no Brasil
não é uma inventividade exclusiva deste estudo; no Brasil, há ao menos desde 2008 , um periódico acadêmico
especializado nesta discussão- a Revista Fenomenologia e Direito, publicação da Escola da Magistratura
Regional Federal da Segunda Região.
Note-se que apesar de este trabalho incorporar o pensamento Fenomenológico no conhecimento
jurídico, não se pretende fazer referência às reflexões manifestadas nos vários volumes deste periódico
brasileiro. De fato, não se pretende (i) reconstituir a História da recepção da Fenomenologia no pensamento
jurídico brasileiro, (ii) avaliar a maneira como o pensamento de Edmund HUSSERL - o criador da
Fenomenologia, tal qual utilizada neste trabalho - fora ou não adequadamente recepcionado pela
Fenomenologia do Direito no Brasil, e, muito menos, se preocupa em (iii) reconstruir a integralidade de todo
o pensamento fenomenológico de Edmund HUSSERL, para o compreender holisticamente em suas
modificações no tempo.
Com efeito, lembre-se de que este trabalho consiste em uma Pesquisa em Direito, não se
preocupando em efetuar uma investigação estrutural e genealógica do pensamento da Fenomenologia (sobre
leitura estrutural, v. considerações no item 3.3.1., infra) em Edmund HUSSERL, apesar de ser um tema leitura estrut

A título exemplificativo, indicamos a leitura (i) do texto de Jean-Paul SARTRE (2005) sobre a intencionalidade - mencionado rapidamente nas linhas a seguir, (ii) de edição inteira do periódico Philosophiques, 2009, dedicada integralmente ao pensamento fenomenológico de Edmund HUSSERL, em comemoração aos 150 (cento e cinquenta) anos do nascimento deste filósofo, e (iii) de Barry SMITH; David Woodruff SMITH (Ed.).The Cambridge Companion to Husserl (1999).

No Brasil, além dos números da supramencionada Revista Fenomenologia e Direito, mencionemse, também a título meramente exemplificativo, (i) os escritos mais especializados de Carlos Alberto Ribeiro de MOURA (2006a, 2006b), e também (ii) dois artigos constantes do periódico Kriterion, 1986, (a) um sobre a evolução do pensamento de Edmund HUSSERL acerca do conceito de redução, de autoria de Lívia Mara GUIMARÃES, e (b) outro sobre a relação entre Fenomenologia Transcendental e Hermenêutica, de Theresa Calvet de MAGALHÃES.

Perceba-se que este trabalho pretende usar de maneira veementemente muito mais modesta, singela e geral as contribuições filosóficas de Edmund HUSSERL. Não há qualquer preocupação em problematizar os conceitos principais do autor e a evolução deles no tempo, como faz a literatura especializada. Do contrário, este trabalho fugiria de seu recorte metodológico preciso e exploraria temática a ele não afeita. Todavia, registramos aqui o convite para futuras investigações conjuntas sobre o tema, dado nosso grande interesse pela matéria. 
pretende utilizar o termo fenômeno para designar a CECA, sua construção histórica e seu

Direito Originário, mas fundamentalmente para sinalizar a inesgotabilidade de discursos possíveis sobre eles ${ }^{233}$. Quando se refere à ideia de fenômeno, há que se notar que

[t]ambém outras ciências há muito conhecidas se voltam para fenômenos. É assim que ouvimos a psicologia ser designada como uma ciência das "manifestações" ou fenômenos psíquicos, a ciência da natureza como ciência das "manifestações" ou fenômenos físicos; da mesma maneira, na história por vezes se fala de fenômenos históricos e, na ciência que estuda as civilizações, de fenômenos da civilização [...]. (HUSSERL, 2006, p. 25).

\subsubsection{Noções Fundamentais da Fenomenologia de Edmund HUSSERL}

A noção de fenômeno utilizada pela Fenomenologia detém uma significação particular. O fenômeno é o produto da redução fenomenológica, isto é, do movimento

Por essa razão, são aqui apontados e desenvolvidos pontos fundamentais do pensamento deste autor, nos estritos limites necessários para elucidar expressões utilizadas neste trabalho e para esclarecer as pressuposições que orientam meta-linguisticamente o presente texto. São estes momentos fundamentais, basilares do pensamento fenomenológico husserlianos, que interessam ao presente estudo, e não a complexa teia significativa produzida por Edmund HUSSERL, nem sua modificação no tempo.

Isso permitirá se fazer melhor compreender pelo público leitor desta Tese de Doutorado com relação a (i) determinados pontos de partida (infinitas possibilidades de leituras igual e validamente possíveis de um mesmo fenômeno); (ii) opções metodológicas (admissibilidade de escolher determinada perspectiva de leitura em detrimento de outras); (iii) especificações terminológicas (a preferência pelo uso do termo fenômeno para designar o objeto de atenção privilegiada deste estudo); ou (iv) posições discursivas específicas sobre questões jurídicas tradicionais acerca da integração na Europa do pós-Segunda Guerra Mundial (exemplificativamente, a postura ao final do item 3.3.2., infra, em que se discute brevemente o tema da natureza jurídica da CECA).

Frise-se que não se trata aqui de utilizar em sua integralidade supostamente coerente e pacífica a Fenomenologia, tal qual desenvolvida por Edmund HUSSERL. Essa pretensão parece ter sido já iniciada com mais propriedade na Ciência Jurídica brasileira por periódico especializado. Menos ambiciosas são as pretensões deste estudo, visto que apenas visa a percorrer determinados conceitos-chave do pensamento husserliano (redução fenomenológica, fenômeno, intencionalidade) e demais correlacionados (tais como orientação natural e orientação fenomenológica) que informam estruturalmente parcela do campo significativo construído meta-linguisticamente para o presente estudo.

Tais noções fundamentais da Fenomenologia apenas doaram sentido e roupagem linguística para parcela das reflexões sobre o tema escolhido, permitindo sobre ele falar com um determinado vocabulário. As linhas que seguem buscam apenas e tão somente explicitar os termos segundo os quais a ideia de Fenomenologia é apropriada parcialmente neste trabalho.

Por fim, note-se que a apropriação seletiva/parcial é recurso já efetuado anteriormente neste texto, como se pode perceber quando da discussão, no item anterior, em torno das significações possíveis da expressão alemã Verrechtlichung. A ressignificação de termos de outros autores é procedimento disseminado e aceito de maneira generalizada nos estudos que pretendem fazer avançar o conhecimento para além dos limites estabelecidos pelo quadro pintado por autores da tradição - ainda que tenham este como ponto de partida de sua reflexão. Sobre o tema da admissibilidade de apropriações conceituais parciais ressignificativas para a construção de conhecimento novo, v. o item 3.3.1., infra.

${ }^{233} \mathrm{E}$, como será visto adiante, é no interior dessa pluralidade de leituras que se revela a importância de assumir uma posição com relação à distinção entre um modo Dogmático e um modo Zetético de desenvolver o conhecimento jurídico. Situar-se em um ou em outro define o modo como o fenômeno jurídico poderá ser lido. 
intelectual que efetua a passagem da orientação natural para a orientação fenomenológica. São necessários maiores esclarecimentos ${ }^{234}$.

Para Edmund HUSSERL (2006, p. 33 e 84), a orientação natural é o modo de conhecimento que principia pela experiência e que nela permanece, tendo por horizonte investigativo apenas o mundo natural. A relação entre os elementos que compõem este mundo são pautadas por relações de causalidade. Sobre eles, formulam-se afirmações que possam ser verdadeiras sobre tais "seres no mundo". (HUSSERL, 2006, p. $33)$.

Em outras palavras, na orientação natural, as coisas corpóreas se apresentam à disposição no espaço para serem percebidas, de tal modo que a consciência se reporta às coisas como "objetos puros e simples" - isto é, desprovidas de quaisquer influências derivadas da presença de uma subjetividade (MOURA, 2006a, p. 16). Formulações desenvolvidas conforme orientação natural pretendem ser desprovidas de toda e qualquer teoria, ou ainda, de influência de todo e qualquer preconcebimento conceitual (HUSSERL, 2006, p. 77 e 117).

\begin{abstract}
A orientação natural é aquela em que nos situamos espontaneamente na nossa vida cotidiana, quando nos dirigimos às coisas para manipulá-las. Ela é também a orientação em que se situa o cientista, quando este se dirige às coisas ou ao mundo para conhecê-los, discernindo suas propriedades e relações "objetivas". (MOURA, 2006a, p. 16).
\end{abstract}

A partir do momento em que se preocupa em desenvolver uma reflexão conceitual sobre fenômenos, a orientação natural deve ser deixada de lado.

Isso não significa a exclusão absoluta dessa forma de posicionar a consciência com relação a aquilo que seria objeto de suas descrições. Antes, seria apenas e tão-somente um deixar fora de ação esse modo de aproximação; nos termos de Edmund HUSSERL (2006, p. 79, grifos do autor), trata-se de uma forma de a "colocar entre parênteses", a fim de que a consciência se dirija segundo "um determinado modo específico de consciência, que vem se juntar à simples tese originária [da orientação natural]”.

Não se trata de um abandono da orientação natural, mas de uma modificação do modo de orientar a consciência. Não se deixa de admitir a existência de uma forma natural de guiar $^{235}$ a consciência: apenas se efetua uma mudança radical do modo como a

\footnotetext{
${ }^{234}$ Ressaltando-se desde já que a orientação natural se distingue da orientação fenomenológica em virtude de se tratarem de "direções de pesquisa radicalmente distintas, comandadas por tópicas muito diferentes, que nem se dirigem ao mesmo sentido da palavra 'objeto"”. (MOURA, 2006a, p. 16).

${ }^{235}$ Inclusive topicamente.
} 
consciência deverá se posicionar perante aquilo que quer conhecer (HUSSERL, 2006, p. 78-9) ${ }^{236}$ por meio da redução destes para a condição de fenômenos.

Este método de parentetização indicado por Edmund HUSSERL é a própria redução fenomenológica, segundo a qual se deixa de lado a orientação natural para assumir a orientação fenomenológica, em que tudo aquilo abrangido pela orientação natural é igualmente mantido à distância. Deste modo, resta-se impedido de produzir afirmações sobre objetos supostamente "puros e simples" (MOURA, 2006a, p. 17, grifos nossos), ou ainda, sobre algo que "está 'para nós aî', 'a nosso dispor', e que continuará sempre aí como 'efetividade' para a consciência” (HUSSERL, 2006a, p. 81).

\begin{abstract}
$\mathrm{Na}$ orientação fenomenológica [...] o interesse não se dirige às "coisas" mas sim aos "fenômenos" [...]. É apenas quando nos situamos nessa orientação que operamos a "redução fenomenológica", quer dizer, a transição da investigação das "coisas" para a consideração dos seus "fenômenos". (MOURA, 2006a, p. $16)$.
\end{abstract}

Ao se efetuar a referida redução fenomenológica, a consciência passa a considerar assim um novo campo de investigação. Trata-se de novo âmbito, localizado fora daquele sobre o qual se debruça a orientação natural - razão pela qual o campo da redução fenomenológica é desconhecido por uma orientação natural. Não há mais vividos vinculados entre si por meio de nexos causais, mas os correlatos da consciência, os quais são apreendidos como estabelecendo entre si relações intencionais ${ }^{237}$.

A parentetização entreabre o campo da Fenomenologia e revela que a realidade que outrora era concebida como independente da consciência perde tal condição. Na verdade, ela passa a manter uma relação de dependência com a consciência, não sendo nada diverso do que uma simples forma de aparecer à consciência.

A realidade deixa de ser assim um absoluto em si, uma coisa em si mesma integralmente conhecível ${ }^{238}$, e passa a ser um nada, ou ainda, apenas algo enquanto representado, o fruto de um ato intencional (HUSSERL, 2006, p. 116-7). Não há um "ser em si" a ser desvendado, um segredo gravado em uma suposta natureza essencial

\footnotetext{
${ }^{236}$ Lembre-se nesse sentido de que a filosofia de Edmund HUSSERL é uma filosofia de dupla orientação, pois a orientação natural e a fenomenológica são "compromissos que nunca devem ser confundidos", mas que permanecem coexistindo: "não nego este 'mundo', como se eu fosse sofista, não duvido de sua existência, como se fosse cético" (HUSSERL, 2006, p. 81, grifos do autor). Afinal, “[a] fenomenologia é apenas um dos lados de nosso universo intelectual, que não suprime o outro, aquele que se desdobra na direção 'natural'." (MOURA, 2006a, p. 16).

${ }^{237}$ Sobre a noção de intencionalidade em Edmund HUSSERL, v. as linhas a seguir. Por enquanto, ainda são necessárias algumas elucidações pontuais sobre o campo de deslizamento da orientação fenomenológica para que seja bem compreendido o papel das intencionalidades nele.

${ }^{238}$ Como se efetua tipicamente na orientação natural.
} 
imutável das coisas cuja inscrição deva ser decifrada. Ou ainda, "em regime de redução fenomenológica é o próprio mundo que se torna subjetivo. E enquanto tal esse mundo pertence à região da consciência." (MOURA, 2006a, p. 22, grifos do autor).

\footnotetext{
É assim que se inverte o sentido comum do discurso sobre o ser. O ser que para nós é o primeiro, é [em orientação fenomenológica] em si o segundo, ou seja, ele é o que é somente em "referência" ao primeiro [à consciência]. (HUSSERL, 2006, p. 116-7).
}

Com a redução fenomenológica e o consequente ingresso da consciência na orientação fenomenológica, as coisas não mais surgem como realidades aptas a serem conhecidas exaustiva e integralmente pela consciência. Elas perdem esse caráter absoluto $^{239}$ e têm seus sentidos determinados, não mais a por de si mesmas, mas a partir da consciência ${ }^{240}$.

As condições de possibilidade de conhecimento das coisas, bem como as próprias significações depreensíveis delas, são determinadas pela consciência que as examina, nos limites cognitivos detidos por essa consciência. No interior de uma reflexão fenomenológica, as coisas não mais se apresentam como algo à espera de uma dissecação supostamente integral que as compreenda por busca e apreensão possessiva. Antes, o sentido passa a ser algo que depende da consciência e das limitações desta para ser revelado (ou melhor, atribuído) (MOURA, 2006a, p. 22).

Não é mais a consciência que depende da realidade, mas exatamente o contrário. A realidade existe como dependente da consciência e do sentido que esta pode e quer àquela atribuir - é a consciência quem o constitui, é ela um centro doador de sentido à realidade. Mais simplesmente, é a realidade um mero ser intencional ${ }^{241}$, um singelo ser para a consciência - e nada além disso (HUSSERL, 2006, p. 116-7 e 128).

\footnotetext{
${ }^{239}$ Tal qual supunham e pressupunham a orientação natural e suas respectivas teses colocadas fora de circuito (HUSSERL, 2006, p. 130).

${ }^{240}$ Nesse sentido, simbolicamente provocativo é o comentário de Jean-Paul SARTRE (2006, p. 55, grifos nossos) sobre a alteração dos sentidos da relação de conhecimento em virtude dessa nova perspectiva: "acreditávamos que o Espírito-Aranha atraía as coisas para sua teia, cobria-as com uma baba branca e lentamente as deglutia, reduzindo-as à sua própria substância. O que é uma mesa, um rochedo, uma casa? Um certo composto de 'conteúdos de consciência', uma ordem desses conteúdos, Ó filosofia alimentar! [...] Nutrição, assimilação. Assimilação, dizia Lalande, das coisas às idéias, das idéias entre elas e dos espíritos entre eles. As poderosas arestas do mundo eram aparadas por essas diligentes diástases: assimilação, unificação, identificação. Os mais simples e os mais rudes dentre nós procuravam por algo de sólido, qualquer coisa, enfim, que não fosse o espírito. Em vão. Por toda parte encontravam tão-somente uma névoa baça e distinta: eles mesmos.".

${ }^{241}$ Como afirmado anteriormente, sobre a noção de intencionalidade, v. especificações mais adiante.
} 
Há com isso uma modificação de sentido, pois aquilo que é conhecido pela consciência fenomenologicamente orientada é distinto daquilo que busca a consciência naturalmente orientada. Com essa mudança de olhar, por exemplo,

\begin{abstract}
[a] árvore pura e simples, a coisa na natureza, é tudo menos esse percebido de árvore como tal, que, como sentido perceptivo, pertence inseparavelmente à percepção. A árvore pura e simples pode pegar fogo, pode ser dissolvida em seus elementos químicos etc. Mas o sentido - o sentido desta percepção, que é algo necessariamente inerente à essência dela - não pode pegar fogo, não possui elementos químicos, nem forças, nem qualidades reais. (HUSSERL, 2006, p. 206, grifos do autor).
\end{abstract}

Diante da redução fenomenológica, a realidade passa a deter a condição de unidade receptora de sentido ${ }^{242}$, ao passo que a consciência desempenha a função de centro doador de sentido ${ }^{243}$. Deste modo, o sentido da realidade deriva especificamente de uma determinada maneira que a consciência se posiciona com relação a ela e lhe atribui um sentido conforme essa maneira - e não de acordo com outra maneira (HUSSERL, 2006, p. 128-9). Cria-se uma profunda relação de dependência necessária da realidade com relação à consciência, pois desta depende para deter (ou melhor, receber) algum sentido que a anime.

Opera-se assim o nexo fundamental, segundo o qual a consciência é sempre consciência de alguma coisa, enquanto esta coisa é sempre algo para uma consciência (HUSSERL, 2006, p. 220). E este ter consciência de algo, ou ser algo para uma consciência, ocorre sempre de determinado modo específico, vale dizer, de um modo tal (HUSSERL, 2006, p. 204-5). Afinal, "toda consciência é consciência de algo, e os modos de consciência são bastante distintos" (HUSSERL, 2006, p. 220), pois dependem de como o algo é trazido à consciência ${ }^{244}$.

Como consequência dessa dependência das coisas com relação à consciência, opera-se o estilhaçamento da possibilidade de se dizer que haveria uma essência sólida das coisas a serem conhecidas. Não haveria uma essência permanente a ser descoberta e explorada nos mínimos detalhes pela consciência. As coisas não teriam

\footnotetext{
${ }^{242}$ Unidade de recepção de sentido dado pela consciência.

${ }^{243}$ Centro de atribuição de sentido à realidade.

${ }^{244}$ Ficará claro mais adiante que a determinação dessa distinção depende da intenção que parte da consciência. Isso exige a especificação da noção de intencionalidade, o que será feito poucas linhas a seguir. Ainda aqui se preocupa com a simples extração das consequências da redução fenomenológica, a fim de mostrar de que modo surgem os fenômenos e suas características. Neste percurso surgirá espontaneamente na narrativa a seguir a importância de se tratar brevemente sobre a intencionalidade.

Não há porque haver uma pressa atribulada para explicar confusa e atropeladamente as noções fundamentais da Fenomenologia de Edmund HUSSERL: isso apenas prejudicaria a adequada compreensão destas e da maneira segundo a qual foram incorporadas pelo presente texto.
} 
seu sentido dado por elas mesmas, mas pela consciência. Elas "se 'constituem' graças aos atos da consciência, [a qual] não precisa da realidade para existir[... ;] a realidade, ao contrário, 'depende’ da consciência.” (MOURA, 2006a, p. 15).

Não haveria que se supor com isso a pré-existência de uma suposta essência absoluta detida em si pelas coisas elas mesmas. Tal suposta essência seria dada relativamente, pois derivada de uma maneira de aproximação da consciência de determinada coisa a ser conhecida. O ser em si essencial, absoluto, segredo íntimo, não existiria: o sentido seria dado pela consciência, e a coisa restaria simplesmente como uma unidade passível de recepção de sentidos (HUSSERL, 2006, p. 117 e 128-9) ${ }^{245}$.

Não se poderia afirmar existir uma essência única, una e identitária das e nas coisas a ser cabalmente encontrada, decifrada e discursivamente descrita. Seu sentido seria fixado por um modo de aproximação ${ }^{246}$ da própria consciência, dentre inúmeros outros possíveis. Enquanto $\mathrm{X}$ único detentor e portador de sentido absoluto e permanente, a essência seria um espaço vazio e de inesgotáveis possibilidades de preenchimento (HUSSERL, 2006, p. 290-3). Não existiria uma essência como chave secreta de explicação integral da coisa e de sua produção: pois não haveria uma "coisa ela mesma", um ser perene, permanente, coisa em si acessível.

É neste momento que se deve perceber a importância do surgimento da ideia de fenômeno para o pensamento fenomenológico. As coisas sobre as quais a consciência se desliza para conhecer não seriam coisas em si a serem dissecadas. Elas seriam, antes, fenômenos, vale dizer, os modos segundo os quais o real se torna consciente (HUSSERL, 2006, p. 290) ou ainda, mais simplesmente, os modos subjetivos de doação da coisa à consciência (MOURA, 2006a, p. 16 e 21) 247. $^{247}$

Em regime de redução fenomenológica, passa-se assim a conhecer não mais coisas em si, mas fenômenos. Os sentidos destes não restariam escondidos em um núcleo

${ }^{245}$ É ao menos imageticamente interessante recorrer aqui mais uma vez a uma provocante afirmação de JeanPaul SARTRE (2006, p. 56) sobre esta temática: "A consciência e o mundo são dados de uma só vez: por essência exterior à consciência, o mundo é, por essência, relativo a ela. É que Husserl vê na consciência um fato irredutível, que nenhuma imagem física pode exprimir. A não ser, talvez, a imagem rápida e obscura da explosão. Conhecer é 'explodir em direção a', desvencilhar-se da úmida intimidade gástrica para fugir, ao longe, para além de si, em direção ao que não é si mesmo, para perto da árvore e no entanto fora dela, pois ela me escapa e me rechaça [...].”.

${ }^{246}$ Dentre tanto outros possíveis.

${ }^{247}$ Aparentemente problemático o uso do termo "subjetivo". Ele restará mais claro ao leitor à medida que se seguir a leitura do presente texto; todavia, note-se que qualificar o modo de doação como subjetivo não implica em reconhecer que se trata de algo pessoal ou carente de certeza. Antes, trata-se de uma maneira de dizer que por um fenômeno estar sempre vinculado a uma consciência, ele está vinculado a um determinado ponto de vista assumido por uma consciência (MOURA, 2006a, p. 21), isto é, à decisão posicional de um sujeito que pretende conhecer com relação a aquilo que almeja conhecer. De todo modo, essa noção restará mais clara no encadeamento lógico que se segue. 
secreto interior, pois derivariam da maneira como a consciência sobre eles se dirige. A ausência de uma essência interior e última das coisas não impediria que se pudesse construir um conhecimento sobre elas: isso seria possível a partir da consciência ela mesma. Ou melhor, das intencionalidades que dela partem.

A noção de intencionalidade é fundamental para compreender como o círculo reflexivo fenomenológico se revela coerente (HUSSERL, 2006, p. 192). O sentido das coisas seria dado a partir das intencionalidades projetadas da consciência sobre aquilo que se procura conhecer ${ }^{248}$. A intencionalidade seria o produto de determinada posição assumida pela consciência com relação à coisa - uma posição escolhida dentre tantas outras possíveis, cada qual apta a gerar um fenômeno distinto sobre uma e mesma coisa.

Perceba-se que a intencionalidade deve ser entendida como um mero deslocamento da consciência sobre um objeto (LEOPOLDO E SILVA, 2006), ou ainda, um singelo deslizar intelectual sobre a coisa traçado pela consciência. Este simples movimento da consciência indicaria a maneira segundo a qual se volta a atenção sobre aquilo a ser conhecido. Trata-se de uma sinalização da maneira segundo a qual algo é tomado pela consciência e tornado consciente $^{249}$ (HUSSERL, 2006, p. 190 e 192-3), isto é, do modo como se descobre o mundo e a ele se atribui sentido.

\footnotetext{
[P]ara Husserl e os fenomenólogos a consciência que tomamos das coisas não se limita em absoluto ao conhecimento delas. O conhecimento ou pura "representação" é apenas uma das formas possíveis da minha consciência "de" tal árvore: posso também amá-la, temê-la, detestá-la, e essa superação da consciência por si mesma, que chamamos de "intencionalidade", reaparece no temor, no ódio e no amor. Detestar outrem é ainda uma maneira de explodir em direção a ele; é encontrar-se subitamente diante de um estranho cuja qualidade objetiva de "odiável" vivemos e sofremos antes de tudo. [...Essas] reações "subjetivas" - ódio, amor, temos, simpatia - [...] são apenas maneiras de descobrir o mundo. (SARTRE, 2005, p. 57, grifos nossos).
}

A intencionalidade é noção efetivamente vaga e imprecisa. Ela se performa na enunciação de sua própria ideia ela mesma ${ }^{250}$ e que se apresenta de maneira diversificada em termos formais, pois sempre se visa de diferentes maneiras a mesma coisa, ou seja,

\footnotetext{
248 A partir da atitude posicional assumida pela consciência, segundo a qual esta se aproximaria da coisa.

${ }^{249}$ Sempre de determinado modo especial, ou ainda, sempre de acordo com um ponto de vista particular. (HUSSERL 2006, p. 193).

${ }^{250}$ Julgar é julgar algo, recordar é recordar algo, etc. São posturas distintas da consciência com relação ao objeto, posturas que o trazem à consciência de determinada forma, conforme uma específica posição (HUSSERL, 2006, p. 291). Aparente laconismo que explicaria a dificuldade de compreender tal noção em um primeiro momento (HUSSERL, 2006, p. 192).
} 
sempre se a anima com sentidos distintos dados por diferentes modos de aproximação (HUSSERL, 2006, p. 192-4 e 206-7) ${ }^{251}$.

Consideram-se na consciência não coisas em si, mas fenômenos. Estes não se desdobram internamente à completa e exaustiva compreensão por parte daquele que os pretende conhecer, vale dizer, nunca se entregam completamente à consciência para ter esgotado o conhecimento de suas significações. Na verdade, são ilimitadas as formas de se aproximar dos fenômenos, pois inúmeras são as posições que podem ser assumidas com relação a eles. Jamais se esgotam as multiplicidades de perspectivas que se pode ter com relação ao fenômeno - implicando a infindável possibilidade de leituras sobre o mesmo (HUSSERL, 2006, p. 116).

[E]m nossa linguagem, as expressões "o vencedor de Iena" e "o vencido de
Waterloo" são distintos "modos de doação", distintas "significações" que
descrevem um mesmo personagem a partir de diferentes pontos de vista. [...]
Esse objeto sempre é exprimido em nossa linguagem em um modo determinado,
e nós só podemos nos referir a determinada pessoa como sendo ou "o vencedor
de Iena", ou "o vencido de Waterloo", ou através de qualquer outra significação
por princípio unilateral e variável. E se o nome próprio [...] parece [...] que nos
daria a "coisa mesma", isso não passa de uma ilusão infantil: "Napoleão"
designa apenas a equivalência das múltiplas e indefinidas significações que o
descrevem, seja como "o vencedor de Iena", seja como "o vencido de Waterloo",
seja como o "prisioneiro da Córsega." (MOURA, 2006a, p. 21, grifos do autor).

Assim, quando se efetua a redução fenomenológica, surgem os fenômenos. As coisas são trazidas deste modo sempre parcialmente à consciência, segundo a maneira pela

${ }^{251}$ Edmund HUSSERL desenvolve uma distinção de intencionalidades entre os atos intencionais intuitivos e atos intencionais significativos, uma diferenciação já enunciada em 1900 em suas Investigações Lógicas (1980). A diferença entre ambas deriva das propriedades de preenchimento. A intenção significativa preencheria um sentido por meio de dessemelhança, ao passo que a intenção intuitiva efetuaria o preenchimento por meio de semelhança.

Isso quer dizer que a significação não exigiria uma correspondência ao mundo sensível ao qual se refere, implicando uma ausência de conexão interna necessária entre matéria e representante-apreendido, ao passo que a intuição exigiria uma relação de correspondência ao mundo sensível ao qual se refere, implicando uma necessária conexão interna entre a matéria e o representante-apreendido (HUSSERL, 1980, p. 44-9 e 71-3). Nas palavras do próprio autor: "A significação não pode, por assim dizer, flutuar nos ares, mas o signo, do qual dizemos que ela é a significação, é totalmente indiferente àquilo que ela significa. [...] Só pode servir de representante-apreendido intuitivo de um objeto aquele conteúdo que lhe é semelhante ou igual." (HUSSERL, 1980, p. 72).

Essa distinção entre intenção intuitiva e intenção significativa é relevante para o pensamento fenomenológico, mas escapa aos interesses deste trabalho. Apesar de este par de conceitos ter sido sumariamente esclarecido nas linhas acima, não serão aduzidas considerações adicionais sobre os mesmos, nem mesmo haverá uma preocupação em os utilizar na explicitação dos principais conceitos de Fenomenologia utilizados por este trabalho - afinal, apenas se apropria parcialmente desse ramo do conhecimento humano nos estritos limites necessários para fornecer a este trabalho um mínimo de Linguagem para poder falar sobre seu tema.

Assim, diante da desnecessidade do recurso a essa distinção - que não poderia ao menos deixar de ser mencionada rapidamente, por se referir à Fenomenologia - para um trabalho de Pesquisa em Direito, encerra-se aqui a exposição diferenciadora entre significações e intuições. 
qual esta se dirige intelectualmente sobre elas. Os seres se revelam assim em perfis, isto é, jamais de forma absoluta, mas de maneira contingente, relativa (HUSSERL, 2006, p. 116), evidenciando-se sempre um conhecimento em partes sobre os mesmos.

Não há dessa forma um sentido único possível, mas vários, vale dizer, há uma multiplicidade inesgotável e verdadeiramente infinita de maneiras de se efetuar a aproximação intelectual com relação a algo que se busca conhecer (HUSSERL 2006, p. 203).

A apresentação dos fenômenos por perfis deve ser entendida precisamente desta maneira: a consciência busca sempre fazer ressaltar no fenômeno aspectos (ora uns, ora outros) sobre os quais se interessa especificamente, jamais o evidenciando inteiramente (HUSSERL, 2006, p. 212-3). A intencionalidade apenas opera como se fosse uma luz projetada sobre um objeto:

\footnotetext{
[a]quilo que se nota, no sentido específico, encontra-se num cone de luz mais ou menos iluminado, mas ele também pode recuar para a penumbra ou para a escuridão total. Mesmo que essa imagem seja insuficiente para marcar distintivamente todos os modos a ser fenomenologicamente fixados, ela é, no entanto, bastante significativa para indicar alterações naquilo que aparece enquanto tal. A oscilação da luminosidade não altera aquilo que aparece em sua própria composição de sentido, mas clareza e obscuridade modificam os seus modos de aparecer, elas já se encontram na orientação do olhar para o objeto [...] e devem ser descritas. (HUSSERL, 2006, p. 212).
}

Ainda que altere sua posição para buscar conhecer a partir de outros pontos de vista distintos, será a consciência sempre parcial e incompleta. Afinal, é impossível ocupar todas as posições possíveis em torno de um e mesmo fenômeno ao mesmo tempo, sempre restando uma dimensão não-dada, a partir de uma dimensão dada, um resquício de nãopercebido, diante de elementos percebidos. Aquilo que é sentido e dito sempre pressupõe um não-sentido e um não-dito.

A consciência de algo se opera dessa forma sempre "por um dos lados", ou ainda, se torna consciente de algo conforme modos particulares, dependendo sempre de desvios e de direcionamentos distintos de olhares. Mais simplesmente, depende da maneira e do ponto a partir do qual se fixa o raio de atenção sobre algo, os quais repartem as atenções e os modos delas com relação a uma e mesma coisa (HUSSERL, 2006, p. 209 e 211-2).

Assim, um e mesmo fenômeno detém inafastável e necessariamente em torno de si uma multiplicidade de modos de ser abordado, cada um deles passível de descrições distintas. Jamais se exaurem as leituras de um fenômeno: a cada instante ele tem privilegiado nele um ou outro aspecto, 
ora este, ora aquele momento objetivo, neste ou naquele caso de comparação, ou em que uma só e mesma coisa é, ora "notada primariamente", ora apenas secundariamente, ou apenas "há pouco notada concomitantemente", quando não "inteiramente não-notada”, embora continue sempre a aparecer. Há justamente diferentes modos especiais da atenção como tal. (HUSSERL, 2006, p. 212).

Com isso, revelam-se diferentes estratos de intencionalidade que permitem compreender o mesmo fenômeno em diferentes momentos, de distintas maneiras, a partir de posições não-idênticas.

A opção por uma camada em detrimento de outras é o que determina em cada momento o sentido a ser atribuído a este fenômeno, sem que essa significação almeje esgotar aquilo que pode este um e mesmo fenômeno encerrar. Este nada mais é do que um suporte de uma pluralidade infinita de significações definíveis a partir dos diferentes modos segundo os quais o mesmo é visado (HUSSERL, 2006, p. 289-90).

É nesse sentido que se pode afirmar que não existe uma essência una, permanente e perene, de caráter absoluto, mas apenas uma multiplicidade de essências relativas e igualmente válidas. Essas seriam oriundas da projeção intencional a partir da posição firmada pela consciência com relação ao fenômeno investigado. Aquilo que usualmente se designa como essência é um singelo espaço vazio, livremente preenchível de maneira inesgotável por diferentes iluminações originadas de distintos atos intencionais (HUSSERL, 2006, p. 291-2).

Em outras palavras, aquilo que usualmente se designa por essência nada mais é do que um suporte de sentido (dos múltiplos sentidos possíveis), o qual jamais é plenificado integralmente por uma singela localização posicional da consciência - pois esta ressaltará um ou outro aspecto, sempre deixando de lado outros.

Saber que se está sempre diante de um perfil do fenômeno ${ }^{252}$ pode ser uma constatação frustrante. Todavia, é uma situação libertadora, pois evidencia a inexistência de uma única possibilidade de leitura sobre um fenômeno: o "objeto" aproximado sob uma orientação fenomenológica apenas pode ser compreendido como "síntese das múltiplas significações que o descrevem[, ou ainda, ...] o $\mathrm{X}$ idêntico e vazio de uma multiplicidade [...].” (MOURA, 2006a, p. 22, grifos do autor).

Com efeito, a essência como X supostamente idêntico e unitário é desprovida de conteúdo perene. A este vazio se adicionam sucessivamente as mais diferentes significações, originadas das mais distintas camadas intencionais. Esse X é apenas uma

${ }^{252}$ Isto é, que sempre é impossível o compreender integralmente. 
unidade sintética desprovida de qualquer predicado, à qual se dirige a multiplicidade infindável de raios sobre este fenômeno. Seu sentido se encontra deste modo subordinado às múltiplas proposições feitas sobre ele próprio. A essência é assim um campo vazio: não há um objeto ele mesmo a ser conhecido, mas apenas aquilo que sobre ele se propõe (HUSSERL, 2006, p. 290-3).

\subsubsection{O Estilhaçamento do Absoluto Interpretativo: A CECA como Suporte} Significativo Vazio Uno e Múltiplo

Este sucinto, porém necessário, recurso ao pensamento Fenomenológico permite compreender o que se pretende efetuar com o conhecimento sobre a construção histórica da CECA neste trabalho: tornar consciente ao público leitor que se considera todo e qualquer processo de integração como um fenômeno. Ou ainda, busca-se tornar consciente que, quando se estudam os elementos da experiência histórica e normativa da CECA - e de outros processos de integração, efetua-se a referida redução fenomenológica.

Considerar a experiência da CECA como um fenômeno adquire uma específica significação neste texto. Se “o objeto que percebo me é dado segundo tal ou tal perspectiva, com essa luz e sombra, quer dizer, me é dado segundo um 'modo subjetivo de doação’ que é por princípio variável” (MOURA, 2006a, p. 20), as possibilidades de leitura em torno do um e mesmo fenômeno da CECA são intermináveis e igualmente válidas enquanto pretenderem se referir a esta unidade designada sinteticamente pelo termo "CECA".

Mostram-se assim possíveis e admissíveis as proposições de diferentes linhas explicativas sobre um e mesmo fenômeno (no caso, a CECA), na medida em que são inesgotáveis as posições e as camadas intencionais passíveis de serem ocupadas pela consciência com relação a ele.

Compreender a CECA fenomenologicamente é lembrar com segurança que esse processo de integração - como qualquer objeto - "sempre nos é dado segundo uma determinada perspectiva, segundo um certo modo de doação ou fenômeno. Podemos variar nossas perspectivas sobre esse objeto, mas ele sempre nos será dado segundo um ou outro modo subjetivo de doação." (MOURA, 2006a, p. 21).

Por essa razão, ao mesmo tempo em que se mostraram historicamente possíveis leituras em torno de origens mitológicas, cristãs, cosmopolitas ou universalistas de uma 
Europa Unida ${ }^{253}$, também se mostram admissíveis leituras atuais distintas sobre as origens da Europa Unida da CECA. Todas devem ser percebidas como igualmente válidas e vigorosas $^{254}$, jamais podendo uma pretender se apresentar como a fonte de explicação última, perfeita e acabada dela. Afinal, “[n]ós nunca temos acesso à 'coisa mesma' se entendemos por isso um ser sem perspectivas subjacente a este ser que nos é dado por perspectivas." (MOURA, 2006a, p. 21).

\begin{abstract}
Ocorre que, tão logo tentamos tomar consciência do modo como se nos apresenta imediatamente a vida, verificamos que se nos manifesta "dentro" e "fora" de nós, sob uma quase infinita diversidade de eventos que aparecem e desaparecem sucessiva e simultaneamente. E a absoluta infinidade dessa diversidade subsiste, sem nenhuma atenuante de seu caráter intensivo, até mesmo quando prestamos nossa atenção, isoladamente, a um único “objeto”. (WEBER, 2006, p. 44).
\end{abstract}

É nesse sentido específico que, por meio da ênfase no caráter jurídico-político da integração, este trabalho pretende deixar entre parênteses as explicações econômicas sobre a experiência histórica e a experiência normativa da CECA feitas por autores mencionados e mantidos nos limites da Introdução Geral deste texto. Não porque se acredite que os aspectos jurídico-políticos possam ser capazes de esgotar a explicação do processo de construção histórica da CECA; trata-se apenas de pretender apontar outra maneira possível de se ler as origens da Europa Unida.

Ao se predispor se orientar fenomenologicamente, este trabalho rejeita desde já sumariamente a pretensão de uma explicação total da CECA por uma perspectiva jurídicopolítica da mesma maneira que repudia automaticamente a suposta prepotência de explicação integral da CECA por uma leitura jurídico-econômica. Tratar-se-iam de proposições igualmente válidas e complementares, as quais deveriam manter diálogos intensos para promover um conhecimento o mais completo possível - porém interminável sobre a $\mathrm{CECA}^{255}$.

Em nenhum domínio dos fenômenos culturais pode a redução unicamente a causas econômicas ser exaustiva, mesmo no caso específico dos fenômenos "econômicos". (WEBER, 2006, p. 42, grifos do autor).

\footnotetext{
${ }^{253}$ Como apontado rapidamente na Introdução Geral deste trabalho, com a indicação dos mitos grego e medievais sobre as origens lendárias da Europa.

${ }^{254}$ Frise-se: enquanto referidas a um e mesmo fenômeno, a CECA.

${ }^{255}$ Por essa razão, registre-se aqui desde já o interesse de efetuar esse diálogo com leituras jurídicoeconômicas e simplesmente econômicas sobre a Europa Unida, em momento posterior ao presente trabalho. Como afirmado anteriormente, e como será reforçado nas linhas a seguir, a perspectiva escolhida para analisar a CECA por este trabalho se reduz intencionalmente à conjunção das posições do Direito, da Política e da História.
} 
Com efeito, nem uma leitura jurídico-política, nem uma leitura jurídico-econômica, podem pretender exaurir as possibilidades de explicações deste fenômeno de integração como ocorre com qualquer fenômeno: "todo conhecimento reflexivo da realidade infinita realizado pelo espírito humano finito baseia-se no pressuposto tácito de que apenas um fragmento limitado dessa realidade poderá constituir de cada vez o objeto da compreensão científica" (WEBER, 2006, p. 44, grifos do autor).

Poder-se-ia perguntar se, em registro de redução fenomenológica, não haveria um limite de leituras possíveis em torno de um e mesmo fenômeno. Reitere-se aqui a posição de Edmund HUSSERL (1980, p. 72) ${ }^{256}$, para quem “"[a] significação não pode, por assim dizer, flutuar nos ares, mas o signo, do qual dizemos que ela é a significação, é totalmente indiferente àquilo que ela significa.”.

Em outros termos, haveria que se notar que as leituras infindáveis sobre a construção histórica da CECA são igualmente válidas enquanto não "flutuarem nos ares", vale dizer, enquanto se propuserem a tratar do um e mesmo fenômeno da CECA. Enquanto este X permanecer a unidade sintética de sentidos comum a essas leituras, todas elas serão admissíveis, pois todos os possíveis raios intencionais da consciência se orientarão em direção a esse espaço vazio e de preenchimento infinito.

\footnotetext{
[A]penas uma parte finita da infinita diversidade de fenômenos é significativa. [... O] número e a natureza das causas que determinaram qualquer acontecimento individual são sempre infinitos, e não existe nas próprias coisas critério algum que permita escolher dentre elas uma fração que possa entrar isoladamente em linha de conta. (WEBER, 2006, p. 53, grifos do autor).
}

É importante relembrar que este estudo se desenvolve no interior de preocupações voltadas à construção de um conhecimento novo a partir de um recorte dado especificamente pelo Direito.

Tal condição é fundamental de ser lembrada, pois esse elemento adicional condiciona a variabilidade de leituras em torna da construção da CECA. De fato, sob uma perspectiva jurídica, admitem-se leituras infindáveis em torno deste fenômeno apenas e tão-somente enquanto elas se referirem a uma unidade sintética de sentido que tenha como ponto de partida o Direito Positivo da CECA (FERRAZ JR., 2001, p. 43 e 48; REALE, 2001, p. 17), ou seja, seu Tratado Constitutivo (Direito Originário).

Mais simplesmente, desde que se apresente continuamente ser o ponto de partida de significação este elemento jurídico-normativo comunitário positivo, as interpretações da

\footnotetext{
${ }^{256}$ Indicada na nota de rodapé 251, supra.
} 
CECA poderão igualmente variar sem deixar de pertencer ao caráter de leituras igualmente válidas.

A significação deixará de fazer sentido para um estudo em Direito somente se tergiversar sobre elementos não passíveis de serem encontrados no texto do Direito Originário da CECA. Sob uma perspectiva jurídica, o deslocamento entre as camadas intencionais pode variar, mas jamais pode deixar de tomar o Tratado da CECA como a unidade sintética de sentido comum à infinidade de leituras possíveis.

Por essa razão, não basta apenas dizer que este trabalho se dedica a uma interpretação do Direito Originário da $\mathbf{C E C A}^{257}$. Por mais que se afirme ter como ponto de partida o Direito Positivo constante do Tratado de Paris de 1951, haveria que se lembrar de que este, por si só, não porta seu sentido - ele carece de uma essência a ser descoberta em si mesma. O Tratado da CECA se revelaria como um vazio, cujo sentido seria dado indefinidamente a partir de perfis determinados pela posição intencional assumida pela consciência com relação a este conjunto normativo ${ }^{258}$.

Desprovida de essência perene também no que se refere aos estudos em Direito, a CECA teria seu sentido definido não por uma suposta quididade própria e singular. Sua significação não seria dada por um pretenso cerne intangível que sorrateiramente a jorraria de dentro de si como algo mais exato, certo ou privilegiado por excelência. Antes, o sentido seria definido de maneira variável, por meio do direcionamento de intencionalidades distintas sobre seu Direito Originário fenômeno em si mesmo vazio, ou ainda, carecedor de sentido próprio.

Por essa razão, há que se precisar neste trabalho quais são os pontos de partida intencionais que enfatizam - trazem à claridade - um determinado perfil do Tratado da CECA dentro de um arco específico de preocupações jurídicas.

\subsubsection{Inter-Relações Fenomenológicas entre Dogmática e Zetética Jurídicas}

No que se refere à construção de um conhecimento propriamente jurídico, é importante observar que os atos intencionais podem ser agrupados em dois grandes grupos.

\footnotetext{
${ }^{257}$ Como efetuado no início deste Segundo Capítulo, supra.

${ }^{258}$ Em outras palavras, não se está distante da maneira como compreende Tercio Sampaio FERRAZ JR. (2001, p. 40) o estudo em Direito: este nada mais faz do que constituir seu fenômeno investigado, pois, ao mesmo tempo em que o informa, também o conforma: "a ciência jurídica não apenas informa, mas também conforma o fenômeno que estuda, faz parte dele. [O fenômeno jurídico analisado] é não apenas o que é socialmente, mas também como é interpretada pela doutrina jurídica.”.
} 
Estes são dois campos gerais representativos de formas distintas - porém relacionadas ${ }^{259}$ de aproximação de um fenômeno jurídico, a saber, a Dogmática e a Zetética Jurídicas. A partir de cada um deles, projetam-se sobre o fenômeno jurídico diferentes espécies de intencionalidades ${ }^{260}$, mas cada uma delas pode ser reunida em um ou em outro grupo em função da maneira pela qual estas se deslizam em direção ao Direito Positivo (FERRAZ JR., 2001, p. 40 e 43$)^{261}$.

A intencionalidade típica da Dogmática Jurídica é caracterizada pela ênfase na dimensão da resposta, por se preocupar especificamente com o problema do direcionamento da ação, ao passo que a intencionalidade que caracteriza a Zetética Jurídica visa a enfatizar a dimensão da pergunta, por visar em si mesma a um problema especulativo (FERRAZ JR., 2001, p. 40-1; ROESLER, 2002, p. 80) ${ }^{262}$.

${ }^{259}$ Como se poderá ver nas linhas a seguir.
${ }^{260}$ Como se poderá ver mais adiante, são possíveis diferentes tipos de intencionalidades Dogmáticas e
diferentes espécies de intencionalidades Zetéticas, conforme a posição assumida pela consciência que
investiga o fenômeno jurídico.
261 Lembrando aqui a pertinente conclusão de Tercio Sampaio FERRAZ JR. (2001, p. 51, grifos nossos): "é
óbvio que o direito, enquanto objeto de conhecimento, há de ser visto de forma diferente, se o enfoque é
dogmático ou zetético.”.
${ }_{262}$ A distinção entre Dogmática e Zetética Jurídicas fora proposta por Theodor VIEHWEG, em textos como
Systemprobleme in Rechtsdogmatik und Rechtsforschung (1968), Ideologie und Rechtsdogmatik
(1969), entre outros. Para uma visão abrangente sobre esta distinção na obra de Theodor VIEHWEG,
indicamos a leitura de Cláudia Rosane ROESLER (2002).
É importante perceber que se recorre neste trabalho, não diretamente aos estudos de Theodor
VIEHWEG em torno dessa diferenciação entre Dogmática e Zetética Jurídicas. Antes, socorre-se a uma
forma determinada de incorporação dessa distinção conceitual da maneira como apontada especificamente
pela tradição do pensamento jurídico brasileiro, principalmente conforme os estudos sobre o tema
desenvolvidos por Tercio Sampaio FERRAZ JR. (2001) e pela Cláudia Rosane ROESLER (2002). No
entanto, não se pode ignorar que estes quais foram lidos aqui à luz das contribuições reflexivas dadas pelo
ponto de partida fenomenológico assumido por este estudo, tal qual indicado nos itens 2.2 .1 . e 2.2.2., ambos supra.

Nesse sentido, perceba-se que este trabalho opera um deslocamento significativo duplo: não apenas com relação à distinção entre Dogmátiza e Zetética Jurídicas feita por Theodor VIEHWEG, conforme as reflexões supramencionadas de Tercio Sampaio FERRAZ JR. e de Cláudia Rosane ROESLER, mas também em relação à leitura desenvolvida por estes dois autores brasileiros, a partir do fundamento fenomenológico assumido por este texto.

Em outras palavras, Dogmática e Zetética Jurídicas são apresentadas aqui em sentido levemente distinto do dado pelo conceito originário estabelecido por Theodor VIEHWEG, ou mesmo do estabelecido por Tercio Sampaio FERRAZ JR. e por Cláudia Rosane ROESLER. Produz-se aqui uma leitura própria desta distinção, a partir do pensamento fenomenológico, pois são tais noções parcialmente reapropriadas no interior de um campo significativo diferenciado, formado a partir das contribuições retiradas da Fenomenologia.

Nesse sentido, note-se que Dogmática e Zetética Jurídicas são apontadas neste texto como duas fontes distintas de dois grandes grupos de intencionalidades passíveis de serem dirigidas pela consciência em uma Pesquisa em Direito, isto é, dirigidas em direção a um fenômeno jurídico. Houve assim uma apropriação parcial dos conceitos de Dogmática e Zetética Jurídicas, os quais foram ressignificados no interior de uma campo de sentido novo, de tal maneira que eles não têm aqui exatamente o mesmo sentido tal qual Thedor VIEHWEG, Tercio Sampaio FERRAZ JR. ou Cláudia Rosane ROESLER teriam estabelecido. Tratou-se assim de um consciente e deliberado empréstimo conceitual, por meio do qual o mesmo significante não necessariamente aponta exatamente para o mesmo significado. Dito de outro modo: a distinção conceitual entre Dogmática e Zetética Jurídicas foi aqui apropriada parcialmente. 
Apenas a título de esclarecimento, tomemos como exemplo a seguinte anedota "histórica". Sócrates estava sentado à porta de sua casa. Nesse momento, passa um homem correndo e atrás dele vem um grupo de soldados. Um dos soldados então grita: agarre esse sujeito, ele é um ladrão! Ao que responde Sócrates: que você entende por "ladrão"? Notam-se aqui dois enfoques: o do soldado que parte da premissa de que o significado de ladrão é uma questão definida, uma "solução" já dada, sendo seu problema agarrá-lo; e o de Sócrates, para quem a premissa é duvidosa e merece um questionamento prévio. (FERRAZ JR., 2001, p. 40, grifos do autor).

Dogmática e Zetética Jurídicas são assim dois grupos possíveis de projeção de intencionalidades sobre um fenômeno a ser pensado no interior de um campo de preocupações tipicamente jurídico (ROESLER, 2002, p. 79).

A Dogmática tem origem na noção de dokein, ensinar, doutrinar, vale dizer, tem a pretensão de exercer uma explícita e imediata função diretiva. Para tanto, afasta a possibilidade de se considerar opiniões e fornece critérios para tomar uma decisão sobre a ação a ser desempenhada, com base em pontos de partida que não devem nem podem ser questionados (FERRAZ JR., 2001, p. 41; ROESLER, 2002, p. 80).

A ordem legal vigente, embora não resolva a questão da justiça ou da injustiça [...], põe fim às disputas sobre o agir, optando por um parâmetro que servirá de base para as decisões (ainda que alguém continue a julgar injusto o parâmetro estabelecido - isto é, a dúvida permaneça no plano dos fatos e das avaliações sociais). (FERRAZ JR., 2001, p. 43, grifos do autor).

Por sua vez, Zetético deriva da palavra grega "cético" (do grego, skepsis/zetesis/zetein, "cetético", perquirir), tratando-se de uma orientação dotada de um afã de investigação que não admite um saber efetivamente firme e estabelecido ou absolutamente seguro (MORA, 2000, p. 437). A intencionalidade Zetética perquire incessantemente, investiga conforme reflexão contínua, ou seja, exerce uma função especulativa que desintegra opiniões para poder conhecer mais algo (FERRAZ JR., 2001, p. 41; LAUMONIER, 1969, p. 166; ROESLER, 2002, p. 80).

“[A] 'zetética' [...] conjura, de uma só vez, a confusão do espírito fascinado pelas mensagens e miragens contraditórias, e a tentação da inércia, da prostração

O deslocamento significativo de conceitos apresentados por autores não é invenção deste trabalho: outros autores seguiram este empreendimento e sinalizaram as vantagens de se seguir este método de leitura por apropriações conceituais parciais ressignificantes para a produção de conhecimento novo, em detrimento de uma leitura que se contente apenas em apreender os conceitos no preciso preciosismo da chave analítica de cada autor. Sobre este método de apropriação conceitual parcial, remetemos o leitor ao item 3.3.1., infra, o qual versa sobre Empréstimos Conceituais e Conhecimento. 
intelectual, pois é uma atividade tanto sem fim como sem ilusões". (TOURNON, 2004, p. 128).

A Dogmática Jurídica é fonte de intencionalidades que assumem como premissa a proibição da negação. Suas intenções se orientam para produzir sentidos sobre um fenômeno, desde que não se neguem determinados pontos de partida estabelecidos como inquestionáveis por um ato de Poder (FERRAZ JR, 2001, p. 43): "sabe-se que a questão comportaria novas indagações, mas põe-se um ponto final nestas possíveis indagações" (ALVES, 2003, p. 377, grifos do autor).

Tomar os pontos de partida como não passíveis de refutação (como dogmas ${ }^{263}$ ) é fundamental para uma perspectiva Dogmática, na medida em que o infinito questionamento poderia paralisar a ação. A preocupação por excelência da intencionalidade tipicamente dogmática é atribuir um sentido sobre as normas jurídicas para, com isso, promover a decidibilidade de conflitos (FERRAZ JR., 2006, p. 43, 48 e 87) com base nos dogmas, os quais “'dominam” as demais respostas que a eles devem se adequar." (ROESLER, 2002, p. 81).

A Dogmática Jurídica efetua um corte na realidade. Ela isola os problemas relevantes e interpreta o Direito Positivo vigente sempre tendo em vista a questão da decidibilidade de conflitos para promover o mínimo possível de perturbação social. Suas intencionalidades visam a constituir condições significativas para que a decisão produzida não seja recebida como arbítrio, mas como algo plausível e aceitável, pois interpretada como detendo aderência a um sentido social. O Direito é assumido como um todo coerente, e a intenção trabalha para efetuar a interpretação do Direito Positivo para decidir (FERRAZ JR., 2001, p. 82, 87 e 92).

Por isso, as interpretações promovidas segundo uma intencionalidade típica de Dogmática Jurídica estarão sempre adstritas aos termos propostos pelo Direito Positivo. Não se mostra possível que este quadro normativo posto seja ignorado nas atribuições de sentido jurídicas. Afinal, deverá sempre optar por determinadas balizas que sustentem uma decisão sobre como agir.

Esta forma de se aproximar do fenômeno jurídico impõe que se pensem os problemas deste ramo do conhecimento com base nas normas, conforme tais normas, mas nunca contra elas (FERRAZ JR., 2001, p. 43 e 48). Na Dogmática Jurídica se desenha um

263 “"A] sseverações são tratadas como dogmata quando, em tese, são excluídas a longo prazo de um ataque, e por isso, não estão submetidas a nenhum dever de defesa, ou seja, a nenhum dever de fundamentação, senão simplesmente a um dever de explicação. Num determinado âmbito cultural, determinadas asseverações são colocadas fora de toda dúvida." (ROESLER, 2002, p. 81-2, grifos da autora). 
arco de conhecimento jurídico que parte do Direito Positivo, que sobre ele se desenvolve, mas que também a ele retorna para, nos termos dele, resolver o conflito.

[A] dogmática [...] explica que os juristas, em termos de um estudo estrito do direito, procurem sempre compreendê-lo e torná-lo aplicável dentro dos marcos da ordem vigente. Essa ordem que lhes aparece como um dado, que eles aceitam e não negam, é o ponto de partida inelutável de qualquer investigação. Ela constitui uma espécie de limitação, dentro da qual eles podem explorar as diferentes combinações para a determinação operacional de comportamentos juridicamente possíveis. (FERRAZ JR., 2001, p. 48, grifos nossos).

Por sua vez, a Zetética Jurídica assume como ponto de partida não um dogma, mas uma evidência ${ }^{264}$, a qual pode ou não ser frágil. Sua preocupação não consiste em fornecer parâmetros para a decidibilidade de conflitos, mas em estabelecer certeza para a construção do conhecimento.

Por isso, as respostas possíveis são sempre provisórias, tentativas questionáveis a todo o momento (ROESLER, 2002, p. 80), permanecendo, por isso mesmo, “o pressuposto de uma indagação anterior e persistente" (ALVES, 2003, p. 377, grifos do autor) que permita tornar a reflexão "melhor fundamentada e construída." (ROESLER, 2002, p. 85).

Sempre permanecem duvidosas as hipóteses estabelecidas. Pode-se até mesmo desconsiderá-las para buscar novas formas de perguntar sobre um problema, a fim de reestabelecer as premissas. Em outras palavras, a explicação de problemas poderia até mesmo desconsiderar o Direito Positivo, pois busca ampliar as dimensões de compreensão do fenômeno jurídico ${ }^{265}$, não detendo outra função que a especulação para fins cognitivos (FERRAZ JR., 2001, p. 43-4; ROESLER, 2002, p. 85).

O sentido produzido por uma intenção projetada a partir de uma orientação de Zetética Jurídica tem seu encaminhamento livremente dirigido. Não há compromisso com dogmas usualmente vinculantes na sociedade, pois não tem a preocupação Zetética uma disposição para ser aplicada enquanto guia de uma ação prescrita. Esse cuidado não se encontra dentre seus objetivos de refinamento cognitivo por meio de contínua abertura para, em todas as direções, questionar incessante e corrosivamente seus objetos (FERRAZ JR., 2001, p. 42, 44 e 46).

\footnotetext{
264 “[A] sseverações [...] são [... consideradas] como zetemata [... quando] estão liberadas a todo ataque, estando sujeitas a ambos os deveres: defesa/fundamentação e explicação. Sempre são questionáveis. Por isso, na zetética o discurso fundamentante chega apenas a um final provisório, possivelmente muito a curto prazo." (ROESLER, 2002, p. 82, grifos da autora).

${ }^{265}$ Por meio da indicação de fontes alternativas de intencionalidades portadoras de sentido.
} 
É importante perceber que a fonte de intencionalidades típicas de Zetética Jurídica tem por origem um âmbito bastante amplo. Este deriva daquelas investigações cuja preocupação com o fenômeno jurídico dialoga com outros ramos do conhecimento humano. Por isso, a intencionalidade gestada por uma abordagem Zetética Jurídica tem diversas fontes, a saber, as disciplinas que admitem dentro de seus próprios campos de investigação uma preocupação com o conhecimento do Direito ${ }^{266}$. Se estas não têm por objeto apenas o Direito, em determinados momentos estas o incorporam como um de seus interesses investigativos (FERRAZ JR., 2001, p. 44 e 47).

[Uma reflexão de Zetética Jurídica] não tem nenhum compromisso com [a solução normativa dos conflitos], pois os resultados de seus estudos podem até mesmo produzir perplexidades que desorientem a ação, isto é, chegar não a soluções, mas a novos problemas que demandem novas investigações e que, no momento, não permitam uma tomada definitiva de posição. (FERRAZ JR., 2001, p. 46, grifos do autor).

É importante salientar que essa distinção é didática. É na verdade difícil estabelecer uma clara linha divisória clara e absoluta entre os dois grupos produtores de intencionalidades (FERRAZ JR., 2001, p. 41).

Por esse motivo, note-se que a Zetética Jurídica pode ter suas conclusões analisadas para o desenvolvimento posterior de soluções novas de orientação de soluções de conflitos. Nesse sentido, a Zetética forneceria informações ao arco de conhecimento a ser desenhado pela Dogmática (FERRAZ JR., 2001, p. 46). Essa não é sua função precípua, mas suas premissas podem ser dogmatizadas e dogmatizáveis. Ainda, a orientação Dogmática pode estabelecer premissas a serem investigadas por uma postura Zetética (ROESLER, 2002, p. 89-94, 112-3 e 115).

Ao mesmo tempo, se a Dogmática Jurídica determina que não é toda interpretação que deve ser aceita, mas somente aquela produzida de acordo com padrões dogmáticos, há que se perceber que não consiste sua atividade intelectual em um mero reproduzir afirmativo puro e simples dos pontos de partida inquestionáveis.

Sua intenção trabalha sobre esses dogmas para lhes atribuir um sentido, o que lhe confere uma margem de manipulação significativa. Cria-se um âmbito hermenêutico de disponibilidade de sentido no interior do qual os dogmas indescartáveis permanecem não sendo abandonados, apesar de terem sido flexibilizados. Nesse sentido, a Dogmática

266 Exemplificativamente, "Sociologia, Antropologia, Psicologia, História, Filosofia, Ciência Política" (FERRAZ JR., 2001, p. 44), entre outras. 
também trabalharia sobre incertezas, mas de um modo controlado ${ }^{267}$ (FERRAZ JR., 2001, p. 49-50; ROESLER, 2002, p. 83-4) ${ }^{268}$.

Mas há que se notar ainda que a impossibilidade de determinação de linhas claras e definitivas entre Dogmática e Zetética Jurídicas ultrapassa este simples intercâmbio de informações - um implicar e influenciar o outro, complementando-se um e outro mútua e reciprocamente -. Antes, é efetivamente impossível haver um conhecimento jurídico que não seja ao mesmo tempo Dogmático e Zetético, devendo as duas maneiras de abordar o mesmo fenômeno estar presentes, por operarem como sístole e diástole do coração conhecimento jurídico $^{269}$.

O jurista trabalha em suas investigações simultaneamente com intencionalidades típicas de Dogmática e de Zetética Jurídicas; elas são vistas como complementares ${ }^{270}$. O conhecimento jurídico apenas pode se reputar como um saber mais completo ${ }^{271}$ e sério de seu fenômeno a partir do momento em que se aproximar do Direito a partir de uma dupla consideração Dogmática e Zetética - pois seu saber não se resume nem ao conhecimento Dogmático, nem ao Zetético (FERRAZ JR., 2001, p. 41, 43 e 47).

O conhecimento jurídico se funda, afinal, pela co-presença de uma investigação Zetética e de uma investigação Dogmática. Apenas deste modo ele poderá se promover em todas as direções possíveis em torno do fenômeno a ser conhecido, da maneira a mais completa possível (ROESLER, 2002, p. 244-59).

[... E]ntre ambas não [há] uma linha divisória radical[, pois] toda investigação acentua mais um enfoque que o outro, mas sempre tem os dois. (FERRAZ JR., 2001, p. 41, grifos do autor).

Na verdade, não existe uma zetética pura, nem uma dogmática pura. O próprio Direito, embora dogmático, pressupõe internamente uma zetética. Se não houvesse uma zetética interna, ele não poderia se plastificar e se ajustar ao mundo. (ALVES, 2003, p. 377-8, grifos do autor).

\footnotetext{
${ }^{267}$ Isto é, nos limites estabelecidos pelo Direito Positivo e por sua certeza normativa.

268 “Assim, ao contrário do que o sentido comum da palavra 'dogmático' indica, o pensamento dogmático não trabalha com as normas como se elas representassem um condicionamento fixo, de sentido único. Embora sejam seus pontos de partida inquestionáveis e nesse sentido funcionem como dogmas, a sua natureza lingüística, com a incerteza conotativa e denotativa que lhe é inerente, confere uma margem relativamente ampla de manipulação, necessária ademais para que os próprios dogmas possam ser continuamente adaptados às circunstâncias sociais mutáveis." (ROESLER, 2002, p. 84).

${ }^{269}$ Todavia, é importante notar que há recortes internos em cada um desses grupos, o que limita em cada estudo as respectivas fontes de produção de intencionalidades - como se poderá ver exemplificativamente no presente estudo, nas próximas linhas -. Há sempre ramos do conhecimento Dogmático e do conhecimento Zetético que são privilegiados por escolha metodológica, em detrimento de outros.

270 "[O] fenômeno jurídico, com toda sua complexidade, admite tanto o enfoque zetético, quanto o enfoque dogmático, em sua investigação.” (FERRAZ JR., 2001, p. 43).

${ }^{271}$ Mas jamais exaustivo.
} 
[O] saber jurídico apresenta-se sempre como um conjunto complexo de conhecimentos que possuem, ao mesmo tempo, vinculação com a direção de comportamentos e necessidade de desenvolvimento reflexivo. (ROESLER, 2002, p. 115).

\subsubsection{Posicionamento Intencional deste Trabalho: A Dupla Orientação} Dogmático-Zetética Jurídica

A partir das considerações acima, é fundamental compreender o posicionamento assumido por este trabalho no que se refere à produção de conhecimento jurídico a partir dos dois grandes grupos de projeção de intencionalidades sobre o fenômeno "Direito". Apenas desta maneira será possível compreender o modo como o fenômeno jurídico da CECA está sendo aqui doado à consciência, isto é, compreender as origens e as características dos atos intencionais que se deslizam intelectualmente em direção à CECA, a sua História e a seu Direito Originário.

Relembre-se aqui a figura do arco do conhecimento jurídico invocada no início desta Parte Primeira ${ }^{272}$, pois ela permite compreender de que maneira se pretende aproximar intencionalmente da CECA, de sua História e de seu Tratado Constitutivo.

Segundo aquela imagem, pretende-se assumir neste estudo um elemento como ponto de partida investigativo (o Direito Originário da CECA) para, posteriormente, desenvolver considerações sobre o mesmo e, sobre ele, retornar.

As reflexões sobre o fenômeno a ser estudado aqui não pretendem permanecer soltas. Antes, elas querem retornar para o ponto de partida, mas este retorno será traçado em conjunto com elementos que permitam o compreender de maneira qualitativamente original e a partir de repertório de significação renovado.

Em outros termos, quer-se efetuar um procedimento investigativo que permita a modificação significativa (ressignificação) daquilo que fora tomado como ponto de partida, de modo a reembaralhar seu campo significativo. A ideia é que ele receba um sentido novo enquanto objeto de atenção privilegiado deste estudo.

O ponto de partida desta investigação ${ }^{273}$, sob uma perspectiva jurídica, é o documento jurídico-normativo positivo constitutivo da CECA, o Tratado de Paris de 1951. Enquanto o ponto de partida característico de uma Pesquisa em Direito (FERRAZ JR.,

${ }^{272}$ V. Introdução Parcial desta Parte Primeira, supra.

${ }^{273}$ Foram realizadas especificações temáticas do item 1.3. e 1.4., supra, com o objetivo de lhe conferir um estatuto no interior do pensamento jurídico contemporâneo, vale dizer, para fornecer os contornos das fundações do modo como é efetuada a recepção da CECA no pensamento jurídico contemporâneo. 
2001, p. 43), será este Tratado o alvo de intencionalidades distintas, Dogmáticas e Zetéticas, conforme a específica situação. Sobre este ponto de partida se desenhará um arco de conhecimento jurídico que partirá dele, que sobre ele se desenvolverá, mas que também a ele retornará. Não para, nos termos dele, resolver conflitos. Antes, volta-se esse empreendimento investigativo para ampliar os limites do saber jurídico brasileiro sobre a CECA.

Para tanto, é importante notar que ao se estudar a História da Construção da CECA (1945 e 1951) para compreender como foi possível produzir as instituições que constam daquele Tratado ${ }^{274}$, pretende-se recorrer nos Capítulos Quarto, Quinto e Sexto a informações constantes de fontes primárias e fontes secundárias. Deste relato histórico será possível apreender informações que permitirão compreender como fora possível, no imediato pós-Segunda Guerra Mundial, unir jurídico-politicamente povos anteriormente opostos militarmente ${ }^{275}$.

Ao mesmo tempo, para interpretar o Tratado da CECA no Sétimo Capítulo deste trabalho, não apenas se recorrerá a uma leitura prosada organizada que vise a simplesmente comentar seu texto de Direito Positivo a partir de disciplinas tradicionais do mundo jurídico, tais como o Direito Internacional Público e o Direito Comunitário.

$\mathrm{Na}$ verdade, a contribuição efetiva deste trabalho consistirá em lançar mão de contribuições dadas pela História Contemporânea da Europa ${ }^{276}$, mas também daqueles dados por outros ramos do conhecimento humano, tais como a Teoria Geral do Direito, a Filosofia do Direito, a Filosofia Política (Antiga e Contemporânea) ${ }^{277}$ e a Fenomenologia.

Nesse sentido, surgiria um aparente problema de indefinição da posição intencional assumida por este trabalho: teria ele por base intencionalidades da Dogmática ou da Zetética Jurídicas? Ou simplesmente, seria o presente estudo orientado por uma abordagem típica de Dogmática ou de Zetética Jurídica?

A pergunta restaria mal formulada. Lembre-se de que toda e qualquer Pesquisa em Direito opera segundo ambas as orientações, isto é, assume internamente uma orientação ao mesmo tempo guiada por uma postura Dogmática e por uma posição Zetética. A única diferença residiria na condição de que em algumas Pesquisas pode "predomina[r] o enfoque zetético, em outras, o dogmático." (FERRAZ JR., 2001, p. 43).

\footnotetext{
${ }^{274}$ Como afirmado ao final do item 1.5., supra.

${ }^{275}$ Ou ainda, como fora possível "unir, non par la violence des armes, mais de leur libre consensus, des pays européens qui, durant de longs siècles, ce sont affrontés, dans des conflits acharnés, déchirés qu'ils étaient par des rancœurs et des haines ancestrales." (MATTERA, 2002, p. 8).

${ }_{276}$ Os Capítulos Quarto, Quinto e Sexto deste trabalho.

${ }^{277}$ Conforme as limitações a serem apontadas nos itens a seguir.
} 
De todo modo, Dogmática e Zetética seriam "funcionalmente necessários e complementares." (ROESLER, 2002, p. 252).

Assim, este trabalho se orienta a rigor por uma dupla orientação, por assumir o concurso simultâneo de intencionalidades de Dogmática e de Zetética Jurídicas. Por esse motivo, esta Tese de Doutorado ${ }^{278}$ admite em seu interior tanto uma postura Dogmática quanto uma posição Zetética, precisamente porque não faria sentido para um conhecimento jurídico assumir unilateralmente uma postura estanque e incomunicável entre os sentidos passíveis de serem produzidos ${ }^{279}$.

Por outro lado, apesar de haver a concorrência de intenções de Dogmática e de Zetética Jurídicas, a presente Pesquisa ${ }^{280}$ se constrói privilegiando um tipo delas.

Há a inafastável presença dos dois polos de intencionalidades. Todavia, um deles é utilizado com maior ênfase para atribuir significações sobre um e mesmo fenômeno. Neste trabalho, esta fonte de intencionalidade privilegiada - mas não exclusiva - é a dada pela perspectiva Zetética.

Isso não significa de forma alguma que a perspectiva Dogmática é afastada deste estudo. Muito pelo contrário: como se poderá perceber quando da leitura do Sétimo Capítulo desta Tese, há uma preocupação em fazer convergir as intencionalidades de Dogmática Jurídica com as de Zetética Jurídica ${ }^{281}$.

A conjugação simultânea de fontes de intenções Dogmáticas e Zetéticas Jurídicas no interior deste trabalho é facilmente perceptível a partir de uma perspectiva material, isto é, a partir da consideração dos recursos materiais (dos conteúdos) a partir dos quais as reflexões são produzidas. Isso implica reconhecer a vocação interdisciplinar deste trabalho, uma preocupação investigativa que se revela mais e mais relevante e potencialmente

\footnotetext{
${ }^{278}$ Como todo estudo em Direito.

279 "Não se pode estudar nem compreender a integração sem atentar para as bases de direito internacional e para as dimensões histórico-culturais inerentes a qualquer processo de tal natureza. Passa o direito internacional clássico da coexistência, ao direito internacional contemporâneo da cooperação, para o direito internacional pós-moderno da integração?” (CASELLA, 2008, p. 212, grifos do autor).

${ }^{280}$ Como também ocorre em todas as investigações em Direito.

281 É importante notar que outros antes deste trabalho efetuaram semelhante opção mais explícita para desenvolver considerações conjuntas de Dogmática e Zetética Jurídicas, conciliando-as a partir da ênfase no pensamento Zetético.

Dentre os que receberam grande reconhecimento na comunidade epistêmica jurídica brasileira, basta mencionar a abordagem preparatória para os estudos em Direito dada por Tercio Sampaio FERRAZ JR. (2001, p. 51), em sua Introdução ao Estudo do Direito - Técnica, Decisão, Dominação, sobre a qual se funda parcela desta Tese.

Perceba-se deste modo que não se está sozinho no pensamento jurídico nacional neste empreendimento metodológico simultaneamente Dogmático e Zetético Jurídico, com a ênfase na Zetética Jurídica, voltado à construção de conhecimento jurídico novo.
} 
inovadora nas explicações jurídicas contemporâneas, principalmente nos estudos em Direito Internacional ${ }^{282}$.

Com efeito, no que se refere ao conjunto de disciplinas ao qual se recorre para produzir a presente Tese, não apenas foram, são e serão utilizadas as contribuições provenientes dos tradicionais ramos Dogmáticos do Direito - sobretudo, Direito Internacional Público e Direito Comunitário. Também serão incorporados discursos produzidos por outras formas de se aproximar do fenômeno, tais como os da Teoria Geral do Direito, da Filosofia do Direito, da Filosofia Política Antiga e Contemporânea, da Fenomenologia e da História Contemporânea da Europa.

A partir das considerações acima, pode-se entender o porquê se assume que a integração promovida pela CECA - como ocorre com todo e qualquer processo de integração - pode ser compreendida como um fenômeno jurídico-político ${ }^{283}$.

Apesar de o ponto de partida desta reflexão em Direito ser precisamente o Direito Positivo (fenômeno jurídico), este estudo se constrói a partir de profunda influência dada por intencionalidades gestadas no interior de ramos Zetéticos cuja preocupação é compreender o Poder normativo e os modos de sua organização na vida em comum - na polis - (fenômeno político).

A conjunção desses dois centros produtores de sentido permite o desenvolvimento de estrutura analítica que projeta simultaneamente sobre o fenômeno da Europa Unida da CECA intenções de Dogmática Jurídica ${ }^{284}$ e de Zetética Jurídica. O Direito é compreendido como fenômeno passível de atrair a atenção de outros ramos do conhecimento humano, para além da especialidade de estudos em Direito.

Desloca-se intencionalmente sobre este fenômeno munido de significações oriundas de preocupações de Direito e de Política. Isso tornará possível o constituir significativamente $^{285}$ como um fenômeno jurídico-político. Dito de outro modo, com este trabalho se busca salientar a possibilidade de atribuir à construção histórica da CECA uma determinada forma de leitura ${ }^{286}$ - uma leitura jurídico-política ${ }^{287}$.

\footnotetext{
282 "Parece-nos que hoje, diante do quadro sombrio em que se situa a humanidade, dilacerada pelos conflitos isolados (Iraque, Irã, Líbano, Polônia), é necessário recorrer ao conhecimento interdisciplinar, envolvendo pesquisa das causas do desequilíbrio internacional, ao mesmo tempo, filosofia e técnicas, educação, sociologia, psicologia social, economia e ciência política. As ciências humanas poderão dar contribuição relevante para o esclarecimento dos enigmas da guerra." (CASELLA, 2008, p. 221).

${ }^{283}$ Tal qual designado pelo título do presente trabalho.

${ }^{284}$ Isto é, "estritamente jurídico-positivas".

${ }^{285}$ Ou ainda, o que é o mesmo, o receber perante a consciência.

${ }^{286}$ Reitere-se, ainda uma vez, que isso não significa qualquer desprezo ou desconsideração de estudos e leituras que tenham optado por outras posições da consciência com relação ao fenômeno estudado. Estas
} 
O enfoque do fenômeno da integração normalmente tende a privilegiar seus aspectos e seu conteúdo econômico, em detrimento de análise jurídica e institucional, muitas vezes relegadas a caráter meramente instrumental, o que tem o condão de inverter a captação do processo, e a adequada avaliação de seus elementos constitutivos e condicionantes estruturais. (CASELLA, 1996, p. 18).

Todavia, não apenas sob uma perspectiva material/conteudística é possível constatar que este estudo efetua uma conjunção de intenções Dogmáticas e Zetéticas Jurídicas. Não é apenas nesta interdisciplinaridade que reside seu vigor intencional duplo. Há ainda sob uma perspectiva formal um procedimento investigativo que visa a efetuar um movimento intelectual caracterizado por ser ao mesmo tempo Dogmático e Zetético. Este aspecto formal permitirá evidenciar no proceder do próprio movimento investigativo o porquê da ênfase na abordagem Zetética Jurídica.

leituras distintas da CECA não podem ser reputadas como eivadas de suposta "menor importância" perante a que se desenvolve nas linhas que seguem.

Igualmente válidas são as abordagens jurídicas que se socorram de outros ramos do conhecimento humano, como a Sociologia, a Economia, ou mesmo apenas de outras áreas do conhecimento jurídico, como o Direito do Consumidor, o Direito do Trabalho, o Direito da Concorrência, o Direito Processual, entre tantos outros. Tratam-se apenas de diferentes pontos de partida, fontes - por isso mesmo - de outras intencionalidades e, dessa forma, de leituras distintas. O que se recusa é o discurso de detenção de monopólio absoluto sobre as possibilidades de interpretação sobre o fenômeno da CECA - seja ele jurídico-político, seja ele jurídico-econômico, seja ainda jurídico-positivo, entre tantos outros possíveis. Afinal, nada nem ninguém pode se supor ou impor como ocupando intemporalmente o lugar do Saber afirmação que fará mais sentido ao leitor quando da leitura do item 3.4., infra.

De todo modo, este trabalho tem apenas a humilde pretensão de buscar colaborar com o conhecimento jurídico sobre o fenômeno estudado, por meio do destacamento de determinados aspectos iluminados por intencionalidades distintas. Em toda projeção, há pontos que residem na sombra, ao mesmo tempo em que outros permanecem na claridade. Sempre há espectros não-significados enquanto outros sentidos são revelados.

O importante não reside tanto em enfatizar os possíveis erros ou acertos de uma leitura em comparação com a outra, e vice-versa. Mais do que enfatizar a diferença entre aquilo que uma e outra relata, há que se procurar promover entre cada uma delas um fértil diálogo. Apenas deste modo se mostra possível uma melhor compreensão acadêmica sobre o mesmo objeto.

${ }^{287}$ A leitura jurídico-política da Europa Unida da CECA também pode ser matizada em diferentes perspectivas, dependendo do modo como a análise será feita. Isso implica reconhecer que há, com isso, diferentes possibilidades de leituras jurídico-políticas da CECA, cada uma delas variando em função dos pontos de partida assumidos para cada uma das investigações.

Quer-se com isso afirmar que não existe uma única leitura jurídico-política sobre todo e qualquer fenômeno, vale dizer, não há uma melhor ou mais acertada leitura jurídico-política da CECA, da mesma maneira que não se pode afirmar a verdade de uma leitura sobre qualquer outra. Tratar-se-iam apenas de leituras igualmente válidas sobre um e mesmo fenômeno, produzidas a partir de posicionamentos intencionais distintos no interior da conjunção entre reflexões de Direito e de Política.

Por essa razão, ainda que tenham sido esclarecidos os pontos de partida intencionais deste trabalho, é suficiente indicar que se trata de apenas uma leitura jurídico-política da CECA - de sua construção histórica e de sua fundação jurídica, dentre tantas outras possíveis. Dessa forma, é necessário ainda efetuar a precisão de quais seriam os critérios voltados a efetuar uma específica projeção significativa política sobre a História e sobre os textos de Direito Positivo da CECA.

A elucidação destes pontos de partida permitirá esclarecer como se desenvolve a específica leitura jurídico-política desta Organização Internacional buscada pelo presente texto. Esses critérios serão especificados com clareza nos itens a seguir, especialmente nos 3.3.3. e 3.4., infra. 
Entenda-se que este estudo não opera no interior de um círculo de preocupações típico de Dogmática Jurídica.

Apesar de assumir como ponto de partida o Direito Positivo da CECA (o Tratado de Paris, de 1951), esta investigação não visa à decidibilidade de conflitos. Antes, este trabalho questiona algumas das premissas existentes em torno das formas arraigadas no pensamento jurídico brasileiro e estrangeiro de compreender jurídico-politicamente a construção histórica da CECA. Para tanto, utiliza vetores significativos ${ }^{288}$ oriundos de ramos do conhecimento humano relacionados ao conhecimento jurídico, os quais foram articulados de maneira singular nesta Tese ${ }^{289}$.

Ao mesmo tempo, esta Tese de Doutorado não se mostra como puramente orientada por um polo de Zetética Jurídica, pois o questionamento não será infinito. De fato, este trabalho procurará partir do Direito Positivo para, após o recurso à matriz significativa interdisciplinar, voltar sobre ele com uma chave de leitura específica.

Esse retorno ao Direito Positivo não fugirá muito daquilo que foi previsto pelo próprio texto normativo. Seu objetivo é tentar compreender o Direito Originário da CECA de maneira distinta, sem ir além dos limites de significação estabelecidos pelo texto do Tratado da CECA, ou ainda, sem do texto se esquecer. Em outras palavras, o Direito Positivo não será nem esquecido, nem ignorado, muito menos desprezado por este estudo, pois é ele seu ponto de partida e de chegada.

Ainda que entre esses dois limites seja desenhado um percurso de vai e volta (em arco), traçado por um tortuoso caminho interdisciplinar, o Direito Originário positivado da CECA será sempre o persistente fio condutor da análise deste trabalho. Zeteticamente orientado, o caminho intelectual buscará fazer florescer do interior dos signos positivados, a partir dos estímulos concedidos por intencionalidades dos outros ramos

\footnotetext{
${ }^{288}$ Como se poderá ver nos itens a seguir.

${ }^{289}$ Neste ponto se mostra a originalidade da chave hermenêutica deste trabalho, a qual estabelecerá uma nova teia significativa para se aproximar deste fenômeno. O caráter inovador dessa chave de leitura proposta será mais bem compreendido a partir da leitura dos itens a seguir, onde serão explicitadas as conjugações e as articulações de sentido estabelecidas para nortear a interpretação nova promovida por este texto.

Lembre-se, por derradeiro, de que a originalidade de um trabalho reside em sua capacidade de invenção, isto é, em sua aptidão a, não apenas produzir uma síntese nova de ideias, mas principalmente, na possibilidade de fornecer um remanejamento significativo dos meios de conhecimento disponíveis (LALANDE, 1999, p. 597). Toda inventividade está necessariamente vinculada assim à consideração renovada dos termos postos e legados pela tradição, da maneira como foram deixados, bem como da maneira como são incorporados.

É neste sentido de dialogar inventivamente com a tradição, recombinando-a de modo novo (conjunção entre método e conteúdo trabalhado), que se pode dizer que este trabalho propõe sua originalidade significativa.
} 


\section{de conhecimento humano, uma significação alternativa que apresente a CECA como um específico fenômeno jurídico-político ${ }^{290}$.}

Nem somente Dogmático, nem simplesmente Zetético, este estudo faz convergir as duas fontes de intencionalidades. A ênfase na orientação Zetética resulta da condição de que este estudo não se volta à decidibilidade de conflitos e de que incorpora contribuições de outros ramos do conhecimento humano para compreender o Tratado da CECA (Direito Originário Positivo da CECA).

Deslocar-se intelectualmente neste meio termo, (i) sem buscar decidir conflitos, (ii) sem ignorar o Tratado da CECA como o princípio e o fim do processo interpretativo, e (iii) pretendendo desenvolver considerações conjuntas sobre o fundamento do Direito e do Poder na CECA, são as características metodológicas da presente Pesquisa em Direito.

\footnotetext{
Esclarecer e questionar os pontos de partida de uma dogmática significa tomar, zeteticamente, os fundamentos de uma determinada organização social como objeto, ainda que indireta ou mediatamente, e pode significar abalar estes consensos nem sempre tematizados. (ROESLER, 2002, p. 88).
}

Se aqui se combate o excessivo apego à letra do texto jurídico-normativo característico de uma abordagem positivista do Direito - em que se procura efetuar um mero comentário prosado do conteúdo constante do documento jurídico, opõe-se aqui igualmente a toda e qualquer forma de supor ser o conhecimento jurídico uma ciência conduzida, isto é, desprovida de conteúdo ${ }^{291}$.

Entenda-se que não se propõe aqui a assunção primordial da condução do processo de conhecimento jurídico-científico pelo conhecimento do Direito Positivo. Antes, procura-se efetuar com esta proposta de abordagem interdisciplinar em Direito a mútua e

\footnotetext{
${ }^{290}$ Ou ainda, como algo passível de ser entendido também de outros modos.

${ }^{291}$ Ou seja, aquilo que Roberto Mangabeira UNGER (s.d., p. 3) denominara ser a interdisciplinaridade conservadora. Segundo o autor, o caráter conservador da interdisciplinaridade deveria ser entendido no seguinte sentido: com a perda da "fé na dogmática jurídica, o conteúdo do direito p[assa a] ser importado de fora, de todas as outras disciplinas, por exemplo, da análise econômica. [... Trata-se d]a idéia que nós devemos importar aquelas outras disciplinas tal como elas existem.” (UNGER, s.d., p. 3).

Isso não implica afirmar que aderimos automaticamente à solução por dada pelo mesmo autor de incorporar ao conhecimento jurídico uma interdisciplinaridade cética, a qual propugnaria pela necessidade de questionar as "ilusões das Ciências sociais existentes" (UNGER, s.d., p. 12). Isso porque este autor parece sinalizar querer atribuir ao conhecimento jurídico o caráter de ciência condutora das demais.

Esse intento de alçar a uma posição de destaque o conhecimento jurídico traria inconsistência e incoerência teóricas ao presente estudo, como se poderá verificar algumas linhas mais adiante especialmente, no item 3.4., infra. Nenhuma forma de conhecimento científico deve pretender assumir a posição de condutor absoluto do processo de construção do conhecimento: nem Direito, nem Política, nem Economia, nem Filosofia, etc., está no centro do Saber. Bem lembra isso a inscrição da Praça do Relógio da Cidade Universitária da Universidade de São Paulo: "no universo da cultura, o centro está em toda parte".
} 
recíproca influência de maneiras de se compreender o mundo, sem jamais desconsiderar o conhecimento do Direito Positivo.

Se recorre à contribuição de outras disciplinas do conhecimento, a ênfase Zetética desta investigação não ignora o solo Dogmático: antes, o pressupõe. O objetivo é viabilizar que Direito e outros ramos do conhecimento humano possam contribuir em pé de igualdade na construção de um conhecimento mais completo - e jamais exaustivo - de um mesmo fenômeno estudado.

Assim, parte-se do texto de Direito Positivo para, a partir de contribuições dadas pelas outras chaves de significação, a ele retornar de maneira modificada no que se refere à linha de interpretação. Com esse duplo movimento ascendente e descendente, fecha-se o percurso em arco de construção de um conhecimento jurídico-científico ${ }^{292}$.

Não se buscará desconsiderar assim o Direito. Este trabalho se manterá adstrito à manifestação formal escrita do fenômeno jurídico positivo, atribuindo-lhe significações alternativas. O realce dessas novas formas de leitura apenas se mostrará possível a partir do intercurso do conhecimento jurídico dogmático com as chaves explicativas fornecidas pelas outras disciplinas do conhecimento humano.

A consideração conjunta da Dogmática e da Zetética Jurídicas ocorre ${ }^{293}$, aqui, para assegurar a horizontalidade na consideração da capacidade de cada disciplina poder igualmente formar conhecimento jurídico científico novo.

Recusa-se a ilusão imoderada na supremacia das demais formas de conhecer o mundo, da mesma maneira que se rejeita a crença de excessiva confiança na capacidade explicativa de fenômenos a partir do exclusivo repertório cognitivo e significativo do cosmos jurídico. A interdisciplinaridade à qual se recorre neste estudo, apesar de partir do Direito Positivo e a ele retornar ${ }^{294}$, de forma alguma deposita integralmente o critério de validade absoluto em um ou em outro ramo do conhecimento humano escolhido para compor este trabalho, mas na conjunção explicativa de todos estes.

Esta maneira de operar a interdisciplinaridade permitirá conduzir uma reflexão segura sobre o conhecimento jurídico sem dele se afastar e sem se deixar seduzir pelo encanto ilusório de respostas imediatas dadas por uma suposta harmonia de outras

\footnotetext{
${ }^{292}$ Sendo essa a razão da escolha da imagem do arco do conhecimento aristotélico, tal qual indicado na Introdução Parcial desta Parte Primeira, supra, para designar imageticamente o caminho a ser perseguido por este trabalho. Parte-se do Direito Positivo e a ele se retorna - como deve ocorrer em toda investigação que se desenvolve dentro do campo do conhecimento jurídico. Nesse processo, o conhecimento jurídico será novo, pois resultará da conjunção de aparato conceitual novo e elementos da experiência histórica (novos ou já conhecidos) e normativos (já conhecidos).

${ }^{293}$ Ainda que haja a ênfase no enfoque Zetético, como ressaltado anteriormente.

${ }^{294}$ Precisamente por se tratar de uma reflexão desenvolvida no interior do quadro de um pen samento jurídico.
} 
disciplinas. Uma vez esclarecidos os pontos acima, resta conferir agora os termos conceituais segundo os quais será feita essa análise Dogmático-Zetética do fenômeno jurídico-político da CECA $^{295}$ para, em seguida, haver sua aplicação neste estudo ${ }^{296}$ sobre os elementos da experiência histórica e da experiência normativa da CECA. 


\title{
TERCEIRO CAPÍTULO - A ANÁLISE JURÍDICA COMO ANÁLISE INSTITUCIONAL: DEFINIÇÃO E MATRIZ DE LEITURA
}

\begin{abstract}
[T]odos nossos termos têm de ser entendidos exclusivamente em conformidade com o sentido que nossas explicações lhes prescrevem, mas não noutro sentido qualquer sugerido pela história ou pelos hábitos terminológicos do leitor. (HUSSERL, 2006, p. 85, grifos do autor).
\end{abstract}

Este texto afirmou reiteradamente que seu objetivo consistia em desenvolver uma leitura jurídico-política da construção histórica da CECA, leitura esta que partiria de uma consideração conjunta da História de constituição desta Organização Internacional e da análise das instituições positivadas em seu respectivo Tratado Constitutivo (Tratado de Paris, de 1951).

O comprometimento deste estudo com um exame detalhado do texto de Direito Positivo do Tratado da CECA lhe asseguraria uma aderência ao campo característico de uma Pesquisa em Direito ${ }^{297}$, apesar de ele buscar polos de intencionalidade em contribuições advindas de outras áreas do conhecimento humano.

Apesar da clareza dos pontos de partida segundo os quais será efetuado o deslocamento intelectual em direção à CECA, poderia ser suscitada uma aparente contradição primordial, a qual poderia constituir efetiva barreira intelectual à consecução dos objetivos deste estudo. Em outras palavras, haveria um elemento supostamente essencial que, se tivesse sido notado desde o início, poderia paralisar a possibilidade de desenvolver a presente análise. São necessárias maiores especificações, não apenas para explicitar o que poderia ser levantado como bloqueio intelectual, como também para dissipar as aparentes aporias potencialmente dele decorrentes.

Seria possível apontar a título preliminar um dado fundamental que poderia macular a presente análise com profundo vício. Tratar-se-ia de uma verdadeira petição de princípio, pois impediria a produção das significações pretendidas e que foram até o presente momento anunciadas. Para tornar explícito este aparente bloqueio essencial, é necessário relembrar, aqui, a afirmação de Edmund HUSSERL (1980, p. 72): “[a] significação [sobre fenômenos] não pode, por assim dizer, flutuar nos ares”. Evidencie-se com distinção o que se pretende suscitar com a presente reflexão.

${ }^{297}$ Como visto no item 2.2., supra. 
Em uma consideração apressada de tudo o que até então fora dito, seria ainda possível suspeitar sobre a aparente impossibilidade de se traçar uma leitura jurídicopolítica da CECA em virtude do seguinte e singelo aspecto - a princípio incontornável.

A despeito de se pretender atribuir uma leitura jurídico-política à História de construção da CECA e de seu Tratado Internacional constitutivo, poder-se-ia objetar ser dado inegável que a maior parte do conteúdo deste documento jurídico-normativo positivo seria constituída por normas de Direito Econômico. Em outras palavras, o Direito Comunitário europeu seria um "verdadeiro Direito Econômico" (VIEIRA, 1999, p. 173), por suas competências dizerem respeito em maior parte ao campo da regulamentação jurídica das relações econômicas internacionais desenvolvidas entre seus países-membros (REUTER, 1965, p. 197).

Com efeito, a parcela normativamente mais complexa do Tratado - todo seu Título Terceiro, destinado a circunscrever as Disposições Econômicas e Sociais do Direito Originário da CECA (artigos 46 a 75 do Tratado da CECA) ${ }^{298}$ - teria se manifestado por meio de normas jurídicas positivas dotadas de conteúdo econômico, isto é, por meio de disposições sobre: (i) Finanças; (ii) Investimentos e Auxílios Financeiros; (iii) Produção; (iv) Preços; (v) Acordos e Concentrações de Mercado; (vi) Atentados às Condições de Concorrência ${ }^{299}$; (vii) Salários e Circulação de Mão-de-Obra; (viii) Transportes; e (ix) Política Comercial.

Diante dessa descrição, não se poderia argumentar que o Direito Comunitário Originário da CECA seria fundamental e exclusivamente econômico?, isto é,

aquele que [...] nasce e se desenvolve nas zonas de "mercado comum", nos processos de integração e formação de blocos econômicos comunitários de Estados. Através deles, os Estados conseguem transformar seus mercados nacionais em um mercado único e compartilhado, denominado "mercado comum". (BASSO, 1997, p. 21).

\footnotetext{
298 Tratam-se de apenas 30 (trinta) artigos, de um total de 100 (cem), vale dizer, de exatos 30\% dos artigos do Tratado. Todavia, se estruturalmente o número de artigos não sinaliza ser a maioria das normas, as Disposições Econômicas e Sociais deste Tratado são, em número de páginas, a maior parcela do Tratado.

De todo modo, como se pode notar desde já, há inúmeras outras normas neste Tratado, fora do Título Terceiro, preocupadas com questões distintas da de regulação jurídica de conteúdo econômico, tais como solução de controvérsias na Comunidade, relações da CECA com outras Organizações Internacionais, entre outros. Isso sinaliza desde já que o próprio conteúdo jurídico-positivo do Tratado não é exclusivamente de Direito Econômico. V., nesse sentido, o Sétimo Capítulo deste trabalho, infra.

Ainda assim, este e o próximo item se dedicarão a resolver o problema de como interpretar jurídicopoliticamente normas de Direito Econômico, a fim de afastar ceticismos interpretativos deste tipo, derivados da constatação da presença de normas de Direito Econômico no Tratado da CECA. Esta objeção, por si só, não impede o desenvolvimento deste empreendimento investigativo.

${ }^{299}$ Isto é, de um mercado estruturado economicamente em ambiente concorrencial.
} 
Nesse sentido, como poderia um estudo pretender produzir uma significação jurídico-política sobre normas jurídicas de Direito Econômico (CELLI JR., 1990, p. 16-9; VIEIRA, 1999, p. 125 e 169-79 ${ }^{300}$ ? Não haveria aqui uma indelével petição de princípio a obstar a construção de um raciocínio jurídico apartado de uma reflexão tipicamente econômica sobre a CECA (CASELLA, 1994c, p. 247)? Não estaria com isso impedida uma reflexão que não tivesse em mente a condição de a CECA ser fundamentalmente processo de integração voltado à unificação econômica construída a partir de um âmbito setorialmente reduzido: o específico mercado do carvão e do aço (BASSO, 1998a, p. 81, 1998b, p. 34; CELLI JR., 1990, p. 87; RAMOS, 2005, p. 49; REUTER, 1965, p. 173-4) ${ }^{301}$ ?

Mais simplesmente, como seria possível manter a suspensão de leituras econômicas sobre a CECA, se esta Comunidade teria se expressado juridicamente por meio de normas positivadas de conteúdo econômico (FRIEDMANN, 1964, p. 63 e 68), as quais somente direcionariam à união exclusiva do setor econômico do carvão e do aço (simples união econômica) (BASSO, 1998a, p. 81, 1998b, p. 34; RAMOS, 1996, p. 648; VEÇOSO, 2006, p. 27, 32 e 249)?

Em suma, se a significação não pode "flutuar nos ares", e se a CECA contemplaria fundamentalmente apenas questões econômicas, como entender ser possível encontrar um sentido jurídico-político em elementos jurídico-normativo positivos desprovidos de uma essência jurídico-política (CASELLA, 1994c, p. 247)?

\footnotetext{
O direito comunitário europeu é direito essencialmente econômico, de inspiração liberal, dotado de conteúdo específico, revestido de caráter supranacional, baseado no reconhecimento da eficácia da economia de mercado, e na primazia desse sistema na Europa "ocidental”. Esses artigos de fé econômica tornaram-se dispositivos jurídicos inseridos nos Tratados de Paris e de Roma, marcando indelevelmente o direito comunitário como direito econômico, tanto por sua essência, bem como pela natureza e direcionamento de sua regulamentação. (CASELLA, 1994c, p. 247, grifos nossos).
}

\footnotetext{
${ }^{300}$ Para este último autor, o Direito Comunitário seria um Direito essencialmente Econômico, estando deste modo dotado de "todas as características básicas doutrinariamente atribuídas ao Direito Econômico" (VIEIRA, 1999, p. 173).

${ }^{301}$ Tendo em vista que o objetivo fundamental da CECA consistiria simplesmente em "gerir a produção e comercialização do carvão e do aço, essenciais para eventual produção de armamentos, diminuindo as tensões entre Estados rivais, a Alemanha e a França, que, a partir de então, compartilhavam um futuro comum" (RAMOS, 2005, p. 49).
} 


\subsection{A Significação Jurídico-Política em torno das Normas de Direito Econômico da CECA}

As indagações acima são legítimas, e certamente fariam soçobrar as pretensões mais fundamentais deste estudo, caso não fossem seriamente consideradas. Por isso mesmo, devem tais objeções passíveis de serem suscitadas pela tradição ser vistas à luz das delimitações efetuadas nos Capítulos anteriores. Suscita-se aqui a dúvida sobre a necessariamente íntima e necessária ligação visceral entre o Direito Comunitário Originário da CECA e a perspectiva Econômica - ou ainda, sobre a possibilidade de se desenvolver apenas e tão-somente uma leitura jurídico-econômica da História da CECA e de suas normas jurídicas positivas originárias, dado se caráter essencialmente de Direito Econômico:

\footnotetext{
diga-me a razão precisa porque você pensa como inseparáveis de direito esses conteúdos distintos e desligados. Essa conexão de direito [...] eu o desafio a encontrá-la: você só poderá, vencido pelo cansaço, invocar a sua experiência passada e a de todos os homens. Mas uma repetição de experiência já garantiu alguma vez a necessidade absoluta de alguma relação? Ora, quando se trata de fatos e eventos, voce [sic] nunca obterá o equivalente dessa certeza geométrica... (LEBRUN, 1993, p. 9, grifos do autor).
}

Dissipado este questionamento e coberta a exposição da nervura deste trabalho, estaria livre o caminho para os adequados desenvolvimento e compreensão coerentes e conscientes dos limites e das possibilidades de explicação jurídico-política da CECA por este estudo. Parcial - como todo e qualquer estudo, como visto nos itens anteriores, porém possível e metodologicamente rigoroso e consistente.

É inegável a presença no Tratado de normas jurídico-positivas dotadas de conteúdo econômico, cujo objetivo consistia em regulamentar as condições do mercado de carvão e do aço no interior da Comunidade. Esquecer essa condição seria um indevido falseamento. Nenhuma Pesquisa séria sobre a CECA poderia ignorar a presença de um tecido normativo de Direito Econômico. Não se pode efetivamente compreender o Tratado da CECA sem suas normas de Direito Concorrencial, de regulamentação da Política Comercial, de circulação de mão-de-obra, entre tantas outras.

No entanto, a despeito da inafastável existência de tais normas de Direito Econômico, é fundamental perceber que a possibilidade de lhes atribuir uma significação jurídico-política permanece. E, para tanto, é crucial que seja mais uma vez lembrada de maneira completa a afirmação de Edmund HUSSERL (1980, p. 72): “[a] 
significação não pode, por assim dizer, flutuar nos ares, mas o signo, do qual dizemos que ela é a significação, é totalmente indiferente àquilo que ela significa.”.

Essa afirmação é imprescindível para compreender o presente estudo. Sua relevância decorre não apenas em virtude de seu próprio teor, mas principalmente porque ela permite recordar a singular condição deste estudo: desenvolver-se no interior de campo do conhecimento constituído a partir de uma redução fenomenológica. Em outras palavras, em momento algum de cada etapa da construção do pensamento neste trabalho foi esquecido que, neste estudo, o conhecimento foi produzido em regime de redução fenomenológica, reconhecendo-se constantemente que se lidava com fenômenos ${ }^{302}$.

Nesse sentido, lembre-se de que não existe uma essência escondida, pré-definida e absolutamente permanente nas coisas que se procura conhecer, pois "quando conhecemos ou formulamos um conhecimento, nada desvendamos de 'Ser em si', não deciframos um texto que teria sido gravado 'nas coisas' [...]. Penetrar por nossa razão nas coisas... Pretensão fanfarrã [...].” (LEBRUN, 1993, p. 11, grifos do autor).

Efetivamente, o sentido das coisas não é por elas guardado em sua intimidade, ou ainda, não é portado por elas mesmas para a consciência: "uma proposição, para ser científica, não precisa inscrever-se num logos que já tivesse organizado o Ser ou o 'fenômeno'." (LEBRUN, 1993, p. 13). Antes, são as intencionalidades projetadas por uma consciência localizada em determinada posição com relação aos fenômenos que constroem o conteúdo das coisas. As coisas são apenas o ponto de convergência ideal, unitário e vazio de cada uma das infinitas possibilidades de interpretação.

Nesse sentido, ao redor das normas de Direito Econômico do Tratado da CECA há inúmeras camadas significativas. Tais normas podem ser objeto de um sem número de formas de interpretação - ainda que sejam um e mesmo fenômeno a ser conhecido. Em outras palavras, não se pode ignorar que nada - nem mesmo as normas de Direito Econômico da CECA - detém uma essência, um caractere permanente, imutável e absoluto.

\footnotetext{
Em nenhum domínio dos fenômenos culturais pode a redução unicamente a causas econômicas ser exaustiva, mesmo no caso específico dos fenômenos “econômicos". (WEBER, 2006, p. 42, grifos do autor).
}

Por esse motivo, por mais que grande parte das normas jurídicas do Tratado da CECA se expressassem por meio de instrumentos regulatórios dotados de conteúdo

\footnotetext{
${ }^{302}$ Sobre redução fenomenológica, fenômeno e conceitos relacionados, v. o itens 2.2.1. e 2.2.2, supra.
} 
econômico, tais normas não eram natural ou essencialmente jurídico-econômicas, pois não existe essência absoluta de coisa alguma, nem mesmo uma suposta essência econômica de tais normas jurídicas positivadas no Tratado da CECA.

Em outras palavras, essas normas não são apenas passíveis de serem entendidas a partir de teia significativa de Direito Econômico: elas não portam a chave secreta (econômica) de seu significado, pois todo fenômeno tem seu significado atribuído pelos pontos de partida de leitura. Isso somente quer dizer que elas podem também ser entendidas economicamente - mas jamais de maneira exaustiva pela Economia.

Isso implica reconhecer que, uma vez assumida pela consciência uma posição preocupada em examinar questões relacionadas aos jogos de Poder normativamente distribuídos entre os diferentes participantes da vida em comum - a fim de compreender o processo de formação do sentido normativo último sobre questões concretas sensíveis tornadas comuns, tal qual estabelecido pelo Tratado da CECA, ainda que tais normas jurídicas positivas tenham se expressado textualmente por meio de Direito Econômico, subsistiria permanentemente uma camada alternativa de significação em torno de tais normas - uma camada jurídico-política. Tudo dependeria da origem do raio da consciência, vale dizer, da posição produtora de intencionalidades jurídico-políticas sobre tais normas.

Reitere-se que não se ignora o fato de que, em uma primeira leitura, parece evidente que as normas de Direito Econômico constantes do Tratado da CECA efetuam somente uma regulamentação jurídica de relações econômicas. Em outros termos, a primeira camada de significação normativa é, sem sombra de dúvida, jurídico-econômica.

Todavia, enquanto fenômeno, isto é, enquanto algo a ser conhecido como dotado de uma infinidade de possibilidades de leitura, tais normas não podem ser compreendidas como efetuando apenas uma regulamentação no plano do Direito Econômico. Isso derivaria de uma ligação costumeiramente repetida, isto é, da imposição de um único vínculo de associação supostamente necessário entre CECA, Economia e Direito Econômico, vínculo este dado por hábitos interpretativos (LEBRUN, 1993, p. 9-10) construídos pela tradição. Todavia, não se pode se esquecer de que

\footnotetext{
o costume é efetivamente pérfido e tirânico [...]. Pouco a pouco, às escondidas, ganha autoridade sobre nós; a princípio terno e humilde, implanta-se com o decorrer do tempo, e se afirma, mostrando-nos de repente uma expressão imperativa para a qual não ousamos sequer erguer os olhos. (MONTAIGNE, 1980, p. 57).
} 
Desprovidas de uma essência econômica única, absoluta e permanente, tais normas jurídicas positivadas, enquanto fenômeno para o qual se dirigem intencionalidades as mais distintas possíveis ${ }^{303}$, também podem ser compreendidas sob uma perspectiva jurídico-política ${ }^{304}$. A abertura desse campo infindável de análises jurídicas se revela como o ganho de se ter consciência de que o presente conhecimento jurídico se desenvolve em regime de redução fenomenológica.

É nesse sentido que a significação sobre algo não "flutua nos ares", apesar de ser completamente distinto deste mesmo algo. Aquilo que é significado opera apenas como um $\mathrm{X}$ idêntico e unitário vazio sobre o qual se produz uma infinidade de significações. Essa significação não representa este algo, não o traz em si mesma como coisa pura e simples à consciência. Antes, ela é produto das intencionalidades projetadas sobre ele pela consciência em virtude de posição por esta assumida: o sentido de algo é definido pelos pontos de partida que a consciência assume com relação a este algo. Sua essência é relativa sempre a uma significação sobre ele lançada.

Deste modo, se se quer analisar jurídico-politicamente também as normas de Direito Econômico do Tratado da CECA, não há com isso qualquer incompatibilidade de pretensões $^{305}$. Em regime de redução fenomenológica, elas não possuem uma incontornável essência econômica: esta é apenas uma forma de as ler, ou seja, esta é apenas um modo de doação de sentido a tais instrumentos jurídico-normativos pela consciência.

Assim, dentre inúmeras outras, é possível em torno das normas da CECA encontrar também preocupações com a regulamentação do fundamento do Direito e do Poder na Comunidade - uma explicação igualmente válida e digna, como a econômica. Persistir na exclusiva possibilidade de leitura econômica da CECA é se manter na

inaudita ausência de espírito crítico relativamente à interpretação econômica da realidade, concebida como método "universal", no sentido de uma dedução de conjunto dos fenômenos culturais - isto é, de tudo o que para nós é essencial neles - a partir de condições que em última instância seriam econômicas. [...

\footnotetext{
${ }^{303} \mathrm{E}$, dessa forma, produtoras das mais diferentes significações.

${ }^{304}$ Bastando selecionar polos de intencionalidades preocupados em enfatizar neste fenômeno elementos outros que a simples camada da regulamentação jurídico-econômica. Em outros termos, seria suficiente apontar ser possível construir e, efetivamente, coser, a partir das mesmas normas positivadas, um tecido jurídico-normativo preocupado em regulamentar também problemas relacionados ao fundamento do Direito e do Poder na Europa Unida da CECA. Essa condição restará mais clara quando da leitura integral deste Capítulo e do Sétimo Capítulo, infra.

${ }^{305}$ Pois não há qualquer incompatibilidade "essencial" ou "por natureza" entre a leitura a ser desenvolvida neste trabalho e aquilo que será interpretado, na medida em que não há, em suma, qualquer essência ou natureza de algo.
} 
Segundo essa posição acrítica] determinantes políticas, religiosas, climáticas ou quaisquer outras não-econômicas [... são] fatores então rebaixados ao nível de "condições" historicamente acidentais, sob as quais os motivos econômicos atuam como "causas", tendo em vista preservar a supremacia do econômico. (WEBER, 2006, p. 40-1, grifos do autor).

Como afirmado linhas acima, não se pode ignorar que uma primeira camada de significação de determinadas normas jurídicas positivas do Tratado da CECA é, sem sombra de dúvida, jurídico-econômica, isto é, voltada a regulamentar as condições de um mercado concorrencial no setor do carvão e do aço na Comunidade.

Entretanto, a produção de um significado jurídico-político sobre as mesmas normas jurídicas de Direito Econômico exige que se ultrapasse essa primeira camada significativa, excessivamente ancorada na epiderme da dimensão textual da regulamentação. Essa leitura se torna ensimesmada, autorreferenciada, e interrompe o processo de comunicação com os outros intérpretes, significando apenas a si própria.

Por isso mesmo, há que se recusar este se deixar seduzir e conduzir permanentemente por esta materialidade literal do significante (JAMESON, 1985, p. 21-2) jurídico-econômico positivado e buscar nele encontrar vias para produzir interpretações alternativas que rompam com esse cego ensimesmamento. No caso deste estudo, para atribuir uma significação jurídico-política ${ }^{306}$.

A superação da vertiginosa condução pela literal materialidade do significante jurídico-econômico é possível, desde que se procure desnaturalizar a imediata, costumeira e automática atribuição de sentido exclusivamente econômico às normas jurídicas do Tratado. Não se deve aceitar a incrustação artificial deste modo de leitura unidimensional sobre tais normas, sob pena de se lhes negar a conexão com outros campos de significação (como o campo jurídico-político).

[I]1 ne suffit pas d'observer que l'interprète exerce une puissance, $[\ldots]$ qu'il s'arroge un certain savoir [...]. L'essentiel est qu'il aménage un champ de discours $[\ldots]$ où les opérations apparaissent comme réglées en vertu de leur

306 Saliente-se mais uma vez que este trabalho não procura afirmar que o Tratado da CECA não regulamentou juridicamente relações econômicas no interior da Comunidade; na verdade, o que este trabalho procura apontar é que este Tratado não procurou apenas regulamentar as relações econômicas.

Como será possível perceber durante a leitura deste Terceiro Capítulo e do Sétimo Capítulo, infra, as mesmas normas jurídicas procuraram construir uma regulamentação sobre o problema do fundamento do Direito e do Poder na Comunidade.

Não se trata assim de afirmar ingênua e obstinadamente que o Tratado da CECA não regulamentou relações econômicas. Antes, se trata de afirmar que este documento jurídico internacional não apenas buscou regular esse tipo de relações. Outras preocupações, não-ditas de forma expressa no texto do Tratado, foram objeto de regulamentação por meio das normas ditas: preocupações de caráter jurídico-político. Como se poderá ver a seguir, neste Terceiro Capítulo e no Sétimo Capítulo. 
efficacité en regard d'un but de connaissance et en vertu de leur légitimité, dans la mesure où elles semblent de nature à y attirer un lecteur qui ne pourra que consentir à la contrainte - la persuasion - sur lui exercée, au nom des principes qui commandent la lisibilité du texte dans le réel. Une telle démarche est seule de nature à lui assurer une autorité qui, bien qu'elle soit au bénéfice de sa personne, trouve sa garantie en dehors d'elle. La position de pouvoir se désigne seulement dans cette perspective ; et l'on voit aussi qu'elle se soutient de la production de signes ou de preuves tirés du discours interprété qui ont pour fonction d'obtenir le consensus des lecteurs en faisant reconnaître l'efficacité et la légitimité de l'interprétation.

Mais non moins remarquable est l'impossibilité où se trouve l'interprète d'occuper pleinement cette position, c'est-à-dire de mettre un terme à l'histoire des interprétations. [... L] a plus grande tentation de l'interprète est d'occuper la position du pouvoir absolu : elle se signale dans l'accomplissement d'un projet grâce auquel s'aboliraient la division de deux discours, la division des temps et celle du discours et du réel. (LEFORT, 1986, p. 308-9, grifos do autor).

Nesse sentido, a experiência de leitura do significante normativo positivo do Tratado da CECA não pode ser reduzida a uma sobrecarga significativa exclusivamente econômica ${ }^{307}$. Isso pode implicar uma desnorteante compreensão do real, pois se passa a ignorar que ele não é uni, mas pluridimensional. Os sentidos dele são plurais e intermináveis, não podendo qualquer experiência de significação pretender totalizar unilateralmente as formas de o compreender, excluindo as demais. Apenas uma escandalosa restrição de formas de compreender o mundo pode querer restringir as possibilidades de leitura de todo e qualquer fenômeno - tal qual o fenômeno jurídicopolítico da CECA.

\begin{abstract}
[T]ão logo tentamos tomar consciência do modo como se nos apresenta imediatamente a vida, verificamos que se nos manifesta "dentro" e "fora" de nós, sob uma quase infinita diversidade de eventos que aparecem e desaparecem sucessiva e simultaneamente. E a absoluta infinidade dessa diversidade subsiste, sem nenhuma atenuante de seu caráter intensivo, até mesmo quando prestamos nossa atenção, isoladamente, a um único "objeto". [...] Assim, todo conhecimento reflexivo da realidade infinita realizado pelo espírito humano finito baseia-se no pressuposto tácito de que apenas um fragmento limitado dessa realidade poderá constituir de cada vez o objeto da compreensão científica. (WEBER, 2006, p. 44, grifos do autor).
\end{abstract}

Busca-se com isso recusar que a presença de normas jurídicas de Direito Econômico possam significar apenas a produção de um discurso jurídico-econômico, precisamente porque as infinitas significações passíveis de serem produzidas devem ser mantidas mais vivas do que a exclusiva dimensão literal do significante. Recusa-se com isso a tendência monista de um conhecimento simplesmente jurídico-econômico da História da CECA e de suas normas jurídicas positivas.

${ }^{307}$ Ou de qualquer ponto de partida outro. 
[A] análise dos fenômenos sociais e dos eventos culturais sob a perspectiva especial de seu condicionamento e alcance econômico foi um princípio científico de fecundidade criadora, e continuará a sê-lo enquanto dele se fizer um uso prudente e livre de inibições dogmáticas. [...].

[E]ncontra-se ainda muito difundido o singular fenômeno de que a necessidade de explicação de um fenômeno histórico não fica satisfeita enquanto não se demonstre (mesmo que só na aparência) a intervenção de causas econômicas. Feito isso, eles passam a contentar-se com as hipóteses mais frágeis e as formulações mais genéricas, pois já se deu satisfação à sua necessidade dogmática segundo a qual as "forças" econômicas são as únicas causas "autênticas", "verdadeiras" e "sempre determinantes em última instância". [Para esta perspectiva, e]sse fenômeno nada te[ria] de extraordinário, de resto. (WEBER, 2006, p. 38-9, grifos do autor) ${ }^{308}$.

No interior do campo de interpretação jurídica sobre o fenômeno da CECA, este trabalho almeja que se deixe de se deslocar o intelecto singelamente no interior de um plano literal das regulamentações jurídicas, dado a partir do desertificante imaginário de explicação unidimensional econômica.

Tenta-se com isso recusar a permanência do fascínio pela preponderância absoluta do significante econômico. Quer-se buscar nele e para além dele outras formas de o compreender, isto é, apontar que nele é possível também encontrar e projetar alternativas à fácil, imediata e encantadora interpretação econômica. Pretende-se, assim, “[u]ltrapassa[r ...] a materialidade das palavras [que] se torn[ou] obsessiva, como ocorre quando crianças repetem sem cessar uma mesma palavra até seu sentido desaparecer e ela adquirir um fascínio inteligível.” (JAMESON, 1985, p. 22).

Para que seja possível sobre este fenômeno projetar uma luminosidade apta a evidenciar a condição jurídico-política de tais normas, é importante que sejam esclarecidos os critérios de análise que nortearão esta investigação.

Isso permitirá descobrir uma regulamentação jurídico-normativa de questões relacionadas ao fundamento do Direito e do Poder concomitante e subjacente às normas jurídicas positivas da CECA, mesmo às responsáveis pela regulamentação jurídicoeconômica. Afinal, é possível construir, a partir das mesmas normas positivadas (econômicas ou não), um tecido jurídico-normativo preocupado em regulamentar

\footnotetext{
${ }^{308}$ A parcela final desta citação se refere a uma crítica de Max WEBER (2006, p. 38) a explicações fundadas no materialismo histórico marxista, vulgarizado nas mentes de "leigos ou diletantes".

Note-se, todavia, que o recurso a essa citação não endossa simplesmente a crítica weberiana à obstinação desta leitura marxista leviana de tudo reduzir a explicações de causas econômicas. Na verdade, extrapola-se o campo desta crítica ao materialismo histórico e se dirige aqui contra toda e qualquer forma de compreensão de um fenômeno que pretenda fornecer uma chave-explicativa única, última, definitiva e acabada - principal, mas não exclusivamente, jurídico-econômica.
} 


\section{também o fundamento não-uniescalar do sentido normativo último sobre questões comuns na CECA.}

\subsection{Análise Institucional: Mapeamento e Crítica do Direito Positivo}

A elucidação dos critérios diretores da análise institucional será efetuada nos itens 3.3.3. e 3.4., infra. Antes disso, é ainda importante compreender um pouco mais em que consiste desenvolver uma interpretação jurídica no interior de uma proposta de análise institucional.

Quando se afirma que se pretende desenvolver uma análise institucional, poder-seia compreender que se busca desenvolver simplesmente uma minuciosa descrição das articulações técnicas de um texto de Direito Positivo. Tratar-se-ia de um extenso catálogo de comentários exaustivos, o qual se restringiria a fazer infinitas combinações mais ou menos inventivamente sagazes entre os mais diferentes significantes textuais de Direito Positivo expressos em cada um dos artigos do Tratado ${ }^{309}$.

Este, todavia, não é o significado preciso de análise institucional assumido por este estudo. Apesar da importância do tipo de investigação acima apontado, não se encontra essa forma de estudo dentro do campo de preocupações deste trabalho. Este texto não quer se cingir a uma descrição detalhada dos significantes de Direito Econômico positivados, pois se recusa a recair na "trivialização ou [n]a mistificação de instituições pelas formas dominantes de análise econômica.” (UNGER, 2004, p. 38).

Antes de tudo, objetiva-se evidenciar a possibilidade de uma significação jurídicopolítica do texto do Tratado, dentre todas as possibilidades interpretativas que se encontram eclipsadas em seu texto. Com isso, será possível compreender a efetividade da prática de contradições escalares estabelecida pelas normas do Direito Originário da CECA para determinar o fundamento do Direito e do Poder na Comunidade ${ }^{310}$.

A realização de uma análise institucional é uma das mais importantes tarefas dos estudos jurídicos contemporâneos. Ela permite que uma sociedade possa encontrar meios para se expressar por meio de seu próprio Direito Positivo ${ }^{311}$. Inserto em teias de

\footnotetext{
${ }^{309}$ Dir-se-ia, "artigo por artigo, parágrafo por parágrafo".

310 "Contradições escalares" significa, aqui, a oposição entre diferentes formas de habitar o mundo - referida nos Capítulos anteriores, isto é, os conflitos entre diferentes maneiras de medir o mundo e de o experienciar portanto, entre diferentes escalas de existência. Essa construção restará mais clara a partir da leitura dos itens 3.3.3. e 3.4., infra, bem como a partir da leitura do Sétimo Capítulo da Tese.

${ }^{311}$ No que se refere à atual UE, essa parece ser precisamente a principal preocupação contemporânea.
} 
Diante do intenso desenvolvimento institucional da União Europeia desde a década de 1990, instaurara-se um "caos institucional" (BOGDANDY, 2001, p. 617): “[1]'interaction des institutions originaires s'est diversifiée et d'importantes institutions sont venues s'ajouter à celles-ci, telles que la BCE, le Comité des Régions ainsi que de nombreuses agences.” (BOGDANDY, 2001, p. 619).

Esta seria, para Fabia Fernandes Carvalho VEÇOSO (2006, p. 25-6), a característica fundamental da UE: "O que efetivamente torna essa evolução na UE algo distinto é o fato de a integração européia estar sempre em processo constitutivo, ou seja, pode-se afirmar que a integração regional ora em análise seria um processo de construção permanente, no sentido de haver constante recriação de sua ordem jurídica, de forma a superar o esquema existente em fase anterior.”.

Pensa-se hoje na UE em como organizar um complexo institucional que vise a conciliar uma dupla tendência de fragmentação e de centralização de instituições, a fim de ajustar essa contradição institucional na qual a própria UE se reconhece (BOGDANDY, 2001, p. 651). Há assim efetiva preocupação em desencadear um profundo processo de imaginação institucional na UE com o objetivo de rever os fundamentos da instrumentalização prática dessa União (JOERGERS, 2010; VÉRON, 2011).

"[L]as reformas institucionales han sido consideradas absolutamente necesarias, en ello todos de acuerdo, pero ¿Cuáles?, ¿Qué cantidad y calidad de reformas? Ah esto ya ha sido otra cosa y las posiciones no han concurrido tanto, por ello el camino recorrido y por hacer en el ámbito de los cambios no resulta fácil." (POZO, 2009, p. 154).

Indique-se, exemplificativamente, que enquanto Christian JOERGERS (2010) se preocupa com a arquitetura institucional da UE de hoje visando a lidar com o problema do déficit democrático de suas instituições após o Tratado Constitucional rejeitado e o Tratado de Lisboa, Nicolas VÉRON (2011) aponta para essa necessidade a partir de uma perspectiva econômica, voltada à construção de uma Europa Federal. Parecendo partilhar de uma perspectiva conjunta de ambos, propõe Joseph H. H. WEILER (2011) a inserção de instrumentos de aumento de participação democrática em uma futura Europa marcada por um pacto federal econômico. No mesmo sentido, a proposta de Jürgen HABERMAS (2011a, 2011b, 2012), no sentido de instaurar um sistema de Soberania partilhada entre os povos e os cidadãos europeus, de maneira a promover uma soberania popular transnacional.

É relevante lembrar a observação de Carlos CLOSA (1995, p. 147), segundo a qual toda reforma da estrutura jurídico-positiva institucional não apenas pode produzir uma modificação da autocompreensão da Comunidade, mas também dela resultar.

Com efeito, não se trata de uma alteração singela de normas jurídicas pontuais, a qual resta adstrita a retoques numéricos ou técnicos. Antes, trata-se de verdadeira assunção de uma ou de outra concepção de mundo - dentre inúmeras possíveis - que pretende conferir à Comunidade condições suficientes para fazer frente aos desafios internacionais que se lhe apresentarão nos próximos anos (POZO, 2009 p. 153-5). Afinal, as reformas institucionais são informadas por "imagina[ción de] un sistema institucional que resulte útil y eficaz para el logro de los objetivos de la integración en el marco de los próximos años o décadas." (POZO, 2009, p. 154).

Como sinalizado por diversas vezes, a leitura econômica é colocada entre parênteses pelo presente estudo. Ademais, este trabalho não se dedica a compreender a Europa Unida de hoje, sob o nome de União Europeia, mas aquela que fora institucionalizada pelo Tratado da CECA. Por essa razão, a menção a esses autores não foi feita para endossar as perspectivas deles, mas apenas para sinalizar que a ideia de se preocupar com uma análise institucional da Europa Unida - tal qual evidenciada pelo presente estudo - é uma forte tendência do pensamento jurídico contemporâneo sobre a União Europeia. O que explicita que este trabalho dialoga de maneira atualizada com preocupações contemporâneas dos estudos jurídicos sobre a integração na Europa - por o pensar o desenho institucional da UE ser um tema de preocupação atual.

De todo modo, a importância de uma imaginação e de uma compreensão institucionais da Europa Unida aparece como desafio fundamental para os juristas contemporâneos, qualquer que seja seu ponto de partida. Todos buscam encontrar hoje uma fórmula para "acomodar el sistema institucional a las nuevas realidades que conforman el panorama rico, amplio y profundo de la integración europea” (POZO, 2009, p. 154). O que evidencia também a atualidade do método e da preocupação que informam a presente reflexão, ainda que direcionados ao estudo da CECA. Precisamente porque o estudo da História jamais pode deixar de deter preocupações atuais, como se poderá v. no início do Quarto Capítulo deste trabalho, infra.

De fato, visa-se aqui a compreender como o arranjo institucional da CECA fora concebido e arquitetado de maneira a lidar com o problema de estabelecer um novo modo de relações entre os países europeus que a compunham no pós-Segunda Guerra Mundial.

A presente Tese não se orienta nesse sentido em virtude de mero interesse de curiosidade histórica. Antes, há uma forte preocupação de compreender o tempo presente, a partir deste estudo histórico. Este evidenciará o exemplo histórico de uma prática institucional virtuosa a ser aprendida e perpetuada. Esta ideia será mais bem compreendida quando da leitura do início do Quarto Capítulo deste trabalho. 
preocupações democráticas, deve o jurista encontrar e compreender os meios para expressar institucionalmente os modos como sua sociedade e as demais concebem as relações que definem o sentido último do Direito e do Poder em uma mesma Comunidade (UNGER, 2004, p. 9) - ou, ao menos, para entender a expressão institucional de tais modos encontrados por cada sociedade.

Nesse sentido, é importante lembrar que as instituições positivadas em documentos jurídicos são a roupagem normativa segundo a qual as sociedades se expressam por meio de estruturas práticas. São elas o meio segundo o qual "um ideal de civilização assume forma institucional detalhada." (UNGER, 2004, p. 9).

Quando se preocupa com uma abordagem jurídico-política de fenômenos em uma análise institucional, busca-se compreender o modo como foram desenvolvidas socialmente estruturas práticas voltadas à regulamentação jurídico-positiva (UNGER, 2004, p. 41) do fundamento do Direito e do Poder em um sistema de convivência entre diferentes.

Dessa forma, ao se aproximar de um arranjo institucional a partir de uma preocupação jurídico-política, não se pode esquecer de que ele se trata de uma resposta específica - dentre tantas outras possíveis - encontrada pela sociedade para se imaginar juridicamente em questões relacionadas ao Poder (UNGER, 2004, p. 41).

A análise jurídica entendida como análise institucional ganha assim contornos distintos. Ela não visa a efetuar uma simples narrativa descritiva das regulações jurídicas dadas pela conjunção dos significantes textuais das normas jurídicas positivadas. Antes, a análise jurídica compreendida como análise institucional pretende reinserir as instituições investigadas em sua complexa trama de significações possíveis. O objetivo é compreendê-las como uma tentativa de auto-expressão jurídico-positiva de uma sociedade perante suas próprias necessidades. Ou ainda, como uma resposta jurídicopositiva possível ao anseio de estabelecer mecanismos práticos que garantam algo por ela própria almejado.

[H]á modos alternativos plausíveis de definir essas condições, e aí, uma vez definidas, de as satisfazer. Para cada direito de escolha, individual ou coletivo, há concepções plausíveis diferentes das suas condições de realização efetiva na sociedade, tal como ela é organizada hoje. Para cada concepção dessas, existem diversas estratégias plausíveis para preencher as condições especificadas. (UNGER, 2004, p. 44, grifos nossos). 
Não interessam à análise institucional produzir as mais engenhosas combinações intelectuais especulativas entre normas jurídicas positivas, combinações estas preocupadas apenas em apresentar aparentes contradições e dúvidas facilmente solucionáveis, pois derivadas de singelos problemas de compreensão de jogos de linguagem ${ }^{312}$. O foco de sua atenção é tentar compreender um determinado arranjo institucional dado como um modo dentre tantos outros possíveis - encontrado por uma sociedade para "assegurar as condições práticas" que a ela permitam o estabelecimento de uma vida em comum e dos limites dentro dos quais direitos são fruídos (UNGER, 2004, p. 44 e 51).

A análise institucional a ser empreendida por este estudo visa assim a reinserir a compreensão da construção da CECA em uma historicidade que the confira uma significação social complexa e diversa, vale dizer, que a perceba como passível de um grande número de leituras que não exclusivamente jurídico-econômicas. Procura-se compreender de que forma as instituições jurídicas-positivadas neste Tratado Internacional responderam ao intento de seus seis países membros de entre eles instaurar, manter e promover as Leis de um viver comum.

Procura-se com isso identificar série de questões jurídico-políticas subjacentes ao texto de Direito Positivo.

Para além da materialidade literal do significante textual de Direito Positivo (Econômico ou não), será possível atribuir uma significação mais profunda, voltada a apreender a regulamentação do problema do fundamento do Direito e do Poder na convivência comum estabelecida entre esses seis países politicamente unidos no pósSegunda Guerra Mundial.

A análise institucional promovida por este estudo procurará compreender a significação das Leis expressas pelo Direito Positivo da CECA. Não há assim uma pretensão em entender a regulamentação textual do Direito Positivo nele mesmo. Almejase por meio deste estudo entender como a arquitetura dessa regulação instaurou e promoveu um Projeto de União Política de países europeus pelas instituições da CECA.

\section{A presente análise não se esgota na materialidade do significante do texto de} Direito Positivo constante do Tratado: ela quer entender este fenômeno para além desta camada/margem do dito ${ }^{313}$ de significação própria e independente com relação ao plural campo de significações possíveis.

\footnotetext{
312 Ou ainda, "qui simplement cherchent midi à quatorze heures.".

${ }^{313}$ Paulo Borba CASELLA (1994a, p. 249) efetuara o mesmo, com base em outros argumentos, e conforme pontos de partida investigativos distintos dos assumidos pelo presente estudo: "A análise do direito
} 
Quer-se com este estudo deseclipsar a dimensão do não-dito jurídico-político encontrável em camada significativa alternativa à de Direito Econômico. A suspensão de uma explicação jurídico-econômica da $\mathrm{CECA}^{314}$ visa apenas a superar essa ciranda de significantes econômicos para, a partir deles, significar algo diverso, algo que reenvie a CECA a sua posição de fenômeno desprovido de qualquer essência absoluta. Afinal, uma pretensamente duradoura essência econômica não se mostra "mais real" do que a realidade da multiplicidade de possibilidades de significações em torno de um fenômeno (WEBER, 2006, p. 44).

Tratam-se em suma de registros distintos de leitura: apontar, a partir do dito textual do Direito Positivo (Econômico ou não) que se apresenta materialmente ao intérprete, a possibilidade de explicitação de significação de um arco não-dito de preocupações regulatórias jurídico-políticas residente em camada além do simples significante materializado na escrita ${ }^{315}$. Para tanto, é fundamental almejar dizer o não-dito, explicitar o implícito, perceber o não-percebido, encontrar o não-dado a partir do dado.

comunitário está necessária e profundamente ligada à história da Comunidade e sua evolução. Parafraseando célebre assertiva, em direito comunitário, a história pode não ser tudo, mas tem papel muito relevante na compreensão das estruturas e mecanismos atuais, à partir de sua configuração inicial e evolução histórica, com as concomitantes e inevitáveis mutações institucionais. Nesse sentido, em vista de melhor visão da estrutura jurídico-institucional daí resultante, justificou-se retomar o processo genético da Comunidade Européia em suas etapas principais.”.

Assim perceba-se que a recusa a efetuar um singelo comentário prosado-relator mais ou menos articulado de um texto de Direito Positivo constante de um Tratado não é invenção do presente estudo. Há exemplos de qualidade em trabalhos anteriores a este. Todavia, a especialidade desta Tese reside precisamente nas posições de leitura assumidas com relação ao específico fenômeno da CECA e ao de seu Direito Originário (Tratado de Paris, de 1951).

${ }^{314}$ Tal qual indicada na Introdução Geral desta Tese.

315 Frise-se aqui que nenhuma das leituras é mais ou menos válida do que a outra. Cada uma apenas elucida aspectos distintos dados a partir de pontos de partida diferentes para o desenvolvimento da investigação. $O$ que se recusa neste estudo é simples e fácil assunção de uma postura absoluta e incontornável por toda e qualquer leitura que pretenda destacar o Direito Positivo de sua complexidade significativa socialmente dada, permitindo a um discurso auto-referencial que se estabeleça como o único discurso possível.

Saliente-se desde já que, em virtude de este trabalho assumir como fundamento pontos de partidas particulares, apenas e tão-somente estes irão nortear o pensamento constante da Parte Segunda desta Tese, principalmente no que se refere ao Sétimo Capítulo.

Dito de outro modo: apesar de haver um grande número de comentários mais ou menos extensos sobre as disposições do Tratado da CECA - tais como os desenvolvidos por Gérard BOSSUAT (1994), Paulo Borba CASELLA (1994a), Umberto CELLI JR. (1990, p. 81-6); Riccardo MONACO (1961b), Massimo PILOTTI (1959), Carlos Molina del POZO (2002, 2004), Fausto de QUADROS (1984), Paul REUTER (1965), entre tantos outros, este trabalho não recorrerá aos ensinamentos produzidos por estes para escrever seus comentários às instituições da CECA.

Essa opção metodológica não deriva de uma suposta ausência de modéstia de seus desígnios. Tratase antes de uma maneira de garantir a coerência metodológica do presente estudo: se se estabeleceu como premissa de estudo um conjunto de conceitos e de campos significativos, apontando-os como aptos a construir a partir apenas deles um comentário consistente, quer-se demonstrar que estes pontos de partida efetivamente bastam para compreender e para interpretar jurídico-politicamente a articulação entre as instituições da CECA constituídas pelo Tratado de Paris de 1951. 
É por essa razão que o presente estudo efetuará necessariamente um duplo movimento comentador do Tratado da CECA. Ao mesmo tempo em que buscará o mapear, também sobre ele desenvolverá uma crítica. Entenda-se que "[o] mapeamento fornece materiais para a crítica, e a crítica estabelece a perspectiva e a agenda para o mapeamento" (UNGER, 2004, p. 163), ou ainda, que “[o]s momentos de mapeamento e crítica formam uma unidade dialética”. (UNGER, 2004, p. 164).

O mapeamento consiste simplesmente em tentar descrever com detalhes a complexa rede de inter-relações institucionais juridicamente positivadas, isto é, ele visa a exibir com precisão a estrutura institucional. Por sua vez, a crítica se orienta no sentido de avaliar as interações instituicionalmente postas para averiguar de que maneira estas foram direcionadas no sentido de cumprir determinado objetivo socialmente relevante, vale dizer, examina como esta engenharia se mostra apta a realizar um determinado compromisso de convivência (UNGER, 2004, p. 160-2).

O mapeamento é a exploração da estrutura institucional detalhada da sociedade, tal como definida juridicamente. Seria um positivismo ingênuo supor que essa

Longe de constituir qualquer inadvertida e imprudente prepotência teórica de um estudo que pretende ingressar na comunidade epistêmica jurídica brasileira, este afastamento dos comentadores acima mencionados - e de outros possíveis, consiste apenas em uma maneira de buscar manter a integridade da coerência metodológica da leitura proposta por este trabalho.

Não se trata assim somente de uma maneira de evitar o uso deslocado de conclusões produzidas em Pesquisas distintas, de maneira a evitar uma insustentável "contaminação" metodológica e o uso inadvertido de discursos metodologicamente incompatíveis entre si sobre o Direito Positivo Comunitário Originário da CECA.

Trata-se também - ou até mesmo, primordialmente - de uma maneira de testar a hipótese assumida no início deste trabalho, qual seja: a de ser viável suspender temporariamente juízos tradicionais que formaram leituras jurídicas parciais (principalmente econômicas) das instituições da CECA para, com isso, desenvolver uma cadeia reflexiva apta a explicar de maneira suficientemente coerente esta Comunidade a partir de posição de consciência assumida no interior de uma específica chave de leitura jurídico-política.

Por essa razão, se neste Capítulo e nos próximos três são mencionados alguns dos estudos da tradição - apenas para, respectivamente, (i) permitir o mapeamento e a localização do objeto de atenção privilegiado deste estudo; e (ii) inserir a CECA em dimensão histórica, há que se perceber que a referência a tais documentos será aos poucos rarefeita neste texto, até desaparecer por completo.

Assim, ao se adentrar no Sétimo Capítulo deste texto, será empreendida a tarefa de construir um edifício significativo sobre o Tratado da CECA estritamente alicerçado nos fundamentos conceituais da leitura jurídico-política assumidos por este estudo - e nada mais. Com isso, tentar-se-á demonstrar ser possível desenvolver com suficiência uma leitura coerente sobre elementos da experiência deste fenômeno por meio de recurso exclusivo ao aparato conceitual desenvolvido e definido nesta Parte Primeira.

Por isso, mais do que imprudente prepotência, trata-se de exercício reflexivo realizado no sentido de efetivamente promover um esforço intelectual destinado a testar uma hipótese: a possibilidade de se apresentar uma leitura jurídico-política de um fenômeno ao qual usualmente se atribui um significado jurídico-econômico.

Esta é, aliás, a solidão típica do caminhar preciso de toda investigação que se pretende inovadora; afinal, "aquele que segue estes singulares caminhos não encontra ninguém, o que é próprio destes 'singulares caminhos'. Ninguém vem em nosso auxílio; é preciso livrar-nos de todos os perigos, de todos os azares, de todas as ciladas, de todos os temporais. [...]. Desde que o mundo é mundo, nenhuma autoridade permitiu tornar-se objeto de crítica [...].”. (NIETZSCHE, 2008, p. 9-10). 
estrutura seja incontroversamente evidente e possa ser retratada sem que se considerem preconcepções teóricas. [...]

A crítica explora a falta da harmonia entre os ideais sociais professados e os compromissos programáticos da sociedade, e também entre os interesses de grupos reconhecidos, e as estruturas institucionais detalhadas que não apenas constrangem a realização desses ideais como lhes fornece[m] seu significado desenvolvido. (UNGER, 2004, p. 160 e 162).

Nesse sentido, é importante notar que a análise institucional a ser desenvolvida no Sétimo Capítulo desta Tese efetuará conjuntamente (i) uma descrição institucional detalhada das normas jurídicas positivas ${ }^{316}$ do Tratado de Paris, de 1951, que instituiu a CECA (mapeamento); e (ii) uma avaliação do modo como fora arquitetado este arranjo institucional, a fim de verificar a qualidade das interações promovidas por estas disposições no sentido de instituir, manter e promover uma União Política (crítica) ${ }^{317}$.

Em outras palavras, o estudo das disposições jurídico-normativas positivadas no Tratado da CECA não apenas se preocupará em apontar a regulamentação jurídico-positiva dita, residente em uma primeira camada de significação adstrita à materialidade do significante de Direito Positivo (mapeamento).

Além deste aspecto ${ }^{318}$, o exame pretende verificar se e como foi possível ao Tratado da CECA instaurar, manter e promover uma convivência entre diferentes no sentido de preservar a diferença entre eles, por meio da trama de uma camada não-dita de regulamentação jurídico-normativa do problema do fundamento Direito e do Poder na Comunidade (crítica).

Mais simplesmente, quer-se compreender se e como a engenharia institucional prevista naquele Tratado Internacional conseguiu responder à necessidade constituída entre seus seis países-membros no pós-Segunda Guerra Mundial de instituir, manter e promover uma aproximação segundo Leis de convivência plural permanente. Se, em suma, suas instituições estiveram aptas a atender a este anseio fundamental de promover uma convivência pública Politicamente unida permanente entre os partícipes desta Comunidade $^{319}$.

\footnotetext{
${ }^{316}$ Que estiverem aptas a responder à pergunta inicialmente formulada para o presente estudo - as normas de oposições escalares; para saber quais os critérios de escolha de tais normas, remetemos o leitor ao item 3.3.3., infra.

${ }^{317}$ Como ocorre, aliás, em todo trabalho intelectual rigoroso que visa a efetuar "fusão de observação, reflexão e emissão de julgamentos por parte do autor", este sempre procura "esmiuçar e questionar o significado" do fenômeno por ele analisado (SEBASTIANI, 2008, p. 39).

${ }^{318}$ Fundamental e indispensável, sob pena de a significação atribuída "flutuar nos ares", isto é, não deter material para desenvolver uma crítica.

${ }^{319}$ Isto é, a crítica "entre os ideais sociais professados e os compromissos programáticos da sociedade [...] e as estruturas institucionais detalhadas que não apenas constrangem a realização desses ideais como lhes fornece[m] seu significado desenvolvido.” (UNGER, 2004, p. 162).
} 
Apenas desta maneira se assegura que este significante passe a estabelecer elos de vinculação com outros campos significativos - e que, com isso, passe a produzir significações adicionais. Trata-se do primeiro passo, não apenas para produzir conhecimento novo (WEBER, 2006, p. 37), mas também para desencadear processo reflexivo alternativo que promova novas perguntas e, com isso, inaugure nova Agenda de Pesquisa em Direito sobre esta temática na comunidade jurídica epistêmica brasileira. Crucial fortalecer um discurso sufocado pela materialidade do escrito jurídico-positivo que insiste em apreender apenas a literalidade do Direito Econômico na experiência histórica e normativa da CECA.

A revitalização da consciência acerca da pluralidade significativa de um fenômeno - cuja leitura se materializara autonomamente - permite que ele se comunique com a diversidade típica da condição social - da qual é uma expressão. A CECA é fenômeno e, como tal, tem essa mesma condição. Sua compreensão mais completa exige que se busque o reconectar com a complexidade infindável de possibilidades de leitura.

Com isso, mostra-se possível inaugurar nova Agenda de Pesquisa em Direito sobre um e mesmo fenômeno - aqui, a CECA, proposta como fenômeno jurídico-político, de maneira a ampliar o arsenal conceitual analítico aplicado e aplicável ao conhecimento e à explicação da integração da Europa do passado e de hoje. Esta Agenda procura entreabrir mais um campo vasto de perguntas e de investigações futuras do que, propriamente, fornecer respostas definitivas ou exaustivas ${ }^{320}$.

Devemos de alguma maneira lutar para sustentar uma cultura de crítica que confronte essas ortodoxias dominantes ao mesmo tempo que se recuse a deixá-las moldar a agenda de investigação e discussão. (UNGER, 2004, p. 37).

The historical-theoretical debate on Europe is in a constant flux, which is how it ought to be in a proper academic environment. (HARST, 2008, p. 8).

É necessário ainda esclarecer as categorias utilizadas para nortear a análise institucional do Tratado da CECA. O que será feito nos itens a seguir.

\subsection{Individuação dos Critérios Componentes da Análise Institucional}

Não posso deixar de me espantar - e de queixar-me - quando considero, de um lado, a veneração que inspiram as coisas antigas [...]; de outro, os atos admiráveis de virtude que a história registra, nos antigos reinos e repúblicas, envolvendo

\footnotetext{
${ }^{320}$ Tendo em vista que estas são, afinal, impossíveis em regime de redução fenomenológica.
} 
monarcas, capitães, cidadãos, legisladores, todos os que trabalharam pela grandeza da pátria. Atos mais friamente admirados do que imitados (longe disto, todos parecem evitar o que sugerem, de modo que é pouco o que resta da sua antiga virtude).

Com maior espanto ainda vejo que, nas causas que agitam os cidadãos e nos males que afetam os homens, sempre se recorre aos conselhos e remédios dos antigos. As leis, por exemplo, não são mais do que sentenças dos jurisconsultos pretéritos, as quais, codificadas, orientam os modernos juristas. A própria medicina não passa da experiência dos médicos de outros tempos, que ajudam os clínicos de hoje a fazer seus diagnósticos. Contudo, quando se trata de ordenar uma república, manter um Estado, governar um reino, comandar exércitos e administrar a guerra ou de distribuir justiça aos cidadãos, não se viu ainda um só príncipe, uma só república, um só capitão, ou cidadão, apoiar-se no exemplo da Antigüidade. (MAQUIAVEL, 2008, p. 17).

Antes de passar ao esclarecimento das categorias utilizadas na análise institucional do Tratado da CECA, é importante advertir o leitor com relação a este próximo passo que se inicia. As ressalvas a seguir se mostram necessárias, pois alguns questionamentos acerca da Metodologia empregada por este trabalho - possivelmente surgidos durante a leitura das partes anteriores deste texto - muito provavelmente ainda não restaram suficientemente respondidos.

Refere-se aqui precisamente à pergunta sobre como seria possível aplicar conjuntos conceituais de diferentes autores ${ }^{321}$ para compreender um fenômeno, sem que isso não seja

321 Diante da afirmação de este trabalho buscar efetuar uma análise institucional, poder-se-ia perguntar porque não teria esta Tese utilizado os ensinamentos de Charles de Secondat, Barão de MONTESQUIEU, em sua obra O Espírito das Leis, onde o autor teria indicado a importância de se avaliar a separação das funções de um Estado de acordo entre órgãos distintos e independentes, porém harmônicos (Executivo, Legislativo e Judiciário).

A justificativa da ausência da obra deste autor deriva de duas razões fundamentais, uma relacionada à coerência metodológica deste trabalho, e outra derivada do fenômeno escolhido a ser examinado.

Sob uma perspectiva de necessidade de mantença de coerência metodológica, há que se lembrar que, no item 2.2.4, supra, o presente trabalho afirmou ter escolhido como ponto de partida desta reflexão autores de Filosofia Política Antiga (como será visto a seguir, no item 3.3.3., infra, principalmente POLÍBIO, para determinar os critérios de escolha das normas a serem objeto de análise institucional). Nesse sentido, em virtude de MONTESQUIEU ser autor de um pensamento filosófico político Moderno, a fim de evitar a introdução de elementos reflexivos metodologicamente incompatíveis com a escolha intencional formulada neste texto, as contribuições deste autor foram afastadas da presente reflexão.

A recusa do uso de preceitos investigativos sinalizados por MONTESQUIEU também se justifica pela diferença de fenômenos estudados. Não se pode ignorar que MONTESQUIEU procurou compreender os órgãos institucionais de um Estado (Poderes Executivo, Legislativo e Judiciário) (DALLARI, 2001, p. 218), condição efetivamente distante e incompatível com relação o fenômeno analisado pelo presente texto.

Sobre esse particular, lembre-se da advertência de Fausto de QUADROS (1984, p. 263-4): não se deveria estabelecer um símile entre a repartição de atribuições no interior do Tratado da CECA e "o sistema de divisão de poderes nos Estados, não só porque os fundadores das Comunidades o não desejaram, como também porque, repetidamente temos vindo a recordá-lo, as Comunidades não se reduzem ao fenómeno estadual.”.

Com efeito, não apenas esta Tese avaliará uma organização jurídico-política - a Organização Internacional da CECA, a qual não assumiu a forma de um Estado (e cuja determinação enquanto tal, até hoje, mostra-se problemática, como será possível ver nos itens 3.3.2. e 3.4.1., ambos infra), como também as normas jurídicas positivas analisadas não opõem apenas órgãos comunitários, mas outras entidades - órgãos comunitários e Estados, por se preocupar, antes de tudo, com a oposição entre diferentes portadores das escalas de existências distintas que compunham a Comunidade. 
compreendido como um raso e imprudente ecletismo conceitual? E como utilizar tal repertório conceitual para compreender a CECA, o fundamento da atual UE - uma entidade que estaria se aproximando de maneira ainda não declarada de contornos jurídicopolíticos de um Estado Federal Europeu (BOBBITT, 2011; KESSEDJIAN, 2010; PLIAKOS, 1993; POZO, 2011a, 2012; SERRANO, 2011; WEILER, 2011). Ou ainda, qual será a compreensão deste trabalho sobre a natureza jurídica da CECA - um suposto proto(quase-) Estado Federal Europeu, ao deter como ponto de partida reflexivo tal repertório conceitual.

Essas indagações entreabrem discussões profundas sobre o presente trabalho, as quais devem ser respondidas de maneira a dissipar dúvidas desnecessárias em torno o percurso investigativo nos próximos itens e nos próximos Capítulos. Apenas por meio do afastamento dessa névoa será possível estabelecer confortável clareira para a compreensão da proposta deste estudo, uma vez que terão sido afastados os últimos bloqueios e incômodos mentais para a completa fruição do texto que se segue.

Surgem com as indagações acima duas principais barreiras cognitivas, a saber, (i) de que maneira se pretende recorrer conjuntamente ao pensamento filosófico de tais autores (risco de inadvertido ecletismo filosófico); e (ii) como se compreende a juridicamente a CECA (a natureza jurídica da CECA), para aferir a adequação da aplicação deste conhecimento a esta entidade jurídico-política. Nos próximos itens se buscará resolver de maneira suficiente - porém não exaustiva - essas duas questões levantadas. Uma compreensão mais completa das respostas apresentadas nos próximos dois itens a essas perguntas será possível a partir da leitura integral do texto desta Tese.

Dessa forma, seja em nome da afirmação de uma rigorosa coerência metodológica do presente texto, seja em virtude da completa distinção entre aquilo que esta Tese examina e o avaliado pelo filósofo político Moderno, justifica-se a não utilização das contribuições de MONTESQUIEU para desenvolver a reflexão que segue neste trabalho.

Sobre leituras em torno do tema da Separação dos Poderes e sobre a proposta formulada por MONTESQUIEU, sugerimos exemplificativamente, na literatura jurídica nacional contemporânea, a leitura de Dalmo de Abreu DALLARI (2001, p. 215-22) e mais especificamente de Jean Paul Cabral Veiga da ROCHA (2004, p. 71-115).

Aliás, sobre a relação entre o pensamento político de MONTESQUIEU e a Europa, sugerimos a leitura de Patrice ROLLAND (1994). Neste texto, o autor não desenvolve uma análise das Organizações Internacionais europeias de seu tempo à luz das contribuições sobre a Separação de Poderes de MONTESQUIEU. Sua perspectiva é interessante por outras razões.

A leitura do texto de Patrice ROLLAND (1994) aponta como o filósofo francês compreendia a Europa em seu período. Esta seria um espaço de liberdade caracterizado pela moderação e pelo equilíbrio. Isso lhe asseguraria a necessária resistência ao surgimento de déspotas, vale dizer, impediria a ascensão de qualquer um a uma pretensa posição de Imperador ou Monarca Universal na Europa, tal qual almejara o rei francês Luís XIV. Este seria, no máximo, o mais forte de todos, mas jamais o único, sendo inevitável a presença de outros Estados. 


\title{
3.3.1. Empréstimos Conceituais e Conhecimento
}

\begin{abstract}
Ce que nous voulons dire n'est pas devant nous, hors de toute parole, comme une pure signification. Ce n'est que l'excès de ce que nous vivons sur ce qui a été déjà dit. Nous nous installons, avec notre appareil d'expression, dans une situation à laquelle il est sensible, nous le confrontons avec elle, et nos énoncés ne sont que le bilan final de ces échanges. La pensée politique elle-même est de cet ordre : c'est où jouent toutes nos connaissances, toutes nos expériences et toutes nos valeurs à la fois, et dont nos thèses ne sont que la formulation schématique. Toute action et toute connaissance qui ne passent pas par cette élaboration, et qui voudraient poser des valeurs qui n'aient pas pris corps dans notre histoire individuelle ou collective ou bien, ce qui revient au même, choisir les moyens par un calcul et par un procédé tout technique, retombent en deçà des problèmes qu'elles voulaient résoudre. La vie personnelle, l'expression, la connaissance et l'histoire avancent obliquement, et non pas droit vers des fins ou vers des concepts. Ce qu'on cherche trop délibérément, on ne l'obtient pas, et les idées, les valeurs ne manquent pas, au contraire, à celui qui a su dans sa vie méditante en délivrer la source spontanée. (MERLEAU-PONTY, 1960, p. 135, grifos do autor).
\end{abstract}

Busca-se com este item rapidamente desarmar a crítica sobre um suposto ecletismo intelectual, ou ainda, sobre uma inadvertida situação de sincretismo de "ideias fora do lugar" neste trabalho. A citação de diferentes autores é tematizada neste item como forma de tornar conscientes as referências e de fortalecer metodologicamente este estudo diante de críticas sobre uma inadequada reprodução escrita da tradição.

As ideias estão neste texto propositalmente "fora do lugar", pois almejam produzir, a partir do dado, conhecimento acadêmico outro, alternativo. Esta é a característica da atuação de escrever uma obra, pois todo escritor transporta seu leitor "du monde déjà dit à autre chose." (MERLEAU-PONTY, 1960, p. 125-6). Para além da dimensão textual dos conceitos, preocupa-se com o horizonte investigativo por eles aberto, isto é, aceita-se o convite reflexivo que eles deflagram em seu incontrolável campo significativo.

Nesse sentido, lembre-se de que esta Parte Primeira indicou serem os principais suportes reflexivos deste estudo: (i) a distinção entre Dogmática e Zetética Jurídicas, principalmente conforme leitura do pensamento de Tercio Sampaio FERRAZ JR. (2001) sobre as reflexões de Theodor VIEHWEG; (ii) a multiplicidade de leituras em torno de um tema, derivada do pensamento fenomenológico de Edmund HUSSERL (1980, 2006); (iii) a compreensão jurídico-politica da CECA e de sua construção histórica, a partir da conjugação das noções de (a) Leis, a partir das contribuições de PLATÃO (1980) e ARISTÓTELES (1998), e (b) Verrechtlichung, de Otto KIRCHHEIMER, segundo relatado por Gunther TEUBNER (1984, 1993); e (iv) a importância de se compreender 
também a análise jurídica como análise institucional, da maneira como preconizada por Roberto Mangabeira UNGER (2004).

Ao mesmo tempo, como se poderá ver nos próximos itens, este trabalho está fundamentado também, (v) para definir o critério de seleção normativa na análise institucional, no pensamento político legado por POLÍBIO (POLYBE, 2003), e (vi) para distinguir tipologicamente as Leis e, dessa distinção, extrair uma chave de leitura crítica em Filosofia Política, nas contribuições desenvolvidas por Claude LEFORT (1986, 1991).

A singela menção destes autores de maneira conjunta nas linhas acima pode suscitar uma preocupação: não produziria este texto um caldo caótico de estranha associação entre pensamentos distintos produzidos por diferentes autores (cada um inserto em condições temporais distintas, preocupado com tópicas diversas, visando a refletir sobre problemas não-relacionados)? Não haveria assim a desconsideração da preciosidade conceitual da contribuição de cada autor, ou mesmo da própria modificação temporal das conclusões de cada autor individualmente considerado diante de sua própria obra?

Este trabalho não detém uma preocupação em seguir uma leitura a partir de uma compreensão estrutural do texto ${ }^{322}$, isto é, não se busca compreender de maneira exclusivamente (inter-)textual a interconexão das ideias de cada um dos autores aqui mencionados a partir de um conhecimento do texto, pelo texto, e no texto ${ }^{323}$., adstrito apenas ao campo signifiactivo proposto pelo próprio autor. Não há aqui a preocupação de desvendar uma ordenação lógica ou cronológica entre as produções de cada um dos autores e no interior de cada texto produzido, exigindo a leitura incessante e exaustiva de cada um

\footnotetext{
322 Desenvolvido por Vitor GOLDSCHMIDT (1963) para os estudos em Filosofia, foi recentemente proposto para os estudos em Direito por Ronaldo Porto MACEDO JR. (2007).

Não cabe entrar aqui em detalhes sobre oque seja a leitura estrutural e os critérios que constituem este tipo de leitura. Indicamos para o leitor eventualmente interessado pela temática a leitura do texto de Vitor GOLDSCHMIDT e de Ronaldo Porto MACEDO JR., além da obra citada na nota de rodapé 323, infra. Esses textos ajudam a esclarecer um pouco mais o que seja a leitura estrutural. Este, no entanto, não é o objetivo deste trabalho, razão pela qual não serão desenvolvidos comentários adicionais sobre esta específica temática neste estudo.

323 “As técnicas da análise estrutural de texto, não obstante o rigor, o academicismo e as 'finezas' que se costumam atribuir-lhe, obedecem a normas bastante simples. Toma-se um segmento do autor, seccionado de seu contexto em pontos que indiquem uma articulação aparentemente natural (parágrafo, capítulo, passo da argumentação), e procura-se explicá-lo internamente, isto é, com os próprios recursos que ele oferece. Unicamente esse segmento é colocado em tela: o contexto - assim como o restante da obra - ficam reduzidos, provisoriamente, à simples condição de gramática ou dicionário, a que se pode recorrer quando alguma exigência do texto o solicitar. O texto, nessa sua materialidade, será interrogado conceitualmente, e não tematicamente: não se procurará saber o que ele diz - muito menos o que o autor quis dizer - mas como ele funciona; não o conhecimento ou informações de que ele seria 'veículo' - eventualmente, a respeito do 'pensamento do autor' - mas o que acontece nele. Uma etapa posterior - e bem distinta, que pressupõe o término dessa primeira abordagem aparentemente formal - é o comentário, em que então se discutirão as idéias construídas pelo texto que foi analisado e suas implicações mais gerais." (TORRES FILHO, 2004, p. 2004, p. 138-9, grifos do autor).
} 
deles. També não se pretende nem mesmo evidenciar e explorar as modificações sofridas no tempo pelo pensamento e pelos conceitos de cada um dos autores selecionados em cada uma de suas obras, nem com o estabelecimento de um diálogo entre cada uma dessas fases.

De nada interessa ao presente trabalho compreender exaustivamente a complexa rede de relações entre as ideias defendidas no tempo por cada um dos autores escolhidos e um suposto desenvolvimento lógico e cronológico do significado de termos no interior de cada um dos textos. Apesar de se tratar de uma investigação de grande relevância, ela se encontra fora do arco de questões estabelecido para este trabalho ${ }^{324}$. Aqui, apenas se parte da contribuição dos autores mencionados, mas para ir além daquilo que eles próprios teriam afirmado, a fim de explorar novas possibilidades de construção do conhecimento mediante o uso dos discursos que podem ser formados tendo como ponto de partida as contribuições conceituais destes autores - pois apenas por meio desta consideração inovadora da tradição é que se pode esperar a construção de conhecimento novo, atento às condições presentes (NASCIMENTO, 2010).

\begin{abstract}
D'un côté, on m'a dit: vous ne décrivez pas comme il faut Buffon, ni l'ensemble de l'œuvre de Buffon, et ce qui vous dites sur Marx est dérisoirement insuffisant par rapport à la pensée de Marx. Ces objections étaient fondées, mais je ne pense pas qu'elles étaient tout à fait pertinentes par rapport à ce que je faisais ; car le problème pour moi n'était pas de décrire Buffon ou Marx, ni de restituer ce qu'ils avaient dit ou voulu dire : je cherchais simplement à trouver les règles selon lesquelles ils avaient formé un certain nombre de concepts ou d'ensembles théoriques qu'on peut rencontrer dans leurs textes. On a fait aussi une autre objection : vous formez, m'a-t-on dit, des familles monstrueuses, vous rapprochez des noms aussi manifestement opposés que ceux de Buffon et de Linné, vous mettez Cuvier à côté de Darwin, et cela contre le jeu le plus visible des parentés et de ressemblances naturelles. Là encore, je dirais que l'objection ne me semble pas convenir, car je n'ai jamais cherché à faire un tableau généalogique des individualités spirituelles, je n'ai pas voulu constituer un daguerréotype intellectuel du savant ou du naturaliste du XVIII ${ }^{\mathrm{e}}$ et du XVIII ${ }^{\mathrm{e}}$ siècle; je n'ai pas voulu former aucune famille, ni sainte ni perverse, j'ai cherché simplement - ce qui était beaucoup plus modeste - les conditions de fonctionnement de pratiques discursives spécifiques. (FOUCAULT, 1994, p. 791, grifos nossos).
\end{abstract}

Nesse sentido, este texto parte do singelo questionamento "o que importa quem fala?" (FOUCAULT, 1994, p, 789), ou ainda, por que teria um autor exclusividade sobre o significado último de seu texto (LEFORT, 1986, p. 308-9). Busca-se apenas deles extrair manifestações de grandes narrativas discursivas (FOUCAULT, 1994, p. 792) que explicitem um campo significativo apto a permitir interpretar o presente a partir de signos legados pela tradição.

${ }^{324}$ Todavia, registra-se aqui o convite para futuras pesquisas conjuntas sobre o tema. 
O autor determina muito menos do que se imagina na delimitação de seus conceitos, pois estes sempre ganham autonomia significativa em outros ambientes investigativos (FOUCAULT, 1994, p. 789). Os conceitos são meros signos, isto é, meros suportes significativos que não detêm circunscritos uma única significação essencial ${ }^{325}$ : eles operam como singela roupagem linguística que viabiliza a fala a partir deles, de acordo as preocupações contextuais espácio-temporais de cada novo autor.

Je crois que les conséquences de nos actions nous échappent. [... Q]ue savezvous de ce qu'on en lit, de ce qui chemine dans la tête des autres ? Pourtant, vous continuez. (LEFORT, 2007c, p. 256).

[L]'œuvre de pensée [...] à la différence de l'œuvre d'art, n'est œuvre que parce qu'elle appelle son lecteur à l'interroger, non pas seulement à hériter silencieusement de son geste, mais à prendre la parole, à trouver dans son enceinte, la voie d'un discours critique, à convoquer des lecteurs toujours nouveaux au débat dont elle s'est faite l'origine et l'enjeu. (LEFORT, 1986, p. $70)$.

A influência do autor no estabelecimento do campo significativo de um conceito é necessária apenas para construir condições mínimas para os continuadores de seu trabalho intelectual deterem a autodeterminação de pensamento suficiente para refletir suas próprias questões da maneira como os conceitos se lhes apresentam. Uma vez apresentado o conceito e suas linhas gerais, deve o autor desaparecer, pois ele apenas aponta discretamente o caminho para que possam seus leitores, em sua própria existência concreta, "imaginar ou viver sua própria vida." (PRADO JR., 1977, p. 42-3, grifos do autor).

O posto ocupado pelo autor é assim um lugar vazio (FOUCAULT, 1994, p. 789): seus conceitos sofrem incisões na medida das necessidades de seus utilizadores posteriores, isto é, os conceitos são modificados para que novas reflexões possam produzir significações sobre o presente sem esquecer a tradição. A fragmentação do trabalho do autor estilhaça a supostamente sólida unidade originária do conceito inaugural e lança-o para assumir outros significados em novos relacionamentos sígnicos.

Isso se mostra possível porque não se supõe epistemologicamente que seja possível hipostasiar a posição do autor de um texto no processo de atribuição de sentido ao que foi por ele escrito, pois nada concede uma preferência sacra ou privilégio transcendente a um

325 Perceba-se como esta assunção está profundamente vinculada aos pressupostos metodológicos deste trabalho: como visto nos itens 2.2.1. e 2.2.2., supra, não existe uma essência, mas um centro receptor de sentidos múltiplos e infinitos. Trata-se de uma simples consequência derivada do ponto de vista fenomenológico assumido, exigida para a manutenção da coerência interna deste estudo. 
autor na significação de seu próprio texto: o que importa ser um autor? (FOUCAULT, 1994; NASCIMENTO, 1983, 1988, 1989, 1996; PRADO JR., 1977). Trata-se efetivamente de uma postura Política ${ }^{326}$ a ser adotada no ato de leitura (LEFORT, 1986, 1991) em contraposição a qualquer desmedida valorização do legado da tradição.

\begin{abstract}
On manque la vérité de l'œuvre si l'on ne fait pas droit à son indétermination, au travail dont elle est le produit et auquel nous ne nous rapportons qu'en nous laissant travailler par elle. Marx [par exemple] ne m'importe pas parce qu'il a marqué une étape, à défaut de laquelle le présent ne serait pas ce qu'il est. Il m'importe parce que, dans le présent, je suis renvoyé à son œuvre, que je n'ai jamais fini de la lire, qu'elle est le lieu d'une interrogation qui va très au-delà des conclusions auxquelles elle parait aboutir. (LEFORT, 2007c, p. 260).
\end{abstract}

Por meio dessa reelaboração em conjunto do sentido de cada um dos conceitos utilizados, eles se apresentam fragmentariamente, isto é, como sendo os mesmos sem ser idênticos. Isso implica reconhecer que eles são diferentes sem se contradizer: tratam-se de meros recortes interpretativos que permitem a construção de interpretações novas sobre as condições históricas do período selecionado para o presente trabalho e sobre o texto de Direito Positivo designado como objeto de interpretação.

Não é nova a ideia dessa independência entre possibilidades de interpretação de uma obra com relação a quem a produziu - autonomia da criação com relação a qualquer determinação dado por seu criador - no conhecimento jurídico. A fragmentação do sentido das contribuições originárias de um predecessor por intérprete - com o objetivo de construir novos fundamentos significativos próprios - fora outrora anunciada no pensamento jurídico, por exemplo, por Hans KELSEN, no início e no final de sua Teoria Pura do Direito (2000, p. 3 e 396): uma vez objetivado o ato subjetivo de dever-ser - a norma jurídica positiva, o legislador perderia seu poder de determinação do sentido último desta.

\footnotetext{
Quando se parte de um pensamento já fundamentado, apesar de não mais ter sido desenvolvido, que um outro nos deixou, pode-se esperar ser possível levá-lo, através da reflexão, mais além do que o perspicaz homem, a quem se deve a primeira centelha desta luz, o levou. (KANT, 1980, p. 10).
}

Note-se que essa transformação dos fundamentos significativos de cada conceito - a qual opera duplamente como fundação e refundação de sentido - é o procedimento discursivo típico seguido por todo aquele que visa ao avanço do conhecimento. Se, por um

${ }^{326}$ Sobre a noção de Político, v. item 3.4., infra. 
lado, há reconhecidamente uma efetiva perda do campo significativo originário, há, por outro lado, a abertura de espaço de sentido novo e a construção da possibilidade de produzir de significações novas sobre questões contemporâneas (conhecidas, reconstruídas ou novas) (NASCIMENTO, 2010).

\begin{abstract}
Je dirais, d'un mot, que ces auteurs se trouvent dans une position «transdiscursive » C'est un phénomène constant - aussi vieux à coup sûr que notre civilisations. [...]. Appelons-les, d'une façon un peu arbitraire, « fondateurs de discursivité ». Ces auteurs ont ceci de particulier qu'ils ne sont pas seulement les auteurs des leurs œuvres, de leurs livres. Ils ont produit quelque chose de plus : la possibilité et la règle de formation d'autres textes. [... i]ls n'ont pas rendu simplement possible un certain nombre d'analogies, ils ont rendu possible (eu tout autant) en certain nombre de différences [par rapport à leurs textes, à leurs concepts et à leurs hypothèses qui relèvent toutes de leurs discours euxmêmes]. Ils ont ouvert l'espace pour autre chose qu'eux et qui pourtant appartient à ce qu'ils ont fondé. (FOUCAULT, 1994, p. 804-6, grifos nossos).
\end{abstract}

É importante notar que outros antes de nós já efetuaram - cada um em seu domínio reflexivo específico, uma apropriação fragmentária de conceitos e de polos discursivos instaurados por predecessores ${ }^{327}$. Essa paternidade fragmentada de conceitos da tradição discursiva legada por predecessores não é comum apenas nas especulações filosóficas. Isso também é passível de ser identificado em disciplinas Zetéticas do pensamento jurídico ${ }^{328}$.

${ }^{327}$ A título meramente exemplificativo, é impossível não perceber modificações conceituais nos legados das obras (i) de Arthur SCHOPENHAUER, com relação ao pensamento de Immanuel KANT; (ii) de Edmund HUSSERL, igualmente em relação à contribuição de Immanuel KANT; (iii) de Maurice MERLEAUPONTY, no que diz respeito às reflexões de Edmund HUSSERL; (iv) de Jean-Paul SARTRE, no que se refere também ao pensamento de Edmund HUSSERL; e (v) da Primeira Geração da chamada Escola de Frankfurt (principal, mas não exclusivamente, Max HORKHEIMER, Theodor ADORNO e Herbert MARCUSE) tem como ponto de partida uma conjunção reflexiva do pensamento de Immanuel KANT, de Georg Wilhelm Friedrich HEGEL, Karl MARX, Friedrich NIETZSCHE, Sigmund FREUD e Arthur SCHOPENHAUER.

Do mesmo modo, não pode ser ignorado ainda que (vi) POLÍBIO produz sua obra como ponto de conjunção das quatro principais correntes da filosofia helênica clássica (platonismo, aristotelismo, epicurismo e estoicismo), sem deixar de fornecer sua própria interpretação sobre os relatos históricos de HOMERO, (vii) Nicolau MAQUIAVEL exerce profundo diálogo com POLÍBIO e também com TITO LÍVIO, e (viii) Claude LEFORT encontra parcela de sua matriz reflexiva em Nicolau MAQUIAVEL e em Maurice MERLEAU-PONTY.

Perceba-se que este breve discurso não tem qualquer pretensão de estabelecer uma linhagem genealógica filosófica definitiva, mas apenas indicar quais grandes discursos são perceptíveis nas obras dos autores ali mencionados, entre outros possíveis. O que também pretende indicar a maneira como se encontram inter-relacionados aqueles que foram, são e/ou serão referidos nesta Tese de Doutorado como fundamentos das reflexões desta.

${ }^{328} \mathrm{Na}$ Sociologia do Direito, não se pode ignorar que (i) Otto KIRCHHEIMER se apropria parcialmente de conceitos de Hugo SINZHEIMER, Max WEBER e Karl MARX; (ii) Gunther TEUBNER, por sua vez, associa a contribuição de Otto KIRCHHEIMER à de Niklas LUHMANN; e (iii) José Eduardo FARIA recorre às reflexões de Gunther TEUBNER.

Também na Filosofia do Direito, não se pode deixar de notar que (i) Jürgen HABERMAS se aproxima também das contribuições de Immanuel KANT, de Otto KIRCHHEIMER, entre tantos outros; (ii) Miguel REALE tem os fundamentos de sua reflexão o pensamento de Emil LASK e de Gustav 
Inclusive, a redefinição significativa de conceitos diante de problemas contemporâneos já foi realizada por nós em outras oportunidades ${ }^{329}$.

\begin{abstract}
[D]ans l'œuvre de ces instaurateurs, on ne reconnaît pas certaines propositions comme fausses, on se contente, quand on essaie de saisir cet acte d'instauration, d'écarter les énoncés qui ne seraient pas pertinents, soit qu'on les considère comme inessentiels, soit qu'on les considère comme «préhistoriques» et relevant d'un autre type de discursivité. Autrement dit, [...] l'instauration discursive ne fait pas partie de ces transformations ultérieures, elle demeure nécessairement en retrait ou en surplomb. (FOUCAULT, 1994, p. 807, grifos nossos).
\end{abstract}

Aliás, este parece ser o destino normal de todo e qualquer conceito: uma vez inaugurado, sofre continuamente um processo de ressignificação, isto é, de redeterminação de seu campo significativo, de modo a abarcar situações distintas (mais amplas ou mais estreitas) da originária (FOUCAULT, 1994, p. 806).

Essa condição deriva precisamente de sua inter-relação com outros núcleos significativos conceituais, nutrientes de sentidos que reformulam perguntas e renovam respostas, pois reorientam o significado inicialmente atribuído a fenômenos (WEBER, 2006, p. 37): o trabalho de retornar às discursividades instauradas por predecessores exige a operação do esquecimento ativo (não acidental) que transforme a própria discursividade originária (FOUCAULT, 1994, p. 807-8).

\begin{abstract}
À medida que se desenvolvem e amadurecem, os conceitos começam a se mover por conta própria e, às vezes, alcançam territórios bastante distantes de seu local de origem. Eles vagueiam pelo passado, que os ignorava na época em que ainda era presente. Ou fazem uma incursão no futuro, que - quem sabe? - pode, de igual modo, ignorá-los quando sobrevier, mais uma vez que não os julgará úteis. Dá a impressão de que os conceitos nasceram como plantas, firmemente enraizados no solo e sorvendo suas seivas - mas, à medida que o tempo passou, desenvolveram pernas e principiaram a busca de alimento mais farto e variado. (BAUMAN, 1998, p. 160).
\end{abstract}

Este estudo está consciente de suas origens, isto é, reconhece e assume sua “impureza" conceitual: "[j]á a análise da história antiga ensinara a TUCÍDIDES, e este aponta quanto, a significação normal das palavras pode mudar; ao sabor da vontade ou dos caprichos dos homens. Nada mudou, deste então" (CASELLA, 2008, p. 185). Afinal,

RADBRUCH; e (iii) Tercio Sampaio FERRAZ JR. também não deixa de se socorrer das contribuições de Theodor VIEHWEG e de Niklas LUHMANN.

${ }^{329}$ Quando do estudo de temas especializados de (i) Direito Internacional Público (GIANNATTASIO, 2009a, 2010b, 2011a, 2011b; GIANNATTASIO; SCUDELLER, 2011); (ii) Direito Econômico (GIANNATTASIO, 2010a, 2010c); (iii) Direito do Trabalho (GIANNATTASIO, 2009c; GIANNATTASIO; PREBIANCA, 2010, 2011); e (iv) Direitos Humanos (GIANNATTASIO, 2009b, 2011a, 2011b). 
reapresentar originariamente a roda não é a reinventar, mas a reapresentar sob uma nova perspectiva - vale dizer, reapresentá-la ciente da dívida que se tem com a tradição que a inventou (CASELLA, 2009a, p. 174-6); afinal, a continuidade do passado não deve se dar segundo a lógica da veneração ou a da revolta, mas conforme a de "l'oublier em profitant de lui" (MERLEAU-PONTY, 1960, p. 128).

Os conceitos foram legados para este estudo como ricos nutrientes conceituais. Uma vez digeridos, permitirão em conjunto sustentar uma nova existência interpretativa, ou melhor, uma nova forma de compreender conceitualmente um fenômeno mediante operação conjunta de sentidos novos gerados pela mútua e recíproca determinação e delimitação significativa. De fato, "[le sens] ne se comprend que par l'interaction des signes, dont chacun pris à part est équivoque ou banal, et dont la réunion seule fait le sens." (MERLEAU-PONTY, 1960, p. 69).

O objetivo é precisamente este: desmontar a narrativa usual, pois esta é a função própria de todo e qualquer trabalho acadêmico que almeje a originalidade, e a exigência típica de uma Tese de Doutorado. O estranhamento é assim esperado, pois todo escritor "introduise [...] des perspectives étrangères, au lieu de nous confirmer dans les nôtres." (MERLEAU-PONTY, 1960, p. 125).

Por isso, nesta Parte Primeira apontaram-se, indicam-se e designar-se-ão de maneira sincera os pontos de partida conceituais desta obra (WEBER, 2006, p. 24), os quais - mediante incisões conceituais (isto é, sobre conceitos) - são reelaborados a partir de uma convivência sígnica plural efetivamente ampla. Pois todo intelectual é um "intelectual a partir de". Consciente ou inconscientemente. Declarada ou não declaradamente.

\subsubsection{Percepções sobre a Natureza Jurídica da Europa Unida da CECA}

\footnotetext{
Esse assunto, para tornar-se claro, merece uma abordagem detida, e o leitor deve deixar de lado por alguns momentos a sua surpresa, até ela ter desaparecido por completo, ou seja, até adquirir uma visão integral de todo o pensamento comunicado nesta obra. (SCHOPENHAUER, 2005, p. 246).
}

O tema da natureza jurídica da CECA se revela como uma questão fundamental para uma Pesquisa voltada a ampliar o conhecimento jurídico nacional. Com efeito, a precisão de uma questão deste tipo tem por objetivo definir de que maneira esta entidade é compreendida como integrando o cosmos do pensamento jurídico, a fim de entender como ela estabelece relações com outros grupos conceituais fundamentais da tradição da reflexão 
jurídica. No entanto, a discussão sobre este problema neste trabalho adquire contornos especiais.

Segundo sistematização proposta por Carlos Molina del POZO (2012), podem ser mencionadas ao menos duas tendências classificatórias da natureza jurídica da atual UE, a saber: (i) Organização Internacional (a) intergovernamental ou clássica, pois seria um mecanismo de cooperação interestatal efetuado no interior de uma Organização Internacional tradicional; (b) supranacional ou sui generis, pois regida por regras jurídicas supranacionais voltadas à promoção da integração entre seus países-membros ${ }^{330}$ (ACCIOLY; NASCIMENTO E SILVA; CASELLA, 2009, p. 395; POZO, 2002, p. 187, 2004, p. 53); ou (ii) estrutura estatal (a) Federal (DESCAMPS, 20111; KESSEDJIAN, 2010; PLIAKOS, 1993; WEILER, 2011) (311 $^{33}$ (b) Confederal (ACCIOLY; NASCIMENTO E SILVA; CASELLA, 2009, p. 242-4) ${ }^{332}$.

Não se pode deixar de mencionar, ainda exemplificativamente, que, por a UE não ser um Estado propriamente dito, Carlos Francisco Molina de POZO (2011a, p. 64-6, 2012) propõe que seja ela percebida como uma Federação sui generis, atípica, em nada aparentada com a das diferentes tradições estatais (dos EUA, da Alemanha, da Áustria, do Brasil, etc.).

Para este autor, principalmente após o Tratado de Lisboa, a UE seria algo inteiramente novo, a ser compreendido e identificado à medida que as práticas institucionais se desenvolverem nos próximos anos. Não mais faria sentido tentar classificá-la em modelos estritos de Organização Internacional intergovernamental (clássica) ou supranacional (sui generis), como um proto-Estado, ou mesmo como um Estado Federal ou Confederal. Haveria uma institucional mescla a ser compreendida

\footnotetext{
330 “[N]inguna organización internacional tiene ni ha ostentado nunca poderes tan amplios en relación a los Estados miembros. Por lo que afecta a la ausencia de dependencia frente a los Gobiernos nacionales, no hay nada que sea tan independiente frente a los nacionalismos de los Gobiernos de los Estados miembros que las propias Comunidades. En lo que concierne a la jurisdicción directa de las Comunidades sobre los particulares, si bien es cierto que todas la organizaciones tienen jurisdicción sobre sus funcionarios, ninguna, más que las Comunidades, establecen relaciones jurídicas directas con los particulares sometidos a su autoridad. [... E]l Derecho comunitario goza de total autonomía, ya que tiene su origen en los Tratados constitutivos de las Comunidades Europeas y [...] puede fijar sus relaciones con los ordenamientos jurídicos nacionales de los Estados miembros." (POZO, 2004, p. 50).

331 Para estes autores, a UE detém contornos de uma Federação, sem que tivesse havido uma "coragem política" para adotar tal designação em seus documentos oficiais mais atuais.

${ }^{332}$ Para estes últimos autores, a UE é uma Confederação, ainda que essa classificação não seja declarada nos documentos principais. Todavia, para eles seria inquestionável o fato de que a União Europeia teria superado o mero modelo de Organização Internacional (ACCIOLY; NASCIMENTO E SILVA; CASELLA, 2009, p. 243-4).
} 
juridicamente apenas no futuro. O único ponto de partida aceitável seria a perceber como uma Federação sui generis, em construção ${ }^{333}$.

A discussão acima foi brevemente apresenta apenas e tão-somente para situar o leitor no interior do atual estado das disucssões sobre a natureza jurídica da UE. Contudo, esse debate em especial não interessa aos objetivos deste trabalho, na medida em que este direciona seus esforços no sentido de compreender a CECA - e não a UE - a partir de um ponto de partida metodológico distinto.

Em outras palavras, pode-se dizer que não importa a este trabalho a oposição das percepções doutrinárias acima indicadas. Essa carência de relevância deriva de dois motivos principais, a saber, (i) um vinculado ao próprio fenômeno estudado (especificamente a CECA), (ii) outro derivado da singular condição de se compreender a CECA como um fenômeno.

É importante lembrar que este estudo se dedica a compreender apenas e tãosomente a Europa politicamente Unida pela CECA, conforme as restrições metodológicas temporais, espaciais e temáticas apresentadas no item 1.5., supra. Naquele momento não se apresentava a questão de a CECA constituir algo distinto de uma mera Organização Internacional de vocação regional (ACCIOLY; NASCIMENTO E SILVA; CASELLA, 2009, p. 424-6; NASCIMENTO E SILVA; ACCIOLY, 2002, p. 246-50; MONACO, 1961b, p. 345; POZO, 2002, p. 181, 2004, p. 51, 2011a, p. 63; PUISSOCHET, 1991, p. 437).

Por esse motivo, de nada adianta tentar compreender as questões trazidas pelas sucessivas alterações do Tratado constitutivo fundamental em direção à formação da UE. É a CECA, e não a UE, o fenômeno investigado por este trabalho. E a natureza jurídica da CECA não se mostrava distinta da de uma Organização Internacional $^{334} 335$

\footnotetext{
333 No mesmo sentido, haveria que se mencionar a Tese de Doutorado de Miriam Rodríguez-Izquierdo SERRANO (2011, p. 30) e, na literatura jurídica nacional, a Dissertação de Mestrado de Carolina Maria LEMBO (2010, p. 163-5).

Indicamos esta tendência à potencial instituição de uma "organização política dos povos europeus de caráter não estatal e supranacional” (GIANNATTASIO; SCUDELLER, 2011, p. 196, grifos dos autores) quando da constatação da impossibilidade de se operar o tradicional conceito Moderno de cidadania (afeito ao conceito de um Estado-nação Moderno) dentro de um ambiente Pós-Moderno. Para maiores especificações, remetemos à leitura deste texto, na medida em que o tema da cidadania europeia não se encontra no rol de preocupações deste trabalho. Já em 1991, Jean-Pierre PUISSOCHET (1991, p. 450) apontava para a condição de que, se a CEE “n’est pas un État, elle exerce, quoique dans une mesure limitée, certaines des prérogatives que le droit international classique réservait aux États. Cette situation n'est pas toujours rationnelle".

${ }_{334}$ Cuja definição foi dada já na nota de rodapé 1, supra.

${ }^{335}$ É por esse motivo que não foram especificadas acima as singularidades internas de cada uma das leituras estatais sobre a UE de hoje, principalmente no que se refere às diferentes formas de Federalismo europeu que
} 
(REUTER, 1965, p. 195-6), pois fundada por Tratado Internacional que lhe conferira personalidade jurídica própria (art. 6 do Tratado de Paris, de 1951), a qual lhe garantiu a aptidão para agir no interior da ordem jurídica internacional de maneira distinta e independente com relação a cada aos seus Estados fundadores.

A única discussão possível em torno desta temática consistiria em tentar localizar juridicamente a CECA entre os modelos de Organização Internacional (i) intergovernamental ou (ii) supranacional (ACCIOLY; NASCIMENTO E SILVA; CASELLA, 2009, p. 395; MONACO, 1961b, p. 345; POZO, 2002, 187, 2004, p. 53; PUISSOCHET, 1991, p. 437), pois haveria que se compreender como os caracteres especiais derivados dos poderes a ela atribuídos qualificavam esta Organização Internacional: “[a]ucune organisation internationale ne détient et n'a jamais détenu des pouvoirs aussi forts et aussi étends à l'égard des États." (REUTER, 1965, p. 198) ${ }^{336}$.

Essa distinção remete à já referida diferenciação entre coexistência e cooperação: a posição assumida anteriormente por este trabalho permite compreender de que modo a CECA pode ser entendida como uma Organização Internacional orientada no sentido de promover nem uma, nem outra, mas a convivência ${ }^{337}$.

É por essa razão vinculada ao fenômeno escolhido para ser estudado (a CECA) que se torna irrelevante remeter às atuais discussões sobre a natureza jurídica da UE. Ainda que se possa apontar que este trabalho propõe compreender a CECA como uma Organização Internacional instituidora de um sistema de convivência, não se pode ignorar que ele concorda com a posição pacífica de a CECA ter sido uma Organização Internacional. A

cada um dos autores mencionados apresenta. Caso contrário, isso implicaria em abordar uma temática localizada fora do recorte metodológico temporal estabelecido rigorosamente nos itens anteriores.

Deste modo, para evitar uma inadvertida incoerência metodológica, mas também para não deixar de informar o leitor de maneira genérica sobre as duas correntes principais de se pensar hoje a natureza jurídica da UE, foram elas mencionadas, mas não detalhadas minuciosamente. Tratou-se assim de esforço duplo de apresentação rápida de informações que possam interessar os leitores do presente e de autocontenção aos limites deste trabalho histórico. Palavra alguma a mais sobre esse tema será dita neste trabalho, adstrito a seu objeto de estudo particularmente delimitado.

${ }^{336}$ Todavia, note-se que para Paul REUTER (1965, p. 198 e 200), mesmo a CECA deteria aparato institucional que a aproximaria mais de uma estrutura Federal - ou pré-Federal - do que de uma simples Organização Internacional. Como será possível ver no Sétimo Capítulo e nas Conclusões Parciais da Parte Segunda desta Tese, não se pode concordar com esta compreensão da CECA. Lembramos ser contrária à postura de Paul REUTER, não apenas a de Fausto de QUADROS (1984, p. 121), como também a de Carlos Francisco Molina del POZO (2011a, p. 63, grifos nossos): “debe quedar claro que la Unión ni era en su origen, ni se ha convertido posteriormente, ni ha de convertirse por necesidad jurídica o por automatismo político, en un Estado federal, aunque, sin embargo, esta perspectiva sigue estando, ciertamente, abierta.".

${ }^{337}$ Nesse sentido, remetemos o leitor à nota de rodapé 2, supra, bem como ao item 2.1., supra. 
qual, inclusive, não poderia ser compreendida como dentro do tradicional paradigma da coexistência entre Estados ${ }^{338}$.

Entretanto, a preocupação em se definir uma natureza do fenômeno jurídico estudado foi acima referida apenas para satisfazer exigências que o conhecimento jurídico tradicional costuma demandar de um estudo em Direito. Como afirmado anteriormente, o fenômeno estudado em si mesmo reitra a importância de mimetizar/espelhar/reproduzir os termos da discussão sobre a natureza jurídica da UE para compreender a da CECA. Todavia, não se pode deixar de notar que, em função do ponto de partida metodológico assumido por este estudo, a própria discussão sobre a natureza jurídica da CECA não faz sentido para este trabalho.

Como visto acima ${ }^{339}$, este trabalho desenvolve suas reflexões no interior de um regime de redução fenomenológica, por assumir a Fenomenologia como critério metodológico meta-lingüístico fundamental. Nesse sentido, lembre-se de que, ao se lidar com fenômenos, retira-se a possibilidade de deles se buscar alguma inscrição secreta gravada em uma suposta intimidade essencial. Essa impossibilidade derivaria do simples fato de os fenômenos não deterem um conteúdo interno intrínseco, próprio, necessário, ou ainda, de não existir uma essência.

Por essa razão, ao se tomar a CECA como um fenômeno, retira-se dela a possibilidade de encontrar uma manifestação essencial qualquer, vale dizer, elimina-se sumariamente qualquer pretensão de nela encontrar uma suposta "natureza" interna determinante de seu ser. Ao ser um suporte significativo, ela jamais deteria qualquer natureza jurídica em si mesma - pois, em regime de redução fenomenológica, não se rege por uma orientação natural que busque uma natureza das coisas.

Não se mostraria coerente, assim, se este trabalho tentasse classificar juridicamente a CECA em função de uma suposta natureza, precisamente porque assume desenvolver reflexões em regime de redução fenomenológica. Apenas por meio de uma desconsideração dos pressupostos metodológicos assumidos por este trabalho é que inadvertidamente se poderia empreender um movimento intelectual no sentido de atribuir uma natureza qualquer (ainda que fosse uma "natureza jurídica") a este processo de integração.

\footnotetext{
338 "Elemento essencial da organização internacional, como tal uniformemente reconhecido pela doutrina, será a existência e a capacidade de manifestar vontade jurídica própria, distinta da vontade dos Estados que a integram, por meio de órgãos, e segundo mecanismos estipulados pelos atos constitutivos da organização." (CASELLA, 1994a, p. 209).

${ }^{339}$ Itens 2.2., 2.2.1. e 2.2.2., supra.
} 
Deste modo, não faz sentido, aqui perquirir sobre a natureza jurídica da CECA, razão pela qual não se desenvolverá linha adicional sobre este tema neste trabalho.

\title{
3.3.3. POLÍBIO e as Normas Jurídicas de Oposições Escalares
}

\begin{abstract}
[P]ara qualquer norma jurídica concreta que se afirme, o ouvinte atento poderá perceber a presença de todas as idéias e todos os pensamentos, sejam estes formais ou substanciais, que compõem o fenômeno jurídico [...]. É esta riqueza de textura, no resultado final do que se chama "formação do direito", que faz da leitura de bom julgamento uma experiência enriquecedora. (CASELLA, 2008, p. 271).
\end{abstract}

Resolvidos os dois últimos impedimentos intelectuais acima suscitados, desbloqueia-se o caminho para o livre acompanhamento do exame a ser desenvolvido por este trabalho. E, para tanto, este item se volta à especificação esclarecida do critério destinado a selecionar, dentre as normas do Direito Positivo Originário da CECA, as que serão objeto da análise institucional no Sétimo Capítulo desta Tese.

Adiante-se que as jurídicas a serem estudadas por este trabalho são aqui designadas normas de oposições escalares, isto é, normas jurídico-positivas do Tratado de Paris, de 1951, as quais articularam um complexo e refinado sistema institucional de oposição entre as medidas de existência participantes do processo de construção, afirmação e conservação de uma Europa Politicamente Unida pela CECA.

Esta classificação é adotada por este trabalho de maneira original, e reconhece-se que certamente tal designação se apresenta perante o público leitor como um critério por demais genérico e indeterminado. Sem dúvida, são necessárias maiores explicações, para tornar mais clara a noção de normas de oposições escalares.

A noção de normas de oposições escalares é um operador significativo conceitual formado especificamente para operar nesta Tese, o qual foi inspirado na análise realizada por POLÍBIO das instituições romanas durante as Guerras Púnicas. Com isso, não se pretende afirmar de forma alguma que POLÍBIO tenha se preocupado com a definição de tal espécie normativa. Antes, como visto anteriormente ${ }^{340}$, trata-se de um critério conceitual de seleção de normas jurídico-positivas elaborado a partir de síntese original sobre as contribuições do pensamento político polibiano desenvolvido em parte específica de suas Histórias.

${ }^{340}$ V. item 3.3.1., supra, sobre empréstimos conceituais e ampliação do conhecimento. 


\title{
3.3.3.1. POLÍBIO e suas Histórias
}

POLÍBIO de Megalópolis (210 a 118 a.C. $)^{341}$ foi um historiador e importante político grego $^{342}$ capturado pelos romanos em 167 a.C., após a batalha de Pidna (168 a.C.)

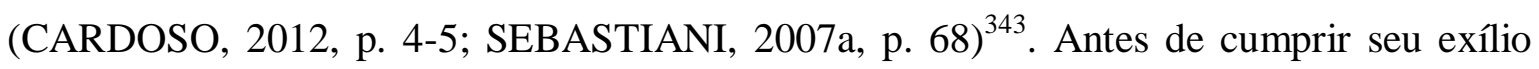
obrigatório em Roma por 17 (dezessete) anos ${ }^{344}$, POLÍBIO exercera intensa atividade política na Grécia ${ }^{345}$.

\begin{abstract}
Já é homem maduro (de mais de trinta e cinco anos) e experimentado em política, seja como filho de um dos líderes mais influentes da federação, seja pelos postos políticos e missões diplomáticas que já assumira. $\mathrm{O}$ pai, próximo do célebre general Philopemen, presidira a Liga em vários momentos e o filho obtivera o segundo posto do Estado em eleições recentes. Esta posição destacada coloca-o entre os obstáculos a serem afastados naquela região para a consolidação da pax romana. (CARDOSO, 2012, p. 5, grifos do autor).
\end{abstract}

Seu destaque político em sua terra natal lhe assegurou a possibilidade de participar dos principais círculos de poder romanos, sem que exercesse o Poder em Roma ou na Grécia (SEBASTIANI, 2006a, p. 56 e 66-7). Durante seu período de exílio, POLÍBIO vivera como protegido da aristocracia romana que liderava a condução do processo iniciado com a Segunda Guerra Púnica: a casa dos Emílios-Cipiões (SEBASTIANI, 2008,

\footnotetext{
${ }^{341}$ Megalópolis foi uma cidade fundada em 368 a.C. por árcades temerosos da expansão espartana; composta por 40 (quarenta) povoados menores, apresentava-se como robusta fortaleza helênica. A cidade de Megalópolis se tornou membro da Liga Aqueia desde 235 a.C., a qual, pretendia assegurar a liberdade dos povos helenos diante de ameaças externas durante os séculos III-II a.C. A Liga Aqueia foi organizada duas vezes na História, (i) de tempos imemoriais até Alexandre 323 a.C.; e (ii) após a $124^{\text {a }}$ Olimpíada (284 a.C.), a fim de conter a expansão militar de macedônios, etólios e espartanos. (SEBASTIANI, 2012, p. 51).

${ }^{342}$ Segundo François HARTOG (2003, p. 10), foi um dos três grandes historiadores gregos, ao lado de Heródoto e Tucídides: o primeiro, dedicado ao relato das Guerras Médicas, o segundo, ao da Guerra do Peloponeso e, POLÍBIO, ao das Guerras Púnicas e do início da expansão imperialista romana.

343 “Após a vitória sobre a Macedônia na batalha de Pidna (168 a.C.), o comandante romano Paulo Emílio escolhe mil reféns a serem levados para Roma como penhor da manutenção dos tratados firmados." (SEBASTIANI, 2010, p. 69).

344 “Tendo já submetido toda a península italiana, a Gália Cisalpina, a Sicília, a Córsega e a Sardenha, conquistado a Ibéria e vencido Aníbal na Segunda Guerra Púnica, Roma derrota a Macedônia na batalha de Pidna (168 a.C.), acarretando realinhamentos políticos em toda a Grécia. A facção encabeçada por Licortas, Árcon e Políbio se mantivera neutra durante o conflito entre o rei macedônio Perseu e os romanos e, por isso, quando neste mesmo ano de 168 a.C. foi sucedida pela facção filo-romana encabeçada por Calícrates, viu seus principais membros denunciados como colaboradores e entregues aos romanos como reféns, junto ao rei vencido e de sua entourage. Contava Políbio de Megalópolis [...] entre os cativos [...]. Levado para Roma, o cativo tem a sorte de travar amizade com o jovem Cipião Emiliano, filho do comandante vencedor, conseguindo assim permanecer na cidade, enquanto todos os outros reféns foram alojados em pequenos povoados dispersos pela Itália.” (SEBASTIANI, 2012, p. 51-2, grifos do autor).

345 Políbio fora hiparca da Liga Aqueia nos anos de 170-169 a.C., isto é, exercera o comando da cavalaria, magistratura subordinada apenas à do estratego (o comandante geral). Era filho de um estratego ilustre (Licortas) e detinha profunda experiência pessoal como militar e como diplomata (SEBASTIANI, 2012, p. $51)$.
} 
p. 39$)^{346}$ - precisamente aquela que causara seu desterro. O autor ocupou assim posição privilegiada para testemunhar pessoalmente não apenas a queda da tradição grega, mas principalmente a surpreendente ascensão do incontestável poderio da República romana (CARDOSO, 2012, p. 5-6).

Em suas Histórias ${ }^{347}$ busca descrever a espantosa formação do extraordinário poder romano sobre o Mediterrâneo entre os pouco mais de 50 (cinquenta) anos que se estendem do início da Segunda Guerra Púnica (219 a. C.) até a batalha de Pidna (168 a. C.), na qual a Macedônia é vencida (CARDOSO, 2012, p. 6). Ela pretende abranger ainda a definitiva submissão da Grécia ${ }^{348}$ e a destruição completa de Cartago, em 146 a. C., por Públio Cipião Emiliano, de Roma (SEBASTIANI, 2006a, p. 56), fato singular por ter sido obra de "um único agente condicionante" (SEBASTIANI, 2005, p. 198) ${ }^{349}$.

Nas palavras do próprio autor, o intento de sua investigação consistia em ${ }^{350}$ : “discerner et comprendre [quand], comment et grâce à quelles institutions les Romains sont parvenus, en

346 “Durante os 17 anos (167-150 a.C.) que passou em Roma, Políbio privou do convívio privilegiado com a elite política e intelectual da urbe por intermédio de Cipião Emiliano. Este era filho legítimo de Paulo Emílio, vencedor de Perseu, e filho adotivo de Públio Cornélio Cipião, filho de Cipião Africano, o vencedor de Aníbal, contemporâneo, de Fábio Máximo e de Catão Antigo e amigo íntimo de Caio Lélio. Os dois últimos, então ainda vivos, figuram entre as testemunhas oculares romanas interrogadas por Políbio a respeito dos anos pós-219 a.C. Além deles, comporão a tertúlia em que se formará o jovem Cipião, além do próprio Políbio, o comediógrafo Terêncio, o filósofo Panécio, os historiadores C. Fânio e Q. Élio Tuberão, o áugure Q. Cévola e outros intelectuais que figurarão no De Republica de Cícero como o 'círculo dos Cipiões'." (SEBASTIANI, 2012, p. 52, grifos do autor).

${ }^{347}$ Obra publicada em 40 (quarenta) livros, dos quais até nós chegaram (i) intactos, apenas os cinco primeiros livros, (ii) a maior parte do Sexto Livro, e (iii) série de fragmentos de trinta livros, mais ou menos ordenáveis pela historiografia. Foram perdidos integralmente os textos dos livros XVII, XIX, XXXVII e XL: "não é pouco [...], o que restou nos permite não só mapear as questões, como também alcançar o essencial da representação que [este autor] constru[iu] de Roma, bem como as inflexões que introduz[iu] na reflexão política." (CARDOSO, 2012, p. 2).

Políbio foi autor também de uma biografia sobre Filopêmen, de um tratado sobre tática militar e de uma monografia sobre a guerra contra Numântia, cujos textos se perderam. À última obra, somente faz referência Cícero (SEBASTIANI, 2012, p. 53). De todo modo, note-se que POLÍBIO dedica à redação de suas Histórias os últimos vinte anos de sua vida (ROUSSEL, 2003, p. 51).

${ }^{348}$ A cidade de Corinto era a principal cidade helênica da Liga Aqueia remanescente que ainda se opunha militarmente contra Roma (SEBASTIANI, 2012, p. 52).

${ }^{349}$ Este único agente condicionante foi, como será visto a seguir, a excelência Política do funcionamento das instituições romanas.

${ }^{350}$ O leitor perceberá imediatamente a partir da leitura da citação abaixo que o tema de investigação do presente trabalho se aproxima bastante da pergunta condutora da reflexão de POLÍBIO em sua obra.

A possibilidade de se recorrer linguisticamente a POLÍBIO para pensar instituições atuais não é pretensão exclusiva deste estudo. Com efeito, essa tentativa fora já realizada durante o século XIX, por Konstantinos PAPARRIGÓPOULOS, professor de História da Universidade de Atenas a partir de 1851, para pensar a preservação e a continuidade da unidade histórica do povo grego - ainda que com motivações nacionalistas românticas e de fundamentalismo religioso, conforme relato feito por Breno Battistin SEBASTIANI (2006a). Tratou-se de uma apropriação parcial do conjunto reflexivo polibiano (SEBASTIANI, 2006a, p. 63), o que não invalidaria a reflexão de Konstantinos PAPARRIGÓPOULOS.

"Tanto Políbio quanto K. Paparrigópoulos escreveram em épocas de grandes sínteses historiográficas, o primeiro em meio ao debate entre a tradição grega e o nascente pensamento romano, o segundo, entre sua formação francesa e a necessidade de definir a identidade nacional de um país cuja cultura oscilava entre o ocidente e o oriente, ou entre passado e presente. Por outras palavras, ambas as obras 
moins de cinquante-trois ans, à étendre leur domination sur la quasi-totalité de la terre habitée, ce qui constituait un fait sans précédent”. (POLYBE, 2003, p. 548) ${ }^{351}$.

constituem imensas tentativas de sínteses ecléticas operadas por intelectos privilegiadamente situados." (SEBASTIANI, 2006a, p. 66, grifos nossos).

Como visto no item 3.3.1., supra, toda apropriação de conjuntos conceituais é necessariamente parcial, na estrita medida da necessidade de produzir um conhecimento distinto do dado pela fonte de reflexão. Apenas assim se pode produzir um conhecimento novo. E é nesse sentido que se pretende se apropriar da reflexão sobre as instituições romanas efetuada por POLÍBIO. Afinal, "três [...] elementos contribuem para aumentar o número de afinidades as quais, mais do que suscitadas pelo ambiente do século XIX a que pertencem, dizem respeito também ao historiador do século XXI: as relações entre história e política, história e filosofia e história e mito." (SEBASTIANI, 2006a, p. 66).

Há que se lembrar de que, mesmo antes do historiador grego do século XIX, POLÍBIO fora retomado pelos autores Renascentistas Italianos nos séculos XV (Leonardo BRUNI) e XVI (Nicolau MAQUIAVEL), por MONTESQUIEU e pelos Federalistas americanos (Alexander HAMILTON; John JAY; James MADISON) no século XVIII e, recentemente, por Antonio NEGRI; Michael HARDT, em sua obra Empire - sempre parcialmente, vale dizer, sempre à luz das idiossincrasias, das tópicas e das condições temporais em que os autores que retomaram a obra polibiana se inseriam. O pensamento de POLÍBIO se mostrou nestes diversos momentos como vigoroso ponto de partida para pensar criticamente o tempo presente analisado por cada um desses autores, de modo a encontrar elementos conceituais chave em um predecessor que legitimasse seus próprios anseios (SEBASTIANI, 2011, p. 122-3, 2012, p. 63-5).

Deste modo, perceba-se que o desenvolvimento nas linhas a seguir do pensamento político de POLÍBIO será feito na estrita medida necessária para fornecer ao presente estudo a indispensável linguagem para falar sobre o tema escolhido.

Apesar de ser interessante, não se preocupará neste trabalho com a exposição integral e minuciosa, nem da vida de POLÍBIO, nem das conclusões de sua principal obra: “[s]e, por um lado, a determinação de um predecessor por via de recortes precisos constitui construção idiossincrática a retratar a técnica hermenêutica do historiador que o faz, por outro, o mesmo procedimento pode ser encontrado já no historiador que é configurado como predecessor: o próprio Políbio já havia tentado transformar Homero, por via de recortes precisos, em predecessor que autorizasse sua própria narrativa." (SEBASTIANI, 2011, p. 120, grifos nossos).

Com efeito, há que se centrar neste trabalho naquilo que constitui sua questão fundamental, a fim de assegurar a coerência metodológica do mesmo. Assim, admitem-se neste texto referências a POLÍBIO e a suas reflexões apenas no que se mostrarem aptas a permitir compreender de que modo alguns dos elementos empregados por ele em sua abordagem da História de construção do poderio de Roma podem contribuir para o desenvolvimento das considerações em torno do tema deste estudo - a construção histórica da CECA, a análise de suas instituições e a qualidade jurídico-política delas.

POLÍBIO aparece neste texto, portanto, como um paradigma argumentativo-interpretativo, e não como fonte de informações a serem desmembradas em seus mínimos detalhes (SEBASTIANI, 2007b, p. 24). Não se trata tanto de entender estrutural e exaustivamente o pensamento político deste autor, mas de compreender como suas categorias operam emblematicamente no interior das questões formuladas para o presente estudo sobre temas contemporâneas.

Se é indispensável fornecer um conjunto de informações para esclarecer o contexto no interior do qual escrevia POLÍBIO, não se pretende se estender em demasia sobre tais questões quando estas não se mostrarem pertinentes para os objetivos investigativos deste trabalho. Lembre-se, apenas, de que resgatar como paradigma um historiador "sinaliza o esforço por identificar vozes que, quando enunciadas, representavam interesses semelhantes mas que, quando ouvidas, denotam perspectivas mais fecundas" (SEBASTIANI, 2006a, p. 76).

Aqui se buscam construir - mediante série de rcorets parciais realizados durante o resgate deste autor - os próprios critérios para uma leitura da CECA a partir de POLÍBIO (a própria visão a ser adotada sobre o paradigma de leitura a ser versado sobre o fenômeno a ser analisado) de maneira coerente com os pressupostos assumidos pelo presente estudo. Este procedimento de "recortes parciais" teria sido ele mesmo utilizado por POLÍBIO com relação a HOMERO para escrever suas próprias Histórias na tentativa de explicar oportunamente seu próprio contexto sociocultural (SEBASTIANI, 2007b, p. 34-6, 2011, p. 120).

${ }^{351}$ Note-se que a aposição do termo "quando" deriva da reflexão feita pelo autor no Livro III, 1, 4-5, no qual também apresentara o intento de sua obra: "Le sujet que nous avons entrepris de traiter, c'est-à-dire, quand, comment et pourquoi toutes les parties connues du monde habité tombèrent sous la domination des Romains, ne constitue qu'une seule et unique action qu'on doit embrasser d'un coup d'œil d'ensemble." (POLYBE, 2003, p. 246, grifos nossos). 
POLÍBIO se considerava como inserido em momento fundamental e único, verdadeiro ponto de inflexão da História de seu mundo, a saber, a transição da tradição grega para o surgimento do pensamento político romano (HARTOG, 2003, p. 9 e 18) ${ }^{352}$. O autor grego não apenas testemunhara o ápice da República romana, como também visara a pensar este momento verdadeiramente original da História de Roma a partir de seu conhecimento político-filosófico gestado em torno do saber grego de seu tempo (CARDOSO, 2012, p. 2-3, 27 e 36).

Nesse sentido, mostra-se importante para ele compreender quando, como e por meio de quais instituições configurou-se o inédito poderio romano perante o mundo habitado de sua época (CASELLA, 2012, p. 318-9; SEBASTIANI, 2005, p. 198-9, 2006a, p. 66 $)^{353}$. O autor grego pensa as instituições de Roma a partir dos referenciais conceituais e das categorias analíticas gregas - isto é, a partir da tradição filosófica no interior da qual se formara, produzindo uma verdadeira intersecção entre o mundo helênico e o romano (CARDOSO, 2012, p. 4; HARTOG, 2003, p. 19; ROUSSEL, 2003, p. 33; SEBASTIANI, 2006a, p. 204).

Para tanto, pretendeu avaliar os eventos das Guerras Púnicas ${ }^{354}$ (SEBASTIANI, 2010, p. 70). Especificamente no Livro VI de suas Histórias ${ }^{355}$, empreendera profundas verificação e compreensão do funcionamento das principais instituições da República Romana de seu tempo. O Livro VI é um momento especial de interrupção da narrativa histórica pelo autor, efetuado com o objetivo de permitir a reflexão sobre as instituições

${ }^{352}$ O qual será profundamente influenciado. Principal atestado deste impacto do pensamento político grego sobre o romano será visto séculos depois com CÍCERO. Este pensava a decadência da República romana a partir das noções fundamentais apresentadas por POLÍBIO sobre Roma em suas Histórias (CARDOSO, 2008, p. 634-5). Com efeito, POLÍBIO teria sido um dos principais meios de absorção do helenismo por Roma, interessada por lições práticas e precisas (CARDOSO, 2002, p. 45; SEBASTIANI, 2007b, p. 36). Ao mesmo tempo, Sérgio CARDOSO (2012, p. 27) argumenta que POLÍBIO teria "romanizado" a teoria política grega, na medida em que se apropriara dela de maneira original. Para François HARTOG (2003, p. 19), "[o]n voit donc, et c'est tout l'intérêt, un historien en plein bricolage.”. No mesmo sentido, Paul PÉDECH (1964, p. 7).

Não é objetivo deste trabalho compreender em que medida POLÍBIO foi ou não fiel à tradição do pensamento político grego (principalmente platonismo, aristotelismo, epicurismo e estoicismo), apesar de ser temática interessante de discussão: “[e]xilé à Rome, Polybe renonce-t-il à la Grèce? Évidemment pas, puisque tout le savoir qu'il mobilise est grec et le bricolage intellectuel auquel il se livre opère avec des notions et des références grecques.” (HARTOG, 2003, p. 29).

Não se tomará aqui posição sobre essa questão, sob pena de extrapolar os limites de investigação desta Tese. Apenas se lembre da observação apontada no item 3.3.1., supra, sobre a inafastável condição de toda apropriação intelectual ser parcial e, ao mesmo tempo, necessária para promover inovações no conhecimento herdado - sem ignorar ou esconder a contribuição legada pelo passado.

${ }^{353}$ A singularidade deste evento, para o autor, derivara do fato de que três continentes teriam se submetido a um único domínio - o domínio romano (SEBASTIANI, 2005, p. 199).

354 "[O] mais importante dos fatos a serem determinados, pois que em torno dele se concentra todo o propósito da existência da obra." (SEBASTIANI, 2008, p. 39).

355 A ser mais detalhadamente analisado no item 3.3.3.2., a seguir. 
romanas a partir do aparato conceitual e reflexivo da tradição helênica alargado à escala “mundial” dada por Roma (CARDOSO, 2012, p. 3; ROUSSEL, 2003, p. 42$)^{356}$.

POLÍBIO "ne chercha pas à discourir, mais à comprendre" (ROUSSEL, 2003, p. 42) em termos helênicos as causas da espantosamente rápida ascensão do poderio romano, o qual lhe permitira destruir a poderosa Cartago e subjugar todo o mundo de sua época. Este movimento de sucesso teria se iniciado com sua vitória inesperada na Segunda Guerra Púnica (CARDOSO, 2012, p. 3-4; ROUSSEL, 2003, p. 42), razão pela qual, é esta escolhida por POLÍBIO como o centro em torno do qual orbita sua análise histórica (POLYBE, 2003, p. 68; SEBASTIANI, 2006a, p. 68-9, 2008, p. 39).

Por volta de 270 a.C., Roma finalizara sua dominação na península itálica e se tornara potência mediterrânea. Em muito pouco tempo, fora confrontada pelo poder de Cartago, localizada no norte da África, quem não apenas controlava esta região, mas também cidades costeiras do sul da Espanha, Sardenha, Córsega e mesmo o norte e o oeste da Sicília: "[a]s rivalidades políticas se somaram a rivalidades comerciais e estas logo se tornaram também rivalidades militares. Os cartagineses logo fechariam os mares ocidentais ao acesso de Roma.” (CASELLA, 2012, p. 311).

A Segunda Guerra Púnica ${ }^{357}$ foi deflagrada por um motivo duplamente jurídico e político. Jurídico, pois derivada de uma distinção entre as interpretações fornecidas pelos romanos e pelos cartagineses com relação ao Tratado entre eles celebrado favoravelmente

\footnotetext{
${ }^{356}$ Conforme indica Sérgio CARDOSO (2012, p. 3): “a ascensão da República Romana, e mesmo toda sua vida, ocorreu num ambiente de ampla hegemonia da cultura grega. O mundo em que ela se inscreve é aquele da civilização comum do helenismo [...]: o grego tornou-se uma língua internacional [...], em que as artes (medicina, arquitetura, leis), a filosofia e, ainda, um 'modo de vida grego' estendem-se por todo o Mediterrâneo e, para além dele, na direção da Mesopotâmia, do Golfo Pérsico e da Ásia. [... M]esmo pelo final da república, os romanos cultos falam grego, os jovens das boas famílias têm preceptores gregos, formam-se na Grécia e alinham-se nas escolas filosóficas chamadas do helenismo.”.

Paulo Borba CASELLA (2012, p. 312-3) menciona o mito de Eneias - relatado por VIRGÍLIO (70 a.C. a 19 a.C.), em sua Eneida - como tentativa de remeter Roma a uma filiação civilizacional grega ("Roma herdeira de Troia"). Tratou-se de um claro anseio por vincular Roma à Grécia - ainda que desconsiderando a distância de séculos entre a queda de Troia e a fundação de Roma, precisamente por esta representar o parâmetro cultural do período: "[e]xiste propósito maior, que vai além de tais dados. [... Trata-se de] dado filo-helênico, constantemente presente na civilização romana, desta repercute para as sociedades neolatinas. E se projeta, até os nossos dias, não obstante alguns percalços.".

${ }^{357}$ Note-se que para POLÍBIO (2003, p. 68), seria esta o evento fundamental da História romana, pois é no final desta que teria Roma se reerguido de maneira surpreendentemente arrasadora com relação ao mundo habitado de seu tempo, vale dizer, tal Guerra representou o preciso momento a partir do qual todos os eventos por ele analisados se encadearam no sentido de produzir, manter e acumular o inaudito poderio romano (SEBASTIANI, 2005, p. 199-200, 2010, p. 74).

Por esse motivo, menciona-se aqui diretamente a Segunda Guerra Púnica, sem prestar muita atenção à Primeira e à Terceira Guerras Púnicas. Apesar de relevantes para compreender o pensamento político de POLÍBIO, elas não interessam aos objetivos reflexivos do presente trabalho.
} 
aos primeiros ao final da Primeira Guerra Púnica ${ }^{358}$. Político, pois motivada por profunda insatisfação de Cartago com relação às pesadas obrigações a ela impostas por aquele Tratado (SEBASTIANI, 2008).

Aníbal atacara e conquistara a cidade de Sagunto (219 a.C.), a aliada de Roma na Ibéria. Essa singela ação foi o motivo mais imediato do segundo conflito: com ela, o comandante militar cartaginês teria deflagrado o início da Segunda Guerra Púnica (CARDOSO, 2012, p. 6; SEBASTIANI, 2006b, p. 171). Essa ação teria autorizado Roma, não apenas a se defender de uma invasão estrangeira, mas também, após a derrota da Cartago ao final da Terceira Guerra Púnica (146 a.C.), a expandir seu império pelo Mediterrâneo (SEBASTIANI, 2006b, p. 183) 359360.

${ }^{358}$ Consistiria na discussão sobre estar autorizada ou não Cartago a atravessar o rio Ebro e atacar os aliados romanos; mais importante do que querer compreender essa questão a partir de perspectiva anacrônica sobre tal temática, é fundamental se deter nos aspectos principais dessa narrativa que possam destacar os elementos linguísticos que permitirão pensar o tema desta Tese de Doutorado.

Faz-se a presente digressão sobre a Segunda Guerra Púnica apenas para tornar presente ao leitor desta Tese a questão que fomentara a reflexão do autor grego sobre as instituições romanas. Por esse motivo, perceba-se que será mencionado apenas o estritamente necessário para compreender como e porquê POLÍBIO introduzira a discussão sobre a necessidade de reflexão sobre as instituições romanas. Caso o leitor tenha interesse nessas questões, remetemos para maiores detalhes à leitura de Sérgio CARDOSO (2012), Paulo Borba CASELLA (2012, p. 302-35) e Breno Battistin SEBASTIANI (2006b, p. 172-7, 2008, p. 41-8).

${ }^{359}$ O que autoriza a Breno Battistin SEBASTIANI (2006b, p. 188) reconhecer que a Segunda Guerra Púnica foi apenas um elemento participante de um projeto maior de expansionismo imperialista romano anteriormente planejado e arquitetado: etapa decisiva, sem dúvida, mas também consequência de interesses políticos anteriores.

Paulo Borba CASELLA (2012, p. 304, 312 e 323-4) ressalta, contudo, que a expansão imperial romana não se exerceu apenas mediante a força, mas também segundo o Direito Internacional da época, com o objetivo de ordenar a convivência entre Roma e os diferentes em seu entorno para além de singelas relações de força ou de princípios. Afinal, estendendo-se desde toda a orla do Mediterrâneo, abrangendo o norte da África, até a atual Europa central e o Oriente Médio, a "universalidade do império se tornava, por assim dizer, impossível sem a existência de ordem jurídica internacional” (CASELLA, 2012, p. 314).

O mesmo autor ressalta ainda a presença de elementos jurídicos internacionais nas relações de Roma com povos de outras entidades políticas autônomas, quer durante o período republicano, quer durante o Império, por meio de instrumentos como foedera, pacto aequo e pacto iniquim, ou mesmo mediante recursos muito parecidos com os do moderno Direito Internacional (troca de cartas seladas, Tratados produzidos nos idiomas dos países envolvidos, regulação internacional de relações comerciais, entre outros) (CASELLA, 2012, p. 304, 323-5 e 333).

"A hegemonia de Roma, durante séculos, nunca pretendeu aniquilar as estruturas e conceitos dos povos que conquistava, mas inseria o elemento romano e as aspirações deste, em meio ao contexto, no qual se formara a sociedade, na qual se inscrevia o domínio romano, acoplado à base daquele povo e identidade étnica e cultural. Em lugar de arrasar, tratava-se de agregar como 'superestrutura' o elemento romano à base do povo local.” (CASELLA, 2012, p. 319). Com efeito, na relação de Roma com os povos vizinhos, lembrese ainda de que "[c]om parceiros considerados iguais eram celebrados tratados de amizade ou neutralidade (amicitia) e alianças defensivas (foedus). Alguns tratados constituíam formas variadas de dependência (deditio in fidem, clientela), mais ou menos correspondentens aos pactos de vassalagem e protetorado do direito internacional moderno ou constituíam submissão à autoridade de Roma (deditio)" (ACCIOLY; NASCIMENTO E SILVA; CASELLA, 2009, p. 22, grifos dos autores).

A adequada compreensão dos modos de relação de Roma com os povos vizinhos - entre tolerância e cosmopolitismo versus militarismo e culto da força (CASELLA, 2012, p. 320) - é temática interessante, mas que não merece maiores atenções neste estudo, por se localizar fora de seus limites metodológicos. É somente interessante recordar que, em oposição à informação anterior, os romanos souberam muito bem arrasar integralmente Cartago e Numântia (CASELLA, 2012, p. 306). De todo modo, é "descabido negar a 
Após a tomada da cidade de Sagunto, Aníbal iniciara uma devastadora marcha em direção à Itália, caracterizada pela consecutiva derrota dos romanos em Trébia, em 218 a.C., em Trasimeno, em 217 a.C. e, finalmente, na batalha de Canas, de 216 a.C. Esta teria deixado Roma mergulhada em situação profundamente desesperadora e desamparada, efetivamente muito próxima da ruína (CARDOSO, 2012, p. 6-7) ${ }^{361}$.

Les Carthaginois, à la suite de leur victoire, se trouvèrent immédiatement maîtres de presque tout le reste du littoral [...]. Les Romains cependant, après une telle défaite, comprirent tout de suite qu'ils ne pourraient plus dicter leur loi à l'Italie. Ils étaient pleins de craintes pour eux-mêmes et pour leur patrie gravement menacée par Hannibal, qu'ils attendaient à voir apparaître d'un moment à l'autre. (POLYBE, 2003, p. 355-6).

O resultado da batalha de Canas foi amplamente desfavorável aos romanos: setenta mil soldados mortos - dentre os quais o cônsul Lúcio Emílio e os cônsules do ano anterior, Cneu Servílio e Marco Régulo - e dez mil soldados capturados (POLYBE, 2003, p. 354-5). Tamanho fora o impacto desta derrota que se poderia até mesmo dizer que, após esta batalha, não mais havia exército romano sobre a Itália (SEBASTIANI, 2006b, p. 283). Muito pouco faltou para que Aníbal pudesse desferir o golpe de misericórdia e tomar a

existência e a operação de sistema internacional antigo, regido por alguns princípios." (CASELLA, 2012, p. 325). Não retornaremos mais a este tema neste trabalho.

360 Os eventos relacionados à Segunda Guerra Púnica serão mencionados muito rapidamente neste texto apenas para esclarecer ao leitor o contexto narrado por POLÍBIO. É no interior deste período que se revela de especial importância a reflexão do autor que efetivamente interessa a este trabalho: o Livro VI.

Deste modo, não se surpreenda o leitor com sumária referência ao início e ao desenvolvimento da Segunda Guerra Púnica até a derrota de Roma na batalha de Canas (216 a.C.). O interesse deste texto não é a narrativa histórica polibiana em si, mas apresentar a contribuição de POLÍBIO para o pensamento jurídicopolítico em torno das instituições romanas. A brevidade da referência à Segunda Guerra Púnica deriva não apenas da intenção de conter esta Tese no interior de seus limites materiais, mas também para lhe assegurar vigorosa coerência metodológica.

${ }^{361}$ Em conjunto com a campanha desenvolvida por Aníbal na Itália (218 a.C. a 203 a.C.) em direção a Roma, há outras três campanhas que se desenvolvem concomitantemente, a saber, (i) na Ibéria (219 a.C. a 206 a.C.), (ii) na Sicília (214 a.C. a 210 a.C.), e (iii) na Líbia (204 a.C. a 202 a.C.).

Apesar de a narrativa do conjunto dessas campanhas ser interessante - e mesmo historicamente relevante para compreender os embates militares entre Roma e Cartago e seus respectivos aliados, não se trata do objetivo deste texto apresentar a completude detalhada das batalhas - sob pena de se extrapolar os limites investigativos deste estudo -. Indicamos para o leitor interessado neste tema a própria obra de POLÍBIO (POLYBE, 2003, p. 245-356, 605-788 e 849-902), Livros III, VII a XI, XIV e XV, e a Tese de Breno Battistin SEBASTIANI (2006b, p. 246-90), onde é feito um breve resumo dessas campanhas.

$\mathrm{O}$ interesse do presente trabalho em invocar as Histórias de POLÍBIO consiste simplesmente em fazer referência ao pensamento político deste autor no Livro VI desta sua obra para, a partir dele, efetuar a apropriação conceitual para os objetivos analíticos desta Tese.

Por esse motivo, basta a sucinta inserção contextual do autor e a breve explicação das razões pelas quais ele desencadeara as reflexões em seu Livro VI para produzir reflexões políticas sobre as instituições romanas - sem que, com isso, se preocupe mais especificamente em apresentar de forma mais ou menos extensa o relato histórico polibiano em si mesmo. Afinal, não são as Histórias de POLÍBIO o objeto de interesse deste trabalho, mas a reflexão por este desenvolvida em seu Livro VI, na exata medida em que for apta a auxiliar na reflexão conceitual produzida por este estudo sobre a experiência histórica e normativa da CECA. 
própria Roma durante a campanha da Itália: mas, com ações isoladas desprovidas da coordenação dos movimentos iniciais, o general cartaginês possibilitara a reestruturação da população romana (SEBASTIANI, 2006b, p. 283-4) ${ }^{362}$.

De todo modo, Aníbal acampara com suas tropas muito perto da Cidade de Roma. Por grande coincidência, os cônsules do ano 211 a.C. haviam convocado legiões romanas armadas exatamente para o dia do cerco da Cidade por Aníbal. Isso possibilitara a Roma apresentar um grande número de homens armados dispostos a defender a Cidade, o que desanimou o empreendimento guerreiro do cartaginês. Este se contentou com saques nas regiões que circundavam Roma para, em seguida, partir (POLYBE, 2003, p. 667-9).

\title{
3.3.3.2. A Análise Polibiana das Instituições Romanas no Livro VI
}

Depois da desastrosa derrota romana na batalha de Canas (216 a.C.), de maneira surpreendente, Roma se reerguera da quase completa destruição e, em pouco mais de 10 (dez) anos saíra vitoriosa também ao final da Segunda Guerra Púnica. Apesar das três derrotas romanas mais significativas na Guerra após a travessia dos Alpes por Aníbal, Roma teria conseguido superar os severos castigos, experienciar provações e vencer Cartago e seus aliados na batalha de Zama, em 202 a.C. (CARDOSO, 2012, p. 7; POLYBE, 2003, p. 871-9; SEBASTIANI, 2006b, p. 289).

O que explicaria esse súbito revigoramento da capacidade responsiva de Roma? (POLYBE, 2003, p. 246).

\begin{abstract}
A narração é suspensa no ponto da grande adversidade dos romanos em Canas, introduzindo-se as considerações "especulativas", para que o leitor possa apreciar e compreender seu triunfo, armado pelo conhecimento do que o sustenta e alimenta: a originalidade e excelência de sua constituição. (CARDOSO, 2012, p. 9, grifos nossos).
\end{abstract}

C'est après la bataille de Cannes, lorsque Rome, vaincue par les armés, pressée par un des plus grands chefs militaires qui aient existé, ne peut plus espérer son salut que de sa politique, de ses corps constitués, de ses traditions. En prenant les affaires romaines au point le plus bas, l'historien a donné à l'efficacité des institutions sa plus grande amplitude. (PÉDECH, 1964, p. 306, grifos nossos).

Com certeza, "ce ne fut pas par hasard, comme certains Grecs imaginent, ni par la force des choses seulement, mais pour de bonnes raisons" (POLYBE, 2003, p. 134) que Roma conseguira se reerguer. Esta boa razão seria especificamente "la qualité des

${ }^{362}$ O período entre a batalha de Canas e o cerco de Roma por Aníbal (216 a.C. a 211 a.C.) é fragmentado na obra de POLÍBIO, razão pela qual se socorre da narrativa de Breno Battistin SEBASTIANI (2006b). 
instruments politiques forgés de génération en génération par le peuple romain et mis en action avec un acharnement méthodique par les dirigeants qui s'étaient succédé au gouvernement de la cité et au commandement des armées.” (ROUSSEL, 2003, p. 43).

O final da Segunda Guerra Púnica em 202 a.C. é dado por uma campanha vitoriosa de Roma. O sucesso da reversão da ação romana se devia ao fato de esta Cidade estar sustentada por uma organização jurídico-política singularmente excelente e estável (ROUSSEL, 2003, p. 47; SEBASTIANI, 2006b, p. 193) ${ }^{363}$, a qual fora a mais apta a conferir a mais vigorosa e rápida resposta à maior derrota oriunda do conflito mais decisivo até então travado por Roma (SEBASTIANI, 2006b, p. 245): afinal, segundo a perspectiva de POLÍBIO, é sempre da organização jurídico-política de um povo que deriva todo o sucesso ou todo o fracasso (POLYBE, 2003, p. 548) ${ }^{364}$.

\begin{abstract}
[D]ans les relations entre individus, ceux qui cherchent à se faire une opinion sur les qualités ou les défauts de tel ou tel ne doivent pas, s'ils veulent véritablement formuler un jugement en connaissance de cause, s'arrêter sur les périodes où les personnes en question n'ont eu qu'à se laisser vivre sans inquiétude. Ils doivent au contraire porter leur attention sur les moments où celles-ci se sont trouvées aux prises avec l'adversité et aussi sur ceux où elles ont été favorisées par la chance. 6. Il faut en effet considérer que le seul et unique critère d'une vertu accomplie, c'est le fait de savoir endurer avec grandeur d'âme et dignité les renversements de fortune les plus complets. Or c'est de la même façon qu'on doit procéder pour juger de la valeur d'une constitution 7. Et je ne vois pas quel renversement plus rapide et plus complet on pourrait trouver à notre époque que celui qui s'est produit dans les affaires romaines. (POLYBE, 2003, p. 548).
\end{abstract}

Esse Regime jurídico-político é minuciosamente pensado e caracterizado pelo autor no Livro VI de suas Histórias. E é a compreensão dessa específica articulação institucional da forma de Governo romana vigente após a derrota de Canas (216 a.C.) - tal qual desenvolvida no Livro VI - que interessa a este trabalho.

\title{
3.3.3.2.1. As Razões e a Estrutura do Livro VI
}

Mais do que se interessar em produzir um resumo mais ou menos extenso sobre as Histórias de POLÍBIO, este texto se centraliza na questão de compreender a reflexão de

\footnotetext{
${ }^{363}$ A qual somente esperara o pleno desastre para que sua "superiorité [s']éclait[ait] pleinement." (PÉDECH, 1964, p. 500).

364 "[L]a connaissance de la [politeia] romaine lui a paru nécessaire à l'explication de la conquête ; c'est le point fondamental de son sujet, comme il annonce dès la préface du livre I et le répète inlassablement du début à la fin de son ouvrage. Il est convaincu que la forme particulière de l'État a puissamment aidé les Romains [...]." (PÉDECH, 1964, p. 303, grifos nossos).
} 
Filosofia Política desenvolvida por POLÍBIO sobre as instituições romanas ${ }^{365}$. Debruça-se sobre o pensamento político deste autor para incorporar parcela de sua teia significativa voltada a estudar os mecanismos da organização jurídico-política das instituições romanas - para compreender o tema escolhido para o presente estudo.

Restringir-se-á deste modo a apresentar e incorporar parcialmente a contribuição do pensamento político de POLÍBIO exposta no Livro VI de suas Histórias, pois é neste momento lógico de seu texto em que se explicitam os elementos fundamentais que permitirão investigar o fenômeno escolhido para este trabalho. Para nós, como para POLÍBIO, apresenta-se a seguinte questão: “quem, dentro da urbs, é responsável por tamanha empresa?" (SEBASTIANI, 2005, p. 200, grifos do autor).

A resposta para POLÍBIO era bastante precisa: foi a organização das instituições políticas romanas de determinado modo específico que teria permitido a Roma se recuperar após a desastrosa derrota na batalha de Canas (216 a.C.) e, em pouco tempo, se tornar senhora do mundo habitado da época após a derrota de Cartago (PÉDECH, 1964, p. 303; POLYBE, 2003, p. 135 e 548; SEBASTIANI, 2012, p. 58). É por esse motivo que POLÍBIO interrompe a narrativa neste Livro VI: tratar-se-ia do "momento mais fecundo para poder emitir juízos a respeito da superioridade da constituição romana em relação a outras estudadas[, pois fora ela que possibilitara a superação do momento mais crítico de sua época]." (SEBASTIANI, 2006b, p. 201);

\footnotetext{
Do historiador que presenciou o nascimento e os primeiros passos do imperialismo romano, restou um relato cujas circunstâncias e subjacente cultura historiográfica levaram ao entrelaçamento de uma guerra a um sistema constitucional como instrumentos de análise para a explicação de um fenômeno histórico entendido como processo. (SEBASTIANI, 2005, p. 208).
}

Compreender a História da construção do poderio romano significou para POLÍBIO desenvolver no Livro VI de suas Histórias uma análise sobre os "poderes que conduzem o processo em questão [dominação do mundo por Roma]" (SEBASTIANI, 2005, p. 200) a partir das instituições romanas (POLYBE, 2003, p. 135 e 356). Não se tratou de compreender apenas as distintas formas de organizar jurídico-politicamente as relações. Antes, consistiu em apreender as características daquela que se mostrara a mais excelente organização jurídico-política (a politeia romana) a partir do estudo minucioso de suas principais instituições (CARDOSO, 2002, p. 45-6) - pois elas teriam sido, segundo

\footnotetext{
${ }^{365}$ No caso deste autor, para entender como em tão pouco tempo Roma teria se reerguido e dominado o mundo habitado de sua época.
} 
sua perspectiva, as efetivas responsáveis pela superação do desastre (PÉDECH, 1964, p. 425).

De maneira semelhante se apresenta o tema para este trabalho. A integração europeia causa até hoje espanto e maravilhamento, pois foi uma reversão absolutamente inesperada e bem sucedida do modo de relações na Europa, a qual ocorrera em muitíssimo pouco tempo após o final da Segunda Guerra Mundial. Países tradicionalmente opostos militarmente por séculos puderam em apenas seis anos constituir institucionalmente mecanismos normativo-jurídicos positivos de Direito Internacional Público que tornaram impossível e impensável a deflagração de uma nova Guerra regional na Europa - condição que se perpetuou nos últimos 60 (sessenta) anos, o que por si só justifica a necessidade de este evento ser examinado de maneira circunstanciada em termos históricos e normativoinstitucionais.

Como ocorreu com POLÍBIO, "[l]e caractère absolument extraordinaire des faits [...] suffit à lui seul pour retenir l'attention du public et inciter jeunes et vieux à se plonger dans cet ouvrage.” (POLYBE, 2003, p. 65). O incontestado sucesso do afastamento da Guerra entre os países da Europa politicamente Unida é surpreendentemente suficiente para justificar uma atenção mais detida sobre os mecanismos jurídico-normativos positivados inteligentemente utilizados para a consecução institucional prática deste objetivo singular na História da Europa.

Nesse sentido, para que seja depreendida a virtuosa astúcia política de articulação de tais mecanismos institucionais promotores deste objetivo plenamente atingido há mais de 60 (sessenta) anos, é fundamental analisar as normas jurídicas positivas constantes do Tratado da CECA que estabeleceram um conjunto institucional específico responsável pela viabilidade prática ao fim de afastar o cometimento de novas Guerras regionais na Europa. Pois somente o cuidadoso estudo destas conferirá uma resposta à indagação (PÉDECH, 1964, p. 304) e satisfará o espanto suscitado até hoje dentre estudiosos de Direito Internacional.

Apenas deste modo será possível identificar ${ }^{366}$ (i) quem é o responsável pela saída do desastre do pós-Segunda Guerra Mundial em virtude da produção de um novo modo de

\footnotetext{
${ }^{366}$ De maneira distinta do que conclui a tradição do conhecimento jurídico sobre a CECA, como apontado na nota de rodapé 202, supra.
} 
relações entre países europeus ${ }^{367}$ - usualmente opostos em termos bélicos; e (ii) como se poderia qualificar essa forma de articulação entre as instituições do Tratado da $\mathrm{CECA}^{368}$.

[J]'estime qu'un exposé sur ce sujet [...] pourra rendre de grands services aux lecteurs soucieux de s'instruire ainsi qu'aux hommes politiques qui voudront, ailleurs, réformer les institutions ou en créer de nouvelles. (POLYBE, 2003, p. 356, grifos nossos).

Nesse sentido, recorre-se às categorias basilares do pensamento político de POLÍBIO - apresentadas no Livro VI de suas Histórias, com o objetivo de, a partir delas, pensar as instituições estruturadas politicamente no Tratado de Paris de $1951^{369}$. Afinal, tanto POLÍBIO, como este trabalho, tratam de eventos históricos efetivamente extraordinários para os períodos que objetivam respectivamente inspecionar.

Depois da batalha de Canas (216 a.C.), os romanos conseguiram se reerguer de forma espantosamente rápida e, em menos de 53 (cinquenta e três) anos, dominaram todo o mundo conhecido. Da mesma maneira, após imensa e intensa destruição material de seu território, os seis países europeus da CECA detiveram a capacidade de constituir em menos de seis anos uma nova forma de relações entre si apta a impedir de toda forma a deflagração de novo combate militar, rompendo com a tradição de mais de seiscentos anos de Machtpolitik (CASELLA, 2000a, p. 81, 2004, p. 537; MAGNETTE, 2006, p. 11 ) ${ }^{370}$.

\footnotetext{
${ }^{367}$ Nos termos definidos nos itens 1.4., supra.

${ }^{368}$ De acordo com a chave hermenêutica descrita no item 3.4., infra.

${ }^{369}$ Não são incorporadas por este trabalho as contribuições polibianas sobre (i) o método histórico fundado na psicologia de grandes homens e na afirmação da existência de uma causa das ações (causa-pretextoinício), (ii) a importância da Geografia para produzir conhecimento histórico mais preciso, (iii) as críticas das fontes históricas e de seu uso; nem as reflexões políticas sobre (iv) a influência dos costumes (inclusive militares) na preservação da excelência política romana ou (v) a oposição entre fortuna e acaso (PÉDECH, 1964; SEBASTIANI, 2012). Tratam-se de temáticas interessantes, mas a discussão delas extrapolaria os limites metodológicos e materiais do presente estudo. Registra-se o convite para eventuais investigações conjuntas sobre elas.
}

Restringe-se aqui a análise a uma parcela da reflexão política políbiana, tal qual concentrada no Livro VI de suas Histórias, a saber, (i) à análise e à interpretação da articulação estabelecida historicamente entre as principais instituições romanas, bem como (ii) à Teoria da Anaciclose. Ressalte-se todavia que esta última é utilizada marginalmente neste estudo, como um pressuposto que acompanha meta-linguisticamente a reflexão à distância, e que fará maior sentido ao final desta Tese enquanto compreendida como racionalidade lateral que ronda extra-textualmente este trabalho. V., nesse sentido, o final das Conclusões Parciais da Parte Segunda desta Tese.

Lembre-se ainda da possibilidade de se efetuar empréstimos conceituais parciais (incisões conceituais) para a produção de conhecimento científico novo, conforme justificativa constante do item 3.3.1., supra. Recorrer à tradição para compreender o presente não significa buscar reproduzir o passado nos dias atuais, mas sim buscar roupagem linguística da tradição - devidamente reformulada significativamente para pensar o agora. V. ainda o início do Quarto Capítulo, infra.

${ }^{370}$ Com a diferença de a pax romana ter sido fruto de expansão imperialista dos povos do Mediterrâneo (nesse sentido, v. observações sobre os elementos de Direito Internacional nas relações entre romanos e povos vizinhos, na nota de rodapé 359, supra), ao passo que a ausência de guerra em território europeu ter 
Pois bem. A análise das instituições políticas de Roma por POLÍBIO se justificara pelo fato de elas terem se revelado como as mais excelentes entre todas as das demais Cidades de seu tempo. As instituições políticas de Roma teriam respondido rápida e eficazmente ao momento mais crítico de sua época - a completa derrota romana perante Cartago na Segunda Guerra Púnica, "quando tudo parecia perdido e já nas mãos de Aníbal" (SEBASTIANI, 2005, p. 200-1, 2012, p. 58). Muito rapidamente, Roma se reerguera e dominara o mundo habitado de sua época (POLYBE, 2003, p. 548) ${ }^{371}$, dando provas do vigor e da maturidade das instituições que "sustentaram seu movimento extraordinário em direção à grandeza" (CARDOSO, 2012, p. 8).

O Livro VI das Histórias de POLÍBIO é dividido em quatro partes: (i) apresentação das formas de Governo e da Teoria da Anaciclose; (ii) análise das instituições romanas e qualificação da forma de Governo resultante como mista; (iii) descrição do sistema militar romano; e (iv) comparação da forma de Governo romana com a de outras Cidades, indicando a inevitável ocorrência do processo degenerativo (SEBASTIANI, 2012, p. 58-9). Conforme afirmado anteriormente ${ }^{372}$, interessam a este estudo apenas as considerações relacionadas aos itens (i), (ii) e (iv).

\subsection{A Anaciclose entre os Oito Regimes Políticos}

POLÍBIO apresenta as tradicionais formas de Governo a ele legadas pela tradição $^{373}$, usualmente distintas entre formas primárias ou puras (Realeza, Aristocracia e Democracia) e formas secundárias ou degeneradas (Tirania, Oligarquia e Oclocracia); ao lado delas, haveria ainda a Monarquia e o Regime Misto, totalizando oito Regimes de Governo (CARDOSO, 2012, p. 9; POLYBE, 2003, p. 549-51; SEBASTIANI, 2012, p. 589).

O princípio da sociedade seria precisamente a completa dispersão dos homens. Estes são reunidos posteriormente, à medida que seu número aumenta, sob o comando daqueles dotados de maior força física e bravura. Sendo apenas um homem quem exerce o

sido produzida por meio da precisa invenção de instituições aptas a instaurar, manter e conservar Leis entre os diferentes países europeus unidos pela CECA.

${ }^{371}$ Breno Battistin SEBASTIANI (2005, p. 206) afirma que "[a] Segunda Guerra Púnica transformou de fato a urbs numa potência imperialista", a qual fora posteriormente lastimada por Marco Túlio CÍCERO (Dos Deveres e De República).

${ }_{372} \mathrm{~V}$. nota de rodapé 369 , supra.

373 "On est là sur un terrain grec bien balisé, depuis Hérodote déjà et illustré par Platon et Aristote." (HARTOG, 2003, p. 25); todavia, sua diferença com a Política de ARISTÓTELES residiria no fato de que ele conectar o sucesso histórico de Roma a suas instituições (PÉDECH, 1964, p. 306). 
Governo, e ainda sob o regime da força, o autor designa esta condição como a de uma típica Monarquia. Este autocrata seria o preciso princípio de agregação política dos homens dispersos por meio da introdução de sentimentos morais entre eles, inaugurando o ciclo $^{374}$ de sucessão entre as organizações jurídico-políticas ${ }^{375}$ (POLYBE, 2003, p. 553).

A partir do desenvolvimento da moral, os homens passam a se preocupar com o bem comum e se tornam gratos com relação a aquele que os reuniu politicamente; neste momento, a Monarquia (Governo da força) se torna Realeza, na medida em que o povo deixa de obedecer em razão da submissão à força e passa a se considerar obrigado por dívida de gratidão: o próprio julgamento popular racional aprova a obediência e torna tal Governo legítimo (POLYBE, 2003, p. 554).

É preciso enfatizar a importância desta análise da passagem da forma monárquica para a régia, porque nela se fixa o princípio de legitimação de todos os regimes retos: a confiança do povo, alçada aqui à condição mesma de "forma" da legitimidade política. Será sempre ao reconhecimento popular de seus méritos (e, logo, aos de suas famílias e antepassados) - sua coragem, prudência, capacidade de julgamento e raciocínio, postos a serviço da proteção do povo, da realização da justiça e do interesse comum - que os governantes deverão seu poder. [...S] erá sempre, para o povo, "os muitos", chancelar com sua confiança a liderança daqueles homens e famílias beneméritos da causa pública, a que deve obrigação por seus serviços. (CARDOSO, 2012, p. $14-5$, grifos nossos) ${ }^{376}$.

[I]l faut considérer comme des royautés non pas tous les régimes monarchiques, mais ceux-là seulement qui sont librement acceptés par les sujets et qui les gouvernent par la persuasion plutôt que par la crainte et la force. 3. Et l'on ne saurait non plus considérer comme aristocraties toutes les oligarchies ; celles-là seulement le sont dans lesquelles la souveraineté appartient à des hommes choisis parce qu'ils sont les plus justes et les plus sages. 4. De même, un régime dans lequel la masse entière des citoyens a tout pouvoir pour faire tout ce qu'il lui plaît et pour imposer tous ses désirs ne saurait passer pour une démocratie. (POLYBE, 2003, p. 550-1).

Enquanto o Rei vivesse como todos e com todos, o Regime da Realeza permaneceria integramente reto; a possibilidade de corrupção adviria da investidura na posição de Rei daqueles que, por hereditariedade, detivessem direito ao trono (POLYBE, 2003, p. 554-5).

\footnotetext{
${ }^{374} \mathrm{~V}$. linhas a seguir, sobre a Teoria da Anaciclose.

375 “'Observe-se que este monarca, 'autocrata' (o mais forte e corajoso), é princípio de agregação; não é um tirano (um fraco, temeroso das conspirações), princípio de dissociação, visto que movido unicamente pelos próprios desejos e interesses" (CARDOSO, 2012, p. 12).

${ }^{376}$ A importância do reconhecimento popular na fundação e na refundação continuada da vida comum será mais bem compreendida nas linhas a seguir, e adquire especial importância na construção da Europa Unida da CECA, como se poderá v. especificamente no item 7.3.2., infra.
} 
Diante da segurança e da abundância legadas por seus antepassados, tais descendentes cederiam a seus apetites e buscariam se distinguir dos demais. Progressivamente, a naturalização do aceite do destacamento deste Um sobre os demais imperceptivelmente transformaria o Rei em Tirano e alteraria o Regime da Realeza para a Tirania. Essa ruptura da igual posição horizontal diante dos outros ensejaria o exercício abusivo do Poder, fomentando discórdia, raiva, reprovação e cólera. Tornando-se insuportável, alguns poucos homens do povo se reuniriam para derrubar o Tirano e, com isso, instaurariam a Aristocracia (POLYBE, 2003, p. 555).

$\mathrm{Na}$ Aristocracia, o povo guardaria relação de gratidão com relação aos homens de escol que destituíram o insuportável Regime do Tirano; de igual modo, os novos homens do Governo assumiriam com igual cuidado o exercício do Poder, dando especial preferência ao interesse comum.

Todavia, por causa da inexperiência diante das adversidades passadas, os herdeiros destes poucos homens bons passariam a desconsiderar a importância da igualdade civil e de liberdade da palavra. Aos poucos estes passam a orientar as questões públicas a partir de sua própria perspectiva e de maneira contrária à perpetuidade da relação de igualdade perante os demais. Diante de um Governo em que o Poder é exercido a partir da perspectiva destacada de Uns poucos com relação aos demais, a gratidão do povo desapareceria: nesta Oligarquia, a lembrança do Tirano lhes confiaria a certeza de fim comum desastroso (CARDOSO, 2012, p. 17; POLYBE, 2003, p. 555-6).

O exílio ou o massacre dos governantes oligárquicos por parte do povo é marcado pela queda do princípio de confiança em algo distinto do povo ele mesmo. Não busca mais este correr o risco de destacamento de Um ou de Uns com relação à posição de igualdade horizontal entre todos os partícipes da Cidade. Por esse motivo, após a queda da Oligarquia, instaura-se a Democracia, Regime em que eles atribuem a si próprios os encargos da administração da vida comum.

É importante notar que a Democracia não é, para POLÍBIO, o Poder "pour faire tout ce qu'il lui plaît et pour imposer tous ses désirs" (POLYBE, 2003, p. 551). No princípio da Democracia, há uma clara percepção da necessidade de se preservar a igual possibilidade de todos participarem da vida pública (igualdade no direito de palavra e de liberdade de expressão). Para tanto, ressurge aqui a dívida de gratidão, estabelecida com relação às tradições e aos seus antepassados (POLYBE, 2003, p. 551 e 556). 
Essa particular condição de "fidelidade ao mos maiorum" torna a Democracia o Governo mais frágil: subsiste apenas enquanto o Regime mais conservador com relação a eles mesmos, ao mesmo tempo que qualquer princípio de corrupção desagrega completamente o corpo - pois enfraquece o próprio princípio de legitimidade (CARDOSO, 2012, p. 16). Em outras palavras, a Democracia se preserva enquanto sobreviver a lembrança da necessidade a manutenção da posição de horizontalidade, desaparecendo este cuidado quando os herdeiros daqueles que instauraram o regime constituem o hábito da desconsideração da igualdade e da desvalorização da igualdade no direito de palavra e de liberdade de expressão (POLYBE, 2003, p. 556).

Surge assim a Oclocracia, o Governo da massa desejante. Esta é guiada por demagogos e exercida mediante o uso da força e das vias de fato. O povo se acostuma com essa lógica de destituir os bens dos outros, sob o nome da imposição do Um-todos sobre os demais e, com isso, o Regime se dissolve na brutalidade e se encaminha em direção à ruína da vida política - retornando à dispersão inicial (CARDOSO, 2012, p. 15-6; POLYBE, 2003, p. 556-7) $)^{377}$.

Mais do que se preocupar com a definição das formas de Governo apontadas pela tradição, POLÍBIO apresenta a ideia do necessário ciclo de alteração das formas de Governo, ou ainda, a Teoria da Anaciclose.

Segundo esta concepção - originalidade produzida pela reflexão polibiana, pouco ou quase relacionada com o pensamento filosófico de PLATÃO (CARDOSO, 2012, p. 101), haveria entre as formas de Governo alternâncias periódicas sucessivas e inevitáveis de uma forma pura para uma forma degenerada e, de uma forma degenerada, para uma forma pura, ininterruptamente. (SEBASTIANI, 2006b, p. 230, 2012, p. 58-9). O princípio das formas de Governo - a dispersão - seria também o produto final da pior delas (POLYBE, 2003, p. 557) - fruto da "ruína da cultura" (CARDOSO, 2012, p. 12).

O ciclo entre surgimento, apogeu e corrupção seria fechado e contínuo: haveria uma lei de sucessão cíclica dos Regimes políticos, cujo conhecimento permitiria (i) explicar o destino da vida de cada organização jurídico-política do social de um modo metódico e, além disso, (ii) antever o futuro a partir do conhecimento adequado do passado - pois a ordem de sucessão seria fixa. O historiador poderia prever o movimento de

\footnotetext{
${ }^{377}$ Até o presente momento foram apresentadas na explicação apenas 7 (sete) formas de Governo. A oitava a mais excelente, conforme POLÍBIO - será apresentada a seguir. Trata-se do Regime Misto, que apenas faz mais sentido quando compreendido no interior da Teoria da Anaciclosem a ser explicada nas linhas a seguir.
} 
sucessão, mas sempre dentro dos limites da própria Anaciclose ${ }^{378}$, podendo apenas pensar em encontrar mecanismos institucionais que pudessem o retardar ao máximo (CARDOSO, 2012, p. 18; PÉDECH, 1964, p. 308-9 e 311; POLYBE, 2003, p. 551 e 557).

\begin{abstract}
Royauté, aristocratie, démocratie: un régime s'installe, se dégrade (la royauté en despotisme, l'aristocratie en oligarchie, la démocratie en ochlocratie), un autre lui succède, selon un enchaînement naturel, jusqu'à ce qu'on revienne au point de départ. [...] Après la naissance et la maturité, vient la chute. (HARTOG, 2003, p. 25).
\end{abstract}

[O] historiador nos faz imediatamente compreender que observamos um movimento circular e que, como logo se constata, a catástrofe não é unicamente natural: ela resulta da dissolução total das ordenações políticas produzida pela última e mais deletéria das figuras do ciclo dos regimes, a oklocracia, na qual o povo corrompido, guiado por demagogos, faz reinar o poder da gentalha (xheirocracia, o governo dos piores), que 'massacra, exila, saqueia, até regredir para a animalidade' (VI, 9, 9) no reino da violência, que determina o ponto zero a partir do qual se assistirá a reemergência da socialidade. (CARDOSO, 2012, p. 12).

Cada um dos Regimes detém em si mesmo o princípio de sua corrupção - sempre a imoderada prevalência de seu princípio instituidor fundamental ${ }^{379}$, por mais que haja meios que visem a impedir a degradação ${ }^{380}$. $O$ único instrumento apto a retardar - mas não a impedir - a degeneração rápida de uma forma em outra seria a introdução de um Regime Misto, onde os três princípios (Realeza, Aristocracia e Democracia) operariam

378 É importante notar que, para POLÍBIO, a Anaciclose tem "uma existência natural, mas os próprios regimes têm um caráter humano, são justamente políticos.” (CARDOSO, 2012, p. 15).

${ }^{379}$ São sempre os abusos e os excessos insuportáveis do princípio fundamental que levam à corrupção de cada uma das formas de Governo (POLYBE, 2003, p. 557): "Les abus de la royauté la font dégénérer en tyrannie. L'aristocratie remplace alors la tyrannie devenue insupportable, puis dégénère à son tour en oligarchie en raison de ses excès. La démocratie renverse l'oligarchie, puis, sous la poussée des passions populaires, devient une ochlocratie. Mais bientôt du sein du désordre et de la violence surgit un monarque, et ainsi le cercle se ferme." (PÉDECH, 1964, p. 308).

Tais abusos são caracterizados pelo desprezo com relação a toda a igualdade de condições requeridas pela vida política em cada um dos Regimes (rompimento da horizontalidade na vida em comum): disputa por vantagens (na Democracia), ostentações (na Realeza), cupidez de bens (na Aristocracia), sempre no sentido de corromper a igualdade política, a liberdade da palavra e a igualdade de condições existentes como condições da vida política em cada um dos Regimes (povo como substrato de legitimidade). "Não é surpreendente que [POLÍBIO] atribua a todas as formas de governo retas traços que a tradição nos fez prever apenas para as democracias" (CARDOSO, 2012, p. 17).

A importância em manter a horizontalidade relacional e evitar seu rompimento mediante oposições entre os diferentes princípios possíveis de direção da vida comum são os elementos fundamentais da reflexão polibiana que serão aproveitados por este estudo. V., nesse sentido, o item 3.3.3.3., infra, onde maiores especificações são apresentadas. O item 3.4., também infra, oferece maiores contornos sobre tais questões, mostrando como estes elementos podem convergir para estudar Leis políticas qualitativamente distintas. A Aplicação de tais critérios é feita de maneira minuciosa no Sétimo Capítulo desta Tese, também infra.

380 "De même que pour le fer, la rouille, et pour le bois, les vers et les tarets sont des fléaux consubstantiels, sous l'action desquels ces matières, fussent-elles protégées contre les agents destructeurs externes, subissent une dégradation dont la cause se trouve en elles, 4. Tout de même les constitutions, par leur nature, sont minées chacune par un mal congénial dont elles ne peuvent se défaire." (POLYBE, 2003, p. 557, grifos nossos). 
conjunta e cuidadosamente conforme um sistema específico de freios e contrapesos que oporia constantemente um ao outro, de maneira a evitar o excesso de cada um deles mediante contínua contraposição de um princípio instituidor em relação ao outro (CARDOSO, 2012, p. 18-9; PÉDECH, 1964, p. 308-9; POLYBE, 2003, p. 557-8).

O Regime Misto tem por objetivo precisamente evitar a instabilidade do ciclo, vale dizer, é o único regime que consegue permanecer mais estavelmente no tempo (de forma mais durável) no interior do necessário movimento de corrupção. Sua virtude adviria precisamente dessa condição de mútua oposição entre os princípios constitutivos fundamentais da vida da Cidade. Todos e cada um deles restariam impedidos de, por um desenvolvimento excessivo, tomar unilateral e exclusivamente o lugar do Poder e, a partir dele, definir a medida/regra segundo a qual o processo nomogenético deveria se orientar (POLYBE, 2003, p. 558).

O Regime Misto visa ao estabelecimento de um complexo e detalhado sistema institucional de resistências e impedimentos mútuos: "l'action de chacun d'eux éta[it] contrabalancée par l'action des autres" (POLYBE, 2003, p. 558), de modo que se mostrava possível conter o "deslizamento de cada uma d[as formas simples] na direção dos interesses particulares dos governantes, mantendo-os então, no eixo dos escopos comuns." (CARDOSO, 2012, p. 21).

Este seria o melhor Regime, por ser o mais estável: uma organização jurídicopolítica institucional arquitetada para estabelecer um equilíbrio "judiciosamente dosado e contrabalançado [entre os três regimes primários] de modo a evitar os excessos de cada um.” (SEBASTIANI, 2012, p. 59). Sempre que um dos participantes da vida em comum pudesse ser reputado como em posição de inferioridade, uma disposição institucional lhe asseguraria o vigor e a autoridade necessários para se opor com relação aos demais, de maneira a fazer descer à horizontalidade aquele que almejasse instaurar a verticalidade unidimensional totalizante e impositiva (CARDOSO, 2012, p. 9; POLYBE, 2003, p. 558).

Todavia, nem mesmo a estabilidade do Regime Misto lhe asseguraria a perenidade. Como todos os Regimes políticos - e como tudo o mais, o Regime Misto necessariamente atravessa os períodos de surgimento, ascensão, apogeu para, em seguida, seguir em direção aos necessários envelhecimento e perecimento (PÉDECH, 1964, p. 309, 312 e 316).

A menção à Anaciclose neste trabalho é feita com dois objetivos principais: (i) explicar de onde POLÍBIO retirara a solução estável do Regime Misto; e (ii) tornar consciente um discurso que acompanhará meta-linguisticamente a narrativa deste 
trabalho $^{381}$. Afinal, essa compreensão permite ao historiador prever, dentro dos limites de ascensão e de decadência da Anaciclose, o encaminhamento histórico de organizações jurídico-políticas (POLYBE, 2003, p. 557) - o que permitirá pensar a CECA como o princípio de um processo de organização jurídico-política das relações entre diferentes países europeus sujeito igualmente à Anaciclose, como todo Regime político.

\subsection{A Análise das Instituições Romanas da Segunda Guerra Púnica}

POLÍBIO desenvolve uma minuciosa análise das instituições romanas no período de seu apogeu (séculos III-II a.C.), isto é, após a quase aniquilante vitória de Cartago sobre Roma. O autor divide sua reflexão em dois momentos: (i) distinguir cada um dos participantes da vida comum romana, diferenciando-os entre si institucionalmente, inclusive por meio da indicação isolada das competências atribuídas a cada um deles; e (ii) avaliar a maneira segundo a qual o arranjo institucional de organizaçã jurídico-política romana arquiteta a interação e a oposição entre cada uma das partes da vida política, de maneira a que todos em conjunto pudessem colaborar para a vida comum (POLYBE, 2003, p. 562-9; SEBASTIANI, 2005, p. 201-2).

Em outras palavras, POLÍBIO abusca pontar o complexo desenho institucional da vida política romana considerando quais são os participantes da vida pública, os quais foram designados institucionalmente para se opor mediante intercruzamento de regimes de distribuição de competências. Para tanto, ele examina os Poderes atribuídos a cada um dos prtícipes da vida comum e procura compreender o relacionamento estabelecido institucionalmente entre eles mediante a compreensão do modo como os Poderes foram normativamente distribuídos entre eles (SEBASTIANI, 2012, p. 59).

POLÍBIO identifica serem os três componentes d a vida comum em Roma: (a) os cônsules; (b) o Senado; e (c) o povo. A organização jurídico-política da convivência romana estava estruturada de tal modo que o Poder se encontrava distribuído completamente entre esses três elementos fundamentais da Cidade (CARDOSO, 2002, p. 46; POLYBE, 2003, p. 563; SEBASTIANI, 2012, p. 59) ${ }^{382}$. Note-se que estes não eram simples órgãos institucionalizados da vida política romana, mas expressões das principais forças que historicamente se opuseram na construção da Cidade (CARDOSO, 2002, p.

\footnotetext{
${ }^{381}$ A qual fará mais sentido à medida que a leitura desta Tese seguir, principalmente nas Conclusões Parciais da Parte Segunda deste trabalho.

${ }^{382}$ Ou melhor, como se poderá ver mais adiante, o Poder estava centralizado entre estes três modos de habitar o mundo que compunham a vida comum em Roma.
} 
46; LEFORT, 1992a, p.166 e 172; MAQUIAVEL, 2008, p. 29-30 e 37-43), isto é, das três principais escalas de existência designadas a constituir a vida em comum e dela participar por meio de sua conjunção mútua para forma o sentido último do Direito e do Poder em Roma (POLYBE, 2003, p. 563) ${ }^{383}$.

\begin{abstract}
Les trois sources de l'autorité politique dont j'ai parlé plus haut avaient leur place dans la constitution romaine. Toutes les activités de l'État, dans chacun des domaines où elles s'exerçaient, étaient organisées et réglées sous la direction de ces trois pouvoirs de façon si équitable et si judicieuse que personne, même pas un citoyen romain, n'aurait pu dire avec certitude si cette constitution était, à tout prendre, aristocratique, démocratique ou monarchique. (POLYBE, 2003, p. 563, grifos nossos).
\end{abstract}

Perceba-se que POLÍBIO não visa a compreender uma simples "separação de competências" entre os três principais componentes da vida pública de Roma. Percebendoas como expressões institucionalizadas de particulares formas de existência fundamentais porque fundantes, o autor grego jamais esquece que, sob esta aparentemente singela distribuição de funções, manifesta-se a construção histórica de uma preocupação constante de assegurar na vida comum romana a cada maneira particular de habitar o mundo uma proporção do Poder (CARDOSO, 2002, p. 46).

Em outras palavras, a consideração institucional dos três elementos fundamentais da vida pública romana pela organização jurídico-política de Roma teria sido o resultado de um movimento histórico virtuoso e excelente, o qual teria buscado garantir a cada medida de existência um meio para vocalizar perante as demais sua forma de compreensão do mundo (LEFORT, 1992a, p. 166-7; MAQUIAVEL, 2008, 37-43; POLYBE, 2003, p. 559). Cada uma delas deteria parte do Poder e, com isso, teria recebido a garantia de influenciar parcialmente a formação do sentido final da decisão sobre o Direito e o Poder em Roma. A confluência de todas as escalas de existência para o centro do Poder em Roma teria permitido a formação de uma mistura jurídico-política a mais excelente possível na organização jurídico-política da vida comum na Cidade (POLYBE, 2003, p. 563).

\footnotetext{
383 Justifica-se aqui a indicação feita na nota de rodapé 321, supra, em que se argumenta pela impossibilidade de se recorrer de maneira coerente ao pensamento de Charles Secondat, Barão de MONTESQUIEU para desenvolver as reflexões do presente trabalho: este substitui a oposição entre as diferentes escalas de existência que compõem a vida política (em Roma, cônsules, Senado e povo; na França, Monarquia, Aristocracia e Povo) por entidades e funções jurídicas (SEBASTIANI, 2012, p. 64), esquecendo a vinculação primordial das magistraturas com as diferentes maneiras de habitar o mundo e ignorando a função originária destas de promover continuamente a interação conflitiva e tensa entre cada uma delas.
} 
Ao se referir aqui às noções de escala de existência, medida de existência, regra de existência ou dimensão de existência ${ }^{384}$, perceba-se que se recorre a uma significação bastante particular. Essa expressão visa a designar um certo modo de relações de um ente com relação ao ser (ao fato e à condição de ser). Trata-se de um "estilo próprio", de um perfil, de um modo de ser idiossincrático, de uma maneira específica de habitar o mundo, de o tratar, de o interpretar, de o experienciar, portada de forma bastante particular espacial e temporalmente localizada - por cada $\operatorname{ser}^{385}$.

Trata-se de um específico ponto de partida segundo o qual determinado fenômeno será observado e constituído a partir das condições específicas onde e quando um ente se apresenta enquanto uma forma específica de ser. Ao viver em determinado

${ }^{384}$ E variações de significantes que apontem para o mesmo sentido, tais como escala existencial, medida
existencial, regra existencial ou dimensão existencial.
${ }^{385}$ Em 1948, ao contrapor o pensamento tradicional ao que se encontrava em gestação em sua época, Maurice
MERLEAU-PONTY (2004, p. 29-40) acenara para a impossibilidade de se perpetuar um arcabouço
conceitual, cognitivo e perceptivo tipicamente calcado nos moldes do clássico mundo da ciência Moderna:
Homem civilizado, maduro e são. Segundo o autor, não se deveria ignorar a dimensão da animalidade, ou
melhor, a existência de outros modos de compreender o mundo em desacordo com o padrão Moderno: os
dos animais (não-homens), dos homens primitivos (não-civilizados), das crianças (não-adultos) e dos loucos (não-sãos).

Em outras palavras, o pensamento Moderno carecia de escalas alternativas de conhecimento (método de aproximação e de constituição do mundo, bem como de construção do saber), as quais são fornecidas por formas de existência distintas do padrão artificialmente construído pela Modernidade. Havia no discurso tradicional a desconsideração dos perfis perceptivos dados por outros seres que igualmente "habit[av]am [o mundo] à sua maneira" (MERLEAU-PONTY, 2004, p. 30), isto é, conforme suas específicas escalas de existência que habitam, medem e conhecem o mundo.

É com base nesta pontual reflexão de Maurice MERLEAU-PONTY que se baseia a presente noção de escala de existência: não se pode ignorar a existência de diferentes padrões de mensuração do mundo, com o objetivo de conhecê-lo. Cada uma delas estabelece perspectivas distintas de constituir o pensamento e os modos de pensar, de saber, de perceber e de viver.

Ao se referir à noção de escala de existência, visa-se a evidenciar que não há uma única régua universalizável para apreender e medir a realidade e para construir o conhecimento sobre a mesma salvo se se quiser permanecer em uma perspectiva limitada, incompleta, insuficiente e insatisfatória. Ao se enfatizar a ideia de escala de existência, quer-se sublinhar apenas que todo sistema de convivência social é marcado por uma composição multiescalar, ou seja, pela presença de distintas visões de mundo. São estas formas desiguais de conceber e de apreender o mundo e o mundo normativo que são designadas a participar obrigatoriamente da vida em comum, com o objetivo de manter a pluridimensionalidade na formação do sentido do Direito e do Poder.

Utilizamos a noção de escalas de existência em nossa apresentação International Law between Two Postmodernisms: Reframing the Relationship between International Law and Domestic Law, realizada em 2011, em Praga, na Conferência Philosophy and the Social Sciences, organizada pela Johann Wolfgang Goethe - Universität Frankfurt am Main, pela Friedrich Schiller - Universität Jena an der Saale, pela Academy of Sciences of the Czech Republic e pela Charles University (GIANNATTASIO, 2011a).

Naquela oportunidade, argumentou-se que o Direito Internacional Pós-Moderno seria regido pela preocupação em progressivamente fazer florescer as mais diferentes e espontâneas escalas de existência na construção do sentido normativa jurídico internacional, mediante a revalorização acadêmica e prática do elemento consuetudinário na formação do Direito Internacional.

Também indicamos reflexão anterior nossa igualmente breve sobre escalas de existência em nosso O Direito Internacional entre Dois Pós-Modernismos: A Ressignificação das Relações entre Direito Internacional e Direito Interno (GIANNATTASIO, 2010b). Apesar da semelhança do título deste texto em relação à apresentação há pouco mencionada, frise-se que os textos diferem em sua argumentação e em suas conclusões. 
local, segundo condições singulares, cada ser porta consigo uma particular medida de existência, vale dizer, uma escala toda especial com a qual irá medir a realidade, interpretá-la, deslocar-se e viver nela.

Com a noção de escala de existência, quer-se ressaltar ser necessário reconhecer haver uma profunda relatividade de compreensões de mundo e dos juízos sobre o mesmo, e principalmente indelével distinção entre todas as manifestações e conclusões normativas tipicamente humanas ${ }^{386}$. Dito de outro modo, não se pode ignorar haver uma incontrolável, livre e espontânea diferenciação de modos de existência, isto é, de modos de agir e de conhecer, bem como de desenvolver o saber e de lidar com conflitos.

Nesse sentido, ao se dizer que POLÍBIO identifica nas instituições romanas a distribuição de competências entre três escalas de existência fundamentais e fundantes da Cidade (cônsules, Senado e povo) (POLYBE, 2003, p. 563), quer-se designar que o autor encontrara precisamente as três principais perspectivas sociais que se dividiam entre si na sociedade romana, as quais, todavia, compunham, em conjunto - e apenas em conjunto, a vida pública comum da Cidade (LEFORT, 1992a, p. 166).

Quer-se ainda indicar com a referência à noção de escala de existência que o autor percebera que a organização jurídico-política estabelecida pelas instituições romanas se orientou para lidar engenhosamente com cada um desses segmentos. Cada um era portador de perspectivas distintas sobre o todo social e sobre como o ordenar - a partir de suas próprias compreensões de mundo singulares - e, por isso, detinha uma determinada hierarquia valorativa no que se refere a como estabelecer a ordem social.

A única maneira de assegurar que Uma única escala de existência não fosse o único centro de referência normativa consistia em arquitetar uma dinâmica institucional voltada a estabelecer normativamente contínuos contatos entre cada dimensão existencial, de modo que nem uma nem outra fosse excluída do "jogo" de definição do sentido do Direito e do Poder na Cidade. Em outra palavra, um maquinário institucional que partilhasse e colocasse em rotação as responsabilidades públicas (POLYBE, 2003, p. 563).

Pois bem. Em Roma, o consulado era importante magistratura republicana e se apresentava como instrumento executivo do Governo senatorial. Sucedâneo do poder real

\footnotetext{
386 "Porquanto os homens sempre projetam os seus anseios e as suas perplexidades no que fazem, a própria construção do pensamento e a exposição deste são seletivas." (CASELLA, 2012, p. 2); afinal, em virtude das específicas posições espacial, temporal e culturalmente assumidas pelo Homem - enquanto ser no mundo -, este é a medida de todas as coisas, isto é - conforme PROTÁGORAS -“das que são enquanto são, e das que não são enquanto não são” (ABRÃO, 1999, p. 38; REALE; ANTISERI, 1990, p. 76-8).
} 
desde a expulsão dos Tarquínios $^{387}$, dela se diferenciava pelas limitações de competência e de período de duração (um ano), bem como pelo fato de se tratar de função compartilhada por dois colegas, eleitos pelos comícios centuriados.

Suas competências abrangiam o comando militar e civil, de administração da Cidade e de distribuir a justiça ${ }^{388}$, e tornava-se praticamente autocrático durante os serviços militares (POLYBE, 2003, p. 563-4). Havia uma limitação formal ao poder consular vigente deste o final do período Monárquico, a saber, a prouocatio ad populum, exercido por um cidadão condenado à morte por um cônsul, a fim de que o comício centuriado pudesse rever essa decisão sem julgamento (SEBASTIANI, 2006b, p. 205-9).

Por seu turno, o Senado era uma instituição política voltada ao exercício de um poder de controle (domínio) sobre o cidadão por parte da oligarquia; em outras palavras, era a máxima expressão da classe dominante patrícia na República romana. Dentre suas competências, deve-se mencionar que ele dispunha ilimitadamente do patrimônio público, na medida em que ele controlava o erário, impunha tributos e, principalmente, regulava o envio ou não de dinheiro aos cônsules em campanhas militares (POLYBE, 2003, p. 564).

Além desta importante administração financeira, o Senado era ainda responsável por (i) funções religiosas (autorização de dedicação de templos); (ii) pela direção militar (declaração de Guerra, organização das operações militares e distribuição de competências aos magistrados nela envolvidos); (iii) pelos negócios internacionais, isto é, pela manutenção estável das relações estabelecidas com outros povos por um comandante (homologação de recebimento de embaixadas estrangeiras ou de tratados celebrados); e (iv) pelos negócios internos, em diversos aspectos, tais como: impedimento à assunção de cargo por um magistrado, controle da aplicação da justiça penal, decreto de triunfo de comandante vitorioso, ou mesmo atividade legislativa (SEBASTIANI, 2006b, p. 209-14).

Por fim, o povo era representado por meio de três assembleias, a saber, (i) o comício curiado, isto é, a reunião mais antiga, fundada em subdivisões sociais (cúrias) sobre as quais se organizava o exército romano, responsável pela investidura de um magistrado em seu imperium (por meio da lex curiata de imperio); (ii) o comício centuriado, responsável pelo julgamento de casos em que se exercia o prouocatio ad

\footnotetext{
387 A partir de quando os romanos "foram tomados de aversão até mesmo pela palavra rei" (CARDOSO, 2012, p. 1).

388 Abrangiam assim os diferentes tipos de imperium (poder deste magistrado): (i) imperium militiae, exercido de forma suprema durante as atividades militares; (ii) imperium domi, exercido dentro da Cidade, quando desapareciam os atributos típicos do período de atividades militares; (iii) ius agendi cum populo, ou seja, o poder de convocar os comícios; e (iv) ius agendi cum patribus, vale dizer, o poder de convocar o Senado (SEBASTIANI, 2006b, p. 207-8).
} 
populum $^{389}$; e (iii) o comício por tribos, divisão social que remontava ao rei Sérvio Túlio (4 tribos urbanas e 31 rurais), responsável pela eleição de magistrados menores e pela votação de leis.

Ao povo havia sido atribuído o exercício de competência igualmente importante, qual seja, a de assegurar a solidez dos Regimes políticos e a coesão em todas as sociedades humanas (POLYBE, 2003, p. 565) 390 $^{390}$ A ele cabia conceder honras por meio da eleição de homens ilustres para magistraturas (reconhecimento de grandeza e de excelência), conceder punições, isto é, julgar crimes passíveis de punição por pena capital e aprovar leis mediante plebiscitos (cuja validade fora reconhecida pela lex Hortensia de 286 a.C.) (SEBASTIANI, 2006b, p. 214-8). Isso asseguraria a permanência da possibilidade de distinguir entre mérito e indignidade (POLYBE, 2003, p. 565-6) e, com isso, manter a percepção de contínua fundação e refundação da Cidade.

A análise de POLÍBIO evidencia que, se qualquer um (cidadão romano ou estrangeiro) analisasse isoladamente cada uma das magistraturas acima mencionadas (cônsules, Senado e povo), poderia restar persuadido simultaneamente (i) ora de que Roma deteria a forma de Governo Régia, por força da amplitude do Poder detido pelos cônsules; (ii) ora de que Roma se orientaria por um regime de Governo Aristocrático, diante da constatação do grande Poder atribuído ao Senado; (iii) ou mesmo, de que Roma seria um Governo Democrático, em virtude da possibilidade de se poder compreender que o povo exerceria a maior influência no sentido último do Direito e do Poder na vida em comum estabelecida (POLYBE, 2003, p. 563-6).

Diante dessa pluralidade de instituições dotadas de grande capacidade de determinar as principais decisões nomogenéticas, revelar-se-ia uma grande dificuldade de se responder à pergunta inicial de POLÍBIO sobre quem seria o responsável pela grandeza de Roma.

Com efeito, a qual instituição caberia a última palavra, ou ainda, qual dentre as escalas de existência teria sido a responsável pelo vertiginoso empoderamento de Roma no mundo habitado de sua época, durante a Segunda Guerra Púnica? Uma análise das instituições não seria suficiente para identificar uma única dentre as dimensões existenciais

\footnotetext{
${ }^{389}$ A partir do século IV a.C., o comício centuriado substituíra a cúria na função de ser a base de organização do exército. Essa redistribuição de funções garantiu a plebeus ricos o acesso a importantes comandos militares (SEBASTIANI, 2006b, p. 216).

${ }^{390}$ V., nesse sentido, as reflexões desenvolvidas no item anterior em torno da questão de o povo constituir a base de legitimidade de todas as formas retas de Regime político; no mesmo sentido, v. Sérgio CARDOSO (2012).
} 
como o núcleo do processo de formação, de manutenção e de acúmulo do surpreendente e rápido domínio de Roma ${ }^{391}$.

É por esse motivo que POLÍBIO passa ao segundo momento lógico de seu texto, onde desenvolve uma reflexão mais detalhada para encontrar qual seria o órgão institucional $^{392}$ que efetivamente poderia ser considerado o mais importante no processo de definição do sentido normativo último na vida política romana.

Segundo o autor, o exame dessa condição apenas seria possível por meio de exaustivo tratamento analítico das inter-relações institucionais estabelecidas entre as escalas de existência. Por meio da compreensão das oportunidades e das maneiras segundo as quais uma delas se opunha à outra se poderia verificar a eventual supremacia de uma ou de outra sobre as demais (POLYBE, 2003, p. 566).

Em outros termos, apenas por meio da compreensão dos modos de oposição institucional das escalas de existência que compunham a vida em comum em Roma é que se poderia visualizar definitivamente a qual das formas de habitar o mundo a organização jurídico-política da vida comum de Roma teria dado preferência no processo decisório. Entender como "funciona o sistema", seria fundamental para compreender "com clareza a engenhosidade e eficácia deste algoritmo prático criado para solucionar os problemas de ajuste e reorientação continuada das ações dos governantes para a causas comum" (CARDOSO, 2012, p. 21).

POLÍBIO se dedica assim a explicitar e compreender cada uma das oposições dimensionais estabelecidas institucionalmente; isso lhe permitiria verificar de que maneira esse movimento de mútua e recíproca anulação poderia apontar, a final, uma resultante a qual indicaria a eleição de $\mathrm{Uma}^{393}$ das escalas como privilegiada em relação às demais (ou os cônsules, ou o Senado, ou o povo).

\footnotetext{
${ }^{391}$ Ou ainda, simplesmente, seria muito difícil atribuir a apenas uma delas o caráter de "motor" da construção do poderio romano. À medida que a leitura avançar, restará mais clara a proposta interpretativa deste trabalho com relação à CECA. Pede-se, por isso mesmo, um pouco mais de paciência por parte do leitor, pois apenas a compreensão destas categorias permitirá entender a construção da leitura desenvolvida no Sétimo Capítulo desta Tese.

392 Portador de uma escala de existência específica.

${ }^{393}$ Perceba-se que, a partir deste momento, este trabalho utilizará conscientemente a grafia da palavra "Um" com a letra inicial em maiúsculo "U", sempre que pretender designar a supremacia (ou pretensão de supremacia) vertical e absoluta de Uma escala de existência sobre as demais. Recorre-se a esse expediente visual para tornar mais facilmente apreensível e reconhecível durante a leitura deste texto adesignação da pretensão de elevação e de destacamento sobre os demais que Um pode almejar sobre os vários outros e múltiplos "uns" (rompimento da relação de horizontalidade, a qual fora institucionalmente garantida).

Com a mesma intenção, Claude LEFORT (1991) se socorreu deste auxílio gráfico visual para indicar a diferença de uma ordem jurídico-política fundada em uma única dimensão de existência total e totalizante, Una, Uma, em relação às demais outras formas. Como se poderá ver no item 3.4., infra, a fundamentação deste trabalho no pensamento político-filosófico deste autor francês ultrapassa a mera esfera
} 
O Poder dos cônsules era regulado pelas Assembleias Populares e pela colaboração do Senado. No primeiro caso, o povo concedia ou não aval para o término de uma Guerra e recebia as prestações de contas do exercício do comando militar consular; no último, o Senado poderia autorizar ou não (i) o envio de mais recursos, (ii) o envio ou a prorrogação de um comando em exercício; e (ii) a concessão do triunfo (POLYBE, 2003, p. 566-7).

Ao mesmo tempo, também não poderia passar despercebido o fato de que o Poder do Senado era balizado por meio de consultas ao povo e pela necessidade de considerar o veto dos tribunos da plebe para encontrar condições necessárias para a execução de suas principais decisões. Ao mesmo tempo, o povo poderia preservar a autoridade e a dignidade senatoriais por meio da rejeição de leis que visassem à destruição delas (POLYBE, 2003, p. 567-8).

Se o povo detinha fundamental importância enquanto elemento de sustentação do equilíbrio do Regime, era ele simultaneamente refreado pelo Senado e pelos cônsules. No primeiro caso, o Senado detinha autoridade sobre os censores para a contratação e a execução de empreendimentos públicos, ao mesmo tempo em que designava juízes para resolver litígios entre os cidadãos. No último caso, o povo temia os cônsules pois estava absoluta e autocraticamente submetido à autoridade militar destes durante as campanhas razão pela qual não era interessante ao povo barrar todos os projetos propostos pelos cônsules (MAQUIAVEL, 2008, p. 29-30 e 40; POLYBE, 2003, p. 568-9; SEBASTIANI, 2006b, p. 219-23, 2012, p. 59).

É importante notar que a análise de POLÍBIO evidencia um fato bastante singular. Diferentemente do que se poderia esperar, a maneira como foram articuladas as instituições da República romana tornara absolutamente impossível designar a preponderância institucional exclusiva e excludente de uma escala de existência sobre as demais. Uma poderia ininterruptamente contrariar a outra, e o funcionamento da vida comum dependia da sustentação mútua e recíproca mediante a presentificação constante de uma dimensão existencial perante a outra nas deliberações sobre a vida em comum (POLYBE, 2003, p. 569).

Havia uma virtuosa e sadia mistura jurídico-política das diferentes escalas de existência, "un parfait concert" (POLYBE, 2003, p. 569) que tornava impossível identificar uma delas como em posição de destaque. Todas, “inteiramente autônomas, não são, entretanto, senhoras de todas as condições e meios de seus empreendimento, intenções

de imitação do recurso a esse expediente gráfico - o que apenas vem a reforçar a justificativa do uso do mesmo recurso visual. 
ou ações, visto que respondem por funções diversas de um mesmo organismo e de uma mesma dinâmica da vida da cidade." (CARDOSO, 2012, p. 22).

Essa impossibilidade de dizer qual delas prevalecia no composto político implicava reconhecer, em outros termos, que todas detinham Poderes impactantes, mas que, ao mesmo tempo, nenhuma delas detinha a aptidão de determinar o sentido normativo último na vida comum - nenhuma delas ocupava intemporalmente o lugar do Poder (POLYBE, 2003, p. 569). Nenhum dos diferentes componentes existenciais da Cidade poderia pretender se destacar e reger a partir de sua própria medida de existência (unidimensionalmente) a Cidade inteira: o sistema de distribuição de funções associado à lógica de estrita dependência teria produzido condições suficientes para um ajuste conveniente da vida política (CARDOSO, 2012, p. 21-2).

\footnotetext{
Quand un des pouvoirs, gonflé de son importance, cherche à l'emporter sur les autres et s'arroge plus d'autorité qu'il ne lui en revient, il est évident, étant donné qu'aucun d'eux, comme nous venons de le dire, ne peut se passer des autres et que les volontés de chacun peuvent être refrénées et paralysées par les autres, que jamais l'un d'eux ne pourra empiéter sur le domaine de l'autre ni le traiter avec mépris. 8. Tout le monde reste à sa place, parce que tout est prévu pour brider les ambitions exorbitantes et que chacun redoute les réactions du voisin. (POLYBE, 2003, p. 569, grifos nossos).
}

Para POLÍBIO, este seria o preciso fato que caracterizaria o modo de organização jurídico-político da sociedade romana como o mais excelente possível (CARDOSO, 2012, p. 22-3; POLYBE, 2003, p. 569; SEBASTIANI, 2006a, p. 204, 2006b, p. 224-5). Suas Leis teriam promovido uma união política bastante particular, pois teriam impedido a imoderada prevalência de uma escala de existência sobre as demais no grande composto político, exigindo institucionalmente sempre a necessidade de interação contínua de uma escala com a outra (CARDOSO, 2012, p. 22). Nenhuma delas poderia pretender utilizar um Poder sem sofrer imediatamente um bloqueio a sua ação por parte de outra.

\footnotetext{
[D]eter, interromper ou paralisar, e assim, resistir e impedir, barrar e represar. No caso em questão, barrar e conter aquilo que, nas potências (dynameis) ou poderes que compõem o regime, tende para o excesso, a perda da orientação e medida impostas por suas funções próprias, destinadas ao serviço e à condução do todo, à realização de seu interesse comum. (CARDOSO, 2012, p. 20-1, grifos do autor).
}

Em outras palavras, o arranjo institucional da organização jurídico-política romana teria constituído tamanho equilíbrio entre cada uma das escalas de existência (cônsules, 
Senado e povo) que teria se tornado impossível designar Um preponderante sobre os demais (CARDOSO, 2002, p. 46; LEFORT, 1992a, p. 169; SEBASTIANI, 2006b, p. 225). Em suma o autor grego percebera a vigência em Roma de um sistema de Governo misto, segundo o qual não se saberia dizer se seria - pois não se poderia dizer - algo diverso de que Roma era ao mesmo tempo Régia, Aristocrática e Democrática (LEFORT, 1992a, p. 164).

[A] politeia [romana seria] o "melhor regime" em função do equilíbrio que ela estabelece entre os diferentes componentes da cidade, neutralizando [mutuamente] seus defeitos e retardando a degradação do composto político. (CARDOSO, 2002, p. 46, grifos do autor).

Neste conviver institucional permanentemente tenso entre tais diferentes modos de habitar o mundo e de compor a vida política romana residira a excelência da coesão política romana e a justificativa de sua exemplar e surpreendente ascensão após esmagadora derrota na Segunda Guerra Púnica perante Cartago (CARDOSO, 2012, p. 23). O sucesso derivara deste Regime Misto, no qual não apenas havia a partilha igual das principais competências, mas em que vigorava uma estrita e estreita dependência entre cada uma das escalas de existências fundamentais da Cidade. Uma e outra poderia se limitar mutuamente ou se sustentar reciprocamente, conforme as necessidades do momento para a permanência de um fio condutor dos negócios públicos (CARDOSO, 2012, p. 23; PÉDECH, 1964, p. 306; POLYBE, 2003, p. 569; SEBASTIANI, 2006, p. 224-5).

Para POLÍBIO, a configuração histórica da união política de Roma ${ }^{394}$ teria a constituído como um sistema de convivência entre diferentes em que estes se preservavam enquanto diferentes. Nem um nem outro poderia pretender se tornar Um sobre os demais e unificar todos segundo sua própria, única e una escala de existência. Um e outro deveriam colaborar entre si visando à preservação do comum (LEFORT, 1992a, p. 171).

\footnotetext{
O estabelecimento de um sistema de contenções constituído por barreiras ou obstáculos mútuos entre as figuras tradicionais de comando (representadas pelo número dos governantes: um, alguns e "os muitos"), associadas para impedir que desandem em abusos e despotismos, parece ser a chave desta invenção constitucional atribuída por Políbio a espartanos e romanos. (CARDOSO, 2012, p. 20, grifos nossos).
}

\footnotetext{
${ }^{394}$ Isto é, suas Leis percebidas materialmente, conforme nossa nomenclatura acima delimitada, no item 1.4., supra.
} 
A excelência do modo de organização de Roma residiria na precisa condição de que suas Leis seriam Leis de convivência plural permanente derivada da solidariedade institucional instaurada por meio da organização jurídico-política construída historicamente a partir de normas que determinaram a contínua oposição entre as diferentes escalas de existência participantes da vida comum. Esta assegurara as condições necessárias para uma tensão equilibrada, de forma a manter a coesão e a estabilidade da vida política por meio da articulação opositora entre as escalas de existência preservadas em suas específicas singularidades (CARDOSO, 2012, p. 19 e 23; PÈDECH, 1964, p. 306 e 320; POLYBE, 2003, p. 558-9).

\subsection{A Comparação das Instituições Romanas com as de Cartago}

POLÍBIO apresenta sua perspectiva sobre as instituições de outras Cidades. Após recusar a comparação com as de Tebas e de Atenas ${ }^{395}$, o autor examina as instituições de Creta e de Esparta (POLYBE, 2003, p. 592-6). Todavia, seu especial foco de atenção é a comparação das instituições de Roma com as de Cartago, sendo esta a questão que interessa ao presente estudo - sempre sem ignorar os limites necessários para estabelecer diretrizes para responder a pergunta inicial deste trabalho, sob pena de extrapolar os limites fixados para ele.

Segundo o autor, as instituições de Roma e de Cartago eram jurídico-politicamente organizadas segundo os ditames de um Regime Misto, de tal modo que se poderia dizer que as duas eram as melhores, isto é, as mais aptas a durar mais estavelmente no tempo (POLYBE, 2003, p. 596-7).

Todavia, como apontado linhas acima, estabilidade não é para POLÍBIO sinônimo de perpetuidade: mesmo o Regime Misto estava submetido ao movimento inevitável da Anaciclose (surgimento, apogeu e corrupção). Por esse motivo, o autor acreditava que todas as instituições, inclusive as de Cartago - como as de Roma - estavam necessariamente submetidas a uma inafastável metabolé. Cartago fora derrotada pois, apesar de deter uma forma de Governo Mista, suas instituições estariam em fase de degeneração mais avançada do que as de Roma - em pleno e vigoroso auge - (HARTOG,

\footnotetext{
${ }^{395}$ Cidades que tiveram uma rápida fulguração de destaque na Grécia por força da atuação exemplar de seus dirigentes, mas não em virtude de suas instituições. Por esse motivo, seu declínio fora espantosamente rápido (POLYBE, 2003, p. 590-1).
} 
2003, p. 25; POLYBE, 2003, p. 597; SEBASTIANI, 2006a, p. 72, 2006b, p. 219 e 230, 2012, p. 59).

"Por outras palavras, Cartago perdeu a guerra porque enfrentou, quando decadente, uma potência no auge de suas capacidades, em que predominavam as melhores decisões, e não as da maioria." (SEBASTIANI, 2006b, p. 231). A excelência romana adviera do fato de que suas melhores decisões teriam sido produzidas a partir do choque, das tensões, dos embates e dos tumultos interiores entre os três princípios fundantes da vida em comum (PÉDECH, 1964, p. 313; POLYBE, 2003, p. 559).

Mesmo a mais excelente forma de Governo inevitavelmente degeneraria ${ }^{396}$, bastando para tanto a desagregação de seu elemento constitutivo fundamental de equilíbrio institucional entre as escalas de existência - condição que apenas retardaria ao máximo a corrupção, mas não impediria a rotação contínua das formas de Governo (POLYBE, 2003, p. 602-3). Em Cartago, a corrupção teria derivado da preponderância do elemento democrático nas deliberações públicas; Roma daria sinais de seu declínio posteriormente mediante tendência crescente de preponderância do elemento aristocrático (PÉDECH, 1964, p. 309-10 e 312; SEBASTIANI, 2006b, p. 298-300, 2012, p. 59).

\begin{abstract}
L'évolution du régime romain est une application concrète de la théorie cyclique. La constitution mixte s'est formée quand la démocratie a obtenu une part égale à celle des deux autres pouvoirs. Elle a déterminé alors une longue période de stabilité, à la fin de laquelle l'élément démocratique la dégrade en ochlocratie suivant la loi du cycle. Polybe a seulement été témoin d'une période de transition, où le régime porte encore le nom de démocratie bien qu'en fait il soit devenu ochlocratie. Mais il a décrit théoriquement la phase suivante, qui amènera le retour de la monarchie après une période de massacres, de proscriptions et de partages des terres. L'histoire de Sylla, de César et d'Octave apporte une éclatante confirmation à cette extraordinaire prévision. (PÉDECH, 1964, p. 316).
\end{abstract}

3.3.3.3. Apropriação da Reflexão Polibiana: Seleção de Normas Jurídico-Positivas de Oposições Escalares Institucionalizadas do Tratado da CECA

Ao desenvolver uma reflexão acurada sobre as instituições jurídico-políticas romanas, POLÍBIO teria tornado consciente o povo romano da originalidade de suas próprias instituições e do elo de solidariedade propriamente político de cada um dos

\footnotetext{
${ }^{396}$ Sendo exemplos concretos para o próprio autor tanto Cartago, como Roma (POLYBE, 2003, p. 1338-9; SEBASTIANI, 2006b, p. 298-300). POLÍBIO "invent[ara] a anaciclose a fim de ordenar dados históricos que explicassem a evolução de Roma desde sua obscura fundação até sua própria época. Com notável perspicácia, Políbio compreendeu que, após a guerra contra Perseu, algo ocorrera pondo em destaque os acontecimentos do período anterior, e permitindo que se discernissem as razões da conquista e suas consequências: [...] 'seu julgamento revelou-se profético'.” (SEBASTIANI, 2012, p. 60).
} 
elementos da Cidade que, em conjunto, formavam um todo (ROUSSEL, 2003, p. 44) (397. $^{397}$. Haveria um vetor diretor constante que teria pautado a construção das instituições romanas, a distribuição de competências entre os componentes da vida comum, bem como a lógica das inter-relações estabelecidas entre eles ${ }^{398}$.

Semelhantes são os objetivos deste trabalho: busca-se trazer à claridade o móvel condutor da racionalidade que informara a construção do desenho institucional da Europa Unida da CECA no pós-Segunda Guerra Mundial. Como visto anteriormente ${ }^{399}$, a racionalidade estruturante da disposição institucional desta Comunidade teria sido caracterizada por uma engenhosidade tipicamente política, vale dizer, pela preocupação em formar, por meio de técnica jurídica, um ambiente institucional caracterizado pelo convite forçado à convivência plural permanente entre diferentes capaz de impedir o desencadeamento de ações mutuamente destrutivas por novas Guerras regionais europeias.

Em outras palavras, a CECA teria detido a virtude (política) de proporcionar por meio de arranjo institucional calcado em normas jurídico-positivas a instauração de um sistema de convivência juridicamente mediado entre diferentes para afastar $\mathrm{o}$ recometimento de Guerras e assegurar a sobrevivência de seus povos politicamente unidos (CASELLA, 2000a, p. 81, 2004, p. 537, 2009a, p. 69) ${ }^{400}$. Esse sistema de convivência teria sido promovido precisamente pelas acima denominadas normas de oposições escalares ${ }^{401}$,

\footnotetext{
${ }^{397}$ O mesmo autor continua: "un peu comme le fera plus tard Montesquieu, en montrant aux Anglais, que leur constitution n'était pas le produit des caprices de l'histoire, mais qu'un principe directeur avait, d'âge en âge, présidé à son élaboration.” (ROUSSEL, 2003, p. 44).

398 Lembre-se de que "les Romains eux-mêmes n'avaient pas une connaissance théorique, parce que leurs institutions s'étaient improvisées sous l'effet des événements : à savoir, le bienfait des tumultes dans une République, d'une effervescence politique qui contrarie les ambitions de la couche dirigeante et lui fait rechercher sa sécurité dans des concessions aux légitimes aspirations du grand nombre.”. (LEFORT, 1992a, p. 155).

Todavia, Paul PÉDECH (1964, p. 599) afirma que a investigação de POLÍBIO visava também a apresentar a virtuosidade das instituições romanas à civilização helênica em profundo declínio: "Déraciné de son pays et transporté de force dans un milieu nouveau, il se penche sur les institutions romaines, il en étudie le fonctionnement pour le révéler à ses compatriotes et y découvrir le secret de la fulgurante conquête qui les a tous stupéfaits.".

De maneira semelhante, este estudo não apenas quer conscientizar os países europeus da UE de hoje sobre o princípio politicamente virtuoso do princípio de seu processo de integração - de modo a fundamentar trabalhos futuros que identifiquem e apontem um suposto desvio de rota da Europa Unida para sua situação atual de crise. Este trabalho visa igualmente a trazer tal conhecimento para a comunidade epistêmica jurídica brasileira, a fim de que possa ser ele tornado útil para suas próprias questões nacionais e internacionais de desenho institucional político estável, conflituoso e excelente. Afinal, o conhecimento jurídico de hoje deve ser continuamente estimulado para notar a necessidade de se desenvolver as mais inventivas imaginações institucionais (UNGER, 2001, 2004).

${ }^{399}$ V. considerações constantes dos itens 1.4. e seguintes, 1.5., 2.1. e seguintes, e 3.1., supra.

${ }^{400} \mathrm{Ou}$, o que é o mesmo, a inteligência que norteara a construção da dinâmica de relação institucional no interior da CECA estava marcadamente preocupada com o estabelecimento de Leis (união política). Sobre a qualidade desta união política (Política ou Teológico-Política), v. o item 3.4., infra.

${ }^{401} \mathrm{~V}$. itens 3.3.3.2.2., 3.3.3.2.3. e 3.3.3.2.4., supra.
} 
isto é, normas preocupadas em lidar com oposições entre diferentes escalas de existência no interior de uma vida comum.

É neste preciso momento que interessa a este trabalho de forma mais expressa a reflexão política desenvolvida por POLÍBIO no Livro VI de suas Histórias. Como este salientara em sua reflexão sobre a organização jurídico-política de Roma, as escalas de existência constitutivas da vida em comum (cônsules, Senado e Povo) estavam entre si articuladas institucionalmente para assegurar a cada uma delas a igual possibilidade de participar do processo de formação do sentido das decisões sobre o Poder e sobre o Direito. Ainda que dotadas de competências distintas, cada uma dessas dimensões existenciais era forçada a estar presente perante as demais para impedir qualquer excesso normativo por parte destas e dela própria.

Se a relação interinstitucional que garantiu a excelência da Cidade de Roma poderia ser designada como mista, isto derivaria da singular condição de que cada uma das medidas existenciais sociais da Cidade (cônsules, senadores e povo) era capaz de tornar presente sua forma de compreender o mundo nas decisões fundamentais da vida pública. Laços políticos indissociáveis constituídos por normas jurídicas positivas costumeiras teriam impossibilitado um deles decidir sem a necessária presença do outro, ou ainda, teriam inviabilizado o destacamento de Um sobre os demais por meio da conservação de todos em uma igual posição relacional horizontal.

A engenharia institucional mista de Roma teria sido juridicamente facultada por disposições normativas que impunham a necessidade de convivência de um e de outro para que cada um pudesse externar sua maneira de habitar o mundo - o que paralisava as pretensões de tomada unilateral do lugar do Poder das demais escalas e dela própria. Em outras palavras, o regime misto teria sido viabilizado tecnicamente por meio de normas de oposição escalares, isto é, por meio de normas que de maneira ininterrupta se voltavam à instituição de sistema de embate entre diferentes escalas de existência (cosmovisões) ${ }^{402}$

402 É importante frisar que a apresentação da Teoria da Anaciclose no item anterior tem uma dupla função neste trabalho.

Em primeiro lugar, isso ajudaria a especificar como POLÍBIO encontrara dentre as tradicionais formas de Regime a forma do Regime Misto - o único apto a estancar temporariamente o processo de degeneração das formas puras. Lembre-se inclusive de que também este não estaria imune ao necessário movimento de metabolé: apesar de suas virtudes, ele apenas conseguiria retardar a degeneração, mas não a impedir - tal qual atestara Cartago, quando vencida por Roma, ao final da Terceira Guerra Púnica, e tal qual suspeitara Cipião Emiliano com relação a sua própria pátria (Roma) e anunciara profeticamente POLÍBIO (POLYBE, 2003, p. 1338-9).

Em segundo lugar, a alusão à Teoria da Anaciclose opera como um significante discursivo paralelo a indicar meta-linguisticamente aquilo que fará mais sentido nas Conclusões Parciais da Parte Segunda deste trabalho: o apogeu jurídico-político institucional de Roma lhe teria permitido vencer Cartago, mas não 
para assegurar a pluridimensionalidade na construção normativa destinada a reger a vida comum.

O presente trabalho visa a identificar no Tratado da CECA a preocupação de estabelecer uma racionalidade arquitetônica bastante peculiar no desenho institucional da Comunidade. Não teria se tratado de uma neutra, leviana, precipitada ou irrefletida divisão de funções. Antes, seria possível identificar no Direito Comunitário Originário a preocupação em desenvolver arranjo institucional voltado a convidar cada um dos elementos componentes da União política a participar continuamente e de forma ativa do processo de formação das principais decisões sobre o Direito Comunitário Derivado ${ }^{403}$.

impedira seu inafastável declínio. Do mesmo modo talvez se poderia pensar sobre a integração europeia iniciada com a CECA.

Com efeito, ainda que esta tenha sido articulada conforme os mandamentos de um Regime Misto (nesse sentido, v. a interpretação do Sétimo Capítulo e as Conclusões Parciais da Parte Segunda desta Tese, infra), a CECA poderia ser entendida como experiência de sucesso pontual que, todavia, talvez tenha cedido posteriormente aos arroubos de uma ou de outra escala de existência (progressiva unidimensionalização).

Esta hipótese não diz respeito ao objeto deste trabalho, apesar de ser uma decorrência necessária dele. Certamente será analisada em trabalhos posteriores, uma vez efetivamente demonstrada por este trabalho a regulamentação jurídico-política institucional mista constante do Tratado da CECA. Mas é precisamente a construção desta nova hipótese ao final deste estudo que assegura a esta Tese a relevância típica de todo e qualquer estudo histórico: compreender conceitualmente o passado para, a partir dele, em pesquisa posterior, pensar e criticar o tempo presente (nova Agenda de Pesquisas em Direito).

Isso não apenas auxiliará na ampliação do campo de questões aptos a esclarecer os primeiros passos da integração europeia. Tais questões poderão fornecer ainda uma nova medida comparativa histórica, a qual, em trabalhos futuros, permitirá avaliar criticamente as condições segundo as quais a integração europeia se apresenta hoje.

Em outras palavras, este trabalho pretende fornecer aparato conceitual para avaliar, em trabalhos posteriores, "se e onde teria ocorrido um suposto "desvio de rota" da Europa Politicamente Unida para uma Europa Unida segundo outro móvel da organização jurídico-política (hipótese de Teológico-Politização da União da Europa).

Assim, a possível degeneração da organização jurídico-Política das instituições da atual Europa Unida em Leis articuladas segundo um móvel Teológico-Político não será objeto de estudo pelo presente texto (apesar de ser conclusão imediatamente derivável dele). Por esse motivo se finaliza, neste ponto, o desenvolvimento da hipótese.

Basta para este trabalho a explicitação deste conteúdo jurídico-Político em camada subjacente à jurídico-econômica e a indicação de uma possível leitura subsequente que poderá fundamentar eventual futuro diagnóstico em Pesquisas posteriores sobre a Europa Unida de hoje, a partir dos Tratados que se seguiram ao da CECA.

Sobre o tema da virtude do conhecimento histórico, v. o início do Quarto Capítulo desta Tese. Sobre os dois móveis da organização jurídico-política institucional (Político ou Teológico-Político), v. o item 3.4., infra.

${ }^{403}$ As literaturas jurídicas nacional e estrangeira apontam que a atividade nomogenética da CECA era centrada na Alta Autoridade (nesse sentido, v. observações e referências feitas na nota de rodapé 202, supra). Para estes, a organização institucional da CECA se daria do seguinte modo: os partícipes comunitários orbitariam em torno da Alta Autoridade, a quem caberia a missão exclusiva de gerir os interesses comuns, em nome do interesse comum, sobre os Estados-Membros e sobre as demais entidades comunitárias (Conselho, Corte e Assembleia).

Todavia, a partir da leitura detalhada e rigorosa do Tratado da CECA, a Tese de Doutorado demonstrará que deve ser mitigada esta conclusão sobre a centralidade da Alta Autoridade: o texto do Tratado teria apontado, muito pelo contrário, pela inexistência de qualquer preferência por uma ou por outra das escalas de existência. Tratar-se-ia de efetivo sistema de convivência entre diferentes, no qual tais atividades práticas "não devem ser privilégio exclusivo de ninguém" (WOLFF, 1999, p. 10-1). 
A CECA teria promovido um efetivo sistema político institucional de contraposição contínua entre diferentes para decidir sobre o sentido do Direito e do Poder na Comunidade. Este arranjo teria sido viabilizado por meio de normas que igualmente estariam voltadas à promoção contínua de ininterrupta de oposições entre as escalas de existência que compunham a Europa Unida da CECA.

Nesse sentido, vigeria no interior do Tratado da CECA um verdadeiro "jogo" de Poder entre os diferentes partícipes comunitários. Este "jogo" estaria voltado à formação de intensos e sucessivos embates escalares no interior da Comunidade para, com isso, assegurar em cada processo nomogenético da CECA a ausência de unidimensionalidade por meio de resistências e de impedimentos mútuos e recíprocos.

Para compreender precisamente os termos segundo os quais este "jogo" se desenvolve, deve ser ele esmiuçado profundamente a partir de análise detalhada, a ser desenvolvida no Sétimo Capítulo desta Tese. Serão identificadas e descritas as principais escalas que participavam deste processo nomogenético comunitário, a fim de compreender as competências distribuídas a cada uma delas. Em seguida, será examinado o funcionamento do sistema institucional previsto no Tratado, com o objetivo de depreender o engenho jurídico da inteligência política prática que informou a arquitetura das instituições da CECA.

Todavia, devem-se identificar as escalas de existência que participavam do processo comunitário inaugurado pela CECA. Para tanto, há que se referir àquelas designadas especificamente pelo próprio texto do Tratado; e, sem adiantar a interpretação a ser desenvolvida no Sétimo Capítulo desta Tese, surpreendentemente se nota que o Tratado da CECA não direcionou suas disposições normativas para estabelecer o complexo arranjo institucional de oposição apenas e tão-somente aos órgãos da Comunidade, mas a um conjunto um pouco mais amplo de portadores de escalas de existência distintas entre si.

Poder-se-ia buscar interpretar as oposições escalares no interior da CECA como uma simples oposição entre órgãos mimetizada de uma contraposição entre Poderesfunções no âmbito estatal. Segundo essa compreensão, haveria uma divisão interna à CECA entre Poderes (i) Executivo, (ii) Legislativo e (iii) Judiciário, cujas posições seriam ocupadas respectivamente (i) pela Alta Autoridade, (ii) pelo Conselho e pela Assembleia, e (iii) pela Corte. No entanto, a oposição escalar à qual se refere este trabalho pouco tem a ver com essa tripartição funcional entre os órgãos da Comunidade. 
Isso porque, em primeiro lugar, o presente trabalho rejeita a hipótese de viabilidade de mimetização do modelo de Estado no interior da CECA e a possibilidade de sua aplicação. Com efeito, isso significaria a aceitação de categoria a priori de que a CECA teria como proposta velada uma orientação no sentido de constituir um Estado, tendência expressamente rejeitada por este trabalho ${ }^{404} 405$.

Em segundo lugar - e principalmente, a análise institucional a ser efetuada pelo presente texto busca identificar nas disposições jurídico-normativas da CECA o modo como foi efetuada a operacionalização prática do sistema de convivência entre as diferentes escalas de existência envolvidas na vida pública da Comunidade. Em outras palavras, visa a compreender a configuração institucional voltada à promoção e à manutenção de uma determinada disposição opositora entre distintas formas de habitar o mundo que participavam da vida em Comunidade da Europa Unida da CECA.

Nesse sentido, como se poderá constatar mais adiante ${ }^{406}$, o Tratado da CECA estabelece um complexo mecanismo institucional de convivência não apenas entre os órgãos que compõem a CECA. Há outras entidades que, apesar de não serem órgãos comunitários, igualmente participam da vida pública da Comunidade. Não se lida aqui somente com a preocupação jurídico-normativa positiva do Tratado em promover oposições de competências entre os órgãos comunitários, mas com oposições instauradas pelo próprio texto do Tratado entre diversas escalas de existência.

Mostra-se mais conveniente trabalhar aqui com a noção de participantes do processo comunitário, e não apenas com os órgãos comunitários. Com isso, não apenas deverão ser mencionados os órgãos principais que compunham a CECA (Alta Autoridade, Conselho e Corte). Deverão ainda ser lembradas aquelas medidas de existência que igualmente encontraram condições institucionais - dadas por normas jurídico-positivas do Direito Internacional Público, expresso pelo Direito Comunitário Originário, para se apresentar diante das demais e, com isso, restringir-se mutuamente na formação do sentido último do Direito e do Poder naquela vivência comum.

Ao mesmo tempo, deverão ser igualmente excluídas aquelas entidades - órgãos comunitários ou não - que não receberam condições normativo-jurídicas positivas de se manifestar pelas vias institucionais asseguradas pelo Tratado (como a Assembleia e as

\footnotetext{
${ }^{404}$ Conforme salientado acima em diversos momentos deste trabalho, sem poder deixar de mencionar as notas de rodapé 106 e 333, supra. Este tema será mais bem compreendido quando da leitura dos Capítulos Sexto e Sétimo abaixo.

${ }^{405}$ Consequência, também, da rejeição do modelo de análise da "distribuição de Poderes" legado por Charles de Secondat, Barão de MONTESQUIEU, tal qual mencionado nas notas de rodapé 321 e 383, supra.

${ }^{406}$ Quando da leitura do Sétimo Capítulo desta Tese.
} 
organizações privadas). De fato, não detendo capacidade para influenciar na formulação do sentido normativo comunitário derivado - por não participarem do "jogo" entre múltiplas escalas de existência, em nada interessam ao presente estudo ${ }^{407}$.

Por esse motivo, a análise institucional do Sétimo Capítulo explicitará como a complexa engenharia jurídico-normativa positiva da CECA constituiu uma determinada organização jurídico-política de convivência entre diferentes escalas de existência. E, para tanto, será fundamental compreender quais são os polos de Poder no interior da CECA - os quais não se resumem aos órgãos da CECA, bem como a maneira pela qual tais polos de Poder tiveram tecidos seus caminhos e mecanismos de ação para estabelecer uma trama de interações de bloqueios e contenções recíprocas.

\begin{abstract}
A grande indagação é a forma de regular a convivência dos estados e demais atores não estatais na ordem internacional, e saber se essa convivência se vai reger pelo direito ou pela força. [...]. Esse dado da necessidade de coordenação, de institucionalização, de normatização jurídica e de instauração de procedimentos permanece presente e recorrente. (CASELLA, 2012, p. 26).
\end{abstract}

Não se trata simplesmente de avaliar mecanismos institucionais que efetuam uma singela oposição entre funções organicamente distintas. Na verdade, busca-se compreender as vias institucionais de vocalização de potenciais de negatividade multiescalar nos processos nomogenéticos desenvolvidos no interior da CECA, residam ou não tais potenciais de negatividade nos órgãos da Comunidade. Quer-se compreender como funciona o sistema de convivência estabelecido no Tratado da CECA, o qual fora estipulado para conter as tendências de usurpação do centro decisório último. E, para isso, é importante identificar quais são as escalas de existência participantes da vida comum da CECA.

A partir da leitura integral do texto de Direito Positivo do Tratado da $\mathrm{CECA}^{408}$, é possível desvelar três principais figuras do processo nomogenético comunitário com as quais a Comunidade procurava lidar conjuntamente na composição da vida pública comunitária. Tratavam-se dos principais elementos parciais que conviviam

407 A Assembleia detém na arquitetura da CECA meras funções consultivas, estando desprovida de capacidade de produção de normas jurídicas (definidas no artigo $14^{\circ}$ do Tratado da CECA; v. nota de rodapé 154, supra); as organizações privadas igualmente não participam do processo nomogenético no interior da Comunidade, apesar de poderem fornecer informações à Alta Autoridade para que esta possa propor, a partir de própria e independente avaliação, uma norma jurídica comunitária. V. ainda o Sétimo Capítulo desta Tese. ${ }^{408}$ O que será mais bem compreendido quando da apresentação dos comentários ao Tratado, no Sétimo Capítulo desta Tese de Doutorado. Apenas se adianta aqui a explicitação das escalas de existência participantes da vida em comum para que se possa visualizar com maior precisão aqueles que são apontados em inúmeros momentos no Tratado como partícipes da nomogênese comunitária. A função exercida por cada um deles restará mais clara no Sétimo Capítulo. 
simultaneamente na CECA, cada um atuando sobre a vida em comum a partir da perspectiva dada por sua própria forma de habitar o mundo ${ }^{409}$, a saber, (i) a "estatalidade", (ii) a supranacionalidade ${ }^{410}$, e (iii) a "populidade". Os dois primeiros se dividem em duas

409 Com Claude LEFORT (1992b, p. 195-6), há que se lembrar que toda organização jurídico-política é dividida entre aqueles que pretendem dominar e aqueles que não querem ser oprimidos - um dado fundamental que não deve ser ignorado -. O fundamental na reflexão jurídico-política sobre cada sociedade seria compreender quem são os participantes dessa divisão e qual a forma e destino dados a essa divisão.

Nesse sentido, enquanto dotada de Leis formais, a CECA seria uma União política, vale dizer, igualmente dotada de uma divisão fundamental entre aqueles que pretendem dominar e aqueles que pretendem não ser dominados. Neste item 3.3.3.3., busca-se apresentar as escalas de existência identificadas que participavam da divisão social instaurada pelo Tratado da CECA. Todas elas deteriam as mesmas pretensões de dominar e de não ser dominadas - razão pela qual teriam recebido iguais Poderes para se opor às demais.

O destino das relações entre elas é aqui rapidamente esboçado como hipótese, cuja interpretação é dada a partir da chave lefortiana apresentada no item a seguir (o que tornará ainda mais claro o conjunto hermenêutico da Tese). Ao mesmo tempo, a comprovação desta hipótese será feita mais especificamente a partir leitura dos comentários ao Tratado da CECA, no Sétimo Capítulo.

${ }^{410}$ Conforme será possível compreender a partir da leitura das linhas a seguir e da integralidade deste texto, a "supranacionalidade" à qual se refere aqui em nada tem relação com a característica supranacional do poder da Comunidade de limitação vertical das soberanias dos Estados-Membros: "O direito comunitário nasce nesse modelo e vincula os Estados-membros, e, no âmbito interno de cada um deles, as pessoas físicas ou jurídicas diretamente, porque esse direito prima sobre todo o direito nacional.” (ACCIOLY, 2003, p. 25).

Hildebrando ACCIOLY; Geraldo Eulálio do NASCIMENTO E SILVA; Paulo Borba CASELLA (2009, p. 432, grifos dos autores) indicam que a supranacionalidade é a característica do ordenamento jurídico comunitário, o qual detém vocação "supra-estatal, afirmada no primado do direito comunitário sobre os ordenamentos internos". No mesmo sentido parece entender Riccardo MONACO (1961b, p. 345), para quem, apesar de toda indeterminação dos limites conceituais de supranacionalidade, haveria que se reter que ela indica, no mínimo, que a Comunidade é um ordenamento jurídico supra-ordenado, localizado em um plano mais alto do que aquele produzido pelos Estados-Membros.

Essa posição superior derivaria do próprio reconhecimento por parte dos Estados-Membros da necessidade de conceder a um poder localizado acima dos Estados nacionais (supra-nacional) a exclusividade na produção, na especificação e na difusão do Direito Comunitário sobre os Direitos Nacionais (ACCIOLY, 2003, p. 163-4) - isto é, na condução jurídico-normativa do aprofundamento do processo de integração -, nos limites da soberania delegada pelos Estados à Comunidade. Para esta mesma autora (ACCIOLY, 2003, p. 161-3), a supranacionalidade seria uma consequência da adoção de um novo paradigma de soberania - o de soberania partilhada.

Especificam ainda Hildebrando ACCIOLY; Geraldo Eulálio do NASCIMENTO E SILVA; Paulo Borba CASELLA (2009, p. 433, grifos nossos) que essa característica supranacional do ordenamento jurídico comunitário se expressa em dois aspectos, (i) normativo, referindo-se à "hierarquia entre as normas jurídicas e políticas comunitárias e as normas jurídicas e políticas emanadas dos estados-membros, de maneira que as primeiras possuem efetiva precedência sobre as segundas"; e (ii) institucional, apontando para a condição de que as normas comunitárias "são tomadas de cima para baixo, partindo dos órgãos supraestatais, onde são iniciadas, debatidas e promulgadas, para em seguida penetrar no interior dos estados-membros, onde deverão ser aplicadas pelos órgãos nacionais.”.

Este trabalho não visa a discutir o conceito de supranacionalidade, nem a problematizar a conceituação dada pela tradição. Não é este o específico objetivo desta Tese. Por esse motivo, não há qualquer preocupação em se aprofundar na discussão comparativa dos múltiplos sentidos que adquire o termo na literatura jurídica nacional ou estrangeira, pois não se quer extrapolar a circunscrição metodológica estabelecida para este trabalho.

Deste modo, apesar de se socorrer do significante usualmente utilizado para tratar de características do Direito Comunitário ("supranacionalidade"), trata-se de uma apropriação parcial de conceito da tradição para poder designar um campo significativo distinto (sobre este tema, v. o item 3.3.1., supra). Ao utilizar o termo "supranacionalidade", não se refere à característica das normas de Direito Comunitário (hierarquicamente superior às diferentes normas nacionais), nem ao aspecto institucional de origem das normas de Direito Comunitário (de "cima a baixo", a partir dos órgãos supra-estatais).

Como se poderá v. mais adiante, designa-se com esse termo, de maneira muito mais modesta, apenas a escala de existência "supranacional" (ou ainda, a "supranacionalidade", enquanto o sufixo "dade" 
distinções existenciais ainda mais específicas ${ }^{411}$, de tal modo que se pode dizer havia ao todo cinco dimensões de existência institucionalmente previstas para compor a vida comum da CECA.

A "estatalidade" é a escala existencial portadora de uma perspectiva de mundo vinculada à dimensão do fenômeno jurídico-político do Estado, vale dizer, refere-se ao modo segundo o qual o Estado percebe o mundo e nele se insere. Quando referida aos Estados-Membros considerados neles mesmos, isto é, aos Estados-Membros tomados isoladamente, designar-se-á de maneira mais específica a estatalidade como estatalidade isolada. Por sua vez, quando referida aos Estados-Membros considerados conjuntamente, em cooperação mútua e recíproca, denominar-se-á a estatalidade de modo mais específico, como estatalidade intergovernamental.

São essas duas dimensões estatais que são introduzidas no ambiente comum da CECA e forçadas institucionalmente a conviver com as demais escalas dentro da Comunidade por meio de disposições normativas específicas do Tratado de Paris, $1951^{412}$. No sistema de convivência estabelecido por este, é cada um dos Estados-Membros um portador solitário de uma própria estatalidade isolada singularmente considerada. Por outro lado, quando os Estados-Membros atuam em grupo no interior do Conselho, no interior deste órgão comunitário se forma uma estatalidade intergovernamental.

A "supranacionalidade" é uma dimensão existencial especificamente constituída pelo Tratado da CECA para que se pudesse assegurar, no pós-Segunda Guerra Mundial, a presença de uma perspectiva distinta da dos Estados-Membros (considerados isolada ou conjuntamente). Este artifício existencial institucionalizado juridicamente por aquele Tratado $^{413}$ visava a construir uma nova maneira de habitar o mundo que pudesse se opor a

permite a substantivação do adjetivo), suas específicas formas de se inserir no mundo comunitário europeu (Alta Autoridade e Corte) e suas respectivas exigências. Esta condição certamente está relacionada ao fato de que a CECA detinha órgãos comunitários e personalidade jurídica próprios, diferentes dos Estados e independentes desles (CASELLA, 1994a, p. 212), mas ultrapassa este singelo aspecto.

Não se refere aqui às características dos órgãos comunitários, nem à simples visão passada de ser algo "acima e sobre os Estados individualmente considerados" - cujo anacronismo já fora denunciado por Paulo Borba CASELLA (1994a, p. 213). Aqui, a supranacionalidade designa apenas e tão-somente a visão que detinham somente dois daqueles órgãos comunitários (Alta Autoridade e Corte) sobre a vida em comum em vista da preservação da Comunidade, isto é, o modo (“o perfill”) segundo o qual tais órgãos apreendiam tal fenômeno.

As percepções de cada um deles (Alta Autoridade e Corte) não apenas eram distintas entre si, mas também certamente diferentes das (i) de cada um dos povos europeus envolvidos no processo de integração, bem como com relação às (ii) dos Estados-membros, dado que os dois órgãos eram de todos independentes e autônomos. Sobre a noção de escala de existência, v. as considerações constantes do item 3.3.3.2.3., supra.

${ }^{411}$ Conforme observações a serem detalhadas a seguir.

412 A serem examinadas no Sétimo Capítulo desta Tese.

${ }^{413}$ Não se pode ignorar que as escalas de existência que compõem a vida comum de uma sociedade jurídicopoliticamente organizada são todas, elas próprias, artificiais, vale dizer, "não-naturais", pois não derivam de 
interesses nacionais e a barganhas intergovernamentais. Seu objetivo consistia em evitar que tais perspectivas pudessem deslizar rapidamente para uma nova solução armada de $\operatorname{conflitos}^{414}$.

A perspectiva supranacional introduzida pelo Tratado de Paris buscava revelar um perfil novo de compreensão das relações entre os Estados-Membros da CECA, independente e autônomo. Por mais que seus portadores organizacionais fossem pessoas físicas oriundas de um ou de outro Estado-Membro, elas deveriam atuar segundo uma perspectiva mais ampla sobre a própria vida em comum, pensando os destinos comuns de maneira diferente da realizada usualmente pelos Estados-Membros.

Duas são as escalas de existência supranacionais continuamente convidadas pelo Tratado da CECA a participar com os demais partícipes da Comunidade do processo nomogenético da vida comunitária. Essa convivência teria por objetivo impedir que o próprio perfil - e os dos demais - pudessem ser tomados como ponto de partida exclusivo para a produção do sentido último do Direito e do Poder na Comunidade.

Quando a supranacionalidade é externalizada pela Alta Autoridade, designa-se esta dimensão existencial como supranacionalidade da Alta Autoridade, ao passo que, quando exercida pela Corte da CECA, nomeia-se esta como supranacionalidade da Corte.

Se apenas houvesse o embate entre medidas de existência supranacionais e estatais, talvez fosse possível concordar com Paul MAGNETTE (2006, p. 34), para quem a CECA teria sido experiência caracterizada por uma mescla entre supranacionalismo e intergovernamentalismo. Todavia, não se pode ignorar a presença fundamental - não apenas porque importante, mas principalmente, porque fundante - de outra escala existencial no processo nomogenético da CECA: a populidade.

O consciente neologismo visa a designar uma dimensão existencial bastante peculiar, a saber, aquela portada fundamentalmente por cada um dos povos europeus reunidos por meio das Leis da CECA. Como se poderá ver mais adiante ${ }^{415}$, se sua dimensão foi restrita a momentos episódicos, não se pode negar a importância desta ${ }^{416}$ para

uma divisão que seja o efeito de uma divisão "natural" (LEFORT, 1992a, p. 167). A supranacionalidade se trata de artifício tão "não-natural" quanto o das demais escalas de existência.

${ }^{414}$ Lembre-se o significado da citação de Jean-Jacques ROUSSEAU (2000, p. 60) feita na nota de rodapé 100, supra: "O legislador é, assim, um autêntico fundador. Ele opera, por suas leis, autoridade e capacidade persuasiva, a transformação dos 'indivíduos absolutos' nos homens relativos da sociedade civil; realiza o 'milagre' da criação política." (CARDOSO, 2004, p. 56).

${ }^{415}$ Nos comentários desenvolvidos no Sétimo Capítulo desta Tese.

${ }^{416}$ As características desta escala de existência não apenas são elucidadas de maneira similar pelas considerações feitas por POLÍBIO sobre o papel atribuído ao povo romano (itens 3.3.3.2.2. e 3.3.3.2.3., 
a fundação continuada da vida comunitária. Com efeito, observe-se sua profunda capacidade de impactar o processo nomogenético na vida em comum pela simples possibilidade de poder ou não rejeitar um Tratado Internacional por meio de seus órgãos representativos nacionais ${ }^{417}$.

De todo modo, é importante notar que a presença da populidade é também regulamentada institucionalmente pelas disposições do Tratado da CECA para que detentora deste considerável Poder - dele não pudesse se socorrer imoderadamente. Como ocorre com as demais escalas de existência, a populidade é convidada a participar da vida comunitária e forçada a conviver ao lado das demais dimensões existenciais para assegurar a pluridimensionalidade. Nem ela própria nem as outras poderiam determinar unidimensionalmente - isto é, unicamente a partir de suas próprias escalas de existência o sentido último do Direito e do Poder na Comunidade.

Será possível observar que a integralidade do Tratado da CECA é normativamente tecida por meio de normas que continuamente colocavam em conflito uma e outra escala de existência para que se equalizassem mútua e reciprocamente em cada processo nomogenético. Não há qualquer lacuna deixada pelo texto do Tratado para que Uma delas se sobressaia sobre as demais e, com isso, estabeleça o sentido do Direito Comunitário Derivado apenas a partir de seu próprio modo de conceber o mundo. Suas instituições foram forjadas para resistir a tais adversidades.

É pela percepção desta específica imposição da necessidade de convivência entre tais cinco escalas de existência no interior da vida em comum estabelecida pela CECA que se pode compreender, de maneira mais acurada, a razão pela qual se afirma que este processo de integração não era apenas um processo de cooperação um pouco

supra), como também pelos comentários constantes do Sétimo Capítulo da Tese especificamente destinados a explicar a importância fundamental da populidade.

${ }^{417}$ Basta mencionar os exemplos citados anteriormente, no conjunto do item 1.4., supra, em que foram rejeitadas as integrações politicamente unificadoras da CED e da CPE, bem como na qual se mitigou a tentativa Federalista do CdE para uma simples condição de mecanismo internacional de cooperação intergovernamental. A populidade deteve em si mesma naquele período a oportunidade de grafar o "mapa genético" do Projeto de Europa politicamente Unida: não-estatalizante, não federalizante (MAGNETTE, 2006, p. 32).

Em outras palavras, a populidade fora incumbida em momentos episódicos de papel fundamental e fundante, a saber, a aceitação (i) da instituição de uma União política da Europa (Leis formais); e (ii) da conformação de determinado tipo de tal organização jurídico-política dos povos europeus (Leis materiais). Assim, o acordo manifestado pela ratificação versaria sobre essas duas dimensões das Leis com relação a cada um dos Projetos de Europa Unida do pós-Segunda Guerra Mundial: (i) instituir ou não uma União política da Europa (convivência); e (ii) em quais termos se deveria operar a referida União política entre povos europeus (unificação ou preservação das pluralidades). A populidade também velaria pela refundação jurídico-normativa contínua das Leis, fosse para alterar a qualidade desta, fosse para as desfazer. 
aprimorado $^{418}$. Fora montado um maquinário institucional virtuosamente vigoroso e eficaz para garantir o compartilhamento e a rotação de incumbências com relação à vida comum entre todas as escalas de existência partícipes da Comunidade.

Com efeito, se apenas houvesse a presença da estatalidade isolada, as relações entre os Estados-Membros da CECA se desenvolveriam ainda conforme o paradigma da coexistência. Todavia, no plano das escalas estatais, havia em conjunto com esta no interior da Comunidade a estatalidade intergovernamental. Se a estrutura do Tratado da CECA se restringisse a dispor jurídico-normativamente somente sobre essas duas formas de habitar o mundo, o máximo que se poderia dizer sobre esta Organização Internacional seria que esta seria um instrumento institucional de cooperação intergovernamental.

Como visto anteriormente ${ }^{419}$, essa conclusão é inaceitável: a CECA não visava a efetuar apenas um aprimoramento das relações diplomáticas entre seus Estados-Membros. Não se pode ignorar que ao lado daquelas duas havia ainda a previsão no interior do próprio Tratado da CECA de duas outras dimensões existenciais as quais estavam igualmente fadadas a determinar em conjunto com as estatalidades o processo nomogenético comunitário. Por esse motivo, se as disposições daquele Tratado se restringissem a regulamentar a supranacionalidade da Alta Autoridade e a da Corte da CECA, esta Organização Internacional poderia ser compreendida como tendo detido a aptidão de instaurar uma simples cooperação em nível supranacional.

No entanto, não se pode ignorar que não havia uma simples preocupação de promover uma cooperação, mas uma efetiva integração. Nesse sentido, mais do que eleger uma ou outra dimensão existencial como a determinante exclusiva do sentido último do Direito e do Poder na vida comum (ou estatalidade, ou supranacionalidade), o Tratado da CECA constituiu sua articulação institucional para que diferentes modos de habitar o mundo pudessem, em conjunto, participar dos processos nomogenéticos.

Não teria havido assim qualquer manifestação institucional de preferência por uma dimensão em detrimento da outra, mas a multilateral convocação de cada uma delas para obrigatoriamente participar da vida em comum instaurada pelo referido Tratado. Estatalidades e supranacionalidades - e, somada a esta, a populidade, teriam sido invocadas para o interior da vida comunitária.

A inserção das cinco escalas conforme a inteligência institucional específica do Tratado da CECA tinha por objetivo (i) instaurar entre elas uma lógica de convivência e,

\footnotetext{
${ }^{418}$ V. item 2.1., supra.

${ }^{419}$ V. a integralidade dos itens 1.4., 1.5. e 2.1., supra.
} 
mais do que isso, (ii) colocar todas elas em conjunto precisamente no meio da arena pública nomogenética para, nela, (iii) fazer que deliberassem em conjunto, por meio de mútuos e recíprocos mecanismos de contenção, sobre o sentido do Direito e do Poder na Comunidade.

Dessa forma, pode-se compreender com um maior grau de especificidade e de concretude a razão pela qual se pode dizer que a CECA se mostrara como uma Organização Internacional voltada à direitificação da convivência entre os partícipes do processo comunitário. Não estaria ela adstrita nem a uma lógica típica de coexistência (estatalidade isolada), nem a uma racionalidade de cooperação intergovernamental (estatalidade intergovernamental), muito menos a um simples acoplamento em vista de uma cooperação supranacional (supranacionalidade da Alta Autoridade ou a da Corte).

Antes, teria a CECA se constituído conforme uma dinâmica relacional de interação multiescalar desprovida de destacamento vertical (todas as quatro escalas anteriores, somadas à populidade). Mais simplesmente, o Tratado da CECA teria se orientado no sentido de instaurar institucionalmente - para além das perspectivas sempre parciais de cada escala de existência - um sistema de convivência absolutamente horizontal entre as diferentes maneiras de habitar o mundo, as quais restariam permanentemente opostas entre si na construção do sentido normativo último para a vida comum. O Direito Comunitário Originário teria operado como locus de promoção de intensos e intermináveis embates escalares para produzir as normas de Direito Comunitário Derivado.

\begin{abstract}
[O] direito internacional rege as relações entre sociedade, agrega-se como superestrutura às concomitantes estruturas políticas internas, e se põe como coroamento do sistema humano de regulação da convivência entre sociedades, normalmente expressas por meio das relações entre estados, mas não somente entre estes, porquanto mais e mais abrange, diretamente criando direitos e obrigações, para os indivíduos, como para outros agentes não estatais - nesta que configura a grande mutação em curso, no direito internacional pós-moderno -, onde este passa de sistema interestatal para conjunto normativo e institucional mais amplo. (CASELLA, 2012, p. 3).
\end{abstract}

Nenhuma das escalas preponderaria ou se destacaria sobre as demais para conformar as normas jurídicas a partir de sua própria perspectiva. O Tratado da CECA teria assegurado a todas elas iguais condições para participar da formação do Direito Comunitário Derivado ${ }^{420}$. Seria a oposição escalar ininterruptamente produzida pelas

420 A expressão "iguais condições" refere-se aqui a iguais possibilidades de exercer um poder de negatividade, isto é, de contenção das demais escalas de existência no processo nomogenético. O poder de 
normas jurídico-positivas da CECA que asseguraria institucionalmente a permanência do vigor da Comunidade, pois todos poderiam buscar fazer valer suas reivindicações próprias na vida em comum.

Ainda sobre essa temática, é necessária precisão adicional que dissipe eventuais confusões quanto ao que pretende a presente Tese. O presente trabalho não tem por objeto estudar toda e qualquer oposição entre escalas de existência, mas apenas aquela em que se encontra tematizada a contenção da possibilidade de ocupação do lugar do Direito e do Poder na Europa politicamente Unida por uma das dimensões existenciais.

Tome-se aqui um exemplo.

Poder-se-ia cogitar da eventual necessidade de comentar o artigo $50^{\circ}$, parágrafo segundo, do Tratado da CECA. Este dispositivo estabelecia uma limitação à possibilidade de a Alta Autoridade impor uma contribuição superior a 1\% (hum por cento) do valor médio da produção de cada produto - salvo se houvesse autorização pelo Conselho - a fim de financiar suas atividades (despesas administrativas e subsídio não-reembolsável de readaptação de atividade das empresas, indicadas pelo artigo $50^{\circ}$, parágrafo primeiro, do Tratado da CECA).

Há o estabelecimento de um mecanismo que instaura a necessidade de diálogo institucional: o Conselho controlaria a possibilidade de imposição de contribuições pela Alta Autoridade. A princípio, haveria neste artigo uma contraposição entre as escalas de existência supranacional e estatal intergovernamental, o que em tese demandaria o desenvolvimento de um comentário especificamente direcionado a este dispositivo.

Todavia, a oposição instituída naquele artigo não está preocupada com as questões referentes ao jogo de Poder entre as escalas de existência ${ }^{421}$, vale dizer, não se conecta às questões de possível determinação do sentido das decisões normativas no interior da Comunidade. Trata-se apenas e tão-somente de uma regulamentação de uma das possíveis fontes de financiamento das atividades Alta Autoridade, estabelecidas no artigo $49^{\circ}$ do mesmo Tratado.

negatividade será esclarecido no próximo item, e mais bem ilustrado a partir da leitura do Sétimo Capítulo da Tese.

De todo modo, diferentemente do que se poderia apressadamente concluir, não se trata de indicar que as diferentes escalas de existência detinham exatamente as mesmas condições de formação do Direito Comunitário Derivado. As possibilidades de negatividade foram estruturadas na medida de capacidade de atuação de cada escala de existência. Essa constatação restará mais clara quando da leitura do Sétimo Capítulo.

${ }^{421}$ Motivo pelo qual, na nota de rodapé 424, infra, menciona-se este artigo entre aqueles que não serão comentados pelo presente estudo. 
Nesse sentido, não se trata de uma preocupação de introduzir uma multiescalaridade na definição do sentido a ser seguido normativamente na Comunidade, mas apenas e tão somente a resolução de uma questão em torno de critérios de uma das fontes de financiamento da Alta Autoridade. Com esta observação, não apenas se justifica aqui a ausência de comentário a este artigo - por não se tratar de texto objeto da metodologia utilizada pelo trabalho, como também se permite visualizar mais claramente o campo de preocupações a ser examinado por este estudo.

Deste modo, não se trata de avaliar neste texto todas e quaisquer oposições entre escalas de existência previstas pelo Tratado. Antes, preocupa-se apenas e tão somente com aquelas consideradas metodologicamente relevantes, vale dizer, com as que permitam confirmar ou não a viabilidade da leitura alternativa a qual este estudo pretende $\operatorname{apresentar}^{422}$. Nesse sentido, apenas serão examinadas as contraposições escalares institucionalmente promovidas pelo Direito Comunitário Originário que estiverem relacionadas à permissão ou à vedação da ocupação do lugar do Poder e do Direito por uma determinada medida de existência - ou seja, vinculadas à manutenção ou não da multiescalaridade na condução da Europa Unida ${ }^{423}$.

Assim, no Sétimo Capítulo, será feita a análise do texto de Direito Positivo do Tratado da CECA - incluindo Anexos, Protocolos e Trocas de Cartas. Especial atenção será concedida às disposições jurídicas que contiverem previsões normativas preocupadas em manter vazio o lugar do Direito e do Poder, ou melhor, que pretendem impedir a direção unilateral e unidimensional da produção do sentido normativo destinado a reger a vida comum - principalmente mediante distribuição de competências entre escalas de existência e estabelecimento de relações entre elas ${ }^{424}$.

${ }^{422} \mathrm{O}$ que implica o reconhecimento de que não se afirma ser impossível efetuar uma eventual avaliação jurídico-política de artigos rejeitados como este. Afirma-se apenas que estes artigos não compartilham do arco de questões estabelecido para este trabalho.

Deste modo, em nome da manutenção de coerência e de uma forte coesão interna neste presente trabalho no que se refere à metodologia adotada, exclui-se o comentário a tais dispositivos. Todavia, registrase aqui o convite para futuras investigações conjuntas no sentido de verificar a possibilidade de interpretar as disposições constantes dos artigos excluídos do comentário desenvolvido no Sétimo Capítulo.

${ }^{423}$ Essas considerações sobre a ocupação ou não do lugar do Direito e do Poder serão mais bem esclarecidas no item 3.4., infra.

${ }^{424}$ Vale dizer, especial, mas não exclusivamente, os Títulos Segundo, Terceiro e Quarto do Tratado e o Protocolo sobre as Relações da CECA com o CdE. Certamente não serão analisadas disposições normativas que nada têm relação com o desenho institucional de uma vida pública na CECA, como será mais bem especificado no início do Capítulo Sétimo desta Tese.

De todo modo, mencionem-se entre tais normas excluídas da análise, a título meramente exemplificativo (pois há outras além destas que foram igualmente desconsideradas na análise), o artigo $46^{\circ}$, o qual estabelece critérios para a elaboração de consultas aos Governos e demais interessados pela Alta Autoridade; o artigo 49 ${ }^{\circ}$, o qual apresenta as fontes de financiamento da Alta Autoridade; o artigo 50 , o qual determina os modos de aplicação dos recursos pela Alta Autoridade. Entre tantas outras normas, estas 
A análise do Tratado seguiu as seguintes etapas: (i) leitura geral e exploratória de cada um de seus artigos, com (a) identificação das normas em que há referência às escalas de existência participantes da vida comum da CECA e consequente (b) descarte daqueles artigos que não as mencionavam; (ii) a partir do grupo selecionado de artigos, ênfase naqueles onde se mencionavam (a) as competências de cada uma das medidas de existência e (b) as inter-relações estabelecidas entre elas; (iii) exame e descrição detalhados das competências atribuídas às diferentes escalas de existência; (iv) exame e descrição minuciosos das relações entre as medidas de existência; e (v) agrupamento tipológico das relações de mútua e recíproca paralisia em função de cada uma das escalas de existência ${ }^{425}$.

A partir desse panorama exaustivo, a leitura atenta do Tratado da CECA permitirá (i) identificar naquele Tratado uma preocupação em estabelecer, ao lado da camada regulatória jurídico-econômica ${ }^{426}$, uma camada adicional, de caráter jurídico-político (Lei formal, isto é, um sistema de convivência entre diferentes) e, a partir disso, (ii) perceber nesta ordenação jurídico-política um padrão racional voltado a (a) estabelecer um sistema institucional de mútuas e recíprocas contenções entre as escalas existências da vida comum durante todo e qualquer processo nomogenético desenvolvido no interior da CECA, de modo a (b) assegurar a cada uma das diferentes formas de habitar o mundo da CECA a possibilidade de participar do processo nomogenético comunitário, sem a preponderância de qualquer delas (Lei material de convivência plural permanente).

também não estão preocupadas em regulamentar a vida pública no interior da Comunidade (o dito "jogo" de Poder entre as escalas de existência), razão pela qual não serão examinadas pelo presente trabalho em seu Sétimo Capítulo, infra.

Lembre-se da observação feita na nota de rodapé 136, supra: este texto é fruto de pensamento único, tratando-se de mero registro de Pesquisa anteriormente realizada. Em outras palavras, cada uma das normas do Tratado da CECA foi minuciosamente examinada, a fim de verificar se se poderia afirmar existir ou não uma camada de regulamentação jurídico-política subjacente ao Direito Positivo.

A fim de não extrapolar os limites materiais deste estudo, não se procurará apresentar as disposições jurídico-normativas que em nada contribuiriam para demonstrar a viabilidade desta leitura jurídico-política, por em nada se relacionarem com a preocupação do "jogo" de Poder misto entre as escalas de existência. E, nesse sentido, não serão aduzidas maiores especificações ou descrições sobre as normas excluídas da análise deste trabalho, tendo em vista que isso significaria o preciso início de desenvolvimento de comentários sobre tais artigos.

Assim, para direcionar de maneira focalizada a reflexão deste estudo e evitar dispersões e digressões desnecessárias, este trabalho apenas exporá aquelas normas que diziam respeito especificamente à oposição escalar promovida no interior do Tratado da CECA - sem se preocupar de forma alguma com maiores considerações sobre normas não relacionadas ao objeto deste estudo. Mais simplesmente, serão apresentadas apenas as normas jurídicas que se encontravam localizadas no interior das preocupações metodológicas deste estudo (promoção de oposição escalar para viabilizar um sistema de convivência entre diferentes). Essa é a virtude de se considerar este trabalho como fruto de um pensamento único - o mero registro textual da Pesquisa.

${ }^{425}$ Essa divisão restará estruturalmente mais clara quando da leitura do início do Sétimo Capítulo, infra.

${ }^{426}$ Não analisada pelo trabalho, como afirmado na Introdução Geral desta Tese. 


\title{
3.4. Duas Possíveis Qualidades das Leis: A Oposição entre a Organização
} Jurídico-Política e a Jurídico-Teológico-Política

\begin{abstract}
[N]ão é preciso combater esse único tirano, não é preciso anulá-lo; ele se anula por si mesmo, contanto que o país não consinta a sua servidão; não se deve tirar-lhe coisa alguma, e sim nada lhe dar; não é preciso que o país se esforce a fazer algo para si, contanto que nada faça contra si. Portanto, são os próprios povos que se deixam, ou melhor, se fazem dominar, pois cessando de servir estariam quites; é o povo que se sujeita, que se degola, que, tendo a escolha entre ser servo ou ser livre, abandona sua franquia e aceita o jugo; que consente seu mal - melhor dizendo, persegue-o. (LA BOÉTIE, 1999, p. 14).
\end{abstract}

Por diversas vezes se recorreu ao termo Político - com "P" maiúsculo - para qualificar o passo inicial da integração europeia realizado pela instauração da CECA. Apesar de em alguns momentos ter sido necessário acima esclarecer parcialmente o significado de Político ao qual se recorre neste trabalho, há que se frisar que compreender jurídico-Politicamente o princípio da integração europeia (CECA) adquire neste trabalho um sentido bastante específico.

Em outras palavras, reconhece-se ser ainda necessário empreender um último movimento reflexivo no sentido de tornar o mais preciso possível o sentido segundo o qual é utilizada a noção de Político, em contraposição a aquilo que a tradição afirma ser o "caráter político" da CECA.

Tal dúvida [...] ofende a todos aqueles cuja riqueza consiste talvez justamente neste pretenso tesouro; assim se explica que aquele que deixa transparecer esta dúvida só encontre resistência à sua volta. Alguns, orgulhosamente cônscios de seus bens, adquiridos há muito tempo, e por isso mesmo considerados legítimos, irão, com seus compêndios [...] na mão, olhá-lo com desdém; outros, que nunca conseguem ver algo que não seja idêntico ao já visto em outra parte, não irão compreendê-lo; e tudo permanecerá assim durante algum tempo, como se nada houvesse ocorrido capaz de acarretar ou de fazer esperar uma transformação próxima. (KANT, 1980, p. 8).

\subsubsection{O Problema da Definição do Político no Tratado da CECA}

Não se trata de uma leviana afirmação de que a CECA era integração jurídicopolítica por ter sido regulamentação jurídica oriunda de negociações políticas entre seus seis Estados-Membros, como faz parte da leitura tradicional sobre a CECA (RAMOS, 1996, p. 647). Essa compreensão percebe o Direito como simples técnica pura resultante de 
jogos políticos fundados nas egoísticas vontades estatais ${ }^{427}$ e negaria ao fenômeno jurídico a possibilidade de ele próprio ser uma ferramenta conscientemente promotora de um modo de vida político ${ }^{428}$.

Lembre-se de que entender a CECA como simples produto de uma barganha política seria ignorar que o período posterior à Segunda Guerra Mundial foi caracterizado pelo surgimento de um modelo de relação entre Estados distinto do anterior (CARRILLO SALCEDO, 1985, p. 183). Se até aquele momento as relações entre Estados eram caracterizadas pelo paradigma de coexistência, a partir do final da Segunda Guerra Mundial o Direito Internacional se arquitetou em torno de um paradigma de cooperação ${ }^{429}$.

A integração na Europa iniciada com o pós-Segunda Guerra Mundial não seria um simples produto do antigo paradigma de coexistência; antes, seria um exemplo mais aprimorado do processo de aproximação cooperativa. Tratar-se-ia de experiência institucional inovadora de convivência $^{430}$ que neutralizara a possibilidade de reinstaurar um conflito armado mediante estímulo institucional conscinete de conflitos políticos contínuos no interior de limites previstos por normas jurídico-positivas, isto é, mediante direitificação das relações que, ao afastar a Guerra, não eliminaram os conflitos antes, os estimularam, sendo a base da eliminaçã do conflito militar o conlito escalar juridicamente mediado por instituições. .

Por isso mesmo, seria conceitualmente inaceitável e historicamente desconectada a percepção da CECA como singela manifestação institucional jurídica de um acordo barganhado entre vontades diplomáticas de Estados. Essa forma tradicional de interpretar a construção da CECA estaria em preciso desacordo com o paradigma estrutural do Direito Internacional do pós-Segunda Guerra Mundial do qual a própria Comunidade foi exemplo inaugural de afastamento da possibilidade de reinstauração de uma Guerra regional para, inclusive, permitir a sobrevivência da humanidade ${ }^{431}$. Por isso, deve-se rejeitar essa

\footnotetext{
${ }^{427}$ Direito como contenção técnica da política por meio de normas de abstenção (FRIEDMANN, 1964, p. 602; LAMBERTI, 1991, p. 47 e 108; MINIUCI, 2012; QUADROS, 1984, p. 386), v. nota de rodapé 2, supra.

${ }^{428}$ Direito como instrumento fomentador de interação política ativa por meio de normas de oposição entre diferentes escalas de existência, mediante direitficação das relações destas; v. item 2.1., supra.

${ }^{429}$ Remetemos à leitura integral da nota de rodapé 2 e do item 2.1., ambos supra.

${ }^{430}$ Nesse sentido, v. item 2.1., supra, bem como a discussão ao final do item 3.3.3.3., supra.

431 Ter a clareza desta condição é perceber como se pode criticar "a instrumentalização do direito internacional, quando este é colocado em posição servil, pelos estudos ditos de relações internacionais, submetendo-o, enquanto sistema, e enquanto propósito, aos imperativos 'políticos', de relações de interesse e de força. Esse enfoque, se levado ao seu paroxismo, torna o direito internacional impotente em face de ameaças como ascensão dos regimes totalitários do século passado, do nazifacismo, aos totalitarismos lastreados em ditaduras de partido único e capitalismos de estado, da era da guerra fria, com algumas excrescências remanescentes, e dos recorrentes fundamentalismos, que se servem ora desta ou daquela
} 
compreensão comum e vulgar de que a CECA seria política por ser mero produto de decisões políticas fundadas em baganha de interesses nacionais.

O Direito Internacional adquirira um novo contorno no pós-Segunda Guerra Mundial: em vez de propugnar pelo não-fazer, ele passara a criar condições para estimular um fazer. Não mais seria ele mero produto técnico resultante de uma atividade de política diplomática, mas, sim, ele próprio seria o centro de impulsão de relações políticas entre países para estabelecerem uma vida em comum $^{432}$ (CASELLA, 2010, p. 173, 2011, p. 17).

\section{A CECA era Organização Internacional dotada de disposições normativas positivas} que perenizaram as vias institucionais no sentido de realizar incessantes interações entre os partícipes da vida comunitária (comum), sem que a escala de existência de qualquer deles pudesse prevalecer unilateral e isoladamente.

Ademais, reconhecer que a condição de a CECA ser passível de uma leitura jurídico-política não pretende afirmar igualmente que esta seria "política por ter sido o primeiro passo em direção à construção de um futuro Estado Federal Europeu fundado nos Direitos Humanos e na Democracia”.

Apesar de esta forma de compreender historicamente a construção da Europa Unida ter se tornado forte nos últimos anos na literatura tradicional brasileira e estrangeira (BERL, 1961, p. 4; BOBBITT, 2011; CARBONELL et alii, 1999a, 1999b; HABERMAS, 2011a; POZO, 2011a, p. 63; RAMOS, 2005, p. 648-9 e 657; REUTER, 1965, p. 198 e 200; ROUGEMONT, 1961; SERRANO, 2011; VEÇOSO, 2006, p. 32-3; WEILER, 2011) ${ }^{433}$, há que se lembrar de que a CECA foi precisamente a opção tomada em 1951 para impedir o sucesso do Projeto Federalista Europeu que desde o período entre guerras rondava os discursos políticos de alguns intelectuais (QUADROS, 1984, p. 121).

Lembre-se de que precisamente para este fim de instaurar uma Federação Europeia por meio da promoção de Direitos Humanos e da Democracia fora fundado em 1949 o CdE, por meio do Tratado de Londres - ainda que tal iniciativa tenha fracassado e tenha sido reduzida, naquele momento, a um mecanismo intergovernamental (RÉAU, 2008, p. 177 e 184-7; REFALO, 1980, p. 72; ROLLAND, 2006, p. 557; VEÇOSO, 2006, p. 30) ${ }^{434}$. Ao mesmo tempo, não se pode ignorar que os termos "Direitos Humanos" e "Democracia" não constavam

confissão religiosa, para ameaçarem a negação de sistema de coordenação entre iguais, em favor de relações de dominação e vassalagem." (CASELLA, 2012, p. 5).

${ }^{432}$ Nesse sentido, v. item 2.1., supra, bem como a discussão ao final do item 3.3.3.3., supra.

${ }^{433}$ Restará demonstrado ao final do trabalho que esta perspectiva de a instauração da CECA deter um caráter proto-federal não detém um fundamento claro nas disposições do Tratado de Paris, de 1951.

${ }^{434}$ V. a breve narrativa histórica constante do item 1.4.3., supra, bem como as conclusões apresentadas no item 1.5., supra. Mais clara restará tal conclusão quando da leitura do Quinto Capítulo desta Tese. 
do texto do Tratado da CECA (RAMOS, 2005, p. 58-61; VEÇOSO, 2006, p. 249; WEILER, $2011)^{435}$.

Por esse motivo, não se pode derivar a condição de fenômeno jurídico-político da CECA de uma suposta afirmação dos Direitos Humanos, da Democracia ou de um Estado Federal Europeu. Tais preocupações não estavam presentes em seu Tratado Constitutivo.

Mais uma vez, evidencia-se aqui a ideia de que a noção de político neste trabalho detém um significado mais circunscrito: diferentemente do discurso Federalista que informou a construção do CdE, a CECA não detinha a pretensão de eliminar a diversidade escalar e a particularidade de cada um de seus Estados-Membros (ROLLAND, 2006, p. $557)^{436}$.

Ao mesmo tempo, não se deve ignorar que o caráter jurídico-político da CECA não deve igualmente ser atribuído a uma eventual suposição de que ela pretendia regulamentar de maneira compartilhada o exercício das atividades militares na Europa ${ }^{437}$ (RAMOS, 1996, p. 646-8) com o objetivo de centralizar institucionalmente na Europa o uso da força. Esta preocupação foi intentada apenas em período posterior: a primeira vez, mediante a proposta da CED, rejeitada em 1954 pela Assembleia Nacional da França (CANSACCHI, 1973, p. 1013; OLIVI; GIACONE, 2007, p. 37; QUADROS, 1984, p. 125; RÉAU, 2008, p. 203-15; REUTER, 1965, p. 44-5 e 47, 1991, p. 241-2 e 245-6; VEÇOSO, 2006, p. 37).

Deste modo, também deve ser rejeitada a própria percepção de que a CECA seria política por ter sido um primeiro passo consciente em direção à centralização institucional do uso da força na Europa - isto é, em direção à construção de um Estado Europeu. A CECA não era um Projeto de proto-Estado Europeu, muito menos de um Estado Federal Europeu.

Por esse motivo, perceba-se que a Tese de Doutorado não apenas coloca em suspenso as explicações econômicas usualmente dadas para compreender a História da $\mathrm{CECA}^{438}$. Este trabalho também nega a possibilidade de se atribuir a esta Organização

\footnotetext{
${ }^{435}$ Curiosamente, apenas após a extinção da CECA, em 2002, introduzem-se os Direitos Humanos na UE de hoje, isto é, precisamente quando a integração europeia assume contornos que permitem confundir sua natureza jurídica com a de um Estado Federal (BOBBITT, 2011; KESSEDJIAN, 2010; PLIAKOS, 1993; POZO, 2011a; SERRANO, 2011; WEILER, 2011).

${ }^{436}$ V. a breve narrativa histórica constante do item 1.4.3., supra, bem como as conclusões apresentadas no item 1.5., supra. Informações adicionais sobre a temática poderão ser encontradas nos Capítulos Quinto e Sexto desta Tese, ambos infra.

${ }^{437}$ Isto é, reorganizar jurídico-normativamente em um centro institucional de Poder político único o uso das forças militares, centralizando o uso da força na Europa.

${ }^{438}$ Conforme afirmado na Introdução Geral desta Tese.
} 
Internacional o caráter de fenômeno jurídico-político (i) por ser mero produto de negociação diplomática (coexistência); (ii) por ter sido manifestação originária de uma pretensão de construir um Estado Federal Europeu sustentado nos Direitos Humanos e na Democracia; ou (iii) por ter visado a regulamentar o uso centralizado da força (militar) na Europa para constituir ao menos um Estado Europeu. O trabalho procura mostrar que a condição jurídico-política da CECA deriva de outro aspecto.

A noção de jurídico-político neste trabalho detém contornos específicos e remete à distinção acima entre coexistência, cooperação e convivência nas relações entre os Estados. A CECA pode ser entendida como um fenômeno jurídico-político simplesmente em virtude de ela ter viabilizado por suas instituições um sistema de convivência entre diferentes, mediante organização jurídica das oposições escalares destes por meio de Leis dotadas de determinada qualidade.

A Política é entendida de acordo com um significado bastante preciso: um regime de convivência entre diferentes juridicamente regulamentado apto a permitir entre eles um sistema de relações capaz de impedir o desencadeamento de ações mutuamente destrutivas (CARDOSO, 2004, p. 50; LEFORT, 1991; VERNANT, 1981, p. 71-2; WOLFF, 1999, p. 7). A CECA teria detido a virtude (política) de proporcionar por meio de suas normas jurídico-institucionais a instauração de um sistema de convivência juridicamente mediado entre diferentes capaz de bloquear escaladas bélicas mutuamente destrutivas - um sistema tipicamente político - por meio de intensificação institucional de conflitos, no interior dos limites desenhados por normas jurídicas positivas de Direito Comunitário Originário

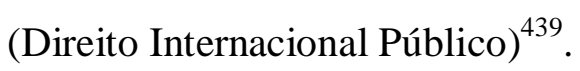

Retomando a distinção efetuada linhas acima entre Leis percebidas formalmente e Leis percebidas materialmente ${ }^{440}$, deve-se notar que se entende que a CECA instaurara uma vida comum entre as cinco escalas de existência apontadas anteriormente ${ }^{441}$. Em outras palavras, a CECA fora o instrumento jurídico-normativo necessário para constituir institucionalmente uma União política mediante engenhoso processo de direitificação de relações entre diferentes (Leis em sentido formal).

Todavia, como salientado anteriormente, toda Lei em sentido formal detém simultaneamente um sentido material. Ela realiza uma organização jurídico-política entre

\footnotetext{
${ }^{439}$ Frise-se: ainda que descomprometido com a centralização do uso da força na Europa e com a construção de um Estado Federal Europeu fundado nos Direitos Humanos e na Democracia.

${ }^{440}$ Itens 1.4.1. a 1.4.3., supra.

${ }^{441}$ Cf. item 3.3.3.3., supra: a estatalidade isolada, a estatalidade intergovernamental, a supranacionalidade da Alta Autoridade, a supranacionalidade da Corte e a populidade.
} 
diferentes conforme basicamente duas tendências: ou visando à unificação entre os diferentes (convivência unificadora), ou visando à preservação destes diferentes em suas diferenças, ainda que unidos (convivência plural permanente).

Nesse sentido, este trabalho visa também a recorrer ao sentido de Político para designar especificamente um dos dois modos de relação entre os diferentes. Trata-se da preocupação em compreender como o sistema institucional previsto no Tratado da CECA organizou as relações entre diferentes escalas de existência no processo de formação do Direito e do Poder na Comunidade e, com isso, em identificar nele uma ou outra das tendências acima apontadas (Leis em sentido material).

Em outras palavras, preocupado com a compreensão dos aspectos institucionais do fenômeno da integração da CECA, este trabalho não apenas encontra nesta Organização Internacional a existência de Leis em sentido formal (uma União política da Europa), mas também a presença de Leis em sentido material (uma determinada qualidade de organização jurídico-política dessa União política).

Para tanto, examina-se a arquitetura institucional desta Comunidade para compreender o modo segundo o qual foi desenhado o "jogo" de Poder intercruzado entre as diferentes medidas de existência na construção do sentido normativo último destinado a reger questões fundamentais da vida comum, de maneira a tentar qualificar as Leis que o instituíram como se apresentando materialmente em um sentido (convivência tendendo à unificação) ou em outro (convivência plural permanente) ${ }^{442}$.

O tema do Poder não é tradicionalmente incorporado pelos estudos da Dogmática Jurídica. Apesar de não ser desprezado, ele é usualmente percebido como um fato extrajurídico, seja no Direito Privado, seja no Direito Público (FERRAZ JR., 2003, p. 19). Em abordagens caracterizadas pela ênfase na Zetética Jurídica - como o presente estudo, a

\footnotetext{
${ }^{442}$ Perceba-se que ambas são tipos União política (isto é, instauram convivências entre diferentes), pois são aproximações direitificadas entre diferentes, construídas por Leis percebidas sob perspectiva formal (v. item 1.4.2., supra). A diferença entre ambas reside na qualidade desta União política, isto é, nas Leis percebidas sob perspectiva material (v. item 1.4.3., supra).

A diferença entre tais tipos será mais bem compreendida nos itens a seguir. A partir das especificações adiante, adotar-se-á a diferença de nomenclatura entre ambas: uma organização jurídicopolítica Política - ou simplesmente, organização jurídico-Política (convivência plural permanente), e uma organização jurídico-política Teológico-Política - ou simplesmente, organização jurídico-TeológicoPolítica (convivência unificadora da pluralidade), por ambas deterem em comum o elemento mínimo do político juridicamente organizado (Leis): convivência direitificada entre diferentes.

Sobre a oposição entre Político e Teológico-Político, é importante adiantar que a adoção desta nomenclatura de Claude LEFORT não visa a criticar a religião ou sua função na sociedade. Trata-se antes de uma crítica sobre seu uso para justificar o exercício de uma dominação por meio de sua inserção no lugar do Direito e do Poder de maneira exclusiva, total e totalizante, como ocorre com qualquer elemento trancendentalizado e uniformizado impositivamente sobre tudo e sobre todos - como restará mais claro quando da leitura do item 3.4.3., infra (PACHET, 2012).
} 
abordagem jurídica do Poder é marcada pela referência a contribuições de autores de outros ramos do conhecimento humano que também pensaram as relações entre Direito e Poder.

Nesse sentido, são inúmeras as contribuições nacionais desenvolvidas em torno do fenômeno do Poder a partir das reflexões de Norberto BOBBIO, Hannah ARENDT, Karl MARX, Max HORKHEIMER, Jürgen HABERMAS, Axel HONNETH, Max WEBER, Niklas LUHMANN e Tercio Sampaio FERRAZ JR. Apesar de o pensamento de tais autores serem relevantes, a presente Tese de Doutorado visa a recorrer a um referencial reflexivo da Filosofia Política Contemporânea igualmente preocupado com as relações entre Direito e Poder: o pensamento político de Claude LEFORT.

A pretensão de recorrer às contribuições deste autor francês não visa a desprezar as contribuições apresentadas pelos demais autores supracitados - afinal, é inquestionável a importância que detiveram para auxiliar na compreensão dos temas nos quais foram incorporados. Todavia, acredita-se que recurso às contribuições de Claude LEFORT pode ampliar o rol de questões sobre as relações entre Direito e Poder passíveis de serem colocadas para o fenômeno da CECA, nos precisos termos que interessa a este trabalho.

Neste sentido, não apenas o recurso a essa forma distinta de compreensão das relações entre Direito e Poder impede o esgotamento dos tipos de perguntas de Filosofia Política a serem feitas a um fenômeno jurídico, como também auxilia no esclarecimento da questão com a qual este trabalho se preocupa. Diante da presença de Leis formais na Europa Unida da CECA, como as qualificar dentro do quadro de duas tendências de União política (unificação ou diferenciação) entre diferentes escalas de existência?

Acredita-se que a distinção lefortiana entre o Político e o Teológico-Político possa auxiliar no esclarecimento da questão. Afinal, não basta saber apenas que havia uma União política - Leis formais - na Europa da CECA: há que se compreender especificamente qual tipo de União política (Política ou Teológico-Política) - Leis materiais - esta Organização Internacional instaurara institucionalmente por meio de sua organização jurídico-política mantida pelas normas jurídicas positivas do Direito Comunitário Originário do Tratado de Paris, de 1951. Apenas deste modo se poderá compreender de maneira integral o significado jurídico-político que este estudo pretende atribuir ao fenômeno da CECA. 


\title{
3.4.2. Claude LEFORT e a Política
}

Claude LEFORT ${ }^{443}$ (1924 a 2010) foi um filósofo-político francês. Foi Professor da Universidade de São Paulo (1952 a 1953), da Sorbonne (1953 a 1955), da Université de Caen (1965 a 1971) e da École des Hautes Études en Sciences Sociales (EHESS), em Paris (1975 a 1989).

“[D]ans la position d'un étranger toléré - grâce à la protection de Merleau-Ponty” (LEFORT, 2007c, p. 229), Claude LEFORT colaborou para o periódico Temps Modernes até 1953, quando se contrapôs explicitamente ao pensamento político de Jean-Paul SARTRE. A razão fundamental da discórdia residiu no simples fato de que Claude LEFORT se negara a aceitar a submissão automática às contribuições da reflexão política comunista sociética para desenvolver seu próprio pensamento político.

Em conjunto com Cornelius CASTORIADIS, o autor fundou o periódico Socialisme ou Barbarie, "dont le programme, si novateur qu'il fût, demeurait d'inspiration marxiste et le projet, révolutionnaire" (LEFORT, 2007b, p. 29), ao qual contribuíra até 1958, quando sua ruptura com o pensamento político de esquerda e com a própria ideia de revolução se consolidara (LEFORT, 2007e, p. 345).

\begin{abstract}
Je militais jusqu'en 1958 dans le groupe Socialisme ou Barbarie. Bien que je fusse souvent en désaccord avec son orientation, tant j'étais opposé à tout ce qui m'apparaissait comme tendant à la reconstitution d'un parti, je trouvais là les conditions d'un travail fructueux. Cependant ce cercle était étroit. Au-delà de ses frontières nos travaux respectifs étaient ignorés ou délibérément passés sous silence. Sans doute bénéficiai-je de quelque audience grâce aux Temps Modernes dans les années d'après-guerre; je ne le dus qu'à la protection personnelle de Merleau-Ponty et mes écrits, dans cette revue, parurent outranciers. Un tel climat n'incitait ni à la prudence dans l'interprétation ni surtout à l'audace qui eût été nécessaire pour une remise en question de la problématique de Marx et pour déraciner le mythe de la révolution prolétarienne. (LEFORT, 1979, p. 9, grifos do autor).
\end{abstract}

Durante sua juventude, Claude LEFORT participara da militância de esquerda do pequeno Partido Trotskista francês do pós-Segunda Guerra Mundial (1945 a 1948)

\footnotetext{
443 Inspirado por título de apresentação feita por Sérgio CARDOSO (2011), a partir de informações biográficas de Claude LEFORT, este item ressaltará a percepção do trajeto intelectual vivido pelo autor como sendo o de um pensamento livre, como exige a condição Política - a ser mais bem explicada no item 3.4.3., a seguir.

Nesse sentido, não se trata de relatar aqui o trajeto político-partidário do autor, nem mesmo de fornecer um quadro da filiação político-filosófica do autor durante sua vida - apesar de ser interessante esta discussão para a Filosofia Política Contemporânea. Em outras palavras, busca-se afirmar, com Sérgio CARDOSO (2011), que Claude LEFORT pode ser exemplo emblemático ele próprio de sua forma de pensar livre - tal qual indica sua noção de Político, como será visto no item a seguir, pois "il n'admettait jamais une incorporation d'une catégorie de pensée fixe à lui-même.” (BATAILLON, 2012b).
} 
(LEFORT, 2007b, p. 29). Todavia, progressivamente questionou os pontos de partida dos pensamentos marxista, leninista e trotskista de seu tempo, principalmente diante do forte controle intelectual exercido intensamente pela vigilância ideológica do Partido Comunista (LEFORT, 1979, p. 8, 2007c, p. 227-9) ${ }^{444}$.

“M'étant évadé du cercle de mes premières croyances, je pensai donc qu'il n'[étai]t tâche plus importante que de réinterroger la démocratie" (LEFORT, 1979, p. 11), tendo por base o questionamento de que esta era um Regime historicamente constituído de maneira fixa em favor de uma classe dominante. Para além deste pontual questionamento, Claude LEFORT reconheceu de modo mais geral que os intelectuais vistos como "progressistas" de seu tempo colocavam fora de qualquer possibilidade de contestação o terror do Regime Comunista vigente e suas práticas imperialistas repressivas internas e externas contra seus dissidentes (LEFORT, 1979, p. 22 e 267-8).

Ao pretender romper com a ilusão comum do pensamento marxista ${ }^{445}$ de $o$ proletariado ser capaz de instaurar uma sociedade livre de todo sistema de dominação ${ }^{446}$, e ao recusar a impossibilidade de contestar os preceitos e as práticas "tutelares" soviéticas ${ }^{447}$, o autor se voltara a compreender e a pensar criticamente a principal questão de seu tempo: a Democracia e seu fácil deslize em direção ao aparelho de dominação do século XX, a saber, o totalitarismo (de direita e de esquerda) ${ }^{448}$ (BATAILLON, 2012a, 2012b; LEFORT, 1979, p. 27-8, 2007e, p. 346).

\footnotetext{
444 ، '[J]'aimerais que le lecteur se souvienne des circonstances dans lesquelles j'écrivais autrefois. Le moins qu'on puisse dire est qu'elles n'étaient guère favorables à un exercice serein de la réflexion politique. Qui n'a pas connu la terreur idéologique que faisait peser sur la gauche le Parti communiste dans les années d'aprèsguerre[?]" (LEFORT, 1979, p. 8).

445 "[U]ne tradition à sa manière aussi oppressive, aussi rigide que celle qu'elle combattait et toujours embarrassée de ses héros fondateurs" (LEFORT, 1979, p. 14).

446 “[L]e maintien d'un pouvoir autoritaire et incontesté, la domination d'un parti unique imposent un modèle rigide qui décourage le jeu de l'initiative, de l'échange et de la participation." (LEFORT, 1979, p. 330).

${ }_{447}$ " $« \mathrm{~A}$ qui fera-t-on croire, s'indigne Sartre, que les Soviétiques ont voulu, en Hongrie, défendre le socialisme hongrois ?» [...], notre auteur en vient finalement à déclarer que la raison profonde de la répression est d'ordre stratégique. Les Russes ont voulu avant tout, nous dit-il en substance, empêcher la Hongrie de s'évader de leur orbite et de s'ouvrir à l'influence occidentale. Or cette dernière hypothèse a de toute évidence une part de vérité, mais en elle-même elle n'introduit aucun élément de justification de l'intervention. Dans la lutte que se mènent à l'échelle mondiale les deux blocs impérialistes, tout affaiblissement de la position de l'un peut contribuer au renforcement de celle de l'autre. Sartre habille donc cette hypothèse en soutenant que la politique internationale de l'U.R.S.S. est orientée vers des objectifs socialistes : «On dit qu'ils ont voulu sauver la chance mondiale du socialisme. Je le crois. » lisons-nous [...]. [...S] on raisonnement a atteint son but : l'U.R.S.S. est à l'abri d'une critique radicale, hors de portée de la réflexion marxiste." (LEFORT, 1979, p. 267-8, grifos do autor).

448 "Je rappelle mon itinéraire sans complaisance, mais il est vrai avec le sentiment de ne rien chercher à dissimuler ou déguiser. Enfin, j'assume cet itinéraire en observant que la déception m'a toujours coûté moins que ne me faisait gagner la conviction de penser plus librement." (LEFORT, 1979, p. 15).
} 
A ruptura do pensamento político de Claude LEFORT com relação a seu percurso intelectual anterior encontra sua fonte bruta em 1956, em sua seminal Tese de Doutorado intitulada Le Travail de l'Cuvre Machiavel.

A pretexto de apresentar uma leitura alternativa sobre o pensamento político do autor florentino do Renascimento Italiano (BIGNOTTO, 2012; LEFORT, 2007c, p. 248), Claude LEFORT (1986) visava neste texto a construir uma reinterpretação da noção de Político ${ }^{449}$, apontando ser necessário dar a devida atenção para "une société qui accueille les effets de la division sociale et les effets de l'histoire, qui précisément fait droit à l'hétérogénéité du social." (LEFORT, 2007c, p. 241-2). Para ele, Nicolau MAQUIAVEL “dissipait l'illusion d'une société qui s'ordonnerait sans division” (LEFORT, 2007g, p. 360), pois marcara a condição incontornável de a sociedade ser não-homogênea, isto é, de ser dividida em diferentes modos de habitar o mundo que deveriam conviver - e que, portanto, necessitavam de instituições para promover adequadamente a ordem desta convivência, sem que nenhuma delas tomasse unilateral e injustamente as rédeas normativas da vida comum.

Note-se que Claude LEFORT examina a obra de Nicolau MAQUIAVEL a fim de identificar especificamente a posição assumida por este último no embate políticofilosófico florentino renascentista entre a preferência por um Regime Republicano ou por um Regime de Principado. Todavia, sua preocupação mais geral consiste em encontrar linguagem o suficiente para lhe permitir reinterpretar e repensar a noção de Político legada pela tradição de seu tempo - livrando-se das amarras intelectuais que visavam a reduzir a compreensão do fenômeno jurídico-político a simples determinações puramente econômicas (BIGNOTTO, 2012; LEFORT, 2007c, p. 242, 2007e, p. 346, 2007f, p. 349).

\footnotetext{
Il m'est apparu que, pour Machiavel, la société est toujours divisée entre dominants et dominés ; que cette division ne peut être imputée à des conditions de fait (degré du développement des forces productives) et qu'elle se combine avec la division du pouvoir et de l'ensemble social. Cette double division est constitutive de toute société politique. Si l'on s'arrêtait à un aspect, on serait tenté d'imaginer le conflit de classes comme celui de deux sociétés, l'une dominant l'autre, en oubliant que, malgré sa division, la société est une. (LEFORT, 2007f, p. 348).
}

449 “[L]e problème politique a été largement refoulé sous l'effet du marxisme dans la mesure où celui-ci prétend trouver le fondement de la réalité sociale dans les seuls rapports de production. C'est pour cette raison que je me suis senti attiré par Machiavel [...]. Je me suis en quelque sorte tourné vers Machiavel comme vers «l'autre » de Marx, sachant confusément qu'il était le penseur moderne qui avait mis le pouvoir au centre de sa réflexion. J'ai d'abord cru trouver chez lui une tentative d'objectivation du champ social à partir des rapports de forces ; interprétation dont je devais bientôt m'apercevoir qu'elle constituait l'une des variantes typiques du commentaire multi-séculaire de la postérité et résultait d'une manipulation des textes, guidée par le souci d'éluder les questions qu'il posait.". (LEFORT, 2007f, p. 347-8). 
Na Tese de Doutorado de Claude LEFORT não há o uso da distinção Político ou Teológico-Político - tal qual o autor apresentou no artigo Permanência do TeológicoPolítico? (1991) -, nem a oposição entre Democracia e Totalitarismo - da maneira como desenvolveu em sua obra Éléments d'une Critique de la Bureaucratie (1979). Todavia, há uma profunda igual preocupação em compreender o Político (e não o Econômico) como fundamento do Direito e do Poder em seu estudo da defesa feita por Nicolau MAQUIAVEL da República em oposição ao Principado ${ }^{450}$. Se se propusera a ler a obra de Nicolau MAQUIAVEL, seu objetivo maior consistiu em desenvolver sua maneira própria de pensar a Política (BIGNOTTO, 2012).

Note-se que o campo significativo subjacente à chave explicativa utilizada pelo autor para examinar especificamente o Principado e a República (LEFORT, 1986) ${ }^{451}$ está igualmente presente em suas explicações temporalmente particularizadas em torno da oposição entre Regimes Totalitários e Regimes Democráticos (LEFORT, 1979, 2007e, 2007f, 2007g). Este campo recebe uma sistematização mais generalizada - isto é, abstraída de qualquer singularidade de casos específicos no tempo e no espaço - na distinção entre Regime Teológico-Político e Político (LEFORT, 1991).

Em outros termos, o próprio autor desenvolve no tempo uma linha reflexiva que remete consecutivamente ao mesmo campo significativo os significantes República, Regime Democrático e Regime Político e os termos Principado, Regime Totalitário e Regime Teológico-Político para designar de apenas dois modos distintos os possíveis fundamentos do Direito e do Poder em função da maneira de ocupar o centro produtor do sentido normativo destinado a reger as questões da vida comum.

\footnotetext{
450 “' [J] n n'avais jamais épousé la conception scientiste, économiste, selon laquelle Marx aurait découvert les lois qui régissent le fonctionnement de la société et l'évolution de l'humanité. Mon tempérament intellectuel, mais aussi la rencontre de Merleau-Ponty, et grâce à lui de la phénoménologie, alors que j'étais très jeune encore, me préservèrent de cette perversion." (LEFORT, 2007g, p. 359).

Perceba-se aqui que não é por acaso que, em diversas passagens, Claude LEFORT, Maurice MERLEAU-PONTY e, por vezes, Nicolau MAQUIAVEL, bem como cada um de seus principais predecessores - tais como Edmund HUSSERL, POLÍBIO, ARISTÓTELES e PLATÃO - são utilizados como citações neste trabalho. É com essa linhagem de autores que se dialoga fundamentalmente neste texto, para construir os pontos de partida metodológicos deste estudo.

Como afirmado na nota de rodapé 136, supra, este trabalho é fruto de um pensamento único - o qual teve apenas de se desdobrar textualmente para se fazer comunicável em vias formais. Cada divisão interna deste texto dialoga com outra divisão, e cada uma destas partes dialoga, isolada e conjuntamente, com a totalidade do texto; em outras palavras, uma apenas é compreensível a partir da adequada compreensão da outra e do todo, simultaneamente. Em resumo, nesta Tese de Doutorado, fenomenologicamente, tudo remete a tudo.

${ }^{451}$ Distinção entre os modos de estabelecer o fundamento do Direito e do Poder na organização jurídicopolítica de uma sociedade.
} 
A fim de desvincular o empréstimo conceitual e dos respectivos significantes utilizados pelo presente estudo de qualquer reflexão político-filosófica determinada espacial e temporalmente (Renascimento Italiano, crítica ao Regime Burocrático Soviético), o presente trabalho opta por recorrer nominalmente à distinção mais geral entre Político e Teológico-Político (LEFORT, 1991) para se referir aos dois modos de ocupação do lugar do Direito e do Poder.

A despeito da distinção de significantes, é possível desvelar no pensamento político do autor a existência de apenas dois campos significativos distintos - cada um deles compartilhado por três significantes (dois específicos e um mais geral, para cada campo significativo). Por esse motivo, as reflexões desenvolvidas pelo autor em textos nos quais utilizara as duas distinções mais específicas anteriormente mencionadas (República versus Principado, Democracia versus Totalitarismo) são igualmente úteis para auxiliar na compreensão dos termos componentes do binômio mais geral Político versus TeológicoPolítico.

Dessa forma, sempre que se recorrer neste trabalho às citações diretas de excertos de Claude LEFORT, há que se perceber que se designará o mesmo campo significativo quando se utilizarem os termos Regime Político, República e Democracia. Do mesmo modo, há que se notar que os termos Regime Teológico-Político, Principado e Totalitarismo remetem a uma arena significativa apenas entre eles três compartilhada, motivo pelo qual, nas citações diretas de trechos de Claude LEFORT, há que se compreender que os três termos são igualmente intercambiáveis.

[Y] a-t-il une logique de la politique ? c'est par excellence [la question] que je me pose. Elle a guidé tout mon travail sur Machiavel, comme mes essais sur la démocratie, le totalitarisme, les transformations de l'idéologie moderne. (LEFORT, 2007c, p. 255, grifos do autor).

O objetivo deste trabalho não consiste em relatar a trajetória pessoal ou intelectual de Claude LEFORT, nem mesmo precisar arqueologicamente a genealogia discursiva de suas principais conclusões. As reflexões apresentadas de maneira efetivamente sucinta nas linhas acima foram desenvolvidas apenas e tão-somente para inserir o leitor no contexto a partir do qual o autor escolhido produzira sua obra, a fim de que a exposição que segue mais diretamente relacionada aos objetivos do trabalho - seja mais bem compreendida.

Nestes termos, a exposição de aspectos gerais em torno do pensamento de Claude LEFORT é feita com o simples objetivo de esclarecer as origens do par conceitual 
desenvolvido pelo autor que será empregado por este trabalho. Dessa forma, o relato acima foi realizado com o simples escopo de preparar o leitor para a compreensão das considerações do próximo item. Não há, assim, qualquer comprometimento em esgotar as nuances históricas e intelectuais do pensamento político de Claude LEFORT $^{452}$.

Todavia, antes de ingressar na descrição do binômio escolhido para reger conceitualmente a noção de Político deste trabalho (Político versus Teológico-Político), é importante apresentar algumas considerações metodológicas acerca da possibilidade de aplicação de seu pensamento a este estudo. Afinal, não se estaria empregando impropriamente a distinção do autor para designar as Leis da Europa unida da CECA?

Há que se lembrar, em primeiro lugar, de que este trabalho partilha da questão fundamental "o que importa ser um autor" na determinação do sentido último dos termos e dos conceitos que ele desenvolve em sua obra ${ }^{453}$ ? Para o desenvolvimento de reflexões acadêmicas inovadoras, usualmente estes são deslocados de seu campo hermenêutico original para produzir novas teias de significações (pensa-se o pensamento):

\begin{abstract}
Quand l'interprète se réfère à une logique de la pensée, il ne s'évade pas de la lettre du texte, certes, mais il fait valoir un ordre de détermination invisible. Le concept d'intention [de l'auteur] perd de sa pertinence. Cette logique [...] se livre dans le non-dit comme dans le dit. Mieux, l'interprète n'hésite pas, dans la conviction où il est de la découvrir, à induire du texte ce qu'il ne contient pas, à faire parler l'auteur au-delà du point où il s'est arrêté. (LEFORT, 2007d, p. 326, grifos nossos).
\end{abstract}

Il est indispensable prendre en compte les contributions de la tradition, mais il faut chercher continuellement un détachement, c'est-à-dire, une reprise historique qui considère ce qui a déjà été dit et écrit avec une intentionnalité d'innovation, dans un constant va et vient. Il y a une inépuisabilité du sens de l'œuvre, car il n'y a jamais un garant externe de la fin du sens de l'œuvre : elle fait naître un discours à la postérité et exige des nouvelles lectures. (MARCOTTE-CHENARD, 2012).

Deste modo, a premissa assumida metodologicamente por este trabalho por si só autorizaria um deslize conceitual do par apresentado por Claude LEFORT. Não seria ele aplicável apenas para embasar uma reflexão crítica sobre a burocracia soviética, mas também para avaliar as fundações da organização jurídico-política efetuada por outros modos de ordenação social (por exemplo, a da União política da CECA).

Todavia, não apenas a premissa metodológica apresentada no item 3.3.1., supra, legitimaria a inserção de tais conceitos em outro campo significativo. O próprio Claude

\footnotetext{
${ }^{452}$ Nesse sentido, v. as considerações do item 3.3.1., supra, sobre a apropriação sempre parcial de conceitos.

${ }^{453}$ Mais uma vez, v. item 3.3.1., supra.
} 
LEFORT identificara - ao final de sua obra Élements d'une Critique de la Bureaucratie (1979) - que sua forma de compreender a organização jurídico-política burocrática soviética ultrapassaria este campo específico de análise. Segundo o próprio autor, seria possível constatar uma "homologie de structure des organisations «révolutionnaires» et des organisations du système industriel qu'elles prétendaient détruire[..., c'est-à-dire] un transfert dans le modèle du Parti des normes de l'entreprise industrielle et de la militarisation du travail." (LEFORT, 1979, p. 370).

Por esse motivo, o próprio autor percebera que, apesar de ter encontrado campo fértil para permitir o desenvolvimento de críticas profundas ao Regime Burocrático Soviético, sua distinção fundamental entre um Regime Político e outro Teológico-Político poderia ser igualmente aplicável para compreender criticamente as práticas políticas desenvolvidas nas sociedades capitalistas ocidentais (LEFORT, 1979, p. 367).

Le régime bureaucratique [soviétique], tout comme les régimes bourgeois, tomberait en ruine s'il ne se nourrissait d'identifications qui voilent la servitude, mais aussi la profondeur des antagonismes, et tiennent le grand nombre sous l'emprise de l'autorité des dirigeants. (LEFORT, 1979, p. 371).

Da mesma forma, como apontado algumas linhas acima, Claude LEFORT (1986) desenvolvera a referida distinção quando apresentara em sua Tese de Doutorado de 1956 uma leitura alternativa sobre o pensamento político de Nicolau MAQUIAVEL.

A chave de leitura permitira a Claude LEFORT compreender como o autor florentino se inserira enquanto defensor do Governo Misto durante o Renascimento Italiano - período em que se colocava em questão a distinção entre Repúblicas e Principados, vis-à-vis a oposição política entre Florença, Veneza e Milão. Tratava-se de realidade completamente distinta daquela onde posteriormente a chave explicativa fora utilizada, mas que, de maneira semelhante, permitiu esclarecer pontos usualmente não percebidos pela tradição de leituras em torno da obra de Nicolau MAQUIAVEL (LEFORT, 1986).

Também não se deve deixar de mencionar que, após a queda do Regime Soviético, o autor recorreu à mesma chave de explicação para reconstruir a história da origem da Europa, a fim de fundamentar sua reflexão acerca das práticas políticas atuais da UE. Em seu artigo L'Europe: Civilisation Urbaine ${ }^{454}$, Claude LEFORT (2007h, p. 1014-5)

\footnotetext{
${ }^{454}$ Cujo tema central não deve ser minuciosamente desenvolvido neste trabalho, apesar de ser interessante. Por se tratar de uma interpretação do autor sobre as práticas da UE nos tempos atuais, o exame deste texto do
} 
argumenta, diferentemente do que a tradição costuma assinalar ${ }^{455}$, que a Europa de hoje teria um vínculo histórico e ideológico muito próximo do Regime de liberdade das Cidades do período medieval.

Em sua análise ${ }^{456}$, Claude LEFORT apresenta a tese de que a civilização europeia que se apresenta hoje surge ao final da Idade Média, com o fenômeno das Cidades, libertas do jugo aos senhores feudais, ao Papado e ao Sacro Império Romano Germânico. Apesar de certamente ter sido inspirada pela experiência da Antiguidade, para o autor, a civilização do final da Idade Média era bastante distinta daquela, pois estabelecera um novo modo de relacionar Direito e Poder: a desnaturalização de uma ordem hierárquica estabelecida por sistema de relações tradicionais assumidos como dados (LEFORT, 2007h, p. 1018).

O burgo era espaço de liberdade, um novo campo para fomentar o estabelecimento de um novo modo de relações: "l'air de la ville rendre libre - la liberté signifiant la dissolution des liens de dépendance personnelle, mais aussi la possibilité pour chacun de changer sa condition, à la faveur du travail, de sa capacité de initiative, de l'éducation, ou de la chance." (LEFORT, 2007h, p. 1005).

Ao final de seu texto, o autor (i) propõe que a viabilidade de construção de uma UE dotada de uma Constituição apenas se mostraria possível se se objetivasse dar expressão à civilização europeia gestada conforme a liberdade das Cidades, ao mesmo tempo em que (ii) questiona (a) a afirmação da possibilidade de serem os Estados da Europa os únicos aptos a conduzir este processo na Europa, os quais miram (b) o objetivo de formar um grande Estado Europeu (LEFORT, 2007h, p. 1018).

De todo modo, note-se ainda que, apesar de a distinção adotada por este trabalho ter sido direcionada de maneira originária por Claude LEFORT para criticar as práticas do Regime Comunista de seu tempo, não se pode ignorar que ela deteve uma origem efetiva em solo completamente distinto deste: a análise do pensamento político constante da obra de Nicolau MAQUIAVEL. Ao mesmo tempo, o próprio autor francês aplicara esta distinção para reconstruir a compreensão histórica sobre as origens das cidades europeias

autor se encontra fora dos limites temporais estabelecidos metodologicamente para este estudo (1945 a 1951). Por esse motivo, deixamos de apresentar maiores considerações sobre este texto em particular.

${ }_{455}$ Mencione-se aqui, a título meramente exemplificativo, Paul VALÉRY (1924, p. 26).

456 A qual, apesar de muito interessante, não deve ser desenvolvida integralmente aqui, sob pena de extrapolar os limites temporais metodologicamente estabelecidos para este estudo. Note-se que este texto de Claude LEFORT se refere a período localizado fora dos anos 1945 a 1951, razão pela qual infelizmente não se pode aqui desenvolver comentários maiores do que já foram realizados até agora. 
no período medieval, como base para fundamentar sua avaliação sobre os encaminhamentos da UE no início do século XXI.

Assim, não apenas a premissa metodológica assumida por este trabalho - que desconsidera uma possibilidade de determinação absoluta dos destinos de conceitos por parte dos autores que os constituíram - autoriza a realização de deslize conceitual para compreender um fenômeno jurídico-político não inserto na realidade da organização jurídico-política burocrática do Regime Soviético (a CECA). A própria origem do par conceitual Político versus Teológico-Político na obra de Claude LEFORT e os usos posteriores do binômio pelo próprio autor indicam que ele mesmo admitira a aplicabilidade dos termos para compreender realidades (i) anteriores ao advento do Regime Soviético, ou mesmo anteriores ao próprio pensamento marxista (origem das cidades na Europa Medieval, o Renascimento Italiano); ou (ii) posteriores ao fim da URSS (inclusive a própria UE).

Perceba-se assim que a distinção entre Político e Teológico-Político está desvinculada da realidade do Regime Soviético, podendo ser aplicada de maneira livre como chave hermenêutica destinada a compreender um sem número de fenômenos jurídico-políticos distintos da URSS. Tal possibilidade não é uma oportunidade aberta simplesmente pela metodologia empregada por este trabalho, pois deriva igualmente do uso efetuado pelo próprio autor em suas reflexões políticas voltadas à problematização das conclusões tradicionais sobre fenômenos por ele analisados.

\subsubsection{A Distinção entre o Político e o Teológico-Político}

Em diferentes momentos deste texto, afirmou-se haver duas tendências principais de qualificação material da organização jurídico-política estabelecida pelas Leis: (i) a tendência à unificação entre diferentes escalas de existência e (ii) a tendência à preservação de tais dimensões existenciais em suas diferenças. Essa distinção deriva da percepção de Claude LEFORT (1991) sobre o fundamento do Direito e do Poder, a saber, um fundamento Teológico-Político ou Político. Neste item, essas tendências serão agrupadas tipologicamente e terão desdobradas suas principais características, as quais permitirão desenhar uma chave conceitual interpretativa de fenômenos jurídico-políticos.

A partir desta distinção será possível apontar as razões pelas quais se pode qualificar ao longo deste trabalho a União política da Europa da CECA como Política, razão pela qual devem ser expostos com mais detalhes os termos principais da distinção. 
Isso permitirá compreender como o sistema de convivência estabelecido pelo Tratado da CECA inaugurara uma dinâmica relacional entre diferentes dimensões de existência que estabelecera uma organização jurídico-política Política da Europa (ou simplesmente, uma organização jurídico-Política), em detrimento de uma organização jurídico-política Teológico-Política da Europa (organização jurídico-Teológico-Política).

A distinção entre um fundamento Político e outro Teológico-Político do Direito e do Poder de uma sociedade entreabre dois diferentes caminhos para organizar jurídicopoliticamente o social. Cada um deles estabelece uma rota específica para fundar o Direito e o Poder e sinaliza espécies alternativas de formatação (mise en forme) da sociedade (LEFORT, 1991, p. 254 e 258). A diferença entre ambos é baseada na maneira pela qual se ocupa o lugar do Poder, isto é, a distinção reside na estipulação da fonte da relação mando-obediência (LEFORT, 1991, p. 262-3).

O lugar do Direito e do Poder é sempre um campo simbólico localizado fora da sociedade, um reino a partir do qual ela pode ver, ler e identificar-se a si mesma, de modo a reconhecer-se como sociedade (não necessariamente como una, única, ou uniforme, mas como uma sociedade unida). Trata-se de um domínio externo por meio do qual uma sociedade pode conhecer e chamar a si mesma como tal, haja vista que cada uma preenche esse lugar diferentemente (LEFORT, 1991, p. 262-3).

Em uma sociedade Politicamente organizada, o lugar do Poder é sempre um lugar vazio. Isso exige um conflito competitivo periódico por meio do qual alguém é escolhido para o ocupar temporariamente. Ninguém preenche permanentemente o lugar do Poder, pois ninguém é considerado seu proprietário: nada ou ninguém é o Poder - isto é, há a recusa da afirmação dogmática (LEFORT, 2007e, p. 342, 2007f, p. 351).

Proíbe-se deste modo que alguém ocupe o referido lugar. Evita-se que qualquer escala de existência domine os diferentes níveis das relações sociais. Exige-se assim uma sucessão periódica e, desta forma, a permanência do conflito. Esta desordem contínua voltada à promoção de uma ordem temporária (Direito e Poder) é viabilizada por meio de instituições jurídico-Políticas - isto é, das instituições jurídicas disponíveis em um regime Político, da polis (LEFORT, 1979, p. 25, 1986, p. 735, 2007f, p. 351).

Em um Regime Político, há a descoberta do caráter sadio da discórdia, do tumulto, da oposição (LEFORT, 1992a, p. 144). Por esse motivo, enfatizam-se as “[d]iversité des groupes et de leurs revendications, compétition de leurs représentants en vue d'une sélection des dirigeants, libre circulation des idées et des informations, libre association, contestation légitime du pouvoir établi, mobilité du pouvoir” (LEFORT, 1979, p. 329). 
Há uma constante disposição a uma abertura contínua ao risco e à mutação. Por isso, as orientações normativas últimas do Direito e do Poder mostram-se sempre de acordo imediatamente com a solução dada a cada momento pela constantemente mutável percepção de uma sociedade sobre sua identidade histórica imanente: "la démocratie se caractérise [...] par son intention d'affronter l'hétérogénéité des valeurs, des comportements et des désirs, et de faire des conflits um moteur de croissance" (LEFORT, 1979, p. 348).

Abre-se com isso um caminho para um ambiente dinâmico de indeterminação desencantada, de tal modo o processo nomogenético tenha como resultado um produto jamais acabado, permanentemente mutável, pois sempre afeito à multiplicidade dimensional de maneiras de habitar o mundo e de o experienciar. Não se admite assim a petrificação da autoridade e de suas soluções normativas "últimas", por se reconhecer como virtuosa a transgressão da ordem estabelecida, isto é, reconhece-se o benefício derivado do tumulto escalar provocado, promovido e mantido pelas próprias instituições (LEFORT, 1992a, p. 145 e 155; WEIL, 2012):

c'est l'improvisation dans l'action, je veux dire, la liberté d'agir ici et maintenant sans se laisser paralyser par les idées traditionnelles de la généralisation des luttes, de la coordination des groupes, de la hiérarchisation des objectifs. (LEFORT, 2007c, p. 252, grifos do autor).

Em um Regime jurídico-Politicamente organizado, por se recusar a imagem de um garante último da identidade e da unidade social, o produto instável da nomogênese é formulado de acordo com "toute la société en effervescence" (LEFORT, 2007c, p. 252), ou seja, conforme a variável síntese da complexidade antropológica vigente em determinadas condições espácio-temporais (LEFORT, 1979, p. 25 e 324, 1991, p. 262-8): "le pouvoir est inventif et la loi vivante parce qu'ils sont exposés à la revendication du peuple" (LEFORT, 2007g, p. 361).

Por essa razão, um Regime Político é caracterizado pela percepção e pela assunção da necessidade e da irredutibilidade do pluralismo escalar, vale dizer, pela aceitação e pelo acolhimento da divisão interna entre múltiplas formas de habitar o mundo. Cada uma delas é um polo de negatividade: ao não pretender ser dominada pelas demais, cada uma delas efetua um requestionar contínuo das decisões vigentes sobre o sentido do Direito e do Poder na sociedade por meio de contestação e reivindicação ininterruptas (BIGNOTTO, 2012; LEFORT, 1986, p. 727-8, 2007f, p. 350 e 355-6). 
Por outro lado, o lugar do Poder em uma sociedade Teológico-Politicamente organizada nunca é um lugar vazio. Ele é pré-ocupado intemporalmente por uma entidade que (i) incorpora o Poder, (ii) com ele se identifica, e (iii) passa a indicar a partir de si mesma o sentido único da direção social. Blinda-se o lugar do Poder ao acesso por parte de outras escalas de existência (LEFORT, 2007f, p. 351, 2007g, p 361).

Há com isso a recusa da negação (LEFORT, 2007e, p. 342), a qual é absolutamente contraposta pela afirmação "pleine[... d']une identité et [d']une cohésion de la société" (LEFORT, 2007f, p. 351). Seu objetivo é conservar, estender e reforçar a posição da própria escala que tomou o lugar do Poder - ainda que sob o argumento de proteção "tutelar" dos Homens.

O Regime jurídico-Teológico-Politicamente organizado é caracterizado pela condição de que algo ou alguém é o Poder: um Deus, um Homem-Deus, a religião, o Estado, o interesse nacional, a necessidade, a fortuna, a religião de Estado, a razão de Estado, a razão, a Revolução, o proletariado, o Partido, a Economia, a razão econômica, entre outros fundamentos sobrenaturais reputados naturais (LEFORT, 1991, 1992a, p. 149, 2007c, p. $246)^{457}$.

A dimensão existencial que toma o lugar do Poder é determinada como a escala - a única escala - destinada a ocupar absolutamente o centro nomogenético. Atribui-se lhe assim supostamente inquestionável legitimidade para pretender proferir um saber ou um discurso único e homogêneo sobre a totalidade, de acordo com uma concepção total e totalizante do mundo gestada dentro de sua própria e singular perspectiva (LEFORT, 2007c, p. 229).

Há com isso a instauração de uma hierarquia social que é naturalizada e impressa impositivamente sobre a realidade, tornando-se impossível inscrever uma ordem humana pluridimensional (LEFORT, 1979, p. 12, 1992b, p. 200, 2007c, p. 246). Disseminam-se difusamente os instrumentos de imposição das resoluções normativas unidimensionais sobre a espontânea pluridimensionalidade social: o detentor exclusivo do lugar do Poder “s'arroge le droit d'être présent partout, à travers ses agents, de diffuser les bonnes normes dans tous les secteurs d'activité" (LEFORT, 2007g, p. 362).

Destaca-se assim um Um, o qual se eleva sobre os demais e sobre estes passa a ditar total e totalizantemente um único modo de habitar o mundo - o seu modo,

457 “J'ai donc pris beaucoup de distance à l'égard de mes premiers écrits. Je ne respire plus l'air du marxisme, l'attente de la vraie révolution me paraît vaine, la croyance en la bonne société ou ingénue ou hypocrite, toujours redoutable". (LEFORT, 1979, p. 12, grifos do autor). 
subordinando todas as relações sociais às resoluções tomadas no centro do Direito e do Poder conforme sua própria medida de existência - porque ele ocupa totalmente o centro nomegenético, tornando-o unidimensional (apenas uma dimensão de existência possível). Nos Regimes jurídico-Teológico-Politicamente organizados se efetua um reencantamento do Direito e do Poder, o qual, por meio de um controle total a partir do monopólio escalar, volta-se a abolir, eliminar, ou mesmo extinguir o campo de indeterminação (LEFORT, 1979 , p. 25 e $328-9,2007$ c, p. 247$)^{458}$.

A ordem é pré-estabelecida de maneira supostamente segura e certa por essa entidade não-humana e externa que permanentemente ocupa e detém o lugar do Direito e do Poder. Estes são um produto do padrão unidimensional instituído pela medida de existência derivada dessa transcendência, apesar das variáveis sínteses culturais possíveis a serem operadas na História de cada sociedade. São argumentos típicos de um Regime Teológico-Político:

la concorde entre les citoyens (l'unione) et le péril des dissensions imputées toujours aux factions; la bonté intrinsèque des institutions primitives et le péril des mutations ; la défense du statu quo [...] ; et aussi la vertu du juste milieu, celles de moindre risque et de la temporisation. (LEFORT, 1992a, p. 149, grifos do autor).

Deste modo, há "le maintien d'un pouvoir autoritaire et incontesté [et] la domination d'un[e échelle] unique [qui] impose un modèle rigide qui décourage le jeu de l'initiative, de l'échange et de la participation." (LEFORT, 1979, p. 330). Seu objetivo é dissolver as distinções escalares para instaurar a artificial condição social homogênea à imagem e semelhança da unidimensionalidade (LEFORT, 2007c, p. 237).

Pressupõe-se e põe-se assim a ilusão de uma sociedade marcada pela ausência de conflitos, vale dizer, a regência da uniformidade pacífica de uma única escala de existência $^{459}$ (LEFORT, 2007c, p. 239). Há o mascaramento da divisão interna e da permanência do conflito. Postula-se simplesmente a instauração (ou mesmo a necessidade de imposição) de uma sociedade sem tensões, sem oposições, homogênea, pacificada, hostilizando a livre diferenciação espontânea das mais distintas escalas de existência (LEFORT, 2007g, p. 361): “[t]out système totalitaire prétend ignorer le conflit et plus

\footnotetext{
458 « Je crois que l'expérience du totalitarisme enseigne que l'image du Peuple-Un est liée à celle d'un Autre détaché qui détient le savoir de l'Un, c'est-à-dire la toute-puissance.” (LEFORT, 2007c, p. 246).

${ }^{459} \mathrm{Na}$ qual vige “[1]'adhésion aux modèles d'autorité et de hiérarchie, la croyance dans le savoir du leader, la fidélité tenace à une tradition, l'attachement à des emblèmes, le fétichisme de l'institution". (LEFORT, 1979, p. 370).
} 
généralement imposer à toutes les activités sociales un dénominateur commun." (LEFORT, 1979, p. 348).

Deste modo, a multiplicidade existencial de maneiras de experienciar o mundo é monoliticamente abafada e sufocada por essa escala transcendente escolhida. Esta rege do exterior um modo puro, único e rígido a sociedade (LEFORT, 1991, p. 262-8). Todos os esforços são dirigidos para cumprir os objetivos e as metas estabelecidos pelos critérios definidos por essa exterioridade pacificadora, de acordo com a forma de medir o mundo dada por esta entidade externa. O objetivo consiste em fazer Um instaurar - apesar da multiplicidade dimensional - uma única singular ordem existencial dada pela abstrata transcendência que se precipita sobre o imanente.

\footnotetext{
[L]'ordre ne s'institue pas dans la rupture avec la désordre, il se conjugue avec un désordre continué ; la concorde est un leurre, sous le couvert duquel l'oppression cherche à désarmer les revendications qui la contraignent à se nommer et la mettent en danger. (LEFORT, 1986 p. 724).
}

A forma de organização mais afeita à multiplicidade escalar típica das variáveis condições da sociedade e produtora de liberdade é a do Regime Político (LEFORT, 1992a, p. 174-5). Em razão da proximidade da ordem político-jurídica instituída com a dinâmica estrutural valorativa, ética, moral e jurídica de cada sociedade ${ }^{460}$, a persistência de uma origem imanente das Leis está mais direta e intimamente fundada na incontrolável e extremamente mutável medida de existência normativa humana (LEFORT, 2007f, p. 350); em suma, "elle se prête au mouvement" (LEFORT, 1992a, p. 176).

A recusa da aceitação de um fundamento transcendente do Poder e das Leis seria o mecanismo destinado a assegurar ao Homem a constante ciência sobre o fundamento direto da ordem jurídico-política na imanente condição humana de pluralidade antropológica e de ininterrupta e arriscada indeterminação espácio-temporal da ordem axiológico-normativa vigente: "la loi s'avère dans la dépendance de la volonté chageante des hommes[; ...] s'ouvre une carrière indéfinie au nouveau." (LEFORT, 1979, p. 12).

A rejeição de qualquer cristalização definitiva do sistema jurídico-político ordenador da sociedade representa a abertura característica dos regimes Políticos à constante renovação por meio das inevitáveis tensões sociais. Estas convidam a uma experiência ininterrupta da heterogeneidade social, consciente de sua divisão interna em

460 “Une société civile se dégage pleinement de l'État ; [...] elle est par principe discordante, théâtre d'un processus de différenciation immaîtrisable, vouée à la coexistence de milieux, de traditions, de comportements, de croyances qui revendiquent leur singularité.” (LEFORT, 1979, p. 25-6). 
diferentes dimensões existenciais em permanente antagonismo. A preservação do sentido do Direito e do Poder na interrogação é condição indispensável para a fruição da livre determinação das ordens normativas de acordo com as diferentes sínteses prescritivas formadas no tempo e no espaço (ARATO, 2012; BIGNOTTO, 2012; LEFORT, 1979, p. 26-7, 1986, p. 735, 2007g, p. 361).

Há, assim, a (re)afirmação constante da consciência de que a causa da ordem jurídico-política é diretamente a variável e instável medida humana, ou seja, é imanente ao Homem - "retour continu de la societé sur elle-même" (LEFORT, 1986 p. 734). A periodicidade e a permanência do conflito exigem a contínua tomada de posição com relação às questões comuns de acordo com as múltiplas possibilidades humanas de experienciar o mundo, isto é, conforme as mais diferentes formas de agir sobre o mundo e de conhecê-lo: "l'entreprise politique laisse découvrir son appui en elle-même, dans un mouvement qui ne repose sur rien et n'a d'autre assurance que son in-détermination." (LEFORT, 1986, p. 733).

Para tanto, é fundamental a presença de instituições que organizem jurídicopoliticamente a sociedade no sentido de não mascarar a divisão fundamental entre múltiplas dimensões de existência. Tais disposições institucionais não apenas devem evidenciar estas distinções, como também devem fomentar o embate escalar entre elas, de modo a que todos possam fazer valer suas próprias formas de habitar o mundo no processo nomogenético, apresentando-as em oposição/choque diante das demais.

As dissensões são nesse sentido fontes geradoras, e não fontes destrutivas. Por isso, são constantemente refeitas para continuamente refundar o sentido do Direito e do Poder mediante a promoção institucional de mútuas negatividades escalares. A arquitetura institucional não deve eliminar o conflito, mas o traduzir no interior de um processo Político que instaure a convivência entre diferentes dimensões existenciais, para que estas formem decisões conjuntas em vistas da preservação do comum (ARATO, 2012; BATAILLON, 2012b; LEFORT, 1986, p. 733, 1992a, p. 167-9, 1992b, p. 192 e 1956).

Ce à quoi tend la [politique], c'est à assurer la liberté. Celle-ci ne se confond pas avec la licence, ou, pour employer un langage plus modéré, elle ne consiste pas dans la reconnaissance publique du droit de chacun de faire ce qui lui plaît. La liberté politique s'entend par son contraire : elle est l'affirmation d'un mode de coexistence, dans certaines frontières, tel que nul n'a autorité pour décider des affaires de tous, c'est-à-dire pour occuper le lieu du pouvoir. La chose publique ne peut être la chose d'un seul ou d'un petit nombre. [...]. Elle implique aussi la 
négation de toute instance qui s'arroge le savoir de ce qu'est le bien commun. (LEFORT, 1992a, p. 171, grifos do autor).

O Regime Teológico-Político atribui a certeza da regulação jurídico-política a uma entidade transcendente. A exterioridade se mostra como fiador unificador a priori do social, condição que exime os Homens de refletirem em conjunto com os diferentes sobre as demandas comuns e que opera um progressivo esquecimento de que a causa da ordem jurídico-política é mundana. Desertificam-se os modos de existência, pois se eliminam as condições do desacordo e do reconhecimento recíproco de um pelo outro em suas próprias singularidades (LEFORT, 2007c, p. 255).

Os Homens passam a buscar e a impor única e exclusivamente a moldagem de si e dos demais segundo os parâmetros, as balizas e os constrangimentos dados pelarégua existencial da transcendência. Ao negar a heterogeneidade social, pressupõe-se a viabilidade de uma "maîtrise totale de son espace, des individus qui le peuplent, des multiples réseaux dans lesquels ils sont impliqués et de ce qu'on est venu à nommer significativement son environnement." (LEFORT, 1979, p. 26).

Nesse sentido, a aceitação e a introjeção da transcendência se mostram como fonte da servidão a esta "Boa Nova" unidimensional e totalizante. Admite-se agir apenas no sentido de moldar as ações conforme uma única medida de existência absoluta, unificadora externa. A realização terrena deste reino transcendente justificaria em seu nome inalcançável e irrealizável todas as dominação, exploração e opressão necessárias para a instauração de tal modelo de sociedade imaginada uniescalarmente homogênea e fixa, a qual seria completamente nova e distinta da vigente.

[L']idée d'une unification imminente de toutes le pratiques] entret[ient] le mythe d'une indivision, d'une homogénéisation, d'une transparence à soi de la société, dont le totalitarisme montrait les ravages en prétendant l'inscrire dans la réalité. (LEFORT, 1979, p. 10-1).

É possível diferenciar a organização jurídico-Política da organização jurídicoTeológico-Política a partir dos quatro binômios a seguir: respectivamente, (i) imanência versus transcendência; (ii) vazio versus preenchimento; (iii) tensão versus pacificidade; e (iv) pluridimensionalidade versus unidimensionalidade. As quatro noções acima apresentadas são agrupáveis do seguinte modo entre os dois tipos de Leis materiais.

Uma organização jurídico-Política pressupõe um lugar vazio do Direito e do Poder, a ser continuamente preenchido de forma indeterminada e irresolúvel por meio de tensões 
ininterruptas entre as diferentes escalas de existência que compõem a sociedade. Por meio desta atenção à pluridimensionalidade, assegura-se o fundamento do sentido do Direito e do Poder na imanente condição humana de antropodiversidade.

Por sua vez, uma organização jurídico-Teológico-Política assume que o lugar do Poder é previamente preenchido por uma escala de existência legada pela transcendência. Esta unidimensionalidade é reputada inquestionável e é percebida como a única escala apta a determinar o sentido do processo nomogenético - deslegitimando o conflito e convidando à aceitação pacífica das imposições superiores.

Tout système totalitaire prétend ignorer le conflit et plus généralement imposer à toutes les activités sociales un dénominateur commun. Ne peut-on dire que la démocratie se caractérise à l'inverse par son intention d'affronter l'hétérogénéité des valeurs, des comportements et des désirs, et de faire des conflits un moteur de croissance ? (LEFORT, 1979, p. 348).

A distinção conceitual entre Regimes Políticos e Teológico-Políticos é feita em termos de oposição absoluta para viabilizar uma melhor compreensão dos elementos característicos de cada um deles. No entanto, a facilidade do deslize degenerativo de estruturas Políticas em Teológico-Políticas ${ }^{461}$ impõe que se reconheça a inevitável igual possibilidade de realização de ambos os móveis organizacionais das Leis: ou o Político ou o Teológico-Político.

Estes se apresentam continuamente como duas qualidades em potencial, as quais são igualmente passíveis de serem assumidas a qualquer momento pelas Leis que organizam jurídico-politicamente o social $^{462}$. Enquanto regimes igualmente políticos, ambos estão dotados de Leis (formais); a distinção de qualificação (material) das Leis restaria mais clara a partir da percepção de que o Teológico-Político é um prolongamento do Político por meio da inversão deste (LEFORT,2007f, p. 350-2).

A possibilidade de se dizer que em determinadas condições espácio-temporais vige uma disposição organizacional jurídico-Política ou jurídico-Teológico-Política deriva do

\footnotetext{
461 “Ce qui me frappe [...] est la résistance à penser ensemble le problème du totalitarisme et celui de la démocratie. Bien sûr, certains jugent qu'il vaut mieux vivre en démocratie bourgeoise, plutôt que sous un régime totalitaire. [...] Ce qu'il faudrait comprendre, c'est pourquoi la démocratie bourgeoise a pu donner naissance à l'idéologie totalitaire, comment le totalitarisme la renverse tout en développant des germes qui sont en elle." (LEFORT, 2007e, p. 346).

462 Bastaria constatar, diante da organização jurídico-política do social, o estímulo ou o desestímulo institucional a progressivos embates multidimensionais no interior de uma sociedade: “c'est l'absence de luttes qui risque de faire que l'ordre se pétrifie et que sous une forme ou sous autre le processus de bureaucratisation débouche sur un régime totalitaire." (LEFORT, 2007c, p. 255).
} 
fato de haver de maneira historicamente variável a hegemonia de uma sobre a outra ${ }^{463}$. É isso que permite compreender a ideia de modificação material (da qualidade) das Leis - a mutação da maneira de organizar jurídico-politicamente uma sociedade que se mantém formalmente unida ${ }^{464}$.

\subsubsection{Apropriação da Reflexão Lefortiana: As Leis Materiais da Europa Unida da}

\section{CECA como Leis de Organização Jurídico-Política}

A duas formas de organização jurídico-política do social (Política ou TeológicoPolítica) devem ser percebidas como qualidades materiais das Leis ${ }^{465}$. Isso implica reconhecer que ambas são formas de organizar politicamente as relações sociais, isto é, as duas são maneiras distintas de se instaurar um sistema de convivência entre diferentes escalas de existência. Se se distinguem os modos segundo os quais cada uma delas institui uma racionalidade de interações escalares, não se pode ignorar que ambas se tratam de perfis distintos de viabilizar institucionalmente uma União política entre diferentes - a qual não necessariamente visa à unificação.

${ }^{463}$ Este trabalho não tem por objetivo examinar as condições e os termos segundo os quais ocorre o referido deslize de uma organização jurídico-Política a uma organização jurídico-Teológico-Política. Apesar de ser interessante temática, este trabalho não apenas não está preocupado com a decantação integral do pensamento político lefortiano, como também este exame é desnecessário para os objetivos propostos para este estudo.

Com efeito, investigar as minúcias do pensamento político de Claude LEFORT, apesar de ser interessante, foge aos limites metodológicos deste trabalho - interessado em estudar a CECA, razão pela qual deve relegar esta tarefa à literatura especializada de Filosofia Política Contemporânea. Por mais que seja relevante compreender o processo de tal deslizamento de um a outro, não se pode deixar de notar que esta Tese de Doutorado se cinge a examinar, muito mais modestamente, o fenômeno jurídico-político da CECA da maneira como ele se apresentou institucionalmente em seu Tratado Constitutivo.

Nesse sentido, não há espaço para tentar avaliar neste trabalho um eventual deslize da estrutura institucional da CECA em direção a uma organização jurídico-Teológico-Política, na medida em que este estudo se centra no documento jurídico-normativo da maneira como se apresentou no Tratado de Paris, de 1951 - não havendo um exame temporal a partir desta data. Como a avaliação de deslize exige uma mobilidade para além daquele ano, e como não se pretende estudar a CECA senão até 1951, não interessa a este trabalho saber como Claude LEFORT pensara os termos segundo os quais tal deslize poderia ocorrer. Tal exame não apenas extrapolaria os limites metodológicos desta Tese de Doutorado, como se revelaria revestido de inutilidade para este estudo - pois não se procura compreender, aqui, como, quando e em quais termos e condições a Europa politicamente Unida deixara de ser jurídico-Politicamente organizada. Esta tarefa reside em preocupações de trabalhos posteriores.

Por essa razão, não interessa aos limites metodológicos deste trabalho compreender e expor - ainda que sucintamente - como Claude LEFORT compreende a passagem de um Regime Político para uma condição Teológico-Política.

${ }^{464}$ Esta conclusão sustenta a hipótese - a ser desenvolvida em trabalhos posteriores - sobre a possibilidade de a Europa politicamente Unida da UE atual poder ser compreendida como uma organização jurídico-política cujas Leis teriam deslizado em direção a um fundamento Teológico-Político. Como salientado anteriormente (notas de rodapé 135 e 402, supra), esta hipótese não será examinada neste estudo, por se localizar fora do arco de questões para ele circunscrito (apesar de decorrer diretamente deste). Fica registrado aqui o convite para futuras reflexões conjuntas sobre o tema.

${ }^{465}$ Nesse sentido, v. item 1.4.3., supra. 
Em outras palavras, cada uma dessas formas pressupõe uma organização jurídicopolítica das relações - vale dizer, a existência de Leis (percebidas em sentido formal) ${ }^{466}$, por meio da qual haja a direitificação de um sistema de convivência entre diferentes (Direito não apenas como resultado, mas como promotor de uma dinâmica política entre escalas de existência distintas ${ }^{467}$. A distinção Político versus Teológico-Político apenas indica a tendência para a qual caminhará a União política entre diferentes (respectivamente, conservação ou unificação da pluralidade).

Para que se possa verificar a via a ser potencialmente seguida por determinada organização jurídico-política, é fundamental que seja examinado o conjunto jurídiconormativo positivo segundo o qual as Leis se expressaram institucionalmente. Uma análise detalhada das articulações escalares promovidas por suas disposições normativas permitirá depreender a racionalidade norteadora do engenho político institucional e, com isso, explicitará não apenas que há Leis formais (uma organização jurídico-política), mas também Leis materiais (uma organização jurídico-Política ou Teológico-Política) ${ }^{468}$.

Durante todo o texto desta Parte Primeira, mas principalmente no item 3.4.1., supra, afirmou-se que a atribuição da qualidade de "Político" para a CECA por esta Tese de Doutorado derivava de motivos distintos dos da tradição do pensamento jurídico. A noção de Político assumida por este trabalho é desde o início deste uma noção que escapa à qualificação dada tradicionalmente pela literatura jurídica.

Lembre-se nesse sentido que se recusa a possibilidade de se atribuir à CECA o caráter de fenômeno jurídico-político (i) por ser mero produto de negociação diplomática (coexistência); (ii) por ter sido manifestação originária de uma pretensão de construir um Estado Federal Europeu sustentado nos Direitos Humanos e na Democracia; ou (iii) por ter visado a regulamentar o uso da força (militar) na Europa (construção de Estado Europeu).

Na verdade, como se buscará demonstrar ao longo da Parte Segunda deste trabalho, a CECA pode ser compreendida como um fenômeno jurídico-político - isto é, de promoção de um sistema de convivência entre diferentes escalas de existência na Europa por ter sido obra de uma engenharia institucional voltada à promoção de uma organização jurídico-política Política (ou simplesmente, uma organização jurídico-Política) das relações entre os partícipes da vida comum.

\footnotetext{
${ }^{466}$ Nesse sentido, v. item 1.4.2., supra.

${ }^{467}$ Nesse sentido, v. item 2.1., supra.

468 Como visto na integralidade do item 1.4., supra, não existem Leis formais que não contenham determinada qualidade material.
} 
Em outras palavras, essa é a razão pela qual se afirma que, com a CECA, a "Europa dos Seis" ${ }^{469}$ pode ser entendida, não apenas como uma Europa politicamente Unida, mas, principalmente, como uma Europa Politicamente Unida. Ao promover um sistema de convivência entre diferentes (Europa politicamente Unida), esta buscara ainda preservar a pluralidade escalar no interior deste sistema de convivência (Europa Politicamente Unida).

Isso quer dizer que não apenas se procurou promover uma leviana, precipitada ou irrefletida organização jurídico-política do social ao final da Segunda Guerra Mundial entre os seis países europeus. Na verdade, será possível perceber uma contínua preocupação no Tratado da CECA em confeccionar uma complexa arquitetura de interação conflitiva entre dimensões existenciais normativamente estimuladas pelo Direito Comunitário Originário desta Comunidade - preocupação que pode ser entendida como efetiva organização jurídico-Política.

Há deste modo toda uma racionalidade específica de caráter Político na construção das normas jurídicas do Tratado da CECA, na medida em que se preocupa com o tema da indefinição da detenção do lugar do Direito e do Poder em cada processo nomogenético da CECA. As disposições do Tratado podem ser vistas como instrumentos jurídicos de promoção de uma efetiva vida política de embate entre escalas de existência na definição do sentido do Direito e do Poder na Comunidade, vale dizer, como expedientes institucionais engenhosamente maquinados para a preservação de um (lugar) vazio de produção do sentido normativo último sobre questões comuns.

Frise-se que a noção de Político assumida por este trabalho tem por alicerce a definição de Regime Político tal qual desenvolvida por Claude LEFORT - referida algumas linhas acima ${ }^{470}$. Essa concepção supõe o atendimento simultâneo de quatro condições: (i) imanência, (ii) vazio de Poder, (iii) tensão e (iv) pluridimensionalidade. Entende-se neste trabalho que as disposições institucionais do Tratado da CECA detiveram virtude Política, pois suas normas jurídicas foram positivadas de tal modo que se atenderam simultaneamente às quatro condições acima indicadas quando da confecção de seu sistema institucional de convivência entre diferentes ${ }^{471}$ - isto é, quando promoveram a direitificação das relações entre os países europeus.

Para compreender melhor esta asserção, não devem ser ignoradas as conclusões anteriores sobre as escalas de existência partícipes da vida comum da CECA, tal qual

${ }^{469}$ Os seis Estados-Membros fundadores da CECA: Bélgica, França, Itália, Luxemburgo, Países Baixos e República Federal da Alemanha.

${ }^{470}$ V. item 3.4.3., supra.

${ }^{471}$ Essa conclusão restará mais clara quando da leitura do Sétimo Capítulo desta Tese de Doutorado. 
designada por seu Tratado Constitutivo ${ }^{472}$. Nesse sentido, não apenas se deve notar que são convocadas para constituir a vida comunitária cinco escalas de existência, como também que estas foram introduzidas conforme lógica bastante peculiar. A presença institucional de normas promotoras de oposições escalares inseriu no Tratado uma lógica de interação entre as diferentes medidas existenciais que impedia algo diverso de uma dinâmica relacional horizontal - isto é, que não permitia a verticalização das relações.

Dito de outro modo, o Tratado da CECA foi composto por um complexo jurídiconormativo $^{473}$ marcado pela presença de normas de oposições escalares: foram estas as responsáveis pela instauração do sistema institucional de convivência entre as cinco diferentes escalas de existência para que vivessem uma vida comum sem que as decisões sobre a nomogênese pudesse ser vista como sendo função exclusiva de Uma dimensão existencial em detrimento das demais. Todas poderiam e deveriam participar da vida comunitária, sem que nenhuma pudesse se compreender como detendo o lugar do Direito e do Poder.

É por essa razão que a vida em Comunidade instaurada pelo Tratado da CECA pode ser percebida como fruto de uma organização jurídico-Política da Europa dos Seis: (i) as normas de promoção de oposições escalares buscaram garantir condições institucionais para a contínua - e controlada - tensão entre os diferentes partícipes comunitários, de modo a (ii) assegurar o sentido misto da nomogênese no interior da Comunidade, isto é, que ele se revelasse como sendo um produto pluridimensional, na medida que todos poderiam tornar presentes perante os demais suas específicas formas de habitar o mundo, as quais necessariamente deveriam ser consideradas conjuntamente.

Para tanto, as normas de oposições escalares (iii) dotaram cada uma das dimensões existenciais de Poder de negatividade, de tal maneira que se pudesse preservar a condição de vazio (no lugar) de definição do sentido do Direito e do Poder na Comunidade. Uma e outra poderiam conter, a todo momento, mútua e reciprocamente, pretensões de imissão sempre usurpadoras, pois institucionalmente não autorizadas - naquele centro nomogenético. Todos poderiam dele participar, mas nenhum poderia tomar o lugar do Direito e do Poder.

Deste modo, (iv) por tais normas terem sido constituídas para "deter, interromper, paralisar, resistir, impedir, barrar e represar" (CARDOSO, 2012, p. 20) toda e qualquer pretensão de rompimento da relação de horizontalidade entre as escalas de existência,

\footnotetext{
${ }^{472}$ V. item 3.3.3.3., supra.

473 A ser explicitado no Sétimo Capítulo desta Tese, infra.
} 
pode-se perceber a preservação da constante da condição imanente do fundamento do Direito e do Poder. Com efeito, o lugar do Poder era mantido no centro, isto é, entre as diferentes escalas de existência da vida em comum - es to meson, em posição mediana, garantindo que "essa arché permane[cesse] en meso" (VERNANT, 1981, p. 60, grifos do autor), isto é, ao próximo alcance de todos os participantes da vida comum, e longe de qualquer determinação normativa unilateral externa à própria vida Comunitária.

Isso implicava reconhecer que o Poder exercido no interior da vida comum da CECA não pairaria distante das escalas de existência e sobre elas, ou ainda, que o sentido nomogenético não seria regido por uma escala transcendente/não-humana - tais como Deus, Economia, Religião, Razão, Revolução, entre outros, nem teria como origem problemas externos à vida comum recém-instaurada na Europa em torno de questões concretas sensíveis comuns.

Assim, as soluções deveriam ser encontradas a partir do embate pluriescalar promovido no interior da Comunidade, sem se dever recorrer a expedientes que remetessem a um garante externo do sentido do Direito e do Poder. As escalas elas próprias seriam o ponto de partida e de chegada das resoluções nomogenéticas, ou seja, enquanto manifestações de modos humanos de habitar o mundo na Europa.

Do mesmo modo, a preservação da consciência do fundamento imanentemente humano do Direito e do Poder implicaria no impedimento a qualquer das dimensões existência visar à própria "transcendentalização". Estando o lugar do Poder ao alcance de todos, no meio, impedir-se-ia a pretensão de uma escala nele se arvorar isoladamente como a medida de existência verticalmente destacada e destinada a reger o todo em nome de um interesse comum gestado "à sua maneira", isto é, conforme apenas e tão-somente a sua particular régua de mensuração de como habitar o mundo (freio ao rompimento da horizontalidade).

Em outras palavras, nenhuma das estatalidades ou das supranacionalidades, nem mesmo a populidade, poderia pretender justificar, a partir de uma suposta maior importância a priori presumida de sua própria medida, a adoção intemporal de um sentido normativo unidimensional na Comunidade. Inadmissível se poder concluir com a tradição, por exemplo, que a Alta Autoridade da CECA era o centro motor da Comunidade ${ }^{474}$. Afinal, naquela vida em comum, o processo nomogenético não era de exclusividade desta escala de existência, como não era das demais. Esta é a virtude de o centro nomogenético

${ }^{474}$ V. nota de rodapé 202, supra. 
estar localizado es to meson, isto é, entre todos os implicados na vida comum, e apenas ao alcance próximo e sempre impossível destes - pois nenhum deles, nem ninguém deles, poderia buscar determinar unilateralemente o sentido normativo a partir de perspectiva unidimensional própria ou estranha/não afeita à vida comum.

As conclusões acima em torno da dinâmica dos "jogos" estabelecidos entre as diferentes dimensões existenciais partícipes da vida comunitária restarão mais claras quando da leitura dos próximos Capítulos desta Tese, os quais estão especificamente direcionados a compreender conceitualmente os elementos da experiência referente (i) à construção histórica da CECA; e (ii) ao engenho institucional das articulações jurídiconormativas positivas do Tratado Constitutivo da CECA. É o que se passa a analisar na Parte Segunda desta Tese de Doutorado. 


\title{
CONCLUSÕES PARCIAIS
}

\begin{abstract}
Ver isso com clareza exige, sem dúvida, não pequeno esforço dos hábitos dominantes de pensar. Colocar fora de circuito todos os atuais hábitos de pensar, reconhecer e pôr abaixo as barreiras espirituais com que eles restringem o horizonte de nosso pensar, e então apreender, em plena liberdade de pensamento, os autênticos problemas filosóficos, que deverão ser postos de maneira inteiramente nova e que somente se nos tornarão acessíveis num horizonte totalmente desobstruído - são exigências duras. Nada menos que isso, no entanto, é exigido. (HUSSERL, 2006, p. 27).
\end{abstract}

Que tenha sido bem vivido e bem visto. Que possa ser útil para quem se detenha a ler o resultado. Que possa ser estabelecido o diálogo, e mesmo sem haver a concordância em relação a todos os pontos, que se tenha a apresentação válida da tese, na qual foram empenhados anos de esforço direto e se inscreve em perspectiva de trabalho e de dedicação ao direito. (CASELLA, 2009a, p. 161).

O objetivo desta Parte Primeira consistiu em efetuar as precisões necessárias para viabilizar a adequada localização desta investigação no que se refere a aspectos temporais, espaciais, temáticos e metodológicos. O discurso desta primeira parte visou a sua própria transparência, um cuidado que não deve ser encarado como desnecessária retórica ou supérflua intervenção reflexiva.

Esta Parte Primeira detém uma função claramente preventiva - afinal, em todo trabalho intelectual crítico da tradição, "o perigo não está em ser contrariado, mas em não ser compreendido." (KANT, 2012, p. 43). Por isso, houve uma detalhada cautela em buscar recolocar em seus lugares as significações dos termos empregados por este trabalho, a fim de impedir confusões quando do emprego de termos específicos e quando da referência às premissas iniciais do trabalho nos Capítulos que se seguem.

\footnotetext{
Se quanto a isso eu consegui realizar aquilo a que me propus é algo que cabe somente ao leitor julgar, pois ao autor incumbe apenas assentar os fundamentos, e não julgar os efeitos perante os seus juízes. De modo a evitar, porém, que algo se torne aqui, de maneira inadvertida, a origem de uma fraqueza teórica, tem de ser permitido ao autor indicar por si mesmo aqueles pontos, mesmo atinentes a fins secundários, que poderiam dar ensejo a alguma desconfiança, prevenindo a tempo, assim, a influência que uma dúvida, mínima que fosse, poderia ter sobre o juízo do leitor relativamente ao fim principal. (KANT, 2012, p. 21).
}

A extensão da primeira parcela deste estudo se justifica diante do edifício reflexivo que se pretende construir. Diante da monumental ostentação do totem da leitura jurídicoeconômica da tradição, mostrou-se fundamental a este trabalho tornar seguras suas próprias fundações para conceder estabilidade para as reflexões dos próximos Capítulos e dos trabalhos que se seguirão à presente Tese, como desdobramentos da mesma. 
De grande relevância se mostrou lapidar o material a ser utilizado como a estrutura fundacional da leitura jurídico-política deste texto. Os vetores interpretativos deste estudo se pretendem ao menos suficientemente esclarecidos perante o público leitor: ainda que não se esteja de total acordo com eles, ao menos que restem elucidados seus pontos principais.

Todo sistema filosófico é vulnerável em pontos isolados (pois não pode ser tão blindado quanto o matemático), sem que a estrutura do sistema, no entanto, considerada como uma unidade, corra com isso qualquer perigo - para o qual concorreriam, sendo novo o sistema, o fato de poucos possuírem habilidade espiritual para uma visão de conjunto do mesmo, e de possuírem menos ainda algum prazer nisso, posto verem toda novidade como um inconveniente. (KANT, 2003, p. 43).

Não se quer designar com isso que se almeja descobrir terras desconhecidas; mais humildemente, pretende-se envolver em névoas o solo que o pensamento da tradição jurídica acreditava ter como sólido e bem conhecido sobre a CECA. Por mais estranhas que possam parecer as conclusões brevemente enunciadas nos itens anteriores ${ }^{475}$, tratou-se da tarefa fundamental deste trabalho apresentar as razões pelas quais se pôde a elas chegar - pois nada mais se pretende do que colocar em questão o modo que segundo o qual se compreendia a CECA no pensamento jurídico tradicional.

Diante da pretensão de extrair do interior da história da construção da CECA e do arcabouço normativo constante de seu Tratado Constitutivo uma forma alternativa de os interpretar, se mostrou mais do que necessário ao autor desta obra que

tom[asse] seu leitor firmemente pela mão e v[isse] que altura [...] ele pode[ria] atingir junto com ele, passo a passo, na trilha da montanha. [... Se eles devem chegar juntos, eles devem antes de tudo partir juntos diante de todas as coisas; do contrário], já de início o leitor fi[caria] sem saber se está ao lado do seu autor ou a milhas de distância dele. (SCHOPENHAUER, 2010, p. 33).

Por esse motivo, foi necessário esclarecer os termos precisos do tema a ser investigado: quando, como e por meio de quais instituições, países europeus tradicionalmente opostos em termos bélicos conseguiram estabelecer entre si um novo modo de relações, o qual tornou impossível e impensável a deflagração de uma nova Guerra regional na Europa. Bélgica, França, Itália, Luxemburgo, Países Baixos e República Federal da Alemanha celebraram entre si o Tratado de Paris, de 1951, o qual instituiu a Comunidade Europeia do Carvão e do Aço (CECA).

${ }^{475}$ Especialmente, itens 3.3.3.3. e 3.4.4., supra. 
Este trabalho dedica sua atenção para compreender a História Contemporânea da Europa nos anos entre 1945 e 1951 - ano em que aquela Organização Internacional foi instituída por aqueles seis países. Se, em um primeiro momento, poder-se-ia pensar que esta Comunidade regulara juridicamente as relações econômicas desenvolvidas entre os seis países dentro do setor econômico do mercado do carvão e do aço, ao mesmo tempo se poderia pensar que a estrutura institucional do Tratado operara como um mecanismo voltado à direitificação de um sistema de convivência entre diferentes.

Nesse sentido, por trás do Direito Positivo do Tratado da CECA, seria possível identificar, além de uma regulação jurídico-econômica usualmente percebida pela tradição, ao menos uma regulação jurídico-Política. Na esteira da tendência do pós-Segunda Guerra Mundial - Direito Internacional considerado também como instrumento técnico promotor da cooperação entre Estados, a CECA pode ser visto como uma especialização deste movimento reestruturante do Direito Internacional, ordenando a convivência entre diferentes escalas de existência no sentido de as integrar politicamente por meio de instituições arquitetadas pelo Direito Positivo.

Em outras palavras, a imaginação institucional fundadora da impulsão à integração europeia fora estrategicamente pensada para tornar as decisões da Comunidade independentes da vontade de seus Estados-Membros - o que neutralizou a possibilidade de repetir um conflito armado entre eles. O "como" foi permitido o novo modo de relações é melhor compreendido quando se percebe que a CECA detivera a aptidão de instituir uma União política entre seus membros (Leis formais). As instituições, por outro lado, qualificaram esta União política por meio de uma organização jurídico-Política de convivência plural permanente.

Por meio de suas disposições jurídico-normativas positivas, a CECA viabilizara um complexo e engenhoso mecanismo institucional de convivência entre diferentes, afastando exemplarmente a possibilidade de repetição de Guerras regionais na Europa. Não apenas as perspectivas estatais estariam em choque entre si, mas estas também deveriam considerar uma perspectiva supranacional e uma aderência às dimensões existenciais dos distintos povos europeus que foram inseridos nesta vida em comum.

Todo o aparato institucional fora construído a partir de um sistema de freios e de contrapesos voltado à simultânea contenção das diferentes escalas de existência (estatalidade isolada, estatalidade intergovernamental, supranacionalidade da Alta Autoridade, supranacionalidade da Corte e populidade). Ao opor cada uma das escalas de existência, foram todas convidadas a participar ativamente da vida em comum, ao mesmo 
tempo que foram multilateralmente repelidas do centro nomogenético: a nenhuma delas - e a ninguém diferente delas - caberia a palavra final sobre o sentido normativo destinado a reger a vida comunitária, pois o produto da nomogênese seria certamente pluridimensional (lugar vazio de Poder, permanência da tensão política, multiescalaridade e imanência).

Sob uma perspectiva interdisciplinar típica de investigações de Zetética Jurídica, nos próximos Capítulos, além de pretender esclarecer os percalços históricos da construção da CECA, este trabalho também esmiuçará e qualificará o "jogo" escalar trazido pela engenharia institucional do Tratado da CECA. Será possível notar que este era marcado por uma dinâmica institucional de série de previsões jurídico-normativas positivas que impunham resistências e impedimentos mútuos entre as escalas de existência, as quais viabilizavam a paralisia de toda e qualquer pretensão de exclusividade por parte de qualquer delas na formação do Direito Comunitário Derivado.

O Tratado da CECA estabelecera consciente arranjo institucional voltado a obrigar cada uma das escalas de existência a participar continuamente e de forma ativa do processo de formação das principais decisões sobre as normas destinadas a reger questões da vida comum.

No final, será possível demonstrar que a CECA é igualmente passível de uma leitura jurídico-política: as disposições de seu Tratado teriam organizado um sistema de convivência caracterizado por disposições de regulação jurídico-política Política, pois teria promovido um sistema institucional de contraposição contínua entre diferentes para decidir sobre o Direito e sobre o Poder na Comunidade. Captar esse virtuoso raciocínio Político subjacente à técnica jurídica de construção do arranjo institucional é o foco da Parte Segunda deste trabalho, orientando-se centralmente para compreender o problema do modo como se trabalhou historicamente para construir normativamente a vida comum instaurada pelo Tratado da CECA. 
PARTE II: A HISTÓRIA E O TRATADO DA CECA: OS ANTECEDENTES E A AFIRMAÇÃO DE UMA ORGANIZAÇÃO JURÍDICO-POLÍTICA DA EUROPA 


\section{INTRODUÇÃO PARCIAL}

[C]eux qui écrivent l'histoire, aussi bien que ceux qui la lisent, doivent appliquer leur attention moins au récit des faits eux-mêmes qu'à ce qui précède, à ce qui accompagne et à ce qui suit les événements proprement dits. (POLYBE, 2003, p. 275).

Deus, forasteiros, ou algum homem é que passa entre vós outros como sendo o instituidor de vossas leis? (PLATÃO, 1980, p. 19).

A compreensão da CECA como exemplo histórico fundamental de inauguração de modo jurídico-Político de relações entre seus seis países-membros exige que não se considere apenas o corpo jurídico-normativo constituinte daquela Organização Internacional. Por si só, o estudo do Tratado de Paris de 1951 não se mostra suficiente para apreender a racionalidade Política subjacente aos mecanismos práticos segundo os quais alguns dos povos europeus se uniram Politicamente para afastar de maneira inédita na História do continente europeu o recometimento de novas Guerras regionais.

Por esse motivo, sem a inserção da CECA na cadeia histórica de eventos da qual faz parte, dificilmente se poderá perceber este fenômeno jurídico-político como manifestação de uma recusa a assumir institucionalmente um modo de organização jurídico-Teológico-Político entre países europeus recém-saídos da Segunda Guerra Mundial. É fundamental que se preste adequada atenção ao conjunto de movimentos históricos que se manifestaram anterior e paralelamente à constituição CECA, pois apenas deste modo será possível compreender a vida comunitária desta como efetiva afirmação de Leis Políticas e como consciente repúdio constante ao ingresso de orientações TeológicoPolíticas na nova dinâmica a ser encetada entre países europeus.

Em outras palavras não apenas as instituições da CECA foram a solução jurídiconormativa positiva prática adotada para instaurar a Política entre seis países europeus. A adoção delas também representou a recusa de Projetos não-Políticos (OECE, Pacto de Bruxelas e $\mathrm{CdE})^{476}$ - ou seja, potencialmente Teológico-Políticos ${ }^{477}$ - de estruturar

\footnotetext{
${ }^{476}$ Para evitar incompreensões, adiante-se desde já que OECE, Pacto de Bruxelas e CdE foram Projetos de Europa Unida que foram aceitos institucionalmente como estratégia consciente de recusar Leis TeológicoPolíticas que rondavam a Europa neste período: OECE e Pacto de Bruxelas foram institucionalizados como forma de proteger a Europa da influência unidimensional estadunidenese, ao passo que o CdE foi institucionalizado de maneira a barrar a irradiação da "Boa Nova" Federalista Europeia. Esses dois aspectos serão mais bem compreendidos quando da leitura dos Capítulos Quarto e Quinto, infra.

Frise-se: não se deve deixar de notar, desde já, que a institucionalização dessas três Organizações Internacionais derivou do intento de as aceitar apenas se institucionalmente limitadas, isto é, se suas disposições institucionais não permitissem a cada um dos três a introdução de Leis Teológico-Políticas (fossem elas estadunidenses, fossem elas propriamente europeístas) na Europa. Apenas a institucionalização
} 
juridicamente as relações na Europa, os quais concorreram simultaneamente com o Projeto de Europa Unida da CECA.

Antes da complexa, extensa e detalhada análise institucional do Tratado da CECA a ser desenvolvida no Sétimo Capítulo, nesta Parte Segunda da Tese de Doutorado se preocupa nos Capítulos Quarto, Quinto e Sexto com o enriquecimento do debate com informações históricas fundamentais do período do pós-Segunda Guerra Mundial. Apenas deste modo se poderá compreender a História da construção da CECA como uma em que se buscou afirmar de diferentes maneiras um modo de organização jurídico-Político de relações na Europa, em detrimento de outros.

Deste modo, os próximos três Capítulos deste trabalho investigarão os anos que se estendem do final da Segunda Guerra Mundial (1945) até a celebração do Tratado de Paris (1951). Durante este período, não apenas serão mencionados os eventos relacionados à construção da CECA, mas também aqueles relacionados à instituição do da OECE, do Pacto de Bruxelas e do CdE.

A avaliação conjunta dessas quatro experiências históricas permitirá evidenciar de maneira mais precisa como a CECA se destacara como a única dentre as propostas que se orientou para instituir Leis de convivência plural permanente (organização jurídicoPolítica), tal qual enunciado anteriormente ${ }^{478}$. Aquelas três outras experiências serão aqui relembradas de maneira limitada, na exata medida em que permitirem compreender como sua adoção consistiu em uma forma de manter à distância (i) Leis não propriamente europeias na Europa (OECE e Pacto de Bruxelas); e (ii) uma organização jurídicoTeológico-Política (Leis de unificação da pluralidade) de origem europeísta Federal nas relações entre povos europeus $(\mathrm{CdE})^{479}$.

da CECA representou consciente opção por uma organização jurídico-política das relações entre países Europeus segundo Leis Políticas. As demais (OECE, Pacto de Bruxelas e CdE) foram simples barreiras institucionais à realização de promessas de Teológico-Politização das futuras relações na Europa. Alerte-se desde agora o leitor, a fim de que sejam dissipadas antecipadamente eventuais dúvidas de interpretação em torno da presente Tese.

${ }_{477}$ Conforme nomenclatura e distinções feitas de maneira mais precisa no item 3.4., supra.

${ }^{478}$ Nesse sentido, v. itens 1.3. a 1.5., supra.

${ }^{479} \mathrm{O}$ leitor poderá pensar que, aqui, o presente estudo teria incorrido em contradição. Todavia, alerta-se que esta situação é apenas aparente. Mais adiante, após a leitura dos Capítulos Quarto e Quinto desta Tese, esta diferenciação entre a criação da OECE e do Pacto de Bruxelas em relação à criação do CdE restará mais bem esclarecida, afastando parcela das dúvidas de interpretação.

Todavia, a fim de facilitar a continuidade da leitura deste texto, busca-se aparar ao menos algumas arestas dessa reflexão. Deve-se compreender desde já que o que diferencia a OECE e o Pacto de Bruxelas (Direito com ausência de Leis), de um lado, e o CdE (Direito com presença de Leis Teológico-Políticas), de outro, é precisamente o modo de desenho dos mecanismos práticos (isto é, institucionais) voltados a realizar seus Projetos de Europa Unida.

Como se poderá verificar mais adiante, enquanto a OECE e o Pacto de Bruxelas foram gestados a partir da oposição escalar EUA versus URSS, o CdE foi concebido a partir da oposição escalar 
Em seguida, no Sétimo Capítulo deste trabalho, será examinado o conjunto de dispositivos constantes do Tratado da CECA. Esta análise terá por objetivo evidenciar os meios segundo os quais os fundadores desta Organização Internacional afirmaram institucionalmente, não apenas as vias de instauração e de promoção de uma vida comum entre seis países europeus, mas também mecanismos práticos destinados a preservar a bem-sucedida organização jurídico-Política das relações.

Os instrumentos jurídico-normativos do Tratado de Paris afastaram a possibilidade de recometimento de Guerras regionais e também paralisaram pretensões de deslizes em direção ao Teológico-Político. Essa imunização da Europa contra a unificação transcendente fora assegurada (i) pelas interações escalares entre as dimensões participantes da vida comunitária da CECA e (ii) pela rejeição da possibilidade de sujeição das decisões da Comunidade a perspectivas de entidade a ela externa - em outras palavras, pela independência mantida pela CECA com relação aos demais Projetos de Europa Unida do período, sobretudo com relação ao $\mathrm{CdE}$.

tradicionalmente encetada no interior da Europa (estatalidades isoladas). Se no primeiro caso houve apenas a instituição de um aparato jurídico comum (Direito sem Leis) para encetar uma cooperação intergovernamental econômica (OECE) e militar (Pacto de Bruxelas), no último caso, o aparato jurídico comum construído carregava em si o germe de uma organização jurídico-Teológico-Política da Europa (Direito + Leis), apesar de ter sido esta iniciativa reduzida a uma simples cooperação política também de caráter intergovernamental (ou seja, institucionalmente se tratava de Direito + "Leis interrompidas").

Note-se que os três Projetos de Europa Unida visaram à instituição de distintas Leis TeológicoPolíticas na organização jurídico-política das relações entre os países europeus. A diferença entre eles se reside no fato de que a realização institucional dos Projetos de Europa econômica e militarmente Unida (respectivamente, OECE e Pacto de Bruxelas) não permitia a estes nem mesmo a pretensão de introduzir na Europa Leis forjadas a partir do molde escalar dado pela dimensão existencial estadunidense frustrando assim a pretensão dos EUA de formar uma Europa Unida à imagem e semelhança de sua própria experiência, ao passo que a realização institucional do Projeto de Europa politicamente Unida em torno do ideário Teológico-Político Federalista Europeu (CdE) manteve em suas disposições estatutárias a missão de instaurar uma Europa Federal, mesmo sem ter conseguido assegurar institucionalmente vias práticas efetivas que possibilitassem a introdução de um Estado Federal Europeu.

Deste modo, perceba-se que nos dois casos foram frustradas (diferentes) pretensões de introdução de Leis Teológico-Políticas (no caso da OECE e do Pacto de Bruxelas, as Leis dos EUA; no caso do CdE, as Leis dos Movimentos Europeístas Federalistas) por meio da redução de cada uma das iniciativas a uma esfera de atuação de cooperação intergovernamental (respectivamente, econômica, militar e política). A diferença entre eles - que justifica, inclusive, a separação da análise em Capítulos distintos (Capítulo Quarto: OECE e Pacto de Bruxelas; Capítulo Quinto: apenas o CdE) - surge na avaliação do modo institucional que foram realizados.

Com efeito, de um lado, a OECE e o Pacto de Bruxelas apenas disponibilizavam cada um deles a seus Estados-Membros um aparato jurídico comum, sem nem mesmo dispor de um mínimo reconhecimento institucional de uma possível missão de organização jurídico-política da Europa segundo a dimensão existencial externa estadunidense (Direito sem Leis). Por outro lado, o CdE disponibilizava a seus EstadosMembros um aparato jurídico comum que, inclusive, atribuía a tal Organização Internacional uma missão institucional de promover uma Europa Unida segundo o discurso Federalista Europeu, sem que esta pudesse dispor, todavia, de mecanismos práticos que lhe permitissem a efetiva realização de seu Projeto TeológicoPolítico (Direito + Leis institucionalmente impedidas).

Espera-se que assim se tenha dissipado a aparente contradição entre o discurso afirmado nos itens 1.3. a 1.5., supra, e a afirmação agora há pouco feita. Remetemos para maiores esclarecimentos à leitura da integralidade dos Capítulos Quarto e Quinto, infra. 
Deste modo, se poderá compreender a fundação jurídica da CECA pelo Direito Internacional Público duplamente como um exemplo inaudito de afirmação histórica e institucional daquele novo modo de relações na Europa do pós-Segunda Guerra Mundial: o modo jurídico-Político. 


\title{
QUARTO CAPÍTULO - DO FINAL DA SEGUNDA GUERRA MUNDIAL AO CONGRESSO DE HAIA DE 1948
}

\begin{abstract}
La pensée peut bien se délivrer de certaines images, mais ce qui résiste c'est le rapport que nous entretenons avec la représentation du passé, c'est la fonction mythique que nous lui faisons jouer pour nous assurer d'une vérité déjà donnée et qui ne trahirait pas, pour conjurer, enfin, l'indétermination qui renaît sans cesse de l'histoire que nous vivons. (LEFORT, 1979, p. 358).
\end{abstract}

Pode ser positivo indagar o tempo, se esta indagação não se tornar fim em si mesma, mas se for com este adiante, em relação a determinado ramo do conhecimento. Por isso pode e aqui proponho mostrar que deve ser usada a perspectiva temporal, como base para a compreensão da construção do direito internacional, enquanto sistema institucional e normativo [...]. (CASELLA, 2012, p. xii).

O relato histórico dos Projetos de Europa Unida desenvolvidos no período entre 1945 e 1951 visa a fornecer conclusões que possibilitarão compreender a reflexão desenvolvida neste trabalho sobre o processo de união de países europeus no pós-Segunda Guerra Mundial encetado por meio da CECA. A construção desta Organização Internacional pode ser vista como afirmação de um novo modo de relações na Europa, o qual foi gestado conforme "uma costura contínua, coerente e orientada dos eventos, que estabele[ceram] sua unidade, correlação e sentido[, m]uito diferente da justaposição de histórias parciais.” (SEBASTIANI, 2012, p. 63).

Volta-se neste Capítulo e nos próximos dois a compreender o processo de construção histórica da CECA - vis-à-vis outras experiências do período de União da Europa - no interior de um movimento intelectual imbuído de objetivo inerente a todo estudo histórico. Há a consciência de ser possível traçar uma trama entre os eventos históricos anteriores e simultâneos à construção da CECA, a qual permite encontrar um sentido no passado que não apenas permite que ele seja intrepretado de forma coerente, mas que também permite ao presente se livrar de uma indeterminação significativa: “[1]'esprit de 1'historien ne doit pas être mû par une curiosité dramatique, mais par une volonté de pure comprehénsion intellectuelle qui cherche dans les faits une structure logique" (PÉDECH, 1964, p. 34).

Compreender o passado é sempre o compreender em situação presente. É tentar extrair do estudo do passado uma racionalidade específica que, ao mesmo tempo, assegura a interpretação coerente e consistente daquilo que outrora ocorreu e também permite compreender também o presente, de maneira a fundamentar uma ação no agora. 
O estudo do passado não se apresenta aqui como fonte de deleite. Muito pelo contrário. Ciente de que o passado é produto de experiência vivida, seu conhecimento mais detalhado deve dialogar em trabalhos posteriores com problemáticas atuais. Apenas deste modo será possível produzir respostas capazes de mudar percepções e revalorizar aspectos até então ignorados (CASELLA, 2012, p. 25; KHOURY, 2012, p. 89; LEFORT, 1992a p. 142; PÉDECH, 1964, p. 34; POLYBE, 2003, p. 228 e 548; SEBASTIANI, 2006a, p. 75, 2007a, p. 71-5).

Nesse sentido, o estudo da História feito neste trabalho não é nem um passatempo, nem uma exposição supérflua ou irrefletida. Trata-se de uma escolha deliberada pelo aprendizado virtuoso diante de exemplos passados para viabilizar "a educação de homens que ocup[em] importantes postos políticos" (SEBASTIANI, 2007a, p. 68). O objetivo desta exposição histórica consiste em tornar útil o conhecimento do processo de construção da CECA pelo fornecimento da "éducation politique la plus efficace et [du] meilleur entraînement à l'action" (POLYBE, 2003, p. 65) mediante a aquisição da "intelligence, tant sur la connaissance des faits présents que des faits passés." (LEFORT, 1992a, p. 142) para que hoje se possa pensar diferentemente a temática da integração europeia.

Deste modo, não se trata de uma singela exposição de fatos. A discussão histórica nos itens a seguir não é um fim em si mesmo, mas um meio: a depreensão circunscrita de raciocínios interpretativos que explicam o encadeamento dos eventos analisados é feita com finalidade didática. Esta consiste em evidenciar ensinamentos do passado e extraí-los para aprimorar as opções jurídico-Políticas do presente, visando ao futuro (CASELLA, 2012, p. 25 e 39; KHOURY, 2012, p. 89; LEFORT, 1992a, p. 141-2; PÉDECH, 1964, p. 50; POLYBE, 2003, p. 664; SEBASTIANI, 2006a, p. 65 e 74, 2010, p. 74).

Não interessa ao presente trabalho um conhecimento histórico voltado a reconstruir literariamente uma realidade - "que passou" - por meio de livre exercício narrativo. Tratase antes de um exercício intelectual voltado a apresentar uma narrativa sobre o passado, sempre tendo em vista um diálogo mais ou menos explícito com a sociedade presente ${ }^{480}$ (CASELLA, 2012, p. xiii). Todavia, este diálogo não quer transformar o presente em passado: eleger o passado não implica em querer retornar a ele, mas em redescobrir aquilo

\footnotetext{
${ }^{480}$ Essa é, inclusive, a postura típica de todos aqueles que utilizam ou utilizaram POLÍBIO como paradigma histórico inspirador para a construção de suas narrativas, conforme indica Breno Battistin SEBASTIANI (2006a, p. 64). Com efeito, “[l]'originalité de Polybe tient à ce qu'il se représente l'histoire, non comme un récit à composer, mais comme un problème à résoudre et se décomposant en séries de questions particulières." (PÉDECH, 1964, p. 33). Nada mais coerente, portanto, assumir essa perspectiva em nosso trabalho.
} 
que foi anterior, a fim de que sua lógica virtuosa - e não seus atos concretos - seja imitada no agora (LEFORT, 1992a, p. 141).

\begin{abstract}
[M]ergulh[ou-se] o mundo [...] na ignorância do espírito genuíno da história. Ignorância que nos impede de aprender o seu sentido real, e de nutrir nosso espírito com a sua substância. O resultado é que os que se dedicam a ler a história ficam limitados à satisfação de ver desfilar os acontecimentos sob os olhos sem procurar imitá-los, julgando tal imitação mais do que difícil, impossível. (MAQUIAVEL, 2008, p. 18).
\end{abstract}

[L]a connaissance du passé est bien faite pour mettre notre esprit en éveil en ce qui concerne l'avenir, à condition que, sur chacun des faits qui ont marqué ces temps révolus, on se livre à une étudie sérieuse. (POLYBE, 2003, p. 824).

Volta-se ao passado para pensar o presente. Não se trata, aqui, de querer imitar no presente as ações concretas tomadas pelos predecessores, mas sim de encontrar a racionalidade Política que exemplarmente o passado legou ao presente e imitá-la na confecção de disposições institucionais atuais de convivência entre diferentes (CASELLA, 2012, p. xii-xiv; HARTOG, 2003, p. 17; LEFORT, 1992a, p. 141-2). Quer-se extrair do relato histórico da CECA o sumo que ele contém, a fim de que este seja a base para a construção de mais amplo conhecimento sobre o necessário encaminhamento jurídico e Político que o tempo atual exige para as relações internacionais na Europa e fora dela, bem como para a direitificação ${ }^{481}$ delas.

Não se busca neste texto o passado aleatoriamente. Tampouco isso é feito para cumprir um mero "rito de passagem" formal de uma Tese de Doutorado em Direito - que tem por objeto eventos passados - por meio do derramamento leviano de bloco de informações que forneça uma mais ou menos articulada "visão histórica" daquela Organização Internacional. O debruçar-se sobre História da CECA neste texto não cessa em um estágio "descritivo" das cenas do "que ocorreu" a serem admiradas desatentamente.

Rejeita-se assim a "impuissance à chercher dans le spectacle du passé autre chose que du plaisir" (LEFORT, 1992a, p. 150). Recusa-se a simples narrativa de galeria de fatos curiosos ou de eventos anedóticos. Assume-se aqui a missão intelectual de apresentar a CECA como opção histórica deliberada pelo estabelecimento de um inaudito modo de relações na Europa (jurídico-Político), escolha esta que implicou a rejeição do uso tradicional das disposições do Direito Internacional (coexistência), bem como a recusa

${ }^{481}$ Sobre direitificação, v. item 2.1., supra. 
pela abrupta opção do Teológico-Político - dos EUA (OECE e Pacto de Bruxelas) ou do Federalismo Europeu (CdE).

O relato da experiência de afirmação histórica da CECA detém a dupla função de (i) facilitar a compreensão do hoje e, principalmente, (ii) desenvolver movimento reflexivo voltado a encontrar a linguagem necessária para formular uma avaliação crítica sobre o tempo presente (CASELLA, 2012, p. 10-1). Apenas deste modo será possível fundamentar novas opções jurídico-Políticas para a Europa Unida de hoje $\mathrm{e}^{482}$. E, por isso, exige-se a operação do intelecto sobre o conjunto dos acontecimentos passados, demanda-se o desprendimento de um certo esforço para os compreender conceitualmente (CASELLA, 2012, p. 42; PÉDECH, 1964, p. 34).

Pretende-se assim ampliar o campo de questões que esclareçam mais ainda os primeiros passos da integração europeia ${ }^{483}$. Tais questões poderão fornecer uma nova medida comparativa histórica, a qual concederá bases para avaliar criticamente em trabalhos futuros ${ }^{484}$ as condições segundo as quais a integração europeia se apresenta hoje $^{485}$ (CASELLA, 2012, p. xii-xiii).

${ }^{482}$ Isto é, não se quer levianamente "repetir hoje a experiência histórica da CECA", mas identificar em sua História o surgimento e a operação da racionalidade Política que informou a fundação jurídiconormativa de seu aparato institucional exemplar. Trata-se de tomar consciência sobre o passado para agir sobre o presente, modificando este à luz dos ensinamentos da tradição (LEFORT, 1992b, p. 195); apenas a partir dessa consciência sobre o móvel Político da História da CECA e de suas instituições é que se poderá propor, em trabalhos futuros, soluções institucionais jurídico-Políticas para a Europa Unida de hoje.

No mesmo sentido, argumenta Alfonso MATTERA $(2002$, p. 7) sobre a importância de se estudar a História da UE atual a partir da adequada compreensão do processo de construção da CECA: "il ne faut pas « réinventer l'Europe », mais il faut puiser dans son histoire. Aussi remémorerons-nous ci-après la page la plus exaltante, celle qui fournit une réponse aux questions les plus débattues. C'est dans la «mémoire du passé » que l'on retrouvera l'inspiration, la puissance de vision et le courage nécessaire."

Como afirmado acima em diferentes passagens, a formulação de propostas para problemas atuais da UE não é objeto do presente trabalho, mas sim de pesquisas a serem desenvolvidas posteriorermente. Apenas se ressalta a importância prospectiva deste texto, pois poderá fornecer o aparato conceitual apto a sugerir que a atual crise da Europa não se trata de uma crise Econômica, mas, talvez, de uma crise jurídicoPolítica.

A requalificação significativa da crise (de Econômica para jurídico-Política) é necessariamente sugerida como consequência deste estudo, e será examinada em trabalhos posteriores. Neste texto, preocupar-se-á em estabelecer as bases para essa futura requalificação e, deste modo, para inaugurar nova Agenda de Pesquisas em Direito no Brasil sobre a fenômeno jurídico-político da integração europeia.

Os leitores atuais da CECA - distanciados no tempo da experiência de sua construção histórica devem ser capazes de ouvir bem o ensinamento da História e, de posse dele, de se instalarem com ele nos horizontes de seu próprio tempo. Este trabalho pretende facilitar hoje, a partir das premissas assumidas nos primeiros Capítulos, esta oitiva do ontem.

${ }^{483}$ Formalizados por meio da instituição da CECA.

484 "Como em qualquer outra obra didática, o texto escrito somente constitui parte do trabalho. É preciso integrá-lo ao conjunto da responsabilidade e da continuidade do trabalho, na construção e desenvolvimento do direito internacional." (CASELLA, 2012, p. xii).

${ }^{485}$ Isto é, "onde teria ocorrido um suposto 'desvio de rota'.". 
La distinction de ce qui fait, en un temps, le présent et le passé, de ce qui appartient aux horizons proches et se perd dans les lointains est [...] plus subtile que nous ne sommes tentés de le croire à considérer seulement les ruptures entre générations ou à relever quelques signes massifs de changement [...]. Le passé n'est vraiment tel que lorsqu'il cesse de hanter les esprits et que nous sommes devenus libres de le redécouvrir en curieux. Mais en tant que les images et les mots continuent de peupler nos pensées et d'exciter la passion, à distance des hommes et des événements que nous n'avons pas connus, ils participent pleinement du présent - soit qu'ils servent à détruire, soit que nous ayons besoin d'eux pour conserver le cadre de vie. (LEFORT, 1979, p. 356).

Por isso, objetiva-se aqui compreender conceitualmente o passado ${ }^{486}$ para, a partir deste trabalho, tratar do tempo atual em pesquisas posteriores, de modo a lançar critérios investigativos alternativos para uma nova Agenda de Pesquisas em Direito Internacional Público ${ }^{487}$; trata-se de "non pas survoler les temps et les espaces, mais les traverser, pour mieux saisir la configuration de [m]on propre espace-temps" (LEFORT, 1992c, p. 13).

O estudo histórico a seguir tem assim a virtude de querer extrair da narrativa da História da Europa, de 1945 a 1951, um ensinamento apto a fundamentar Pesquisas futuras sobre o percurso seguido pela atual integração europeia a partir da adequada inserção histórica da CECA. Este ensinamento consiste precisamente no estabelecimento de uma nova maneira de se compreender o princípio do processo de integração da Europa Unida: a CECA teria sido a manifestação institucional de tendência histórica do pós-Segunda Guerra Mundial voltada a submeter alguns dos diferentes povos europeus a Leis Políticas.

Há assim uma questão histórica a ser resolvidano relato a seguir ${ }^{488}$ (PÉDECH, 1964, p. 45): a instituição da CECA pode ser entendida como afirmação histórica da opção por uma organização jurídico-Política das relações entre alguns dos povos europeus no pósSegunda Guerra Mundial. Esta opção pela CECA engendrara entre 1945 e 1951 a paulatina recusa de outras formas propostas de relações (Teológico-Políticas) no continente europeu mediante a instituição de singelos mecanismos jurídicos de cooperação intergovernamental (i) desprovidos de Leis (Pacto de Bruxelas e OECE), ou (ii) formados a partir de pretensão de Leis unificadoras, mas que institucionalmente foram impedidos de as realizar (CdE).

\footnotetext{
${ }^{486}$ A partir da chave de leitura estabelecida na Parte Primeira deste estudo.

487 "Com relação a isto, deixo a estes homens esforçados, que são tão felizes em ligar ao rigor do discernimento também o talento para uma exposição iluminada (que eu mesmo não percebo em mim), a tarefa de completar os meus trabalhos, ainda lacunares em muitos aspectos”. (KANT, 2012, p. 43).

${ }^{488} \mathrm{Ou}$, o que é o mesmo: há a preocupação em demonstrar na narrativa a seguir a possibilidade de se extrair um ensinamento sobre o passado dos Projetos recentes de Europa politicamente Unida. Este ensinamento poderá lastrear futuras investigações sobre as etapas posteriores à CECA na integração europeia do pósSegunda Guerra Mundial.
} 
Dessa maneira, além de ter sido um exemplo inaudito de afirmação institucional daquele novo modo de relações na Europa do pós-Segunda Guerra Mundial ${ }^{489}$, a CECA poderá igualmente ser compreendida como manifestação histórica da preferência por um sistema de convivência entre diferentes - o qual não apenas deveria ser instituído, e promovido, mas também vigorosamente preservado por suas normas jurídicas positivas de oposições escalares $^{490}$.

Por esse motivo, os itens a seguir apresentarão as informações ${ }^{491}$ que permitam compreender a construção histórica da CECA também como uma forma de afirmação espacial e temporalmente localizada de um modo jurídico-Político de relações entre alguns povos europeus. Colhem-se princípios explicativos entre fontes primárias e secundárias, adotando-se uns e rejeitando-se outros diante da questão a ser resolvida, sem se limitar a simplesmente "contar o que ocorreu” (PÉDECH, 1964, p. 355): há aqui uma interpretação da CECA a ser conceitualmente testada a partir de elementos de experiência histórica.

Este trabalho não descerá a minúcias na narrativa histórica do período localizado entre 1945 e 1951. Ele apenas organizará significativamente - à luz da chave hermenêutica proposta na Parte Primeira deste estudo - o conjunto de informações ao qual se teve acesso, a fim de indicar a possibilidade de uma leitura que aponte a CECA como a afirmação histórica daquele novo modo de relações. Em outras palavras, este estudo apontará na narrativa daqueles anos apenas e tão-somente os fatos que permitirão destacar a viabilidade de uma explicação jurídico-Política da Europa Unida da CECA.

Opera-se aqui apenas uma reorganização significativa de informações que a comunidade epistêmica jurídica brasileira detém sobre a construção da CECA, sem se preocupar em revelar qualquer informação histórica "nova"492. Por este estudo se desenvolver no interior de um arco de preocupações jurídico, preserva-se à literatura histórica específica sobre a Europa Contemporânea a incumbência exclusiva de descobrir eventos e informações novas. Apenas se encontram, a partir daquilo que já se conhece, elementos aptos a fornecer indícios para novas vias interpretativas sobre a origem histórica da CECA.

\footnotetext{
${ }^{489}$ Indagação objeto do Sétimo Capítulo desta Tese de Doutorado.

490 Afinal, o objetivo de todo Regime Político é precisamente cumprir o compromisso assumido consigo mesmo de se perpetuar no tempo enquanto comunidade ativa e viva: seu fim "é a própria realização da comunidade política, através da lei, como a expressão do 'justo meio’ ou do compromisso entre os interesses das partes fundamentais da cidade.” (CARDOSO, 2002, p. 41).

491 Extraídas de documentos históricos do período consultados - rascunhos, manuscritos, cartas, atas de reuniões ou de Congressos, transcrição de discursos, entrevistas, entre outros - e das narrativas historiográficas sobre os diferentes Projetos de Europa Unida do imediato pós-Segunda Guerra Mundial.

${ }^{492}$ Nesse sentido, remetemos o leitor à nota de rodapé 19, supra.
} 
É importante relembrar, por esse motivo, que o estudo de qualquer fenômeno se insere - de um modo ou de outro - em uma arena de batalhas entre as inesgotáveis significações possíveis em torno dele. Dito de outro modo, todo estudo - inclusive o estudo histórico - é "parcial", pois ilumina eventos em detrimento de outros, de acordo com escolhas feitas previamente por seu autor ${ }^{493} 494$ diante de questões e condições que o tempo presente a este coloca $^{495}$ (CASELLA, 2012, p. xiii-xiv e 38).

Não haveria assim uma "verdade histórica", pois coisa alguma poderia ser percebida como detendo uma "essência" enigmática a ser desvelada como explicação secreta/-chave última, absoluta e total das coisas (LEFORT, 2007e, p. 342). Não haveria que se acreditar que uma reconstrução histórica seja capaz de reconstruir e recontar "tudo como efetivamente ocorrera", pois não há qualquer verdade histórica essencial a ser desvelada (JOERGERS, 2010, p. 9). Apenas se reabrem aqui as interrogações em torno das interpretações sobre o passado a partir da seleção de indícios específicos em detrimento de outros ${ }^{496}$; afinal, "a história não é somente pano de fundo do tempo, nem tampouco é neutra." (CASELLA, 2012, p. 60).

1. Imaginons deux boxeurs, également remarquables par leur vaillance et leur robustesse, qui se disputent la couronne dans le combat décisif. Sans relâche, ils échangeant coup pour coup et il est impossible, aussi bien pour les combattants que pour les spectateurs, de compter ou de prévoir chacune de ces attaques et chacun de ces coups, 2. Ce qui n'empêche pas que, d'après l'ardeur et la combativité manifestées d'une façon générale par l'un et l'autre, on peut se faire une idée assez précise de leur science, de leur force et de leur courage. [...]. 3. L'historien serait sans doute incapable de dire à quelle occasion et de quelle manière s'engageaient les opérations qui avaient lieu jour après jour [...]. Ce serait du reste un récit fastidieux et sans intérêt pour le lecteur. 4. C'est plutôt en

\footnotetext{
493 " $[\mathrm{H}]$ istorians continually work with theories, attempting to search among the full range of facts for the essential ones and establish links between them. The selection of what is essential to consider as well as the reconstruction of links depend on theoretical presuppositions - independently of whether the historian is aware of them or not. Thus, even those historians who are outspokenly opposed to theory in their works are themselves influenced by theory." (LOTH, 2008, p. 9, grifos nossos).

${ }^{494}$ Relembramos aqui o fundamento Fenomenológico deste trabalho - Segundo Capítulo, supra, o qual lastreia a admissibilidade do não-esgotamento das possibilidades de leitura em torno de um fenômeno.

495 “[T] oute analyse socio-historique est par principe interminable, parce qu'elle est faite de questions qu'on pose à un objet qui n'existe qu'en faisant question pour lui-même. [... L'historien] le construit en raison de questions qui se forment en lui, ici et maintenant, au contact de son expérience du monde d'une expérience confuse qu'il ne maîtrise pas. [...]. Pour ne prendre qu'un exemple : Marx ou Weber analysent le capitalisme, mais la question de la nature du capitalisme habite le monde où il a surgi, elle est rigoureusement contemporaine de son institution." (LEFORT, 2007e, p. 343, grifos do autor).

496 "Logicamente e materialmente, é impossível pretender mostrar todas as facetas do direito internacional, em todos os tempos. Seria preciso numerosa equipe de profissionais altamente qualificados, com fluência em dezenas de idiomas, e acesso às fontes de todo o mundo para se aflorarem todos os continentes. E o resultado alcançaria tal extensão, que se tornaria dificilmente manejável. Trata-se assim de perspectiva pessoal desse amplo fenômeno temporal e cultural. [...]. Isso não se formula como desculpa, nem como tentativa de isenção de responsabilidades. Mas como inexorável percepção dos limites aos quais todos estamos sujeitos. E como reflexo de escolhas e de condicionantes que pautam a vida de cada um.” (CASELLA, 2012, p. 9).
} 
dégageant les caractères généraux de ces opérations ainsi que des résultats finalement obtenus par les efforts des uns et des autres que l'on peut donner une idée de ce qui passa au cours de ces années. (POLYBE, 2003, p. 128-9, grifos nossos).

Nos itens a seguir serão desconsideradas as informações históricas que nada guardam relação com o objetivo deste trabalho ${ }^{497}$, sem que isso possa ser considerado como um prejuízo investigativo deste texto ${ }^{498}$. Serão apresentados nos itens a seguir apenas os elementos da experiência histórica do período de 1945 a 1951 que auxiliarem na elucidação da construção da CECA como movimento voltado à afirmação histórica da preferência por uma Europa jurídico-Politicamente Unida ${ }^{499}$. A menção às outras três tentativas ${ }^{500}$ será feita apenas e tão somente naquilo que permitir esclarecer este específico processo $^{501}$.

Assim, ao assumir o objetivo de apresentar uma leitura alternativa sobre a CECA, este texto busca encontrar indícios a partir dos quais seja possível colocar, ao lado da leitura jurídico-econômica da História do princípio da UE, a leitura jurídico-Política da

497 “Lorsqu'on retire de l'histoire tout ce qui peut être utile, ce qui reste est dépourvu d'intérêt et n'apporte rien." (POLYBE, 2003, p. 826).

498 "L'historien a déjà pris position; il sait qu'il ira chercher dans l'histoire de cette période [...]. L'auteur a trouvé un fil conducteur; il s'y tiendra solidement, parfois même avec une pédanterie un peu naïve ; mais cette naïveté a l'avantage d'éclairer sa méthode." (PÉDECH, 1964, p. 34-6).

${ }^{499}$ Isto é, dotada de (i) Leis, as quais organizaram (ii) uma convivência plural permanente, por meio de (iii) normas jurídicas positivas de Direito Comunitário Originário.

${ }^{500}$ Isto é, OECE, Pacto de Bruxelas e CdE.

Note-se, ademais, que não serão desenvolvidas considerações sobre o Tratado celebrado em Londres, em 5.9.1944, entre Bélgica, Países Baixos e Luxemburgo, o qual instituiu o BENELUX (BITSCH, 2006, p. 26; BOSSUAT, 1994, p. 89 e 119-20; DAVID, 2008, p. 137-8; MATTERA, 2002, p. 20; PERTEK, 2011, p. 13; REUTER, 1965, p. 36). Apesar de estes três países participarem conjuntamente das iniciativas de aproximação de países europeus a serem examinadas a seguir, o BENELUX se encontra localizado fora do campo metodologicamente desenhado para o presente trabalho.

Com efeito, em primeiro lugar, não se pode ignorar que seu Tratado foi celebrado em 1944, vale dizer, em período não correspondente ao lapso temporal metodologicamente escolhido para este estudo (1945 a 1951). Em segundo lugar, não deve ser esquecido o fato de que o BENELUX visou apenas e tãosomente à promoção de uma União Aduaneira e uma progressiva cooperação econômica intergovernamental entre seus países-membros. Em outras palavras, o BENELUX não foi um processo de integração voltado a instaurar Leis - tal qual a CECA -, mas sim de uma aproximação engendrada em termos econômicos. Como nota Paulo Borba CASELLA (1994a, p. 69), o BENELUX era esforço pioneiro de integração econômica na Europa, cuja leitura foi afastada desde a Introdução Geral deste estudo, como visto supra.

Assim, em termos metodológicos temporais e temáticos, o BENELUX se encontra fora do campo de questões circunscrito para o presente estudo, motivo pelo qual mais linha alguma sobre ele será desenvolvida nas considerações que se seguirem.

${ }^{501}$ Pretende-se que as reflexões históricas aqui desenvolvidas sejam a base de desdobramentos interpretativos em trabalhos posteriores, os quais possam elucidar quando, como e por meio de quais instituições, as Leis da Europa politicamente Unida de hoje podem ser consideradas talvez qualitativamente distintas das da CECA. 
$\mathrm{CECA}^{502}$ sugerida por este trabalho. "Mon espoir est que le lecteur y trouve, comme moimême, incitation à poursuivre." (LEFORT, 1979, p. 371).

Como sei que muitos já escreveram sobre este assunto, temo que, escrevendo eu também, seja considerado presunçoso, sobretudo porque, ao discutir esta matéria, me afastarei das linhas traçadas pelos outros. Porém, sendo meu intento escrever algo útil para quem me ler, parece-me mais conveniente procurar a verdade efetiva das coisas do que o que se imaginou sobre elas. (MAQUIAVEL, 2004, p. 73) ${ }^{503}$.

\subsection{O Saldo da Segunda Guerra Mundial: A Europa Ano Zero}

Fomos, depois, aportar ao país dos soberbos Ciclopes [...]. Leis desconhecem, bem como os concílios nas ágoras públicas. Vivem agrestes, somente nos cimos

${ }^{502}$ Por tudo ser percebido fenomenologicamente por este estudo, considera-se que qualquer via de explicação da História da integração da Europa - como a assumida por este trabalho - é um caminho interpretativo válido e plausível. Tratam-se apenas de visões diferentes sobre um e mesmo fenômeno, nenhuma delas melhor ou pior - simplesmente distintas.

Perceba-se, assim, a existência de amplo e fértil campo de estudos sobre a História da Europa Unida, desde a CECA até os dias de hoje, mesmo no interior de preocupações de uma Pesquisa em Direito. Este trabalho apenas elegeu, de acordo com seus fundamentos metodológicos explicitados na Parte Primeira desta Tese, um dos inúmeros e inesgotáveis caminhos hermenêuticos possíveis.

As leituras sobre a História da Europa Unida - como sobre qualquer fenômeno - não se esgotam. Apesar de a discussão estar centrada geograficamente na Europa (LOTH, 2008, p. 12), procura-se expandir para além destas fronteiras a possibilidade de formular leituras históricas sobre o percurso iniciado e seguido pela integração europeia. Deste modo, este estudo visa também a contribuir, nos limites a que se propõe, para a ampliação geográfica das fontes de leitura histórica sobre o princípio da Europa Unida.

${ }^{503}$ Que esta citação d'O Príncipe de Nicolau MAQUIAVEL (2004) não desconcerte o leitor: não se trata de afirmar que a interpretação jurídico-Política gestada no interior deste trabalho seja a única, verdadeira e derradeira leitura sobre a construção histórica da CECA.

$\mathrm{Na}$ verdade, recorre-se à citação do autor florentino apenas para tornar ainda mais evidente o ponto de partida deste trabalho: a origem de toda organização jurídico-política (quer ela seja Política, quer ela seja Teológico-Política) reside no reconhecimento da inafastável condição (verità effetuale) política da necessidade de se fazer conviver diferentes escalas de existência e de conceder a cada uma delas mútuos Poderes restritores mediante intensos jogos de Poder intercruzados e normativamente previstos entre tais dimensões existenciais (ou, simplesmente, na oposição entre escalas de existência).

Esta compreensão sobre a origem de uma politeia se fundamenta na leitura de Claude LEFORT sobre a obra de Nicolau MAQUIAVEL, referida brevemente no item 3.4., supra, para o qual remetemos o leitor. Apenas se relembre aqui que, para Claude LEFORT (2007c, p. 241-2, 2007e, p. 346, 2007f, p. 347-9, 2007g, p. 360), o pensamento maquiaveliano teria revelado ser a condição primeira de toda comunidade política a oposição entre dois polos existenciais principais (dominar e não ser dominado), os quais devem conviver institucionalmente em condições de igualdade para estabelecer uma vida comum. Essa seria a interpretação de Claude LEFORT (1992a, p. 166 e 172-4) sobre a noção maquiaveliana de verità effetuale da vida política, a qual rejeita explicações sobre a origem da vida política que tenham por fundamento o campo significativo da Economia.

Por esse motivo, o recurso à citação de Nicolau MAQUIAVEL apenas fora efetuado neste texto para reforçar linguisticamente perante o público leitor os pontos de partida assumidos por este trabalho, evidenciando a sólida ancoragem metodológica desta Tese de Doutorado: ao lado de uma leitura jurídico-econômica da História da Europa, seria possível apresentar uma leitura jurídico-Política. Esta se preocuparia em apresentar, por seu turno, o cuidadoso intento histórico na Europa de fazer conviver, por vias institucionais, distintas escalas de existência em contínua oposição no processo de decisão normativa sobre questões comuns sensíveis à vida na Europa.

Isso significa que a leitura jurídico-Política exporá o trabalho histórico na construção institucional da Europa Unida da CECA de se saber lidar com a verità effetuale da vida política: fazer conviver diferentes dentro de um sistema institucional comu estruturado pelo Direito Positivo. 
das altas montanhas, em grutas côncavas, tendo cada um sobre os filhos e a esposa plenos direitos, sem que dos demais o destino lhe importe. (HOMERO, 2002, p. 156-7).

Nous savions que des camps de concentration existaient, que les juifs étaient persécutés, mais ces certitudes appartenaient à l'univers de la pensée. Nous ne vivions pas encore en présence de la cruauté et de la mort, nous n'avions jamais été mis dans l'alternative de les subir ou de les affronter. [...].

Pendant l'hiver 39-40, notre condition de soldats n'a rien changé pour l'essentiel à nos pensées. Nous avions encore le loisir de considérer les autres comme de vies séparées, la guerre comme une aventure personnelle, et cette étrange armée se pensait comme une somme d'individus. Même quand elle s'appliquait avec bonne volonté à ses tâches guerrières, elle ne s'y sentait pas prise, et tous les critères restaient ceux du temps de paix. [...]. (MERLEAU-PONTY, 1996, p. 169-70 e 172).

A Europa de 1945 é considerada como a "Europa Ano Zero" (RÉAU, 2008, p. 127). Esta designação visa a simbolizar a condição do continente europeu do pós-Segunda Guerra Mundial: tamanha fora a destruição pessoal, material e intelectual proporcionada pela experiência da Segunda Grande Guerra - mais devastadora do que a Primeira - que se mostrava muito difícil acreditar na possibilidade de que os Estados europeus se reergueriam em plenitude jurídica, política, econômica e social nos anos subsequentes ${ }^{504}$ - principalmente diante da ascensão de um mundo bipolarizado entre os EUA e a URSS ${ }^{505}$.

Este trabalho não tem por objetivo reconstruir as narrativas sobre a profundidade da destruição provocada pelos combates militares durante a Segunda Guerra Mundial no continente europeu ou fora dele $\mathrm{e}^{506}$.

${ }^{504}$ Desta constatação deriva o caráter extraordinário da vertiginosa recuperação encontrada por meio da solução jurídico-Política discutida neste trabalho: "[1]e caractère absolument extraordinaire des faits [...] suffit à lui seul pour retenir l'attention du public et inciter jeunes et vieux à se plonger dans cet ouvrage." (POLYBE, 2003, p. 65).

505 Vale destacar que o estudo dos embates entre EUA e URSS, enquanto oposição política, militar, econômica e ideológica não será objeto do presente trabalho. Apesar de ser condição característica do período da Guerra Fria, é importante notar que estes elementos muito pouco auxiliarão para compreender a construção histórica da CECA ela mesma - apesar de elucidarem aspectos relacionados à construção da OECE e do Pacto de Bruxelas, a seguir rapidamente referidos.

Assim, como o foco deste estudo é a construção da CECA, a menção ao embate entre os dois principais polos do período será limitada a aquilo que for estritamente necessário para facilitar na compreensão da História da CECA como opção autonomamente europeia pela instauração de um Regime jurídico-Politicamente organizado entre alguns países europeus.

Para o leitor especificamente interessado pela temática da influência dos EUA e da URSS na formulação de Projetos de aproximação de países europeus - que, por essa razão, escapam ao campo circunscrito por um dos limites metodológicos adotados por este trabalho (Projetos de Europa Unida providos de Leis propriamente europeias) -, sugerimos a leitura das obras utilizadas como referência neste texto ao longo deste período.

${ }^{506}$ Endossamos aqui a consciente e prudente reflexão de Paulo Borba CASELLA (1994a, p. 157): “[s]em pretender esboçar mais um capítulo pobre da história mundial no segundo pós-guerra, no tocante ao processo de unificação européia, é, contudo, impossível captar o ímpeto desse movimento, à partir de 1945, sem associá-lo, direta e necessariamente às conseqüências da II Guerra Mundial.”. 
Apesar de esta exposição ser fundamental para compreender o grau das condições materiais que ensejaram a reabertura ${ }^{507}$ da discussão em torno dos Projetos de aproximação integradora entre países europeus a partir de 1945, o relato deste saldo humano, material e intelectual do pós-Segunda Guerra Mundial em pouco contribui para o esclarecimento da questão que orienta a presente exposição histórica ${ }^{508}$. Talvez baste mencionar longa observação sobre o tema feita por Tony JUDT (2008, p. 30-2, grifos do autor):

É com essas questões que devemos começar, se quisermos compreender o trauma que estava por trás das imagens de desolação e de desesperança que atraíram a atenção dos observadores em 1945.

Poucas aldeias e cidades européias, a despeito do seu tamanho, conseguiram escapar ilesas da guerra. Por um acordo informal, ou por sorte, os centros clássicos, medievais e renascentistas de algumas célebres cidades européias Roma, Veneza, Praga, Paris, Oxford - jamais foram alvejados. Mas, no primeiro ano da guerra, bombardeiros alemães arrasaram Roterdã e destruíram Coventry, cidade industrial inglesa. A Wehrmacht riscou do mapa muitos vilarejos nas rotas de invasão através da Polônia e, mais tarde, também da Iugoslávia e da União Soviética. Bairros inteiros no centro de Londres, sobretudo nas áreas pobres em torno das docas do East End, foram vítimas da bliztkrieg da Luftwaffe no decorrer da guerra.

Mas o maior dano material foi causado pelos bombardeios sem precedentes realizados pelos Aliados ocidentais em 1944 e 1945 e pelo avanço implacável do Exército Vermelho, desde Stalingrado até Praga. [...] Quando a guerra na Europa acabou - quando Berlin caiu nas mãos do Exército Vermelho, em maio de 1945, depois de agüentar 40 mil toneladas de bombas nos 14 dias finais - grande parte da capital alemã estava reduzida a montes de escombros e metal retorcido soltando fumaça. Dos prédios da cidade, $75 \%$ estavam inabitáveis.

As cidades em ruínas eram a prova mais evidente - e captada em fotografias - da devastação e passaram a servir de uma espécie de emblema que expressava a tristeza da guerra. Uma vez que a maior parte da destruição fora imposta a casas e prédios residenciais e que, consequientemente, era imenso o número de semtetos (estimativas apontavam 25 milhões na União Soviética; 20 milhões na Alemanha, dos quais 500 mil só em Hamburgo), a paisagem urbana coberta de escombros constituía a lembrança mais imediata da guerra recém-acabada. Mas

${ }^{507}$ Utiliza-se aqui o termo "reabertura" com consciência. No início do século XX, mais precisamente nos anos subsequentes ao final da Primeira Guerra Mundial, houve propostas de aproximação de países europeus com o objetivo de instituir a Paz no continente.

Podem ser mencionados principalmente quatro principais autores: Richard COUDENHOVEKALERGI e suas obras Pan-Europa (1923), A Luta pela Europa (1931) e a Europa Unida (1939), Gaston RIOU e suas obras Europa, minha Pátria (1928) e Unir-se, ou Morrer (1929), Aristide BRIAND e seus dois discursos por ele proferidos perante a Assembleia Geral da Sociedade das Nações (SdN), a saber, o Discurso para a União Europeia (1929) e o Discurso à Terceira Sessão Plenária da Sociedade das Nações (1930), bem como o Memorando redigido por este último em conjunto com Alexis LÉGER, conhecido como Memorandum sobre a Organização de um Regime Federal Europeu (1930). Para uma indicação mais precisa destes e de outros Projetos de Europa Unida anteriores ao século XX, remetemos o leitor ao item 1.1., supra.

Ressalte-se ainda que a presença de propostas de aproximação de países europeus no período entre Guerras torna frágil a afirmação de ter sido a liberalização multilateral do Comércio Internacional do pósSegunda Guerra Mundial o princípio inventor fundamental e fundante do processo de integração na Europa do século XX (v. sobre este tema os comentário constantes da nota de rodapé 203, supra). Se foi talvez um fator que contribuíra parcialmente para sua implementação (aspecto que não será examinado neste trabalho, haja vista a suspensão da leitura econômica mencionada na Introdução Geral desta Tese), não se pode atribuir a esta variável jurídico-econômica a qualidade de causa primeira e absoluta.

${ }^{508}$ Conforme observações aduzidas no item anterior. 
não era a única. No Oeste Europeu, os sistemas de transportes e comunicação estavam seriamente avariados: das 12 mil locomotivas existentes na França antes de guerra, apenas 2.800 funcionavam quando da rendição alemã. [...].

Mas os franceses - tanto quanto os britânicos, belgas, holandeses [...] dinamarqueses, noruegueses [...] e até italianos - tiveram sorte, embora não soubessem disso. Os verdadeiros horrores da guerra ocorreram mais a leste. [...]. As perdas materiais sofridas pelos europeus durante a guerra, por mais terrível que tenha sido o conflito, foram insignificantes, comparadas às perdas humanas. Estima-se que cerca de 36,5 milhões de europeus sucumbiram, entre 1939 e 1945, de causas relacionadas com a guerra (o que equivale à totalidade da população da França quando o conflito eclodiu) - número que não inclui mortes naturais nos anos em questão, tampouco qualquer estimativa da quantidade de crianças não-concebidas ou que deixaram de nascer à época e mais tarde, em conseqüência do confronto.

O número total de mortos é assombroso (os cálculos aqui apresentados não incluem baixas de japoneses, norte-americanos, nem de povos não-europeus). Essa estatística torna pequeno o índice de mortandade registrado na Grande Guerra de 1914-1918, já absolutamente vergonhoso. [... O] mais impactante é o número de mortos entre os civis não-combatentes: ao menos 19 milhões, ou seja, mais da metade do total. O número de mortos entre a população superou as baixas militares na União Soviética, Hungria, Polônia, Iugoslávia, Grécia, França, Holanda, Bélgica e Noruega. Somente no Reino Unido e na Alemanha as baixas militares superaram significativamente as baixas entre civis.

A citação acima liberta este estudo da pretensão imoderada de tratar com precisão do tema do "saldo da Segunda Guerra". Uma vez encontrado um resumo bastante plástico das deploráveis consequências humanas e materiais produzidas pela Segunda Guerra, pode-se nos itens a seguir iniciar o exame dos aspectos históricos relacionados aos Projetos de aproximação entre povos europeus no pós-Segunda Guerra Mundial até a instituição da $\mathrm{CECA}^{509}$. Isso permitirá evidenciar que três deles não compartilhavam do mesmo Projeto de Europa Politicamente Unida inaugurado pela CECA. Compreende-se assim que a expressão "Europa Ano Zero" de 1945 também designa o marco inicial de série de tentativas qualitativamente distintas voltadas à aproximação de povos europeus. Desse laboratório de iniciativas, a CECA se destaca como objeto privilegiado deste estudo ${ }^{510}$ como a mais inovadora.

Ao tratar da OECE e do Pacto de Bruxelas, será possível perceber que estas propostas se preocuparam apenas com a instituição de uma simples cooperação entre países em um setor especializado (respectivamente, Economia e força militar) por força de jogos de oposições escalares extra-europeus $^{511}$. Ao mesmo tempo, quando da abordagem do CdE, será possível notar que este visara a uma integração culturalmente unificadora entre países europeus e,

\footnotetext{
${ }^{509}$ A título exemplificativo, sugerimos ao leitor eventualmente interessado no tema sobre o saldo humano, material e intelectual da Guerra também o texto de Serge BERSTEIN; Pierre MILZA (2002, p. 227-31).

${ }_{510}$ Por razões metodológicas suficientemente esclarecidas na Primeira Parte desta Tese, supra.

${ }^{511}$ Como se poderá ver a seguir, a polarização EUA versus URSS explica em parte o surgimento do Pacto de Bruxelas e da OECE: seriam respostas institucionais de cooperação na Europa à oposição vigente durante o período da Guerra Fria - ou seja, uma resposta jurídico-normativa local a um confronto que transcendia as questões da própria Europa Ocidental. O que restará claro mais adiante.
} 
posteriormente, do mundo ${ }^{512}$. Se no primeiro caso se recusou o estabelecimento de Leis externas entre países europeus, no último caso se evitou constituir Leis jurídico-TeológicoPolíticas - objetivos institucionais distintos do Projeto da CECA de instauração de Leis de convivência plural permanente (Leis Políticas) ${ }^{513}$.

As duas citações que abrem este item 4.1. evidenciam a questão desta primeira parcela do relato histórico. Diferentemente do cuidado jurídico-Político da $\mathrm{CECA}^{514}$, foram institucionalizadas (i) ou iniciativas despreocupadas com a constituição de Leis de origem externa na Europa - com a respectiva inovação de técnica jurídica não muito além da simples cooperação intergovernamental ${ }^{515}$, (ii) ou uma integração em que a percepção do outro era mediada unidimensionalmente, de acordo com critérios estabelecidos por uma única escala de existência voltada sobre si mesma - critérios que deveriam ${ }^{516}$ pautar a direitificação da convivência segundo moldes de absorção uniescalar ${ }^{517}$. É o que se passa a analisar, a seguir.

\title{
4.2. Relações Transatlânticas e suas Repercussões Institucionais na Europa
}

\begin{abstract}
[N]unca homem fez leis; sempre o acaso e os mais disparatados acontecimentos que chovem em cima de nós é que decidem de todas as leis. Ora é uma guerra que derruba as instituições e modifica as leis; ora a penúria da indigência absorvente. [...]. Quando se leva tudo isso em consideração, a gente é inclinada a falar como se dá comigo neste momento, que nunca mortal algum elaborou leis e que todos os negócios humanos dependem essencialmente da fortuna[, sendo esta quem governa] os negócios humanos em universal. Todavia, convirá abrandar algum tanto a aspereza da proposição [...]. (PLATÃO, 1980, p. 118).
\end{abstract}

A data de 2.9.1945 marca o final da Segunda Guerra Mundial. A assinatura do termo de rendição pelo Japão determinara o fim em escala mundial do confronto militar. Todavia, em âmbito europeu ${ }^{518}$, o conflito armado terminara alguns meses antes, em

\footnotetext{
512 De maneira a ficar mais explícita nos itens a seguir, quer-se sugerir que a oposição escalar da Guerra Fria também não é chave explicativa suficientemente apta a permitir a compreensão integral da instituição da integração jurídico-Teológico-Política do CdE. As razões de sua afirmação adviriam de problemas próprios às relações entre os países europeus. Não teria sua origem, assim, nas relações transatlânticas da Europa, mas em uma pulsão interna de buscar solucionar os próprios problemas por uma via específica: a da unificação escalar. Neste último aspecto, o Projeto do CdE não partilharia do da CECA, apesar de ambos igualmente não se explicarem pela oposição EUA versus URSS.

${ }^{513}$ Este último período restará mais claro à medida que a leitura avançar neste e nos dois próximos Capítulos. Reiteremos as observações feitas na nota de rodapé 479, supra.

${ }^{514}$ Objeto dos Capítulos Sexto e Sétimo desta Tese, infra.

${ }^{515}$ As experiências da OECE e do Pacto de Bruxelas, como será visto nos itens 4.2. e 4.3., infra.

${ }_{516}^{516}$ Mas que não conseguiram, como será visto no Quinto Capítulo, infra, referente ao CdE.

517 Perceba-se aqui a operação da distinção entre (coexistência,) cooperação e convivência, nos termos desenvolvidos principalmente na nota de rodapé 2 e nos itens 1.4., 1.5. e 2.1., todos supra.

${ }^{518}$ O qual é, como visto no Primeiro Capítulo desta Tese, o âmbito espacial de interesse deste trabalho. Esta delimitação geográfica do centro de preocupações deste trabalho à região da Europa Ocidental justifica, ainda, a não-menção a exemplos de experiências históricas institucionais de vocação universal voltadas ao
} 
8.5.1945, quando da assinatura do termo de rendição pela Alemanha nazista, após a tomada de Berlim em 7.5.1945.

O ano de 1945 simboliza não apenas o término de um dos mais destrutivos conflitos militares do século XX, mas também a reordenação jurídica das relações internacionais no mundo e na Europa. No interior deste ambiente polarizado entre as duas principais potências do período (EUA e URSS) ${ }^{519}$ se desenvolveram as duas primeiras iniciativas de aproximação de povos europeus no pós-Segunda Guerra Mundial por meio de uso não-tradicional (cooperação) das normas jurídicas positivas de Direito Internacional Público clássico (coexistência): a OECE e o Pacto de Bruxelas (BITSCH, 2006, p. 31; RÉAU, 2008, p. 134).

Não é demais lembrar que nos dois primeiros anos subsequentes ao final da Segunda Guerra Mundial não se mostrou como opção interessante aos países europeus (Ocidentais ou não) escolher de pronto pelo alinhamento incondicional a uma ou a outra das duas potências. Não havia uma especial predileção em romper de maneira irremediável com os EUA ou com a URSS. Os dois países foram chamados para participar conjuntamente de conferências no imediato pós-Segunda Guerra Mundial, a fim de que ambos percebessem a rejeição imediata de uma definição restrita de Europa - ou capitalista, ou comunista - por parte dos europeus eles mesmos (RÉAU, 2008, p. 137-8).

É importante destacar a simbologia desta condição bipolar manifesta poucos meses antes do final da Segunda Guerra Mundial. Alguns dos países aliados (EUA, Reino Unido e URSS) se encontraram em Yalta, na Crimeia - península ligada à Ucrânia. O objetivo era pensar em conjunto o futuro da Europa continental após o término das hostilidades. Esta reflexão sobre o destino da Europa continental desenvolvida em fevereiro de 1945 se engendrara "em nome da Europa continental", isto é, pensada para ela e no lugar dela ${ }^{520}$.

afastamento do cometimento de Guerra, tal como a da Organização das Nações Unidas (ONU). Manifesta-se aqui a profunda e constante aderência consciente deste trabalho ao estudo de uma dimensão estritamente regional europeia ocidental.

519 "Le conflit mondial à peine terminé, commence à se développer une tension Est-Ouest, entre deux blocs sous leadership, l'un de l'Union soviétique, l'autre des États-Unis. Si l'origine de ce que l'on désigne à partir de 1947 comme la «guerre froide » reste sujet de discussion entre spécialistes, il est clair que les points de friction entre le deux superpuissances ne manquent pas dès 1945-1946. La bombe atomique utilisée à deux reprises contre le Japon, en modifiant l'équilibre de forces entre les Grands, ne peut qu'inciter l'URSS à la méfiance et la pousser à consolider son glacis en Europe centrale, en refusant - entre autres - des élections libres en Pologne au risque de mécontenter gravement les Occidentaux. Les désaccords à l'ONU, au sein du Conseil de sécurité [...] et les rivalités en maints points du globe (Iran, Turquie, Grèce...) se multiplient.". (BITSCH, 2006, p. 31-2).

${ }^{520}$ Tendência da postura britânica que se repete em diversos momentos da História da construção da Europa Unida a ser relatada nos próximos itens, especialmente simbolizada pelo Discurso de Winston CHURCHILL, proferido em 1946, na Universidade de Zurique, Suíça, a ser mencionado no Sexto Capítulo, infra. 
A Conferência de Yalta de 1945 simboliza $^{521}$ a mutação da ordem política, econômica e diplomática das relações internacionais, com a qual os países europeus deveriam saber lidar. Tendo o mundo abandonado o paradigma eurocêntrico, a Europa continental deveria se posicionar com prudência diante do equilíbrio de forças entre as duas principais escalas de existência globais do pós-Segunda Guerra Mundial (EUA e URSS). O mundo não mais dependia apenas das decisões do continente europeu (BERSTEIN; MILZA, 2002, p. 223; BITSCH, 2006, p. 26; RÉAU, 2008, p. 134-5).

\begin{abstract}
[S]'il faut dénoncer [1]e mythe de Yalta [d'un "partage du monde"], il convient cependant de rappeler que, dès les lendemains de la signature de ces accords, l'URSS intervient en Roumanie et y installe un gouvernement où les communistes détiennent les «postes-clés ». Or, les États-Unis et le RoyaumeUni, membres d'un organe de contrôle tripartite, ne dénoncent pas ouvertement cette violation de la «déclaration sur l'Europe libérée». De l'hiver 1945 à l'hiver 1948, le rapport des forces à l'Est de l'Europe évolue en faveur de l'URSS qui étend progressivement son contrôle économique et politique à travers des «traités bilatéraux inégaux » avec ses «partenaires » devenus des « démocraties populaires » fort peu autonomes. (RÉAU, 2008, p. 135).
\end{abstract}

As aproximações entre países europeus promovidas pela OECE e pelo Pacto de Bruxelas podem ser entendidas no interior desta chave das relações internacionais. Teriam sido elas respostas institucionais às relações transatlânticas mantidas pela Europa voltadas à promoção da cooperação entre alguns países europeus ${ }^{522}$ que haviam rompido com o Leste Europeu. Como se poderá ver a seguir, o ingresso do mundo na Guerra Fria empurrou a Europa Ocidental em direção a uma cooperação econômica e militar vinculada a suas relações transatlânticas (BITSCH, 2006, p. 31).

A despeito do temor inicial de adoção de uma noção mais restrita de Europa, a opção final pela sombra protetora estadunidense pode ser entendida como o resultado de forças constritoras (de ambos os lados) que pesaram sobre a escolha dos países da Europa Ocidental (RÉAU, 2008, p. 139-40). O que será especificado nas linhas a seguir.

\footnotetext{
${ }^{521}$ Alfonso MATTERA (2002, p. 15) parece acreditar ter sido esta Conferência efetivo encontro de divisão do mundo entre as diferentes potências. Em sentido contrário, mencionem-se Élisabeth du RÉAU (2008, p. 134-5) e Serge BERSTEIN; Pierre MILZA (2002, p. 220). A questão sobre a adequada interpretação deste evento histórico, apesar de interessante, não diz respeito aos objetivos visados por este trabalho, razão pela qual não será examinada nas linhas a seguir.

${ }_{522}$ Aqui se evidencia a condição específica da OECE e do Pacto de Bruxelas - a ser mais bem delineada linhas a seguir: a origem do problema a ser solucionado é externa à Europa Ocidental e a solução gestada fora a instituição de dois mecanismos de cooperação intergovernamental (econômica e militar). Nestes dois casos (origem externa e cooperação), como se poderá perceber, os Projetos da OECE e do Pacto de Bruxelas se afastavam do da CECA (origem interna à Europa e convivência). Remetemos o leitor, ainda, às considerações constantes da nota de rodapé 479 , supra.
} 


\subsubsection{O Plano Marshall e a Cooperação Econômica da OECE}

A cooperação econômica instaurada por meio da OECE tem profunda relação com o Plano Marshall. A instauração desta Organização Internacional teve por objetivo conferir mecanismos práticos para implementar este Plano de Recuperação Econômica da Europa $^{523}$. A origem do Plano Marshall reside na suspensão do auxílio econômico estadunidense destinado aos países europeus que foram seus aliados durante a Segunda Guerra Mundial e no correlato temor de ascensão e difusão sucessivas na Europa Ocidental do campo de influência do bloco soviético.

Desde o final de 1941 a setembro de 1945, os EUA emprestaram mais de 50 (cinquenta) bilhões de dólares a seus aliados para sustentarem seu combate militar contra os países do Eixo ${ }^{524}$. Os países europeus esperavam que esses empréstimos fossem mantidos após o final da Segunda Guerra Mundial, mas ele foi interrompido após a rendição do Japão, em 2.9.1945. A conveniência de sua continuidade havia sido questionada já após a capitulação da Alemanha em 8.5.1945, diante da invasão da Polônia pela URSS (RÉAU, 2007, p. 6-7, 2008, p. 141).

Os países europeus se tornaram grandes dependentes da Economia americana desde o final da Primeira Guerra Mundial, principalmente em função da crescente dívida de Guerra assumida durante os dois conflitos. Cessar o recebimento do auxílio americano representava precarizar potencialmente de modo incontornável as condições materiais de sobrevivência dos povos dos países da Europa Ocidental.

Ao mesmo tempo, a expansão das forças comunistas na Europa continental se estendia de maneira surpreendente no Leste Europeu. Era previsível ser plano da URSS se difundir também pelos países da Europa Ocidental ${ }^{525}$, o que era fortemente sinalizado pela força, pela postura, pela influência e pela defesa ideológica exercidas pelos Partidos

${ }^{523}$ A OECE foi instituída por meio do Tratado de Paris, de 16.4.1948, assinado por Áustria, Bélgica, Dinamarca, França, Grécia, Irlanda, Islândia, Itália, Luxemburgo, Noruega, Países-Baixos, Portugal, Reino Unido, Suécia, Suíça e Turquia.

${ }^{524}$ As somas mais expressivas foram destinadas ao Reino Unido e a seu Império $(61,9 \%)$ e à URSS $(22,3 \%)$. A França se beneficiara deste auxílio de maneira tardia, recebendo no total o correspondente a $6,4 \%$ dos empréstimos (RÉAU, 2008, p. 141).

525 "L'ancien collaborateur de George Marshall, le général Walter Bedell Smith, devenu ambassadeur à Moscou, confirmait des renseignements déjà parvenus au Département d'État sur les ambitions soviétiques en Europe au-delà de sa zone d'influence au Centre et à l'Est. La guerre civile qui se déroulait en Grèce et qu'aggravait la crise économique, inquiétait particulièrement Washington, depuis que les Britanniques avaient fait savoir en février 1947 qu'ils n'avaient pas les moyens d'intervenir.". (RÉAU, 2008, p. 145). 
Comunistas localizados nos diferentes países europeus ${ }^{526}$ (MATTERA, 2002, p. 15-6; NOËL et alii, 2008, p. 113-4; WÆVER, 1998, p. 81-2). Isso poderia ameaçar inclusive a possibilidade de os países do Oeste europeu honrarem suas dívidas contraídas com os EUA ao longo da Segunda Guerra Mundial (BITSCH, 2006, p. 34; RÉAU, 2008, p. 132 e 142-4; SALERNO, 1981, p. 382).

A conjugação da fragilidade material com o monolítico bloco ideológico poderia estimular os principais países da Europa Ocidental a ceder às tentações soviéticas ${ }^{527}$. Em ambiente de completa destruição, a Europa Ocidental não encontrava condições suficientes para se reerguer por si só economicamente e para fazer frente às dívidas assumidas anteriormente. Ademais, havia a percepção de que a miséria e a pauperização eram a fonte motora da ação revolucionária soviética em âmbito nacional. Temia-se com isso a difusão da propaganda comunista no interior dos principais órgãos administrativos e Políticos dos países europeus do Oeste ${ }^{528}$ e mesmo a insurreição clandestina para a tomada do Poder na mesma região ${ }^{529}$ (RÉAU, 2007, p. 7).

${ }^{526}$ Cujo cenário de "patrulha ideológica", mesmo de intelectuais ocidentais, por intelectuais e demais membros do Partido, foi especialmente sentida e descrita por Claude LEFORT, como indicado no item 3.4., especialmente no item 3.4.2., supra.

No que se refere ao Leste Europeu e à Europa Central, “[s]uprême mensonge, tous s'intitulent Démocraties populaires. Purges, procès politiques, liquidation légale et physique des opposants déclarés ou supposés se succèdent, sur le modèle stalinien. Les consciences libres, celles des écrivains, des poètes sont opprimés ; les Églises sont systématiquement affaiblies et mises au pas. La culture russe devient la référence imposée à tous les peuples d'Europe centrale et orientale." (CARBONELL et alii, 1999b, p. 302). A tendência destes Partidos Comunistas nacionais era fomentar a formação de regimes políticos única e exclusivamente pautados pelos moldes comunistas "that did not dependend on - indeed, would not permit the legitimacy conferred by an open electoral process. This was most dramatically demonstrated in Poland where, in January of 1945, Stalin recognized the communist-dominated Lublin Committee as the rightful government [...]” (BOBBITT, 2003, p. 45).

No mesmo sentido, ressalta Rudolf BERNHARDT (2010, p. 48) a diferença de caminhos jurídicoinstitucionais no plano internacional entre o Oeste Europeu e o Leste e Centro Europeus no que se refere à proteção dos Direitos Humanos no pós-Segunda Guerra Mundial: "Der sogenannte Eiserne Vorhang und die Konfrontation zwischen West und Ost, zwischen rechtsstaatlichen Democratien und dem sozialistischkommunistichen Block, fürhten daze, da $\beta$ sowohl der Menschenrechtsschutz als auch die zu schaffenden internationalen Organisation in Westeuropa einerseits, im östlichen Mittleuropa und in Osteuropa andereseits lange Zeit völlig unterschiedliche Wege gingen".

Sobre o caráter unidimensional totalizante Teológico-Político de um Projeto Bolchevique para a Europa, remetemos o leitor ainda à nota de rodapé 694, infra.

${ }^{527}$ Lembrando, inclusive, a postura europeia inicial do pós-Segunda Guerra Mundial de não romper pronta e irremediavelmente com nenhuma das duas potências (RÉAU, 2008, p. 137).

528 'La situation politique dans l'Ouest européen était également préoccupant aux yeux du petit groupe d'experts qui conseillaient Truman. La présence de ministres communistes au sein de trois gouvernements était jugée périlleuse par ceux qui étaient les plus déterminés à lutter contre l'emprise communiste.". (RÉAU, 2008, p. 145).

529 "En Italie, au mois de juin, l'ambassadeur des États-Unis craignait que les communistes (qui avaient quitté le gouvernement Gasperi le 13 mai) en préparent une action clandestine en vue d'une inssurection dans le nord de l'Italie. Le Département d'État étudiait sérieusement les moyens de lutter contre cette menace." (RÉAU, 2008, p. 147). 
Em março de 1947, o Presidente estadunidense Harry TRUMAN discursou perante o Congresso dos EUA em favor de uma política de contenção da expansão da zona de influência da URSS na Europa mediante novos auxílios econômicos em favor da Europa $^{530}$. Tratava-se de um Plano de Recuperação Econômica da Europa voltado a instaurar um grande mercado europeu por meio da reconstrução da economia europeia nos moldes pensados pelos EUA, isto é, de uma proposta de contenção do avanço soviético na Europa por meio da Economia estadunidense, a fim de manter elo de solidariedade econômica e financeira da Europa Ocidental com relação aos EUA ${ }^{531}$ - iniciativa futuramente mais bem desenvolvida sob a denominação de Plano Marshall ${ }^{532}$ (BARNAVI; POMIAN, 2008, p. 79-80; BERSTEIN; MILZA, 2002, p. 237; BITSCH, 2006, p. 32; BOBBITT, 2003, p. 47; DREYFUS, 2008, p. 129; PERTEK, 2011, p. 12; RÉAU, 2008, p. 132, 141-2 e 144-5).

Le choix de « l'arme économique » pour contrer l'expansionnisme de l'URSS en Europe et contribuer à la stabilité politique du vieux Continent apparaît dès mars 1947 dans le message du Président Truman. Ces vues correspondent bien à celles du Sous-secrétaire d'État Dean Acheson qui écrit peu après : «Il va falloir utiliser de plus et plus notre second instrument de politique extérieure, à savoir, le pouvoir économique, de façon à stopper l'expansionnisme, l'infiltration politique de l'URSS ». (RÉAU, 2008, p. 147).

O discurso de Harry TRUMAN perante o Congresso dos EUA fora bastante claro: era fundamental conceder auxílio econômico e financeiro aos países europeus livres para que estes não pudessem ceder a qualquer ameaça oriunda de "potências estrangeiras ou de minorias armadas". Segundo ele, caberia aos EUA a missão de ajudar a conservar a liberdade de tais povos. De posse deste argumento, o Presidente estadunidense conseguiu a

\footnotetext{
${ }^{530}$ A racionalidade da política de contenção da expansão soviética na Europa e no mundo era simples: "[f]or the United States to achieve its strategic goals [...] it had to contain communism within its Second World boundaries and thus prevent this movement from taking over fresh societies that would enrich its system with the accumulated human capital and other resources of the states it took over. If containment could be managed, then - so the Americans believed - the steady impoverishment of the socialist system would begin to tell. Like an engine requiring oxygen but producing carbon monoxide, the Soviet system would steadily grow more anaerobic until it collapsed." (BOBBITT, 2003, p. 56-7, grifos do autor).

531 'Les États-Unis, qui suscitent la coopération multilatérale en Europe, ne sont pas désintéressés et leurs desseins sont économiques et politiques, les cercles économiques en sont bien conscients mais pensent qu'il n’y a pas d'alternative." (RÉAU, 2008, p. 132). Com efeito, por meio do auxílio econômico, os EUA visavam assegurar condições suficientes para "l'endiguement du communisme [...]. Redresser les États européens, c'est aussi refaire d'eux partenaires commerciaux dignes de ce nom et ainsi remettre en marche l'économie mondiale et éviter un risque de surproduction, hantise des américains depuis 1929. Si l'aide proposée est gratuite, elle n'est donc pas complètement désintéressée.” (BITSCH, 2006, p. 35). No mesmo sentido, v. Elie BARNAVI ; Krzysztof POMIAN (2008, p. 80), Charles-Olivier CARBONELL et alii (1999b, p. 304), Paul REUTER (1965, p. 38) e Francesco SALERNO (1981, p. 382).

${ }^{532}$ Denominação mais bem compreendida algumas linhas a seguir, neste mesmo item.
} 
imediata aprovação pelo Congresso da versão de 400 (quatrocentos) milhões de dólares à Grécia e à Turquia para que estes organizassem forças suficientes que refreassem as tentativas internas de expansão da URSS na Europa (BITSCH, 2006, p. 32-3; RÉAU, 2008, p. 147-8).

Esta contribuição econômica pontual dos EUA era o princípio bruto do Plano de Recuperação Econômica da Europa. Todavia, tal Plano deveria receber contornos mais bem precisos e detalhados, a fim de assegurar um programa global de auxílio e assistência para a Europa. Esta especificação foi realizada no mesmo ano de 1947 pelo Secretário de Estado dos EUA, o General George MARSHALL, em conjunto com seus colaboradores do Departamento de Estado dos EUA. A partir deste momento, o referido Plano de Recuperação Econômica da Europa passou a ser conhecido como Plano Marshall (RÉAU, 2008, p. 148; SALERNO, 1981, p. 382).

O intento estadunidense de auxiliar economicamente a reconstrução da Europa foi conhecido antes de seu anúncio oficial por alguns países europeus. Ao menos França e Reino Unido já tinham tomado conhecimento desta pretensão no início de maio de 1947, em virtude de conferência confidencial entre os embaixadores dos três países (EUA, França e Reino Unido) em Washington. O acesso privilegiado a tal informação estimulou uma rápida concertação franco-britânica para facilitar a aceitação desta proposta em alguns países do continente europeu meses depois.

O anúncio oficial do Plano Marshall estava programado para 5.6.1947, na Universidade de Harvard, em Discurso a ser proferido pelo próprio General George MARSHALL. Naquela oportunidade, o Secretário de Estado dos EUA salientou especificamente que seu país pretendia fornecer auxílio econômico aos Estados europeus segundo um grande Plano Global, composto por medidas econômicas de curto e longo prazo (NASCIMENTO E SILVA; ACCIOLY, 2002, p. 246; QUERMONNE, 2010, p. 14; RÉAU, 2008, p. 148-9; REUTER, 1965, p. 38-9; SALERNO, 1981, p. 382; ZORGBIBE, 1997, p. 15-6).

[T] he governments are forced to use their foreign money and credits to procure the[ir] necessities abroad. This process exhausts funds which are urgently needed for reconstruction. Thus a very serious situation is rapidly developing which bodes no good for the world. [...]. The remedy lies in breaking the vicious circle and restoring the confidence of the European people in the economic future of their own countries. [... T] The United States should do whatever it is able to do to assist in the return of normal economic health in the world [...]. (MARSHALL, 1966, p. 270). 
Os EUA seriam o ponto de partida da ajuda à necessária reconstrução econômica da Europa. A incomparável destruição material provocada pelos combates da Segunda Guerra Mundial e o surpreendente direcionamento cego de praticamente todas as atividades produtivas na Europa para a indústria bélica exigiam muito mais tempo do que o esperado para que a Europa retornasse à normalidade saudável de suas atividades econômicas. Por esse motivo, o auxílio econômico estadunidense visava a empreender profunda reconstrução da Economia Europeia, não visando a meros paliativos pontuais (BITSCH, 2006, p. 34-5; MARSHALL, 1966, p. 268-70).

Apesar de o Plano não ser surpresa para alguns países da Europa, outros (como a URSS) foram surpreendidos pela amplitude do Programa e pela exigência de célere resposta por parte dos principais países europeus. A proposta estadunidense não excluía imediatamente nem o Centro nem o Leste Europeus, nem mesmo a URSS, da possibilidade de se beneficiarem dos auxílios previstos pelo Plano. Mesmo os EUA ${ }^{533}$ percebiam que poderia ser perigosa a assunção de uma concepção restrita de Europa ${ }^{534}$ (BARNAVI; POMIAN, 2008, p. 79-80-1; BERSTEIN; MILZA, 2002, p. 238; BITSCH, 2006, p. 36; CARBONELL et alii, 1999b, p. 304; RÉAU, 2007, p. 7-8, 2008, p. 149 e 151).

A implementação prática do Plano dependia ainda da resolução de determinadas questões das relações internacionais características da Europa naquele período - na medida em que os países europeus deveriam primeiramente se estabelecer de acordo e se coordenar para, apenas depois, receberem o auxílio econômico (MARSHALL, 1966, p. 270). A Europa deveria se estabelecer internamente de tal modo que a recepção da contribuição estadunidense não pudesse significar uma ruptura de relações com a URSS para não parecer ter se formado um bloco europeu contra a União Soviética (RÉAU, 2008, p. 151-2; SALERNO, 1981, p. 382).

\footnotetext{
533 "Our policy is directed not against any country or doctrine but against hunger, poverty, desperation and chaos. Its purpose should be the revival of a working economy in the world [...]." (MARSHALL, 1966, p. 270, grifos nossos).

${ }_{534}$ De todo modo, não se pode se esquecer de que, do mesmo modo que ocorrera com os países da Europa Ocidental, os EUA condicionaram o recebimento do auxílio do Plano Marshall pelos países do Centro e do Leste Europeu à renúncia "à l'orientation de leur économie vers l'Union soviétique" (RÉAU, 2008, p. 151). O que sinaliza clara pretensão estadunidense consciente e não-desinteressada de pretender moldar uma vasta Europa a partir de sua própria dimensão de existência Econômica.

Mencione-se ainda a advertência do próprio George MARSHALL (1966, p. 270) em seu discurso na Universidade de Harvard, proferido em 1947: "Any government which manoeuvres to block the recovery of other countries cannot expect help from us. Furthermore, governments, political parties, or groups which seek to perpetuate human misery in order to profit therefrom politically or otherwise will encounter the opposition of the United States.”. Ainda que não explicitamente mencionada, a oposição dos EUA com relação à URSS era mais do que clara nas entrelinhas do Discurso sobre o Programa de Recuperação Econômica da Europa.
} 
Por esse motivo, o Ministério de Relações Exteriores da França iniciou em 14.6.1947 série de discussões com a URSS para um mútuo esclarecimento sobre a posição da União Soviética com relação ao Plano Marshall. Percebeu-se um temor soviético com relação a um pretenso "complô ocidental" em detrimento da Europa Oriental e da URSS.

Para afastar a suspeita de pré-existência de um plano de concertação entre franceses e britânicos previamente aprovado pelos EUA, França e Reino Unido se reuniram em 178.6.1947 e entenderam por bem convidar a URSS para participar de uma Conferência tripartite em Paris para o final do mesmo mês. Nesta Conferência seria possível à França e ao Reino Unido certificar à União Soviética a inexistência de uma "maquinação capitalista" e, por isso, a existência de sincera abertura da Europa Ocidental a pensar um Plano de Recuperação Econômica para todos os países europeus (BITSCH, 2006, p. 35-6; NOËL et alii, 2008, p. 114; SALERNO, 1981, p. 382).

A suspeição da URSS com relação às pretensões ideologicamente comprometidas do Plano Marshall determinou a urgência da realização deste encontro. A fim de não adiar mais os mútuos esclarecimentos, a União Soviética fixou a data de realização da Conferência de Paris para 27.6.1947. O resultado desse encontro determinaria os termos segundo os quais a zona de influência soviética ${ }^{535}$ se relacionaria com os demais países europeus e definiria os novos termos das relações internacionais na Europa.

A Conferência tripartite de Paris foi realizada entre 27.6.1947 e 4.7.1947. Durante cada uma das sessões, pouco a pouco os delegados da URSS se revelaram contrários à proposta estadunidense. Estes percebiam o Plano Marshall como o princípio de criação de um bloco ocidental capitalista sob a proteção dos EUA. Apesar de também precisar de auxílio econômico para se reconstruir, a União Soviética se manifestara oficial e claramente seu desinteresse em participar do Plano Marshall e sua oposição à execução da Reconstrução Econômica da Europa conforme o Programa dos EUA, pois percebia se tratar de um atentado em potencial contra as soberanias nacionais (BITSCH, 2006, p. 36; SALERNO, 1981, p. 382).

Ademais, não se pode ignorar que a URSS percebia o Plano de Recuperação Econômica da Europa como uma pretensão estadunidense de influenciar também os países do Leste Europeu - sob reconhecida influência soviética ${ }^{536}$. Apesar do interesse

\footnotetext{
535 Especial atenção dada aos Governos da Polônia, da Tchecoslováquia, e da Iugoslávia, que haviam se interessado pelo auxílio econômico estadunidense (RÉAU, 2008, p. 153-4).

536 "I sovietici che pur avevano bisogno di seri aiuti finanziari, si opponevano sopratutto alle proposte occidentali di realizzare una qualche forma de direzione « esterna » delle economie nazionale. Essi, invece, ritenevano che andava privilegiato il rapporto diretto bilaterale rimettendo all'organismo internazionale il
} 
inicialmente manifestado em participar dos auxílios econômicos sob égide do Plano Marshall, países como a Polônia, a Tchecoslováquia e a Iugoslávia rejeitaram a participação imediatamente após a recusa da URSS (BARNAVI; POMIAN, 2008, p. 81; BERSTEIN; MILZA, 2002, p. 238; BITSCH, 2006, p. 36; CARBONELL et alii, 1999b, p. 304; NOËL et alii, 2008, p. 114; RÉAU, 2007, p. 8, 2008, p. 151-6; REUTER, 1965, p. 39; ZORGBIBE, 1997, p. 16).

L'URSS entraîne dans son refus huit pays d'Europe orientale dont certains auraient souhaité profiter l'aide: six pays dominés par les communistes (Albanie, Yougoslavie, Bulgarie, Roumanie, Hongrie, Pologne), la Tchécoslovaquie, dont le gouvernement de Front national, après avoir donné un accord de principe, doit revenir sur sa décision à la suite de pressions soviétiques, et la Finlande qui ne peut se permettre une politique inamicale vis-àvis de Moscou. Le refus de l'Union soviétique, mise au pied du mur, conduit à la rupture entre les deux blocs et accélère leur cristallisation. (BITSCH, 2006, p. 36).

Diante desta fulgurante ruptura entre os Projetos Econômicos pensados para o Oeste e para o Leste Europeus, resta clara a divergência dos modos visados para operar a reconstrução econômica da Europa no pós-Segunda Guerra Mundial. As críticas apontadas pelos delegados da URSS indicaram acuradamente que a diferença entre cada uma das vias econômicas pensadas para reerguer a Europa era fruto específico da oposição escalar entre dimensões existenciais externas à Europa do Oeste.

Em outras palavras, a não participação da URSS e de sua respectiva zona de influência do Programa Econômico de Reconstrução da Europa Ocidental conhecido como Plano Marshall escancarara que o Projeto Econômico de uma entidade externa à Europa Ocidental era incompatível com o de outra entidade externa à Europa Ocidental.

A aproximação entre países europeus estimulada pela propositura do Plano Marshall se revela por si só como uma aproximação econômica e ideologicamente motivada e operada sob cuidado atento e constante dos EUA ${ }^{537}$ - em outras palavras, o Plano Marshall tinha a pretensão de efetuar a concertação econômica entre países europeus

solo compito di redigere la lista delle richieste provenienti dai Paesi europei. [...]. È probabile che l'URSS cercasse di « dirottare » presso la più «neutrale » Commissione economica per l'Europa delle Nazioni Unite (ECE-ONU) tali compiti di coordinamento in modo da evitare una eventuale " egemonia » (como pontualmete si verificò) della Potenza creditrice. [...] Dopo la rottura del 1947 l'ECE-ONU rimase, tuttavia, l'unica sede di confronto tra europei del'Ovest e dell'Est anche se l'attività di tale organismo assunse per lo più un significato meramente accademico." (SALERNO, 1981, p. 382).

537 "Il disegno statunitense era perciò quello di sfruttare la figura di « creditore » per indurre i Paesi europei ad avviare, tramite i necessari strumenti di concertazione, una politica di liberalizzazione degli scambi in modo da favorire l'importazione di prodotti americani." (SALERNO, 1981, p. 382). 
a partir de uma oposição escalar (EUA versus URSS) que transcendia as oposições que marcavam as relações tradicionais entre os Estados da Europa Ocidental (estatalidades isoladas europeias).

Desconectada desse ambiente multiescalar propriamente europeu, a fonte da aproximação econômica encetada pelo Plano Marshall não dizia respeito às relações da Europa Ocidental, mas sim àquelas estabelecidas entre os EUA e a URSS. Estes dois - a suas maneiras específicas - percebiam a Europa do Oeste como o ambiente onde deveriam ser impostas de cima a baixo suas respectivas formas econômicas de habitar o mundo. A ruptura autodeclarada da URSS com relação aos países da Europa Ocidental abrira a possibilidade de os EUA despejarem avassaladoramente sua maneira de compreender o mundo sobre e por entre a Europa do Ocidente.

Todavia, essa potencial avalanche estadunidense não encontrou condições para se espraiar total e unidimensionalmente da maneira como pôde se desdobrar a URSS sobre sua zona de influência. Uma das possíveis explicações dessa impossibilidade de totalização uniescalar pela pretensão econômica estadunidense por entre a Europa Ocidental consistiu precisamente na presença do aparato jurídico-institucional da OECE: "[c]ette première expérience institutionnelle s'opérait sous le regard américain, mais elle était l'œuvre des Européens.” (RÉAU, 2008, p. 142, grifos nossos).

Com efeito, preocupada em instaurar uma simples cooperação econômica entre os países da Europa Ocidental, esta Organização Internacional não almejou transformar tal concertação em convivência ${ }^{538}$. Se a OECE foi experiência institucional de aproximação entre países europeus operada sob o olhar atento dos EUA, ela pode ser entendida como obra países dos europeus que, ao reconhecer as investidas de oposição escalar externa a suas próprias oposições internas, criou a Organização Internacional com o objetivo de impedir a internalização automática e integral dos produtos daquele estranho embate dimensional.

É necessário prosseguir um pouco mais na narrativa do surgimento da OECE para essa resistência institucional à unidimensionalização econômica estadunidense na Europa possa ser mais bem compreendida. Será possível perceber que a preocupação em efetuar a aproximação estritamente econômica entre países europeus no pós-Segunda Guerra Mundial foi envolta em uma armadilha institucional voltada a conter qualquer pretensão de

\footnotetext{
${ }^{538}$ Isto é, cingiu-se a estabelecer um Direito Positivo que regulamentou as ações de seus Estados-Membros, sem pretender com isso instaurar Leis entre eles - apenas uma cooperação; remetemos o leitor aos comentários da nota de rodapé 479, supra.
} 
unidimensionalizar as relações da Europa Ocidental de acordo com a oposição escalar encabeçada pelos EUA.

Não dizendo respeito ao conflito entre estatalidades isoladas da Europa Ocidental, o embate da Guerra Fria (EUA versus URSS) não poderia ser tornado uma questão interna desta - e, por isso, deveria ser mantido à distância. A OECE - enquanto singelo mecanismo de cooperação econômica - pode ser entendida como um escudo protetor de resistência da Europa Ocidental à intromissão unidimensional sorrateira da escala de existência transcendente $\operatorname{dos} \operatorname{EUA}^{539}$.

Pois bem. Uma vez determinado o direcionamento exclusivo dos auxílios econômicos estadunidenses do Plano Marshall para a Europa Ocidental, era necessário estabelecer mecanismos jurídicos positivos que dessem execução prática ao Programa de Recuperação Econômica daquela parcela da Europa.

Para tanto, foi organizada a Conferência de Cooperação Econômica Europeia (CCEE), em Paris, entre 12.7.1947 e 27.9.1947 ${ }^{540}$, entre Áustria, Bélgica, Dinamarca, França, Grécia, Irlanda, Islândia, Itália, Luxemburgo, Noruega, Países-Baixos, Portugal, Reino Unido, Suécia, Suíça e Turquia ${ }^{541}$. Esta Conferência também ficou conhecida como Conferência dos Dezesseis (DAVID, 2008, p. 132; SALERNO, 1981, p. 382).

${ }^{539}$ Em outras palavras, a questão do pós-Segunda Guerra Mundial para a Europa Ocidental consistia principalmente em saber como estabelecer um novo modo de relações entre tais países tradicionalmente opostos militarmente e não incorporar em seu interior conflitos estranhos a essa preocupação; mais do que internalizar esta oposição da Guerra Fria para a Europa Ocidental, naquele momento, antes de tudo, “[c]onstruire l'Europe, c'[était] tisser des liens entre États européens et prévenir la résurgence des nationalismes.” (RÉAU, 2008, p. 133).

Perceba-se aqui como a interpretação desta narrativa histórica se aproxima da questão formulada na Parte Primeira deste trabalho: muito antes de se decidir sobre uma posição ideológica ou outra (oposição escalar típica da Guerra Fria), era fundamental para a Europa do pós-Segunda Guerra Mundial encontrar mecanismos que encaminhassem satisfatoriamente as tradicionais relações entre Estados-nacionais (estatalidades isoladas), a fim de que elas não fossem solucionadas por vias bélicas.

Nesse sentido, já em 1944 observara Hans KELSEN (2011, p. xi) ser importante para a Europa evitar o revigoramento da "insensatez nacionalista" por meio de institutos jurídicos de Direito Internacional. $\mathrm{O}$ autor percebera perspicaz e acuradamente que esta seria a tarefa mais importante do pós-Segunda Guerra Mundial para a Europa e para o mundo, antes mesmo de se decidir entre capitalismo ou socialismo (KELSEN, 2011, p. xii).

É interessante lembrar aqui, sobre este ponto, a condenação do nacionalismo imoderado formulada em 1953 por Jean MONNET (2001b, p. 180), o primeiro Presidente da Alta Autoridade da CECA: "nos pays d'Europe [...] pendant siècles ont conduit le monde, mais [...] depuis des générations, se sont dressés les uns contre les autres au nom de leur souveraineté nationale, pour finalement se détruire de leurs propres mains.”. Em outros termos, e de maneira mais direta, percebe-se que o fundamental no pós-Segunda Guerra Mundial era que "nationalism [had to be] banished in the immediate post-World War II years because of war" (WÆVER, 1998, p. 91). Sobre Jean MONNET, v. o Sexto Capítulo, infra, especialmente o item 6.1.4.

${ }^{540}$ A Conferência dos Dezesseis efetuara duas sessões plenárias durante o mês de julho de 1947 (13.7.1947 e 15.7.1947) e suspendera suas atividades no final de julho de 1947. As atividades foram retomadas ao final do mês de agosto do mesmo ano (RÉAU, 2008, p. 160).

541 "Sont provisoirement exclues, l'Espagne franquiste tenue en quarantaine et l'Allemagne, encore dépourvue de structures étatiques mais que les Américains entendent bien faire bénéficier de l'aide par le 
Nesta Conferência foram formuladas as vias segundo as quais os recursos econômicos estadunidenses seriam repartidos entre os países participantes do Programa de Recuperação Econômica. Visava-se ao estabelecimento de cooperação econômica monetária, produtiva e comercial entre os dezesseis países, a ser executada (i) por um Comitê de Cooperação, composto por todos os países; (ii) por um Comitê Executivo, restrito a cinco países (França, Itália, Noruega, Países Baixos e Reino Unido) ${ }^{542}$; e (iii) por quatro subcomitês técnicos (Agricultura e Abastecimento, Siderurgia, Transportes e Energia), submetidos ao Comitê Executivo (RÉAU, 2008, p. 158).

Com base nos estudos desenvolvidos por estes Comitês, os participantes dessa Conferência avaliaram ser necessária para sua reconstrução econômica a soma de 29 (vinte e nove) bilhões de dólares. Essa primeira proposição foi apresentada ao Congresso dos EUA em 24.7.1947 e fora criticada, (i) pelo elevado valor solicitado; (ii) porque a Conferência não parecia aos EUA um instrumento eficaz para a Europa Ocidental como um todo, na medida em que não mostrava claramente como as políticas econômicas nacionais seriam prática e juridicamente coordenadas de modo eficiente.

A principal crítica do Congresso estadunidense centrava-se no fato de que o mecanismo de instrumentalização prática do Plano Marshall era demasiado frágil para garantir o adequado uso dos recursos para uma global recuperação econômica na Europa Ocidental (SALERNO, 1981, p. 383). Mais do que se preocupar com aspectos de curto prazo - tal qual sinalizavam os países europeus por meio de sua organização em uma simples Conferência intergovernamental nos moldes da tradicional barganha de interesses nacionais (coexistência), os participantes da CCEE deveriam se preocupar, segundo o Congresso dos EUA, com o estabelecimento de uma Organização Internacional permanente que dispusesse de instituições aptas a dar o adequado encaminhamento à repartição dos recursos ${ }^{543}$.

A proposta dos EUA visava ao fomento institucional de uma solidariedade intereuropeia para que, por meio de uma Organização Internacional econômica, houvesse

biais des trois zones d'occupation occidentales." (BITSCH, 2006, p. 36-7). Sobre a divisão da Alemanha, remetemos o leitor à nota de rodapé 701, infra.

542 "Deux objectifs sont assignés à ces comités : dresser un inventaire des ressources et des besoins de l'Europe, et proposer un programme de redressement incluant l'intervention de l'aide américaine." (RÉAU, 2008, p. 160).

543 "La struttura e i compiti del Comitato apparvero, tuttavia, insufficienti agli Stati Uniti che, come testimoniava lo stesso Economic Cooperatoin Act relativo alle condizioni dell'assitenza finanziaria ai Paesi europei, consideravano il « Piano Marshall » come l'occasio per coordinare, su basi liberiste, l'economia europea con il nuovo « ordine » mondiale emerso dagli accordi di Bretton Woods." (SALERNO, 1981, p. 383 , grigos do autor). 
uma distribuição de recursos moldada conforme os ditames de uma organização jurídicoeconômica liberal das relações entre os países europeus - devendo esta ser a base de uma Europa economicamente integrada (CARBONELL et alii, 1999b, p. 304; SALERNO, 1981, p. 383). Perceba-se, assim, o intento estadunidense de aos poucos conformar as relações na Europa segundo uma escala de existência própria, a qual deveria ser disseminada, não mediante uma simples concertação de coexistência entre Estados, mas, sim, por intermédio do concurso de uma Organização Internacional responsável pela readequadação das relações entre os países da Europa Ocidental.

Aquela sugestão foi estudada entre 14.8.1947 e 22.9.1947 pelos participantes da CCEE, tendo em mente o objetivo de constituir uma união aduaneira franco-italiana que fosse a base de futuras e mais amplas integrações europeias ${ }^{544}$ (RÉAU, 2008, p. 160-2). Todavia, os países da Europa Ocidental se mostraram fortemente contrários a uma fórmula institucional constritora para além do âmbito da simples cooperação econômica $^{545}$. Os países europeus revisaram a avaliação inicial e apresentaram, em 22.9.1947, uma estimativa um pouco mais modesta: 22,4 (vinte e dois e quatro décimos) bilhões de dólares.

Com base nesta proposta, o Presidente Harry TRUMAN submetera ao Congresso dos EUA uma lei de auxílio interino em 17.11.1947. Esta foi aprovada em 17.12.1947 e estabeleceu como soma total do auxílio a ser destinado aos aliados o montante de 17 (dezessete) bilhões de dólares, a serem vertidos no prazo de quatro anos, sobretudo sob forma de doações ${ }^{546}$. Os países imediatamente beneficiados naquela data por essa lei foram Áustria, França e Itália, mas acordos bilaterais com os demais países - com exceção da Suíça, em condições econômicas reputadas prósperas - foram posteriormente celebrados para dar execução ao Plano Marshall (BITSCH, 2006, p. 37; BLUM, 1950, p. 2; NOËL et alii, 2008, p. 114-5; RÉAU, 2008, p. 162-4; SALERNO, 1981, p. 383).

Como consequência deste processo, poucos meses depois, foi instituída a primeira Organização Internacional Europeia de cooperação econômica, a OECE. Instituída por

\footnotetext{
${ }^{544}$ Um eufemismo para designar a realização de um modelo de existência jurídico-econômico e político constituído a partir da medida de existência pensada pelos EUA para a Europa Ocidental e forjado a partir da oposição estadunidense com relação a dimensão existencial da URSS.

545 “Comme l'ont bien montré les travaux des historiens français, cette idée avait été bel et bien enterrée [...]. Mais quel que soit l'intérêt de cette initiative, aucun engagement sérieux n'est pris par les États pour lesquels l'Union douanière est un objet d'études. Toutefois, avant de se séparer, les Seize proposaient de créer un «organisme commun chargé de suivre les progrès de la coopération intereuropéenne»." (RÉAU, 2008, p. 161-2).

546 "[Le Plan Marshall] mobilise chaque année, entre 1948 et 1952, l'équivalent de 0,5\% de la richesse nationale des États-Unis.” (PERTEK, 2011, p. 12).
} 
meio do Tratado de Paris, de $16.4 .1948^{547}$, a cooperação econômica na Europa foi juridicamente viabilizada por meio das instituições da OECE para continuar a aplicação do Plano Marshall entre seus dezesseis países-membros por meio da coordenação, da organização e da administração dos recursos previstos pelos Programas do auxílio econômico estadunidense ${ }^{548}$.

Esta Organização Internacional não deveria almejar outra coisa além da repartição coordenada de recursos entre os Estados, isto é, não poderia pretender se imiscuir em campos mais amplos e profundos de aproximação entre os países europeus. Suas normas jurídico-institucionais não poderiam visar à constituição de Leis (paradigma da convivência), mas se restringir ao campo da simples organização jurídica (Direito Positivo) da cooperação econômica de caráter intergovernamental (paradigma da cooperação) ${ }^{549}$ (BITSCH, 2006, p. 37-8; BOSSUAT, 1994, p. 137-8; CASELLA, 1994a, p. 77; DREYFUS, 2008, p. 145; GLAESNER, 1991, p. 287-8; MATTERA, 2002, p. 20; OLIVI; GIACONE, 2007, p. 12; PERTEK, 2011, p. 13; PRIOLLAUD; SIRITZKY, 2011, p. 15; REUTER, 1965, p. 39 e 41).

Assim, a preocupação de aproximação entre países europeus por meio da OECE foi motivada por uma perspectiva econômica adstrita à escala existencial estadunidense, vale dizer, ela não foi produto das oposições escalares internas tradicionais da Europa Ocidental $^{550}$. Tratou-se de efetiva proposta oriunda de embates escalares externos a tais países e gerada de acordo com a escala de existência estadunidense ${ }^{551}$. A transcendência escalar rondava a Europa e buscava meios institucionais duradouros para se estabelecer e se disseminar unidimensionalmente ${ }^{552}$.

547 Assinado por Áustria, Bélgica, Dinamarca, França, Grécia, Irlanda, Islândia, Itália, Luxemburgo, Noruega, Países-Baixos, Portugal, Reino Unido, Suécia, Suíça e Turquia.

548 "La Convenzione poneva innanzi tutto a carico delle Parti contraenti una serie di obblighi generali volti a favorire, anche nei riguardi dei Paesi terzi, il processo di liberalizzazione richiesto dall'Economic Cooperation Act." (SALERNO, 1981, p. 383, grifos do autor).

549 “A cooperação econômica internacional. [...] Estamos [...] no campo da cooperação quando os Estados limitam-se a celebrar acôrdos de colaboração econômica, técnica, cultural, sem chegar a abolir as barreiras aduaneiras ou outras formas de discriminação - Exemplos: Plano Marshall, Aliança para o Progresso, USAID, OECDE, BID.” (AZEVEDO, 1971, p. 74, grifos nos original).

550 “La coopération n'est pas l'intégration. [...] L'OECE n'avait rien de supranational. Elle n'avait pas de responsable unique à sa tête, elle était liée à la distribution de l'aide américaine. Elle réussit cependant [et seulement] à libérer les échanges intereuropéens." (BOSSUAT, 1994, p. 138, grifos do autor).

551 "[L]e plan Marshall veut agir sur le long terme et fortifier l'Europe occidentale contre les risques de subversion [...]" (DAVID, 2008, p. 129), isto é, contra os riscos de definirem por si só um estatuto jurídicopolítico - e também econômico - mais próximo do regime soviético do que gostariam os EUA.

552 “Questo ruolo di « garante esterno » della Potenza nordamericana era oltretutto accentuato dal fatto che gli accordi bilaterali offrivano agli Stati Uniti la possibilità di condizionare in vario modo il Paese europeo inadempiente degli obblighi contratti con la Convenzione per la cooperazione economica europea. Innanzi tutto deve ricordarsi che $\mathrm{i}$ vari accordi in questione contenevano in più punti un rinvio «mobile» all'Economic Cooperation Act : tale rinvio consentiva agli Stati Uniti di modificare unilateralmente le 
Por esse motivo, para evitar o ingresso integral, total e totalizante de uma perspectiva econômica uniescalar descolada das implicações escalares próprias da Europa do Oeste, foi erguida a OECE. Esta seria escudo protetor de resistência à estranha totalização econômica estadunidense. Adstrita conscientemente ao campo da cooperação econômica, esta Organização Internacional conformou uma armadilha institucional que se auto-recusara a incorporar qualquer Projeto de promoção de convivência (união política) conforme os parâmetros ditados de cima a baixo pela escala econômica única dos $\mathbf{E U A}^{553}$.

Em outras palavras, quando o impulso unicamente orientador da aproximação de países europeus detinha um vetor especificamente econômico e de origem transcendental exterior às oposições escalares entre estatalidades isoladas, tradicionais da Europa Ocidental, foi-lhe negada a possibilidade de se manifestar como Projeto de União política. Para tanto, o campo de atuação da OECE foi juridicamente restrito ao da promoção de cooperação econômica entre seus membros. Apesar de ela permitir a entrada da escala existencial produzida por aquele garante externo (os EUA), a estrutura institucional da OECE fora erguida como mecanismo voltado a impedir a completa disseminação daquela dimensão existencial pela Europa Ocidental: isso evitaria a construção de Leis na Europa incompatíveis com o embate escalar propriamente europeu ${ }^{554}$.

condizioni di assitenza finanziaria mediante semplici emendamenti alla legge nacionale. Inoltre gli accordi bilaterali consentivano pesanti ingerenzi statunitensi nella politica economica dei singoli Paesi europei specie con riguardo alla destinazione delle materie prime locali - per le quali anzi, veniva assicurato agli Stati Uniti un vero e proprio diritto di accesso - e alla utilizzazione delle somme depositate presso la Banca nazionale di ciascuno dei Paesi interessati in controvalore degli aiuti ottenuti. Queste diverse disposizioni offrivano indubbiamente agli Stati Uniti una copertura giuridica alle loro richiesti, anche le più esose, senza che la controparte europea potesse obiettare alcunché proprio perchè "garantite » dal diritto internazionale." (SALERNO, 1981, p. 383-4, grifos do autor).

553 'Le besoin d'aide matérielle, la soif de capitaux de l'Europe sont tels, au lendemain de la Libération, que les États-Unis ne peuvent résister à la tentation d'exploiter leur position de force. Les prêts généreusement consentis, les aides octroyées sont le plus souvent assortis de contreparties politiques et économiques importantes. Il est ainsi, entre autres choses, demandé au gouvernement de la France de stopper ses nationalisations et d'ouvrir le marché français aux compagnies pétrolières états-uniennes. [...]. En réalité, accepter l'aide Marshall, en admettre les conditions, équivalait à s'aligner économiquement, socialement, donc politiquement sur les États-Unis. Le modèle de développement proposé aux Européens de l'ouest est aussi un piège tendue aux gouvernements de l'Europe occupée par l'Armée Rouge." (CARBONELL et alii, 1999b, p. 304, grifos nossos).

No mesmo sentido, v. Francesco SALERNO (1981, p. 382). V., ainda, os comentários na nota de rodapé 554, a seguir.

${ }_{554}$ Dominique BARJOT (2008, p. 9) sinteticamente resume esta percepção com a seguinte frase: "Le plan Marshall ouvre également sur la problématique immense de l'Américanisation.”.

Com efeito, não se pode deixar jamais de notar que o Plano Marshall não consistia em uma simples transferência de montantes financeiros, pois as doações eram acompanhadas de série de exigências de transformações econômicas, sociais e políticas nos Estados europeus e nas relações entre eles: "Le Plan Marhsall veut moderniser les technologies et les esprits. Les Européens ne connaîtraent pas la vraie liberté d'entreprise. Ils ignoraient les vraies lois du marché et craindraient l'ouverture à la concurrence de leurs économies nationales. Enfin, les producteurs européens auraient tout à gagner à s'imprégner des 
Assim, a entrada do Plano Marshall e consequentemente o ingresso da respectiva uniescalaridade estadunidense (RÉAU, 2008, p. 132) foram filtrados por essa instituição de cooperação econômica europeia. A origem da OECE pode ter sido a proposta da escala existencial estadunidense (produto da Guerra Fria), mas sua execução foi feita conforme aceitação dada pela medida da Europa Ocidental (atenta às estatalidades isoladas). Em outras palavras, a OECE continha - porque paralisava - a pretensão unidimensionalizante da escala de existência estadunidense ${ }^{555}$.

Une coopération intergouvernemental est bien prévue, mais pas de
supranationalité $[\ldots]$. L'OECE n'est donc pas un début de "fédération"
européenne. Mais elle permet de mettre en place pour bon l'ERP (European
Recovery Program américain) destiné à financer la reconstruction de l'Europe de
l'Ouest pendant quatre ans. Elle oblige les Européens à un minimum de
coopération $[\ldots]$. (NOËL et alii, 2008, p. 115, grifos nossos).

[D]ès le départ, on n'ose pas donner à l'OECE un caractère supranational et on préfère un schéma intergouvernemental [...] composé des représentants des États, et non de membres indépendants. On s'éloigne inexorablement des intentions américaines. (DAVID, 2008, p. 132-3, grifos nossos).

méthodes américaines de gestion, de production et d'organisation du travail. C'est le sens des « missions de productivité » qui enverront des ingénieurs, des hommes d'affaires et des syndicalistes outreatlantique." (DAVID, 2008, p. 131, grifos nossos).

Lembre-se ainda de que, em Declaração de 1.2.1950, o então Administrador da Cooperação Econômica estadunidense, Paul G. HOFFMAN (1950, p. 2), manifestou a preocupação dos EUA com o estabelecimento de uma organização jurídico-política na Europa de acordo com a percepção dos EUA sobre aquilo que seria melhor para os países europeus.

Nesse sentido, a atuação econômica do garante externo à Europa não se cingia ao espectro econômico: havia profunda vocação auto-assumida de disseminar, ao lado da organização jurídicoeconômica (liberal), um modo jurídico-político também estadunidense de organizar as relações entre os países europeus. Por isso mesmo, aceitar o Plano Marshall a partir das instituições da OECE pode ser percebido como mecanismo de resistência institucional a tal introdução de Leis estranhas à oposição escalar própria à Europa (estatalidades isoladas belicamente contrapostas): aceitara-se a ajuda dos EUA, sem dúvida, mas com condições: não introduzir Leis estranhas à Europa - não se devendo, assim, estranhar que a OECE tenha sido institucionalizada como cooperação econômica intergovernamental, enão como princípio de União política (convivência).

As reformas tecnológica e econômica a partir das lições estadunidenses não deveriam reformar a autocompreensão do problema jurídico-político europeu - a resolução não-armada das oposições escalares tradicionalmente encetadas no continente europeu. Enquanto mera cooperação econômica intergovernamental, o auxílio econômico não conseguiria fundar Leis. E, por isso, o Projeto estadunidense de reformar a vida política na Europa por meio da Economia liberal permanece afastado por escolha institucional consciente dos países europeus - ninguém além deles poderia estabelecer a medida de existência para uma vida comum na Europa. V. ainda a nota de rodapé 555, infra.

555 Como sagazmente percebera François DAVID (2008, p. 132, grifos nossos), "les nations européennes veulent bien réceptionner l'aide américaine, mais la marche vers l'unité politique et économique ne les intéresse pas pour l'instant.". 


\subsubsection{A Cooperação Militar do Pacto de Bruxelas}

Da mesma maneira que a instituição da cooperação econômica entre os países da Europa Ocidental por meio da OECE foi erigida a partir da oposição escalar entre os EUA e a URSS no pós-Segunda Guerra Mundial, a cooperação militar promovida por meio do Pacto de Bruxelas foi igualmente concebida, gestada, instaurada e mantida no interior do contexto da Guerra Fria (BERSTEIN; MILZA, 2002, p. 243; BITSCH, 2006, p. 31 e 39; CAHEN, 1996, p. 22; CARBONELL et alii, 1999b, p. 304-5; DAVID, 2008, p. 138; NOËL et alii, 2008, p. 119; OLIVI; GIACONE, 2007, p. 12; RÉAU, 2008, p. 139 e 203; REUTER, 1965, p. 39; WÆVER, 1998, p. 81-2) ${ }^{556}$.

O Pacto de Bruxelas foi assinado por força de pressões estadunidenses, em 17.3.1948, entre Bélgica, França, Luxemburgo, Países Baixos e Reino Unido, com o objetivo de instituir uma cooperação militar internacional. Esta deveria oferecer aos paísesmembros suficente proteção armada na hipótese de agressão por parte de uma potência inimiga $^{557}$.

A estrutura de cooperação militar do Pacto de Bruxelas prontamente foi considerada como o polo europeu de defesa da região do Atlântico Norte diante de potencial invasão soviética que pudesse fragilizar a Europa Ocidental. Este acordo era parte da tática estadunidense de auxiliar a Europa apenas se esta fizesse um esforço em auxiliar os EUA em suas tensões com a URSS (BITSCH, 2006, p. 39; CANSACCHI, 1973, p. 1013; CARBONELL et alii, 1999b, p. 305; MATTERA, 2002, p. 21; NAPOLETANO; MOLINARO, 1992, p. 734 e 736; NOËL et alii, 2008, p. 119; PERTEK, 2011, p. 14).

556 A preocupação em desenvolver essa cooperação em matéria de defesa na Europa Ocidental deterá contornos bastante similares dos da OECE: ter sido pensada pelos EUA para assegurar em território europeu um mecanismo de defesa apto a conter o avanço da influência soviética.

A partir dessa constatação, é possível antecipar aqui a conclusão deste item: não tendo sido forjada para dar a solução às oposições escalares do interior da Europa Ocidental (estatalidades isoladas), mas para dar instrumentos militares aos EUA para que combatesse materialmente a escala de existência da URSS, o Pacto de Bruxelas poderia ser entendido como detendo origem escalar transcendente aos embates entre as dimensões existenciais próprias da Europa Ocidental. Por isso mesmo, não teria recebido aparato institucional voltado a constituir Leis, mas apenas normas jurídicas comuns (Direito) de cooperação militar entre os Estados-Membros (paradigma de cooperação intergovernamental).

557 O referido Tratado entrou em vigor em 25.8.1948. O texto é modificado em 23.10.1954, por força dos Acordos de Paris, por meio dos quais a Itália e a República Federal da Alemanha ingressaram no Pacto de Bruxelas. A partir deste momento, a cooperação militar entre os sete passou a ser conhecida como União da Europa Ocidental (UEO). Esta Organização Internacional cessou de existir em 30.6.2011, em virtude da entrada em vigor do Tratado de Lisboa, onde se previu cláusula de assistência militar mútua entre os Estadosmembros da UE (artigo 42, parágrafo sete, do Tratado sobre a UE). 
A proposta de criação de um polo europeu de defesa partiu do Secretário de Estado do Reino Unido, Ernest BEVIN, em discurso proferido perante a Câmara dos Comuns, em 22.1.1948. O objetivo de sua intervenção consistiu em propor um maior estreitamento nas relações entre os EUA e a Europa, de maneira a tornar mais forte o acoplamento do eixo de cooperação transatlântico diante da ameaça representada pelo fortalecimento bélico da União Soviética (RÉAU, 2008, p. 139 e 203-4).

Apesar de ter surgido de proposta originalmente britânica, como se pode notar pela proposta de Ernest BEVIN, o Pacto de Bruxelas foi forjado no interior da lógica específica da Guerra Fria (oposição EUA versus URSS), isto é, suas instituições foram também pensadas no sentido de responder à necessidade de fazer frente a uma oposição escalar estranha à tradicionalmente desenvolvida nas relações da Europa Ocidental (oposições entre estatalidades isoladas europeias) ${ }^{558}$. O objetivo do referido Pacto era assegurar mútua assistência automática, por todos os meios, militares ou não, entre os signatários, na hipótese de agressão armada na Europa (BITSCH, 2006, p. 41).

Preocupado com a aposição de mecanismos aptos a fazer frente ao conflito EUA versus URSS, o Pacto de Bruxelas não se dedicara a resolver a questão do tradicional choque entre as dimensões existenciais da Europa Ocidental (estatalidades isoladas opostas internamente entre si militarmente). Seus instrumentos se voltaram a resolver questão externa a ela: aperfeiçoar as relações transatlânticas por meio da sinalização de que seriam fornecidas condições materiais e geográficas estratégicas aos EUA para que estes pudessem encontrar na Europa Ocidental meios para manter seu embate escalar contra a URSS.

Em vez de ter sido pensada para buscar estabelecer vias institucionais específicas para solucionar o embate militar habitual entre estatalidades isoladas da Europa, o Pacto de Bruxelas fora concebido apenas para sinalizar uma preferência por uma aproximação ainda

\footnotetext{
558 Apesar de a Alemanha ser mencionada no Tratado instituidor como potencial agressor, o processo de negociação evidenciou que, com exceção da França, os demais participantes recusaram um texto normativo marcadamente "anti-alemão" e que inviabilizasse o futuro ingresso deste país na cooperação militar europeia posteriormente.

Perceba-se que, na verdade, a principal preocupação dos países-membros do Pacto de Bruxelas consistiu em conferir uma resposta europeia à ameaçadora oposição escalar da Guerra Fria, especialmente no que se refere à ameaça de uma possível invasão soviética da Europa Ocidental (BITSCH, 2006, p. 40-1). Ademais, como relatado nas notas de rodapé 64 e 557, supra, após a rejeição da CED e da CPE, com a assinatura dos Acordos de Paris, a República Federal da Alemanha ingressou na estrutura do Pacto de Bruxelas. Isso permite compreender com mais facilidade que o "inimigo comum" do Pacto de Bruxelas não era especificamente a Alemanha, mas a União Soviética, enquanto portadora de escala de existência em permanente tensão com a dos EUA - não envolvendo, assim, a tradicional oposição entre estatalidades isoladas europeias.
} 
maior das relações entre alguns países do Oeste Europeu e os EUA e, com isso, refoçar condições para que estes dispusessem de arsenal maior para se opôr à URSS.

Pensada como resposta a um problema externo à Europa continental - a oposição EUA versus URSS, as fundações do Pacto de Bruxelas transcendiam aquelas que diziam respeito à imanente e premente questão fundamental das relações da Europa Ocidental: buscar solucionar de maneira inédita (não-armada) os choques habituais entre as estatalidades isoladas do continente europeu (BITSCH, 2006, p. 39-41; BOSSUAT, 1994, p. 120; CARBONELL et alii, 1999b, p. 305). Por isso mesmo, o Projeto de União da Europa por meio do Pacto de Bruxelas foi também institutcionalmente reduzido à condição de simples cooperação intergovernamental - não detendo assim, condições para fundar Leis na Europa a partir de sua dimensão existencial transcendente.

Contrairement à certains espoirs suscités, le pacte de Bruxelles et son organisation permanente - très légère - ne constitueront pas le noyau d'une future organisation de l'Europe. (NOËL et alii, 2008, p. 120, grifos nossos).

O intento de alguns países europeus reforçarem - na esteira aberta anteriormente pela OECE - suas relações transatlânticas com os EUA por meio de Organização Internacional de uma cooperação militar foi imediatamente captado pelo Senado estadunidense. Em 11.6.1948, este aprovou a Resolução proposta por Arthur VANDENBERG, por meio da qual se permitiu ao Governo Federal dos EUA propor e assinar mesmo em tempos de Paz um pacto de assistência mútua e multilateral que abrangesse o território geográfico da Europa Ocidental. Esse futuro pacto de defesa complementaria e englobaria sem reservas o Pacto de Bruxelas.

Em 4.4.1949 foi assinado o Tratado de Washington que instituiu a Organização do Tratado do Atlântico Norte (OTAN) entre o Canadá, os Estados Unidos da América, os cinco membros do Pacto de Bruxelas, Dinamarca, Islândia, Itália, Noruega e Portugal (RÉAU, 2008, p. 205-7). De interesse mais estadunidense do que europeu Ocidental ${ }^{559}$, rapidamente toda a estrutura do Pacto de Bruxelas foi colocada sob o comando da OTAN $^{560}$ - tendo sido, portanto, integrado à estrutura militar estadunidense e colocado

559 Pois voltada ao fornecimento de condições materiais que tornassem os EUA aptos a combater militarmente a escala de existência da URSS, sob o argumento da proteção dos países da Europa Ocidental diante de uma invasão por parte da União Soviética. O Pacto de Bruxelas é produto da oposição escalar externa à Europa Ocidental, não dizendo respeito à solução institucional das tradicionais oposições dimensionais típicas da Europa (estatalidades isoladas contrapostas militarmente).

560 "Si le Pacte de Bruxelles subsiste, ses structures militaires propres disparaissent au profit de la nouvelle organisation intégrée. L'aggravation de la menace à l'Est a conduit les Européens au réalisme. L'aide américaine se manifeste en effet par la présence sur le sol européen de 400000 hommes 
sob o comando dos EUA - centro do sistema de cooperação militar transatlântico (BITSCH, 2006, p. 41-2; CAHEN, 1996, p. 22; CARBONELL et alii, 1999b, p. 305; NAPOLETANO; MOLINARO, 1992, p. 736; NOËL et alii, 2008, p. 125; REUTER, 1965, p. 41 e 133; ZORGBIBE, 1997, p. 18-9).

A transferência integral de toda a competência e de toda a estrutura do Pacto de Bruxelas à OTAN em intervalo de tempo verdadeiramente muito curto é compreensível quando se percebe que as questões daquele Pacto transcendiam a imanente e premente questão fundamental das relações da Europa Ocidental: o Pacto de Bruxelas fora instituído para fazer frente à oposição típica da Guerra Fria. Por isso, "fazia mais sentido" estar a Organização Internacional do Pacto de Bruxelas sob a regência da OTAN $^{561}$ - diretamente implicada nas oposições EUA versus URSS - do que sob o comando direto dos países do Oeste Europeu ${ }^{562}$.

Desconectada institucionalmente dos embates escalares da Europa Ocidental, a cooperação militar do Pacto de Bruxelas deveria ser viabilizada por meio de normas jurídico-positivas de regulação da ação de seus Estados-Membros (Direito Positivo). Contudo, tais normas não poderiam pretender se ordenar no sentido de constituir convivência entre diferentes (Leis) - do contrário, o paradigma regente das relações jurídico-políticas estaria contaminado de antemão por Uma decisão uniescalar perante a oposição dimensional da Guerra Fria, a qual em nada estaria relacionada à pluriescalaridade do Oeste Europeu.

\footnotetext{
Stimulée aussi par la politique de réarmement américain galvanisée par l'explosion de la première bombe atomique soviétique (juillet 1949), la défense intégrée se met en place, à partir de 1950, dans le cadre de l'OTAN. Ainsi, l'Union occidentale se trouve englobée et supplantée par une organisation plus vaste et plus efficiente, dirigée par les Américains. (BITSCH, 2006, p. 42, grifos nossos).
}

"Fazia mais sentido" a transferência integral da estrutura organizacional do Pacto de Bruxelas à OTAN, assim, precisamente porque pouco dizia respeito a origem da

stationnés en grande partie en Allemagne fédérale et par l'aménagement de nombreuses bases aériennes ou navales en Europe. Par ailleurs, le «Mutual Defense Assistance Act» puis le «Mututal Security Act » à partir de 1951 financent une large partie du programme de réarmement des partenaires européens." (RÉAU, 2008, p. 207, grifos nossos).

${ }^{561}$ A qual foi pouco a pouco submetida, logo após sua instituição, ao comando de Oficial das forças armadas estadunidenses (Comandante Supremo das Forças Aliadas na Europa), o General Dwight EISENHOWER (RÉAU, 2008, p. 206-7).

562 "Il Trattato di Bruxelles appare così, innanzi tutto, un patto di garanzia colletiva contro un'aggressione in Europa, costituendo una sorta di nucleo europeo della NATO [...].” (NAPOLETANO; MOLINARO, 1991, p. 737, grifos nossos). 
Organização do Pacto de Bruxelas ao problema fundamental da Europa Ocidental do pós-Segunda Guerra Mundial. Por estar preocupada com a oposição EUA versus URSS, o Pacto de Bruxelas deveria restar sob regência centralizada dos EUA. Afinal, a preocupação da Europa Ocidental era outra: diante da inevitável multiescalaridade na Europa Ocidental, haveria que se estabelecer uma convivência institucional entre tais diferentes, de tal maneira que a incontornável tensão pluriescalar entre tais países não fosse solucionada mediante novo conflito armado.

Assim, a cooperação militar juridicamente operacionalizada respondia às percepções de ordenação do mundo externadas e vividas pela escala de existência dos EUA em oposição à da $\mathbf{U R S S}^{563}$, e não ao problema tradicional das relações entre países na Europa. Por essa razão, não poderia se converter em instrumento de imposição de Leis e, por isso mesmo, foram as instituições dessa Organização Internacional - escalarmente comprometida com uma causa estranha à Europa Ocidental - reduzidas à condição de instrumentos jurídicos promotores de uma simples cooperação militar de caráter intergovernamental ${ }^{564}$.

\subsection{OECE e Pacto de Bruxelas: Reconhecimento Institucional contra Leis}

\section{Externas à Europa}

[L]es mobiles américains ont été [...] inspirés par [...] la croyance que l'excellence des méthodes qui ont conduit à la formation des États-Unis les recommande également pour l'Europe. (REUTER, 1965, p. 38).

Nos itens anteriores se salientou que a OECE e o Pacto de Bruxelas tiveram como origem comum o problema da oposição escalar entre EUA e URSS, isto é, o confronto entre as duas principais medidas de existência da Guerra Fria (BARJOT, 2008, p. 7 e 46; BARNAVI; POMIAN, 2008, p. 80-1 e 85; BOSSUAT, 1994, p. 118-9; DAVID,

\footnotetext{
563 "[O]nce the U.S. homeland became vulnerable [to a nuclear attack from USSR], the United States could not make its nuclear threat credible on behalf of Europe unless there were also ground forces under U.S. command in Europe that could both parry modest conventional threats (without forcing the United States to commit to a nuclear attack in political circumstances that would not justify such devastation) while at the same time serving as hostages whose destruction by a large-scale Soviet ground attack would immediately create the political will to ensure a nuclear American response.” (BOBBITT, 2003, p. 49, grifos nossos).

564 "Secondo la prevalente dottrina 1'U.E.O. non ha raggiunto una tale instituzionalizzazione ed uma tale autonomia di azione esterna rispetto agli Stati membri [...].” (CANSACCHI, 1973, p. 1013), precisamente porque seu objetivo não consistiu em operar o início de uma unificação político-militar da Europa, vale dizer, porque não se voltou a resolver as oposições escalares estatais isoladas europeias no interior de um sistema de convivência na Europa. No mesmo sentido, com acuidade percebera Gérard BOSSUAT (1994, p. 121): "Le pacte de Bruxelles [...] n'instaurait pas de véritables institutions européennes capables d'être à la base d'un processus unitaire continu'.
} 
2008, p. 138; MONNET, 1950, p. 2; NOËL et alii, 2008, p. 113 e 365; OLIVI; GIACONE, 2007, p. 12; QUERMONNE, 2008b, p. 27-8, 2010, p. 15; WÆVER, 1998, p. 91; ZORGBIBE, 1997, p. 15) ${ }^{565}$. Ambas “ont en commun [...] d'être nées non sous la pression du mouvement européen mais sous l'influence des États-Unis et de constituer des jalons significatifs dans l'escalade de la guerre froide." (BITSCH, 2006, p. 31, grifos nossos).

Nesse sentido, devem ser entendidas tais iniciativas de instituição de um sistema de cooperação intergovernamental econômico e militar na Europa como tentativas institucionalmente frustradas - frustradas em virtude de específico arranjo instituicional de transformação dos países europeus em dependentes econômicos e políticos dos EUA, ou ainda, de negar à Europa a condição de ser senhora de seu próprio destino (CARBONELL et alii, 1999b, p. 305 e 311).

\footnotetext{
European governments [...] were not simply the passive recipients of American generosity. They had effectively thwarted a return to isolationism by dragging Washington back into Europe with their scare stories of the menace of communism. If the Americans were now the imperialists, they were there [...] 'by invitation'. The Europeans too had their priorities and strategies [...]. (MAZOWER, 1998, p. 300, grifos nossos).
}

Não direta e imediatamente relacionadas às oposições escalares internas à Europa Ocidental, as origens da OECE e do Pacto de Bruxelas visaram à resolução de um problema distinto do visado pela CECA e mesmo pelo CdE - experiências preocupadas autonomamente com a resolução das tradicionais oposições escalares estatais bélicas interiores à Europa do Ocidente e anteriores mesmo à oposição ideológica e política representada pelos EUA e pela URSS.

A solução institucional pensada para resolver na Europa Ocidental questões relacionadas à oposição escalar gestada externamente a ela consistiu em afirmar um mecanismo jurídico de cooperação intergovernamental entre alguns países europeus em setores especializados (Economia e força militar) (BITSCH, 2006, p. 31; CANSACCHI, 1973, p. 1013; CLERGERIE; GRUBER; RAMBAUD, 2010, p. 41; PERTEK, 2011, p. 13-5; QUERMONNE, 2008b, p. 23; RÉAU, 2007, p. 11-2; VEÇOSO, 2006, p. 29 e 31; ZORGBIBE, 1997, p. 15).

Assim, a decisão pela instituição da OECE e do Pacto de Bruxelas não visou a afirmar um modo de relações de convivência entre diferentes - isto é, a instituir Leis,

$565 \mathrm{Ou}$, o que é o mesmo, os Projetos de aproximação de países europeus promovidos institucionalmente por estas duas soluções tinham por origem uma questão localizada em âmbito externo à Europa Ocidental. 
tal qual buscaram a CECA e a proposta do CdE. Antes, as cooperações econômica e militar se voltaram a disponibilizar meios jurídicos aptos a preservar a Europa Ocidental vis-à-vis o embate escalar extra-europeu mediante a preferência pelas relações transatlânticas. Em outras palavras,

\footnotetext{
les constructions de l'année 1948 font figure de créations de circonstance[, car ont été voulues] par les États-Unis pour contribuer à l'endiguement du communisme en Europe [...]. Spécialisées chacune dans un domaine, économique pour l'une, militaire pour l'autre, les deux organisations répondent à des besoins précis - redresser les économies, assurer la sécurité - beaucoup plus qu'à une profonde aspiration à l'unité européenne. (BITSCH, 2006, p. 43, grifos nossos).
}

Todavia, a fundação transcendente - escala de existência estadunidense em oposição à soviética - da OECE e do Pacto de Bruxelas não encontrou condições suficientes para tornar institucionalmente sua organização jurídico-normativa cooperativa em uma organização jurídico-política de convivência - ou, simplesmente, para instaurar Leis. A introdução na Europa Ocidental desses dispositivos institucionais gerados de acordo com as preocupações de oposições escalares externas à Europa Ocidental foi condicionada à restrição do campo de atividades desses mecanismos ao âmbito da cooperação intergovernamental.

A prudência da solução institucional de questões que transcendiam as preocupações internas à Europa Ocidental consistiu em admitir a presença daquelas desde que não visassem à instituição de Leis na Europa. Aceitaram-se tais instituições originadas de preocupações externas somente se não ultrapassassem os limites do campo de simples aproximação cooperativa entre países. O Direito Internacional Público clássico, arquitetado na modalidade de cooperação, operara aqui como armadilha de contenção de pretensões jurídico-políticas integrativas por parte de iniciativas pouco relacionadas às oposições escalares internas à Europa Ocidental (EUA versus URSS).

O cenário da Guerra Fria explica a origem e a opção pelos meios (cooperação econômica e cooperação militar) da OECE e do Pacto de Bruxelas: a aceitação jurídiconormativa destes implicou a concomitante recusa a lhes atribuir instrumentos institucionais que lhes permitissem organizar jurídico-politicamente as relações entre os países europeus. A instituição de ambas as Organizações Internacionais operara como escudo protetor da Europa com relação a arroubos escalares de origem extraeuropeia - e, portanto, de caráter Teológico-Político, pois transcendiam as tradicionais relações conflituosas entre as estatalidades isoladas da Europa Ocidental. 
Assim, aquilo que assumia potencialmente contornos jurídico-Teológico-Políticos se encontrasse os meios institucionais necessários para organizar as relações na Europa Ocidental segundo a estrita escala de existência estadunidense - foi privado da possibilidade de compor o campo das Leis na Europa. Reconhecidos institucionalmente, foram rejeitados como princípio de organização jurídico-política na Europa Ocidental, pois, com estas Organizações Internacionais, os países europeus visavam precisamente apenas a assegurar a limitada e distante interferência das oposições escalares extraeuropeias na construção de uma vida comum na Europa ${ }^{566}$.

[L]'OECE n'est pas une organisation fédérale, elle prévoit la coopération mais non l'intégration entre les politiques de ses membres. Il en va de même pour l'Union occidentale [le Pacte de Bruxelles]. (NOËL et alii, 2008, p. 1201 , grifos nossos).

Por sua vez, o CdE e a CECA demonstrariam possuir outra raiz explicativa ${ }^{567}$ : a resolução institucional autônoma das oposições escalares tradicionalmente desenvolvidas no interior das relações entre povos europeus - uma via de aproximar politicamente os países europeus para que estes não cedessem à previsível unidimensionalização diante da sedução resultante da influência exercida pelos dois polos de atração do pós-Segunda Guerra Mundial (EUA e URSS) (ADENAUER, 1980d, p. 326, 1980f, 1980h, p. 339).

Deste modo, "construir a Europa" exigia, antes de tudo, estabelecer uma organização jurídico-política entre os principais países europeus apta a formar uma União

566 'GEst-il vrai que l'Europe puisse être sauvée du dehors, par le remède américain ou le remède russe ?

Il est incontestable que les USA se sentent beaucoup plus jeunes que nous, qu'ils nous regardent avec une pitié et un certain mépris qui ne s'expliquent que trop bien. Pour eux, il n'y a pas de problème social, il y a des problèmes sociaux, et le propre d'un problème, c'est d'être, à leurs yeux, éminemment pratique et de comporter une solution. Ils nous accusent d'être sentimentaux, " philosophes », et de chercher midi à quatorze heures. Ils ne sont pas tourmentés comme nous le sommes.

Mais ce qui fait leur force fait en même temps leur faiblesse. Ils peuvent nous donner, non seulement leurs dollars, mais aussi leur esprit, d'initiative, leur dash, leur manque de préjugés sociaux, leur horreur des complications idéologiques. Mais ils ne nous feront pas surmonter notre crise spirituelle. Ils en souffrent eux-mêmes, et s'ils ne s'en aperçoivent encore que rarement, c'est qu'ils essayent encore de passer à côté.

Les Russes ne l'essayent, d'ailleurs, pas moins. Ayant trouvé une solution étonnante à leurs propres problèmes, ils écartent tout ce qui n'entre pas dans leur cadre. Ils n'ont pas, eux non plus, vaincu la crise, ils l'ont « liquidée », ou plutôt, ils ont liquidé ceux qui pourraient leur en rappeler l'existence. Lorsqu'ils parlent de l'Occident, c'est avec autant d'incompréhension que de pertinence. [...].

L'Europe devra donc « se faire elle-même », non pas, sans doute, comme une société spirituellement et politiquement autarcique, mais en ne comptant finalement que sur elle-même." (BRUGMANS, 1947, p. 3, grifos do autor).

567 Como percebera Paulo Borba CASELLA (1994a, p. 80): "Fosse a Europa concebida somente como contraposição ao comunismo, teríamos hoje, Comunidade tão esvaziada de sentido quanto o parece estar a Organização do Tratado de Defesa do Atlântico Norte, a OTAN.”. 
política de países da Europa - vale dizer, exigia o estabelecimento de Leis. Para tanto, não bastaria estabelecer normativamente cooperação intergovernamental: deveriam ser propostos e/ou arquitetados mecanismos qualitativamente distintos, os quais promoveriam a integração da Europa no interior de um sistema de convivência, cuja impulsão deveria advir diretamente dos europeus - e não dos EUA ou da URSS (BITSCH, 2006, p. 45) 568 .

Projetos distintos de aproximação de países europeus exigiram, assim, soluções institucionais distintas, por meio de articulações jurídico-normativas positivas distintas do Direito Internacional Público clássico. No caso da OECE e do Pacto de Bruxelas, restritas a uma dimensão não preocupada com a convivência entre diferentes, bastava a estrita cooperação intergovernamental, por meio de normas de ação. No caso do CdE e da CECA, a resolução interna da oposição entre diferentes dimensões existenciais exigiu o recurso a aranjo institucional inédito das normas jurídicas de Direito Interncional clássica, o qual deveria visar ao estabelecimento de Leis, a fim de evitar a solução armada das tradicionais tensões escalares ${ }^{569}$. É o que se passa a analisar.

\footnotetext{
${ }^{568} \mathrm{~V}$. nesse sentido as considerações dos itens 1.4. e 2.1., supra.

569 “'Or, l'année 1948 constitue, dans l'histoire de la construction européenne, une étape importante. Elle voit en effet l'émergence de différents courants favorables à l'Union européenne et, fait plus significatif, le printemps 1949 est marqué par une volonté de rassemblement de toutes les forces vives qui œuvrent pour l'Europe [...]." (RÉAU, 2008, p. 166).
} 


\title{
QUINTO CAPÍTULO - O CONGRESSO DE HAIA E SUAS REPERCUSSÕES INSTITUCIONAIS NA EUROPA
}

\author{
Seria melhor [...] prevenir, desde o princípio, a superioridade, do que remediá-la \\ depois de tê-la experimentado. [...]. \\ O mal está na origem. Em tudo, o que começou já está feito pela metade. O \\ menor erro cometido no início repercute em tudo que se segue. \\ (ARISTÓTELES, 1998, p. 203 e 207).
}

O Congresso de Haia (CGH) foi realizado nos dias 7-10.5.1948 e deteve importância fundamental na construção do Conselho da Europa (CdE). Sua organização representou a rápida ascensão do ideário europeísta dentre parcela influente da opinião pública europeia.

Sem qualquer compromisso ou vinculação com alguma autoridade pública - por ter sido uma iniciativa privada, o Congresso vocalizou os mais diferentes discursos europeístas desenvolvidos no período do pós-Segunda Guerra Mundial voltados, de uma maneira ou de outra, à promoção de diferentes caminhos para encetar e direcionar uma aproximação institucional permanente e juridicamente mediada entre os países europeus (BITSCH, 2006, p. 46; BOSSUAT, 1994, p. 122; GLAESNER, 1991, p. 287; OLIVI; GIACONE, 2007, p. 13 e 18; PERTEK, 2011, p. 14; RÉAU, 2008, p. 134, 166 e 172; REFALO, 1980, p. 72; REUTER, 1965, p. 40; ROUGEMONT, 1961, p. 410) ${ }^{570}$.

\footnotetext{
${ }^{570}$ Élisabeth du RÉAU (2008, p. 173) destaca poder ser compreendido o CGH de 1948 como evento voltado a convocar "de véritables «États généraux de l'Europe », composés non seulement d'hommes politiques et de militants européens, mais aussi de représentants des forces vives et sociales, économiques, culturelles et spirituelles de la société européenne à construire.". No mesmo sentido, v. relatos de Elie BARNAVI; Krzysztof POMIAN (2008, p. 94), Marie-Thérèse BITSCH (2006, p. 46) e Jean-Louis QUERMONNE (2008b, p. 30).

Com efeito, a pretensão em tornar o CGH local de realização efetiva dos revolucionários "estados gerais da Europa" resultava do Projeto Federalista Europeu de imprimir na Europa condições para instituir uma vida política europeia apta a sustentar um Governo europeu estatal fundado em preceitos Federalistas (ROUGEMONT, 1968, p. 4).

Nesse sentido, importante lembrar aqui a percepção de um dos organizadores do CGH, Alexandre MARC (1948, p. 6-7, grifos nossos) de não tornar o CGH um Congresso "como os outros": "le premier Congrès de l'Europe, s'imposant une discipline librement consentie, échappe au danger de se laisser submerger par un flot de discours sans portée, de discussions sans objet et de déclarations sans lendemain. Il s'agit d'empêcher toute tentative de transformer ce congrès en un concours d'éloquence académique dont le seul résultat pourrait être de paralyser toute velléité d'action. Or, ce n'est pas de discours, c'est d'actes que l'Europe a besoin. Rien ne serait plus néfaste que de se laisser influencer par la fausse prudence de ceux qui prétendent que «l'heure n'est pas encore venue », que « les solutions n'ont pas été suffisamment étudiées », que "les masses ne suivent pas ». Non, l'heure est venue ! La Fédération européenne doit être fondée très rapidement... ou elle ne le sera jamais ! Certes, les solutions toutes faites n'existent pas, mais ce sont précisément les véritables structures fédéralistes qui, seules, permettront de les découvrir. Quant aux « masses », que demandent-elles sinon l'union et la paix ? En vérité, ce sont les chefs qui ne suivent pas !”.
} 
É importante salientar desde já ter sido o Memorando redigido ao final do CGH a principal fonte que lastreou o ideário constitutivo do $\mathrm{CdE}$, cujo caráter inovador reside principalmente na afirmação expressa de almejar a proteção e a promoção dos Direitos Humanos e da Democracia na Europa. Não se queria apenas discutir a Europa Unida: visava-se efetivamente a passar à ação política concreta de União dos diferentes povos europeus $^{571}$. Por isso, mostra-se fundamental examinar as origens, as atividades e as repercussões institucionais para a construção de uma Europa politicamente Unida deste Congresso (RÉAU, 2008, p. 139).

A realização do $\mathrm{CGH}$ foi efetuada de maneira consciente com relação aos projetos de cooperação econômica e militar anteriores (OECE e Pacto de Bruxelas). Em seu Discurso de Abertura do CGH, o então ex-Primeiro Ministro britânico Winston CHURCHILL (1948, p. 3) salientou que apesar de serem fundamentais a ajuda mútua no setor econômico e a organização de um instrumento de defesa militar comum, a melhor coordenação destes seria dada no interior de um programa paralelo de União política da Europa que não ameaçasse as soberanias nacionais ${ }^{572}$.

Se o resultado institucional final obtido foi menor do que o esperado por seus organizadores Federalistas e pela promessa de seus Relatórios Finais ${ }^{573}$, não se pode ignorar que se tratou de primeira tentativa de organização jurídico-política de países europeus. Suas tendências fortemente Teológico-Políticas foram rapidamente obstadas quando da construção do respectivo aparato institucional. Como se poderá verificar a seguir.

\footnotetext{
571 A imagem político-revolucionária detida pelos principais participantes do CGH é evidenciada com bastante clareza no seguinte testemunho do Federalista Europeu Hendrik BRUGMANS (1969, p. 3): "les participants de la conférence initiale ont [...] pu avoir le sentiment d'être soulevés par un vaste espoir et par une volonté ardente de passer à l'action [..., l'un d'eux pu [...] dire que, si La Haye avait possédé une Bastille nationaliste, les Européens l'auraient prise d'assaut ce jour-là".

572 Interessante notar que, contra esta perspectiva de Winston CHURCHILL, no Discurso de Abertura do CGH imediatamente posterior ao do ex-Primeiro Ministro britânico, Hendrik BRUGMANS (1948, p. 2), Presidente da União Europeia dos Federalistas (UEF), apresentara como questão prévia fundamental o estabelecimento, não de uma simples União política da Europa, mas de efetiva Unidade política, isto é, de uma Federação Europeia que, segundo uma perspectiva supranacional, que eliminasse as compartimentações nacionais das decisões.

Mais adiante, no item 5.2., infra, será possível compreender com maiores precisões a contraposição entre o ideário defendido por Winston CHURCHILL (Unionismo Europeu) e o promovido por Hendrik BRUGMANS (Federalismo Europeu).

Por enquanto, cabe apenas evidenciar essa importante oposição de concepções desde o início do $\mathrm{CGH}$, pois é essa a tensão que permeará todas as discussões e, principalmente, os documentos aprovados ao final do Congresso. Conhecer esta divergência de modos de conceber a aproximação política entre os povos europeus permitirá compreender ainda os conflitos que determinaram a constituição do $\mathrm{CdE}$ da maneira como ele se apresentou institucionalmente em 1949: ampla missão (orientação Federalista), mas estruturas institucionais limitadas (orientação Unionista).

${ }^{573}$ Como será visto nos itens a seguir.
} 


\subsection{Origens do Congresso de Haia de 1948}

O grandioso CGH de $1948^{574}$ foi convocado entre 13-14.12.1947 pelo recém-criado Comitê Internacional de Coordenação dos Movimentos pela Unidade Europeia. O CGH reuniu nomes importantes dos Poderes Públicos de diferentes Estados europeus, mas também representantes de associações, de sindicatos e dos demais movimentos que pensavam no período a união entre países europeus, não se podendo esquecer ainda a presença de economistas, de intelectuais e de personalidades publicamente reconhecidas como símbolos da Europa Unida (BARNAVI; POMIAN, 2008, p. 93; BERSTEIN; MILZA, 2002, p. 236; BOSSUAT, 1994, p. 114; LUCATELLO, 1959, p. 131; REUTER, 1965, p. 36; ROLLAND, 2006, p. 523; ROUGEMONT, 1961, p. 409; ZORGBIBE, 1997, p. 19).

O CGH foi realizado nos dias 7-10.5.1948. Nele foram discutidas as principais questões políticas, econômicas e culturais que poderiam facilitar a aproximação dos países europeus. O objetivo do encontro consistia em estimular uma ação concertada entre os Governos da Europa no sentido de encaminhar a uma União política entre os países europeus.

Ce Congrès a réuni les personnalités dirigeantes dans le domaine de la pensée et
dans celui de l'action ; représentant tous les pays libres de l'Europe. Nous voyons
réunis ici des hommes d'État de tous les partis politiques, des dirigeants de toutes
les croyances religieuses, des écrivains en renom, des représentants éminents des
professions libérales, des chefs-industrie, des syndicalistes distingués. Bref, un
cénacle de tout ce qui est essentiel à la vie politique industrielle, culturelle et
spirituelle de l'Europe se trouve réuni dans cette salle historique. Et bien que
chacun ait été invité à titre individuel, le Congrès pourra dans toute conclusion
qu'il atteindra se réclamer à juste titre d'être le porte-parole de l'Europe. Il n'est
que temps en effet que cette voix s'élève, au milieu du chaos et de l'effondrement
résultant des torts et des haines du passé, et parmi les dangers qui menacent
l'heure présente et assombrissent l'avenir. Nous n'échapperons aux périls qui
s'annoncent qu'en oubliant les haines du passé, en laissant s'apaiser les rancoeurs
nationales et l'esprit, de revanche, en faisant disparaitre progressivement les
frontières nationales et les barrières qui aggravent et cristallisent nos divisions
[...]. (CHURCHILL, 1948, p. 2).

O referido encontro se desenvolveu em torno de cerca de 1000 (mil) pessoas, dentre as quais 800 (oitocentas) eram, ou delegados dos diferentes movimentos europeístas, ou

574 Também conhecido como o Congresso da Europa (ROUGEMONT, 1961, p. 409). 
personalidades convidadas. No total, o conjunto de participantes representou 19 (dezenove) países europeus $^{575}$ - dentre os quais a própria Alemanha ${ }^{576}$.

Dentre os congressistas puderam ser identificados 12 (doze) ex-Chefes de Governo, mais de 40 (quarenta) ex-Ministros de Estado, quase 20 (vinte) Ministros em exercício e cerca de uma centena de deputados de diferentes parlamentos nacionais ${ }^{577}$. Destaquem-se entre as principais personalidades presentes os nomes de Konrad ADENAUER, Raymond ARON, Winston CHURCHILL ${ }^{578}$ e Denis de ROUGEMONT.

O CGH foi dividido em três Comissões de Trabalho distintas, a fim de viabilizar a discussão em torno de três principais eixos temáticos (político, econômico e cultural). Após os debates, as Comissões deveriam elaborar um Relatório Preparatório, o qual seria em seguida debatido pelas Comissões Plenárias. Por fim, estas deveriam aprovar Resoluções Finais sobre cada temática (BOSSUAT, 1994, p. 114; RÉAU, 2008, p. 172-6).

Assim, o CGH foi dividido em três Comissões: Comissão política ${ }^{579}$, Comissão econômica e Comissão cultural, cada qual incumbida pela redação de um Relatório Preparatório tematicamente especializado. Cada uma delas foi composta por membros oriundos de diferentes movimentos europeístas do período - condição que marcou profundamente os textos de seus respectivos documentos.

\footnotetext{
575 Os países europeus representados em maior número absoluto foram França - com 168 (cento e sessenta e oito) delegados, Reino Unido - com 145 (cento e quarenta e cinco) delegados e Bélgica - com 68 (sessenta e oito) delegados. (RÉAU, 2008, p. 175-6).

${ }^{576}$ Note-se que a criação da República Federal da Alemanha (RFA), em oposição à República Democrática da Alemanha (RDA), ocorreria um ano depois do Congresso da Haia. Sobre a divisão da Alemanha, remetemos o leitor à nota de rodapé 701, infra.

577 A organização do evento foi completamente privada. Por isso, os congressistas originários dos diferentes Poderes Públicos nacionais estavam presentes no Congresso a título meramente pessoal, isto é, em caráter extraoficial, sem comprometer ou vincular oficialmente seus respectivos Governos (BITSCH, 2006, p. 46; NOËL et alii, 2008, p. 121; RÉAU, 2008, p. 176).

${ }^{578}$ Convidado ao evento a título de Presidente de Honra (BARNAVI; POMIAN, 2008, p. 93-4; RÉAU, 2008, p. 176).

${ }^{579}$ A classificação de uma das Comissões do CGH de 1948 como Comissão política é dada pelos próprios organizadores do evento. Por essa razão, essa designação em nada guarda relação com a distinção entre Político e Teológico-Político adotada pelo presente trabalho (v. item 3.4.3., supra).

Assim, aqui se designa esta Comissão como "Comissão política" para ser fiel às próprias divisões internas do CGH de 1948 e, além disso, para comungar com a terminologia empregada pela tradição historiográfica sobre o referido Congresso ao indicar tal Comissão. Optou-se pela menção às Comissões segundo tradicionalmente a ela se refere para, com isso, evitar desentendimentos desnecessários ou interpretações desviadas sobre o mesmo evento histórico estudado.

Para evitar confusões ou contradições aparentes com a terminologia empregada por este trabalho, optou-se conscientemente pela referência a esta Comissão mediante o uso do termo "político" com "p" minúsculo. Espera-se que, com isso, se possa tornar claro ao leitor o quanto se procurou distanciar a terminologia adotada pelo trabalho da designação dada pela tradição à Comissão.
} 
Antes de apontar especificamente a origem dos componentes de cada Comissão ${ }^{580}$, é fundamental compreender em linhas gerais quais eram os principais movimentos europeístas participantes do Congresso. Isso permitirá evidenciar com maior precisão a diversidade de preocupações e de escalas de existência que entraram em choque nesta "arena privada" de oposições de visões de mundo ${ }^{581}$. É o que se passa a analisar no item a seguir $^{582}$.

\subsection{Principais Movimentos Europeístas Participantes do Congresso de Haia}

${ }^{580} \mathrm{O}$ que permitirá compreender mais profundamente o caráter das proposições de cada uma delas, bem como os encaminhamentos institucionais derivados de seus respectivos Relatórios Preparatórios e Resoluções Finais. V., nesse sentido, os itens 5.3. e 5.4., infra.

581 “Au lendemain de la Seconde Guerre, un vrai débat d'idées oppose les partisans du fédéralisme et ceux qui plaident en faveur de l'unionisme. Le Congrès de La Haye organisé en mai 1948 permet d'explorer les diverses voies de la construction européenne." (RÉAU, 2008, p. 134).

$582 \mathrm{O}$ interesse em expor os principais movimentos europeístas que compunham o CGH de 1948, distintos grosso modo entre Unionistas e Federalistas deriva do fato de que os anos em torno da década de 1950 foram profícuos no que diz respeito aos debates sobre diferentes vias para a realização dos Projetos de Europa Unida no pós-Segunda Guerra Mundial.

Mais do que pretender passar ao largo dessas clivagens dimensionais em torno do sentido a ser dado a uma Europa politicamente Unida no pós-Segunda Guerra Mundial, é fundamental que o conhecimento das origens da construção daquilo que hoje se apresenta como UE tenha consciência histórica precisa sobre essas divisões e sobre esses conflitos entre diferentes escalas de existência.

Em outras palavras, não se podem calar no estudo histórico as vozes divergentes daquilo que hoje se apresenta como um dado. É precisamente nestes momentos de hesitação entre escolhas históricas que à divergência se deve dar a devida atenção, pois nela se revela a riqueza de condições do período estudado evitando-se, assim, tratar apenas de Projetos de Europa Unida "bem-sucedidos", porque presentes nos dias contemporâneos. Essa riqueza é fundamental para o conhecimento, pois ela pode iluminar a reflexão sobre o tempo presente e, com isso, motivar alternativamente não apenas os modos de compreender um fenômeno, mas também motivar a ação no presente em sentido novo.

Assom, perceber a diversidade de possibilidades e a hesitação em torno de algumas das escolhas realizadas no tempo é um meio de viver/realizar utilmente o estudo da História, sem pretender que ela culmine em um fim pretensamente pré-determinado e desprovido alteridade. A intranquilidade no debate sobre modelos de Europa politicamente Unida daquele período deve ser retomada e rememorada com rigor e seriedade no tempos presente, a fim de que a História se mostre útil e revele, para os tempos atuais, que determinada opção institucional vigente não seja preservada como a única possibilidade de institucionalizar juridicamente a União Política da Europa. A consciência sobre as hesitações do passado e sobre as soluções excelentes outrora formuladas pode, se consolidada e considerada a tempo, orientar um novo rumo à ação de imaginação institucional que possa retardar ainda mais o inevitável curso de degeneração.

De todo modo, nota Élisabeth du RÉAU (2008, p. 189-90, grifos nossos) ser aquela a tendência do conhecimento historiográfico europeu atual sobre a História da UE: "[à] l'aube des années cinquante, les débats qui s'engagent entre Européens venus de divers horizons et parmi lesquels figurent des intellectuels originaires de l'Est européen, témoignent de la richesse foisonnante des projets concernant l'Union de l'Europe. Les regards sont bien pluriels et les approches souvent divergentes. L'historiographie européenne a surtout mis en évidence les réalisations concrètes qui ont jalonné les étapes de la construction européenne des années cinquante aux années soixante, et négligé l'examen des grandes controverses qui ont marqué ces années.”. Segundo a mesma autora, dever-se-ia buscar privilegiar a compreensão do ideário que informara os debates em torno dos múltiplos sentidos possíveis a serem dados ao Projeto Europeu nos anos em torno da década de 1950, pois apenas deste modo se poderia compreender mais completamente a condição presente da Europa Unida na UE.

É por esse motivo que este trabalho procura enfatizar no relato de seu estudo histórico, ainda que em linhas gerais, o embate dimensional entre os principais movimentos europeístas; registra-se aqui, assim, o convite para futuras investigações conjuntas sobre o período em trabalhos posteriores. 
Ainda que possam ser matizadas em diferentes subdivisões internas, podem ser distingüidas dentre os movimentos europeístas participantes do CGH de 1948 duas principais tendências, a saber, a Unionista e a Federalista.

Desde o final da Segunda Guerra Mundial estas duas perspectivas foram intensamente debatidas e desenvolvidas por diferentes "écrivains, philosophes, historiens, poètes, juristes [et] théoriciens politiques" (CLERGERIE; GRUBER; RAMBAUD, 2010, p. 34). Cada uma delas detinha uma preocupação própria, isto é, uma era distinta da outra, pois cada uma pensou caminhos institucionais e sentidos normativos específicos para determinar o ritmo e o percurso do processo de construção de uma União política dos países europeus (BARJOT, 2008, p. 9 e 14): “[t]outes ces organisations se veulent à la fois laboratoires d'idées, mouvements de propagande, et groupes de pression capables d'agir sur les gouvernements." (BITSCH, 2006, p. 28).

Cada uma das tendências concebera um Projeto distinto de Europa Unida. E cada um destes deteve a oportunidade de se confrontar discursivamente de maneira bastante intensa no CGH (BARJOT, 2008, p. 7 e 20; BERSTEIN; MILZA, 2002, p. 236; BOSSUAT, 1994, p. 114; NOËL et alii, 2008, p. 121-2; OLIVI; GIACONE, 2007, p. 13; RÉAU, 2008, p. 134; REUTER, 1965, p. 36; ROLLAND, 2006, p. 523; RUTTEN, 2006b, 1:00/3:00).

\subsubsection{Unionismo Europeu: Cooperação Política Intergovernamental $e$} Intangibilidade das Soberanias

O Unionismo tinha o paradigma da cooperação jurídica intergovernamental entre Estados nacionais por meio do Direito Internacional Público clássico como referência fundamental ${ }^{583}$. Os movimentos unionistas são também ditos como portadores de uma concepção confederalista, de coalisão, ou mesmo diplomática de União política da Europa (CLERGERIE; GRUBER; RAMBAUD, 2010, p. 41; MATTERA, 2002, p. 18; OLIVI; GIACONE, 2007, p. 14; PITTA E CUNHA, 2004, p. 38; QUERMONNE, 2008b, p. 23$)^{584}$.

\footnotetext{
${ }^{583}$ Para maiores especificações do paradigma de cooperação, v. considerações constantes da nota de rodapé 2, supra, bem como dos itens 1.4., 1.5. e 2.1., igualmente supra.

${ }^{584}$ Como se poderá compreender mais adequadamente a partir da leitura das linhas a seguir.
} 
Para o Unionismo, as progressivas cooperações entre Estados não deveriam desrespeitar as soberanias estatais ou abandonar a unanimidade como o critério de tomada de decisões. A premissa do Unionismo seria a inquebrantável intangibilidade dos Poderes e das atribuições estatais soberanas. A prevalência exclusiva da vontade estatal sobre a orientação das normas jurídicas internacionais seria a regra, ainda que Organizações Internacionais fossem instituídas. Estas apenas poderiam operar a partir do acordo unânime resultante da barganha política realizada entre as diferentes vontades estatais ${ }^{585}$.

Deste modo, os movimentos europeístas unionistas eram avessos a toda e qualquer tentativa de aproximação política entre Estados que excedesse a estrita cooperação intergovernamental $^{586}$. Os Projetos de Europa Unida concebidos de acordo com esta dimensão se opunham às proposições de estabelecimento de uma Federação europeia, bem como a toda e qualquer fórmula de integração que ameaçasse a soberania estatal ${ }^{587} 588$ (BARNAVI; POMIAN, 2008, p. 94; BERSTEIN; MILZA, 2002, p. 235; BITSCH, 2006, p. 47; CLERGERIE; GRUBER; RAMBAUD, 2010, p. 34; MATTERA, 2002, p. 18; NOËL et alii, 2008, p. 122 e 378-9; OLIVI; GIACONE, 2007, p. 14; QUADROS, 1984, p. 117; QUERMONNE, 2010, p. 13; RÉAU, 2008, p. 167; ROLLAND, 2006, p. 487 e $523)$.

Diferentes discursos europeístas do pós-Segunda Guerra Mundial defenderam na Europa Ocidental a construção de uma Europa politicamente Unida segundo os termos da cooperação intergovernamental unionista. A título exemplificativo, mencionem-se os dois

\footnotetext{
585 “La voie de l'unionisme n'avait rien d'original puisqu'elle s'inspirait de modèles déjà proposés avant guerre." (RÉAU, 2007, p. 10).

586 Por essa razão os movimentos unionistas são também ditos confederalistas de coalisão, ou mesmo diplomáticos.

${ }^{587}$ Em outras palavras, a toda forma de uso alternativo dos institutos de Direito Internacional Público no sentido de direitificar a convivência entre diferentes (ou ainda, ao estabelecimento de Leis sob uma perspectiva formal), fosse ela uma direitificação Política, fosse ela uma direitificação Teológico-Política. Para as definições de cada um dos qualificativos acima utilizados, remetemos à leitura da Parte Primeira desta Tese, principalmente dos itens 1.4., 1.5., 2.1. e 3.4.3., supra.

588 Já em 1944, Hans KELSEN (2011, p. 9-10) observara que "[o] governo de um Estado soberano é pela própria natureza inclinado a resistir a qualquer restrição a sua independência[. S]er membro de um Estado federativo significa abrir mão completamente da independência própria. A resistência contra esse suicídio dos Estados deve, claro, alcançar o grau mais alto imediatamente depois de uma guerra vitoriosa, que aumenta inevitavelmente os sentimentos nacionalistas do povo.”

Talvez por esse motivo consiga Élisabeth du RÉAU (2008, p. 167) afirmar ser esta a postura típica do Reino Unido com relação à proposta de uma Europa politicamente Unida desde os primeiros anos do pósSegunda Guerra Mundial. Vitoriosos, não visualizariam motivos suficientes para abandonar - ainda que parte de - sua Soberania em nome de um Estado Europeu. Remetemos o leitor, ainda, às considerações feitas no item 6.1.1., infra, em torno do Discurso de Winston CHURCHILL, proferido em 1946, na Universidade de Zurique, Suíça, bem como aos comentários constantes da nota de rodapé 753, também infra, sobre a postura britânica com relação à proposta de construção da CECA.
} 
de maior projeção e de maior projeção no CGH, a saber, o Movimento pela Europa Unida (UEM) ${ }^{589}$ e o Conselho Francês pela Europa Unida (CFUE).

O UEM foi oficialmente fundado em janeiro de 1947. Presidido por Winston CHURCHILL e dirigido pelo genro deste - Duncan SANDYS, o UEM obteve maior adesão de suas ideias no Reino Unido. Seu objetivo consistia em produzir uma vasta propaganda que fomentasse a pressão popular necessária para estimular uma concertação política gradual entre os Governos nacionais europeus. O objetivo era produzir entre os países uma união política fundada na lógica de uma cooperação intergovernamental e interparlamentar. Fundado em junho de 1947, o CFUE foi influenciado diretamente pelo UEM e pode ser compreendido como iniciativa espelhada daquele primeiro na França (BOSSUAT, 1994, p. 113-4; BRUGMANS, 1969, p. 5; NOËL et alii, 2008, p. 122; RÉAU, 2007, p. 10, 2008, p. 167-9).

5.2.2. Federalismo Europeu: a Unidade Cultural e o Estado Federal Europeu da Civilização Europeia

O Federalismo europeu é bastante segmentado internamente e ainda hoje se manifesta como fonte produtora de reflexões sobre os destinos institucionais da União da Europa $^{590}$. Apesar disso, suas principais subdivisões detêm em comum a ideia fundamental de que a solução para estabelecer uma União política entre os países europeus derivaria da implantação na Europa de uma organização jurídico-política similar à estabelecida entre os Estados componentes dos EUA, ou mesmo se se seguisse o exemplo dos cantões Suíços.

Para os Federalistas europeus, a única via admissível, esperável e viável para a construção de uma Europa politicamente Unida seria a adoção arrebatadora, imediata e integral de instituições Federais entre todos os Estados europeus. Estes deveriam ser unificados culturalmente em torno de valores comuns derivados de um passado ancestral supostamente compartilhado pela civilização europeia em torno dos Direitos Humanos e da Democracia (CASELLA, 1994a, p. 77 e 84; MATTERA, 2002, p. 17-8; MAZOER, 1998, p. 202-4; MORAVCSIK, 2005, p. 70; NOËL et alii, 2008, p. 378; QUERMONNE, 2010, p. 10 e 13; ROLLAND, 2006, p. 557).

\footnotetext{
${ }^{589}$ Sigla em inglês, referente ao nome original do Movimento: United Europe Movement.

${ }^{590}$ Como restará mais claro a partir da leitura do item 5.4. infra, concernente às repercussões institucionais do CGH. A crescente atuação de importantes centros epistêmicos na atividade de reforço discursivo do pensamento Federalista Europeu na formação do pensamento sobre a UE na própria Europa será mais facilmente percebida. Tudo restará mais claro à medida que a leitura avançar.
} 
Le mot magique d'«Europe» indique, non seulement une région du globe, mais aussi un mode de vie individuelle et commune. Jamais l'Européen n'a accepté durablement la suprématie d'un groupe dominateur. Jamais il n'acceptera d'autorités, si elles ne garantissent les droits de l'homme. L'Europe, c'est un sens de la liberté, dont l'immense majorité des hommes qui ont vécu sous le soleil n'a jamais soupçonné ni les drames, ni les douceurs. [...]

L'Europe, c'est la civilisation des non-conformistes, c'est la terre des hommes continuellement en lutte avec eux-mêmes, c'est le lieu où aucune certitude n'est acceptée comme vérité si elle n'est continuellement redécouverte. D'autres continents se vantent de leur «efficacité», mais c'est le climat européen seul qui rend la vie dangereuse, aventureuse, magnifique et tragique... et par là digne d'être vécue. Partout, le drapeau de l'Europe sera celui de la liberté. (BRUGMANS, 1948, p. 2, grifos nossos).

Os Federalistas europeus eram portadores de uma perspectiva efetivamente ambiciosa e audaciosa. Para estes, o único caminho que livraria definitivamente o continente europeu do flagelo da Guerra seria a introdução abrupta e impetuosa de um Governo Federal Europeu que revolucionasse - ou melhor, eliminasse - o dogma da soberania estatal nacional. Deveriam ser adotadas/impostas imediatamente estruturas institucionais jurídico-políticas típicas de um Estado Federal Europeu ${ }^{591}$, de modo a que este pudesse tomar de uma vez por todas o lugar dos diferentes Estados-nação da Europa ${ }^{592}$

${ }^{591}$ Dentre os próprios Federalistas, é possível efetuar ainda uma distinção. Havia os ditos maximalistas, os quais visavam a convocar uma Assembleia Constituinte Europeia para estabelecer uma Constituição para a Europa, e os possibilistas - ou simplesmente moderados, os quais defendiam ser preferível a simples assinatura de um pacto Federal entre os Estados europeus que transferisse progressivamente e de maneira negociada as soberanias estatais (BITSCH, 2006, p. 47; RÉAU, 2008, p. 170).

${ }^{592}$ Interessante é a provocante crítica de Joseph H. H. WEILER (2005, p. 94) ao caráter "suicida" do discurso defendido pelo Federalismo Europeu: "[i]t would be [...] ironic that an ethos that rejected the nationalism of the Member States gave birth to a new European nation and European nationalism. The problem with the unity vision [within a political union of federal governance] is that its very realization entails its negation.". Segundo o autor, tratar-se-ia de uma mera reprodução mimética em escala europeia - dita supranacional - de uma experiência outrora realizada em âmbito estatal nacional - uma potencial contradição interna ao próprio discurso Federalista Europeu.

No mesmo sentido, Hans KELSEN (2011, p. 5, grifos nossos) salientara, já em 1944, que “[a] proposta de garantir a paz internacional por meio de um Estado mundial [federal] se baseia na suposta analogia entre um Estado mundial e o Estado nacional, no qual se assegura a paz de forma tão eficiente. Essa analogia, entretanto, não parece muito favorável às intenções daqueles que desejam produzir a paz mundial por métodos que concordam com os princípios da democracia: liberdade e igualdade, aplicadas às relações internacionais.”.

Especial atenção se deve dar à parcela final da observação de Hans KELSEN, onde com perspicácia o autor já salientara o potencial ameaçador à liberdade do totalizante discurso Federalista Europeu, na medida em que sua realização poderia implicar o desrespeito à livre escolha do próprio estatuto político por seus integrantes. Haveria uma potencial contradição totalizante no interior do libertário discurso Federalista Europeu. Remetemos o leitor às considerações desenvolvidas no item 5.2.2.2., infra, em que se critica o discurso Federalista Europeu de modo circunstanciado. À medida que a leitura avançar, será possível perceber no interior do ideário do Federalismo Europeu uma grande proximidade deste com relação a uma orientação Teológico-Política.

Ademais, como se poderá ver mais adiante, a projeção de modelo de União Federal do interior da experiência estatal para uma dimensão maior não se restringia a um simples Projeto de Federação Europeia. O discurso Federalista Europeu visava em última instância à instituição de uma União Federal Mundial, concebendo a via Federalista como a única possível para instaurar universalmente a Paz entre os Homens - 
(BARNAVI; POMIAN, 2008, p. 94; BERSTEIN; MILZA, 2002, p. 235; CASELLA, 1994a, p. 84; CLERGERIE; GRUBER; RAMBAUD, 2010, p. 34 e 41; GERBET, 2004, 0:31/0:50; MATTERA, 2002, 17-8; MORAVCSIK, 2005, p. 70; OLIVI; GIACONE, 2007, p. 14-5; PITTA E CUNHA, 2004, p. 38; QUADROS, 1984, p. 118; RÉAU, 2007, p. 10; ROLLAND, 2006, p. 487 e 557; SFORZA, 1950, p. 2).

\begin{abstract}
Au delà des traités, toujours révocables, au delà des conciliabules toujours susceptibles de s'enliser, nous voulons que soient créées des institutions européennes fédérales, ayant force d'autorité, et capables de cristalliser une société nouvelle des peuples. [...].

Rien ne sert d'élaborer des comités intergouvernementaux, où des fonctionnaires ministériels, continueraient à représenter leurs «raisons d'État». Jamais un rassemblement des États souverains ne nous sauvera du nationalisme - de ce nationalisme à la fois pitoyable et redoutable, qui (selon le congrès des catholiques allemands en 1923) constitue «la plus grande hérésie de notre époque».

Coopération des Seize, pacte de Bruxelles - nous y applaudissons.

Mais nous ajoutons que rien n'aura été fait, tant que le dogme de la sacrosainte souveraineté nationale n'aura pas été renversé [...]. (BRUGMANS, 1948, p. 3, grifos nossos).
\end{abstract}

Deste modo, segundo a perspectiva Federalista Europeia, haveria que se operar uma súbita limitação das soberanias estatais nacionais europeias em favor de uma autoridade central comum na Europa: o Estado Federal Europeu ${ }^{593}$. Este deveria estabelecer supranacionalmente e de forma descendente - "de cima a baixo" - os termos padronizados da União política entre os países europeus em todas as dimensões da vida humana. A condição prévia fundamental era a assunção integral e inquestionada de uma imaginada escala de existência europeia derivada da tradição dos Direitos Humanos e da Democracia $^{594}$ para, a partir dela, promover a unificação política e cultural da Europa

como comprovam os Programas Federalistas aprovados nos Congressos da UEF, examinados no item 5.2.2.2., infra, e mesmo a supramencionada análise de Hans $\operatorname{KELSEN~(2011,~p.~5).~}$

Note-se, ainda, que em seu Memorandum sobre o CGH, Duncan SANDYS $(1948$, p. 2) apontava acidamente ser desconcertante a leviana crença de que "all that is needed is to apply the same ideals, seek the same goal, and work the same machinery on a bigger scale, and all will be well.". A crítica ao pensamento Federalista Europeu desenvolvida por este trabalho restará pouco a pouco mais clara, à medida que a leitura avançar.

593 'Les fédéralistes étaient en effet les plus audacieux des partisans de la construction européenne ; ils souhaitaient l'instauration d'un gouvernement fédéral européen. Ils admettaient donc la limitation de la souveraineté des États au profit d'une institution centrale." (RÉAU, 2008, p. 169).

${ }^{594}$ Note-se aqui a forte pretensão civilizatória do pensamento Federalista Europeu: "[Le Fédéralisme], plus ambitieu[x], porte [...] un projet de civilisation européenne. [...]. Il s'agit bien de créer un État fédéral européen. [Mais 1]'ambition de ce fédéralisme est donc de ne pas s'en tenir aux structures inter-nationales mais aussi intra-nationales. L'idée européenne au sens strict est [...] ici le véhicule d'un projet qui la dépasse: il s'agit de sauver «les valeurs fondamentales de la civilisation européenne »; de lutter «contre l'anarchie spirituelle, économique et politique » et «l'absence d'un grand but constructif commun » [...]." (ROLLAND, 2006, p. 557, grifos nossos). 
(BRUGMANS, 1948, p. 2-3; NOËL et alii, 2008, p. 122; PITTA E CUNHA, 2004, p. 38; RÉAU, 2008, p. 165 e 169-71; ROLLAND, 2006, p. 523 e 557) ${ }^{595}$.

595 Aqui começam a se revelar os primeiros caracteres Teológico-Políticos do Federalismo, os quais restarão mais evidentes à medida que esta vertente for mais bem detalhada nas próximas linhas: o Federalismo tem como princípio motor a imposição vertical e integral - em avalanche - de um novo modo de vida único entre os países europeus. De acordo com seu discurso pedagógico-doutrinador, os povos que compunham tais países deveriam tomar consciência de seus pretensos termos comuns unificadores (RÉAU, 2008, p. 166), os quais estabeleceriam sua pretensa unidade imaginada.

O Federalismo seria a "luz" escolhida para promover a revelação desta verdade inabalável da unidade comum dos povos europeus, ou ainda, a centelha destinada a difundir a "Boa Nova" ressurgida no pós-Segunda Guerra Mundial. E inúmeros seriam os meios instituídos para disseminar a palavra Federalista e seus cânones.

Se o Unionismo participara do CGH de 1948, foi o Federalismo quem lograra maior êxito nas discussões daquele grandioso encontro. Isso implica reconhecer desde já que as Resoluções Finais deste serão profundamente marcadas pelos caracteres do Federalismo - oportunamente aproximados, nas linhas a seguir, de um discurso Teológico-Político. Apesar deste sucesso do Federalismo no CGH, este será institucionalmente rejeitado quando da determinação normativa dos jogos de Poder entre escalas de existência jurídico-politicamente organizadas - como restará mais evidente quando da leitura das repercussões institucionais do $\mathrm{CGH}$, o que refreou pretensões unidimensionalizantes do CdE (item 5.4.2., infra). Todavia, centros culturais de aperfeiçoamento e difusores do evangelho Federalista serão logo após instituídos na Europa (item 5.4.1., infra).

Em virtude do sucesso da influência Federalista nas Resoluções Finais formuladas no CGH de 1948, maior atenção foi dedicada neste item 5.2. ao detalhamento do discurso Federalista, em detrimento do discurso Unionista. Isso permitirá evidenciar mais claramente os contornos Teológico-Políticos informadores do Federalismo europeu.

Em outras palavras, o foco privilegiado no Federalismo neste Capítulo se justifica precisamente pelo fato de ter sido ele a vertente ao mesmo tempo bem-sucedida no CGH de 1948, mas institucionalmente rejeitada quando da criação do CdE. Essa aprovação privada do Federalismo, seguida de sua rejeição pública por meio do CdE, sugere a opção na Europa Ocidental por uma organização jurídico-Política das relações entre as diferentes escalas de existência implicadas na vida comum da Europa.

Ademais, há que se delinear com mais precisão o Federalismo - comparativamente ao Unionismo também porque é precisamente desta posição Federalista Europeia (e de suas respectivas Leis Teológico-Políticas) que o trabalho busca afastar conceitualmente a CECA. Se em um primeiro momento pode restar claro que a CECA (convivência direitificada para a permanência da pluralidade escalar em múltiplos níveis: estatalidade, supranacionalidade e populidade) se afasta das propostas Unionistas (cooperação meramente intergovernamental), podem surgir dúvidas com relação à diferença entre a CECA e as propostas Federalistas (convivência direitificada para a unificação da pluralidade estatal por meio dos Direitos Humanos e da Democracia).

Com efeito, mais adiante será possível perceber que nem o Unionismo, nem o Federalismo, prevaleceram quando da construção da CECA. Enquanto o primeiro propugnara pela assunção de uma simples cooperação intergovernamental (presença de Direito Positivo, mas ausência de Leis), o último defendia a introdução de Leis Teológico-Políticas por meio de Direito Positivo (convivência unificadora da pluralidade). V., nesse sentido, a nota de rodapé 479, supra, e a nota de rodapé 734, infra.

Se é claro que a CECA se afasta de um esquema tradicional de cooperação entre países (Unionismo), a Parte Primeira deste estudo identificou alguma dificuldade na literatura nacional e estrangeira em afirmar que a integração promovida pelas instituições da CECA era qualitativamente diferenciada daquela pretendida pelas do CdE (Federalismo) (ACCIOLY; NASCIMENTO E SILVA; CASELLA, 2009, p. 427; BERL, 1961, p. 4; BOBBITT, 2011; CARBONELL et alii, 1999a, 1999b; CLERGERIE; GRUBER; RAMBAUD, 2010, p. 42; HABERMAS, 2011a; PILOTTI, 1959, p. 76; POZO, 2011a, p. 63; RAMOS, 2005, p. 648-9 e 657; ROUGEMONT, 1961, p. 411-2; SERRANO, 2011; VEÇOSO, 2006, p. 32-3; WEILER, 2011).

A CECA foi precisamente a opção tomada em 1951 para impedir o sucesso do Projeto Federalista Europeu que rondava a Europa (QUADROS, 1984, p. 121). Tratou-se a CECA de efetiva via institucional alternativa ao caminho arquitetado unidimensionalmente pelo Federalismo para o período (RÉAU, 2008, p. 195-6). E, por isso, nada mais coerente do que pretender apontar os elementos característicos do Federalismo Europeu, a fim de especificar com detalhes mais precisos de que maneira a CECA se distancia do Federalismo Europeu. Sabendo aquilo que não era a CECA, pode-sesaber mais sobre o que era a CECA ela mesma. 
Diferentes discursos europeístas do pós-Segunda Guerra Mundial defenderam na Europa Ocidental a construção de uma Europa Federalmente Unida. A título exemplificativo, mencionam-se aqui os dois que participaram do CGH e que detiveram maior projeção, a saber, as Novas Equipes Internacionais (NEI) e a União Europeia de Federalistas (UEF).

\subsubsection{As Novas Equipes Internacionais (NEI)}

\subsection{Origens das NEI}

As NEI foram constituídas em março de 1947, em Lucerna, na Suíça. Compostas por membros oriundos de diferentes realidades geográficas cristãs - tais como da Alemanha, refugiados ou exilados do País Basco, da Tchecoslováquia, da Polônia, da Romênia, da Hungria e da Bulgária.

O nome NEI foi escolhido para aparentar uma maior neutralidade possível. Buscara-se não comprometer o impacto da atuação internacional da NEI nos países cujas Constituições asseguravam a laicidade do Estado; assim, para afastar a percepção de que haveria eventual influência religiosa nas questões políticas fundamentais daqueles países, optou-se pela designação mais neutra de NEI (RUTTER, 2006, 1:44/2:52).

\subsection{O Projeto Europeu das NEI: Diálogos com o Teológico-Político}

Inicialmente as NEI foram concebidas para apenas discutir as variadas formas possíveis de cooperação entre os partidos cristãos existentes no interior de cada um dos países europeus, sem qualquer Projeto de Unificação política da Europa pré-definido (RUTTEN, 2006a, 1:28/1:42 e 3:00/4:30). Todavia, após a cristalização de um ideário

Com efeito, a CECA teria adotado pragmaticamente - tal qual sugerido pela Parte Primeira desta Tese (principalmente no item 2.1., supra), e como se mostrará neste estudo histórico, bem como no Sétimo Capítulo, infra - a disposição em se organizar jurídico-Politicamente no sentido de estabelecer Leis de convivência plural permanente. O exato meio-termo entre a completa unificação transcendente (Federalismo) e a persistência de uma simples dispersão apenas mais racionalmente organizada (Unionismo) parece ter sido a opção institucional (Funcionalista) dos fundadores da CECA - União Política, isto é, não-unificadora, mediante direitificação das relações dos países fundadores por modo novo de arranjar as clássicas normas do Direito Internacional Público.

Assim, nada mais correto concluir que pequena fora a influência do Unionismo (cooperação) e do Federalismo (convivência Teológico-Política) na construção da CECA (convivência Política), segundo a perspectiva dita Funcionalista (v. nota de rodapé 734, infra). E, portanto, que a CECA se tratou de articulação institucional singular do período selecionado para estudo por esta Tese de Doutorado (1945 a 1951). Como se poderá ver a seguir, especialmente ao final do item 6.2., infra. 
europeísta na Europa, pouco a pouco as NEI forjaram uma proposta de Federalização de países europeus com fundamento nos valores cristãos.

Segundo o Projeto desenvolvido pelas NEI, a Europa Unida deveria ter como cimento e como objetivo a realização de valores democráticos cristãos. Para tanto, especial enfoque deveria ser dado à temática social, principalmente por meio da realização dos universais Direitos Humanos e do respeito à pessoa humana. Um de seus principais nomes foi o futuro primeiro Chanceler da República Federal da Alemanha, Konrad ADENAUER $^{596}$ (BRUGMANS, 1969, p. 6; NOËL et alii, 2008, p. 122; RÉAU, 2008, p. 169-71 e 191-2).

Revela-se aqui uma perspectiva que permite desvelar um primeiro elemento Teológico-Político no discurso Federalista europeu: o lastro na assumida universalidade dos Direitos Humanos e da Democracia ${ }^{597}$. O discurso Federalista europeu que vai se manifestar vigorosamente no interior do $\mathrm{CGH}$ de $1948^{598}$ detinha forte comprometimento com a busca da realização universal e uniforme dos preceitos dos Direitos Humanos e da Democracia na Europa - discursos absolutos potencialmente tão unidimensionais e totalizantes quanto o discurso religioso ${ }^{599}$.

596 “En janvier 1948, à Luxembourg, Konrad Adenauer prononçait son premier discours devant le Congrès des NEI. Il fit alors une forte impression et quelques mois plus tard, il était invité à participer au Congrès de La Haye." (RÉAU, 2008, p. 171).

${ }^{597}$ Não é jamais demasiado lembrar que os termos "Direitos Humanos" e "Democracia" não constam do texto do Tratado da CECA (RAMOS, 2005, p. 58-61; VEÇOSO, 2006, p. 249; WEILER, 2011). Como se poderá conferir nos itens 6.2. e 6.3., bem como nos comentários aduzidos no Sétimo Capítulo, todos infra.

${ }^{598}$ Como será visto nos itens a seguir.

599 Interessante lembrar a observação de Elie BARNAVI; Krzysztif POMIAN (2008, p. 105), “[c]e n'est d'ailleurs pas un hasard si l'Église soutient avec enthousiasme le projet européen: ne serait-ce pas là la résurrection de la République chrétienne morte sous les coups conjugués de la réforme et de l'État moderne?". No mesmo sentido, a observação final feita por Teresa Molina SCHMIDT (2012), ao final de sua apresentação, de que mais e mais se poderia perceber no atual Projeto de Unificação política da Europa uma profunda influência do discurso religioso cristão.

De todo modo, lembre-se aqui de que o fundamento Teológico-Político de uma organização jurídico-política de relações entre diferentes escalas de existência não reside apenas em discursos religiosos, mas em todo discurso que pretender se instaurar impositivamente sobre a pluralidade escalar do real para, com isso, passar a ditar o sentido normativo último sobre as questões envolvendo o Direito e o Poder a partir de sua própria regra de existência (unidimensionalmente).

Assim, como visto anteriormente, na Parte Primeira desta Tese, são discursos fundadores do Teológico-Político aqueles que reconhecem que algo ou alguém é o Poder: um Deus, um Homem-Deus, a religião, o Estado, o interesse nacional, a necessidade, a fortuna, a religião de Estado, a razão de Estado, a razão, a Revolução, o proletariado, o Partido, a Economia, a razão econômica, entre outros fundamentos sobrenaturais reputados naturais (inclusive, "racionalmente naturais", ou ainda, "racionais por natureza") (LEFORT, 1991, 1992a, p. 149, 2007c, p. 246).

Nesse sentido, a qualidade Teológico-Política do discurso Federalista evidenciado pelas propostas das NEI não derivam simplesmente do fato de estas (i) suporem uma comunidade cultural europeia em torno de valores religiosos cristãos; (ii) visarem à realização de valores religiosos cristãos; e (iii) identificarem os valores da religião cristã com os Direitos Humanos e a Democracia. Não se trata de discutir aqui a Religião como fundamento cultural de uma comunidade. 
Trata-se, antes, de colocar em evidência uma perspectiva instrumental de uso (Teológico)político da pretensão universalista, impositiva e incondicional de origem religiosa cristã por meio de sua associação imediata - por meio de artifícios retóricos - ao discurso dos Direitos Humanos e da Democracia, a fim de lançar as bases do discurso do Federalismo europeu. Esse universalismo, sustentáculo de uma incondicionalidade de realização, é bastante semelhante a diversos discursos extremistas e fundamentalistas em nome de Deus, em suas diferentes formas. Há aqui profundo intento de efetuar uma mescla entre religião e politica...

Alexander von CAMPENHAUSEN (2010, p. 42) teria identificado este vínculo visceral entre a religião ocidental cristã e a tradição dos Direitos Humanos e da Democracia: "Ein Blick in die Geschichte zeigt, da $\beta$ das Christentum eine wesentliche Voraussetzung für das Funktionieren des modernes säkularen grundrechtsgestützen Rechtsstaats ist. Heute fragt man sich, ob die Idee allgemeiner Grundrechte als Produkt der europäisch-nordatlantischen Zivilisation auch nach Asien und Afrika exportiert werden kann. Es ist offen, ob und inwieweit andere Kulturen mit anderen Wertvorstellungen, Sozialstrukturen Nährboden und Entfaltungsmöglichkeiten für Menschenrechte bieten. Allgemeiner formuliert: Es ist eine offene Frage, ob Grund- und Menschenrechte und Demokratie in einer Welt ohne Christentum auf Dauer bestehen könnten.”. É nesta linha que argumenta o Federalismo Europeu que informou a redação da Resolução cultural aprovada ao final do CGH (2006b, p. 538): seria possível esperar ao menos da Europa Ocidental a possibilidade de se manter os Direitos Humanos e a Democracia no interior de um Estado Federal Europeu, tendo em vista uma suposta identidade cultural una na Europa, dada pela tradição religiosa cristã.

De todo modo, há que se notar que Paulo Borba CASELLA (2012, p. 56) já advertia que "[n]ão se vá, como tantos, sem razão, o fazem, de arrogar-se o direito de falar em nome de Deus - tantos, na política internacional, como na interna, fazem isso, de modo desastrado e desastroso.”. Por isso, não se poderia se esquecer de que "[e]xistem as coisas de Deus, como existem as coisas de César, no sentido das coisas do mundo: cada uma tem a sua esfera de atuação e competência distintas.". Tantas outras formas menos religiosas buscaram alçar a unidimensionalização igualmente traçada pelo discurso em nome de Deus: nacionalismos, capitalismo, socialismo... (v., nesse sentido, as notas de rodapé 612 e 694, ambas infra).

E, por que não, o Federalismo Europeu, fundado nos Direitos Humanos e na Democracia? Não se pode ignorar que Direitos Humanos e Democracia foram recentemente invocados como justificativas universais para o cometimento de monstruosidades: "Mesmo uma potência altamente moderna como os EUA reincidem no falso universalismo dos antigos impérios, quando em questões de justiça internacional substituem o direito positivo pela ética e a moral. Na perspectiva de Bush 'nossos' valores são universalmente válidos, que tod[a]s as outras nações devem aceitar pelo seu próprio bem. O falso universalismo é um etnocentrismo alargado ao geral. E uma teoria da guerra justa, que deriva de tradições teológicas e do direito natural, não faz nenhuma objeção a esse universalismo, ainda que hoje em dia apareça sob um manto comunitarista.”. (HABERMAS, 2006, p. 105-6, grifos nossos).

"[P]recisamos sempre lembrar que os Estados Unidos são, em certa medida, uma potência ideológica que se originou, tanto quanto a União Soviética, de uma revolução; por esse motivo, eles sentem a necessidade de impor ao mundo seus próprios princípios, como parte essencial de sua política externa. Isto pode ser muito perigoso. Não tenho dúvida de que os Estados Unidos gostariam de mudar o mundo, e que a defesa dos direitos humanos faz parte dessa ambição; a despeito disso, não consigo citar um caso em que os Estados Unidos tenham ido à guerra apenas para fazer o bem, sem que estivessem em risco interesses nacionais importantes." (HOBSBAWM, 2000, p. 25, grifos nossos). Mesmo que se aja sinceramente em nome da concretização dos Direitos Humanos, deve-se colocar outra questão, ainda mais importante, dada a pluralidade escalar: "Seria justo que os direitos humanos se transformassem em recurso ocidental de uniformização da mundialidade, a partir de seus critérios e formas culturais?" (BITTAR, 2005, p. 354, grifos nossos), visto que “[n]ada nos justifica 'colocar em risco' a vida e o sofrimento de outros por objetivos que nós mesmos escolhemos. Todo assassinato é excessivo." (HABERMAS, 2006, p. 20).

Do mesmo modo, com o argumento da Democracia, vale mencionar a reflexão da Paulo Borba CASELLA (2008, p. 718, grifos do autor), em que se ressalta a proximidade de sua afirmação incondicional e pretensamente universal com o extremismo religioso: "A má leitura do Corão pelos supostos fundamentalistas-extremistas é claramente manipulada, para usar da fé como elemento instigador de conflito. O ocidente em armas, invadindo países árabes, em nome da 'democracia' e alegações dessa laia em nada facilitam seja o diálogo entre os dois mundos, seja a veiculação de idéias moderadas, afastando a confrontação, entre os povos árabes. Diálogo de 'surdos' com deploráveis resultados, que estamos vendo. O acirramento dos conflitos, da tensão e do medo somente beneficiam os terroristas. [...] Não é matéria na qual um lado possa pretender aniquilar o outro, para impor a sua vontade e o seu modelo. Portanto, somente a contemporização e a acomodação entre as diferentes correntes poderia ser validamente tentada. Não é o que se está vendo, lamentavelmente. [...]". 
Há aqui um primeiro sinal de que a organização jurídico-política proposta pelo movimento europeísta Federal das NEI se aproxima do intento de instaurar Leis TeológicoPolíticas (unificação da pluralidade): a diversidade Federal propugnada pelas NEI era a diversidade da pluralidade controlada, ou ainda, domada pela suposta unidade cultural de origem religosa cristã.

Nesse sentido, não se pode deixar de observar aqui que o discurso a favor da organização jurídico-política da Europa se mescla com outro, de caráter religioso. Este último se autoproclamava elemento fundante da nova ordem política a ser estabelecida na Europa: a União política dos países europeus deteria uma raiz religiosa (o
cristianismo) entendida como universalmente compartilhada entre os países.

É esta matriz religiosa assumida como comum que pauta os termos da realização da planejada futura organização jurídico-política da Europa. Os Estados-membros seriam reconhecidos como aptos a integrar a futura Europa politicamente Unida e chamados compô-la desde que detivessem de antemão uma compatibilidade genética prévia: (i) respeito dos Direitos Humanos e da Democracia; como manifestação direta de um (ii)

Lembre-se que já em 1944 Hans KELSEN (2011, p. xi) observara uma pretensa "equivalência" dos resultados dos sacrifícios religiosos com os resultados dos nacionalismos no início do século XX: "[q]uando, na história das religiões, aprendemos sobre os sacrifícios humanos oferecidos pelos povos primitivos a seus deuses; quando lemos que os incas, índios relativamente civilizados, imolavam até os próprios filhos nos altares de seus ídolos da maneira mais cruel possível, permitindo que os sacerdotes abrissem o peito da vítima e lhe retirassem o coração ainda pulsando; quando em vão procuramos entender como os próprios pais podiam suportar esse sofrimento, sentimos alívio na confortável consciência de viver em uma época esclarecida, sob as bênçãos de uma religião superior, que nos faz compreender o supremo dever de preservar a vida humana. Será que nós, integrantes de uma civilização cristã, temos mesmo o direito de sentir esse alívio moral? Podemos nos considerar tão mais avançados em comparação com os aborígines do Peru? O nosso século XX não deu à humanidade, juntamente com as realizações mais prodigiosas da tecnologia, duas guerras mundiais cujos sacrifícios humanos ofuscaram com grande vantagem o assassínio de crianças pelos incas pagãos? Será que podemos nos recusar a compreender esses pais e mães enquanto nós mesmos nos orgulhamos tanto de depositar a flor de nossa juventude em altares que só diferem daqueles dos incas pelo fato de não haver nenhuma religião que justifique o derramamento do precioso sangue por nada a não ser a insensatez nacionalista?'.

Outras escalas de existência não-religiosas podem ser igualmente produtoras de sofrimentos tão profundos quanto os realizados em nome de Deus - principalmente quando utilizadas instrumentalmente no campo da organização jurídico-política de relações pluridimensionais. Nacionalismo, socialismo, capitalismo, Federalismo, Direitos Humanos e Democracia talvez também não escapem do intento civilizador, colonizador, evangélico, de profusão uniforme da Paz do cemitério da uniescalaridade (v., nesse sentido, as notas de rodapé 612 e 694, ambas infra).

"Trata-se também de se perceber que a questão de direitos humanos não é um legado ocidental a ser imposto a povos orientais, e muito menos um legado do norte a ser imposto ao sul. Com clareza é que se pode dizer que nem o extremismo individualista europeu e americano, nem o extremismo fundamentalista muçulmano e asiático colaboram com uma visão de mundo que não dê origem a maiores desentendimentos étnicos, religiosos, políticos, sociais e econômicos." (BITTAR, 2005, p. 351-2).

De todo modo, há que se lembrar de que em outras oportunidades, argumentamos pelo caráter Teológico-Político dos Direitos Humanos como fundamento do Direito Internacional (ou ainda, do DIDH) (GIANNATTASIO, 2010b, 2011a, 2011b). Não é o caso de retomar a extensão do argumento neste texto, sob pena de extrapolar os objetivos deste trabalho. Apenas foram mencionados aqui os principais aspectos do raciocínio, a fim de reforçar a conclusão pelo fundamento Teológico-Político do discurso Federalista, calcado na realização dos Direitos Humanos e da Democracia. 
fundamento da vida política nos valores religiosos cristãos. A dupla "Palavra" deveria ter sido previamente aceita no coração da organização jurídico-política de cada Estadomembro para que pudesse formar igualmente uma União política da Europa marcada pela "Boa Nova" Federalista das NEI.

Todavia, é imprescindível ainda esclarecer com maiores precisões os fundamentos mais importates dessa tendência de unificação. A análise do próximo item permitirá tornar mais claro que o Projeto Federalista Europeu assumia contornos muito próximos dos de um discurso Teológico-Político - bastante distinto do assumido institucionalmente pela $\mathrm{CECA}^{600}$. Passa-se a discutir com detalhes o discurso difundido pelo movimento europeísta Federal de maior projeção, a saber, a UEF.

\subsubsection{A União Europeia dos Federalistas (UEF)}

\subsubsection{Origens da UEF}

A UEF foi o principal órgão de coordenação dos movimentos Federalistas Europeus e representou um dos movimentos europeístas Federalistas mais ativos (ROLLAND, 2006, p. 487) ${ }^{601}$. Primeira grande associação transnacional (BITSCH, 2006, p. 27), a UEF se reuniu pela primeira vez em Genebra, em Maio de 1945, em caráter ainda informal. Sua constituição oficial e formalizada ocorreu em 1946, em reunião realizada em Paris. Pouco a pouco a UEF aumentou seu alcance entre os Estados europeus: já em seu encontro realizado em Amsterdã, em Abril de 1947, foram reunidos membros de doze países europeus. Seu primeiro Presidente foi o holandês Hendrik BRUGMANS.

Em seu primeiro grande Congresso, realizado em Montreux, na Suíça, em Agosto de $1947^{602}$, a UEF sinalizara que apenas uma Europa Unida nos termos de um pacto federativo simultaneamente econômico e político poderia absorver a Alemanha e solucionar de maneira definitiva o relacionamento tumultuado desta com o restante do continente. Naquele momento, a UEF já sinalizava sua convicção de ser um pacto

${ }^{600}$ Como se poderá ver a seguir, no item 6.2., infra.

601 O próprio Programa de Ação da UEF adotado por esta entidade em seu Congresso realizado em Montreux, em Agosto de 1947, reconhecia ser a UEF o principal centro de reunião e de coordenação dos movimentos europeístas Federalistas. O objetivo desta coordenação consistia em articulá-los no interior de uma única entidade, a fim de se formar entre todos, a despeito do variado conjunto, uma única voz (UEF, 2006b, p. 489).

602 "À cette date, l'organisation rassemblait déjà plus de 100000 membres et était très bien représentée en Italie, en Europe centrale, en France, où l'un des mouvements représentés, la Fédération, regroupe 25000 personnes.” (RÈAU, 2008, p. 170). 
federativo o único caminho admissível para resolver adequadamente as oposições entre os Estados-nacionais europeus. Um de seus principais nomes foi o suíço Denis de ROUGEMONT, reconhecido defensor literário do Federalismo europeu ${ }^{603}$.

\title{
5.2.2.2.2. O Projeto Europeu da UEF: Diálogos com o Teológico-Político
}

\subsection{A Catequese do Credo Federalista}

A UEF aproximava sua perspectiva de organização jurídico-política da Europa de um discurso Teológico-Político: o Federalismo era uma "Boa Nova" a ser disseminada totalmente entre os países e os povos europeus mediante catequese efetuada em todas as dimensões e escalas as relações humanas. Para a UEF, o Federalismo não deveria ser compreendido como simples doutrina política destinada a solucionar as querelas entre os Estados-nacionais. Antes, deveria ser percebido como uma doutrina de vida, ou melhor, um modo todo especial de viver entre os Homens, o qual deveria ser amplamente incorporado por estes em cada uma das dimensões das relações humanas (BITSCH, 2006, p. 46; NOËL et alii, 2008, p. 122; RÉAU, 2008, p. 192).

\begin{abstract}
[L]e fédéralisme des fédéralistes n'a pas seulement une signification politique et constitutionnelle. Son ambition est bien plus vaste : être « un principe dynamique qui transforme toutes les activités humaines ». Au-delà donc des problèmes de la paix en Europe et de la critique virulente des États-nations, il existe toute une philosophie de la vie que leur permet de proclamer: « fédéralisme partout, fédéralisme sur tous les plans et à tous les échelons de la société humaine, depuis la base jusqu'au sommet». (ROLLAND, 2006, p. 487, grifos nossos).
\end{abstract}

Assim, há uma tendência à unidimensionalização totalizante do discurso do Federalismo Europeu derivada precisamente de uma postura pedagógicodoutrinadora e civilizatória de seus partidários ${ }^{604}$. Estes estariam incumbidos de

603 "Le rôle de Denis de Rougemont dans toute cette période au sein du mouvement fédéraliste et des militants pour l'Europe n'est plus à souligner. Il est l'auteur du rapport culturel au Congrès de La Haye et dirigera le Centre européen pour la culture.” (ROLLAND, 2006, p. 516). Segundo Patrice ROLLAND (idem, ibidem), não se pode deixar de perceber que é Denis de ROUGEMONT quem estabelece em grande parte as diretrizes fundamentais do pensamento Federalista seguido pelos partidários deste movimento europeísta: a rejeição dos nacionalismos e a integração federal das nações.

${ }^{604}$ Sobre essa temática específica e as demais a seguir enumeradas nas próximas linhas, v. as referências e os comentários ao discurso Federalista plasmado nas conclusões dos documentos dos primeiros Congressos da UEF, realizados durante o período analisado por este trabalho. Esta consulta a documentos de época elucida ainda mais os contornos Teológico-Políticos da "causa" Federalista Europeísta a partir a ilustração figurada pelas próprias palavras e intenções pregadas por seus partidários. Como se poderá ver mais adiante, neste mesmo item. 
disseminar a "Palavra Federalista" entre os povos europeus, a fim de revelar a estes os exatos termos daquilo que "desejavam, porém não sabiam", ou que "desejavam, mas não sabiam expressar": a instauração de uma Paz absoluta, a qual seria possível apenas mediante a solução única de constituir um Estado Federal Europeu. Os Federalistas saberiam melhor do que os países e os povos europeus aquilo que estes próprios queriam.

Com grande clareza se revela a perspectiva "pedagógico-profética" do discurso Federalista Europeísta a partir da consideração dos termos utilizados pela UEF no Programa de Ação por ela adotado em seu Congresso de Montreux, em Agosto de 1947:

\footnotetext{
nous avons à réaffirmer, passionnément, la nécessité du fédéralisme et de l'union européenne intégrale, obscurément désirée par les masses européennes. Si nous ne répondons pas à cette attente des peuples, d'autres viendront, qui les entraîneront dans on ne sait pas quelle aventure. (UEF, 2006b, p. 489, grifos nossos).
}

Neste momento, pode-se começar a perceber no interior do discurso do Federalismo Europeu a preocupação em efetuar completa reorganização geral e universal das relações entre os povos europeus. Esta não apenas deveria ser política, mas abranger todas as dimensões existenciais humanas. Contudo, a organização jurídico-política deveria ser o instrumento de disseminação unidimensional deste novo modo de vida total: a partir da aproximação política dos Estados europeus, seria possível esperar a difusão interna - e, como será visto mais adiante, também internacional - de uma nova forma de civilização.

Os Federalistas Europeus seriam assim missionários incumbidos de divulgar um credo de organização jurídico-política da Europa que, por sua vez, seria responsável por uma universal reeducação, não apenas da Europa, mas também do mundo. Esse projeto de conversão universal à causa Federalista revela assim indícios de uma tendência TeológicoPolítica em seu discurso sobre o Projeto de Europa politicamente Unida.

Os Federalistas Europeus se autopercebiam como os "únicos e legítimos portadores eleitos" do discurso destinado a salvar os povos europeus (UEF, 2006b, p. 489). Aos Federalistas incumbiria revelar para os povos europeus - e em nome dos povos europeus aquilo que estes mesmos estariam ocultamente procurando, mas que não encontravam condições e elementos discursivos aptos para o expressar. A "Boa Nova" trazida pelo Federalismo Europeu nada mais faria do que avivar internamente/introduzir na convicção de cada um algo que desconhecia sobre si mesmo em nome do qual deveria buscar unir politicamente a Europa e, com isso, amalgamar de acordo com a perspectiva Federalista 
todas as dimensões da vida humana na Europa e no mundo. Era a régua de existência do Federalismo Europeu que deveria estabelecer o fundamento normativo de todas as esferas da vida humana, a começar pelas decisões políticas fundamentais de cada Estado-membro da futura Federação Europeia.

Isso permite compreender a razão pela qual, mais uma vez no Programa de Ação aprovado no Congresso de Montreux, em Agosto de 1947, a UEF (2006b, p. 492) reconhecera ser fundamental '[p]ar la parole, par la presse, par l'action syndicale et coopérative, par l'action parlamentaire, nous devrons affirmer notre volonté de coopération et de paix.". Haveria que se disseminar a "Palavra Federalista" na Europa por todos os meios, em todas as direções, entre todos os segmentos sociais ${ }^{605}$.

A mesma perspectiva pedagógico-doutrinária se mantém na Exposição de Motivos do Anteprojeto sobre a Constituição Europeia formulado pela UEF, em seu Congresso de Roma, em Novembro de 1948:

\begin{abstract}
Malheureusement, il n'existe pas encore de force réelle, organisée, consciente, capable d'assumer et de faire triompher ce point de vue [une refonte institutionnelle des structures selon la perspective fédéraliste européenne]. Notre volonté est de faire du Mouvement Fédéraliste cette force créatrice, sans l'existence et sans le développement de laquelle les plus beaux projets resteraient lettre morte. L'opinion publique, dans son ensemble [...] n'a pas encore pris conscience du lien nécessaire, intrinsèque, qui relie ce fédéralisme-là à ses fondements et à son couronnement, économiques, politiques et sociaux. (UEF, 2006c, p. 565-6, grifos nossos).
\end{abstract}

5.2.2.2.2.2. "Unidade na Diversidade" I: A Substituição da Diversidade Estatalnacional pela Unidade Supranacional Federal Europeia

Os partidários do Federalismo Europeu estavam convictos de que o principal culpado pelos flagelos causados na Europa e no mundo nos últimos anos eram os Estados e suas respectivas intocáveis Soberanias. Essa situação derivaria simplesmente do fato de que as Soberanias normalmente eram direcionadas a resolver os problemas apenas a partir de uma perspectiva puramente nacional. Por isso, o documento adotado pela UEF no Congresso de Montreux, de Agosto de 1947, era bastante direto sobre essa temática, ao reconhecer que " $[\mathrm{u}]$ ne seule solution existe: l'union de peuples autour d'un pouvoir fédéral efficace." (UEF, 2006b, p. 489, grifos no original).

${ }^{605}$ Ou como diria o mesmo documento, algumas páginas adiante: "fédéralisme partout, fédéralisme sur tous les plans et à tous les échelons de la société humaine, depuis la base jusqu'au sommet !” (UEF, 2006b, p. 494). 
Por isso, a proposta adotada pela UEF naquele mesmo Congresso consistia precisamente em reduzir a Soberania - por eles qualificada absoluta - dos Estados (UEF, 2006b, p. 492). Para a UEF, apenas desta maneira seria possível impedir o recometimento das barbáries que "ont réussi seulement à plonger leurs peuples dans la misère, à faire perdre aux citoyens leurs libertés personnelles et à créer ainsi une situation dangereuse qui peut mener à chaque instant à une catastrophe terrible et peut-être definitive" (UEF, 2006b, p. 489).

Esta percepção já havia sido anteriormente reconhecida pela UEF no item número 4 do Programa adotado em seu Congresso realizado em 1946, em Hartenstein, na Suíça. Todavia, essa convicção ganhou paulatinamente contornos mais precisos, tendo recebido um reforço intelectual no Congresso de Montreux, de 1947 e, posteriormente, no Congresso de Roma, de 1948. A leitura do conteúdo dessas três declarações permite perceber em que medida se planejava "apenas" diminuir a soberania estatal: em todas elas, mostrava-se ser imprescindível constituir um efetivo Estado Federal Europeu, ou seja, substituir a diversidade estatal-nacional pela unidade Federal supranacional.

No Programa de Hartenstein, de 1946, a UEF sugerira a mera transferência de direitos soberanos por parte dos Estados à Federação por eles composta, abrangendo competências econômicas, políticas e militares (UEF, 2006a, p. 488). No Programa de Montreux, de 1947, tornara-se mais clara a proposta: a Federação deveria estar dotada de uma força armada própria, a fim de fazer respeitar e cumprir as decisões federais no interior dos Estados-membros (UEF, 2006b, p. 492).

No Congresso de Roma, de 1948, contudo, a proposta da UEF se revelou ainda mais vigorosa e incisiva. Não apenas parcelas das soberanias dos Estados deveriam ser transferidas, mas também o Federalismo Europeu deveria subordinar os interesses nacionais aos interesses superiores supranacionais da Federação - estando resguardada a autonomia dos Estados ${ }^{606}$ (UEF, 2006c, p. 563 e 568-9).

\footnotetext{
${ }^{606}$ Perceba-se que aqui o documento da UEF não utilizou o termo Soberania, mas autonomia. O que já indica sincera, convicta e forte intenção de fazer os Estados europeus perderem a precisa condição de Estados soberanos, em prol de uma Federação. Seria esta - e não os Estados-membros - o Estado propriamente dito, detentor da Soberania em seu aspecto interno (estabilidade das relações) e externo (segurança frente a ameaças e representação) (v., nesse sentido, comentários nas linhas a seguir, neste mesmo item).

Hildebrando ACCIOLY; Geraldo Eulálio do NASCIMENTO E SILVA; Paulo Borba CASELLA (2009, p. 244, grifos nossos) salientam que um Estado Federal é "a união permanente de dois ou mais estados, em que cada um deles conserva apenas sua autonomia interna, sendo a soberania externa exercida por um organismo central, isto é, pelo governo federal, plenamente soberano nas suas atribuições, entre as quais se salientam a de representar o grupo nas relações internacionais e a de assegurar a sua defesa externa.".
} 
O mais sintomático e característico da proposta Federalista do Congresso de Roma de 1948 consistiu em prever aberta, direta e expressamente a transferência integral do monopólio legal do uso da violência dos Estados europeus ao super-Estado Federal

Europeu. Seria o Estado Federal a única entidade competente para deliberar sobre as atividades militares (organização, instrução, fabricação e fornecimento de equipamento militar), de maneira a assegurar internamente a ordem entre os Estados-membros e a defesa externa de toda a Federação contra toda agressão (UEF, 2006c, p. 573).

Perceba-se, assim, que o discurso Federalista Europeu efetivamente visava a constituir um novo Estado na Europa, responsável pela união e pela unificação jurídicopolítica dos países europeus no interior de uma Federação. Esta seria a única detentora do monopólio legal do uso da violência na Europa, seja nos assuntos internos (garantia de estabilidade nas relações), seja nos assuntos externos (segurança perante eventual agressão). Tratava-se de proposta de construção de um autêntico Estado: um Estado Federal Europeu ${ }^{607}$. Apenas ele seria o instrumento jurídico-político apto a dominar e a domesticar o uso regional da força, assegurando estabilidade interna e segurança externa.

No mesmo sentido, caracteriza José Afonso da SILVA (2005, p. 100, grifos do autor): "No Estado federal há que distinguir soberania e autonomia e seus respectivos titulares. Houve muita discussão sobre a natureza jurídica do Estado federal, mas, hoje, já está definido que o Estado federal, o todo, como pessoa reconhecida pelo Direito internacional, é o único titular da soberania, considerada poder supremo consistente na capacidade de autodeterminação. Os Estados federados são titulares tão-só de autonomia, compreendida como governo próprio dentro do círculo de competências traçadas pela Constituição Federal.". No mesmo sentido, Celso Ribeiro BASTOS (2001, p. 292).

Mencione-se ainda que, usualmente, um Estado Federal é composto pelos seguintes elementos, entre outros: (i) surgimento de um novo Estado, seguido da perda da condição de Estados por parte daqueles que ingressaram na Federação; (ii) uma base jurídico-política estabelecida mediante um documento jurídicopolítico constitucional (Constituição), e não por meio de um Tratado Internacional; (iii) inexistência de direito de secessão por parte dos Estados que compõem a Federação; e (iv) exclusividade da Soberania detida apenas pelo Estado Federal, enquanto que os Estados federados têm preservada apenas uma parcial autonomia política limitada (DALLARI, 2001, p. 257-8).

Com relação ao item (ii) do último parágrafo, cumpre observar existir uma experiência histórica que ao menos fragiliza este ponto em particular: foi o Tratado de 31.8.1990, celebrado entre a RFA e a RDA que deu origem à atual República Federal da Alemanha por meio da reunificação alemã. Em 3.10.1990, a RDA deixou de existir e os cinco Estados que a compunham integraram a RFA (WEILER, 2005, p. 294). No mesmo sentido, já em 1944, Hans KELSEN (2011, p. 38) ressaltara teoricamente esta possibilidade: "O direito nacional pode surgir do direito internacional como no caso da constituição de um Estado federativo criado por um tratado internacional. Essa constituição é direito nacional uma vez que é a base do direito de um Estado e, ao mesmo tempo, é direito internacional, já que é o conteúdo de um tratado internacional.”.

De todo modo, não cabe aqui discutir as características fundamentais de uma Federação, nem mesmo aprofundar nas discussões em torno das diferenças entre autonomia e Soberania, sob pena de extrapolar os limites investigativos deste estudo. Apesar de ser temática interessante, não há relação direta com o tema explorado por este trabalho, razão pela qual se deixa de tecer considerações adicionais. Sobre a separação da Alemanha entre RFA e RDA, v. a nota de rodapé 701, infra.

${ }^{607}$ Sobre o caráter estatal de toda organização jurídico-política em que se estabelece o monopólio legal do uso da força, não é demais lembrar a lição de Hans KELSEN (2011, p. 4, grifos nossos) de que "[q]uando o exercício desse monopólio [do uso da força] é centralizado, quando direito de empregar a força como sanção é retirado dos ofendidos e transferido para uma agência central, quando passa a existir um poder executivo centralizado, a comunidade jurídica se transforma em um Estado.”. 
Por fim, o mesmo documento da UEF aprovado no Congresso de Roma, de 1948 declarara que as relações exteriores a serem mantidas pela Federação seriam de competência do Estado Federal Europeu, não sendo possível aos Estados europeus federados a negociação ou a conclusão de Tratados Internacionais sem a aprovação da Federação (UEF, 2006c, p. 573). Assim, o Estado Federal Europeu seria a única entidade apta a desenvolver negociações de Tratados Internacionais, sempre a partir de uma perspectiva supranacional.

Assim, pode-se perceber com clareza todo o vigor da proposta do Federalismo Europeu para a União política da Europa: as Soberanias estatais não seriam "apenas reduzidas" mediante transferência de competências. Na verdade, as Soberanias estatais nacionais seriam absolutamente eliminadas em favor do Estado Federal Europeu, o qual agiria sempre a partir de uma perspectiva supranacional.

As estatalidades isoladas ${ }^{608}$ restariam relegadas ao singelo plano da autonomia política interna, desprovidas de condições de exercer a força interna e externamente, ou mesmo de negociar Tratados Internacionais. Este esmagamento da diversidade das estatalidades nacionais soberanas em prol da unidade supranacional Federal seria a única solução possível para o Federalismo Europeu ${ }^{609}$.

O mesmo autor pondera, algumas páginas adiante: “[u]ma força policial internacional [...] só é 'internacional' no que diz respeito a sua base jurídica, o tratado internacional. Mas é 'nacional' no que se refere ao seu grau de centralização, pois uma liga com um poder executivo centralizado não mais é uma confederação internacional de Estados, e sim um Estado em si. [...]. Uma força policial 'internacional' equivale a uma restrição radical, quando não à total destruição da soberania dos Estados." (KELSEN, 2011, p. 18, grifos nossos). O que esclarece ainda mais as conseqüências do Projeto do Federalismo Europeu para os Estados-nacionais membros da planejada Federação Europeia: reunião em torno de Uma única Soberania central, Federal supranacional, em detrimento das Soberanias estatais nacionais, ou ainda, o SuperEstado Federal Europeu em detrimento dos Estados-nacionais europeus.

${ }^{608}$ Conforme a distinção entre as cinco escalas de existência participantes da vida comum na Europa feita no item 3.3.3.3., supra, perceba-se que as estatalidades isoladas seriam absolutamente controladas pela supranacionalidade Federal.

Em outras palavras, a proposta Federalista propugnava pela introdução intemporal da escala supranacional do lugar do Direito e do Poder, a fim de que apenas esta pudesse pautar as decisões normativas sobre questões comuns a todas as estatalidades. Isso seria o mecanismo institucional que, segundo a perspectiva Federalista Europeia, eliminaria o conflito escalar entre as estatalidades isoladas nacionais europeias.

No entanto, note-se que também seria eliminada a possibilidade de tensões entre as estatalidades e a supranacionalidade - diferente da proposta e da realização institucional Políticas da CECA, em que estatalidades permaneceriam opostas entre si e com relação à supranacionalidade, como se poderá v. mais adiante. É assim perceptível na proposta da UEF um movimento de unidimensionalização escalar na Europa a partir da dimensão existencial proposta pelo Federalismo Europeu. O caráter Teológico-Político do Federalismo restará ainda mais evidente à medida que se desenvolver a leitura das linhas a seguir.

${ }^{609}$ Entende-se aqui, com maior precisão, a observação de Joseph H. H. WEILER (2005, p. 94) sobre o caráter "suicida" do discurso do Federalismo Europeu, mencionado na nota de rodapé 592, supra.

O Federalismo Europeu apenas visaria à construção de uma nova e única entidade detentora de Soberania na Europa: o supranacional Estado Federal Europeu. Como o Estado-nação, o Estado Federal Europeu deteria exatamente os mesmos os atributos básicos da Soberania - com a diferença de atuar em 
O quadro do discurso Teológico-Político Federalista Europeu se completa com a percepção de que tal super-Estado Federal Europeu seria símbolo do reavivamento de uma suposta unidade cultural europeia calcada no discurso universal dos Direitos Humanos e da Democracia. $O$ respeito incondicional interna e externamente destes por parte dos países europeus seria condição não apenas para o ingresso nesta estrutura estatal Federal europeia, como também para nela se manter.

Sobre tais aspectos, mais uma vez se mostra importante examinar o conteúdo dos Programas aprovados nos primeiros Congressos realizados pela UEF.

5.2.2.2.2.3. "Unidade na Diversidade" II: A Diversidade Cultural Europeia enquanto Unidade Escalar Civilizada ditada pelos Direitos Humanos e pela Democracia

A unidade cultural dos países europeus seria assegurada por meio da suposição - e da imposição - de uma escala de existência europeia única supostamente compartilhada desde tempos imemoriais por uma arruinada civilização europeia. Contribuíam para isso não apenas a imagem da unidade europeia perdida desde o esfacelamento do Império de Carlos MAGNO (CASELLA, 1994a, p. 85; MATTERA, 2002, p. 17; QUERMONNE, 2008, p. 11 e 13), mas também a forte influência do discurso religioso católico (BARNAVI; POMIAN, 2008, p. 105; CAMPENHAUSEN, 2010, p. 42; CASELLA, 1994a, p. 67-8 e 85-8; SCHMIDT, 2012) ${ }^{610}$.

Desde o Programa aprovado em Hartenstein, em 1946, a UEF reconhecia ser possível formar a referida Federação em torno de Estados detentores de um caráter europeu, desde que estes respeitassem internamente os Direitos Humanos e a Democracia - as marcas contemporâneas da dita civilização europeia perdida (UEF, 2006a, p. 488). E, por essa razão, no Programa aprovado em Montreux, em Agosto de 1947, não deixara a UEF de reafirmar ser fundamental fazer aflorar da base a liberdade democrática entre os países europeus, para assegurar o devido respeito os Direitos do Homem (UEF, 2006b, p. 490).

escala geográfica maior, a saber, toda a Europa: a centralização do uso legal da violência em âmbito interno (estabilidade e centralidade na produção normativa) e independência na determinação de sua vontade nas relações externas (autodeterminação e segurança).

Como poderá ser visto a seguir, no item 6.2., infra, não é deste discurso que se aproxima a proposta e a construção da CECA.

${ }^{610}$ Nesse sentido, v. ainda as considerações referentes às NEI (item 5.2.2.1., supra), bem como as feitas com respeito à Resolução cultural do CGH (item 5.3., infra). 
É nas Resoluções do Congresso de Roma, de 1948, que a UEF torna amplamente visível e compreensível o que pretende com sua afirmação da importância da proteção dos Direitos Humanos e da Democracia no futuro Estado Federal Europeu. O objetivo desta proposta adquire tons claramente civilizatórios em torno de uma unidade cultural europeia imaginana, pois a Federação Europeia seria não apenas o lugar de realização da União política dos diferentes países europeus, mas principalmente o reduto de salvação "[d]es valeurs fondamentales de la civilisation européenne." (UEF, 2006c, p. 558). Ela seria efetivo ponto geométrico de encontro de todos aqueles que partilhariam daquela herança cultural una e comum.

Nesse sentido, note-se que naquela declaração, a UEF entendia ser imprescindível incluir na futura Federação Europeia todos Estados que histórica e geograficamente pertenciam à Europa - isto é, os países da Europa Ocidental e da Europa Oriental. Todavia, aqueles que ainda não estivessem "prontos", isto é, que não estivessem organizados jurídico-politicamente em âmbito interno no sentido de proteger os Direitos Humanos e de preservar a Democracia ${ }^{611}$ não poderiam ainda compor aquele Estado Federal Europeu (UEF, 2006c, p. 560).

Isso significa que o ingresso destes não estava proibido, mas apenas temporalmente impedido, pois era condição principal para a participação da Federação Europeia o respeito daqueles valores civilizados fundamentais e inalienáveis herdados e compartilhados pelos países europeus (UEF, 2006c, p. 568).

O caráter civilizador desta previsão se torna especialmente mais claro quando se nota que tal condição não apenas é requisito para entrada na futura Federação Europeia, como também para nela se manter.

Nesse sentido, mencione-se o Anteprojeto sobre a Constituição Europeia - também aprovado no Congresso da UEF, realizado em Roma, em 1948. Aquele documento previa igualmente a elaboração de uma Carta de Direitos Humanos aos povos europeus, a qual deveria ser superior às leis constitucionais dos Estados-membros da Federação. $O$ respeito absoluto e incondicional ao discurso dos Direitos Humanos e da Democracia valores considerados típicos e próprios da civilização europeia ${ }^{612}$ - deveria ser contínuo:

\footnotetext{
${ }^{611}$ Isto é, os países sob o domínio da URSS.

${ }^{612}$ Nesse sentido, não se pode deixar de mencionar a crítica feita por Mark MAZOWER (1998, passim, especialmente p. 14, 20-5, 143-5, 194 e 403) a esse suposto compartilhamento universal dos Direitos Humanos e da Democracia pela cultura europeia: poucos teriam se oposto internamente aos horrores cometidos durante a Segunda Guerra Mundial, tendo havido consciente repúdio ao "pobre e faminto" Regime Democrático em favor de um forte Governo autoritário que pudesse atender às necessidades sociais materiais mais básicas.
} 
desde a pretensão de ingressar no Estado Federal Europeu e durante a permanência nesta União política Federal da Europa.

\begin{abstract}
Article Premier - Entre les États se réclamant du caractère européen et ayant ratifié la Charte des Droits et la présente Constitution, il est formé une Fédération Européenne.

La Fédération Européenne reste ouverte à l'adhésion de tout État autre que les membres fondateurs sous réserve qu'il remplisse les conditions formulées à l'alinéa précédent. (UEF, 2006c, p. 569).
\end{abstract}

Perceba-se que, em termos estritamente técnico-jurídicos, o descumprimento dos preceitos da Carta de Direitos Humanos era impensável, pois todas as normas jurídicas nacionais seriam hierarquicamente inferiores a tal Carta de Direitos. Por isso, não haveria possibilidade alguma de qualquer norma jurídica nacional - mesmo Constitucional contradizer preceito supranacional: a regulação jurídico-normativa que desrespeitasse os Direitos Humanos e a Democracia seria inválida e nem mesmo teria partilhado do ordenamento jurídico Federal na Europa.

Por outro lado, em termos jurídico-polícos havia interessante previsão. No mesmo Anteprojeto sobre a Constituição Europeia, o eventual descumprimento dos preceitos constantes da Carta de Direitos Humanos não implicaria a exclusão do Estado-membro com relação à Federação Europeia. Antes, seria simplesmente negado o reconhecimento da autonomia política do Estado-membro violador de tais previsões (interpretação a contrario sensu):

[a]rt. 2. - La Fédération garantit à chaque État-membre des principes d'organisation et de gouvernement conformes à la Charte des Droits et à la présente Constitution. (UEF, 2006c, p. 569).

Assim, a possibilidade de um Estado-membro da Federação Europeia exercer sua autonomia política interna ${ }^{613}$ estava condicionada ao dever de respeito integral, incondicional e contínuo às previsões de proteção dos Direitos Humanos e da Democracia.

Ainda que esta posição deva ser balizada, não se pode ignorar sua importância enquanto provocação atenta à condição de serem os Direitos Humanos e a Democracia efetivamente frágeis e esporadicamente aceitos com tranquilidade na História Europeia. A provocação de Mark MAZOWER (1998) se completa ao sugerir ser a Europa um Continente de Escuridão, por poder ser percebido como marcado mais por tradições autoritárias em sua História do que por uma tradição Democrática atenta aos Direitos Humanos.

${ }^{613}$ Lembrando, como visto acima, que, segundo a proposta Federalista, os Estados europeus federados em um Super-Estado Federal Europeu perderiam suas respectivas Soberanias nacionais em prol de uma Soberania supranacional, permanecendo apenas com uma autonomia política limitada - limitada precisamente pelas disposições jurídico-normativas constantes do documento Constitucional; sobre este tema, v. ainda a nota de rodapé 606 , supra. 
Na hipótese de eventual descumprimento, não haveria uma opção por parte do Estadomembro faltoso se retirar da Europa Federal: este imediatamente (ipso jure) não mais teria garantida sua autonomia política, isto é, não teria mais assegurada juridicamente nem mesmo o reconhecimento da possibilidade de se auto-organizar.

A margem de liberdade jurídico-política delineada pela Constituição Europeia supranacional revelava-se assim efetivamente estreita. Não há aqui apenas o reforço do vínculo Federal entre os Estados-membros federados no futuro Super-Estado Federal Europeu por meio de artifício jurídico-normativo ${ }^{614}$, mas verdadeiro esforço de produção e de preservação de uma suposta coesão cultural interna. A negação da autonomia política significava a rejeição expressa da possibilidade de um dos Estados-membros produzir uma organização jurídico-política e exercer um Governo incompatíveis com os “valores da civilização europeia”, isto é, incoerente com os mandamentos de respeito aos Direitos Humanos e à Democracia.

Em termos mais simples, a referida previsão recusava ao Estado europeu federado - por meio da limitação da singela autonomia política que com ele restara - a capacidade de produzir e decidir autonomamente seu próprio estatuto político em sentido diverso daquele pregado pelo discurso dos Direitos Humanos e da Democracia $^{615}$. Com isso, a futura Federação Europeia cumpriria seu objetivo, não apenas

${ }^{614}$ Há uma ausência de previsão normativa por meio da qual um Estado-membro poderia solicitar seu desligamento com relação à Federação Europeia por não concordar com a limitação de sua autonomia política em virtude de não aceitação posterior da Carta de Direitos Humanos (autodefinição de seu próprio estatuto político-jurídico).

Assim, na hipótese de inobservância do preceito de se organizar jurídico-politicamente em torno dos Direitos Humanos e da Democracia o vínculo Federal se manteria vale dizer, ele não seria desfeito em benefício de um ou de outro Estado-membro. Na verdade, apenas o Estado-membro descumpridor das previsões perderia sua autonomia política, mas ele não reconquistaria sua Soberania. Nesse sentido, pode-se dizer que aqui há um dispositivo juridico destinado a reforçar o vínculo Federativo entre os Estadosmembros, ainda que um deles não concordasse posteriormente com o integral respeito aos Direitos Humanos e à Democracia.

${ }^{615}$ Ganha assim contornos mais precisos a vaga declaração constante no Programa aprovado pela UEF em seu Congresso realizado em Montreux, em 1947: "fédéralisme partout, fédéralisme sur tous les plans et à tous les échelons de la société humaine, depuis la base jusqu'au sommet !” (UEF, 2006b, p. 494).

Com efeito, como previa a própria Exposição de Motivos do Anteprojeto sobre a Constituição Europeia aprovada pela UEF em seu Congresso de Roma, de 1948: “A. Nous sommes nombreux à croire que le Fédéralisme [...] ne saurait se réaliser qu'en entraînant une transformation totale des structures, non seulement « internationales », mais aussi « intra-nationales », non seulement politiques, mais économiques, sociales et même spirituelles.” (UEF, 2006c, p. 565, grifos nossos).

Assim, fundado nos Direitos Humanos e na Democracia, o Federalismo Europeu deveria se espraiar ao mesmo tempo internacional e internamente para, dessa forma, produzir uma revolução nos espíritos e nas convicções jurídico-políticas, de maneira a preservar unanimemente no interior da Europa o respeito à tradição dos Direitos Humanos e da Democracia.

Ainda que bem intencionada, fazia-se presente a impossibilidade de se pensar e de se agir alternativamente a este círculo de valores europeus transcendentalizados, os quais passaram a ser venerados como a única forma possível de se organizar jurídico-politicamente uma sociedade e como único centro de referência de padrões normativos na Europa. O culto a um inquestionável discurso dos 
de preservar os valores europeus herdados de uma tradição supostamente imemorial (UEF, 2006c, p. 558), mas principalmente de contribuir "à renouveler en commun l'apport civilisateur de l'Europe" (UEF, 2006c, p. 568, grifos nossos).

Não é excessivo observar que é precisamente neste ponto que se revela com maior vigor a propensão à unidimensionalização totalizante do discurso civilizatório Federalista Europeu. A escala de existência "propriamente europeia"616 deveria se espraiar a partir deste centro estatal Federal europeu e alcançar diversos outros polos, de modo a integrálos. Não apenas a política, mas todas as esferas da vida e da atividade humanas deveriam ser colonizadas de "cima a baixo" pela perspectiva Federalista europeia, até que todas vibrassem em uníssono ${ }^{617}$ conforme a harmonia ditada uniformemente pelo discurso dos Direitos Humanos e da Democracia.

Se no Programa de Hartenstein, de 1946, a UEF não apresenta de maneira tão explícita sua perspectiva totalizante do discurso Federalista, este revela com todas as palavras o vigor de sua empreitada unidimensionalizante no Programa adotado no Congresso de Montreux, de 1947. Neste documento, a UEF reconhece de maneira expressa o Federalismo como um princípio dinâmico voltado a transformar todas as atividades humanas, isto é, como algo que "n'apporte pas seulement um nouveau cadre politique, mais encore de nouvelles structures sociales, économiques et culturelles." (UEF, 2006b, p. 490).

Assim, não apenas a dimensão política deveria ser impregnada pela perspectiva Federalista ${ }^{618}$. Economia, cultura e todas as demais esferas da vida e atividades humanas

Direitos Humanos e da Democracia - de forte propensão civilizatória - se torna progressivamente mais acirrado na pregação da UEF, como se poderá nas linhas a seguir.

Note-se que já em 1944, Hans KELSEN alertara a reflexão em Direito Internacional para o perigo de a defesa da causa Federalista Europeia implicar redução da liberdade de cada um dos povos definirem seu estatuto político próprio - uma potencial contradição totalizante no interior do libertário discurso Federalista Europeu: “[a] proposta de garantir a paz internacional por meio de um Estado mundial [federal] se baseia na suposta analogia entre um Estado mundial e o Estado nacional, no qual se assegura a paz de forma tão eficiente. Essa analogia, entretanto, não parece muito favorável às intenções daqueles que desejam produzir a paz mundial por métodos que concordam com os princípios da democracia: liberdade e igualdade, aplicadas às relações internacionais.” (KELSEN, 2011, p. 5, grifos nossos).

Sobre a postura de Hans KELSEN, remetemos o leitor ainda à nota de rodapé 592, supra; com relação ao problema da defesa dos Direitos Humanos e da Democracia como imposição Teológico-Política similar a experiências históricas não tão remotas, remetemos o leitor à nota de rodapé 694, infra.

${ }^{616}$ Isto é, o respeito aos Direitos Humanos e à Democracia.

617 Como visto acima, o Anteprojeto sobre a Constituição Europeia previra, em seu artigo segundo, o reconhecimento das particularidades por meio da garantia da autonomia política dos Estados europeus federados. Todavia, estas particularidades admitidas no interior da possibilidade de determinação de cada autonomia política eram limitadas, pois apenas aceitas se de acordo com os discursos jurídiconormativamente previstos de respeito aos Direitos Humanos e à Democracia.

${ }^{618}$ Não é demais reiterar: a "perspectiva Federalista" deve ser entendida como o resgate da unidade cultural da tradição europeia imaginada em torno do discurso dos Direitos Humanos e da Democracia. Sobre o 
deveriam se pautar pela tradição dos valores da civilização europeia defendida pelo Federalismo, pois apenas deste modo se poderia moldar um novo Homem. Símbolo desta pretensão de unidimensionalização da escala de existência europeia dos Direitos Humanos e da Democracia é o apaixonado trecho do Programa do Congresso de Montreux, de 1947, o qual já fora referido aqui algumas vezes: “fédéralisme partout, fédéralisme sur tous les plans et à tous les échelons de la société humaine, depuis la base jusqu'au sommet !" (UEF, 2006b, p. 494, grifos nossos).

Há aqui consciente exposição de verdadeiro credo Federalista profundamente comprometido com a única e incondicional totalização da dimensão existencial dos Direitos Humanos e da Democracia por entre todos os segmentos possíveis da vida humana. A promessa de instaurar integral e totalmente um novo modo de vida na Europa se revela como indício forte do grau de adoração em torno do discurso dos Direitos Humanos e da Democracia. A "Boa Nova Federalista" deveria se disseminar entre todos os redutos possíveis, de maneira a não restar qualquer possível entrave obscuro que pudesse comprometer a luz daquela nova ordem europeia ${ }^{619}$. A força da coesão interna da futura Federação Europeia adviria precisamente desta uniformidade cultural una, não apenas suposta, mas pressuposta e imposta ${ }^{620}$.

5.2.2.2.2.4. "Unidade na Diversidade” III: Da Paz do Estado Federal Europeu à Paz do Estado Federal Mundial

A busca de plena realização de uma única escala de existência europeísta Federalista se mostra com ainda mais vigor no Anteprojeto sobre a Constituição Europeia aprovado pelo UEF em seu Congresso realizado em Roma, em 1948.

Em sua Exposição de Motivos se afirma categoricamente que o Federalismo se orienta no sentido de transformar as estruturas políticas e culturais intranacionais e internacionais (UEF, 2006c, p. 565). Ainda na mesma Exposição de Motivos, declara-se

problema da defesa dos Direitos Humanos e da Democracia como imposição Teológico-Política, remetemos o leitor à nota de rodapé 694, infra.

${ }^{619}$ A afirmação do próprio Hendrik BRUGMANS (1947, p. 6) de que esta nova ordem europeia permitiria à Europa sair de sua Pré-história reforça a percepção de que os membros do Federalismo Europeu se autocompreendiam como portadores de um discurso destinado a inaugurar o novo e completamente inaudito na História da Europa: esta sairia de sua Pré-história e ingressaria na História! Profunda pretensão apressada e audaciosa de fazer absoluta e prepotente tábula rasa com relação às tradições, em torno valores supostamente compartilhados em virtude de uma ancestralidade comum imaginada.

${ }^{620}$ Lembre-se aqui das considerações feitas algumas linhas acima sobre a previsão da impossibilidade de um Estado-membro da Federação Europeia poder se socorrer de sua autonomia política interna na hipótese de desrespeitar os Direitos Humanos e a Democracia. 
expressamente que esta reforma radical deveria inserir a harmonia Federalista em todos os planos, em todas as direções, em todas as condições, da "base ao topo" (UEF, 2006c, p. $567)$.

O objetivo último do Federalismo Europeu consistia em trabalhar de modo a que o Estado Federal Europeu atuasse como efetivo “foyer de rayonnement d'où le fédéralisme puisse rapidement se propager en éventail et embrasser de proche en proche l'ensemble des structures." (UEF, 2006c, p. 567, grifos no original). Nada poderia ou deveria escapar à pretensão de capilarização totalizante na Europa daquela régua normativa elaborada por uma única forma de habitar o mundo: a do Federalismo Europeu, centrado incondicionalmente na defesa dos valores tradicionais da civilização europeia imaginada dos Direitos Humanos e da Democracia.

Segundo esta perspectiva, apenas mediante esta solução abrupta e única a Europa prometia poder voltar a ser uma terra de esperança e de felicidade ${ }^{621}$. Nela e a partir dela, todas as organizações jurídico-políticas internas, todas as normas jurídicas, e mesmo todas as formas de habitar o mundo culturalmente constituídas no interior de uma Federação jamais sequer pensariam em contradizer o dogma sacrossanto dos Direitos Humanos e da Democracia. Não poderia haver espaço livre algum para a introdução de mínima oposição escalar engendrada alternativamente ao discurso pedagógico-doutrinário pregado pelos fautores do messiânico Federalismo Europeu.

A dimensão existencial europeia Federalista ungida pelo discurso dos Direitos Humanos e da Democracia almejava deste modo a exclusividade no que se refere ao exercício do papel de servir como referência a padrões normativos na Europa. Todavia, não se pode ignorar que o Estado Federal Europeu seria apenas a primeira parte de um processo civilizador unidimensionalizante maior.

\footnotetext{
${ }^{621}$ Esta provocação ácida ao discurso da "nova Terra Prometida da Europa" fundada nos Direitos Humanos e na Democracia foi feita, com outros contornos, também por Joseph H. H. WEILER (2011). Não cabe aqui apresentar todas as nuances do pensamento deste autor, sob pena de extrapolar os objetivos de investigação deste estudo.

Cumpre apenas salientar que, naquela oportunidade, o autor indicara que o Projeto de União política da Europa buscara fundar sua legitimidade sobre tais afirmações genéricas, haja vista que não teria sido diretamente recebido uma aceitação imediatamente popular. Segundo o autor, tratava-se naquele momento de construir uma legitimidade derivada dos fins buscados - e não tanto dos meios utilizados - para construir a Europa politicamente Unida.

Note-se que autor também ressaltara que, inexplicavelmente, enquanto o CdE assumira este estandarte com profunda, expressa e explícita convicção, a CECA não pronunciara sequer uma palavra sobre estes dois termos.

Como será visto a seguir, este trabalho reitera que tal ausência de previsão de respeito aos Direitos Humanos e à Democracia na construção da CECA não deteve o condão de retirar o caráter Político (no sentido determinado nos itens 3.3.3.3. e 3.4.3., supra) da União da Europa promovida pela CECA. V., nesse sentido, as considerações feitas nos Sexto e Sétimo Capítulos, ambos infra.
} 
Com efeito, o objetivo último deste movimento doutrinador era assegurar a plena realização da Paz mundial. Esta deveria ser alcançada por meio de uma conformação universal e total dos padrões de referência normativa ao redor do mundo às exigências dos valores da tradição da civilização europeia (Direitos Humanos e Democracia). O outrora caído fardo civilizador europeu se reerguia sob novas asas, dando plena compreensão à missão assumida pelo Federalismo Europeu - e por ele mesmo atribuída a si próprio - no Anteprojeto sobre a Constituição Europeia aprovado pela UEF em seu Congresso realizado em Roma, em 1948: “renouveler en commun l'apport civilisateur de l'Europe” (UEF, 2006c, p. 568).

Desde o Programa de Hertenstein, de 1946, a vocação pretensamente universalista do discurso do Federalismo Europeu se revelava como missão conscientemente reconhecida e assumida pelo ideário da UEF.

Naquele documento se previa que a construção de um Estado Federal Europeu seria o passo fundamental e essencial em direção à construção de uma Comunidade mundial dos povos. Esta deveria, segundo o discurso Federalista Europeu, erguer-se a partir de um molde jurídico-político dado por uma orientação Federal mundial. O objetivo seria mostrar a Europa como laboratório de experiência bem sucedida de resolução de conflitos, a qual deveria ser transplantada e generalizada para fundar uma União política mundial (UEF, 2006a, p. 488-9).

Desde aquele momento se apresenta uma profunda convicção por parte do discurso Federalista Europeu de que sua perspectiva - centrada, frise-se, na contínua proteção incondicional dos Direitos Humanos e da Democracia - era universalizável. Esta valeria, não apenas para os países dotados do "caráter europeu", mas igualmente com relação aos demais países do mundo.

Em outras palavras, o discurso do Federalismo Europeu já mostrava sua tendência à unidimensionalização escalar também para fora do ambiente estritamente estruturado conforme a tradição da civilização europeia. Para eles, as demais tradições também seriam passíveis de serem reunidas jurídico-politicamente em torno da proposta Federalista, vale dizer, em torno do discurso dos Direitos Humanos e da Democracia ${ }^{622}$.

A percepção de que esta ampliação mundial do discurso Federalista Europeu era possível é mais facilmente compreensível a partir da leitura do Programa adotado no

\footnotetext{
${ }^{622}$ Sobre o problema da universalização do discurso dos Direitos Humanos e da Democracia, remetemos o leitor à nota de rodapé 694, infra.
} 
Congresso realizado em Montreux, em 1947. Neste documento, a UEF afirmava reconhecer desde já ser o respeito aos Direitos Humanos e à Democracia um princípio "à la fois européen [mais] universellement humain" (UEF, 2006b, p. 490, grifos nossos).

Compreender os Direitos Humanos e a Democracia não apenas como uma causa europeia, mas propriamente humana, legitimava os partidários do Federalismo Europeu a pensar sobre a necessidade de uma organização jurídico-política mais vasta que o simples território que abrangia os países da tradição da civilização europeia: “[d]ès l'origine, la cause du fédéralisme européen se situe volontairement dans une perspective mondiale." (UEF, 2006b, p. 493).

A realização universal e total desta medida especificamente europeia seria o ensinamento mais amplo que a Europa poderia apresentar para as demais tradições civilizadas, assegurando assim "que le fédéralisme [puisse] accomplir sa mission et édifier un monde nouveau, au service de l'homme et de la paix." (UEF, 2006b, p. 494, grifos nossos).

Percebe-se de maneira clara uma preocupação tipicamente Teológico-Política no discurso do Federalismo Europeu: reinaugurar a ordem das coisas de maneira universal e incondicional a partir de uma dimensão existencial única. Esta deveria ser responsável pela instauração de uma Paz Homogênea derivada da imposição total de uma única escala de existência: a da civilização europeia. Seria esta que deveria ocupar o lugar do Direito e do Poder e, assim, reger de fora a produção dos padrões normativos, não apenas na Europa, mas em todo o mundo ${ }^{623}$.

Essa tendência se revela com mais clareza na Resolução adotada pela UEF em seu Congresso realizado em Roma, em 1948, na qual se revela ter o Federalismo Europeu por objetivo principal salvar os valores fundamentais da civilização europeia para, deste modo, assegurar, em nome de toda a humanidade, a manutenção da Paz (UEF, 2006c, p. 558-9).

Nesse sentido, aquele documento reitera que a UEF entendia serem igualmente admissíveis no interior do futuro Estado Federal Europeu todos os países geográfica e historicamente vinculados à tradição europeia que, todavia, não estivessem naquele momento organizados jurídico-politicamente segundo os preceitos dos Direitos Humanos e da Democracia. Mas esses países "não-preparados" deveriam satisfazer primeiro esta condição antes de ingressar na Federação Europeia (UEF, 2006c, p. 560).

\footnotetext{
${ }^{623}$ Mais e mais se torna preciso o alcance civilizatório do mote Federalista por diversas vezes citado acima: "fédéralisme partout, fédéralisme sur tous les plans et à tous les échelons de la société humaine, depuis la base jusqu'au sommet !” (UEF, 2006b, p. 494).
} 
Essa previsão indicava a tendência de o Federalismo Europeu buscar eliminar a divisão na Europa entre aqueles que respeitavam tal tradição imaginada e aqueles que não pretendessem a respeitar (no presente e no futuro). Em outras palavras, determinava esta resolução que a referida divisão entre diferentes modos de habitar o mundo deveria ser substituída em favor de uma uniforme observância integral e incondicional dos Direitos Humanos e da Democracia - conforme o discurso propugnado pelo Federalismo Europeu.

Isso implica reconhecer que nada deveria restar como padrão de referência normativo único em toda a Europa senão a escala de existência do discurso formulado pelo Federalismo Europeu. Apenas este estaria autorizado a ocupar intemporalmente o lugar do Direito e do Poder, excluindo-se de antemão toda e qualquer proposta de alteridade dimensional ${ }^{624}$.

Lembre-se ainda de que a "Palavra Federalista" percebia a Federação Europeia como importante locus, não apenas de preservação e de salvaguarda dos valores da civilização europeia - Direitos Humanos e Democracia, mas, principalmente, como sede central de irradiação de todo um modo específico de habitar o mundo em direção às mais diferentes estruturas jurídico-políticas nacionais, intranacionais e internacionais. Nesse sentido, há preocupação explicitamente assumida de acabar com a Soberania estatal tanto na Europa, como no mundo: "La souveraineté absolue de l'État, par exemple, doit être battue en brèche [parce que] elle s'exerce aux dépens de la communauté européenne [et] mondiale" (UEF, 2006c, p. 567, grifos nossos).

Essa demolição da Soberania estatal em escala mundial deveria ser feita em nome da plena realização da Paz e da concórdia europeias e mundiais, e apenas seria possível se empreendida "au sein d'une organisation fédérale mondiale" (UEF, 2006c, p. 568). A eliminação das Soberanias nacionais seria precisamente o meio adequado para produzir a uniformização política e cultural pasteurizante dos países e dos povos europeus federados que perderiam a capacidade de definir por si sós seus próprios estatutos culturais e politicos.

\footnotetext{
${ }^{624}$ Aqui se compreende com maior força ao outrora referido trecho da Exposição de Motivos do Anteprojeto sobre a Constituição Europeia, aprovado no Congresso de Roma da UEF, realizado em 1948: “A. Nous sommes nombreux à croire que le Fédéralisme [...] ne saurait se réaliser qu'en entraînant une transformation totale des structures, non seulement « internationales », mais aussi « intra-nationales », non seulement politiques, mais économiques, sociales et même spirituelles.” (UEF, 2006c, p. 565, grifos nossos).

A reforma das crenças políticas, econômicas e sociais deveria ser tão profunda que implicaria a modificação do peso dado às diferentes tradições no interior da própria Europa. Como visto acima, as particularidades apenas deteriam a devida autonomia política se observassem os Direitos Humanos e a Democracia. Qualquer disposição interna incompatível com isso implicaria a retirada da capacidade de qualquer Estado-membro escolher seu próprio estatuto político.
} 
Assim, percebe-se com fina clareza de que o objetivo do discurso Federalista Europeu não se restringia a transformar as convicções e as estruturas jurídicopolíticas apenas dos países que poderiam invocar um "caráter europeu originário". Ele almejava principalmente moldar as demais tradições culturais segundo uma perspectiva Europeia - proteção incondicional dos Direitos Humanos e da Democracia.

As pretensões dos Federalistas acima brevemente expostas permitem perceber com um pouco mais clareza de que modo se manifestavam as tendências Teológico-Políticas do Federalismo Europeu: haveria efetivo intento de disseminar totalizantemente seu próprio modo de existência Federal, não apenas nas relações entre Estados, mas também em todas as esferas da vida humana. Mais do que isso, a perspectiva Federalista seria concebida como a única dimensão apta a resolver todos os conflitos entre nações e Homens e conteria em si mesma a promessa de realização plena e última da Paz - na Europa e no mundo.

5.2.2.2.2.5. A Diversidade na Unidade: Elementos Teológico-Políticos do Evangelho Federalista Europeu

Perceba-se aqui a concorrência dos quatro elementos que caracterizam toda proposta de organização jurídico-política segundo um discurso Teológico-Político ${ }^{625}$ :

(i) transcendência, por meio da transcendentalização do discurso dos Direitos Humanos e da Democracia - supostos como compartilhados por todos os Homens, a ser universalmente respeitado e imposto como escala de existência suprema, absoluta e única destinada a solucionar as diversas oposições escalares internas à Europa;

(ii) preenchimento, isto é, a ocupação do lugar do Direito e do Poder pelo discurso dos Direitos Humanos e da Democracia, na medida em que apenas estes poderiam ser reputados como os únicos referenciais normativos admissíveis para fundar - em posição hierarquicamente superior - as normas jurídicas a serem produzidas pelos Estadosmembros federados e mesmo a organização jurídico-política interna (autonomia) destes;

(iii) pacificidade, tendo em vista que o objetivo primeiro seria a instauração de situação em que os conflitos seriam de antemão resolvidos, apaziguados e eliminados por meio de uma segurança interna dada pelas supostas unidade e coesão culturais, vale dizer, tendo em vista que o objetivo fundamental não era simplesmente a eliminação da Guerra, mas a introdução de situação de plena Paz; e

${ }^{625}$ V. item 3.4.3., supra. 
(iv) unidimensionalidade, em virtude da (a) inquestionabilidade do partilhamento cultural da escala de existência Federalista forjada a partir discurso dos Direitos Humanos e da Democracia; e (b) necessidade do respeito absoluto a esta dimensão existencial única por todos aqueles países que se autocompreendiam, se autopercebiam e se autoafirmavam como afeitos à tradição da civilização europeia.

Em outras palavras, apenas uma medida de existência tomada como inquestionável estaria apta a assegurar a persistência da Paz na Europa: a Federação europeia imaginada a partir da suposta unidade cultural da Europa forjada a partir da medida de existência dos Direitos Humanos e da Democracia.

Por esse motivo, pode-se dizer que o Federalismo europeu ${ }^{626}$ se manifestava segundo profundas tendências Teológico-Políticas. Seria este discurso Federal o que unicamente poderia ser aceito como viável para instaurar o sonhado paraíso terrestre da Paz absoluta na Europa, esperança alimentada a partir da imaginada unidade cultural europeia (RÉAU, 2008, p. 195). Para tanto, sua dimensão existencial deveria colonizar unidimensionalmente todas as esferas da vida humana e reger inquestionavelmente as relações de acordo com seus próprios critérios na Europa e no mundo ${ }^{627}$.

Aliás, símbolo dessa pretensão de unificação uniescalar da Europa em torno de uma favorecida unidade cultural imaginada Federal é o discurso de Denis de ROUGEMONT proferido em 1948 e dirigido aos europeístas do CGH, quando da realização da Sessão Plenária de Encerramento do CGH (BITSCH, 2006, p. 46):

La conquête suprême de l'Europe s'appelle la dignité de l'homme [...]. Tel est l'enjeu final de notre lutte. C'est pour sauver nos libertés acquises, mais aussi pour en élargir le bénéfice à tous les hommes, que nous voulons l'union de notre continent. (ROUGEMONT, 1966, p. 271-2, grifos nossos).

Buscando estender a todos os Homens os benefícios dos Direitos Humanos e da Democracia, o movimento Federalista Europeu sinalizava consciente e sincera pretensão de abrir e ampliar as oportunidades de escolha para todos os povos europeus e nãoeuropeus. A irradiação dessa luminosa promessa de construção de novos mundos é

\footnotetext{
${ }^{626}$ Representado aqui por um dos movimentos europeístas mais proeminentes no CGH de 1948, a UEF, o qual impactou profundamente as discussões sobre futuros caminhos da Europa Unida inclusive nos anos seguintes à instituição da CECA. Mencionadas no item 5.2.2.1., as NEI reforçam o argumento geral de que o discurso do Federalismo Europeu flertava profundamente com discursos religiosos com pretensões políticas (discurso Teológico-Políticos).

${ }^{627}$ Aqui, vale ser lembrada a crítica de Hans KELSEN (2011, p. xii), formulada já em 1944, ao Federalismo Europeu e sua pretensão ideal e utópica de moldura das relações entre todos os países segundo os termos de uma Federação mundial: se "o sonho de um Estado Mundial sem dúvida é demais", não se deve ignorar que "o pacifismo utópico em qualquer caso é um grave perigo.".
} 
persuasiva, pois sinaliza o alargamento das possibilidades de escolha pelos Direitos Humanos e pela Democracia por novos caminhos por aqueles que acreditarem naqueles discursos.

Todavia, note-se que, segundo esta perspectiva, é este seleto grupo de intelectuais e militantes que passaria a determinar os termos de organização jurídico-política da Europa e do mundo com base em uma única escala de existência: a do Federalismo Europeu. Essa tarefa autoproclamada implicitamente retirava de outras medidas de existência a possibilidade de assumir ou de sugerir discursivamente organizações jurídico-políticas alternativas ao mote dos Direitos Humanos e da Democracia da maneira imaginada por uma suposta tradição imemorial de uma civilização europeia perdida.

Aquelas potencialidades de construção de mundos novos se abririam desde que a escolha fosse "certa", isto é, somente se estivesse de acordo com a preservação, a defesa e a promoção dos Direitos Humanos e da Democracia. A escolha política fundamental porque fundante da organização jurídico-política - já teria sido previamente feita pelos Federalistas europeus. Estes autoproclamados "eleitos" teriam de antemão determinado a opção por um único estatuto político primeiro a todos os povos (europeus e não-europeus).

Seriam assim os padrões culturais jurídico-políticos dos Federalistas Europeus os que estabeleceriam os termos a serem perseguidos para a constituição de Leis na Europa e no mundo Unidos para a prometida Paz. Uma vez convertidos ao evangelho Federalista, os povos organizados jurídico-politicamente segundo os termos dos Direitos Humanos e da Democracia estariam certamente livres: livres para orientar suas específicas escalas de existência apenas segundo (os limites de) uma vida comum percebida como adequada pelos Federalistas, e não de acordo com a efetiva livre decisão deles mesmos sobre o próprio estatuto político.

O empoderamento jurídico-político assim prometido pelo universalismo Federalista não significaria nada além de um simples executar precisamente aquilo que outrem gostaria. Em outras palavras, tratava-se de tentativa de enraizar predisposição interna a uma submissão voluntária ao império de uma visão transcendentalizada, uniescalar e totalizante sobre as Leis. Assim, a "Boa Nova" Federalista mostra aqui com todo vigor sua tendência a se aproximar das qualidades de um discurso Teológico-Político, discurso este que fundamentou a proposição das Leis da Europa Unida durante o CGH e a missão a ser assumida pelos resultados institucionais do Congresso. 
Mais uma vez, a Europa buscava assumir a posição de modelo de civilização, não apenas para si mesma, mas também para o mundo mediante a exaltação e a entronização do discurso da incondicional promoção e realização universais dos Direitos Humanos e da Democracia $^{628}$. É o que se passa a analisar, nos itens a seguir.

\subsection{As Comissões Especializadas do Congresso de Haia: O Vetor Teológico-}

\section{Político de suas Resoluções Finais}

Como indicado anteriormente ${ }^{629}$, os trabalhos do CGH foram divididos em três Comissões - Comissão política, Comissão econômica e Comissão cultural. Cada uma delas foi incumbida pela redação de um Relatório Preparatório tematicamente especializado a ser avaliado nas Sessões Plenárias.

Os textos dos Relatórios Preparatórios foram fortemente influenciados pelas origens dos membros de cada uma das Comissões. A menção efetuada acima ${ }^{630}$ aos diferentes movimentos europeístas do período permite compreender mais precisamente as características gerais das Comissões.

A Comissão econômica foi composta por Daniel SERRUYS pelo Lorde Walter LAYTON, economistas de inspiração liberal. Seu Relatório foi aprovado pela Sessão Plenária e sugeriu o desenvolvimento de uma União Econômica na Europa fundada na

\footnotetext{
628 "In the 1870-71 Franco-Prussian War the death-toll was 184.000; in the First World War it was above eight million, and more than forty million Europeans - half of them civilians - died in the Second World War. The depth of these wounds was directly proportionate to the grandeur of the ambitions held by the various protagonists, each of whom aspired to remake Europe - inside and out - more thoroughly than ever before. It is not surprising if today Europe is suffering form ideological unvisionary activity. As Austria's former chancellor Franz Vranitsky once supposedly remarked: 'Anyone with visions needs to see a doctor.'. [...]. [The] trust in Europe's world mission was already evident in the seventeenth and eitghteenth centuries and reached its apogee in the era of imperiaism. Hitler was in many ways its culminating figure and through the Nazi New Order came closer to its realization than anyone else." (MAZOWER, 1998, p. 404-5, grifos nossos). A que custo humano e político pretender assumir uma nova missão civilizatória unidimensional?

Lembre-se ainda da observação de Hans $\operatorname{KELSEN~(2011,~p.~} 9$ e 11-2), formulada já em 1944, sobre a proposta Federalista Europeia de se organizar posteriormente um Estado Federal mundial: "[u]m Estado federativo mundial [...] composto de vários Estados diferentes quanto ao tamanho e à cultura, dificilmente pode ser erigido imediatamente após esta guerra [a Segunda Guerra Mundial]. Somente um pensamento fantasioso e a pura e simples ignorância de fatos decisivos nos permitem subestimar as extraordinárias dificuldades que encontraremos para organizar esse Estado federativo mundial. Isso vale, principalmente, se a constituição desse Estado tiver caráter democrático", ou ainda, mais simplesmente "[a]licerçar a esperança da construção desse Estado federativo sobre o mero exemplo dos Estados Unidos e da Suíça é uma ilusão perigosa. [...] É óbvio que a princípio só se pode criar uma união internacional de Estados, não um Estado federativo.".

${ }^{629}$ Final do item 5.1., supra.

${ }^{630} \mathrm{~V}$. item 5.2., supra.
} 
livre circulação de bens e de mão-de-obra, visando a uma unificação monetária integral ${ }^{631}$ (ROLLAND, 2006, p. 524).

A Comissão cultural foi composta em sua maior parte por europeístas Federalistas note-se a presença fundamental nesta Comissão de dois Federalistas convictos: o escritor e diplomata espanhol Salvador de MADARIAGA, o Presidente da Comissão, e o escritor suíço Denis de ROUGEMONT, autor da versão final do Relatório Preparatório. Por isso, pode-se mesmo dizer que o coração do texto produzido por esta Comissão foi o pensamento Federalista (BITSCH, 2006, p. 46; CGH, 2006b; RÉAU, 2008, p. 175).

Dentre as propostas desta Comissão que foram aprovadas pela Sessão Plenária do Congresso $^{632}$, devem ser destacadas (i) a elaboração de uma Carta de Direitos Humanos; e (ii) a criação de uma Corte Suprema de Direitos Humanos, de caráter supranacional, voltada à aplicação das sanções necessárias para fazer respeitar a referida Carta (ROUGEMONT, 1966, p. 272, 1968, p. 6; ROLLAND, 2006, p. 524).

${ }^{631}$ Perceba-se que a perspectiva econômica de aproximação dos países europeus proposta por esta Comissão do CGH pouco se inspira nos dois movimentos europeístas supramencionados no item 5.2. (Unionismo ou Federalismo) (RÉAU, 2008, p. 175). Com efeito, sem se interessar com a resolução do tema de convivência de escalas de existência distintas, pode-se perceber que ela não estava preocupada com a resolução da questão dos jogos de Poder entre cada uma das dimensões por meio de Leis de convivência entre diferentes.

Deste modo, não interessa ao presente estudo acompanhar mais detidamente as preocupações desta Comissão em especial, tendo em vista que escapa ao arco de questões formulado para este trabalho, razão pela qual se deixa de desenvolver maiores considerações sobre ela. De fato, por diversas vezes foi reiterado ao longo deste texto que não se preocupa aqui com a exposição de uma leitura jurídico-econômica do princípio do processo de aproximação de países europeus desenvolvido segundo Leis. Esta leitura foi desde a Introdução Geral colocada em suspenso.

A coerência metodológica deste trabalho exige assim que apenas seja mencionado este evento histórico - a fim de que não seja produzida uma obstinada cegueira na narrativa com relação aos fatos passados - sem que se aprofunde neste trabalho o exame das pretensões desta Comissão em especial - por escapar aos objetivos interpretativos desta Tese. A presença desta informação neste texto tem por objetivo apontar questões históricas a serem desbravadas e desenvolvidas por outros autores - interessados especificamente pelos antecedentes econômicos da atual UE - em seus próprios trabalhos.

Ademais, note-se que não foi o Relatório Preparatório desta Comissão econômica o produto do CGH de 1948 que produzira as principais repercussões institucionais na formulação do CdE (v. item 5.4., a seguir), mas os Relatórios político e cultural. Por mais este motivo, justifica-se o desinteresse em relatar com mais detalhes as características da Comissão econômica, de seu Relatório e de sua Resolução Final.

${ }^{632}$ Não se pode ignorar que a Resolução cultural do CGH também defendera a criação de um Centro de Cultura Europeu e de um Instituto da Infância e da Juventude Europeias, por acreditar que o futuro da Europa residia nos jovens e que estes deveriam passar a pensar europeiamente os problemas europeus (CGH, 2006b, 538-9). Sobre esta percepção da necessidade de se moldar a educação dos jovens dos diferentes países da Europa segundo uma perspectiva propriamente Federal Europeia, remetemos o leitor ao item 5.4.1., infra, sobre o Centro Europeu de Cultura (CEC) e o Colégio Europeu de Bruges (CEB).

Como se poderá compreender mais a seguir, a estes dois organismos institucionais caberia a tarefa de formar e de conformar os futuros líderes da Europa segundo a perspectiva cultural europeia defendida pelos componentes da referida Comissão cultural do CGH: o Federalismo Europeu de Denis de ROUGEMONT. Tratou-se de aprovação de artifício estrategicamente conveniente voltado a manter, aprofundar, reforçar e disseminar epistemicamente uma perspectiva bastante singular de compreender o modo de conduzir a futura União da Europa, perspectiva que parece hoje produzir frutos na Europa. A uniescalaridade totalizante do Federalismo Europeu parece ter encontrado condições acadêmicas eficazes para se enraizar ao longo do tempo nas convicções europeias como a única ou a mais adequada forma de se construir uma Europa Unida... 
O objetivo da proposta da Comissão cultural - moldada a partir das convicções Federalistas Europeias - era garantir a tutela dos Direitos Humanos e da Democracia na Europa - reputados como eixos fundamentais para construir uma Europa Unida (CGH, 2006b, p. 540), pois preservariam "un héritage de civilisation chrétienne, de valeurs spirituelles et culturelles" (CGH, 2006b, p. 538) ${ }^{633}$.

A Comissão política foi composta por representantes de diferentes correntes do pensamento europeísta, agregando mais da metade de todos os Congressistas. Membros do UEM e do CFUE detiveram grande participação nas atividades e nas propostas desta Comissão - com especial atenção a, respectivamente, Duncan SANDYS e Paul RAMADIER. Mas não se pode ignorar o destacado e o profundo impacto dos ideais do Federalismo Europeu (por força de atuação enérgica principalmente de Hendrik BRUGMANS) no texto do Relatório Preparatório desta Comissão - cujo objetivo era delinear o futuro caminho político de uma Europa Unida (BITSCH, 2006 p. 46-7).

A versão final do documento apresentado à Sessão Plenária foi aprovada por unanimidade. Apesar da contraposição intensa entre as duas principais perspectivas acerca do sentido jurídico-político e institucional a ser seguido pela futura aproximação política de estados europeus, a unanimidade foi possível precisamente porque o Relatório Preparatório foi um compromisso entre a proposta de União de Europa mediante termos de cooperação intergovernamental e a de Unificação dos países europeus em um pacto Federal $^{634}$ (BITSCH, 2006, p. 47).

De um lado foi proposta a cooperação intergovernamental por meio de um mecanismo de concertação permanente que fomentasse uma campanha de formação de opinião pública favorável à contínua cooperação entre os países europeus. De outro lado, sugeriu-se que a União Geral da Europa não deveria descuidar da igualdade de direitos entre os países, a ser determinado pelo padrão único dado pelos Direitos Humanos e por

\footnotetext{
${ }^{633}$ A influência do discurso do Federalismo Europeu (UEF e NEI) se apresenta aqui com grande força, não apenas pela reiteração da importância da defesa dos Direitos Humanos e da Democracia, mas também pela referência a uma unidade cultural europeia compartilhada por herdeiros de uma civilização comum, a qual estaria fundada, inclusive, sobre os universais valores da religião cristã.

Segundo relato do próprio Denis de ROUGEMONT (1968, p. 4), a Comissão cultural foi constituída precisamente porque ela deveria explicitar e consagrar os valores norteadores de toda e qualquer futura tentativa de promover uma União política dos países europeus. Nesse sentido, a Comissão cultural detinha a importante incumbência de pavimentar o caminho intelectual a ser trilhado pelas demais Comissões: havia assim uma preferência pelos organizadores do CGH pela condução integral do processo de União da Europa segundo o ideário do Federalismo Europeu.

634 "Les débats sur les grandes lignes de ce rapport confirmaient le maintien d'importantes divergences entre unionistes favorables à une simple « union organique » et repoussant toute solution fédéraliste, et fédéralistes souhaitant la création de un lien fédéral réel". (RÉAU, 2008, p. 176).
} 
critérios democráticos ${ }^{635}$ a serem satisfeitos e mantidos pelos membros desta União da Europa: a missão da Europa politicamente Unida consistia na "réalisation progressive de la [...] démocratie politique" (CGH, 2006a, p. 532).

A Resolução Final da Comissão política aprovada pela Sessão Plenária do CGH de 1948 incorporou a dupla proposta de maneira bastante engenhosa. Esta afirmou ser indispensável fundar uma unidade sólida e durável entre os países europeus com base na dignidade humana, nos princípios democráticos e na preservação das tradições nacionais ${ }^{636}$, as quais, por sua vez, não deveriam deixar de se comprometer e de se engajar “à respecter une Charte des Droits de l'Homme” (CGH, 2006a, p. 533).

Além da proposta de elaboração de uma Carta de Direitos Humanos para a Europa e de criação de uma Corte de Justiça que garantisse a aplicação daquela Carta, o mesmo documento afirmava que o futuro Conselho deveria permanecer aberto a todos os países europeus que quisessem dele participar. Todavia, era condição fundamental que os ingressantes respeitassem a referida Carta de Direitos Humanos ${ }^{637}$ (BERNHARDT, 2010, p. 48; BOSSUAT, 1994, p. 114-5; ROLLAND, 2006, p. 524).

${ }^{635}$ Os critérios exigidos de Democracia seriam definidos pela própria Comissão política, ao passo que os Direitos Humanos a serem respeitados deveriam ser declarados posteriormente por uma Carta Europeia de Direitos Humanos (RÉAU, 2008, p. 175).

${ }^{636}$ Perceba-se que aqui se mostram os primeiros sinais daquela "unidade na diversidade" que nada mais significava o controle da diversidade por parte de Uma escala de existência Única (ou simplesmente, Diversidade na Unidade): a do Um representado pelos Direitos Humanos e pela Democracia.

Com efeito, esta Resolução política aprovada em 1948 pelo CGH determinava a formação de uma Comissão especializada para elaborar uma Carta de Direitos do Homem. Esta deveria estabelecer os critérios segundo os quais um país poderia ou não ser considerado como detendo um regime jurídico-político efetivamente Democrático - pois apenas estas poderiam e deveriam participar da futura Europa politicamente Unidade (CGH, 2006a, p. 533).

Assim, não se pode deixar de notar, desde já, que a Resolução Final desta Comissão foi também fortemente influenciada pela perspectiva Teológico-Política Federalista, apesar da constatada presença do ideário Unionista: apenas seriam membros da Europa politicamente Unida os países que fossem por esta considerados dignos e aptos a dela participar, isto é, desde que respeitassem os valores cristãos europeus naquele documento associados à Democracia e aos Direitos Humanos.

A uniformidade cultural propugnada pelo Federalismo Europeu encontrava aqui condições para se manifestar jurídico-politicamente sob forma de exigências a serem satisfeitas para participar da Europa politicamente Unida e para nela se manter. A diversidade nacional (cultural e jurídico-política) era aceita, desde que compatível com a inquebrantável unidade supranacional (cultural e jurídico-política) imaginada. O Um dos Direitos Humanos e da Democracia também se apresentava aqui como requisito perpetuamente exigido de sujeição total a uma única escala de existência. V. ainda as considerações desenvolvidas sobre o ideário da UEF, em todo o item 5.2.2.2, supra.

${ }^{637}$ Percebe-se com toda sua força a profunda influência exercida pelo ideário Federalista Europeu na composição da referida Resolução Final: as propostas desta dialogavam conscientemente com as formuladas pela Comissão cultural, bem como o discurso defendido pela UEF (v. item 5.2.2.2., supra). A influência do Unionismo fora relegada ao circunscrito campo do Conselho Intergovernamental - a ser progressivamente "convertido" ao ideário Federalista, mediante a atuação da Assembleia Europeia.

Deste modo, o plano Federalista de usar o futuro Conselho da Europa como instrumento de disseminação e de realização de seu arcabouço existencial parece mais claramente arquitetado. Mas será institucionalmente impedido, como mencionado na nota de rodapé 479, supra, e como será mais bem especificado mais a seguir. 
Se era fundamental a instituição de um Conselho extraordinário da Europa que viabilizasse de forma permanente a cooperação entre os países europeus, este deveria trabalhar para cultivar progressivamente sentimentos que permitissem avançar a União da Europa a etapas posteriores, até alcançar a Unificação política da Europa. Para tanto, seria fundamental constituir a Assembleia Europeia, a fim de auxiliar o Conselho neste empreendimento (CGH, 2006a, p. 521-3).

Assim, o CGH de 1948 aprovara em sua Sessão Plenária a sugestão de se constituir um Conselho da Europa, a ser composto por um Conselho Intergovernamental e por uma Assembleia Europeia eleita. Esta deveria aconselhar o Conselho Intergovernamental a atuar no sentido da Unificação europeia em torno dos Direitos Humanos e da Democracia $^{638}$.

As Resoluções Finais de cada Comissão do CGH examinada (cultura e política) propugnaram pela unificação da Europa em cada uma de suas áreas temáticas específicas. Ainda que com divergências internas durante os trabalhos, o discurso que se manifestou com maior força naquele encontro foi o da unificação europeia em torno do ideário

\footnotetext{
${ }^{638}$ Mais uma vez, apresenta-se o movimento que explicita a maior influência exercida pelo ideário Federalista Europeu na redação da Resolução Final do CGH sobre os trabalhos da Comissão política. Se o Conselho Intergovernamental, composto por Estados Soberanos, permitia a preservação das tradições e das Soberanias nacionais (Unionismo Europeu), a seleção de seus membros seria feita a partir de critérios bem específicos: respeito aos Direitos Humanos e à Democracia (Federalismo Europeu). Ao mesmo tempo, ao lado do Conselho Intergovernamental (Unionismo Europeu), deveria ser colocada uma Assembleia Europeia que deveria auxiliar o Conselho Intergovernamental na tarefa de unificar politicamente a Europa em torno dos Direitos Humanos e da Democracia (Federalismo Europeu).

Nesse sentido, conforme a Resolução política Final do /cgh, se um dos elementos do CdE deriva do Unionismo Europeu (Conselho Intergovernamental), todo o resto - requisitos de admissão de Estados, objetivos e um elemento institucional novo - derivava do Federalismo Europeu (respectivamente, respeito aos Direitos Humanos e à Democracia, unificação política e cultural e Assembleia Europeia).

Certamente, não se pode ignorar que a Resolução política aprovada ao final do CGH vacila, em alguns momentos, ao dizer que a Europa Unida será constituída mediante uma Federação ou uma União (CGH, 2006a, p. 532). Contudo, deve-se se lembrar aqui da ressalva de Joseph H. H. WEILER (2011) de que, mais do que prestar atenção ao nome utilizado para designar algo, há que se compreender detidamente o modo como este algo foi - ou pretendeu ser - institucionalmente constituído em termos práticos.

Nesse sentido, perceba-se que a redação da Resolução política do CGH foi efetivamente sagaz: sem se comprometer explicitamente com uma decisão definitiva sobre o modo de designar a futura Europa politicamente Unida entre Federação ou União, ela afirmou pontual e progressivamente a necessidade de a Europa politicamente Unida dever se fundar nos preceitos tipicamente Federalistas da proteção incondicional dos Direitos Humanos e da Democracia. Apesar de não assumir posição de modo declarado, o credo Federalista Europeu pouco a pouco se revela com força no texto desta Resolução política Final do CGH.

Assim, longe de ser um mero compromisso político entre Unionismo e Federalismo, a Resolução política Final do CGH representara efetiva bandeira de vitória despercebida de vocalização bemsucedida do ideário Federalista Europeu. Independentemente da forma de organização jurídico-política a ser adotada (União ou Federação), a substância da Europa politicamente Unida seria a do Federalismo Europeu (Direitos Humanos e Democracia). Por esse motivo, pode-se perceber uma maior inclinação deste "compromisso político" em direção ao Federalismo Europeu, em detrimento do Unionismo Europeu.
} 
Federalista Europeu (GLAESNER, 1991, p. 287; RÉAU, 2007, p. 10-1; REFALO, 1980, p. 72; VOYENNE, 1948, p. 4).

Após o término do CGH de 1948, seus participantes se comprometeram a utilizar todos os meios existentes para influenciar seus respectivos Governos nacionais para que adotassem tais propostas. Outro objetivo seria também tentar convencer de modo contínuo a geração presente e as gerações futuras sobre a necessidade de se perseverar na perseguição dos objetivos declarados pelas Resoluções Finais aprovadas pela Sessão Plenária em direção à Unificação Europeia ${ }^{639}$.

Deste modo, ao final daquele encontro foi instituído o Movimento Europeu (ME). Este seria responsável pela continuidade permanente dos trabalhos do Congresso e deveria atuar para manter, fortalecer e difundir ainda mais a convicção da importância de permanecer buscando a realização das Resoluções ali tomadas em prol da Unificação Federal da Europa ${ }^{640}$ (BARNAVI; POMIAN, 2008, p. 95; BERSTEIN; MILZA, 2002, p. 236; BOSSUAT, 1994, p. 115-6; GLAESNER, 1991, p. 287; MATTERA, 2002, p. 21-2; NOËL et alii, 2008, p. 122; PERTEK, 2011, p. 14-5; QUADROS, 1984, p. 119; QUERMONNE, 2010, p. 14; RÉAU, 2008, p. 174-7; REUTER, 1965, p. 36; ROLLAND, 2006, p. 524; ROUGEMONT, 1961, p. 410).

\subsection{Repercussões Institucionais do Congresso de Haia e a Contenção Parcial} do Teológico-Político

Em virtude da suspensão da leitura econômica efetuada no início deste trabalho e reiterada por diversas vezes ao longo do texto, não serão examinadas neste item as repercussões institucionais da Comissão econômica do CGH de $1948^{641}$. O foco da narrativa neste momento consistirá em enfatizar os produtos institucionais do ideário

\footnotetext{
${ }^{639}$ Esta preocupação pedagógica uniescalar Federalista do final do CGH não poderia deixar de ser salientada, para não passar despercebida pelo leitor: um Projeto de fundar e de defender academicamente um discurso Teológico-Político Federalista Europeu era um objetivo claro do CGH. E não será sem repercussões institucionais, como será visto a seguir (v. item 5.4., infra).

${ }^{640}$ Há que se notar, neste particular, que o ME contribuiu especialmente para a criação do CEC, do CdE, bem como da CDH, sempre segundo uma orientação mais e mais Federalista (BOSSUAT, 1994, p. 116; NOËL et alii, 2008, p. 242).

O Memorando redigido pelo Comitê Executivo do ME, em 23.11.1948, deixa bastante clara essa tendência fundamentalmente Federalista do ideário do movimento: "Si les nations décident de transférer une partie de leurs droits souverains à une autorité européenne internationale, et quand elles en décideront, il sera sans doute nécessaire de créer une forme quelconque de parlement fédéral avec certains pouvoirs législatifs." (ME, 2006, p. 579, grifos nossos).

${ }^{641}$ Essa postura é exigida pela necessidade de se manter as devidas coerência e coesão metodológicas do presente texto.
} 
afirmado nas Resoluções Finais das Comissões cultural e política do Congresso, pois apenas estas guardam relação com o arco de questões circunscrito no início deste estudo.

A conjunção das Resoluções Finais daquelas duas Comissões contribuiu efetivamente para a construção de instituições novas na Europa responsáveis pelo fomento da integração entre alguns países europeus. Com efeito, não se pode ignorar ter sido o Memorando redigido ao final do $\mathrm{CGH}$ a fonte de inspiração direta do futuro $\mathrm{CdE}$, bem como dos subsequentes Projeto de Convenção Europeia de Salvaguarda dos Direitos Humanos $(\mathrm{CDH})^{642}$ e Corte Europeia de Direitos Humanos (CEDH) ${ }^{643}$ (BITSCH, 2006, p. 46; GLAESNER, 1991, p. 287; PERTEK, 2011, p. 14; RÉAU, 2008, p. 134, 139, 166 e 172; ROUGEMONT, 1961, p. 410). Destas três iniciativas, as que interessam mais diretamente ao presente trabalho são o $\mathrm{CdE}$ e a $\mathrm{CDH}^{644}$, razão pela qual uma breve História sobre a formação de cada uma delas será apresentada nas linhas abaixo - nos estritos limites que interessarem ao objetivo específico deste item ${ }^{645}$.

Estas são as principais - mas não as únicas - contribuições institucionais do CGH para a construção de um Projeto específico de Europa Unida mediante unificação política

${ }^{642}$ A ser denominada Convenção Europeia dos Direitos do Homem (CDH), de 4.11.1950.

${ }^{643}$ Instituída em Estrasburgo em 1959.

${ }^{644}$ Como afirmado na nota anterior, a CEDH foi instituída em 1959. A necessidade de assegurar coerência e coesão metodológicas ao presente trabalho determina que não seja estudada a História completa de construção da $\mathrm{CEDH}$, na medida em que esta foi criada definitivamente em momento localizado fora do lapso temporal estipulado para o presente estudo (1945 a 1951).

Por esse motivo, muito pouco será dito a seguir sobre a CEDH neste texto, a fim de que a solidez metodológica deste trabalho não seja ameaçada. Registra-se desde logo o convite para futuras investigações conjuntas sobre o tema da inserção ou não da CEDH no interior do Projeto Teológico-Político Federalista.

Cumpre salientar que muito pouco será dito também sobre a própria CDH neste trabalho, na medida em que não é o foco deste estudo tratar minuciosamente do processo de afirmação dos Direitos Humanos na Europa do pós-Segunda Guerra Mundial.

$\mathrm{Na}$ verdade, a proposta e a aprovação da $\mathrm{CDH}$ serão mencionadas rapidamente neste texto apenas no que for necessário para evidenciar a tendência unidimensionalizante de caráter Teológico-Político do Projeto Federalista subjacente à constituição do $\mathrm{CdE}$ - isto é, a $\mathrm{CDH}$ como artifício jurídico-normativo criado para possibilitar por vias transversas a ampliação da capacidade de influência política e cultural do CdE sobre a Europa.

Ademais, não se deve ignorar que o exame da $\mathrm{CDH}$ por este trabalho será restrito ao período de tempo metodologicamente designado para este estudo (1945 a 1951): se a referida Convenção foi aprovada em 4.11.1950, ela entrou em vigor apenas em 3.9.1953, vale dizer, em momento posterior ao lapso temporal escolhido para ser analisado.

Assim, também em virtude da coerência metodológica temporal deste trabalho, não é possível analisar a $\mathrm{CDH}$ depois que entrou em vigor. Serão examinados aqui apenas e tão-somente aqueles aspectos históricos a ela relacionados, os quais se desenvolveram durante o período que coincidiu com o presente recorte temporal: as razões unidimensionalizantes de sua aprovação, conforme o Projeto Federalista de Unificação Teológico-Política da Europa.

${ }^{645}$ A saber, reforçar o movimento lógico de explicitação dos fundamentos Teológico-Políticos da bemsucedida vertente Federalista, a qual caracterizou a formação do CdE.

Nesse sentido, lembre-se de que o objetivo deste trabalho consiste em analisar a significação jurídico-Política da construção histórica específica da CECA, e não de outras organizações. Por esse motivo, a menção a ser feita ao processo histórico de construção do CdE e da CDH não será integral, mas sim limitada a expor aquilo que puder auxiliar na apresentação da CECA como modo inédito de aproximação política de países europeus no período de tempo selecionado (1945 a 1951). 
Federal. Não se pode deixar de mencionar outras duas contribuições institucionais diretas das Resoluções Finais do CGH de 1948, a saber, o Centro Europeu de Cultura (CEC) e o Colégio Europeu de Bruges (CEB).

Apesar de não estarem diretamente relacionadas aos objetivos deste trabalho ${ }^{646}$, devem ambas as instituições ser indicadas neste texto - ainda que de maneira bastante breve, pois uma rápida compreensão das duas permitirá reforçar a conclusão em torno da tendência Teológico-Política do Projeto institucional de Europa Unida diretamente derivado do $\mathrm{CGH}^{647}$.

Se podem ser indicados como resultados imediatos do $\mathrm{CGH}$ o $\mathrm{CdE}$, a $\mathrm{CDH}$, o CEC e o CEB, não se pode deixar de notar que estes detinham forte compromisso com a perspectiva que mais se destacou na formulação dos Relatórios Preparatórios e das Resoluções Finais daquele evento: o Federalismo Europeu ${ }^{648}$. Mais simplesmente, há que se notar nas linhas a seguir o movimento que permite compreender os quatro como formas encontradas pelos europeístas Federalistas de construir uma Europa Unificada à imagem e semelhança da dimensão de existência por apenas eles mesmos concebida.

\subsubsection{O Centro Europeu de Cultura e o Colégio Europeu de Bruges}

No que se refere ao CEC e ao CEB, deve-se lembrar que são eles o resultado da atuação do supramencionado Movimento Europeu (ME), fundado após o CGH, em 25.10.1948 (DESCHAMPS, 2009b, p. 175). O ME representava o conjunto de todos os movimentos europeístas que, após o final do $\mathrm{CGH}$, se mostravam favoráveis à formação de uma Europa Unida em termos Federais - dentre os quais podem ser mencionadas as NEI e a UEF ${ }^{649}$ (BOSSUAT, 1994, p. 116-7).

\footnotetext{
${ }^{646}$ Por se tratarem, como se poderá ver a seguir, de instituições "privadas" de manutenção epistêmica do ideário Federalista, e não de instituições Públicas, vale dizer, de instituições em que há a preocupação em resolver jurídico-politicamente conflitos entre distintas dimensões existenciais de uma vida comum na Europa mediante a aposição institucional de normas jurídico-positivas de oposições escalares.

${ }^{647}$ Há que se lembrar de que a referência às duas repercussões institucionais "privadas" é metodologicamente autorizada por questões temporais, pois ambas foram criadas dentro do lapso temporal estipulado para o presente estudo (1945 a 1951), como se poderá ver nas linhas a seguir.

648 “" [V]ictoire européenne, le congrès de La Haye fut aussi une victoire fédéraliste. [... I]ls étaient les seuls à savoir exactement ce qu'ils voulaient - et non pas seulement, comme beaucoup d'autres, ce qu'ils ne voulaient pas - [et, pour cela] ont pu faire passer dans les résolutions votées à l'unanimité par le congrès une part importante de leurs idées." (VOYENNE, 1948, p. 4).

${ }^{649}$ Apesar de não se poder ignorar a contradição apontada por Élisabeth du RÉAU (2008, p. 192) de ter a primeira presidência do Comitê Executivo do ME ter sido concedida ao unionista Duncan SANDYS - não favorável à realização de uma Europa Unida fora dos limites de uma cooperação intergovernamental.
} 
O ME tinha por objetivo guiar a opinião pública. Para tanto, ele se autoincumbira da tarefa de promover uma consciência europeia comum a ser esclarecida e amplamente difundida por entre a opinião pública ${ }^{650}$.

A partir de sua primeira sessão oficial - em fevereiro de 1949 - o ME percebeu ser necessário o desenvolvimento de estudos políticos, jurídicos, culturais, sociais e econômicos para constituir um repertório discursivo comum. Este arcabouço de significações comuns deveria estar apto a (con-)formar culturalmente a opinião pública europeia, a fim de que esta reconhecesse a si própria como portadora de uma consciência comum europeia. Para os integrantes Federalistas do ME, apenas por meio desta nova auto-compreensão ético-política seria possível calar definitivamente os nacionalismos em nome de uma União maior e mais universal.

Com o objetivo de cumprir esse intento de reforço epistêmico legitimador da perspectiva política Federal, em dezembro de 1949 foi instituído o CEC. O CEC foi instalado no castelo de Coppet, próximo a Genebra, e foi incumbido de (i) constituir uma Revista Cultural Mensal para aprofundar o lastro teórico dos intentos Federalistas; e (ii) influenciar a formação educacional dos jovens da Europa por meio de um centro de formação europeu centrado unicamente na perspectiva Federalista ${ }^{651}$. Para atender a este último objetivo, no final de 1950 foi fundado o CEB, o qual teve como primeiro Presidente o Federalista Hendrik BRUGMANS (BOSSUAT, 1994, p. 116; DESCHAMPS, 2009b, 2009c). O CEC e o CEB deteriam conjuntamente o papel educativo de profunda transformação da cultura política europeia.

Não é demais lembrar que a cultura política europeia a ser fomentada e divulgada por estes dois centros estava visceralmente comprometida com o discurso Federalista Europeu. Em outras palavras, não era "neutra" a "formação europeia" por eles prometida em torno de temáticas europeias. Particularmente no que se refere ao CEB, Alfonso

${ }^{650}$ Perceba-se aqui a reafirmação e a permanência do forte tom pedagógico e doutrinário da dogmática perspectiva Federalista: a seu fautores caberia revelar à opinião pública europeia a verdade inabalável - porém "indevidamente oculta" - de serem os povos europeus apenas Um. Eles teriam esquecido este aspecto e ainda não deteriam condições para dele se lembrar por si sós.

A sedutora imagem deste Um pacificador forjado a partir da escala Federalista revela aqui sua grande proximidade com os intentos característicos do Teológico-Político: disseminar a "palavra" do Federalismo, fazer ser ouvida a "Boa Nova" da Europeia Unificada entre todos os europeus. Mas apenas entre aqueles europeus que "souberem ouvir" o chamado dos Direitos Humanos e da Democracia... V., nesse sentido, as observações feitas sobre o Federalismo Europeu ao longo do item 5.2.2., supra.

651 "Dirigé et véritablement pensé par Denis de Rougemeont, le CEC [Centre Européen de la Culture] doit avant tout remplir un rôle d'organe indépendant de coordination, de formation critique de l'opinion et de documentation, afin de développer, d'exprimer et d'illustrer le sentiment européen auprès du plus grand public possible. L'objectif essentiel de Rougemont est en effet de promouvoir, dans un sens fédéraliste et personnaliste, la culture européenne perçue comme le fondement principal de l'union des Européens [...]."(DESCHAMPS, 2009b, p. 175, grifos nossos). 
MATTERA (2002, p. 18) ressalta que este pode ser visto hoje como experiência de "véritable laboratoire de futurs dirigeants européens", o que torna evidente seu objetivo de exercer papel de propulsão do ideário Federalista na Europa até os presentes dias principalmente dentre os principais quadros burocráticos europeus (DESCHAMPS, 2009c, p. 204).

Aliás, este era também o preciso e precioso objetivo atribuído ao CEC pela UEF, segundo a Resolução aprovada em seu Congresso realizado em Roma, em 1948: "le rôle [du Centre Européen de la Culture] ne sera pas seulement académique, mais [...] il contribuera effectivement à la formation des nouvelles élites et des nouveaux cadres sur lesquels s'appuiera la reconstruction de l'Europe" (UEF, 2006c, p. 561). Afinal, para eles, o futuro da Europa Unida residia entre os jovens da Europa e, por isso, estes deveriam ser preparados e formados para saber atuar na Europa segundo uma perspectiva Europeia (Federal).

O CEC deveria ser independente de qualquer Estado, vale dizer, ele não poderia ser controlado por qualquer Estado em suas atividades acadêmicas, na medida em que deveria desenvolver e difundir uma perspectiva europeia formadora das convicções dos futuros líderes europeus. Apenas deste modo seria viável esperar a adequada formação e vocalização de uma consciência e de um sentimento europeus a serem disseminados por todos os meios existentes - imprensa, livros, filmes, rádios, Escolas, Universidades ${ }^{652}$, de modo a influenciar europeiamente as diferentes opiniões públicas e os Governos nacionais (ME, 2006, p. 538-9).

Assim, por meio dessas duas instituições, os Federalistas europeus encontraram condições não apenas para ampliar o convencimento das gerações de europeus de seu tempo em torno da "causa" Federalista. Mais importante do que isso, estes centros

${ }^{652}$ Havia naquela mesma Resolução cultural do CGH, de 1948, interessante proposta de "procéder à une révision des manuels d'histoire" (CGH, 2006b, p. 539). Não foi possível - pois não se encontrava no interior do arco metodológico definido para a investigação deste trabalho - averiguar de que maneira se pretendeu efetuar a dita "revisão histórica" dos conteúdos veiculados nos manuais de História da Europa. Mas a tendência Teológico-Política uniformizante da cultura portada pelo Federalismo Europeu permite prever o sentido da revisão da História da Europa: a afirmação absoluta de uma suposta unidade cultural compartilhada entre os diferentes países europeus legada por uma civilização europeia imemorial e perdida...

Apenas a título exemplificativo, mencione-se que as obras de Charles-Olivier CARBONELL (1996a, 1996b, 1996c), de Charles-Olivier CARBONELL et alii (1999a, 1999b) e, principalmente, de Denis de ROUGEMONT (1961), são exemplos de uma historiografia europeia contemporânea voltada à construção de uma imagem histórica da Europa a partir de uma perspectiva estritamente europeia, isto é, não vinculada aos ditos reducionismos estatais. Talvez nestes autores se possam encontrar indícios do percurso intelectual da historiografia europeísta preocupada com a revisão da História da Europa conforme perspectiva Federalista.

A questão é bastante interessante, mas escapa aos objetivos investigativos deste trabalho. Fica registrado aqui o convite para futuras Pesquisas em torno desta temática. 
deveriam semear a concepção unidimensional de Europa Federal nas bases de formação das gerações vindouras de europeus (RÉAU, 2008, p. 177 e 191-4) ${ }^{653}$. Estavam estabelecidos assim os primeiros instrumentos de "evangelização" da Europa e de sua juventude, conforme os ditames estabelecidos pela unidimensionalidade Teológico-Política do Federalismo Europeu ${ }^{654}$.

Le Mouvement européen se tourna vers la jeunesse européenne. Il organisa à partir de 1951 une Campagne européenne de la jeunesse destinée à éduquer à l'esprit fédéraliste les jeunes d'Europe occidentale [...].

Pourtant l'intelligentsia européenne était-elle favorable à l'unité européenne ? Elle pensait alors souvent que l'Europe représentait l'impérialisme, le colonialisme et le racisme. Sartre, Macciochi, Morin, Fanon, Aragon criaient leur dégoût de l'Europe. L'Europe entrait dans la «vieillesse de l'esprit». (BOSSUAT, 1994, p. 117, grifos do autor). ${ }^{655}$

Todavia, mais do que se centrar nessas repercussões institucionais epistêmicas das Comissões cultural e política do CGH de 1948, o movimento investigativo deste trabalho se debruça sobre as contribuições destas para a formação do ideário que implicou na constituição do $\mathrm{CdE}$ e da $\mathrm{CDH}^{656}$.

653 As obras mencionadas na nota de rodapé anterior são exemplos deste corpo doutrinário que busca construir a imagem de a História da Europa ter seguido desde tempos imemoriais um caminho em linha reta em direção à realização de valores supostamente comuns e universais (Direitos Humanos e Democracia), cujo destino final máximo seria um Estado Federal Europeu.

${ }^{654}$ Cujos frutos talvez sintamos na UE atual, a qual teria adotado - segundo leituras propostas por Philip BOBBITT (2011), Catherine KESSEDJIAN (2010), Carolina Maria LEMBO (2010), Carlos Francisco Molina del POZO (2012), Miryam Rodríguez-Izquierdo SERRANO (2011), Nicolas VÉRON (2011) e Joseph H. H. WEILER (2011) - uma estrutura institucional Federal, apesar de não ter assumido essa condição de forma expressa e com sinceridade.

De todo modo, lembre-se de que, apesar de interessante, a discussão deste tema em especial não cabe a este trabalho por força da delimitação metodológica (temporal e temática) assumida no início deste estudo. Fica aqui registrado o convite para futuras investigações sobre essa questão.

${ }^{655}$ Para maiores informações sobre a Campanha Europeia de Juventude, indicamos a leitura de Étienne DESCHAMPS (2009a), onde também se evidencia com mais elementos a tendência Teológico-Política de evangelização Federalista que caracterizara o encontro: "le but poursuivi est clair: il s'agit de convaincre les jeunes de la nécessité de réaliser l'unité européenne” (DESCHAMPS, 2009a, p. 162).

${ }^{656}$ Por mais que o estudo específico da História da construção do CdE não seja o objeto de interesse deste trabalho, não se pode ignorar que o surgimento desta Organização é evento importante realizado durante a construção da integração europeia, bastante distinto da CECA (v., nesse sentido, a nota de rodapé 479, supra).

Assim, a fim de se poder diferenciar a lógica de convivência pretendida pelo Projeto de Europa Unida original do CdE daquele por ele mesmo realizado, bem como com relação ao promovido pela CECA, são fundamentais os breves esclarecimentos históricos a serem formulados nas linhas a seguir. Apenas deste modo se poderá mostrar de modo claro e distinto como e em que medida o Projeto do CdE e o da CECA se distinguem entre si.

Em outras palavras, pela apresentação sucinta da História de proposição do CdE (convivência de pretensões unificadoras da pluralidade, ou Leis Teológico-Políticas) e de sua concretização institucional (cooperação política intergovernamental) - Organização de inspiração Federalista, será possível perceber de que modo a antípoda CECA se apresenta como integração europeia singular (convivência plural permanente, ou Leis Políticas). Por meio da definição do outro - daquilo que não é a CECA, é possível compreender mais precisamente a CECA em si mesma. 


\subsubsection{O Tratado de Londres de 1949 e o Conselho da Europa (CdE)}

\subsubsection{Origens do $\mathrm{CdE}$}

O $\mathrm{CdE}^{657}$ foi instituído por meio do Tratado de Londres, assinado em 5.5.1949 entre dez Estados, a saber, Bélgica, Dinamarca, França, Irlanda, Itália, Luxemburgo, Noruega, Países-Baixos, Reino Unido e Suécia, com o objetivo de instituir uma aproximação política entre seus países-membros. Sua fundação tem origem oficial na proposta formulada em 19.7.1948 pelo Ministério das Relações Exteriores da França, mediante intervenção de Georges BIDAULT perante o Conselho Consultivo do Pacto de Bruxelas.

Após o $\mathrm{CGH}^{658}$, o Ministério das Relações Exteriores da França entendeu haver em solo europeu ambiente favorável a uma proposta diplomática formal que convidasse as principais potências regionais a promover a defesa de um patrimônio comum europeu informado por princípios democráticos e pelos Direitos Humanos - precisamente de acordo com os preceitos aprovados durante o CGH (BOSSUAT, 1994, p. 116; ME, 2006,

Há assim um procedimento histórico-comparativo de definição e de especificação do fenômeno estudado de modo privilegiado (CECA) com relação a outros que foram metodologicamente afastados (OECE, Pacto de Bruxelas, CdE) (v. reflexões do Primeiro Capítulo, supra).

Haveria que também se conhecer a História daquilo que não corresponde originariamente ao processo de integração europeu atual, a fim de que ele próprio seja mais bem compreendido em sua própria especificidade. "L'intérêt de cette initiative $[\mathrm{CdE}]$ est souvent occulté de nos jours par une historiographie de la construction européenne très largement consacrée à l'histoire de l'intégration européenne mais le rôle de cette organisation $[\mathrm{CdE}]$ mérite un réexamen à la lumière des apports récents de la recherche historique" (RÉAU, 2008, p. 178).

${ }^{657}$ Não deve o Conselho da Europa (CdE) ser confundido com o Conselho Europeu (CEU). A análise da construção histórica do CdE será feita nas linhas a seguir.

O CEU consiste na reunião periódica dos Chefes de Estado e de Governo dos países-membros da UE. Não foi previsto pelos Tratados Constitutivos das Comunidades Europeias (CECA, CEEA ou CEE), mas foi objeto de progressiva institucionalização até ter se tornado, hoje, órgão supremo de orientação e de estabelecimento de prioridades políticas na UE. Tem sua origem na multiplicação das reuniões informais realizadas entre os Chefes de Estado e de Governo dos Estados-Membros: Cúpula de Paris (10-11.2.1961), Cúpula de Bad-Godesberg (18.7.1961), Cúpula de Roma (30.5.1967), Cúpula de Haia (1-2.12.1969), Cúpula de Paris (19-21.10.1972) e Cúpula de Copenhagen (14-15.12.1973).

Na Cúpula de Paris (9-10.12.1974), por iniciativa do então Presidente da França, Valéry Giscard D'ESTAING, estabeleceu-se que tais reuniões deveriam se realizar com uma frequência maior e com maior regularidade, a fim de debater os temas mais importantes para a integração europeia. O CEU foi mencionado oficialmente pela primeira vez no Ato Único Europeu (AUE), de 1986, mas recebeu uma definição de competência mais precisa a partir do Tratado de Maastricht, de 1992. Com o Tratado de Lisboa, de 2007, o CEU recebeu delimitações mais específicas e foi dotado de uma presidência estável.

A discussão sobre a História do CEU escapa aos objetivos deste trabalho, pois se encontra fora do campo temporal metodologicamente delimitado na Parte Primeira deste texto. Por esse motivo, após estes breves esclarecimentos destinados a diferenciá-lo do CdE, não será escrita linha alguma a mais sobre ele. Para maiores informações sobre o CEU, indicamos, a título exemplificativo, a leitura de Pierre GERBET (2009b) e de François-Xavier PRIOLLAUD (2008).

${ }^{658}$ Como visto nos itens anteriores, realizado entre os dias 7-10.5.1948. 
p. 576; MONACO, 1961c, p. 209; NOËL et alii, 2008, p. 123; PRIOLLAUD; SIRITZKY, 2011, p. 15-6; ZORGBIBE, 1997, p. 19-20).

Por essa razão, em 19.7.1948, Georges BIDAULT incitara os países-membros do Pacto de Bruxelas a ler as Resoluções Finais do recém-realizado CGH para que pensassem a partir delas a organização de um mecanismo mais aperfeiçoado e profundo de aproximação política entre os países europeus no interior de uma Assembleia Europeia. A constituição desta deveria ser estudada e ter seus termos delineados pelo Comitê permanente do Pacto de Bruxelas. Em seguida, a proposta deveria ser aprovada na próxima reunião do Comitê consultivo da mesma Organização, a ser realizada ainda no mesmo ano $^{659}$.

De pretensões mais amplas do que uma simples cooperação militar, o mecanismo de aproximação política de países europeus (Assembleia Europeia) que havia sido proposto visava a abranger não apenas os cinco membros do Pacto de Bruxelas, mas todo e qualquer país europeu que se dispusesse a conservar aquele patrimônio comum da civilização europeia. Havia um claro objetivo de incluir não apenas a Alemanha, mas também países localizados além dos limites da Europa Ocidental: o único critério a ser necessariamente satisfeito era o respeito, a conservação e a promoção da tradição da civilização europeia Direitos Humanos e Democracia (LUCATELLO, 1959, p. 133; MONACO, 1961c, p. $210)^{660}$.

A proposta francesa foi muito influenciada pelo ideário Federalista Europeu do CGH de 1948. Todavia, os mecanismos institucionais destinados a dar realidade concreta e viabilização prática para esta proposta deveriam ser examinados e aprovados pelos demais países-membros do Pacto de Bruxelas.

\footnotetext{
659 “[S]a proposition est mal accueillie par E. Bevin [Ministre des Affaires Extérieures du Royaume-Uni] si bien que les Cinq la renvoient à la Commission permanente de Londres qui l'examine d'autant que Bidault est obligé de quitter le quais d'Orsay peu après. Son successeur aux Affaires étrangères, Robert Schuman, s'engage immédiatement et résolument en faveur du projet du Mouvement européen qu'il entend inscrire dans la continuité de la proposition Bidault. Dès le 18 août, il fait approuver le projet par le gouvernement qui décide de saisir les autres puissances signataires du pacte de Bruxelles pour mettre en route le processus permettant de créer une Assemblée européenne.” (BITSCH, 2006, p. 49).

${ }^{660}$ Perceba-se aqui a forte influência nesta proposta francesa do ideário Federalista Europeu constante das Resoluções Finais das Comissões cultural e política da Conferência de Haia de 1948, bem como do discurso europeísta Federalista das NEI e da UEF. Remetemos o leitor aos itens 5.2.2. e 5.3., supra.
} 


\subsubsection{A Controvérsia da Realização Institucional da Assembleia Europeia:}

\section{Unionismo versus Federalismo}

Foi precisamente neste momento de discussão do desenho institucional a ser imaginado para aquela futura Assembleia Europeia Federalista que surgiram as primeiras manifestações de resistência à pretensão unidimensionalizante da proposta original. Como se verá a seguir, durante este percurso de concepção dos mecanismos práticos de realização institucional da proposta original francesa, esta foi modificada em prejuízo do ideal Teológico-Político Federalista Europeu.

De acordo com a declaração de Georges BIDAULT, a segunda reunião do Comitê consultivo do Pacto de Bruxelas a ser realizada em 1948 seria responsável pela discussão dos termos práticos segundo os quais a futura nova Organização Europeia deveria ser encaminhada, bem como pela aprovação de sua criação.

Em 25.10.1948, o referido Comitê se reuniu em Londres, onde a proposta francesa de Assembleia Europeia - nos moldes do ideário Federalista - foi relembrada pela delegação daquele país. Naquela oportunidade, a delegação britânica mostrou de modo mais claro que não concordava com uma integração política na Europa que visasse à construção de uma unidade política Federal. Segundo a perspectiva britânica - mais afeita à proposta Unionista - os mesmos objetivos poderiam ser atingidos mediante uma cooperação política de caráter intergovernamental.

Ao final daquele encontro se determinou que seria criado um Comitê especial de estudos responsável pela discussão dos contornos institucionais a serem assumidos por aquele futuro organismo europeu. O novo Comitê deveria se reunir o quanto antes e seria composto por representantes dos cinco países-membros do Pacto de Bruxelas (BITSCH, 2006, p. 49-50; ME, 2006, p. 576; MONACO, 1961c, p. 209).

O Comitê especial de estudos se reuniu em Paris, entre os dias 26.11.1948 e 18.1.1949, e foi composto por 18 (dezoito) membros: 5 (cinco) ingleses, 5 (cinco) franceses $^{661}, 3$ (três) belgas, 3 (três) holandeses e 2 (dois) luxemburgueses. Este deveria examinar e discutir as propostas de desenho institucional da referida Assembleia Europeia

${ }^{661}$ Élisabeth du RÉAU (2008, p. 182) aponta que a delegação francesa era composta em sua maior parte por representantes que, de diferentes maneiras, participavam do $\mathrm{ME}$ - e, portanto, mais afeitos a uma perspectiva Federalista. 
que lhe fossem apresentadas ${ }^{662}$. Foram objeto de discussão dois Memorandos, um de origem britânica, outro de origem francesa (ME, 2006, p. 576).

O documento elaborado pelo Reino Unido foi apresentado logo na abertura da reunião daquele Comitê, em 26.11.1948. Sua proposta se restringia a sugerir a criação de um Conselho da Europa de caráter intergovernamental, a fim de instituir uma dinâmica de cooperação política entre seus países-membros que não abrangesse os setores da Economia e do uso de força militar ${ }^{663}$ e que não atentasse contra as Soberanias estatais nacionais. Segundo esta proposta, os membros seriam originalmente os cinco países componentes do Pacto de Bruxelas, mas se poderia admitir o ingresso posterior dos Estados que participavam da OECE. A proposta britânica sinalizava, assim, a intenção de preservar uma lógica de simples cooperação política intergovernamental entre os países europeus. Entre as diferentes Organizações Internacionais de cooperação deveria haver uma simples diferença de competência (econômica, militar e política).

A França preparou documento distinto, trazido perante o Comitê de estudos em 29.11.1948. Sua proposta (i) reforçou a necessidade e a urgência de se preocupar com uma união política mais estreita entre os países-membros do Pacto de Bruxelas e entre estes e os demais países europeus, bem como (ii) sublinhou a importância de este novo mecanismo de aproximação deter objetivos mais ambiciosos e profundos (Federação). Todavia, diante da manifestação britânica, o documento sugerira que a Assembleia Europeia poderia deter um caráter meramente consultivo, desde que lhe fossem asseguradas ampla liberdade de expressão e vasta representatividade (BITSCH, 2006, p. 50-1; LUCATELLO, 1959, p. 131; REUTER, 1965, p. 40; ZORGBIBE, 1997, p. 20).

Perceba-se que, diante da contraposição da proposta britânica, houve efetivo recuo na proposta francesa com relação a seu intento original.

Com efeito, em um primeiro momento a França propusera a instituição de um mecanismo de unificação Federal da Europa por meio de uma Assembleia Europeia forjada conforme as Resoluções Finais do CGH de 1948. Todavia, a hesitação britânica motivou o reconhecimento pela delegação francesa da necessidade de ser mais prudente em sua

\footnotetext{
${ }^{662}$ Segundo o Memorando preparado pelo Comitê Executivo do ME, datado de 23.11.1948, a organização desta Comissão Especial tinha por objetivo atrair representantes de outros Estados europeus eventualmente interessados em promover a Assembleia Europeia Federalista. Essa percepção reforça a ideia de que não se pretendia restringir a experiência da União política da Europa apenas aos cinco países participantes do Pacto de Bruxelas (ME, 2006, p. 577).

${ }^{663} \mathrm{Na}$ medida em que cada uma delas já era exercida por uma Organização Internacional específica: a cooperação econômica, pela OECE, e a cooperação militar, pelo Pacto de Bruxelas. Remetemos o leitor às considerações do Quarto Capítulo, supra, em que a construção histórica de ambas as Organizações foi rapidamente mencionada.
} 
sugestão e de seguir a indicação dada já em 23.11.1948 pelo ME em criterioso Memorando especialmente redigido para tais discussões: "tourn[er] vers la coopération intergouvernementale et rejeter toute apparence de fédéralisme: l'Assemblée qui sera créée ne doit pas apparaître comme un parlement fédéral.” (ROLLAND, 2006, p. 558).

A oscilação dos dois principais países componentes do Pacto de Bruxelas contribuiu para que o ME sugerisse em seu Memorando uma opção mais cuidadosa: somente intensificar e acelerar uma cooperação política intergovernamental na Europa. A Assembleia Europeia deveria deter mera missão de estabelecer os fundamentos "espirituais" necessários para reforçar e conservar uma União de países europeus fundada nas exigências de uma cooperação política intergovernamental (ME, 2006, p. 577-9). Bastante esclarecedoras são as próprias palavras do referido documento:

7) Les récents débats publics ont donné naissance à quelques craintes provenant de malentendus sur les pouvoirs et attributions de l'Assemblée proposée. Si les nations décident de transférer une partie de leurs droits souverains à une autorité européenne internationale, et quand elles en décideront, il sera sans doute nécessaire de créer une forme quelconque de parlement fédéral avec certains pouvoirs législatifs. Toutefois, ces perspectives futures ne doivent pas être confondues avec le projet beaucoup plus limité, mais immédiatement réalisable, qui est actuellement envisagé.

8) Afin d'éviter tout malentendu, il est souhaitable que l'Assemblé reçoive un nom et des attributions marquant clairement qu'elle n'est pas un parlement fédéral, ni même une assemblée constituante ou préconstituante, et qu'elle ne possède aucun pouvoir législatif ou constituant. En conséquence, il est suggéré de l'appeler officiellement «Assemblée Consultative Européenne » [...]. (ME, 2006, p. 579, grifos nossos).

O mesmo Memorando do ME reforçava ser necessário considerar seriamente a proposta britânica e colocar ao lado da referida Assembleia Europeia Consultiva um Comitê Europeu de Ministros. Este não deveria substituir a Assembleia e deveria ser o principal instrumento de realização da cooperação política intergovernamental entre os países europeus. O Comitê deveria operar como um conveniente locus para que os Governos europeus examinassem em comum as recomendações aprovadas pela Assembleia (ME, 2006, p. 583).

Assim, a contraposição entre a proposição original francesa e a proposta da delegação britãnica implicou uma realização concreta institucional afastada do Projeto de Assembleia Europeia formulada originalmente de acordo com os planos Federalistas. Segundo a prudente observação do Memorando do ME, a Assembleia deveria ser acompanhada por um Comitê de Ministros, e ambos comporiam conjuntamente o futuro mecanismo de cooperação política intergovernamental. Foi mediante a elaboração de um 
termo de compromisso - o CdE - que se solucionou o confronto entre as propostas britânica e francesa, a saber:

\begin{abstract}
les défenseurs du processus d'unification européenne ont été contraints d'accepter [un « démi-échec»] pour éviter un «échec total». En effet, si l'on avait accueilli la proposition des fédéralistes, une telle décision aurait conduit à une rupture traumatisante avec la Grande-Bretagne, dont la participation est estimée indispensable en tant que contrepoids à une Allemagne qui, lentement, commence à se relever de décombres de la guerre. (MATTERA, 2002, p. 22, grifos nos original).
\end{abstract}

Assim, se Comitê intergovernamental de Ministros seria acompanhado por uma Assembleia ${ }^{664}$, esta não deteria qualquer Poder Executivo ou Legislativo quando da avaliação de medidas de integração política da Europa. O campo de atuação do CdE estaria limitado a elaborar recomendações à concertação política cooperativa a ser empreendida entre seus Estados-membros, estando ainda autorizado o CdE a elaborar uma Carta de Direitos Humanos e a instituir uma Corte de Justiça (BITSCH, 2006, p. 48 e 52; LUCATELLO, 1959, p. 133).

Ce projet fut examiné par les membres de la Commission d'Études et inspira le texte finalement adopté en mai 1949 à Londres. Mais celui-ci [...] fut le résultat d'un compromis et le système institutionnel retenu parut bien timoré aux yeux des partisans du fédéralisme au sein du Mouvement européen. (RÉAU, 2008, p. 194, grifos nossos).

A Conferência Final de discussão foi realizada em Londres, entre os meses de março e abril de 1949. Em 5.5.1949 foi assinado na capital do Reino Unido o Tratado Constitutivo do CdE, inicialmente estabelecido entre Bélgica, Dinamarca, França, Irlanda, Itália, Luxemburgo, Noruega, Países-Baixos, Reino Unido e Suécia (ADENAUER, 1980d, p. 317; LUCATELLO, 1959, p. 131; MONACO, 1961c, p. 209-10; QUADROS, 1984, p. 119; QUERMONNE, 2010, p. 14-5) ${ }^{665}$.

664 “[L]a première Assemblé parlementaire internationale dans l'histoire.” (BITSCH, 2006, p. 45).

${ }^{665}$ Dentro do lapso temporal escolhido para este estudo, é importante notar que a Grécia ingressa no CdE em 1949, seguida pela Islândia e pela Turquia em 1950, e pela República Federal da Alemanha em 1951. Hoje o CdE é composto por 47 (quarenta e sete) países, dentre os quais também a Rússia. 
5.4.2.3. A Realização Institucional do CdE: Persistência da Tensão entre $\underline{\text { Unionismo e Federalismo }}$

O novo mecanismo de aproximação política de países europeus era um híbrido entre a proposta cooperativa intergovernamental britânica e a sugestão francesa de Federação Europeia (BARNAVI; POMIAN, 2008, p. 95-6; BOSSUAT, 1994, p. 117; NOËL et alii, 2008, p. 123 e 364; RÉAU, 2007, p. 11; ZORGBIBE, 1997, p. 20).

De um lado, seus objetivos eram bastante ambiciosos e vastos. De acordo com o credo europeísta Federalista, o CdE se comprometia com a defesa da Paz e com a conservação dos princípios democráticos e dos Direitos Humanos - componentes do "patrimônio comum da Europa". Dessa forma, todos os seus membros deveriam se comprometer a aderir integralmente a esses preceitos, bem como a respeitá-los e a promovê-los interna e internacionalmente.

Por outro lado, a estrutura institucional prevista para a consecução de tais objetivos impedia a efetiva realização concreta de seus intentos. Nesse sentido, não se atribuíra a esta Organização meios mais vinculantes do que os de uma lógica de cooperação intergovernamental para empoderar suas ações. Isso significa que suas instituições não eram efetivamente capazes de instituir Leis entre os países europeus que compunham o CdE.

\footnotetext{
L'organisme crée par le traité de Londres est donc sensiblement différent du projet lancé un an plus tôt par le Congrès de la Haye et c'est le pays plus réticent, l'Angleterre, qui a largement réussi à faire prévaloir ses préférences institutionnelles. Certes, une Assemblée voit le jour, ce qui constitue une grande nouveauté, mais elle a moins de marge de manœuvre que prévu au départ. Pour Robert Schuman, c'est un demi-échec, mais il a voulu faire des concessions pour ne pas courir à l'échec total qui aurait provoqué des déceptions en Europe [...] et pour ne pas risquer la rupture avec le Royaume-Uni dont la présence paraissait indispensable [...]. (BITSCH, 2006, p. 52-3, grifos nossos).
}

il Consiglio d'Europa presenta [il carattere] di consultazione [...], o forse meglio di coordinamento e consiglio: il Consiglio non può infatti esplicare un'attività vincolante verso i suoi membri [...], ed è ciò che lo distingue essenzialmente dalle confederazioni di Stati, ma soltanto [...] rivolgere raccomandazioni ai suoi membri ad opera del Consiglio, [...] mentre l'Assemblea [...] può soltanto rivolgere proposte al Comitato. (LUCATELLO, 1959, p. 133, grifos do autor).

Um CdE limitado institucionalmente e de ampla vocação foi a consequência principal da concepção britânica de União da Europa: esta deveria ser operada praticamente por meio de instituições aptas a instaurar apenas uma simples cooperação 
política intergovernamental entre os países europeus (ROLLAND, 2006, p. 584) ${ }^{666}$. Apenas mediante a preservação de um sistema de cooperação intergovernamental na área política se asseguraria a não transferência de Poderes soberanos uma Organização Internacional - ou, o que é o mesmo, garantiria a intangibilidade das Soberanias estatais nacionais por recorrer a normas de Direito Internacional Público clássico articuladas apenas para realizar uma cooperação política intergovernamental (BERNHARDT, 2010, p. 48; MATTERA, 2002, p. 22; MONACO, 1961c, p. 218; PERTEK, 2011, p. 14-5; PRIOLLAUD; SIRITZKY, 2011, p. 16; REUTER, 1965, p. 40-1).

Essa pungente contradição entre os objetivos do $\mathrm{CdE}$ e seus mecanismos institucionais foi imediatamente percebida pelos Federalistas: "è stato avvertito che il Consiglio d'Europa non avrebbe potuto né accentrare né controllare le varie correnti rivolte ad attuare l'una o l'altra forma d'integrazione europea" (MONACO, 1961c, p. 217). A despeito de sua ampla missão, o CdE não detinha qualquer autoridade política efetiva sobre os países que o compunham (GERBET, 2004, 1:14/1:22).

5.4.2.4. A Primeira Reunião do CdE: Uma Tentativa Frustrada de Reveter as Instituições em prol de uma Federação Europeia

Descontentes com a vigorosa limitação institucional de seus intentos, já na primeira sessão realizada em agosto-setembro de 1949 buscaram os Federalistas reverter a situação. Para tanto, estudaram em conjunto a possível confecção de mecanismos novos que assegurassem ao $\mathrm{CdE}$ condições de empreender uma integração política afinada com os preceitos Federalistas assumidos pela Organização - isto é, para "faire du Conseil d'Europe une réalité", para usar uma expressão do Federalista Europeu Léon BLUM (1950, p. 2).

Deste modo, os membros da Assembleia assumiram como "mero ponto de partida" o estatuto que institucionalmente limitara as capacidades de atuação da Organização. O objetivo desta primeira reunião se tornou formular e instituir mecanismos alternativos que ultrapassassem/desconsiderassem as limitações do estatuto, a fim de

\footnotetext{
666 "L'ordinamento del Consiglio d'Europa è un esempio tipico di ordinamento internazionale, derivato dall'ordinamento internazionale generale. In vero il sopra menzionato «Statuto » è un atto, $e$ precisamente un accordo internazionale plurilaterale, posto in essere sulla base della norma di diritto internazionale pacta sunt servanda $[\ldots \mathrm{L}] \mathrm{e}$ norme contenute nello Statuto $[\ldots]$ costituiscono tuttora nel loro complesso un particolare ordinamento internazionale che non lede minimamente la sovranità degli Stati partecipanti [...]. " (LUCATELLO, 1959, p. 132, grifos nossos).
} 
instaurar mecanismos institucionais que dessem execução prática efetiva à missão do CdE de atuar como autoridade política de unificação de todo o continente europeu.

Em outras palavras, por meio da desconsideração da limitação institucional inicial dada por seu próprio estatuto - que reduzira institucionalmente o $\mathrm{CdE}$ a uma simples cooperação política intergovernamental, os Federalistas almejaram alcançar uma liberdade plena de atuação mediante a confecção de meios institucionais alternativos que permitessem a fiel execução da vocação Federalista original do CdE (BITSCH, 2006, p. 53-4).

\section{A Assembleia do $\mathrm{CdE}^{667}$ empreendeu assim vigorosa tentativa de revisão de seu estatuto original, com o objetivo de dotar a recém-criada Organização} Internacional Europeia dos meios institucionais necessários para realizar a tarefa de unificação política da Europa ${ }^{668}$. Para os membros da Assembleia, o CdE deveria ser compreendido como autorizado a unificar os Governos nacionais dentro de uma lógica Federalista e a própria Assembleia do CdE deveria ser percebida como uma Assembleia Constituinte pouco dependente dos Governos nacionais.

A despeito do esforço realizado, a Assembleia conseguira aprovar apenas uma moção por meio da qual reafirmara ser a finalidade do CdE exercer com Poderes efetivos, mas limitados, a função de autoridade política fundamental da Europa. A grande reforma institucional visada logo após a Primeira Reunião do CdE não produziu efeito modificativo algum (BITSCH, 2006, p. 54; BOSSUAT, 1994, p. 124; BRUGMANS, 1969, p. 10-1; NOËL et alii, 2008, p. 364; ZORGBIBE, 1997, p. 21) $)^{669}$.

[F]alhada a primeira tentativa de imprimir uma dinâmica federal à integração europeia, os seus sequazes não esmoreceram. E foi assim que logo nas duas primeiras sessões da Assembleia Consultiva do Conselho da Europa, que tiveram lugar em 1949 e 1950, a maioria dos Estados membros do Conselho da Europa propôs a constituição daquela Assembleia em Assembleia Constituinte europeia, tomando como base dos seus trabalhos o « Pacto federal » que a União Europeia dos Federalistas dera a conhecer em Outubro de 1949. A reacção dos britânicos

\footnotetext{
${ }^{667}$ Neste ponto, é importante observar que as pretensões Federalistas permaneciam a tônica fundamental da Assembleia : “[s]urtout dans le cadre de l'assemblée consultative du Conseil de l'Europe, les « fédéralistes » plaidaient la création du des États-Unis de l’Europe immédiatement [...].” (GLAESNER, 1991, p. 288).

668 "[L]es conviction européennes y sont très fortes, les antieuropéens notoires comme le communistes étant exclus de fait tandis que près des deux tiers des membres appartiennent au Mouvement européen.” (BITSCH, 2006, p. 53).

669 “'[E]n dépit de la pression qui s'exerce de l'extérieur, par les campagnes de mobilisation organisées par l'UEF (signature de pétitions, organisation à Strasbourg d'une Assemblée de militants, [...]) ces projets ne sont pas adoptées. [...]. [L]'Assemblée a du mal à trouver une majorité des deux tiers pour voter un projet audacieux qui risque de toute façon de ne jamais être adopté par le Comité des ministres où les décisions importantes se prennent à l'unanimité." (BISTCH, 2006, p. 54). Nesse sentido, compreensível a percepção formalizada por Konrad ADENAUER (1980c, p. 314), já em Março de 1950, sobre a limitação do CdE: "Der Europarat könne bisher noch keine nennenswerten Ergebnisse aufweisen.”.
} 
e escandinavos não se fez, porém, esperar: ameaçaram imediatamente abandonar o Conselho da Europa caso fosse tomada qualquer resolução nesse sentido. $E$ conseguiram, por essa forma, fazer abortar pela segunda vez o projecto da criação de uma Federação europeia. (QUADROS, 1984, p. 119, grifos nossos).

En octobre, le Comité des Ministres se réunit à Paris, et ce fut un jeu de massacre. Pratiquement aucune des résolutions de l'Assemblée ne fut prise en considération, et la session de l'été 1950 fut houleuse. Dans les paroles d'André PHILIP (délégué général du Mouvement Européen à l'époque), ce Comité s'était montré un ,sénat réactionnaire“ [...]. L'euphorie de La Haye était terminée. (BRUGMANS, 1969, p. 10, grifos nossos).

De todo modo, lembre-se ainda de que o ME - movimento europeísta herdeiro do CGH de 1948 - elaborou ${ }^{670}$ uma proposta de Convenção Europeia dos Direitos do Homem $(\mathrm{CDH})$ e do Estatuto da respectiva Corte Europeia de Direitos Humanos (CEDH) e apresentou-as em 12.7.1949 ao Comitê de Ministros do CdE.

Diante (i) da intransponível limitação institucional do $\mathrm{CdE}$ - percebido como legado institucionalmente fracassado do CGH de 1948 671 ; (ii) da constatação de ser a proteção dos Direitos Humanos e da Democracia na Europa a principal tarefa restante do $\mathrm{CdE}$, enquanto herdeiro do $\mathrm{CGH}$; e (iii) da presença de uma proposta pronta de $\mathrm{CDH}$ e CEDH, a Assembleia do CdE aprovou também em sua Primeira Reunião ${ }^{672}$ uma Resolução sobre a possibilidade de se estabelecer uma Convenção de proteção dos Direitos Humanos na Europa ${ }^{673}$ (BERNHARDT, 2010, p. 48-9; RÉAU, 2008, p. 194-6; REUTER, 1965, p. 119-20).

${ }^{670}$ Com a colaboração do francês Pierre-Henri TEITGEN, do britânico Sir David MAXWELL-FYFE e do belga Fernand DEHOUSSE (BERNHARDT, 2010, p. 48).

${ }^{671}$ De mecanismo voltado a instituir na Europa Leis de unificação da pluralidade (Teológico-Político) em torno do ideário Federalista dos Direitos Humanos e da Democracia (Estado Federal Europeu), tornara-se simples Organização Internacional de cooperação política intergovernamental (Direito Positivo desprovido de Leis). V. também, nesse sentido, a nota de rodapé 479, supra.

${ }^{672}$ Como visto acima, realizada em agosto-setembro de 1949.

${ }^{673}$ Com Gerald FITZMAURICE (1983, p. 205), é importante lembrar que a memória das catástrofes empreendidas pouco antes da Segunda Guerra Mundial e durante ela certamente habitava as mentes daqueles que constantemente se preocuparam em rapidamente instituir um documento jurídico-normativa positivo de proteção e de tutela jurisdicional internacional dos Direitos Humanos na Europa.

É por esse motivo que talvez se possa compreender também como justificada a obstinada preocupação de - diante do esvaziamento institucional dos Poderes do CdE - estabelecer um documento que pudesse tornar impensável e impossível o recometimento das atrocidades que a humanidade experienciou entre 1939-1945 - mesmo se tal proteção não estivesse prevista pelos ordenamentos jurídicos positivos nacionais. A proteção dos Direitos Humanos deveria deter ao menos um fundamento jurídico-normativo positivo internacional, pois se percebera que a dimensão nacional não era garantia de que eles seriam respeitados pelos Estados em âmbito interno.

No mesmo sentido, na literatura jurídica internacional, v. Rudolf BERNHARDT (1977, p. 4), Luca MEZZETTI (2012), Herman MOSLER; Rudolf BERNHARDT (1977, p. 205) e Calogero PIZZOLO (2012a); na literatura jurídica nacional, Hildebrando ACCIOLY; Geraldo Eulálio do NASCIMENTO E SILVA; Paulo Borba CASELLA (2009, p. 451), Eduardo Carlos Bianca BITTAR; Guilherme Assis de ALMEIDA (2006, p. 530-64), Paulo Borba CASELLA (2007b, 2008, 2009a, 2009c, 2009d), Luis Guilherme 
Assim, em 4.11.1950, em Roma, o CdE estabeleceu a CDH, a qual entrou em vigor em 3.9.1953. O compromisso político em torno do dispositivo institucional responsável pela tutela jurisdicional dos Direitos Humanos no interior do CdE - a CEDH - foi concluído meses antes da assinatura da $\mathrm{CDH}$, em 12.6.1950 ${ }^{674}$. A CEDH foi instituída em

Arcaro CONCI (2012), Marcelo FIGUEIREDO (2012), Bruno MIRAGEM (2005), Flávia PIOVESAN (2003, p. 59-72, 2007, p. 7-16) e José Ribas VIEIRA (2010).

De todo modo, perceba-se que, desta maneira, se a unificação (Teológico-)política da Europa havia sido barrada por meio de instituições de cooperação política intergovernamental, ao menos o CdE poderia agir no sentido de evitar a repetição da barbárie no continente europeu entre seus países-membros mediante previsão internacional de proteção dos Direitos Humanos jurisdicionalmente assegurada.

Todavia, esse fundamento descendente ("de cima a baixo") da proteção dos Direitos Humanos e da Democracia - frise-se: ainda que contra disposições nacionais internas - pode ser também entendido como manifestação da tendência unidimensionalizante (Teológico-Política) do Federalismo Europeu, na medida em que se mostrou como opção por mecanismo apto a domar, domesticar, disciplinar, ou ainda, civilizar as diferentes nações europeias do pós-Segunda Guerra Mundial em torno do discurso uniforme e uniformizador dos Direitos Humanos e da Democracia.

Nesse sentido, não se pode deixar de notar que em torno da CDH orbitava uma expectativa de produzir uma unidade cultural mediante a unificação dos valores nos quais todos os países europeus membros do CdE deveriam acreditar, mas principalmente preservar, proteger e tutelar. O objetivo dessa previsão consistia precisamente em instaurar a prometida calma, tranquila, uniforme e homogênea Paz derivada do artificioso Um dos Direitos Humanos e da Democracia.

Este seria precisamente um dos efeitos claramente perceptíveis derivados da $\mathrm{CDH}$ e de sua aplicação: uma ",größere Einigkeit" unter allen Mitgliedern des Europarats durch die Wahrung und die Entwicklung der Menschenrechte und Grundfreiheiten zu fördern", pois não se poderia ignorar que "[d]ie Anwendung der Konvention durch die Organe der Mitgliedstaaten und die Konkretisierung der Bestimmungen der Konvention durch die Straßburger Organe sind ein Einigungsfaktor im Sinne der Satzung des Europarats." (MOSLER; BERNHARDT, 1977, p. 206-7). Afinal, a própria CDH estabelecera de antemão qual catálogo de Direitos Humanos deveriam ser posteriormente objeto de proteção por parte das diferentes Constituições de cada um dos Estados europeus membros do CdE (MOSLER; BERNHARDT, 1977, p. 207).

Por isso, não se poderia deixar de perceber que se buscou com a referida Convenção produzir uma harmonização pasteurizante dos padrões normativos e das normas jurídicas de proteção dos Direitos Humanos entre os países europeus membros do CdE. Deste modo, ainda que por vias transversas, o poder-se-ia mesmo cogitar que Federalismo Europeu instituíra um poderoso entrave Teológico-Político no interior do Projeto de cooperação política intergovernamental.

A discussão é interessante, mas foge do arco de questões circunscrito ao presente trabalho, razão pela qual não serão desenvolvidas maiores considerações sobre este tema. Registre-se aqui o convite para futuras reflexões conjuntas sobre o tema. Remetemos o leitor, ainda, às considerações desenvolvidas no item 5.2.2.2.2., supra.

674 "Der Berichterstatter faßte am 12. Juni 1950 die Positionen dahin zusammen, da $\beta$ vier Staatenvertreter sich für, sechs gegen einen Gerichtshof ausgesprochen hätten, aber eine Kompromißlösung, die nur eine fakultative Kompetenz des Gerichtshofs mit einer entsprechenden Optionklausel vorsehe, eine Mehrheit von neun zu drei Stimmen erhalten habe. Auf dieser Basis wurden die Beratungen fortgesetzt; die weiteren Texte sahen vor, da $\beta$ ein Gerichtshof geschaffen werden sollte, aber seine Zuständigkeit von der ausdrücklichen Anerkennung durch eine besondere Erklärung abhänge. Damit waren die Weichen gestellt. Sowohl in der Beratenden Versammlung als auch im Ministerkomitee des Europarats wurden die Beratungen noch fortgesetzt. Unmittelbar vor der Unterzeichnung der Konvention trat ein Komitee juristischer Experten zusammen, die den vorliegenden Entwurf auch hinsichtlich des Gerichtshofs für Menschenrechte noch einmal Revue passieren ließen." (BERNHARDT, 2010, p. 51). 
Estrasburgo em $1959^{675}$ (BERNHARDT, 2010, p. 49-51; BITSCH, 2006, p. 57-8; LUCATELLO, 1959, p. 136; MONACO, 1961c, p. 217; RÉAU, 2008, p. 178-88) ${ }^{676}$.

De todo modo, há que se notar que no final do período selecionado para o estudo por parte deste trabalho (1951), o CdE se mostrou como uma opção institucional de aproximação europeia bastante decepcionante para os Federalistas ${ }^{677}$. É o que se passa a analisar a seguir.

5.4.2.5. CdE: Uma Cooperação Intergovernamental Institucionalizada contra Leis Teológico-Políticas na Europa

Se o CdE inicialmente se apresentou como uma proposta dos europeístas Federalistas voltada à consecução de seus intentos Teológico-Políticos de unificação da Europa em torno de uma Federação ${ }^{678}$ alicerçada no discurso dos Direitos Humanos e da Democracia $^{679}$, a realização concreta do CdE naquele período implicou um progressivo afastamento com relação ao Projeto original ${ }^{680}$.

${ }^{675}$ A CEDH, como afirmado linhas acima, não será objeto de estudo por este trabalho, uma vez que se encontra localizada fora do lapso temporal delimitado metodologicamente para esta Tese.

${ }^{676}$ Paul REUTER (1965, p. 107 e 120) ressalta que a preocupação em proteger na Europa os Direitos Humanos e a Democracia derivava precisamente da orientação jurídico-política fundada nos preceitos do Federalismo Europeu. Seu caráter Teológico-Político pode ser evidenciado a partir da exigência de incondicional cumprimento e respeito de tais preceitos por parte dos Estados-membros do mecanismo de cooperação intergovernamental. Tratava-se certamente de efetiva ingerência uniformizante das orientações jurídico-política internas de cada Estado-membro ou daqueles que pretendessem participar daquele sistema de cooperação... V. nesse sentido as observações feitas no item 5.2.2.2.2., supra.

677 "Si l'on compare les vœux exprimés à La Haye en mai 1948 par les congressistes des mouvements européens et les résultats acquis lors de cette réunion de Strasbourg, bien des déceptions peuvent s'exprimer. Elles sont particulièrement vives chez les fédéralistes, qui soulignent le caractère consultatif de l'Assemblée et rappellent le rôle essentiel du Comité des ministres disposant du droit de veto." (RÉAU, 2008, p. 188, grifos nossos).

678 "Der Europarat sei ein erster Versuch, Westeuropa zu einer Föderation zusammenzufassen." (ADENAUER, 1980h, p. 340).

${ }^{679}$ Este Projeto visava a efetivamente construir a Paz, não apenas na Europa, mas no mundo como um todo. Como reconhecera Konrad ADENAUER (1980e, p. 329) no interior do CdE a clara pretensão de assumir o caráter de "friedlicher Faktor in der Welt".

Nota-se aqui mais uma vez a presença velada do intento de que o CdE exercesse um papel de centro de propagação mundial da Paz a partir da escala de existência formada no interior da almejada Federação Europeia. A Boa Nova da pacificação mundial gestada a partir do CdE seria assim a nova promessa europeia a ser futuramente difundida universal e incondicionalmente pelo mundo sob o nome do ou ainda, em nome do - "evangelho" dos Direitos Humanos e da Democracia (v. nesse sentido as cosniderações desenvolvidas no item 5.2.2.2., supra).

Reforça-se aqui a evidência da orientação Teológico-Política dos motivos que levaram à instauração do CdE. Os quais ao mesmo tempo permitem compreender a razão pela qual sofrera o CdE profunda contenção institucional por meio da redução de seus mecanismos práticos à condição de simples viabilizador de uma cooperação política intergovernamental.

680 "L'ambiguïté du compromis est [...] : un large domaine d'intervention est reconnu au Conseil d'Europe, mais ses moyens d'actions effectifs sont très limités. "(ZORGBIBE, 1997, p. 20). 
A maneira segundo a qual o $\mathrm{CdE}$ foi institucionalmente realizado implicou uma efetiva redução de sua capacidade de ação com relação aos desígnios originais do Federalismo Europeu. O CdE se mostraria incapaz de realizar a integração política europeia forjada conforme a unidimensionalidade dos Direitos Humanos e da Democracia, haja vista que ele fora relegado à singela posição de órgão viabilizador de simples cooperação política intergovernamental ${ }^{681}$ (BERNHARDT, 2010, p. 48; BERSTEIN; MILZA, 2002, p. 237; BITSCH, 2006, p. 45; BOSSUAT, 1994, p. 125; BRUGMANS, 1969, p. 3; GLAESNER, 1991, p. 287; MONACO, 1961c, p. 212; PERTEK, 2011, p. 15; PRIOLLAUD; SIRITZKY, 2011, p. 16; QUERMONNE, 2008b, p. 23 e 27-8; RÉAU, 2007, p. 11, 2008, p. 188; REUTER, 1965, p. 106; RUTTEN, 2006b, 3:05/3:30).

Da concepção original à realização efetiva houve considerável diminuição de mecanismos práticos para operacionalizar o ideal Federalista (BITSCH, 2006, p. 45 e 523). No último momento, foram aprovadas instituições bastante peculiares e contidas: voltadas a dar uma concretude real ao $\mathrm{CdE}$, tais disposições jurídico-normativas positivas modificaram profundamente a capacidade de atuação da Organização Internacional vis-àvis o plano original ${ }^{682}$.

Nesse sentido, apesar de o CdE ter sido pensado a partir de uma perspectiva Federalista de unificação política dos povos europeus a partir de Leis dadas por uma unidade cultural europeia imaginada (Direitos Humanos e Democracia), essa nova Organização Internacional se apresentou formalmente - mediante seus mecanismos institucionais práticos - como simples instrumento de cooperação política intergovernamental.

Le Conseil de l'Europe, au lieu de répondre à ce vœu [de la Résolution politique du Congrès de la Haye, orientée au transfert des droits souverains des États], se trouva réaliser plutôt [une union plus étroite]. [... N]'est-il pas question de «lien fédéral» ni de «transfert de souveraineté » [...]. (ROUGEMONT, 1961, p. 411, grifos nossos).

Assim, a arquitetura institucional pensada para construir e realizar praticamente a União política de países europeus se configurou como efetiva armadilha jurídico-normativa

681 “Ses status ne prévoyaient cependant aucun transfert de pouvoir des États à la nouvelle institution. C'était là la preuve que les gouvernements européens n'étaient pas disposés à déléguer ne fût-ce qu'une partie de leurs prérogatives à des organismes de type supranational.” (OLIVI; GIACONE, 2007, p. 18, grifos nossos).

682 "Le caractère intergouvernemental de la plupart des organisations européennes créées entre 1947 et 1949 résulte de la crainte éprouvée par les gouvernements de l'époque de perdre une part de la souveraineté que certains d'entre eux venaient seulement de recouvrer [...]." (QUERMONNE, 2008b, p. 28, grifos nossos). 
voltada a impedir institucionalmente a concretização unidimensional do ideário totalizante do Federalismo Europeu. Quando da confecção dos mecanismos práticos para aproximar politicamente a Europa a partir da proposta do CGH, percebeu-se a grande ameaça à multiescalaridade representada pela revolução Federalista subitamente intentada. A tendência Teológico-Política desta deveria ser prontamente impedida, a fim de assegurar a permanência da pluralidade escalar na Europa.

Assim, um "embuste institucional" surgira para afirmar que a instauração de um sistema de convivência entre diferentes (Leis) na Europa não poderia implicar uma ameaça à pluralidade dada por qualquer pretensão totalizante uniescalar - ainda que esta tivesse sido gestada pelo discurso da defesa incondicional dos Direitos Humanos e da Democracia. Seu ideal de instaurar Leis de unificação das pluralidades (Leis Teológico-Políticas) foi verticalmente reduzido à simples dimensão de cooperação política intergovernamental viabilizada por instrumentos normativos de Direito Internacional Público clássico, os quais não visariam a atentar de forma alguma contra a Soberania estatal nacional de seus Estados-Membros.

Assim, “il apparaît très vite que l'organisation de Strasbourg n'a pas les moyens de jouer le rôle de chef d'orchestre de l'unification européenne" (BISTCH, 2006, p. 55) : o CdE se apresentara institucionalmente como dispositivo jurídico-normativo arquitetado conscientemente voltado contra a introdução e a difusão prática da organização jurídicopolítica unidimensional do Federalismo Europeu - ou seja, contra a introdução de Leis Teológico-Políticas.

Até a escolha da cidade-sede do CdE teria sido proposital. Estrasburgo teria sido eleita para promover um rápido isolamento da Organização Internacional com relação aos principais centros políticos decisórios de cada um dos Estados-Membros. A eleição desta cidade teria derivado da intenção de evitar que os ideais europeístas Federalistas do CdE em algum momento pudessem sair de controle e produzir alguma repercussão significativa na condução da aproximação política da Europa (BITSCH, 2006, p. 53).

Deste modo, o CdE tal qual realizado se mostrou como disposição institucional contra o CdE tal qual idealizado pelo Federalismo Europeu: não deveria haver o controle da diversidade pelo recurso a uma pressuposta adesão necessária a uma unidade jurídico-política e cultural comum abstrata e transcendente que justificasse o abandono das Soberanias nacionais e de suas correlatas particularidades. O CdE real negou o CdE ideal e, com isso, preservou a pluralidade escalar na Europa: ele atuou contra o desígnio 
unificador e uniformizante dos europeístas Federalistas mediante a precisa preservação institucional da intangibilidade das Soberanias estatais nacionais.

Portanto, para impedir a realização de uma diversidade na unidade - a totalização da unidimensionalidade do Federalismo Europeu, a capacidade de constituir de Leis do CdE foi vertiginosamente diminuída por meio da realização institucional prática do Projeto idealizado pelos Federalistas do CGH de 1948 (BITSCH, 2006, p. 57; QUERMONNE, 2008b, p. 30-1; REFALO,1980, p. 72; VEÇOSO, 2006, p. 30).

Mecanismo institucional de resistência à potencial unidimensionalização, essa vigorosa emboscada intergovernamental deteve a aptidão de conter a potencial inserção do Teológico-Político na primeira tentativa de organização jurídico-política da Europa. Com isso, desanimou-se momentaneamente a realização do Projeto Federalista na Europa ${ }^{683}$. Contudo, a permanência do intento de aproximar politicamente os países europeus segundo um novo modo de relações perpetuara a disposição em realizar o necessário exercício de imaginação institucional alternativa para promover uma organização jurídico-política europeia internacional qualitativamente distinta da da tradição ${ }^{684}$.

\begin{abstract}
Dès l'été 1950 , le scepticisme dominait dans les rangs des fédéralistes. A cette date, d'autres initiatives européennes se faisaient tour. Une nouvelle voie était explorée par des Européens convaincus, résolus à tirer la leçon de ce qu'ils considéraient un échec. Le Conseil de l'Europe ne pouvait être l'instrument apte à créer une vraie Union européenne. Il fallait créer du neuf. (RÉAU, 2008, p. 195-6).

[E]n 1950, la question de l'intégration européenne se pose sous un jour nouveau à la suite de la déclaration Schuman du 9 mai, point de départ de la CECA, première communauté supranationale et sectorielle. [...]. Aux yeux de beaucoup d'européistes, les meilleures perspectives pour l'unification se placent désormais hors de l'enceinte strasbourgeoise. (BITSCH, 2006, p. 54).
\end{abstract}

Se era insatisfatória a via da cooperação intergovernamental (CdE real, composto por Direito Positivo desprovido de Leis), igualmente se mostrava inaceitável o caminho da convivência voltada à unificação da pluralidade (CdE ideal, composto por Direito Positivo e Leis Teológico-Políticas). Era necessário para a Europa erigir "efforts créateurs à la mesure des dangers qui la mena[çaient]" (SCHUMAN, 2000, p. 1).

Certes, l'Assemblée constitue une tribune politique où sont débattus tous les problèmes internationaux et elle sert de laboratoire d'idées pour la construction

\footnotetext{
${ }^{683}$ V., nesse sentido, os debates em torno da criação da CED e da CPE, referidos no Primeiro Capítulo deste trabalho.

${ }^{684}$ Vale dizer, distinto com relação às tradicionais saídas de instituição de coexistência, de cooperação ou de convivência mediante unificação (Teológico-)política em torno de Leis.
} 
européenne, mais dès les années 1950, l'essentiel pour l'unification se passe ailleurs, à Luxembourg et Bruxelles où se mettent en place des Communautés à caractère supranational. (BITSCH, 2006, p. 57).

Estava aberto assim o caminho para a imaginação de experiência institucional absolutamente singular e inovadora no interior da dinâmica relacional entre os países europeus: o preciso meio da convivência segundo Leis Políticas. É o que se passa a analisar a seguir, com a História da constituição da CECA. 


\title{
SEXTO CAPÍTULO - A DECLARAÇÃO DE ROBERT SCHUMAN DE 1950: FUNCIONALISMO E IMANÊNCIA
}

\begin{abstract}
[A] fortuna [...] demonstra sua força onde não encontra virtù ordenada, pronta para resistir-lhe e volta seu ímpeto para onde sabe que não foram erguidos diques ou barreiras para contê-la. (MAQUIAVEL, 2004, p. 120).
\end{abstract}

In retrospect there can be little doubt that even in defeat Germany held the key to Europe's fate [...]. (MAZOWER, 1998, p. 240).

Apesar de ter sido discutido durante o Congresso da UEF de agosto 1947, quando da realização do CGH de 1948, ou mesmo durante os debates desenvolvidos em 1949 concernentes aos países-membros do $\mathrm{CdE}^{685}$, o tema da inserção da Alemanha no interior de uma nova dinâmica relacional entre os países da Europa Ocidental - principalmente com a França - não havia encontrado até 1950 uma adequada solução.

Desde o final da Primeira Guerra Mundial era clara a percepção de que a construção de uma Europa Unida apenas seria viável mediante a incorporação da Alemanha no quadro de uma vida comum europeia em conjunto com a França, isto é, mediante a reconciliação franco-alemã ${ }^{686}$. A despeito da consciência deste discurso, não havia sido ainda formulado um mecanismo institucional suficientemente adequado para estabelecer entre Alemanha e França elos de solidariedade que requalificassem significativamente os termos de suas relações e, com isso, que impedissem o ressurgimento entre ambos de mútuas pretensões nacionalistas de totalização uniescalar ${ }^{67}$ (BITSCH, 2006, p. 27; RÉAU, 2008, p. 133; WEILER, 2005, p. 91).

A pretensão de dar novo encaminhamento à questão - que até aquele momento não encontrara condições institucionais para se manifestar e para ser solucionada - era patente.

${ }^{685}$ V. comentários desenvolvidos no Quinto Capítulo, supra.

686 “Si cette finalité est bien au cœur des premières initiatives de Briand [1929 et 1930] et si elle est la préoccupation majeure de nombreux mouvements nés pendant les années vingt, elle resurgit très tôt dans les projets de reconstruction de l'Europe, puisqu'elle apparaît dans certains plans rédigés avant la fin de la Deuxième Guerre. Or, la «Déclaration des Résistances européennes » publiée à Genève en juillet 1944 proposait précocement la création d'une union fédérale européenne qui rendrait possible la « participation pacifique du peuple allemand à la vie européenne »." (RÉAU, 2008, p. 133).

687 "Le problème allemand semble, aux yeux de beaucoup d'observateurs, insoluble dans le cadre traditionnel d'une Europe des nations. [... I]l et impossible d'anéantir un peuple ou de lui imposer des mesures punitives draconiennes sans provoquer une volonté de revanche.” (BITSCH, 2006, p. 26-7).

A Europa já teria vivido tal amarga experiência histórica durante o período entre guerras juridicamente inaugurada pelo Tratado de Versailles, de 28.6.1919, a qual não se queria repetir. Haveria que definitivamente se "aprender o que se pode e o que não se pode pretender impor a outros estados, sob pena de preparar efeitos tão devastadores como os que resultaram da implantação do regime hitlerista, na derrocada da Alemanha de Weimar. As lições da história podem ser difíceis, mas nem por isso são menos necessárias." (CASELLA, 2007b, p. 60). 
Diferentemente dos Projetos de Europa Unida anteriores ${ }^{688}$, a construção da Europa não poderia ser vista como passível de ser realizada em um único ato, "num piscar de olhos", por um grande arquiteto que pudesse tomar de uma só vez o conjunto no interior de estrutura institucional una. Haveria que se seguir uma estratégia distinta: encontrar e trilhar um caminho concreto que criasse normativamente condições institucionais novas aptas a resolver o tradicionalmente turbulento impasse relacional entre Alemanha e França (RÉAU, 2008, p. 198; WEILER, 2005, p. 91) ${ }^{689}$.

A constituição institucional da CECA pretendeu encontrar - como encontrou ${ }^{690}$ uma via jurídico-normativa positiva inédita para o estabelecimento institucional de um novo modo de relações entre ambos, a fim de que o antagonismo franco-alemão deixasse de produzir consequências desastrosas para o continente europeu. A instituição desta Organização Internacional se mostrou como forma de assegurar o abandono da política "punitiva ao antigo inimigo agressor" de 1945 por meio da integração da Alemanha no interior de uma nova dinâmica relacional em que esta poderia decidir sobre questões comuns em pé de igualdade.

${ }^{688}$ Examinados nos Capítulos Quarto (OECE e Pacto de Bruxelas) e Quinto (CdE), supra.

${ }^{689}$ Essa também era a precisa opinião do Secretário de Estado dos EUA, Dean ACHESON (1975, p. 2-3), expressa em Telegrama Confidencial redigido à Embaixada Estadunidense em Paris, em 19.10.1949.

Para o Secretário de Estado dos EUA, a proposta de início de uma integração (política) na Europa centrada na reconciliação franco-alemã deveria partir primordialmente da França, pois apenas semelhante postura permitiria a participação da RFA nas decisões fundamentais concernetes à Europa Ocidental: "The key to progress towards integration is in French hands. In my opinion France needs, in the interests of her own future, to take the initiative promptly and decisively if the character of Western Germany is to be one permitting healthy development in Western Europe. Even with the closest possible relationship of the US and the UK to the continent, France and France alone can take the decisive leadership in integrating Western Germany into Western Europe." (ACHESON, 1975, p. 2, grifos nossos).

Esta posição de Dean ACHESON foi confirmada posteriormente por Bernard CLAPPIER, antigo Chefe de Gabinete do Ministro de Relações Exteriores da França, Robert SCHUMAN, em entrevista concedida em 11.11.1980, referindo-se a encontro realizado entre Dean ACHESON (EUA), Robert SCHUMAN (França) e Ernest BEVIN (Reino Unido): "Dean Acheson posa la question: «Qu'allons-nous faire avec l'Allemagne?» Le Secrétaire d'Etat américain ajouta: «Je propose que nous demandions à notre collègue français, qui connaît fort bien les affaires allemandes, de définir les grandes lignes de la politique commune que nous devrions suivre vis-à-vis de l'Allemagne.» Il y eut un grand silence. Puis Ernest Bevin émit une sorte de grognement qui pouvait signifier surprise ou mécontentement, ou les deux, et que Dean Acheson feignit de prendre pour une approbation. Robert Schuman, quant à lui, manifesta une intense émotion. Son crâne se mit à rougir. Dean Acheson confirma alors sa proposition. R. Schuman était chargé par ses collègues de préparer des propositions pour la mise en oeuvre d'une politique commune vis-àvis de l'Allemagne." (CLAPPIER, 1985, p. 2-3, grifos nossos).

Ademais, naquele mesmo Telegrama Confidencial, Dean ACHESON (1975, p. 2-3) por diversas vezes declarara o reconhecimento da importância de o Reino Unido buscar se aproximar mais das iniciativas de integração política empreendidas no continente europeu. Todavia, de maneira muito prudente, o Secretário de Estado dos EUA sempre reafirmara que essa observação jamais poderia ser entendida como pressão para que o Reino Unido participasse além daquilo que quisesse e pretendesse seguir. Sobre a participação britânica na CECA, v. o item 6.3.2. e nota de rodapé 753, ambos infra.

${ }^{690}$ Como será visto nas linhas a seguir, bem como no Sétimo Capítulo, infra. 
Note-se desde já que a preocupação em construir a CECA não procurou eliminar as tensões entre Alemanha e França. Antes de tudo, a direitificação das relações entre esses dois países por meio da CECA representou consciente esforço em criar condições institucionais para que - mediante engenhoso e cuidadoso intercruzamento normativo de deveres de participação entre as escalas de existência - tais oposições se mantivessem, se produzissem e viessem à superfície de maneira contínua sem que isso implicasse o retorno da possibilidade de se optar pelo recurso à Guerra.

Tratou-se precisamente de aproximar e integrar aqueles que tradicionalmente se opunham belicamente, aproximação a ser promovida por meio do Direito Positivo Internacional. Essa aproximação direitificada se voltara para erigir um sistema institucional de convivência permanente entre diferentes por meio de normas positivas de Direito Internacional Público, o qual foi arranjado de maneira inovadora em relação à tradição ${ }^{691}$.

A manifestação oficial exatamente anterior à instituição da CECA amplamente reconhecida como responsável pela fundação desta Organização Internacional é a Declaração de Robert SCHUMAN, de 9.5.1950 ${ }^{692}$. Entretanto, apesar da indiscutível importância da atuação do Ministro das Relações Exteriores da França da época, não se pode ignorar que a sugestão de se direitificar as relações entre Alemanha e França foi formulada igualmente por outros europeus no pós-Segunda Guerra Mundial, antes mesmo de Robert SCHUMAN.

\title{
6.1. Antecedentes da Declaração Schuman: As Reflexões de Winston CHURCHILL, Konrad ADENAUER e Jean MONNET
}

\begin{abstract}
Pode parecer paradoxal, [mas a Segunda Guerra Mundial], em razão dos movimentos que criou, nas massas e entre os governantes, fez assumir viva consciência da realidade da comunidade universal: tornou-se manifesto que essa comunidade deve se organizar, dotar-se de regras de direito próprias para responder aos seus fins naturais de proteção e de desenvolvimento de seus integrantes. (CASELLA, 2008, p. 189).
\end{abstract}

Ainda que com algumas diferenças circunstanciais, (i) o Discurso de Winston CHURCHILL na Universidade de Zurique, de setembro de 1946, (ii) a proposta de uma

\footnotetext{
${ }^{691}$ Ou simplesmente a direitificação da convivência, tal qual indicado no item 2.1., supra. Como poderá ser verificado quando da leitura do Sétimo Capítulo, infra.

${ }^{692}$ Segundo Gérard BOSSUAT (1994, p. 160), tal Declaração foi “[1]'acte fondateur par excellence”, opinião igualmente partilhada de maneira explícita por, por exemplo, Dominique BARJOT (2008, p. 38). O dia 9.5.1950 é compreendido até hoje como a data oficial de nascença da Europa e, assim, como o dia festivo fundamental dos Projetos de Europa Unida atualmente em vigor (DREYFUS, 2008, p. 144). Dada a relevância da Declaração Schuman, seu texto será examinado no item 6.2., infra.
} 
União política da Europa formulada por Konrad ADENAUER, desde o início de 1950, e mesmo (iii) o Memorando de Jean MONNET a Georges BIDAULT e ao próprio Robert SCHUMAN, de maio de 1950, podem ser entendidos como propostas que reconheciam a utilidade e a necessidade de um meio jurídico-normativo positivo que assegurasse institucionalmente o choque permanente e efetivo das oposições escalares entre os dois países.

Nos próximos itens será possível perceber que as reflexões acima mencionadas têm em comum a percepção de que a ausência de um mecanismo institucional regular para vocalizar as diferentes dimensões existenciais entre Alemanha e França manteria permanente a odiosa possibilidade de se optar pelo recurso à solução militar na Europa. Delineou-se de maneiras distintas o reconhecimento da necessidade de estabelecer Leis de convivência entre diferentes sobre as quais nenhuma escala de existência poderia nem mesmo ter a possibilidade de eventual ambição ou audácia de se erguer e se impor total e totalizantemente sobre as demais.

\subsubsection{As Reflexões de Winston CHURCHILL: Leis na Europa Continental}

Em 19.9.1946, o ex-Primeiro Ministro britânico Winston CHURCHILL proferiu na Universidade de Zurique, Suíça, um discurso conhecido como primeiro passo fundamental para se pensar a construção de uma Europa continental Unida a partir da reconciliação franco-alemã (BITSCH, 2006, p. 27; GLAESNER, 1991, p. 287; NASCIMENTO E SILVA; ACCIOLY, 2002, p. 246; ROLLAND, 2006, p. 481): "we must re-create the European family in a regional structure [...] established on solid foundations [...]. In all this urgent work, France and Germany must take the lead together." (CHURCHILL, 1966, p. 266, grifos nossos).

Em pouco menos de 18 (dezoito) meses após o final da Segunda Guerra Mundial, deve-se considerar o mérito de o ex-Primeiro Ministro britânico ter detido a fina capacidade de perceber - e a firmeza de ânimo para propor - a necessidade de a aproximação política entre os países europeus dever principiar por alguma iniciativa que almejasse institucionalmente uma solução permanente dos tradicionais conflitos entre Alemanha e França ${ }^{693}$.

\footnotetext{
693 Segundo Marie-Thérèse BITSCH, o discurso de Winston CHURCHILL não era original no período. Todavia, seria inegável reconhecer que foi ele a centelha fundamental que impulsionou definitivamente o desenvolvimento de preocupação mais especificamente voltada à solução do problema alemão: "[Winston
} 
I am now going to say something that will astonish you. The first step in the recreation of the European family must be a partnership between France and Germany. [...]. There can be no revival of Europe without a spiritually great France and a spiritually great Germany. (CHURCHILL, 1966, p. 265).

Winston CHURCHILL sugerira a necessidade de se constituir uma aproximação política entre os países europeus a partir da reconciliação franco-alemã (BARNAVI; POMIAN, 2008, p. 92-3; BERSTEIN; MILZA, 2002, p. 235; GLAESNER, 1991, p. 287; QUERMONNE, 2008b, p. 30; REUTER, 1965, p. 36; ROLLAND, 2006, p. 481). A reconciliação entre Alemanha e França deveria ser a base de uma constância jurídicopolítica institucional que conduzisse para fim diverso do belicismo as oposições escalares estatais do continente europeu.

Para o ex-Primeiro Ministro britânico, havia sido precisamente a pretensão alemã de impor unidimensionalmente sua própria escala de existência ao mundo da época a principal causa da Segunda Guerra Mundial ${ }^{694}$. Isso justificava de maneira inquestionável a

Churchill] ne fait que reprendre des idées déjà avancées depuis plusieurs années dans de notes confidentielles ou des déclarations publiques. Mais, avec ce « discours historique », elles vont connaître un retentissement exceptionnel." (BITSCH, 2006, p. 27).

Com efeito, "[c'] est un discours qui trouve aussitôt un large écho en Europe parce que c'est une personnalité de tout premier plan de la scène politique européenne qui le prononce, l'homme-symbole de l'indomptable résistance britannique." (MATTERA, 2002, p. 19). Como bem notam Serge BERSTEIN; Pierre MILZA (2002, p. 234), apesar da derrota de seu Partido nas eleições parlamentares no Reino Unido, Winston CHURCHILL contava com grande prestígio no mundo Ocidental no pós-Segunda Guerra Mundial. Por esse motivo, grande impacto politico em escala mundial detivera o pronunciamento de seu discurso na Universidade de Zurique, em 1946.

${ }^{694}$ A purificação racial encetada durante o regime nazista e voltada à produção de "une Europa sans juifs" (BARJOT, 2008, p. 46) era uma dimensão social parcial de um grande Projeto hitlerista para uma "nova Europa". Esta "nova ordem europeia" (BERSTEIN; MILZA, 2002, p. 165-6) seria unificada "sob a hegemonia do III' Reich alemão" (ACCIOLY; NASCIMENTO E SILVA; CASELLA, 2009, p. 427): "[1]a conception de l'Europe diffusé par la propagande nazie [...] prétend[ait] organiser «l'Europe nouvelle » autour d'un État directeur (l'Allemagne nazie) et cimenter ce «nouvel ordre » par une idéologie inspirée des principes du fascisme." (BITSCH, 2006, p. 24).

Segundo Gérard BOSSUAT (1994, p. 72), tratava-se precisamente de uma unidade europeia fundada exclusivamente na conviç̧ão do mais forte, voltada a "élargir l'Allemagne à l'europe entière, imposant finalement sa loi et sa race.", isto é, voltada a unidimensionalizar o modo de existência alemão nazista: “[1]'Europe nazie est: 1) une Europe anti-bolchevique [ou anticommuniste], 2) une Europe contrôlée politiquement, 3) une Europe exploitée économiquement, 4) une Europe dégradée moralement par le racisme [antisémite].”.

Philip BOBBITT (2003) resume interessantemente o ideário de tal Projeto Nazista - sem diferenciar profundamente nazismo e fascimo, como também faz Mark MAZOWER (1998, p. xiii): “[t]he fascists believed in a sort of social Darwinism for states, by which the competition for survival among species was mirrowed in the struggle among, and the domination of, genetically determined national groups among human beings. For all their differences about political action, on this fundamental social scientific point they were united." (BOBBITT, 2003, p. 61-2).

A partir da breve descrição apresentada acima, poder-se-ia suscitar inclusive ter tido este Projeto Hitlerista contornos Teológico-Políticos de difusão total e totalizante de uma única dimensão de existência a partir de um centro nomogenético tomado intemporalmente pelo detentor por excelência desta medida: a Alemanha nazista (sobre o Teológico-Político, v. item 3.4., supra). A mais absoluta 
punição da Alemanha, pois somente a aplicação desta pena a impediria de se rearmar e de principiar outra Guerra (CHURCHILL, 1966, p. 265).

Uma vez devidamente punidos os culpados da Segunda Guerra Mundial, haveria que se preocupar com o futuro do continente. E, para garantir a salvação deste em relação a possíveis novos processos de destruição militar, seria imprescindível superar os horrores do passado sem preservar o ódio com relação aos alemães. Este ato fundamental e fundante seria o primeiro passo para encetar a construção de uma Europa politicamente Unida, lastreada na mais primeira das condições: o mútuo reconhecimento da igual capacidade de um e de outro contribuir para a solução de questões comuns (CHURCHILL, 1966, p. 265).

Assim, era urgente uma aproximação política juridicamente mediada entre países europeus, por meio de instituições que permitissem permanentemente a "[s]mall nations [to] count as much as large ones and gain their honour by their contribution to the common cause" (CHURCHILL, 1966, p. 265). Seria imperativo se preocupar com a imaginação

disciplina deveria ser aceita; caso não fosse, deveria ser imposta mediante a reconhecida "virtude" do uso da força e da violência (MAZOWER, 1998, p. 14).

Anos depois, a ameaça da totalização unidimensional nazista pareceu tender a ser substituída pela ameaça da totalização bolchevique da URSS (MAZOWER, 1998, p. x): "profitant de la fin de la guerre et de l'avancée de l'armée rouge, Staline impose à la partie de l'Europe située à l'est d'une ligne BaltiqueAdriatique la soviétisation et la russification." (CARBONELL et alii, 1999b, p. 301, grifos nossos). No mesmo sentido, a descrição da pretensão universalista do bolchevismo feita por Charles SEIGNOBOS (1947, p. 384): logo após a Revolução Bolchevique, a URSS se apresentara como uma "fédération [...] créée pour faire la révolution communiste universelle [...]".

"What all [these] ideologies have in common is that they like to present their own utopia as an End of history - whether in the form of universal communism, global democracy or a Thousand Year Reich." (MAZOWER, 1998, p. xi.). Poder-se-ia até mesmo sugerir que haveria assim uma potencial comunhão/proximidade de caracteres Teológico-Políticos entre o Projeto Bolchevique, o Federalismo Europeu e o Projeto Hitlerista? Essa questão, apesar de interessante, escapa aos objetivos deste trabalho.

A investigação em torno daquele Projeto Europeu Nazista e daquele Projeto Europeu Bolchevique (BARNAVI; POMIAN, 2008, p. 45-9; BERSTEIN; MILZA, 2002, p. 165-9; BOBBITT, 2003, p. 47, 61-2 e 215; BOSSUAT, 1994, p. 72-80; CARBONELL et alii, 1999b, p. 238 e 301; HUSSON, 2008, p. 118-24; MAZOWER, 1998, p. ix-xv e 141-84; OLIVI; GIACONE, 2007, p. 19; REUTER, 1965, p. 37-8) não se encontra dentro dos limites temporais, espaciais e temáticos metodologicamente estabelecidos para o presente trabalho, razão pela qual não serão examinados. Fica registrado aqui o convite para futuras Pesquisas conjuntas sobre o tema.

De todo modo, o absurdo daqueles dois Projetos Europeus (Nazista e Bolchevique) permite evidenciar o despropósito de outros Projetos de unificação (igualmente Teológico-Políticos) usualmente mais bem vistos, cujo caráter unidimensionalizante costuma ser dulcificado por discursos igualmente universalistas (Direitos Humanos e Democracia, no interior de um Estado Federal Europeu)... Há que se desconfiar de discursos nos quais a disciplina dada por medida uniescalar deve ser aceita e que, caso não seja, deve ser imposta universal e incondicionalmente - em nome da transcendência, mediante "virtudes não tão virtuosas", como o uso da força ou a retirada da Soberania e da autonomia política (v., nesse sentido, o item 5.2.2.2., supra).

Nesse sentido, não é demais lembrar, como fizera outrora Alfonso MATTERA (2002, p. 17, grifos nossos) com relação ao passado da construção de uma Europa Unificada, que "[p]endant des siècles en effet l'unification européenne avait suscité les visées hégémoniques d'empereurs et de dictateurs (les empereurs, de la Rome antique, Charlemagne, Napoléon, Hitler). [P]ar le passé cette conquête était basée sur la violence des armées et sur l'oppression de peuples [...].”. 
inventiva de fundações jurídico-normativas sólidas de instituições regulares que pudessem enfraquecer toda e qualquer pretensão de tomada do lugar do Direito e do Poder na Europa continental - apenas deste modo se poderia realizar uma União política na entre os países do continente europeu ${ }^{695}$ (CHURCHILL, 1966, p. 265-6).

Para Winston CHURCHILL (1966, p. 263-4), a ausência de uma União política em igualdade de condições entre estatalidades isoladas foi a principal causa das duas Grandes Guerras no início do século XX. Assim, era fundamental estabelecer um robusto sistema institucional de convivência entre diferentes que - mediante uma renovada organização jurídico-política das relações entre as diferentes escalas de existência, instaurasse uma nova forma de relacionamento apta a impedir a Guerra na Europa. Para tanto, haveria que se pensar inventivamente em modos de articular Direito Positivo Internacional diante das recentes experiências da Segunda Guerra Mundial: "[t]here [was] therefore much knowledge and material with which to build: and also bitter dear-bought experience." (CHURCHILL, 1966, p. 264).

O ex-Primeiro Ministro britânico não apenas sugerira em seu discurso a importância de uma União política entre os países do continente europeu. Ele também indicara com precisão os termos segundo os quais concebia que deveria se desenvolver o estabelecimento desta União: os vigorosos laços políticos que deveriam passar a reger as relações entre alguns países da Europa - notadamente, as relações entre Alemanha e França - deveriam viger apenas e tão-somente na dimensão do continente europeu. Em outras palavras, o estabelecimento de um sistema de Leis na Europa deveria excluir o Reino Unido, pois este já comporia outro agrupamento de países ${ }^{696}$.

695 De modo que, segundo sua apressada sugestão, esta União pudesse ser inclusive denominada Estados Unidos da Europa. Mas não se deve concluir levianamente que Winston CHURCHILL sugerira a instauração de um Estado Europeu. Certamente influenciado pela experiência dos EUA, o ex-Primeiro Ministro britânico afirmara que se deveria construir alguma coisa "como" os "Estados Unidos da Europa" (CHURCHILL, 1966, p. 264).

A rigor, pode-se perceber nesta expressão vaga e claramente hesitante "We must build a kind of United States of Europe" que Winston CHURCHILL (1966, p. 264, grifos nossos) se preocupava mais em apontar a necessidade de se instituir um vigoroso vínculo jurídico-político entre os Estados da Europa continental (União política segundo Leis), do que propriamente sugerir de imediato a construção de um aperfeiçoado Estado Europeu (União política segundo Leis, na qual há o monopólio legal da violência por uma autoridade única e superior às demais). Nesse sentido, deve-se se lembrar de que, no mesmo texto, mais adiante, o autor afirmara enfaticamente que se deveriam formar os "United States of Europe or whatever name or form it may take” (CHURCHILL, 1966, p. 266, grifos nossos).

Assim, mais do que simplesmente propor de maneira impensada a importação automática e acrítica da organização jurídico-política dos EUA para o continente europeu, Winston CHURCHILL parece ter advertido apenas sobre a importância de se instaurar uma organização jurídico-política das relações entre Alemanha e França - independentemente da denominação ou da qualidade formal que esta regência por Leis da vida comum na Europa pudesse assumir.

696 "We British have our own Commonwealth. [...]. And why should there not be a European group which could give a sense of enlarged patriotism and common citizenship to the distracted peoples of this turbulent 
Assim, a União política entre países europeus formulada por Winston CHURCHILL claramente apresentava o Reino Unido como um "amigo protetor da nova Europa", como alguém que apenas indicaria um caminho a seguir, sem dele pretender participar (CHURCHILL, 1966, p. 266). Por isso mesmo, o Reino Unido se contentaria com os papéis de impulsionador e de árbitro externo da nova Europa continental politicamente Unida.

Assim, o Reino Unido não estabeleceria com os países de Europa continental o mesmo tipo de laço político ${ }^{697}$ (BARNAVI; POMIAN, 2008, p. 93; BERSTEIN; MILZA, 2002, p. 235; BITSCH, 2006, p. 27; GLAESNER, 1991, p. 287; MATTERA, 2002, p. 19; PERTEK, 2011, p. 12-3; QUERMONNE, 2010, p. 14; RÉAU, 2008, p. 166-7; REUTER, 1965, p. 36). Apenas entre os países da Europa continental haveria uma aproximação política mais profunda e enérgica (Leis) que impediria, mediante instituições permanentes e sólidas, a deflagração de novos conflitos armados ${ }^{698}$.

Il est clair, malgré quelques prudences oratoires, qu'il s'agit de créer une Europe occidentale (et d'ailleurs une Europe continental), la Grande-Bretagne restant à l'écart pour être $[\ldots]$ «les amis et les parrains de la nouvelles Europe». (BITSCH, 2006, p. 27).

A postura assumida pelo Reino Unido se mostrava já em 1946 avessa à assunção de Leis comuns entre este e a Europa continental. Apesar de Winston CHURCHILL reconhecer a importância de serem constituídas Leis entre os países da Europa do Ocidente, estas deveriam vigorar apenas no continente e não vincular o Reino Unido. Este estaria de fora desse vínculo jurídico-político para uma vida comum ${ }^{699}$.

and mighty continent and why should it not take its rightful place with other great groupings in shaping the destinies of men?" (CHURCHILL, 1966, p. 264-4, grifos nossos). Segundo Patrice ROLLAND (2006, p. 481), com tal declaração, Winston CHURCHILL parecia "laisse[r] à penser que l'Angleterre continu[ait] quelque peu de se penser comme en-dehors du continent.".

${ }^{697}$ A divergência entre Projetos de Europa Unida explica a não adesão do Reino Unido à CECA (item 6.3.2., infra): “[c]'est l'annonce de ce qui sera défini comme « le splendide isolement » du vieil empire d'Albion. La Grande-Bretagne arrivera [...] avec retard aux grands rendez-vous de l'Histoire européenne: elle sera absente à la signature des traités instituant les trois Communautés européennes (elle demandera cependant d'y adhérer, quelques années plus tard).” (MATTERA, 2002, p. 19).

698 "If at first all the States of Europe are not willing or able to join the Union, we must nevertheless proceed to assemble and combine those who will and those who can." (CHURCHILL, 1966, p. 266, grifos nossos). 699 A conclusão de Hendrik BRUGMANS (1969, p. 4) sobre o pronunciamento de Winston CHURCHILL resume o modo como o Reino Unido compreendia: (i) sua posição na construção de uma Europa politicamente Unida (não partilharia de qualquer organização jurídico-política com os demais países europeus); e (ii) a "prudência" de realização da União política (desejável, desde que bastante vaga, sem se preocupar com instituições internacionais que comprometessem as Soberanias estatais): “Ce texte indique clairement les limites dans lesquelles la conception churchillienne voulait maintenir l'Europe Unie. Limites géographiques d'abord: non-participation de la Grande-Bretagne. Limites institutionnelles aussi: les organisations proposées ne sont esquissées que d'une manière très vague.”. 


\title{
6.1.2. O Interstício Europeu (1946-1950): A Percepção da Importância da
}

\author{
Fundação de Leis Políticas entre Alemanha e França
}

A impossibilidade de as discussões desenvolvidas até o momento sobre possíveis Projetos de Europa Unida ${ }^{700}$ darem um adequado encaminhamento à reconciliação francoalemã e a importância de se evitar o recometimento de novos conflitos armados entre os dois países permitiram formar tanto na República Federal da Alemanha ${ }^{701}$, como na França, a percepção de que as relações entre ambos deveria se pautar pela igualdade de condições na decisão sobre questões comuns ${ }^{702}$.

${ }^{700}$ Como visto, o Congresso da UEF de agosto de 1947, a OECE de 1948, o Pacto de Bruxelas de 1948, o CGH de 1948 e os debates desenvolvidos em 1949 sobre o CdE (v. Capítulos Quarto e Quinto, supra).

${ }^{701}$ Lembre-se de que, após sua derrota de 8.5.1945, a Alemanha foi ocupada militarmente pelas tropas dos quatro países Aliados vencedores (EUA, França, Reino Unido e União Soviética), situação que ensejou o posterior desmembramento do país entre a RFA e a RDA.

"[Uma Alemanha] dividida era, provavelmente, preferível por todos os países envolvidos a uma Alemanha unida contra eles. Em maio de 1945, ninguém planejou tal desfecho, mas poucos se sentiram profundamente contrariados com o que ocorreu. Alguns políticos alemães, sobretudo o próprio Konrad Adenauer, chegaram a dever a própria carreira à divisão do país: se a Alemanha permanecesse um país organizado em quatro zonas, ou então unificado, um político desconhecido, egresso de uma região distante como a Renânia católica, dificilmente teria chegado ao topo do poder. [... O] principal oponente [de Adenauer], nos primeiros anos de República Federal, o socialdemocrata Kurt Schumacher, era um protestante originário da Prússia Ocidental e defensor incansável da unidade alemã. Ao contrário de Adenauer, Schumacher teria aceito, prontamente, uma Alemanha neutralizada, se tal fosse o preço a ser pago pela criação de um Estado alemão unificado, o que parecia ser a oferta de Stalin. E posição de Schumacher era, provavelmente, a que à época predominava na Alemanha [...]." (JUDT, 2008, p. 140).

A proposta americana inicial consistiu em desmantelar a Alemanha e reduzi-la a um status puramente agrícola. Mas esta sugestão não foi adotada. Ela foi dividida em quatro zonas de ocupação e perdeu parcela de seus territórios a Leste em favor da Polônia. Durante o período da ocupação pelas quatro potências, as principais decisões sobre os destinos da Alemanha foram tomadas por cada um dos Aliados com relação a suas respectivas zonas de influência. Quando as decisões diziam respeito ao conjunto do território alemão, os quatro países ocupantes se reuniam para deliberar em um Conselho de Controle Interaliado, o qual existiu até 1948.

Parcela da soberania alemã foi restituída em 1949 com a divisão de seu território em dois países distintos: a Oeste, a República Federal da Alemanha (RFA), cuja capital era Bonn, onde foram realizadas eleições em Setembro de 1949 - tendo sido escolhido majoritariamente o Partido que posteriormente elegeu Konrad ADENAUER como Chanceler (chefe do Poder Executivo), e, a Leste, a República Democrática da Alemanha (RDA), cuja capital era Berlim - a qual permaneceu sob controle soviético (BERSTEIN; MILZA, 2002, p. 223; BOBBITT, 2003, p. 45; DREYFUS, 2008, p. 144; GERBET, 2009d; JUDT, 2008, p. 125 e 140-1; MAZOWER, 1998, p. 232 e 240-9; NOËL et alii, 2008, p. 120-1; REUTER, 1965, p. 41; SCHUMAN, 1953, p. 2-3; WILKENS, 2008). Sobre a reunificação alemã, v. o final da nota de rodapé 606, supra.

${ }^{702}$ Interessante notar, nesse sentido, um auto-reconhecimento esboçado no discurso de Robert SCHUMAN proferido em 22-23.10.1953, em Bruges, sobre o método norteador das decisõs tomadas no imediato pósSegunda Guerra Mundial entre os Aliados em torno dos destinos da Alemanha (barganha fundada na coexistência) - a ser comparado com a descrição do método anunciado pela Declaração Schuman e utilizado nas negociações do Tratado da CECA (igualdade de condições entre escalas em convivência; v. itens 6.2. e 6.3., infra): "en ce qui concerne plus particulièrement l'Allemagne, la politique nouvelle qui avait été inaugurée par les trois Alliés Occidentaux, en juin 1948, les accords de Londres avaient pour objet la restauration politique et économique de l'Allemagne, la création d'un nouveau cadre administratif. En effet, la constitution de Bonn se situe en septembre 1949, les élections allemandes, le même mois, le Gouvernement Fédéral également en septembre-octobre. Nous avons eu tout de suite les accords du Petersberg, en novembre 1949; mais tout ceci laissait un malaise croissant. En effet on appliquait une 
A inefetividade das discussões até aquele momento desenvolvidas derivava da incapacidade de se pensar mecanismos institucionais que colocassem em pé de igualdade Alemanha e França de acordo com uma nova dinâmica relacional não mais afeita a uma lógica de simples barganha ou afirmação impositiva de posições entre Soberanias nacionais permanentemente inimigas (RÉAU, 2008, p. 197).

Por o Direito poder pautar as interações escalares entre diferentes que, apesar de pretenderem preservar sua diferença e sua independência, percebem a importância de conviverem entre si para decidir em conjunto questões comuns que poderiam ensejar a mútua destruição, cogitou-se que se deveria manejar de maneira inovadora as normas do Direito Internacional Público clássico para que se pudesse afastar o cometimento de novas Guerras regionais na Europa iniciadas a partir de Alemanha e França.

Por esse motivo, mostrava-se fundamental encontrar uma via jurídico-normativa positiva de Direito Internacional Público alternativa para que nem o potencial nacionalismo revanchista da primeira, nem o possível nacionalismo preventivo da última, pudesse buscar decidir por si só os termos normativos segundo os quais um e outro deveriam se portar perante si e perante os demais países da Europa com relação a questões comuns sensíveis.

Assim, passou-se a considerar o conjunto normativo do Direito Internacional Público clássico segundo uma perspectiva inédita e inaudita: a partir dele, instituições deveriam ser engenhosamente forjadas no interior de um novo tipo de arranjo institucional que direitificasse as relações entre Alemanha e França e, mediante esta livre abertura de condições de mútua oposição, afastasse o cometimento de novas Guerras regionais.

O Direito Positivo deveria ser assim rearranjado de maneira inovadora nas relações entre os dois países, pois deveria se orientar para instaurar uma nova dinâmica relacional entre as escalas de existência de ambos: uma dinâmica típica de organização jurídicopolítica entre diferentes que pretendem conservar suas diferenças e independência, apesar da comunhão de questões a serem conjuntamente resolvidas (Leis Políticas).

politique nouvelle avec des méthodes anciennes : c'est-à-dire, on faisait bien des concessions très larges, importantes, bien intentionnées mais toujours âprement marchandées, concessions que les vainqueurs réticents, méfiants, se laissaient arracher par une nation qui avait été vaincue, et se trouvait humiliée du fait qu'elle devait mendier ces concessions, mais qui avait d'autre part, de plus en plus, la conscience de sa force renaissante. La réhabilitation morale n'allait pas de pair avec la restitution progressive des libertés politiques. En face de l'Allemagne, la France était toujours hésitante, elle mesurait, timidement, les risques de chaque renonciation nouvelle, renonciation à un droit ou à une garantie, à ce qu'elle considérait comme constituant une garantie. Je vous donne quelques exemples. La France revendiquait des réparations, ces réparations devaient être fournies sous forme de démontages et transferts d'usines. Combien tout ceci est aujourd'hui dépassé ! On n'en parle même plus." (SCHUMAN, 1953, p. 3, grifos nossos). 
Sem se contentar com o simples arranjo jurídico-normativo internacional cooperativo que pouco comprometia as Soberanias nacionais, mas também sem pretender ousar com a supressão integral das Soberanias nacionais mediante uma Federação, o Direito Internacional deveria instituir uma vida comum entre tais diferentes que racionalmente operacionalizasse as Soberanias para que estas devessem encontrar soluções comuns. O Direito permaneceria sendo Internacional - por não ser um Direito Federal, mas não deveria ser um Direito fundado exclusivamente nas medidas estatais isoladas (barganha cooperativa), por ser um Direito preocupado em instaurar uma vida comum ou um Direito Comunitário Originário, no interior na qual os participantes deveriam manter paridade de condições e de deveres de participação na formação do sentido normativo sobre questões comuns.

Dessa forma, era necessário pensar um maquinário institucional jurídico-normativo original que engenhosamente impusese o compartilhamento dos deveres de cada um e colocasse estes em rotação contínua, de modo que para que nem apenas um, nem somente outro, pudesse decidir por si só normativamente a medida destinada a reger o destino comum. Afinal, dar um lugar à Alemanha para participar da nova Europa ao lado da França era percebida em 1950 como questão fundamental tanto para o Governo de Bonn, como para o Governo de Paris (RÉAU, 2008, p. 133 e 197).

Haveria que ser adotada assim uma solução institucional de Direito Internacional Público inaudita na História da Europa: estabelecer ineditamente uma organização jurídico-Política, isto é, instaurar entre Alemanha e França Leis no interior das quais nenhuma das escalas de existências tradicionalmente opostas militarmente pudesse ocupar intemporalmente o lugar do Direito e do Poder ou buscar solucionar suas tensões por via outra que a das próprias instituições comuns (convivência plural permanente).

Tratava-se assim da percepção da necessidade de instaurar uma situação em que o Direito Internacional Público asseguraria normativamente plenas condições institucionais para que um se apresentasse diante do outro de maneira conflitiva para decidir sobre o destino comum e, com isso, criaria condições para que a Guerra regional não retornasse como opção para a solução de conflitos entre as escalas. Afinal, afastar a Guerra por meio do Direito não seria impor juridicamente a Paz uniforme (política e cultural), mas criar condições jurídicas para que a solução armada não surgisse como opção viável diante da possibilidade de haver a resolução dada a partir do estímulo institucional à contínua oposição dimensional no interior de uma vida em comum - permanente convivência 
tensiva entre diferentes típica da vida Política. Engenhosa construção jurídico-Política, volatda a instaurar e a fazer funcionar a Política na Europa.

\subsubsection{As Reflexões de Konrad ADENAUER: Paridade de Condições $e$ Compartilhamento de Deveres entre Alemanha e França na Construção Comum}

Desde o princípio de 1950, o Chanceler da República Federal da Alemanha Konrad ADENAUER sinalizava sua predisposição a promover uma união política entre alemães e franceses, de maneira a reconciliar os dois países e permitir que entre eles se instaurasse uma relação de mútuos entendimento e compreensão ${ }^{703}$ (ADENAUER, 1980a, p. 295, 1980c, p. 311; BITSCH, 2006, p. 63; RÉAU, 2008, p. 197-8; REUTER, 1965, p. 43).

\footnotetext{
Die Herstellung eines guten Verhältnisses zwischen Frankreich und Deutschland war die grundlegende Voraussetzung für eine bessere Zukunft nicht nur unserer beiden Länder, sondern Europas und eines großen Teiles der Erde. Ich war mir klar darüber, daß eine dauernde Verständigung nur durch ausdauernde und zielbewußte Arbeit erreicht werden konnte. (ADENAUER, 1980a, p. 295).
}

Quando de seu primeiro encontro com o então Ministro das Relações Exteriores da França, Robert SCHUMAN para discutir o futuro da região do Sarre $^{704}$, realizado em Outubro de 1948, teria Konrad ADENAUER (1980a, p. 296) percebido por parte da França a confiante abertura em estabelecer um diálogo franco com a Alemanha. Segundo sua própria avaliação, a abertura em tratar daquela questão espinhosa para ambos os países sinalizara efetiva mútua predisposição para o restabelecimento de boas relações vindouras entre Alemanha e França ${ }^{705}$ (BOSSUAT, 1994, p. 157).

De todo modo, é importante salientar nesta parte do trabalho apenas os pensamentos de Konrad ADENAUER especificamente relacionados ao objeto de investigação deste estudo. Independentemente da resolução encontrada entre Alemanha e

\footnotetext{
${ }^{703}$ Konrad ADENAUER (1980h, p. 340) ressaltara em suas Memórias que a tônica principal da política externa do pós-Segunda Guerra Mundial de seu país consistiu precisamente em buscar assegurar a inserção internacional da RFA em iguais condições jurídico-políticas (direitos e deveres) na Europa.

${ }^{704}$ Sobre o problema da região do Sarre, remetemos o leitor à nota de rodapé 718 , infra.

${ }^{705}$ E, com efeito, foi o que anunciara Robert SCHUMAN em sua primeira visita a Bonn, em 14.1.1950, em conversa privada com Konrad ADENAUER (1980a, p. 297-8, grifos nossos): “Zuerst brauchen wir Freimütigkeit der Aussprache und dann viel Geduld. Ich glaube, es muß heutzutage zu den Haupteigenschaften eines Politikers gehören, seine Nerven zu beherrschen. Es ist dies nicht immer leicht, weil das, was hüben und drüben vorgefallen ist, nicht immer darauf angelegt war, Kaltblütigkeit zu fördern. Wir müssen uns beiderseits auch die psychologischen Schwierigkeiten vor Augen halten: Sie die unsrigen und wir die Ihrigen. Erst, wenn wir diese Hemmnisse überstehen und überwinden, haben wir freie Bahn für unser Schaffen.”.
} 
França para a região do Sarre $^{706}$, especial atenção deve ser dada à percepção consciente da importância de aqueles dois países iniciarem uma reaproximação mutuamente conciliadora. Se em 1948 teria sido reciprocamente notada uma predisposição à abertura bilateral a um diálogo franca e sinceramente voltado a uma construção conjunta do futuro comum (ADENAUER, 1980a p. 297-8), apenas posteriormente essa preocupação ganhou contornos mais concretos e precisos.

Somente em 6.3.1950, Robert SCHUMAN voltara a anunciar em uma Conferência de Imprensa que a França ainda mantinha conscientemente a percepção de que era importante manter bons entendimentos com a Alemanha. A tal declaração, pouco após respondera publicamente Konrad ADENAUER (1980b, p. 308 e 310) que reconhecia como importante a adequada resolução do secular conflito franco-alemão, pois apenas deste modo se poderia desencadear efetivamente qualquer processo de aproximação política entre países europeus.

Nesse sentido, em 7.3.1950, Konrad ADENAUER (1980c, p. 311) concedera uma entrevista onde formulara em termos genéricos sua proposta de União política europeia. Naquela oportunidade, o Chanceler da RFA salientara que a União política da Europa deveria estar centrada na paridade de condições a serem desenvolvidas nas relações entre Alemanha e França e pressupunha mútuo reconhecimento e confiança recíproca: "nur kühne Gedanken und schnelle Taten konnten die Bildung Europas vorantreiben." (ADENAUER, 1980c, p. 312).

A reconciliação franco-alemã era para Konrad ADENAUER a pedra fundamental não apenas porque importante, mas principalmente porque fundante - de uma União política da Europa $^{707}$ (BOSSUAT, 1994, p. 157). A reconciliação deveria se desenvolver segundo o intento de conferir um adequado encaminhamento das diferenças de

${ }^{706}$ Acerca do desenlace da questão sobre região do Sarre v. nota de rodapé 718 , infra.

Lembre-se de que a narrativa histórica deste Capítulo está voltada a esclarecer especificamente a história da construção da CECA, não tendo por objetivo elucidar integralmente o encaminhamento de questões que simultaneamente surgiram, mas que escaparam à formação da Comunidade. Lembre-se aqui ainda da própria Declaração de Governo da RFA proferida por Konrad ADENAUER de que, apesar de ser a solução da questão do Sarre um ponto delicadíssimo das relações entre Alemanha e França, "unter keinen Umständen die Saarfrage zu einer Störung der Beziehungen zwischen Frankreich und Deutschland und damit zu einer Erschwerung des Aufbaues von Westeuropa führen dürfe.” (ADENAUER, 1980b, p. 311). Em outras palaras, a orientação das relações entre Alemanha e França era a de que, independentemente da solução futura ao problema da região do Sarre, se deveria perseverar acima de tudo na permanência da mútua predisposição à progressiva aproximação reconciliatória entre os dois países. Por esse motibo, não se mostra como elemento histórica a ser necessariamente desenvolvido no texto principal deste trabalho o detalhamento do problema da região do Sarre e sua solução, por não ter sido considerado fundamental para encaminhar à formação da CECA - o objeto privilegiado deste estudo. Apesar de ser temática histórica relevante, não interessa aos objetivos deste estudo.

${ }^{707}$ Pois, para o Chanceler da RFA, sua proposta estava aberta à participação de outros países europeus, tais como: Bélgica, Itália, Luxemburgo, Países Baixos e Reino Unido (ADENAUER, 1980c, p. 312). 
perspectivas entre os dois países. Não se deveria eliminar a tensão escalar, mas apenas a retirar de seu ímpeto aniquilador de rivalidade revanchista: "[e]ine Union zwischen Frankreich und Deutschland würde einem schwerkranken Europa neues Leben und einen kraftvollen Auftrieb geben." (ADENAUER, 1980c, p. 312).

Todavia, a proposta do Chanceler da RFA carecia de clareza sobre a prática deflagradora da aproximação política entre Alemanha e França que deveria ser adotada.

Em 21.3.1950, em nova entrevista, Konrad ADENAUER esclarecera alguns dos elementos principais que compunham as linhas mestras de seu Projeto de Europa Politicamente Unida. Esta deveria induzir o estabelecimento de uma nova dinâmica e de um novo sentido no modo das relações desenvolvidas - principal, mas não exclusivamente - entre Alemanha e França. Ela deveria abranger igualmente outros países europeus eventualmente interessados em estabelecer com elas uma aproximação política em um mesmo sistema de convivência (ADENAUER, 1980c, p. 312-5).

Para a constituição de tal sistema de convivência, seria fundamental o estabelecimento de instituições comuns a todos os participantes. Nelas, cada uma das escalas de existência poderia (i) se apresentar perante as demais e, com isso, (ii) manifestar seus respectivos modos de habitar o mundo e, em seguida, (iii) contrapor-se às demais em igualdade de condições, a fim de (iv) compartilhar deveres e responsabilidades sobre questões sensíveis comuns.

Para Konrad ADENAUER (1980c, p. 314-5), era inevitável prever a produção de consequências econômicas positivas aos participantes daquele sistema; todavia, sem dúvida alguma eram mais importantes e mais impactantes as notáveis repercussões derivadas dessa aproximação política inaudita entre Alemanha e França baseada no estabelecimento jurídico-normativo de igualdade de condições institucionais na formação do sentido normativo de problemas oriundos de uma vida comum:

Fraglos würde es einen großen Schritt vorwärts bedeuten, wenn Franzosen und Deutsche in einem Hause und an einem Tisch säßen, um miteinander zu arbeiten und gemeinsam Verantwortung zu tragen. Die psychologischen Auswirkungen seien so groß, daß sie kaum abzuschätzen seien. Die französischen Ansprüche auf Sicherheit könnten auf diese Weise befriedigt und das Wachstum eines deutschen Nationalismus verhindert werden. Ich glaubte, daß die Verständigung zwischen Deutschland und Frankreich auf einer solchen Grundlage noch bedeutungsvoller sei als alle wirtschaftlichen Vorteile, die fraglos mit einer französisch-deutschen Union verbunden seien. (ADENAUER, 1980c, p. 315, grifos nossos). 
Para o início da União política da Europa entre Alemanha e França proposta por Konrad ADENAUER, seus participantes deveriam ser insertos em ambiente de convivência direitificada propício à formação de condições institucionais que permitissem a cada um trabalhar e decidir em condições de igualdade e em conjunto para assumir incumbências comuns reciprocamente implicadas para a construção do destino de questões comuns.

Assim, a igualdade de condições e de deveres para decidir sobre questões comuns era para ele o elemento fundamental e fundante da aproximação política entre os países europeus, devendo principiar de decisão conjunta tomada pioneiramente por Alemanha e França (ADENAUER, 1980c, p. 315-6; BITSCH, 2006, p. 63; RÉAU, 2008, p. 197-8). O mesmo sentimento encontrou ambiência igualmente favorável para se desenvolver na França, como se poderá ver no item a seguir.

\subsubsection{As Reflexões de Jean MONNET: Ponto de Partida Concreto para uma União} Política entre Alemanha e França

De acordo com ideário semelhante pode ser compreendida a proposta formulada em 3.5.1950 por Jean MONNET, Comissário Geral do Plano de Modernização da França ${ }^{708}$. Naquela data, ele apresentou a Georges BIDAULT, Presidente do Conselho de Ministros da França, e a Robert SCHUMAN, Ministro das Relações Exteriores da França, um Memorando onde explicitou detalhadamente os termos da proposta por ele mesmo sugerida genericamente poucos dias antes - 28.4.1950 - a Georges BIDAULT.

Jean MONNET (1970, p. 6) argumentou pela importância de inserir a RFA no coração da Europa. Esta deveria ser colocada em pé de igualdade nas relações internacionais, de maneira a que pudesse decidir sobre o uso dos recursos necessários para sua reconstrução e para seu eventual rearmamento. Segundo sua perspectiva, seria fundamental transformar imediata e urgentemente o modo de relacionamento entre os países europeus, principalmente as relações entre Alemanha e França, a fim de solucionar o "problema alemão":

\footnotetext{
${ }^{708}$ E futuro primeiro Presidente da Alta Autoridade da CECA: "[i]l devient commissaire général du Plan en 1945 et lance un vaste plan de modernisation et d'équipement de l'économie française. Il occupe cette fonction lorsqu'il rédige, avec ses collaborateurs du Plan, le texte fondateur de la construction européenne. En 1952, il devient le premier président de la Haute Autorité de la Communauté Européenne du charbon et de l'acier (CECA), jusqu'à sa démission en 1954, à la suite de l'échec de la Communauté européenne de défense (CED) [...]." (PRIOLLAUD; SIRITZKY, 2011, p. 17). Sobre a CED, remetemos ao item 1.3., supra.
} 
La situation allemande devient rapidement un cancer dangereux pour la paix dans un avenir prochain, et pour la France immédiatement, si son développement n'est pas dirigé pour les Allemands vers l'espoir et la collaboration avec les peuples libres. [...].

Il ne faut pas chercher à régler le problème allemand qui ne peut être réglé avec les données actuelles. Il faut en changer les données en les transformant.

Il faut entreprendre une action dynamique qui transforme la situation allemande et oriente l'esprit des Allemands, et non pas rechercher un règlement statique sur les données actuelles. (MONNET, 1970, p. 6).

Haveria que deixar de se conduzir pela lógica da Guerra no período do pósSegunda Guerra Mundial, isto é, abandonar a perspectiva de "faire céder l'adversaire" (MONNET, 1970, p. 6, grifos nossos). Nesse sentido, Jean MONNET sugerira que se confiasse na possibilidade de se aceitar a Alemanha como país detentor de igual capacidade de apresentar sua escala de existência perante as demais e de conter as pretensões de dominação dela própria e das demais: “l'Allemagne demande d'augmenter sa production [...]. Nous refuserons, mais les Américains insisteront. Finalement nous ferons de réserves, mais nous céderons.” (MONNET, 1970, p. 6).

O espírito dos Homens deveria ser modificado profundamente. Estes deveriam ser lembrados de que não mais estavam em Guerra, não sendo mais coerente seguir a lógica de aniquilação de um inimigo. Os outros países deveriam ser reconhecidos como iguais e se deveria buscar com eles trabalhar conjuntamente sobre questões comuns: "[i]1 faut une action profonde réelle, immédiate et dramatique qui change les choses et fasse entrer dans la réalité les espoirs auxquels les peuples sont sur le point de ne plus croire." (MONNET, 1970, p. 6).

Apenas por meio do restabelecimento desta relação horizontal entre os países europeus poderia ser criada uma dinâmica de relações inédita que se afastasse das formas relacionais do passado (resolução armada de conflitos oriundos de oposição entre diferentes escalas de existência) (BARNAVI; POMIAN, 2008, p. 97; RÉAU, 2008, p. 1967):

[t]he idea of Europe presented in such circles after the war was not one of restoration, of recapturing the good traditions of Europe; it was rather an argument about a necessary break with European traditions, especially the tradition of organizing on the basis of sovereign states. (WÆVER, 1998, p. 83, grifos nossos).

A transformação qualitativa do modo de interação entre Alemanha e França apenas se mostraria possível se se preocupasse em instaurar uma integração política entre tais países que partisse de elementos concretos, reais, imediatos. 
Por esse motivo, a sugestão de Jean MONNET apontava como princípio viável da construção desse espírito de reconhecimento mútuo e de solidariedade política partir de um elemento bastante concreto, a saber, o sensível setor franco-alemão da exploração do carvão e do aço: "cette solution crée [...] pour l'industrie tant allemande que française et européenne des conditions d'expansion commune dans la concurrence, mais sans domination.” (MONNET, 1970, p. 6).

A racionalidade da proposta era bastante simples: haveria que se partir de um elemento concreto para, em seguida, estabelecer uma primeira experiência - de fundamento concreto - de compartilhamento da decisão sobre o sentido normativo último de questões comuns sensíveis, sobre as quais todos deteriam deveres comuns. Deste modo, seria estabelecida uma solidariedade política de fato e efetivamente real sobre a qual poderiam trabalhar em conjunto as diferentes escalas de existência, sem qualquer predominância de uma sobre a outra. O ponto de partida sugerido por Jean MONNET foi começar pela administração e pelo uso de recursos escassos necessários a ambos para reconstruir e para potencialmente rearmar um e outro: o carvão e o aço.

A constituição de uma adequada organização jurídico-política institucional das relações permitiria conter previsíveis tentativas nacionais de dominação estatal isolada uniescalar da determinação do sentido normativo sobre o setor regulaodo em comum: “[soit le] dumping allemand à l'éxportation; [soit la] demande de protection pour les industries françaises" (MONNET, 1970, p. 6). A instituição da Política por meio da direitificação de um sistema de convivência entre diferentes sobre uma questão comum bastante concreta e sensível (o uso do carvão e do aço) permitiria refrear potenciais posturas nacionalistas insensatas e perigosas para o futuro da Europa, tanto por parte da Alemanha, quanto por parte da França.

Uma nova autoridade na Europa deveria ser instaurada, a fim de decidir sobre questões comuns concernentes aos destinos do carvão e do aço. Esta autoridade deveria, não apenas ser aceita pelas distintas escalas de existência, mas, compartilhada por elas: “cette association sera fondée sur la liberté, donc, sur la diversité[;] l'Europe [...] adaptée aux nouvelles conditions du monde, développera ses facultés créatrices et ainsi, graduellement, apparaitra une force d'équilibre.” (MONNET, 1970, p. 6).

A convivência desta pluralidade dimensional na tomada de decisão nesta integração setorial seria excelente oportunidade de instituir normativamente um laboratório de experiência política que produzisse um sistema institucional de interações escalares 
voltado a produzir decisões normativas tomadas em conjunto por força de deveres partilhados em torno de questões concretas sensíveis comuns.

A Europa Politicamente Unida mediante instituições (i) abertas à participação plural na forma de autoridade compartilhada multiescalarmente e (ii) voltadas à preservação de tal multiplicidade escalar no processo decisório sobre questões comuns reais (administração do carvão e do aço) seria uma solução mais concreta para inaugurar a construção efetiva da Europa politicamente unida: “[1]'Europe n'a jamais existé. Ce n'est pas l'addition de souverainetés réunies dans des conseils qui crée une entité". (MONNET, 1970, p. 6, grifos nossos).

As iniciativas de aproximação de países europeus anteriormente instauradas (OECE, Pacto de Bruxelas e CdE) eram entendidas como insuficientes para realizar o intento de constituir Leis entre os povos europeus. Elas não teriam se diferenciado qualitativamente e de modo efetivo das Organizações Internacionais tradicionais, na medida em que se restringiram todas ao âmbito da singela cooperação intergovernamental (CLERGERIE; GRUBER; RAMBAUD, 2010, p. 42; MATTERA, 2002, p. 23; PERTEK, 2011, p. 13-5; QUERMONNE, 2010, p. 9 e 15). Por essa razão Jean MONNET (1970, p. 6, 2001d, p. 274) percebera que estas experiências anteriores não teriam produzido qualquer resultado concreto.

As soluções tradicionais de cooperação econômica, militar e política até então desenvolvidas se mostraram por demais genéricas e abstratas, isto é, careciam de fundamento real (BITSCH, 2006, p. 66; DREYFUS, 2008, p. 145): “les peuples d'Europe n'entendent que des paroles. Ils ne croiront bientôt plus à l'idéal que les gouvernements persistent à leur offrir et qui n'en reste qu'à de vains discours et à des réunions futiles." (MONNET, 1970, p. 6).

Haveria que se encontrar um novo termo norteador das relações que, por sua vez, detivesse um ponto de partida concreto, a fim de que o impasse europeu e a efetiva reconciliação franco-alemã fossem adequadamente solucionados a partir de termos reais (ADENAUER, 1980c, p. 315, 2001, p. 174; QUERMONNE, 2008b, p. 23-4 e 31).

Conforme este mesmo diagnóstico e igualmente voltado à instituição de Leis de convivência plural permanente nas relações entre Alemanha e França, Robert SCHUMAN emitira sua famosa Declaração, na Sala do Relógio do Ministério das Relações Exteriores da França, em 9.5.1950 (MONNET, 2001d, p. 274). As principais características desta Declaração serão examinadas no item a seguir. 
6.2. A Declaração de Robert SCHUMAN de 1950: A Via Funcionalista e a Opção pela Imanência

Como diz o provérbio, o começo é a metade de tudo, não havendo quem não deixe de aplaudir todo belo começo. Para mim, este vale mais da metade, sendo certo que ninguém ainda o elogiou devidamente. (PLATÃO, 1980, p. 166).

Antes de iniciar um comentário mais detido sobre a Declaração Schuman de 1950, é importante salientar aspectos preliminares sobre o documento que fundou a manifestação feita por Robert SCHUMAN.

\subsubsection{Origens da Declaração Schuman de 1950}

Em primeiro lugar, deve ser sublinhado que o então Ministro das Relações Exteriores da França baseou sua Declaração em texto escrito, não apenas por ele próprio, mas também por Jean MONNET e um grupo de colaboradores próximos a este último ${ }^{709}$ (BARJOT, 2008, p. 38; BERSTEIN; MILZA, 2002, p. 249; BOSSUAT, 1994, p. 161; CLAPPIER, 1985, p. 3-4; CLERGERIE; GRUBER; RAMBAUD, 2010, p. 42; DREYFUS, 2008, p. 147; NOËL et alii, 2008, p. 126; OLIVI; GIACONE, 2007, p. 27; PRIOLLAUD; SIRITZKY, 2011, p. 17; QUADROS, 1984, p. 120). Por esse motivo, a assim conhecida Declaração Schuman de 1950 não é de autoria exclusiva daquele a quem se atribui nominalmente a paternidade ${ }^{710}$.

Independentemente da efetiva autoria, tendo sido Jean MONNET um dos principais autores do texto base da Declaração, é completamente compreensível e esperável que suas pretensões de instituir uma organização jurídico-Política (Leis Políticas) entre Alemanha e

709 Além do próprio Jean MONNET, colaboraram para a redação do texto-base do Discurso proferido por Robert SCHUMAN dois membros do Comissariado do Plano de Modernização da França, a saber, Etienne HIRSCH e Pierre URI, e também um jurista, Professor da Faculdade de Aix-en-Provence, Paul REUTER (BITSCH, 2006, p. 64; MATTERA, 2002, p. 24).

Para mais informações sobre a gênese do Plano Schuman, remetemos o leitor à entrevista concedida em 8.2.2002 por Jacques-René RABIER (2002c), antigo Chefe de Gabinete de Jean MONNET quando Comissário Geral do Plano de Modernização da França.

710 "Si le plan Schuman porte devant l'Histoire le nom du ministre des Affaires étrangères qui en a pris la responsabilité politique, il est en fait imaginé par Jean Monnet [...] avec une petite équipe de collaborateurs." (BITSCH, 2006, p. 61). Por esse motivo, nesta mesma obra e nesta mesma página, esta autora afirma explicitamente ter sido a CECA “[u]ne invention de Jean Monnet" (idem, ibidem). Mais categórica e diretamente, Alfonso MATTERA (2002, p. 22, grifos nossos) afirma ser Jean Monnet "l'initiateur de la grande aventure européenne.”.

De todo modo, em entrevista realizada em 22.1.1972, o próprio Jean MONNET (1972, 8:45/8:57) reconhecera que não se poderia dizer que o Plano Schuman era, na verdade, o "Plano Monnet". Segundo o entrevistado, certamente sem sua própria contribuição o Plano não teria existido; todavia, de maneira igualmente certa, sem a iniciativa de Robert SCHUMAN, ele não teria sido feito. 
França a partir de elementos concretos (carvão e aço) - visando à criação de iguais condições institucionais reais para uma solidariedade política de fato entre os dois países estejam igualmente presentes na Declaração.

De fato, é de acordo com o ideário de bastidores de Jean MONNET que se compreende o argumento de Robert SCHUMAN pela reconciliação franco-alemã ${ }^{711}$ : mediante instituição de uma União Política, a qual seria dada, por sua vez, por meio do reconhecimento de iguais condições e deveres de estar presente perante as demais escalas de existência para definir o destino comum concernente a questões concretas sensíveis. Por essa razão, pode-se compreender o motivo pelo qual Konrad ADENAUER (1980g, p. 336) qualificara Jean MONNET como o motor principal de todo Plano Schuman (Hauptmotor des ganzen Planes).

Em segundo lugar, o texto-base da Declaração Schuman de 1950 foi objeto de nove versões. A primeira foi finalizada em 17.4.1950, tendo sido revisada no mesmo dia, quando foi apresentada a segunda versão. A terceira - cuja data não pôde ser precisada - foi disponibilizada na última semana do mês de abril. A quarta versão do documento foi redigida em 26.4.1950, ao passo que a quinta foi finalizada no dia seguinte. A sexta versão foi exibida em 28.4.1950, tendo sido modificada para a sétima no mesmo dia. A oitava versão do discurso foi redigida em 4.5.1950. Por fim, a nona e última versão foi terminada em 6.5.1950 e foi oficialmente publicada em 9.5.1950, quando Robert SCHUMAN expusera seu Discurso na Sala do Relógio do Ministério das Relações Exteriores da França $^{712713}$.

A despeito de haver distinções entre cada um dos nove documentos acima mencionados, este trabalho se dedicará a compreender apenas e tão-somente a nona e última versão. A escolha por esta em especial deriva do fato de ela ter sido o

\footnotetext{
711 "Robert Schuman décide rapidement de faire sien le Projet de Monnet." (BITSCH, 2006, p. 67).

712 "Jean Monnet a par ailleurs identifié la personnalité idéale pour le lancement de son projet : c'est Robert Schuman. D'origine lorraine, celui-ci est né à Luxembourg en 1886. À cette date il est donc citoyen allemand puisqu'il n'a pas opté pour la citoyenneté française. Il fait en Allemagne des études de droit et de philosophie politique. Sa profonde répulsion à l'égard des horreurs du régime nazi le pousse à devenir citoyen français. En 1919, il est élu député au Parlement français. Homme politique de tout premier plan de la IV République, il est élu en 1947 président du Conseil de ministres et devient ensuite ministre des Affaires étrangères, charge qu'il occupe de 1948 à 1953. Robert Schuman apparait donc, de par ses origines, sa formation et son expérience, l'homme tout indiqué pour proposer aux Allemands un pacte de réconciliation." (MATTERA, 2002, p. 24-5).

${ }^{713}$ A cronologia entre tais documentos foi estabelecida a partir da consulta ao acervo do Centre Virtuel de Connaissance sur l'Europe (CVCE), Centro de Estudos e de Documentação Histórica sobre a Europa criado em 7.8.2002 pelo Governo de Luxemburgo, sediado no Castelo de Sanem. O CVCE tem por objetivo conceder acesso digital direto a diversos documentos da construção da Europa. Abrange não apenas a UE atual, mas também Organizações Europeias anteriores a ela, tais como a do Pacto de Bruxelas, a OECE, o CdE, a CECA, a CEEA e a CEE.
} 


\section{fundamento direto da Declaração de Robert SCHUMAN e, por conseguinte, da} instituição da CECA - o objeto de estudo privilegiado por este trabalho.

Assim, apesar de poder ser interessante eventual exercício histórico-comparativo entre cada uma das versões anteriores da Declaração, este exame de curiosidade histórica foge ao escopo investigativo deste estudo. Por esse motivo, não serão analisadas as oito variantes anteriores do texto-base da Declaração Schuman de $1950^{714}$.

\subsubsection{O Sentido Jurídico-Político da Declaração Schuman de 1950}

\subsubsection{Aspectos Gerais da Declaração Schuman de 1950}

A despeito do intenso trabalho em torno do texto da Declaração, foi possível aos colaboradores de Robert SCHUMAN e de Jean MONNET manter a necessária discrição antes de seu anúncio oficial ${ }^{715}$. Sobre este particular, lembre-se de que os duzentos

\footnotetext{
714 Todavia, fica registrado aqui o convite para futuras investigações conjuntas sobre o tema.

715 "Il est élaboré dans le plus grand secret car Monnet veut créer un effet de surprise, un «choc psychologique » capable d'emporter la conviction; il veut aussi éviter d'alerter les lobbies susceptibles de s'y opposer." (BITSCH, 2006, p. 64, grifos da autora).
}

Poucos anos após o proferimento de sua famosa Declaração, Robert SCHUMAN sinceramente reconhecera o consciente segredo em torno da elaboração e da proposição do Projeto de Europa Politicamente Unida a ser objeto da Declaração de 9.5.1950. O sigilo foi intencionalmente cultivado em território francês: "Du côté français on se rendait bien compte, que si on jetait prématurément dans le débat public ces idées nouvelles on risquerait de voir surgir les objections, les doutes, les critiques ; les hostilités s'organiseraient même avant que les idées aient pu prendre corps. Il y a eu de multiples consultations, on a demandé l'avis de tous les intéressés, au moment choisi et en s'adressant à des personnes particulièrement compétentes, choisies à cet effet. On n'a pas eu recours au Parlement; son rôle n'est pas d'élaborer, mais de juger les textes." (SCHUMAN, 1953, p. 8).

A crítica ensaiada já em 1951 por Pierre-Étienne FLANDIN (1951, p. 2), antigo Presidente do Conselho de Ministros da França, consistia em denunciar o caráter não-democrático da proposta e do Projeto de Europa Politicamente Unida por meio da vida comunitária da CECA. Todavia, note-se que a questão do caráter Político da vida comunitária na Europa - de acordo com as categorias examinadas no Terceiro Capítulo, supra, principalmente nos itens 3.3. e 3.4. - não significava introduzir na vida comum da Europa uma organização jurídico-política Democrática. Fosse este o intento, haveria a ocupação do lugar do Direito e do Poder pela escala de existência da populidade e a eliminação da oposição escalar entre diferentes dimensões existenciais (supranacionalidades e estatalidades).

Uma Europa Politicamente Unida seria deste modo não necessariamente uma Europa Democrática, mas uma Europa jurídico-politicamente organizada em torno de um Regime Misto, isto é, onde se criassem condições institucionais aptas a manter um vácuo neste centro normativo e nomogenético precisamente em virtude do choque entre diferentes medidas de existência da vida em comum (supranacionalidades, estatalidades e populidade, todas conjuntamente).

Assim, um déficit democrático na construção da Europa Unida não seria apenas uma característica "tecnocrata" inata da Europa. Tratar-se-ia, antes, de um código genético genuinamente Político intentado desde sua primeira constituição institucional. Longe de ser um defeito, seria a precisa fonte vigorosa de sua virtude Política: por meio de um Regime Misto, uma única escala de existência jamais determinaria o sentido último do Direito e do Poder na Comunidade, fosse ela a populidade, fosse alguma supranacionalidade, ou mesmo uma das estatalidades.

A precisa dinâmica do sistema de convivência plural permenante impedia qualquer tomada do lugar do Direito e do Poder por quaisquer delas, na medida em que exigia a co-presença ativa e permanentemente 
jornalistas reunidos no Salão do Relógio do Ministério de Relações Exteriores da França para participar da Conferência de Imprensa convocada por Robert SCHUMAN em 9.5.1950 ignoravam até aquele momento o objetivo do encontro ${ }^{716}$ (BITSCH, 2006, p. 64; DREYFUS, 2008, p. 147-8; MATTERA, 2002, p. 25-6; OLIVI; GIACONE, 2007, p. 27; RABIER, 2002c, 5:50/6:52; RÉAU, 2008, p. 198; REUTER, 1965, p. 42-3) ${ }^{717}$.

\begin{abstract}
Surprise générale; personne ne s'attendait à un projet de ce genre, ni en France, ni hors de France, et surtout de la part de la France. Nous avons pu constater cette stupeur (et le mot est encore trop faible), lorsque le 10 mai j'ai débarqué à Londres, pour une conférence qui était prévue depuis un certain
\end{abstract}

tensa de uma perante as demais. Nem uma escala - nenhuma delas, e nenhuma além delas, poderia ocupar o lugar do Direito e do Poder: antes, todas poderiam de maneira igual deter condições de definir em conjunto o sentido normativo da vida comum sobre questões sensíveis compartilhadas. V., nesse sentido, os comentários desenvolvidos em torno das instituições do Tratado da CECA, no Sétimo Capítulo, infra.

Note-se, por fim, que as observações acima não pretendem por ora fornecer uma opinião sobre a condição atual da UE, na medida em que essa espécie de questionamento está localizada fora do recorte metodológico temporal estipulado pela Parte Primeira deste trabalho.Tratou-se do fornecimento de maiores explicações sobre a aplicação da chave de leitura construída para o presente estudo apenas e tão-somente sobre o específico processo de construção histórica da CECA.

${ }^{716}$ Jean-Louis QUERMONNE (2008b, p. 30) relata que o discurso fora tão inesperado que, imediatamente após o anúncio oficial da proposta de Robert SCHUMAN, organizou-se uma nova reunião para reconstituir e repetir o evento desde o início, a fim de que nesta segunda encenação ele pudesse ser registrado por meio audiovisual.

Essa anedota histórica é confirmada por Jacques-René RABIER (2002c, 5:26/5:28) - antigo Chefe de Gabinete de Jean MONNET, enquanto Comissário Geral do Plano de Modernização da França, quem assitira pessoalmente ao pronunciamento da Declaração Schuman no Salão do Relógio, em 1950.

${ }^{717}$ Além de Robert SCHUMAN, de Jean MONNET e da equipe de colaboradores deste, tinham também conhecimento prévio do texto confidencial o Chefe de Gabinete de Robert SCHUMAN, o senhor Bernard CLAPPIER, o Secretário de Estado dos EUA, Dean ACHESON e o Chanceler alemão Konrad ADENAUER (BARNAVI; POMIAN, 2008, p. 97; BOSSUAT, 1994, p. 162; CLAPPIER, 1985, p. 4; DREYFUS, 2008 , p. 148; MATTERA, 2002, p. 25; NOËL et alii, 2008, p. 127; PERTEK, 2011, p. 17; REUTER, 1965, p. 43; SCHUMAN, 1953, p. 8).

Sobre o prévio conhecimento de Konrad ADENAUER da existência da Declaração Schuman e de seus termos, bem notara Jacques-René RABIER (2002c, 4:46/4:52) - antigo Chefe de Gabinete de Jean MONNET, enquanto Comissário Geral do Plano de Modernização da França - que Robert SCHUMAN apenas proporia ao Governo francês tal Projeto de Construção de uma União da Europa se soubesse haver prévia concordância por parte do Governo da RFA. Esta precisa condição foi reconhecida pelo próprio Robert SCHUMAN (1953, p. 8).

De todo modo, no próprio dia 9.5.1950, após a Declaração de Robert SCHUMAN, Konrad ADENAUER também se pronunciara em uma Conferência de Imprensa. Naquela oportunidade, ele salientou abertamente a importância política de um Projeto de aproximação de países europeus ancorado na igualdade de direitos e manifestou publicamente ainda o interesse da RFA de dele participar. O interesse da RFA visava não apenas a vinculá-la mais fortemente ao Ocidente da Europa, como também a encontrar meios outros para solucionar o problema da região do Sarre (ADENAUER, 1980e, p. 327-8) - sobre o Sarre, v. a nota de rodapé 718, a seguir.

Assim, para a República Federal da Alemanha, uma integração política com a França se mostrava fundamental : "la construction européenne fut ainsi le moyen d'obtenir « l'égalité de droits » par rapport aux pays vainqueurs, et d'acquérir une nouvelle marge de manœuvre sur la scène internationale." (OLIVI; GIACONE, 2007, p. 25).

De todo modo, apenas no dia 23.5.1950, Jean MONNET se encontrara com o Chanceler alemão, a fim de discutir os primeiros pontos destinados a reger o futuro Tratado a ser celebrado entre Alemanha e França. Naquele encontro, Konrad ADENAUER manifestara sua concordância em ter como ponto de partida das negociações os elementos gerais principais constantes da Declaração Schuman (ADENAUER, $1980 \mathrm{~g}, \mathrm{p}$. 336; BITSCH, 2006, p. 64 e 68-9). 
temps. Je sentis tout de suite, que notre initiative avait provoqué un froid auprès de nos amis anglais. J'avais emmené Monnet; nous fournissions des précisions sur nos idées, non seulement sur celles qui étaient développées sommairement dans la déclaration du 9 mai mais aussi sur nos pensées, nos arrière-pensées, nos intentions finales. Cet échange de vues, d'abord oral, puis par notes dura plusieurs semaines. On s'est rapidement rendu compte qu'il ne s'agissait pas d'un de ces pétards diplomatiques qui font beaucoup de bruit, mais sont dépourvus d'efficacité. Cette fois-ci c'était sérieux. (SCHUMAN, 1953, p. 9, grifos nossos).

Enquanto anúncio oficial e sincero do interesse de um país europeu em afastar o cometimento de novas Guerras na Europa Ocidental, a proposta de Robert SCHUMAN era não apenas surpreendente, mas, antes de tudo, inovadora e muito mais concreta e realista se comparada com as anteriores (BITSCH, 2006, p. 63; NOËL et alii, 2008, p. 125; ROLLAND, 2006, p. 584). O que será examinado nos itens a seguir.

6.2.2.2. Elementos para uma Organização Jurídico-Política das Relações FrancoAlemãs: Nem Coexistência, Nem Cooperação, Nem Federação, mas Direitificação da Convivência

A Declaração Schuman teria reconhecido ser mais importante cessar as discussões sobre a Europa e agir concretamente no sentido de construí-la de modo efetivo (MONNET, 2001b, p. 184). Nesse sentido, ela propôs e introduziu uma concepção de Europa "revolucionária" na condução jurídica tradicional das relações entre os povos europeus (BARNAVI; POMIAN, 2008, p. 99-102; CLERGERIE; GRUBER; RAMBAUD, 2010, p. 42; MATTERA, 2002, p. 24; PERTEK, 2011, p. 16; QUERMONNE, 2010, p. 9; ZORGBIBE, 1997, p. 25).

6.2.2.2.1. Reconhecimento e Permanência da Tensão Escalar Fundamental: Rejeição da Guerra e da Paz

A permanente divisão entre Alemanha e França era perigosa para a construção de uma vida comum na Europa ${ }^{718}$ (ACCIOLY, 2003, p. 46; ACCIOLY; NASCIMENTO E

\footnotetext{
718 “[D]epuis la naissance de la RFA, les relations ne sont pas très faciles entre une France contrainte à de nombreuses concessions (abandon des démontages et des réparations, organisation d'un état fédéral beaucoup moins décentralisé que ne le souhaitait Paris...) et une Allemagne irritée de voir la plus faible des puissances d'occupation continuer à vouloir freiner son redressement et son retour à la souveraineté. La tension se cristallise dans l'hiver 1949-1950 à propos de la question de la Sarre. Détachée du reste de l'Allemagne depuis la guerre, érigée en État autonome avec sa constitution, son parlement, son gouvernement, la Sarre forme avec la France une Union douanière, économique et monétaire acceptée par les
} 
SILVA; CASELLA, 2009, p. 428; DREYFUS, 2008, p. 148; PILOTTI, 1959, p. 75; QUERMONNE, 2008b, p. 13).

Le rassemblement des nations européennes exige que l'opposition séculaire de la France et de l'Allemagne soit éliminée : l'action entreprise doit toucher au premier chef la France et l'Allemagne. (SCHUMAN, 2000, p. 1).

A inabalável, irredutível e incontornável perseverança das oposições escalares entre Alemanha e França na Europa - mesmo após dois amargos conflitos mundiais - exigia a urgente busca de "efforts créateurs à la mesure des dangers qui la mena[çaient]" (SCHUMAN, 2000, p. 1). Apenas uma inédita rearticulação jurídico-normativa das relações entre os dois países no interior de instituições novas de Direito Internacional Público poderia evitar que se buscasse resolver mais uma vez as questões comuns sensíveis segundo uma ou outra exclusiva e única escala de existência: ou a vontade da estatalidade isoladamente considerada da Alemanha, ou a da França.

Assim, diante do reconhecimento inquestionável da necessidade de se reconciliar Alemanha e França - países que incontrastavelmente mantinham uma tradicional e irresoluta oposição escalar que potencialmente deslizava em direção a uma solução armada, a Declaração de Robert SCHUMAN propôs a mutação jurídico-normativa positiva da ordem internacional regente das relações entre os dois países europeus.

O salto lógico "revolucionário" da Declaração Schuman residiu na acurada percepção da necessidade de se pensar na confecção de instituições qualitativamente

Anglo-Américains en 1947, au moins à titre provisoire jusqu'à la signature d'un (éventuel) traité de paix. Elle se trouve, de plus, privée de compétences internationales et représentée à l'extérieur par le gouvernement français. Ce statut est de plus en plus mal accepté par les Allemands qui protestent contre le «protectorat» français et réclament le retour de la Sarre à la mère-patrie. Une violente campagne empoisonne le voyage de Robert Schuman mal accueilli outre-Rhin en janvier 1950.” (BITSCH, 2006, p. 66-7).

Com relação especificamente à região do Sarre, não se pode esquecer a observação de Konrad ADENAUER (1980a, p. 295): "Eines der Haupthindernisse, das einer deutsch-französischen Annäherung nach 1945 im Wege stand, war die Saarfrage. Frankreich wollte das Saargebiet an sich ziehen, wir leisteten jeden möglichen Widerstand. Mit den Vertretern der drei noch nicht offiziell zugelassenen Parteien an der Saar, die den Widerstand gegen die französischen Aspirationen leiteten, stand ich in ständiger persönlicher Verbindung. Das Saargebiet war seit dem Jahre 1945 ein Teil der französischen Besatzungszone. Frankreich erstrebte jedoch den politischen und wirtschaftlichen Anschluß des Saarlandes an Frankreich.”.

Apesar da profunda intenção alemã de resolver rapidamente a questão do Sarre, esta não fora solucionada definitivamente por meio do Tratado que instituiu a CECA - objeto da troca de cartas entre o Governo da RFA e a França que acompanhou o texto do Tratado de Paris, de 1951, que instituiu a CECA.

Apenas em 4.6.1956, o então Presidente do Conselho de Ministros da França, Guy MOLLET, e o ainda Chanceler da RFA, Konrad ADENAUER, conseguiram chegar a um acordo definitivo sobre a região do Sarre, juridicamente formalizado em 27.10.1956. Segundo este pacto, a partir de 1.1.1957, a região do Sarre seria novamente vinculada politicamente à RFA e, em três anos a contar daquela data, perderia seu vínculo econômico (união aduaneira) com a França. Em contrapartida, a RFA financiaria a canalização do rio La Moselle, na região francesa La Lorraine, e permitiria também o fornecimento de carvões da região do Sarre à França (BITSCH, 2006, p. 114; BOSSUAT, 2009, p. 915). 
distintas das da tradição por meio de um uso alternativo das normas jurídicas do Direito Internacional clássico.

Isto significava, em primeiro lugar, que não se poderia adotar um regime jurídico não internacional - ou seja, Federal, pois não se poderia comprometer as Soberanias estatais nacionais: haveria que se preservar juridicamente no campo da norma jurídica positiva do Direito Internacional Público. Ao mesmo tempo, em segundo lugar, o objetivo de tais normas jurídico-positivas não poderia ser nem reafirmar a racionalidade típica de uma dinâmica de coexistência, nem se contentar com o singelo estabelecimento de um sistema de cooperação estatal intergovernamental.

Dessa forma, a ordenação das disposições jurídico-normativas do futuro Tratado deveria trilhar um caminho institucional novo, sem abandonar a perspectiva de lidar com normas que atuariam como normas jurídicas internacionais ${ }^{719}$, isto é, fundadas originariamente em Tratado Internacional celebrados por Estados-nacionais Soberanos. A vida comunitária/comum entre diferentes direitificada seria originariamente fundada juridicamente (Direito Comunitário Originário) por meio de um Tratado Internacional (Direito Internacional Público) (CASELLA, 1994a, p. 212; MONNET, 1972, 1:50/2:26; QUADROS, 1984, p. 179; RABIER, 2002b, 2:32/2:40; WEILER, 2005, p. 295).

Para evitar o recometimento de novas barbáries em virtude do recurso à solução armada de conflitos, sugeriu-se a alteração do modo jurídico-normativo de desenvolvimento das relações entre os países da Europa. Uma organização jurídica das relações europeias deveria ser desenvolvida no interior de uma nova Organização Europeia, a qual deveria ser qualitativamente distinta das experiências anteriores, pois deveria reconhecer e consagrar a condição de plena igualdade recíproca entre Alemanha, França - e todos os demais participantes da vida em comum, sem que nenhuma de suas escalas pudesse se sobrepor às demais.

Em outras palavras, propunha-se que um futuro mecanismo institucional fosse juridicamente arquitetado, a fim de que operasse engenhosamente como canalização institucional suficiente de todas as oposições escalares possíveis. Apenas deste modo seria afastada a possibilidade de a tensão inter-relacional entre as diferentes escalas de existência

\footnotetext{
719 [L]a révolution fut-elle double: à l'inverse du Traité de Versailles issu du « paradigme westphalien », qui entendait imposer la logique du vainqueur au vaincu, elle opère la réconciliation des États et des peuples, en commençant par réaliser la fusion des sources d'énergie et de matières premières de leurs industries; et par delà l'habituelle coopération diplomatique, elle institue une autorité supranationale dotée de pouvoirs effectifs, issus de transferts de compétence en provenance des États. (QUERMONNE, 2010, p. 9).
} 
se desdobrar em solução armada ${ }^{720}$, conforme o tradicional espírito de dominação de um sobre o outro (MONNET, 1972, 1:50/2:26 e 2:45/3:19; SCHUMAN, 1953, p. 3-4).

A futura Comunidade prometia ser um rearranjo organizacional distinto do da tradição $^{721}$ em virtude de seu específico desenho institucional (CLERGERIE; GRUBER; RAMBAUD, 2010, p. 40 e 46; WEILER, 2005, p. 91) ${ }^{722}$. A aproximação política nova não apenas abandonaria a lógica do paradigma de coexistência, como também não se pautaria pela racionalidade típica da cooperação intergovernamental, nem almejaria suprimir Soberanias nacionais.

Quelle était l'origine de cette initiative ? Cette fois-ci, on n'a pas voulu copier ce qui avait déjà existé. On n'avait pas non plus le souci, comme si souvent dans la vie politique internationale, de reprendre, comme on dit, l'initiative diplomatique lorsque les affaires sont en train de s'enliser. Vous en voyez des exemples tous les jours actuellement.

En 1949 on avait constitué successivement l'Alliance Atlantique, le 5 avril 1949, le Conseil de l'Europe le 5 mai 1949; fin 1949 on avait obtenu la Constitution Allemande Fédérale, l'installation du Gouvernement de Bonn. Vous constatez donc une activité diplomatique d'une efficacité tout à fait exceptionnelle. Or déjà à ce moment-là, au lendemain de ce qui avait été entrepris, nous avions la conviction que tout cela se révélerait insuffisant et inefficace, à brève échéance, qu'il fallait, en d'autres termes, quelque chose de tout à fait nouveau. (SCHUMAN, 1953, p. 2, grifos nossos).

Em outras palavras, lidar com o antagonismo nacionalista potencialmente bélico entre ambos de uma maneira até então não realizada ${ }^{723}$ (MONNET, 2001c, p. 259) detinha um sentido preciso: era de suma importância "dénouer les difficultés politiques franco-allemandes" (BITSCH, 2006, p. 66), mas não se deveria pretender ilusoriamente que, com isso, as tensões entre ambos desapareceriam. Muito pelo contrário, elas

720 “Devant l'Assemblée, à Strasbourg, l'un de vos compatriotes, [le belge] M. Roger Motz, a dit « Nous sortons enfin du royaume des nuées ". C'est vrai, c'est à cette réalité de l'Europe, afin de lui faire un pas, un premier pas mais un pas essentiel pour régler les problèmes ou, tout au moins, rendre possible le règlement des problèmes, c'est à cette réalité que ce qu'on a appelé le plan Schuman s'est attelé." (MONNET, 2001b, p. 184, grifos nossos).

${ }^{721}$ Centralizada na perspectiva estrita da cooperação.

$722 \mathrm{O}$ qual constituiria um sistema de convivência entre diferentes, como será mais bem percebido a partir da leitura do Sétimo Capítulo, a seguir.

723 "La volonté de trancher avec l'ambition des grands projets évoqués lors du débat sur le Conseil de l'Europe est manifeste. [...]. Il s'agit bien de mettre en œuvre ce que la diplomatie de l'entre-deux-guerres n'avait pu réaliser à l'époque de Briand.”. (RÉAU, 2008, p. 198). No mesmo sentido, ressalta Jean-Louis QUERMONNE (2008b, p. 30) que a Declaração de Robert SCHUMAN deve ser entendida como ato fundador de uma nova racionalidade de aproximação entre os países europeus, pois ela "opéra pour la première fois une rupture avec la pratique diplomatique fondée sur la souveraineté des États, ainsi qu'avec la relation inégalitaire créée par les guerres entre nations victorieuses et pays vaincus.".

Também não se pode ignorar a própria percepção de Jean MONNET (1972, 2:28/2:42) sobre o caráter inaudito da proposta: para ele, a proposta de estabelecimento de uma relação de plena igualdade entre os países do Europa não havia ainda sido intentada no passado, pois sempre se buscara a máxima extração de proveitos por parte de um país com relação aos demais, na medida que suas próprias forças de conquista permitissem. 
permaneceriam. E, para eliminar a Guerra, não haveria que se buscar a Paz: antes, haveria que se buscar saber trabalhar juridicamente o conflito por meio de instituições comuns (direitificação).

Assim, sem negar a existência de uma efetiva distinção de dimensões existenciais entre os dois termos do binômico franco-alemão, Robert SCHUMAN anunciou estar a França disposta a trabalhar no sentido de atuar em conjunto com a Alemanha para resolver conjuntamente questões comuns sensíveis. Sua proposta apontava deste modo que se deveriam criar condições institucionais permanentes que viabilizassem a contínua e tensa interação em igualdade de condições entre as diferentes escalas de existência para, com isso, evitar respostas potencialmente disruptoras na solução dos conflitos (MONNET, 1972, 3:52/4:20 e 4:42/4:55, 2001b, p. 184, 2001d, p. 274; QUERMONNE, 2010, p. 16). Sem a Guerra, sem a Paz, a convivência entre ambos seria possível.

6.2.2.2.2. Solidariedade de Fato e Pluriescalaridade: Confiança, Reconciliação e Preservação de Igualdade de Condições entre Escalas de Existência

O intento do Plano Schuman era estabelecer um sistema de relações entre os países europeus no interior do qual a tensão escalar permanecesse acesa. Para tanto, as instituições assim constituídas deveriam permitir juridicamente a permanente possibilidade de discussão entre as escalas de existências envolvidas na vida em comum, a fim de que estas solucionassem as dificuldades comuns a partir da consciência compartilhada de que havia interesses comuns absolutamente vitais.

Para que as tensões escalares promovidas pelas instituições não deslizassem em solução armada, era necessária a adoção de uma atitude nova com relação aos implicados neste sistema de convivência: “[d]ans les tentatives antérieures, l'Allemagne représentait en quelque sorte l'ennemi à contrôler [...]. Force est donc de changer de stratégie: tendre la main à l'Allemagne, lui proposer de s'associer sur un pied d'égalité absolue [...]." (MATTERA, 2002, p. 26-7, grifos nossos).

Em outros termos, haveria que se guiar por uma relação de confiança entre os mais diferentes interlocutores interessados pela construção e pela manutenção de uma vida em comum. Para tanto, era importante atribuir a todos iguais condições para participar da definição do sentido normativo da vida comum. Nesse sentido, o mecanismo institucional deveria se preocupar com uma arquitetura jurídico-normativa que continuamente permitisse aos diferentes participantes da vida comum a presença 
perante os demais em pé de igualdade, a fim de que a permanente oposição escalar permitisse a construção de uma solução comum (MONNET, 1972, 3:52/4:20 e 4:42/4:55; RABIER, 2002a).

\begin{abstract}
Au lieu de signer un traité de paix de plus avec le vaincu - juridiquement ont était toujours en état de guerre avec l'Allemagne -, le vainqueur l'invite à sa table, d'égal à égal, et lui offre de participer à une autre initiative constructive conjointe prévue pour durer. Dans l'histoire des relations internationales, c'est une nouveauté absolue. (BARNAVI; POMIAN, 2008, p. 100, grifos nossos).
\end{abstract}

[En 1950] nous nous trouvions dans une Europe détruite, au milieu de laquelle couvait encore le vieil antagonisme franco-allemand. Allions-nous recommencer comme après la première guerre ou allions-nous nous engager dans la voie de l'égalité des peuples ? Tout le monde peut aujourd'hui mesurer aux résultats déjà obtenus, l'importance du choix qui a été fait alors. (MONNET, 2001c, p. 259).

A Declaração Schuman percebera assim que a reconciliação arquitetada entre Alemanha e França deveria partir do necessário reconhecimento mútuo de iguais condições de decidir normativamente em conjunto sobre questões comuns (BITSCH, 2006, p. 67; MATTERA, 2002, p. 27; PRIOLLAUD; SIRITZKY, 2011, p. 18; QUERMONNE, 2010, p. 16). A atribuição recíproca de igualdade de condições para definir o sentido último do Direito e do Poder sobre elemento vital comum seria o reconhecimento da importância da manutenção de um referencial normativo afeito à pluralidade escalar nas relações comuns entre aqueles países.

Para se instaurar a experiência de exercício de deveres de participação e de obediência cruzados pluriescalarmente compartilhados, era necessário encontrar um ponto de partida concreto comum bastante sensível e caro a cada um dos partícipes da futura vida em comum. Optou-se por partir de elemento concreto, de base real e material que possibilitasse a instituição efetiva de uma solidariedade de fato entre Alemanha e França: o carvão e o aço. Sobre a administração e sobre o uso destes recursos passariam a ser desempenhados os deveres comuns conforme um mutuamente reconhecido patamar de igualdade de direitos entre distintas escalas existenciais.

D'une pareille situation, il n'est qu'un moyen de sortir : une action concrète et résolue, portant sur un point limité mais décisif, qui entraîne sur ce point un changement fondamental et, de proche en proche, modifie les termes mêmes de l'ensemble des problèmes. (MONNET, 1970, p. 6). 
Em outras palavras, as contraposições entre Alemanha e França não poderiam ser resolvidas em um único ato, com uma única assunção abstrata de unidade cultural suposta, imaginada e imposta. Elas deveriam ser antes encaminhadas em conjunto para serem operadas e opostas simultaneamente por meio de uma solidariedade de fato constituída a partir de uma organização jurídico-Política de suas relações em torno de uma questão comum sensível bastante concreta ${ }^{724}$ (BITSCH, 2006, p. 67; MONNET, 2001d, p. 274; RÉAU, 2008, p. 198-9; SCHUMAN, 2000, p. 1).

As oposições escalares tradicionais seriam rearranjadas institucionalmente por meio de um novo uso do aparato jurídico-normativo internacional. Isso asseguraria que as tensões seriam prontamente direcionadas para o interior de um sistema de Leis segundo o qual a permanente contraposição seria trabalhada institucionalmente de acordo com uma perspectiva Política, vale dizer, segundo um sistema de convivência plural permanente consciente e cuidadosamente direitificado.

Desta maneira, o novo modo de relações deveria principiar pelo selamento autêntico e definitivo da aproximação entre Alemanha e França, a qual deveria se fundar em uma União Política. Esta deveria ser juridicamente instrumentalizada por meio do compartilhamento de deveres comuns e por meio da igual e horizontal submissão de todos à decisão comum de origem pluriescalar (SCHUMAN, 2000, p. 2 e 4) - pois, afinal, todos os participantes da vida comum seriam integrados segundo reconhecida plena e absoluta igualdade de direitos (BITSCH, 2006, p. 64).

A aproximação Política entre eles seria importante laboratório de experiência renovada: ela colocaria em comum o processo de decisão sobre o sentido último das normas jurídicas e do Poder envolvendo o uso dos escassos recursos comuns indispensáveis para a reconstrução dos dois países - o carvão e o aço - e, com isso, asseguraria o caráter pluriescalar de tais decisões normativas (ADENAUER, 1980e, p. 327; MONNET, 2001b, p. 184).

Segundo a Declaração Schuman de 1950, as relações entre Alemanha e França não mais deveriam seguir a dinâmica da coexistência entre vencedores e vencidos, nem a da cooperação intergovernamental. Antes, deveriam se orientar em função da busca de instaurar uma organização jurídico-Política das relações entre os dois países - a fim de não suscitar uma oposição potencialmente tendendo a uma solução armada. Isso poderia

\footnotetext{
${ }^{724}$ Isto é, mediante a instituição de Leis de direitificação de convivência entre diferentes modos de habitar o mundo.
} 
“changer le destin des régions longtemps vouées à la fabrication des armes de guerre dont elles ont été les plus constantes victimes" (SCHUMAN, 2000, p. 1) ${ }^{725}$.

Assim, com a proposta de Robert SCHUMAN, a arquitetura de um aparato institucional por meio do Direito Internacional que instaurasse um sistema de convivência entre os dois países passou a ser a questão fundamental. Era necessário pensar a confecção de uma convivência juridicamente institucionalizada, a ser fundada no consciente e deliberado reconhecimento mútuo da importância da presença das diferentes escalas de existência em iguais condições de participação e de obediência - pois apenas deste modo seria possível construir um sentido normativo comum pluriescalar sobre questões sensíveis compartilhadas.

\subsubsection{Desdobramentos da Direitificação I: A Oposição Escalar e o Vazio de}

\section{Poder Subjacentes à Produção Comum das Normas sobre o Carvão e o Aço}

O Plano derivado da Declaração Schuman de 1950 propôs a constituição de um novo modo de relações entre os países europeus do continente: não mais coexistência, nem mais cooperação, mas a convivência direitificada. Há nessa preocupação um sentido todo especial que deve ser adequadamente examinado para ser mais bem compreendida tal “conception audacieuse du gouvernement français" (ADENAUER, 2001, p. 173) ${ }^{726}$.

Não se tratava apenas e tão-somente de colocar em comum a produção francoalemã de carvão e de aço. Havia na verdade o intento de garantir em última instância a todos os países participantes da vida em comum a possibilidade de fruir daqueles produtos em mesmas condições. Isso significa que os produtos deveriam deter condições idênticas para serem acessados igualmente entre os Estados-Membros, pois "[1]e plan Schuman procèd[ait] d'idées três simples. Tout d'abord cette idée que les ressources [étaient] communes et [devaient] être mises en valeur au profit de tous." (MONNET, 2001b, p. 184).

Todavia, há uma significação ainda mais profunda por trás dessa preocupação.

$\mathrm{O}$ intento de formar tal Comunidade consistia principalmente em tentar determinar que, ainda que em condições econômicas distintas, cada um dos participantes deveria deter iguais possibilidades para definir as disposições destinadas a reger a produção

\footnotetext{
725 "Pour Schuman le pool était avant tout un moyen de régler le problème franco-allemand." (CLAPPIER, 1985, p. 4).

${ }^{726}$ Qualificação dada por Konrad ADENAUER à proposta da CECA, em seu Discurso de Abertura proferido durante a Primeira Sessão do Conselho de Ministros, realizada em 8.9.1952.
} 
em comum e, ao mesmo tempo, para obedecê-las de maneira exatamente igual (SCHUMAN, 2000, p. 1-3). Tratava-se de Projeto de constituição de vida em comum pautada pela horizontalidade relacional entre diferentes escalas de existência, fundada na igualdade de direito.

\begin{abstract}
Pour cela, il faut des institutions communes, ayant la responsabilité de voir l'ensemble - c'est-à-dire l'Europe - et de décider pour le bien de la communauté. Naturellement, il faut que ces institutions [...] présentent toutes les garanties nécessaires et soient contrôlées. Ce contrôle doit être exercé par une assemblé, par un parlement commun, qui doit pouvoir se prononcer sur l'action de l'exécutif, et le renvoyer s'il a mal rempli sa tâche, s'il a manqué à son devoir. (MONNET, 2001b, p. 184, grifos nossos).
\end{abstract}

As instituições da nova Comunidade deveriam organizar a vida em comum entre seus participantes e assegurar o uso comunitariamente regulamentado de recursos escassos fundamentais (carvão e aço). Todas as escalas de existência estariam igualmente implicadas na vida comum, pois normas promotoras de oposições escalares forçariamnas a dela participar ativa e continuamente. Haveria assim o estabelecimento de uma autoridade comunitária, ou melhor, de uma autoridade (da vida em) comum dada pluriescalarmente à qual todos se submeteriam igualmente - mas também da qual todos participariam em condições iguais (ADENAUER, 1980e, p. 327).

Assim, o aparato institucional deveria garantir mediante normas promtoras de oposições escalares que (i) as estatalidades (a) se contrapusessam entre si (isolada e intergovernamentalmente) - de maneira a uma impedir a sobreposição de uma sobre a outra; e (b) controlassem também as demais escalas de existência participantes da vida em comum - como a supranacionalidade (da Alta Autoridade e da Corte) ${ }^{727}$; e (ii) as supranacionalidades (a) pudessem e devessem participar ativamente da vida em comum para mutuamente se controlar; e, principalmente, (b) barrassem eventuais pretensões unidimensionalizantes das estatalidades (isoladas ou intergovernamentais).

La Haute Autorité commune chargé du fonctionnement de tout le régime sera composée de personnalités indépendantes désignées sur une base paritaire par

\footnotetext{
${ }^{727}$ Como será visto no Sétimo Capítulo, a seguir, a populidade também está implicada na vida em comum da CECA, mas em momentos fundamentais - porque fundante, a saber, o momento da fundação e da refundação da Comunidade. Nesta oportunidade, o controle residiria na certificação prévia de que assentiam ao desenvolvimento institucional de oposições escalares. Isso restará mais claro no próximo Capítulo.

Mas, certamente, não se pode ignorar desde já que a complexidade do aparato institucional da estrutura da CECA gira principalmente em torno das diferentes maneiras possíveis de opor quatro dimensões existenciais: estatalidade isolada, estatalidade intergovernamental, supranacionalidade da Alta Autoridade e supranacionalidade da Corte. Sobre tais escalas de existência no interior da CECA, indicamos a leitura do item 3.3.3.3., supra.
} 
les Gouvernements ; un Président sera choisi d'un commun accord par les Gouvernements ; ses décisions seront exécutoires en France, en Allemagne et dans les autres pays adhérents. (SCHUMAN, 2000, p. 4, grifos nossos).

A Declaração de Robert SCHUMAN visara ao estabelecimento de profundo laço de solidariedade entre Alemanha e França por meio de uma União Política institucionalmente mediada. Seu sistema de convivência seria institucionalmente arquitetado por mecanismos jurídico-normativos (normas de oposições escalares) que garantiriam uma aproximação segundo lógica qualitativamente distinta da tradicionalmente empreendida na História.

Assim, as relações franco-alemãs - e dos demais partícipes da vida em comum deveriam se pautar pela igualdade de direitos e de condições de um e de outro na definição do destino comum. Nenhuma das dimensões existenciais poderia pretender de antemão definir a partir de sua própria escala de existência o sentido normativo final sobre as questões comuns - devendo restar, assim, um vazio de Poder derivado da mútua repulsão multilateral originária entre todos os participantes da vida comum (ADENAUER, 1980e, p. 331; BITSCH, 2006, p. 67; SCHUMAN, 2000, p. 2).

6.2.2.4. Desdobramentos da Direitificação II: Rejeição da Transcendência do Federalismo Europeu por meio do Vazio de Poder

Há que se notar que a proposta de União Política de Robert SCHUMAN difere da Teológico-Política do CdE.

Com efeito, fruto da atividade missionária do Federalismo Europeu, o CdE assumia previamente uma imaginada unidade cultural da Europa como dado a ser evangelizado sobre os eventuais futuros aderentes. O Plano Schuman, por outro lado, tinha por ponto de partida uma dimensão material bastante concreta - a realidade incontornável da necessidade de se decidir normativamente em comum sobre o uso dos recursos escassos do carvão e do aço: "[1]a solidarité de production qui sera ainsi nouée manifestera que toute guerre entre la France et l'Allemagne devient non seulement impensable, mais matériellement impossible." (SCHUMAN, 2000, p. 2).

Nesse sentido, a União Política proposta por Robert SCHUMAN deve ser compreendida como localizada fora da sombra das pretensões Federalistas (BITSCH, 2006, p. 54; MAGNETTE, 2006, p. 31; NOËL et alii, 2008, p. 235; QUADROS, 1984, p. 106-8 e 119-21; QUERMONNE, 2008b, p. 33; RÉAU, 2008, p. 196-9; WEILER, 2005, p. 
$295)^{728} 729$. Sem prever sequer uma palavra sobre Direitos Humanos e Democracia ${ }^{730}$ (isto é, estando longe do ideário do Federalismo Europeu), nem mesmo sobre a organização da exclusividade do uso centralizado da força na vida comum (isto é, longe de pretender organizar um Estado Europeu $)^{731}$, seu objetivo consistiu em fazer funcionar a experiência Política de aproximação entre diferentes a partir de dados concretos e de

${ }^{728}$ Não se deixem de mencionar ainda as observações constantes das notas de rodapé 732, 738 e 740, todas infra.

729 Lembre-se de que Robert SCHUMAN utiliza em seu discurso o termo "Federação europeia": (SCHUMAN, 2000, p. 1 e 2). Mas o simples uso dessa expressão não autorizaria a concluir aqui de maneira apressada que o intento dele consistia em instituir uma Federação Europeia nos termos de um Estado Federal Europeu - tal qual preconizado pelos europeístas Federalistas do CdE.

O afastamento dessa conclusão apressada por este trabalho é autorizado, não apenas porque metodologicamente se reconhece a impossibilidade de um autor determinar por si só o campo significativo último de seu próprio texto - ou ainda, porque assume para si a pergunta "o que importa ser um autor?" (v. item 3.3.1., supra).

Mais do que esta simples tomada de posição, este trabalho também reconhece, mais uma vez com Joseph H. H. WEILER (2011), ser metodologicamente mais importante do que analisar o que alguém falou, analisar como alguém realizou o que disse em termos práticos institucionais.

Nesse sentido, é importante notar que a definição das instituições da CECA não foi realizada isoladamente pela França, pela Alemanha, ou apenas pelo casal franco-alemão: tal discussão foi alvo de intensos debates entre os que pretendiam instituir a vida comum (v. item 6.3.3., a seguir). Lembre-se aqui de que "[c]ontrairement à une idée reçue, on ne trouve pas au sein des partenaires du Bénélux une impulsion en faveur d'une structure fédérale, mais au contraire la défense des prérogatives des États." (RÉAU, 2008, p. 202, grifos nossos).

Mais importante do que prestar atenção ao que foi dito, deve-se examinar com cuidado de que modo foi realizado aquilo que foi dito. As instituições que deram viabilidade prática para a União política da Europa mediante a integração setorial da CECA - como será mais bem percebido quando da leitura do Sétimo Capítulo, infra - assumiram uma conformidade de organização jurídico-política que se afastou muito do Projeto Federalista.

Por isso mesmo, antes de se deixar levar exclusiva e levianamente pelos significantes utilizados em um discurso, haveria que se prestar atenção ao modo como foi dada de maneira prática significação ao termo utilizado. Como reconhecera poucos anos depois o próprio Jean MONNET (2001b, p. 188-9, grifos nossos): "L'Europe se fait concrètement, non pas par un plan préconçu, mais selon des principes qui [...] s'appliquent et donnent leurs solutions graduellement aux problèmes tels qu'ils se présentent.".

Assim, perceba-se que visar ao estabelecimento de uma "federação europeia" em Robert SCHUMAN nada mais seria do que visar ao estabelecimento de um foedus entre os países europeus, vale dizer, de um simples vínculo Político entre aquelas entidades autônomas - isto é, visar ao estabelecimento de Leis de convivência entre diferentes - apto a "introdui[re] le ferment d'une communauté plus large et plus profonde entre des pays longtemps opposés par des divisions sanglantes" (SCHUMAN, 2000, p. 2).

Nesse sentido, lembre-se de que no período em que eram pensados os Projetos de Europa politicamente Unida, "[a] própria flutuação terminológica se fazia presente [...] e era sintomática" (CASELLA, 1994a, p. 57). Por esse motivo, o uso do termo "federal" para a CECA deve ser percebido como designando o "sentido original [de foedus, isto é] de vínculo contratual envolvendo divisão de poder, entre indivíduos, entre grupos, entre estados, sendo [este] uso mais adequado do que a definição das modernas federações, quando aplicado à Comunidade Européia" (CASELLA, 1994a, p. 213-4).

${ }^{730}$ Como se pode depreender da simples leitura do texto do Tratado Constitutivo da CECA.

731 V., nesse sentido, as características do Projeto de Europa (Teológico-)politicamente Unida dos Movimentos Europeístas Federalistas, no item 5.2.2., supra, principalmente no que se refere à perspectiva defendida pela UEF. Sobre esta questão, também não se deve deixar de remeter o leitor à nota de rodapé 609, supra: nem a proposta da CECA, nem sua realização institucional, se voltaram a construir um Estado Europeu, muito menos um Estado Federal Europeu, pois não se visou nem mesmo a regulamentar qualquer espécie de uso exclusivo da violência em âmbito supranacional. Os comentários ao Tratado da CECA, constantes do Sétimo Capítulo, infra, esclarecerão ainda mais esta questão. 
necessidades reais: o uso do carvão e do aço ${ }^{732}$ (CASELLA, 1994a, p. 70; MATTERA, 2002, p. 24 e 27; MONNET, 2001b, p. 188-9; RÉAU, 2007, p. 12-3).

Buscaram-se fundamentos sólidos, reais, para inaugurar institucionalmente um novo modo de relações entre Alemanha, França e eventuais parceiros nela interessados (ADENAUER, 1980e, p. 331; SCHUMAN, 2000, p. 2). Vencedores e vencidos não perpetuariam entre si uma lógica de Guerra e estabeleceriam um pacto segundo o qual todos deteriam iguais condições jurídico-políticas para decidir em conjunto questões comuns sensíveis ${ }^{733}$ (ACCIOLY, 2003, p. 46; QUERMONNE, 2008b, p. 31; RAMOS,

${ }^{732}$ Diferentemente da crença Federalista de que uma unidade cultural imaginada permitiria realizar em um só golpe a unificação da Europa, a Declaração de Robert SCHUMAN (2000, p. 1) de 9.5.1950 mostrava seu ceticismo com relação a este pretenso fundamento de origem transcendente: “[1]'Europe ne se fera pas d'un coup, ni dans une construction d'ensemble: elle se fera par de réalisations concrètes, créant d'abord une solidarité de fait.".

Note-se assim que o ponto de partida para a reunião jurídico-politicamente organizada dos países europeus seria precisamente o convite forçado a que todos pudessem decidir em conjunto sobre questões concretas (reais) comuns, e não um imaginário de difícil instauração concreta sem mediação por um discurso totalizante.

Mais uma vez, pode-se perceber uma qualidade mais jurídico-Política da proposta da Declaração Schuman do que propriamente jurídico-Teológico-Política: a criação de Leis que organizassem jurídicoPoliticamente as relações entre os povos europeus estaria voltada, não à realização de um Reino imemorialmente imaginado e revitalizado por um discurso profético, mas para resolver, aqui e agora, questões sensíveis fundamentais para uma vida em comum.

Com a Declaração Schuman, o Projeto de Europa politicamente Unida descera à terra, perdera sua dimensão transcendente e se direcionara para resolver uma questão mundana. A direitificação das relações na Europa implicou o desenho de complexa arquitetura institucional para realizar juridicamente a Política: reconhecendo a permanência inevitável das tensões escalares, não pretendeu realizar a Paz, mas apenas evitar o recometimento de Guerras pelo adequado manejo institucional das oposições escalares.

Nesse sentido, são esclarecedoras as palavras de Robert SCHUMAN, em discurso proferido em 2223.10.1953, em Bruges: “au début de cette déclaration du 9 mai 1950, nous avons surtout eu en vue les avantages immédiatement atteints dans le domaine politique. Conclure une union durable et contrôlée au sujet du charbon et de l'acier, ce serait enlever à chacun des pays ainsi associés la possibilité, non seulement de faire, mais même de préparer une guerre contre les autres associés. Car on ne fait pas la guerre lorsqu'on n'a pas la libre disposition de l'énergie, c'est-à-dire du charbon et du métal qui est à la base de toute entreprise de ce genre, l'acier. La guerre, avons-nous dit, non seulement est devenue impossible mais impensable. Et je puis dire aujourd'hui sans crainte d'un démenti que ce résultat est actuellement acquis. Nous ne nous sommes pas confinés dans le domaine du pur raisonnement. Nous avons pu résoudre dans le concret plusieurs problèmes irritants que j'ai évoqués tout à l'heure.” (SCHUMAN, 1953, p. 5-6, grifos nossos).

733 “Ils sont conscients de ce que les peuples du vieux Continent se sont fait violence entre eux au cours d'une guerre fratricide et sont d'accord sur un fait: vainqueurs et vaincus doivent s'asseoir à la même table et conclure un entre eux un pacte de fraternité.” (MATTERA, 2002, p. 16). No mesmo sentido, Elizabeth ACCIOLY (2003, p. 46): "E porque carvão e aço? [... C]omo os grandes produtores do carvão e do aço eram a França e a Alemanha, punha-se dessa forma a França e a Alemanha do mesmo lado"; como bem lembrara Jean MONNET, em entrevista realizada em 22.1.1972, os elementos e os recursos econômicos mais importantes dos dois países eram o carvão e o aço (MONNET, 1972, 4:25/4:41).

Deste modo, o temor de o embate escalar entre ambos se traduzir em respostas militares mutuamente destrutivas seria substituído pela recíproca confiança derivada do reconhecimento bilateral da possibilidade igualmente partilhada de decidir sobre o destino comum sobre questões sensíveis - como o carvão e o aço, recurso fundamental para ambos no pós-Segunda Guerra Mundial, seja para a reconstrução, seja para eventual rearmamento (ADENAUER, 1980h, p. 338; NASCIMENTO E SILVA; ACCIOLY, 2002, p. 248).

$\mathrm{O}$ uso do carvão e do aço estava intrinsecamente associado à prática de Guerras. Para que se tornasse real e factível a pretensão de que novas Guerras não seriam mais cometidas para solucionar controvérsias entre Alemanha e França, era indispensável que se submetesse seu uso à avaliação pública. 
2005, p. 49). Foi esta preocupação em estabelecer uma solidariedade de fato e material entre Alemanha e França que permitiu a passagem do "ideal europeu distante para a realidade concreta" (ACCIOLY; NASCIMENTO E SILVA; CASELLA, 2009, p. 428, grifos nossos).

Nesse sentido, a proposta de Robert SCHUMAN simbolizara a recusa por uma orientação Teológico-Política. sua Declaração rejeitara a plenificação prévia do lugar do Direito e do Poder da futura vida comum por um discurso transcendente de afirmação incondicional de uma tradição imaginada da civilização europeia fundada nos Direitos Humanos e na Democracia. Antes, a referência normativa de sua aproximação Política seria dada mediante a aberta, íntima e constante contraposição entre diferentes escalas de existência participantes da vida em comum. E esta tensão irresolúvel seria a fonte do sentido normativo último sobre um elemento concreto: a administração e o uso do carvão e do aço - e não uma opção prévia automática por qualquer entidade transcendente ou transcendentalizada.

6.2.2.5. Desdobramentos da Direitificação III: Funcionalismo como Técnica Jurídico-Política Institucional de Preservação da Imanência

A proposta de integração europeia setorial de Robert SCHUMAN detinha efetivo cunho prático (BITSCH, 2006, p. 63): estava ela comprometida com o fazer funcionar a Política no continente europeu (ADENAUER, 1980h, p. 338). Essa precisa condição lhe

Se a questão sensível comum não fosse trazida ao meio entre todos (à terra) à terra para ser resolvida humanamente por meios humanos (instituições), isto é, se não fosse solucionada a partir de uma perspectiva imanente, nada mais restaria do que o descontrole típico do se entregar às incontroláveis e fortuitas adversidades imprevisíveis do acaso: "Die Initiatoren des Planes haben bewusst die Grundstoffe Kohle und Stahl zur Grundlage des Planes gemacht, weil mit der Herrschaft über die Grundstoffe die Problematik unseres ganzen europäischen Lebens in der Vergangenheit und Gegenwart auf das Engste verknüpft ist. Eisen und Stahl sind am stärksten mit dem Gedanken des Krieges verbunden. Deshalb stellt es geradezu eine Verpflichtung dar, sie gegenüber der öffentlichen Meinung der Welt einer echten Gemeinschaft dienstbar zu machen. Wenn wir die Dinge jetzt nicht selbst entscheiden, wird das Schicksal sie gegen uns entscheiden.” (BUNDESREPUBLIK DEUTSCHLAND. Auswärtiges Amt, 1950, p. 2, grifos nossos).

Por esse motivo se pode compreender como a escolha concreta do setor do carvão e do aço para iniciar a partir de termos reais a prática efetiva da aproximação Política entre Alemanha e França foi percebida por Konrad ADENAUER (1980e, p. 331) como sendo a grande virtude e o mais profundo significado do Plano Schuman para a eliminação da solução armada de conflitos entre os dois países e na Europa como um todo: "Ich erklärte, die Zusammenlegung der Grundproduktion von Kohle, Eisen und Stahl schaffe eine echte Voraussetzung dafür, daß zwischen Frankreich und Deutschland in Zukunft jeder Konflikt ausgeschaltet sein werde. Hierin erblicke ich die äußerst große Bedeutung des Beschlusses der französischen Regierung. Ich sei überzeugt, daß aus den Verhandlungen, die von Seiten der französischen Regierung vorgeschlagen waren, sich ein großer Fortschritt entwikkeln werde für die Zukunft unserer beiden Länder und für die Zukunft Europas.”. 
permitiu ser conhecida como a opção funcionalista ${ }^{734}$ : não seria uma suposta (ou mesmo imposta) unidade cultural que viabilizaria subitamente a convivência entre diferentes, mas o próprio intento de realizar progressiva e continuamente, aqui e agora, a

\author{
${ }^{734}$ Há aqui conscientemente um deslocamento significativo em torno da expressão "funcionalismo". \\ Na determinação do arco de significações possíveis em torno do termo "Funcionalismo", a tradição
} oscila entre

(i) apenas designar genericamente o Funcionalismo como uma terceira via entre o "Federalismo Europeu" e o "Unionismo Europeu" (sobre Federalismo e Unionismo, v. item 5.2., supra), sem se preocupar com maiores especificações sobre o sentido da expressão "Funcionalismo" para além da ideia geral de que se centrou sobre questões concretas em torno do carvão e do aço. Entre estes autores, mencionem-se exemplificativamente Marie Thérèse BITSCH (2006), Hans-Joachim GLAESNER (1991), Alfonso MATTERA (2002), Jacques PERTEK (2011) e Élisabeth du RÉAU (2008); e

(ii) associar o Funcionalismo a uma perspectiva econômica não necessariamente oposta ao Federalismo. A nova autoridade internacional é percebida como responsável pelo exercício parcial de funções restritas limitadas a um setor da atividade econômica, as quais tradicionalmente são associadas ao Estado. A incumbência da Organização Internacional derivaria da distribuição ramificada de tarefas técnicoeconômicas limitadas - tarefas usualmente compreendidas no interior da competência estatal - entre diferentes Organizações Internacionais setorialmente distintas. Isso não poderia ser considerado, todavia, como oposto ao Federalismo: a integração seria integração econômica, integração "setor por setor" da Economia (CLOSA, 1994, p. 340), até constituir gradual e multisetorialmente uma integração europeia estatal Federal. Tal integração econômica teria sido o primeiro passo para uma integração política Federal.

Parecem compreender neste último sentido o Funcionalismo os seguintes autores, mencionados apenas a título exemplificativo: Araminta Mercadante de AZEVEDO (1971, p. 75 e 79), Dominique BARJOT (2008, p. 46), Paulo Borba CASELLA (1994a, p. 77), Jean-Louis CLERGERIE; Annie GRUBER; Patrick RAMBAUD (2010), Emmanuel DREYFUS (2008, p. 144, 147 e 150-1), Pierre GERBET (2004, 1:24/4:29, 2009c), Gilbert NOËL et alii (2008, p. 128, 235-6 e 365), Bino OLIVI; Alessandro GIACONE (2007, p. 15-6), Fausto de QUADROS (1984, p. 119-24), Jean-Louis QUERMONNE (2008a), Jacques-René RABIER (2002c, 7:16/7:42), Paul REUTER (1965, p. 42) e Patrice ROLLAND (2006, p. 584 e 587).

Não se contentando com a leviana e genérica afirmação solta de que "a opção proposta por Jean MONNET e por Robert SCHUMAN foi a Funcionalista", e concordando em parte com Paulo Borba CASELLA (1994a, p. 70, grifos nossos) que "[c]om a assinatura, e posterior entrada em vigor do Tratado da CECA, mais do que acordo técnico, representando o resultado de negociação diplomática clássica, ocorre a criação de novo sistema jurídico-político", o presente estudo insere esta expressão no interior de sua específica proposta de leitura jurídico-Política da Europa Unida.

Com efeito, desde o início deste trabalho se colocou em suspenso a leitura econômica da construção da União da Europa. Ao pretender delimitar contornos mais precisos da noção de Funcionalismo, por força de exigência de coerência e coesão metodológicas, esta Tese necessariamente precisou se afastar do campo significativo da tradição que especifica o funcionalismo em termos técnico-econômicos para, em seguida, a inserir no interior do arco significativo específico deste estudo - uma leitura jurídico-política do fenômeno da integração.

Por esse motivo, há neste estudo uma ressignificação simultaneamente necessária e consciente do termo "Funcionalismo". Esta inserção da expressão "Funcionalismo" em nova teia de significações busca associar a proposição de Europa Unida de Jean MONNET e de Robert SCHUMAN à opção pela imanência típica da Política.

Deste modo, não apenas permanece o cumprimento do ponto de partida metodológico de suspensão da leitura econômica da Europa (o que exige a construção de novos significados para termos tradicionais), como também se torna mais claro de que modo o Funcionalismo (vetor de um sistema de convivência plural permanente entre diferentes) se opõe jurídico-politicamente ao Federalismo (vetor de sistema de convivência de unificação de diferentes) e ao Unionismo (vetor de uma simples cooperação política intergovernamental).

O Funcionalismo se configuraria assim como efetiva terceira via jurídico-política institucional de fomento de uma organização jurídico-Política das relações entre os países europeus no interior de um sistema de integração, ou seja, de convivência plural permanente entre diferentes. Esta via em particular reside, por assim dizer, no meio/es to meson entre os dois extremos de (i) convivência unificadora (Federalismo) ou (ii) cooperação intergovernamental (Unionismo). Por nem a um, nem a outro, conceder intemporalmente o lugar do Direito e do Poder, manteria ser a condição permanente da integração política a de um necessário vácuo de Poder. Como será mais bem compreendido a partir da leitura do Sétimo Capítulo, infra, e das Conclusões Parciais desta Parte Segunda, também infra. 
convivência em si mesma ${ }^{735}$, à medida que os problemas de viver em comum se apresentarem para o conjunto e exigirem, em cada momento, uma nova solução sobre questões concretas sensíveis comuns (MONNET, 2001c, p. 260, 2001d, p. 275; WÆVER, 1998, p. 82-4).

A proposta de Robert SCHUMAN era sem dúvida uma solução técnica para a construção de uma Europa Unida. Todavia, tratou-se de solução técnica de profunda inspiração Política (ADENAUER, 1980g, p. 336; CASELLA, 1994a, p. 70; MONNET, 1986a, p. 2; SCHUMAN, 1950, p. 3, 1953, p. 3-4; ZORGBIBE, 1997, p. 26) ${ }^{736}$, a qual evidenciou sincero esforço em se pensar a fundação jurídica de um sistema institucional de convivência (Leis) caracterizado pela permanência da oposição entre diferentes escalas de existências.

Nesta organização jurídico-Política da vida comum europeia, distintas dimensões existenciais deteriam condições institucionais suficientes para constranger e controlar uma e outra reciprocamente. Tais condições singularmente Políticas assegurariam não apenas a observância das regras comuns, mas, principalmente, a possibilidade de se formular conjuntamente uma decisão normativa (Direito e Poder) sobre o sentido multiescalar a ser impresso para resolver questões concretas comuns a todos os implicados comunitariamente e bastante sensíveis.

Nesse sentido, o caráter "revolucionário" da solução Funcionalista - entendida no interior de uma chave de leitura jurídico-política ${ }^{737}$ - consistiu em sugerir uma engenhosa utilização de dispositivos de Direito Internacional clássico para constituir institcionalmente uma dinâmica relacional absolutamente inédita entre os países europeus. Não se trataria assim de uma simples Organização Internacional (cooperação política intergovernamental), nem teria sido almejada a constituição de um Estado Europeu, ou mesmo de um Estado Federal Europeu (Leis de unificação da pluralidade).

\footnotetext{
${ }^{735}$ Nesse sentido, lembre-se a observação de Sérgio CARDOSO (2004, p. 52 e 53, grifos nossos) sobre ser o fim da politeia, ela mesma: "A politeia [...] define-se, assim, formalmente, como uma distribuição dos poderes públicos estruturada segundo uma finalidade especificamente integradora das diversas partes ou classes da cidade, ordenada, enfim, em vista de sua própria existência, de sua produção e conservação como comunidade política.", ou ainda "[a] existência da cidade [...] deve-se à própria eficácia dos dispositivos criados em vista da integração real de suas partes [...] o fim visado por esse regime, como mostra Aristóteles, revela-se imanente à sua própria forma: a forma busca a si mesma, busca a permanência de sua virtude política ou da capacidade integradora atualizada [...], naquela determinada configuração da distribuição dos poderes capaz de produzir a acomodação e articulação dos interesses diversos, sua convivência possível".

${ }^{736}$ Como reconhecera também Jean MONNET, em carta endereçada a Robert SCHUMAN, redigida em 14.10.1950, em Paris, sobre as negociações em curso em torno da futura CECA, a dimensão política "a reçu une première expression dans le Plan Schuman", era mesmo sua "signification profonde", que prometia dar ao Tratado contornos além "d'un simple accord technique" (MONNET, 1986a, p. 2).

737 Conforme salientado na nota de rodapé 734, supra.
} 
[C'était] une structure politique nouvelle. Nous n'avons pas aujourd'hui à nous étendre sur cette structure politique éventuelle. Sera-ce une fédération ? Ce n'est pas nécessairement une telle solution qu'il faut envisager. Nous, en tous cas, en 1950, nous ne pensions pas devoir commencer par là. C'eût été trop ambitieux et nous aurions échoué certainement devant la montagne de difficultés et d'obstacles qui auraient surgi sur notre route. (SCHUMAN, 1953, p. 4, grifos nossos).

As normas de Direito Internacional Público clássico deveriam ser articuladas de maneira inovadora. Elas deveriam constituir um maquinário institucional de profundas interdependências entre as diferentes escalas de existência, sem eliminar as particularidades de cada uma delas. Com este sistema relacional internacional inédito, cada uma das medidas de existência teria condições institucionais suficientes para exigir que as normas comuns fossem elaboradas por todas elas e, consequentemente, respeitadas também por todas.

Em outras palavras: entre absolutamente todas as escalas de existência vigeria, mediante o desenho institucional inaudito dado por normas de Direito Internacional, uma relação inteiramente horizontal, não sendo admitida a nenhuma delas o rompimento dessa condição plana para, em seu nome, ou no de outrem, ocupar o lugar do Direito e do Poder. Muito pelo contrário: cada uma delas deveria deter plenas condições de interromper, paralisar, resistir, impedir, barrar e represar toda e qualquer pretensão de rompimento da relação de horizontalidade entre as escalas de existência pretendida por uma ou por outra.

Deste modo, a solidariedade de fato - constituída institucionalmente mediante um regime jurídico internacional e lastreada no compartilhamento de deveres comuns asseguraria a participação e o cumprimento mesmo pelas dimensões existenciais sobre as quais pairasse uma pequena desconfiança de que cederiam à grande tentação de não participar do processo nomogenético compartilhado ou de não cumprir as decisões sobre o sentido normativo destinado a reger a vida comum na Europa - como as estatalidades isoladas da Alemanha ou da França.

$\mathrm{Ou}$ ainda, mais simplesmente, a solidariedade de fato - instaurada institucionalmente mediante deveres de participação e de obediência intercruzados e horizontalmente compartilhados, e que deveriam ser designados conscientemente por meio de articulação inovadora de um regime jurídico-normativo positivo internacional constituiria assim uma organização jurídico-Política das relações entre os países europeus a partir de um uso inventivo/não-tradicional de normas jurídicas do clássico Direito 
Internacional. Este asseguraria a imanência do fundamento do Direito e do Poder, pois manteria o lugar de produção do sentido normativo no centro, entre todos, isto é, diante de todas e de cada uma das escalas de existência, e próxima ao alcance de todas elas - e apenas do alcance delas.

Este regime jurídico internacional deveria ser um regime jurídico qualitativamente novo: o lugar do Direito e do Poder estaria no centro, entre todos, mas não seria centralizado ou tomado por qualquer escala existencial. Não se contentando com as regras de cooperação intergovernamental das clássicas Organizações Internacionais, deveria conceder a possibilidade a uma entidade não-nacional decidir em nome das Soberanias nacionais em determinadas questões setoriais comuns que as afetariam. Isso não poderia significar, por outro lado, o abandono ou a eliminação das Soberanias estatais, pois a autoridade não-nacional seria comum - ou melhor, compartilhada - entre diferentes escalas de existência politicamente unidas - pois a União da Europa não teria por centro nem qualquer dos Estados envolvidos, nem qualquer das entidades supranacionais (WEILER, 2005, p. 131).

Mais do que uma simples cooperação, e menos do que uma Federação Europeia, o Funcionalismo da proposta de Robert SCHUMAN apontava para a construção de um regime jurídico internacional cujas disposições constituiriam Leis de convivência plural permanente, em que ninguém (i) deteria por si só intemporalmente o lugar do Direito e do Poder e (ii) poderia romper com o delicado e tenso equilíbrio escalar derivado das atribuições de Poderes e deveres institucionalmente compartilhados sobre questões comuns.

Deste modo, as tensões entre as diferentes escalas de existência seriam institucionalmente reconhecidas (estatalidades e populidade) ou criadas (supranacionalidades), preservadas e promovidas pelas próprias normas jurídicas - de indubitável origem no Direito Internacional (WEILER, 2005, p. x, 93, 292-3 e 295) - da futura Comunidade - Direito Comunitário Originário. O conjunto da atuação comum de todas as escalas de existência e de cada uma delas formaria um nova autoridade na Europa continental: a autoridade da vida comunitária internacionalmente constituída por normas jurídicas de Direito Internacional Público, fundamentalmente pluriescalar.

A autoridade comum na Europa seria marcada assim pela presença de Poderes e deveres efetivos compartilhados entre cada uma das escalas de existência participantes da vida comunitária, de maneira a se instaurar uma dinâmica interativa entre "fonctions limitées et pouvoirs réels." (GLAESNER, 1991, p. 288) dentro da Comunidade. As 
questões seriam trazidas para o meio (es to meson), a fim de serem discutidas entre todos e por todos, sem que a solução derivasse unidimensionalmente de qualquer escala transcendente ou transcendentalizada - tal qual a imagem ideal sustentada pelo Federalismo Europeu ${ }^{738}$.

Trazida para resolver aqui e agora, no mundo dos Homens, toda e qualquer questão estaria impedida de ser solucionada fora de uma lógica de pluralidade escalar e, por isso mesmo, a opção pelo funcionalismo pode ser entendida, assim, como uma opção pela imanência. Ela não buscava introduzir no interior das relações entre países europeus a medida de existência única dada por uma escala estabelecida a partir de um sonho imaginado de unificação imemorialmente construída ${ }^{739}$, nem pretendia eleger uma dimensão existencial como privilegiada a ditar padrões normativos. Antes, pressupondo a horizontalidade relacional entre distintas escalas de existência, reconheceu a localização da produção referencial normativo no preciso entrechoque escalar exercido sobre questões oriundas de termos concretos que se revelaram fundamentais no pós-Segunda Guerra Mundial.

Deste modo, a solução proposta por Robert SCHUMAN sinalizou a consciente opção pela inovadora recusa em continuar a incansável busca pela concretização de uma enigmática e essencial Europa ancestral, imaginada e inalcançável. Em vez de tais “improvisations fantaisistes” (SCHUMAN, 1955, p. 3), a Declaração reconhecera seriamente a necessidade de se preocupar sobretudo com o adequado manejo institucional, por meio de articulação normativa inovadora do Direito Internacional Público, daquilo que tradicionalmente caracterizara as relações seculares da Europa: as divisões propriamente mundanas derivadas das diferentes escalas de existência estatais imediatamente presentes no continente (SCHUMAN, 1953, p. 8).

\footnotetext{
738 Poder-se-ia dizer que o culto ritualístico retórico em nome da Paz no Templo imaginado da Europa foi abandonado e voltou-se à ação sobre aquilo que era a vida imanente da Europa dos últimos séculos: os conflitos escalares intermináveis. Estes não deveriam ser eliminados em nome de uma "Terra Prometida de Homogeneidade e de Paz", mas sim juridicamente equacionados para surgirem, se desenvolverem e se resolverem sem recurso a meios armados, vale dizer, sem escapar ao controle das instituições: "The idea of Europe presented in such circles after the war was not one of restoration, of recapturing the good traditions of Europe; it was rather an argument about a necessary break with European traditions, especially the tradition of organizing on the basis of sovereign states." (WÆVER, 1998, p. 83, grifos nossos).

${ }^{739}$ Tradicionalmente de tendências avassaladoramente Teológico-Políticas : “[p]endant des siècles en effet l'unification européenne avait suscité les visées hégémoniques d'empereurs et de dictateurs (les empereurs, de la Rome antique, Charlemagne, Napoléon, Hitler). [P]ar le passé cette conquête était basée sur la violence des armées et sur l'oppression de peuples [...]." (MATTERA, 2002, p. 17); no mesmo sentido de mitos que embasaram empreitadas de unificação da Europa mediante o emprego da opressão do poderio militar, v. Paulo Borba CASELLA (1994a, p. 85) e Jean-Louis QUERMONNE (2008b, p. 11 e 13).
} 
L'expérience des initiatives précédentes a en effet montré qu'il serait illusoire d'engager une entreprise aussi ambitieuse et avec des intérêts en jeu aussi importants en suivant la pratique de la liturgie traditionnelle, faite de conciliabules ouatés entre diplomates et de consultations préliminaires utilisant une prose édulcorée et nébuleuse. (MATTERA, 2002, p. 24).

Ich befände mich in voller Übereinstimmung mit der französischen Regierung, wenn ich sagte, die Bedeutung des Schuman-Vorschlages sei in allererster Linie eine politische und nicht eine wirtschaftliche. [...]. Die politische Bedeutung des Vorschlages sei so stark wie nur denkbar unterstrichen, und aus persönlichen Gesprächen, die ich mit Monnet bisher geführt hätte, könne ich nur bestätigen, das politische Moment fiele nach französischer Auffassung am meisten in die Waagschale. (ADENAUER, 1980h, p. 338, grifos nossos).

\subsubsection{A Declaração Schuman de 1950: Fundação de Leis Políticas na Europa}

A Declaração de Robert SCHUMAN de 1950 reconheceu como irredutível a oposição escalar entre Alemanha e França e apontou para a necessidade de esta ser conciliada - e não simplesmente eliminada por suposição hipotética de uma Paz imaginada $^{740}$ - por meio de mecanismos institucionais comuns erigidos a partir de minuciosa composição de um quadro jurídico-normativo de Direito Internacional Público arranjado em termos novos, voltado à construção de uma vida comum entre estatalidades isoladas - mas não apenas entre estas: entre estas e as respectivas populidades, bem como

\footnotetext{
${ }^{740}$ Note-se que aqui surge um indício de que, diferentemente do discurso tendencialmente Teológico-Político do Federalismo Europeu (como visto no item 5.2.2.2.2.4., supra), a proposta da Declaração Schuman de 1950 não se preocupava com a instauração de um regime de Paz na Europa: "A lembrança da guerra era tanto mais próxima quanto se coloca o fato de que a vitória militar dos Aliados sequer se concluíra juridicamente por meio de Tratado de Paz entre os beligerantes. [...]. Na ausência de Tratado de paz entre os antigos beligerantes, a primeira Comunidade europeia constitui ato de confiança na vontade da França e da Alemanha, bem como de seus parceiros, de ultrapassarem os erros do passado [...]." (CASELLA, 1994a, p. 70-1, grifos nossos).

Isto implica reconhecer que, antes mesmo da Paz, ou ainda, mesmo sem sua declaração formal por documento jurídico internacional tradicional, percebeu-se ser mais adequado naquele momento dar um encaminhamento aos conflitos escalares - que deveriam ser mantidos e enfatizados, para serem juridicamente trabalhados dentro de uma via institucional comum. Nesta, nenhuma das dimensões existenciais deteria o lugar do Direito e do Poder, mas, ao mesmo tempo, todas deteriam iguais condições de se opor entre si para decidir em conjunto as questões comuns sensíveis.

Em outras palavras, pôr fim às guerras intra-europeias não significava instaurar a $\mathrm{Paz}$ (da uniformidade escalar), mas fazer perseverar intensamente os conflitos dimensionais e buscar os resolver no interior de mecanismos institucionais previamente constituídos pelo Direito para tanto, a fim de assegurar a desmilitarização das contínuas oposições escalares. É neste sentido que a eliminação da Guerra não poderia ser entendida como a busca pela Paz, mas apenas como o arranjo de vias jurídico-políticas institucionais de resolução de conflitos enquanto forma de rejeição da solução armada.

Deste modo, aquele voto de confiança excluía a necessidade mesma de se declarar a Paz (v. ainda, nesse sentido, a observação feita na nota de rodapé 738 , supra). Não era esta última o fim almejado - como outrora fora buscado no passado, durante o período entre guerras, mas a persistência contínua do conflito escalar. Aqui se apresenta um elemento que parece afastar a proposta de Robert SCHUMAN do Projeto do Federalismo Europeu - tão cioso, como no passado, da necessidade de se instaurar a calma unidimensional da Paz Homogênea Europeia. V. ainda o item 6.2.2.4., supra.
} 
entre estas e as supranacionalidades especificamente constituídas para participar da vida comum.

Em outras palavras, a referida Declaração apontou concordar plenamente com a percepção da necessidade da urgente reconciliação franco-alemã por meio da direitificação da convivência. Esta deveria manter um regime jurídico-político de pluralidade permanente definido, por sua vez, a partir da atribuição de iguais condições de participação entre os diferentes participantes da vida em comum.

Ich hob hervor, der französische Vorschlag beruhe auf der Basis der Gleichberechtigung. Es sei vorgesehen, falls die Deutschen und die Franzosen sich in dem vorgesehenen Gremium nicht einigen könnten, daß ein Schiedsrichter, der von beiden Staaten gewählt würde, die Entscheidung über strittige Fragen fällen solle. Ich betrachtete den Vorschlag Schumans als einen sehr wichtigen Fortschritt in den deutschfranzösischen Beziehungen, dessen Bedeutung nicht nachdrücklich genug unterstrichen werden könne. (ADENAUER, 1980e, p. 331, grifos nossos).

\section{A reunião de países europeus iniciada pela aproximação entre Alemanha e} França seria efetiva organização jurídico-Política das relações na Europa. Nesta, todos poderiam fruir - não da Paz homogênea, mas da permanência de conflitos, por meio - de iguais condições institucionais de aposição e de confrontação escalares nas deliberações sobre o sentido normativo último a ser dado a questões comuns sobre o uso de recursos escassos fundamentais (SCHUMAN, 2000, p. 1).

Perceba-se que havia clara consciência por parte de Konrad ADENAUER e de Robert SCHUMAN de que esta proposta detinha profundo viés político.

O Chanceler da RFA relatara em suas Memórias que, no dia 9.5.1950, recebera duas cartas de Robert SCHUMAN informando sobre a Declaração a ser proferida no Salão do Relógio. Em uma das Cartas estava transcrita a Declaração de Robert SCHUMAN ela mesma, enquanto que, na outra, endereçada em caráter privado a Konrad ADENAUER, teria o Ministro das Relações Exteriores da França confessado o intento marcadamente político de sua proposta:

In dem persönlich an mich gerichteten Brief schrieb mir Schuman, der Zweck seines Vorschlages sei nicht wirtschaftlicher, sondern eminent politischer Natur. In Frankreich bestehe die Furcht, daß Deutschland, wenn es sich wieder erholt habe, Frankreich angreifen werde. Er könne sich denken, daß umgekehrt auch in Deutschland der Wunsch nach Sicherheit bestehe." (ADENAUER, 1980e, p. 328, grifos nossos). 
A proposta de Robert SCHUMAN de submeter Alemanha e França e demais participantes de uma futura vida comunitária a uma autoridade por todos igualmente compartilhada (pluriescalar) mediante a constituição de instituições comuns era detinha um viés profundamente Político. A direitificação a ser futuramente empreendida deveria construir juridicamente um espaço comum na Europa no interior do qual seriam estimulados os mais diferentes tipos de oposições escalares em torno de questões concretas sensíveis comuns.

Perseverar o conflito escalar - ainda que de maneira qualitativamente distinta, pois operado no interior de instituições comuns fundadas juridicamente, e excluir a solução das tensões por meio de resposta armada, era o objetivo procurado por Robert SCHUMAN ${ }^{741}$.

\begin{abstract}
Ce qui caractérise, au surplus, la proposition française, c'est qu'à côté de sa portée économique, susceptible de développements qu'à l'heure actuelle on ne peut que deviner, elle a eu et conserve une valeur politique qui dès la première heure a avant tout autre considération frappé l'opinion dans les divers pays. (SCHUMAN, 1950, p. 3, grifos nossos).
\end{abstract}

[A]u début de cette déclaration du 9 mai 1950, nous avons surtout eu en vue les avantages immédiatement atteints dans le domaine politique. Conclure une union durable et contrôlée au sujet du charbon et de l'acier, ce serait enlever à chacun des pays ainsi associés la possibilité, non seulement de faire, mais même de préparer une guerre contre les autres associés. [...]. La guerre, avonsnous dit, non seulement est devenue impossible mais impensable. Et je puis dire aujourd'hui sans crainte d'un démenti que ce résultat est actuellement acquis. Nous ne nous sommes pas confinés dans le domaine du pur raisonnement. Nous avons pu résoudre dans le concret plusieurs problèmes irritants que j'ai évoqués tout à l'heure. (SCHUMAN, 1953, p. 5-6, grifos nossos).

A proposta de Robert SCHUMAN apontava para a necessidade de se assegurar vias institucionais engenhosa e cuidadosamente direitificadas. Isso porque, havendo tão proximamente mecanismos práticos que permitissem trabalhar constantemente as oposições escalares potencialmente disruptoras, não haveria razão para recorrer a uma solução dos embates fora da ambiência institucional prevista - isto é, para ceder à tentação de recorrer a uma solução armada. Por isso, era fundamental instituir uma organização jurídico-política (Leis) entre Alemanha e França para impedir o recometimento de Guerras (SCHUMAN, 1953, p. 4).

É por essa razão que se pode compreender que, em sua declaração privativa a Konrad ADENAUER (1980e, p. 328), Robert SCHUMAN indicara que seu intento era

\footnotetext{
741 “[L]'intention des auteurs de la Déclaration Schuman était aussi de permettre à l'Europe de sortir de destructions causées par la guerre [...].” (QUERMONNE, 2008b, p. 32).
} 
estabelecer uma aproximação entre Alemanha e França em termos políticos. Seu objetivo fundamental era constituir entre os dois países uma vida comum (Leis) por via institucional específica (Direito Internacional Público em termos de normas de oposições escalares).

Deste modo, a previsão de instituições voltadas a promover juridicamente oposições escalares constituiria uma dinâmica onde teria lugar de maneira ininterrupta uma efetiva arena de embates dimensionais, sem que isso significasse a explosão do sistema de convivência por meio de resposta armada. Afinal, nenhum dos partícipes poderia de antemão se arrogar na posição absoluta e inquestionável de detentor da referência normativa padrão, ou seja, nenhum deles ocuparia prévia e intemporalmente o lugar do Direito e do Poder. E, por isso, as instituições restariam permanentemente abertas ao livre entrechoque entre as diferentes escalas de existência quando da formação do sentido normativo sobre questões comuns sensíveis.

O político se tornaria, assim, Político (Leis de convivência plural permanente). Robert SCHUMAN teria sinalizado se preocupar com a disponibilização de meios institucionais para que as oposições escalares pudessem ampla, integral e incessantemente se realizar dentro de margem de segurança estabelecida e controlada pelo desenho institucional da futura vida comunitária, o qual impediria a possibilidade de deflagração de novas Guerras regionais na Europa.

A proximidade do intento de Robert SCHUMAN das expectativas e da proposição de Konrad ADENAUER - instaurar uma União Política entre Alemanha e França em condições de igualdade entre os participantes - foi imediata e prontamente identificada e reconhecida por este último. Após a leitura daquelas duas cartas, o Chanceler da RFA expressou ato contínuo seus integrais assentimento e suporte ao Plano Schuman: "Ich teilte unverzüglich Robert Schuman mit, daß ich seinem Vorschlag aus ganzem Herzen zustimme." (ADENAUER, 1980e, p. 328) ${ }^{742}$.

Deste modo, mediante a instituição de Leis, seria possível conter pretensões ambiciosas e audaciosas de ocupar o lugar do Direito e do Poder - vazio, porque compartilhado, e porque mantido desocupado por meio de instituições que multiralteralmente repeliam todas as escalas de existência do centro. Entendida como instituição jurídico-política distribuidora de Poderes, a União Política a ser empreendida seria meio virtuoso e vigoroso para conter qualquer pretensão de aquisição imoderada,

\footnotetext{
${ }^{742}$ Sobre a proposta de União Política de países europeus formulada por Konrad ADENAUER em Março de 1950, remetemos o leitor ao item 6.1.3., supra.
} 
excepcional e excessiva de Poder por uma dimensão escalar singularmente considerada na definição normativa dos destinos comuns.

Nesse sentido, uma vez estabelecidas as Leis de convivência plural permanente entre os participantes da vida comum (no começo, Alemanha e França), nenhum destes poderia pretender querer se colocar acima delas (transcendentalizar-se) e tomar o lugar do Direito e do Poder, plenificando-o a sua imagem e semelhança. Este permaneceria intacto em seu imanente vazio escalar - para que ninguém dentre eles, e ninguém além deles, pudesse direcionar unilateral e uniescalarmente as normas regentes da vida comum.

Do mesmo modo, as decisões da Alta Autoridade não poderiam ser reputadas de pronto inquestionáveis, sendo fundamental que "[d]es dispositions appropriés assur[aient] les voies de recours nécéssaires contre le décisions de la Haute Autorité" (SCHUMAN, 2000, p. 4), principalmente para garantir que a nova Organização não implicasse uma exploração do carvão e do aço para fins bélicos na Europa. O lugar do Direito e do Poder se mostraria inabitado também pela supranacionalidade, pois ela seria mantida em posição horizontal com relação às demais escalas (isto é, igualmente impedida de se elevar sobre as demais e, com isso, transcendentalizar-se).

Robert SCHUMAN sinalizou assim se preocupar com a construção jurídica de engenhoso mecanismo institucional regular que vocalizasse tensamente as diferentes dimensões existenciais e as convidasse a uma convivência forçada, sem que qualquer delas (i) pudesse ser percebida como ocupando o lugar do Direito e do Poder e (ii) suprimisse o vazio deste. Neste novo modo de relações promovido institucionalmente pelo Direito Internacional Público, todos estariam forçados a se apresentar perante as demais dimensões existenciais para, com elas, promover um contínuo embate escalar no interior da vida comunitária para definir o sentido normativo a ser impresso sobre questões concretas sensíveis.

A interessante engenharia institucional proposta asseguraria a permanência do repúdio a se optar pelo recurso à solução militar dos conflitos. Enquanto fosse preservado o vazio do lugar do Direito e do Poder, os conhecidos limites das enérgicas oposições escalares não seriam transpostos e subvertidos, na medida em que seria clara a conservação contínua de um canal institucional permanentemente autorizado a operar como arena pública aberta às oposições escalares e livre de qualquer dominação ou ocupação uniescalar preferencial transcendentalizada ${ }^{743}$ ou transcendente ${ }^{744}$.

\footnotetext{
${ }^{743}$ Relacionada à elevação de uma escala de existência sobre as demais, conforme item 6.2.2.3., supra.
} 


\subsection{O Tratado de Paris de 1951: A Constituição Institucional da CECA}

Como possuíam em casa o remédio para o mal, não tinham necessidade de ir buscá-lo em outra parte. (MAQUIAVEL, 2008, p. 43).

O elemento fundamental - porque fundante - da integração setorial empreendida em torno da produção de carvão e do aço na Europa Ocidental foi a preocupação em estabelecer um entendimento definitivo entre Alemanha e França de caráter Político (ADENAUER, 1980h, p. 338; SCHUMAN, 1950, p. 3). Este seria assegurado por meio de instituições cuidadosamente confecionadas a partir de normas jurídicas de Direito Internacional Público voltadas à promoção contínua de embates escalares mediante previsão de igualdade de condições (i) de participação na formação do sentido normativo sobre questões comuns e (ii) de obediência à decisão formada pela autoridade comum.

Por esse motivo, a questão fundamental a ser resolvida para viabilizar a União Política franco-alemã - posteriormente estendida aos demais futuros países-membros da CECA: Bélgica, Itália, Luxemburgo, Países Baixos $^{745}$ - consistiu em pensar adequadamente nas estruturas comuns a serem traçadas para dar viabilidade prática à construção jurídico-normativa deste fim compartilhado por meio do Direito Internacional

\footnotetext{
744 Relacionada à introdução no centro nomogenético de escala externa à oposição escalar, fundada na afirmação da necessidade de concretizar uma entidade abstrata, tal como a tradição imemorial imaginada da civilização europeia, fundada nos Direitos Humanos e na Democracia (Federalismo Europeu), conforme itens 6.2.2.4 e 6.2.2.5., supra.

745 “En dépit d'une sidérurgie peu développé à l'époque et de l'opposition d'une gauche communiste et socialiste, l'Italie s'y montre très favorable pour des raisons politiques car elle y voit, comme l'Allemagne, l'occasion de reprendre sa place au sein de l'Europe. Le Luxembourg, où la mono-industrie sidérurgique fournit $90 \%$ des exportations, ne peut qu'être séduit par un projet susceptible de lui ouvrir de vastes marchés, même si les industriels émettent quelques réserves de précaution et si les syndicats s'inquiètent pour les salaires, nettement plus élevés au Luxembourg que dans les pays voisins. En Belgique, par contre, de réelles inquiétudes se font jour dans les charbonnages qui connaissent des conditions d'exploitation difficiles et redoutent de ne pouvoir tenir la concurrence au sein d'un marché commun. Mais si les milieux politiques sont divisés et hésitants, il semble cependant préférable de chercher à résoudre les problèmes au sein d'une organisation européenne plutôt que dans un cadre national. Quant aux PaysBas, ils sont, parmi les trois du Benelux, le pays le moins concerné par les industries du charbon et de l'acier et le moins favorable aux abandons de souveraineté. Mais malgré l'absence d'enthousiasme, le gouvernement ne souhaite pas rester à l'écart et accepte de souscrire à la déclaration Schuman en se réservant le droit de se retirer des négociations si l'organisation devait prendre une orientation trop supranational." (BITSCH, 2006, p. 70, grifos nossos).

Se os interesses de alguns deles para participar da vida comunitária resvala em preocupações econômicas, estavam todos cientes do compromisso de que, uma vez dentro da vida em comum, independentemente do interesse econômico, as relações entre os participantes se desenvolveriam conforme os termos de uma organização jurídico-política (segundo Leis). A qualidade dessas Leis seria circunscrita no campo de Leis Políticas durante as negociações em torno do desenho institucional a ser assumido pela CECA. Especial atenção deve ser dada, nesse sentido, à ressalva feita ao final pela Bélgica e pelos PaísesBaixos. V., nesse sentido, observações constantes do item 6.3.3., infra.
} 
Público (MONNET, 2001d, p. 274; RÉAU, 2008, p. 199). Como afirmara Jean MONNET (2001b, p. 179, grifos nossos), quando de seu discurso à Sociedade de Economia Política de Bruxelas, em 30.6.1953:

[L]a Communauté européenne du charbon et de l'acier est un succès. Ce n'est pas mon succès, croyez-le bien. Les résultats qui ont été obtenus l'ont été non pas par une personne ou grâce à un homme, mais par des institutions.

Em outras palavras, mais do que apenas perceber o sucesso da iniciativa audaciosa proposta pelo Governo francês de reaproximar em paridade de condições jurídico-Políticas Alemanha e França, é de suma importância investigar com precisão a específica causa do virtuoso resultado alcançado pela CECA.

O elemento fundamental daquela festejada excelência da vida comunitária instaurada pela CECA residiria precisamente no arcabouço institucional desenhado para dar condições práticas reais e concretas ao Projeto de Europa Politicamente Unida enunciado ${ }^{746}$. Por essa razão, era crucial naquele momento estabelecer as características das instituições que atenderiam à exigência de performação de sistema de convivência entre diferentes usualmente contrapostos em termos bélicos e que, assim poderiam "jette[r] les bases d'un avenir nouveau et commun [... et] commence[r] ce qui est appelé [aujourd'hui] l' « intégration européenne »." (MONNET, 2001d, p. 274-5).

\subsubsection{Vetores Jurídico-Politicos do Futuro Sistema Institucional da CECA}

\subsubsection{Organizar Leis Políticas I: Fundação contra Questões Externas à Europa}

Diferentemente do que ocorrera com a OECE e com o Pacto de Bruxelas ${ }^{747}$, a proposta de constituição da CECA não tinha por fundamento a oposição escalar típica da Guerra Fria (EUA versus URSS).

Com efeito, longe de procurar ser uma resposta às oposições escalares exteriores à Europa, a Organização da Declaração Schuman propunha construir um mecanismo institucional voltado a lidar com - e não a eliminar - a tradicional oposição escalar existente nas relações entre os países europeus: a oposição entre as estatalidades isoladas da Alemanha e da França.

\footnotetext{
746 "Le grand problème de la construction européenne est celui de son efficacité : donc celui de ses institutions." (CLERGERIE; GRUBER; RAMBAUD, 2010, p. 40, grifos dos autores).

${ }_{747}$ Como visto em todo o item 4.2., supra, e especialmente no item 4.3., também supra.
} 
O encaminhamento das oposições escalares deveria ser dado no interior de uma solução institucional original de Direito Internacional Público. Um espaço comum deveria ser constituído na Europa para, nele, serem colocadas para se influenciar mutuamente diferentes escalas de existência. Não apenas as duas tradicionais estatalidades isoladas se oporiam: outras estatalidades poderiam vir a compor a arena pública, como também deveriam ser criadas novas entidades, as quais portariam escalas de existência distintas das da tradição (supranacionalidades). No interior desta área normativa comungada, todas as escalas implicadas na vida comum estariam autorizadas e obrigadas a mutuamente se controlar e conter na determinação do sentido normativo de questões concretas comuns.

Deste modo, a CECA seria instituída para canalizar de maneira inaudita o tradicional choque entre estatalidades típica e propriamente europeu, não sendo assim produto direto da oposição escalar entre os EUA e a URSS.

Il a fallu onze mois d'un labeur acharné, fourni par une centaine d'hommes appartenant à six délégations, pour élaborer et signer un traité de six nations, traité qui n'avait pas de précédent, à aucune époque dans aucun domaine, traité qui a été le fruit d'une libre et confiante détermination et non d'une pression extérieure.

Il y a lieu de mettre fin à la légende, d'après laquelle il y aurait eu à l'origine une initiative ou insistance américaine : je puis certifier que le Gouvernement américain a été, comme tous les autres, informé de notre projet 48 heures seulement avant la proclamation du 9 mai. (SCHUMAN, 1955, p. 2, grifos nossos).

\subsubsection{Organizar Leis Políticas II: Fundação contra a Uniescalaridade}

As instituições da futura Organização deveriam colocar em comum o processo de decisão sobre o sentido normativo último das questões envolvendo o uso dos escassos recursos comuns indispensáveis para a reconstrução e eventual rearmamento dos países europeus (carvão e aço). A definição do sentido final derivaria da decisão dada pela autoridade comum a todos - a qual, todavia, não seria de nenhum deles. Nenhuma das demais outras escalas participantes da vida em comum - pois ninguém seria o Poder ou o deteria intemporalmente em uma União Política ${ }^{748}$ - poderia se julgar como estando no centro de definição do sentido normativo.

\footnotetext{
${ }^{748}$ É importante precisar neste ponto que usualmente a tradição da historiografia nacional e estrangeira sobre a CECA compreende esta integração setorial sob uma perspectiva econômica: a CECA teria simplesmente colocado em comum a produção franco-alemã de carvão e de aço, submetendo-a à autoridade comum representada pela Alta Autoridade por delegação de Soberania pelos Estados-Membros (nesse sentido, v. nota de rodapé 202, supra).
} 
Em outros termos, a necessária solidariedade derivaria de série de disposições jurídico-normativas engenhosamente arquitetadas para estabelecer uma complexa e judiciosa rede institucional de inter-relações entre Poderes e de deveres compartilhados sobre questões comuns, de tal modo que nenhuma dimensão existencial poderia decidir por si só os destinos do sentido normativo último. O lugar do Direito e do Poder permaneceria vazio de maneira igual a todas as escalas.

Nesse sentido, comparativamente com relação à tradição do modo de se estabelecer relações na Europa, a proposta francesa de reconciliação franco-alemã se destacava precisamente em virtude do se colocar contra a reintrodução temerária de qualquer

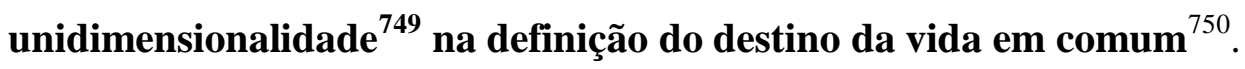

A Comunidade (vida comunitária) a ser instaurada por meio da CECA visava à preservação institucional da presença da multiescalaridade no interior de deliberações

Por diversas vezes se reiterou neste texto que a leitura econômica da integração europeia é mantida em suspenso. Por isso mesmo, há que se notar a sutileza do argumento: não se tratou a CECA de uma simples colocação em comum da produção de carvão e do aço. A nova Comunidade Europeia visou a estabelecer institucionalmente, mediante normas jurídico-positivas de Direito Internacional Público preocupada com a construção de vida comum (Direito Comunitário Originário) uma comunhão escalar do processo de decisão sobre as normas jurídico-positivas (Direito Comunitário Derivado) destinadas a reger as mais diferentes questões envolvendo a produção de carvão e de aço.

Como reconhecera Jean MONNET (2001d, p. 275, grifos nossos), em artigo publicado em 1962, a virtude da CECA residiria precisamente na "mise en commun de l'ensemble de leurs productions, régie par des règles communes et administrée par des institutions communes", pois se tratava de "la méthode la plus sûre et la plus efficace pour surmonter les divisions et les limitations héritées du passé". Em outras palavras, não se tratou de instituir uma "Política Econômica Europeia" sobre o carvão e o aço - isto é, de propor a realização de fins econômicos por meio de instrumentos jurídico-políticos, mas, sim, de realizar da Política a partir de normas jurídicas positivas - ainda que dotadas de conteúdo econômico, as quais foram jurídico-Politicamente organizadas.

Com efeito, uma vez que - a partir da chave de leitura selecionada para este trabalho - o lugar do Direito e do Poder se torna vazio (comunhão escalar do processo nomogenético), trata-se mera consequência lógica compreender - diferentemente do que conclui a tradição (mais uma vez, v. nota de rodapé 202, supra) - que, na integração Política da CECA, nem mesmo a Alta Autoridade detinha o lugar do Direito e do Poder. Em outras palavras, nem mesmo sua escala de existência supranacional submeteria absolutamente qualquer outra (estatalidades, supranacionalidade ou populidade) na definição do sentido nomogenético sobre o uso dos recursos escassos comuns.

Como se poderá ver mais adiante, no Sétimo Capítulo deste trabalho, esta consequência não é apenas uma singela derivação lógica abstrata da chave de leitura escolhida: as disposições jurídiconormativas do Tratado de Paris de 1951 também permitem concluir da mesma maneira. Mas há que ainda se chegar ao próximo Capítulo, quando ficarão mais claros os meios e os momentos institucionais desta integração Política. V., ainda, a intuição dos países-membros do BENELUX, quando da negociação do Tratado da CECA, no item 6.3.3., infra.

${ }^{749}$ Como será visto mais adiante, e mais precisamente durante a leitura do Sétimo Capítulo, infra, a recusa da unidimensionalidade visava ao afastamento especial, mas não exclusivo, de possíveis unidimensionalidades estatais (isolada ou intergovenamental) transcendentalizadas. Mas a rejeição de uma autoridade dada a partir apenas da supranacionalidade era igualmente presente, como se poderá constatar, não apenas mediante a leitura do Sétimo Capítulo, infra, mas também de considerações constantes do item 6.3.3., também infra.

750 "[C]inq ans seulement après la fin de la Seconde Guerre mondiale, il dut en résulter la possibilité d'édifier l'Europe sur la base de l'égalité des droits entre France et Allemagne ; ce qui revenait à inverser la logique de traité de Versailles." (QUERMONNE, 2008b, p. 31, grifos nossos). 
fundamentais concernentes ao destino comum $^{751}$. As instituições desenhadas para dar viabilidade prática à vida em comum deveriam não apenas supor, mas, principalmente, promover ininterruptamente a igualdade de condições entre os participantes da vida comum, de maneira a assegurar o mesmo peso Político a cada uma das diferentes formas de habitar a vida comunitária a ser inaugurada (MATTERA, 2002, p. 30).

\begin{abstract}
À mesure que s'établissent les premières institutions européennes et que les intérêts des pays participants deviennent communs pour le charbon et l'acier, leur attitude vis-à-vis l'un de l'autre commence à changer. La création de conditions nouvelles dans un domaine pourtant limité, entraîne progressivement dans la manière de penser et d'agir des hommes, des modifications de plus grande portée. C'est ainsi que la France et l'Allemagne, si longtemps opposées en une rivalité sanglante, se rapprochent au point de concevoir aujourd'hui qu'un même destin les lie. (MONNET, 2001d, p. 275, grifos nossos).
\end{abstract}

\title{
6.3.1.3 Organizar Leis Políticas III: Fundação contra o Preenchimento Total e
}

\section{$\underline{\text { Pacificador do Lugar do Direito e do Poder }}$}

As instituições da futura vida em comum deveriam ser organizadas juridicamente para assegurar que nenhum dos participantes poderia voltar a conseguir - nem mesmo voltar a almejar - a totalização de sua dimensão existencial sobre os demais. Não mais o lugar do Direito e do Poder na Europa deveria ser visto como fonte de purificação dimensional pacificadora, isto é, como centro de difusão de uma única medida de existência - que poderia se espraiar incondicionalmente sobre todas e se realizar plenamente, em detrimento absoluto das tensões escalares. As instituições deveriam restar preocupadas com a preservação do vazio de Poder.

Para tanto, haveria que ser conservado institucionalmente o espírito de tensão escalar, isto é, os mecanismos práticos da futura vida comum deveriam manter vigorosamente firmes os embates dimensionais voltados exponencialmente a todas as mais

\footnotetext{
${ }^{751}$ No caso específico, o direcionamento do uso dos recursos escassos do carvão e do aço. Estes eram de fundamental importância no período, sendo um recurso escasso bastante sensível para a dinâmica das relações internacionais, "avec la même importance stratégique que revêt aujourd'hui l'énergie nucléaire." (MATTERA, 2002, p. 23).

Nesse sentido, lembra Jacques PERTEK (2011, p. 17) que “[p]our mesurer l'ampleur et l'ambition du projet, et constater qu'était véritablement en jeu une question de souveraineté, il faut se souvenir de la place occupé à cette époque par le charbon et l'acier et leur rôle dans la guerre.”. Com efeito, “[1]e charbon et l'acier se trouvent dans les profondeurs de la Ruhr et de la Lorraine, dont ils ont été extraits massivement en jouant un rôle clé dans le dernier conflit mondial. Il s'agit de deux instruments de guerre terrifiants qui seront désormais neutralisés par le nouveau pacte de solidarité et destinés à des fins pacifiques." (MATTERA, 2002, p. 27). No mesmo sentido, apontam Konrad ADENAUER (1980h, p. 338), Emmanuel DREYFUS (2008, p. 146), Gilbert NOËL et alii (2008, p. 126) e André de Carvalho RAMOS (1996, p. 648).
} 
diferentes situações e direções. Apenas deste modo nem sequer uma única dimensão existencial poderia totalizar a sua imagem e semelhança o sentido normativo a ser seguido em conjunto pelas disposições normativas em torno da administração e do uso dos recursos comuns.

Assim, a pretensão de dominação unidimensional pacificadora dos termos de regulamentação da vida na Europa deveria ser paralisada mediante instrumentos jurídicopolíticos comuns. Estes barrariam por meio da direitificação tentativas de usurpação do lugar do Direito e do Poder. A conservação da tensa dinâmica relacional entre escalas de existência preservaria o saudável vazio Político do lugar do Direito e do Poder típico da multiescalaridade.

\begin{abstract}
Quand on regarde un peu en arrière et que l'on voit le désastre extraordinaire que les Européens se sont causé à eux-mêmes au cours des cinquante, soixantequinze ou cent dernières années, on est littéralement effrayé. Cependant, la raison en est simple, c'est que chacun, au cours de ce siècle, a poursuivi sa destinée ou ce qu'il croyait être sa destinée, en appliquant ses propres règles. Chacun n'en faisait qu'à sa tête, selon ce qu'il pensait être la nécessité de son prestige national. Finalement, en cherchant à résoudre leurs problèmes dans cette voie, les pays étaient incités à sortir de leurs frontières pour tenter de dominer les autres. (MONNET, 2001b, p. 180, grifos nossos).
\end{abstract}

\title{
6.3.2. A Rejeição de Leis Políticas pelo Reino Unido
}

Foi precisamente o debate em torno da estrutura institucional da Organização Europeia proposta por Robert SCHUMAN que motivou em 30.5.1950 a formulação da recusa britânica a participar da vida em comum a ser organizada jurídico-Politicamente pela CECA (BITSCH, 2006, p. 70-1; NASCIMENTO E SILVA; ACCIOLY, 2002, p. 248; OLIVI; GIACONE, 2007, p. 29-30; QUERMONNE, 2008b, p. 28-9 e 33; RÉAU, 2008, p. 200).

Portador de concepção de Projeto de Europa Unida ${ }^{752}$ diferente daquela apresentada pela proposta de reconciliação franco-alemã (BITSCH, 2006, p. 71; RÉAU, 2008, p. 190; SAINT-MARTIN, 2012; SCHUMAN, 1950, p. 3) ${ }^{753}$, o Reino Unido não concordou com a precisa condição vazia do lugar do Direito e do Poder na Europa da CECA.

\footnotetext{
${ }^{752}$ Segundo o qual seu comprometimento com o continente europeu deveria se manter limitado.

753 Lembre-se aqui a hesitação já constante do Discurso proferido por Winston CHURCHILL na Universidade de Zurique, Suíça, em 1946 - mencionado no item 6.1.1., supra, para que se possa compreender precisamente esta diferença de Projetos de Europa Unida entre o Reino Unido e a proposta de reconciliação franco-alemã de Robert SCHUMAN.

Lembre-se de que, apesar de o ex-Primeiro Ministro britânico entender ser fundamental estabelecer Leis (convivência entre diferentes) entre os países da Europa continental, para ele não haveria razão para o
} 
Reino Unido participar ele próprio desta União política. Para ele, ao Reino Unido caberia o simples papel de "amigo impulsionador", de árbitro supervisor à distância.

Deste modo, se para o continente europeu o estabelecimento de Leis era recomendável, necessário e urgente, esta mesma lógica não seria cabível na relação entre os países da Europa continental e o Reino Unido: seria suficiente uma cooperação política intergovernamental - ou seja, assegurar aos britânicos o cioso cuidado com sua Soberania.

Como reconhecera em 1953 Jean MONNET (2001b, p. 187), quando de seu discurso à Société d'Économie Politique de Bruxelas, a Inglaterra "ne peut pas, sur une hypothèse, modifier la vue qu'elle prend de ses intérêts ou de ses institutions". Por essa razão, em 13.6.1950 Konrad ADENUER (1980h, p. 338) declarara que, apesar de lamentar a ausência do Reino Unido, ele duvidava muito que, nos anos seguintes à instituição da futura Comunidade, o Reino Unido deixaria de lado suas conviçcões jurídico-políticas de cooperação tradicional para ingressar no sistema de convivência inaugurado pela CECA.

Não pode deixar de ser notado que havia naquele momento "un débat plus subtil entre deux conceptions de l'Europe. L'une, très libérale, est voulue par les Britanniques qui veulent créer une grande zone de libre-échange, c'est-à-dire, un grand espace marchand. L'autre se veut communautaire[; 1]'Europe des Six qui est en marche se donne pour ambition de trouver une articulation entre espace marchand, un marché commun élargi, et l'espace public, un espace communautaire [...]." (REAU, 2008, p. 190, grifos nossos). Este debate pode ser entendido como persistindo desde aquele momento, até os dias de hoje.

A posição assumida pelo Reino Unido com relação à CECA é mais bem compreendida quando enquadrada em seu Projeto de Europa Unida particular - distinto daquele encetado entre Alemanha, França e os quatro demais países-membros da CECA: "[c]omme Churchill à la fin de la guerre, les travaillistes estiment que le Royaume-Uni ne doit pas se lier trop étroitement avec le continent et, en aucun cas, accepter d'entrer dans une fédération." (BITSCH, 2006, p. 33).

Ao Reino Unido não interessava estabelecer com os demais países da Europa continental uma União Política - implicando, assim, a abertura à possível indeterminabilidade e à potencial incerteza de um Poder compartilhado com outras escalas de existência - porque lhe bastava a realização de um grande mercado fundamentado na liberalização do comércio. Suas pretensões com a futura Europa politicamente Unida da CECA se reduziam ao simples estabelecimento de relações comerciais privilegiadas.

Em outras palavras, a compreensão do Reino Unido sobre seu papel a ser exercido perante a Europa Politicamente Unida da CECA consistia em não estabelecer com ela qualquer comprometimento de caráter Político que pudesse envolver deveres compartilhados sobre questões de uma vida (tornada) comum, ou ainda, de uma vida comunitária. Do contrário, haveria profundo prejuízo de sua Soberania. Suas relações deveriam se restringir estritamente ao âmbito de um comércio internacional preferencial.

Deste modo, não sendo uma necessidade fundamental estabelecer com a Europa Politicamente Unida da CECA laços mais profundos e duradouros - em termos estritamente comerciais, as exportações para o Commonwealth representavam naquele período cerca de 50\% do total das exportações do Reino Unido (RÉAU, 2008, p. 200), não haveria qualquer razão para o Reino Unido se submeter a um sistema de relações interestatais completamente novo, no qual estaria de desprovido da capacidade de decidir por si só os destinos de sua normatização sobre questões envolvendo sua produção de carvão e de aço.

Assim, preocupado em assegurar apenas melhores relações comerciais com os países da Europa continental (cooperação intergovernamental por meio do Direito), e não com o estabelecimento de uma vida comum Politicamente mediada por instituições (Leis de convivência plural permanente), o Reino Unido não compartilhava com a Europa dos Seis do mesmo Projeto de Europa Politicamente Unida. Em virtude desta divergência de Projetos, mostra-se plenamente compreensível e justificável a recusa britânica em dele participar naquele momento.

Apenas a título de complementação de informação histórica - destinada a reforçar a renitência temporal do Reino Unido em seu Projeto particularmente Econômico da aproximação de países europeus, lembre-se de que, após a instituição da CEEA e da CEE no ano de 1957, o Reino Unido liderara um processo de aproximação entre países europeus não participantes das Comunidades Europeias com o objetivo de competir economicamente com estas.

Tratou-se da Associação Europeia de Livre Comércio (AELC), instituída por meio do Tratado de Estocolmo, celebrado em 4.1.1960 entre Áustria, Dinamarca, Noruega, Portugal, Reino Unido, Suécia e Suíça (v. nota de rodapé 39, supra), cuja vigência iniciou em 3.5.1960. Seu objetivo consistiu em estabelecer um regime de liberalização das relações comerciais entre seus países signatários por meio da supressão dos direitos aduaneiros e das restrições quantitativas às exportações (BITSCH, 2006, p. 130).

Todavia, o contínuo sucesso da integração promovida pelas Comunidades Europeias (CECA, CEEA e CEE) também no que se refere a performances econômicas atraiu a atenção do Reino Unido, reiteradamente preocupado apenas com o estabelecimento de melhores condições para livres relações 
Com efeito, era fundamental para o Reino Unido garantir a prevalência de algum controle soberano ${ }^{754}$. Isso significa que para este país era demasiado arriscado encetar institucionalmente uma associação jurídica entre países fora do espectro de uma cooperação intergovernamental, na medida em que os Estados não poderiam determinar completamente seu sentido por força de regência dada por autoridade não-estatal, comunitária, construída por normas de Direito Internacional Público ${ }^{755}$ (CLERGERIE;

comerciais entre os países europeus. No mesmo sentido percebe Jean-Louis QUERMONNE (2008b, p. 39): "[L]a C[ommunauté Economique Européenne] fut [...] pour la Grande-Bretagne un substitut à l'échec de l'association européenne de libre-échange (AELE) [AELC, em português]".

Assim, pode-se por isso compreender um pouco melhor a razão pela qual, nas duas vezes (em 1963 e em 1967) que o Reino Unido procurou ingressar nas Comunidades Europeias, este sofrera dupla rejeição por parte da França. O General Charles DE GAULLE teria percebido a divergência de Projetos de Europa Unida entre o continente europeu e o Reino Unido: a presença britânica ameaçaria transformar as Comunidades Europeias em uma Zona de Livre Comércio - e, portanto, de modificar integralmente a natureza do Projeto de Europa Unida (BITSCH, 2006, p. 142-7; BRONDEL, 2001, p. 79-80; QUERMONNE, 2008b, p. 39).

Em outras palavras teria sido notada a ameaça de possível substituição do Projeto Original de Europa Politicamente Unida por uma Europa apenas coordenada por mecanismos de cooperação intergovernamental erigida em torno de simples interesses econômicos. Mais uma vez, manifesta-se a divergência de concepções de Projetos de Europa Unida entre Reino Unido e Europa Continental Ocidental.

Com a saída do general DE GAULLE e sua substituição na Presidência da França por Georges POMPIDOU, em 1969, as negociações foram retomadas. Em 1973, o Reino Unido ingressou nas Comunidades Europeias, junto com a Irlanda e com a Dinamarca: "Il est plus exact d'admettre que la dérive économique du processus, qui connut son évolution au cours des années 1970, fut à la fois la conséquence d'une conjoncture économique difficile et de l'adhésion britannique à la CEE. [... L]'arrivée au pouvoir à Londres de Margaret Thatcher renforça encore ce diagnostic, dans la mesure où elle chercha inlassablement à limiter l'ambition de la construction européenne à sa dimension économique et commerciale." (QUERMONNE, 2008b, p. 39).

Apesar de ser interessante, o esclarecimento completo dos principais termos desta discussão exigiria maiores precisões históricas. Estas, por sua vez, não devem ser desenvolvidas neste trabalho, sob pena de serem extrapolados os limites metodológicos temporais previstos para o presente estudo. Apenas se mencionaram os eventos acima com o objetivo de reforçar o argumento sobre a distinção histórica entre o Projeto encetado por meio da reconciliação franco-alemã e aquele oficialmente defendido pelo Reino Unido. Registra-se aqui o convite para futuras investigações conjuntas sobre o tema.

${ }^{754}$ Isto é, por parte das estatalidades isoladas.

Não se pode deixar de mencionar ainda a observação feita por Elie BARNAVI; Krzysztof POMANI (2008, p. 105-6) especificamente sobre a recusa britânica em participar da vida comum a ser inaugurada pela CECA. Para estes, a preocupação em garantir um controle por parte das estatalidades isoladas não se cingia a preservar a Commonwealth, pois esta era apenas a perspectiva dos membros do Partido conservador britânico. Segundo os mesmos autores, a rejeição da CECA por parte do Reino Unido também seria justificada pelo partido trabalhista que estava no Poder naquele momento. De tendência esquerdista, os membros do partido trabalhista percebiam a CECA como uma ameaça supranacional potencialmente reacionária voltada a controlar a política industrial nacional.

Apesar de ser uma discussão interessante, maiores especificações sobre as questões políticopartidárias internas do Reino Unido escapam aos objetivos investigativos deste trabalho. Por esse motivo, não serão escritas linhas adicionais sobre essa temática neste trabalho. Registra-se aqui o convite para futuras Pesquisas conjuntas sobre o tema.

755 'Nous-mêmes, nous ne nous rendions pas compte au premier abord. Nous avions sérieusement l'espoir, du côté français, que l'Angleterre pourrait adhérer pleinement à notre plan, avec peut-être certains ajustements. Ce n'est qu'au moment où nous demandions l'institution d'une conférence, à laquelle seuls les pays qui accepteraient d'avance le principe d'une autorité supranationale auraient le droit de participer que nous avons constaté qu'il y avait un fossé entre nous. Cette exigence du commitment, d'un engagement de principe a amené un partage des esprits. [...]. Comment expliquer le point de vue anglais? J'ai toujours devant mon esprit la figure de mon ami Bevin, qui parlait à ce moment là au nom du gouvernement anglais. Il 
GRUBER; RAMBAUD, 2010, p. 46; DREYFUS, 2008, p. 149; MATTERA, 2002, p. 30 1; NOËL et alii, 2008, p. 127; PRIOLLAUD; SIRITZKY, 2011, p. 18; REUTER, 1965, p. 43; ZORGBIBE, 1997, p. 27).

As discussões em torno das estruturas da nova Organização Europeia não se resumiram na discordância por parte do Reino Unido. Outros países interessados em participar da vida em comum a ser juridicamente instaurada entre Alemanha e França discutiram de forma determinante as características que deveriam pautar a organização do arranjo institucional inovador de Direito Internacional Público que estabeleceria novas relações na Europa. É o que se passa a analisar no item a seguir.

6.3.3. A Instrumentalização Prática das Leis Políticas: Um Método Pluriescalar para Instituições Multidimensionais

6.3.3.1. Abertura das Discussões em torno do Futuro Tratado: Produção Pluriescalar de Centro Normativo Comum Vazio e Descentralizado

Uma vez aceita a proposta pela RFA no próprio dia $9.5 .1950^{756}$, as negociações também se desenvolveram com os demais interessados em participar da futura Comunidade - Bélgica, Itália, Luxemburgo e Países Baixos.

Em 8.6.1950, os países do BENELUX realizaram uma reunião confidencial onde discutiram questões relacionadas à realização institucional da Declaração de Robert SCHUMAN. Naquela oportunidade, os três Governos afirmaram não aceitar uma Alta

lui paraissait impossible, impensable, qu'il puisse y avoir pour un Anglais, pour un Gouvernement anglais, pour le Parlement anglais, une autorité supérieure à celle du Parlement anglais. Aucun argument ne pouvait faire changer cette position, non par suite d'une espèce d'entêtement — l'Anglais est capable de beaucoup de souplesse empirique - mais par suite d'un raisonnement logique : un Gouvernement anglais ne saurait accorder à un organisme européen plus d'autorité que n'ont les organes du Commonwealth. Comme il n'y a aucune trace de supranational à l'intérieur du Commonwealth, il n'est pas concevable qu'on reconnaisse une autorité supranationale à des organismes européens. Pour l'Anglais, la primauté appartient au Commonwealth, non seulement chronologiquement mais aussi, je dirais, sentimentalement. Il faut comprendre cela, nous ne l'avons peut[-]être pas suffisamment saisi au début, c'est pour cela que nous avions l'illusion qu'il serait possible d'avoir l'adhésion de l'Angleterre. Dans aucun domaine, un Gouvernement anglais, un Parlement anglais, ne peut admettre des décisions qui seront prises en dehors de lui, et peut-être contre lui. [... En Angleterre, t] outes les décisions politiques sont réservées au Conseil des ministres, aux Gouvernements unanimes, dans aucun de ces cas, ni pendant la guerre, ni après la guerre, aucun organisme international ou supranational n'a pu imposer au gouvernement britannique une décision à laquelle il n'avait pas expressément acquiescé. " (SCHUMAN, 1953, p. 9, grifos do autor)

756 "Ich ging dann auf den Beschluß des französischen Ministerrates ein, der an diesem Vormittag des 9. Mai 1950 gefaßt worden war. Ich betonte nachdrücklich, daß ich ihn als einen großherzigen Schritt Frankreichs und seines Außenministers Schuman gegenüber Deutschland und gegenüber der europäischen Frage betrachte. Er sei zweifellos von der denkbar größten Bedeutung für die Beziehungen zwischen Deutschland und Frankreich und für die ganze europäische Entwicklung." (ADENAUER, 1980e, p. 331). 
Autoridade impassível de qualquer forma de controle por parte dos EstadosMembros. Nesse sentido, desde aquele momento os três detinham forte convicção conjunta em não admitir um direcionamento exclusivamente supranacional das decisões normativas sobre as questões concretas sensíveis da futura vida comum a ser constituída (ROYAUME DES PAYS-BAS; ROYAUME DE BELGIQUE; GRANDDUCALE DE LUXEMBOURG, 1950, p. 2).

A partir da Conferência de Paris, realizada entre Junho e Julho de 1950, o debate em torno da realização da União Política entre Alemanha e França foi definitiva e oficialmente estendido à Bélgica, à Itália, a Luxemburgo e aos Países Baixos ${ }^{757}$. Em 20.6.1950, as seis delegações se reuniram na Sala do Relógio do Ministério das Relações Exteriores da França para pensar as atribuições da autoridade comum ${ }^{758}$ e os meios de se recorrer dos diferentes tipos de decisões tomadas no interior da dinâmica comunitária da CECA.

A metodologia daquele encontro entre Estados era distinta da seguida pela tradição, pois não se visava à negociação de interesses, isto é, à barganha e à conquista intergovernamental de posições estatais as mais vantajosas possíveis (BARNAVI; POMIAN, 2008, p. 101; MONNET, 2001b, p. 184; QUERMONNE, 2008b, p. 23-4; SCHUMAN, 1950, p. 2, 1953, p. 10). A orientadoção das atividades dos representantes dos países interessados em formar a nova vida comum na Europa era "auf europäischem Boden stünden und europäisch dächten" (ADENAUER, 1980g, p. 336), de modo a que as "négociations s[oient] mieux et plus que des marchandages étroitement égoïstes qui se refus[ai]ent à la fois au risque et à la confiance.” (SCHUMAN, 1950, p. 2).

La promptitude de ce résultat a été due en majeure partie à une méthode de travail qui a été appliquée pour la première fois dans un climat nouveau, inconnue jusque là : au lieu de marchander péniblement une transaction médiocre entre des intérêts nationaux divergents, on s'est attaché à ériger en commun une ouvre commune, dans une émulation qui a mis à profit l'expérience et la science de chacun, sans distinction de nationalité. (SCHUMAN, 1955, p. 2, grifos nossos)

O modo segundo o qual as discussões do futuro Tratado foram conduzidas sinalizou se tratar de interessante e inédita experiência na Europa: visava-se a efetivamente

\footnotetext{
${ }^{757}$ É importante lembrar a observação feita por Konrad ADENAUER (2001, p. 174, grifos do autor), durante seu Discurso de Abertura da Primeira Sessão do Conselho de Ministros da CECA: "La Communauté du charbon et de l'acier porte le nom «Communauté européenne du charbon et de l'acier ». Par là, on a tenu à exprimer que d'auprès l'espoir des états fondateurs elle ne devra pas se limiter à ces derniers".

${ }_{758}$ Isto é, da autoridade partilhada entre todos os participantes da vida em comum a ser inaugurada pela CECA. Sobre este tema, v. item 3.3.3.3., supra.
} 
construir em conjunto, por meio de normas jurídicas de Direito Internacional Público, uma dinâmica relacional europeia completamente nova. Esta deveria ser concebida de tal modo que se mostrasse a seus participantes permanentemente aberta ao conflito e reconciliadora, em que nenhum deteria mais ou maiores condições institucionais do que o outro para decidir normativamente o sentido das questões comuns (MATTERA, 2002, p. 31). Para tanto, os representantes deveriam pensar e agir "europeiamente", isto é, não poderiam descuidar de sempre ter em seus "pés, mentes e mãos" as condições materiais concretas da Europa $^{759}$ para erigir originariamente uma vida comum por meio de normas de Direito Internacional Público - Direito Comunitário Originário.

Assim, nesta Conferência de Paris de Junho-Julho de 1950, as delegações nacionais teriam percebido que "l'intérêt national consist[ait] justement à dépasser parfois les limites nationales." (BITSCH, 2006, p. 71) ${ }^{760}$, pois todos atuariam no constituição da Comunidade da mesma maneira que a vida comunitária seria regida (SCHUMAN, 1950, p. 2). Ou seja: em iguais condições de submeter uma decisão ao controle e à contenção por outras escalas

${ }^{759}$ Exemplo interessante da visão tradicional - contrária ao novo método proposto por Robert SCHUMAN durante as negociações do texto do Tratado da CECA - foi a apressada crítica formulada por Pierre-Étienne FLANDIN em 1951 - antigo Presidente do Conselho de Ministros da França. Naquela manifestação, PierreÉtienne FLANDIN (1951, p. 8) concluíra que, por meio do Tratado da CECA, "l'Allemagne en tire tous les profits. La France en supporte les charges et en subit tous les risques.".

Segundo esta perspectiva exemplificada, a oposição escalar ainda era vista como apenas passível de solução por meio de lógica de conquista (seja por meio de barganha, seja por meio de recursos armados), e não como sendo passível de ser encaminhada para a formação e para a reafirmação permanente de uma vida comum a partir de mecanismos institucionais de convivência plural - tal qual proposta por Robert SCHUMAN durante as tratativas.

${ }_{760}$ Perceba-se assim que imperava no ambiente a clara determinação de assegurar a todos os interessados a participação efetiva na construção da vida comum da futura Comunidade. Nesse sentido, os entendimentos tiveram sempre por base o mandamento da igualdade de condições para determinar em conjunto as disposições jurídico-normativas voltadas a organizar jurídico-Politicamente as relações.

Essa ambiência pode ser inferida claramente do convite formulado pelo Governo francês ao Chanceler da República Federal da Alemanha: "François-Poncet sagte hinsichtlich des Schuman-Plans, daß die französische Regierung beabsichtige, die an dem Schuman-Plan interessierten Regierungen zu befragen, ob sie an einer Studienkommission, die die französische Regierung einberufen wolle, teilnehmen würden. Selbstverständlich werde auch die deutsche Regierung eingeladen, sich in diesem Ausschuß vertreten zu lassen. Bis jetzt lägen für den Schuman-Plan erst sehr allgemeine Grundlinien vor. Nunmehr müßte man daran gehen, die Einzelheiten zu definieren. Monnet werde in der kommenden Woche nach Bonn kommen, um mit mir die Grundzüge des Schuman-Plans zu besprechen.” (ADENAUER, 1980f, p. 335, grifos nossos).

Assim, todos aqueles que estivessem dispostos a participar da futura Comunidade seriam - e deveriam ser - mutuamente reconhecidos como igualmente aptos a participar da formulação dos marcos institucionais destinados a reger a vida comunitária. A ampla abertura à participação a qualquer país europeu interessado e a dinâmica seguida durante a fase das discussões em torno das disposições do Tratado da CECA são símbolos que escancaram a tônica Política a ser seguida pela CECA, desde a discussão de seus elementos institucionais constitutivos até sua performance.

Neste último aspecto, não é demais lembrar a observação de Jean MONNET (2001b, p. 187) em seu relato sobre um possível paralelo entre o modo seguido durante as discussões em torno do Tratado da CECA e o funcionamento da Comunidade: "[1]a Communauté charbon-acier a été établie [...] non pas d'accord avec tous et sur tous les points, mais avec une compréhension commune et dans une confiance complète. Les intérêts divers et parfois opposés sont pris en considération : c'est toujours après une explication complète, après avoir entendu le point de vue de chacun, que les décisions sont prises.”. 
de existência envolvidas na vida comum, a qual exigia "travailler ensemble, d'après des plans concertés, dans des institutions créées et fonctionnant avec le concours actif de tous" (SCHUMAN, 1955, p. 2).

\begin{abstract}
[C]es six délégations se sont mises au travail dans un esprit tout à fait différent de l'esprit qui prévalait jusqu'ici dans les négociations internationales. Il ne s'agissait plus à proprement parler de négocier, car négocier veut dire marchander, défendre des intérêts nationaux qui s'opposent à d'autres intérêts nationaux. On allait construire une œuvre commune, à six. Ces six délégations étaient en quelque sorte des alliés, qui mettaient en commun leurs connaissances, leur bonne volonté. A la place de l'ancien esprit de compétition et de méfiance s'instaurait un esprit de coopération et cela dès le début du travail entrepris. (SCHUMAN, 1953, p. 10, grifos nossos).
\end{abstract}

Não se tratava assim de negociação de vantagens para os Estados, ou seja, não se buscava um compromisso intergovernamental ${ }^{761}$. Tambem não se buscava a desconsideração ou sobrevalorização simultânea, ou da perspectiva estatal, ou da dimensão supranacional: buscava-se a instauração de uma vida comunitária entre as escalas de existência - tradicionais e futuramente constituídas, de modo a que todas estivessem lado a lado para decidir em conjunto o sentido normativo comum.

Em outras palavras, a Conferência foi convocada e organizada para definir pluriescalarmente mecanismos institucionais por meio dos quais seria inaugurado um sistema de convivência afeito a uma racionalidade jurídico-Política, isto é, fundado em Poder comum vazio, em que todos deveriam participar do processo nomogenético originário (BUNDESREPUBLIK DEUTSCHLAND. Auswärtiges Amt, 1950, p. 4; CVCE, 2011, p. 2; MATTERA, 2002, p. 31; MONNET, 2001a, p. 175, 2001b, p. 183; SCHUMAN, 1950, p. 2$)^{762}$.

\footnotetext{
761 "Toujours le compromis est le dénominateur le plus bas et le plus faible, et les problèmes ne sont pas vraiment résolus." (MONNET, 2001b, p. 184).

${ }^{762}$ Há que se notar resoluta preocupação em não reduzir a discussão em torno dos mecanismos institucionais da futura Organização Internacional a esquemas estritamente técnico-econômicos.

Conforme relata Konrad ADENAUER (1980g, p. 336), antes de qualquer decisão sobre questões técnicas referentes à CECA, entendeu-se por bem que deveriam ser ajustadas as condições institucionais jurídico-políticas a serem mutuamente acordadas entre os Estados europeus participantes. Especial atenção deveria ser dada à precisa e detalhada circunscrição dos limites de atuação de cada um dos portadores institucionais das diferentes escalas de existência que comporiam a vida em comum, principalmente no que se refere à supranacionalidade da Alta Autoridade.

Ainda de acordo com as memórias do Chanceler da RFA (ADENAUER, 1980g, p. 336), entendeuse que apenas após a ratificação do texto do Tratado da CECA por cada um dos países-membros - isto é, após a aceitação pelos Parlamentos nacionais (populidade) das disposições institucionais jurídico-políticas destinadas a compor uma organização jurídico-Política das relações entre os países europeus participantes da vida em comum - é que poderiam ser iniciadas, em um segundo momento, as discussões sobre os aspectos econômicos mais técnicos.

Assim, conforme se percebeu naquela oportunidade, se invertidas fossem as fases, pouco entendimento haveria entre os participantes e o Projeto derivado da Declaração Schuman poderia ter
} 
6.3.3.2. A Intuição Jurídico-Política dos Países-Membros do BENELUX: O Último Nicho de Resistência do Teológico-Político na Futura Vida Comum

Na fase final das negociações (final de 1950 e início de 1951), preocupados com a possibilidade de se formar um bloco franco-alemão que sufocasse os demais componentes da Comunidade, os países-membros do BENELUX reforçaram a importância de se assegurar um equilíbrio institucionalmente assegurado entre os Poderes a serem distribuídos entre os participantes da Comunidade. Para eles, especial cuidado deveria ser dado ao controle da atividade da Alta Autoridade, pois as decisões desta deveriam sofrer um contrapeso a partir da consideração da perspectiva estatal.

Nesse sentido, sugeriu-se a reafirmação da importância de um Conselho intergovernamental $^{763}$ no interior da vida comunitária a ser instaurada (ADENAUER, 2001, p. 173; BITSCH, 2006, p. 72; QUERMONNE, 2010, p. 9; ZORGBIBE, 1997, p. 26),

prejudicada a realização de sua vocação de promover a União Política da Europa. Em outras palavras, tal Projeto poderia ser sufocado por discussões tortuosas em torno de questões de mera técnica econômica que em nada contribuiriam para a constituição institucional de uma vida comum jurídico-Politicamente organizada (ADENAUER, 1980g, p. 336).

Deste modo, note-se aqui a presença de consciente preocupação em priorizar a realização jurídico-política institucional do intento de aproximação Política entre os participantes da futura vida comunitária/em comum (Alemanha, França e demais interessados), em detrimento de formular apressada decisão sobre os aspectos jurídico-econômicos da Comunidade. Nesse sentido, em outras palavras, é possível perceber a precedência ao menos lógica da Política com relação ao econômico, a fim de que as disposições institucionais orientadas para constituir, promover e manter a Política pudessem sustentar de maneira controlada as futuras decisões concernentes ao campo do econômico. V. ainda o item 6.2.2.6., supra, em que se menciona a consciência partilhada entre o Governo da RFA e o da França sobre a qualidade fundamentalmente Política da futura Organização Europeia, desde mesmo a Declaração de Robert SCHUMAN.

De todo modo, note-se que a sutileza deste campo Político anterior ao Econômico permite compreender porque se mostra possível discorrer sobre a CECA no interior de uma teia significativa jurídicopolítica que antecede - mas não ignora - as questões técnicas de economia e de Direito Econômico. O destacamento desta camada de regulamentação jurídico-política não apenas foi realizado por este trabalho (v. Parte Primeira, supra), mas fora efetivamente pensado e realizado por aqueles que participaram das discussões da Conferência de Paris de 1950 que levou à redação e à assinatura do Tratado da CECA.

Tratava-se de plano histórico obliterado, mas recuperado a partir de consulta às fontes que relatam a construção da CECA, e que, tornado consciente, permite compreender a racionalidade dos comentários do Sétimo Capítulo, infra: desvelar a racionalidade jurídico-Política (oposições escalares) que informou a arquitetura institucional constante do Tratado da CECA. Há que se desdobrar detalhadamente os mecanismos de freios e contrapesos mutuamente constituídos para uma escala se colocar perante as demais para, com isso, revelar-se a produção de uma recíproca contenção impeditiva de pretensões de tomada do lugar do Direito e do Poder. Esta é a tarefa empreendida durante a análise do Sétimo Capítulo, infra.

763 "Comme organe de la Communauté, le conseil [...] sera entendu au sujet de toutes les mesures essentielles de la Haute Autorité, dans les cas importants, son assentiment ou sa décision seront nécessaires, dans les questions d'une particulière importance sa décision unanime sera indispensable." (ADENAUER, 2001, p. 172).

A resposta de Jean MONNET (2001a, p. 175) ao referido discurso - proferido em 8.9.1952- foi imediata, no sentido de reforçar a perspectiva ressaltada momentos antes por Konrad ADENAUER: “C'est le soin d'assurer cette harmonie constante entre l'action de la Communauté et celles des États membres qui est la tâche essentielle de votre conseil.". 
ainda que a estatalidade não pudesse desconsiderar a perspectiva da Comunidade ${ }^{764}$. Isso asseguraria que as estatalidades encontrariam meios e condições para se apresentar na vida comum em igualdade de condições perante as supranacionalidades. Em outras palavras, essa preocupação visava a manter a continuidade da tensão pluriescalar no interior da vida comum (DREYFUS, 2008, p. 149-50; NOËL et alii, 2008, p. 127-8; QUADROS, 1984, p. 259-61; WEILER, 2005, p. 93).

Assim, salientando a necessidade de se pensar meios de se recorrer das decisões da Alta Autoridade, os Estados-Membros do BENELUX lembraram a importância de não se esquecer de que nem mesmo a independente Alta Autoridade poderia ser reputada como impassível de controle ${ }^{765}$. A escala de existência supranacional portada por ela como toda e qualquer dimensão existencial da vida em comum da CECA - teria recebido um Poder limitado e não intemporal ${ }^{766}$.

Em outros termos, a Alta Autoridade da CECA não estaria no centro normogenético da vida comunitária, isto é, ela não seria este centro normativo, pois estaria igualmente submetida a um sistema engenhoso de mútuo e recíproco controle e contenção pelas diferentes escalas de existências partícipes da vida comum (MONNET, 1951, p. 3). Não se tratava de mero impedimento de abuso de Poder por parte da escala de existência supranacional; significava outrossim a opção pela pluriescalaridade, pelo vazio de Poder, pela tensão escalar constante e pela imanente horizontalidade relacional, isto é, pela recusa a qualquer tendência unidimensional totalizante - ainda que esta se originasse da independente e supranacional Alta Autoridade da CECA.

Assim, "supranacional, mas não ditatorial”, a Alta Autoridade da CECA - como qualquer outro portador das diferentes escalas de existência da vida comum da CECA não ocuparia o lugar do Direito e do Poder. Ela também não poderia decidir por si só o sentido normativo do encaminhamento das questões concretas sensíveis comuns. A Alta

\footnotetext{
764 "Le Conseil de ministres [...] ne représente pas seulement les intérêts de la Communauté dans le domaine des droits souverains qui lui sont transmis, mais il assume aussi les intérêts des États membres eux-mêmes dans le domaine des droits souverains qui leur restent attribués.” (ADENAUER, 2001, p. 172).

${ }^{765}$ Era necessário "fix[er] de manière claire les pouvoirs de la Haute Autorité pour éviter une ingérence excessive dans les économies nationales et organis[er] des contre-pouvoirs, notamment par la création d'un Conseil de ministres." (BITSCH, 2006, p. 72, grifos nossos).

766 Seriam instituídas assim duas entidades novas, portadoras da supranacionalidade (Alta Autoridade e Corte), sendo com cada uma delas compartilhada parcela da Soberania dos Estados. Estes perderiam a competência para decidir com exclusividade sobre questões comuns relacionadas ao setor econômico do carvão e aço. Todavia, seriam instituídos mecanismos de controle estatais da ação e da inação das entidades portadoras da supranacionalidade, a fim de que estas não restassem com plenas condições de determinar por si só o sentido último do Direito e do Poder na vida em comum da CECA. Este comentário será mais bem compreendido quando da leitura do Sétimo Capítulo, infra.
} 
Autoridade da CECA estaria assim desprovida de Poderes exorbitantes: afinal, não seria sua supranacionalidade (i) a única referência para padrões normativos na CECA, ou ainda,

(ii) o Poder da vida comum constituída pelo futuro Tratado da Comunidade.

Jean Monnet [...] a réussi à préserver l'essentiel, une Haute Autorité indépendante dotée de pouvoirs réels, mais il a dû accepter la création de trois autres institutions encadrant la Haute Autorité pour lui faire contrepoids. (BITSCH, 2006, p. 73, grifos nossos).

Le gouvernement français négocie avec ses partenaires l'organisation et le fonctionnement de la future Communauté européenne du charbon et de l'acier. Sous la présidence de Jean Monnet, les négociateurs se concentrent tout d'abord sur des questions institutionnelles et des voies de recours. Les délégués des trois pays du Benelux réclament un traité qui précise très clairement les pouvoirs techniques accordés, pour une durée limitée dans le temps, à la Haute Autorité dont certains craignent l'ingérence dans des domaines nationaux sensibles. Ils suggèrent ensuite la création d'institutions politiques afin de contre-balancer les pouvoirs de la Haute Autorité. L'idée d'un organe intergouvernemental, le Conseil spécial des ministres, est adoptée. Une Assemblée commune, qui représente les peuples des États membres, est instituée. On projette également la mise sur pied d'une Cour de justice pour régler les différends. (CVCE, 2011, p. 2, grifos nossos).

Em nome da preservação do vazio de Poder típico de uma vida comum jurídicoPoliticamente organizada, a intuição dos Estado-Membros do BENELUX teve virtude de reforçar a ressalva de que nenhuma das escalas de existência - nem mesmo a independente Alta Autoridade - poderia suprimir o vazio institucional de Poder constituído pelo sistema de convivência entre diferentes estabelecido pela vida comunitária da $\mathrm{CECA}^{767}$. A

\footnotetext{
${ }^{767}$ V. notas de rodapé 202 e 748 , ambas supra.

Se - diferentemente do que foi sugerido aqui, naquelas duas notas de rodapé anteriormente mencionadas, e conforme será visto durante todo o Sétimo Capítulo, infra, bem como nas Conclusões Parciais desta Parte Segundo do trabalho, também infra - a tradição do conhecimento jurídico nacional e estrangeiro não consegue demonstrar histórica e jurídico-normativamente as razões pelas quais entende a CECA composta por partícipes comunitários em torno da Alta Autoridade - a quem, detentora de posição superior, caberia a missão exclusiva de gerir os interesses comuns, em nome do interesse comum, sobre os Estados-Membros e as demais entidades comunitárias, isso deriva do fato que essa afirmação se funda nas nuvens da repetição retórica ou impensada de declarações vazias e desprovidas de fundação certa, ou melhor, a afirmação se tornou uma questão de fé - ou ainda, um saber supostamente compartilhado de maneira universal, e não uma questão de conhecimento.

Há que se lembrar, nesse sentido, de que não há nada pior para a produção e para o desenvolvimento de conhecimento novo do que a submissão voluntária ao despotismo de um discurso dogmático e a conseqüente adoção irrefletida de suas conclusões sem um exame crítico prévio: “Ouvem-se muitas queixas sobre a superficialidade do modo de pensar de nossa época e o declínio da ciência rigorosa. [...]. Nossa época é a verdadeira época da crítica a que tudo tem de submeter-se. A religião por meio de sua sacralidade, e a legislação, por meio de sua majestade, querem em geral escapar a ela. Desse modo, porém, levantam contra si uma legítima suspeita e não podem aspirar ao sincero respeito que a razão dedica apenas àquele que pôde suportar o seu livre e público teste." (KANT, 2012, p. 19, grifos nossos). Afinal, "não há ateísmo conseqüente sem destruição de todas as fórmulas de "saber universal'. Eu disse mesmo: todas." (LEBRUN, 1993, p. 13, grifos do autor).
} 
horizontalidedade relacional deveria ser institucionalmente preservada entre todas as dimensões existenciais.

Assim, a multiescalaridade decisória deveria ser condição destinada a reger o sentido pluridimensional das decisões normativas sobre o uso dos recursos escassos comuns fundamentais. Suas instituições deveriam preservar e organizar os embates escalares, de maneira que a persistência do conflito e da discórdia no interior de uma união assegurasse o Politicamente necessário vazio de Poder e a impossibilidade de romper com a imanente horizontalidade relacional entre escalas de existência.

Com isso, a realização prática da Declaração Schuman de 1950 buscaria conferir mecanismos concretos que a aproximariam institucionalmente de um discurso tipicamente Político de organização jurídico-política das relações na Europa ${ }^{768}$.

La Communauté charbon-acier a été établie [...] non pas d'accord avec tous et sur tous les points, mais avec une compréhension commune et dans une confiance complète. Les intérêts divers et parfois opposés sont pris en considération : c'est toujours après une explication complète, après avoir entendu le point de vue de chacun, que les décisions sont prises. (MONNET, 2001b, p. 187, grifos nossos).

[L]a démarche fut novatrice et fondatrice. Rompant avec les politiques de revanche fondées sur le «paradigme westphalien », ainsi qu'avec la structure intergouvernementale habituelle des organisations internationales, elle ouvrira la porte vers l'avenir [...] sans qu'il soit besoin de créer d'emblée un État fédéral [...]. (QUERMONNE, 2008b, p. 32, grifos nossos).

\subsubsection{A Assinatura do Tratado de Paris de 1951 e a Escolha da Sede da CECA}

Enfim, em 19.3.1951, a versão final do Tratado foi redigida em um único exemplar, em francês (PERTEK, 2011, p. 18; PILOTTI, 1959, p. 76) ${ }^{769}$. Em menos de seis anos após o final da Segunda Guerra Mundial, e em menos de um ano de negociações, em 18.4.1951 foi celebrado em Paris, entre Bélgica, França, Itália, Luxemburgo, Países Baixos e RFA, o Tratado Constitutivo da $\mathrm{CECA}^{770}$.

\footnotetext{
${ }^{768}$ Sobre a noção de Político, v. item 3.4., supra.

${ }^{769}$ Conforme o artigo 100, do próprio Tratado da CECA. Por esse motivo, preferiu-se neste trabalho utilizar a versão em francês do Tratado de Paris, de 1951, como a base das interpretações desenvolvidas no Sétimo Capítulo desta Tese, infra.

${ }^{770}$ Após a assinatura do Tratado, o texto foi aprovado pelos órgãos do Poder Legislativo de cada um dos países signatários do seguinte modo (CECA. Assemblée Commune, 1958, p. 2):

(i) na Bélgica, o Senado (Sénat) aprovou o texto do Tratado por 102 (cento e dois) votos a favor, 4 (quatro) votos contrários e 58 (cinquenta e oito) abstenções e, em seguida, a Câmara de Representantes (Chambre des Répresentants) aprovou o texto do Tratado por 191 (cento e noventa e um) votos a favor, 13 (treze) votos contrários e 13 (treze) abstenções, tendo sido o documento ratificado finalmente em 12.6.1952;
} 
Esta nova Organização Europeia era símbolo jurídico-Político da reconciliação entre antigos beligerantes ${ }^{771} \mathrm{e}$, mais do que isso, do estabelecimento de um novo modo de relações entre países: o da direitificação da convivência entre diferentes. A partir de então, este adensamento jurídico das relações desenvolvidas em âmbito internacional preservaria de modo permanente a pluralidade escalar por via jurídico-Política institucional. As relações entre os países europeus não mais seriam pautadas pela lógica da imposição de uma escala de existência sobre as demais: “c'est un renversement sans précédent de nos conceptions politiques. L'idée de communauté doit être à la base de toutes les relations futures entre les pays belligérants." (SCHUMAN, 1953, p. 6).

A sede da CECA foi definida apenas no final de julho de 1952, em uma reunião marcada poucos dias antes do início de vigência vigor do Tratado de Paris (25.7.1952). O Governo francês propusera as cidades de Estrasburgo e de Sarrebruck. O Governo belga defendera a candidatura de Liège. Também se sugeriram as cidades de Bruxelas, de Turim e de Haia. Sem qualquer unanimidade na escolha, e para não atrasar o início das atividades da CECA, decidiu-se apenas por questões práticas que os trabalhos da Alta Autoridade e das outras instituições da CECA seriam começados em Luxemburgo, sendo que, posteriormente, seria definida a escolha do local. Todavia, a Assembleia Comum da CECA se reuniria nas mesmas dependências do CdE, em Estrasburgo ${ }^{772}$ (BITSCH, 2006, p. 75-6; CASELLA, 1994a, p. 69-70; PERTEK, 2011, p. 18).

(ii) na França, a Assembleia Nacional (Assemblée Nationale) aprovou texto do Tratado por 377 (trezentos e setenta e sete) votos a favor, 232 (duzentos e trinta e dois) votos contrários e, em seguida, o Conselho da República (Conseil de la Repúblique) aprovou o texto do Tratado por 182 (cento e oitenta e dois) votos a favor e 32 (trinta e dois) votos contrários, tendo sido o documento ratificado em 1.4.1952;

(iii) na Itália, a Câmara dos Deputados (Camera dei Deputati) aprovou o Tratado por 265 (duzentos e sessenta e cinco) votos a favor e 98 (noventa e oito) contrários, tendo sido o documento ratificado em 16.6.1952;

(iv) em Luxemburgo, a Câmara dos Deputados (Chambre des Députés) aprovou o Tratado por 47 (quarenta e sete) votos a favor e 4 (quatro) votos contrários, tendo sido o documento ratificado em 13.5.1952;

(v) nos Países-Baixos, a Segunda Câmara dos Estados Gerais (Tweede Kamer der StatenGeneraal) aprovou o Tratado por 62 (sessenta e dois) votos a favor e 6 (seis) votos contrários, e a Primeira Câmara dos Estados Gerais (Eerste Kamer der Staten-Generaal) aprovou o Tratado por 36 (trinta e seis) votos a favor e 2 (dois) votos contrários, tendo sido o documento ratificado em 19.2.1952; e

(vi) na RFA, a Câmara Federal (Bundestag) aprovou o texto do Tratado por 378 (trezentos e setenta e oito) votos a favor e 143 (cento e quarenta e três) votos contrários, tendo sido o documento ratificado em 11.1.1952.

Após a ratificação pelos seis países signatários, o Tratado da CECA entrou em vigor em 25.7.1952 e, nos termos de seu artigo 97, permaneceu em vigência por 50 (cinquenta) anos, atingindo seu termo final em 23.7.2002.

771 "Un détail très suggestif est rappelé par Jean Monnet: le traité soumis à la signature des États membres est une œuvre commune jusque dans sa présentation ; «la typographie » est française, le «papier fileté » est néerlandais, «l'encre » est allemande, la « reliure » a été l'œuvre d'artisans belges et luxembourgeois, les « signets de soie » ont été offerts par l'Italie." (MATTERA, 2002, p. 31, grifos do autor).

772 "La Haute Autorité s'installe provisoirement à Luxembourg le 10 août 1952. L'Assemblée commune siège à Strasbourg, pour être en lien avec l'Assemblée Consultative du Conseil de l'Europe." (DREYFUS, 
Apresentadas acima as linhas gerais de orientação da arquitetura institucional desenhada para a CECA, passa-se ao exame do complexo institucional de seu Tratado Constitutivo. Deste modo será possível compreender de maneira juridicamente completa $^{773}$ os mecanismos que (i) deram forma prática à União Política entre os seis Estados-Membros daquela Comunidade; e, por isso mesmo, (ii) disponibilizaram meios que (a) a instauraram; e, principalmente, (b) a preservaram em sua "politicidade" "774. Se trabalhoso e árduo fora a construção histórica dessa integração como direitificação da convivência, não poderiam seus autores descuidar da tarefa igualmente importante de estabelecer instrumentos que conservassem a virtude Política de tal vida em comum.

No próximo Capítulo serão examinadas as maneiras jurídico-normativas por meio das quais se logrou recusar institucionalmente Leis Teológico-Políticas mediante a conservação constante da opção pela perpetuidade da tensão, da pluriescalaridade, da imanente horizontalidade relacional e da condição vazia do lugar do Direito e do Poder. Será verificada como foi feita a cuidadosa preservação jurídico-normativa de estrutura institucional afeita a uma ordenação jurídico-Política das relações entre os países europeus que compuseram a CECA:

\begin{abstract}
[c]abe ao legislador ou a quem quer que tenha sabido traçar o plano de um governo não apenas realizá-lo, mas sobretudo prover a permanência de sua obra. [... D]eve-se tentar garantir sua existência, evitando tudo o que lhe for pernicioso e tomando, através de leis escritas ou não-escritas, todas as medidas necessárias à sua conservação [...]. (ARISTÓTELES, 1998, p. 231).
\end{abstract}

2008, p. 150). A relação da CECA com o CdE foi jurídico-politicamente estabelecida pelo Tratado Constitutivo da CECA, em um de seus Protocolos. Todavia, adiante-se desde já que esta relação, segundo o referido documento jurídico, de forma alguma significaria qualquer submissão da CECA ao CdE, como se poderá ver mais a seguir.

Também neste momento de inter-relações institucionais se pode notar a escolha explícita por uma ausência de hierarquia entre uma Organização Internacional de cooperação política intergovernamental e de vocação Federalista e uma Organização Internacional voltada ao estabelecimento de uma União Política segundo Leis de convivência plural permanente. O Teológico-Político era assim mantido afastado de maneira vigorosa por meio das disposições do próprio Tratado da CECA: Direitos Humanos e Democracia totalizantes não deveriam nem mesmo submeter por vias transversas as atividades da vida comum instituída pelo Tratado da CECA.

Ademais, como se poderá ver no Sétimo Capítulo, a Assembleia Comum da CECA era órgão institucional desprovido de qualquer poder de influência no processo de formação do sentido normativo sobre o carvão e o aço na vida comum. Por esse motivo, não haveria qualquer perigo em mantê-la próxima ao CdE - como visto acima, no Quinto Capítulo, Organização Internacional Europeia igualmente desprovida de dispositivos institucionais enérgicos o suficiente para atrapalhar o desenvolvimento Político da vida comunitária da CECA...

${ }^{773}$ Tendo em vista que este trabalho se desenvolve no interior de um arco de preocupações jurídicas; remetese o leitor às considerações feitas no item 2.2, supra, sobre as relações entre Zetética e Dogmática Jurídicas.

774 "La Communauté européenne du charbon et de l'acier est maintenant sortie du domaine de la constitution et des projets [...]. On a émis beaucoup de projets et on a beaucoup parlé au sujet de la création de l'Europe. [...] Maintenant, le premier pas qui mène du projet à la réalité est accompli. Comme nous l'espérons pleins de confiance, c'est une nouvelle époque qui commence pour notre continent." (ADENAUER, 2001, p. 174). 


\title{
SÉTIMO CAPÍTULO - ANÁLISE JURÍDICA DO TRATADO DA CECA: INSTITUIÇÕES PRÁTICAS DE LEIS JURÍDICO-POLÍTICAS
}

\begin{abstract}
O legado, intelectual e filosófico, da Grécia clássica, influenciando direta e imediatamente Roma, que a conquistara, e a partir daí, todo o conjunto da Europa e das civilizações, que repercutiram a partir desta, não é elemento contingente, mas estrutural para a compreensão do mundo, com base nessa mesma perspectiva. Fenômenos aparentemente díspares podem ter elementos basilares comuns, e trazer a partir destes, bases mais amplas e mais seguras, para a compreensão desses eventos em curso no mundo. (CASELLA, 2009a, p. 25).
\end{abstract}

[A] perfeição do amálgama é não mais poder dar [...] nome [...] ao governo misto que dela resulta. A dificuldade de qualificação torna-se índice de excelência. (ARISTÓTELES, 1998, p. 116).

O objetivo deste Sétimo Capítulo consiste em apresentar o Tratado da CECA como locus institucional jurídico-normativo de realização prática do Jurídico-Político ${ }^{775}$. Lembrando o que foi dito anteriormente ${ }^{776}$, a referida Comunidade pode ser entendida, não apenas como um exemplo inaudito de afirmação histórica de um novo modo de relações entre países europeus ${ }^{777}$; antes, a CECA pode ser compreendida também como experiência inovadora de imaginação institucional que visou ao estabelecimento de meios jurídiconormativo práticos que tornassem possíveis tal novo modo de relacionamento entre países.

Dessa forma, como anunciado por diversas vezes ao longo deste trabalho, este Capítulo tem por objeto a análise do Tratado de Paris, de 1951, que instituiu a Comunidade Europeia do Carvão e do Aço. Como visto anteriormente ${ }^{778}$, trabalhoso e árduo fora o processo histórico construtor da integração europeia como direitificação da convivência. Por esse motivo, seus autores se preocuparam em estabelecer instrumentos institucionais que conservassem a virtude Política da vida em comum iniciada em 1951.

\footnotetext{
${ }^{775}$ As observações preliminares feitas neste item introdutório do Sétimo Capítulo são meros esclarecimentos e especificações de decisões metodológicas feitas anteriormente por este trabalho. A preocupação desta parcela inicial consiste em apenas refrescar a memória do leitor com relação às linhas mestras outrora determinadas para a realização da análise institucional empreendida há mais de três Capítulos. Para maiores esclarecimentos das decisões metodológicas mencionadas neste item introdutório, convidamos o leitor à releitura das considerações constantes da Parte Primeira desta Tese, especialmente nos Capítulos Segundo e Terceiro, supra.

${ }^{776}$ No final da Introdução Parcial da Parte Segunda desta Tese.

${ }^{777}$ Como a leitura dos Capítulos Quarto, Quinto e Sexto permitem concluir: uma relação jurídico-Política entre países tradicionalmente opostos em termos bélicos, institucionalmente mediada por normas jurídicas positivas de Direito Internacional Público organizadas de modo novo, para instaurar uma vida comum (Direito Comunitário Originário).

${ }^{778}$ No final do Sexto Capítulo, supra.
} 
O exame atento e profundo a ser empreendido nos itens a seguir tem por objetivo extrair da regulamentação comunitária originária ${ }^{779}$ trazida pelo Tratado da CECA dispositivos que evidenciem a presença de cuidadosa preocupação em tecer institucionalmente elos jurídico-normativos entre os diferentes partícipes daquela vida em comum no sentido de constituir entre eles um Regime de Leis de pluralidade permanente. Será possível visualizar por quais mecanismos institucionais se buscou recusar Leis Teológico-Políticas no interior da Europa mediante a conservação institucional constante da opção pela perpetuidade da tensão, da pluriescalaridade, da imanente horizontalidade relacional e da condição vazia do lugar do Direito e do Poder.

Nesse sentido, este trabalho visa a efetuar uma análise institucional do texto do Tratado da $\mathrm{CECA}^{780}$. Por isso mesmo, a exposição a seguir não visa a uma exposição descompromissada e minuciosamente descritiva das inúmeras possíveis articulações técnicas do texto de Direito Positivo do Tratado. Trata-se, antes, de buscar evidenciar no interior deste documento jurídico-normativo internacional sua significação jurídicoPolítica, a qual será iluminada mediante a ênfase na fina compreensão da efetividade prática dada às oposições escalares regulamentadas no interior do Tratado.

Frise-se desde já que não serão examinadas nos itens a seguir todas as normas do Tratado da CECA: este texto escrito não se trata da Pesquisa realizada para a Tese, mas o registro escrito da Pesquisa outrora realizada ${ }^{781}$. Por este texto não ser a Pesquisa propriamente dita, mas apenas o registro lógico, coerente e ordenado da Pesquisa efetuada em momento anterior, não se mostra cabível esperar aqui a apresentação integral de todos os comentários desenvolvidos anteriormente em torno de cada um dos artigos do Tratado da CECA. Tais anotações preliminares do autor deste texto apenas foram suporte para o exercício reflexivo que organizou estruturalmente este Capítulo em cada um dos itens a seguir.

Dito de outro modo: em momento anterior à redação do presente texto, houve uma leitura geral, exploratória e integral de cada um dos artigos que compunham o Tratado da CECA, seguido dos necessários descartes para fazer frente às exigências metodológicas delineadas anteriormente ${ }^{782}$.

\footnotetext{
${ }^{779}$ Sobre as normas de Direito Comunitário Originário, v. item 2.1., supra.

${ }^{780} \mathrm{~V}$. as considerações sobre análise jurídica como análise institucional, no item 3.2., supra.

${ }^{781}$ Remetemos o leitor à nota de rodapé 136, supra, em que se distinguem o momento da Pesquisa e o da redação escrita dela em versão formal.

${ }^{782} \mathrm{~V}$. nesse sentido o final do item 3.3., supra.
} 
O produto desta exaustiva atividade interpretativa foi posteriormente objeto de nova indagação reflexiva, a fim de melhor ordenar os comentários, no sentido de buscar tornar o mais claro possível ao leitor de que maneira se pode compreender a CECA como exemplo institucional de realização de um sistema de convivência regido por Leis Políticas. Este Capítulo é assim o resultado deste último movimento reflexivo que buscou ordenar o mais didaticamente possível as conclusões formuladas a partir da leitura e da interpretação do texto do Tratado da CECA.

Assim, longe de esperar que nos próximos itens se seguirá um simples comentário “artigo por artigo, parágrafo por parágrafo" do Tratado de Paris de 1951, o leitor deverá atentar para o fato de que serão apresentadas aqui apenas e tão-somente aquelas disposições que corresponderam ao recorte normativo escolhido no início deste trabalho: as normas de oposições escalares, responsáveis pela edificação do complexo sistema de convivência constituído pelo Tratado da CECA entre as escalas de existência participantes daquela vida em comum.

O Tratado examinado por este trabalho não era composto apenas por normas de oposições escalares: havia por certo série de disposições que não continham em si uma preocupação em lidar com embates entre dimensões existenciais no interior da Europa. Nesse sentido, por este trabalho se preocupar apenas e tão-somente com a compreensão minuciosa da regulamentação jurídico-Política dada pelas normas de oposições escalares, as disposições que não foram introduzidas por essa espécie normativa não constam dos comentários desenvolvidos nos itens a seguir. Estes se preocuparam apenas em elucidar a significação jurídico-Política das previsões que foram trazidas por normas de oposições escalares.

As normas de oposições escalares encontradas no texto do Tratado da CECA são aquelas normas que de alguma forma buscaram lidar com o tema das oposições entre diferentes medidas de existência no interior da vida comum constituída pela CECA. Tendo por base essa noção de normas de oposições escalares, pode-se com isso compreender a exclusão de série de dispositivos da possibilidade de serem objeto de interpretação por este trabalho.

Nesse sentido, foram excluídas deste estudo as disposições normativas do Tratado da CECA que não continham em si qualquer preocupação de operar com oposições escalares. Mencionem-se dentre as normas excluídas desta análise, a título 
exemplificativo $^{783}$, as constantes (i) dos Anexos I, II e III ao Tratado da $\mathrm{CECA}^{784}$; (ii) do Protocolo sobre os Privilégios e Imunidades da Comunidade, (iii) do Protocolo sobre o Estatuto da Corte de Justiça, (iv) da Convenção relativa às Disposições Transitórias ${ }^{785} 786$.

A aplicação da chave de leitura proposta na Parte Primeira deste trabalho (Político versus Teológico-Político) e a consideração do processo histórico de construção da CECA permitem compreender que o Tratado de Paris de 1951 operou de duas maneiras distintas a confecção da vida em comum a partir de normas de oposições escalares. Tais normas foram direcionadas para realizar, ou uma tarefa negativa, ou uma tarefa positiva.

A tarefa negativa exercida pelas normas de oposições escalares consistiu em reconhecer e simultaneamente afastar oposições escalares que poderiam introduzir uma orientação Teológico-Política nas Leis reguladoras das relações empreendidas no interior da nova vida comum na Europa. Por seu turno, a tarefa positiva exercida pelas normas de oposições escalares consistiu em criar e promover de maneira contínua os embates entre dimensões existenciais no interior da vida comum na Europa, com o objetivo de fazer perseverar uma dinâmica Política nas Leis que regulamentavam as decisões normativas sobre a administração e o uso do carvão e do aço na CECA.

A leitura das informações históricas sobre a construção da CECA constantes especificamente do Sexto Capítulo ${ }^{787}$ auxilia na compreensão desses dois modos de se direcionar as normas de oposições escalares.

A vertente negativa se dirigiu exclusivamente para preservar a imanência na fundamentação do sentido normativo a ser dado no interior da vida comum da Europa mediante a rejeição de submissão às oposições escalares externas à Europa

\footnotetext{
${ }^{783}$ Pois há tantas outras que não serão sequer mencionadas no texto desta Tese precisamente em virtude dessa mesma condição. A nota de rodapé 424, supra, menciona igualmente de forma exemplificativa outras normas excluídas da interpretação por este trabalho.

${ }^{784}$ O Anexo I ao Tratado da CECA é responsável pela definição técnico-normativa das expressões “carvão" e "aço"; o Anexo II ao Tratado da CECA dispõe sobre as "sucatas" da Comunidade; e o Anexo III dispõe sobre "aços especiais".

${ }^{785}$ Esta Convenção não será analisada precisamente porque, em seu considerando único, bem como na alínea 1 de seu $\S 1$, afirma-se que ela se destina a regulamentar especificamente o artigo 85 do Tratado da CECA. Como este artigo 85 não é objeto de interpretação por este Sétimo Capítulo - pois apenas determina a realização de medidas concretas a serem praticadas pelos Estados-Membros para rapidamente iniciar o vigor do Tratado, não há razão para comentar a referida Convenção.

${ }^{786}$ Há ainda no Tratado uma Troca de Cartas entre o Governo da RFA e o Governo da França referente à região do Sarre. Este documento não é analisado por este trabalho por dois motivos, de caráter metodológico. Em primeiro lugar, não se trata de questão resolvida no lapso temporal escolhido para o presente estudo (v. nota de rodapé 718 , supra), não merecendo qualquer destaque durante o estudo histórico empreendido nos Capítulos anteriores; em segundo lugar, por não se tratar de uma disposição normativa, não se trata de um texto de Direito Positivo passível de análise institucional por este Sétimo Capítulo.

${ }^{787}$ Especialmente da integralidade dos itens 6.2.2., 6.3.1. e 6.3.3., supra.
} 
(principalmente, EUA versus URSS) ou mediante a rejeição da regência do sistema de convivência pela medida de existência do Federalismo Europeu.

A vertente positiva se dirigiu, por seu turno, tanto para (i) instituir e conservar a imanência na fundamentação do sentido normativo a ser dado no interior da vida comum da Europa - mediante a garantia de manutenção da horizontalidade nas relações entre as diferentes escalas de existência quando da solução de controvérsias, inclusive mediante a vedação da atribuição de Poderes semelhantes ao de um Estado aos órgãos comunitários, quanto para (ii) criar e assegurar a condição vazia do lugar do Direito e do Poder mediante contínua repulsão pluriescalar e multilateralmente direcionada do centro normativo da vida comum, quando da determinação do sentido último a ser dado às regulamentações previstas pelo Tratado sobre o carvão e o aço.

A conjunção histórica da vertente negativa e da vertente positiva é facilmente passível de ser compreendida a partir da leitura do Sexto Capítulo.

Deveriam ser rejeitadas as escalas de existência potencialmente Teológico-Políticas do interior da futura Europa Unida da CECA para (i) assegurar que escalas de existência estranhas às dinâmicas do interior da Europa não pautariam as decisões normativas (recusa da oposição escalar externa à Europa: EUA versus URSS), isto é, que as decisões sobre o sentido normativo na vida comum fossem dadas apenas e tão somente a partir de escalas de existência localizadas no interior da Europa; e (ii) garantir que o referencial normativo para lidar com questões concretas da vida em comum fosse pautado por condições imediatas dadas por uma solidariedade de fato, e não por uma entidade abstrata, ideal e imaginada (recusa da transcendência na definição dos referenciais normativos: Federalismo Europeu).

Ao mesmo tempo, haveria que se promover ativamente oposições escalares entre as diferentes dimensões existenciais componentes da vida em comum, de maneira a instaurar e a manter de maneira contínua uma dinâmica Política na organização jurídico-política das relações entre os países europeus unidos pela CECA. Não apenas (i) se reconheceram as medidas de existência que tipicamente conformavam as relações tradicionais na Europa (estatalidades), mas também (ii) se atribuiu papel fundamental a uma escala já existente (populidade) e (iii) criaram-se novas entidades portadoras de uma dimensão de existência nova (supranacionalidades). Foram todas elas mantidas em (iv) condições de igualdade, isto é, em uma posição igualmente horizontal na definição pluriescalar do sentido normativo sobre questões comuns; e (v) situação de permanente tensão entre si, a fim de assegurar um vazio no lugar do Direito e do Poder. 
O presente Capítulo analisa assim a tradução normativa de tal conjunção mediante a dupla aplicação (negativa e positiva) das normas de oposição escalares. Essa avaliação permitirá compreender a via propriamente jurídico-positiva por meio da qual foi realizado por mecanismos institucionais o estabelecimento prático da vida comum na Europa. $\mathrm{O}$ Direito Positivo (fenômeno jurídico) será objeto aqui de intencionalidades oriundas de distintos ramos do conhecimento (jurídicos e não-jurídicos), de maneira a conjugar simultaneamente as perspectivas Dogmática e Zetética Jurídicas e, com isso, interpretar o Tratado da CECA como fenômeno jurídico-político, isto é, passível de ter atribuído a si uma significação jurídico-política ${ }^{788}$.

Deste modo, o item 7.1. se dedicará ao exame da conservação normativa da imanência no interior da Europa Politicamente Unida a partir da vertente negativa. O item 7.2. analisará a instauração e a conservação normativas da imanência realizada por meio do uso positivo das normas de oposições escalares. Por fim, o item 7.3. terá por objeto as disposições normativas que instauraram e conservaram o vazio no lugar do Direito e do Poder mediante a criação e a promoção normativa de oposições escalares - entre estatalidades, supranacionalidades e populidade - no interior da CECA, também mediante isso positivo de normas de oposições escalares.

O leitor atento deve ter notado que, seguindo a divisão em quatro elementos das condições que caracterizam as Leis Políticas (tensão, pluridimensionalidade, imanência e vazio do lugar do Direito e do Poder) ${ }^{789}$, os três itens a seguir foram agrupados em torno de dois eixos principais, a saber: (i) instauração e conservação da imanência, mediante normas de oposição escalares atuando negativa e positivamente (itens 7.1. e 7.2.); e (ii) instauração e conservação de um vazio no lugar do Direito e do Poder mediante normas de oposição escalares atuando positivamente (7.3.).

Uma leitura apressada poderia sugerir que se teria esquecido a importância de ressaltar previamente a presença de normas de oposição escalares voltadas à promoção de tensões dimensionais, voltadas à manutenção de uma situação de plena pluridimensionalidade. Todavia, tão apressada seria essa leitura quanto rápida a percepção do engano derivado desta leitura superficial.

Com efeito, não é jamais demasiado esclarecer que o primeiro movimento desta análise institucional foi precisamente buscar entre as diversas normas jurídicas do Tratado

\footnotetext{
${ }^{788}$ Remetemos o leitor à integralidade do item 2.2., especialmente os subitens 2.2.3. e 2.2.4., todos supra, para maiores esclarecimentos em torno deste parágrafo no que se refere à conjunção de perspectivas Dogmática e Zetética Jurídicas.

${ }^{789}$ Conforme visto no item 3.4.4., supra, e aplicado ao longo dos três últimos Capítulos desta Tese.
} 
da CECA aquelas que continham em si alguma preocupação em lidar com oposições escalares. Em outras palavras, o ponto de partida da análise institucional do Tratado da CECA foi - em momento anterior à redação desta Tese, quando da realização da Pesquisa em si mesma ${ }^{790}$, encontrar naquele documento jurídico normas de oposições escalares. A presença mesmo destas era condição primeira para a realização bem sucedida da análise que se segue.

Dessa forma, uma vez feita a primeira leitura analítica, de caráter exploratório, e constatada a presença de tais espécies normativas, foi possível agrupá-las - da maneira como se manifestaram no Tratado da CECA - em torno de normas de oposições escalares voltadas à preservar a imanência negativa e positivamente, bem como em normas de oposições escalares voltas à conservar o vazio no lugar do Direito e do Poder por meio de atuação positiva.

O reconhecimento em si mesmo da existência de normas de oposições escalares no texto do Tratado de Paris de 1951 permite concluir pela presença de uma regulamentação jurídico-política pautada pela importância da co-presença em igualdade de condições de diferentes escalas de existência internas à Europa na definição do sentido normativo último de questões concretas comuns sensíveis.

Essa situação de valorização da pluriescalaridade em paridade de condições para executar uma tarefa compartilhada (deveres de participação e de obediência ${ }^{791}$ ) por si só permite concluir pela preferência de um ambiente institucional em que se compreende a importância da permanência de uma tensão escalar constante para decidir sobre questões comuns. Encontrar normas de oposições escalares significa encontrar de antemão uma ênfase na pluriescalaridade e na tensão escalar. Nesse sentido, para completar o quadro de interpretação proposto acima ${ }^{792}$, uma vez encontradas normas de oposições escalares, bastaria encontrar apenas a presença da preocupação com a imanência e com o vazio no lugar do Direito e do Poder em tais normas.

Assim, este Capítulo buscará apresentar que uma significação jurídico-política passível de ser extraída do Tratado da CECA é concluir que o Tratado de Paris de 1951 chamou para si a tarefa normativa de tornar explícita a posição Política das Leis constituintes da vida comum da CECA. O desempenho jurídico-institucional deste encargo foi realizado mediante o recurso, de diferentes maneiras, a normas de oposições, visando a

\footnotetext{
${ }^{790}$ Mais uma vez, retorna aqui a distinção entre o momento da Pesquisa e o da redação do relato lógica e coerentemente ordenado para a registrar por via escrita, mencionada na nota de rodapé 136, supra.

${ }^{791}$ Como ressaltado ao longo do Sexto Capítulo, supra, no relato da construção histórica da CECA.

${ }^{792}$ Item 3.4.4., supra.
} 
dois fins específicos - instaurar e preservar a imanência e o vazio no lugar do Direito e do Poder. A análise detalhada de cada um desses caminhos normativos traçados pelo Tratado da CECA é efetuada nos itens a seguir.

Por derradeiro, é importante efetuar uma última observação preliminar, de caráter formal, referente à lógica de exposição dos comentários aos artigos do Tratado da CECA, a fim de afastar eventuais confusões ou questionamentos referentes ao modo de apresentação das interpretações.

O mesmo leitor atento perceberá que a maneira de construir a argumentação variará em alguns momentos nos itens a seguir, o que não lhe deve causar estranheza ou qualquer suspeição de ausência de preocupação em estruturar sistematicamente as observações referentes aos artigos do Tratado da CECA. Em todos os casos, tratou-se de opção consciente por determinado modo de exibir as considerações sobre os artigos em função da extensão e da complexidade dos comentários.

Dito de outro modo, mais diretamente, quando o artigo em análise ensejar:

(i) um comentário mais curto e menos complexo, seja por ser um artigo menor, seja porque a parcela da disposição normativa do artigo que interessa metodologicamente ao presente estudo ${ }^{793}$ for menor, a exposição do comentário seguirá a seguinte racionalidade: (a) apresentação de uma paráfrase integral do(s) artigo(s) em questão; (b) breve explicação de seu significado normativo geral; (c) desenvolvimento de comentários que extraiam da integralidade do artigo sua significação jurídico-política; e

(ii) um comentário mais longo e mais complexo, seja por ser um artigo longo, seja porque o texto normativo condense em seu interior uma complicada trama regulatória que mereça ser cuidadosa e minuciosamente desenredada, a exposição do comentário seguirá a seguinte racionalidade: (a) apresentação de uma paráfrase integral do artigo, segmentada por cortes lógicos, que facilitem a compreensão de cada parte; (b) breve explicação do significado normativo geral de cada trecho, imediatamente após cada um deles; (c) desenvolvimento de comentários que extraiam de cada um dos segmentos seu significado jurídico-político, imediatamente após cada explicação dada em (b), procurando sempre estabelecer enlaces lógicos entre um trecho e outro, a fim de não perder a compreensão da integralidade da previsão normativa.

Deste modo, perceba-se que, em (i), a possibilidade de se desenvolver um comentário menos complicado permite a apresentação geral do artigo seguida

${ }^{793}$ Como visto acima, que lide normativamente com oposições escalares. 
imediatamente de interpretações jurídico-políticas, ao passo que, em (ii), a necessidade de se desdobrar um comentário mais complexo exige uma segmentação estruturada que impede a aposição de uma rápida e pronta interpretação jurídico-política do dispositivo do contrário, a compreensão da especificidade da leitura proposta por este estudo pelo leitor restaria prejudicada.

Para evitar mal-entendidos, o alerta acima visa a preparar o leitor aos próximos passos do percurso que iniciou. Sem dúvida, são os derradeiros passos desta Tese, mas também são certamente os mais áridos e os menos convidativos, por consistirem precisamente no momento em que a chave de leitura operará com todo o vigor, com seus conceitos e propostas novos, sobre a massa de um texto jurídico-normativo facilmente apreensível em sua simples materialidade do significante de Direito Positivo (Econômico ou não). Sobre este aspecto difícil da exposição, são pertinentes as palavras de Immanuel KANT (1980, p. 11, grifos do autor):

[r]eceio, porém, que aconteça à exposição do problema [...], apresentada da maneira mais extensa possível [...], o mesmo que aconteceu ao próprio problema como foi apresentado pela primeira vez. Será julgada incorretamente, porque não é compreendida; não será compreendida, porque se tem prazer em folhear o livro, mas não em meditar sobre ele; não se quererá dispender tal esforço, porque a obra é árida, obscura, porque é contrária a todos os conceitos costumeiros e por demais pormenorizada. Confesso que não esperava ouvir [...] queixas quanto à falta de popularidade, entretenimento e comodidade, quando se trata justamente da existência de um conhecimento de alta relevância, indispensável à humanidade [...; ] se seguirá com o tempo, a popularidade, mas jamais $\operatorname{logo}$ de início. A queixa só é justa no que se refere a uma certa obscuridade, causada em parte pela extensão do plano, que não permite que se deixem de lado os pontos principais, dos quais depende a investigação.

O alerta acima enunciado sobre a racionalidade expositiva a ser seguida nos itens a seguir visou a elucidar como se tentou construir neste trabalho uma maneira a mais didática possível para facilitar a compreensão pelo leitor da construção argumentativa seguida neste estudo.

Em outras palavras, buscou-se detalhar exponencialmente todos os aspectos que nas normas selecionadas para os comentários a seguir - pudessem trazer à claridade e evidenciar a possibilidade de se interpretar jurídico-politicamente as disposições normativas do Tratado da CECA para além da superfície dada pelos signos do Direito Positivo (Econômico ou não), sem se esquecer da importância de se recorrer a alguns meios estruturais ou a alertas prévios - como o feito acima - para auxiliar na produção da clareza discursiva ao leitor. 
Assim, a preocupação com o preciso desdobramento significativo jurídico-político de cada enlace normativo foi acompanhada igualmente por um cuidado sistemático de facilitar a leitura e o seguimento do raciocínio. Mas se reconhece desde já que a escolha por uma exposição didática talvez não tenha sido a mais privilegiada pelo presente texto, tendo em vista ter sido priorizada a necessidade de trazer a lume a camada jurídicopolítica subjacente à da materialidade do significante de Direito Positivo do Tratado da CECA $^{794}$.

\begin{abstract}
No que diz respeito à clareza, por fim, o leitor tem o direito de exigir não apenas, em primeiro lugar, uma clareza discursiva (lógica) por meio de conceitos, mas também, em seguida, uma clareza intuitiva (estética) por meio de intuições, i. e., exemplos ou outras elucidações in concreto. Da primeira eu cuidei suficientemente. Mas isso, que dizia respeito à essência de meu projeto, acabou sendo também a causa contingente de eu não poder dar a devida atenção à segunda exigência, que, embora não tão forte, é todavia justa. Em quase todo o curso de meu trabalho, fiquei constantemente em dúvida quanto a como lidar com isso. Exemplos e elucidações me pareciam sempre necessários e, assim, encontraram de fato, no primeiro esboço, os seus devidos lugares. Eu logo percebi, contudo, a grandeza de minha tarefa e a variedade dos objetos com que teria de lidar, e, como me dei conta de que estes talvez fossem suficientes para, numa linguagem seca [...] completar o trabalho, julguei pouco aconselhável estendê-lo ainda mais com exemplos e elucidações que somente são necessários de um ponto de vista popular; afinal, este trabalho não poderia pautar-se de modo algum pelos costumes populares, e os verdadeiros conhecedores das ciências não necessitam tanto desta suavização, que é sempre agradável, mas aqui poderia até mesmo ir contra os fins do trabalho. [...M] uitos livros poderiam tornar-se bem mais claros se não tentassem ser tão claros. Pois os meios auxiliares da clareza, que de fato ajudam no detalhe, com frequência atrapalham no geral, na medida em que não permite ao leitor chegar rápido o suficiente a uma visão de conjunto do todo e, mesmo com todas as suas cores brilhantes, acabam por embaralhar e tornar irreconhecível a articulação ou estrutura do sistema, da qual em geral depende, todavia, a possibilidade de julgar sobre a unidade e a solidez do mesmo. (KANT, 2012, p. 22-3, grifos do autor).
\end{abstract}

Deste modo, entenda-se que foram utilizados neste trabalho meios estruturais de elucidação de cada movimento lógico seguido pela interpretação do Tratado da CECA apenas quando estritamente necessários para uma elucidação temática geral da questão a ser debatida em cada item ou subitem a seguir. Entre a mais perfeita e fluida clareza da questão analisada e o mais profundo exame conceitual de cada dispositivo normativo a partir da chave de leitura selecionada, privilegiou-se o segundo aspecto.

\footnotetext{
${ }^{794}$ Afinal, "[é] verdade que nem a todos é dado escrever tão sutil e atrativamente [...] ou tão profunda e ao mesmo tempo elegantemente [...]." (KANT, 1980, p. 12); por essa razão, compromete-se em trabalhos posteriores a desdobrar separadamente diferentes aspectos e derivações analíticos singulares do exame empreendido neste estudo, a fim de que o trabalho de Pesquisa iniciado com esta Tese possa ser mais facilmente compreendido nos próximos anos.
} 


\title{
7.1. Conservação da Imanência por Vertente Negativa: Rejeição Normativa da
} Transcendência

\begin{abstract}
A significação não pode, por assim dizer, flutuar nos ares, mas o signo, do qual dizemos que ela é a significação, é totalmente indiferente àquilo que ela significa. (HUSSERL, 1980, p. 72).
\end{abstract}

O foco da atuação negativa das normas de oposições escalares do Tratado da CECA preocupadas em preservar a imanência do fundamento do sentido normativo sobre questões concretas sensíveis comuns ${ }^{795}$ consistiu em rejeitar normativamente uma eventual decisão futura pela introdução de um elemento transcendente na organização jurídicoPolítica estabelecida entre os seis Estados-Membros da Comunidade. Por meio da recusa deste elemento caracterizador de uma orientação Teológico-Política das Leis na nova forma de Europa Unida, o Tratado buscava assegurar à Comunidade a permanência de seu caráter Político.

A rejeição da transcendência praticada por algumas das normas do Tratado da CECA adquire preciso significado no interior da chave de leitura proposta por este trabalho: os autores daquele documento jurídico internacional reconheceram a presença de escalas de existência que rondavam as relações entre alguns países europeus e que ameaçavam introduzir na Europa uma regência normativa a partir unicamente de seus próprios padrões $^{796}$.

Com o objetivo de manter afastada a possibilidade do ingresso totalizante daquelas medidas de existência, os autores do Tratado de Paris de 1951 reconheceram tais dimensões existenciais e buscaram com elas lidar por meio das instituições da CECA, de maneira a impedir a introdução sorrateira nesta nova Comunidade destes modos de habitar o mundo. Dessa forma, os autores do Tratado incorporaram normativamente tais escalas de existência ameaçadoras para declarar de maneira explícita que suas instituições não admitiriam de forma alguma a introdução desses padrões existenciais estranhos aos objetivos Políticos da Comunidade ${ }^{797}$.

Este mecanismo de resistência jurídico-normativa à intromissão não-autorizada do Teológico-Político na CECA se orientou contra dois tipos distintos de ameaças

\footnotetext{
${ }^{795}$ Isto é, o uso e a administração do carvão e do aço.

${ }^{796}$ Como relatado de diferentes modos ao longo dos Capítulos Quarto e Quinto, supra.

${ }^{797}$ Por se tratarem de normas que buscaram lidar com escalas de existência que se opunham de alguma maneira às escalas de existência opostas no interior da Europa Unida da CECA, tais normas foram aqui reunidas sob a denominação comum de normas de oposições escalares.
} 
transcendentes, a saber: (i) uma oposição escalar externa à Europa (principalmente, EUA versus URSS); (ii) uma oposição escalar interna à Europa (Federalismo Europeu).

No primeiro caso, o caráter transcendente se origina do fato de a oposição escalar deriva da ambiência típica da Guerra Fria, na qual duas potências mundiais disputavam entre si o padrão normativo do mundo, ao passo que, no último caso, o caráter transcendente decorre da origem ideal, abstrata e imaginada do padrão normativo dos Direitos Humanos e da Democracia. Em outras palavras, se a rejeição deste representava a preocupação em garantir que a solução a ser dada ao tradicional conflito entre estatalidades isoladas não se pautaria pela realização concreta de um padrão normativo de um imaginário histórico em torno de uma "civilização europeia perdida", a recusa daquele consisia precisamente em pretender que as soluções a serem dadas na vida comum na Europa tivessem uma origem direta nas inter-relações da vida comunitaria - isto é, ninguém além dos envolvidos na vida em comum poderia pretender influenciar na formação do sentido normativo comum.

Assim, a conservação da imanência mediante normas de oposições escalares negativas visou a assegurar que (i) as decisões sobre o sentido normativo na vida comum seriam dadas apenas e tão somente a partir de escalas de existência localizadas no interior da Europa politicamente Unida; e (ii) o referencial normativo para lidar com questões concretas da vida em comum seria pautado por condições imediatas dadas por uma solidariedade de fato. São estes dois elementos que serão analisados nos dois subitens a seguir.

\subsubsection{A Rejeição Normativa da Transcendência Externa à Europa}

O artigo 93 do Tratado da CECA dispunha que a Alta Autoridade asseguraria com a Organização das Nações Unidas (ONU) e com a Organização Europeia de Cooperação Econômica (OECE) a manutenção de vínculos úteis e que manteria as duas Organizações Internacionais regularmente informadas sobre as atividades exercidas pela Comunidade ${ }^{798}$.

Em primeiro lugar, é importante ressaltar que o artigo não exclui qualquer relacionamento entre a CECA e a ONU, ou mesmo entre a CECA e a OECE. Muito pelo contrário, o referido dispositivo determinava de maneira expressa que a CECA não

798 Lembre-se de que a ONU não foi objeto de estudo por este trabalho por estar localizada metodologicamente fora do arco de questões desenhado para esta Tese por razões de ordem espacial (v., nesse sentido, a nota de rodapé 518, supra). A OECE foi examinada no Quarto Capítulo, supra. 
deixaria de manter com aquelas duas Organizações Internacionais relações que pudessem ser consideradas proveitosas e que, ainda por cima, a CECA não deixaria de as informar sobre as atividades desempenhadas pela vida comum instaurada entre os seis EstadosMembros da CECA. Todavia, há uma significação jurídico-Política que reside nesta singela disposição que merece ser mais bem detalhada.

Note-se que o texto normativo determina de forma bastante clara qual o tipo de relação que a CECA estabeleceria com a ONU e com a OECE: vínculos que fossem proveitosos e, ao mesmo tempo, apenas para as informar sobre as atividades praticadas pela Comunidade. Isso implica em reconhecer que esta norma jurídica em especial estabelecia de forma explícita quais seriam os limites dessa relação com as duas organizações: a CECA não poderia, mediante suas relações, se submeter a qualquer orientação oriunda dessas duas Organizações Internacionais. Dito de outro modo, sua relação com elas seria caracterizada pelo signo da independência.

Lembre-se nesse sentido de que, fundada juridicamente pela Carta de São Francisco, de 26.6.1945, a ONU se constituiu como uma Organização Internacional de vocação universal, isto é, uma Organização Internacional global ${ }^{799}$ dotada de objetivos gerais, tais como manter a Paz e a Segurança Internacionais, desenvolver relações amistosas entre as nações, entre outros ${ }^{800}$. Seu foco de atuação não era especificamente a Europa, mas a reorganização jurídica das relações entre todos os povos do globo.

Ao mesmo tempo, como visto algumas linhas acima, a $\mathrm{OECE}^{801}$ foi uma Organização Internacional europeia moldada a partir de oposições escalares desenvolvidas durante o período da Guerra Fria entre os EUA e a URSS, a fim de assegurar a execução do auxílio econômico estadunidense consubstanciado no Plano Marshall, destinado a reconstruir economicamente a Europa. Seu objetivo era assegurar que a Europa Ocidental se desenvolvesse economicamente segundo a orientação jurídico-econômica estadunidense $^{802}$.

\footnotetext{
799 Isto é, não adstrita a uma região específica do globo, como a CECA, a OECE, o CdE, a atual UE, entre tantos outros exemplos possíveis.

${ }^{800}$ A mera leitura do artigo primeiro da Carta de São Francisco, de 1945, esclarece com maiores precisões os objetivos da ONU.

Como visto nas notas de rodapé 518 e 798, ambas supra, um estudo mais aprofundado da ONU não cabe neste trabalho, razão pela qual não se voltará a tecer qualquer outro comentário sobre ela neste texto. A ONU surge aqui apenas como um reforço para a argumentação que segue neste item em particular: a independência da CECA com relação às orientações normativas oriundas de escalas de existência habitantes da exterioridade.

${ }^{801}$ V. comentários desenvolvidos no Quarto Capítulo, especialmente nos itens 4.2.1. e 4.3., todos supra.

802 Apesar de, como visto acima, ter sido este intento de ingresso de Leis Teológico-Políticas na Europa barrado pela realização concreta da OECE em uma Organização Internacional intergovernamental, a qual
} 
Em outras palavras, não se pode deixar de notar que tanto a ONU como a OECE não tinham como referência um padrão normativo gestado internamente na Europa, vale dizer, aquelas duas Organizações Internacionais não procuravam resolver o problema da tradicional oposição escalar entre as estatalidades isoladas da Europa por meio do recurso a uma dinâmica tipicamente europeia. Se uma visava a Europa a partir de uma escala de existência cosmopolita e pretensiosamente universal (ONU), a outra visava a Europa a partir de uma dimensão existencial local estadunidense enquanto em oposição à URSS (OECE).

Por esse motivo, apesar de o dispositivo ora em comento declarar haver a preocupação em se manter utilmente relações regulares de informação entre CECA e ONU e entre CECA e OECE, há que se notar que o Tratado de Paris de 1951 teve o cuidado em apor de maneira escrita que de maneira alguma esta relação ultrapassaria essa mera colaboração entre Organizações Internacionais. Dito de outro modo, o Tratado da CECA estabelecera normativamente que sua Organização Internacional europeia não estabeleceria qualquer vínculo de submissão com as outras duas Organizações Internacionais - apesar de não negar a importância de se estabelecerem contatos contínuos e potencialmente proveitosos entre as três.

Nesse sentido, note-se que há uma significação jurídico-Política peculiar neste dispositivo. As escalas de existência gestadas fora do ambiente europeu não deveriam ser consideradas como adequadas para fornecer um sentido normativo para a resolução dos conflitos escalares tradicionais entre os Estados europeus. Por essa razão, estas oposições dimensionais externas à Europa deveriam ser mantidas à distância, isto é, fora da possibilidade de influenciar as decisões normativas a serem tomadas na vida comum/comunitária estabelecida pelo Tratado de Paris de 1951.

Assim, o artigo 93 do Tratado da CECA surge como um dispositivo normativo que (i) percebe a ronda efetuada por escalas existenciais externas que poderiam pretender eventualmente e de maneira progressiva se imiscuir na produção do sentido normativo a ser dado sobre questões comuns, e que, por essa razão, (ii) declara de maneira expressa que as relações a serem mantidas entre a CECA e essas escalas de existência não ultrapassarão a estrita dimensão da colaboração entre Organizações Internacionais.

Trata-se deste modo de explícita recusa jurídico-normativa manifesta a eventual tentativa futura de sujeição da vida comum da CECA a parâmetros dimensionais gestados 
na exterioridade da Europa e apenas orientados pela exterioridade. A norma aqui comentada operava assim como baluarte voltado à preservação de orientações imanentes na condução das soluções normativas comuns da Europa.

Bastião ostensivo da independência da vida comum da Europa com relação à determinação externa de suas próprias questões, o artigo 93 representava evidente recusa à introdução na formação compartilhada da vida em comum europeia de mecanismo não especificamente voltado a solucionar a tradicional oposição escalar entre estatalidades isoladas na Europa ${ }^{803}$. Assim, rejeitada a transcendência oriunda da exterioridade da Europa, tais disposições normativas procuraram manter institucionalmente a imanência na definição do sentido normativo comum.

\subsubsection{A Rejeição Normativa da Transcendência Interna à Europa}

A principal ameaça Teológico-Política de unidimensionalização das relações na Europa não residia na exterioridade da Europa. Ela habitava antes no interior da Europa, ou ainda, no coração de determinado pensamento jurídico-político europeu sobre uma União política da Europa, a saber, no centro mesmo dos preceitos de uma organização jurídico-política da Europa segundo os termos do Federalismo Europeu. Por esse motivo, essa questão recebeu tratamento específico no Tratado da CECA, tendo em mente afastar a influência de um arcabouço significativo imaginado na formulação das decisões normativas sobre questões comuns.

\subsubsection{Observações Gerais acerca do Protocolo}

$\mathrm{O}$ artigo 94 do Tratado da CECA estipulou de maneira expressa que as relações entre as instituições da CECA e o CdE teriam suas condições determinadas de maneira

\footnotetext{
${ }^{803}$ Poder-se-ia indagar aqui sobre a ausência da menção à Organização do Pacto de Bruxelas, que instituíra uma cooperação militar intergovernamental entre os países da Europa.

Como visto no item 4.2.2., supra, imediatamente após a instituição da OTAN, toda a Organização do Pacto de Bruxelas foi absorvida pela OTAN e submetida à regência estadunidense. Nesse sentido, talvez se pudesse cogitar que se compreendera que já se havia anteposto limite institucional suficiente para barrar o ingresso das pretensões unidimensionalizantes estadunidenses na vida comum da Europa Politicamente Unida.

Por esse motivo, talvez não se entendesse ser necessário mencionar aqui um igual afastamento velado do Pacto de Bruxelas com relação à determinação do sentido normativo a ser impresso pela vida comum da CECA mediante uma norma que limitasse suas interações a relações de útil colaboração: a manutenção à distância da Organização do Pacto de Bruxelas já estaria assegurada pelo submissão integral de sua estrutura à OTAN!
} 
específica por regulamento próprio, constante de um Protocolo anexo ao texto do Tratado. Em outras palavras, em vez de relegar a solução desta temática a esparsas e potencialmente lacônicas linhas de um único artigo do Tratado, essa questão se mostrava de tão grande importância que se optou institucionalmente por um tratamento jurídico-normativo especializado e detido por parte do Direito Internacional: o Protocolo sobre as Relações da CECA com o Conselho da Europa.

Neste Protocolo em especial, os autores do Tratado da CECA procuraram detalhar em seis artigos de que maneira percebeiam que se deveria se desenvolver vínculos entre a nova Organização Internacional europeia e o CdE. Afinal, não é demais lembrar que diferentemente da CECA - o CdE se estruturara institucionalmente para realizar uma cooperação política de caráter intergovernamental, apesar de ter assumido a missão de instaurar uma organização jurídico-Teológico-Política (Leis Teológico-Política) na Europa segundo o ideário Federalista Europeu ${ }^{804}$.

As duas Organizações Internacionais se orientavam à solução de questão interna à Europa. Todavia, cada uma delas era representante de distintos Projetos de Europa politicamente Unida: (i) o $\mathrm{CdE}$, por meio da submissão de todas as relações entre as estatalidades ao padrão normativo único do Federalismo Europeu - Direitos Humanos e Democracia no interior de um Estado Federal Europeu (Leis Teológico-Políticas); (ii) a CECA, mediante a manutenção de relações continuamente tensas entre diferentes escalas de existência, sem qualquer opção normativa prévia por alguma referência escalar única e universal (Leis Políticas).

Assim, (i) cada uma delas exercia institucionalmente a tarefa de efetuar a aproximação política de países europeus (respectivamente, cooperação política intergovernamental versus convivência entre diferentes), mas (ii) as propostas de cada um delas eram qualitativamente distintas (respectivamente, Leis de unificação da pluralidade versus Leis de convivência plural permanente).

Por esse motivo, era fundamental (i) não apenas estabelecer de maneira genérica se haveria uma relação entre o CdE e a CECA; mas, principalmente, uma vez decidido que seriam mantidas relações entre ambas, (ii) detalhar e delimitar especificamente em que termos essa relação deveria se desenvolver.

\footnotetext{
${ }^{804}$ Vale dizer, alicerçado na afirmação da necessidade imperiosa de instituir um Estado Federal Europeu comprometido com a realização absoluta e incondicional dos Direitos Humanos e da Democracia na Europa e, posteriormente, no mundo. Nesse sentido, remetemos o leitor aos Capítulos Quinto e Sexto, supra, principalmente aos itens 5.2.2., 5.4.2. e 6.2.2.
} 
É possível compreender no interior dessa chave explicativa a remissão do artigo 94 do Tratado da CECA ao referido Protocolo: tratar-se-ia de tecido normativo preocupado com entrechoques entre distintas dimensionalidades, pois havia no Tratado uma preocupação em lidar normativamente com um embate escalar entre um discurso de afeito à unidimensionalização $(\mathrm{CdE})$ e outro afinado a uma perspectiva pluriescalar permanente (CECA). Em outras palavras, tratava-se de uma construção jurídico-normativa típica de normas de oposições escalares.

O referido artigo 94 foi explícito ao declarar que o Tratado da CECA reconhecia ser importante estabelecer e manter relações entre as instituições da CECA e o CdE. Ele realizara a tarefa de declarar de modo genérico que os autores do Tratado da CECA reconheciam ser importante se relacionar com o CdE. Todavia, dada a contradição entre os Projetos de Europa politicamente Unida portados por um e por outro, os autores do Tratado entenderam por bem estabelecer no Protocolo anexo ao Tratado de que maneira a relação deveria se desenvolver.

É neste segundo momento que se revela com clareza o movimento de cristalizar institucionalmente a rejeição da transcendência interna à Europa. Malgrado o reconhecimento da importância de se estabelecer relações entre CECA e CdE, estas seriam voltadas de maneira consciente a impedir a introdução do credo Teológico-Político do Federalismo Europeu no centro pluriescalarmente compartilhado de formação do sentido normativo da CECA. Mais simplesmente, tais relações seriam orientadas para manter afastado o perigo da unidimensionalização.

\subsubsection{A Chave de Compreensão: Paridade e Independência}

A chave de compreensão do conjunto normativo constante do Protocolo sobre as Relações da CECA com o CdE exsurge precisamente a partir da leitura do último artigo daquele documento jurídico: neste dispositivo se determinava que acordos entre as duas Organizações Internacionais poderiam prever todas outras formas de assistência mútua e de colaboração entre ambas (artigo seis do Protocolo).

A expressão todas outras formas introduzida pelo dispositivo ora em comento inaugura dois feixes de significações que permitem esclarecer a concepção dos autores do Tratado de Paris de 1951 sobre o modo segundo o qual deveriam se desenvolver as relações entre a CECA e o CdE. Ela exerce um papel de conector de sentido entre as 
modalidades de relações anteriormente regulamentadas pelo Protocolo e as futuras relações a serem acordadas entre CECA e CdE, visando à equalização qualitativa delas.

Em outros termos, isso quer dizer que o referido artigo reconhece como iguais em espécie tanto as relações disciplinadas anteriormente ao próprio artigo no mesmo Protocolo, quanto aquelas a serem eventualmente formalizadas no futuro mediante acordos específicos entre CECA e CdE.

Nesse sentido, o artigo seis do Protocolo agrupava as relações reguladas pela disciplina jurídico-normativa a ele anterior sob um atributo único e comum e projetava tais características a eventuais relações futuras, determinando normativamente que deveriam ter exatamente o mesmo vigor tanto as relações regulamentadas anteriormente, como as ainda não regulamentadas.

Ao recorrer à expressão todas outras formas, o artigo estabelece normativamente, ao mesmo tempo, (i) o reconhecimento de um preciso caráter comum entre as formas de relações já disciplinadas; e, diante da regulamentação imediatamente anterior, (ii) um limite jurídico-político geral de caráter prospectivo. Todas outras formas quer dizer aqui todas as formas outras, qualitativamente iguais às anteriores, que poderão ser estabelecidas eventualmente entre CECA e CdE no futuro e que terão, pelo fato de serem iguais, potência vinculante equivalente.

É necessário examinar um pouco mais os termos do mesmo artigo seis, na medida em que ele estabelece quais são exatamente as características que deverão reger de maneira igual, tanto as relações entre CECA e CdE já disciplinadas pelo Protocolo, como as novas relações entre ambos. São os termos que seguem a expressão todas outras formas que circunscrevem o tipo de vinculação entre as duas Organizações Internacionais europeias admitido pelo Protocolo.

Pois bem. Como visto acima, o artigo seis afirma que acordos futuros entre CECA e CdE poderão estabelecer todas outras formas de assistência mútua e de colaboração entre as duas Organizações Internacionais.

Diante da bipartição significativa acima mencionada, pode-se concluir que o texto do Protocolo reconhece como equivalentes - ou ainda, o que é o mesmo, disciplina normativamente a equalização entre - as relações regulamentadas em seus outros artigos e aquelas a serem futuramente pactuadas em um sentido bastante específico. O primeiro tipo de relações não era, como o último não poderia almejar ser, nada além de mera concertação entre entidades independentes e iguais, haja vista que ambas apenas podem colaborar entre si e assistir-se mutuamente. 
Em outras palavras, o artigo seis do Protocolo ora em comento determinava normativamente um marco jurídico que atuava em duas direções, com o objetivo de afirmar de maneira incondicional que tanto a CECA, como o CdE, deteriam o mesmo status jurídico-político em suas relações: seriam Organizações Internacionais europeias preocupadas com uma aproximação política entre países europeus que, todavia, não manteriam entre si qualquer relação de hierarquia de uma com relação à outra.

Deste modo, perceba-se que a disposição do próprio Protocolo estabelecia uma situação paritária da CECA com relação ao CdE, na medida em que a CECA estaria em pé de igualdade com relação ao CdE. Consideradas como pares internacionais jurídico-políticos, CECA e CdE poderiam relacionar-se, celebrar acordos, e mesmo aprofundar suas relações, mas em nenhum dos casos uma poderia se perceber como submissa ou superior à outra. O leque de relações que poderiam ser assumidas pela CECA perante o CdE era limitado à simples categoria comum de assistência mútua ou de colaboração - mas jamais de subalternidade (obediência) ou de supremacia (mando).

Por isso, o artigo seis do Protocolo estabelece qual é a tônica normativamente aceita pelo documento jurídico para guiar as relações institucionais entre CECA e CdE: Organizações Internacionais europeias autônomas, independentes e iguais, não devendo haver qualquer pretensão de uma colocar-se acima ou abaixo da outra. Diante dessa conclusão, pode-se agora compreender o conjunto dos demais dispositivos que constavam do Protocolo.

\subsubsection{Derivações Interpretativas: Explicitação Normativa da Não-Subordinação} da CECA ao CdE

A marca característica das relações a serem estabelecidas entre CECA e o CdE foi enunciada de maneira mais explícita no artigo seis do Protocolo ora analisado: igualdade de condições, mútua independência e ausência de qualquer forma de submissão. Os demais artigos do referido documento jurídico regulamentam situações que podem ser compreendidas como exemplos pontuais que apenas reforçam de maneira mais explícita a opção normativa dos autores do Tratado da CECA pela declaração de completa nãosubordinação desta Organização Internacional ao CdE. 
7.1.2.3.1. Informação e Declaração da Independência Jurídico-Política da CECA

Essa situação se revela de maneira clara a partir da simples leitura do artigo cinco do mesmo Protocolo, o qual estabelecia que o Tratado que institui a CECA e seus anexos seriam registrados perante a Secretaria Geral do CdE. Essa previsão apenas ressalta a condição independente da CECA perante o CdE.

$\mathrm{Na}$ esteira da regulamentação constante do artigo seis ${ }^{805}$, não se pode deixar de notar que o artigo cinco reconhecia ser importante à CECA manter alguma relação com o CdE: este deveria ter disponível diante de si uma cópia do instrumento constitutivo daquela, a fim de que tomasse conhecimento e se informasse sobre as estruturas institucionais da CECA e sobre sua lógica de funcionamento.

A remessa do Tratado da CECA à Secretaria Geral do CdE detinha a função precisa de informar este precisamente sobre a existência, sobre instituição e sobre o funcionamento da CECA. E é neste específico ponto que se revela, ao menos em dois sentidos, a decisão normativa de excluir a possibilidade de se mesmo pensar uma eventual subordinação da CECA ao CdE.

Com efeito, em primeiro lugar, o artigo cinco elimina qualquer possibilidade de dúvida em torno da não-submissão da CECA ao CdE: o Tratado Constitutivo da nova Organização Internacional europeia não seria enviado ao $\mathrm{CdE}$ para ser examinado e eventualmente aprovado. Muito pelo contrário: este texto seria somente encaminhado à Secretaria Geral daquela outra Organização Internacional para ser registrado - isto é, apenas para, com isso, "dar ciência" ao CdE sobre a existência, a estrutura e o funcionamento da CECA.

Deste modo, sem dizer expressamente - mas também não dispondo de maneira diversa, o dispositivo ora em análise exclui a possibilidade de qualquer espécie de avaliação do texto do Tratado Constitutivo da CECA por parte do CdE. A este caberia a simples tarefa de receber o documento jurídico-normativo e registrá-lo em sua Secretaria Geral, sendo impossível qualquer questionamento jurídicopoliticamente válido sobre o texto do Tratado. Em outras palavras, a ação do CdE sobre o Tratado da CECA estaria adstrita a um mero conhecimento dos termos deste e ao posterior registro do documento em sua Secretaria Geral - e nada mais.

${ }^{805}$ Examinado no item exatamente anterior, 7.1.2.2. 
Por outro lado, em segundo lugar, o mesmo artigo cinco pode ser compreendido ainda no interior de outra chave interpretativa: exercer normativamente a função de efetiva “declaração de independência” jurídico-política da CECA perante o CdE. Isso porque não apenas o Protocolo retirara a necessidade de qualquer aprovação prévia dos termos do Tratado da CECA por parte do CdE, como também comunicara a esta Organização Internacional que os autores do Tratado da CECA haviam conscientemente retirado essa necessidade.

Dito de outro modo: no interior desta segunda perspectiva, ao determinar que o Tratado da CECA seria encaminhado à Secretaria Geral do CdE para um simples registro, o artigo cinco do Protocolo sobre as Relações entre a CECA e o CdE estampava e escancarava ao CdE que este não poderia exercer qualquer espécie de controle sobre este novo Projeto de Europa Politicamente Unida.

Nesse sentido, ao "apenas" informar o CdE sobre o conteúdo do Tratado da CECA, os autores da nova Organização Internacional europeia também performavam uma deliberada declaração ao CdE. Mediante esta "simples" comunicação, o CdE deveria se tornar consciente que, apesar de ser uma iniciativa temporalmente anterior de aproximação política de países europeus, a criação, o estatuto e o funcionamento da CECA não assegurariam qualquer forma de controle ou de interferência na formação do sentido normativo sobre decisões concretas comuns sensíveis por parte do ideário que informara a constituição do $\mathrm{CdE}$.

Deste modo, a aproximação política encetada pela CECA não dependeria de qualquer forma de aprovação por parte do processo jurídico-político iniciado pelo CdE e, mais do que isso, ela se autocompreendia de maneira consciente como desvinculada absolutamente de qualquer forma de determinação por parte do CdE. A comunicação e o registro do Tratado da CECA perante a Secretaria Geral do CdE informariam este não apenas da existência, do estatuto e do funcionamento da CECA, mas principalmente também que a CECA se autoconhecia como independente de qualquer possível determinação jurídico-política estranha à vida comum inaugurada sobre sua solidariedade de fato. 


\subsection{A Alta Autoridade perante o CdE: Deveres de Mera Comunicação}

Em sentido bastante próximo podem ser entendidos conjuntamente os artigos três e quatro do mesmo Protocolo, os quais regulamentavam as relações entre a Alta Autoridade e as duas principais instituições do CdE (Assembleia Consultiva e Comitê de Ministros).

$\mathrm{O}$ artigo três do Protocolo determinava que a Alta Autoridade deveria encaminhar a cada ano ao Comitê de Ministros e à Assembleia Consultiva do CdE o Relatório Geral sobre a Atividade da Comunidade e sobre suas Despesas Administrativas previsto no artigo 17 do Tratado da $\mathrm{CECA}^{806}$. Por sua vez, o artigo quatro do mesmo Protocolo estabelecia que a Alta Autoridade daria conhecimento ao Conselho da Europa sobre o resultado que ela dera às recomendações que eventualmente lhe fossem dirigidas pelo Comitê de Ministros do $\mathrm{CdE}^{807}$.

É ao menos interessante notar um aspecto formal bastante peculiar: as duas tarefas da Alta Autoridade acima brevemente descritas derivam de deveres estabelecidos pelo Protocolo anexo ao Tratado da CECA. Em outras palavras, tais obrigações a serem cumpridas pela Alta Autoridade da CECA perante o CdE decorrem, não de qualquer pretensa submissão sua ao $\mathrm{CdE}$, mas de incumbência dada pelos autores do Tratado da CECA.

Isso implica reconhecer desde já que não se poderia admitir a compreensão de que a Alta Autoridade da CECA estaria de alguma forma prestando contas de sua atividade perante os órgãos do $\mathrm{CdE}$, ou melhor, que ela estaria relatando o cumprimento ou descumprimento de deveres a ela designados pelos órgãos do CdE. Com efeito, a base jurídica de sua obrigação não era qualquer documento jurídico-normativo produzido por um dos dois principais órgãos do CdE, mas o próprio Tratado Constitutivo da CECA.

${ }^{806}$ O artigo 17 do Tratado da CECA não será examinado neste Capítulo, haja vista que não se insere no recorte metodológico estabelecido por este trabalho para selecionar as normas jurídicas a serem comentadas. Assim, basta mencionar neste texto - a fim de esclarecer ao leitor as informações que são mencionadas pelo dispositivo normativo examinado - que o artigo 17 do Tratado da CECA determina que a Alta Autoridade deveria publicar anualmente, um mês antes da abertura da Sessão da Assembleia Comum, um Relatório Geral sobre a Atividade da Comunidade e sobre suas Despesas Administrativas.

${ }^{807}$ O Poder do Comitê de Ministros do CdE de elaborar recomendações era previsto no artigo 15, alínea b, do Estatuto do CdE e era dirigido, na verdade, aos Governos dos países membros do CdE. A referência a este artigo 15, alínea b, é feita pelo próprio artigo 4 do Protocolo, o que pode causar estranheza.

De todo modo, a possibilidade de se relacionar com autoridades especializadas criadas entre membros do CdE em território europeu foi prevista pela Resolução adotada pela Oitava Sessão do Comitê de Ministros, em 3.5.1951 - isto é, cerca de quinze dias após a assinatura do Tratado da CECA. A partir daquela oportunidade, o CdE estava autorizado (item v do tópico sobre Autoridades Especializadas) a enviar recomendações também a tais autoridades europeias especializadas - e, dessa forma, também seria admissível o eventual envio de recomendações à CECA. Diante dessa autorização expressa, aquele estranhamento inicial desapareceria. 
Nesse sentido, não se poderia pensar em qualquer cumprimento de deveres perante o CdE, simplesmente porque a fonte da obrigatoriedade desta atividade residia autonomamente no próprio texto jurídico-normativo constitutivo da CECA e de suas principais instituições.

Neste particular, note-se que a Alta Autoridade estava obrigada a desempenhar tais atividades perante o $\mathrm{CdE}$ apenas e tão-somente porque assim fora estabelecido em no Tratado de Paris de 1951 - um documento jurídico-normativo internacional absolutamente independente de qualquer avaliação ou aprovação por parte do $\mathrm{CdE}$, como visto anteriormente $^{808}$. Dessa forma, a permanência dessa obrigação da Alta Autoridade perante os órgãos do $\mathrm{CdE}$ apenas seria mantida caso tal previsão fosse conservada no estatuto jurídico-normativo internacional que instituíra esse dever - ou, o que é o mesmo, que lhe dera fundamento jurídico-normativo.

Assim, antes que uma leitura apressada quisesse poder concluir por uma submissão jurídica da Alta Autoridade da CECA perante o $\mathrm{CdE}$, é imprescindível que haja o estabelecimento claro do fundamento deste dever: uma ordem jurídica particular completamente independente da ordem jurídica produzida pelo $\mathrm{CdE}$, a saber, a ordem jurídico-positiva constante do Tratado da CECA.

Deste modo, submetendo-se apenas ao próprio arranjo jurídico-normativo positivo constante do Tratado da CECA, a Alta Autoridade firmava sua independência e sua autonomia perante o CdE. Sem dúvida deveria se relacionar com este, não em virtude de qualquer subordinação sua ao $\mathrm{CdE}$, mas por estar vinculada a sua própria ordem jurídicopositiva constitutiva: o Tratado de Paris, de 1951.

Se apenas a análise formal do fundamento do dever a ser desempenhado pela Alta Autoridade da CECA perante o CdE já demonstra que a primeira permanece vinculada à própria ordem normativa, e não submetida ao CdE, um exame mais atento da espécie de conduta a ser desempenhada por aquela instituição da CECA permite reforçar a percepção de que o vínculo entre ambas apenas ressaltava a não-subordinação jurídico-política da CECA ao CdE.

Como afirmado acima, o artigo três do Protocolo determinava que a Alta Autoridade deveria encaminhar a cada ano ao Comitê de Ministros e à Assembleia Consultiva do CdE o Relatório Geral sobre a Atividade da Comunidade e sobre suas Despesas Administrativas previsto no artigo 17 do Tratado da CECA. A mera descrição 
desse dever ressalta por si o quão autônomas a Alta Autoridade da CECA e a própria CECA se autocompreendiam perante o CdE.

Note-se que a Alta Autoridade deveria encaminhar aos dois órgãos principais do CdE um Relatório de Atividades e de Despesas Administrativas da Comunidade. A apresentação deste Relatório não pode ser percebida como uma atividade especialmente dedicada da Alta Autoridade com relação ao CdE. Na verdade, ele se tratava precisamente do mesmo Relatório que, por força do artigo 17 do Tratado da CECA, a Alta Autoridade deveria publicar anualmente um mês antes da abertura da Sessão da Assembleia Comum.

Nesse sentido, a Alta Autoridade não se submeteria a um desgaste adicional para comunicar um documento especialmente solicitado pelo CdE: antes, ela apenas remeteria uma simples cópia deste mesmo Relatório, a fim de que a Assembleia Consultiva e o Comitê de Ministros tomassem ciência de suas atividades. Não se tratando de prestação de contas a uma entidade superior, tal Relatório apenas comunicaria às duas instituições do $\mathrm{CdE}$ informações concernentes à CECA, não havendo qualquer comprometimento de suas atividades.

Isso é mais bem explicitado pelo seguinte aspecto: não havia qualquer previsão no Protocolo ora em análise, referente à remessa de tal cópia do Relatório Anual ao CdE, de necessidade de aprovação das contas ou das atividades da CECA pelo CdE. O envio de tal documento apenas fazia as vezes de um comunicado formal daquilo que praticava a Comunidade ao CdE. Deste modo, não havia qualquer possibilidade de o CdE influenciar nas atividades e nas despesas da CECA, porque esta não reconhecera normativamente qualquer possibilidade de ser nestes termos controlada pelo $\mathrm{CdE}$.

Assim, esse dispositivo apenas assegurava que as informações da Comunidade tornadas públicas pelo Relatório chegariam às principais instituições do CdE e seriam por elas conhecidas. Nada além desta mera ciência por parte do CdE seria admitida pelo Tratado da CECA com relação às atividades da Comunidade.

Não se pode deixar de comentar ainda o artigo quatro do mesmo Protocolo. Este dispositivo estabelecia que a Alta Autoridade daria conhecimento ao Conselho da Europa sobre o resultado que ela dera às recomendações que eventualmente lhe fossem dirigidas pelo Comitê de Ministros do CdE. Da mesma maneira que o último artigo comentado, esse dever da Alta Autoridade não poderia ser compreendido como manifestação de prestação de contas a uma entidade superior. 
Lembre-se que, como visto anteriormente ${ }^{809}$, a atividade dos órgãos do $\mathrm{CdE}$ não detinha a aptidão de vincular seus Estados-Membros. Enquanto iniciativa de aproximação política em caráter de cooperação intergovernamental, o CdE era bastante limitado em sua capacidade de atuação. Nesse sentido, se as decisões de seus órgãos poderiam ser imediatamente vinculantes em âmbito interno, o mesmo não dizia respeito com relação a seus Estados-Membros ou com relação às Organizações Internacionais europeias que estes compunham.

Dessa forma, o referido artigo se refere a recomendações produzidas pelo Comitê de Ministros do CdE com relação à CECA, isto é, a disposições normativas nãovinculantes em termos jurídicos. Não sendo juridicamente obrigatórias, não haveria como exigir da Alta Autoridade da CECA seu cumprimento, isto é, a incorporação destas meras sugestões do Comitê de Ministros no interior da atividade normativa da Comunidade. Assim, o artigo quatro do Protocolo exerce uma tripla função normativa:

(i) em primeiro lugar, ele lembra de maneira explícita que as decisões do Comitê de Ministros do CdE sobre as atividades da CECA não são nada além de meras recomendações, simples conselhos desprovidos de exigibilidade jurídica e, que, como tal, não são nem obrigatórios, nem vinculantes; por essa razão mesmo,

(ii) em segundo lugar, ele frisa a condição de independência detida pelo centro normativo da CECA: o lugar do Direito e do Poder da vida em comum estaria imunizado a qualquer forma de influência direta ou indireta pretendida por decisões do $\mathrm{CdE}$ - pois estas não passariam de simples recomendações; e, deste modo,

(iii) em terceiro lugar, ele busca lembrar de maneira escancarada ao CdE sua própria condição de entidade frágil e desprovida de Poderes efetivos para efetuar qualquer União política da Europa: a Alta Autoridade era continuamente obrigada pelo Tratado da CECA a lembrar de maneira ininterrupta o quão distante estava a realização normativa das recomendações a ela dirigidas pelo Comitê de Ministros do CdE com relação às decisões deste órgão. Suas recomendações eram apenas diretrizes e jamais poderiam pretender determinar de um modo ou de outro as atividades da CECA.

Tratava-se assim de uma maneira de trazer incessantemente perante o CdE e perante a própria CECA a consciência renovada de inexistir por parte do CdE qualquer capacidade de sujeição das atividades da CECA - inclusive de suas atividades normativas. Ou ainda, mais simplesmente, tratava-se de uma opção normativa por escancarar ao

${ }^{809}$ Capítulo Quinto, supra. 


\section{CdE sua profunda impotência jurídico-política perante a CECA, de maneira a lembrar tanto a Alta Autoridade, como o $\mathrm{CdE}$, que este jamais poderia pretender alçar uma posição de mando esperando, daquela, obediência.}

\subsection{A Interação entre Assembleias: Um Diálogo Inofensivo}

Há que se comentar ainda os dois primeiros artigos do Protocolo. A leitura de ambos permite reforçar ainda mais de que maneira os autores do Tratado da CECA pretenderam estabelecer relações entre a nova Organização Internacional europeia e o CdE, sem que isso pudesse implicar qualquer forma de subordinação da CECA ao CdE.

$\mathrm{O}$ artigo um do Protocolo convidava os Estados-Membros da CECA a recomendarem a seus respectivos Parlamentos que indicassem para compor a Assembleia Comum da CECA pessoas que já exercessem a função de representantes na Assembleia Consultiva do CdE. Por sua vez, o artigo dois do mesmo Protocolo determinava que a Assembleia Comum da Comunidade deveria apresentar a cada ano um Relatório de suas atividades à Assembleia Consultiva do CdE.

A leitura conjunta dos dois artigos poderia suscitar a impressão de que, neste momento, o Protocolo estabelecera uma vinculação muito mais íntima entre as duas Assembleias do que se comparado com as disposições analisadas anteriormente ${ }^{810}$. Afinal, talvez deste modo houvesse a possibilidade de se cogitar uma eventual coerência de trabalhos entre as duas Assembleias, na medida em que ambas compartilhariam não apenas fisicamente o mesmo espaço ${ }^{811}$, como também as mesmas pessoas. E talvez, de maneira distante, uma eventual influência recíproca, principalmente do CdE na CECA.

Essa perspectiva é, todavia rapidamente mitigada a partir da análise a seguir.

$\mathrm{O}$ artigo um do Protocolo estabelecia um mecanismo jurídico profundamente debilitado: os Estado eram apenas "convidados" - e não obrigados - a fazer algo, a saber, a "recomendar" - e não mandar, determinar, impor - que seus respectivos Parlamentos nacionais escolhessem dentre seus representantes na Assembleia Consultiva do CdE os membros da Assembleia Comum.

A orientação normativa quase perde aqui sua robustez jurídica: em momento algum houve a atribuição de uma ordem a qualquer entidade. Nesse sentido, essa previsão de método de escolha se mostra como simples indicação sem qualquer objetivo de ensejar

\footnotetext{
${ }^{810}$ V. os itens 7.1.2.2., 7.1.2.3.1. e 7.1.2.3.2, supra.

${ }^{811}$ Como visto no final do item 6.3.4., supra, bem como na nota de rodapé 772, igualmente supra.
} 
qualquer comprometimento jurídico vinculante: apenas se se quisesse seguir este conselho é que os Parlamentos nacionais eventualmente poderiam escolher da maneira como apenas - sugerida pelo Protocolo.

Se havia a expectativa de que haveria uma coordenação na atividade entre as duas instituições - e, portanto, que haveria uma potencial influência do CdE na atividade da CECA, há que se notar que apenas por um simples feliz acaso alguns dos membros da Assembleia Comum da CECA corresponderiam à Assembleia Consultiva do CdE: nem os Estados estariam obrigados a mandar em seus Parlamentos a efetuar tal escolha, como também nem os Parlamentos deveriam necessariamente escolher daquela maneira designada. A coordenação eventualmente esperada era fragilizada.

Não é aoenas este aspecto, contudo, que denota a não subordinação da CECA ao CdE. Há que se fazer uma leitura mais atenta do artigo um para se depreender a afirmação jurídico-política da independência da CECA. Na verdade, o referido dispositivo talvez possa ser entendido, não como iniciativa dos autores do Tratado da CECA voltada a ligar mais estreitamente a nova Organização Internacional europeia e o CdE, mas, sim, como uma “declaração normativa de escárnio" dos autores do Tratado pela pretensão de direção política da Europa pelo CdE segundo sua escala de existência unidimensional Federalista.

Com efeito, em primeiro lugar, apesar de o artigo um do Protocolo reconhecer que era importante estabelecer relações entre as duas Assembleias, o mesmo dispositivo restringia a possibilidade de esta concertação ser empreendida. O diálogo entre estas duas instituições apenas seria possível na estrita medida autorizada pela regulamentação dada pelo Protocolo.

Isso implica reconhecer que qualquer pretensão de fazer convergir as atividades das duas Assembleias era limitada ao modo estrito como foram regulamentadas as possíveis relações: os membros que comporiam as duas Assembleias poderiam ser as mesmas pessoas, mas isso não seria necessário - e a exclusão desta necessidade era precisamente autorizada pelo referido Protocolo.

Em outras palavras, a pretexto de buscar fazer convergir as atividades da CECA e do CdE mediante a comunhão de membros das duas Assembleias, o Protocolo lembrava com todo o vigor em sua disposição jurídico-normativa que ninguém poderia obrigar nem os Estados-Membros da CECA, nem seus respectivos Parlamentos, a escolher dentre os representantes da Assembleia Consultiva do CdE os membros da Assembleia Comum da CECA. 
Em outras palavras, o Protocolo em questão operava normativamente como um lembrete contundente de que era impossível haver uma determinação jurídico-política externa - tal qual pretendida afoitamente pelos Federalistas, de escolhas internas aos Estados. Mais do que isso, o referido artigo um do Protocolo mostrava ser uma opção normativa deliberada dos autores do Tratado da CECA que a nova Organização Internacional europeia não era a favor de qualquer dever de nomear necessariamente os membros de sua Assembleia Comum a partir da Assembleia Consultiva do CdE. Caso isso fosse desejado pelos Estados e pelos Parlamentos nacionais, isso poderia ser feito - mas a CECA não estipularia qualquer dever nesse sentido.

Assim, se se deveria se preocupar com o estabelecimento de relações entre as duas Assembleias, tais relações não deveriam jamais descuidar dessa precisa regulamentação normativa arquitetada pela CECA: não haveria um dever que obrigasse juridicamente a comunhão de membros entre as duas Assembleias.

Em segundo lugar, ainda com relação ao mesmo artigo um do mesmo Protocolo sobre as Relações entre a CECA e o CdE, há que se mencionar um aspecto fundamental: o eventual diálogo institucional mais estreito entre as duas Organizações se daria por meio dos órgãos juridicamente mais fracos de ambas.

De fato, como visto anteriormente ${ }^{812}$, a Assembleia Consultiva do CdE era um órgão absolutamente desprovido de qualquer capacidade normativa, ou ainda, juridicamente vinculante. Ao mesmo tempo, não se pode deixar de observar que, apesar do nome, a Assembleia Comum da CECA era também um órgão da Comunidade absolutamente desprovido de qualquer capacidade de influência na produção de sentido normativo sobre as questões concretas comuns sensíveis da Comunidade ${ }^{813}$.

${ }^{812}$ V. Quinto Capítulo, especialmente o item 5.4.2., supra.

${ }^{813}$ Como mencionado anteriormente no final da nota de rodapé 772, supra.

Dentre os artigos do Tratado da CECA que descrevem as competências atribuídas à Assembleia Comum - artigos 20 a 25 do Tratado, não examinados por este trabalho precisamente por não envolverem quaisquer oposições escalares na determinação do sentido normativo a ser dado a questões comuns, não havia qualquer previsão que concedesse à Assembleia Comum competência alguma para participar do processo de produção de normas referentes ao uso e à administração do carvão e do aço. Operando como simples representantes dos povos dos Estados-Membros no interior da Comunidade, a Assembleia da CECA carecia de previsões que lhe concedessem qualquer Poder normativo, pois em nada impactava na nomogênese de normas de Direito Comunitário Derivado.

Como apontado anteriormente (v. item 3.3.3.3., supra), o Tratado da CECA estabelece oposições escalares para decidir o sentido normativo da vida comum apenas entre cinco escalas de existência: estatalidade isolada (Estados-Membros), estatalidade intergovernamental (Conselho de Ministros), supranacionalidade da Alta Autoridade (Alta Autoridade), supranacionalidade da Corte (Corte) e populidade (exercida pelos Parlamentos nacionais) - sobre tais previsões, remetemos aos itens a seguir, especialmente 7.2. e 7.3. Deste modo, note-se que a Assembleia Comum da CECA foi excluída desta análise exatamente porque ela fora excluída pelo próprio Tratado da CECA do jogo de relações de Poder em torno do sentido normativo último sobre questões comuns. 
O referido Protocolo efetuara um engenhoso mecanismo de início de relações entre a CECA e o CdE: a fórmula de estreitamento de diálogos entre as duas Organizações Internacionais europeias seria a de buscar aproximar precisamente as instituições "menos perigosas" normativamente, pois nenhuma das duas deteria quaisquer condições de influenciar normativamente na condução política da Europa Unida. Se a Assembleia do CdE era apenas uma Assembleia Consultiva, a Assembleia Comum da CECA era uma instituição incapacitada pelo Direito Comunitário Originário de exercer qualquer influência sobre a decisão normativa sobre a vida comum - pois não influenciava em nada a produção de Direito Comunitário Derivado.

Deste modo, a conversa a ser estabelecida mais estreitamente entre CECA e CdE jamais ultrapassaria o campo de entendimentos e diálogos, os quais, por sua vez, nunca passariam à ação normativa efetiva. A opção normativa pelo estabelecimento de relações tão perigosas quanto lúdicas para a vida em comum da CECA consistiu precisamente em uma forma de reforçar abertamente a declaração de que o CdE, ainda que em contato mais próximo e íntimo com uma das instituições da CECA, não deteria capacidade de influenciar as decisões normativas da nova Organização Internacional europeia.

Se eventualmente o $\mathrm{CdE}$ conseguisse produzir algum resultado modificativo sobre o ideário dos membros que compunham a Assembleia Comum da CECA, a Comunidade não teria com o que se preocupar. Ainda que influenciados pelo discurso Federalista Europeu do CdE e de sua Assembleia Consultiva, os representantes dos povos dos EstadosMembros da CECA não conseguiriam jamais exercer qualquer influência sobre as futuras normas jurídicas destinadas a reger a vida comum da CECA; afinal, a Assembleia Comum da CECA estava desde sempre impedida pelo Tratado de Paris de 1951 de participar do jogo de relações de Poder em torno do sentido normativo último sobre questões concretas comuns sensíveis. Por isso mesmo, sua atuação concertada com a Assembleia do CdE era inofensiva.

Por fim, há que se comentar o artigo dois do Protocolo sobre as Relações entre a CECA e o CdE. Como descrito algumas linhas acima, aquele artigo dois determinava que a

De todo modo, para aquilo que interessa ao texto relacionado a esta nota de rodapé, é importante guardar apenas a seguinte informação: a Assembleia Comum da CECA fora excluída pelo Tratado da CECA do jogo de relações de Poder em torno do sentido normativo último sobre questões comuns. Por isso, sua atuação concertada com a Assembleia do CdE seria inofensiva para a perpetuidade da organização jurídico-Política da Europa estabelecida pela CECA. 
Assembleia Comum da Comunidade deveria apresentar a cada ano um Relatório de suas atividades à Assembleia Consultiva do CdE.

Após a leitura dos comentários sobre as atividades da Alta Autoridade com relação ao $\mathrm{CdE}^{814}$, mostra-se fácil compreender de que maneira o Protocolo também procurou declarar a demarcação da independência da CECA com relação ao CdE. Remetemos o leitor ao item anterior, para maiores especificações do argumento, pois neste item se segue de perto o mesmo raciocíonio.

Em primeiro lugar, note-se que a base jurídica deste dever da Assembleia da CECA perante a Assembleia Consultiva do $\mathrm{CdE}$ não era uma disposição jurídica do $\mathrm{CdE}$, mas uma previsão normativa prevista pelo próprio Tratado da CECA em um de seu Protocolos. Nesse sentido, sob uma perspectiva formal, a origem dos deveres da Assembleia Comum da CECA era independente de qualquer regulamentação jurídico-normativa do CdE. A Assembleia Comum da CECA não estaria desempenhando qualquer prestação de contas ou de atividades, mas, sim, cumprindo apenas um dever estabelecido pela Comunidade da qual ela fazia parte.

Assim, antes de obedecer a potenciais normas de origem externa à vida comum da qual participava, a Assembleia Comum obedecia a si própria, enquanto membro da Comunidade. Neste primeiro sentido, formal, afirmava-se a autonomia e a independência da Assembleia Comum da CECA com relação à Assembleia Consultiva do CdE - e, deste modo, sob uma primeira perspectiva, reforçava-se a não-subordinação da CECA ao CdE.

Em segundo lugar, o tipo de dever ao qual estava obrigada a Assembleia Comum da CECA em relação à Assembleia Consultiva do CdE também ressaltava uma nãosubmissão hierárquica da primeira à última. Isso porque a Assembleia Comum da CECA apenas comunicaria à Assembleia Consultiva do CdE o conjunto de atividades por ela desempenhada, mediante Relatório Anual.

Em outras palavras, não havia qualquer previsão de possibilidade de controle das atividades ali relatadas pela Assembleia Consultiva do $\mathrm{CdE}$, isto é, não havia qualquer disposição normativa que determinasse qualquer espécie de avaliação das atividades da Assembleia da CECA pela Assembleia do CdE. Nesse sentido, ainda que a relação estreita entre as duas Assembleias fosse frágil, eventual, e não produzisse qualquer impacto na produção normativa da Comunidade, ainda assim se garantia - como último bastião de independência da CECA perante o CdE - que a Assembleia da CECA apenas remeta à 
Assembleia do CdE um Relatório de Atividades com finalidade meramente informativa. Sobre este, nada poderia exercer ou executar a Assembleia do CdE, se não a simples atividades de conhecer e se calar.

\subsubsection{O Significado Jurídico-Político do Protocolo: Não-Subordinação da CECA} $\underline{\text { como Recusa da Transcendência Federalista Europeia do CdE }}$

Diante da convergência de fins entre as duas Organizações Internacionais europeias - organização jurídico-política de países europeus - e da concomitante desarmonia com relação aos meios utilizados - Leis Políticas versus Leis Teológico-Políticas, os autores do Tratado da CECA optaram pelo estabelecimento claro e indubitável da qualidade norteadora das relações entre esta Organização e o CdE.

A fim de eliminar possíveis confusões entre os Projetos portados por cada uma das Organizações Internacionais e mesmo infundadas suposições de submissão de uma em relação a outra, determinou-se de maneira expressa, escrita e explícita que a relação entre ambas as Organizações não seria pautada por uma lógica de diferenciação hierárquica. CECA e CdE manteriam entre si espécies de relações que jamais poderiam ser confundidas com qualquer tipo mais ou menos inadvertido de reconhecimento de submissão ou de superioridade de uma em relação à outra.

Apesar de a exposição dos itens anteriores ${ }^{815}$ ter deixado clara a presente condição, é fundamental extrair ainda uma última conclusão em torno da arquitetura normativa geral assumida pelo Protocolo que detenha uma significação jurídico-política especial para este trabalho.

A não-subordinação da CECA ao CdE - normativamente reconhecida e declarada pelo Protocolo ora analisado - pode ser compreendida como um mecanismo jurídicoinstitucional que optara por lidar de determinada maneira com a oposição escalar enunciada algumas linhas acima ${ }^{816}$ : a pretensão unidimensionalizante do Federalismo Europeu $(\mathrm{CdE})$ e a afirmação da necessidade de conservação de uma mais ampla possível pluralidade escalar (CECA) na definição do sentido normativo a ser dado para questões comuns.

Se o CdE se mostrava como uma iniciativa institucional que buscava afirmar incondicionalmente a realização de um Estado Federal Europeu fundado normativamente

\footnotetext{
${ }^{815}$ Itens 7.1.2.2. e 7.1.2.3., ambos supra.

${ }^{816}$ Final do item 7.1.2.1., supra.
} 
no discurso dos Direitos Humanos e da Democracia, ao estabelecer que a CECA apenas poderia guardar com o CdE uma relação horizontal ${ }^{817}$, o Protocolo determinou que as duas Organizações Internacionais - e suas respectivas escalas de existência - seriam pares internacionais dotados de mesmo status jurídico-político.

Em outras palavras, pode-se entender que o Protocolo determinara que a CECA de maneira alguma poderia se compreender como sujeita jurídico-politicamente às determinações do $\mathrm{CdE}$. Se de qualquer maneira o $\mathrm{CdE}$ pretendesse afirmar ou mesmo impor à CECA sua forma de habitar o mundo, a CECA estaria autorizada - ou ainda, obrigada - pelo referido Protocolo a colocar-se contra toda e qualquer pretensão de ingresso do discurso transcendente do $\mathrm{CdE}$ na solução de suas próprias questões concretas comuns sensíveis.

Por isso, o Protocolo afirmava de maneira explícita que, no interior dos processos decisórios da CECA referentes ao sentido a ser dado no lugar compartilhado do Direito e do Poder, não se admitiria a introdução sorrateira de uma escala de existência ideal, abstrata e imaginada estranha à condição concreta que embasara a solidariedade de fato entre os países-membros da Comunidade.

No interior do embate escalar entre unidimensionalização transcendente e conservação da pluriescalaridade imanente, a opção normativa constante deste Protocolo consistia em garantir à CECA um mecanismo institucional de resistência aos arroubos do Teológico-Político, em favor da preservação da condição Política da União por ela inaugurada.

Colocar-se institucionalmente contra qualquer forma de submissão perante o $\mathrm{CdE}$ era assim um expediente do Protocolo da CECA para garantir à vida comum recéminstaurada um ambiente livre e desimpedido de qualquer determinação normativa prévia, incondicional e inquestionada, principalmente se forjada a partir de um imaginário abstrato e ideal em torno de uma suposta civilização europeia perdida. Era assim um engenhoso mecanismo institucional de recusa do Federalismo Europeu portado pelo $\mathrm{CdE}$ e de conservação da imanência no fundamento do Direito e do Poder na CECA. Era, portanto, um dispositivo voltado a rejeitar e a manter à distância talvez a mais perigosa forma de transcendência: a que buscava se transcendentalizar a partir de uma disseminação sorrateira no interior da própria Europa.

${ }^{817}$ Isto é, de igual para igual, em paridade de condições. 


\title{
7.2. Instauração e Conservação da Imanência por Vertente Positiva: Afirmação e Preservação Normativas da Horizontalidade na Solução de Conflitos
}

\begin{abstract}
7. Quand un des pouvoirs, gonflé de son importance, cherche à l'emporter sur les autres et s'arroge plus d'autorité qu'il de lui en revient, il est évident, étant donné qu'aucun d'eux, comme nous venons de le dire, ne peut se passer des autres et que les volontés de chacun peuvent être refrénées et paralysées par les autres, que jamais l'un d'eux ne pourra empiéter sur le domaine de l'autre ni le traiter avec mépris. 8. Tout le monde reste à sa place, parce que tout est prévu pour brider les ambitions exorbitantes et que chacun redoute les réactions du voisin... (POLYBE, 2003, p. 569).
\end{abstract}

O foco da atuação positiva das normas de oposições escalares do Tratado da CECA preocupadas em instaurar e preservar a imanência do fundamento do sentido normativo sobre questões concretas comuns sensíveis consistiu em afirmar e buscar fazer perseverar normativamente uma relação de horizontalidade entre as escalas de existência participantes da vida em comum.

Em virtude da presença de normas de oposições escalares referentes ao processo de definição do sentido normativo do uso e da administração do carvão e do aço ${ }^{818}$, cada uma delas é continuamente convidada e forçada a se apor perante as demais, a fim de opor seu modo de habitar o mundo diante dos dos demais. A permanência do caráter Político da Comunidade inaugurada pela CECA deveria ser assegurada na hipótese de tais conflitos entre diferentes dimensões existenciais poderem ensejar o rompimento da condição horizontal igualmente detida de umas perante as outras - isto é, o Tratado deveria prever disposições normativas que mantivessem constantemente os envolvidos em condições de pares.

A instauração e a preservação da imanência praticada por algumas das normas do Tratado da CECA adquire preciso significado no interior da chave de leitura proposta por este trabalho: os autores daquele documento jurídico internacional reconheceram a

\footnotetext{
${ }^{818}$ Com efeito, é importante lembrar que, como frisado inúmeras vezes nos Capítulos anteriores deste trabalho, o objetivo da CECA não era o de instaurar uma pacificação nas relações entre as escalas de existência por meio de seu ambiente jurídico-institucional. Muito pelo contrário: quando da necessidade de se definir o sentido normativo a ser dado às questões concretas comuns sensíveis (carvão e aço), as diferentes escalas de existência não teriam sido chamadas para atuar em colaboração para construir uma vida em comum: antes, elas eram nem mesmo convidadas, mas convocadas em caráter obrigatório a se colocar em choque escalar com as outras dimensões de existência.

Assim, longe de estimular um leviano pacificismo relacional, o ambiente institucional do Tratado da CECA - como será visto tambem no item 7.3.1., infra - fomentava uma permanente situação conflitiva entre as escalas de existência, a fim que a tensão contínua entre suas medidas existenciais pudesse produzir um resultado normativo. A construção Política da vida comum da CECA não era, assim, produto de uma colaboração multiescalar, mas sim de um permanente conflito multiescalar. Daí a necessidade de se prever série de dispositivos que também encaminhassem - também pluriescalarmente, como será visto nos subitens a seguir, principalmente no 7.2.2., infra - a resolução de tais embates escalares.
} 
presença da possibilidade de os conflitos escalares estimularem um movimento disruptor da vida comum derivada do surgimento de uma pretensão à verticalização das relações.

Em outras palavras, conservar o caráter imanente das fundações da vida comunitária significava criar condições institucionais que bloqueassem eventuais investidas uniescalares rumo à transcendentalização - isto é, rumo à elevação de uma das escalas de existência sobre as demais (rompimento da horizontalidade), de maneira a impedir que este destacamento em potencial introduzisse na Europa Unida pela CECA uma regência normativa dada a partir unicamente dos padrões existenciais da dimensão que pretendera se arvorar em posição superior.

Assim, mesmo na solução de conflitos escalares institucionalmente estimulados, não haveria possibilidade de uma escala de existência se colocar como superior às demais para decidir o sentido normativo último. Nestas situações extremas de potencial rompimento da horizontalidade, o Tratado da CECA afirmava a necessidade de se perpetuar nas soluções institucionais, isto é, de se voltar conscientemente à solução multiescalar institucionalmente constituída, conservada e perpetuada.

É importante lembrar que era viva a memória entre os autores do Tratado da CECA que a Segunda Guerra Mundial poderia ser compreendida como produto de uma pretensão de totalização unidimensional de uma única escala de existência estatal: a da Alemanha nazista $^{819}$. A complexa estrutura normativa jurídico-institucional fundada em normas de oposições escalares constituía ambiente propício para a manutenção de uma vitalidade tensiva entre dimensões existenciais que poderia implicar igualmente o surgimento de possíveis tentativas de desconsideração do sistema de convivência em nome da instauração de uma regência total uniescalar.

Com efeito, como não esperar que a promoção ininterrupta de conflitos entre as escalas de existência participantes da vida comunitária não estimularia, por exemplo, (i) um dos Estados (estatalidade isolada) a denunciar o Tratado da Paris de 1951 e a declarar mais uma vez a Guerra contra os outros Estados europeus participantes da CECA; (ii) uma concertação intergovernamental de alguns dos Estados (estatalidade intergovernamental) a denunciar o Tratado e (a) a declarar a Guerra contra os demais Estados europeus que compunham a CECA, ou (b) a recorrer ao mecanismo de cooperação política intergovernamental do $\mathrm{CdE}$, marcado profundamente pelos caracteres missionários do Federalismo Europeu; ou mesmo, (iii) um dos órgãos comunitários supranacionais (Alta

${ }^{819}$ V., nesse sentido, os itens 6.1. e 6.2., supra, especialmente a nota de rodapé 694. 
Autoridade ou Corte) a pretender impor sobre a organização jurídico-Política do Tratado uma dinâmica relacional próxima à de um Estado supranacional Europeu ${ }^{820}$ ? As

820 É importante notar que neste parágrafo são mencionadas apenas as estatalidades (isolada e intergovernamental) e as supranacionalidades (Alta Autoridade e Corte). É apenas entre essas quatro dimensões existenciais - representadas respectivamente pelos Estados-Membros, pelos Estado-Membros no interior ou fora do Conselho de Ministros (v., por exemplo, o item 7.3.2.1., infra), pela Alta Autoridade e pela Corte - que se estrutura o sistema de solução de controvérsias surgidas entre escalas de existência.

Essa situação deriva precisamente do fato de que a populidade não participava diretamente da definição do sentido normativo a ser dado ao uso e à administração do carvão e do aço. Sua atuação na vida comum detinha um mais profundo significado jurídico-Político, cuja relevância será mais bem esclarecida quando da leitura da integralidade do item 7.3.2., infra.

De todo modo, como não há como a populidade se opor normativamente às outras escalas de existência quando da definição do sentido do Direito e do Poder a ser aplicado sobre o carvão e o aço, desnecessária era a previsão de um mecanismo institucional de solução de controvérsias que envolvesse a populidade.

É importante introduzir aqui, ainda, algumas considerações preliminares. Até o presente momento, repetiu-se ao longo deste trabalho que as cinco dimensões existenciais participantes da vida em comum da CECA eram portadas por cinco entidades distintas; (i) Estados-Membros (estatalidade isolada); (ii) EstadosMembros intergovernamentalmente concertados, dentro ou fora da instituição comunitária do Conselho de Ministros (estatalidade intergovernamental); (iii) Alta Autoridade (supranacionalidade da Alta Autoridade); (iv) a Corte de Justiça da CECA (supranacionalidade da Corte); e (v) os Parlamentos nacionais, enquanto órgãos estatais responsáveis pela representação popular (populidade).

Essa distinção diverge um pouco da divisão institucional constante do Tratado e, por isso, há que se efetuar uma breve justificativa jurídico-normativa positiva para ser entendida como adequada às preocupações típicas de um estudo em Direito.

O artigo 6 do Tratado estabelecia (parágrafos primeiro e quarto) que a CECA deteria personalidade jurídica e seria representada por suas instituições. $\mathrm{O}$ artigo 7 do mesmo Tratado definia serem as instituições da Comunidade (i) a Alta Autoridade, auxiliada pelo (ii) Comitê Consultivo; (iii) a Assembleia Comum; (iv) o Conselho Especial de Ministros; e (v) a Corte de Justiça da CECA.

Perceba-se que destas cinco instituições mencionadas pelo artigo 7 do Tratado da CECA, são excluídos imediatamente da presente análise (i) o Comitê Consultivo; e (ii) a Assembleia Comum. A exclusão da Assembleia Comum foi devidamente justificada a partir da disposição normativa do Tratado da CECA na nota de rodapé 813, supra, quando foi tematizada a relação entre a Assembleia Comum da CECA e a Assembleia Consultiva do CdE, no item 7.1.2.3.3., razão pela qual remetemos o leitor para aquela nota de rodapé.

Nos termos do artigo 18 do Tratado da CECA, o Comitê Consultivo da CECA era órgão comunitário responsável pela representação de produtores, trabalhadores, consumidores e negociadores relacionados ao setor econômico do carvão e do aço, nomeados pelo Conselho de Ministros. A justificativa normativa da exclusão é bastante semelhante à feita para à Assembleia Comum: os artigos 18 e 19 do Tratado da CECA, responsáveis pela regulamentação da competência do Comitê Consultivo não previam para este órgão comunitário um âmbito de atuação que lhe permitisse ultrapassar sua condição de entidade detentora de caráter consultivo. Em outras palavras, não havia qualquer disposição que lhe concedera uma eventual possibilidade compartilhar da definição do sentido normativo a ser impresso sobre as decisões em torno do Direito e do Poder sobre o uso e a administração do carvão e do aço na Comunidade. Por esse motivo, o Comitê Consultivo foi afastado deste estudo.

Restariam, assim, apenas três órgãos comunitários que deveriam ser analisados, pois participantes ativos da vida em comum instaurada pela CECA, naquilo que se refere à atribuição de Poderes de apresentação e de contenção que influenciariam na definição normativa da regulamentação do uso e da administração do carvão e do aço: (i) a Alta Autoridade; (ii) o Conselho Especial de Ministros; e (iii) a Corte de Justiça da CECA.

A estes três órgãos da Comunidade, o presente trabalho acrescentou na análise ainda duas outras entidades, tendo em vista que o próprio Tratado da CECA as incluía neste jogo de Poder (proposição versus contenção) entre diferentes escalas de existência; são elas: (iv) os Estados-Membros considerados isoladamente; e (v) os Parlamentos nacionais.

Mesmo sem serem propriamente órgãos comunitários, tais entidades foram providas de condições institucionais pelo próprio Tratado da CECA - a serem examinadas oportunamente mais adiante, especialmente nos itens 7.2.2., 7.3.1. e 7.3.2., infra - que permitiriam normativamente a apresentação de suas dimensões existenciais perante as demais. 
Assim, a existência de normas de oposições escalares que também envolviam os Estados-Membros considerados isoladamente e os Parlamentos nacionais garantiam que suas medidas de existência influenciavam na própria composição jurídico-Política da vida em comum - seja no dia-a-dia da atividade normativa, seja mesmo na fundação e/ou refundação das Leis Políticas da Comunidade. Tudo restará mais bem explicado a partir da leitura dos itens que se seguem, especialmente no que se refere ao fundamental papel atribuído aos Parlamentos nacionais - os quais, apesar de não impactarem diretamente na produção normativa derivada da Comunidade, exerciam funções igualmente relevantes com relação às das demais escalas: fundação e refundação da Comunidade Política.

De todo modo, resta ainda compreender a partir de um fundamento normativo a razão pela qual se poderia atribuir a cada um dos órgãos comunitários o caráter de portador de uma escala de existência em especial. Pressupõe-se aqui que seja imediatamente reconhecido que (i) os Estados-Membros isoladamente considerados são - enquanto entidades nacionalmente Soberanas - portadores da estatalidade isolada; da mesma maneira que (ii) os Parlamentos nacionais - enquanto órgãos estatais nacionais de representação popular - são portadores cada um deles de parcelas particulares da populidade.

Entende-se que a Alta Autoridade era portadora de uma dimensão existencial supranacional pois o artigo 9, parágrafo sexto, do Tratado da CECA, determinava que ela detinha um caráter supranacional, o qual não poderia ser influenciado pelos Estados-Membros da CECA. O objetivo consistia em garantir que os membros da Alta Autoridade fossem independentes de qualquer possível influência na condução de suas atividades, fosse esta originária dos Estados-Membros, fosse ela de qualquer outra entidade.

O próprio parágrafo quinto do mesmo artigo 9 do Tratado afirmava que os membros da Alta Autoridade eram independentes mesmo de qualquer outro organismo. Sua atuação era completamente centrada na perspectiva supranacional que deveria deter a Alta Autoridade sobre o uso e a administração do carvão e do aço na vida em comum.

Nesse sentido, note-se desde já que a Alta Autoridade é considerada portadora de uma escala de existência supranacional própria (supranacionalidade da Alta Autoridade), diversa da portada pela Corte, visto que - como decorrência do mesmo artigo 9, parágrafo quinto, do Tratado da CECA - sua postura supranacional perante a Corte deveria ser independente e distinta desta.

Dessa forma, também se poderia concluir que a Corte de Justiça da CECA era detentora de uma supranacionalidade distinta da da Alta Autoridade (supranacionalidade da Corte). Com efeito, o artigo 31 do Tratado da CECA incumbia a Corte de assegurar o respeito do Direito na interpretação e na aplicação dos Tratados e dos regulamentos de execução deste.

A função consistia em assegurar a observância e o cumprimento do resultado normativo comunitário que era fruto do jogo de Poder entre as diferentes escalas de existência da Comunidade. Tendo uma origem multiescalar, pois não comprometidas com nenhuma estatalidade - nem apenas isoladamente considerada, nem somente intergovernamentalmente concertada, as normas pelas quais a Corte deveria tutelar seriam assim supranacionais, pois não vinculadas a qualquer nacionalidade específica. Ao atuar em nome da preservação de tais normas fruto do compartilhamento próprio da vida comunitária, a Corte portaria consigo a tarefa de assegurar o respeito a tal Direito supranacional - e, portanto, portaria consigo a escala da supranacionalidade.

Como afirmado acima, todavia, a supranacionalidade da Corte seria distinta da da Alta Autoridade. Essa condição derivaria, não apenas da independência de atuação da Alta Autoridade com relação a toda e qualquer entidade que não ela própria - independência prevista no artigo 9, parágrafo quinto, mas também em virtude do próprio caráter do Direito em nome do qual a Corte atuava: este agia para assegurar o respeito a arcabouço normativo fruto de efetiva síntese multidimensional (estatalidades e supranacionalidade da Alta Autoridade).

Em outras palavras, se este era supranacional por não se deter nas singelas perspectivas nacionais (isolada ou intergovernamentalmente consideradas), tal Direito não era apenas fruto da impressão normativa dada pela supranacionalidade da Alta Autoridade (como será visto a seguir, no item 7.3.1., infra). Deste modo, no interior deste Direito supranacional - pois não pertencente a nenhuma nacionalidade em particular, não haveria apenas a medida de existência supranacional da Alta Autoridade, mas também a confluência das diferentes perspectivas estatais (isoladas ou intergovernamentalmente consideradas).

Deste modo, esse Direito em nome do qual a Corte atuava era supranacional, mas não era supranacional da mesma maneira que habitava supranacionalmente o mundo a Alta Autoridade, na medida em que ele era também produto de perspectivas estatais. Assim, a Corte era responsável pela apresentação de uma supranacionalidade que era assim distinta da da Alta Autoridade, pois fundada em síntese normativa multidimensional. Era, assim, portador de uma supranacionalidade específica: a supranacionalidade da Corte.

Por fim, no que se refere ao Conselho Especial de Ministros, pode-se entender que se trata de um órgão comunitário portador da estatalidade intergovernamental na medida em que, segundo o artigo 27 do 
instituições do Tratado da CECA importavam duplamente: não apenas para promover oposições escalares quando da produção de normas sobre o uso e a administração do carvão e do aço, como também para promover embates dimensionais quando da solução de conflitos escalares oriundos precisamente das decisões normativas sobre o uso e a administração de tais recursos.

Nesse sentido, em um ambiente institucional favorável à proliferação de tendências voltadas ao rompimento da horizontalidade, era fundamental estabelecer um mecanismo institucional bastante peculiar. Este deveria encaminhar a solução de controvérsias escalares mediante um reenvio ao próprio sistema de convivência que, ao assegurar a também a plena presença simultânea das inúmeras constelações escalares participantes da vida em comum, não implicaria a implosão da vida comunitária.

Em outras palavras, a solução a ser buscada deveria ser a direitificação mais completa possível de um sistema de convivência, a qual seria responsável inclusive pela edificação de um mecanismo de solução de conflitos escalares no interior do qual fosse assegurada ao máximo a possiblidade de se encetarem conflitos multiescalares no interior da vida em comum. A solução de conflito escalar seria dada por novos conflitos escalares institucionalmente estimuladas pela multiescalaridade.

Sendo percebida a existência de canais institucionais que favorecessem a explosão regular dos ressentimentos entre as escalas de existência que com tanta frequência agitariam a vida em comum, nenhum dos participantes da CECA desenvolveria em seu interior a ambição desmedida de querer se elevar sobre os demais e, principalmente, sobre

Tratado da CECA, ele seria composto por representantes dos Estados-Membros: cada um destes designaria um membro de seus respectivos Governos para compor o Conselho.

Nesse sentido, perceba-se que o Conselho de Ministros tinha por característica ser, introduzir e fazer operar no interior da engenharia institucional da Europa Unida da CECA a perspectiva da escala de existência estatal enquanto concertada em conjunto com as demais escalas estatais participantes da CECA. O Conselho estabelecia uma relação entre os Estados, a fim de que sua perspectiva conjunta (intergovernamental) pudesse ser também considerada nas atividades normativas sobre o uso e a administração do carvão e do aço na Comunidade.

Ao mesmo tempo, não se pode ignorar que, em determinados momentos, o Tratado da CECA atribuíra a possibilidade de a estatalidade intergovernamental se manifestar na construção diária da Comunidade Política da Europa Unida mediante mecanismos de concertação extracomunitários - ou seja, por meio de mecanismos de concertação distintos do do Conselho de Ministros. Estas situações serão especificamente mencionadas nos itens a seguir, quando estiverem relacionadas especificamente com os temas analisados.

De todo modo, talvez se possa agora compreender um pouco melhor - a partir de referenciais jurídico-normativos - a razão pela qual se afirmou ao longo de todo este trabalho que as cinco dimensões existenciais participantes da vida em comum da CECA eram portadas por cinco entidades distintas; (i) Estados-Membros (estatalidade isolada); (ii) Estados-Membros intergovernalmente concertados, dentro ou fora da instituição comunitária do Conselho de Ministros (estatalidade intergovernamental); (iii) Alta Autoridade (supranacionalidade da Alta Autoridade); (iv) a Corte de Justiça da CECA (supranacionalidade da Corte); e (v) os Parlamentos nacionais, enquanto órgãos estatais responsáveis pela representação popular (populidade). 
as Leis ${ }^{821}$ para se socorrer de expedientes outros que apenas prejudicariam a permanência da Comunidade Política da Europa Unida pela CECA.

Deste modo, assegurar a horizontalidade relacional era assegurar a imanência, na medida em que os autores do Tratado de Paris de 1951 optaram normativamente por manter institucionalmente afastada a possibilidade da elevação potencialmente totalizante (transcendentalização) de uma das medidas de existência que compunham a vida em comum, mesmo no que se refere à solução dos conflitos escalares.

Dessa forma, os autores do Tratado declararam as disposições jurídicoinstitucionais deste não admitiriam de forma alguma a regência da vida da Comunidade por padrões normativos unidimensionais. Do contrário, o caráter Político da vida em comum seria imediatamente perdido em nome da introdução sorrateira de uma orientação Teológico-Política das Leis oriunda do próprio interior da dinâmica opositiva ${ }^{822}$.

Este mecanismo normativo de preservação da imanência mediante a conservação de uma relação horizontal entre os participantes da vida em comum foi estruturado por meio de quatro previsões distintas:

(i) uma cláusula geral de reenvio do Tratado a ele mesmo, entendido como o mecanismo institucional privilegiado para a solução de controvérsias entre escalas de existência;

(ii) uma complexa engenharia jurídico-institucional de resolução de embates escalares mediante normas de oposições escalares;

(iii) um duplo impedimento de transcendentalização das duas principais escalas de existência (estatalidade isolada e supranacionalidade da Alta Autoridade) quando do cumprimento das decisões da Corte; e

(iv) uma recusa à formação de um sistema de execução das decisões da Corte e da Alta Autoridade semelhante ao de um Estado (rejeição de uma organização jurídicopolítica estatal europeia).

Esta divisão em quatro partes orienta o desenvolvimento dos comentários apresentados nos itens a seguir. Tratam-se de análises sobre as diferentes formas encontradas pelo Tratado para assegurar a horizontalidade entre as escalas de existência

\footnotetext{
${ }^{821}$ Isto é, sobre a organização jurídico-Política instaurada originariamente pelo Tratado da CECA.

822 O que demonstra o caráter frágil dos Regimes Políticos, facilmente deslizáveis em direção ao TeológicoPolítico. Essa possibilidade interpretativa é autorizada pela chave de leitura escolhida para orientar a interpretação deste trabalho, baseada nas contribuições de Claude LEFORT à Filosofia Política Contemporânea. Remetemos o leitor aos itens 3.4.2. e 3.4.3., supra, onde o tema do deslizamento do Político em direção ao Teológico-Político é rapidamente desenvolvido.
} 
quando do surgimento da possibilidade de uma delas pretender alçar sobre as demais e sobre elas impor unilateralmente sua escala de existência.

7.2.1. A Chave de Compreensão dos Dispositivos sobre Solução das Oposições Escalares: Opção Reiterada pelo Uso das Vias Institucionais previstas pelo Tratado

A chave de compreensão do conjunto normativo que regulamenta o sistema de solução das oposições escalares no interior da vida comum da CECA exsurge precisamente a partir da leitura de dois artigos localizadas ao final do Tratado da Paris de 1951, a saber, os artigos 87 e 89. A análise conjunta desses dois dispositivos permite antever a estipulação de uma regra geral voltada a afirmar a opção do Tratado pela necessidade de se recorrer apenas às vias institucionais previstas pelo Tratado para solucionar os conflitos surgidos das oposições escalares incansavelmente produzidas por suas disposições jurídico-normativas.

O artigo 87 do Tratado da CECA estabelecera que as Alta Partes Contratantes se comprometeriam a não utilizar mecanismos de solução de controvérsias previstos em outros Tratados, Convenções ou Declarações existentes entre elas para resolver questões que surgissem em virtude da aplicação ou da interpretação do Tratado da CECA. A parcela final do mesmo artigo é mais enfática: a solução de conflitos envolvendo a aplicação ou a interpretação do Tratado da CECA não poderia ser dada por vias distintas da prevista pelo próprio Tratado de Paris de 1951.

Do mesmo modo, o artigo 89, parágrafo primeiro, do Tratado da CECA previa que todo conflito entre Estados-Membros relativo à aplicação do Tratado que não tivesse recebido a previsão de um procedimento específico de resolução, deveria ser submetido à Corte para ser solucionado, desde que um dos Estados-Membros envolvidos na controvérsia assim solicitasse. O parágrafo segundo do mesmo artigo estabelecera, ainda, que a Corte era competente para decidir sobre questões entre Estados-Membros que estivessem em conexão com o objeto do Tratado, mas apenas se tal questão lhe fosse submetida por força de um compromisso.

A consideração conjunta dos dois artigos permite perceber que os autores do Tratado da CECA se preocuparam em estabelecer de maneira clara a preferência normativa pelo recurso ao mecanismo institucional de solução de conflitos entre escalas de existência estruturado e sedimentado pelo próprio Tratado de Paris de 1951. 
Nesse sentido, perceba-se que o artigo 87 do Tratado da CECA estabelecia expressamente um impedimento normativo dirigido aos Estados-signatários a recorrer a mecanismos de solução de controvérsias internacionais alternativos ao da engenharia institucional prevista no Tratado da CECA, sempre que a questão envolvida se originasse da interpretação ou da aplicação deste.

Ademais, note-se que, segundo o artigo 89 do Tratado da CECA, o mecanismo seria tão suficiente para resolver questões controversas sobre a construção do sentido normativo sobre o uso e a administração do carvão e do aço que, ainda que não tivesse havido a previsão de procedimento específico no Tratado para solucionar uma questão pontual, e ainda que o objeto do conflito não fosse diretamente um tema regulado diretamente pelo Tratado, mas a tema a ele conexo, a via institucional por ele edificada era considerada apta para as resolver.

De maneira resumida, as duas previsões sinalizavam que o Tratado da CECA se autocompreendia como suficientemente apto a estabelecer os próprios mecanismos institucionais de solução de embates escalares, de tal maneira que os Estados-Membros jamais poderiam - pois jamais precisariam - recorrer a outro caminho, ainda que este não estivesse especificado no Tratado da CECA, e ainda que não tivesse sido regulamentada diretamente pelo objeto do Tratado.

Em outras palavras, a leitura dos dois dispositivos permite perceber que o Tratado da CECA percebia suas instituições voltadas à solução de conflitos escalares como suficientemente preparadas para dar plena vazão normativa às oposições dimensionais que se desenvolveriam em seu interior.

Especialmente dedicados aos Estados-Membros da CECA, estes dois dispositivos apontavam para uma característica geral do sistema de soluções de controvérsias surgidas entre diferentes escalas de existência: o Tratado de Paris de 1951 se comprometia perante os participantes da vida em comum a direitificar um sistema de convivência bastante original e sofisticado. Este disporia inclusive de um engenhoso mecanismo institucional que faria confluir diferentes medidas de existência, não apenas para decidir normativamente sobre questões concretas comuns sensíveis (carvão e aço), mas também para as aproximar quando as oposições escalares pudessem ameaçar a ruptura do sistema.

Nesse sentido, nos momentos delicados da vida em comum, em que talvez se mostrassem insatisfatoriamente solucionadas as oposições escalares pela via normativa de 
entrechoque e impedimentos mútuos para a regulação das normas sobre o carvão e o aço ${ }^{823}$ ou de situações a ela conexas, o Tratado lembrava aos Estados-Membros - e, dessa forma, aos demais participantes implicados na vida em comum ${ }^{824}$ - que seria desnecessário se socorrer de expediente a ele estranho.

Deste modo, em vez de estes eventualmente cederem à tentação de superar a ordem de convivência e se elevar sobre os demais e sobre as próprias Leis de organização jurídico-Política das relações entre os países europeus, este poderiam e deveriam parar para pensar e perceber que encontrariam plenas condições jurídico-normativas de terem suas perspectivas reavaliadas pelos próprios termos institucionais do Tratado. Em outras palavras, ao invés de optarem rápida e facilmente por uma solução que desconsiderasse o sistema de convivência do Tratado e que, por essa razão, possibilitasse a um dos participantes a elevação sobre os demais e o rompimento da relação de horizontalidade, o Tratado relembrava que o vigor Político das próprias instituições estava ali presente para garantir igualmente a todas as escalas de existência o adequado encaminhamento institucional pluridimensional das próprias controvérsias.

Assim, os dois dispositivos ora brevemente comentados operariam como regra geral que apontaria para a simples condição de que a virtude multidimensional do sistema de solução de controvérsias escalares previsto pelo Tratado da CECA era a via mais adequada para as resolver no interior dos termos institucionais do próprio Tratado. Por esse motivo, era desnecessário mesmo pensar em se socorrer do outros instrumentos estranhos à própria dinâmica relacional da vida em comum.

Uma vez percebido que o próprio Tratado da CECA apostava fielmente em sua virtude multiescalar para solucionar os conflitos oriundos de normas de oposições escalares, é importante tentar compreender os mecanismos por meio dos quais funcionava este complexo sistema pluriescalar de solução de embates entre diferentes medidas de existência. Detalha-se este maquinário institucional a seguir.

\footnotetext{
${ }^{823}$ O qual será descrito detalhadamente no item 7.3.1., infra.

${ }^{824}$ Como será visto no item 7.2.2., a seguir.
} 
7.2.2. A Significação Jurídico-Política do Sistema de Solução de Controvérsias da CECA: A Resolução Judicial de Conflitos Escalares por meio de Normas de Oposições Escalares

A confiança dos autores do Tratado da CECA na virtude e na capacidade de este canalizar institucionalmente no maior grau possível as escalas de existência em permanente conflito durante a vida comunitária é facilmente compreensível a partir da leitura dos comentários aos artigos que seguem.

A oposição entre diferentes escalas de existência participantes da vida em comum é resolvida mediante remessa expressa às próprias instituições (judiciais) do Tratado da CECA. Neste âmbito institucional, poder-se-á perceber a partir da consideração dos itens a seguir que o envio do Tratado da CECA a um procedimento de solução de controvérsias judicial não deixava de preservar a pluriescalaridade na formação do sentido normativo, pois redirecionava a Comunidade Política a encontrar nela mesma sua própria solução. Como se poderá ver a seguir.

7.2.2.1. O Artigo 33 do Tratado da CECA: Anulação de Decisões e de Recomendações da Alta Autoridade como Recusa da Estrutura Mando-Obediência entre as Escalas de Existência

\subsection{Observações Gerais sobre o Artigo 33}

O parágrafo primeiro do artigo 33 do Tratado da CECA determinava que, mediante recurso de anulação interposto por um Estado-Membro ou pelo Conselho, uma decisão ou uma recomendação proferida pela Alta Autoridade poderia ser objeto de questionamento perante a Corte. Tal recurso deveria ter como fundamento a alegação de incompetência, violação de formalidades essenciais, violação do Tratado ou de norma jurídica relacionada a sua aplicação, ou desvio de Poder. Nestas hipóteses, a Corte poderia decidir pela anulação do ato normativo da Alta Autoridade.

Note-se aqui a previsão de complexa rede de relações interescalares. Para o exercício de um controle entre os próprios órgãos comunitários portadores da dimensão existencial supranacional, era necessária a mobilização contrária de uma escala estatal (isolada ou intergovernamental). Há deste modo a previsão da possibilidade de se instaurar institucionalmente perante a Corte o embate entre uma perspectiva normativa 
supranacional $^{825}$ e outra gestada no interior de uma escala estatal, isolada ou intergovernamentalmente considerada.

7.2.2.1.2. Resistência da Estatalidade a Investidas da Supranacionalidade sobre o Lugar do Direito e do Poder

A previsão de vias institucionais para o exercício deste controle visava a assegurar o caráter multiescalar no processo de formação das normas comunitárias derivadas engendradas nos órgãos comunitários supranacionais ${ }^{826}$.

As hipóteses de controle previstas neste dispositivo - incompetência, violação de formalidades essenciais, violação do Tratado ou de norma jurídica relacionada a sua aplicação, ou por desvio de Poder - eram situações nas quais se poderia supor uma tentativa de rompimento do delicado equilíbrio institucional entre as escalas de existência vigentes. Caso a Alta Autoridade tivesse formalizado o ato normativo comunitário derivado conforme uma daquelas situações, poder-se-ia notar um potencial privilegiamento de sua escala de existência em detrimento das demais.

Por essa razão, o dispositivo em análise atuava no sentido de assegurar que antes que o Um supranacional da Alta Autoridade pudesse visar ao seu destacamento perante os demais - fendendo a horizontalidade de relações e se instalando intemporalmente no lugar do Direito e do Poder, haveria no Tratado um último nicho de resistência. As instituições da CECA almejariam com esse dispositivo à garantia da manutenção do vazio de Poder característico das Leis Políticas assumidas originariamente pela Comunidade Política da

\footnotetext{
${ }^{825}$ A rigor, como será visto no item 7.3.1., infra, e como mencionado na nota de rodapé 820, supra, o ato normativo emanado da Alta Autoridade não detém a marca da supranacionalidade, haja vista ser fruto de embates entre diferentes escalas de existência. A Alta Autoridade apenas formulava e formalizava a resultante normativa desse embate escalar.

Todavia, entende-se que especificamente neste artigo 33 o ato normativo da Alta Autoridade adquirira caráter fundamentalmente supranacional porque se trataria de um sentido normativo impresso no lugar do Direito e do Poder mediante incompetência, violação de formalidades essenciais, violação do Tratado ou de norma jurídica relacionada a sua aplicação, ou desvio de Poder.

Em outras palavras, a unilateralidade escalar de origem supranacional é suposta aqui como presente neste ato normativo combatido mediante o recurso à Corte precisamente porque a norma teria sido elaborada mediante mecanismos de tentativa ocupação do lugar do Direito e do Poder, isto é, que ignoravam a importância da multiescalaridade na formação do sentido normativo. Por nestes casos a Alta Autoridade sinalizar produzir norma jurídica positiva comunitária a partir de sua exclusiva escala de existência mediante incompetência, violação de formalidades essenciais, violação do Tratado ou de norma jurídica relacionada a sua aplicação, ou desvio de Poder, pode-se perceber que se introduziria aqui um potencial destacamento uniescalar da supranacionalidade da Alta Autoridade. Diante dessa supoisção, o Tratado submete o ato à avaliação pela multiescalaridade.

${ }^{826}$ Sobre a distinção entre Direito Comunitário Originário e Direito Comunitário Derivado, remetemos o leitor ao item 2.1.2., supra.
} 
Europa Unida da CECA: nenhuma das escalas de existência poderia determinar por si só e unilateralmente o sentido normativo último.

Tratava-se assim de mecanismo que abria um nicho de resistência para que uma estatalidade pudesse opor óbice a uma possível desconsideração pela Alta Autoridade do necessário conflito entre dimensões de existência no processo comunitário de produção de normas derivada.

A previsão deste recurso era fundamental, uma vez que - como será mais detalhado a seguir - o artigo 41 do Tratado retirava dos Estados-Membros a possibilidade de questionar ou rejeitar internamente por via judicial nacional a aplicação das normas jurídicas comunitárias sob o argumento de invalidade. A transferência de competências dos Estados para a vida em comum $^{827}$ somada à impossibilidade de questionamento interno (estatal) jurisdicional abria ampla margem à possível totalização de uma medida de existência sobre as demais - o que justifica a presença do instrumento de contenção neste artigo 33.

Há que se notar que aos Estados-Membros era atribuída a possibilidade de controle jurisdicional da atividade normativa de Alta Autoridade, mas não existia atribuição semelhante com relação ao Conselho. Isso significa que a atuação deste não era objeto de controle jurisdicional pois sua atividade normativa não era percebida aqui como perigosa e disruptora da horizontalidade.

Isso se explica pelo fato de que a maior probabilidade de tomada unilateral e uniescalar do lugar do Direito e do Poder residia na nova entidade supranacional recémcriada. E, para evitar o surgimento de um desejo de mando por parte desta, proclamou-se no Tratado de maneira expressa uma medida de controle jurídico-Político dissuasório dessa possível orientação de a supranacionalidade da Alta Autoridade paulatinamente visar à tomada do lugar do Direito e do Poder.

Com efeito, em virtude da transferência de competência para também decidir sobre questões concretas comuns sensíveis, a Alta Autoridade passava a ser dotada de funções fundamentais outrora detidas pelos Estados com exclusividade. Deste modo, haveria que se prever um mecanismo de contenção de possíveis tentativas de alargamento do espectro normativo de atuação por parte da supranacionalidade da Alta Autoridade, a fim de que esta não instaurasse um móvel de submissão da vida comum por meio do extrapolamento de seu âmbito de competência.

\footnotetext{
${ }^{827}$ Isto é, a retirada da capacidade de os Estados determinarem exclusivamente o sentido normativo a ser impresso sobre questões concretas comuns sensíveis (carvão e aço) na Comunidade.
} 
O refreamento contínuo de qualquer movimento tendendo à unidimensionalização e ao correlato rompimento da horizontalidade é a marca característica do Tratado da CECA: a nenhuma escala de existência se teria facultado a possibilidade de se supor autorizada a se transcendentalizar. Isso era necessário porque não se poderia pretender - tal qual o discurso Federalista Europeu almejara - a instituição da homogeneidade, pois apenas por meio da recusa da sacralização de qualquer Um no lugar do Direito e do Poder é que se mostrava possível evitar a Teológico-Politização da vida comum, isto é, assegurar a permanência de Leis Políticas na Europa Unida pela CECA.

Assim, a possibilidade de utilização do recurso de anulação por parte das estatalidades (isoladas ou intergovernamentalmente consideradas) se tratava de institucionalização da possibilidade de afastamento do potencial de submissão a um pretenso ocupante intemporal do lugar do Direito e do Poder. Diante dessa hipótese de pretensão de elevação sobre os demais, o Tratado assegurava instrumentos institucionais às estatalidades. Recorrendo a este contra-Poder contra a afirmação normativa irregular da supranacionalidade, as estatalidades faziam a Comunidade Política voltar a si própria e manter plenamente a horizontalidade relacional entre os participantes comunitários.

\subsection{A Limitação da Resistência: Autocontenção do Contra-Poder}

Todavia, o controle das estatalidades sobre a supranacionalidade não poderia ser entendido como ilimitado. Na verdade, o exercício de tal contra-Poder era admitido desde que de acordo com condições previstas no interior do próprio Tratado - de maneira que ele também não se desmesurasse e implicasse uma sucessiva e insuperável contestação contínua e desarrazoada por parte das estatalidades de um ato normativo formalizado pela Alta Autoridade.

Diante do vigoroso contra-Poder (Poder de controle) atribuído às estatalidades por meio do recurso à Corte, o próprio Tratado previu mecanismos voltados à frenagem deste. A aposição deste condicionamento interno operava como barreira que sempre tinha em mente não permitir a superação da necessidade de se manter a horizontalidade relacional, ou ainda, a importância de se enfatizar e de promover a diferenciação entre medidas de existência consideradas como pares comunitários - unidos Politicamente, porém não unificados - aptos a, em igualdade de condições, participar da formação do sentido normativo sobre questões concretas sensíveis comuns. 
Os condicionamentos internos ao contra-Poder atribuído aos Estados-Membros são de dois tipos, a saber: (i) uma limitação jurídico-processual temporal, isto é, derivada da estipulação jurídico-normativa positiva de um determinado lapso de tempo para a apresentação de tal recurso de anulação - isto é, para iniciar o processo; nos termos do artigo 33, parágrafo terceiro, tratava-se do período de "um mês a contar, conforme o caso, da notificação ou da publicação da decisão ou da recomendação"; ou (ii) uma limitação jurídico-institucional Política (artigo 33, parágrafo primeiro), vale dizer, uma restrição decorrente de expressa consideração das instituições jurídico-normativas da Comunidade, as quais tinham por base a orientação Política da vida em comum recém-instaurada na Europa da CECA.

Apesar de serem condições a serem supridas concomitantemente, as duas barreiras a esta atuação das estatalidades de controle da Alta Autoridade operavam em registros distintos com um mesmo objetivo: garantir institucionalmente o estabelecimento de uma convivência entre diferentes escalas por meio do estímulo à prática de interação ativa entre elas. Em outras palavras, garantir a permanência da imanência na Comunidade, pois se pretendia evitar que uma escala de existência - ainda que dotada de contra-Poder - se reputasse autorizada a se sobrepor às demais.

7.2.2.1.3.1. O Significado Jurídico-Político da Limitação Jurídico-processual Temporal: Risco de Unidimensionalização Supranacional e Tarefa Política das Estatalidades

Apesar de a primeira limitação poder ser vista como estabelecendo um simples marco temporal com o objetivo prático de definir uma condição de admissibilidade de uma ação judicial recursiva, há que se notar que ela operava a função de instrumento de realização do Político. Dito de outro modo, a despeito de ser um critério que atuava no plano processual, esta limitação detinha um objetivo de estimular a realização fática de uma interação Politicamente estruturada entre as escalas de existência.

Com efeito, uma vez decorrido o período de um mês após a notificação ou a publicação do regulamento ou da diretiva, tais atos normativos comunitários derivados forjados em irregularidade uniescalar - incompetência, violação de formalidades essenciais, violação do Tratado ou de norma jurídica relacionada a sua aplicação, ou por desvio de Poder - se tornariam impassíveis de futuro questionamento perante a Corte de Justiça da CECA pelas estatalidades. Assim, essa previsão do Tratado conferia aos atos 
normativos irregularmente marcados pela supranacionalidade a possibilidade de plena validade na hipótese de o recurso de anulação não ter sido interposto dentro do prazo de um mês. A ameaça de unidimensionalização supranacional rondava a vida em comum por expressa previsão do Direito Comunitário Originário do Tratado da CECA.

Todavia, essa previsão deve ser compreendida com maior precisão. Não se pode compreender que esse dispositivo se apresentava como opção por um abandono dissimulado da multiescalaridade típica da organização jurídico-Política originária da Comunidade. Antes, deve-se interpretar este dispositivo como buscando trabalhar de maneira coerente com a pretensão Política de impedir a incorporação exclusiva de uma dimensão existencial no lugar do Direito e do Poder mediante instrumentos institucionais que estimulassem a operação constante e ativa do entrechoque entre escalas de existência.

Entenda-se que esta previsão normativa apenas apresentava normativamente a lembrança do temível espectro da unidimensionalização escalar totalizante, a fim de que ele fosse combatido consciente e constantemente. Ao conferir sob um plano jurídico-processual temporal uma válvula para uma desautorizada apropriação do lugar do Direito e do Poder pela entidade supranacional, o Tratado nada mais buscava que estimular um controle e uma vigilância atenta e contínua por parte das estatalidades e, com isso, impulsionar a re-instauração do conflito entre as escalas de existência no interior da vida comum.

Nesse sentido, essa ressalva jurídico-processual temporal era um convite/alerta expresso às estatalidades para que acompanhassem de forma efetiva a produção normativa comunitária derivada. A ameaça institucional de unidimensionalização supranacional era na verdade uma armadilha voltada a atrair as estatalidades da CECA perante as demais escalas de existência, a fim de que permanecessem vigilantes e voltassem incansavelmente suas atenções para evitar qualquer possibilidade de introdução totalizante sub-reptícia de outras escalas de existência no lugar do Direito e do Poder.

Antes de promover um caminho institucional ardiloso para o enraizamento de uma medida unidimensional supranacional no centro nomogenético da CECA, essa previsão normativa se orientava para promover a conservação da uma dinâmica tensa e tensiva da interação Política entre as diferentes escalas de existência no interior da Comunidade. Mais do que autorizar eventuais desmandos em potencial da Alta Autoridade, ou mesmo mais do que simplesmente demandar a constante vigilância por parte das estatalidades, o Tratado vai mais longe: ele estimula institucionalmente uma reação ativa em direção à realização 
continuada do Político por meio da aposição de um fator de risco de totalização do espaço do Direito e do Poder pela supranacionalidade.

Deste modo, por meio desta disposição em especial, o Tratado apresentara institucionalmente a possibilidade ameaçadora de se reinstaurar uma pretensão de unificação escalar na Europa Unida a partir de uma perspectiva supranacional em virtude do decurso de prazo muito curto. Contra isso, caso quisessem preservar a paridade comunitária, as estatalidades deveriam permanecer alertas para impedir essa totalização supranacional.

Compreende-se assim que essa previsão normativa do Tratado conclamava as estatalidades para uma efetiva e ativa a atuação Politicamente orientada: a ação destas não deveria se resumir à posição de espectadores passivos do processo de formação do sentido normativo comunitário. Antes, elas deveriam também acompanhar ativa e atentamente engajadas a atividade da Alta Autoridade - entidade portadora de um grande potencial de totalização dimensional do lugar do Direito e do Poder na vida em comum. Deste modo seria sempre possível relembrar e reinstaurar a divisão, a diferença de escalas, o conflito entre modos de habitar o mundo e, com isso, afastar a ascensão de Um sobre os demais.

Por isso, a limitação jurídico-processual temporal opera como instrumento de efetivação concreta e prática de efetivação institucional do Político: diante da ameaça da supranacionalização da vida em comum por um mero decurso de prazo exíguo, as estatalidades deveriam estar sempre prontas para impedir que a supranacionalidade rompesse o delicado equilíbrio Político instituído pelo Tratado por meio de ato eivado incompetência, de violação de formalidades essenciais, de violação do Tratado ou de norma jurídica relacionada a sua aplicação, ou de desvio de Poder.

7.2.2.1.3.2. O Significado Jurídico-Político da Limitação Jurídico-institucional Política: Explicitação da Divisão e Convite à Oposição Pluriescalar

A limitação jurídico-institucional Política prevista no artigo 33, parágrafo primeiro, do Tratado da CECA também se mostrava orientada para a conservação do Político nas relações entre os povos europeus. Este outro dispositivo atuava em registro distinto - porque mais explícito - se comparado com o da outra limitação recémexaminada $^{828}$. Com efeito, ele não agia no plano da técnica processual, mas derivava da 
expressa consideração das instituições jurídico-normativas da Comunidade, as quais tinham por base a orientação Política originária desta.

Este outro tipo de limitação procurava efetuar de maneira renovada a reabertura de um espaço indeterminável unilateralmente pelas escalas de existência para as convidar à convivência (espaço da dinâmica típica da Política). Essa regulamentação visou à definição de critérios normativos que forçassem os partícipes comunitários a se apresentar uns perante os outros de maneira ininterrupta, a fim de que não cessassem de se opor.

Em outras palavras, a limitação em análise foi composta normativamente por mecanismos de oposições escalares, os quais foram arquitetados tendo em mente mais uma vez o impedimento de que alguma das escalas pudesse se autocompreender como a medida eleita destinada a reger totalmente as relações entre os países europeus Politicamente Unidos pela CECA. Ou ainda, a limitação examinada neste item também teria sido prevista no Tratado da CECA para preservar a horizontalidade relacional entre as diferentes escalas de existência mediante a introdução da explosiva multiescalaridade.

$\mathrm{O}$ artigo 33, parágrafo primeiro, do Tratado da CECA estipulava efetivamente um mecanismo de controle das estatalidades sobre a atividade normativa comunitária derivada formalizada pela Alta Autoridade. Todavia, nota-se a presença de expressa ressalva com relação à atuação jurídico-política da Alta Autoridade: ela apenas poderia ter seu ato anulado pela Corte, mediante recurso formulado pelas estatalidades, caso agisse normativamente por meio de ato eivado incompetência, de violação de formalidades essenciais, de violação do Tratado ou de norma jurídica relacionada a sua aplicação, ou de desvio de Poder.

Nestes termos do dispositivo a Alta Autoridade encontrava seus limites; contudo, nestes mesmo termos, ao mesmo tempo, ela encontrava de maneira mais bem delineada seu campo de atuação. A anulação dos atos normativos comunitários derivados por ela formalizados apenas seria possível se ela visasse a romper o equilíbrio escalar cuidadosamente constituído pelas instituições do Tratado da CECA. Todavia, caso não se tratasse dessa situação, tais atos não seriam passíveis de anulação, na medida em que não representariam uma ameaça de unidimensionalização supranacional.

Dito de outro modo: se a Alta Autoridade não atuasse fora de seu campo de atuação mediante incompetência, desvio de Poder, entre outros, ela teria o resultado de sua atividade resguardado de eventuais anulações injustificadas. Se se tratava de uma limitação explícita à Alta Autoridade, também se encerrava neste dispositivo uma limitação direcionada às estatalidades, pois não poderiam questionar atos normativos derivados se 
estes tivessem sido praticados sem incorrer naquelas situações extremas de princípio de unidimensionalização escalar.

A Alta Autoridade tinha assegurado pelo Tratado a permanência de seu campo de atuação válido, desde que não buscasse o extrapolar. As estatalidades poderiam questionar tais atos normativos, mas apenas se estes sinalizassem em sua formalização final uma tentativa de usurpação do lugar do Direito e do Poder pela supranacionalidade da Alta Autoridade.

Sem dúvida, o contra-Poder representado pelo recurso de anulação freava a Alta Autoridade. Todavia, ele próprio era barrado por autocontenções internas, pois o Tratado da CECA igualmente não descuidava da contenção das estatalidades envolvidas na vida em comum. Enquanto pares comunitários, nem a supranacionalidade da Alta Autoridade, nem as estatalidades (isolada e intergovernamentalmente consideradas) poderiam deter uma capacidade de ação maior do que a da outra, sob pena de se incorrer no risco de unidimensionalização.

\subsection{A Complexa Rede de Oposições Escalares do Dispositivo}

É fundamental perceber que o texto normativo em exame efetuava uma tripla limitação simultânea. Sua regulamentação jurídico-institucional envolvia não apenas (i) as estatalidades (isolada e intergovernamental) e (ii) a supranacionalidade da Alta Autoridade) $)^{829}$, mas também (iii) a supranacionalidade da Corte. Havia uma única previsão normativa sintética, a qual estabelecia três formas distintas de aproximação entre escalas de existência diferentes, segundo a lógica de promoção de uma dinâmica Política entre elas mediante um conflito instaurado continuamente pelas instituições do Tratado da CECA.

Em outras palavras, este artigo do Tratado provocava um triplo e simultâneo desdobramento de contenção da atividade de controle exercida por uma escala sobre a outra no necessário embate multiescalar. Tratava-se efetivamente de uma limitação, mas de uma limitação comprometida com a conservação da Política na vida comum da Europa Unida da CECA. Mediante a oposição aberta e incessante entre diferentes escalas de existência, não apenas a pluriescalaridade seria mantida, mas também a própria ciência da manutenção incontrastável da horizontalidade relacional.

${ }^{829}$ Como visto até o item anterior. 
Essa aparentemente singela disposição normativa portava consigo uma complexa articulação institucional que, em si, evidenciava os termos da divisão social que marcava as relações entre os países europeus Politicamente unidos - porém, não unificados, na vida comum da CECA. Cada um dos mencionados desdobramentos visava à contenção mútua e recíproca de três âmbitos de controle da atuação normativa da Alta Autoridade, sempre com o objetivo de assegurar a partir do maior número possível de perspectivas a impossibilidade de o lugar do Direito e do Poder ser tomado por uma ou por outra escala de existência.

Essa constatação é mais bem compreendida a partir do exame dos itens a seguir.

\subsection{A Contenção do Controle da Corte de Justiça da CECA}

O dispositivo estabelecia um limite ao campo de atuação da Corte. Definia-se a margem de exercício do controle pelo órgão jurisdicional comunitário mediante a estipulação de balizas certas a sua atividade: seu julgamento sobre o recurso de anulação apresentado pelas estatalidades poderia apenas se orientar por dois vetores analíticos, a saber, um exame de legalidade do ato normativo ou um exame de legitimidade deste ${ }^{830}$.

O exame de legalidade era realizado nos casos em que o recurso de anulação tinha por objeto um ato normativo comunitário derivado marcado pela predominância de uma perspectiva supranacional em virtude de sua origem em uma possível violação de legalidade - inadequação institucional, formal ou material resultante da atividade da Alta Autoridade durante o processo nomogenético comunitário ${ }^{831}$. Nos termos do artigo 33 , parágrafo primeiro, tratavam-se das situações em que o ato detivera por vício de origem "incompetência, violação de formalidades essenciais, violação do presente Tratado ou de qualquer norma jurídica relativa a sua aplicação".

${ }^{830}$ O Tratado da CECA não efetuara essa distinção entre exame de legalidade ou de legitimidade do ato normativo. Esse agrupamento tipológico das atividades de controle da Corte em torno do ato objeto do recurso apresentado pelas estatalidades é feito pelo autor desta Tese, com o objetivo de separar didaticamente a exposição e, com isso, tentar evidenciar diferentes aspectos possivelmente analisados pela Corte sobre um e mesmo ato normativo. O objetivo é mostrar que ambas as formas de atuação da Corte visavam à preservação de um modo de vida Político na CECA, ainda que tendo por orientação a verificação de questões distintas (legalidade ou legitimidade).

Ademais, se as classificações não podem ser certas ou erradas, mas apenas úteis ou inúteis, variando segundo a perspectiva de cada autor, entendeu-se aqui que esta diferenciação poderia ser chave útil para identificar e para permitir compreender um pouco mais o regime deste dispositivo ora em análise. Um exemplo da variabilidade terminológica utilizada em classificações foi designada na nota de rodapé 87, supra, referente à variação da classificação entre tipos normativos.

De todo modo, fica registrado aqui o convite para futuras precisões terminológicas adicionais em torno destes dois termos utilizados (legalidade e legitimidade) neste item.

${ }^{831}$ A ser examinado no item 7.3.1., infra. 
Nestes casos, a Corte deveria considerar apenas tal relação de adequação entre o ato normativo formalizado pela Alta Autoridade e as disposições do Tratado no que se refere (i) às regras de divisão de competência; (ii) às regras que versavam sobre o procedimento formal de produção jurídico-normativa no interior da Comunidade; e (iii) às previsões materiais constantes do Tratado ou de outra norma jurídica que visasse à aplicação deste.

Em outros termos, nesta hipótese normativa não era conferida à Corte a possibilidade de julgar o recurso de anulação com base em ambiente discursivo distinto daquele fornecido pelo - largo, é verdade - campo do raciocínio jurídico-positivo.

Com efeito, sua atividade jurisdicional se restringiria aqui a uma simples avaliação que somente deveria considerar, respectivamente, (i) um eventual exercício de competência pela Alta Autoridade que a ela não fora originalmente atribuída pelo Tratado; (ii) a não-integral satisfação pela Alta Autoridade de formalidades do processo de produção normativa previstas pelo Tratado; ou ainda, (iii) a criação de uma norma jurídica de caráter comunitário cujo conteúdo estaria em contradição com as normas constantes do Tratado ou de outras que visassem à aplicação deste.

A lógica da atividade de controle jurisdicional estaria adstrita, deste modo, a um exame de relação de legalidade entre o novo ato normativo e a ordem jurídica instituída pelo Tratado. A oposição instaurada entre supranacionalidades (Alta Autoridade versus Corte) não conferiria ao órgão jurisdicional comunitário a possibilidade de desencadear um processo integral de revisão normativa da produção nomogenética comunitária derivada. Este deveria se cingir a um exame de caráter estritamente legal.

Deste modo, perceba-se que se assegurava com tal disposição normativa o impedimento de uma eventual ocupação desautorizada do centro normativo da Comunidade pela dimensão de existência da Corte. Dito de outro modo, a previsão de um caminho de avaliação de legalidade refreava a atuação da Corte em estritos limites, de maneira a não permitir que nenhuma das supranacionalidades (a da Alta Autoridade ou a da Corte) pudesse se instalar no lugar do Direito e do Poder.

Por isso, ao excluir a possibilidade de sua apropriação por uma ou por outra das entidades detentoras da supranacionalidade, o Tratado se ocupara neste momento com a conservação de uma horizontalidade relacional mesmo entre os órgãos comunitários, a fim de que suas respectivas escalas de existência se mantivessem em condições de paridade e de não-sujeição de uma com relação à outra. Se a Corte poderia ser provocada para rever os atos normativos formalizados pela Alta Autoridade, esta não se sujeitaria a eventual 
unidimensionalização supranacional iniciada pela Corte, pois a jurisdição desta se cingia a um simples exame de legalidade.

Por sua vez, como afirmado acima, o mesmo artigo 33, parágrafo primeiro, previa ainda a possibilidade de um exame de legitimidade por parte da Corte. Esta poderia apreciar "situação decorrente de fatos ou circunstâncias econômicas em atenção à qual foram proferidas as referidas decisões ou recomendações". Tal previsão atribuía à Corte a possibilidade controlar a formalização de normas exercida pela Alta Autoridade sobre um campo cognitivo bastante abrangente: este abarcaria certamente um espaço localizado além da estreiteza de um estudo comparativo da legalidade do ato normativo com relação ao texto do Tratado.

Nestes casos, havia uma potencialização extrema da contraposição entre as supranacionalidade, pois teria havido uma grande ampliação do espectro de possíveis fundamentos para o julgamento pela Corte - a qual alargaria os vetores analíticos destinados a orientar a formação de seu juízo sobre o recurso de anulação. Note-se, todavia, que tal possibilidade surgia apenas em situações de extrema excepcionalidade, a saber, nas hipóteses em que a Alta Autoridade fosse acusada de ter cometido um desvio de poder ou de ter ignorado de forma manifesta as disposições do Tratado ou qualquer norma jurídica relativa à sua aplicação.

A previsão da possibilidade de exercer um exame de legitimidade visava a conter o eventual cometimento de excessos por cada uma das medidas supranacionais da Comunidade. O caráter excepcional deste controle jurisdicional sobre a legitimidade da atuação normativa da Alta Autoridade pela Corte se justificava era normativamente balizado: tratava-se de um mecanismo vigoroso - porém condicionado internamente destinado a barrar a pretensão de destacamento de um ou de outro com relação aos demais que compunham a Comunidade Política da Europa Unida pela CECA.

Com efeito, o Tratado determinava que o início do exame de legitimidade pela Corte não era espontâneo, vale dizer, ela não poderia atuar de ofício. Nesse sentido, mantido em sua inércia, o órgão jurisdicional permaneceria em tal posição até quando e se fosse convidado a atuar mediante recurso de anulação apresentado por um Estado-Membro ou pelo Conselho de Ministros. Além da necessidade de provocação, não se pode ignorar que, para verificar se se tratava da hipótese em questão, a Corte dependia ainda de uma precisa acusação por parte da estatalidade de que o recurso versava sobre desvio de poder ou sobre a ignorância de forma manifesta das disposições do Tratado ou de qualquer norma jurídica voltada à aplicação dele. 
Dessa forma, nos termos do Tratado, não caberia livre e independentemente à Corte a escolha sobre (i) se e quando deveria agir para controlar a atividade da Alta Autoridade, e (ii) se poderia efetuar ou (a) o exame de legalidade ou (b) o exame de legitimidade. $\mathrm{Na}$ verdade, a Corte dependia, antes de tudo, da apresentação de um recurso e, mais do que isso, dos precisos termos segundo os quais o recurso fora interposto - isto é, dos limites específicos da alegação do recurso.

Nesse sentido, a previsão da possibilidade de se exercer um exame de legitimidade não retirava a Corte de seu estado inercial de imobilidade; antes, ela pressupunha tanto a necessidade de provocação por parte das estatalidades (isoladas ou intergovernamentais), como ainda a imprescindibilidade de acusação expressa e precisamente formulada. Tais filtros visavam a conter a enérgica possibilidade de controle da Corte, de maneira a relembrar pelos distintos modos de condicionamento a permanência inquestionável de sua posição de igual perante as demais medidas participantes da vida em comum.

Seu controle era sem dúvida vigoroso - justificado pela excepcionalidade da situação, em que a gravidade do remédio correspondia à gravidade da doença: ameaça de extrema unidimensionalização supranacional da vida em comum. Todavia, tal controle não era desprovido de elementos internos que continham sua atuação e que refreavam a própria possibilidade de surgir uma pretensão totalizante por parte da Corte da CECA.

Nesse sentido, pode-se compreender porque o artigo 33, parágrafo primeiro, dispunha que a possibilidade de apreciação pela Corte dos fatos e das circunstâncias econômicas que motivaram a elaboração do ato normativo comunitário derivado não era completamente livre e imediata. Na verdade, haveria que se superar esses filtros iniciais para que a Corte pudesse controlar eventual desvio cometido pela Autoridade.

Ademais, há que se notar que, se apenas em um último caso ela poderia controlar a Alta Autoridade, tal controle não poderia significar nem a substituição desta em sua atividade normativa, nem mesmo suprir - segundo sua própria dimensão existencial supranacional da Corte - o processo nomogenético multiescalar da Comunidade. Assim, ainda que superados todos os condicionamentos internos para o exercício do exame de legitimidade, o máximo vigor da decisão da Corte seria apenas uma simples anulação do ato normativo - e nada mais ${ }^{832}$.

Dessa forma, não apenas se retirava da Corte a possibilidade de iniciar imediata e espontaneamente pelo exame da legitimidade: limitava-se ainda por cima o

${ }^{832}$ Como será mais bem compreendido, a partir da leitura do item 7.2.2.2., infra. 
campo de consequências possíveis de sua atividade de controle (mera anulação). A conjunção de tais condicionamentos internos refreava o exercício do Poder pela Corte e, com isso, evitava-se que ela pudesse se autocompreender como detendo livre e incondicional autorização para seguir um caminho que lhe permitisse desenvolver uma pretensão de enraizamento totalizante de sua própria escala de existência supranacional no interior do lugar do Direito e do Poder da CECA.

O Poder de controle atribuído à Corte era uma previsão que instituía uma autorização de bloqueio condicionada: atribuía-se uma grande competência de controle à Corte, a qual encontrava, por sua vez, uma fórmula de contenção de sua atividade. A despeito da maior ou menor abrangência possível do controle a ser realizado pela Corte, os exames de legalidade e de legitimidade deveriam se pautar por critérios normativos largos, é verdade, mas não inexistentes.

Em outros termos, não poderia a Corte os extrapolar na análise das questões a ela submetidas com o objetivo de frear eventuais perturbações do lugar do Direito e do Poder, pois ele próprio não poderia suprimir o vazio e o vácuo: previu-se no embate entre supranacionalidades complexa teia de mútua e recíproca contenção. $\mathrm{O}$ exame de legalidade e o de legitimidade operavam assim como dois exatos patamares de ação deste órgão e, por mais largo que fosse o tratamento a eles dado na formulação de seu juízo, eram ao mesmo tempo os únicos fundamentos possíveis previstos no Tratado de sua eventual decisão.

Ao grande Poder assegurado à Corte correspondia um forte dispositivo de contenção de sua atuação, o que constituía uma efetiva armadilha jurídico-institucional: ao mesmo tempo lhe concedia e lhe retirava a possibilidade de determinar as normas jurídicas comunitárias derivadas. Este contrapeso à eventual unidimensionalização da Alta Autoridade era, ele mesmo, limitado por sucessivas previsões do Tratado da CECA.

Assim, no interior da operação de tal instrumento de controle, não se buscara efetuar uma previsão normativa que conferisse preferência absoluta e a priori a uma específica "versão de supranacionalidade", fosse a dada pela Alta Autoridade, fosse a portada pela Corte. Neste embate escalar entre supranacionalidades, não havia qualquer preferência que sinalizasse facilitação a eventual apropriação do lugar do Direito e do Poder por um ou por outro; antes, pode-se apenas identificar a delicada e fina tentativa equilibrada de tentar manter de maneira engenhosa uma articulação institucional voltada a conservar a paridade comunitária típica de Leis Políticas. 
7.2.2.1.4.2. A Institucionalização de Oposições Escalares: O Controle de Anulação da Corte como Nicho de Resistência à Unidimensionalização da Supranacionalidade da Alta Autoridade

Por fim, não se pode deixar de notar que o dispositivo ora em análise exercia o papel de importante nicho de exercício de resistência na Europa Unida à possibilidade de ascensão do Um, homogêneo e homogeneizante, total e totalizante, sobre os demais.

Com efeito, a previsão de um mecanismo institucional para que as diferentes escalas de existência participantes da vida em comum se opusessem umas às outras deve ser percebida como a direitificação de um sistema de convivência. Segundo essa dinâmica, os diferentes seriam continuamente convidados a se posicionar de maneira ativa para conter qualquer tentativa de impressão de uma única dimensão - ainda que supranacional da Alta Autoridade - sobre o lugar do Direito e do Poder.

Nesse sentido, diante do grande potencial de Uma medida de existência supranacional buscar precipitar sobre as demais escalas sua imagem e semelhança, a solução dada pelo Tratado objetivara constituir um último círculo de liberdade e de garantia da vigência de Leis Politicamente orientadas na Europa Unida. De fato, nas hipóteses em que o exame de legitimidade se mostrava cabível segundo os termos do Tratado, era ele um enérgico instrumento de bloqueio, necessário para assegurar a permanência do vazio de Poder tipicamente Político.

As situações em que o exame de legitimidade poderia ser exercido eram momentos de gravidade última, pois se tratavam de ocasiões temerárias de potencialmente sérios comprometimento e rompimento do delicado e virtuoso equilíbrio conflitivo que caracteriza o vigor de instituições Politicamente orientadas. De fato, um ato normativo supranacionalmente orientado - pois fundamentado em desvio de Poder ou na ignorância manifesta das disposições do Tratado ou de norma voltada a sua aplicação - nada mais simbolizava do que perigosa inovação jurídica que hipertrofiaria uma única dimensão de existência sobre a heterogeneidade escalar do social.

Deste modo, as duas hipóteses que autorizavam o exercício desse vigoroso bloqueio por parte da Corte de possíveis arroubos inventivos da atividade normativa da Alta Autoridade devem ser compreendidas como situações extremas de necessidade de contenção de um potencial trituramento da dinâmica Política das relações da Europa Unida da CECA. Afinal, agir no interior do campo de competência originalmente atribuído (i) para o ultrapassar e se imiscuir sub-reptícia e veladamente no interior de outro; ou (ii) em 
manifesta desconsideração do Tratado ou de norma que visasse à aplicação deste, eram duas hipóteses de absoluta desconsideração da arquitetura institucional configurada para assegurar a prevalência do Político naquele Projeto de Europa Unida ${ }^{833}$.

Por isso mesmo, seguindo a lógica de promoção e de preservação institucional do equilíbrio escalar entre os pares comunitários da Europa Politicamente Unida, diante de tentativa concretamente constatada de introdução na vida comum de excepcionalidade normativa por parte da Alta Autoridade, à Corte era assegurada a oportunidade de exercer importante e contundente nicho de resistência voltado a assegurar a permanência da recusa da plenificação uniescalar do lugar do Direito e do Poder na CECA - desde que provocado pelas estatalidades.

Não se pode deixar de ignorar, por fim, que o Tratado previa uma simultânea contenção adicional da atividade de controle exercida por uma ou outra das demais escalas de existência. Há, no interior da própria limitação à atividade de controle jurisdicional exercida pela Corte, uma limitação adicional dirigida contra o controle exercido pelas estatalidades ou contra o Poder da supranacionalidade da Alta Autoridade.

Com efeito, note-se que neste artigo havia um comando dirigido duplamente contra estatalidades e Alta Autoridade, para que se mantivessem conscientes de seus limites institucionais e, diante isso, para que temperassem continuamente suas ações no exercício de suas respectivas atividades, sem buscar a tomada do lugar do Direito e do Poder. Havia assim um bloqueio recíproco ainda mesmo entre estatalidades e a supranacionalidade da Alta Autoridade, pois:

(i) os Estados tinham assegurada a possibilidade de contenção do eventual transbordamento normativo da Alta Autoridade (supranacionalidade), mas sempre condicionada (a) ao lapso temporal de um mês; (b) à intermediação da atividade por outro órgão comunitário também detentor da supranacionalidade (Corte), quem avaliaria o pedido e sua procedência; e (c) à necessidade de fundamentação precisa de que se tratava de hipótese de exame de legalidade ou de legitimidade, ao passo que

(ii) a Alta Autoridade detinha completa liberdade de agir no interior de seus limites de competência institucionalmente assegurados, mas desde que se concentrasse a permanecer neles; deste modo, estava ela consciente de que a qualquer momento sua

\footnotetext{
833 Tratavam-se de situações em que havia excessiva valorização autoproclamada de uma medida de existência sobre as demais - deliberada desconsideração das Leis Políticas, imbuída da mais elevada presunção que acreditava ser necessário ver triunfante como único modo de habitar o mundo sua dimensão parcial. Tamanha ameaça à pluriesscalaridade justificava correlata atribuição de mecanismo igualmente potente para seu controle institucional.
} 
atividade normativa poderia ser controlada por outro órgão comunitário (Corte), o qual, ao operar sua própria medida de existência supranacional contra a da Alta Autoridade, impedia que esta se difundisse incondicionalmente sobre as demais mediante ato normativa comunitário derivado uniescalar.

A Corte atuava, nesse sentido, não apenas como uma entidade de controle jurisdicional limitado dos atos normativos comunitários derivados da atividade da Alta Autoridade. Além de promover e de participar o embate entre duas supranacionalidades, a Corte também representava o papel de local institucional de encontro e de oposição entre a supranacionalidade da Alta Autoridade e a estatalidade da entidade que apresentara o recurso.

Nesse sentido, visualiza-se facilmente como um conflito derivado de oposições escalares era institucionalmente encaminhado pelo próprio Tratado da CECA para ser resolvido novamente mediante normas de oposições escalares - isto é, sem atribuir a uma entidade a possibilidade de fornecer com exclusividade a última palavra sobre os conflitos. Pois, afinal, em uma Comunidade Política, mesmo em situações extremas de ameaça de introdução da excepcionalidade, nenhuma das escalas de existência poderia se autocompreender como podendo ocupar unidimensionalmente o lugar do Direito e do Poder. Nem mesmo a solução de controvérsias.

7.2.2.2.: O Artigo 34 e o Significado Jurídico-Político das Consequências da Anulação do Ato Normativo pela Corte

\subsection{Observações Gerais sobre o Artigo 34}

Uma vez decidido o recurso de anulação interposto perante a Corte ${ }^{834}$, e uma vez considerada procedente a anulação do ato normativo da Alta Autoridade, à Corte competia reenviar a questão à Alta Autoridade, a fim de que esta tomasse as necessárias medidas de execução da decisão de anulação. À Corte não era concedida a faculdade de reeditar do ato normativo em substituição à Alta Autoridade, nem a competência para diretamente a condenar ao pagamento de indenização a eventuais entidades prejudicadas pela edição de sua decisão ou de sua recomendação.

\footnotetext{
${ }^{834}$ Previsto no artigo 33 do Tratado da CECA, o qual foi examinado no item 7.2.2.1., supra.
} 
O primeiro parágrafo do artigo 34 operava como mais um instrumento de limitação do exercício do mecanismo de controle da atividade da Alta Autoridade atribuído à Corte, o que deve ser entendido como outra disposição voltada ao freio da ação desta última em nome da preservação da imanência na vida em comum. Não é demais observar que o termo utilizado pelo artigo não é o substantivo "cumprimento", o que por si só denotaria uma submissão da Alta Autoridade à Corte, mas "execução". A escolha destes termos não é desarrazoada ou ocasional quando se compreende estruturalmente a arquitetura institucional da CECA.

Com efeito, ao se optar por execução, denotou-se a preferência por sinalizar viger um regime jurídico-Político de convivência entre diferentes inseridos em iguais condições de participação da vida comunitária, isto é, entre diferentes em mesma posição horizontal na vida em comum, sem que houvesse jamais qualquer determinação de relação hierárquica entre os pares comunitários da CECA.

Nesse sentido, os termos do Tratado se preocuparam em frisar - mesmo em nível lógico - a percepção de que a relação entre as diferentes escalas de existência envolvidas no Tratado era sempre pautada pela horizontal igualdade de posições. Afinal, a igualdade de condições entre os pares comunitários seria efetivo marco da horizontalidade relacional na Comunidade Política da Europa apenas se jamais uma escala de existência pudesse nem mesmo pretender submeter outra igual participante da vida em comum.

Por isso, não poderia a Corte de pronto, nem decidir normativamente no lugar da pluralidade escalar, nem a condenar a Alta Autoridade a cumprir determinada decisão jurisdicional. Mas não apenas na dimensão linguística deste artigo do Tratado residia a opção por privar qualquer medida de existência de uma possível exclusividade na ocupação do lugar do Direito e do Poder quando da anulação de um ato normativo da Alta Autoridade.

7.2.2.2.2. A Circunscrição da Anulação como Constrição Constrita da Alta Autoridade

O controle jurisdicional da atividade da Alta Autoridade não apenas repudiava a introdução preferencial ou a priori desta no lugar do Direito e do Poder. A previsão do artigo 34, parágrafo primeiro, afastava também o eventual surgimento da pretensão de unidimensionalização por parte da própria Corte da CECA - operando assim de acordo 
com o sentido originário da Comunidade de evitar dar condições ao destacamento de qualquer escala de existência da vida comunitária. Tratava-se na verdade de um engenho de contenção - ele mesmo contido - em nome da preservação e da promoção da dinâmica da Política na Europa Unida da CECA.

\subsection{A Armadilha da Anulação I: Repulsa Mútua à Supranacionalidade}

A previsão da possibilidade de se decidir pela anulação da norma formalizada pela Alta Autoridade não conferia diretamente à Corte nenhum Poder além deste específico de decidir pela anulação da norma jurídica comunitária. No interior da prática deste controle da atividade da Alta Autoridade, nada além desse Poder de invalidação de normas jurídicas era concedido à Corte.

Deste modo, o grande Poder constritor da Corte era, na verdade, nada mais do que um Poder ele mesmo constrito, pois não lhe competia a prática imediata de qualquer outra atividade além da mera declaração de anulação. $O$ círculo de atividades da Corte delimitado pelo artigo 34 era bastante circunscrito, o que pretendia impedir nesta o surgimento de uma autocompreensão jurídico-política que a percebesse como autorizada a ocupar o lugar do Direito e do Poder na Comunidade em caráter preferencial em relação aos demais participantes da vida comunitária.

Neste conflito institucionalizado entre as duas supranacionalidades não havia a previsão de um ganhador ou de um perdedor, ou melhor, não se previa um aniquilamento escalar seguido pela substituição de uma medida de existência por outra. Antes, previa-se apenas e tão-somente isto: o temperamento mútuo e recíproco das ações e das contra-ações, das afirmações e das negações, dos pesos e dos contrapesos, ou ainda, simplesmente, o estabelecimento de um modo de convivência que a todos permitiria a participação na construção do sentido normativo sobre questões concretas comuns.

Por esse motivo, uma vez declarada a anulação, à Corte cabia apenas a devolução do processo à Alta Autoridade, a fim de que esta tomasse as medidas necessárias à execução da decisão de anulação. Nos termos da arquitetura institucional Politicamente orientada da Europa Unida da CECA, não apenas a Corte somente declarava a anulação, mas também era somente à Alta Autoridade conferida a atribuição da possibilidade de escolher quais caminhos deveria seguir para executar tal decisão.

Assim, a Corte estava impedida de, de antemão, pretender fazer substituir sua própria escala à da Alta Autoridade na definição do sentido normativo do ato questionado. 
O órgão jurisdicional da CECA encontrava um vigoroso bloqueio ao eventual surgimento de pretensão de combater a unidimensionalização supranacional (da Alta Autoridade) mediante a (perversa) totalização da própria escala de existência.

Em outras palavras, a supranacionalidade da Corte não poderia barrar o movimento da supranacionalidade de Alta Autoridade de tomada do lugar do Direito e do Poder da Comunidade por meio da colocação de sua própria escala de existência nele. Antes, a previsão normativa refletia a preocupação de o manter em sua condição Política de ser um centro tipicamente escalarmente desocupado - ou ainda, vazio, pois marcado continuamente pela pluralidade escalar.

Nesse sentido, à Corte incumbia apenas devolver o processo à Alta Autoridade, vale dizer, retirava-se qualquer possibilidade de se suscitar a atribuição ao órgão jurisdicional da CECA qualquer outro Poder normativo substitutivo que pudesse ir além desta sua simples decisão de anulação. Em outras palavras determinara-se claramente que à Corte não caberia buscar reeditar a norma jurídica anulada - ainda que tivesse sido realizado o acima chamado exame de legitimidade.

Poder conter a potencial supremacia da medida de existência da supranacionalidade da Alta Autoridade não garantia à Corte a possibilidade de se fazer substituir no lugar do Direito e do Poder e de nele introduzir sua própria visão supranacional. Essa contenção visava a garantir o vazio com relação às divergentes maneiras de se compreender supranacionalmente a Comunidade (a supranacionalidade da Alta Autoridade versus a supranacionalidade da Corte), isto é, obstava a instalação de uma medida supranacional (qualquer delas) que excluísse totalmente as demais do centro nomogenético comum.

Assim, havia uma engenharia institucional cuidadosamente voltada a repelir do lugar do Direito e do Poder simultaneamente a perspectiva supranacional portada pela Alta Autoridade e aquela que era veiculada pela Corte. Todavia, a arquitetura institucional não descuidava também da importância de assegurar que na vida da Europa Politicamente Unida não houvesse a prevalência de qualquer escala de existência. A única certeza possível consistiria na permanência de um lugar do Direito e do Poder permanentemente desocupado, em virtude da absoluta horizontalidade relacional entre todos os partícipes da vida em comum. 
7.2.2.2.2.2. A Armadilha da Anulação II: O Poder “sem Poder" da Corte

O mesmo artigo 34, parágrafo primeiro, do Tratado da CECA afastava a possibilidade de qualquer determinação das atividades da Alta Autoridade pela Corte mediante sua decisão de anulação. Em outras palavras, o Tratado reforçava a independência da Alta Autoridade enquanto par comunitário, mesmo quando ela fosse passível de ser julgada pela Corte como entidade que pretendera ocupar o lugar do Direito e do Poder na vida em comum. Apesar de se ter percebido que ela almejara romper com o equilíbrio relacional, a resposta institucional prevista pelo Tratado jamais retiraria da Alta Autoridade o reconhecimento de ela ser uma entidade dotada permanentemente de igual condição de participação da vida em comum em comparação com as demais escalas de existência.

O referido artigo determinava que apenas à Alta Autoridade caberia a escolha das medidas necessárias à execução da decisão de anulação. Isso implica reconhecer que, em sua decisão, a Corte não estava autorizada a condenar a Alta Autoridade a desempenhar qualquer conduta no sentido de cumprir uma "ordem".

Dito de outro modo, era à Alta Autoridade que cabia (i) a revogação da norma anulada, (ii) sua substituição por outra de acordo com os parâmetros estipulados no Tratado - à luz da decisão proferida pela Corte, e (iii) a opção pelos instrumentos necessários para que os efeitos derivados de tal norma anulada deixassem de ser produzidos ${ }^{835}$. Tratava-se da previsão de um efetivo um Poder "sem Poder" à Corte: se recebia um grande Poder - possibilidade de declarar a anulação de uma norma jurídica comunitária derivada, a Corte não era munida de qualquer capacidade de proferir uma "decisão condenatória a ser eventualmente cumprida pelo condenado" (Alta Autoridade).

Perceba-se a situação bastante particular da previsão normativa constante deste artigo: ainda que, a pedido de empresas ou grupo de empresas, a Corte constatasse ter havido um dano direto e especial sofrido por elas em virtude da anulação de uma norma jurídica comunitária emanada da Alta Autoridade ${ }^{836}$, era a esta última, e não à primeira,

\footnotetext{
${ }^{835}$ É importante lembrar que, em regra geral, o artigo 39, parágrafo primeiro, do Tratado da CECA estipulava a ausência de efeito suspensivo nos recursos apresentados perante a Corte. Isso significa que todos os efeitos decorrentes de qualquer norma anulada pela Corte permaneceriam sendo produzidos até sua definitiva exclusão do ordenamento jurídico comunitário.

No entanto, o parágrafo segundo do mesmo artigo 39 autorizava à Corte a suspensão de decisão ou recomendação da Alta Autoridade que fora impugnada, nos casos em que a Corte considerasse que as circunstâncias exigiam a adoção dessa medida.

${ }^{836}$ Pedido possível a partir de previsão constante do artigo 33, parágrafo segundo, do Tratado da CECA. Este não foi examinado no item anterior (7.2.2.1., supra) pois, de acordo com o recorte metodológico feito no
} 
que caberia a determinação das medidas adequadas para efetuar uma reparação equitativa do dano ${ }^{837}$.

Em outras palavras, não estava diretamente dentro do rol de funções atribuídas à Corte estipular, quando do controle da atividade da Alta Autoridade, as vias e os critérios para a reparação e para a indenização de empresas ou grupo de empresas diretamente prejudicadas pela norma anulada, mas apenas e tão somente reconhecer que tais entidades sofreram algum dano, de modo que a Alta Autoridade não restaria submetida a uma entidade que ocupava a mesma posição na vida em comum - pois, entre pares, não haveria hierarquia.

7.2.2.2.2.3. A Armadilha da Anulação III: Novos Freios e Contrapesos entre Alta Autoridade e Corte

A previsão normativa do parágrafo segundo do artigo 34 também não pode ser ignorada. Se o início do artigo 34 controlava o próprio Poder de controle da Corte, o final do mesmo artigo também apresentava uma baliza adicional no jogo de constantes oposições e contraposições para assegurar a permanência da horizontalidade relacional na Europa Politicamente Unida.

Efetivamente à Corte não era concedido qualquer Poder de condenação direta e imediatamente decorrente de sua decisão de anulação da norma jurídica da Alta Autoridade. Por outro lado, uma vez constatada a inação desta no que se refere à escolha dos critérios e das medidas necessárias para executar a referida decisão, à Corte era concedida em caráter subsidiário a possibilidade de decidir sobre tais medidas, desde que fosse apresentado perante a Corte um pedido de indenização.

Havia assim a introdução de nova medida de bloqueio duplo por este artigo. Se o parágrafo primeiro estabelecia que era assegurada uma independência de escolha por parte da Alta Autoridade dos meios para dar execução à sentença, por outro lado, o parágrafo segundo previa o rompimento dessa independência visando à efetivação da dinâmica estrutural Política da Europa Unida. Revitalizava-se ainda mais uma vez o conflito entre escalas de existência, a fim de dar continuidade ao sentido Político do conflito

início do trabalho e deste capítulo, ele, por si só, não continha uma norma de oposição escalar entre participantes da vida em comum - na medida em que se dirigia a empresas ou grupo de empresas, facultando-lhes não um Poder de contenção de outra escala de existência, mas apenas um direito à ação judicial perante a Corte da CECA.

${ }_{837}$ Conforme o final do artigo 34, parágrafo primeiro, do Tratado da CECA. 
anteriormente instaurado pelo recurso de anulação: retomava-se a contraposição no âmbito supranacional.

Antes de tudo, há que se frisar que este dispositivo não suspendia "sorrateiramente" a contenção outrora oposta ao Poder de controle da Corte. O bloqueio a uma condenação direta e imediatamente decorrente da decisão de anulação persistia de forma efetiva. Não se operava assim uma exceção ao freio estipulado à atividade de controle da Corte, pois permanecia sendo vetado que esta pudesse, em uma única vez, em um mesmo ato, declarar a anulação da norma jurídica e determinar o cumprimento de tal ordem à Alta Autoridade.

Assim, a contenção acima descrita ${ }^{838}$ não desaparecera, nem fora excepcionada. $\mathrm{O}$ parágrafo segundo do artigo 34 do Tratado da CECA apenas previra uma nova concessão de competência à Corte para que, diante do novo fato de inação desarrazoada da Alta Autoridade, fosse possível, mediante a apresentação de um pedido de indenização, a realização de um novo mecanismo de controle entre os participantes da vida comum. Por meio de um novo procedimento, distinto do anterior, com outro objeto e com outro autorizativo normativo de oposição escalar, seria possível estimular a Alta Autoridade a tomar as medidas necessárias para a factibilidade da anulação.

Não se tratava de uma exceção. Instaurar um regime de exceção neste ponto crucial de estabelecimento de novo conflito entre medidas de existência significaria introduzir sub-repticiamente válvulas para autorizar maneiras alternativas de verticalizar as relações entre as escalas de existência participantes da vida em comum das Leis Políticas da Europa Unida pela CECA.

Em outras palavras, a previsão normativa não poderia ser entendida como inserindo a exceção institucional nas relações direitificadas entre os participantes da vida em comum precisamente porque tal inovação jurídico-normativa implicaria uma indevida e sorrateira introdução da possibilidade de sujeitar uma das escalas de existência a outra. Como ocorria sucessivamente com qualquer dos participantes da vida comunitária, a Corte não poderia se autocompreender como privilegiada por um regime de exceção.

É preciso, todavia, compreender um pouco melhor como se desenvolve a dinâmica de reinstauração do Político neste parágrafo único, por meio da explicitação dos freios e dos pesos que nele estão contidos de maneira embaraçada. Nesse sentido, é fundamental desdobrar a complexa rede de contenções e de negatividades institucionais recíprocas presente nessa singela descrição normativa.

\footnotetext{
${ }^{838}$ Especialmente no item 7.2.2.2.2.2., supra.
} 
Por um lado, à positividade da independência da Alta Autoridade outrora afirmada no artigo 34, parágrafo primeiro, opunha-se a constrição do parágrafo segundo. Por outro lado, ao refreamento do Poder da Corte de impactar na atividade da Alta Autoridade por meio da sentença de anulação, contrapunha-se a concessão à Corte da possibilidade suplementar de constranger - de modo condicionado - a Alta Autoridade, caso esta não escolhesse medidas de execução da decisão de anulação.

Como visto no item anterior ${ }^{839}$, o Tratado da CECA havia concedido um Poder “sem Poder" à Corte: esta poderia determinar a anulação de um ato, mas reservara-se à Alta Autoridade a possibilidade escolher as medidas de execução da sentença de anulação. Todavia, nos termos do parágrafo segundo do mesmo artigo 34, esta independência facultada à Alta Autoridade não poderia ser entendida como de validade absoluta e incondicional - do contrário, seria um dispositivo jurídico-normativo que escaparia à lógica institucional de organização jurídico-Política das relações entre os participantes da vida em comum.

De fato, caso a faculdade concedida à Alta Autoridade não encontrasse um mecanismo institucional de resistência, este órgão comunitário teria reforçada de maneira imoderada sua perspectiva supranacional. E, na ausência de um potencial direcionamento posterior por parte da Corte, ainda que a norma comunitária tivesse sido declarada nula pelo órgão jurisdicional da CECA, a Alta Autoridade não teria estímulos do ambiente institucional para dar meios concretos de execução à decisão de anulação.

Em outras palavras, a Alta Autoridade poderia até mesmo desconsiderar a decisão da Corte e manter a norma jurídica comunitária eivada desmedidamente da supranacionalidade, o que inseriria sua escala de existência em posição privilegiada e destacada na definição do sentido normativo sobre questões comuns. Ou, mais simplesmente, o que alçaria sua perspectiva para posição superior com relação à dos demais participantes da vida comunitária - fomentando uma progressiva totalização unidimensionalizante no centro nomogenético comunitário. Sem dúvida a escolha de medidas pela Alta Autoridade era independente da Corte.

Todavia, diante de uma possível desconsideração da sentença de anulação pela primeira, o Tratado previa a possibilidade de reinstaurar a oposição entre as medidas de existência para configurar institucionalmente um novo conflito Politicamente orientado - o qual seria responsável por doar um sentido concreto ao conflito Político anterior. 
Objetivava-se com isso conformar normativamente nova oposição entre as escalas de existência por força de estímulo institucional, de maneira dar sentido concreto ao controle jurisdicional multiescalar efetuado por força do artigo 33 do Tratado.

Por esse motivo, não se pode deixar de notar que a contenção a favor da independência da Alta Autoridade era ela mesma contida, sempre tendo em mente a factibilidade das Leis Políticas nas relações da Europa Unida pela CECA. A garantia da permanência do Político seria dada, assim, pelo fato de não se admitir que um dos órgãos da Europa Unida se recusasse a se submeter à decisão formada multiescalarmente em direção à regulamentação compartilhada de questões concretas comuns sensíveis, vale dizer, por se repelir qualquer pretensão de a Alta Autoridade se considerar proprietária do lugar de produção do Direito e das decisões do Poder.

Uma vez decidida a necessidade de promover a anulação fática da norma jurídica anulada pela Corte, deveria a Alta Autoridade executar - à sua maneira, é verdade - tal procedimento. Ignorar tal orientação significaria subverter o vetor Político do controle estabelecido pelas instituições da CECA e a progressiva admissão da entrada de uma dimensão única no lugar do Poder. Um se consideraria apto a se destacar sobre os demais e a ditar Ele próprio, sobre os demais, as regras às quais poderia ou não Ele obedecer.

Recusava-se por meio deste engenho institucional a instauração da verticalidade no seio da Europa Unida: haveria que se cuidar para manter aplainadas as relações entre as diferentes escalas de existência participantes da vida em comum, o que apenas seria possível mediante a manutenção do conflito por meio de normas de oposições escalares. Tratava-se assim de mais uma disposição orientada contra a transcendentalização de uma dimensão existencial em relação às demais: contra a transcendentalização do Um supranacional.

Entretanto, a configuração e a articulação institucionais dos jogos normativos de freios e contrapesos entre os participantes da vida comum da CECA em nenhum momento esquecera a importância de manter a organização jurídico-Política das relações na Europa Unida. Se, diante da inação da Alta Autoridade, mais uma vez se previra a instauração do conflito escalar por meio de renovada atuação da Corte, não se pode deixar de notar que, ainda uma vez, a medida constritora era ela mesma constrita.

Observe-se que também neste caso específico, a atuação de bloqueio exercida pela Corte contra a potencial unidimensionalização da Alta Autoridade era condicionada à satisfação simultânea de três elementos. Estes assegurariam a autocontenção da atividade jurisdicional e, deste modo, preservariam a horizontalidade relacional na CECA. O 
parágrafo segundo do artigo 34 determinava categoricamente que eram condições para a atuação da Corte (i) a inação da Alta Autoridade; (ii) o decurso de um período razoável; e (iii) a apresentação de um pedido à Corte.

Nos termos do Tratado, deste modo, mais uma vez não apenas a Corte não poderia atuar ex officio para constranger a Alta Autoridade, como também estaria impedida de agir sem aguardar a possibilidade de desempenho da conduta esperada pela Alta Autoridade. Seu Poder de constrangimento não era, dessa forma, imediato, mas residual, subsidiário. Não derivaria de seu Poder de controle diretamente e não poderia ser exercido logo após o proferimento de sua sentença de anulação.

Em outras palavras, sem a inação da Alta Autoridade, sem o decurso de um prazo razoável e sem a apresentação de um pedido perante a Corte, esta não poderia constranger a Alta Autoridade. Tais condições foram pensadas propositalmente para emperrar qualquer funcionamento automatizado que pudesse encaminhar ao destacamento da supranacionalidade da Corte em detrimento dos demais participantes da vida em comum.

7.2.2.2.2.4. A Armadilha da Anulação IV: O Significado Jurídico-Político do Constrangimento Econômico

Ainda sobre as contenções efetuadas ao Poder de freio atribuído à Corte pelo parágrafo segundo do artigo 34 do Tratado da CECA, há que se notar uma derradeira previsão que simbolizava de maneira ainda mais candente os limites jurídico-Políticos do controle jurisdicional dos atos normativos comunitários derivados eivados da supranacionalidade da Alta Autoridade: a previsão do pedido de indenização.

Perceba-se que a capacidade de atuação da Corte era vigorosamente restringida pelo texto do Tratado. O Tratado se recusava diretamente a conceder a possibilidade de a Corte se fazer substituir à Alta Autoridade e estabelecer os critérios e os meios para a execução da sentença de anulação. A previsão de semelhante medida poderia permitir um progressivo destacamento à medida de existência da Corte e, por isso, o Tratado apenas facultava à Corte a possibilidade de julgar um pedido de indenização.

Assim, perceba-se que diante da gravíssima e extrema situação de ausência de tomada de medidas para a execução da sentença de anulação, o contrapeso exercido pela Corte à inação da Alta Autoridade se restringia apenas e tão-somente ao julgamento de um pedido de indenização. Isso implica reconhecer que todo o potencial de controle jurisdicional residual que este órgão poderia realizar da atividade ameaçadora da 
Alta Autoridade - situação limite de reincidência de desconsideração do fino equilíbrio Político da Comunidade - era reduzido ao julgamento de um pedido de indenização.

A previsão institucional teria limitado o espectro de atuação do controle jurisdicional a uma mera dimensão pecuniária, ou ainda, em outras palavras, estava a Corte desprovida de meios constritores outros - de caráter coercitivo - para fazer executar a sentença de anulação. A Corte não teria meios para "executar" por meio do uso da força sua decisão, em desfavor da Alta Autoridade. O Poder de controle jurisdicional estava assim esvaziado: de nada adiantaria deter um Poder de constrangimento econômico se, além de ser condicionado ${ }^{840}$, ele também não produziria qualquer efeito definitivamente determinante e modificador da situação de inação da Alta Autoridade.

Todavia, é precisamente este esvaziamento do Poder de controle da Corte que se previra neste artigo. A redução do campo de atuação do órgão jurisdicional da CECA a aspectos pecuniários pode parecer, à primeira vista, uma situação verdadeiramente contraditória e sem sentido. Afinal, se se pretendia instituir normativamente um mecanismo de controle jurisdicional para assegurar a execução da sentença de anulação, qual o motivo de se ter sugado toda a vitalidade desse instituto, reduzindo-o a um exclusivo aspecto pecuniário ${ }^{841}$

Perceba-se que o esgotamento do Poder atribuído à Corte era visado por esse dispositivo em um sentido jurídico-Político bastante específico, o qual apenas é revelado a partir da consideração das Leis que passaram a reger as relações entre os países europeus unidos pela CECA: a manutenção da Política por um lugar do Direito e do Poder vazio (isto é, multiescalarmente determinado) e desprovido de qualquer elemento coercitivo.

Nesse sentido, ao se restringir a atividade jurisdicional à dimensão pecuniária, o Tratado assegurava normativamente a instauração de mais uma contraposição entre os modos de existência que compunham supranacionalmente a Europa Unida da CECA. Contudo, não atribuía a qualquer deles a prevalência: nem mesmo na última oportunidade

\footnotetext{
${ }^{840}$ Como visto ao final do item anterior, 7.2.2.2.2.3., supra.

${ }^{841}$ A reflexão a seguir dialoga profundamente com a que é realizada no item 7.2.4., infra, sobre a execução das decisões da Corte e da Alta Autoridade nos Estados-Membros, razão pela qual remetemos o leitor também a aquele item.

A leitura daquele próximo item, e deste, permite que um dos argumentos deste texto se torne ainda mais claro: é possível perceber a recusa na Europa da assunção de uma forma de organização jurídicoPolítica fundada na força e na centralização de seu uso por uma entidade. Em outras palavras, o estabelecimento de Leis Políticas na Europa do pós-Segunda Guerra Mundial se preocupara em estabelecer uma organização jurídico-Política contra a adoção da forma estatal na Europa Unida. Ou ainda, não se visava à construção de um Estado Federal Europeu, nem mesmo um Estado Europeu. Essa linha reflexiva se revela como possível também historicamente, a partir da consideração conjunta da construção histórica do CdE e da CECA. Por isso a importância da leitura dos já examinados Capítulos Quinto e Sexto desta Tese, aos quais também remetemos o leitor.
} 
de controle jurisdicional da potencial inação da Alta Autoridade, o Tratado conferira à Corte um instrumento de coerção que forçasse a Alta Autoridade a cumprir sua sentença.

$\mathrm{O}$ fortalecimento coercitivo de apenas um dos participantes desequilibraria todo o sistema de convivência entre diferentes fundado em contrapesos aos freios arquitetados pelo Tratado e implicaria a possibilidade de ascensão de Um sobre os demais, pois enfraqueceria a vitalidade da dinâmica Política. Por esse motivo, com o objetivo de manter a horizontalidade relacional e o consequente vazio de Poder, o Tratado freava a própria atividade de contenção a ser exercida pela Corte: tratava-se da negação da atividade de negação, opção jurídico-normativa institucional que esvaziava a posição de um e de outro e, com isso, revigorava a organização jurídico-Política da Europa Unida.

Compreenda-se, assim, o inteligente mecanismo de engenharia institucional deste Tratado que, mais uma vez, revelava sua preocupação com a manutenção de uma dinâmica Política na Europa Unida por meio contenções e constrições recíprocas.

Se à Corte era concedido o vigoroso Poder de controle da atividade da Alta Autoridade, logo em seguida o referido Poder era completamente esvaziado, uma contenção pujante de sua ação, uma vez proferida a decisão. Ao mesmo tempo, a capacidade de autodeterminação da Alta Autoridade para escolher as medidas necessárias para executar a decisão de anulação é refreada pela previsão de recurso à Corte na hipótese de desarrazoada morosidade para as adotar.

Não se pode ignorar a presença de uma complexa trama de oposições escalares tecidas por esse dispositivo, o qual normativamente estabelecera fortes limitações mútuas e recíprocas às tendências de potencial transcendentalização da Alta Autoridade e da Corte. Neste caso, no embate entre as duas escalas supranacionais, não havia qualquer preferência por uma ou pela outra: ambas detinham seus respectivos campos de atuação certamente delimitados e deveriam estar em constante interação conflitiva entre si para que nenhuma delas pretendesse ou conseguisse implantar unilateralmente sua dimensão existencial no lugar do Direito e do Poder da Comunidade.

7.2.2.3. O Artigo 35 do Tratado da CECA: O Controle da Inação da Alta Autoridade e seu Significado Jurídico-Político

O artigo 35 do Tratado da CECA dispunha em seus parágrafos primeiro e segundo o seguinte: nos casos em que, por força de disposição do Tratado da CECA ou de regulamentos de aplicação deste, a Alta Autoridade (i) estivesse obrigada a tomar uma 
decisão ou a formular uma recomendação, ou (ii) recebesse a faculdade de tomar uma decisão ou de formular uma recomendação e, respectivamente, (iii) não cumprisse sua obrigação, ou (iv) se abstivesse de exercer tal faculdade por desvio de Poder, conforme fosse o caso, um dos Estados-Membros ou o Conselho de Ministros poderia provocar a Alta Autoridade a desempenhar sua conduta ${ }^{842}$. Há que se procurar compreender nesse dispositivo a presença de uma articulação jurídico-normativa institucional Politicamente orientada da CECA.

Perceba-se que o dispositivo concedera à estatalidade - isolada (Estado-Membro) ou intergovernamental (Conselho) - a possibilidade de controlar a Alta Autoridade em situação bastante particular, a saber, na que se manifestava uma tendência à inação. Tratava-se de efetivo freio contrário à tendência de enraizamento no lugar do Direito e do Poder da supranacionalidade da Alta Autoridade.

\subsection{A Inação Participativa como Ameaça à Horizontalidade Relacional}

É importante entender que essa tendência de unidimensionalização derivava precisamente da inação da Alta Autoridade: ao não agir, este órgão comunitário sinalizaria se autocompreender como estando acima de todos os participantes da vida em comum e das próprias Leis da Comunidade, pois se arrogaria da pretensão de descumprir normas comunitárias originárias ou derivadas, ou de ao menos não praticar sua ação por desvio de Poder.

Em outras palavras, a tentativa de unidimensionalizar supranacionalmente a determinação do sentido do Direito e do Poder na CECA decorreria desse específico nãoagir da Alta Autoridade. Por esse motivo, o mecanismo atribuído às estatalidades visava à manutenção da horizontalidade relacional, isto é, retirava da Alta Autoridade a possibilidade de se compreender como estando autorizada a se apropriar intemporalmente do lugar do Direito e do Poder da Comunidade.

\footnotetext{
${ }^{842}$ É importante observar ainda que o mesmo artigo 35 do Tratado da CECA atribuía a mesma faculdade a empresas e associações, nas hipóteses de inação da Alta Autoridade.

Todavia, por não envolver o embate entre oposições escalares de dimensões existenciais participantes da vida em comum, não será examinada essa atuação das empresas e das associações no interior do processo de integração. Com efeito, frise-se que estas não participam do jogo de divisões de Poder do Tratado, isto é, não constituem uma escala de existência que seja pelo Tratado reputada como detendo aptidão para ocupar o lugar do Direito e do Poder no processo de condução Política da Europa Unida. Essa ressalva deriva precisamente do reconhecimento da importância de se primar pela manutenção da coesão e da coerência metodológicas no presente trabalho.
} 
Dessa forma, diante de possível descumprimento da obrigação, ou mesmo de nãoação motivada por desvio de Poder, o Tratado procurava relembrar à Alta Autoridade a necessidade de promover sua ação, ou melhor, a importância de ela sair de sua posição de silêncio e se expressar para formar o sentido normativo comum. O Tratado frisava o caráter fundamental da promoção contínua do embate escalar entre os pares comunitários, a fim de evitar a ocupação do lugar do Direito e do Poder pela supranacionalidade da Alta Autoridade por força de sua inação.

A maneira para conservar a paridade comunitária entre os partícipes da vida em comum residia especificamente na aposição de um mecanismo que a instaria a agir. De maneira mais simples, enigmaticamente, entendia-se que era por meio da inação que a Alta Autoridade poderia buscar se identificar com o lugar do Direito e do Poder, plenificando-o, ao passo que se entendida que era por meio do forçar seu agir - sempre em conjunto com outras escalas de existência - que se garantiria o vazio escalar no centro nomogenético da Europa Unida da CECA e a correlata igualdade comunitária entre as diferentes escalas de existência.

O mistério da produção de um vazio por meio de ação, contraposto à totalização do Poder por meio de inação pode ser esclarecido. A recusa de exercer sua atividade normativa da maneira como estabelecida pelo Tratado se revelava como a manifestação da pretensão de afirmar a medida de existência supranacional sobre as das demais entidades na medida em que sinalizaria se autocompreender como não determinada pelas normas que organizaram jurídico-Politicamente as relações na Europa Unida da CECA.

Em outros termos, a não-manifestação normativa da Alta Autoridade significaria a desconsideração da horizontalidade vigente entre as medidas de existência em constante contraposição institucional. De fato, avaliando-se como estando em uma posição privilegiada - isto é, como não mais ocupando posição igual à dos demais, a Alta Autoridade se compreenderia como podendo se destacar deles e sobre eles se elevar. A escolha sobre quando dever se manifestar ou não - para além ou a despeito da disposição normativa do Direito Comunitário Originário ou Derivado - representaria uma indisposição a se conformar à condição de igualdade com relação aos demais. Ou ainda, simplesmente, que a Alta Autoridade se reputava acima de todos - inclusive, das próprias Leis Políticas da Comunidade.

É por esse motivo que se pode compreender que o Tratado temia o não-falar normativo da Alta Autoridade. E, por isso, pode-se compreender que ele buscava construir mecanismos de controle que apenas fizessem a Alta Autoridade discursar normativamente 
sobre aquilo que lhe designou o Tratado. A contenção exercida pela estatalidade teria por fundamento o "convite forçado" à Alta Autoridade se apresentar perante as demais escalas de existência e formar em conjunto com elas o sentido normativo sobre questões concretas sensíveis comuns.

A Alta Autoridade não deteria assim absoluta capacidade de optar sobre quando ou não agir - do contrário, ela seria portadora de uma desigualdade a ela favorável que lhe concederia condições para desconsiderar o Tratado em nome próprio. Na verdade, exatamente como todos os demais participantes da vida comunitária, a Alta Autoridade teria o dever de se manifestar sobre o sentido normativo, pois todos os componentes da Comunidade estariam implicados institucionalmente pelo Tratado na rede de um engenhoso maquinário institucional de igual compartilhamento de deveres de participação.

O bloqueio estatal operava aqui, portanto, como um dispositivo para fazer agir normativamente a Alta Autoridade. O que se procurava conter não era a atuação desta, mas um movimento de transcendentalização derivado de uma situação de inação. Tratava-se assim de uma armadilha normativa: era por meio de seu agir normativo que a Alta Autoridade manifestava sua conformidade institucional às Leis Políticas da Europa Unida da CECA, ao mesmo tempo em que era por meio de sua inação que ela revelava o florescimento de sua disposição a se destacar sobre os demais, isto é, de se transcendentalizar e de não se manter como igual aos demais.

\subsection{A Contenção da Inação da Alta Autoridade: Limites e Possibilidades}

O parágrafo terceiro do artigo 35 contribui para reforçar o arco de conservação da dinâmica Política da Europa Unida. Em caso de inação da Alta Autoridade, poderiam atuar as estatalidades para a fazer agir normativamente. E, na hipótese de reiteração de inação da Alta Autoridade - ainda que tivesse havido a provocação por parte das estatalidades, um recurso perante a Corte poderia ser formulado, a fim de combater tal "decisão implícita de recusa que é reputada resultar do silêncio" da Alta Autoridade. Este recurso deveria ser interposto dentro do prazo de 3 (três) meses, contados da provocação inicial apresentada por alguma das estatalidades ${ }^{843}$.

\footnotetext{
${ }^{843}$ As estatalidades deveriam esperar necessariamente o decurso de 2 (dois) meses, contados da notificação à Alta Autoridade para que esta agisse normativamente. Apenas após o decurso deste período inicial é que
} 
Note-se, em primeiro lugar, que este dispositivo não concentrou a atividade de controle da atuação da Alta Autoridade na Corte. Antes, o Tratado da CECA também partilhou este Poder de contenção da transcendentalização da Alta Autoridade entre a medida supranacional da Corte e a estatal, isolada ou intergovernamental. Em outras palavras, não se sobrevalorizou a figura da Corte, a fim de que esta não se considerasse como a detentora exclusiva do último nicho de resistência da Política à apropriação do lugar do Direito e do Poder pela Alta Autoridade: a Corte seria igualmente responsável, como os Estados-Membros e o Conselho, pelo dever de manter a horizontalidade relacional e de conservar a imanência mediante o fazer retornar ao meio toda medida de existência tendendo à totalização unidimensional.

Havia assim um compartilhamento do Poder de controle da Alta Autoridade entre as estatalidades e a supranacionalidade da Corte, o qual se revelava como um engenho relevante para manter o funcionamento Político das relações na Europa Unida. Ou ainda, havia um esvaziamento do lugar do Direito e do Poder de controle da atividade normativa da Alta Autoridade, pois a ninguém era dado ocupá-lo intemporalmente. Não apenas seu uso era limitado ${ }^{844}$, como também ele não era exclusivo de uma ou de outra escala de existência: era um lugar vazio em torno do qual agiam as diferentes escalas para, em conjunto, lhe darem operacionalidade prática.

O Tratado da CECA lembrava assim a importância de se considerar também a escala estatal (isolada e intergovernamental) para a formação do Direito e do Poder na Comunidade. Pode-se entender essa disposição jurídico institucional como uma maneira normativa de frisar a relevância da conservação da multiplicidade escalar que derivava do próprio conviver no interior de uma comunidade política - tal qual a institucionalmente forjada pelo Tratado da CECA.

A possibilidade de execução desse bloqueio também por parte das estatalidades se mostrava como tentativa de impedir a escalada da dimensão supranacional e como sinalização da preocupação em constantemente reabrir no interior da União a divisão e o conflito. Em outras palavras, essa previsão enfatizava a diferença entre escalas de existência, recusava a homogeneização totalizante por uma medida uniescalar e, por meio do convite ao entrechoque dimensional, revitalizava o vigor da organização jurídico-

poderia ser apresentado o recurso: ao cabo desses 2 (dois) meses, as estatalidades poderiam em até 1 (um) mês interpor o referido recurso.

${ }^{844}$ Como se verá nas linhas a seguir. 
Política da vida em comum mediante o aplainamento das posições de cada um dos implicados na vida da CECA.

Contudo, não se pode ignorar a presença de limitações previstas diretamente no texto do Tratado da CECA, as quais objetivavam tornar vazio também o Poder atribuído à medida estatal. O próprio artigo 35 estipulava condicionamentos à prática desse poder constritor pela estatalidade - isolada ou intergovernamental, de maneira a evitar que seu uso também pudesse permitir o surgimento de qualquer pretensão de unidimensionalizar a orientação do lugar do Direito e do Poder por uma das inúmeras medidas de existência estatais.

A primeira das limitações constritoras do Poder constritor está prevista no próprio parágrafo primeiro do artigo 35: os Estados-Membros ou o Conselho deveriam em primeiro lugar suscitar a questão perante a Alta Autoridade. Ou seja, diante de uma inação de produção normativa por parte desta, a ação de contenção das estatalidades se reduzia a suscitar a necessidade de a Alta Autoridade se manifestar por meio de tomada de decisão ou de formulação de uma recomendação. Este lembrete dos Estados à Alta Autoridade teria como objetivo apenas a fazer retomar suas atividades, e não deteria qualidades coercitivas (forçar a atuar normativamente) nem substitutivas (agir no lugar da Alta Autoridade).

Havia assim uma repelição mútua que, mais uma vez, mantinha as escalas normativamente opostas entre si em uma mesma posição de par comunitário. O Tratado permitia que se instasse a Alta Autoridade a falar por meio da suscitação provocada pela estatalidade, mas esta não detinha instrumentos que lhe permitissem se substituir à Alta Autoridade, nem mesmo que a constrangessem no sentido de a forçar a atuar normativamente. Também não havia qualquer previsão normativa que assegurasse às estatalidades a definição dos critérios segundo os quais a Alta Autoridade deveria agir. Antes, era mais uma vez deixada a esta a possibilidade ou não de se manifestar, bem como a estipulação dos critérios de acordo com os quais deveria produzir suas normas.

Contenção contida, peso portador de seu próprio contrapeso, o mistério do Poder “sem Poder" ressurgia aqui enquanto garante do vazio no lugar do Direito e do Poder na Comunidade e, com ele, assegurava a perpetuação da dinâmica Política na Europa Unida: pois nem a um, nem a outro, era concedida posição preferencial na produção do sentido normativo sobre questões concretas sensíveis comuns. Se a nenhum era dado se destacar sobre os demais, a todos era determinada a permanência na precisa mesma posição de par comunitário. 
A limitação desse mecanismo de controle era reforçada ainda pela previsão do parágrafo segundo do mesmo artigo 35. Nele, estipulavam-se três critérios adicionais para, em uma fase subsequente, diante da obstinada inação da Alta Autoridade, fosse possível a continuidade do controle por parte da escala estatal. Com efeito, lembre-se de que o dispositivo normativo determinava que, diante da inação renitente da Alta Autoridade, era facultado às estatalidades apresentar um recurso perante a Corte da CECA, o qual deveria ser interposto dentro do prazo de 2 (dois) meses contados da provocação anterior.

Deste modo, após a primeira suscitação diante da imobilidade da Alta Autoridade, caso houvesse a reafirmação inflexível de sua inação normativa, às estatalidades ainda estaria assegurado o exercício da atividade de controle. Esta visaria a conter ainda mais vigorosamente a deliberada recusa silenciosa da Alta Autoridade a se manter em sua posição de igual em relação às demais escalas de existência. E, assim, assegurava-se a continuidade de um embate multiescalar no interior da própria Europa Unida pela CECA.

No entanto, perceba-se que o exercício de tal instrumento de bloqueio estava condicionado à satisfação de três requisitos: (i) duas condições temporais e (ii) o seguimento de um procedimento específico.

Com efeito, não apenas deveria a estatalidade (i) aguardar o período de dois meses contados da suscitação inicial, a fim de conceder à Alta Autoridade a possibilidade de examinar o lembrete e agir, mas também, (ii) após esses dois meses iniciais, constatada a decisão implícita de recusa da Alta Autoridade a atuar normativamente, apresentar o recurso dentro de um mês, a fim de dar seguimento a seu controle.

Ademais, conforme a previsão do parágrafo terceiro do artigo 35, este segundo mecanismo de controle operado pelas estatalidades não poderia ser direcionado diretamente contra a Alta Autoridade - tal qual o primeiro, previsto no artigo 35, parágrafo primeiro $^{845}$. Ele deveria seguir um procedimento específico, isto é, ele deveria ser necessariamente intermediado pela atuação da Corte, mediante a interposição de um recurso contra tal "decisão implícita de recusa".

Deste modo, diante de mais uma situação de possível gravidade de recusa a observar as normas comunitárias, o Tratado da CECA reenviara a solução da questão a mecanismos institucionais da própria Comunidade, os quais seriam responsáveis pela reafirmação da multiescalaridade. O objetivo consistia em continuamente apresentar as instituições da vida em comum como confiáveis por parte dos partícipes comunitários, isto

${ }^{845}$ Examinado no item 7.2.2.3.1., supra. 
é, como mecanismos ininterruptamente abertos e receptivos à produção de soluções conjuntas, marcadas pela pluralidade escalar.

É por esse motivo que se pode compreender que o controle previsto no artigo 35 Tratado da CECA agia em duas direções distintas: ao mesmo tempo em que existia para impedir a tomada do lugar do Poder pela Alta Autoridade, também operava no sentido de afastar seu próprio utilizador (estatalidades) do mesmo lugar do Direito e do Poder. Em sentido duplo, criava um espaço vazio entre as escalas em conflito (supranacional e estatal), de modo a que nenhuma delas dele se apoderasse e o plenificasse a sua imagem e semelhança, arrebanhando as demais escalas.

7.2.2.4. O Artigo 37 do Tratado da CECA: O Trabalho Multiescalar no Controle Judicial das Repercussões Econômicas de Ação ou Inação da Alta Autoridade

Neste item será examinado o controle judicial das consequências econômicas derivadas de decisões da Alta Autoridade, controle este exercido mediante normas de oposições escalares. Será possível perceber que o Tratado da CECA estipulara regras adicionais às de Direito Econômico, com o objetivo de dar um sentido jurídico-Político ao conjunto dessa ordenação jurídica de conteúdo econômico. Se a Alta Autoridade poderia impactar as esferas econômicas dos Estados-Membros, o recurso a este mecanismo não poderia ocorrer sem limites, estando sujeito a uma complexa estrutura de controle multiescalar.

\subsection{Observações Gerais sobre o Artigo 37}

$\mathrm{O}$ artigo 37, parágrafos primeiro e segundo, do Tratado da CECA previa a possibilidade de um Estado-Membro reclamar perante a Alta Autoridade a superveniência de problemas persistentes e fundamentais em sua Economia em virtude de ação ou de inação daquela entidade supranacional. A Alta Autoridade deveria consultar o Conselho e, uma vez reconhecida a procedência da alegação, caberia a esta a escolha das medidas necessárias para interromper a produção de tal situação perniciosa para a Economia deste Estado-Membro. Essa decisão da Alta Autoridade não poderia deixar de atender, contudo, a perspectiva da Comunidade. 
A disposição normativa deste artigo era bastante relevante, uma vez que se orientava para reinstaurar o conflito entre as escalas de existência que compunham o jogo de Poder na Europa Unida.

Com efeito, (i) estabelecer a viabilidade de um contato direto entre Estado-Membro (estatalidade isolada) e Alta Autoridade (supranacionalidade) para colocar imediatamente em questão a ação ou a inação desta última com relação ao primeiro e, ademais, (ii) prever a possibilidade de um reconhecimento por parte da própria Alta Autoridade do caráter prejudicial de sua ação ou de sua inação - após consulta ao Conselho (estatalidade intergovernamental), consistia em interessante construção jurídico-institucional voltada a manter permanentemente vitalidade conflitiva do Político no interior da CECA.

Nesse sentido, ao surgir um problema comunitário, ele seria tratado comunitariamente, vale dizer, sua solução seria encaminhada mediante o recurso às próprias instituições da vida em comum, seguindo a específica lógica de multiplicidade escalar. A confiança nas instituições da Comunidade se reapresentaria aqui como possível, na medida em que mais uma vez elas se mostrariam abertas à recepção das diferentes espécies de oposições no interior da CECA.

7.2.2.4.2. Oposições Escalares em torno da Economia: Orientação Jurídico-Política Multiescalar de Questões Econômicas

A engenharia normativa deste artigo 37 parece ter sido pensada para contrapor intensamente as escalas de existência. Se à Alta Autoridade era permitido optar entre agir ou não-agir sobre determinada questão, caso sua postura deliberadamente escolhida fosse a origem de transtorno permanente e fundamental à Economia de um Estado-Membro, a este era possível solicitar à Alta Autoridade que deixasse de persistir na mesma conduta (ativa ou passiva) para interromper a produção de prejuízos em sua Economia nacional.

O Tratado da CECA assegurava à escala de existência estatal isolada a possibilidade de reclamar diretamente à escala supranacional da Alta Autoridade o repensar de seu próprio agir, com o objetivo de estimular esta a interromper a produção de graves perturbações à Economia estatal. Em outras palavras, as duas escalas fundamentalmente contrapostas no interior da Europa Unida (estatalidade versus supranacionalidade) detinham uma oportunidade para se colocarem em embate sobre uma questão bastante específica: a Economia. 
Há deste modo uma opção deliberada por parte dos autores do Tratado por efetuar uma fenda no interior do trabalho comunitário em torno da questão econômica e permitir sua administração a partir de uma perspectiva Política.

Com efeito, o artigo 37 nada mais viabilizava do que a abertura de mais uma possibilidade de se estabelecer uma situação de vazio de Direito e de Poder sobre a qual nenhuma medida detinha capacidade de se apropriar. Deste modo, nem aos Estados se assegurava uma integral capacidade de resposta, nem à Alta Autoridade se concedia a faculdade de permanecer silente quanto à continuidade ou não de seu agir prejudicial. Antes, estes eram aproximados, com o concurso de uma medida estatal intergovernamental, para pensar em conjunto o encaminhamento da questão econômica.

Nesse sentido, perceba-se que o Tratado da CECA afastava a possibilidade de unilateral determinação pelo Estado-Membro da solução das questões que originaram tais perturbações - este apenas poderia as suscitar perante a Alta Autoridade. Deste modo, não se lhe concedia a possibilidade de atuar de maneira imediata e eficientemente responsiva a partir de perspectiva local, nem mesmo a de substituir a Alta Autoridade na supressão ou na execução da conduta causadora do dano.

Assim, diante dos grandes transtornos sofridos por sua Economia nacional, a contenção da atividade ou da passividade da escala supranacional encontrava um limite vigoroso, o qual residia precisamente nesta simples comunicação do problema à Alta Autoridade, pois apenas esta poderia tomar as medidas que julgasse necessárias. Se aos Estados-Membros era assegurada a reivindicação de mudanças na conduta da Alta Autoridade, contra eles era obstada qualquer forma de ir além desta singela reclamação. Instaurava-se o conflito entre estatalidade e supranacionalidade, sem se dar preferência a uma ou a outra: a contenção da supranacionalidade era, ela mesma, contida.

Após a manifestação dos Estados-Membros, caberia exclusivamente à Alta Autoridade definir as medidas necessárias para que a produção de tais efeitos nocivos fosse interrompida, na hipótese de - após oitiva do Conselho a título meramente consultivo - ela própria reconhecer a presença dessa situação. O resguardo deste domínio de ação à Alta Autoridade era garantia do afastamento de qualquer intromissão unilateral da escala de existência estatal na definição dos sentidos a serem seguidos pelo Direito e pelo Poder na Comunidade. Havia assim uma limitação do Poder de enfrentamento praticável pelos Estados contra a Alta Autoridade.

No entanto, a fim de manter a horizontalidade relacional na vida comunitária, o Tratado da CECA também estabelecia limitações a este mecanismo de contenção garantido 
à escala supranacional, mediante a aposição de contrapesos. À Alta Autoridade igualmente não se reservava, com efeito, um campo largo de ação autônoma diante dessa manifestação: ela deveria levar em consideração também a opinião manifesta pelo Conselho, mediante consulta. Nesse sentido, para a formação de sua convicção sobre a presença ou ausência de uma situação econômica prejudicial a um Estado-Membro e sobre as medidas necessárias a serem tomadas, à supranacionalidade opunha-se a estatalidade intergovernamental, ainda que em caráter consultivo.

Isso significa que, para a formação de seu juízo, a Alta Autoridade não deveria considerar apenas e tão somente a perspectiva supranacional. Antes, ela deveria se manter em convivência com outras formas de expressão dessa escala estatal, ainda que sob a perspectiva intergovernamental, a fim de que pudesse decidir. Isto é, em outras palavras, a Alta Autoridade, em sua decisão, não poderia ignorar a perpectiva comum.

Nesse sentido, perceba-se que o artigo 37 reintroduzia a oposição escalar no seio da Comunidade e impedia institucionalmente que uma ou outra dimensão existencial pudesse deter pretensões de ocupar o lugar do Direito e do Poder na CECA. Nenhuma delas poderia visar a determinar por si só o sentido das decisões sobre o Direito e sobre o Poder, devendo sempre estar diante das outras escalas para a produção compartilhada do sentido normativo sobre questões concretas sensíveis comuns.

Há ainda duas limitações adicionais no parágrafo segundo do mesmo artigo 37 ao exercício desta contenção por parte da Alta Autoridade: (i) a necessidade de consulta do Conselho e (ii) a impossibilidade de desconsideração dos "interesses essenciais da Comunidade". Ambas devem ser entendidas como formas encontradas para conter simultaneamente a possível ascensão da escala de existência portada pelos Estados e a daquela veiculada pela Alta Autoridade - de maneira a preservar a horizontalidade relacional pela ênfase no conflito escalar. Esse refreamento simultâneo deve ser mais precisamente compreendido, nos termos que se seguem.

Impor a necessidade de consulta ao Conselho para que a Alta Autoridade pudesse, após, decidir sobre a existência da situação econômica perturbadora e sobre as medidas relacionadas, não apenas afastava a possibilidade de um regramento gestado unicamente no interior de uma perspectiva supranacional e a consequente unidimensionalização da condução da Comunidade por parte desta. Esse mandamento tinha por objetivo também efetuar um simultâneo controle da atuação de três destinatários: a Alta Autoridade, o Conselho e os Estados-Membros, com a finalidade de manter todos na mesma condição de pares comunitários na Europa Unida da CECA. 
A atividade de produção da resposta da Alta Autoridade era duplamente freada em prol de uma indeterminação tipicamente Política da Comunidade: não apenas deveria considerar a perspectiva estatal intergovernamental na formulação de seu juízo - a fim de não permitir que sua orientação supranacional transbordasse e conduzisse as demais escalas de existência, como também apenas poderia considerar a manifestação do Conselho como o produto de uma atividade consultiva.

Nesse sentido, se a Alta Autoridade deveria necessariamente se manter aberta à contribuição dada pela perspectiva estatal intergovernamental, estava ela impedida de considerar como vinculante de per se a resposta proferida pelo Conselho, ou ainda, a ela não se autorizava conceder a tal declaração valor jurídico distinto do de uma consulta. Deveria a Alta Autoridade restar, deste modo, vigorosamente vigilante para que nem a sua medida supranacional, nem a estatal intergovernamental, fosse tomada como a única resposta possível para orientar unidimensionalmente as práticas decisórias sobre a vida econômica da Comunidade.

Da mesma forma, buscava-se apor uma dupla constrição à atuação de limitação do próprio Conselho, também com o objetivo de retirar de sua medida estatal intergovernamental qualquer pretensão de totalização uniescalar do lugar do Poder e do Direito. Apesar da obrigatoriedade de sua manifestação, a capacidade de sua influência na formulação da decisão pela Alta Autoridade sobre a questão prevista neste artigo era imediatamente reduzida à condição de consulta.

Se por um lado o Conselho deveria se manifestar - pois ele deveria atuar ativamente para evitar que a supranacionalidade da Alta Autoridade tomasse o lugar do Direito e do Poder, por outro lado, deveria ele zelar para que sua própria escala de existência não viesse a se colocar de modo absolutamente determinante e vinculante. Deveria o Conselho permanecer ativamente vigilante sobre a supranacionalidade e sobre sua própria escala, pois a nenhuma delas era assegurada a possibilidade de homogeneizar o espaço social e buscar dissipar a divisão na vida em comum. Antes, segundo o estímulo institucional, o Conselho deveria perceber a importância da ênfase na diferença e agir no sentido de contribuir para manter a convivência entre diferentes.

No que se refere à delimitação da capacidade constritora dos Estados, deve-se notar que se tratava de uma garantia que visava também a afastar a presença da medida estatal isolada do centro de determinação do sentido do Direito e do Poder na Comunidade. A necessidade de consulta da Alta Autoridade ao Conselho significava que não apenas a reclamação estatal isolada seria contraposta à medida supranacional da Alta Autoridade, 
mas também que sofreria uma forte oposição por parte da outra escala estatal possível - a intergovernamental, manifesta pelo Conselho.

Há que se precisar a lógica duplamente contenedora da escala dos EstadosMembros que constava desta previsão de necessidade de consulta ao Conselho. Há uma operação conjunta e simultânea de dois entrechoques escalares com a medida de existência estatal isolada, de modo a impedir que esta se instalasse intemporalmente como a única dimensão possível de ordenação da vida em comum.

O primeiro embate - bastante claro - era o estabelecido entre a supranacionalidade da Alta Autoridade e a estatalidade isolada, já descrito acima. O segundo conflito que se instaurava - bastante interessante - é aquele entre as medidas estatais, o qual se operava em dois níveis, a saber, (i) entre as estatalidades, no interior do Conselho, onde se desenvolvia um embate intergovernamental típico para sua própria tomada de decisão sobre qual seria a opinião final deste órgão em seu parecer consultivo; e (ii) entre a medida intergovernamental - produto da decisão em (i) - e a estatal isolada, na medida em que a avaliação final dada pelo Conselho opera como filtro à receptividade da reclamação manifesta pelo Estado-Membro.

Assim, ao lado da esperável reprimenda mútua entre a medida estatal (isolada e intergovernamental) e a supranacional da Alta Autoridade, estabelece-se outra oposição entre as próprias medidas de existência estatais. Essa previsão garantia assim que nenhuma dessas duas escalas estatais pudesse se orientar para se destacar com relação às outras e, em detrimento do vazio do Poder, introduzisse uma direção unidimensional na Europa Politicamente Unida na solução de questões econômicas.

Há ainda que se compreender adequadamente como a obrigação imposta pelo mesmo artigo 37, parágrafo segundo, do Tratado da CECA à Alta Autoridade de salvaguardar os "interesses essenciais da Comunidade" permitia a reconfiguração do conflito Político entre diferentes medidas de existência.

A previsão da necessária não-desconsideração da perspectiva da Comunidade opera como uma forma de limitação da ação constritora da Alta Autoridade. Ao dever considerar o parecer consultivo formulado pelo Conselho para sua decisão, não poderia a Alta Autoridade deixar de incluir a perspectiva da Comunidade, precisamente porque estava ela obrigada a não adotar como palavra última a orientação dada pelo produto de oposição de escalas estatais integovernamentalmente opostas.

Ao mesmo tempo, não se pode ignorar ainda que essa previsão tinha por objetivo lembrar à Alta Autoridade de que ela não poderia impor sua perspectiva supranacional 
sobre as demais para formular sua decisão. De fato, ao dever considerar a necessidade de salvaguardar os interesses da Comunidade em sua decisão, neste momento era a Alta Autoridade alertada para atuar no sentido de manter a convivência Politicamente orientada entre as diferentes escalas de existência. Não pensaria aqui supranacionalmente, mas sim a partir de uma perspectiva comunitária.

Nesse sentido, deveria a Alta Autoridade incluir em suas considerações não apenas as diferentes escalas estatais (isolada ou conjuntamente) ou sua orientação supranacional, mas o conjunto de todas elas, enquanto diferentes formas de habitar o mundo em incessante convivência para decidir em conjunto o destino comum - inclusive no que se refere à não-unidimensionalização dos caminhos escolhidos para ações de repercussão econômica tomadas por órgãos da Comunidade.

Todavia, havia ainda no mesmo artigo 37 a introdução de instrumentos adicionais que estavam orientados à promoção renovada de oposições escalares no interior da CECA.

Os parágrafos terceiro e quarto do artigo 37 estipulavam que, na hipótese de interposição de recurso contra a decisão proferida pela Alta Autoridade ${ }^{846}$, competia à Corte processar e julgar o recurso. Após o proferimento de sua sentença, caso se determinasse a anulação da decisão da Alta Autoridade, esta deveria definir, conforme os limites dados pela Corte, as iniciativas necessárias para fazer cessar o prejuízo à Economia do país que originalmente reclamara.

Previa esse dispositivo a inclusão de mais uma escala de existência - a da Corte, o que tornava ainda mais complexo o intrincado jogo de freios e contrapesos entre os diferentes modos de experienciar a Europa Unida. Nesse sentido, o Tratado garantia também à supranacionalidade da Corte a possibilidade de se manifestar sobre uma questão que envolvia o direcionamento de questões econômicas que envolviam não apenas um Estado-Membro em particular, mas toda a Comunidade.

Em outras palavras, a perspectiva da Corte também aqui não estava privada da possibilidade de conviver do processo de formação em conjunto do sentido normativo a ser dado na Comunidade - aqui, sobre questões que envolviam também a Economia na Europa. Contudo, não se pode ignorar que também nessa disposição se esvaziou o Poder de atuação da Corte, visando, com isso, a repelir a possibilidade de ela buscar operar à sua imagem e semelhança a construção da Europa Unida.

\footnotetext{
846 Cujo conteúdo reconhecesse ou negasse, expressa ou implicitamente, a situação de perturbação fundamental e persistente à Economia de um Estado-Membro.
} 
Com efeito, uma vez decidida pela Corte a anulação da decisão da Alta Autoridade, era a esta última que caberia a definição dos mecanismos destinados a cessar a produção da situação economicamente prejudicial a um Estado-Membro. O Poder constritor concedido à Corte neste artigo era mais uma vez restringido pela própria previsão do Tratado da CECA, na medida em que a Corte não poderia se substituir completamente à Alta Autoridade e determinar, a partir exclusivamente de sua própria escala, os meios pelos quais deveria ser interrompida a produção de efeitos prejudiciais à Economia de um Estado-Membro. Entre pares (comunitários), não havia como se prever um superior (comunitário).

Entretanto, o contra-Poder atribuído à Corte não era esvaziado por completo. Igualmente não se atribuía à Alta Autoridade posição exclusiva de determinação dos meios para dar execução à sentença da Corte. Ela necessariamente deveria considerar os limites estabelecidos pela decisão proferida pelo órgão jurisdicional da Comunidade.

Por este motivo, este artigo estabelecia uma derradeira contenção do próprio mecanismo de contenção. A medida supranacional da Corte detinha um limitado Poder de controle da ação praticada pela Alta Autoridade: podendo anular as decisões desta e estabelecer seus limites, não podia, contudo, determinar os meios que deveriam ser seguidos pela Alta Autoridade. Por outro lado, na livre escolha de instrumentos assegurada à Alta Autoridade, não se deixou de prever a importância de esta observar os limites estabelecidos pelo controle jurisdicional.

7.2.2.4.3. Significado Jurídico-Político do Controle Judicial das Repercussões Econômicas de Ação ou Inação da Alta Autoridade

Pode-se perceber no artigo 37 do Tratado da CECA uma preocupação voltada a garantir institucionalmente a permanência de um funcionamento Politicamente orientado das relações entre os participantes da vida em comum da CECA. Uma série de dispositivos procurou delinear minuciosamente jogos entre freios e contrapesos atribuídos a cada uma das escalas de existência. As instituições foram responsáveis pelo progressivo tensionamento da vida em comum, forçando mais e mais a promoção de uma situação conflitiva entre as escalas de existência - enfatizando a diferença e colocando-as para conviver e deliberar em conjunto sobre o destino comum.

Esse artigo em especial tinha a preocupação singular em articular questões econômicas comunitárias fundamentais a partir de um desenho institucional Politicamente 
orientado. Mesmo no caso de se decidir sobre um campo que afetaria a Economia da Comunidade e dos Estados-Membros, haveria que se garantir a presença multiescalar no centro nomogenético em torno de questões econômicas fundamentais da Comunidade. Os instrumentos jurídicos de conteúdo econômico foram aqui previstos para permitir que problemas econômicos fossem Politicamente geridos, a fim de não permitir a produção de fissuras que permitissem a transcendentalização de Uma dimensão escalar em detrimento de outras.

Assim, como em tantas outras oportunidades no Tratado, houve neste dispositivo a forte edificação de instrumentos de repulsão mútua voltados à implantação de um vigoroso sistema de convivência multidimensional. Essa negatividade institucional tinha por norte precisamente a manutenção da virtude Política no espaço de Direito e de Poder aberto na Europa Unida da CECA no pós-Segunda Guerra Mundial - ainda que se tratassem de questões econômicas.

7.2.2.5. O Artigo 38 do Tratado da CECA: A Anulação Multiescalar de Ato da Assembleia ou do Conselho

\subsection{Observações Gerais sobre o Artigo 38}

O artigo 38 do Tratado da CECA abria outra oportunidade para a deflagração institucionalmente motivada de um embate entre as diferentes escalas de existência que compunham sua Europa Politicamente Unida. Tratava-se da possibilidade de apresentar um pedido de anulação de ato da Assembleia ou do Conselho perante a Corte, por meio de solicitação feita por qualquer Estado-Membro ou pela Alta Autoridade.

A previsão de semelhante dispositivo era de fundamental importância no interior de uma arquitetura institucional voltada à promoção e à preservação de uma dinâmica Política na Comunidade. Com efeito, perceba-se que ele abria a possibilidade de se questionar decisões e atos (normativos ou não-normativos) de outros órgãos comunitários que não apenas a Alta Autoridade.

Note-se, assim, que interessantemente o foco do controle institucional muda neste dispositivo: diferentemente do previsto nos artigos 33 a 35 e no artigo 37 do Tratado da CECA, ele não se dirigira para apor freios à entidade de orientação supranacional (Alta 
Autoridade), mas para conter o portador da medida estatal intergovernamental no interior da Comunidade (Conselho) ${ }^{847}$.

Em outras palavras, mediante essa disposição, o Tratado assegurava que, além dos freios e contrapesos até agora estabelecidos na articulação interna dos referidos artigos anteriormente mencionados dirigidos - de forma limitada, é verdade - contra a Alta Autoridade, seria também preservado um vazio no lugar do Direito e do Poder com relação a outras escalas que não apenas a supranacionalidade. Mais simplesmente, este artigo em especial reforçava a dinâmica Política progressivamente construída ao longo do Tratado e operava como estandarte símbolo da lógica de mútuo controle reciprocamente esvaziado: a estatalidade intergovernamental poderia ter seus atos questionados por outras dimensões existenciais participantes da vida comum da CECA.

De fato, esse dispositivo sinalizava a presença de uma preocupação institucional em conservar permanente e multilateralmente um delicado equilíbrio entre diferentes escalas consideradas como pares comunitários. Ele reiterava a condição de que não importava a medida de existência: supranacional (da Alta Autoridade) ou estatal (do Conselho), nenhuma delas deteria qualquer preferência para ocupar o lugar do Direito e do Poder na Comunidade - ainda que portadas por um órgão comunitário, pois todas manteriam entre si uma inabalável relação de horizontalidade.

Deste modo, perceba-se que a relevância do dispositivo derivava do fato de que ele, ao seguir a perspectiva de manter o vazio no lugar do Direito e do Poder mediante um afastamento multiescalarmente dirigido, (i) enfatizava a diferença entre as formas de habitar o mundo que participavam da vida em comum da CECA (supranacionalidades e estatalidades jamais poderiam se confundir entre si); (ii) completava o quadro normativo jurídico-Político cuidadosamente construído ao longo de todo o Tratado da CECA de estabelecer mecanismos institucionais para que as escalas de existência - enquanto pares comunitários - se apresentassem umas perante as outras como antípodas entre si (supranacionalidades e estatalidades guardariam percepções específicas e homogêneas sobre a condução da vida em comum); e (iii) criava instrumentos que fariam aflorar, chocar e conviver em conjunto tais diferentes escalas de existência, sem que uma pudesse determinar de maneira decisiva a outra mediante sua própria inserção em caráter

\footnotetext{
${ }^{847}$ Apesar de o artigo prever a anulação de atos da Assembleia, a fim de garantir a coerência metodológica neste trabalho, este aspecto não será analisado por esta Tese. Com efeito, há que se lembrar de que este órgão comunitário foi excluído dos comentários por este estudo, por não participar do jogo de formação multiescalar do sentido normativo da Comunidade, conforme mencionado nas notas de rodapé 772 e 813 , supra, bem como ao final do item 3.3.3.3, supra.
} 
intemporal do lugar do Direito e do Poder na Comunidade (supranacionalidades e estatalidades deveriam manter entre si uma permanente tensão dimensional na definição do sentido da vida em comum).

7.2.2.5.2. Detalhamento da Intrincada Rede de Oposições Escalares do Artigo e seu Significado Jurídico-Político

O parágrafo segundo do artigo 38 previa abertura institucional de arenas de tensão dimensional no interior da Europa Unida da CECA a partir de duas possíveis origens ${ }^{848}$. Independentemente das origens, as arenas analisadas por este trabalho se referiam à anulação de um ato proferido pelo Conselho (medida estatal intergovernamentalmente considerada), isto é, ambas deteriam por fundamento uma indisposição com relação a uma prática desempenhada a partir de uma escala de existência estatal intergovernamental.

A primeira origem de conflito possível era estatal isolada, pois poderia ser deflagrada mediante requisição feita por todo e qualquer Estado-Membro da Comunidade, enquanto que a segunda origem prevista era supranacional, pois a oposição normativamente autorizada poderia também ter seu início a partir de requisição feita pela Alta Autoridade. Este pedido deveria ser dirigido à Corte, a fim de que a esta decidisse pela anulação.

A previsão desta possível dupla origem explicita que (i) havia diversos pontos de discórdia possíveis no interior da Europa Unida da CECA e (ii) não vigia deste modo uma contraposição na Comunidade simplesmente redutível à oposição (a) entre as estatalidades isoladas dos Estados-Membros, entendidos como pólos inconciliáveis entre si; ou (b) entre supranacionalidade da Alta Autoridade e a estatalidade isolada dos Estados-Membros. A previsão ora em análise exprimia com uma clareza maior do que a da luz do meio-dia que pólos de tensão poderiam surgir também entre (c) os Estados-Membros (estatalidade isolada) e Conselho (estatalidade intergovernamental), (d) a supranacionalidade da Alta Autoridade e a estatalidade intergovernamental do Conselho, (e) a supranacionalidade da

\footnotetext{
${ }^{848}$ Qualquer ato, normativo ou não-normativo, na medida em que o parágrafo primeiro do artigo 38 se refere de maneira geral às "déliberations de l'Assemblée ou du Conseil”. O artigo se referia assim às deliberações em geral destes dois órgãos comunitários, dos quais, como frisado nas notas de rodapé 772 e 813 , ambas supra, apenas o Conselho detinha capacidade para atuar normativamente - isto é, em torno do centro nomogenético comunitário, em conjunto com as demais escalas de existência. Ao mencionar a possibilidade de anulação de atos da Assembleia (os quais não podem deter caráter normativo), pode-se compreender que o artigo se refere ao controle de atos normativos e de atos não-normativos.
} 
Corte e a estatalidade intergovernamental do Conselho, e (f) a supranacionalidade da Alta Autoridade e a supranacionalidade da Corte.

Perceba-se assim que o dispositivo desenhava uma complexa rede multiescalar de possíveis tensões entre os participantes da vida em comum. Não apenas poderia se opor à medida estatal aquela portada pela Alta Autoridade, mas também os Estados entre si, sendo possíveis inúmeras outras formas anagramáticas de interação escalar na CECA. Este dispositivo atuava para criar condições jurídico-normativas suficientes aptas a delinear os mecanismos institucionais aceitos para que tais contraposições escalares pudessem igualmente ser vocalizadas sem que, com isso, o lugar do Direito e do Poder da Comunidade pudesse ser ameaçado de ser apropriado.

A norma jurídica aqui analisada se mostrava assim como instrumento voltado a reinstaurar de forma permanente no interior da Comunidade o insolúvel conflito multiescalar tipicamente Político da CECA. Fosse a partir da oposição entre o supranacional da Alta Autoridade e a estatalidade do Conselho, fosse a partir do embate entre o estatal isolado dos Estados-Membros e o estatal intergovernamental do Conselho, a regra jurídico-Política vigente na Europa Unida da CECA era a da tensão contínua entre pares comunitários - fossem eles órgãos comunitários ou não.

Nesse sentido, note-se ainda que o percurso institucionalmente previsto para realizar esse embate exigia a presença e a atuação da Corte. Por isso, também não se pode deixar de observar que o Tratado convocava para participar do jogo de conflitos entre escalas de existência na Comunidade mais uma medida que também partilhava de deveres de participação no processo de definição do destino comum - a supranacionalidade da Corte.

Assim, visualize-se a complexa trama institucional de oposições escalares construída por essa singela previsão normativa de atribuição cruzadas de Poderes e de contra-Poderes. A exigência última da presença da Corte deve ser compreendida como um mecanismo que procurava reiterar enfaticamente e explicitar a importância da permanente co-presença de todas as medidas de existência da vida em comum para que se pudesse definir em conjunto a dinâmica de bloqueio e de frenagem entre uma e outra.

Se à Alta Autoridade e aos Estados-Membros era facultada a contestação de um ato do Conselho, tal ação de bloqueio era ela mesma limitada pelo controle jurisdicional desta faculdade. Ao mesmo tempo, o Tratado estabelecia por meio da Corte caminhos para que as oposições entre supranacionalidade e intergovernamentalidade e as oposições entre estatalidade isolada e intergovernamentalidade se realizassem plenamente, mas desde que 
sempre com a presença da perspectiva supranacional da Corte - o que permitiria que a necessidade da permanência de uma vida comum Politicamente orientada fosse desconsiderada nas oposições existenciais.

Se a controvérsia fosse iniciada por uma motivação estritamente estatal, isto é, se ela partisse especificamente da iniciativa de um Estado-Membro - a fim de que seu modo de habitar o mundo se opusesse ao do Conselho, o Tratado assegurava a presença ao menos de uma escala de existência supranacional - a da Corte. Esse dispositivo assegurava assim que ao menos uma perspectiva supranacional não seria excluída das discussões sobre o sentido comum na Europa Unida da CECA, isto é, que não haveria a totalização da medida estatal mediante a centralização do debate sobre a vida em comum somente entre as diferentes formas de estatalidade.

Por outro lado, se a iniciativa de tensão partisse de uma orientação supranacional por pedido da Alta Autoridade, a fim de que sua perspectiva não se revelasse como a única forma supranacional possível de combater a intergovernamentalidade do Conselho, o Tratado convocava de forma ativa a escala de existência da Corte para também opor à Alta Autoridade o seu modo de existência. Deste modo, apresentavam-se perante o lugar do Direito e do Poder da Comunidade, em conjunto com a intergovernamentalidade, duas possibilidades supranacionais de formar o sentido comum. Todos estavam assim plena e continuamente cientes de que jamais a decisão teria por fundamento uma única escala de existência, pois todas elas estariam em mesma e intransponível posição horizontal.

7.2.2.5.3. As Limitações do Controle Judicial-Multiescalar dos Atos do Conselho: A Reiteração da Constrição Contida

O controle previsto pelo referido artigo era ele mesmo limitado, como ocorria continuamente ao longo de toda previsão jurídico-institucional do Tratado. Seu exercício era condicionado ao cumprimento das condições previstas no interior do próprio Tratado, e esta limitação tinha por objetivo assegurar que a atuação das medidas de existência em choque não implicasse, a final, a ocupação de lugar do Direito e do Poder por qualquer delas.

Nesse sentido, observe-se que o próprio Tratado previra, além da necessária presença da Corte, série de mecanismos outros voltados à frenagem desta possibilidade de controle por parte dos Estados-Membros e da Alta Autoridade. O objetivo desta 
autcontenção interna consistia precisamente em impedir a superação da necessidade de se manter e de se promover a divisão e o conflito entre diferentes medidas de existência.

Como no artigo 33 do Tratado da $\mathrm{CECA}^{849}$, as limitações previstas pelos parágrafos segundo e terceiro do artigo 38 do mesmo Tratado detinham características distintas e são divisíveis em dois, saber:

(i) limitação jurídico-processual temporal, isto é, a estipulação jurídiconormativa de um determinado lapso de tempo para a apresentação deste pedido de anulação - nos termos do artigo 38, parágrafo segundo, o período de um mês contado da comunicação da deliberação do Conselho aos Estados-Membros ou à Alta Autoridade; e

(ii) limitação jurídico-institucional Política, tal qual prevista do terceiro parágrafo do mesmo artigo 38, vale dizer, uma restrição decorrente de expressa consideração das instituições jurídico-normativas da Comunidade, as quais tinham por base a orientação Política da vida em comum recém instaurada na Europa da CECA (incompetência ou violação de formalidades essenciais).

Há que se notar que, nos termos do artigo 38, tratavam-se de dois tipos distintos de condições, os quais deveriam ser supridos concomitantemente: o recurso deveria ser interposto no prazo de um mês e poderia versar apenas e tão somente sobre incompetência ou violação de formalidades essenciais.

Todavia, tratavam-se de duas barreiras à atuação dos Estados-Membros e da Alta Autoridade na atividade de contenção da ação do Conselho. Operavam em registros distintos, mas tinham um mesmo objetivo: garantir institucionalmente a preservação de um modo de convivência entre as diferentes escalas por meio do estímulo à prática de interação ativa entre elas: a contenção de uma escala de existência pelas demais deveria ser, ela própria, contida. Como se poderá constatar a partir da leitura dos itens a seguir.

7.2.2.5.3.1. O Significado Jurídico-Político da Limitação Jurídico-Processual Temporal: Risco de Unidimensionalização da Intergovernamentalidade e Tarefas da Supranacionalidade da Alta Autoridade e das Estatalidades Isoladas

Também como no artigo 33 do Tratado da CECA, apesar de a limitação jurídicoprocessual temporal poder ser vista como um simples marco temporal com o objetivo prático de definir uma condição de admissibilidade de uma ação judicial recursiva, tal

${ }^{849}$ Examinado no item 7.2.2.1., supra. 
previsão operava como instrumento de realização do Político. Nestes termos, a despeito de ser um critério que atuava no plano jurídico-processual, essa limitação detinha claramente um objetivo de estimular a realização fática de uma interação Politicamente estruturada de forma ativa entre as escalas de existência participantes da vida comum.

Uma vez decorrido o período de um mês após a comunicação da deliberação, esta se tornava impassível de futuro questionamento perante a Corte por qualquer dos EstadosMembros ou pela Alta Autoridade. Do mesmo modo como ocorreu com o artigo 33, essa disposição normativa não deve ser encarada como configurando um elemento disruptor do conjunto da arquitetura institucional Política do Tratado da CECA. Não se tratava de uma velada carta branca concedida ao passe livre do Conselho, mas de um dispositivo que operava dentro da lógica de criar instrumentos institucionais que estimulassem o constante e ativo entrechoque entre escalas de existência na Europa Unida pela CECA.

Nesse sentido, a previsão dessa limitação deve ser compreendida como a institucionalização de um alerta expresso aos Estados-Membros e à Alta Autoridade para que acompanhassem de forma atenta e ativa a atuação do Conselho. Tal acompanhamento era relevante principalmente no caso deste último órgão: portador da de uma dinâmica estatal intergovernamental, ele poderia também buscar ocupar intemporalmente o lugar do Direito e do Poder na CECA e orientar a produção normativa fora de uma lógica própria de convivência comunitária ${ }^{850}$.

A limitação temporal operava aqui como convite/estímulo à adoção de uma atitude consciente e constantemente vigilante por parte dos Estados-Membros e da Alta Autoridade para que, em casos de tentativa de totalização unidimensional por parte da intergovernamentalidade, fosse impedido imediata e tempestivamente o movimento de sub-reptícia transcendentalização da medida do Conselho no centro nomogenético da Comunidade. Deste modo, a previsão de uma limitação temporal era um mecanismo jurídico-institucional que se voltava também à promoção de uma realização ativa do Político na Europa Unida pela CECA.

\footnotetext{
${ }^{850}$ Isto é, segundo uma perspectiva de cooperação intergovernamental, a qual era repudiada pela instituição da CECA, como visto acima, durante a narrativa histórica dos Capítulos Quarto, Quinto e Sexto desta Tese.
} 
7.2.2.5.3.2. O Significado Jurídico-Político da Limitação Jurídico-Institucional Política: Delimitação de um Círculo Multiescalar de Liberdade e de Resistência

A limitação jurídico-institucional Política prevista no artigo 38 difere ligeiramente de disposição similar do artigo 33 do Tratado da CECA. Apesar de também se voltar para conservar institucionalmente uma dinâmica Política na Comunidade mediante manutenção da horizontalidade relacional, a reabertura de um espaço vazio e permanentemente em tensão de Poder se mostra aqui mais limitada.

Com efeito, o artigo 38, parágrafo terceiro, do Tratado da CECA, previa que só poderiam ser fundamentos deste recurso a alegação de incompetência ou a alegação de violação de formalidade essencial pelo Conselho quando de sua deliberação. Se havia uma complexa tessitura de tensões escalares multidirecionadas visando a conter, de diferentes modos, a atividade do Conselho, não se poderia deixar de notar que havia uma profunda limitação ao Poder de controle.

A referida limitação consistia na imposição à Corte da realização daquilo que se denominou no comentário ao artigo 33 de exame de legalidade ${ }^{851}$. Este tinha por foco, aqui, a contenção de atos praticados pelo Conselho que detivessem por origem uma possível violação de legalidade (incompetência ou violação de formalidades essenciais).

Assim, a Corte somente poderia julgar procedente o pedido de anulação se verificada a inadequação entre a deliberação e as disposições do Tratado referentes (i) às regras de divisão de competências; ou (ii) às regras que versavam sobre o procedimento formal para a deliberação pelo Conselho. Deste modo, sua atividade de controle somente deveria considerar, respectivamente, (i) um exercício pelo Conselho de competência que a ele não fora originalmente atribuída pelo Tratado; ou (ii) a não-integral satisfação de formalidades relacionadas à prática de seus atos.

Nesse sentido, perceba-se que o Poder de contenção atribuído à Corte era limitado: esta previsão não lhe permitira realizar contra o Conselho aquilo que se chamou no comentário ao artigo 33 de exame de legitimidade. Havia um profundo silêncio nessa disposição com relação a essa possibilidade - vis-à-vis à explícita previsão do artigo 33.

Esse silêncio normativo é, no entanto, gritante, pois opera como uma forte coluna invisível que se presentifica comparativamente por força de sua ausência. Se no artigo 33 havia expressa concessão de possibilidade de se efetuar o tal exame de legitimidade, este

${ }^{851}$ V. item 7.2.2.1.4.1., supra. 
diametralmente oposto silêncio do parágrafo terceiro do artigo 38 pode ser compreendido como expressa recusa à concessão da possibilidade de se avaliar fatos ou circunstâncias econômicas justificadoras da produção de tais atos. Assim, excluída estava de sua competência a avaliação de um possível desvio de poder ou de manifesta violação das disposições do Tratado ou qualquer norma jurídica relativa à sua aplicação por parte do Conselho.

O controle jurisdicional estava adstrito, deste modo, a um mero exame de relação de legalidade entre a deliberação e a ordem jurídico-positiva instituída pelo Tratado. Isso implica reconhecer que o Poder de oposição conferido à Corte não lhe garantia nem o exame de legitimidade, nem mesmo, no interior do próprio exame de legalidade, a possibilidade de avaliar questões relacionadas à incompatibilidade material de um ato com disposições do Tratado ou de qualquer norma jurídica relativa a sua aplicação.

Havia nesse dispositivo mais uma vez o cuidado em assegurar o impedimento de uma ocupação do centro normativo da Comunidade por qualquer dimensão de existência da CECA, pois essa norma restringia profundamente o círculo de ação da Corte, ao mesmo tempo em que se preocupava em limitar a atuação do Conselho. Em outras palavras, a previsão de um caminho único de avaliação (legalidade) dos atos do Conselho detinha por finalidade, não apenas conter a atuação deste em estritos limites que não permitissem sua transcendentalização, mas também refrear o próprio controle do controlador do Conselho isto é, da Corte.

O contra-Poder da Corte era, assim, nada mais do que um profundamente limitado Poder, pois inspirado pela necessidade de se assegurar a persistência de um vazio no centro nomogenético da Comunidade mediante a manutenção do Conselho (controlado) e da Corte (controlador) em posição de igualdade. Deste modo, teria sido construído aqui também um delicado mecanismo institucional de convivência entre diferentes, pois, conservados na posição de pares comunitários, teriam sido excluídos da possibilidade de se apropriar do lugar do Direito e do Poder na CECA.

Contudo, não se pode deixar de frisar que, ao estabelecer apenas a necessidade de exame de legalidade e da observância do decurso temporal, o Tratado também previa uma simultânea contenção adicional da atividade de controle exercida por iniciativa das demais escalas de existência. Do interior da limitação à atividade de controle jurisdicional da Corte surgia também um bloqueio contra o controle exercido pelos Estados-Membros e contra aquele efetuado pela Alta Autoridade e uma abertura à atividade do Conselho. 
Deste modo, havia ainda neste dispositivo um comando restritor dirigido contra os Estados-Membros e contra a Alta Autoridade - enquanto possíveis proponentes do pedido de anulação. Ao mesmo tempo, o mesmo artigo dirigia seu mandamento normativo à medida estatal que seria o polo passivo desse pedido - o Conselho. Não apenas a Corte deveria conhecer seus limites de formulação de julgamento, mas também as demais escalas de existência em conflito deveriam se manter conscientes quanto a seus limites institucionais - para saber até onde, e a partir de onde, deveriam agir.

Em outras palavras, esta previsão não portava consigo apenas um estreito patamar sobre o qual poderia se deslocar a Corte para proferir seu julgamento. Antes, ela estabelecia igualmente o campo de abrangência possível do fundamento do pedido dos Estados-Membros e da Alta Autoridade, ao mesmo tempo em que estabelecia a linha demarcatória da amplitude de ação do Conselho - potencializando a noção de haver em uma Comunidade Política o compartilhamento de deveres de participação na vida em comum nos mais diferentes graus e tipos.

Deste modo, no embate promovido por esta norma de oposições escalares, cada uma das perspectivas em contato tenso por meio deste dispositivo deveria saber que estava institucionalmente orientada a frear e a reprimir umas às outras, sem que isso pudesse significar, ao final, a ocupação do lugar do Direito e do Poder por qualquer delas. Assim,

(i) a medida estatal isolada e a supranacional da Alta Autoridade - enquanto escalas autorizadas a formular o pedido de anulação - detinham assegurada a possibilidade de conter a atividade da estatalidade intergovernamental, desde que (a) observassem o lapso temporal de um mês; (b) se submetessem à intermediação controladora da escala supranacional de outro órgão comunitário (Corte) - quem avaliaria o pedido e sua procedência; e (c) fundamentassem precisamente que se tratava de hipótese de exame de legalidade - estando, assim, impedidas de propor um recurso de anulação da deliberação do Conselho com base em um argumento que foi denominado acima como de legitimidade; e

(ii) se a estatalidade intergovernamental do Conselho poderia ter seus atos questionados, ela detinha simultaneamente completa liberdade de agir no interior de seus limites de competência institucionalmente assegurados - desde que se concentrasse a permanecer neles, pois estava alerta e consciente sobre a contínua possibilidade de haver o controle de seus atos por outro órgão comunitário (Corte), a pedido dos demais participantes da vida em comum (Estados-Membros e Alta Autoridade). 
Pela descrição acima desenvolvida, é possível perceber a presença de uma preocupação que buscava tornar cada uma das escalas de existência participantes da vida em comum conscientes de suas limitações - e, portanto, de que a nenhuma delas era dado se apropriar do lugar do Direito e do Poder na Comunidade.

Com efeito, condições institucionais teriam sido criadas para viabilizar a promoção, a manutenção e o resguardo da dinâmica Política da Europa Unida pela CECA: teria sido efetuado um consciente esvaziamento do Poder de controle previsto neste artigo à Corte, à Alta Autoridade e aos Estados-Membros. Isso assegurava que a capacidade de contenção destes pares comunitários era tão contida quanto a do Conselho: a abrangência do campo de atuação de cada uma deles era imediatamente inserta em uma armadilha institucional que impossibilitava uma determinação unidimensional efetiva do sentido normativo na Comunidade, em detrimento das outras escalas de existência que com ela se entrechocassem.

A amplitude do espectro de atuação de todos era, assim, capturada pelo círculo do Político, círculo este passível de ser compreendido como círculo de resistência na Europa Unida à possibilidade de ascensão do Um unitário, homogêneo e homogeneizante, total e totalizante. Contrário à transcendentalização de qualquer das medidas de existência, a Europa Unida da CECA se blindava de diferentes maneiras à possibilidade de Um imprimir sua única dimensão supranacional sobre o centro nomogenético comum. Prever a capacidade de ação de uma escala de existência exigia, assim, a previsão simultânea de mecanismos que impedissem uma precipitação normativa da dimensão existencial desta sobre as demais.

O Tratado não sinalizava assim qualquer preferência por uma ou outra escala de existência no que se refere à ocupação do lugar do Direito e do Poder. Antes, ele se mostrava reiteradamente preocupado em preservar o delicado e fino equilíbrio de Poder entre diferentes inseridos igualmente em posição horizontal, de maneira a preservar a imanência na fundamentação do sentido normativo. Toda transcendentalização potencial de uma escala, isto é, todo possível destaque era pronta e bruscamente contido para evitar, a todo momento, a totalização da medida estatal (isolada ou intergovernamental) ou a da supranacional (da Alta Autoridade ou da Corte) na definição do sentido normativo sobre questões concretas sensíveis comuns. 
7.2.2.6. O Artigo 41 do Tratado da CECA: O Exame Prejudicial Jurisdicional da Validade de Deliberações e seu Significado Jurídico-Político

\subsection{Observações Gerais sobre o Artigo 41}

O artigo 41 do Tratado da CECA estabelecia a competência exclusiva da Corte para decidir em caráter prejudicial o questionamento da validade das deliberações da Alta Autoridade e do Conselho quando, em Tribunal nacional, tivesse sido questionada a validade de tais atos.

Nesta singela disposição normativa atributiva de competência à Corte da CECA, é possível perceber o ressurgimento do enigmático Poder "desprovido de Poder" na Europa Politicamente Unida. E ela teria mais uma vez escolhido a atuação jurisdicional para operar como símbolo desse mútuo repelir de escalas de existência do interior do lugar do Direito e do Poder. Nesse sentido, há que se avaliar com um pouco mais de detalhe sua sintética e clara disposição textual sobre a competência da Corte, pois apenas deste modo será possível identificar nela a preocupação em conservar a Política na CECA mediante instrumento institucional de promoção do embate entre diferentes escalas de existência.

É importante perceber que se estabelece um domínio reservado de atuação à Corte: apenas a ela incumbia a tarefa de decidir sobre a validade de deliberações proferidas pelos demais órgãos comunitários detentores de poder normativo, a saber, a Alta Autoridade e o Conselho. Há expressa exclusão multilateral da possibilidade de que essa avaliação seja efetuada por qualquer outra medida de existência participante da vida em comum - fosse ou não órgão comunitário, ou mesmo por qualquer dimensão existencial que não participasse da vida em comum.

Por isso mesmo, o artigo claramente determinava que estavam excluídas da possibilidade de exercer essa espécie de controle prejudicial todas as demais escalas de existência envolvidas no processo de construção da Europa Unida da CECA - a supranacional da Alta Autoridade e as estatalidades isoladas e intergovernamentais. Ao mesmo tempo, o mesmo artigo definia que estavam igualmente excluídas dessa possibilidade toda e qualquer escala que não participasse do jogo de Poder no interior da Comunidade - neste caso, mais diretamente, as jurisdições nacionais.

O objetivo dessa previsão era duplo: não apenas assegurar à Corte a exclusividade da possibilidade de decidir sobre essa questão, mas principalmente garantir que controvérsias sobre a validade de normas comunitárias fossem resolvidas 
comunitariamente, isto é, mediante o recurso às próprias instituições. Mais uma vez, o Tratado da CECA se preocupou em mostrar que o desenho institucional previsto para constituir, preservar e promover a Comunidade Política da Europa Unida era suficiente ele próprio para resolver as mais diferentes questões que pudessem eventualmente surgir sobre o caminho normativo dado a questões concretas sensíveis comuns.

Em outras palavras, o Tratado da CECA buscou refirmar que os participantes da vida comum poderiam confiar plenamente nas instituições disponíveis, pois elas seriam amplos canais de vocalização das mais diferentes questões possíveis, no interior dos quais todo e qualquer participante poderia ser convidado, a qualquer tempo, a prestar informações e se opor escalarmente perante as demais dimensões existenciais. Prevendo-se interiormente um remédio, não haveria razão para buscar a solução fora da própria vida em comum da CECA.

Deste modo, na aplicação do Direito Comunitário, não poderia o juiz nacional afastar a aplicabilidade deste sob o potencial argumento de não validade da norma comunitária (originária ou derivada), pois o próprio Tratado da CECA reenviava imediatamente o exame dessa questão para a própria esfera comunitária (multiescalar). No interior desta, contudo, nenhum outro órgão além da própria Corte poderia efetuar tal exame, na medida em que tal competência seria de seu domínio reservado: a Assembleia não poderia se manifestar sobre a questão, nem mesmo a própria Alta Autoridade ou o Conselho - ainda que estes dois últimos tivessem sido os responsáveis pela formalização da norma comunitária derivada ${ }^{852} 853$.

\subsection{A Rede de Oposições Escalares do Artigo 41}

Uma primeira avaliação do artigo poderia ensejar uma indevida percepção de que, por meio desse dispositivo, o lugar do Direito e do Direito na Comunidade residiria de maneira finalmente clara em um órgão comunitário: a Corte. Poder-se-ia concluir deste modo, pois a ela caberia, segundo uma leviana interpretação deste dispositivo, o supremo papel de guardião das instituições jurídico-normativas da Europa Unida, isto é, teria havido uma sinalização por parte desta previsão normativa que o Tratado dera preferência à

\footnotetext{
${ }^{852} \mathrm{Na}$ medida em que, como visto acima na nota de rodapé 813, a Assembleia não detinha capacidade normativa, isto é, de participar da construção do sentido normativo a ser dado a questões concretas comuns sensíveis.

${ }^{853}$ Possibilidade que será mais bem compreendida a partir da leitura integral do item 7.3.1., infra.
} 
medida de existência supranacional da Corte sobre todas as demais participantes da vida comum da CECA e também sobre as dos Tribunais nacionais.

É necessário, contudo, efetuar uma análise um pouco mais detida desse artigo, pois ela permitirá revelar algumas resistências com relação a esse apressado encadeamento lógico. Não poderia ser diferente o caminho da normatização do Tratado da CECA: até o presente momento, ele teria se manifestado incessantemente no sentido de assegurar a manutenção de uma recusa constante a atribuir qualquer preferência a uma ou outra escala de existência na Europa Unida da CECA.

O complexo embate entre escalas de existência que tal disposição congregava também haveria que ser adequadamente desvelado. Deve-se adiantar desde já que esse sintético artigo também portava consigo toda uma intrincada cadeia de relações de freios e contrapeso entre as escalas de existência que compunham a Europa Unida da CECA. Nesse sentido, há que se tornar mais explícita essa teia institucional de negatividade mútua e recíproca entre as escalas de existência que, por sua vez, mantinham-nas em plena relação de horizontalidade.

A previsão de que a Corte detinha com exclusividade o Poder de decidir sobre a validade das normas jurídicas produzidas pela Alta Autoridade e pelo Conselho tinha um significado bastante peculiar: ela buscava introduzir de antemão um mecanismo constritor de qualquer tentativa semelhante por parte dos Estados-Membros (isto é, de seus juízes nacionais) ou por parte dos demais órgãos comunitários (Assembleia, Alta Autoridade e Conselho).

Havia aqui um potente e deliberado bloqueio com relação à possibilidade de que uma medida de existência isolada de um indivíduo funcionário de um Estado-Membro pudesse vir a quebrar, com seu julgamento sustentado em formação em Direito dada pelos ordenamentos jurídico-positivos nacionais, a coerência sistêmica do ordenamento jurídico comunitário. Se um Estado-Membro estava autorizado a questionar a validade de uma disposição comunitária derivada, não lhe era garantida a igual possibilidade de, em virtude deste questionamento, afastar automaticamente sua aplicação: ele deveria encaminhar prejudicialmente o exame da questão à Corte.

Entenda-se assim que a previsão do Tratado da CECA visava a obstar que, por vias transversas, o Direito de um Estado-Membro pudesse significar - por força de norma jurídica interna: a sentença judicial - a recusa ao cumprimento das obrigações internacionais assumidas por meio do Tratado ou dele derivadas por decisões ou recomendações. Por meio deste dispositivo, o Tratado procurava assegurar um meio de 
impedir que fosse encontrado um expediente imprevisível que permitisse uma sorrateira ascensão da medida estatal isolada - a do Direito nacional de um dos Estados-Membros ao lugar do Direito e do Poder na Comunidade.

Mais simplesmente, este dispositivo deve ser compreendido como declaração do Tratado de que não seria admitido o uso de quaisquer artifícios que pudessem introduzir a escala de existência estatal - neste caso, dada pelo julgamento do Tribunal nacional, segundo o Direito nacional - no centro nomoegenético da CECA. Nestes termos, a exclusão dos Tribunais nacionais nada mais significava que uma preocupação em instaurar um conflito entre a escala supranacional da Corte e a escala estatal isolada.

Por outro lado, há ainda nessa previsão uma cláusula de múltiplo afastamento simultâneo de cada uma das demais escalas de existência partícipes da dinâmica comunitária no que se refere ao controle prejudicial da validade das deliberações da Alta Autoridade e do Conselho. Essa repulsão multilateralmente dirigida também deve ser compreendida como mecanismo voltado a não permitir o surgimento de qualquer pretensão de destaque de Uma medida de existência sobre as demais.

Perceba-se que a Assembleia não detinha qualquer faculdade para se pronunciar sobre a validade de uma norma comunitária. Desprovida de maneira reiterada da possibilidade de participar da formação do sentido normativo comum ao longo de todo o Tratado, uma previsão que a autorizasse a se pronunciar sobre este tema poderia significar a incoerente concessão indireta de uma capacidade que lhe fora negada desde o início do Tratado: a capacidade normativa.

Ao mesmo tempo, a despeito de serem os órgãos detentores de capacidade normativa na Comunidade, a Alta Autoridade e o Conselho estavam absolutamente impedidos de se pronunciar sobre a questão da validade de suas próprias normas, ou sobre as normas do outro. Essa proibição derivava do reconhecimento de que, caso isso lhes fosse autorizado, haveria a atribuição de um controle absoluto sobre o destino das normas jurídicas por eles próprios formalizadas. Todavia, não se pode ignorar que, apesar de estas normas serem por eles formalizadas, elas não eram de sua propriedade, na medida em que eram frutos de embate multiescalar ${ }^{854}$. Nesse sentido, uma possível última palavra sobre tais normas não poderia recair sobre os órgãos comunitários que apenas as formalizaram.

As próprias instituições da Comunidade seriam o mecanismo mais indicado para lidar com questionamentos de validade de normas comunitárias derivadas, pois isso

${ }^{854}$ Como restará mais claro a partir da leitura do item 7.3.1., infra. 
reintauraria a multiescalaridade na discussão sobre o sentido normativo comum. Assim, diante da incapacidade normativa da Assembleia e da impossibilidade de um mero formalizador do Direito Comunitário Derivado ser o referencial último da validade desta, o Tratado estipulara um instrumento de controle apto a ser exercido pela Corte -um órgão comunitário que não estava comprometido, nem com a origem da norma jurídica, nem com o questionamento da validade desta.

Assim, note-se que o dispositivo promovia uma pujante tensão entre as medidas de existência que operavam no interior da Europa Unida: a escala supranacional da Corte se opunha simultaneamente à supranacional da Alta Autoridade e à estatal do Conselho e dos Estados-Membros (via seus Tribunais nacionais).

7.2.2.6.3. As Limitações do Exame Prejudicial da Corte: Freios e Contrapesos da Comunidade Política da CECA

Por fim, não se pode ignorar que o Poder de contenção atribuído por esse dispositivo à Corte era ele mesmo limitado - como se poderia prever em uma arquitetura institucional orientada Politicamente. Aqui, como ocorreu ao longo de todo o Tratado da CECA, não se poderia cogitar ter havido uma sobrevalorização da atuação da Corte em detrimento dos demais portadores das diferentes escalas de existência componentes da vida em comum.

Em outras palavras, aqui, como em todo o Tratado, e como ocorrera com cada uma das diferentes escalas de existência da Comunidade Política da CECA, a Corte não encontrara qualquer manifestação de uma preferência a priori em seu favor, a qual pudesse lhe dar respaldo para ocupar do lugar do Direito e do Poder na CECA. Por isso, haveria que se explicitar também nesta previsão ora em análise os mecanismos de contenção da ascensão de seu Um sobre os demais.

Apesar de a Corte deter a última palavra sobre a validade de normas de Direito Comunitário Derivado, não era ele o detentor da última palavra sobre seu conteúdo. A ela era assegurada a exclusividade para se manifestar prejudicialmente sobre a validade de tais normas, mas o Tratado da CECA não lhe concedera qualquer faculdade que lhe permitisse sequer pensar em fazer imprimir nelas a sua medida de existência supranacional em particular. Afinal, o questionamento suscitado em nível estatal apenas lhe atribuíra a possibilidade de dizer sobre a conformidade da norma jurídica comunitária derivada com o ordenamento jurídico comunitário originário - mas lhe 
recusava a possibilidade de influenciar unilateralmente, a sua imagem e semelhança, na determinação do conteúdo delas.

Perceba-se assim a presença de uma armadilha institucional neste dispositivo: o Tratado facultava à Corte o exercício de controle sobre norma jurídica formalizada pela Alta Autoridade e pelo Conselho, mas imediatamente esvaziava este contra-Poder por meio de autocontenção interna. De fato, acompanhava simultaneamente este contra-Poder a exclusão da possibilidade de a Corte ocupar o lugar do Direito e do Poder na Comunidade, haja vista que ela apenas poderia exprimir sua perspectiva supranacional sobre questões de validade e invalidade da norma jurídica - mas jamais poderia determinar o conteúdo desta. Em outras palavras, sua atuação se restringiria a designar a validade ou não validade de uma norma jurídica - o que não lhe permitia imprimir sua própria escala sobre questão concreta sensível comum.

Por isso, entre os diferentes participantes da vida em comum, abria-se também por meio deste dispositivo um espaço vazio, em relação ao qual todas as escalas de existência aparentavam deter todo e nenhum Poder ao mesmo tempo. O lugar do Direito e do Poder não poderia ser ocupado por nenhuma das dimensões existenciais, pois ao longo de todo o tecido normativo deste dispositivo teria sido forjado um maquinário bastante específico de compartilhamento de deveres limitados de participação mutuamente implicados, o qual asseguraria a exclusão multiescalar do interior do centro nomogenético da Comunidade.

Reciprocamente repelidas, as escalas eram assim mantidas em igual posição de incapacidade de tomar o lugar do Direito e do Poder ou de sorrateiramente o plenificar unidimensionalmente a sua imagem e semelhança. A norma de oposição escalar em comento se voltara a impedir, assim, a transcendentalização/o destacamento de Um sobre os demais.

\subsubsection{O Cumprimento Estatal de Decisões dos Órgãos Comunitários: A Sujeição} Compartilhada a Deveres Comuns e à Preservação da Horizontalidade

Não se pode ignorar ainda a previsão constante dos artigos 86 e 88 do Tratado da CECA, os quais se referem pontualmente a possíveis respostas da Alta Autoridade a determinadas ações dos Estados-Membros que implicassem a não observância das disposições de decisões dos órgãos comunitários. 
Uma vez formalizada a decisão da Corte ${ }^{855}$, ou ainda, uma vez formalizada uma decisão ou uma recomendação pela Alta Autoridade ${ }^{856}$, no caso de estes atos normativos comunitários derivados serem dirigidos aos Estados-Membros, haveria que se prever um mecanismo que averiguasse se estes estavam preocupados em cumprir ou em fazer cumprir o Direito Derivado da Comunidade ${ }^{857}$.

De nada adiantaria estabelecer no Direito Originário da CECA um minucioso e trabalhoso procedimento de produção multiescalar de normas jurídicas comunitárias derivadas sem que se previsse instrumento que vigiasse o cumprimento - ou que criasse condições jurídicas que estimulassem o cumprimento - de tais normas jurídicas pelos principais interessados originalmente em compor a vida em comum na Europa: as estatalidades isoladas, outrora opostas belicamente.

A análise jurídico-política das duas previsões normativas selecionadas permitirá perceber a presença no Tratado de outros mecanismos institucionais de conservação da imanência nas relações desenvolvidas entre as escalas de existência implicadas na vida em comum. Não apenas os Estados-Membros seriam possivelmente controlados por meio dessas duas disposições: estas teriam se preocupado também em formular uma engenhosa oposição escalar favorável à manutenção da paridade comunitária entre os implicados no vida comum da CECA.

Será possível compreender que, sob o argumento de apenas pretender regulamentar um mecanismo de acompanhamento da conduta estatal no que se refere ao cumprimento de atos normativos comunitários, os artigos 86 e 88 do Tratado da CECA se voltaram conjuntamente também a conter as pretensões de disrupção do sistema, as quais poderiam se iniciar no interior das estatalidades isoladas ou da supranacionalidade da Alta Autoridade.

Assim, mais uma vez será possível constatar que o objetivo das duas previsões normativas consistira em impedir a transcendentalização de uma escala de existência ou de outra sobre as demais - ou ainda, de sujeitar todos de maneira igual a diferentes tipos de deveres comuns, de modo a preservar a horizontalidade nas relações entre medidas de existência e, com isso, conservar a imanência na Comunidade. Como será verificado nos itens a seguir.

\footnotetext{
${ }^{855}$ Examinada no item 7.2.2., supra.

${ }^{856} \mathrm{O}$ que será examinado no item 7.3.1., infra.

${ }^{857}$ Para a distinção entre Direito Comunitário Originário e Direito Comunitário Derivado, remetemos o leitor ao item 2.1.2., supra.
} 
7.2.3.1. Fiscalização do Estado-Membro pela Alta Autoridade: Limites do Controle $\underline{\text { entre Pares Comunitários }}$

\subsection{Apresentação Geral do Artigo 86 do Tratado da CECA}

O artigo 86 do Tratado da CECA dispunha em seu parágrafo primeiro que os Estados-Membros se comprometeriam a tomar todas as medidas gerais ou particulares próprias para assegurar a execução das obrigações resultantes das decisões e das recomendações dos órgãos comunitários e para facilitar a Comunidade a cumprir sua missão. Ao mesmo tempo, o parágrafo quarto do mesmo artigo previa ainda a possibilidade de uma fiscalização das atividades de cumprimento das decisões e dos regulamentos emanados dos órgãos comunitários pela Alta Autoridade ${ }^{858}$.

Uma primeira análise da conjunção dos dois parágrafos acima mencionados do artigo 86 permite construir a seguinte disposição normativa: por meio do Tratado da CECA, cada um dos portadores da estatalidade isolada se comprometera a assegurar a execução das obrigações resultantes de atos normativos produzidos por órgãos comunitários supranacionais ${ }^{859}$, sendo facultada ainda à Alta Autoridade fiscalizar o cumprimento de tais atos normativos por parte dos Estados-Membros.

\footnotetext{
${ }^{858}$ Observe-se que não serão comentados neste item os parágrafos segundo e terceiro do artigo 86, na medida em que não consistem em normas de oposições escalares voltadas à contenção da atividade estatal. $\mathrm{O}$ parágrafo segundo daquele artigo determinava que os Estados-Membros se absteriam da prática de medidas incompatíveis com a existência do mercado comum. O parágrafo terceiro previa, por sua vez, que os EstadosMembros se comprometeriam a tomar, no âmbito de suas respectivas competências, medidas adequadas para garantir o pagamento internacional referente de transações envolvendo o carvão e o aço no mercado comum, bem como concorreriam mutuamente para facilitar tais pagamentos. Nesse sentido, tratavam-se de disposições gerais de regulamentação de questões que em nada guardam relação com a preocupação temática deste item, razão pela qual não serão comentadas.

A rigor, o parágrafo primeiro também pouco teria a ver com o comentário deste item, na medida em que a disposição normativa diretamente relacionada com a metodologia deste trabalho (normas de oposições escalares) constaria precisamente do parágrafo quarto. Todavia, caso não houvesse o comentário do parágrafo primeiro do artigo, ficaria profundamente comprometida a compreensão da disposição normativa como um todo, pois não se entenderia exatamente aquilo que o parágrafo quarto regulamentava. Dessa mesma maneira, o comentário ao parágrafo primeiro do artigo 86 opera assim como forma de introduzir a temática ao leitor e permitir que este compreenda como este artigo se inseria na temática geral de contenção de condutas estatais com relação ao cumprimento de decisões tomadas pelos órgãos comunitários.

${ }^{859}$ Isto é, a Alta Autoridade e a Corte de Justiça da Comunidade, ambas detentoras da supranacionalidade, como visto na nota de rodapé 820 , supra. Com efeito, note-se que apenas estes dois órgãos comunitários eram dotados de competência para produzir um ato normativo: a Alta Autoridade, mediante decisões e recomendações, tal qual previstas no artigo 14 do Tratado da CECA, a Corte de Justiça, mediante suas decisões judiciais (isto é, uma norma jurídica produzida para regulamentar o caso concreto a ela submetido), conforme previsto nos artigos do Tratado da CECA que foram objeto dos comentários desenvolvidos ao longo do item 7.2.2, supra.

Lembre-se de que, como visto na nota de rodapé 820, supra, o artigo 7 do mesmo Tratado definia serem as instituições da Comunidade (i) a Alta Autoridade; auxiliada pelo (ii) Comitê Consultivo; (iii) a Assembleia Comum; (iv) o Conselho Especial de Ministros; e (v) a Corte de Justiça da CECA. Naquela
} 
Isso significa que, uma vez formados os atos normativos supranacionais, as estatalidades isoladas deveriam se comprometer a garantir sua execução em seus respectivos territórios nacionais, podendo a Alta Autoridade ainda verificar se esse comprometimento estava sendo cumprido pelos Estados-Membros.

Reside no interior desta singela previsão uma complexa rede de previsões normativas que colocam em choque diferentes escalas existenciais de maneiras distintas. Essa malha regulatória deve ser adequadamente desdobrada para se poder verificar como os enlaces normativos presentes neste artigo como um todo foram hábeis para produzir uma regulamentação voltada a manter a horizontalidade nas relações entre os participantes da vida comum da CECA e, com isso, puderam conservar a imanência.

mesma nota de rodapé 820 , supra, justificou-se exclusão da análise por este trabalho de dois órgãos comunitários - o Comitê Consultivo e a Assembleia Comum - pois não detinham capacidade para participar do jogo de Poder de formação do sentido normativo sobre questões concretas comuns sensíveis, ou melhor, precisamente porque não detinham qualquer competência normativa.

O Conselho de Ministros era órgão comunitário que residia em posição especial. Por um lado, ele estava desprovido de competência normativa - basta lembrar que o artigo 26, parágrafo terceiro, do Tratado da CECA, apenas autorizava o Conselho a solicitar à Alta Autoridade que estudasse proposições e medidas que ele julgasse necessários ou oportunos à vida comum, isto é, determinava que as medidas normativas sejam efetivamente tomadas pela Alta Autoridade, e não pelo Conselho; por outro lado, a consideração de sua posição como ator fundamental da construção normativa da vida comum é justificada também mediante disposições constantes do Tratado.

Com efeito, há que se notar que, se o Conselho não detinha competência normativa, ele foi órgão comunitário previsto em série de dispositivos do Tratado da CECA que lhe impuseram o dever de se apresentar perante as demais escalas de existência para opor contra elas sua própria medida de existência. $\mathrm{O}$ embate escalar deveria ser promovido levando necessariamente em consideração o modo estatal intergovernamental de habitar o mundo, ainda que este não detivesse competência normativa.

Para tanto, o Tratado previu em favor do Conselho série de dispositivos que lhe concederam um Poder fundamentalmente impeditivo (e não propositivo, como no caso da Alta Autoridade): uma determinada medida normativa dependeria de uma aprovação expressa do Conselho, a ser manifesta por meio de parecer emitido por este órgão comunitário. Essa condição pôde talvez ser verificada durante a leitura do item 7.2.2., supra, mas restará com certeza mais clara quando da leitura do item 7.3.1., infra.

Deste modo, ainda que não detentor de uma competência normativa propositiva, a presença do Conselho de Ministros no jogo de Poder voltado à construção compartilhada do sentido normativo a ser impresso ao uso e à administração do carvão e do aço era justificada também por disposições do Tratado da CECA que lhe asseguravam uma "competência normativa" impeditiva, ou seja, um Poder de barrar eventuais atos normativos da Alta Autoridade ou de influenciar de alguma forma as decisões da Corte. E, por esse motivo, mostra-se justificada a possibilidade de se comentar neste trabalho a atividade do Conselho de Ministros na construção da vida comum da CECA, na medida em que também era uma escala de existência obrigada institucionalmente a se opor perante as demais participantes da Comunidade.

De todo modo, para os efeitos de compreensão do artigo 86, é importante apenas reter que, quando ele se refere ao cumprimento de atos normativos (decisões ou recomendações) de órgãos comunitários, há que se entender que ele se refere apenas e tão-somente à Alta Autoridade e à Corte de Justiça da CECA entidades portadoras da supranacionalidade, como visto no item 3.3.3.3., supra. É nesse sentido que se introduzirá, também por meio desse artigo, uma oposição escalar preocupada em conservar a horizontalidade nas relações desenvolvidas no interior da vida comunitária. 
7.2.3.1.2. Observância do Direito Comunitário: Submissão da Estatalidade Isolada à Supranacionalidade?

Estabelece-se por meio deste dispositivo uma contraposição entre as supranacionalidades emissoras de um ato normativo e cada uma das estatalidades isoladas: os Estados-Membros devem se comprometer a cumprir tais normas jurídicas gestadas no interior da vida comum da CECA.

Todavia, é importante notar que, como visto acima ${ }^{860}$, e como será mais bem compreendido a seguir ${ }^{861}$, os atos normativos aos quais se submetem os Estados-Membros não são produtos apenas e tão-somente da impressão da escala de existência supranacional da Corte ou da Alta Autoridade. Tanto no caso das decisões da Corte, como no caso das decisões e das recomendações da Alta Autoridade, o sentido normativo nada mais é do que síntese multiescalar derivada de embates dimensionais fomentados ativamente por normas de oposições escalares em torno do lugar vazio do Direito e do Poder.

A oposição entre estatalidade isolada e supranacionalidades não deriva do fato de os Estados-Membros se submeterem de antemão, por expressa previsão constante do Tratado da CECA, aos atos normativos moldados à imagem e semelhança das escalas de existência daqueles dois órgãos comunitários. Isso porque, o Direito Comunitário resultante, se não era Direito nacional - por não ser produto exclusivo de uma estatalidade isolada, também não era um Direito supranacional - por não ter sido produzido apenas a partir da escala de existência supranacional ${ }^{862}$.

\footnotetext{
${ }^{860}$ Item 7.2.2., supra.

${ }^{861}$ Item 7.3.1., infra.

${ }^{862}$ Perceba-se que, como visto no item 7.2.2., supra, bem como no item 7.3., infra, a Alta Autoridade e a Corte apenas exercem o papel de formalizadores dessa confluência multidimensional em um documento jurídico-normativo formal.

O ambiente institucional do Tratado da CECA incumbira estes dois órgãos comunitários, não da tarefa de produzir normas jurídicas em nome da Comunidade, a partir de seus respectivos modos de habitar o mundo (supranacional). Caso assim fosse, estas duas entidades ocupariam o lugar do Direito e do Poder na Comunidade com suas próprias escalas de existência, levando à conclusão apressada - como faz a tradição das literaturas jurídicas nacional e estrangeira, conforme indicado na nota de rodapé 202, supra - de que estas - mas principalmente a Alta Autoridade - seriam o centro de gravidade da CECA e seriam responsáveis por gerir os interesses comuns, em nome do interesse comum, sobre os Estados-Membros e as demais entidades comunitárias. Para esta conclusão da tradição, o referencial normativo comunitário seria o padrão estabelecido pela supranacionalidade.

Todavia, como reiterado por diversas vezes neste trabalho, a preocupação na construção histórica da CECA (como visto no Sexto Capítulo, supra) consistiu em instaurar uma organização jurídico-política na Europa segundo os ditames de Leis Políticas. Este objetivo de constituir uma organização jurídico-Política das relações entre os países europeus deveria ser realizado mediante instituições específicas que buscariam preservar continuamente - mediante normas de oposições escalares - um lugar do Direito e do Poder permanentemente vazio, onde o sentido normativo último seria dado por meio do contínuo entrechoque entre
} 
Em outras palavras, a confluência de diferentes medidas existenciais na produção do ato normativo comunitário derivado ao qual os Estados-Membros se comprometiam a se submeter tornava-o multidimensional, isto é, nem estatal, nem intergovernamental, nem supranacional, mas tudo isso em conjunto concertado tendo em vista a vida em comum. Tratava-se de um arcabouço jurídico que tinha por padrão normativo a pluralidade escalar, isto é, algo que diferente da estatalidade isolada nacional, mas que não lhe era estranho. Se fosse produto exclusivo de medida de existência outra, não conseguiria vincular os Estados-Membros; se os vinculava, isso derivava do fato ser também um produto de sua própria dimensão de existência.

Por esse motivo, pode-se dizer que o Direito assim produzido era um Direito Comunitário. Com efeito, tratava-se de um repertório de normas jurídicas derivadas do Direito Originário do Tratado da $\mathrm{CECA}^{863}$ oriundo da submissão a deveres multiescalarmente compartilhados de participação no processo de definição do sentido normativo a ser dado sobre questões concretas comuns sensíveis - o que não afeta, assim, a independência dos Estados-Membros, na medida em que estes se submetem a uma norma jurídica internacional produzida, não apenas por eles, mas também por eles.

as mais diferentes dimensões existenciais inseridas em igualdade de condições de apresentação umas diante das outras (como foi visto no item 7.2.2., supra, e conforme será visto quando da leitura do item 7.3., infra).

Diante de uma arquitetura institucional cuidadosamente voltada à preservação da multidimensionalidade permanentemente tensa na formação do sentido normativo sobre questões concretas comuns sensíveis (carvão e aço), pode-se perceber - diferentemente do que o discurso monolítico da tradição jurídica afirma - que o Tratado da CECA não atribuíra a nenhuma das supranacionalidades vigentes em seus dois órgãos comunitários (Alta Autoridade e Corte de Justiça) um papel central de destaque na produção normativa. Estes não dariam a palavra última sobre as normas jurídicas, pois deveriam levar em consideração as medidas de existência apresentadas pelos demais partícipes da vida em comum.

Em outras palavras, Alta Autoridade e Corte não eram o centro da vida comunitária da CECA precisamente porque não ocupavam intemporalmente o lugar do Direito e do Poder na Comunidade Política da Europa Unida pela CECA. Este era mantido vazio mediante repulsão multilateral dirigida a todas as escalas de existência, as quais eram consideradas pares comunitários na formação das normas jurídicas.

O Direito assim produzido deveria ser compreendido como Direito efetivamente Comunitário, na medida em que seria produto da dinâmica propriamente Política de compartilhamento do processo de formação da decisão sobre o sentido normativo sobre questões comuns - ou ainda, simplesmente porque seria um arcabouço jurídico-normativo derivado de uma organização jurídico-Política de convivência entre diferentes no interior de uma vida comum, ou melhor, de uma vida tornada comum, uma de vida comunitária, a qual fora instituída mediante direitificação originária das relações (Direito Comunitário Originário).

Nem nacional, nem intergovernamental, nem supranacional, mas produto do encontro de cada uma das respectivas escalas de existência - sob a atenta vigilância da populidade (como será visto no item 7.3.2., infra), este Direito era um produto da vida comum multiescalar (Direito Comunitário Derivado), organizada jurídico-Politicamente por um Direito também comumente construído conforme uma dinâmica multiescalar (Direito Comunitário Originário).

${ }^{863}$ Opera-se aqui nas entrelinhas com a distinção entre Direito Comunitário Originário e Direito Comunitário Derivado, como referida ao final do item 2.1.2., supra. Perceba-se que há neste trecho uma preocupação em inserir essa distinção no interior da teia de significação jurídico-política especificamente adotada por este trabalho. Da mesma maneira como efetuado, por exemplo, com a noção de Funcionalismo, no item 6.2.2.5., supra. 
Deste modo, se a oposição entre estatalidade isolada e supranacionalidade não deriva de uma sujeição a norma jurídica produzida por outrem - na medida em que os Estados-Membros participavam da produção das normas comunitárias derivadas ${ }^{864}$, é importante analisar com mais cuidado a disposição normativa.

7.2.3.1.3. Fiscalização dos Estados-Membros pela Alta Autoridade: Instauração de Oposição Escalar

Há que se perceber que a oposição escalar prevista neste dispositivo surge com a previsão de que a Alta Autoridade poderia fiscalizar as atividades de cumprimento dos atos normativos por parte dos Estados-Membros. Neste momento, há o entrechoque entre a possível performance do portador da estatalidade isolada (cumprir ou não os atos normativos comunitários derivados) e a possibilidade de fiscalização por parte do portador da supranacionalidade da Alta Autoridade.

A presença desta previsão jurídico-normativa no Tratado da CECA poderia suscitar eventual suspeita de uma inserção expressa da Alta Autoridade em posição de destaque com relação às demais escalas de existência. Segundo essa perspectiva, a Alta Autoridade poderia ser compreendida como tendo sido escolhida para ser a guardiã comunitária do Direito produzido em comum e em posição superior com relação aos Estados-Membros na medida em que garantiria, mediante fiscalização, o cumprimento de tais normas por estes.

Todavia, não seria de todo acertado concluir de acordo com essa perspectiva. É possível compreender de maneira diferente a construção jurídico-normativa deste dispositivo, segundo a perspectiva jurídico-Política proposta por este trabalho. Com efeito, pode-se visualizar neste texto normativo de que modo os autores do Tratado da CECA se preocuparam em assegurar a horizontalidade nas relações entre essas duas escalas de existência (imanência), sem descuidar do problema do cumprimento do das normas jurídicas comunitárias derivadas pelos Estados-Membros.

O parágrafo primeiro do artigo 86 do Tratado da CECA consubstanciava um comprometimento jurídico-normativo entre os Estados-Membros de tomar todas as medidas gerais ou particulares para assegurar a execução das obrigações resultantes dos atos normativos emanados formalmente da Alta Autoridade e da Corte. Nesse sentido, o

${ }^{864}$ V. nesse sentido os comentários constantes dos itens 7.2.2., supra, e 7.3.1., infra. 
Tratado da CECA estabelecera uma presunção - relativa, é verdade - de que os EstadosMembros se ocupariam da incumbência de dispor de todos os meios possíveis para cumprir ou para fazer cumprir os atos normativos comunitários derivados.

Dessa forma, o Tratado da CECA tinha como ponto de partida de seu dispositivo jurídico-normativo a pressuposição de que os Estados-Membros componentes da Comunidade performariam o dever constante de tal previsão, isto é, de que efetivamente atuariam no sentido de cumprir ou de fazer cumprir as obrigações constantes dos atos normativos produzidos por aqueles dois órgãos comunitários. Esta seria a regra geral constante do dispositivo, da qual o Tratado da CECA contaria de antemão com o cumprimento: os Estados-Membros teriam em seu favor a presunção de que honrariam o comprometimento declarado por este artigo.

Assim, o documento jurídico-normativo internacional assumiria como regra geral o reconhecimento por parte dos próprios Estados-Membros da consciência da importância de agir conforme este comprometimento. Isso significa que o Tratado da CECA confiara antecipadamente uma suposta honestidade detida por parte dos Estados-Membros em alinhar suas próprias convicções ao conjunto normativo comunitário derivado formado multiescalarmente.

Dito de outro modo: em um primeiro momento - e antes mesmo de qualquer outra consideração - o Tratado da CECA assumira que os Estados-Membros deveriam ser percebidos como íntegros perante o compromisso assumido perante a vida em comum e, portanto, como aptos a atuar espontaneamente de modo a que as percepções sobre as próprias utilidades estatais isoladas não prejudicassem o novo modo de relações estabelecido na Europa mediante a União Política da CECA.

Por esse motivo, em um primeiro movimento lógico, o dispositivo ora em análise tinha em alta consideração os Estados-Membros: eles eram percebidos como aptos a deixar suas estreitas nacionalidades de lado quando da necessidade de cumprir ou de fazer cumprir os atos normativos comunitários. A estima comunitária plasmada no Tratado da CECA jogava assim em favor dos Estados-Membros, pois estes eram de antemão reputados como presumidamente virtuosos para por si só atuarem no sentido de praticar tal compromisso.

Todavia, há que se notar que, caso a previsão normativa do Tratado da CECA cessasse neste ponto, talvez se pudesse concluir que os Estados-Membros teriam sido objeto de uma estima desmesurada. Esta poderia ser entendida como uma previsão normativa que revestira os Estados-Membros de tamanha imoderada confiança que poderia 
engendrar nestes, por seu turno, uma convicção de que talvez fossem superiores aos demais - isto é, que deteriam uma posição destacada no lugar do Direito e do Poder.

Com efeito, tendo sido elevados a uma presunção tão grandemente destacada por parte do Tratado da CECA, os Estados-Membros poderiam se julgar como efetivamente o centro normativo da vida em comum e, com isso, almejar posteriormente o rompimento da dinâmica horizontal das relações. Em virtude de uma suposta desigualdade de condições, segundo essa perspectiva, os Estados-Membros não precisariam até mesmo cumprir os mandamentos jurídico-normativos comunitários...

Deste modo, para evitar que os Estados-Membros pudessem formar em seu interior uma disposição a elevar-se sobre os demais - e, com isso, submetê-los por vias transversas a sua escala de existência estatal isolada, o Tratado da CECA estabelecera imediatamente após a declaração dessa mais alta elevada estima pelos Estados-Membros que estes poderiam ser fiscalizados pela Alta Autoridade no que se refere ao cumprimento de seu comprometimento inicial.

O Tratado da CECA adotara perante as estatalidades isoladas uma postura dupla de confiança e de desconfiança. Por um lado, admitira que os Estados-Membros eram capazes de adotar medidas para cumprir ou fazer cumprir as normas jurídicas comunitárias derivadas. Por outro lado, reconhecera que essa presunção deveria ser relativa, isto é, que os Estados-Membros poderiam não honrar seu comprometimento e que, por isso, deveria haver a possibilidade de estes serem fiscalizados pela Alta Autoridade.

Por isso, há que se perceber que, quando a parcela inicial do parágrafo quarto do artigo 86 do Tratado da CECA abria a possibilidade de a Alta Autoridade recorrer a um procedimento de fiscalização da atividade estatal, este mecanismo de controle fora a ela previsto não em favor desta ou de sua escala de existência. O Tratado de Paris de 1951 apenas buscara uma entidade portadora de escala de existência distinta da estatal para exercer um Poder de contenção de uma possível ruptura da relação horizontal por parte das estatalidades isolada, em nome da preservação do sentido normativo construído para a vida comum (Direito Comunitário Derivado) e pela vida comum (Direito Comunitário Originário).

A dimensão existencial escolhida para receber o Poder de refreamento de uma possível tomada do lugar do Direito e do Poder não deveria agir em próprio nome - isto é, a Alta Autoridade não defenderia perante os Estados-Membros sua própria e específica forma de habitar o mundo jurídico-normativamente plasmada. Antes, ao receber o Poder de fiscalização, a Alta Autoridade deveria atuar apenas para assegurar que uma norma 
jurídico-comunitária derivada multiescalarmente formada ${ }^{865}$ seria adequadamente cumprida no interior dos territórios dos Estados-Membros.

7.2.3.1.4. Limites à Fiscalização pela Alta Autoridade: Restrição e Esvaziamento do Poder e Preservação da Paridade Comunitária

Ao agir, não em seu próprio nome, para defender os próprios interesses ou suas específicas formas de experienciar o mundo, mas para garantir que o resultado normativo comunitário multiescalarmente formado pudesse prevalecer, a Alta Autoridade não deveria ser aqui compreendida como detendo uma pretensa posição privilegiada por parte do Tratado da CECA. Os autores deste Tratado apenas elegeram entre os diferentes órgãos comunitários uma entidade que poderia se opor de maneira vigorosamente igual às estatalidades isoladas.

Compreender essa conjunção normativa desta maneira permite perceber que começa a ruir aquela conclusão inicial de que a Alta Autoridade teria recebido tratamento diferenciado por parte do Tratado; todavia, há outros aspectos no mesmo parágrafo quarto do mesmo artigo 86 que permitem mitigar ainda mais aquela interpretação inicial e, com isso, reafirmar a presença de cuidadosa preocupação em construir um arcabouço institucional que manteria normativamente a horizontalidade relacional entre as diferentes escalas de existência participantes da vida em comum.

Nesse sentido, apesar de o Poder de contenção dos Estados-Membros ter sido atribuído à Alta Autoridade, este não poderia ser considerado como instrumento de imoderado empoderamento da supranacionalidade da Alta Autoridade. Inclusive, este órgão comunitário não deveria recorrer a esse mecanismo para sem a satisfação de determinados critérios, os quais de pronto limitavam o exercício de tal Poder pela Alta Autoridade.

Em outras palavras, aqui se manifestava mais uma vez o engenho institucional do Tratado da CECA: Poderes de limitação atribuídos a escalas de existência seriam, eles próprios, limitados por meio de série de previsões de autocontenção. O objetivo era assegurar que o controle exercido não fosse ele próprio desmedido, ou ainda, que ele não pudesse ser encarado como introdução inadvertida de uma fenda no edifício Político

${ }^{865}$ Isto é, uma norma jurídico-positiva que não era "sua", ou melhor, que não fora forjada por ela apenas, mas mediante a conjunção plurilateral de cada uma das escalas de existência componentes da vida em comum da Europa Politicamente Unida da CECA. Sobre esse tema, remetemos o leitor à nota de rodapé 862, supra. 
originalmente estabelecido pelos autores do Tratado de Paris de 1951 e, portanto, como germe de um desequilíbrio escalar na Europa Unida da CECA que pudesse potencialmente romper com a horizontalidade relacional.

\subsection{Notificação Prévia ao Estado-Membro e Acompanhamento da} Fiscalização por Agentes Nacionais

Lembre-se de que o mesmo parágrafo quarto do artigo 86 previa que a realização de tais fiscalizações estava condicionada à prévia notificação ao Estado-Membro interessado acerca especificamente da missão de controle e da qualidade dos agentes. Inclusive, os agentes das Administrações Públicas do Estado poderiam acompanhar as atividades dos agentes da Alta Autoridade para auxiliar estes no cumprimento de suas tarefas. O acompanhamento de tais atividades por parte de agentes nacionais poderia ser requerido tanto pelo Estado-Membro interessado quanto pela Alta Autoridade.

O processo de esvaziamento do Poder de contenção concedido à Alta Autoridade se iniciava com a primeira parcela acima relatada: a Alta Autoridade deveria notificar previamente o Estado-Membro a ser investigado de que seria alvo de uma fiscalização. A Alta Autoridade deveria especificar naquela notificação de maneira detalhada os objetivos da missão de controle e deveria informar minuciosamente a qualidade dos agentes a serem utilizados $^{866}$.

Isso significa reconhecer que o próprio parágrafo quarto do mesmo artigo 86 já delimitava formalmente a atuação de controle da Alta Autoridade - se a fiscalização poderia ser iniciada, ela não poderia ser exercida de maneira livre, desimpedida ou incondicionada. Por outro lado, o mesmo dispositivo continha a própria contenção do Poder de controle da Alta Autoridade: não havia a previsão de um direito de o EstadoMembro opor alguma forma de impugnação ou de rejeição ao início do procedimento fiscalizatório.

Deste modo, se havia uma limitação à atividade da Alta Autoridade, a qual derivava da aposição de condições formais, do mesmo modo haveria que se notar que o EstadoMembro estava igualmente impedido de opor à Alta Autoridade outras condições que não fossem apenas aquela, de caráter formal. O entrechoque escalar operara aqui para viabilizar a fiscalização, ainda que ela devesse ser realizada sem excessos pela Alta Autoridade, e

\footnotetext{
${ }^{866}$ Sobre os agentes a serem utilizados na fiscalização realizada pela Alta Autoridade, v. comentários nas linhas a seguir, neste mesmo subitem.
} 
ainda que a própria contenção da atividade da Alta Autoridade por uma oposição estatal devesse também ser limitada.

Nesse sentido, pode-se perceber que o Tratado da CECA buscara manter estatalidade isolada e supranacionalidade da Alta Autoridade em posição de pares comunitários. Um e outro deteriam mútuos Poderes de contenção, a fim de que nenhum deles pudesse romper com a relação de horizontalidade e pudesse, com isso, transcendentalizar-se e impor-se sobre as demais. Se a Alta Autoridade deveria notificar previamente o Estado-Membro, este não poderia exigir a satisfação de outra formalidade que não esta especificamente prevista.

Havia deste modo a construção de um delicado mecanismo de equilíbrio escalar no interior do Tratado, a fim de não privilegiar uma escala em detrimento de outra. Todavia, se ainda há a percepção de que a Alta Autoridade detinha uma posição destacada, haveria que se notar a presença de uma limitação ainda mais fundamental de sua atividade fiscalizatória: seus agentes poderiam ser acompanhados por agentes das Administrações Públicas do Estado envolvido.

Nesse sentido, note-se que o referido acompanhamento por parte de agentes nacionais poderia ser requerido tanto pela Alta Autoridade quanto pelo Estado-Membro interessado. Houve aqui a tecedura de uma interessante trama de direitos e de deveres contrapostos entre Alta Autoridade e Estados-Membros, que ao mesmo tempo em que limitava a atividade descumpridora dos Estados-Membros, barrava também o exercício do controle pela Alta Autoridade. Nenhum deles estava autorizado a encontrar lacunas normativas que permitissem sua elevação sobre as demais escalas de existência e a ocupação do lugar do Direito e do Poder.

No caso de o acompanhamento das atividades ter sido solicitado pela Alta Autoridade, torna-se claro que este pedido tinha por objetivo facilitar os agentes desta a cumprir sua tarefa fiscalizatória mediante esclarecimentos diversos envolvendo as mais diferentes questões. Neste caso, havia a concessão de mecanismos voltados a reforçar as condições de exercício de seu Poder por parte da Alta Autoridade, em relação ao EstadoMembro em torno do qual orbitava uma atmosfera de suspeição.

Com efeito, se a Alta Autoridade detinha o Poder de conter os Estados-Membros mediante a previsão de procedimento fiscalizatório, esta deveria deter então o direito de exigir os mais diferentes esclarecimentos perante os agentes da Administração Pública nacional. Ao mesmo tempo, o Estado-Membro em questão deteria o dever que 
disponibilizar imediatamente seus agentes nacionais para auxiliar a Alta Autoridade a realizar a atividade de fiscalização.

Não se ignore assim que, a fim de conter o eventual surgimento de uma pretensão de superioridade por parte de um Estado-Membro, o Tratado da CECA previra um mecanismo segundo o qual a estatalidade isolada não poderia recusar a fornecer de maneira a mais ampla possível informações que deveriam ajudar a Alta Autoridade a cumprir sua missão fiscalizatória. A presunção de idoneidade e de integridade dos EstadosMembros inicialmente formulada no parágrafo primeiro do artigo 86 era, assim, deixada de lado para permitir que a Alta Autoridade verificasse a criação de condições para o cumprimento interno de atos normativos comunitários.

Por outro lado, também não seria adequado deixar de notar que o mesmo dispositivo previa um instrumento jurídico-normativo que permitia aos Estados-Membros opor uma forma de contenção à própria atividade de controle exercida sobre eles mesmos pela Alta Autoridade.

Se o Estado-Membro não poderia recusar a realização da fiscalização em seu território pelos agentes da Alta Autoridade ${ }^{867}$, ao mesmo tempo este não restaria sujeito à livre e desimpedida atuação da Alta Autoridade. O mesmo parágrafo quarto do mesmo artigo 86 previa que o Estado-Membro envolvido na fiscalização poderia solicitar o acompanhamento das atividades dos agentes da Alta Autoridade por parte de membros de sua própria Administração Pública nacional.

Isso implica reconhecer que o Tratado da CECA estabelecera neste momento um importante contrapeso em favor dos Estados-Membros, a fim de conter a atividade de fiscalização da Alta Autoridade e, ato contínuo, o surgimento de eventual pretensão de ocupação do lugar do Direito e do Poder.

Se o Estado-Membro tinha o dever de aceitar a realização de uma fiscalização em seu território por parte dos agentes da Alta Autoridade, ele detinha o direito de ter agentes nacionais seus acompanhando as atividades da Alta Autoridade, ao mesmo tempo em que esta tinha o dever de aceitar ter as ações de fiscalização de seus agentes acompanhadas por agentes nacionais ${ }^{868}$. Deste modo, pode-se perceber que a parcela ora em comento do

\footnotetext{
${ }^{867}$ Lembre-se de que bastava à Alta Autoridade notificar o Estado-Membro a ser investigado, não havendo a previsão da possibilidade de o Estado-Membro impugnar ou rejeitar a fiscalização.

${ }^{868}$ Ressalta-se que o acompanhamento por parte de membros da Administração Pública do Estado-Membro poderia ser favorável ao Estado-Membro.

Com efeito, prever tal possiblidade de acompanhamento não apenas assegurava a higidez na fiscalização da Alta Autoridade - na medida em que vigiavam e controlavam a própria atividade de controle da Alta Autoridade, mas também permitia que o Estado-Membro tivesse plenas condições para apresentar
} 
referido dispositivo tinha por objetivo conter também o eventual surgimento de uma pretensão de superioridade por parte da Alta Autoridade.

Diante das considerações acima, pode-se terminar de interpretar o restante do texto normativo do referido artigo 86, parágrafo quarto: neste dispositivo, o Tratado da CECA também não teria descuidado de compor cuidadosamente um intenso mecanismo institucional voltado a assegurar a preservação de pares comunitários entre as escalas de existências envolvidas por suas normas de oposições escalares. A preservação da horizontalidade mediante o represamento de tentativas de transcendentalização mantinhase como nota característica também deste artigo, componente do conjunto voltado à conservação da imanência. Como se poderá ver a seguir.

7.2.3.1.4.2. Agentes de Fiscalização da Alta Autoridade: Independentes, Autônomos e Iguais

O ainda parágrafo quarto do mesmo artigo 86 estabelecia que a Alta Autoridade deveria exercer sua atividade de fiscalização por meio de agentes próprios, independentes dos Estados-Membros. Nos termos do mesmo dispositivo, os agentes dotados de missão de controle sobre a atividade das estatalidades isoladas deveriam dispor nos territórios dos Estados-Membros precisamente dos mesmos direitos e Poderes atribuídos pelas respectivas legislações nacionais aos agentes de fiscalização da Administração Pública.

O primeiro elemento desta previsão normativa que deve ser mencionado consiste precisamente na determinação de que a Alta Autoridade deveria fiscalizar os EstadosMembros por meio do uso de agentes próprios. Esta condição em especial deve ser mencionada, na medida em que aqui ela buscava assegurar a preservação de uma independência da atividade de fiscalização com relação ao Estado-Membro em torno do qual pairava a suspeita de descumprimento do comprometimento a cumprir ou a fazer cumprir os atos normativos comunitários.

Lembre-se aqui de que o início do artigo 86 do Tratado da CECA tem como ponto de partida a pressuposição - relativa, é verdade - de que os Estados-Membros detinham por convicção o objetivo de honrar seu comprometimento com a vida comunitária. Todavia, na hipótese de haver uma suspeita acerca da impossibilidade de o Estado-Membro honrar tal

razões e informações as mais diversas possíveis para esclarecer e dirimir em seu favor dúvidas por parte dos agentes da Alta Autoridade. Isso asseguraria aos Estados-Membros, por exemplo, a possibilidade de eventualmente demonstrar que a suspeita em torno deles seria infundada. 
comprometimento, essa presunção era afastada para que a Alta Autoridade pudesse averiguar se o Direito Comunitário multidimensionalmente produzido foi cumprido no território nacional.

Para tanto, o Tratado da CECA escolhera uma entidade portadora de escala de existência completamente distinta daquela em torno da qual pairava a suspeição: tendo em vista que a estatalidade isolada mostrava sinais de que eventualmente não poderia honrar seu compromisso, haveria que se recorrer a um procedimento de controle fiscalizatório por parte de escala de existência envolvida na vida em comum e com ela comprometida, mas que não mantivesse com a dos Estados-Membros qualquer relação de dependência ou de confusão.

Tendo sido escolhida a Alta Autoridade para desempenhar essa função de controle no interesse da vida comunitária ${ }^{869}$, os agentes que deveriam dar realidade prática a essa tarefa fiscalização também deveriam guardar em si as mesmas condições: não poderiam manter com as estatalidades isoladas qualquer relação de dependência ou de confusão, sob pena de prejudicar ou tornar imperfeita a higidez e a seriedade do procedimento de fiscalização. Por esse motivo, o Tratado da CECA assegurava à Alta Autoridade a possibilidade de se utilizar de agentes próprios, independentes dos de qualquer EstadoMembro da Comunidade, para proceder à fiscalização.

Todavia, cumpre salientar que o Tratado da CECA não apenas autorizava ou possibilitava à Alta Autoridade o uso de tais agentes: antes, este documento jurídiconormativo estabelecia que a Alta Autoridade deveria se socorrer de agentes vinculados a ela, independentes dos Estados-Membros. Mais do que simples previsão de um direito em favor da Alta Autoridade, este dispositivo afirmava um dever para ela.

Deste modo, note-se que esta parcela do parágrafo quarto do artigo 86 do Tratado da CECA determinava que, se a Alta Autoridade fosse fiscalizar o cumprimento de atos normativos comunitários pelos Estados-Membros, ela mesma deveria efetuar a fiscalização mediante o recurso a agentes próprios, isto é, sem ser auxiliada nem por agentes do EstadoMembro a ser fiscalizado, nem por agentes de qualquer outro Estado-Membro. Dito de outra maneira: se a Alta Autoridade se dispusesse a fiscalizar os Estados-Membros, ela deveria apenas recorrer a seu próprio pessoal - o qual estaria comprometido com a preservação da independência de sua entidade, a fim de não causar embaraços à orientação multidimensional da fiscalização.

${ }^{869}$ Como visto acima, no início deste mesmo subitem. 
Apenas deste modo se poderia garantir que a avaliação do cumprimento de atos normativos por parte dos Estados-Membros não contaria com a influência estrita de uma parcialidade pessoal de um agente da Administração Pública das estatalidades isoladas anteriormente rivais na Europa. Ou ainda, apenas dessa maneira a fiscalização não seria impactada por eventual compromisso prévio com a busca de fazer prevalecer na Comunidade uma medida de existência nacional em detrimento da multiescalaridade compromisso que poderia tanto afastar apressadamente uma eventual conclusão pelo descumprimento, quanto rapidamente afirmá-la.

O segundo aspecto da previsão normativa acima mencionada está contido na disposição que os agentes dotados de missão de controle sobre a atividade das estatalidades isoladas deveriam dispor nos territórios dos Estados-Membros precisamente dos mesmos direitos e Poderes atribuídos pelas respectivas legislações nacionais aos agentes de fiscalização da Administração Pública.

Havia aqui outra interessante normatização de oposição escalar entre a supranacionalidade da Alta Autoridade e a estatalidade isolada, na qual se estabelece uma nova articulação entre direitos e deveres contrapostos, a qual mais uma vez reforçava e ao mesmo tempo limitava o Poder concedido à Alta Autoridade.

Em outras palavras, esse dispositivo reafirmara a tendência encontrada em todo o Tratado da CECA de conceder um Poder a uma medida de existência da vida em comum, sem descuidar de, imediatamente após tal previsão, esvaziá-lo. Permanece também neste dispositivo a preocupação em conservar a horizontalidade das relações entre as dimensões existenciais participantes da vida em comum, a fim de manter a imanência.

A chave de interpretação deste dispositivo reside na afirmação de que os agentes da Alta Autoridade deveriam dispor nos territórios dos Estados-Membros precisamente dos mesmos direitos e Poderes atribuídos pelas respectivas legislações nacionais aos agentes de fiscalização da Administração Pública. Quando a Alta Autoridade buscasse fiscalizar os Estados-Membros, seriam entreabertos feixes distintos de correlação entre direitos e deveres que reforçariam e limitariam a capacidade de ação desta.

De um lado, parece claro que a previsão estabelecia interessante garantia à atuação da Alta Autoridade.

Com efeito, ao determinar que os agentes deste deveriam "dispor nos territórios dos Estados-Membros precisamente dos mesmos direitos e Poderes atribuídos pelas respectivas legislações nacionais aos agentes de fiscalização da Administração Pública”, o Tratado da CECA assegurava a este órgão comunitário plenas condições para o desempenho de sua 
atividade de fiscalização em igualdade de condições com relação aos agentes de fiscalização dos Estados-Membros. Estes não poderiam opor aos agentes da Alta Autoridade requisitos, condições ou impedimentos que não estivessem previstos em sua própria legislação.

Por outro lado, também não se pode deixar de notar que o dispositivo ora em análise determinava uma limitação à atividade da Alta Autoridade.

Nesse sentido, o Tratado da CECA excluía qualquer possibilidade de a Alta Autoridade pretender privilegiar seus agentes com prerrogativas especiais com relação aos Estados-Membros. Estes estariam igualmente seguros de que a fiscalização a ser empreendida pela Alta Autoridade não iria produzir efeitos práticos que pudessem implicar uma sujeição dos Estados-Membros à outra entidade comunitária, pois esta não poderia impor a estes formas jurídicas novas de atuação.

A ideia era bastante simples.

Para que as atividades dos agentes da Alta Autoridade encontrassem amplas condições para se desenvolver, os Estados-Membros deveriam assegurar a estes de maneira irrestrita o gozo dos mesmos direitos e Poderes atribuídos por suas próprias legislações aos fiscais de sua própria Administração Pública. Os agentes da Alta Autoridade não encontrariam qualquer embaraço ao exercício de sua atividade de fiscalização diferente dos que usualmente os agentes de fiscalização de seu próprio Estado poderiam encontrar.

Ao mesmo tempo, a Alta Autoridade poderia apenas esperar e exigir que seus próprios agentes pudessem fruir dos mesmos direitos e Poderes usualmente atribuídos pelos Estados-Membros por meio de suas próprias legislações nacionais aos fiscais de sua Administração Pública. O Estado não seria assim surpreendido por ter de se submeter a exigências práticas de fiscalização que fossem diferentes das que ele estava normalmente habituado.

Em outras palavras, ao se comprometer poder ser fiscalizado pela Alta Autoridade em nome da vida comunitária, o Estado-Membro encontrou no Tratado da CECA a garantia de que não obedeceria a Direito estranho a suas próprias práticas jurídicas usuais de sua Administração Pública. À Alta Autoridade era facultado exigir e o Estado-Membro estava autorizado a esperar apenas a reprodução de condições de fiscalização iguais às normalmente estipuladas pelo Estado-Membro para si próprio. Do mesmo modo, respectivamente, o Estado deveria criar e a Alta Autoridade deveria esperar as mesmas condições de fiscalização. 
Assim, perceba-se que este dispositivo visava ao estabelecimento de uma nãodiscriminação entre os agentes da Alta Autoridade e os do Estado-Membro a ser fiscalizado. De acordo com esta previsão, os agentes das duas entidades estariam submetidos precisamente às mesmas regras jurídicas nacionais de Administração Pública do Estado-Membro fiscalizado, por força de expressa previsão constante do Tratado da CECA.

Deste modo, era previsto pelo Direito Comunitário Originário da CECA constante do Tratado de Paris de 1951 nada mais, nada menos, em favor ou em desfavor, seja da Alta Autoridade, seja dos Estados-Membros. A primeira detinha o Poder comunitário de fiscalizar o último (direito), mas apenas a partir e de acordo com as regras jurídicas nacionais de fiscalização (dever), ao passo que o último, ao dever aceitar ser fiscalizado por mandamento comunitário (dever), não se submeteria a ordem jurídica de fiscalização diversa daquela por ele já conhecida (direito).

Mais uma vez, o Poder de uma escala de existência era contrabalançado pelo Poder de outra, dinâmica segundo a qual, a uma possível imposição, seguia um possível impedimento. E, por isso, é importante notar a presença de cuidadosa rede normativa de oposições escalares engenhosamente desenhada para manter permanente o equilíbrio de posições detidas por uma e por outra escala de existência na vida em comum.

Perceba-se assim que o objetivo desta malha normativa era bastante simples: assegurar a preservação da igualdade de condições entre todos os implicados na vida comunitária, ou ainda, preservar a horizontalidade das relações entre todos os implicados na Comunidade. Esta previsão pretendia impedir simultaneamente que um deles pudesse pretender se alçar a posição superior sobre o outro e que um deles se inserisse em posição subalterna com relação ao outro.

Assim, ao procurar manter a condição de pares comunitários entre EstadosMembros e Alta Autoridade, a parcela final do dispositivo ora em análise operava como escudo protetor voltado a impedir o surgimento e a deflagração de imoderadas pretensões de mando e de obediência uniescalares na Europa Politicamente Unida pela CECA, seja por parte de um, seja por parte de outro. 
7.2.3.2. Inadimplemento Estatal e Possíveis Respostas da Alta Autoridade: Indícios de um Controle a serviço da Horizontalidade

\subsection{Apresentação Geral do Artigo 88 do Tratado da CECA}

O procedimento fiscalizatório iniciado pela Alta Autoridade - descrito no item anterior $^{870}$ - poderia concluir pelo descumprimento por parte de um Estado-Membro do dever de cumprir ou de fazer cumprir um ato normativo comunitário derivado.

Nesse sentido, o artigo 88 do Tratado da CECA foi especificamente pensado para as situações em que um Estado-Membro poderia ter sido reputado como fugindo ao cumprimento de uma obrigação derivada de disposições do Tratado da CECA abrangendo, assim, as hipóteses de não cumprimento de decisões ou de regulamentos emitidos por órgãos comunitários.

É interessante notar desde já que o artigo em questão não previa uma eventual exclusão sumária do Estado-Membro faltoso da Comunidade, ou mesmo uma retirada da Soberania deste mediante intervenção direta da Comunidade sobre o Estado-Membro ${ }^{871}$. Há, pelo contrário, uma preocupação meticulosa em assegurar jurídico-normativamente condições de levar um eventual Estado-Membro inadimplente a realizar sua obrigação, sem que isso pudesse ser percebido como ofensa abrupta e irremediável à Soberania deste - e, portanto, a sua específica escala de existência, a qual poderia introduzir fissuras no edifício comunitário.

Os próximos itens procurarão descrever de maneira minuciosa como este dispositivo em especial se preocupou em lidar com essa delicada situação de inadimplemento estatal de um ato normativo comunitário derivado, sem que isso pudesse estimular posteriores desconsiderações das normas jurídicas comunitárias (originárias ou

\footnotetext{
${ }^{870}$ Item 7.2.3.1., supra.

${ }^{871}$ Precisamente por não se tratar de uma Federação Europeia; nesse sentido, remetemos o leitor ao item 5.2.2.2.2.3., supra, onde se comentou o Anteprojeto do Federalismo Europeu para uma Constituição da Europa.

Lembre-se de que naquele item se pôde perceber a presença de dispositivo que eliminaria o último resquício da Soberania estatal perdida em favor da Federação: o descumprimento das normas daquela Constituição poderia ensejar a retirada do reconhecimento da autonomia política do Estado-membro da Federação. Não segue esta linha de raciocínio a previsão ora em comento, como se poderá v. neste item 7.2.3.2.

Compare-se assim mais uma vez o quão longe estava o desenho institucional pensado jurídiconormativamente pelo Tratado para a construção da vida comum da CECA das pretensões unidimensionalizantes do Federalismo Europeu. O objetivo da CECA não era configurar um Estado Federal Europeu, da mesma maneira que não almejava nem mesmo se organizar jurídico-politicamente sob a forma de um Estado Europeu (o que restará mais claro no item 7.2.4., infra).
} 
derivadas) por parte dos Estados-Membros por meio de recurso a vias outras (não institucionais) de afirmação de sua escala de existência. Ou ainda, simplesmente, será possível compreender como o Tratado da CECA desenhou interessante arcabouço institucional voltado a levar o cumprimento de ato normativo comunitário derivado, sem que isso pudesse prejudicar a permanência da vida em comum da CECA.

7.2.3.2.2. Controle Contido I: Necessidade de Confirmação do Resultado da Fiscalização

O parágrafo primeiro do artigo 88 estabelecera que a Alta Autoridade deveria entrar em contato com o Estado-Membro suspeito para que este apresentasse à Alta Autoridade suas considerações em torno da alegação. Após a oitiva das observações do EstadoMembro, a Alta Autoridade poderia ainda decidir pela constatação de que o referido Estado-Membro havia realmente faltado ao cumprimento de suas obrigações, abrindo um prazo para que o Estado-Membro pudesse adimplir sua obrigação. A decisão da Alta Autoridade deveria ser motivada.

É importante ressaltar que, mesmo com todas as contenções previstas e analisadas minuciosamente no interior ${ }^{872}$, a Alta Autoridade teria recebido um significativo Poder, a saber, o de fiscalizar se um Estado-Membro cumpriu ou fez cumprir os atos normativos comunitários e de poder, a final afirmar eventualmente que este Estado-Membro descumprira tal obrigação.

Lembre-se ainda de que, como visto acima, o exercício do Poder de físcalização previsto no artigo 86 do Tratado da CECA era pouco a pouco limitado por Poderes concedidos ao Estado-Membro pelo mesmo dispositivo jurídico-normativo - o que certamente não poderia impedir a possibilidade de a Alta Autoridade chegar à conclusão de que o Estado-Membro não cumprira com este dever. O artigo 88, parágrafo primeiro, surgira precisamente para inaugurar a imposição de sucessivas outras limitações a momento posterior de atuação da Alta Autoridade em relação com Estados-Membros faltosos: a tomada de medidas para levar o Estado-Membro a cumprir seu dever não poderia ser, ela própria, descontrolada e imoderada.

Nesse sentido, perceba-se que, se por um lado, a Alta Autoridade poderia constatar eventual descumprimento do dever de cumprir ou de fazer cumprir um ato normativo

${ }^{872}$ Item 7.2.3.1., supra, para o qual remetemos o leitor. 
comunitário mediante o referido procedimento fiscalizatório, por outro lado, estava ela impedida de iniciar qualquer medida mais drástica para levar o Estado-Membro a adimplir sua obrigação.

Deste modo, apesar do detalhado procedimento fiscalizatório, a Alta Autoridade não poderia reputar ter certeza absoluta de que o Estado-Membro faltara ao cumprimento daquele seu dever. Por essa razão, a Alta Autoridade deveria, antes de qualquer ação concreta, entrar em contato com o mesmo Estado-Membro para que este pudesse apresentar à Alta Autoridade suas considerações acerca da alegação formulada a partir da fiscalização. Apenas após esse procedimento inicial, é que a Alta Autoridade poderia se considerar como detendo certeza plena de que teria ocorrido eventual inadimplemento por parte do Estado-Membros.

Aqui se percebem progressivas limitações internas ao Poder concedido à Alta Autoridade, as quais foram previstas pelo próprio texto do Tratado da CECA. Se a portadora de uma das facetas da supranacionalidade poderia suspeitar e afirmar que uma das estatalidades isoladas havia descumprido uma norma comunitária, ela não poderia de forma alguma iniciar medida concreta que incidisse diretamente sobre o Estado-Membro em questão e o obrigasse de algum modo a adimplir sua obrigação.

A primeira limitação surgia precisamente da presunção absoluta posta pelo Tratado de que, mesmo com a fiscalização, a Alta Autoridade não poderia considerar ser certo que o Estado-Membro não havia cumprido com seu dever - ou seja, tratava-se de um mecanismo de autocontenção previsto internamente pelo próprio Poder concedido à Alta Autoridade.

A segunda limitação derivava da previsão de que o Estado-Membro deveria ser ouvido diretamente pela Alta Autoridade, antes de qualquer decisão sobre a certeza de descumprimento, vale dizer, uma tal decisão apenas poderia ser proferida se, e somente se, o Estado-Membro tivesse detido plenas condições para se apresentar perante a Alta Autoridade e vocalizar diante deste suas mais diferentes considerações.

A necessidade de que a decisão fosse, ainda por cima, motivada, reduzia ainda mais a liberdade de exercício do Poder pela Alta Autoridade, condicionando-o: a consideração dos comentários dos Estados-Membros deveria ser efetiva e sincera, isto é, não poderia a Alta Autoridade descuidar em suas decisões da inserção de elementos que, mesmo diante das explicações, pudessem justificar a certeza de que o Estado-Membro descumprira o ato normativo comunitário. 
Em outras palavras, a fiscalização apenas originaria a sinalização de um possível descumprimento, e não uma certeza. Esta somente poderia ser considerada como tendo sido formada se o Estado-Membro tivesse sido ouvido e se, ainda assim, ela pudesse ser considerada como plenamente fundada - a despeito dos comentários do Estado-Membro na fundamentação constante da motivação da decisão da Alta Autoridade. Apenas desta maneira poderia a Alta Autoridade cogitar sobre qualquer medida com relação ao EstadoMembro.

Neste ponto, é importante observar que este primeiro parágrafo do artigo 88 do Tratado da CECA era também bastante claro: o documento jurídico-normativo afirmava que, caso fosse constatada a certeza de que o Estado-Membro não havia cumprido seu dever, a Alta Autoridade poderia tomar uma medida que convidasse o Estado-Membro a cumpri-lo. Há aqui uma previsão interessante, a qual acentua a profundidade de uma significação bastante precisa em torno do dispositivo de impedir a ascensão imoderada da Alta Autoridade sobre os Estados-Membros.

A expressão acima utilizada - "convidasse" - é bastante adequada para compreender essa previsão. Perceba-se que a Alta Autoridade não poderia recorrer a um procedimento de execução que forçasse o Estado-Membro a cumprir seu dever, nem mesmo usar qualquer medida que, em nome do Estado-Membro, e se substituindo a ele, fizesse com que a obrigação deste fosse adimplida. Dito de outro modo, uma vez que a Alta Autoridade detivesse certeza de que o Estado-Membro não havia cumprido seu dever comunitário, não poderia ela tomar o lugar dele e agir por ele: antes, ela deveria abrir um prazo para que o Estado-Membro pudesse por si só adimplir sua obrigação.

Perceba-se assim que a previsão normativa acima descrita construía série de condicionamentos ao exercício do Poder detido pela Alta Autoridade em relação a um Estado-Membro que teria faltado ao cumprimento de um ato normativo comunitário. $\mathrm{O}$ Tratado da CECA eliminava de antemão uma possível pretensão de certeza, impunha a necessidade de oitiva, e exigia ainda que a decisão da Alta Autoridade se reduzisse a (i) declarar - de maneira suficientemente motivada, isto é, que considerasse os comentários do Estado-Membro e, ainda assim, se sustentasse em suas fundações - que o Estado-Membro não cumprira com seu dever; e (ii) determinar a abertura de prazo para que o EstadoMembro faltoso pudesse adimplir sua obrigação ${ }^{873}$.

\footnotetext{
${ }^{873}$ Sobre as consequências ao não-cumprimento do prazo estipulado pela Alta Autoridade, v. comentários constantes do item 7.2.3.2.4., infra.
} 
Deste modo, o Tratado da CECA plasmara nesse dispositivo normativo mais uma vez sua preocupação em tecer cuidadosamente um complexo de oposições escalares, a fim de preservar uma relação horizontal entre os dois participantes da vida comunitária da CECA. Se a Alta Autoridade poderia afirmar que um Estado-Membro não havia cumprido seu dever comunitário, em um primeiro momento, a estatalidade isolada estava preservada de se ver substituída pela supranacionalidade da Alta Autoridade.

Com efeito, por se tratar da concessão à Alta Autoridade de um Poder de produzir uma alegação simbolicamente forte para participantes de uma vida em comum, o Tratado da CECA refreou possíveis intentos repreensivos mais drásticos ou mais diretos que pudessem comprometer o delicado equilíbrio entre escalares de existência. O Poder da Alta Autoridade é limitado pelo Tratado, o qual atribuíra aos Estados-Membros um contraPoder: o de estar presente perante a Alta Autoridade e apresentar a esta suas específicas formas de habitar o mundo, e exigir que que a Alta Autoridade ouvisse de modo sincero suas alegações.

Deste modo, pode-se compreender a razão pela qual a Alta Autoridade recebera série de limitações no exercício dos Poderes facultados pelo parágrafo primeiro do artigo 88: mesmo quando certa de que o Estado-Membro descumprira seu dever, a Alta Autoridade jamais poderia inserir sua supranacionalidade no lugar da estatalidade isolada do Estado-Membro e, com isso, adimplir a obrigação em substituição a este. Apenas abrir o prazo para que o Estado-Membro cumpra espontaneamente seu dever - e nada mais do que isso - era o resultado do "grande" Poder da Alta Autoridade - "grande", porque mais uma vez, esvaziado. Nada além dessa conduta era facultada à Alta Autoridade e dela esperada, podendo o Estado-Membro estar seguro e certo de que não seria afetado internamente por medida de existência a ele estranha.

Assim, o dispositivo reiterava a lógica do Tratado de sempre recorrer a oposições escalares para preservar a condição de pares comunitários entre Alta Autoridade e EstadosMembros, ou ainda, para conservar a condição de que nenhum deles poderia pretender se inserir em posição superior ou inferior com relação ao outro.

\subsection{Controle Contido II: Possibilidade de Questionamento Judicial A}

O parágrafo segundo do mesmo artigo 88 previra ao Estado-Membro sobre o qual recaíra da decisão da Alta Autoridade a possibilidade de recorrer deste ato normativo 
perante a Corte. Este recurso deveria ser interposto dentro do prazo de 2 (dois) meses contados a partir da notificação da decisão.

O presente dispositivo pode ser compreendido como explicitando mais uma vez a preocupação do Tratado em preservar a horizontalidade de relações entre os participantes da vida em comum. Deixando de lado aqui os comentários sobre a preocupação dos autores do Tratado da CECA de conservar a igualdade de condições entre escalas de existência durante o procedimento judicial ${ }^{874}$, a análise enfatiza a permanência da contraposição entre Alta Autoridade e Estado-Membro.

Lembre-se de que, uma vez certa de que o Estado-Membro havia faltado ao cumprimento de seu dever, a Alta Autoridade poderia apenas e tão-somente abrir um prazo para convidar o Estado-Membro a realizar sua tarefa. Note-se que esta incidência da supranacionalidade da Alta Autoridade sobre a estatalidade isolada era bastante leve - pois não ocorria, nem de fato, nem de direito, a imposição de uma nova obrigação comunitária, de origem unilateral da Alta Autoridade sobre ele.

Ainda assim, o Estado-Membro poderia sentir ter havido uma excessiva intromissão da Alta Autoridade sobre ele, seja porque não houvesse a Alta Autoridade observado a série de condicionamentos prevista no artigo 86 do Tratado da CECA, ou mesmo os requisitos previstos no primeiro parágrafo do artigo 88 do mesmo Tratado ${ }^{875}$. Deste modo, o parágrafo segundo do mesmo artigo 88 facultava ao Estado-Membro a possibilidade de recorrer perante a Corte de Justiça da CECA da decisão a ele dirigida pela Alta Autoridade.

Dessa maneira, perceba-se aqui a presença de mais um mecanismo normativo de oposições escalares: ele reforça a posição dos Estados-Membros no interior da Comunidade, quando este visualizava a possibilidade de estar ocorrendo, ainda que subrepticiamente, a plenificação do lugar do Direito e Poder por parte da escala de existência da Alta Autoridade. Se a Alta Autoridade não tivesse satisfeito os requisitos formais outrora previstos, ou mesmo se o Estado-Membro percebesse que a fundamentação da decisão não fora suficiente, poderia ele recorrer à tutela da Corte de Justiça ${ }^{876} 877$.

\footnotetext{
${ }^{874}$ Examinadas ao longo de todo o item 7.2.2., supra.

${ }^{875}$ Remetemos o leitor aos itens 7.2.3.1. (integralmente) e 7.2.3.2.2., ambos supra.

${ }^{876} \mathrm{O}$ procedimento de solução judicial de conflitos oriundos de oposições escalares no interior da CECA era pautado, como visto na integralidade do item 7.2.2., supra, por uma perspectiva igualmente multiescalar, isto é, voltada à preservação da horizontalidade - precisamente por recorrer também a normas de oposições escalares. Nesse sentido, o recurso à Corte pelo Estado-Membro consistia em uma mera reabertura do embate entre diferentes medidas de existência no interior do ambiente institucional da Corte, a fim de que estatalidades e supranacionalidades pudessem se contrapor e formar um sentido comum sobre o conflito dimensional de outrora. Remetemos o leitor mais uma vez ao item 7.2.2., supra.
} 
Nesse sentido, o Poder concedido à Alta Autoridade encontrava mais uma vez uma forte resistência por parte do Estado-Membro, na medida em que o dispositivo ora em análise assegurava a este outro contra-Poder. Este visava a conter uma possível imoderada ascensão da supranacionalidade da Alta Autoridade sobre as estatalidades isoladas ${ }^{878}$, podendo-se perceber a permanência neste dispositivo da preocupação normativa em seguir no curso de esvaziamento do Poder atribuído à Alta Autoridade. Instrumento de contenção de pretensiosas usurpações sorrateiras do lugar do Direito e do Poder, esta previsão buscava também preservar a horizontalidade nas relações e a condição de pares comunitários entre estes partícipes da vida em comum.

Por outro lado, há que se perceber que, neste momento, se poderia cogitar que o contra-Poder atribuído ao Estado-Membro teria se tornado muito mais forte e vigoroso do que o próprio Poder atribuído à Alta Autoridade. Em outras palavras, tamanhos condicionamentos e garantias em favor do Estado-Membro teriam sido previstas, que se poderia até mesmo entender que o Tratado da CECA teria concedido neste dispositivo uma privilegiada posição aos Estados-Membros: ainda que faltosos, os Estados estariam cercados de proteções perante a Alta Autoridade e, por isso, poder-se-ia pensar que estes ocupariam o lugar do Direito e do Poder na Comunidade.

A análise não é assim tão simples.

O final da previsão deste parágrafo segundo deste artigo 88 apontava já uma primeira limitação ao exercício deste segundo contra-Poder por parte dos EstadosMembros. Estes certamente poderiam se socorrer de um questionamento judicial diante de decisão da Alta Autoridade perante a Corte, mas não poderiam utilizar tal instrumento de maneira indefinida: o recurso deveria ser interposto no prazo de até 2 (dois) meses contados a partir da notificação da decisão da Alta Autoridade. O Tratado da CECA começa a redesenhar aqui a distribuição dos Poderes e a fazer voltar o equilíbrio entre as escalas de existência.

Com efeito, se até o presente momento, os Estados-Membros encontravam série de mecanismos de contenção de eventual imposição desmedida por parte da Alta Autoridade,

\footnotetext{
${ }^{877}$ Cabe notar que a Corte não se tornava, assim, o centro do Direito e do Poder na Comunidade. Apesar de esta formalizar o sentido normativo comum formado a partir de novas oposições escalares (v. nota de rodapé imediatamente anterior, e mesmo o item 7.2.2., supra), a Corte mesmo não detinha iniciativa de conter a supranacionalidade da Alta Autoridade e de proteger a estatalidade isolada em questão. Apesar de a Corte dever atuar para assegurar a interpretação e a aplicação do Tratado da CECA, esta apenas atuaria mediante provocação do interessado, estando vedada uma ação de ofício por parte da Corte. Esta não estaria presente para prejudicar a outra supranacionalidade ou para privilegiar a estatalidade isolada.

${ }^{878} \mathrm{Na}$ medida em todas poderiam ser fiscalizadas pela Alta Autoridade e reputadas por ela como não cumprindo com seus deveres comunitários, sempre de acordo com os artigo 86 e 88 do Tratado da CECA.
} 
estes mesmos instrumentos de impedimento deveriam ser controlados, para que se pudesse refrear eventual pretensão de elevação da escala das estatalidades isoladas sobre as demais. Em outras palavras, perceba-se que se os Estados-Membros recebessem tanto Poderes a ponto de anular a própria capacidade de influência da Alta Autoridade e de sua medida de existência sobre a vida em comum, estes ocupariam o lugar do Direito e do Poder na CECA e romperiam com a horizontalidade originariamente estabelecida pelo Tratado.

Por esse motivo, neste momento, os autores do Tratado de Paris de 1951 entenderam por bem inserir uma previsão normativa que estabelecesse uma autocontenção interna ao contra-Poder atribuído aos Estados-Membros: recurso passível de interposição em até 2 (dois) meses contados a partir da notificação da decisão da Alta Autoridade. Mais do que esse prazo, não poderia a dinâmica Política da vida em comum restar na dependência do bel-prazer do Estado-Membro faltoso.

Inicia-se aqui uma série de dispositivos que se voltam a conter o próprio Poder de contenção dos Estados-Membros, a qual continua no seguimento do dispositivo ora em análise, no item a seguir.

7.2.3.2.4. Controle Contido III: Limitação das Principais Consequências ao Inadimplemento Estatal

O parágrafo terceiro do ainda artigo 88 do Tratado da CECA determinava que, caso o Estado-Membro não tivesse cumprido sua obrigação no prazo estipulado pela Alta Autoridade, ou ainda, caso o recurso interposto tivesse sido rejeitado pela Corte, a Alta Autoridade poderia, desde que admitido por parecer do Conselho de Ministros aprovado por dois terços de seus membros: (i) suspender a transferência ao Estado-Membro das somas que lhe fossem devidas em virtude das disposições do Tratado; ou (ii) tomar - ou autorizar os outros Estados-Membros a tomar - medidas derrogatórias às referentes à manutenção do mercado comum $^{879}$, a fim de corrigir os efeitos derivados do inadimplemento constatado.

Observe-se que neste dispositivo, o Tratado da CECA seguira seu percurso anunciado ao final do item anterior ${ }^{880}$ de afirmar progressivas contenções do próprio Poder

\footnotetext{
879 Tais como restrições à entrada ou saída de produtos, discriminação entre produtores, compradores ou utilizadores, exigência de tributos aduaneiros ou cobranças pecuniárias equivalentes, entre outros. Essas medidas eram incompatíveis com estabelecimento de um mercado comum, segundo as previsões do artigo 4 do próprio Tratado da CECA, ao qual o artigo 88 fizera expressa referência.

${ }^{880}$ Item 7.2.3.2.3., supra.
} 
de contenção atribuído aos Estados-Membros. Assim, nas hipóteses de o Estado-Membro não ter cumprido a obrigação no prazo estipulado pela Alta Autoridade, ou ainda, se o recurso interposto tivesse sido rejeitado pela Corte, a Alta Autoridade poderia decidir por determinadas imposições de caráter econômico em detrimento do Estado-Membro inadimplente.

Nesse sentido, é importante reconhecer a preocupação do Tratado de não criar condições que permitissem a intangibilidade e a impunidade de um Estado-Membro que, ou descumprira de maneira renitente e consciente seu dever comunitário, ou tivera reconhecido perante procedimento de solução de conflitos realizado na Corte que deveria realizar sua tarefa outrora não adimplida. Se fossem estes os casos, a Alta Autoridade poderia recorrer a medidas interventivas com relação ao Estado-Membro.

Note-se que tais medidas não eram tomadas em "desfavor" da estatalidade isolada daquele específico Estado-Membro e em "favor" da supranacionalidade da Alta Autoridade. Não se tratava de uma imposição unilateral e unidimensional da Alta Autoridade em detrimento do Estado-Membro, mas de uma atuação em nome da preservação do comum.

Com efeito, como sinalizava o final do dispositivo mencionado, tratava-se de buscar "corrigir os efeitos derivados do inadimplemento constatado", isto é, de recompor com os demais partícipes da vida comunitária condições que tornassem viável a permanência das estruturas que compunham a Comunidade Política da Europa Unida pela CECA. Não se tratava de unidimensionalização da supranacionalidade da Alta Autoridade, mas de encontrar mecanismos que pudessem assegurar a própria pluriescalaridade originária da CECA.

Assim, os instrumentos de contra-Poder previstos ao Estado-Membro perante a Alta Autoridade não poderiam operar como expedientes destinados a estruturar um escudo protetor de práticas perniciosas à preservação da vida em comum. Por esse motivo, se, de um lado, diante do Poder da Alta Autoridade, o Estado-Membro encontrava dispositivos que se contrapunham a potenciais unidimensionalizações desta supranacionalidade, por outro lado, o Estado-Membro detinha ele próprio um âmbito de proteção largo, porém limitado, limitação esta derivada da necessidade de se preservar a vida em comum.

Deste modo, mostra-se com clareza a permanência da preocupação dos autores do Tratado da CECA em contribuir para um funcionamento efetivo da vida em comum, sem que com isso houvesse qualquer precarização ou favorecimento de uma escala de existência com relação às demais implicadas na Comunidade. O Poder de imposição de 
uma era limitado por um Poder de contraposição de outra, este último igualmente limitado por Poderes de outras escalas ou por autocontenções internas. A paridade comunitária se preservava assim por vias institucionais efetivas, em que um e outro participariam efetivamente da vida em comum, sem que nem um, nem outro, pudesse se arrogar do lugar do Direito e do Poder.

Mas a análise deste artigo não pode terminar por aqui. É importante ainda perceber que o presente dispositivo continha ainda em sua previsão normativa outras oposições escalares que permitiam tornar ainda mais evidente a contínua e cuidadosa preocupação institucional de refrear qualquer iniciativa atrevida de uma escala de existência imoderadamente querer se inserir no lugar do Direito e do Poder na CECA. Inicia-se neste dispositivo mais um complexo ciclo - sempre cioso de preservar a horizontalidade nas relações comunitárias - de atribuição de Poderes e de contra-Poderes mediante normas jurídico-institucionais a diferentes escalas de existência, o qual se estende até o próximo item $^{881}$.

Lembre-se de que, caso o Estado-Membro não tivesse cumprido sua obrigação no prazo estipulado pela Alta Autoridade, ou caso o recurso por ele interposto tivesse sido rejeitado pela Corte, a Alta Autoridade poderia, desde que admitido por parecer positivo do Conselho de Ministros aprovado por dois terços de seus membros, tomar algumas medidas de caráter econômico em relação ao Estado inadimplente.

Evidencia-se neste primeiro trecho destacado da previsão que a possibilidade de a Alta Autoridade atuar no sentido de impor medidas de caráter econômico com relação ao Estado-Membro faltoso não era ilimitada ou livre.

Muito pelo contrário, a adoção de tais medidas estava condicionada à satisfação concomitante de dois requisitos, de um total de três previstos: (i) não interposição de recurso pelo Estado-Membro e, ainda assim, o não cumprimento de sua própria obrigação comunitária originária; ou (ii) interposição de recurso pelo Estado-Membro perante a Corte e rejeição do recurso pela Corte; e (iii) aprovação das medidas pelo Conselho de Ministros da Comunidade. Se (i) e (ii) eram condições alternativas, isto é, ou deveria ocorrer uma, ou deveria ocorrer outra, a condição (iii) deveria ser necessariamente satisfeita em qualquer dos dois casos.

Ao mesmo tempo em que atribuía à Alta Autoridade Poder de tomar medidas concretas em relação a um Estado-Membro que descumprira o dever comunitário, é 
importante notar que o Tratado da CECA negava à Alta Autoridade uma liberdade de apreciação e de tomada de decisão. No mesmo instante que o Tratado da CECA concedia um impactante Poder à Alta Autoridade, este era imediata e simultaneamente esvaziado pela própria previsão do Tratado, seja mediante a aposição de um elemento de autocontenção interno, seja por meio da previsão da necessidade do concurso de Poder por parte de outra escala de existência.

Dessa forma, perceba-se que o texto do Tratado de Paris de 1951 se preocupou de maneira cuidadosa com a efetividade do cumprimento das normas comunitárias sem pretender romper com a horizontalidade das relações entre as dimensões existenciais participantes da vida em comum - isto é, estabelecer um desenho institucional que preservasse a CECA, o qual não pudesse contribuir progressivamente à desconstrução da vida comunitária, pautada geneticamente pela marca da horizontalidade nas relações.

Por esse motivo, perceba-se que a Alta Autoridade poderia tomar, sem sombra de dúvida, medidas concretas que poderiam prejudicar economicamente o Estado-Membro, em nome da preservação da vida em comum. Todavia, a atuação desta não poderia implicar o rompimento da condição de pares comunitários que vigia entre todos.

Por isso, a Alta Autoridade deveria não apenas encontrar motivos suficientes que a autorizassem a tomar as medidas - isto é, (i) ou (ii) acima descritos. Diante da gravidade da situação ${ }^{882}$, ela também não poderia deixar de ter sua proposta apreciada e aprovada por outra escala de existência que, até o presente momento, não havia se manifestado no jogo de Poder: a estatalidade intergovernamental do Conselho de Ministros. Neste momento, a complexidade institucional do dispositivo jurídico-normativo de oposição escalar começa a se revelar de maneira ainda mais evidente.

Nesse sentido, caso a Alta Autoridade entendesse ser adequada a aplicação das medidas em relação ao Estado-Membro, essa decisão apenas poderia ser aplicada se, e somente se, (i) o Estado-Membro não houvesse cumprido sua própria obrigação comunitária originária no prazo determinado pela Alta Autoridade; ou (ii) o recurso interposto pelo Estado-Membro perante a Corte houvesse sido rejeitado. Não satisfeitos

\footnotetext{
${ }^{882} \mathrm{O}$ embate escalar fundamental e crítico instaurado se manifesta pelo seguinte cenário: um Estado-Membro se considera como superior às demais escalas de existência e pretende de maneira obstinada não cumprir seu dever comunitário - isto é, crê ser ele próprio um Um que pode simplesmente se abster de viver no interior da Comunidade Política da CECA, sendo superior mesmo às Leis Políticas da vida em comum. Ao mesmo tempo, a possibilidade de a Alta Autoridade poder tomar medidas concretas que prejudicariam economicamente o Estado-Membro em particular poderia engendrar uma autocompreensão jurídico-política de que ela poderia se alçar sobre os demais e, a partir de então, pensar em progressivamente impor sua escala de existência. Neste momento bastante delicado, o Conselho de Ministros surgia para antepor - não impor sua própria dimensão existencial para preservar a multiescalaridade horizontal da vida Comunitária.
} 
esses requisitos, jamais poderia a Alta Autoridade pretender produzir algum prejuízo econômico em relação ao Estado-Membro.

Ao mesmo tempo, se a satisfação destas duas condições de autocontenção do Poder da Alta Autoridade era necessária para a aplicação da medida, elas não eram suficientes: era fundamental haver a presença da escala de existência típica da atuação conjunta dos Estados-Membros: a estatalidade intergovernamental. A exigência da aprovação por parte do Conselho de Ministros da medida a ser tomada pela Alta Autoridade era previsão de vigoroso impedimento a qualquer tentativa por parte desta de se introduzir sorrateiramente no lugar do Direito e do Poder. Mas não era instrumento dirigido apenas contra ela.

Enquanto entidade composta diretamente por representantes dos Estados-Membros, a escala de existência (estatalidade intergovernamental) portada pelo Conselho de Ministros nada mais era do que o fruto da concertação entre cada uma das estatalidades isoladas. Em outras palavras, tendo a vida comum na CECA se inserido em situação de gravidade (descumprimento do dever comunitário por um Estado-Membro e a correlata ameaça de intervenção da Alta Autoridade sobre este), o problema deveria ser trazido também diante da concertação de todos os Estados envolvidos na vida comunitária. Por meio deste procedimento, o problema seria trazido definitivamente perante todas as medidas para deliberarem em conjunto, de modo a que todos estivessem abertamente cientes acerca da gravidade da situação e da necessidade de pensar em conjunto sobre os destinos da Comunidade.

Certamente, em um primeiro momento, o foco da atuação do Conselho de Ministros era constituir uma barreira a eventuais intromissões imoderadas da Alta Autoridade no interior dos Estados-Membros. A intervenção da supranacionalidade deveria se limitar às condições e às medidas previstas no Tratado, e não pretender significar a substituição da estatalidade isolada por ela própria.

Parece bastante claro que ao Conselho era atribuído um grande contra-Poder, no sentido de conter eventuais abusos por parte da Alta Autoridade. Havia aqui o desenho de um interessante arranjo institucional fundado em normas de oposições escalares, expondo mais uma vez a nervura do embate fundamental: supranacionalidade e estatalidade.

A não autorização por parte do Conselho seria uma maneira estatal intergovernamental de impedir a imposição eventual da escala de existência supranacional da Alta Autoridade sobre um Estado-Membro. Tratava-se uma maneira de alertar à Alta Autoridade de que ela não estava sozinha no centro do Direito e do Poder da Comunidade, pois suas decisões sofreriam o adequado contrapeso por parte de outras escalas de 
existência. Afinal, antevendo a potencial auto-sobrevalorização da Alta Autoridade com relação às demais dimensões existenciais implicadas na vida em comum, a estatalidade intergovernamental lembraria vigorosamente à Alta Autoridade que os Estados-Membro em conjunto poderiam se colocar contra esse possível e indesejado movimento de destacamento existencial e de verticalização das relações na vida em comum.

Ao mesmo tempo, não se pode ignorar que a autorização do Conselho - manifesta por dois terços de seus membros - seria a expressão da concordância de que teriam as demais estatalidades isoladas - intergovernamentalmente concertadas - decidido ser fundamental tomar uma posição forte perante o Estado-Membro faltoso, precisamente porque seria necessário assegurar a permanência da vida em comum. Dete modo, se tratava de lembrar os Estados-Membros isoladamente considerados de que estes não teriam suas escalas de existência automaticamente preservadas de uma interferência que partisse da Alta Autoridade quando tal interferência tivesse por base a preservação da vida comunitária.

A atuação do Conselho de Ministros também visava assim a refrear eventual tentativa de tomada do lugar do Direito e do Poder por um de seus Estados-Membros. Isso significa que o Poder de contenção da estatalidade intergovernamental se dirigia também contra a estatalidade isolada, visando a limitar a presença desta no centro de produção do sentido normativo último da Comunidade. Afinal, o Conselho de Ministros - enquanto local de encontro e de concertação de cada uma das estatalidades isoladas - deveria considerar também qual seria o significado para a perpetuação da vida em comum de uma eventual não autorização à realização da medida escolhida pela Alta Autoridade.

A princípio, todos os Estados-Membros reconheciam a importância de observar seus deveres comunitários - razão pela qual se comprometeram, no artigo 86, parágrafo primeiro, a cumprir e a fazer cumprir em seus territórios nacionais os atos comunitários derivados do entrechoque multiescalar ${ }^{883}$. Por outro lado, a submissão à aprovação pelo Conselho da decisão proferida pela Alta Autoridade era uma possibilidade institucionalmente constituída em virtude da vigência de situação peculiarmente grave: um Estado-Membro não teria adimplido sua obrigação comunitária originária mais fundamental.

Esta situação por si só sinalizava uma ameaça à conservação do equilíbrio escalar na vida em comum. A estatalidade isolada era uma escala de existência que parecia se

${ }^{883}$ Como visto nos itens 7.2.3.1.1. e 7.2.3.1.2., supra. 
autocompreender naquele momento como podendo desconsiderar a minuciosa organização jurídico-Política da Europa e, com isso, deixar, não apenas de cumprir ou de fazer cumprir o ato normativo comunitário derivado, mas também de honrar seu comprometimento jurídico-normativo comunitário originário.

Em outras palavras, dimensão da estatalidade isolada parecia se arrogar estar acima das Leis Políticas da Europa Unida da CECA e, caso o Conselho de Ministros não autorizasse a medida escolhida pela Alta Autoridade, isso significaria que ele estaria chancelando não apenas este, mas todo e qualquer movimento de usurpação do lugar do Direito e do Poder originado de pretensões unidimensionalizantes de um dos EstadosMembros.

Deste modo, tendo em mente a importância da conservação da Comunidade Política da Europa, o Tratado da CECA determinava por meio deste dispositivo que Conselho deveria também refletir cuidadosamente em seu parecer sobre as consequências possíveis de sua rejeição das medidas escolhidas pela Alta Autoridade: o prejuízo futuro da preservação da vida em comum.

É por essa razão, inclusive, que o parágrafo terceiro do artigo 88 do Tratado determinava que essa decisão poderia ser tomada por dois terços dos membros do Conselho: as demais estatalidades isoladas intergovernamentalmente concertadas poderiam superar eventual resistência renitente do Estado-Membro faltoso e autorizar que as medidas escolhidas pela Alta Autoridade fossem praticadas.

Deste modo, a disposição normativa ora em análise teve o cuidado em garantir que a eventual desconsideração das Leis por um Estado-Membro poderia ser igualmente desconsiderada pelas demais escalas de existência (supranacionalidade da Alta Autoridade, estatalidades isoladas e estatalidade intergovernamental), a fim de que fosse preservada a ordem jurídico-Política instaurada originariamente por meio das instituições do Tratado da CECA.

Todavia, é importante continuar a interpretação do mesmo parágrafo terceiro, do ainda artigo 88 do Tratado, a fim de compreender completamente o significado jurídicopolítico dessa complexa rede de relações entre escalas de existência. O aspecto sobre o qual se deve se centrar neste momento é o fim visado pelas medidas passíveis de serem tomadas pela Alta Autoridade, com a aprovação do Conselho. 
Lembre-se de que, como afirmado anteriormente ${ }^{884}$, a previsão do artigo 88 não estabelece medidas qualitativamente semelhantes ao do Projeto Federalista Europeu ${ }^{885}$, isto é, se também não trazia como hipótese uma eventual exclusão sumária do Estado-Membro faltoso da Comunidade, ao menos também não estabelecia a eventual retirada da Soberania deste mediante intervenção política direta da Comunidade sobre o Estado-Membro.

Isso significa que se deve reconhecer a existência de engenhosa construção jurídico-normativa que jamais pretendia anular qualquer das escalas de existência participantes da vida comum. Ou, o que é o mesmo, a arquitetura institucional do Tratado da CECA pretendia reafirmar - principalmente em momentos de tensão como este - a importância de se perseverar no interior do sistema de convivência direitificado, isto é, de se buscar no interior das próprias instituições instrumentos que solucionassem as oposições escalares de uma maneira que não fendesse o edifício comunitário Político.

Assim, se a conjunção da supranacionalidade da Alta Autoridade e da estatalidade intergovernamental poderia implicar uma atuação das demais escalas de existência sobre a do Estado-Membro faltoso, isso não deve ser percebido como a previsão normativa que autorizava uma possível intervenção da Comunidade que anularia politicamente a estatalidade isolada em questão - tal qual previa o Projeto Federalista Europeu.

Nesse sentido, basta examinar a específica qualidade das medidas disponibilizadas pelo Tratado à Alta Autoridade para se perceber que o documento jurídico-normativo internacional não previu forma alguma de substituição da medida de existência da estatalidade isolada pela dimensão existencial da supranacionalidade da Alta Autoridade ou pela estatalidade intergovernamental. Não se exclui o Estado-Membro da Comunidade, como também este não tem negada sua condição jurídico-política fundamental da Soberania.

Ressalte-se que o Tratado da CECA não deixa à livre escolha pela Alta Autoridade do tipo de medida que ela poderia tomar com relação ao Estado-Membro que não cumprisse com seu dever comunitário originário.

Muito pelo contrário, o Tratado estabelecia de maneira expressa e bastante precisa dois tipos de ação, dentre os quais deveria a Alta Autoridade escolher, a saber, ou (i) suspender a transferência das somas devidas ao Estado-Membro em questão em virtude das

\footnotetext{
${ }^{884}$ Item 7.2.3.2.1., supra.

${ }^{885}$ Precisamente por não se tratar de uma Federação Europeia, como visto no item 5.2.2.2.2., supra.
} 
disposições do Tratado; ou (ii) tomar, ou autorizar os outros Estados-Membros a tomar, medidas derrogatórias às referentes à manutenção do mercado comum.

Em outras palavras, a Alta Autoridade não estava livre para pensar os tipos de consequências que ela poderia aplicar em relação ao Estado-Membro inadimplente: ela deveria escolher apenas uma opção dentre este rol bastante diminuto. Deste modo, perceba-se que o Tratado da CECA procurou evitar dar à Alta Autoridade condições para que se autocompreendesse como em posição privilegiada com relação aos demais participantes da vida em comum: imediatamente após conceder um Poder de atuação em detrimento de um Estado-Membro, negou à Alta Autoridade a possibilidade de esta decidir arbitrariamente as consequências.

Revela-se aqui mais uma vez o esvaziamento do Poder atribuído a uma entidade da vida em comum por meio de previsão de mecanismo de autocontenção, isto é, surge aqui o problema de um vigoroso Poder que, por outro lado, é "sem Poder" - na medida em que ele era inteiramente previsto como composto por série de limitações desde suas fundações mais primárias.

Ao mesmo tempo, por meio do estabelecimento conscientemente limitado de consequências institucionais previstas, os autores do Tratado conseguiriam estimular a adesão do Estado-Membro à Comunidade Política da CECA. Eles garantiram a cada uma das estatalidades isoladas a segurança de que, caso não cumprissem seu dever originário, estas não seriam ameaçadas por tentativas de desconsideração jurídico-política de sua escala de existência como par comunitário em igualdade de condições plenas com relação às demais ${ }^{886}$.

Em outras palavras, o Estado-Membro se sentia efetivamente seguro em aderir à Europa Politicamente Unida pela CECA porque sabia que, no máximo, ele não seria excluído da convivência, nem teria sua Soberania ameaçada pelo potencial recurso organizado e centralizado da força pela Comunidade - pois esta não dispunha desses $\operatorname{meios}^{887}$. Pelo contrário, a previsão normativa deste dispositivo sinalizava que, mesmo nestes casos de obstinado descumprimento, ao Estado-Membro seria garantida a contínua e ampla oportunidade de se apresentar perante as demais escalas de existência ${ }^{888}$ para opor

\footnotetext{
${ }^{886}$ Como constava do Projeto de um Estado Federal Europeu, como visto anteriormente, no item 5.2.2.2.2., supra.

${ }^{887}$ V. comentários a seguir, neste mesmo subitem 7.2.3.2.4., e principalmente os constantes do item 7.2.3.2.6., infra.

888 Como visto até aqui, desde o início, perante a supranacionalidade da Alta Autoridade, a supranacionalidade da Corte, a estatalidade intergovernamental e as demais estatalidades isoladas.
} 
contra elas seu modo de habitar o mundo e, com isso, participar efetivamente da formação do sentido jurídico-normativo comum.

Assim, perceba-se que se reforça a percepção de que a nenhuma das escalas de existência da vida comunitária - nem mesmo à do Estado-Membro faltoso - era assegurada a suposição prévia de poder ocupar posição superior ou inferior com relação às demais. Todas seriam iguais entre si: nem mais, nem menos do que as outras, de tal modo que, mesmo se descumprissem os deveres comunitários mais fundamentais, o Estado-Membro não teria sua escala de existência eliminada do sistema de convivência. A substituição de uma delas por qualquer Uma das demais, isto é, o destacamento de qualquer Um em detrimento dos outras era institucionalmente interditado pelo Tratado em nome da preservação da mais plena horizontalidade relacional - e, portanto, da imanência - na vida comum da CECA.

Há que se notar, ainda, que a atuação da Alta Autoridade não era apenas limitada no número de hipóteses de consequências previstas como passíveis de serem aplicadas em relação ao Estado-Membro faltoso. Também não se pode deixar de observar que estas detinham um profundo caráter econômico: ou (i) suspender a transferência das somas devidas ao Estado-Membro em questão em virtude das disposições do Tratado; ou (ii) tomar, ou autorizar os outros Estados-Membros a tomar, medidas derrogatórias às referentes à manutenção do mercado comum.

Nesse sentido, o Tratado da CECA tinha ainda um último cuidado na construção de um significado jurídico-político de um dispositivo voltado a prejudicar um Estado-Membro em razão de seu descumprimento de dever comunitário originário: o Estado-Membro faltoso apenas sofreria uma repreensão de caráter econômico.

Isso implica reconhecer que retaliação comunitária jamais ultrapassaria a esfera econômica, isto é, ela não buscaria outros meios para resolver o impasse. Restringindo ao campo da Economia as consequências passíveis de aplicação pela Alta Autoridade em nome da vida comum, o Tratado da CECA retirou de forma declarada de seu próprio interior a possibilidade de a CECA ser compreendida como planejada para constituir um Estado Europeu ${ }^{889}$, ou um Estado Federal Europeu. Afinal, nenhum de seus órgãos comunitários deteria meios para exercer de maneira centralizada o uso da força ou mesmo para praticar qualquer forma de diminuição jurídico-politica de uma escala de existência na

\footnotetext{
${ }^{889}$ Essa constatação em torno da orientação não-estatal das instituições do Tratado da CECA restará ainda mais clara a partir da leitura do item 7.2.4., infra. Aqui apenas se enuncia essa preocupação para preparar o terreno intelectual para leitura daquele item, infra.
} 
dinâmica relacional comum - mesmo se uma delas descumprisse deveres comunitários originários.

Havia assim uma simultânea recusa à possibilidade de um uso da força contra uma escala de exitência participante da vida comum e à possibilidade de se negar a condição de par comunitário a tal dimensão existencial. A repreensão apenas poderia se cingir aos aspectos econômicos - e nada mais além disso.

Dessa forma, o "grande e vigoroso Poder" concedido à Alta Autoridade pelo dispositivo ora em análise se revelava jurídico-politicamente como "desprovido de Poder": intensamente condicionado em seu aspecto interno e limitado por contra-Poderes atribuídos a outras escalas de existência, ele também não poderia se traduzir em uma ação concreta que pudesse significar uma intervenção sobre os Estados-Membros que desconsiderasse suas Soberanias - ou seja, não poderia significar a eliminação da estatalidade da vida em comum.

\subsection{Controle Contido IV: Possibilidade de Questionamento Judicial B}

O parágrafo quarto do artigo 88 previra que era facultada ao Estado-Membro a apresentação de um recurso perante a Corte para questionar as duas possíveis decisões que poderiam ser tomadas pela Alta Autoridade. Este recurso deveria ser interposto dentro do prazo de 2 (dois) meses contados a partir da data da notificação da decisão.

Este dispositivo deve ser entendido - como também ocorreu no comentário desenvolvido em item anterior ${ }^{890}$ - como mecanismo voltado a lidar com esta específica grave situação de descumprimento de dever comunitário originário por um EstadoMembro, sem que isso pudesse comprometer a preservação da vida em comum.

Com efeito, note-se que este parágrafo quarto do artigo 88 facultava ao EstadoMembro a contínua e ampla oportunidade de se apresentar mais uma vez perante as demais escalas de existência para opor contra elas seu modo de habitar o mundo.

Se as demais estatalidades isoladas intergovernamentalmente concertadas haviam concordado com a decisão da supranacionalidade da Alta Autoridade, a previsão normativa ora em análise assegurava à estatalidade isolada a renovada possibilidade de participar ativamente da formação do sentido jurídico-normativo comum. Para tanto, a ela era garantida a possibilidade de invocar a presença da última escala de existência que restava 
para atuar neste intrincado complexo de freios e de contrapesos: a supranacionalidade da Corte.

Nesse sentido, o recurso à discussão judicial perante a Corte de Justiça da CECA representava expressa autorização do Tratado da CECA ao Estado-Membro faltoso solicitar um requestionamento comunitário de toda a questão envolvida. Diante da gravidade da situação ${ }^{891}$, ao determinar que o Estado-Membro poderia solicitar a presenta da supranacionalidade da Corte, o Tratado determinara que esta deveria atuar no sentido de reabrir institucionalmente a possibilidade de o tema ser rediscutido a partir de um procedimento amplo e favorável à multiescalaridade ${ }^{892}$.

Deste modo, mais uma vez o Tratado da CECA previra um expediente efetivamente voltado a esvaziar ainda mais o Poder concedido à Alta Autoridade: mesmo que sua decisão tivesse sido aprovada pelo Conselho de Ministros, caberia ainda um último recurso à Corte, onde todo o tema poderia e deveria ser rediscutido sob uma perspectiva comunitária - multidimensional e horizontal, ou ainda, imanente.

Assim, o contra-Poder previsto em favor do Estado-Membro estava direcionado especificamente para lembrar à Alta Autoridade que, ainda que pudesse produzir efeitos econômicos prejudiciais em relação a um Estado-Membro, e ainda que de maneira justificada, sua decisão não poderia jamais ser considerada como autorização dada pelo Tratado da CECA a se autocompreender como em posição privilegiada em relação às estatalidades isoladas ou a qualquer outra escala de existência participante da vida em comum. Afinal, o exercício de seu Poder encontraria sucessivamente inúmeros filtros, condições e barreiras que poderiam conter potenciais atuações desmedidas da supranacionalidade em direção à tomada do lugar do Direito e do Poder.

Todavia, como também constatado no final de item anterior ${ }^{893}$, a previsão deste parágrafo quarto do artigo 88 instituía igualmente uma limitação ao exercício deste contraPoder por parte dos Estados-Membros. A possibilidade de questionamento judicial da decisão da Alta Autoridade não poderia autorizar à estatalidade isolada a concluir que ela havia sido colocada em posição privilegiada na vida em comum.

\footnotetext{
${ }^{891}$ Afinal, tratava-se de um Estado-Membro que sofreria repercussões econômicas prejudiciais em virtude de decisão originada em âmbito comunitário - o que poderia representar internamente ao Estado-Membro uma ameaça a sua própria integridade.

${ }^{892}$ Como visto na integralidade do item 7.2.2., supra.

${ }^{893}$ Item 7.2.3.2.3., supra, ao qual remetemos o leitor, na medida em que as considerações deste parágrafo seguem bastante proximamente - mudando o que deve ser mudado - a linha de raciocínio dos comentários desenvolvidos ao final do item 7.2.3.2.3.
} 
Com efeito, se os Estados-Membros poderiam questionar judicialmente a decisão da Alta Autoridade, não poderia o uso de tal instrumento restar indefinido: o recurso deveria ser interposto no prazo de até 2 (dois) meses contados a partir da notificação da decisão da Alta Autoridade. Havia aqui também a previsão de uma autocontenção interna ao contra-Poder atribuído aos Estados-Membros: a dinâmica Política da vida em comum não poderia restar a bel-prazer do Estado-Membro faltoso.

Deste modo, ao mesmo tempo em que o Tratado da CECA previra um mecanismo destinado a barrar eventual pretensão unidimensionalizadora de outras medidas de existência em detrimento da do Estado-Membro faltoso, este último também não poderia se autocompreender como ocupando de tal modo o centro da dinâmica de Poder da vida comunitária que pudesse, se e quando quisesse, questionar a decisão da Alta Autoridade perante a Corte.

Assim, como todos os demais, os Estados-Membros - inclusive os faltosos - eram pares comunitários, isto é, estavam implicados em um sistema de convivência marcado pela horizontalidade que impedia a tomada clandestina do lugar do Direito e do Poder. Nem mesmo um Poder de contenção de outro Poder deveria ser considerado como autorizado a introduzir um ou outro em posição privilegiada, isto é, todo Poder concedido pelo Tratado da CECA - ainda que fosse um contra-Poder - era cuidadosamente trabalhado pelas instituições para impedir a transcendentalização da dimensão existencial que o recebera. A conservação da imanência foi mais uma vez a preocupação central dos autores do Tratado.

7.2.3.2.6. Controle Contido V: A Última Consequência Limitada ao Inadimplemento Estatal como Atestado da Não-Sujeição do Estado aos Órgãos Comunitários

O parágrafo quinto do artigo 88 dispunha que, caso as medidas acima previstas não fossem suficientes para levar ao cumprimento das obrigações pelo Estado-Membro faltoso, a Alta Autoridade estava autorizada a remeter o assunto à apreciação pelo Conselho de Ministros. A compreensão deste dispositivo no interior de uma chave de leitura jurídicopolítica não é complicada.

Este mandamento jurídico-normativo tem um foco de atuação bastante preciso: caso as medidas escolhidas pela Alta Autoridade não tivessem surtido o efeito desejado de levar o Estado-Membro faltoso a cumprir seu dever comunitário originário, esta situação 
não restaria impune. A Alta Autoridade poderia agir, mas de maneira limitada: ela deveria remeter a questão para ser apreciada no interior do Conselho de Ministros.

Isso significa que o Tratado da CECA procurou lidar com a situação limite de todo o tratamento normativo iniciado desde o artigo 86: caso o Estado-Membro reiterasse sua obstinação em não cumprir com seu dever comunitário, a situação não poderia permanecer como tal, vale dizer, seu agir faltoso não era reconhecido pelo Tratado como autorizado e, por isso, deveria ser institucionalmente solucionado. Ao mesmo tempo, a Alta Autoridade deteria possibilidade de agir, mas sua atuação seria limitada: ela não poderia decidir segundo sua própria perspectiva sobre a questão. Antes, ela deveria remeter o problema ao Conselho.

Nesse sentido, note-se que o Tratado da CECA encaminhava a solução deste problema limite mediante uma dupla negação: recusava-se a reconhecer a atitude perniciosa da estatalidade isolada como adequada, ao mesmo tempo em que se negava à supranacionalidade a possibilidade de tomar por si só uma medida mais drástica. A questão deveria ser resolvida, enfim, em âmbito intergovernamental, isto é, onde as estatalidades isoladas deveriam se concertar e se opor intergovernamentalmente para discutir a questão e apreciar a melhor solução para o impasse.

Perceba-se que a discussão sobre os destinos da Comunidade passava por vias institucionais praticamente similares ao ambiente de discussão origário sobre as fundações da Comunidade. Tratava-se de uma situação verdadeiramente perigosa e, por isso, o tema da preservação da vida em comum retornava ao ambiente original em que toda a União Política da Europa pela CECA fora formulada, a fim de que ela pudesse ser por todos repensada em conjunto.

O que deve ser observado neste ponto é a presença de uma preocupação do Tratado em trabalhar incansavelmente com situações paulatinamente mais graves por meio das próprias instituições da CECA. Em outras palavras, a fim de que a solução de um problema tão perigoso - descumprimento de dever comunitário - não implicasse a explosão do sistema de convivência judiciosamente direitificado, o Tratado previra que, no final, mesmo a discussão mais grave e mais fundamental - permanência da Comunidade Política - não seria remetida para um ambiente localizado fora das instituições da própria CECA.

O remédio para o mal deveria ser encontrado dentro das próprias instituições. E as instituições da CECA buscavam continuamente se mostrar abertas para os mais diferentes tipos e níveis de discussão multiescalar sobre a vida em comum instaurada entre os países europeus opostos tradicionalmente em termos militares. E, para isso, suas relações 
deveriam se desenvolver continuamente em termos de oposições institucionalmente viabilizadas por meio do arcabouço jurídico-normativo originário da vida em comum - isto é, por meio da direitificação efetuada pelo Direito Comunitário Originário.

Deste modo, se houvesse um problema interno envolvendo o questionamento sobre as fundações da própria vida em comum, ele deveria ser discutido e resolvido internamente, mediante o uso das próprias instituições - e não ensejar a desconsideração imediata e completa de todo o desenho institucional minuciosamente construído para constituir um novo modo de relações na Europa.

Em outras palavras, a organização jurídico-Política instaurada deveria ser preservada e, por isso mesmo, nesta situação limite levada ao extremo, os EstadosMembros não estariam autorizados a denunciar o Tratado da CECA e a recorrer a meios externos. Antes, eles deveriam se colocar multidimensionalmente uns perante os outros para resolver a questão no interior de uma instituição propriamente comunitária - o Conselho de Ministros, a fim de que a perspectiva da vida comum não fosse esquecida.

Isso significa que, neste momento extremo, a opção do Tratado da CECA foi a de não permitir a instauração de situação excepcional para a vida comunitária, vale dizer, a de recusar a desconsideração da organização jurídico-política da vida comum na Europa segundo Leis Políticas. Por isso, a concertação intergovernamental deveria se desenvolver tendo sempre em mente e em vista a preservação da Comunidade Política da Europa. Tratava-se de reenvio institucional da vida Política a ela mesma, para evitar a suspensão das Leis Políticas da CECA.

Além deste aspecto de remissão do Tratado da CECA a suas próprias instituições como manifestação da Comunidade Política de se voltar a ela mesma para se refundar em situações limite, e além da negação normativa duplamente dirigia à Alta Autoridade e ao Estado-Membro faltoso - a fim de impedir a ascensão de qualquer deles ao lugar do Direito e do Poder, há que se observar que este dispositivo também delineava indícios daquilo que a vida em comum na Europa não poderia nem representar, nem almejar ser: um Estado Europeu.

Essa constatação será mais bem compreendida no item a seguir ${ }^{894}$, onde se comentam conjuntamente os dispositivos normativos referentes à execução de decisões da Corte e da Alta Autoridade. Contudo, convém ressaltar aqui alguns aspectos, pois eles 
ajudarão a evidenciar progressivamente aquilo que será tematizado de maneira um pouco mais detida a seguir.

O parágrafo quinto do artigo 88 era bastante parcimonioso em sua previsão: caso as medidas da Alta Autoridade não fossem suficientes, ela estava autorizada a remeter o assunto ao Conselho de Ministros. Essa disposição bastante sintética guardava ainda um último elemento de profunda significação jurídico-política: a não-sujeição do EstadoMembro faltoso à Alta Autoridade ou ao Conselho de Ministros, por estes não serem órgãos de um Estado Europeu. Como afirmado por várias vezes anteriormente, estes seriam apenas iguais partícipes da vida em comum, guardando entre si uma mera relação horizontal.

Nesse sentido, observe-se que o parágrafo quinto do artigo 88 se mostrava explícito: mesmo em situação profundamente grave, em que se expunha uma calamidade potencial da vida Política da CECA, o Estado-Membro não poderia ser forçado por nenhuma entidade que não ele próprio para adimplir sua obrigação. Nem a Alta Autoridade, nem o Conselho de Ministros, disporiam de mecanismos coercitivos que poderiam imediatamente implicar o cumprimento do dever pelo Estado-Membro.

Com efeito, o Tratado da CECA retirara da Alta Autoridade a possibilidade de continuar a agir em qualquer outro sentido sobre a mesma temática, ao passo que, com relação ao Conselho de Ministros - apesar de se lhe autorizar a apreciação do problema, o Tratado da CECA não previra em favor deste qualquer disposição normativa que lhe facultasse o uso de instrumentos que dessem meios práticos aptos a fazer o EstadoMembro cumprir sua obrigação.

Estes dois órgãos comunitários haviam sido autorizados a agir, mas de maneira limitada, pois não poderiam nem mesmo pretender empregar qualquer mecanismo que pudesse ser entendido como atentando contra a Soberania dos Estados-Membros. Recusando à Alta Autoridade e ao Conselho de Ministros a possibilidade de dispor de maneira central sobre o uso da violência para coagir participantes comunitários a adimplir suas obrigações, o Tratado da CECA assegurara de maneira efetiva a perpetuidade de tal condição estatal apenas aos Estados-Membros.

Por esse motivo, pode-se concluir haver aqui um primeiro indício que sinalizaria para a introdução de opção institucional de não tornar a organização jurídico-Política da vida comum na Europa da CECA um Estado Europeu. Seus dois órgãos responsáveis para lidar com a situação mais extrema da vida em comum não deteriam quaisquer meios ou condições institucionais para dispor do uso da força em desfavor de um Estado-Membro. 
Esta condição derivava precisamente daquilo que foi ressaltado por diversas vezes neste trabalho: Estados-Membros, Alta Autoridade e Conselho de Ministros seriam todos iguais partícipes da vida em comum, guardando entre si uma mera relação horizontal. Nenhum deles se submeteria ao outro, nem normativa, nem coercitivamente, pois a nenhuma das escalas de existência era dado ocupar o lugar do Direito e do Poder, muito menos a tentativas de tomada deste por meio da força. Antes, os partícipes comunitários estariam apenas sujeitos às normas jurídicas produzidas multidimensionalmente no interior da vida comum - ou seja, às normas comunitárias, cujo sentido normativo fora dado a partir da garantia de amplo processo de entrechoque entre diferentes medidas de existência.

Sem prever a seus principais órgãos comunitários meios coercitivos para fazer observar as normas comunitárias, como teria previsto o Tratado da CECA um procedimento de execução das decisões da Corte e da Alta Autoridade? Em que sentido se pode compreender que tais normas comunitárias seriam observadas sem o recurso ao uso da força pelos órgãos comunitários? É o que se passa a analisar no próximo item.

7.2.4. Execução de Decisões da Corte (e também da Alta Autoridade): Preservação da Imanência e Recusa à Formação de um Estado Europeu

O tema a ser analisado neste item se refere à discussão sobre a execução de decisão formalizada pela Alta Autoridade ${ }^{895}$, de decisão da Corte $^{896}$, por expressa previsão concedida pelo artigo 44 do Tratado da CECA, ou da constatação, derivada de fiscalização empreendida pela Alta Autoridade, de que Estado-Membro não cumprira ou não fizera cumprir os atos normativos comunitários ${ }^{897}$.

O conjunto normativo do Tratado da CECA que se refere a essas três situações distintas é disciplinado pelo artigo 92 deste documento jurídico-normativo internacional. Sem uma análise direta e minuciosa do dispositivo, é impossível compreender a lógica do cumprimento das decisões acima enumeradas, motivo pelo qual se realizará neste item uma análise do artigo 92 do Tratado da CECA - englobando, por força de expressa atribuição normativo pelo artigo 44, as decisões da Corte ${ }^{898}$.

\footnotetext{
${ }^{895}$ Cujo processo de formação será examinado no item 7.3.1., infra.

${ }^{896}$ Cujo processo de formação foi analisado no item 7.2.2., supra.

${ }^{897}$ Comentado no item 7.2.3., supra.

${ }^{898} \mathrm{O}$ que permite justificar o tratamento conjunto desta temática no interior deste item 7.2.
} 
Por fim, note-se que o exame deste dispositivo permitirá ainda reforçar a percepção continuamente repetida neste trabalho de que a opção pela preservação do caráter Político da relação entre os participantes da Europa Unida pela CECA não significou senão uma consciente e deliberada recusa à constituição de um Estado Europeu - isto é, nada mais do que uma escolha por uma organização jurídico-Política contra o Estado, ou ainda, contra a centralização do uso da força ${ }^{899}$.

\subsubsection{O Artigo 92 do Tratado da CECA: O Dado Jurídico-Normativo Positivo e o} Não-Dado Jurídico-Político Institucional

\subsection{Observações Gerais sobre o Artigo 92}

O artigo 92 do Tratado da CECA imputava determinada qualidade às decisões da Alta Autoridade que contivessem obrigações econômicas e a qualquer tipo de decisão da Corte $^{900}$, bem como estabelecia o modo de execução destas. A compreensão integral deste dispositivo permitirá construir uma interpretação que o identifique como um mecanismo institucional adicional voltado à promoção e à manutenção de uma dinâmica tipicamente Política entre as escalas de existência da CECA.

O primeiro parágrafo do artigo 92 determinava que as decisões da Alta Autoridade que impusessem obrigações pecuniárias constituíam título executivo, devendo seguir a forma de execução do artigo. Por expressa disposição do artigo 44, as decisões da Corte deteriam a mesma qualidade e seguiriam a mesma forma de execução.

Apesar de serem instrumentos distintos, as decisões dos dois órgãos comunitários deteriam a mesma qualidade e se submeteriam ao mesmo regime jurídico de execução. Nesse sentido, esse comentário estabelece uma interpretação comum sobre a qualidade e a forma de execução dos dois instrumentos, pois a consideração conjunta de ambos permite perceber a preocupação em conservar a Política no interior da Europa de acordo com uma perspectiva específica.

\footnotetext{
899 Diferente, portanto, do discurso Federalista Europeu examinado no Quinto Capítulo, supra, e como mencionado nos itens 6.2.2.4. e 6.2.2.5., também supra.

${ }^{900}$ Por força do artigo 44 do Tratado da CECA, todas as decisões da Corte receberam tratamento equivalente ao da disciplina estabelecida neste artigo 92, o qual versava sobre as decisões da Alta Autoridade que contivessem obrigações econômicas.
} 
7.2.4.1.2. Equivalência do Tratamento Jurídico da Execução das Decisões da Corte e da Alta Autoridade e Horizontalidade Relacional

Antes de passar ao exame do significado jurídico-Político dos parágrafos segundo e terceiro do artigo 92, é importante se deter ainda sobre a disposição constante do primeiro parágrafo. Um exame mais atento deste dispositivo permite des velar um primeiro indício de seu cuidado com a conservação do Político. Esse elemento se torna evidente em virtude da expressa referência feita ao artigo 92 pelo artigo 44 do Tratado da CECA ao regime a ser aplicado às decisões da Corte.

O Tratado efetuava uma equivalência da qualidade jurídica dos dois tipos de decisão: tanto as proferidas pela Corte, como as emanadas da Alta Autoridade, constituíam título executivo. Isso implica reconhecer que ambas recebiam do Tratado um reconhecimento expresso de seu caráter obrigatório, vinculante e exigível perante um Tribunal - o qual, como será visto mais adiante, era um Tribunal nacional de um EstadoMembro.

Nesse sentido, não haveria dúvidas quanto à possibilidade de execução dos dois e quanto à necessidade de cumprimento das decisões, uma vez proferidas. Por isso, não haveria como se questionar a força normativa por elas portada - isto é, seu valor jurídico efetivo, pois essa tarefa já havia sido resolvida normativamente pelo próprio Tratado da CECA.

Ao equivaler a qualidade jurídica das decisões da Corte e à das decisões Alta Autoridade, o Tratado desenhava mais uma forma de articulação institucional que buscava conservar diferentes escalas de existência em iguais condições de formação do sentido normativo comum, a fim de que elas convivessem em um regime de horizontalidade permanente. Ao determinar um regime de equivalência entre as decisões, o Tratado declarava abertamente que não se deveria entender existir qualquer diferença jurídica entre as decisões dos órgãos supranacionais da Comunidade, pois elas receberiam o mesmo tratamento, isto é, elas deteriam exatamente a mesma qualidade e o mesmo regime jurídicos.

Em outras palavras, o Tratado afirmava por este dispositivo que, em âmbito comunitário, não haveria uma hierarquia entre os órgãos produtores de decisões: independentemente da origem institucional, as decisões deteriam exatamente a mesma qualidade. Ao deter a mesma força normativa - não havendo assim qualquer atribuição de supremacia ou de preferência normativa a um ou outro órgão comunitário, o Tratado 
visava a impedir que qualquer das duas escalas de existência pudesse pretender se destacar perante a outra e, principalmente, sobre as demais e, com isso, visar à ocupação do lugar do Direito e do Poder na Comunidade.

O dispositivo deixava mais claro do que a luz do meio-dia que as duas entidades supranacionais eram providas de um instrumento equivalente para a execução de suas decisões. O Tratado da CECA escancarava para os dois órgãos comunitários que, apesar de eles deterem a possibilidade de ter suas decisões executadas em âmbito nacional, entre eles não teria sido escolhido Um para ocupar uma posição de destaque, vale dizer, nenhum deles poderia nem mesmo pretender ocupar uma posição supranacional privilegiada em relação ao outro.

Deste modo, a construção normativa afirmava que as duas medidas de existência deveriam manter entre si uma relação de igualdade: a despeito da diferença de escalas de existência que portavam, o lugar do Direito e do Poder estaria resguardado de uma possível usurpação por parte da Corte ou da Alta Autoridade.

Relegadas a uma mesma posição horizontal e obstado o destacamento escalar de ambas, estavam as duas entidades impedidas de formar ou de insinuar qualquer autocompreensão jurídico-política que supostamente legitimasse uma corrida em direção à tomada do centro nomogenético da Comunidade. Iguais entre iguais, o Tratado reiterava a convicção de ser necessário afastar do lugar do Direito e do Poder toda e qualquer escala de existência potencialmente ameaçadora.

Há que se notar que o artigo efetuava uma equivalência entre as decisões dos dois órgãos supranacionais enquanto manifestações condenatórias - implicando a observância imediata por parte da parte que sofrera a condenação dada por entidade supranacional, o que pode ser compreendido como uma inovação efetiva no modo de conceber as relações na Europa em virtude da nova organização jurídico-Política.

Esse tratamento especial dados às supranacionalidades derivava precisamente da ideia de tratar desigualmente desiguais, para manter todos os participantes em uma igual condição horizontal. Lembre-se nesse sentido de que a medida estatal já se encontrava provida, no âmbito de seus próprios territórios nacionais, de meios para determinar o cumprimento de suas decisões enquanto medida estatal: o próprio Direito Constitucional, o próprio Direito Processual, etc. Dessa forma, o Tratado fortalecia por meio dessa previsão as escalas de existência supranacionais vis-à-vis as medidas estatais no que se refere à capacidade de tornar possível a execução de suas condenações também no interior dos Estados-Membros. 
Todavia, antes de se tratar de uma previsão de desequilíbrio favorecedor da escala de existência supranacional, há que se notar que tal dispositivo operava como um mecanismo de concessão de paridade de armas às duas principais escalas de existência que participavam do jogo de relações de Poder na Europa Unida: a supranacional e a estatal. Apenas por meio de uma tal arquitetura institucional seria possível preservar de maneira igual a condição de pares comunitários a diferentes escalas de existência: considerando as especificidades de cada medida de existência, forçando-as a conviver mediante mútuas e recíprocas limitações.

Assim, a constituição de cuidadosos mecanismos institucionais seria fundamental para assegurar que a ambição desmedida de uns ou a subserviência imoderada de outros não permitissem a plenificação uniescalar do lugar do Direito e do Poder na Europa Politicamente Unida pela CECA. Se os órgãos comunitários supranacionais encontravam instrumentos iguais de efetivo valor jurídico executório, não apenas estes seriam em si limitados $^{901}$, mas também teriam sido tais instrumentos concebidos precisamente para refrear possíveis investidas originadas de outras escalas de existência.

Lembre-se de que em âmbito nacional costumeiramente se reconhecia a executoriedade das decisões proferidas pelas respectivas medidas estatais. Por outro lado, a criação de uma entidade supranacional era verdadeira inovação nas práticas jurídicopolíticas e jurídico-processuais internas e internacionais na Europa do pós-Segunda Guerra Mundial - o que poderia ensejar dúvidas sobre ao caráter jurídico (exigibilidade e executoriedade) de decisões jurídicas formalizadas por entidades supranacionais. Por esse motivo, o Tratado buscara solucionar neste dispositivo imediata e expressamente qualquer dúvida sobre a possibilidade de as decisões condenatórias tomadas supranacionalmente poderem ou não ser executadas dentro dos Estados-Membros.

Dessa forma, perceba-se que, com a previsão do parágrafo primeiro do artigo 92, o Tratado da CECA não apenas estabeleceu uma equivalência entre as decisões condenatórias dos órgãos comunitários supranacionais entre si, a fim de excluir qualquer possibilidade de hierarquização entre eles. O mesmo documento jurídico se preocupara em conceder aos atos das escalas supranacionais a mesma condição de obrigatoriedade, de exigibilidade e de efeito vinculatório presente nos atos tomados internamente pelas escalas estatais de existência, visando a assegurar também à escala supranacional iguais condições de ver efetivados no âmbito interno dos Estados-Membros os atos por ela formalizados.

${ }^{901}$ Como se poderá verificar quando da leitura das considerações do item 7.2.4.1.3., infra. 
Por isso mesmo, a contraposição entre supranacionalidade as equivalia e as mantinha em mesma posição. Todavia, a mesma contraposição também lhes concedia iguais possibilidades para que pudessem entrar em conflito com as estatalidades sem que estas pudessem se opor à execução em seus respectivos territórios. Continha-se deste modo potencial insurgência dos Estados-Membros à execução de tais decisões comunitárias dentro de seus territórios, mediante alegação de não serem tais atos jurídicos executáveis em âmbito interno por não serem uma decisão estatalmente produzida.

Assim, multidimensionalmente se conservava a condição de pares comunitários mediante a concessão de instrumentos paritários na construção do sentido normativo comum - considerando as especificidades, as limitações e os potenciais arroubos de uma ou de outra medida de existência durante o entrechoque escalar institucionalmente promovido e incitado. A supranacionalidade deteria capacidade de determinar também o sentido normativo comum se encontrasse condições institucionais que lhe permitissem também impactar os Estados-Membros em sua dimensão interna - ainda que essa capacidade de determinação fosse limitada, como será visto a seguir.

De todo modo, perceba-se que havia neste dispositivo a negação da possibilidade de um Estado-Membro invocar disposição de Direito interno para se esquivar do cumprimento de uma decisão gerada por força de mecanismos institucionais decisórios de uma Organização Internacional comunitária. Em outras palavras, retirava-se da escala de existência estatal a exclusividade de produzir decisões condenatórias a serem aplicadas em seu território, devendo agora conviver com fonte normativa alternativa à estatal, igualmente obrigatória, exigível e vinculante.

É por meio desta análise que se revela com toda a força o conflito entre as modalidades de existência que esse artigo promovia: construíram institucionalmente condições que visariam à atribuição de efetiva força normativa às decisões formalizadas supranacionalmente (pela Alta Autoridade ou pela Corte) no interior da vida em comum. Essa arquitetura institucional visava a assegurar que, dentro do território dos EstadosMembros, tais decisões comunitárias - formadas multiescalarmente sob o signo da plena horizontalidade - seriam cumpridas de maneira equivalente às geradas no interior deles conforme uma dinâmica interna própria e típica da dimensão de existência estatal, pois deteriam exatamente o mesmo valor jurídico.

Revelava-se aqui o dispositivo institucional que visava a dar contornos mais definidos à retirada dos Estados-Membros da exclusividade de produção normativa derivada do maquinário institucional de intenso e ininterrupto compartilhamento de 
deveres de participação na formação do sentido normativo na vida comunitária - sobre questões concretas comuns sensíveis - a produção de carvão e de aço ${ }^{902}$.

De fato, se os Estados-Membros haviam concordado historicamente em não mais decidir isoladamente sobre o sentido normativo a ser atribuído a tais questões concretas sensíveis comuns ${ }^{903}$, ao mesmo tempo, não poderiam eles pretender introduzir óbices institucionais que impedissem de maneira absoluta que as decisões condenatórias forjadas no interior da vida em comum não detivessem efetividade jurídica.

Em outras palavras, esse dispositivo visava precisamente a promover de maneira renovada a divisão entre escalas de existência e as enfatizar no interior do sistema de convivência: os Estados-Membros não poderiam recusar a cumprir as decisões forjadas fora de sua exclusiva escala de existência isolada sobre o sentido normativo a ser dado ao uso e à administração comum do carvão e do aço. Estes não escapavam ao dever de cumprir normas jurídicas que eles próprios não tivessem constituído exclusivamente a sua imagem e semelhança - pois elas, por terem sido multiescalarmente formadas, a partir da dinâmica Política própria da vida comunitária, também teriam recebido de alguma forma a contribuição de sua própria escala de existência isolada.

O conflito entre as escalas de existência se instaurava virtuosamente com todo seu vigor nas demais disposições do artigo 92. Estas não apenas esclareciam a dinâmica processual a ser seguida para executar as decisões condenatórias, mas também principalmente estabeleciam claramente os termos segundo os quais a dinâmica da Europa Politicamente Unida da CECA se desenvolveria.

Se as supranacionalidades poderiam pretender que as decisões por elas formalizadas seriam cumpridas no interior dos Estados-Membros - por expressa autorização dada pelo Tratado da CECA, essa pretensão encontrava uma intensa limitação. E, como se poderá ver a seguir, essa limitação vigorosa detinha um significado jurídicoPolítico ainda mais profundo e ainda mais caracterizador da União Política da Europa promovida pela CECA.

\footnotetext{
${ }^{902}$ Essa perda da exclusividade normativa restará mais clara quando da leitura do item 7.3.1., infra.

${ }^{903}$ Como visto no Sexto Capítulo, supra, especialmente em seu item 6.3.3., ao qual remetemos o leitor.
} 
7.2.4.1.3. Limitações à Execução das Decisões da Corte e da Alta Autoridade: Marcas de uma Organização Jurídico-Política da Europa contra um Estado Europeu

O parágrafo segundo do artigo 92 do Tratado da CECA determinava que a execução do título executivo comunitariamente gestado deveria seguir o direito processual estabelecido no interior do Estado-Membro em que seria executado, de acordo com a fórmula executória nele utilizada por força de sua legislação nacional. A decisão condenatória receberia tal formula executória por meio de determinação de um Ministro nacional designado por cada Governo especificamente para tais questões, a fim de que a execução se iniciasse. A única condição passível de ser oposta era a necessidade de verificação da autenticidade das decisões.

O referido dispositivo continha inúmeros elementos que evidenciavam uma preocupação institucional detalhada em efetuar uma oposição entre medidas de existência no interior da Europa Unida, de maneira a orientá-la Politicamente. Por um lado, a partir de um exame minucioso, é possível perceber neste texto a preocupação de construir série de consecutivas limitações à unilateral possibilidade de iniciar um processo de execução concedida à medida supranacional. Por outro lado, como se poderá ver mais adiante, o próprio parágrafo segundo apresentava elementos que também introduziam freios a tal possibilidade de contenção, isto é, ele trazia consigo instrumentos que conteriam a própria capacidade de limitação atribuída aos juízes nacionais, enquanto portadores do conhecimento sobre a escala de existência estatal.

O parágrafo segundo claramente promovia um imediato esvaziamento da grande capacidade de influência e de impacto atribuída à medida supranacional, com o objetivo de conter seu movimento interventivo na ordem jurídica nacional. Se o primeiro parágrafo previra a possibilidade de uma decisão formalizada pela supranacionalidade como produto de interação multiescalar comunitária - portanto, não exclusivamente estatal - ser imediata e diretamente aplicável em processo de execução em território nacional - isto é, de produzir efeitos sensíveis em âmbito nacional, o parágrafo segundo apresentava série de condicionamentos a tal perturbação das ordens jurídicas internas.

O movimento de instituir um Poder "sem Poder" a ser atribuído à medida supranacional pode ser identificado diante da previsão de que a decisão - fosse da Corte, fosse da Alta Autoridade - deveria ser reconhecida e recepcionada formalmente pelo Direito Processual nacional, a fim de que pudesse ser executada nos exatos termos jurídico-processuais de cada Estado-Membro. Isso significa que a perturbação provocada 
pela possibilidade de imediata e direta execução nacional de decisão formalizada supranacionalmente dependeria de um revestimento deste ato por uma qualidade jurídica reconhecida como aceitável por cada uma das ordens jurídicas nacionais que deveriam executar e cumprir tal decisão.

A contenção do Poder atribuído à supranacionalidade se manifestava de modo mais claro a partir da compreensão da série de limitações que o parágrafo segundo expressamente previa contra a imediata e direta efetividade das decisões comunitariamente forjadas. Além de dever se orientar pelo Direito Processual do Estado-Membro onde seria aplicada, a decisão deveria (i) ter sua autenticidade verificada; (ii) ser recepcionada pelo Direito Processual nacional para que adquirisse a especial forma jurídica nacionalmente admitida como apta a ensejar o início de uma execução nos termos do devido processo legal cada Estado-Membro; e (iii) receber esse invólucro formal por meio de reconhecimento dado por Ministro nacional especialmente designado para essa tarefa.

Dessa forma, note-se que os Estados-Membros detinham uma capacidade de contenção bastante forte da atuação das entidades supranacionais, pois estavam dotados de diversificadas formas sucessivas de oposição à imediata e direta produção de efeitos de decisões comunitárias formalizadas supranacionalmente. Estas apenas poderiam pretender se tornar efetivas se cumprissem simultaneamente tais requisitos formais de terem sua autenticidade certificada e de terem recebido, a partir de determinação de um Ministro de Estado, a adequada forma processual para ser executada segundo o processo de execução próprio do Estado-Membro.

Havia deste modo uma contenção daquele Poder "sem Poder" - porém convulsionador - atribuído à escala de existência supranacional, tendo em vista que ele não poderia de pronto ser executado sem que houvesse a observância da tradição jurídica nacional afetada. Em outros termos, não se pode ignorar que esse mecanismo de contenção nacional permitia que fossem preservadas as culturas jurídicas locais, evitando uma súbita padronização nas práticas jurídico-judiciárias nacionais a partir de uma escala de existência supranacional que, assim, pudesse implicar uma desconexão do processo legal de execução com os hábitos nacionais arraigados de operacionalização processual executória de título executivos.

Nesse sentido, a despeito de o artigo 92 do Tratado da CECA assegurar a efetividade nacional das decisões supranacionais, a medida de existência supranacional era afastada da possibilidade de ocupar total e totalizantemente o lugar do Direito e do Poder na Europa Unida, em nome da garantia da permanência das tradições jurídicas de cada 
Estado-Membro. Mais simplesmente, este dispositivo declarava expressamente que não se permitiria a unidimensionalização na Comunidade a partir de qualquer perspectiva, pois não seria seguido nem um sistema jurídico-processual de um Estado-Membro em especial, nem um especialmente formado a partir de uma racionalidade supranacional europeia.

Deste modo, o parágrafo segundo do artigo 92 afirmava que não se concederia qualquer possibilidade de ascensão destacada de Um sobre os demais - nem supranacional, nem estatal. Se as decisões comunitariamente gestadas deveriam ser executadas nacionalmente, cada uma delas deveria respeitar e seguir os mandamentos jurídicoprocessuais nacionais que germinaram a partir da construção das tradições jurídicas de cada Estado-Membro, variando o modo de execução em função do Estado em que deveria ser executada a decisão.

A busca de uma Europa Politicamente Unida recusou qualquer afastamento de multiescalaridade no interior da determinação do sentido do Direito e do Poder na Comunidade, pois se rejeitara, também aqui, a tendência à uniformização jurídica (jurídico-processual) a partir de qualquer escala de existência (supranacional ou estatal). O conflito escalar normativamente instigado por esse dispositivo se explicitava ainda mais: se os Estados-Membros não poderiam se recusar a executar as decisões formalizadas supranacionalmente, os órgãos supranacionais não imprimiriam suas escalas de existência sobre os sistemas jurídico-processuais nacionais.

O dispositivo valorizava e respeitava assim o saber privilegiado dos juízes nacionais sobre o Direito Processual dos Estados-Membros onde atuavam: o Tratado da CECA declarava manter e não tocar as tradições dos instrumentos com os quais estavam habituados, ainda que tivessem de fazer produzir efeitos em seu território nacional um mandamento jurídico gerado a partir de uma organização jurídico-Política comunitária isto é, estranho a princípio à estatalidade isolada, por ser multiescalar, ou seja, não apenas fruto exclusivo da estatalidade isolada.

Em outras palavras, a efetivação de normas jurídicas comunitárias derivadas não autorizava introduzir uma inovação no saber jurídico-processual nacional, isto é, a busca de dar efetividade às decisões formalizadas supranacionalmente não autorizava o rompimento com as tradições jurídicas do local onde elas deveriam ser executadas. Supranacionalidade e estatalidade se opunham intensamente: uma visando à efetivação das decisões normativas comunitárias, mas sempre de maneira limitada às formalidades estatais previstas pelo próprio Tratado da CECA; outra, devendo executar as decisões 
comunitárias, mas tendo em seu favor a preservação soberana de suas tradições jurídicas nacionais quando da execução de tais decisões.

Observe-se que a Comunidade não detinha nem mesmo possibilidade de influenciar na uniformização do saber-fazer e saber-praticar as normas jurídicas de execução de cada Estado-Membro, pois não introduzia sua forma de perceber o mundo nem sobre o Saber de cada um dos Estados-Membros acerca de como fazer executar decisões. Tratava-se de forte capacidade de negação e de interrupção atribuída à medida estatal, com o objetivo de manter afastada a supranacionalidade e assegurar um vazio de Poder na Europa Unida.

Não se pode deixar de mencionar ainda um último aspecto deste parágrafo segundo que produzia um vertiginoso esvaziamento da escala de existência supranacional. Na medida em que a execução de suas decisões deveria ser necessariamente mediada por um juiz nacional e por sua forma de saber lidar, aplicar, conduzir e viver o processo em seus respectivos territórios, o Poder atribuído à supranacionalidade era aqui praticamente nulificado a tal ponto que se poderia ver com toda a clareza a manifestação vigorosa e imediata da conversão deste Poder em um Poder "sem Poder".

Ao estabelecer a necessidade daquela mediação, o Tratado retirava completamente de quem formalizara supranacionalmente a decisão comunitária o controle sobre o destino (efetivação) da norma jurídica, ou ainda, não lhe dava a possibilidade de conduzir ou de impulsionar o processo que visava a executá-la. Dito de outro modo, a Corte e a Alta Autoridade estavam absolutamente desprovidas de quaisquer instrumentos coercitivos que pudessem fazer o cumprir as decisões condenatórias por elas formalizadas. Antes, pode-se até mesmo dizer que estavam proibidas de tentar buscar dispor de tais instrumentos, pois este dispositivo reservava aqui aos Estados-Membros a exclusividade na centralização do monopólio legal do exercício da violência.

Deste modo, o parágrafo segundo deste artigo revelava nessa especificidade de tratamento de uma questão jurídico-processual um precioso detalhe que não se deve deixar de notar, nem mesmo permitir que ele passe despercebido: na construção de uma Europa Politicamente Unida, nos momentos em que eventualmente se mostrasse necessário o uso da força, não seriam atribuídos instrumentos coercitivos à Comunidade ou aos órgãos comunitários - principalmente aos portadores da medida supranacional. Este domínio do uso da força estaria reservado aos Estados-Membros, precisamente porque essa transferência de competência não havia sido feita em favor da Comunidade pois a Comunidade não detinha pretensões de se tornar um Estado. 
Assim, apesar de o artigo 92 conceder em seu parágrafo primeiro uma grande possibilidade interventiva e perturbadora da medida de existência nacional à escala supranacional - pois de pronto as decisões deteriam o caráter de título executivo, imediatamente o mesmo artigo a esvaziara em seu parágrafo segundo. Desprovida de capacidade coercitiva - isto é, de meios para tornar faticamente efetiva sua atuação decisória supranacional em âmbito nacional, à escala de existência portada pela Alta Autoridade e pela Corte restava apenas aguardar a execução de sua decisão por parte dos juízes nacionais.

Assim, com a aposição de série de faculdades que freavam uma possível tentativa de totalização da escala supranacional, não apenas este dispositivo repelira de imediato a supranacionalidade de uma potencial inserção de sua dimensão no lugar do Direito, do Saber e do Poder na Europa e nos Estados-Membros. Ele também buscou afirmar de maneira categórica que, desprovida de instrumentos coercitivos, a fonte comunitária da decisão condenatória e a fonte supranacional de formalização desta decisão estariam igualmente descompromissadas com a assunção de uma organização jurídico-política estatal - isto é, com a construção de um Estado Europeu.

Todavia, não se pode ignorar que, neste ponto, o parágrafo segundo do artigo 92 estabelecia, a partir de seu dito - intensa contenção da capacidade de impacto e de influência da medida supranacional no território os Estados-Membros, um não-dito Politicamente orientado para também conter o Poder de contenção atribuído aos EstadosMembros. O enigma do Poder "sem Poder" se mostrava novamente com robustez neste dispositivo.

Note-se nesse sentido que o texto do referido artigo também determinava potentes limitações aos Estados-Membros, a fim de que o exercício do Poder de controle pelos juízes nacionais também fosse ele mesmo controlado. Se o texto do Tratado respeitava as tradições jurídico-processuais dos Estados-Membros e valorizava o saber aplicar tais regras pelos juízes nacionais, ele os fazia enquanto técnica de preservação de possibilidade da efetivação da vida comunitária em território nacional. Em outras palavras, a conservação do repertório e do saber jurídicos dos Estados-Membros era um meio engenhoso para assegurar a realização da decisão comunitária supranacionalmente formalizada.

Havia sem dúvida uma valorização e uma preservação, mas tais cautelas eram instrumentais: o objetivo era introduzir pelas vias jurídico-processuais tradicionais conservadas um elemento novo, a saber, a execução definitiva e integral de uma ordem proferida a partir de uma escala não gestada exclusivamente conforme a tradição uniescalar 
do Estado-Membro. Em outras palavras, a conservação das tradições jurídico-processuais nacionais não consistiu senão em um meio de assegurar que um mandamento normativo seria cumprido, ainda que (i) não correspondesse exclusivamente às condições culturais do território onde seria executado ${ }^{904}$ e (ii) não detivesse qualquer elemento coercitivo ${ }^{905}$.

Nesse sentido, note-se que não havia como o juiz nacional, no exercício de sua função de executor nacional de norma comunitária, questionar tal decisão com base em dispositivo interno material ou processual. Se a execução deveria seguir os ritos nacionalmente atribuídos, uma vez revestido da forma processual nacional adequada, ela não poderia ser interrompida. Se, por um lado, a supranacionalidade era afastada do lugar do Direito, do Saber e do Poder na Comunidade para dar execução às decisões comunitárias, por outro lado, afastara-se a possibilidade de a medida estatal imiscuir-se na decisão, isto é, retirara-se desta a capacidade de questionar a decisão comunitariamente forjada, ainda que em desacordo com as tradições nacionais.

Essa disposição do Tratado da CECA revelava assim mais uma vez o intento em operar um cuidado normativo minucioso em constituir institucionalmente uma Europa Politicamente Unida: mesmo na aplicação de decisões comunitárias supranacionalmente formalizadas, nem a escala de existência supranacional, nem a estatal, deteriam o monopólio absoluto sobre o destino delas. Limitando-se e frenando-se mutuamente por meio de pesos e contrapesos fornecidos pelo Tratado, uma dimensão afastaria a outra por um recíproco controle limitado. Este abria e mantinha, por sua vez, um espaço vazio no lugar do Direito e do Poder na Comunidade: apenas por convivência entre as diferentes escalas marcada por um incessante entrechoque recíproco é que se mostrava possível encaminhar o destino comum por um tenso controle mútuo.

Deste modo, apesar de sua sintética exposição das condições a serem satisfeitas pela decisão comunitária para que fosse executada nacionalmente, esse dispositivo revelava com vigor o sentido da condução da Europa Politicamente Unida: assumiram-se compromissos e autolimitações recíprocos para assegurar a manutenção de um espaço vazio que ao mesmo tempo (i) preservava a coerção centralizada no âmbito dos Estados, mas impedia a estes a recusa a obedecer mandamento normativo a eles estranho; e (ii) retirava da Comunidade e da supranacionalidade a possibilidade de pretender se organizar em torno da figura de um Estado Europeu, mas lhes assegurava a possibilidade de

\footnotetext{
${ }^{904}$ Isto é, não formado exclusivameten a partir da estatalidade isolada onde seria executado.

905 Isto é, ainda que não fosse uma norma jurídica oriunda de organização jurídico-política que centralizava o exercício da violência (ou ainda, de um Estado).
} 
execução de suas decisões em território nacional. Instaurava-se assim um complexo mecanismo de ancoragem mútua progressivamente mais aprofundada entre as escalas de existência que, mediante sucessivas limitações e contenções, as mantinha em uma dinâmica marcada pela horizontalidade relacional.

7.2.4.1.4. Suspensão da Execução de Decisão da Corte e da Alta Autoridade: Contenção e Horizontalidade Multiescalares

O parágrafo terceiro do artigo 92 estabelecia que a execução das decisões de condenação em território nacional apenas poderia ser suspensa por meio de decisão da Corte. Como poderá ser visto neste item, esta derradeira previsão tinha por objetivo reinstaurar o conflito entre as escalas de existência participantes da vida em comum, seja no âmbito das relações comunitárias, seja no que se refere na contraposição entre supranacionalidade e estatalidade.

Havia aqui um mandamento expresso ao afastamento de série de medidas de existência que compunham a vida comunitária da possibilidade de obstar o andamento do processo de execução das condenações: nem a supranacionalidade da Alta Autoridade, nem a estatalidade do Conselho ou a dos próprios Estados-Membros poderiam impedir a execução da decisão de condenação.

O objetivo dessa disposição era bastante simples: impedir que por vias transversas no interior do âmbito comunitário, cada uma das escalas de existência pudesse visar a romper o delicado equilíbrio institucionalmente construído nas relações entre elas desenvolvidas. A estatalidade intergovernamental do Conselho não poderia pretender influenciar unidimensionalmente, por caminhos alternativos, a execução de uma decisão gerada no interior de uma escala comunitária, cuja exclusividade temática fora assegurada à vida comum pelo Tratado, mediante o compartilhamento de competências normativas.

Assim, não poderiam os Estados-Membros atuar de maneira concertada para impedir estrategicamente a execução de decisão gerada comunitariamente - ainda que fosse desfavorável apenas a sua específica escala de existência, pois isso lhes atribuiria instrumentos que reforçariam sua capacidade de determinação unidimensional sobre o lugar do Direito e do Poder na Comunidade - o que esvaziaria por completo todo sentido buscado pelo Projeto de promoção de uma União Política da Europa. O afastamento da possibilidade de suspensão da execução da sentença freava a estatalidade 
intergovernamental por meio de um repelir absoluto desta em questões cuja competência havia sido atribuída para a Comunidade.

A supranacionalidade da Alta Autoridade também não estava autorizada a determinar absolutamente o destino de suas decisões, pois a concessão desta outra possibilidade poderia vir a reforçar demasiadamente sua capacidade de ação na Europa Unida. Como se poderá ver mais adiante ${ }^{906}$, o rol de competências a ela atribuídas era bastante grande e qualitativamente poderoso $^{907}$ : a atribuição de mais uma forma de intervenção direta e imediata sobre os territórios nacionais poderia implicar a concessão de mecanismos sorrateiros que levariam a seu destacamento sobre as demais medidas de existência na Europa: a seu bel-prazer, poderia determinar o início, a suspensão e o seguimento de suas próprias decisões levadas à execução nos territórios nacionais.

Assim, do mesmo modo que ocorrera com o Conselho, a fim de evitar a desmesura de atribuições à Alta Autoridade, e com o objetivo de assegurar a manutenção de um vazio no lugar do Direito e do Poder nas relações entre as diferentes medidas de existência que compunham a Europa Unida, o Tratado conferira apenas à Corte - um órgão cuja atuação era limitada e reiteradamente marcada pela presença de um Poder "sem Poder""908 - a possibilidade de proferir uma decisão que suspendesse o andamento da execução.

Em outras palavras, se o controle da execução de uma decisão gestada de acordo com uma perspectiva comunitária (multiescalar) deveria ser feito por um órgão comunitário, ele apenas poderia ser desempenhado por um órgão que estivesse tão bem controlado institucionalmente que não poderia ameaçar tomar o lugar do Direito e do Poder na Comunidade. Como visto outrora, de atuação limitada na solução de controvérsias (marcada sempre por normas de oposições escalares que tornava o processo decisório multiescalar), a Corte aparecia assim como o órgão mais apto exercer tal atividade de controle.

É inclusive nesse último sentido que se pode compreender o estabelecimento de conflito entre a supranacionalidade da Corte e a estatalidade isolada dos Estados-Membros. O Tratado determinara que apenas a Corte poderia suspender o andamento da execução nacional da decisão comunitária supranacionalmente formalizada, retirando tal possibilidade do interior de rol de ações possíveis do juiz nacional.

\footnotetext{
906 No item 7.3.1., infra.

907 Apesar de cuidadosamente contido por mecanismos institucionais, de maneira a impedir sua totalização sobre a Europa Unida da CECA, como se poderá ver adiante, no item 7.3.1., infra.

${ }^{908}$ Como visto nos itens anteriores deste item 7.2., a Corte dispunha de meios de ação na vida em comum consecutivamente limitados internamente ou por faculdades atribuídas a outras escalas de existência.
} 
Essa previsão tinha por objetivo conter a ação do juiz executor: a despeito de ele deter o Poder e o Saber sobre o aplicação do procedimento de execução do Estado do qual era juiz e de poder/dever aplicar este ordenamento jurídico nacional no processo de execução, não poderia ele encontrar qualquer argumento de dispositivo de Direito interno que impossibilitasse o seguimento do feito.

Deste modo, o Poder e o Saber derivados do saber aplicar o próprio Direito Processual nacional - valorizado pelo parágrafo segundo do artigo 92 - era imediatamente esvaziado por tal constrição: o juiz nacional não poderia suspender o andamento do processo, mas apenas e tão-somente determinar o seu seguimento - isto é, fazê-lo seguir adiante, para executar a decisão. A possibilidade de o obstar era atribuída a outra entidade de caráter supranacional, é verdade, mas igualmente detentora de um Poder "sem Poder", tamanhas as limitações apostas em cada um dos dispositivos examinados anteriormente.

$\mathrm{Na}$ execução de decisões comunitárias, parcela diminuta da determinação do destino dos processos residia nos juízes nacionais - apenas dar seguimento técnico à aplicação da decisão, conforme o Saber do próprio do Direito nacional. Ou seja, este parágrafo terceiro assegurava a impossibilidade de controle de uma decisão comunitária por parte de uma medida de existência nacional (estatal isolada), na medida em que afastava os Tribunais nacionais e suas respectivas medidas de existência expressas pelo Direito nacional - executor da decisão comunitária - da possibilidade de se imiscuir desautorizadamente na condução uniescalar de questões concretas comuns sensíveis - ou ainda, de questões comunitárias. Afinal, não podendo obstar o andamento da execução, não poderiam em último momento influenciar na efetivação de uma norma jurídica comunitariamente gestada.

Se a suspensão do processo de execução residia nas mãos da Corte, haveria que se notar que isto não implicava um favorecimento de sua escala em detrimento das demais. Como se pôde perceber ao longo dos artigos que disciplinavam o sistema jurisdicional de solução de controvérsias na Comunidade, a Corte jamais determinava por si só o sentido normativo de suas decisões sobre questões comuns: antes, era fundamental a presença de uma intensa multiescalaridade que influenciasse na formalização da decisão pela Corte. Em outras palavras, o Poder de suspensão residia precisamente naquela entidade comunitária que poucos instrumentos detinha para impactar no sentido normativo comum - isto é, na Corte, caracterizada reiteradamente como um órgão detentor de um Poder "sem Poder". 
7.2.4.2. O Significado Jurídico-Político da Execução de Decisões da Corte e da Alta Autoridade: A Opção por uma Horizontalidade Relacional marcada pela Ausência de Coerção

A partir do exposto nos itens anteriores, pode-se perceber que o artigo 92 do Tratado da CECA fora concebido também para conservar a dinâmica Política no desenvolvimento da vida comunitária inaugurada pela CECA. A horizontalidade seria preservada na Comunidade precisamente porque, ao disciplinar a execução de decisões condenatórias formadas comunitariamente, este dispositivo estabelecia que ninguém poderia se autocompreender como detentor de posição privilegiada no lugar do Direito e do Poder na Europa Unida pela CECA - nem mesmo na execução nacional de decisões comunitárias.

Deste modo, se uma medida de existência poderia formalizar a decisão comunitária e, com isso, determinar sua execução e a suspender, ela não deteria condições práticas para efetivar a execução, pois estava desprovida (i) de meios para dar execução à decisão comunitária, na medida em que o regime jurídico processual a ser seguido era o especificado por cada uma das legislações processuais nacionais, (ii) do conhecimento da aplicação do Direito Processual nacional para efetuar a execução nacional da decisão comunitária, e, principalmente, (iii) de instrumentos de coerção que lhe garantissem imediata e diretamente sobre os Estados-Membros a execução e o cumprimento das decisões comunitárias.

Por outro lado, se outra medida de existência tinha assegurado pelo Tratado a possibilidade de dispor de meios que dessem efetividade à execução nacional da decisão comunitária - meios coercitivos e conhecimento especializado sobre o Direito Processual nacional para tanto, ela não apenas (i) estava obrigada a cumprir nacionalmente uma decisão que tinha sido forjada fora do parâmetro exclusivo da estatalidade isolada - sem poder questionar, como também (ii) era incapaz de determinar por si só o início da execução e sua suspensão.

Neste mútuo repelir entre escalas de existência formalizado pelo conjunto do artigo 92 do Tratado da CECA era possível encontrar ainda uma vez permanência da reafirmação institucional de uma Europa Politicamente Unida. Mesmo na execução nos territórios nacionais de decisões comunitárias formalizadas pela Corte e pela Alta Autoridade, as instituições da CECA mantinham um vazio no lugar do Direito e do Poder marcado pela multiescalaridade. 
Deste modo, mais uma vez, pode ser notada a constante aposição de pesos e de contrapesos que apenas permitiam a abertura de um espaço vazio de contenção mútua: freios e bloqueios se limitavam reciprocamente, para que nada e ninguém pudesse totalizar sua escala de existência nas decisões sobre o sentido normativo último das questões concretas sensíveis comuns.

As diferentes escalas de existência continuamente opostas na CECA por virtude de disposição jurídico-normativa positiva nada mais poderiam guardar entre si do que uma relação entre diferentes igualizados, isto é, de diferentes tornados pares comunitários de uma absoluta dinâmica horizontal em virtude de engenhosa arquitetura institucional. Impedindo o destacamento de um e de outro, o Tratado da CECA obstava a transcendentalização de qualquer das escalas de existência participantes da vida em comum. E, com isso, ele conservava mais uma vez a imanência na fundamentação do sentido normativo sobre questões concretas da vida comunitária.

\title{
7.3. Instauração e Conservação do Vazio no Lugar do Direito e do Poder na Comunidade: A Europa Politicamente Unida da CECA e a Multiescalaridade na Formação do Sentido Normativo Comum
}

\begin{abstract}
A ideia de integração na Europa [...] se faz, não somente como organização internacional, mas abrange o conjunto dos estados e das tradições nacionais, amalgamados em novo conjunto [...]. (CASELLA, 2008, p. 219-20).

Community [...] its Member States and the individual. Or should I have written the Member States, their Community and the individual? Or, perhaps, individuals, their States and their Community? There you have it; [the relationship between them] is a lot about power but the permutations of empowerment in European integration are rarely obvious and always fascinating. (WEILER, 2005, p. x).
\end{abstract}

Como visto anteriormente ${ }^{909}$, o Tratado da CECA utilizara em sua articulação institucional da vida em comum normas de oposições escalares segundo duas perspectivas: negativa e positivamente. Os dois itens anteriores ${ }^{910}$ se dedicaram a examinar como as normas de oposições escalares foram arquitetadas visando à manutenção negativa e positiva da imanência na formação do sentido normativo sobre questões concretas comuns sensíveis. Por outro lado, este item tem por objetivo investigar um outro uso positivo de

\footnotetext{
${ }^{909}$ Isto é, no início deste Capítulo.

${ }^{910}$ Itens 7.1. e 7.2., supra.
} 
normas de oposições escalares identificado no Tratado da CECA: a preservação de um vazio no lugar do Direito e do Poder.

Nesse sentido, há que se perceber que neste item será examinada outra espécie de tarefa positiva exercida pelas normas de oposições escalares, a saber, a que se preocupou em criar e promover de maneira contínua os embates entre dimensões existenciais no interior da vida comum na Europa, com o objetivo de fazer perseverar uma dinâmica Política multiescalar na formação do Direito e do Poder que regulamentavam a administração e o uso do carvão e do aço na Comunidade.

Deste modo, a vertente positiva de atuação das normas de oposições escalares estudada neste item 7.3. se dirigiu especificamente à criação e à conservação da condição vazia do lugar do Direito e do Poder mediante contínua repulsão pluriescalar e multilateralmente direcionada do centro normativo da vida comum, quando da determinação do sentido último a ser dado às regulamentações sobre o carvão e o aço previstas pelo Tratado.

Há que se notar desde já que o objetivo desta afirmação normativa de posições escalares consistia em preservar a multiescalaridade no processo nomogenético da Comunidade precisamente mediante a conservação do vazio no lugar do Direito e do Poder. Uma vez que o centro nomogenético da vida comunitária fosse mantido imune à ocupação intemporal por uma escala de existência, a necessidade de agir normativamente sobre questões comuns exigia a permanente tomada de posição. Todavia, esta não poderia ser uniescalar, sob pena de permitir o destacamento sorrateiro de Um sobre os demais e sua inserção Única no lugar do Direito e do Poder.

Dessa forma, a percepção de ser necessário manter vazio o centro nomogenético comum para preservar Leis Políticas associada à necessidade de ação normativa sobre questões concretas sensíveis comuns (administração e uso do carvão e do aço na Europa Unida), convidou à opção por um desenho institucional que favorecesse a tomada de posição normativa mediante conjunção das diferentes escalas de existência implicadas na vida em comum.

$\mathrm{O}$ arcabouço institucional do Tratado da CECA a ser examinado neste item deve ser compreendido como um arco de disposições de normativas de oposições escalares preocupadas em promover a multiescalaridade no centro nomogenético da Comunidade sobre a administração e sobre o uso do carvão e do aço.

Nesse sentido, o destino comum seria obra do entrechoque múltiplo dos diferentes modos de habitar o mundo da Europa Unida pela CECA e, para tanto, fora previsto pelo 
respectivo Tratado um complexo maquinário jurídico-normativo de compartilhamento institucional de deveres de participação entre as dimensões existenciais da Comunidade. Deste modo, seria possível que estas (i) se mantivessem à distância do centro nomogenético (lugar vazio), mas que, ao mesmo tempo, (ii) detivessem condições para decidir em conjunto o sentido normativo comum.

É importante notar que a multiescalaridade incapaz de ocupar intemporalmente lugar do Direito e do Poder não era caracterizada apenas pelo convite multidirecional à participação, mas principalmente por efetiva série de mandamentos normativos que forçavam a convivência tensa entre os diferentes componentes da vida em comum. Esse "convite forçado" à convivência era institucionalmente incitado por consecutivos freios e contrapesos dispostos normativamente uns contra os outros, os quais colocavam as diferentes escalas de existência umas perante as outras para que contrapusessem suas perspectivas sobre a questão concreta sensível comum e, com isso, para que pudessem formar em conjunto (isto é, multiescalarmente) um sentido normativo sobre questões envolvendo a administração e o uso do carvão e do aço ${ }^{911}$.

Os dois itens a seguir examinarão dois modos distintos encontrados pelo Tratado para afirmar um vazio no lugar do Direito e do Poder na Comunidade.

O item 7.3.1. terá por objeto o Direito Positivo Comunitário Originário da CECA que disciplinou o conjunto normativo do Título Terceiro do Tratado, intitulado Disposições Econômicas e Sociais, em seus artigos 57 a $67^{912}$. O item 7.3.2. terá por objeto também o

${ }^{911}$ Essa afirmação será mais bem compreendida a partir da leitura da integralidade do item 7.3.1., infra.

912 É importante notar que as Disposições Econômicas e Sociais do Tratado da CECA se iniciam no artigo 46 e terminam no artigo 75, tendo sido divididas em dez Capítulos.

De acordo com a observação do texto principal, foram desconsiderados por este trabalho os artigos 46 a 48, referentes ao Capítulo Primeiro, intitulado Disposições Gerais, os artigos 49 a 53, referentes ao Capítulo Segundo, intitulado Disposições Financeiras, e os artigos 54 a 56, referentes ao Capítulo Terceiro, intitulado Investimento e Auxílios Financeiros. A exclusão destes onze artigos do Título Terceiro do Tratado deriva precisamente do fato de que eles não trazem em sua disciplina normativa a preocupação em promover oposições escalares.

Deste modo, a análise jurídico-Política das normas jurídicas de conteúdo econômico do Tratado da CECA se debruçaria apenas sobre aquelas que se encontravam nos sete últimos Capítulos do Título Terceiro do Tratado da CECA (Capítulos IV a X), os quais eram disciplinados pelos artigos 57 a 75.

Todavia, não se pode ignorar que, mesmo dentre esses dezenove artigos, há alguns que também não foram comentados pelo presente estudo, pois não se preocupavam diretamente com o problema das relações de Poder - em torno do lugar do Direito e do Poder - entre as escalas de existência componentes da Europa Unida pela CECA. A coerência metodológica deste estudo exige que se centre apenas nas normas de oposições escalares e que, portanto, se quede silente nas próximas páginas sobre os artigos localizados entre o 57 e o 75 que não se incluíam no recorte estipulado para o presente trabalho.

Ao mesmo tempo, há que se observar que os itens a seguir não comentaram os artigos 68 a 75 do Tratado da CECA, mas por outros motivos. Com efeito, apesar de estes se encontrarem dentro do recorte do metodológico estipulado para o presente estudo - isto é, apesar de preverem normas de oposições escalares, estes 8 (oito) artigos foram deixados de lado por esta Tese. 
Direito Positivo Comunitário Originário da CECA, mas analisará apenas dois artigos - os artigos 96 e 99 - do Título Quarto do Tratado, intitulado Disposições Gerais. Se o primeiro esclarecerá o arranjo institucional do procedimento originariamente direitificado de formação de normas comunitárias derivadas sobre a administração e uso do carvão e do aço na Comunidade, o último evidenciará o papel especificamente concedido à populidade na fundação da vida comum.

Isso porque os artigos 68 a 75 do Tratado da CECA repetem a racionalidade jurídico-Política da regulação estabelecida pelos artigos 57 a 64 - manejo jurídico-Político da formação do sentido normativo a ser dado sobre situações concretas sensíveis comuns que poderiam impactar na formação dos preços do carvão e do aço na Comunidade (como será visto no item 7.3.1.1.3., infra).

Deste modo, para evitar a repetição desnecessária da argumentação desenvolvida em torno dos artigos 57 a 64 do Tratado da CECA, optou-se metodologicamente por não comentar os artigos 68 a 75 do mesmo Tratado. Afinal, apesar de se dirigirem a situações específicas diferentes, a racionalidade de orientação jurídico-Política de tais normas jurídicas de conteúdo econômico é semelhante.

Composto pelos artigos 68 e 69, o Capítulo VIII regulamentava o regime de definição de salários e a circulação de mão-de-obra na Comunidade, ao passo que, composto apenas pelo artigo 70, o Capítulo IX disciplinava o regime de transportação do carvão e do aço no interior da CECA. Estes dois conjuntos normativos determinavam a possibilidade de uma resposta normativa comunitária - isto é, da multiescalarmente conflitiva vida em comum - sobre os salários, sobre a circulação de mão-de-obra e sobre o transporte do carvão e do aço quando estes aspectos impactassem no sistema de formação de preços de tais produtos comunitarizados.

O Capítulo X do Título Terceiro do Tratado da CECA era composto pelos artigos 71 a 75 . Seus dispositivos jurídico-normativos eram responsáveis pela definição de um sistema de relações conflitivas entre os diferentes participantes da vida em comum para que estes pudessem decidir, em conjunto, o sentido normativo comunitário a ser dado sobre as Políticas Comerciais nacionais. O objetivo desta regulamentação consistia em criar condições institucionais que impedissem comunitariamente decisões uniescalares acerca dos direitos aduaneiros estatais incidentes sobre o carvão e o aço.

A argumentação em torno destes 8 (oito) artigos apenas reitera redundantemente a argumentação feita linhas abaixo aos artigos 57 a 64 de que normas jurídico-econômicas teriam sido apostas tendo em vista uma orientação jurídico-Política. Por isso, mostra-se desnecessária a inclusão dos comentários a tais artigos no texto do trabalho.

Em outras palavras, apesar de estes 8 (oito) artigos reforçarem o argumento de que por trás das normas jurídicas de conteúdo econômico havia uma complexa engenharia institucional de orientação jurídico-Política - dada por normas de oposições escalares - da produção normativa derivada, a ausência deles na Tese não prejudica em nada na corroboração desta conclusão - pois, com efeito, se tivessem sido incluídos no texto do trabalho, tais artigos teriam o condão de apenas tornar mais robusto o argumento, mas jamais de o modificar.

Assim, para evitar uma supérflua repetição ad nauseam dos mesmos argumentos - que apenas aumentaria desnecessariamente ainda mais a extensão do texto do trabalho e que poderia gerar uma indisposição intelectual por parte do leitor, cansado de argumentos semelhantes sobre situações semelhantes, optou-se por não comentar neste trabalho os artigos 68 a 75 do Tratado da CECA. E, deste modo, por meio da exclusão destes 8 (oito) artigos - referentes aos Capítulos VIII, IX e X do Título Terceiro do Tratado da CECA, pode-se concluir que o presente trabalho analisará nas linhas a seguir apenas os artigos que, entre os Capítulo IV, V, VI e VII do Título Terceiro do Tratado da CECA - isto é, entre os artigos 57 a 67, inclusive - contiverem normas de oposições escalares. Como será mais compreendido nos itens a seguir. 
7.3.1. A Camada Jurídico-Política das Regras Jurídico-Econômicas da CECA: O Sentido Normativo Econômico e o Não-Sentido Jurídico-Político

Antes de iniciar propriamente o comentário à disposições normativas constantes do Título Terceiro do Tratado da CECA, é importante relembrar ressalva feita no início deste trabalho $^{913}$ sobre a possibilidade de se conferir interpretação jurídico-Política a normas jurídicas de conteúdo econômico.

Não se pode ignorar que o conjunto normativo das Disposições Econômicas e Sociais é composto precipuamente por normas jurídico-econômicas - esquecer essa condição consistiria em um insincero e indevido falseamento. Todavia, como visto anteriormente, a dimensão econômica das normas jurídicas do Tratado da CECA é apenas uma possibilidade de leitura adstrita à materialidade do significante jurídico-normativo positivo, sendo possível atribuir uma significação jurídico-Política que não anula a interpretação jurídico-econômica.

Nesse sentido, os próximos subitens procurarão desvelar a camada de significação jurídico-Política em torno de tais normas jurídicas, sem pretender invalidar ou desqualificar as interpretações jurídico-econômicas possíveis que outros estudos poderiam pretender enfatizar em suas análises. O que ocorre neste trabalho é que a chave de leitura metodologicamente escolhida ilumina aspectos distintos de um e mesmo fenômeno, isto é, algo desprovido de qualquer essência pré-determinada e predeterminante de um sentido único, essencial, primevo, intangível, pétreo, imutável.

Por fim, destaque-se ainda que a análise a ser desenvolvida nos itens abaixo não necessariamente seguirá a ordem dos artigos interpretados, tal qual eles aparecem no texto do Tratado. Se em grande parte da interpretação a seguir a divisão da estrutura deste trabalho acompanhará a estrutura constante do Tratado, em alguns momentos haverá uma realocação analítica dos artigos examinados para agrupar tematicamente os comentários. O objetivo desses agrupamentos temáticos consiste em tentar facilitar a compreensão das reflexões empreendidas neste estudo por parte do leitor.

A análise a seguir mostrará que o conjunto de artigos que disciplinava (i) a administração e o uso do carvão e do aço na Europa Unida da CECA e (ii) o respectivo campo de atuação normativa atribuído sobre esta temática às medidas de existência

913 Item 3.1., supra, ao qual remetemos o leitor para relembrar as reflexões metodológicas fundamentais desenvolvidas sobre a questão. Estas serão apenas retomadas aqui rapidamente, para garantir que esteja dissipada a dúvida sobre tal possibilidade interpretativa. 
participantes da vida em comum se preocupou em definir entre as dimensões existenciais os recíprocos âmbitos de competência e de incompetência e os correlatos mecanismos de contenção mútua.

Será possível perceber que a distribuição dos deveres de participação na formação do sentido normativo comunitário mediante atribuição de mecanismos de contenção recíprocos não foi prevista para supostamente preservar eventual exclusividade de atuação de uma ou de outra medida de existência, mas para assegurar o constante equilíbrio conflitivo multiescalar voltado a fazer perseverar o Político na CECA mediante a conservação do vazio no centro nomogenético.

7.3.1.1. Os Capítulos IV e V do Título Terceiro do Tratado da CECA: A Disciplina Jurídico-Política da Produção e do Consumo do Carvão e do Aço na Comunidade

Os Capítulos IV e V do Título Terceiro do Tratado da CECA são responsáveis em conjunto pela regulamentação da produção e do consumo do carvão e do aço na Europa Unida pela CECA - o que justifica o agrupamento dos comentários aos seus respectivos dispositivos normativos neste mesmo item ${ }^{914}$.

A disciplina jurídico-Política minuciosa subjacente a tais normas jurídicoeconômicas se apresentará de maneira mais evidente à medida que se seguir a leitura dos comentários abaixo. Será possível perceber que a disciplina das competências das entidades participantes da vida em comum sobre a administração e sobre o uso de tais recursos escassos estava orientada pela (i) conservação do vazio no lugar do Direito e do Poder e (ii) opção de formação multiescalar do sentido normativo a ser impresso sobre as decisões envolvendo (a) níveis de produção diante da variação do grau de consumo do carvão e do aço na Comunidade e (b) formação do sistema de preços deste setor econômico.

O Capítulo IV do Título Terceiro do Tratado da CECA compreendia os artigos 57 a 59. Como será visto no item seguir, o artigo 57 estabelecia a chave de compreensão do conjunto normativo abrangendo os Capítulos IV e V do Título Terceiro do Tratado da CECA. Os artigos 58 e 59 deste Capítulo IV regulamentavam normativamente a arena de

\footnotetext{
${ }^{914}$ A justificativa jurídico-normativa do agrupamento dos Capítulos IV e V do Título Terceiro do Tratado da CECA é dada pelo artigo 57 do mesmo Tratado, tal qual examinado no item 7.3.1.1.1., infra, ao qual remetemos o leitor.
} 
embates escalares referentes à produção do sentido normativo a ser dado à decisão sobre a produção do carvão e do aço frente à redução ou ao aumento do consumo na Comunidade.

O Capítulo V do Título Terceiro do Tratado da CECA compreendia os artigos 60 a 64. Este conjunto de artigos disciplinava os embates multiescalares em torno da produção do sentido normativo subjacente ao sistema de formação de preços do setor econômico do carvão e do aço. Seus dispositivos normativos foram responsáveis por uma complexa arquitetura de um campo de intensas oposições escalares voltada a permitir a formação de uma resposta comunitária - e, portanto, oriunda de um lugar vazio do Direito e do Poder a potenciais determinações unilaterais dos preços a serem praticados em torno dos recursos escassos tornados comuns.

Os próximos itens analisarão de maneira circunstanciada cada um dos aspectos acima destacados ${ }^{915}$.

O item 7.3.1.1.1. explicitará como o artigo 57 do Tratado da CECA operava como chave de leitura jurídico-Política geral para compreender a disciplina jurídico-econômica da produção e do consumo do carvão e do aço - isto é, dos Capítulos IV e V. O item 7.3.1.1.2. terá por objeto a compreensão do regime jurídico específico do Capítulo IV (artigos 58 e 59) voltado à regulamentar a nomogênese multiescalar relativa aos níveis de produção frente à variação dos níveis de consumo do carvão e do aço na Comunidade. $\mathrm{O}$ item 7.3.1.1.3. se debruçará sobre o conjunto normativo do Capítulo V (artigos 60 a 64), referente aos embates multiescalares em torno do sistema de formação de preços do setor econômico do carvão e do aço.

7.3.1.1.1. A Chave de Compreensão da Disciplina da Produção e do Consumo do Carvão e do Aço: O Artigo 57 do Tratado da CECA

O caput do artigo 57 estabelecia que a Alta Autoridade deveria preferencialmente utilizar meios de ação indireta para atuar sobre a produção do carvão e do aço. Nesse sentido, (i) para regularizar ou influenciar o consumo geral de tais recursos, deveria a Alta Autoridade cooperar com os Governos nacionais (primeira alínea), enquanto que, (ii) a atuação da Alta Autoridade sobre o setor econômico se limitava a intervenções

\footnotetext{
915 Estes dois eixos analíticos são o grande fio condutor da análise dos itens a seguir. Não se deve compreender, todavia, que o estabelecimento destes grandes campos estruturais de comentários possa impedir o exame de questões laterais que eventualmente possam surgir quando da interpretação empreendida individualmente nos itens a seguir. O foco dos próximos itens será, contudo, a explicitação destes dois eixos temáticos principais, sendo suscitadas discussões laterais apenas para indicar futuras possibilidades de aprofundamento investigativo em trabalhos posteriores sobre o tema.
} 
pontuais - e nos limites estabelecidos pelo Tratado da CECA, sobre a formação do sistema de preços e sobre a definição das Políticas Comerciais nacionais sobre a produção do carvão e do aço (segunda alínea).

A lógica de atuação atribuída à Alta Autoridade na disposição acima era a da nãointervenção direta ou automática. A Alta Autoridade deveria manter com os EstadosMembros uma posição de coordenação no que se refere à regulamentação do consumo geral do carvão e do aço, e ela era autorizada a atuar sobre os preços apenas da maneira como estabelecida pelo Tratado da CECA.

Isso implica em reconhecer desde já que, ao inaugurar a série de dispositivos destinados a regulamentar jurídico-economicamente o uso e a administração do carvão e do aço, o Tratado da CECA definia já neste pórtico de entrada a chave de leitura da atuação da vida em comum sobre estes recursos escassos. A resposta deveria se dar comunitariamente, isto é, a decisão sobre o sentido a ser impresso normativamente sobre o carvão e o aço seria estabelecida pela concertação entre iguais e mediante o concurso de diferentes escalas de existência. E, nos casos de exceção, em que a Alta Autoridade poderia intervier diretamente, o Tratado não descuidaria de intensas limitações à ação dela por meio de série de dispositivos que se voltariam à contenção desta.

Dessa forma, apesar de uma suposta larga atribuição de Poder nomogenético à escala supranacional sobre o setor do carvão e do aço ${ }^{916}$, o Tratado definia ser a regra da lógica de sua atuação a coordenação com as estatalidades, ou ainda, a nãointervenção direta da Alta Autoridade nos territórios dos Estados-Membros da CECA.

Isso significava que, em tempos de normalidade ${ }^{917}$, o Tratado reservava ainda às estatalidades os meios de ação direta sobre a produção relacionada aos choques de consumo e sobre os preços. À Alta Autoridade caberia apenas atuar em conjunto com os Estados-Membros, sem poder assumir de antemão a pretensão de determinar

\footnotetext{
916 Conforme leitura dada tradicionalmente pelo pensamento jurídico nacional e internacional, como mencionado diversas vezes neste trabalho, principalmente na nota de rodapé 202, supra.

${ }^{917}$ A ideia aqui expressa por "tempos de normalidade" é mais compreendida a partir dos comentários aos demais artigos do Tratado da CECA a serem examinados ao longo do item 7.3.1.1. Basta aqui um rápido resumo, para encaminhar o raciocínio.

A regra geral do Tratado da CECA nestes dispositivos era a de determinar a não-intervenção direta da Alta Autoridade (item 7.3.1.1.1.1.). Todavia, a partir do momento em que se poderia verificar a superveniência de crises profundas, o Tratado da CECA disciplinava mecanismos de intervenção direta da Alta Autoridade no território dos Estados-Membros, mas não de maneira uniescalar (itens 7.3.1.1.2. e 7.3.1.1.3, infra) - isto é, não sobre os Estados-Membros, em desconsideração das estatalidades. O Tratado da CECA continuaria primando, desde os tempos de normalidade, até os tempos de exceção, pela preservação da multiescalaridade e pelo vazio do lugar do Direito e do Poder na Comunidade. Como se poderá ver, oportunamente.
} 
unilateralmente, a partir da própria escala de existência supranacional, o sentido normativo a ser dado sobre tais questões concretas sensíveis comuns.

Exatamente no primeiro artigo do conjunto de Capítulos destinado ao estabelecimento específico das competências da atuação da Alta Autoridade no domínio, o Tratado esvaziava esse Poder - comumente compreendido como tendo sido absolutamente transferido dos Estados-Membros à Alta Autoridade ${ }^{918}$. Todavia, a medida supranacional deste se revelava como detentora da capacidade de um Poder "sem Poder", ou ainda, de um Poder extremamente limitado, tendo em vista que, em regra, nos momentos de normalidade, não poderia determinar normativamente e de forma direta a produção e os preços em torno do carvão e de aço no interior do território dos EstadosMembros.

Perceba-se, assim, este primeiro campo significativo deste arcabouço normativo: as instituições previstas no Tratado não se orientariam no sentido de totalizar uma uniforme escala de existência supranacional na definição regulatória da produção e da formação do sistema de preços sobre o específico setor econômico abrangido tematicamente pelo Tratado. Antes, a principal preocupação deste era afastar a possibilidade de uma nãoautorizada tomada do lugar do Direito e do Poder que pudesse impor uma súbita verticalização nas relações entre as escalas de existência da Europa Unida em favor da supranacionalidade da Alta Autoridade.

Este dispositivo normativo sinalizara assim uma recusa de antemão a uma preferência apriorística, absoluta e incondicional a um sentido normativo formulado no interior da escala de existência supranacional da Alta Autoridade. Por esse motivo, a presença desta na regulação cotidiana dessa atividade econômica se orientava por uma lógica cuja regra era a da não-intervenção direta. Dito de outro modo: diferentemente do que se poderia esperar a partir da leitura oferecida pela tradição, de pronto, no início das disposições jurídico-econômicas do Tratado da CECA, a Alta Autoridade sofrera um bloqueio vigoroso contra um eventual movimento de tomada do lugar do Direito e do Poder.

Deste modo, neste momento o Tratado declarara de antemão o afastamento da Alta Autoridade. Todavia, o Tratado não procurara unidimensionalizar o lugar do Poder e do Direito na regulação da atividade econômica do setor produtivo do carvão e do aço a partir

\footnotetext{
918 Isto é, como compreende a literatura jurídica tradicional nacional e estrangeira, já mencionada na nota de rodapé 202, supra.
} 
de uma medida uniescalar - fosse ela supranacional, fosse ela estatal isolada ou intergovernamental.

Com efeito, se as normas do Tratado buscavam manter o vazio no lugar do Direito e do Poder e a multiescalaridade de sua determinação na Europa Politicamente Unida da CECA, seus dispositivos institucionais não apenas afastavam a supranacionalidade da Alta Autoridade do centro nomogenético, mas também as estatalidades. E, nesse sentido, há que se notar que tais normas promoviam uma oposição vigorosa entre as diferentes medidas estatais, de maneira a assegurar que pela repulsão mútua, nenhuma delas poderia totalizar unidimensionalmente o lugar do Direito e do Poder. Não apenas a supranacionalidade era afastada, como também toda e qualquer estatalidade era mantida igualmente à distância.

Note-se a presente decorrência da regra geral estabelecida pelo artigo 57: em tempos de normalidade, o afastamento da possibilidade de a Alta Autoridade interferir mediante normas e de maneira direta sobre o carvão e o aço no interior dos territórios dos Estados-Membros implicava a preservação em cada Estado-Membro da competência exclusiva de tratar diretamente sobre este tema em seus respectivos territórios. Afinal, a Alta Autoridade apenas poderia intervir cooperativamente, e de acordo com as limitações estabelecidas pelo Tratado.

Ao mesmo tempo, o Tratado também procurou evitar conceder qualquer preferência a priori a uma específica regulação jurídico-econômica na Comunidade dada por uma escala de existência estatal, isolada ou conjuntamente: cada Estado-Membro seguiria sua própria tradição jurídico-econômica e poderia estabelecer a si próprio uma determinada orientação. Isso significa que se assegurou a impossibilidade de haver o direcionamento unidimensional do sentido das regulações jurídico-econômicas a partir de uma escala de existência estatal em particular - nem mesmo a intergovernamental.

Assim, os Estados-Membros se contraporiam e se anulariam mutuamente e a Alta Autoridade, apesar de dever atuar sobre as questões comuns, não poderia jamais pretender se impor normativamente sobre os Estados-Membros, mas sim apenas agir em regime de cooperação. Da mesma forma, não poderiam os Estados-Membros impedir uma intervenção indireta e cooperativa por parte da Alta Autoridade, tendo em vista que essa margem de atuação lhe fora assegurada pelo Tratado da CECA. Imunizara-se o lugar do Direito e do Poder na Comunidade da potencial unidimensionalização supranacional ou de uma totalização por parte de uma ou outra estatalidade e conservaram-se o vazio e a multiescalaridade na orientação do sentido normativo sobre questões concretas comuns. 
Todavia, não era este o regime a ser seguido quando dos momentos de ruptura das situações de normalidade. O caput do artigo 57 do Tratado da CECA determinava expressamente que a Alta Autoridade "de preferência" pautaria sua ação no sentido de influenciar na atividade produtiva de carvão e aço por meio do uso de mecanismos indiretos. Haveria, assim, uma autorização para o recurso a outras espécies de instrumentos mais diretos e mais incisivos, mas apenas e tão somente em situações específicas, para orientar a atividade econômica de carvão e de aço na Europa Unida: nas situações de crises econômicas sofridas no setor.

Nestas situações de exceção, o esvaziamento do Poder de ação normativa atribuído à Alta Autoridade também deveria encontrar limites, pois de nada adiantaria deixar nas mãos dos Estados-Membros a condução por si só, isoladamente, das decisões normativas a serem impressas sobre a administração e o uso dos recursos escassos em seus territórios $^{919}$. Isso poderia ensejar o surgimento da anacrônica percepção de que as estatalidades deteriam na vida em comum uma preferência absoluta e a priori no lugar do Direito e do Poder.

Por isso mesmo, nestas situações de crise econômica ${ }^{920}$, o Tratado procurou afastar as estatalidades isoladas do interior do centro nomogenético comunitário por mecanismos institucionais ainda mais vigorosos, os quais contraporiam não apenas as estatalidades isoladas entre si, mas estas e os demais participantes comunitários. Afinal, o destino sobre questões comuns deveria ser dado a partir de perspectiva comum, ou seja, a partir da consideração multiescalar das diferentes dimensões existenciais componentes da Comunidade - o que revelava o intento institucional de reforçar o vazio no lugar do Direito e do Poder enquanto meio e fim da Europa Politicamente Unida.

Neste particular, é importante perceber que, ao estipular hipóteses nas quais, em momentos de profunda calamidade, era autorizada a exceção à regra da não-intervenção direta da medida supranacional da Alta Autoridade sobre os recursos escassos localizados no interior dos territórios dos Estados-Membros, o Tratado não previra um regime excepcional - isto é, não se colocavam em suspenso as Leis Políticas da Europa.

Pelo contrário, como se poderá ver, os momentos de crise eram especialmente as situações em que a validade das Leis era ainda mais vigorosamente reafirmada pelo Tratado da CECA, na medida em que as instituições da Europa Unida conclamavam às

\footnotetext{
${ }^{919}$ Após a traumática experiência da Segunda Guerra Mundial, não haveria como se pensar em acreditar na preservação de um sistema institucional de Direito Internacional calcado no paradigma da coexistência. Sobre este paradigma, remetemos o leitor à nota de rodapé 2, supra.

${ }^{920}$ A serem minuciosamente examinadas nos itens 7.3.1.1.2. e 7.3.1.1.3., infra.
} 
escalas de existência a se articular de maneira ainda mais minuciosamente tensa, visando à preservação de uma dinâmica Política na Europa Unida pela CECA - vazio no lugar do Direito e do Poder e multiescalaridade na definição do sentido normativo.

Assim, as hipóteses previstas no texto do Tratado de tangibilidade da resguardada esfera de competência dos Estados-Membros não eram mecanismos sorrateiramente permissivos de um estado de exceção, isto é, que autorizavam a instauração de uma ordem uniescalar temporária e excepcional ditada pela medida da supranacionalidade. Antes, elas se revelavam como disposição institucional voltada a afirmar comunitariamente a necessidade de se manter continuamente revitalizada a dinâmica da Política enquanto meio e fim para se conservar a Europa Unida pela CECA, sem haver preferência por quaisquer das medidas que a compunham.

A análise dos itens a seguir permitirá perceber que a orientação institucional do Tratado da CECA consistiu em assegurar que, mesmo nestes momentos em que se abrira a possibilidade à Alta Autoridade de intervir diretamente sobre a (i) produção de carvão e de aço na Comunidade (primeira alínea), e (ii) formação do sistema de preços desse setor (segunda alínea), seria mantida a busca constante de promover e de preservar institucionalmente a Política na Europa Unida. Em outras palavras, seriam preservadas as Leis Políticas vigentes na Comunidade.

7.3.1.1.2. A Nomogênese Multiescalar nas Crises de Produção e de Consumo de Carvão e de Aço na Comunidade nos Artigos 58 e 59 do Tratado da CECA

\subsection{Observações Gerais Comuns aos Artigos 58 e 59}

A atuação direta da Alta Autoridade sobre a produção de carvão e de aço na Comunidade era prevista separadamente nos artigos 58 e 59 do Tratado da CECA. Apesar de cada um deles se dedicar a uma situação crítica específica, é apenas a partir de uma interpretação conjunta de ambos que se pode visualizar adequadamente a motivação Política dessa previsão institucional.

A Alta Autoridade estava autorizada a atuar diretamente sobre a produção do carvão e do aço na Comunidade em duas situações emblemáticas e opostas de grave crise econômica manifesta, a saber: (i) crise de superprodução de carvão ou de aço (ou redução da demanda, nos termos do artigo 58, parágrafo primeiro); ou (ii) crise de sub- 
produção de carvão ou de aço (ou profunda escassez de alguns ou de todos os produtos submetidas à vida comunitária, nos termos do artigo 59, parágrafo primeiro).

Essas duas situações consistiam precisamente naquelas em que os meios de ação indiretos previstos no artigo 57 não permitiam superar a crise ${ }^{921}$. Nesse sentido, o equilíbrio Político estabelecido pelo arcabouço institucional no artigo $57^{922}$ deveria ser modificado para um constituir um equilíbrio Político novo, qualitativamente distinto do anterior - mas que assegurasse a permanência de uma dinâmica Política na Comunidade por meio de um constante vazio no lugar do Direito e de Poder.

O Tratado da CECA efetuara aqui uma inventiva imaginação institucional Politicamente motivada: diante de uma situação fundamentalmente grave, ele se preocupara em efetuar renovada articulação entre as instituições da Comunidade para colocar em novos termos Políticos as relações entre as escalas de existência que compunham a vida em comum. A engenhosa articulação institucional era a forma encontrada pela Europa Política da CECA em assegurar a previsão de meios suficientemente aptos a conceder respostas efetivas a situações de grave crise no interior da própria Comunidade, sem implicar o abandono do sistema de convivência entre diferentes instaurado pela CECA.

Os artigos a serem comentados promoviam em momentos de crise uma modificação da articulação institucional do Tratado sem efetuar uma alteração do modo Político como as instituições se articularam. Se diante da situação de crise tinha sido fundamental prever mecanismos para responder eficazmente a tais rupturas da normalidade, a necessária rearticulação institucional não poderia ignorar a preservação do móvel Político das Leis que regiam multiescalarmente o processo nomogenético de crise na Europa Unida pela CECA.

Como se poderá ver na análise dos itens a seguir, ainda que de maneiras distintas, os dois artigos determinaram a reorganização das instituições para que as crises fossem lidadas em conjunto pelas diferentes escalas de existência. O Tratado não procurara pacificar a contraposição de modos de habitar o mundo por um critério escolhido como $a$ priori para reger as decisões em tais momentos de crise. Antes, ele estipulara maneiras outras para reafirmar a divisão entre escalas e para garantir, por meio de mecanismos adicionais de oposições escalares, que seria estabelecida multiescalarmente série de

${ }^{921}$ Essa construção encontra na versão francesa do Tratado da CECA a mesma redação nos artigos 58 , parágrafo primeiro, e 59, parágrafo primeiro: "les moyens d'action prévus à l'article 57 ne permettent pas d'y faire face".

${ }_{922}$ Examinado rapidamente no item 7.3.1.1.1., supra. 
decisões sobre o sentido a ser impresso normativamente para que a grave situação sobre a administração e o uso do carvão e do aço na Comunidade em momentos de crise fosse comunitariamente lidada.

Tratava-se, assim, da percepção da necessária busca constante de reinvenção Política de modos de se estabelecer um novo mecanismo institucional que preservasse o vazio no lugar do Direito e do Poder mediante o impedimento do enraizamento de qualquer escala de existência naquele centro nomogenético comum. Eventual alegação de necessárias centralização e totalização uniescalares em virtude de momentos de crise não poderia ser suficiente para que as instituições deixassem de responder Politicamente para a preservação da própria vida em comum. As instituições deveriam prever a mudança dos termos segundo os quais o equilíbrio e o respectivo vazio no lugar do Direito e do Poder seriam produzidos, mas jamais poderiam eliminar a necessidade ela mesma de que, em uma organização jurídico-Política, eles deveriam ser conservados.

7.3.1.1.2.2. O Artigo 58 do Tratado da CECA e a Tutela Jurídico-Política da Superprodução de Carvão e de Aço

7.3.1.1.2.2.1. A Contenção Recíproca entre Supranacionalidade da Alta Autoridade e Estatalidades

Nos termos do artigo 58, parágrafo primeiro, do Tratado da CECA, nas hipóteses de crise de superprodução derivada de vertiginosa queda na procura por carvão e aço, a Alta Autoridade poderia instaurar um regime de cotas de produção. Para tanto, não apenas deveria ser consultado o Comitê Consultivo, como também o Conselho deveria emitir parecer favorável sobre tal decisão da Alta Autoridade. O objetivo desta disposição consistia em estabelecer um teto de produção por empresa, a fim de assegurar a manutenção de um adequado atendimento à procura daqueles recursos.

A disposição deste primeiro parágrafo especificava o limite de ação da Alta Autoridade e dos Estados-Membros sobre a determinação da produção de carvão e aço na Comunidade, nos casos críticos de superprodução. Em tais situações de vertiginosa redução de demanda, estavam absolutamente proibidos os Estados-Membros de efetuar isoladamente escolhas sobre esse setor econômico. Em outras palavras, as estatalidades isoladas estavam impedidas de fornecer uma resposta normativa "nacional" ao problema 
econômico que dizia respeito a todos - restando afastada assim a possibilidade de determinação unilateral de uma Única solução estatal para este problema comunitário.

Nesse sentido, este primeiro parágrafo afastava a possibilidade de se inserir no lugar do Direito e do Poder da Comunidade a perspectiva estatal isolada: os EstadosMembros estavam impedidos de se lançar em direção a soluções estatais corrosivamente auto-interessadas em torno da problemática de buscar escoar forçadamente a produção. Antes, nestes momentos de grave e forte crise, atribuía-se à Alta Autoridade a possibilidade de deflagrar uma condução comunitária do aparelho produtivo comum de carvão e aço, de maneira a impedir que uma perspectiva estatal privilegiada (isolada ou concertada) pudesse pretender solucionar absoluta e homogeneamente - sob uma perspectiva inteiramente favorável a si própria - a crise econômica.

Perceba-se que essa disposição evitava não apenas o destacamento de Uma parcial medida de existência estatal sobre as demais, isto é, pretendia afastar uma possível unidimensionalização estatal. Além deste desestímulo à ascensão privilegiada de uma perspectiva estatal e de seu exclusivo modo de experienciar o mundo, o Tratado buscava enfatizar que a solução da crise econômica deveria ser dada por meio do conflito escalar no interior das instituições Políticas da CECA.

Apostava-se assim na reafirmação da necessidade de se manter o sistema de convivência entre diferentes escalas de existência, as quais deveriam permanecer constantemente preocupadas com a decisão comum sobre questões concretas sensíveis. $\mathrm{O}$ Tratado mostrava articular suas instituições para instaurar um compartilhamento de deveres de participação multiescalar na formação do sentido normativo comum sobre questões comuns, a fim de preservar, por meio de oposições escalares intensas, a pluriescalaridade na decisão sobre o encaminhamento da crise econômica.

Ao primar pela direção multiescalarmente formada também neste momento, o Tratado sinalizava ainda uma vez sua preocupação em preservar o vazio no centro nomogenético da Comunidade.

Com efeito, o Tratado atribuíra à Comunidade - e não a uma medida de existência específica - a incumbência de conduzir o conjunto para uma solução que, orientada senão pelo conflito, pudesse lidar com a crise econômica instaurada. Caberia ao espaço vazio de produção do Direito e do Poder na CECA - mediante interação tensiva entre as diferentes escalas de existência participantes da vida em comum - arquitetar uma solução que considerasse o conjunto das medidas de existências. Mais simplesmente, a Comunidade como um todo - e não qualquer estatalidade (isolada ou intergovernamental), ou qualquer 
supranacionalidade (Alta Autoridade ou Corte) - se ocupava com a promoção e a solução Políticas da crise econômica.

É dessa maneira que se deve compreender a transferência da capacidade decisória dos Estados-Membros à Comunidade sobre este setor econômico estratégico: reconhecedores de que qualquer solução nacionalmente gestada deteria a indelével marca exclusiva da perspectiva estatal isolada, quando da elaboração do Tratado, os EstadosMembros se retiraram da possibilidade de determinar por si só o sentido de tais decisões. A Comunidade - representada pelo espaço comum vazio em torno do qual cada escalas de existência deteria deveres de participação - deveria em conjunto sobre tais questões decidir.

Para compreender melhor a reflexão acima suscitada, é necessário retomar o texto do artigo 58. A decisão sobre o sentido normativo a ser impresso sobre a questão concreta comum sensível seria formada no interior daquele espaço vazio, mediante o entrechoque de diferentes escalas de existência. E, para que o embate escalar pudesse ser deflagrado, o dispositivo em análise concedia alternativamente a iniciativa à Alta Autoridade (supranacionalidade) ou aos Estados-Membros (estatalidade isolada).

$\mathrm{O}$ artigo 58, parágrafo primeiro, primeira parte, determinava que, nos casos de superprodução, à Alta Autoridade incumbia instaurar um regime de cotas de produção. Em um primeiro momento, isso poderia ser interpretado como concessão de efetivo grande Poder à Alta Autoridade: tratar-se-ia de um mecanismo por meio do qual se permitiria a introdução sorrateira da possibilidade de sua escala de existência se destacar sobre as demais participantes da vida em comum.

Seguindo-se tal raciocínio, poder-se-ia rapidamente concluir que, ao poder definir unilateralmente o regime de produção de empresas localizadas no interior do território dos Estados-Membros da CECA, a Alta Autoridade teria sido agraciada com instrumento potencialmente ameaçador do delicado equilíbrio Político da Europa Unida pela CECA: em outras palavras, ela poderia impor sua supranacionalidade sobre as diferentes estatalidades isoladas, ou mesmo, desconsiderá-las.

Todavia, diferentemente do que se poderia concluir de maneira apressada, a Alta Autoridade não podia definir cotas de produção unilateralmente, isto é, ela não tinha garantido em seu favor um Poder de se substituir inteiramente às perspectivas estatais isoladas. Na verdade, o Tratado havia previsto série de contenções ao exercício de tal faculdade por parte da Alta Autoridade, contenções que impediriam a formulação de qualquer solução para a crise econômica fora de uma lógica propriamente multiescalar. 
Não havia sido concedida carta branca para a atuação da Alta Autoridade: ao retirar a possibilidade de o lugar do Poder e do Direito poder ser ocupado por um ou alguns Estados, o Tratado não atribuíra a preferência à escala supranacional. Antes, ao efetuar esse afastamento, o Tratado mantivera intacto o vazio no lugar do Direito e do Poder por meio de série de condicionamentos mútuos e recíprocos, imediatamente previstos neste parágrafo primeiro e desdobrados nos próximos dispositivos.

$\mathrm{O}$ advento de condição de profunda crise econômica e a consequente atribuição de competência à Alta Autoridade não significou conceder a este órgão comunitário a possibilidade de proferir uma decisão privativa de sua escala de existência. Sua faculdade de ação era imediatamente esvaziada pela necessidade de aprovação de início deste regime especial de produção (por cotas) pelo Conselho.

Deste modo, o dispositivo afirmava uma absoluta exclusão de uma medida de existência estatal poder decidir por si só o sentido do Direito e do Poder na Comunidade. Se a medida estatal almejasse orientar decisões sobre o processo produtivo na Europa Politicamente Unida, ela não poderia se manifestar isoladamente: o Tratado forçava-a a se manifestar em conjunto com as diferentes escalas estatais presentes no Conselho, a fim de configurar a escala estatal intergovernamental.

A escala supranacional também não poderia, por si só, determinar o regime de produção por cotas. A unilateralidade da Alta Autoridade era afastada na vida em comum precisamente porque o Tratado determinava que sua escala supranacional deveria se colocar em oposição à estatal intergovernamental: a Alta Autoridade apenas poderia agir comunitariamente se fosse hábil o suficiente para convencer o Conselho a aprovar sua proposta de solução da crise econômica.

Deste modo, o afastamento da estatalidade isolada pelo artigo 58 não significava uma incondicional concessão de um lugar privilegiado de Direito e de Poder à supranacionalidade. A articulação institucional prevista desde o início deste dispositivo afirmava a preocupação com a conservação da multidimensionalidade no processo de decisão sobre o sentido normativo na Comunidade.

Com efeito, a supranacionalidade deveria se opor à estatalidade intergovernamental - formada por diversas estatalidades isoladas opostas entre si - no interior de uma articulação institucional cuidadosamente constituída em torno de um lugar do Direito e do Poder vazio. Esta precisa condição de ausência de um ocupante intemporal e absoluto asseguraria que fosse formada uma solução normativa compartilhada sobre a questão 
concreta comum sensível - a administração e o uso do carvão e do aço em momentos de crise de superprodução.

É nesse sentido, inclusive, que se pode interpretar a segunda parte do parágrafo primeiro do mesmo artigo 58. Lembre-se de que, como afirmado acima, apesar de a proposta de introdução de um regime de cotas de produção ser de iniciativa da Alta Autoridade, esta faculdade não era exclusiva deste órgão comunitário. De fato, nos casos em que, diante de premente crise de superprodução, a Alta Autoridade não utilizasse tal faculdade, qualquer Estado-Membro poderia apresentar um pedido ao Conselho. Caso aprovasse a solicitação por unanimidade, este poderia ordenar à Alta Autoridade que instaurasse um regime de cotas de produção.

Por meio desta disposição, o Tratado da CECA apresentava com forte vigor sua orientação para organizar jurídico-Politicamente a vida em comum na Europa Unida, ainda que em momentos de profunda crise econômica.

Isso porque, apesar de a instituição do novo equilíbrio Politicamente conflituoso poder partir de iniciativa da Alta Autoridade (artigo 58, parágrafo primeiro, primeira parte), havia ainda a possibilidade de a Alta Autoridade ser ordenada a exercer tal faculdade em virtude de determinação dada pela medida de existência estatal intergovernamental (artigo 58, parágrafo primeiro, segunda parte). A palavra "ordenar" 923 utilizada pelo Tratado detém uma forte significação - especialmente no conjunto do Tratado, onde raramente aparece.

Não há aqui, como se poderia imaginar apressadamente, o estabelecimento de uma relação vertical que rompia com a relação horizontal entre as escalas de existência participantes da vida em comum. Havia, na verdade, a previsão de uma interessante armadilha de Poder dirigida aos Estados-Membros que, ao conter a prejudicial inação da Alta Autoridade, mirava também a atuação destes. À estatalidade era facultada a provocação isolada do Conselho, mas apenas intergovernamentalmente poderia ela ordenar à Alta Autoridade que instaurasse um regime de cotas de produção.

A decisão do Conselho deveria ser cumprida pela Alta Autoridade, nos termos do Tratado. Todavia, a nenhuma das estatalidades (isolada ou intergovernamental) se beneficiaria pelo exercício de tal faculdade, pois ele não implicaria a concessão furtiva da possibilidade de ocupação do lugar do Direito e do Poder a qualquer delas.

923 "Prescrire", no original em francês. 
Com efeito, apesar de ter sido dado ao Conselho o Poder de decidir que a Alta Autoridade deveria estabelecer o regime de cotas de produção, ele não recebera maiores e outros Poderes. Na verdade, apenas mediante pedido de um Estado-Membro ao Conselho, e somente na hipótese de aprovação por unanimidade por este, a Alta Autoridade estaria obrigada a estabelecer um regime de cotas de produção.

Isso implica reconhecer que o Conselho estava somente autorizado a obrigar a Alta Autoridade tomar uma decisão sobre o regime de produção, precisamente por estar fora do lugar do Poder e do Direito na Comunidade. O Tratado vetava de forma expressa este órgão comunitário estatal intergovernamental a possibilidade de tomar a frente e de suprimir o centro nomogenético da Comunidade. Com efeito, o Conselho por si só não poderia estabelecer o regime de cotas de produção - pois esta faculdade cabia à Comunidade, mediante proposta da Alta Autoridade, nem mesmo atuar de ofício - pois necessariamente aguardaria a provocação de um Estado-Membro.

Perceba-se assim que a estatalidade intergovernamental não ocupava qualquer posição destacada na vida em comum: não apenas o Conselho não poderia se substituir à decisão comunitária e estabelecer o regime de cotas de produção no lugar da proposta da Alta Autoridade, nem mesmo atuar de ofício no sentido de incitar a Alta Autoridade a agir.

Se a atuação do Conselho era fundamental para contribuir para uma solução da questão concreta sensível comum, ela não era suficiente para a resolver: o Tratado assegurava permanentemente a necessidade de um entrechoque multiescalar.

Ao mesmo tempo, o Estado-Membro que solicitasse a instauração de tal regime especial perante o Conselho igualmente não recebia qualquer tratamento preferencial por parte do Tratado: o lugar do Direito e do Poder na Comunidade não seria nem mesmo por ele ocupado, na medida em que sua atuação se cingia a provocar o Conselho e inaugurar oposições escalares entre as estatalidades, visando a uma concertação intergovernamental. Deste modo, a decisão de um Estado-Membro de provocar o Conselho para que instasse a Alta Autoridade a agir era, na verdade, uma decisão de autolimitação: as estatalidades isoladas também receberam a faculdade de exercer um Poder em si mesmo contido.

Todavia, também não se pode deixar de observar que este artigo reforçava ainda mais o fato de que o Poder atribuído à Alta Autoridade era um Poder sobre o qual ela não detinha o controle absoluto - um Poder "sem Poder", pois imediatamente bloqueado pelo próprio Tratado atribuidor. Não cabia exclusivamente a ela a decisão sobre se deveria agir ou não dele lançar mão em situações de profunda crise econômica. Ainda que não acreditasse se tratar dessa situação, ou ainda que seu modo de habitar o mundo 
supranacional não quisesse atuar no direcionamento da produção de carvão e de aço na Europa Politicamente Unida, ela deveria agir se assim ordenada por outra escala.

O Tratado relembrava com todo vigor que o Poder não era da Alta Autoridade, mas uma faculdade de ação a ela atribuída para preservar institucionalmente a dinâmica Política da Europa Unida no tratamento de crises econômicas concretamente prejudiciais para a vida em comum. O Poder concedido à supranacionalidade era instituído como mecanismo a ser utilizado, não em prol da Alta Autoridade, dos Estados-Membros ou do Conselho, mas em benefício da preservação da vida comunitária, ainda que em momentos de profunda crise econômica.

Ainda no que se refere ao exame detalhado do regime de freios e contrapesos instaurado normativamente entre a supranacionalidade da Alta Autoridade e as estatalidades pelo Tratado, há que se lembrar de que o regime de cotas era temporário, isto é, ele deveria ser arquitetado para perdurar apenas enquanto houvesse uma justificativa (crise de superprodução) para o regime especial.

Assim, a despeito de o Tratado não ter previsto um prazo fixo de duração do regime de cotas de produção, seu artigo 58, parágrafo terceiro, estipulara duas iniciativas distintas: (i) após consulta prévia ao Comité Consultivo, a Alta Autoridade poderia apresentar um pedido de encerramento do regime de cotas ao Conselho, o qual deveria decidir por unanimidade para que a solicitação fosse aceita; ou (ii) a pedido de qualquer EstadoMembro, mediante requisição direta ao Conselho, quem deveria decidir por maioria simples para aceitar a solicitação. Nos dois casos, a Alta Autoridade deveria por conta própria tornar pública a informação sobre o término do regime de cotas na Comunidade.

Este dispositivo final revelava com máxima força o aspecto Político da condução deste regime de cotas de produção instituído em virtude de profunda crise econômica de superprodução. Lembre-se de que a possibilidade de a Alta Autoridade intervir diretamente sobre empresas localizadas no território dos Estados-Membros - ainda que contida por série de dispositivos preocupados com a preservação do vazio no lugar do Direito e do Poder na Comunidade - derivava precisamente de um regime institucional de exceção, fundado na situação de profunda calamidade econômica.

Com efeito, sendo um regime de exceção ao mandamento geral de atuação indireta e em cooperação com os Estados-Membros ${ }^{924}$, e apesar de ser inscrito em uma articulação institucional cuidadosamente voltada à manutenção do delicado equilíbrio Político

${ }^{924}$ V. nesse sentido os comentários ao artigo 57 do Tratado da CECA, no item 7.3.1.1.1., supra. 
conflitivo na Comunidade, ele continha em si mesmo um princípio potencialmente disruptor que poderia fornecer subsídios ao destacamento da escala de existência supranacional ou da estatal intergovernamental no interior da Europa Unida.

Nesse sentido, observe-se que a despeito das previsões de mútua e recíproca contenção, o Poder de intervenção direta da Alta Autoridade sobre o território dos EstadosMembros mediante proposta de regime de cotas de produção poderia implicar a construção de um hábito de compreender a supranacionalidade como em posição superior às demais escalas de existência. Do mesmo modo, a possibilidade de o Conselho ordenar o princípio de ação da Alta Autoridade, ou mesmo o fato de ser necessária sua aprovação para o início de tal regime - seja por solicitação da Alta Autoridade, seja por requisição apresentada por um Estado-Membro, poderia também ensejar a construção de um hábito de perceber uma autorização velada à verticalização entre os participantes comunitários em torno de um suposto vértice ocupado pelo Conselho.

É para evitar o surgimento e o enraizamento de possíveis percepções de verticalização nas relações entre as escalas de existência na Comunidade que se deve entender a previsão no Tratado de duas formas distintas de finalizar o regime de cotas de produção - seja no que se refere à iniciativa do pedido, seja no que se refere à decisão que aprova o seu termo.

A iniciativa do pedido de término do regime de cotas de produção era atribuída à Alta Autoridade e a qualquer Estado-Membro, não havendo diferença se o início do regime de cotas houvesse sido deflagrado por solicitação da Alta Autoridade ou de um EstadoMembro. E nos dois casos era instaurada institucionalmente nova oposição escalar entre as diferentes escalas de existência que compunham a Europa Unida - o que permitia reafirmar a importância da reiterada necessidade de se perpetuar o sistema de convivência e de contenções recíprocas entre diferentes para a formação de uma decisão em conjunto sobre o destino comum.

Com efeito, note-se que se previram neste dispositivo formas de mútua contenção entre a medida de existência supranacional e a estatal isolada com relação à continuidade de um regime jurídico-econômico instaurado com autorização - ou por ordem - do Conselho (escala estatal intergovernamental) e executado pela Alta Autoridade (escala supranacional): Estados-Membros e Alta Autoridade poderiam, quando e se julgassem pertinente, solicitar a finalização deste regime especial.

Este fim, todavia, não poderia ser deflagrado uniescalarmente. Da mesma maneira que ocorrera com o início do regime de exceção, esta norma jurídica instituíra a 
necessidade de uma contínua e ativa contraposição entre as dimensões que compunham a Europa Unida (supranacionalidade e estatalidades). Cada uma era colocada normativamente como vigilante ativa da execução do regime especial e, quando e se julgasse necessário, poderia propor a abertura de intenso embate escalar para discutir, em dimensão comunitária, o fim do regime de cotas de produção.

Em outras palavras, os Estados-Membros e a Alta Autoridade não estavam autorizados pelo Tratado da CECA a, por si só, decretar unilateral e absolutamente, a partir da percepção da própria forma de habitar o mundo, o término imediato e abrupto do regime de cotas de produção. Na verdade, para que ele fosse finalizado, haveria que haver a deflagração de mais um embate escalar, no interior do qual uma medida de existência deveria repelir as demais do lugar do Direito e do Poder.

Por esse motivo, pode-se compreender que essa disposição institucional visava a impedir a supressão do vazio no centro nomogenético e a reafirmar a importância (Política) da multiescalaridade na decisão sobre questões concretas comuns sensíveis principalmente quando se tratavam de decisões sobre momentos de grave crise econômica.

Observe-se, todavia, que esse Poder de contenção atribuído à Alta Autoridade e aos Estados-Membros era igualmente contido. Estatalidades isoladas e supranacionalidade da Alta Autoridade poderiam refrear o regime econômico a partir de suas próprias perspectivas de existência, mas tal solicitação deveria ser, em ambos os casos, aprovada pelo Conselho (estatalidade intergovernamental).

Com tal previsão, o Tratado promovia institucionalmente um freio à atuação do bloqueio potencialmente iniciado por atuação da Alta Autoridade ou de um EstadoMembro, mediante a atribuição de vigoroso contra-Poder ao Conselho. Não se poderia atribuir absolutamente à supranacionalidade ou à estatalidade isolada a possibilidade de determinar de forma unilateral o fim do regime de cotas de produção, pois isso significaria atribuir-lhes de maneira sub-reptícia uma preferência na determinação do sentido do Poder e do Direito na Europa Politicamente Unida.

Dessa forma, as duas iniciativas deveriam ser contrabalançadas por um contrapeso exercido pelo Conselho. Há aqui intenso mecanismo de oposições - deter, interromper, paralisar, represar: de maneira sucessiva, as três escalas de existência poderiam se colocar em choque e, mediante um processo deliberativo de formação conjunta de uma perspectiva comunitariamente conveniente, poderiam arquitetar uma solução comum sobre o destino de questões concretas sensíveis tornadas comuns. Se a estatalidade intergovernamental era excluída da atribuição do Poder de propor o início ou o término do regime de cotas de 
produção, ela necessariamente deveria ser considerada para ele ter iniciada sua execução, ou para a finalizar.

O manejo dos instrumentos jurídico-econômicos na Comunidade era operado assim segundo uma lógica Política. Em situações de crise de superprodução, mesmo na determinação do término do regime de cotas de produção, nem uma nem outra medida de existência detinha absolutamente a faculdade de a decretar, isto é, nenhuma delas ocupava o lugar do Direito e do Poder. A supranacionalidade e as estatalidades dependiam uma da outra reciprocamente para que uma decisão comum pudesse ser tomada: a oposição entre os diferentes sistemas métricos do mundo se revela como mais uma vez institucionalizada no seio da Europa Unida no Tratado da CECA.

Todos e nenhum pareciam deter - e, ao mesmo tempo, não deter - capacidade de determinação do sentido do Direito e do Poder na Europa Unida: a execução de uma ação por uma escala de existência dependia em demasiado de alguma decisão - a ser tomada de acordo com outro sistema métrico de experiência do mundo - para formar o sentido normativo da vida em comum. Aqui, mais uma vez, a Comunidade parecia ter construído cuidadosamente instituições destinadas a fazê-la perseverar em seu ser, ou ainda, destinadas a preservar suas próprias Leis Políticas.

7.3.1.1.2.2.2. Outros Aspectos Institucionais caracterizadores da Organização Jurídico-Política da Europa Unida da CECA: Opção Normativa pela Recusa ao Uso Centralizado da Força

O objetivo de todo este item 7.3. consiste em evidenciar no texto normativo do Tratado da CECA série de disposições institucionais que promoviam oposições escalares no interior da Comunidade, a fim de apontar a presença de uma preocupação constante com a manutenção de um vazio no lugar do Direito e do Poder e com a conservação da formação multiescalar de um sentido normativo sobre questões concretas sensíveis comuns.

Todavia, não se pode deixar de notar neste artigo 58 do Tratado da CECA série de elementos que permitem reforçar a caracterização da organização jurídico-Política da CECA como a de uma organização voltada contra a assunção de uma forma estatal. Essa recusa à construção de um Estado Europeu é evidenciada - sugere este trabalho - a 
partir da constatação da ausência reiterada da possibilidade de entidades comunitárias utilizarem de maneira central a coerção para fazer cumprir suas decisões.

Esta reflexão foi mencionada anteriormente, não apenas durante os Capítulos Quarto, Quinto e Sexto deste trabalho, mas também de maneira específica no item 7.2.4., supra. Apesar de este item 7.3. não se destinar a discutir especificamente essa temática, julga-se ao menos pertinente apontar aqui breves indícios normativos constantes deste artigo que poderiam reforçar a conclusão exposta em outras oportunidades neste trabalho. Esta exposição não será longa, a fim de não prejudicar a continuidade da argumentação em torno da preocupação normativa em preservar o vazio no lugar do Direito e do Poder, razão pela qual se cingirá a apontar aspectos que reforçam a reflexão outrora desenvolvida.

Pois bem. Há que se observar que a decisão da Alta Autoridade de impor um regime de cotas de produção poderia ser acompanhada por um reforço jurídico instaurado por recomendações ${ }^{925}$. Na hipótese de descumprimento destas por parte das empresas, a Alta Autoridade poderia aplicar multas que, por sua vez, não poderiam superar o valor da produção irregular (artigo 58, parágrafo primeiro conjugado com o parágrafo quarto).

O final do parágrafo primeiro do artigo 58 autorizava expressamente à Alta Autoridade o estabelecimento de um regime de produção juridicamente obrigatório, a ser introduzido por meio de recomendações. Estas caracterizavam-se, como visto anteriormente $^{926}$, por serem obrigatórias quanto aos fins (neste caso, diminuição da produção, conforme cotas estabelecidas), mas facultavam aos destinatários a escolha dos meios para o cumprimento deste objetivo comum.

A atuação direta da Alta Autoridade sobre empresas localizadas nos territórios dos Estados-Membros da Comunidade se resumia a estipular um regime de cotas de produção juridicamente obrigatório direcionado a tais empresas. A imposição deste regime especial necessariamente autorizada pelo Conselho ${ }^{927}$ - poderia ser acompanhada pela aplicação multas às empresas que descumprissem as recomendações.

Perceba-se assim que se retirava da Alta Autoridade a possibilidade de utilizar outros meios constritores da produção, estando circunscrita a atuar somente no plano de determinação do regime produtivo a ser seguido e no da imposição de multas, a fim de estimular economicamente a diminuição da quantidade de recursos disponíveis na Comunidade. A Alta Autoridade poderia assim inovar juridicamente, determinar condutas

\footnotetext{
${ }^{925}$ Sobre o estatuto normativo jurídico-positivo das recomendações, v. a nota de rodapé 154 , supra, sobre o artigo 14 do Tratado da CECA.

${ }_{926}$ V. nota de rodapé 154 , supra.

${ }^{927}$ Como visto no item 7.3.1.1.2.2.1., supra.
} 
vinculantes e exigíveis, punir economicamente empresas que descumprissem as recomendações, mas não poderia pretender que houvesse um cumprimento de seu regime jurídico compelido mediante o uso da força.

Perceba-se que não se lhe atribuíam instrumentos coercitivos tradicionalmente disponibilizados aos Estados-Membros para garantir a observância de suas normas jurídicas. A ameaça da aplicação da multa não constituía senão um estímulo ao cumprimento da obrigação jurídica de observar os limites de produção, mas não equivalia a constrições derivadas do uso da força. O regime jurídico-econômico especialmente arquitetado para lidar com a situação de crise era assim caracterizado por estar desprovido de garantia por força.

O Tratado não atribuíra à Alta Autoridade poderes de atuação direta semelhantes aos de um Estado para garantir o cumprimento de sua norma jurídica: apesar de poder determinar um regime juridicamente obrigatório de produção a ser cumprido por empresas nacionais em território dos Estados-Membros, tal órgão comunitário, como toda a Comunidade, não poderia ser entendido como um "proto-"Estado Europeu, isto é, como uma entidade dotada da centralização do uso da violência, ou que visasse a centralizá-lo.

A possibilidade de sua atuação mais incisiva significava assim apenas que sua ordem seria considerada obrigatória em nível estatal e que deteria a possibilidade de ter aplicada uma sanção econômica. Isso, todavia, não poderia pretender equivaler ao uso da força da maneira tradicional atribuída aos Estados-Membros. Sua margem de ação estava dentro do círculo de ação determinado pelo Tratado: sua ação era contida dentro do espectro do vazio do lugar do Direito e do Poder.

7.3.1.1.2.3. O Artigo 59 do Tratado da CECA e a Tutela Jurídico-Política da Subprodução de Carvão e de Aço

7.3.1.1.2.3.1. A Contenção Recíproca entre Supranacionalidade da Alta Autoridade e Estatalidades

O artigo 59 do Tratado da CECA disciplinava a construção do sentido normativo comunitário sobre outra situação concreta sensível comum: a sub-produção de carvão e de aço derivada de grave escassez de tais produtos. 
Nestes casos, diante da constatação de que a produção na Comunidade não conseguia mais atender à crescente demanda de carvão ou de aço, a Alta Autoridade poderia, após consulta ao Comitê Consultivo, formular um pedido ao Conselho para propor medidas de combate à situação. Na hipótese de não cumprimento das decisões tomadas pela Alta Autoridade e/ou pelo Conselho ${ }^{928}$, caberia à Alta Autoridade a aplicação de multas cujo montante não deveria exceder o dobro do valor da produção ou das entregas ordenadas e não executadas ou desviadas de sua utilização normal (artigo 59, parágrafo primeiro conjugado com o parágrafo sétimo, do Tratado da CECA).

Por se tratar de situação diversa da regulamentada pelo artigo 58, o Tratado da CECA neste dispositivo abria a possibilidade de uma busca por uma solução comunitária também para tal situação de escassez de recursos. E, como se poderá ver a seguir, diante de mais um momento de grave penúria econômica - aparelho produtivo incapaz de atender à crescente demanda de carvão ou de aço, o artigo 59 instituía uma renovada expressão de um entrechoque multiescalar no interior da Europa Unida.

Observe-se desde já que o mecanismo institucional previsto neste arigo 59 também efetuava uma rearticulação institucional Política distinta, segundo a qual um equilíbrio Político entre as tensões escalares seria substituído por outro equilíbrio institucionalmente voltado à preservação da dinâmica Política, a fim de solucionar grave questão concreta sensível comum sob o signo da multiescalaridade comunitária.

Dessa forma, a solução institucional configurada pelas normas jurídicas do Tratado

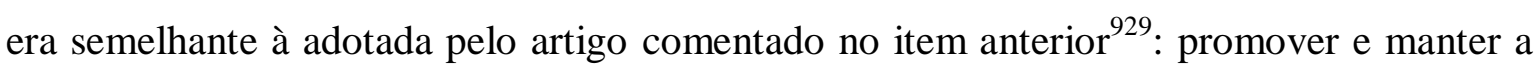
lógica Política de oposição entre as escalas de existência implicadas na vida em comum da CECA, mesmo em momentos de profunda crise.

Assim, foi também possível a este dispositivo construir um mecanismo que articulasse Politicamente os problemas econômicos potencialmente disruptores da vida em comum. Diante da grave situação de falta de recursos, o Tratado procurou forçar institucionalmente a convivência entre as diferentes escalas de existência para mais uma vez afastar a introdução de qualquer possivelmente esperada reação unilateral e autointeressada por parte das diferentes estatalidades isoladas na condução desse processo.

Também neste artigo, visando a impedir a disseminação de um pânico competitivo por recursos escassos entre as escalas de existência estatais isoladas, o Tratado da CECA propusera a instauração institucional de novo conflito escalar. O objetivo desta nova

\footnotetext{
${ }_{928}$ Conforme disposições do próprio artigo a serem a seguir examinadas.

${ }^{929}$ Item 7.3.1.1.2.2., supra.
} 
formação conflituosa era o de evitar a disseminação total de uma única medida de existência sobre as decisões acerca do sentido normativo a ser dado a tal questão concreta criticamente sensível na Comunidade. E, para isso, estabelecera uma interdependência orgânica entre as medidas de existência da Comunidade visando à manutenção de um vazio no lugar do Direito e do Poder.

Em outras palavras, mesmo nos momentos de profunda crise, o caminho institucionalmente selecionado para lidar com a potencial calamidade da vida comum era precisamente o da Política: reiterar a divisão e conclamar a necessidade de um conflito multiescalar para resolver em conjunto a crise econômica.

Atribuíra-se à Alta Autoridade, por meio do parágrafo primeiro do artigo 58, a faculdade de apresentar, após consulta ao Comitê Consultivo, e diante da constatação da insuficiência dos mecanismos de intervenção indireta previstos no artigo 57, uma solicitação ao Conselho para que este, ao reconhecer a situação de grave crise econômica de sub-produção, aprovasse as medidas por ela propostas. Este pedido apenas seria rejeitado se o Conselho o recusasse por unanimidade.

Como mencionado acima, à Alta Autoridade era também facultada a possibilidade de aplicar sanções econômicas, a título de multas, para as empresas que descumprissem as decisões tomadas no interior deste novo arranjo institucional. $\mathrm{O}$ valor da multa não poderia ultrapassar o dobro do valor das produções ou das entregas prescritas e não efetuadas ou desviadas de sua destinação original.

Em um primeiro momento, por meio deste artigo, o Tratado evitava que uma estratégica corrida competitiva entre as escalas de existência estatais isoladas desestabilizasse o sistema de convivência da Europa Politicamente Unida. Para tanto, o Tratado determinava que a Alta Autoridade poderia sugerir uma solução à crise econômica de sub-produção e aplicar multas às empresas.

Assim, antes que se instaurasse sorrateiramente no lugar do Direito e do Poder da Comunidade a escala de uma ou mais escalas estatais (isoladas ou intergovernamental), o Tratado determinava a imediata suspensão dessa possibilidade e a afastava imediatamente para manter a convivência Política na CECA por meio de um novo equilíbrio institucional conflituoso de caráter Político a pedido da Alta Autoridade.

Todavia, não se deve compreender essa suposta liderança pela Alta Autoridade como facilitação à ocupação preferencial do lugar do Poder e do Direito na Comunidade por sua supranacionalidade. Na verdade, a esse Poder de contenção da potencial ascensão disruptora da medida estatal de existência sobre a Comunidade era previsto igualmente um 
mecanismo de represamento. Em outras palavras, previra-se também neste artigo um progressivo esvaziamento de tal Poder atribuído à Alta Autoridade, visando à manutenção de um vazio no centro nomogenético da Comunidade.

Nesse sentido, perceba-se que o próprio primeiro parágrafo do artigo 59 previa limitações ao Poder limitador à Alta Autoridade: esta não poderia nem sequer solicitar a instauração desse novo embate escalar na CECA sem haver uma comprovação da insuficiência dos mecanismos de intervenção indireta previstos no artigo 57. E, ainda que houvesse constatado tal insuficiência, sua proposição deveria ao menos aguardar consulta formulada ao Comitê Consultivo antes mesmo de se dirigir ao Conselho para aguardar aprovação.

Não se tratava apenas da necessidade de haver uma avaliação prévia por outro órgão comunitário sobre a insuficiência dos instrumentos disponíveis ${ }^{930}$ : tratava-se, antes, de buscar encontrar indícios que justificassem suficientemente a necessidade de se instaurar o "regime Político de exceção", segundo o qual a Alta Autoridade poderia utilizar de meios diretos de intervenção para responder à corrosiva crise econômica - desde que contrabalançadas pelas contenções previstas no mesmo artigo 59. Pois era pré-requisito mesmo à apresentação de seu pedido demonstrar a Alta Autoridade que seus mecanismos de intervenção indireta - e em cooperação com os Estados-Membros - não eram capazes de dar uma resposta à crescente escalada instrumental de decisões tomadas em âmbito estatal nacional.

Todavia, não bastava à Alta Autoridade demonstrar a insuficiência de atendimento ao crescimento da demanda em torno do carvão e do aço. Este argumento deveria ser verificado por outra escala de existência comunitária, a saber, a portada pelo Conselho. Enquanto motor comunitário de um sistema métrico estatal intergovernamental, o Conselho deveria avaliar a solicitação da Alta Autoridade e examinar as proposições dela. A ele caberia a possibilidade de rejeitar o pedido formulado - desde que por unanimidade.

\footnotetext{
${ }^{930}$ Lembre-se de que, como reiteradamente afirmado neste trabalho, o Comitê Consultivo não participava do jogo de formação do sentido normativo comum (v. nota de rodapé 820, supra). Nesse sentido, perceba-se que a atuação deste órgão comunitário definida por este artigo - e pelo artigo 58, parágrafo primeiro, do mesmo Tratado, analisado no item 7.3.1.1.2.2.1., supra - se restringia a opinar, sem qualquer capacidade de aprovar ou rejeitar a proposta da Alta Autoridade.

Assim, pode-se tentar compreender que sua presença era assegurada por este artigo com um objetivo distinto de qualquer pretensão de lhe garantir a possibilidade de participar da construção do sentido normativo comunitário. Na verdade, pode-se interpretar essa presença do Comitê Consultivo apenas para auxiliar a Alta Autoridade a verificar se os meios indiretos de atuação efetivamente não eram suficientes para solucionar a grave situação econômica pela qual passava a Comunidade.
} 
Neste ponto, não se pode deixar de notar que o próprio Conselho sofria um bloqueio de seu Poder de contenção da eventual ascensão da supranacionalidade da Alta Autoridade. Com efeito, o órgão comunitário intergovernamental apenas poderia rejeitar a solicitação e as propostas formuladas pela medida de existência supranacional por meio de uma decisão unânime de rejeição - o que implicava um acirramento exponencial das tensões escalares, pois pressupunha embates entre estatalidades isoladas internas ao Conselho que implicariam uma unânime rejeição intergovernamental da proposta formulada pela Alta Autoridade.

Diante desta breve descrição, é possível perceber no interior do aparato jurídiconormativo do Tratado a preocupação em introduzir na Comunidade mais uma vez a operação institucional de uma dinâmica Política voltada a um constante afastamento do lugar do Direito e do Poder de medidas de existência, sem qualquer preferência a priori por qualquer delas. Em outras palavras, ainda uma vez as instituições da Europa Unida contrapunham escalas de existência sem conceder a qualquer delas uma preferência absoluta, pois a todas se atribuíra um Poder de contenção multilateral prontamente esvaziado.

Essa previsão jurídico-Política de esvaziamento do Poder de cada uma das medidas de existência da Comunidade torna-se mais clara diante da previsão do final do parágrafo primeiro deste artigo e daquela constante do início do parágrafo segundo do mesmo. Não apenas o Conselho poderia reconhecer a existência dessa situação de calamidade econômica, independentemente de solicitação por parte da Alta Autoridade, como também ele deveria, em conjunto com esta, deliberar sobre as medidas a serem tomadas para resolver a grave situação econômica pela qual passa a Comunidade.

Com efeito, o artigo 59, parágrafo primeiro, segunda parte, do Tratado da CECA instituíra uma iniciativa suplementar por parte das estatalidades: caso a Alta Autoridade não houvesse iniciado a proposição de medidas para combater a crise de sub-produção, qualquer Estado-Membro poderia apresentar diretamente solicitação ao Conselho para que este, após decisão por unanimidade, reconhecesse a existência da grave situação e a necessidade de se elaborarem medidas para a resolver.

Da mesma maneira que no artigo 58, o Tratado atribuíra pelo artigo 59 funções de participação na formação do sentido normativo comunitário às estatalidades isoladas e intergovernamental. Essa disposição do Tratado sinalizava uma deliberada opção por estabelecer uma não-exclusividade de iniciativa por parte da supranacionalidade - afinal, medidas de combate à grave crise não poderiam ser propostas apenas quando lhe fosse 
conveniente. Por se tratar de profunda crise econômica, caso o modo de existência supranacional se mantivesse em inação, caberia a qualquer Estado-Membro apresentar semelhante pedido - a ser avaliado posteriormente pelo Conselho.

Com a aposição de possibilidade de participação ativa por parte das estatalidades, o Tratado sinalizava buscar evitar que a supranacionalidade almejasse suprimir o vazio de Poder por meio de uma conveniente inação - a qual poderia prejudicar os EstadosMembros. Afinal, não se tratava de um Poder a seu pleno dispor, a ser acionado a seu belprazer, mas sim pensado para viabilizar a manutenção da Comunidade Política instaurada na Europa pela CECA.

Instituíra-se assim um sistema de dependência mútua e de controles recíprocos de uma medida de existência pela outra em caráter subsidiário, verdadeiro mecanismo de contenção da escala ao lugar do Poder e do Direito por outra: as normas apontavam para a necessidade de um cioso zelo Político por parte das estatalidades isoladas, a fim de que percebessem possíveis investidas sobre o lugar do Poder pela supranacionalidade - no caso, quando esta agisse nos casos em que não deveria, ou também quando esta não agisse nas hipóteses em que deveria.

Nesse sentido, esse deslocamento de Poder de iniciativa consistia em um estímulo institucional para que os Estados-Membros acompanhassem detidamente cada ação ou inação desempenhada pela Alta Autoridade. Tratava-se assim de um convite a um acompanhamento atento que despertaria a vitalidade da virtude política entre as escalas de existência, pois as motivava a permanecer em constante contato com os demais diferentes, não somente por questões de vigilância, mas principalmente porque cada uma delas e todas elas - deveria estar com a outra e com ela saber em conjunto definir continuamente o destino comum.

Todavia, não se pode deixar de reparar que a faculdade de contenção da escalada ao Poder e ao Direito pela supranacionalidade atribuída às estatalidades era virtuosamente contida - como se poderia esperar em uma organização institucional Politicamente orientada. Havia determinados condicionamentos para sua atuação que não devem ser ignorados, sob pena de se poder também perceber erroneamente alguma preferência por sua medida de existência no interior da Comunidade.

A primeira contenção prevista ao poder limitador atribuído à dimensão estatal isolada consistia precisamente no caráter subsidiário de sua faculdade: apenas e tãosomente se a Alta Autoridade não tomasse a frente no exercício desta iniciativa é que se atribuía a qualquer Estado-Membro a possibilidade de apresentar a solicitação ao 
Conselho. Deste modo, da mesma maneira que não se tratava de um Poder detido absolutamente pela Alta Autoridade a seu livre dispor, este Poder não se encontrava dentre o rol imediato de opções por parte dos Estados-Membros.

Ao mesmo tempo, o segundo condicionamento também inseria um elemento de contenção da medida estatal isolada, desta vez, exercida pela outra medida estatal, a intergovernamental (Conselho). Os Estados-Membros não detinham a possibilidade de declarar de imediato a necessidade de instauração de um novo arranjo institucional que permitisse uma atuação multiescalar mais incisiva sobre a crise econômica. Ainda que diretamente atingidos pela penúria econômica de escassez, estes deveriam fazer sua medida de existência se contrapor à dos demais Estados-Membros em conjunto, no interior do Conselho.

A disposição normativa do Tratado previa desta forma um mecanismo que instaurava uma oposição multidimensional entre o sistema métrico do Estado-Membro requerente e o dos demais que compunham o Conselho. Isso permitia que também uma iniciativa para momentos de crise gerada no interior da medida de existência estatal pudesse ser objeto de oposições escalares.

Cumpre salientar que o parágrafo primeiro do artigo 59 trazia consigo uma forte contenção da atuação da outra estatalidade implicada na vida em comum: a intergovernamental, portada pelo Conselho. Tal contrapeso à faculdade de contenção atribuída ao Conselho pode ser identificado na "expressamente não-dita" recusa ao Conselho de exercer por si só a iniciativa de combater a crise de sub-produção.

De fato, se às demais medidas de existência da Europa Unida (supranacional e estatal isolada) cabia o Poder de iniciativa, o mesmo não ocorria com a estatal intergovernamental. Apesar de deter função determinante com relação aos destinos da solicitação apresentada pela Alta Autoridade ou por um dos Estados-Membros, não estava o Conselho autorizado a por si só provocar o início de um regime especial. Seu Poder de contenção era assim contido nos estritos limites de sua capacidade contenedora.

Não havia deste modo o estabelecimento de qualquer preferência por uma ou por outra medida de existência na vida em comum da CECA. As três mencionadas pelo artigo ora em análise poderiam se utilizar de Poderes que, contudo, não eram capazes de determinar absoluta e exclusivamente o destino sobre a premente questão concreta comum: a carência crônica de carvão e de aço na Comunidade. Por uma engenhosa combinação institucional voltada contra a entrada de qualquer das medidas de existência no lugar do Poder e do Direito na Europa Unida da CECA, assegurava-se que nem Alta Autoridade, 
nem Estados-Membros, nem Conselho, poderiam determinar unilateralmente o sentido normativo comum nos momentos de crise.

É importante notar, contudo, que, no artigo 59 do Tratado da CECA, a preocupação em promover institucionalmente uma intensa oposição escalar no interior da Comunidade não se restringia ao regime acima descrito em torno do Poder de iniciativa. Durante todo o processo de formação do sentido normativo a ser impresso sobre a questão concreta sensível comum, o Tratado procurou preservar uma orientação comunitária, isto é, marcada pela persistente multiescalaridade.

O parágrafo segundo o mesmo artigo 59 determinava que a Alta Autoridade deveria apresentar uma proposta de medidas ao Conselho, o qual, por meio de deliberação unânime que considerasse a constante consulta com a Alta Autoridade, decidiria (i) as prioridades de utilização dos recursos produtivos disponíveis, bem como (ii) a repartição deles (a) entre as empresas sujeitas à competência da Comunidade; (b) para fins de exportação; e (c) entre outros setores de consumo. Apenas após o estabelecimento dessa prioridade de utilização por parte do Conselho é que a Alta Autoridade poderia e deveria estabelecer programas de produção a serem executados pelas empresas interessadas.

A disposição normativa constante deste parágrafo segundo revelava com clareza ainda mais nítida do que a produzida pelo Sol do meio-dia o vetor Político condutor da operacionalização dos instrumentos jurídicos de conteúdo econômico previstos no interior do Tratado. Afinal, a determinação do sentido normativo a ser dado às medidas de solução da crise econômica não teria origem exclusiva na perspectiva estatal, nem em uma orientação supranacional. Reiterava-se aqui a preocupação em assegurar a mantença de um vazio no lugar do Direito e do Poder na Europa Unida pela CECA.

Nesse sentido, se apenas à Alta Autoridade cumpria determinar um programa de ação para empresas, não era ela quem estabeleceria as diretrizes estruturantes de tais planos de ação. A despeito de o programa ser gestado supranacionalmente, um elemento anterior à elaboração de tais programas condicionava essa arquitetura programática à avaliação por parte das outras escalas, de maneira a assegurar uma multiplicidade escalar comunitária na formação de tal decisão.

Havia aqui uma vigorosa contenção do Poder gerenciador das atividades produtivas das empresas: não seria a Alta Autoridade quem determinaria, por si só - isto é, uniescalarmente - as prioridades de utilização dos recursos disponíveis, pois, por meio desta previsão normativa, era excluída a supranacionalidade da possibilidade de ocupar o lugar do Direito e do Poder na Europa Unida com exclusividade. Se ela deveria certamente 
atuar incisivamente sobre empresas localizadas nos territórios nacionais para determinar programas de ação e de produção, não poderia ter sua ação uma fundamentação unicamente em sua medida de existência.

Perceba-se assim que não se concedera qualquer preferência ou carta branca à dimensão supranacional para que impusesse seu sistema métrico como padrão a ser seguido para a formação das decisões normativas da Comunidade em situações de grave crise. Era a estatalidade intergovernamental do Conselho a responsável pela decisão em torno da (i) utilização dos recursos produtivos disponíveis; e (ii) repartição destes (a) entre as empresas sujeitas à competência da Comunidade; (b) para fins de exportação; e (c) entre outros setores de consumo.

Assim, paralisava-se a partir da atuação do Conselho uma possível escalada ao lugar do Direito e do Poder por parte da Alta Autoridade: esta apenas poderia decidir seus programas de ação no interior de limites determinados intergovernamentalmente. A contenção da supranacionalidade derivava precisamente destes contornos a serem estabelecidos por decisão do Conselho. Mas não se pode deixar de perceber que esse poder limitador do Conselho era ele mesmo limitado.

Apenas se mostrava possível à Alta Autoridade definir um programa de ação se delimitado o campo de atuação pelo Conselho. Todavia, ainda que este pudesse determinar os termos segundo os quais ocorreriam o uso prioritário dos recursos e a repartição deles, não dispunha ele próprio de meios para tornar efetiva sua decisão: uma vez estabelecidos tais vetores por sua decisão, não poderia ele mesmo seguir com o estabelecimento dos programas de ação a partir de sua perspectiva intergovernamental. Afinal, o Tratado determinava que tal tarefa incumbia à Alta Autoridade.

Deste modo, ao circunscrever o campo de atuação da Alta Autoridade, o Conselho não estava autorizado a ultrapassar esta estrita tarefa de delimitação do círculo no interior do qual a decisão da Alta Autoridade deveria se desenvolver. Mais uma vez, o Tratado mostrava por meio desta disposição normativa que optara pela promoção institucional de uma oposição entre supranacionalidade e as estatalidades (isoladas, no interior do Conselho $^{931}$, e a própria estatalidade intergovernamental), visando à construção comum de um sentido normativo a ser impresso sobre questões concretas sensíveis comunitarizadas.

Um apenas poderia agir nos estritos limites que o outro não poderia agir, mas este determinava precisamente os limites da ação daquele - e, seguindo esse raciocínio, o

${ }^{931}$ Como será ressaltado algumas linhas a seguir. 
Tratado continuava a afirmar sua opção institucional constante pela promoção normativa de oposições escalares ininterruptas, em que um Poder nada mais significava do que a contenção de outro Poder.

Mas não apenas nesta distribuição de parcela de funções entre os dois órgãos comunitários havia o estabelecimento de freios e de bloqueios mútuos entre diferentes escalas de existência por meio do artigo 59, parágrafo segundo. O fomento de uma contenção recíproca da ascensão de Um em direção ao lugar do Direito e do Poder era promovido pelo presente dispositivo em outros aspectos.

Nesse sentido, observe-se que este parágrafo determinava que tal decisão do Conselho deveria ser tomada por unanimidade, sem jamais desconsiderar uma consulta constante à Alta Autoridade antes de a proferir. Ademais, não se pode deixar jamais de notar que o Conselho apenas poderia deliberar sobre uma proposta apresentada pela Alta Autoridade. A capacidade de contenção do Conselho era por esta previsão contida, a fim de que sua própria escala de existência não almejasse a totalização unidimensional de sua medida intergovernamental.

Em primeiro lugar, esse dispositivo determinava ser necessária a apresentação prévia de uma proposta por parte da Alta Autoridade. Se esta não detinha a capacidade decisória última sobre sua proposta - ou ainda, se sua proposta não detinha de pronto uma validade jurídica certa, ao menos ela poderia - e deveria - dar início ao procedimento de determinação das balizas de seu futuro programa de ação a ser dirigido às empresas. E, ao mesmo tempo, sua perspectiva não poderia ser ignorada pelo Conselho quando da formação de sua própria decisão.

Em outras palavras, a proposta inicial da Alta Autoridade era indispensável para conferir ao Conselho um material sobre o qual este deveria se debruçar. Se sem a decisão deste, a Alta Autoridade não poderia definir seu programa de ação, ao mesmo tempo, sem a apresentação da proposta por esta, o Conselho não poderia ter sobre o que decidir. E, inclusive, para poder decidir, o Conselho deveria ainda estabelecer contatos constantes com a Alta Autoridade, isto é, ele deveria consultá-la continuamente antes de tomar sua decisão. Deste modo, já neste primeiro aspecto se deflagrava uma intensa oposição escalar no interior da Europa Unida, a qual era manifesta por instrumentos de contenção recíprocos. Um dependia do outro, não apenas para decidir, mas também para ter algo sobre o qual deveria decidir.

Havia, porém, um segundo aspecto neste dispositivo que evidenciava ainda mais a preocupação em manter a Política na Europa mediante contínua oposição escalar para se 
formular a decisão sobre o uso prioritário dos recursos escassos, a saber, o critério estipulado para que o Conselho decidisse sobre a proposta da Alta Autoridade: a necessidade de uma decisão unânime.

Neste específico ponto, havia a confluência de série relações multidimensionais que implodia qualquer pretensão de se construir uma via de acesso direto à plenificação total do lugar do Poder e do Direito na Europa Politicamente Unida. Também as estatalidades isoladas deveriam atuar em conjunto entre si, no interior do Conselho, para formar a própria orientação intergovernamental. Em outras palavras, mediante intensa contraposição escalar estatal isolada no Conselho, a formação do sentido da intergovernamentalidade destinada a se opor à supranacionalidade seria imunizada de pretensões unidimensionalizantes por parte de uma ou outra estatalidade isolada.

Assim, para além da singela oposição entre supranacionalidade e intergovernamentalidade, o Tratado se dirigira às estatalidades isoladas para as opor entre si no interior do Conselho, de maneira a que absolutamente nenhuma medida pudesse nem mesmo pretender a unilateralmente determinar as diretrizes gerais de ação da Comunidade, nem mesmo nos momentos de mais grave crise econômica. Por meio dessa simples previsão de necessária unanimidade no interior do Conselho, o dispositivo reiterava a necessidade de convivência ativa e constante entre cada uma das diferentes escalas de existência que habitavam a Europa Unida.

Em outras palavras, ainda uma vez, o Tratado da CECA mostrava perpetuar sua preocupação em instituir continuamente intensa oposição escalar entre as diferentes dimensões que compunham a CECA, a fim de que uma decisão sobre o uso de instrumentos jurídicos de conteúdo econômico não implicasse a introdução de vias escusas para qualquer estabelecimento a priori por qualquer dos sistemas métricos que estavam em convivência.

Deste modo, mais uma vez se sinalizara que mesmo em situação de profunda crise econômica na Europa Unida pela CECA não poderia haver o destacamento de Um sobre os demais e a sucessiva introdução de sua escala de existência no centro nomogenético da Comunidade. A oposição multiescalar deveria ser mantida para produzir o sentido comum na administração prioritária do uso de recursos escassos rarefeitos por incapacidade produtiva.

O esvaziamento do Poder concedido ao Conselho era reforçado pela disposição do parágrafo terceiro do mesmo artigo 59. Pensando em preservar a dinâmica Política na Europa Unida pela CECA, o texto normativo dispunha sobre as hipóteses em que o 
Conselho não tivesse obtido decisão unânime sobre as medidas que deveriam ser tomadas. Nestes casos, facultava-se à Alta Autoridade a determinação da repartição dos recursos da Comunidade entre os Estados-Membros em função dos consumos e das exportações, independentemente da localização das empresas produtoras.

Havia aqui uma previsão jurídico-normativa preocupada com o estabelecimento institucional de mais uma situação de mútua e recíproca contenção, pois se facultava à Alta Autoridade a possibilidade de agir em substituição ao Conselho nas hipóteses de inação deste. Na hipótese de inação e de indecisão, a escala supranacional poderia agir, mesmo contra a vontade da intergovernamentalidade.

De uma maneira apressada, poder-se-ia compreender que esse dispositivo permitira instaurar uma preferência a priori pela escala de existência supranacional na determinação do sentido normativo e de Poder na Comunidade, justificado pela necessidade premente de rápida resolução da crise econômica vigente na Europa Unida. Segundo essa leitura descuidada, teria havido um implícito reconhecimento de uma prevalência da supranacionalidade da Alta Autoridade sobre as demais.

No entanto, não se tratava disso. Como visto acima, nos casos de profunda penúria econômica, o Tratado da CECA estipulara um regime que não estaria fora da validade das Leis Políticas da Europa Unida. Tratava-se antes de manifestação de um reenvio institucional da Comunidade a ela mesma, para que ela própria pudesse encontrar em si mesma, mediante contínua oposição escalar, uma resposta à grave inação diante da premente necessidade de ação. E é nestes termos que se deve compreender esse parágrafo, para que não se deixe levar pela facilidade de um discurso de exceção lastreador de pretensões de unidimensionalização do centro nomogenético comunitário.

Em primeiro lugar, deve-se entender que esse dispositivo operava como instrumento de alerta ao Conselho e a cada uma de suas medidas estatais isoladas que o compunham: nas hipóteses de indecisão, estes poderiam se ver substituídos imediatamente pela Alta Autoridade na formulação de sua decisão - o que poderia conter em si um gérmen disruptor da Europa Unida.

Por essa razão, diante da ameaça dessa substituição, as escalas de existência estatais isoladas não deveriam se indispor por meras querelas auto-interessadas. Antes, por mais grave que fosse a situação, deveriam saber conviver entre si para, assim, poderem agir em conjunto de modo a formar a perspectiva intergovernamental - sob pena de serem absolutamente desconsiderados na formação do sentido normativo comum e substituídos pela supranacionalidade. 
Em outros termos, o Tratado da CECA jogava, aqui, com o elemento do risco típico de uma organização jurídico-política Politicamente orientada ${ }^{932}$, a fim de afastar unidimensionalizações e a supressão do vazio no lugar do Direito e do Poder, isto é, da própria condição de possibilidade da multiescalaridade. Não se tratava de fazer convergir interesses por um processo de barganha e de negociação, mas sim de saber estabelecer com a diferença um efetivo diálogo pluriescalar que viabilizasse uma decisão em conjunto sobre o destino comum ${ }^{933}$.

Nesse sentido, não se poderia esperar uma "harmonização de interesses", mas sim uma hesitante moldagem multiescalar das decisões normativas e de Poder no Conselho. Haveria que se promover neste uma ação multidimensional de pavimentação de um destino comum entre as próprias estatalidades isoladas e desestimular a inação letárgica vulgar preocupada com repartições auto-interessadas. Tais negociações apenas retardariam o processo, na medida em que buscariam renitentemente repartir entre todos cotas de satisfação para produzir a unanimidade. Assim, fosse este o sentido da ação conjunta adotado no Conselho, as estatalidades sofreriam um atropelamento escalar por parte da supranacionalidade.

Deste modo, o Tratado da CECA impediria a prevalência de uma escala de existência estatal específica que soubesse negociar melhor: todas deveriam se concertar de maneira a produzir um sentido normativo comum. Por não se tratar de barganha, mas de um regime voltado à preservação da Comunidade em momentos de grave crise, sob a ameaça de perda da possibilidade de condução multiescalar da Comunidade, o Conselho deveria buscar formar uma decisão não pautada pela mesquinhez de interesses, mas pela solução Política sobre questões comuns.

Por isso, o risco introduzido por essa disposição tinha por objetivo estimular a assunção pelo Conselho de uma postura Politicamente ativa e interessada, voltada à produção de uma decisão unânime. Mais do que buscar introduzir subterfúgios ao transbordamento escalar da supranacionalidade da Alta Autoridade, o Tratado se preocupara em trazer um estímulo institucional para que o móvel Político não deixasse de ser jamais procurado pelo Conselho na formação de sua decisão. Continha-se assim a ascensão das escalas de existência estatais dos Estados-Membros e do Conselho, mediante a ameaça de totalização por parte da supranacionalidade.

\footnotetext{
932 Como visto no item 3.4.3., supra, ao qual remetemos o leitor.

$933 \mathrm{Ou}$ seja, a reprodução perpetuadora da disposição Política vigente durante as negociações do Tratado da CECA, como relatado no item 6.3.3., supra, ao qual remetemos o leitor.
} 
Perceba-se, no entanto, que a nem mesmo à supranacionalidade se atribuía qualquer indício de preferência absolutamente determinada - nem mesmo em profunda calamidade econômica: este dispositivo introduzia também uma limitação à atividade contenedora da Alta Autoridade. De certo, ela poderia se substituir ao Conselho na tomada de decisão caso este não agisse, mas essa sua possível substituição era limitada por critérios que condicionavam o agir da Alta Autoridade.

Em outras palavras, o próprio Tratado da CECA previra mecanismos institucionais voltados a refrear o potencial impulso supranacional preocupado com sua totalização no lugar do Direito e do Poder na Comunidade. Com efeito, o Tratado excluía a possibilidade de substituição imediata do Conselho pela Alta Autoridade. Não apenas sua ação substitutiva era subsidiária ${ }^{934}$, como restava indeterminado quando efetivamente ela poderia agir, pois o artigo fala de "na falta de decisão unânime do Conselho" "935. Não havia assim uma atribuição direta e incondicional de tal Poder substitutivo à Alta Autoridade, pois esta deveria aguardar ao menos uma decisão não unânime para poder agir - não havendo previsão do tempo para a tomada de decisões, nem mesmo da quantidade de decisões necessárias para configurar a situação de falta de decisão unânime do Conselho.

Ademais, não se pode ignorar que o parágrafo terceiro estipulava de pronto um critério fundamental a ser considerado pela Alta Autoridade em sua decisão substitutiva à não tomada pelo Conselho. A definição sobre a repartição dos recursos produtivos deveria ser formulada em função dos consumos e das exportações de totais de cada EstadoMembro, e independentemente da localização das empresas produtoras.

Deste modo, a Alta Autoridade não apenas não poderia de pronto, ou a qualquer tempo, se substituir ao Conselho, como também ela não poderia tomar uma decisão desprovida de qualquer critério ou baliza, direcionando desarrazoadamente uma maior ou uma menor quantidade de recursos para um ou para outro Estado-Membro, nem deveria necessariamente privilegiar as regiões onde a produção de carvão e aço foi maior.

Note-se que apenas a previsão de uma possível de ação substitutiva desprovida de critérios balizadores permitiria o destacamento da supranacionalidade e a supressão do vazio no lugar do Direito e do Poder. Isso reforça a percepção destacada acima de que a repartição dos recursos deveria ser pensada comunitariamente, isto é, deveria ser pensada tendo em mente a multiescalaridade característica da vida em comum da CECA. Ou,

\footnotetext{
${ }^{934}$ Inação do Conselho.

935 "À défaut d'une décision unanime du Conseil sur les mesures", no original em francês.
} 
simplesmente, que a solução econômica de problemas econômicos concretos deveria se dar mediante uma dinâmica Política.

Por isso, há que se notar que por meio dos condicionamentos acima explicitados, o parágrafo terceiro não apenas bloqueava o Poder concedido ao Conselho, como também promovia uma forte contenção ao substitutivo atribuído à Alta Autoridade, de maneira a que a nenhum deles fosse permitida a busca pela ascensão a um lugar privilegiado na determinação do sentido do Direito e do Poder na Comunidade. Especialmente no que se refere à Alta Autoridade, a existência de critérios de orientação e de condicionamentos represavam sua capacidade de ação para não transbordar unidimensionalmente sobre o centro nomogenético da CECA. A substituição era possível, mas não poderia significar unidimensionalização por parte da Alta Autoridade.

Mas é necessário prosseguir, a fim de evidenciar mais completamente o engenho institucional do Tratado de afirmar sua opção contínua pela conservação da dinâmica Política na Europa, mesmo em momentos de profunda crise econômica. Havia no mesmo artigo 59 previsões adicionais que sinalizavam a perseverança da preocupação em manter vazio o lugar do Direito e do Poder na Comunidade como condição de possibilidade da multiescalaridade.

A conjugação do parágrafo terceiro, primeira alínea, do artigo 59 Tratado da CECA, com o parágrafo quarto do mesmo artigo 59, permite depreender um regime normativo bastante interessante no interior do qual se abria mais uma complexa rede de freios e contrapesos mútuos preocupados em promover intensamente ainda mais diferentes oposições escalares no interior na Comunidade.

$\mathrm{O}$ artigo 59, parágrafo quarto, determinava que a repartição de recursos pela Alta Autoridade deveria se basear em estudos feitos em colaboração com empresas e associações de empresas e se orientar pela equidade. E o parágrafo terceiro, primeira alínea, do mesmo artigo determinava que caberia ao Governo de cada Estado-Membro executar tal partilha, sem que isso implicasse prejuízo para as entregas previstas para os outros Estados-Membros. A Alta Autoridade deveria sempre ser consultada diretamente para se saber as quantidades que foram designadas à exportação e as que foram direcionadas para serem utilizadas pelas indústrias de carvão e de aço.

Preste-se atenção na potente contenção operada nesta atuação da Alta Autoridade. Definidas as prioridades de utilização e a repartição dos recursos produtivos, cabia à Alta Autoridade definir um programa de ação que planificasse em âmbito comunitário as 
respectivas dotações territoriais de carvão e aço com o objetivo de atender às demandas de consumo interno, de exportação e de produção de cada um dos Estados-Membros.

Antes de tudo, o parágrafo declarara para a Alta Autoridade que sua medida supranacional não poderia julgar a partir de seu próprio sistema métrico a quem caberiam mais ou menos recursos, pois a ela não teria sido outorgado de antemão a possibilidade de ocupar o centro nomogenético na Comunidade. Ela não poderia decidir sobre a repartição como se sua dimensão de existência pudesse livremente optar entre qualquer caminho possível, a seu bel-prazer, como se ela fosse o Direito e o Poder na Comunidade: é nesse sentido que se compreende que ela deveria decidir com base nos estudos feitos em colaboração com empresas e associações de empresas.

Ao mesmo tempo, ao se determinar a necessidade de distribuição equitativa dos recursos de produção escassos disponíveis, o condicionamento da supranacionalidade era voltado a impedir a tomada do lugar do Direito e do Poder na Comunidade, mas por outras escalas: as estatalidades isoladas. Aliás, por mais genérico que pareça determinar que a repartição deveria ser feita pela Alta Autoridade com base na equidade, este mandamento assumia neste Tratado uma significação Política - garantir a perpetuação do vazio no centro nomogenético da Europa Unida.

Nesse sentido, ao dever repartir de maneira equitativa os recursos na Comunidade, a supranacionalidade não deveria fomentar condições tais que permitissem (i) o destacamento de Uma estatalidade isolada - a detentora de maior quantidade de recursos, nem (ii) a difusão de uma subserviência contagiante entre as demais medidas de existência - detentoras de menor quantidade de recursos.

O equitativo neste parágrafo operava institucionalmente assim como alerta para a Alta Autoridade manter entre as estatalidades isoladas a condição de pares comunitários, de tal modo que não se ameaçasse o vazio no centro nomogenético comum. Sua atuação deveria erigir um escudo bifronte simultaneamente voltado a impedir uma ambição desmedida e uma curvatura desmesurada por uma ou por outra estatalidade isolada.

Enquanto elemento constante do arranjo institucional Político de crise econômicoprodutiva na CECA, o condicionamento equitativo da ação da supranacionalidade tinha por objetivo determinar institucionalmente à Alta Autoridade que, na repartição de recursos, ela buscasse atuar no sentido de preservar a Europa Unida em suas Leis Políticas. E, por isso mesmo, a equidade neste parágrafo era um mecanismo de contenção multilateralmente orientado, isto é, voltado a preservar a multiescalaridade na Europa Unida pela CECA. 
Para que não fosse rompido o sistema de convivência estabelecido institucionalmente pelo Tratado da CECA, a distribuição dos recursos escassos não deveria nem aprofundar o abismo produtivo entre os Estados-Membros, nem distorcer a divergência da capacidade de produção entre cada um deles. Para que nem Um deles se sobrepusesse por meios escusos sobre os demais (uso da força, submissão voluntária), terceiro asseguraria uma solução que preservaria equitativamente o móvel Político da União impedindo que fosse operada uma supressão do vazio - fosse por um altear-se em demasia, fosse por um descomedido vergar-se.

De todo modo, retornando à específica contenção da atividade da Alta Autoridade, cumpre observar que o mesmo parágrafo terceiro, primeira alínea, do mesmo artigo 59, reforçava a contenção do Poder de direção concedido à supranacionalidade - desta vez, no plano de sua factibilidade. Apesar de caber apenas à Alta Autoridade a planificação da repartição dos recursos escassos disponíveis, a execução efetiva de tal programa de ação era incumbência expressamente atribuída pelo Tratado da CECA ao Governo de cada Estado-Membro.

Havia aqui uma imediata forte limitação do Poder atribuído à Alta Autoridade: a decisão por ela tomada não deteria os meios práticos para produzir efeitos, isto é, ela estaria desprovida dos instrumentos necessários para se tornar eficaz. A supranacionalidade estaria de antemão impedida de recorrer a qualquer mecanismo externo ao próprio Poder de planificação para dar início à distribuição por ela planejada - esta incumbência caberia exclusivamente à medida estatal.

Antes mesmo de haver a oposição escalar entre as duas escalas de existência (supranacional e estatal isolada), aponte-se aqui rapidamente a afirmação pelo Tratado de outro elemento caracterizador da organização jurídico-Política da Europa Unida da $\mathrm{CECA}^{936}$ : a não admissão de concessão de instrumentos coercitivos para a entidade supranacional. Tratava-se de uma recusa consciente a se revestir as decisões desta de caráter coercitivo, semelhantes aos detidos pelos Estados.

Neste caso específico, a despeito de haver uma preocupação em assegurar à Alta Autoridade a possibilidade de planejar a repartição de recursos escassos disponíveis, a

936 A questão trabalhada neste item 7.3.1.1.2.3.1. é a da contraposição entre supranacionalidade e estatalidades. Assim, para assegurar coerência na exposição deste trabalho, não se dedica aqui a detalhar a reflexão em torno da negação do caráter estatal à Europa Unida mediante recusa de concessão de instrumentos coercitivos aos órgãos comunitários.

A reflexão acima indicada encontra acolhimento estrutural no presente trabalho no item 7.2.4., supra, e no item 7.3.1.1.2.3.2., infra. Para não deixar de mencionar oportunamente o ressurgimento constante dessa questão no Tratado da CECA, basta apenas referir pontualmente essa temática neste momento do trabalho. 
execução de tal divisão era relegada ao âmbito dos Estados-Membros. Mantinha-se a possibilidade de uso de tais ferramentas apenas no interior da esfera estatal nacional. Assim, relegar ao âmbito estatal a execução da planificação gestada supranacionalmente era reafirmar a condição não-estatal da Europa Politicamente Unida da CECA.

Além desse impedimento institucional de um encontro entre supranacionalidade e instrumentos coercitivos, o dispositivo construía mais uma vez a partir de oposições escalares uma condução Política da solução à grave situação econômica. Ainda uma vez, se caberia à supranacionalidade a concepção do plano, por outro lado, caberia apenas à estatalidade isolada sua execução. Nesse sentido, o Tratado estabelecera uma mútua e recíproca interdependência orgânica entre a concepção e a execução de tal modo que uma sem a outra, e a outra sem a uma, perderia significado institucional a resposta comunitária sobre a crítica situação econômica.

A partir da determinação institucional desta interdependência funcional entre Alta Autoridade e Estados-Membros, pode-se identificar a introdução normativa de uma pujante oposição mútua e recíproca entre suas respectivas escalas de existência. A dinâmica relacional Politicamente orientada em torno de um vazio no lugar do Direito e do Poder permanecia: inúmeros mecanismos promoviam freios e contrapesos que, ao mesmo tempo em que conferiam Poderes às escalas de existência, prontamente limitavam-nos, a fim de que nenhuma delas pudesse se unidimensionalizar.

Perceba-se que apenas à Alta Autoridade se facultava a possibilidade de conceber definitivamente o planejamento da repartição dos recursos ${ }^{937}$, excluindo-se desta atividade todo e qualquer outro sistema métrico que participava da Europa Unida. Ao mesmo tempo, uma vez delineado o programa pela supranacionalidade, a execução era atribuída diretamente à medida estatal isolada em seus respectivos territórios.

Excluía-se com essa previsão a possibilidade de qualquer órgão comunitário vir dar execução à decisão da Alta Autoridade (ela mesma, o Conselho, etc.) ${ }^{938}$ e garantia-se uma esfera de ação direta aos Estados-Membros para que estes pudessem atuar sobre a crise econômica que os afetava mais sensivelmente. A capacidade de influência nacional da escala de existência supranacional se limitava a conceber o plano - e nada mais. As condições para sua factibilidade eram assim mantidas pelos Estados-Membros. Dessa forma, a estatalidade isolada detinha uma expressa capacidade de contenção de toda e

\footnotetext{
937 Ainda que limitadamente, seja por força da necessidade de ser equitativa, seja por ter de levar em consideração as prioridades estabelecidas pelo Conselho, como visto nos comentários linhas acima.

${ }^{938}$ Como visto acima, com o objetivo de evitar a concessão de contornos estatais a uma organização jurídicopolítica não estatal.
} 
qualquer investida não autorizada sobre seus territórios no que se referia à execução da partilha programada.

Entretanto, não se pode deixar de notar que o Poder limitador detido pela escala estatal isolada era também represado pelas disposições do Tratado: apenas parcialmente os Estados-Membros poderiam conter a determinação dada pela supranacionalidade. Realmente, se a execução da partilha era atribuída aos Estados-Membros, cumpre salientar que não havia a possibilidade de estes se recusarem a efetuar a partilha determinada pela Alta Autoridade, nem mesmo de rediscutir os termos segundo os quais a repartição havia sido planejada (quantidade, qualidade, prazos, etc.).

Por isso mesmo, a partir desta efetiva distinção entre concepção e execução, aos Governos nacionais cumpria apenas a fiel execução em âmbito nacional dos objetivos determinados comunitariamente pela escala supranacional. Nesse sentido, é significativa a previsão correlata do próprio Tratado: nos casos de dúvida quanto ao emprego dos recursos produtivos, não caberia às escalas estatais decidir improvisadamente; antes, deveriam elas seguir precisamente o planejamento da Alta Autoridade, ainda que esta devesse ser consultada diretamente para se saber as quantidades designadas à exportação e as direcionadas às indústrias de carvão e de aço.

Se a Alta Autoridade determinava a planificação da partilha, ela era imediatamente afastada de sua execução nos âmbitos nacionais; ao mesmo tempo, se a execução da partilha apenas poderia ser efetuada pelos Estados-Membros, estes não poderiam subrepticiamente modificar a decisão comunitária formalizada pela Alta Autoridade ${ }^{939}$.

Assim, além da interdependência, esta disposição normativa promovia uma forma adicional de manter o vazio de Poder e de Direito na Comunidade por meio do afastamento simultâneo da supranacionalidade e da estatalidade isolada de uma potencial posição de detentora absoluta dos meios de ação comunitários sobre a situação de profunda penúria econômica derivada da escassez de recursos produtivos. Impedia-se assim que um ou outro pudesse pretender ocupar totalizantemente o lugar do Poder e do Direito na Comunidade. E assim eram mantidas as condições de possibilidade da permanência da multiescalaridade tipicamente Política.

\footnotetext{
${ }^{939}$ Diz-se aqui, "decisão comunitária formalizada pela Alta Autoridade", na medida em que, como visto acima, a Alta Autoridade era responsável pela edição final do ato em que se estabeleceriam as medidas destinadas a combater a crise de sub-produção, mas ela não determinava livremente o sentido desta decisão: haveria que se considerar a equidade e as prioridades estabelecidas pelo Conselho, como visto nos comentários linhas acima. Comunitária, assim, pois seu sentido normativo teria sido determinado pelo embate escalar típico da vida em comum sobre questões concretas sensíveis comunitarizadas.
} 
O parágrafo quinto do mesmo artigo 59 institucionalizara a opção normativa por uma orientação Politicamente multiescalar das decisões sobre recursos escassos na Comunidade, mas segundo outro aspecto: o do direcionamento de recursos produtivos ao mercado externo mediante exportação.

Segundo esta previsão, após consulta ao Comitê Consultivo, e desde que recebido um parecer favorável do Conselho, facultava-se à Alta Autoridade a possibilidade de estabelecer em todos os Estados-Membros restrições às exportações de carvão e aço para países terceiros. Caso a Alta Autoridade não tomasse a iniciativa a ela assegurada, garantia-se igual faculdade a qualquer Estado-Membro, cujo Governo poderia apresentar diretamente ao Conselho uma proposta de estabelecimento de tais restrições, a qual deveria ser aprovada por unanimidade.

A previsão desta possibilidade no Tratado da CECA deve ser entendida como reiteração normativa do desenho institucional preocupado com a preservação do vazio no lugar do Direito e do Poder na Comunidade, como forma de viabilizar a conservação da multiescalaridade. O artigo promovera ainda uma vez profundo conflito escalar no interior da Europa Unida, com o objetivo de assegurar a possibilidade de uma orientação multidimensional na formação do sentido normativo sobre a eventual restrição da quantidade de produtos a serem exportados.

Nesse sentido, note-se que em momentos de crise de disponibilidade de recursos produtivos, a restrição da quantidade de carvão ou aço a ser exportada para países nãoparticipantes da Comunidade poderia apenas ser efetuada por meio de decisão tomada por um participante da vida em comum. Todavia, não seria apenas seu sistema métrico quem forjaria única e unilateralmente os termos da decisão. Em função da dimensão de existência que exercera a iniciativa (Alta Autoridade ou Estado-Membro), estabelecia-se um determinado conflito multiescalar específico, o qual, por sua vez, estipulava a necessidade de a decisão ser tomada por um ou por outro partícipe da Comunidade.

Nas hipóteses em que a iniciativa era deflagrada pela Alta Autoridade, apesar de a ela caber a decisão final sobre a necessidade de se efetuar a restrição da quantidade de recursos à exportação, antes eram necessárias uma prévia consulta ao Comitê Consultivo e a emissão de um parecer favorável por parte do Conselho. Por outro lado, nos casos em que a iniciativa partia de um Estado-Membro, a decisão sobre a restrição deveria ser tomada pelo Conselho, por unanimidade. Ainda uma vez, manifestara-se no Tratado o refinado entrechoque multidimensional entre diferentes sistemas métricos que compunham a CECA. 
A supranacionalidade detinha a faculdade de avaliar a necessidade de se efetuar ou não uma restrição às exportações; no entanto, caso não desempenhasse tal conduta, não se privava que outra escala de existência o fizesse - ainda que em caráter subsidiário, hipótese na qual, inclusive, a Alta Autoridade estava privada de um Poder decisório. Por outro lado, ao mesmo tempo em que os Estados-Membros estavam impossibilitados de apresentar tal proposta sem que se constatasse a inação da Alta Autoridade, previra-se que estes poderiam assim agir perante inclusive outro órgão comunitário, caso a Alta Autoridade não agisse.

Prever uma iniciativa originária à Alta Autoridade, seguida da avaliação por outros órgãos comunitários, implicava impedir o abandono da dinâmica de se procurar resolver em instituições comuns as questões sensíveis à Comunidade: os Estados-Membros não poderiam individualmente decidir mais sobre a quantidade de exportação de tais produtos, em nome do atendimento de seus respectivos índices macroeconômicos. Estes deveriam observar o sentido normativo produzido comunitariamente, a partir de proposta formulada pela Alta Autoridade (supranacionalidade) e avaliada pelo Conselho (intergovernamentalidade).

Por outro lado, garantir-se a iniciativa subsidiária por parte dos Estados-Membros nas hipóteses de inação da Alta Autoridade implica reconhecer a atribuição de limitação imediata ao Poder de determinação da supranacionalidade. Se o sistema métrico desta compreendesse que não deveria agir, poderia haver hipóteses em que o da segunda escala percebesse estar sofrendo um sensível impacto diante da impossibilidade de modificação da quantidade de recursos voltados à exportação. Nestes casos, para além da atuação da supranacionalidade, poderia a estatalidade isolada apresentar uma proposta de redução do volume de exportação - a qual necessariamente deveria ser avaliada pela estatalidade intergovernamental do Conselho.

Nesse sentido, nenhuma das escalas de existência que compunham a Europa Unida da CECA detinha um Poder orientador absoluto e exclusivo sobre a possibilidade de se recorrer ou não a esta faculdade. Essa condição derivava precisamente de uma previsão normativa fundada na preocupação constante de promover e de assegurar o mútuo e recíproco afastamento institucional entre as diferentes escalas de existência do centro nomogenético da Comunidade. O Conselho apenas avaliava as propostas e as autorizava, mas não as formulava: estas ficavam a cargo primeiro da Alta Autoridade e, em caráter subsidiário, dos Estados-Membros. 
A supranacionalidade encontrava assim iguais limitações a sua possibilidade de determinação absoluta do sentido do Direito e do Poder na Comunidade quanto a estatalidades. O Poder não se identificava nem com a primeira escala, nem com a segunda, pois o exercício ou o não-exercício dele por uma ou por outra não impedia sua utilização pela outra: partilhado, não era de propriedade de nenhuma delas.

Assim, as escalas de existência da CECA não apenas encontravam, como também determinavam, limites institucionais umas nas outras, ou seja, nenhuma delas poderia totalizar o espaço do Direito e do Poder na Europa Unida. Ao mesmo tempo em que detinham amplo leque de determinação que impedia a ascensão da outra escala, esta sua possibilidade de impor um freio encontrava um imediato contrapeso em si mesma, o qual inclusive lhe impunha a necessidade de considerar as demais para definir o destino comum sobre questões concretas sensíveis a todos.

Por fim, há que se observar ainda que a duração deste regime de redistribuição crítica de recursos era temporária, pois a qualquer tempo poderia ser suscitado seu término. Nos termos do artigo 59, parágrafo sexto, do Tratado da CECA, após consulta ao Comitê Consultivo, a Alta Autoridade poderia solicitar o fim desse regime ao Conselho. Este apenas poderia rejeitar o pedido mediante parecer desfavorável tomado por unanimidade. Ao mesmo tempo, caso a Alta Autoridade não tomasse a iniciativa, o Conselho ele próprio poderia pôr termo a este regime mediante decisão unânime.

O referido dispositivo mais uma vez instituíra uma teia de relações multiescalares no interior da Europa Unida da CECA, mas visando a uma situação específica, a saber, o término do regime especial de combate à crise de sub-produção. Nestas situações, o Tratado da CECA parece também ter sinalizado a pretensão de reforçar a preservação da Política na condução da Comunidade.

Perceba-se que se previa neste artigo a possibilidade de se suscitar o término do regime a qualquer tempo, por iniciativa de portadores de escalas de existência distintas: diante de uma constatação por uma de uma possível ascensão da unidimensionalidade totalizante por parte de outra, mostrava-se possível apor um controle imediato, súbito, poderoso, de contenção da outra.

Em um primeiro momento, compreenda-se a previsão dos dois tipos de iniciativa: uma originária, atribuída à Alta Autoridade, e outra subsidiária, concedida ao Conselho. Para o desfazimento de uma ação empreendida comumente sobre recursos comunitários, a proposta deveria ser estabelecida igualmente no interior de uma dinâmica propriamente comunitária. 
Em outras palavras, por meio dessa previsão, excluíra-se imediatamente a possibilidade de uma única medida auto-interessada - principalmente a estatalidade isolada - propor o término do arranjo institucional Político de condução da Economia: ele não poderia ser questionado unilateralmente por uma escala de existência eventualmente descontente com a manutenção de um sistema de convivência Político. A ideia era precisamente assegurar a exclusão de todo e qualquer sistema métrico do interior do lugar do Direito e do Poder na Comunidade: o início e o fim deste regime de combate à subprodução deveriam ser decididos igualmente de maneira multiescalar.

Especial atenção deve ser dada ao embate entre as escalas portadas pela Alta Autoridade e pelo Conselho: havia aqui também a preocupação em manter entre eles uma relação de mútua repulsão, a fim de preservar um vácuo na determinação do sentido normativo. Mútuos freios e contrapesos foram normativamente previstos entre supranacionalidade e estatalidade intergovernamental com o objetivo de instaurar nova arena de contraposição escalar, como expressão do desígnio de fazer conviver diferentes para deliberação conjunta sobre o destino comum.

Após consulta ao Comitê Consultivo, a Alta Autoridade poderia solicitar o fim desse regime ao Conselho, sendo que tal solicitação seria aprovada se não fosse rejeitada por parecer unanimemente desfavorável. Aqui se pode perceber que a supranacionalidade não poderia por si só determinar o fim da disposição institucional para momentos de grave crise econômica: era necessária prévia consulta ao Comitê Consultivo e, acima de tudo, uma manifestação do Conselho.

Atribuíra-se assim à estatalidade intergovernamental um poder de limitação à proposta da supranacionalidade. Esse poder de bloqueio existia, não para preservar qualquer esfera de atuação do Conselho, mas sim para determinar a necessidade de um diálogo inclusivo multiescalar entre supranacionalidade e estatalidade intergovernamental $^{940}$. Haveria que se possibilitar um entendimento entre os diferentes modos de habitar o mundo, a fim de que se pudesse decidir sobre a interrupção do regime encontrado para lidar com a ameaça provocada pela crise econômica.

Mas não se pode deixar de notar que o poder de contenção atribuído à medida estatal intergovernamental era ele também contido. Se sua capacidade de afastar a supranacionalidade da determinação unilateral do Direito e do Poder na Europa era

\footnotetext{
${ }^{940}$ Sem ignorar também que o embate escalar era efetivamente amplo, pois abrangia também as oposições entre as estatalidades isoladas no interior do Conselho, quando da formação de sua orientação estatal intergovernamental.
} 
expressamente afirmada neste dispositivo, ela era prontamente esvaziada com o objetivo de impedir que essa própria capacidade de limitação não fosse compreendida pela própria estatalidade intergovernamental como carta branca para suprimir o vazio no lugar do Direito e do Poder.

O Conselho não detinha qualquer absoluta capacidade de determinação do fim ou do não-fim do regime, quando do exercício da iniciativa pela Alta Autoridade. Se ele deveria produzir uma decisão sobre o pedido formulado pela supranacionalidade, sua manifestação apenas poderia impedir a cessação do regime especial quando sua decisão desfavorável fosse unânime, isto é, somente se todas as escalas de existência estatais isoladas concordassem unanimemente.

Se a supranacionalidade encontrava vigorosa barreira por parte da estatalidade intergovernamental, esta última também descobria contra si um forte bloqueio interno em sua própria capacidade de contenção. Isso assegurava que a estatalidade intergovernamental não impediria levianamente a interrupção das ações empreendidas daquele regime especial. Tratava-se de uma previsão normativa diretamente voltada a repelir também o Conselho de qualquer tentativa de totalização unidimensional do sentido normativo comunitário da Europa Unida da CECA.

Todavia, o próprio dispositivo previa uma forma de contenção de eventual movimento de supressão do vazio no centro nomogenético por parte da supranacionalidade. Lembre-se de que, caso a Alta Autoridade não tomasse a iniciativa, o Conselho ele próprio poderia pôr termo a este regime mediante decisão unânime.

Antes de tudo, frise-se que essa previsão concedia um poderoso mecanismo de bloqueio de eventual ascensão da supranacionalidade à estatalidade intergovernamental: a Alta Autoridade não detinha a seu livre e absoluto dispor a faculdade de uso deste instrumento. Não apenas sua não-utilização não impedia o exercício subsidiário pelo Conselho, como também, principalmente, se retirava dela a possibilidade de tentar tomar o lugar do Direito e do Poder por meio de uma inação prejudicial à vida comunitária ${ }^{941}$.

\footnotetext{
${ }^{941}$ Lembre-se de que a inação era prejudicial precisamente porque a disciplina normativa examinada neste item 7.3.1.1. consistia precisamente em facultar modos excepcionais de atuação da Alta Autoridade sobre questões concretas sensíveis localizadas no interior do território dos Estados-Membros (exceção ao regime geral de atuação indireta, estipulado no artigo 57 do mesmo Tratado, conforme analisado no item 7.3.1.1.1., supra).

De todo modo, como vem sendo explicado ao longo do presente Capítulo, mesmo este regime de atuação direta da Alta Autoridade não deixava de estabelecer sucessivas formas de controle da supranacionalidade, primando pela perseverança de soluções normativas multiescalares sobre o uso e a administração do carvão e do aço na Europa Politicamente Unida pela CECA.
} 
Da mesma maneira que não caberia a ela exclusivamente a proposição de seu início, também não caberia à Alta Autoridade a exclusividade de propor o fim do regime de combate à escassez de recursos. Diante de inação da Alta Autoridade em momentos que o sistema métrico do Conselho considerasse desaparecida a gravidade, este poderia recorrer a esta previsão e determinar o desfazimento do novo arranjo institucional mediante decisão unânime.

É nesse específico ponto que se deve compreender, contudo, que o próprio potencial de contenção detido pelo Conselho era também limitado pelo próprio Tratado: este poderoso contrapeso era igualmente refreado de modo vigoroso mediante a previsão de que tal faculdade apenas poderia ser exercida em caráter subsidiário e de que tal decisão deveria ser tomada por unanimidade entre as estatalidades isoladas componentes e formadoras da intergovernamentalidade.

Ao atribuir apenas subsidiariamente a faculdade ao Conselho, o Tratado da CECA garantia que este não poderia de imediato buscar interromper a decisão comunitariamente formada a seu bel-prazer. Antes, ele deveria aguardar uma inação da Alta Autoridade que pudesse significar por parte desta a busca pela supressão do vazio no lugar do Direito e do Poder. Apenas nestes casos de contenção da supranacionalidade o Conselho poderia exercer tal faculdade. A ação deste estava nesse sentido condicionada a uma inação supranacional potencialmente perigosa para a manutenção do sistema de convivência instituído pela CECA.

Ademais, a própria concessão subsidiária de tal faculdade ao Conselho implicava também um simultâneo desapossamento: tratava-se da reiteração da condição de que o Poder a ele imputado não era previsto em seu favor, ou ainda, que não era dele. Previsto pelo Tratado que instituíra a Comunidade, o Poder era atribuído ao Conselho precisamente para garantir a preservação da vida em comum - e não para privilegiar ou para prejudicar uma ou outra escala de existência. Tratava-se de forma de lembrar que não lhe estava autorizada a possibilidade de ocupar intemporalmente o lugar de definição do sentido do Direito e do Poder na Comunidade.

Em outras palavras, da mesma maneira que a Alta Autoridade não dispunha de exclusividade absoluta sobre o uso de tal Poder no interior da Comunidade, o Conselho estava igualmente impedido de se considerar senhor único deste recurso, precisamente em virtude de seu caráter subsidiário. Supranacionalidade e intergovernamentalidade se encontravam novamente conscientes de estarem diante de uma condição de concorrência pelo Poder, sem que nenhuma delas pudesse o ocupar intemporal e unidimensionalmente - 
pois com ele nenhuma delas se identificava, haja vista que se tratava de um Poder previsto para manter a Comunidade Política da CECA.

Além disso, a exigência de uma decisão por unanimidade enfatizava a própria divisão escalar vigente no interior do Conselho: a formação do sistema métrico deste órgão dependia necessariamente das reiteradas e renovadas sínteses dimensionais operadas por força de uma convivência sistematicamente retomada entre as diferentes estatalidades isoladas.

Deste modo, por mais que se tivesse sido iniciada por ele uma proposição pelo fim do regime de combate à crise econômica que assolava a Comunidade, esta decisão apenas poderia ser tomada diante de uma unanimidade afirmada em conjunto pelas diferentes maneiras estatais isoladas de habitar o mundo, no interior de uma lógica comunitária forjada no Conselho. Uma e todas as escalas de existência estatais (intergovernamental e isoladas) se afastariam mutuamente, mantendo o vazio de Poder na Comunidade.

Reafirmava-se aqui outra armadilha do Poder: o uso deste recurso por parte do Conselho não apenas impedia a plenificação do lugar do Direito e do Poder pela supranacionalidade ou pela estatalidade isolada, mas também gerava uma autolimitação. Contraditoriamente, o Conselho optaria por um agir subsidiário ao da Alta Autoridade com o objetivo de a conter em sua desvirtuada inação que, ao mesmo tempo, desencadearia uma contenção das variadas escalas estatais isoladas de existência e provocaria principalmente uma consciente autolimitação, nos termos do Tratado. Mas apenas aparentemente é uma contradição, pois se repetira neste dispositivo a virtuosa construção de uma União Política na Europa por meio de um Poder "sem Poder".

Deste modo, nota-se a reiterada preocupação em se manter o vazio em toda e qualquer mínima decisão atinente sensivelmente ao destino comum, a fim de que ele fosse publicamente pensado. Mesmo em profunda crise econômica, a regulação jurídicoeconômica da atividade produtiva dos recursos comuns ou da distribuição destes não se afastaria de uma dinâmica Política, pois as instituições do Tratado recusavam normativamente uma regência multiescalar do sentido normativo sobre questões concretas sensíveis comuns. 
7.3.1.1.2.3.2. Outros Aspectos Institucionais caracterizadores da Organização Jurídico-Política da Europa Unida da CECA: Opção Normativa pela Recusa ao Uso Centralizado da Força

Por fim, o artigo 59, parágrafo sétimo, previa normativamente também um elemento que reforça a caracterização da organização jurídico-Política da CECA como uma recusa pela assunção de uma forma estatal. Os motivos são precisamente os mesmos apontados no item 7.3.1.1.2.2.2., supra, ao qual se remete o leitor para uma compreensão geral do argumento. Aqui serão apontados apenas aspectos específicos do artigo 59 que podem ser entendidos como aptos a reforçar esta percepção de recusa à formação de um Estado Europeu.

$\mathrm{O}$ artigo 59, parágrafo sétimo, atribuía à Alta Autoridade a faculdade de aplicar multas a empresas que descumprissem as decisões formuladas para lidar com tal grave situação econômica de escassez de recursos. E apesar de se dever admitir de que se tratava de atribuição de Poder voltado a estimular o cumprimento das decisões jurídicas, não se pode ignorar que este dispositivo era opção clara por restringir a uma singela dimensão econômica a capacidade constritora da supranacionalidade sobre entidades localizadas em territórios nacionais.

Nesse sentido, note-se que à Alta Autoridade era claramente negada a possibilidade de tentar se socorrer de mecanismos alternativos de caráter coercitivo para garantir o cumprimento das decisões. Esta possibilidade de se recorrer ao uso da força lhe era privada precisamente porque o Tratado da CECA não buscava tornar a Comunidade ou qualquer de suas entidades algo nem mesmo próximo ao de uma organização jurídico-política estatal. Não estava nos planos dos autores do Tratado a formação de um Estado Europeu a partir da CECA, e esta não deveria nem mesmo conter elementos que indicassem uma eventual tendência para assim se encaminhar no futuro.

Deste modo, ao se centrar sobre a possibilidade de poder determinar apenas constrangimentos econômicos sobre as empresas localizadas nos territórios nacionais, a Alta Autoridade - como qualquer outro órgão comunitário - estava imediatamente impossibilitada de recorrer à coerção. Isto significava, simplesmente, que seu âmbito de atuação estava restrito a um círculo de ação obrigatório - sem dúvida, porém nãocoercitivo. Ou ainda, isso significava que seu modo de agir para assegurar a perseverança do Político era diverso do tradicionalmente reconhecido à medida estatal nacional, pois não lhe era concedida a centralização do uso da força. 
7.3.1.1.3. Artigos 60 a 64 do Tratado da CECA: A Organização Jurídico-Política das Soluções Normativas Comunitárias para Condutas de Afecção Direta na Formação dos Preços de Carvão e Aço na CECA

Como anunciado anteriormente ${ }^{942}$, o presente trabalho interpretaria parcela de normas do Tratado da CECA sem seguir a ordem dos artigos tal qual ele constavam do referido documento jurídico-normativo. E, conforme justificado anteriormente ${ }^{943}$, neste item 7.3.1.1.3., essa reorganização do espaço interpretativo das disposições jurídiconormativas do Tratado - sem se preocupar em seguir o desenho (topo)gráfico do Tratado da CECA - será feita de maneira ainda mais explícita, tendo por objetivo enfatizar a organização jurídico-Política da regulação jurídico-econômica da formação dos preços do carvão e do aço na Comunidade.

O rearranjo do campo significativo em ordem parcialmente diversa da de exposição do texto normativo tem por objetivo rearticular os termos normativos disponíveis para além da letra do Tratado, a fim de facilitar a explicitação e a visualização da possibilidade de interpretação jurídico-Política que as próximas páginas desenvolverão em torno de normas jurídicas de conteúdo econômico.

Como indicado algumas linhas acima ${ }^{944}$, este item se procurará compreender jurídico-Politicamente a intervenção da Comunidade sobre variáveis componentes do sistema de formação de preços do carvão e do aço. Para tanto, do Título Terceiro do Tratado da CECA, será analisado aqui o Capítulo V- Preços (artigos 60 a 64).

É importante notar que essa rearticulação interpretativa das normas tem por orientação o exame da disciplina jurídico-Política que regulamentava a produção de soluções normativas comunitárias diante de condutas que impactavam de forma direta por meio do falseamento do preço de mercado (Capítulo V) - a manutenção de um sistema de formação de preços estável na Comunidade.

Não se pode ignorar que os dispositivos a serem examinados a seguir se tratam de instrumentos jurídicos de conteúdo econômico preocupados com a preservação em bloco de uma dinâmica específica na formação do sistema de preços no interior da Comunidade. Todavia, se neste momento da análise serão examinados instrumentos jurídicos de

\footnotetext{
${ }^{942}$ Final do item 7.3.1., supra.

${ }^{943}$ Final do item 7.3.1.1., supra.

${ }^{944}$ Final do item 7.3.1.1., supra.
} 
conteúdo fortemente econômico, é importante reiterar ser a especificidade investigativa deste trabalho a preocupação em evidenciar a possibilidade de se compreender jurídicoPoliticamente tais normas.

É impossível desenvolver comentários interpretativos dos textos jurídico-normativo dos dispositivos a seguir sem efetuar qualquer menção à disciplina jurídico-econômica do Tratado, precisamente por se tratar de um arcabouço normativo composto por normas jurídicas dotadas de conteúdo econômico que regulavam a formação do sistema de preços na Comunidade. Negar essa particularidade seria odiosa e insincera cegueira acadêmica.

Contudo, a preocupação deste trabalho não é detalhar uma interpretação econômica do Tratado, precisamente porque foi colocada em suspenso desde a Introdução Geral a este trabalho uma leitura econômica da CECA, em prol da possibilidade de se compreender jurídico-Politicamente, não apenas sua História, mas também as instituições de seu Tratado. Em outras palavras, objetivo deste texto não é compreender a disciplina econômica regulatória que estruturava a formação dos preços de carvão e aço na CECA, mas sim entender a organização jurídico-Política em que esta disciplina jurídicoeconômica se inseria.

A preocupação consiste assim em compreender de que maneira o arranjo institucional do Tratado da CECA determinou nestes dispositivos um conjunto de oportunidades de realização de oposições escalares e de esvaziamento do lugar de definição do sentido do Direito e do Poder na Europa Unida para produzir soluções comunitárias multiescalares voltadas a combater condutas que impactavam direta ou indiretamente a formação dos preços na Comunidade.

A superfície regulatória dita é assim composta por instrumentos jurídicoeconômicos. Contudo, ao se ultrapassar a materialidade do significante jurídicoeconômico, será possível desvelar nesses dispositivos a presença de normas de oposições escalares responsáveis pela deflagração de entrechoques multiescalares no interior da Europa Unida pela CECA e o esvaziamento do lugar do Direito e do Poder derivado de sucessivos freios e contrapesos. Será possível explicitar assim a presença de vigorosa preocupação em organizar jurídico-Politicamente a regulação jurídico-econômica do preço do carvão e do aço na CECA.

O conjunto jurídico-normativo representado pelos artigos 60 a 64 do Tratado da CECA incide sobre as práticas de preços pelas empresas que atuavam no espaço da Comunidade dentro do setor econômico abrangido pelo Tratado. Em outras palavras, tais artigos se referiam a todas as transações comerciais relacionadas à exploração econômica 
do carvão e do aço (tais como a extração, a produção, a distribuição, o fornecimento, a venda, a compra) realizadas no interior do mercado comunitário, as quais poderiam afetar a formação do preço de tais produtos.

\subsection{O Artigo 60 e as Condutas Desleais e Discriminatórias na CECA}

O parágrafo primeiro do artigo 60 estabelecia duas proibições gerais no interior da Comunidade, no que se refere à prática de preços pelas empresas do setor econômico do carvão e do aço, a saber: (i) práticas desleais que reduzissem preços temporária ou regionalmente, tendendo a permitir a aquisição de posição dominante; e (ii) práticas discriminatórias que, em transações comparáveis, impusessem condições desiguais a compradores distintos, notadamente para aqueles de nacionalidades diferentes.

O Tratado estipulava ainda de forma genérica, no parágrafo segundo do mesmo artigo 60, em suas alíneas "a" e "b", que deveriam ser publicadas as Tabelas de Preços e de Condições de Venda por todas as empresas exploradoras do carvão e do aço, a fim de que não fosse permitida a majoração de preços em relação à referida Tabela, ou uma redução de preços por força de condições favoráveis em virtude do lugar de entrega ao comprador, ou em função da origem ou do destino dos produtos.

Ao lado das tais disposições típicas de Direito Econômico acima brevemente descritas, não se pode ignorar a presença de elementos que denotavam a preocupação do Tratado em assegurar a multiescalaridade na formação do sentido normativo sobre questões concretas sensíveis comuns relacionadas à prática de preços pelas empresas. Isso apenas pode ser percebido a partir de uma análise mais atenta deste artigo.

Além de estabelecer as duas obrigações genéricas de não-deslealdade e de nãodiscriminação supramencionadas, o final do parágrafo primeiro do artigo 60 do Tratado da CECA determinava que maiores especificações concretas sobre quais práticas poderiam ser compreendidas como configurando tais condutas poderiam ser definidas normativamente pela Alta Autoridade, com o objetivo de precisar a exatidão das condutas empresariais proibidas pelo Tratado.

Em outras palavras, o Tratado da CECA (i) estipulou de maneira genérica as linhas gerais de condutas desleais e discriminatórias relacionadas à prática de preços no interior da Comunidade e (ii) atribuiu à Alta Autoridade a possibilidade de produzir normas jurídicas adicionais voltadas a especificar positivamente as condutas visadas pela proibição constante do referido artigo. A percepção desses dois momentos permite compreender um 
primeiro indício da reiteração da preocupação em conservar o vazio no lugar do Direito e do Poder.

Enquanto instrumento de inserção de normas jurídico-positivas e de instituições no interior das relações entre os povos europeus tradicionalmente opostos entre si em termos militares, o Tratado da CECA foi ele próprio produto de intenso embate multiescalar entre as estatalidades isoladas comprometidas em direitificar intergovernamentalmente um arranjo institucional apto a criar condições para formar uma vida comum na Europa do pós-Segunda Guerra Mundial ${ }^{945}$ - intergovernamentalidade comprometida com a Comunidade, ou ainda, comunitariamente comprometida ${ }^{946}$.

Assim, ao estruturar um mecanismo de tutela do sistema de formação de preços neste primeiro parágrafo do artigo 60, o mesmo Tratado sinalizava mais uma vez que não se afastaria do mesmo objetivo de instituir e de preservar um regime de convivência entre diferentes multiescalarmente orientado. Se o Tratado determinava a preservação da formação de preços por meio de duas disposições genéricas, mas não determinava minuciosamente as condutas proibidas, há que se compreender o sentido jurídico-Político destes dois momentos.

Ao proceder deste modo, abria-se um vazio de indeterminação no interior do cosmos regulatório: uma perspectiva intergovernamental, precisamente porque Politicamente orientada, não poderia pretender estipular de imediato e prontamente a orientação integral, absoluta e total do sentido do Direito e do Poder na Comunidade. Haveria que haver a consideração conjunta de todas as demais formas de habitar o mundo que coexistissem na Comunidade para que este sentido normativo fosse produzido.

Em outras palavras, era possível aos Estados-Membros formular normativamente de antemão quais seriam as condutas desleais e discriminatórias proibidas na Comunidade - na medida em que a redação do Tratado fora tarefa originariamente assumida por eles. Contudo, tendo em mente a importância de se estabelecer multiescalarmente o sentido normativo sobre questões concretas sensíveis que, a partir daquele momento, foram tornadas comuns, eles espontaneamente se abstiveram de tal atividade para evitar de antemão comprometer futuramente a produção do sentido normativo comum com uma possível contaminação totalizante uniescalar dada pela estatalidade intergovernamental.

\footnotetext{
${ }^{945}$ Sobre o processo de negociação do Tratado da CECA, remetemos o leitor ao Sexto Capítulo, supra, principalmente a seu item 6.3.3. Sobre o sentido de direitificação - enquanto direitificação da convivência comum entre diferentes escalas de existência, remetemos o leitor ao item 2.1., também supra.

${ }^{946}$ Lógica que deveria não apenas permear a elaboração do Tratado, mas também seguir na prática cotidiana das relações institucionalizadas por suas normas jurídicas, após sua entrada em vigor. Como visto no item 6.3.3., supra.
} 
Assim, visando a afastar a possibilidade de a intergovernamentalidade inserir no interior do Tratado uma disposição jurídico-normativa econômica constituída singela e uniescalarmente à sua imagem e semelhança, a opção por tal redação pode ser entendida como uma forma de buscar preservar o vazio no centro nomogenético da Comunidade como condição de possibilidade de multiescalaridade na produção de sentido normativo sobre questões concretas sensíveis comuns. Ao impedir o destacamento prévio de Uma medida de existência sobre as demais - a da intergovernamentalidade, o Tratado reafirmara sua disposição em firmar sua orientação normativa multiescalar.

Por isso mesmo, esta previsão do Tratado pode ser entendida como mecanismo de autoimposição de limitação originária às medidas de existência responsáveis pela própria redação do Tratado. Esse dispositivo traduzia normativamente o ânimo em se garantir a abertura do lugar do Direito e do Poder na Comunidade mediante a rejeição de qualquer unilateralidade escalar. Mais simplesmente, tratava-se de uma garantia de permanência de uma incerteza regulatória multiescalar contraposta à certeza de uma única maneira de formatar o regime jurídico-regulatório econômico: este era percebido assim como necessariamente dentro de uma organização jurídico-Política.

Por esse motivo, note-se que, ao mesmo tempo em que este dispositivo impôs um freio à intergovernamentalidade, ele também bloqueava a intromissão não-autorizada e totalizante de qualquer outra escala participante da vida em comum. A auto-retirada da estatalidade intergovernamental do lugar do Direito e do Poder se mostrou como condição necessária e fundamental para a criação deste locus vazio, mas ainda assim era insuficiente para sua manutenção: haveria que se evitar a reintrodução de qualquer Um neste espaço de determinação do sentido do Direito e do Poder.

A leitura do final do primeiro parágrafo do artigo 60 esclarece essa perspectiva: a definição precisa das condutas desleais e discriminatórias proibidas pelo Tratado da CECA seria dada por meio de decisão formulada pela Alta Autoridade ${ }^{947} 948$. Todavia, para a

${ }^{947}$ Sobre as características das decisões, v. nota de rodapé 154, supra.

${ }^{948}$ A título de curiosidade, mencionem-se a Decisão n. 30-53, de 2.5.1953, e a Decisão n. 1-54, de 7.1.1954, como decisões da Alta Autoridade da CECA elaboradas para especificar as práticas interditas pelo artigo 60, parágrafo primeiro, do Tratado da CECA.

Dentre algumas das práticas constantes desses documentos, salientam-se exemplificativamente a concessão de condições favoráveis de execução da prestação no tempo sem um respectivo aumento do preço, de acordo com os usos comerciais da região do vendedor (artigo 4 da Decisão n. 30-53), ou mesmo a inclusão no preço final dos produtos do valor de impostos sobre os quais o vendedor obteve isenção ou repetição de indébito (artigo 5 da Decisão n. 30-53).

Frise-se que o exame minucioso das duas decisões mencionadas nesta nota de rodapé não será efetuado neste trabalho, haja vista a necessidade de se manter a coerência com o recorte metodológico anunciado ao início desta Tese, no item 2.1.2., supra, e especialmente referido na nota de rodapé 227 , 
formação desse ato normativo, era necessária prévia consulta ao Comitê Consultivo e ao Conselho. A ideia era não prever neste dispositivo qualquer manifestação de preferência pela moldagem do Direito e do Poder por uma ou outra forma europeia de experienciar o mundo: todas em conjunto deveriam produzir o sentido normativo para solucionar a questão concreta sensível sobre a definição das condutas desleais e discriminatórias proibidas na Comunidade, e não apenas qualquer das estatalidades, ou apenas a supranacionalidade.

É inegável reconhecer que de maneira bastante direta o Tratado atribuíra tal iniciativa à Alta Autoridade da CECA, uma adjudicação que implica a imediata e simultânea exclusão dos demais participantes da Comunidade. O ato normativo seria emanado formalmente do interior da Alta Autoridade. Todavia, diferentemente do que se poderia pensar de maneira apressada, não haveria com isso uma especial predileção pela supranacionalidade da Alta Autoridade. À concessão do Poder à Alta Autoridade seguirase imediatamente um esvaziamento desta mesma capacidade de ação decisória nomogenética.

Com efeito, se o veículo jurídico formal de introdução dessa orientação normativa jurídico-política era precisamente um ato normativo que apenas a Alta Autoridade poderia elaborar (decisão), a construção do campo significativo jurídico-normativo se daria não apenas com a presença da perspectiva do modo supranacional de habitar o mundo. Antes, a supranacionalidade seria também excluída em virtude da necessária contraposição existencial exercida pela estatalidade intergovernamental do Conselho (carro-forte do conjunto dos Estados-Membros) e, por isso mesmo, pela igual presença das estatalidades isoladas (Estados-Membros formadores da perspectiva intergovernamental do Conselho e formadores da perspectiva deste) $)^{949}$.

Assim, se se atribuíra à Alta Autoridade a incumbência de formalizar o ato jurídiconormativo de acordo com um instrumento formal de introdução de normas jurídicas no ordenamento comunitário (decisão), não poderia ela por si só formular os termos destinados a delinear o campo normativo-significativo, pois o Conselho deveria em conjunto com ela atuar na definição do sentido normativo sobre questão concreta sensível

também supra: o Direito Positivo a ser interpretado por este trabalho é o do Direito Comunitário Originário da CECA, e não o do Direito Comunitário Derivado.

${ }_{949}$ É por esse motivo que em diversos momentos neste trabalho, principalmente na integralidade do item 7.2., supra, afirmou-se que o ato normativo comunitário era apenas formalizado pela Alta Autoridade, e não por ela produzido exclusivamente à sua imagem e semelhança uniescalar. Era sem dúvida alguma sua competência privativa produzir tais decisões, mas elas não seriam forjadas unicamente a partir de sua dimensão existencial: sempre o Tratado previra o concurso de outras escalas de existência, a fim de evitar a concessão do lugar do Direito e do Poder à supranacionalidade da Alta Autoridade. 
comum. Ao mesmo tempo, se as outras escalas de existência poderiam e deveriam introduzir sua forma de experienciar o mundo no processo de orientação do sentido do Direito e do Poder na Comunidade, elas não detinham a faculdade de iniciar o processo decisório, nem de o formalizar definitivamente em decisões, pois esta tarefa residia no campo de ação da Alta Autoridade.

Perceba-se nesse sentido que se efetua a exclusão simultânea do lugar do Direito e do Poder tanto da supranacionalidade da Alta Autoridade, quanto das escalas estatais isoladas (Estados-Membros) e da intergovernamentalidade (Conselho), haja vista que nenhuma delas encontrava meios para afirmar de maneira determinante e unidimensional o sentido normativo na Europa Unida. Esta tinha assegurada assim um vazio em seu centro nomogenético.

Neste ponto, há que se realizar um rápido salto no texto do Tratado e interpretar neste momento seu artigo 63, parágrafo terceiro, tendo em vista que ele expressamente fazia referência ao artigo 60, parágrafo primeiro. O comentário conjunto a este outro artigo permitirá compreender que ele operava como complemento jurídico-normativo à previsão do artigo 60, parágrafo primeiro, em um sentido todo especial. O artigo 63, parágrafo terceiro, não apenas buscava contribuir para assegurar a abstenção pelas empresas da prática das condutas desleais e de discriminação proibidas no interior da Comunidade, como também auxiliava na promoção e na manutenção da dinâmica Política na Europa Unida pela CECA.

O artigo 63, parágrafo terceiro, atribuía à Alta Autoridade a faculdade de dirigir aos Estados-Membros interessados todas as recomendações apropriadas para assegurar o respeito das decisões formuladas nos termos do artigo 60, parágrafo primeiro, por empresas ou organismos que explorassem a atividade econômica de distribuição dos produtos relacionados ao carvão e ao aço no interior da Comunidade.

A conservação de Leis Políticas na Europa Unida era realizada pelo dispositivo ora em análise por meio de uma ação em dois registros distintos, a saber, (i) gerar ainda uma vez uma arena de oportunidades para oposições escalares; e (ii) reiterar a orientação em preservar uma organização jurídico-Política de relações desprovida de elemento coercitivo. A missão geral da integralidade deste item 7.3.1. é apontar e descrever as oposições escalares constates nas normas de Direito Econômico da CECA, razão pela qual será enfatizado nas linhas a seguir mais minuciosamente (i) do que (ii) ${ }^{950}$.

\footnotetext{
${ }^{950}$ Afinal, o raciocínio demonstrativo da presença de uma recusa normativa reiterada do elemento coercitivo à Europa Unida da CECA foi mencionado por diversas vezes neste trabalho, não apenas no Sexto Capítulo,
} 
Analise-se primeiramente o primeiro aspecto desta previsão normativa: a Alta Autoridade poderia dirigir recomendações aos Estados-Membros para assegurar o respeito das decisões formuladas nos termos do artigo 60, parágrafo primeiro. O Tratado da CECA atribuía à supranacionalidade por meio deste texto um instrumento jurídico-formal bastante específico para interagir diretamente com a estatalidade isolada, e esta especificidade deve ser detalhada, para melhor compreender a qualidade desta aproximação escalar fomentada por esse dispositivo.

A fim de formalizar a decisão normativa multiescalarmente engendrada prevista pelo artigo 60, parágrafo primeiro, do Tratado da CECA, a Alta Autoridade deveria consultar necessariamente o Conselho. Por outro lado, para assegurar o respeito no interior dos Estados-Membros a tais decisões pelas empresas localizadas nos territórios destes, o Tratado dispensava em seu artigo 63, parágrafo terceiro, a presença do Conselho na formulação das recomendações dirigidas pela Alta Autoridade aos Estados-Membros. Isto é, o Tratado da CECA estipulava nesse dispositivo uma possibilidade de interação direta entre Alta Autoridade e Estados-Membros.

É nesse sentido que se deflagra um embate escalar direto apenas entre supranacionalidade e estatalidade isolada: nas hipóteses em que no interior de um EstadoMembro as empresas de distribuição não estivessem cumprindo as decisões formalizadas pela Alta Autoridade, esta poderia direcionar especificamente a este Estado-Membro em particular uma recomendação.

Assim, tendo havido já a participação do Conselho na elaboração da decisão, bastaria apenas e tão-somente a presença da Alta Autoridade e de sua recomendação para orientar normativamente os Estados-Membros - sem a necessidade de qualquer mediação pelo Conselho. Em outras palavras, bastava a interação direta entre supranacionalidade e estatalidade isolada, sem que isso pudesse significar uma preferência pela Alta Autoridade ou a desconsideração pela estatalidade: o embate escalar suscitado normativamente pelas instituições do Tratado da CECA entre Alta Autoridade e os Estados-Membros era muito mais sutil e, em sua sutileza, bastante vigoroso.

mas também nos itens 7.2.4., 7.3.1.1.2.2.2. e 7.3.1.1.2.3.2., todos supra. Por essa razão, este aspecto será apenas sugerido rapidamente nas próximas linhas, mas não será desenvolvido, motivo pelo qual remetemos o leitor aos itens e ao Capítulo acima mencionados.

A ideia de mencionar este aspecto nesta parcela do texto é de apenas reforçar o argumento de que, em diferentes momentos e situações do Tratado, negou-se à CECA a possibilidade de dispender de instrumentos coercitivos, ou ainda, dito de outro modo, que se recusou em diferentes previsões normativas a esta Organização Internacional europeia a possibilidade de se assemelhar institucionalmente a um Estado Europeu, ou a um Projeto de futuro Estado Europeu. Ou seja, mais simplesmente, que sua organização jurídico-política não era a de um Estado, ou de um “proto-”Estado em formação. 
A oposição escalar instaurada por este dispositivo entre supranacionalidade e estatalidade isolada era bem peculiar e é mais bem compreendida a partir da consideração específica da espécie normativa eleita pelo Tratado para ser o instrumento de ação da Alta Autoridade neste caso em especial: a recomendação. Como visto anteriormente ${ }^{951}$, a recomendação se diferenciava da decisão pelo fato de ser obrigatória com relação aos fins, mas de deixar a seus destinatários a livre escolha regulatória dos meios para os atingir, ao passo que a decisão era integralmente obrigatória em seu conteúdo para seus destinatários (meios e fins).

Em outros termos, a própria escolha pelo Tratado da CECA de uma determinada fonte de Direito Comunitário Derivado (recomendação) em detrimento de outra (decisão) assinalava a preferência por um modelo regulatório que, ao mesmo tempo em que determinava o seguimento de um objetivo jurídico-Político comunitariamente estabelecido $^{952}$, privilegiava a manutenção de um campo de ação normativa por parte dos Estados-Membros.

Assim, se os Estados-Membros estavam obrigados a se orientar pelas indicações dadas pela Alta Autoridade por meio das recomendações, esta não poderia interferir na escolha dos meios normativos preferidos pelos Estados-Membros para atingir o fim jurídico-Politicamente por ela determinado. Em outras palavras, a atuação da Alta Autoridade com relação aos Estados-Membros era fortemente restringida à simples determinação dos fins a serem regulatoriamente atingidos por eles, não podendo influenciar na própria escolha dos meios normativos que os Estados-Membros articulariam para observar a recomendação.

O embate escalar se manifestava aqui de maneira sutil, mas vigorosa: ao mesmo tempo em que se conferia à Alta Autoridade um imenso Poder normativo, estabelecia-se aos Estados-Membros um robusto contra-Poder também normativo, de tal modo que nenhum deles pudesse determinar por si só o sentido normativo último da solução destinada a solucionar a questão concreta sensível comum surgida.

Havia assim um engenhoso mecanismo de freios e contrapesos neste dispositivo, mediante separação de funções: à Alta Autoridade estava reservada a determinação dos fins; aos Estados-Membros, a dos meios. Preservava-se o vazio no lugar do Direito e do Poder na Comunidade mediante convivência institucionalmente forçada entre

\footnotetext{
${ }^{951} \mathrm{~V}$. nota de rodapé 154 , supra.

952 A especificidade das condutas desleais e discriminatórias proibidas na Comunidade, definidas multiescalarmente, em virtude do artigo 60, parágrafo primeiro, do Tratado da CECA.
} 
supranacionalidade e estatalidade isolada, pois nenhuma delas detinha uma faculdade de agir suficiente para controlar e definir por si só e de maneira integral o princípio e o fim do Poder a cada uma atribuído, pois uma dependia da outra para o desempenhar.

Ademais, pode-se reforçar, a partir da parcela final do mesmo parágrafo terceiro, do artigo 63, a percepção da opção contínua do Tratado por uma organização jurídico-política da Europa não-estatal, mediante a recusa de instrumento de ação de caráter coercitivo a qualquer órgão da CECA. Essa constatação é facilmente perceptível.

Esse texto normativo estabelecia que a Alta Autoridade poderia dirigir recomendações aos Estados-Membros interessados, a fim de que estes assegurassem normativamente o respeito às regras estabelecidas pelas decisões da Alta Autoridade - nos termos do artigo $60^{\circ}$, parágrafo primeiro, por parte das empresas ou dos organismos que exploravam a atividade econômica de distribuição dentro do setor econômico do carvão e do aço.

De maneira geral, o vácuo de Poder trazido por este dispositivo derivava do modo por meio do qual o texto normativo procurava desenvolver garantias institucionais de respeito às normas jurídicas comunitárias derivadas por parte das empresas. Ao mesmo tempo em que se reservava um domínio de ação à Alta Autoridade para buscar assegurar a observância de tais normas (edição de recomendações), retirava-se dela a possibilidade de atuar diretamente sobre (as empresas localizadas n)o território dos Estados-Membros mediante o uso de instrumentos coercitivos supranacionais.

Em outras palavras, o âmbito de atuação da Alta Autoridade se resumia à simples dimensão da linguagem normativa (recomendações), sendo mantida a centralização do uso da força aos Estados-Membros. A Alta Autoridade teria a garantia de que suas normas produzidas na Comunidade seriam devidamente observadas pelos agentes econômicos, haja vista que os Estados-Membros atuariam no sentido de assegurar a observância delas. Todavia, por a Alta Autoridade não centralizar o uso da força na Europa Unida, ela estava desprovida dos meios de concretização dos fins estipulados por suas recomendações.

A Alta Autoridade deveria aceitar assim sua impotência no que se refere à possibilidade de conferir sentido concreto e prático efetivos a sua normatização, haja vista que os mecanismos diretos restariam com os Estados-Membros, ou ainda, precisamente porque ela não era uma organização jurídico-política estatal europeia ${ }^{953}$.

\footnotetext{
953 Como afirmado anteriormente, remetemos o leitor às reflexões constantes do Sexto Capítulo e também dos itens 7.2.4., 7.3.1.1.2.2.2. e 7.3.1.1.2.3.2., todos supra, a fim de compreender mais completamente este raciocínio de negação normativa de instituições estatais (centralização do uso da força) à CECA.
} 
Formuladas as considerações necessárias a parcela do artigo 63 do Tratado da CECA, retorna-se no próximo item à ordem de exposição do Tratado, a fim de apresentar os comentários ao artigo 61 que permitirão visualizar a presença de uma possível leitura jurídico-Política de seus dispositivos.

\subsection{O Artigo 61 e os Preços Máximos e Mínimos dos Produtos}

O artigo 61, parágrafo primeiro, alíneas "a", "b" e "c", do Tratado da CECA previa que à Alta Autoridade seria atribuída a possibilidade de fixar preços máximos ou mínimos para a comercialização de um ou mais produtos submetidos a seu campo de atuação (carvão e do aço), tanto no interior do mercado da Comunidade, como no que se refere à exportação para mercados externos a ela.

Antes de se passar propriamente a uma análise minuciosa das oposições escalares instauradas por este $\operatorname{artigo~}^{954}$, é fundamental reconhecer que a própria previsão da possibilidade de a Alta Autoridade estipular tais preços máximos e mínimos continha, nela mesma, elementos que esvaziavam tal Poder. Será possível perceber que estes operavam como exigências normativas apostas precisamente para assegurar, por meio do arranjo institucional, a preservação do vazio no lugar do Direito e do Poder na vida comum. Afinal, a concessão de um Poder em uma organização jurídico-Política não seria feita jamais sem condições ou balizas.

Em primeiro lugar, note-se que a determinação de limites máximos ou mínimos de preços exigia que a Alta Autoridade decidisse a partir de estudos feitos em conjunto com empresas e associações de empresas produtoras de carvão e aço, associações de trabalhadores empregados no setor, e associações de consumidores de carvão e aço (artigo 61, parágrafo primeiro, conjugado por expressa previsão com os artigos 46 e 48, todos do Tratado da CECA). Nesse sentido, o fundamento da decisão a ser tomada pela Alta Autoridade jamais poderia ser apenas a convicção ou os estudos formados supranacionalmente: esta deveria necessariamente considerar aspectos apontados por estudos realizados conjuntamente com as entidades acima apontadas.

É importante destacar, sobre este ponto, que a previsão dessa necessidade de um estudo prévio já estabelecia um condicionamento à atividade da Alta Autoridade: sua decisão deveria necessariamente levar em consideração estes estudos, não podendo deixar

${ }^{954}$ Que é a missão específica de toda a integralidade do item 7.3.1. deste trabalho. 
de os considerar quando pretendesse estipular o regime de preço máximo ou de preço mínimo. Mais do que isso, há que se compreender mesmo que ela estava impedida de tomar tal decisão se não considerasse antes tais estudos.

Apenas este primeiro aspecto é suficiente para apontar que a possibilidade de agir da Alta Autoridade nestas situações não era incondicionada e livre, a seu bel-prazer. Ela estava efetivamente obrigada a levar em consideração os estudos referidos pelo artigo. Todavia, há que se ressaltar a presença de ainda outros condicionamentos à atuação deste órgão comunitário, a fim de tornar mais evidente o movimento de esvaziamento do Poder a ela concedido por este dispositivo.

À Alta Autoridade era facultada a possibilidade de estabelecer limites máximos e mínimos de preços no interior do mercado comunitário estruturado em torno do carvão e do aço (alíneas "a" e "b", do parágrafo primeiro do artigo 61 do Tratado da CECA), ou para o mercado externo à Comunidade (alínea "c" do mesmo dispositivo).

Quando a medida da Alta Autoridade se referisse ao mercado interno, o preço máximo a ser praticado deveria ser estabelecido se essa decisão se mostrasse necessária para assegurar a todos condições comparáveis de acesso às fontes de produção e para impedir o aumento do nível geral de preços na Comunidade (artigo 61, parágrafo primeiro, alínea "a", conjugado com o artigo 3, parágrafo único, alíneas "b" e "c", todos do Tratado da CECA). Por sua vez, o estabelecimento de preços mínimos era importante quando fosse reconhecida a existência ou a iminência de uma crise manifesta, e deveria visar (i) às necessárias amortizações e as normais possibilidades de remuneração aos capitais investidos, bem como (ii) à modernização e ao aprimoramento qualitativo dos potenciais de produção das empresas, de modo a evitar o esgotamento irracional de recursos, e também (iii) à melhoria das condições de vida e de trabalho dos trabalhadores, para que este se integrassem ao progresso (artigo 61, parágrafo primeiro, alínea "b", conjugado com artigo 3, parágrafo único, alíneas “c”, “d” e "e", todos do Tratado da CECA).

No que se refere ao estabelecimento dos limites máximos e mínimos de preços dos produtos destinados ao mercado externo (exportação), a decisão da Alta Autoridade não deveria desconsiderar a especificidade do comércio internacional e, por isso, deveria consultar associações de empresas interessadas ou diretamente tais empresas (artigo 61, parágrafo primeiro, alínea "c", do Tratado da CECA). Ademais, essa decisão apenas poderia ser tomada desde que se apresentasse como necessária, isto é, se sem ela se constatasse (i) a instauração de situação de comércio internacional prejudicial às empresas da Comunidade; ou (ii) inexistência de comércio internacional baseado sobre preços 
praticados segundo limites equitativos (artigo 61, parágrafo primeiro, alínea "c", conjugado com o artigo 3, parágrafo único, alínea “f”, todos do Tratado da CECA).

Dessa forma, antes de qualquer regra de oposição escalar, o presente dispositivo estabelecia balizas gerais para a ação da Alta Autoridade: a decisão em torno da definição ou não de limites máximos ou mínimos em cada um dos mercados era condicionada, seja pela necessidade de verificação de determinada situação (crise interna, comércio internacional prejudicial, entre outros), seja pelos fins aos quais a medida deveria visar (impedir aumento de preços, integração dos trabalhadores, entre outros).

Assim, mesmo antes de apor freios e contrapesos entre escalas de existência na decisão sobre o sentido normativo a ser dado na regulamentação de preços na Comunidade (condução Política da decisão em torno de instrumentos jurídico-econômicos), o Tratado da CECA introduzira no interior do Poder concedido à Alta Autoridade condições objetivas (prévias ou finalísticas).

Essa previsão assegurava que o Poder não seria integralmente concedido de maneira absoluta à Alta Autoridade: seu exercício não se mostrava como podendo ser arbitrário ou incondicional, pois ele encontrava desde já certos limites - anteriores mesmo a uma oposição multiescalar explícita, que pouco a pouco o esvaziavam. Este órgão comunitário era mais uma vez lembrado de que não deveria buscar se apropriar do lugar do Direito e do Poder na Comunidade, pois o Poder a ele concedido era de antemão limitado pelo próprio arranjo institucional do Tratado.

Todavia, há que se notar que se tratam apenas das primeiras e mais superficiais limitações do Poder de regulação do nível geral dos preços na Comunidade atribuído à Alta Autoridade. Outras formas de controle ao exercício de tal Poder foram apostas imediatamente pelo Tratado da CECA, mediante normas de oposições escalares precisamente direcionadas a, mediante contrapesos, refrear a supranacionalidade.

O parágrafo primeiro do artigo 61 do Tratado da CECA determinava que a Alta Autoridade apenas poderia formalizar a decisão de determinar limites máximos e mínimos de preços - seja no que se refere ao mercado comum, seja no que se refere ao comércio internacional, se se consultassem previamente o Comitê Consultivo e o Conselho. A referida consulta deveria se centrar sobre dois aspectos principais, a saber, a oportunidade das medidas escolhidas com relação à conjuntura vigente e os níveis de preços que tais medidas determinavam.

Note-se que essa disposição de pronto forçava diferentes escalas de existência supranacionalidade da Alta Autoridade e a estatalidade intergovernamental do Conselho - 
a conviverem entre si para, em conjunto, definirem o sentido da decisão jurídico-normativa e de Poder. A nenhuma delas se atribuía a possibilidade de unilateral e isoladamente indicar de que maneira a determinação dos limites máximos ou mínimos de preços deveria ocorrer, pois nenhuma das dimensões poderia almejar uma totalização preferencial no lugar do Direito e do Poder de seu próprio sistema métrico.

Há que se perceber, por esse motivo, a presença de mais um engenho institucional voltado ao estabelecimento de um virtuoso sistema de bloqueio e de contenções mútuos. A supranacionalidade não detinha condições institucionais que lhe permitissem imprimir unilateral e isoladamente seu modo de habitar o mundo e suas perspectivas e julgamentos sobre uma melhor regulamentação jurídico-econômica dos preços. Antes, deveria ela necessariamente se colocar em contraposição com a escala estatal intergovernamental ${ }^{955}$, para assegurar sua convivência com esta, a fim de que todas e cada uma, em conjunto, pudessem definir o sentido da regulamentação dada pelos instrumentos jurídicos de conteúdo econômico.

Instituíra-se assim um mecanismo de mútuo controle e limitação, pois uma vez que a iniciativa originária desta ação era atribuída apenas e tão-somente à Alta Autoridade, esse Poder não era por ela exercido de forma isolada. Fundamentalmente, a presença da forma de experienciar o mundo dada pela intergovernamentalidade era necessária, pois apenas deste modo se asseguraria uma decisão não-unidimensional sobre a oportunidade e sobre o próprio conteúdo dos instrumentos jurídico-econômicos a serem aplicados no interior da Europa Politicamente Unida pela CECA.

Perceba-se que a arquitetura institucional vigente procurava preservar a lógica Política na condução e no manejo dos instrumentos jurídico-econômicos na Comunidade. A multiplicidade escalar era ainda uma vez por meio dessa disposição prevista e introduzida, assegurando a regência mista e multidimensional dos moldes do sentido do Direito e do Poder no interior da Comunidade. E, antes disso, como condição de possibilidade da multiescalaridade, previra-se institucionalmente a instauração de uma oposição escalar que escancarava a todos a permanência do vazio no lugar do Direito e do Poder.

O objetivo de esvaziar o Poder concedido à Alta Autoridade é reforçado pelo parágrafo terceiro do mesmo artigo 61. Segundo este dispositivo, caso a Alta Autoridade não desempenhasse tal iniciativa a ela originariamente atribuída, o Governo de qualquer

${ }^{955}$ E com a estatal isolada, enquanto formadora da intergovernamental. 
Estado-membro poderia pleitear ao Conselho que este, mediante decisão unânime, convidasse a Alta Autoridade a fixar os limites máximos ou mínimos de preço. Mais uma vez, uma previsão normativa do Tratado se orientava para configurar uma engenharia institucional voltada ao esvaziamento do lugar do Direito e do Poder na Comunidade mediante uma oposição escalar.

O Poder objeto do artigo 61 não era detido exclusivamente pela Alta Autoridade, isto é, não era uma faculdade de agir livremente disponível por ela com relação e sobre as demais formas de habitar o mundo que compunham a Europa Politicamente Unida. Ela teria recebido apenas a possibilidade de desempenhar em primeiro lugar essa ação, nas hipóteses em que a limitação máxima ou mínima de preços se mostrasse necessária. Todavia, a inação da Alta Autoridade não significava o exaurimento integral ou a anulação absoluta da possibilidade de este Poder ser exercido: outros participantes da vida em comum poderiam se concertar no sentido de obter a definição de preços máximos e mínimos dos produtos.

De fato, a disposição do terceiro parágrafo do artigo 61 era um lembrete à Alta Autoridade de que sua posição com relação às demais escalas de existência não era de destaque, pois a nem a ela mesma era dada a possibilidade de se diferenciar das outras e sobre elas se alçar como Uma medida única, una e unificadora. Imediatamente após a concessão do Poder à Alta Autoridade, o Tratado da CECA subsidiariamente direcionava a possibilidade de exercício de tal iniciativa a um Estado-Membro. A inação da supranacionalidade não mitigaria ou exterminaria a possibilidade de um controle Politicamente orientado dos preços máximos e mínimos na Comunidade.

Qualquer estatalidade isolada poderia demandar a avaliação da presença das condições que justificavam a realização do controle dos preços no interior da Comunidade, mesmo nas hipóteses de inação da Alta Autoridade: o lugar do Direito e do Poder na Europa Politicamente Unida se revelaria mais uma vez como não ocupado pela Alta Autoridade, pois o mero suscitar da necessidade de se deflagrar o referido controle não residiria concentradamente nas mãos dessa escala supranacional. Assim, se a ela se concedera a possibilidade de exercer primeiramente esse Poder, isso não excluíra por si só as demais formas de existência da possibilidade de participar da determinação de seu sentido.

A Alta Autoridade se tornava assim consciente sobre sua não-exclusividade posicional no interior do jogo de relações de Poder na Comunidade. Caso não desempenhasse esse Poder, ela era imediatamente relembrada sobre sua não-preferência 
entre as escalas existenciais Politicamente unidas: outra forma de habitar o mundo poderia exercer tal iniciativa, ainda que a própria Alta Autoridade julgasse desnecessária a determinação dos limites máximos ou mínimos de preços.

Ademais, ainda que a Alta Autoridade não concordasse com essa decisão, ela deveria estabelecer os critérios de controle dos preços a pedido do Conselho. Em outras palavras, ela deveria efetuar sua regulação jurídico-econômica mesmo contra o julgamento formulado no interior de sua própria escala de existência. Isto é: o exercício da definição do sentido normativo a ser impresso sobre a situação de crise não era um Poder de sua propriedade, mas de disposição de toda a Comunidade - precisamente porque nenhuma das escalas de existência poderia se autocompreender como detendo posição privilegiada na ocupação do lugar do Direito e do Poder na CECA.

Todavia, note-se que essa previsão não apenas afastava a Alta Autoridade do lugar do Direito e do Poder na Europa Unida. Havia efetivamente uma vigorosa rejeição multilateral de cada uma das possíveis dimensões de existência que pudessem almejar a se totalizar no interior deste espaço de decisões nomogenéticas. Não apenas era rejeitada a supranacionalidade, como também esse local era imunizado com relação às investidas por parte das duas possíveis estatalidades (isolada e intergovernamental). Havia assim a aposição de freios a um possível auto-destacamento por parte da Alta Autoridade, como também se introduziam barreiras a um possível igual movimento de elevação por parte dos Estados-Membros ou do Conselho.

Sem dúvida, o Tratado da CECA determinava que caso a Alta Autoridade não desempenhasse sua iniciativa, um Estado-Membro poderia iniciar a execução deste Poder. Entretanto, à estatalidade isolada apenas se conferia parcela desse Poder, na medida em que não era ela quem avaliaria a oportunidade da medida ou os limites de preços máximos e mínimos a serem praticados. A decisão sobre essas duas variáveis não era atribuída aos Estados-Membros, pois a oportunidade seria decidida pelo Conselho, e os referidos limites seriam fixados apenas pela Alta Autoridade. Em outras palavras, era reservada à estatalidade isolada apenas a capacidade de suscitar a necessidade de avaliação perante o Conselho - e nada mais.

A atribuição desta faculdade à estatalidade isolada paralisaria pretensões de investida da supranacionalidade no sentido de consumir o exercício do Poder regulatório por seu não-exercício. Todavia, esta mesma previsão apunha imediata contenção de qualquer pretensão semelhante por parte da estatalidade isolada, pois a ela caberia apenas iniciar o procedimento de reflexão sobre a oportunidade conjuntural da medida, mas jamais 
totalizar seu exercício conforme sua escala de existência - não poderia nem decidir isoladamente sobre a oportunidade de tomada das medidas, muito menos sobre o conteúdo delas.

Havia aqui vigorosa armadilha institucional. Ela não apenas esvaziava o Poder atribuído aos Estados-Membros, como também instaurava uma oposição entre a estatalidade isolada e as outras participantes da Comunidade: bloqueado o acesso absoluto ao lugar do Direito e do Poder na União Política da Europa, as estatalidades isoladas deveriam conviver com as demais (Conselho e Alta Autoridade) para que pudessem definir em conjunto o sentido das decisões sobre o sentido normativo a ser impresso sobre o manejo dos instrumentos jurídico-econômicos.

Com relação ao Conselho de Ministros, o parágrafo terceiro do artigo 61 determinava que este órgão comunitário poderia ser provocado por qualquer EstadoMembro para avaliar, mediante decisão por unanimidade, a oportunidade conjuntural de se adotar uma medida jurídico-econômica para estabelecer os limites máximos e mínimos de preço na Comunidade. Ao mesmo tempo em que atribuía um campo decisório ao Conselho, essa previsão normativa estabelecia série de bloqueios e de limitações recíprocos destinados a promover mais uma interessante oposição escalar.

A intergovernamentalidade certamente recebia por meio deste dispositivo a possibilidade de avaliar a oportunidade conjuntural da medida e de constranger a Alta Autoridade a adotar os limites de preços máximos e mínimos. Uma vez proferida a decisão unânime do Conselho, a supranacionalidade não poderia se recusar a efetuar este controle haja vista que não detinha qualquer autorização para formar um juízo contrário ao do Conselho.

A inação regulatória da supranacionalidade não significava assim a sobrevalorização de sua escala de existência, pois o Tratado admitia o reconhecimento desta oportunidade pelos demais participantes da Europa Politicamente Unida (EstadoMembro e Conselho de Ministros). Contudo, o contra-Poder atribuído ao Conselho era imediatamente esvaziado pelo Tratado da CECA: seu exercício era igualmente incapaz de significar a introdução de qualquer preferência pela intergovernamentalidade em detrimento das demais. Em outras palavras, também eram apostos contrapesos ao próprio Poder de refreamento concedido à estatalidade intergovernamental.

Nesse sentido, o Conselho estava impedido de efetuar, como visto acima, a suscitação da necessidade de se avaliar a oportunidade de adoção da medida, tendo em vista que essa tarefa era atribuída em momento anterior aos Estados-Membros, 
subsidiariamente à inação da Alta Autoridade. Ao mesmo tempo, retirava-se da esfera decisória do Conselho a possibilidade de decidir sobre o conteúdo das medidas de regulação jurídico-econômica, pois este fragmento era reservado à Alta Autoridade, e apenas e tão-somente nos casos em que houvesse a decisão unânime do Conselho.

Dessa forma, o Tratado da CECA delimitava de forma precisa o cercado do campo de ação do Conselho: este estava circunscrito ao mero agir no sentido de decidir sobre a oportunidade da adoção das medidas de regulação jurídico-econômica, desde que mediante provocação de um Estado-Membro, e não detendo controle sobre o conteúdo a ser dado ao conjunto de medidas pela Alta Autoridade.

A intergovernamentalidade não apenas poderia decidir sobre a oportunidade de adoção de limites máximos ou mínimos de preços: antes, ela deveria decidir sobre essa questão, uma vez apresentada a requisição por uma estatalidade isolada. Ao mesmo tempo, a intergovernamentalidade jamais poderia determinar totalmente o sentido de sua decisão, pois era exigida a presença da dimensão supranacional para selar os termos definitivos do sentido do Direito e do Poder.

Nesse sentido, apesar da importância da função posicional detida pelo Conselho na cadeia de produção de sentido normativo a ser impresso Politicamente sobre os instrumentos jurídico-econômicos, sua capacidade de ação era limitada e restrita a este singelo aspecto decisional sobre a oportunidade das medidas.

Ademais, no próprio bojo do processo de formação da decisão do Conselho se excluía a possibilidade de se absolutizar qualquer escala de existência. Para assegurar este vazio no lugar do Direito e do Poder, exigia-se uma tomada de decisão por unanimidade, vale dizer, a instância decisória do Conselho operava como arena de oposições dimensionais entre as próprias estatalidades isoladas, a fim de que o sentido normativo tipicamente intergovernamental do Conselho fosse formado.

Deste modo, também a nenhuma das formas estatais isoladas de experienciar o mundo se conferia qualquer preferência na formação do sentido normativo no interior do Conselho, nem mesmo àquela que apresentara a requisição de avaliar a oportunidade da regulação jurídico-econômica. Todas deveriam se estabelecer em conjunto no interior do Conselho - arena de contraposição escalar - a fim de efetuar cada uma a seu modo a moldagem do sentido normativo final da estatalidade intergovernamental.

Por fim, no que se refere ao Poder definitivo atribuído à supranacionalidade da Alta Autoridade no texto do parágrafo terceiro do artigo 61, é importante frisar que a despeito de o Tratado da CECA conceder a este órgão comunitário a exclusividade na definição do 
conteúdo das medidas de regulação jurídico-econômica sobre limites máximos e mínimos de preços, há que se notar a presença simultânea de elementos que controlavam um movimento de eventual destacamento por parte da Alta Autoridade.

A concessão desta faculdade à supranacionalidade era acompanhada por elementos de contenção de eventuais investidas desta e das demais escalas com relação ao lugar do Direito e do Poder na Europa Unida. Não se concedia um pleno Poder à Alta Autoridade, pois esta não poderia escolher entre exercê-lo ou não: uma vez decidido pelo Conselho, o Tratado apenas conferira à Alta Autoridade o direito de obedecer à determinação por este formulada e desenvolver a regulamentação jurídico-econômica específica.

Todavia, é importante observar que o dever de fiel cumprimento atribuído à Alta Autoridade não pode ser entendido como rompimento da horizontalidade. A despeito de se prever à supranacionalidade um dever de regulamentação jurídica, tal previsão não buscara submeter a supranacionalidade às demais escalas de existência.

Essa previsão completava o quadro multiescalar desenhado pelo próprio parágrafo terceiro: na inação da Alta Autoridade, os demais participantes da vida em comum poderiam iniciar o procedimento de adoção de medidas de emergência, mas seria a Alta Autoridade que, no fim, determinaria quais seriam as medidas, com base nos critérios definidos nos parágrafo primeiro e segundo do mesmo artigo.

Não havia assim a previsão de uma reserva de esfera de ação obediente à supranacionalidade, mas sim se estipulava uma maneira de evitar que ela, como todas as demais escalas partícipes dos jogos de Poder no interior da Europa Politicamente Unida, buscassem totalizar suas formas de habitar o mundo. No interior da cadeia de formação do sentido normativo comum da decisão em torno da regulação jurídico-econômica sobre os preços na Comunidade, se as estatalidades encontraram Poderes de iniciar esse procedimento (Estado-Membro) e de determinar o seu seguimento (Conselho), a formulação final do conteúdo dessas medidas não poderia residir sobre tais escalas de existência, sob pena de se alçar a estatalidade ao centro nomogenético da Comunidade.

Deste modo, o dispositivo preservava a operacionalização de uma lógica Política no interior da Europa Unida, pois buscava evitar a preferência a priori por uma das diferentes formas de habitar o mundo. Para evitar a unidimensionalização do sentido do Direito e do Poder na Europa Politicamente Unida, o Tratado determinara a convivência de diferentes perspectivas.

Essa previsão instituíra assim uma fórmula de triplo bloqueio escalar, isto é, operava como um freio multilateral com relação a cada uma das escalas de existência que 
compunham a Europa Unida: não apenas a Alta Autoridade sofria uma limitação em sua possibilidade de exercício do Poder de controle econômico regulatório por instrumentos jurídicos, como também os próprios Estados-Membros e o Conselho também encontravam obstáculos a uma atuação livre no sentido de totalizar o lugar do Direito e do Poder neste sistema de convivência.

7.3.1.1.3.3. O Artigo 63 e a Discriminação Motivada por Regulação JurídicoEconômica Nacional

Ainda no que se refere à tutela de condutas relacionadas à prática de preços na Comunidade, o Tratado apresentava em seu artigo 63 disposições complementares visando a atores que, a despeito de não explorarem a atividade econômica do carvão e aço, por sua conduta também influenciavam na dinâmica de formação dos preços do carvão e do aço na Europa Politicamente Unida. Tratavam-se de entidades nacionais responsáveis pela regulação jurídico-econômica dos mercados que, de alguma forma, impactavam na formação de preços de carvão e aço na Comunidade.

O parágrafo primeiro do referido artigo facultava à Alta Autoridade a possibilidade de dirigir aos Estados-Membros as recomendações necessárias para impedir que seus respectivos Poderes Públicos nacionais pudessem estimular regulatoriamente uma prática de discriminação na Comunidade por parte dos compradores. A ideia consistia em manter a orientação das diferentes regulações jurídico-econômicas nacionais próxima da dinâmica Política constituinte da vida em comum da CECA - evitando que sistemas métricos estatais isolados impactassem por vias transversas e de forma unilateral a formação do sentido normativo na Comunidade.

$\mathrm{O}$ artigo conferia uma capacidade de ação normativa à Alta Autoridade por meio de recomendações em hipóteses restritas: se constatado um impacto na formação dos preços praticados na Comunidade por força da procura discriminatória por tais recursos pelos compradores, a Alta Autoridade deveria em primeiro lugar identificar se a origem dessa deturpação adviria do estímulo dado pelo ambiente regulatório disponibilizado por organismos reguladores de cada Estado-Membro.

Especial atenção deve ser dada ao fato de que o parágrafo se refere a "organismos dependentes dos Poderes Públicos", isto é, ele visava a estabelecer um campo de incidência amplo. Seu objetivo era precisamente se dirigir a toda e qualquer entidade que estivesse de alguma forma vinculada a um Poder Público nacional e que, com isso, 
detivesse ou tivesse recebido uma capacidade para atuar normativamente para regular jurídico-economicamente determinado mercado.

Nesse sentido, perceba-se que a preocupação deste primeiro parágrafo não se tratava tanto de combater diretamente as condutas discriminatórias em si praticadas pelos compradores. Seu foco era antes refrear a ação normativa de cada Estado-Membro que, ao estabelecer uma determinada moldura jurídico-econômica nacional, poderia induzir as condutas dos compradores em direção a uma prática discriminatória. Nestas hipóteses, a atuação da Alta Autoridade por meio de recomendações era autorizada, a fim de impedir que o ambiente regulatório estabelecido continuasse a fomentar um desvio na formação de preços.

Há que se notar aqui a preocupação em manter a Política: há também neste dispositivo uma disposição institucional determinada que visava a promover e a estabelecer uma oposição escalar e o consecutivo esvaziamento do lugar do Direito e do Poder na Europa Politicamente Unida. Esta precisa condição indicaria ainda uma vez que o móvel orientador dos instrumentos de regulação jurídico-econômica da vida em comum era Político - e, por isso mesmo, havia aqui a reafirmação da preocupação em determinar que nada ou ninguém poderia ser considerado ou se considerar como detendo a exclusividade na produção do sentido normativo na Europa Politicamente Unida pela CECA.

Um exame adstrito à singela letra do parágrafo primeiro do artigo 63 do Tratado da CECA apenas conseguiria identificar um suposto direcionamento unilateral e unidimensional da produção normativa na Europa Unida pela supranacionalidade. Segundo esta leitura, teria havido a concessão de um Poder à Alta Autoridade em detrimento dos Estados-Membros, para quem cumpriria apenas direito-dever de se sujeitar às orientações normativas apresentadas pela Alta Autoridade. Essa interpretação passageira apenas consegue depreender um Poder de influência supranacional sobre a estatalidade isolada: a Alta Autoridade ditaria recomendações normativas a serem seguidas pela estatalidade isolada, quem desestimularia, por meio de seus respectivos ambientes regulatórios nacionais, práticas discriminatórias pelos compradores.

Todavia, esse dispositivo aduzia mais um interessante engenho institucional de promoção de oposições escalares no interior da Europa Unida. Antes de conferir a uma ou a outra dimensão de existência um determinado Poder, o Tratado da CECA o limitava internamente, a fim de que nenhuma delas pudesse se auto-compreender como detentora 
do lugar do Direito e do Poder na Comunidade, com o objetivo de reafirmar a permanência do vazio de Poder e a necessidade de convivência multiescalar.

Certamente, é inegável que o Tratado atribuíra à supranacionalidade um grande grau de determinação da produção normativa na Europa Unida: nas situações regulamentadas pelo dispositivo, a Alta Autoridade recebera autorização expressa para recorrer às recomendações - obrigatórias com relação aos fins que estabeleciam, mas que deixavam livre a estipulação dos meios para os atingir por parte de seus destinatários. E é precisamente nesta previsão que se pode perceber a presença simultânea de um Poder e de nenhum Poder concedido à Alta Autoridade.

O parágrafo primeiro do artigo 63 expressamente determinava que a Alta Autoridade poderia utilizar como instrumento introdutor de normas jurídicas uma recomendação. Nesse sentido, apesar de a supranacionalidade poder se dirigir normativamente à estatalidade isolada, esta não teria em hipótese alguma suprimida a possibilidade de produzir o sentido normativo sobre a temática em questão. Em outras palavras, à Alta Autoridade caberia apenas a determinação dos fins a serem perseguidos, mas não poderia retirar dos Estados-Membros a capacidade normativa de estabelecer os meios para os alcançar.

Por esse motivo, ao mesmo tempo em que o Tratado concedia um Poder normativo à Alta Autoridade, ele efetuava um imediato esvaziamento de tal Poder, pois muito pouco, ou quase nada, ele assegurava à supranacionalidade: seu Poder por si só pouco ou nada significava, pois desprovido de mecanismos por meio dos quais poderia se especificar para se tornar concreto.

Ao mesmo tempo, o primeiro parágrafo do artigo 63 estabelecia também com relação aos Estados-Membros a previsão normativa de um Poder de ação imediatamente refreado pelo Tratado. O dispositivo assegurava uma margem de ação aos EstadosMembros frente à atuação normativa da entidade supranacional, margem esta que, por sua vez, não era ilimitada, precisamente por ter em vista a manutenção de Leis Políticas na Europa Unida pela CECA.

A reserva de um nicho de liberdade regulatória é facilmente perceptível: a supranacionalidade apenas poderia determinar em caráter obrigatório os fins a serem visados pela regulamentação normativa a ser dada por cada uma das estatalidades isoladas, ao passo que o sentido concreto definitivo seria dado pelos Estados-Membros mediante a definição dos meios de acordo com os quais tais fins seriam atingidos. Essa previsão não 
significava, contudo, uma autorização à totalização da dimensão existencial dos EstadosMembros em detrimento das dos demais participantes da vida em comum.

A reserva desse espaço de ação seguia a orientação de se manter uma dinâmica Política: aos Estados-Membros se facultava a possibilidade de agir nomogeneticamente de maneira livre, mas jamais poderiam deixar de buscar assegurar e reforçar as Leis Políticas na Europa, precisamente derivado do necessário vínculo aos fins comunitários indicados pela Alta Autoridade. Promovia-se aqui uma potente oposição escalar, na medida em que a ação de um era precisamente o freio da ação de outro - os quais, apenas mediante atuação em conjunto, poderiam definir o sentido normativo comum.

À Alta Autoridade caberia estabelecer a orientação normativa, mas ela não deteria meios materiais para incentivar o cumprimento de seu mandamento, nem mesmo poderia estabelecer os meios segundo os quais os fins deveriam ser alcançados. Ao mesmo tempo, não apenas os Estados-Membros deteriam consigo ainda os instrumentos materiais aptos a incentivar internamente o cumprimento de um regime jurídico, como também poderiam regulamentar livremente o modo segundo o qual os fins seriam atingidos, a despeito de nenhum deles poder optar por um fim distinto do determinado pela Alta Autoridade.

Deste modo, ambas escalas de existência estavam desprovidas de condições de totalizar suas respectivas formas de habitar o mundo na determinação do sentido normativo do Direito e do Poder na Europa Unida - a despeito de às duas ter sido atribuída igual capacidade de exercício de princípio de ação decisória sobre o Direito e o Poder entre os povos europeus. A supranacionalidade era agraciada com a concessão de um grande Poder - imediatamente esvaziado pela própria previsão normativa, como também a estatalidade isolada detinha o contra-Poder de atuar no interior de um domínio de ação a ela reservado - ele também imediatamente esvaziado pela própria previsão normativa.

Mais uma vez, o Tratado enfatizava a diferença de escalas de existência no interior da Europa Unida e, ao mesmo tempo, estimulava institucionalmente a convivência entre cada uma delas. Este primeiro parágrafo do artigo 63 do Tratado da CECA reiterava a preocupação em se criar jurídico-normativamente condições institucionais para a configuração de uma arena de convivência e de interação constante entre uma e outra escala de existência como modo fundamental para a definição do sentido normativo a ser impresso sobre questões concretas sensíveis comuns.

Assim, evitar ações discriminatórias dos compradores na Comunidade por meio da regulação jurídico-econômica exigia que tais normas fossem produzidas multiescalarmente, isto é, sem a sobrevalorização de uma orientação supranacional, nem a 
de uma dimensão estatal isolada. Antes, haveria que se preocupar com a consideração conjunta de ambas na produção do sentido do Direito e do Poder: todas as escalas se encontravam ao mesmo tempo providas e desprovidas de Poder. Ou ainda, (apenas) todos e (jamais) ninguém definiria o destino comum.

Há que se notar aqui, rapidamente, que antes mesmo da aposição desse freio de contenção mútua, o primeiro parágrafo do artigo 63 do Tratado da CECA apresentava um interessante mecanismo de bloqueio da atuação da Alta Autoridade. Anterior mesmo à própria concessão do Poder normativo, este limite era ele mesmo mais sutil - mas não menos vigorosamente negativo.

O Tratado da CECA reduzira a atuação da Alta Autoridade a uma dimensão meramente nomogenética, isto é, restringira o próprio rol de possibilidades da Alta Autoridade. De maneira inegável, o Tratado concedera a este órgão comunitário uma importante capacidade de agir: elaboração de recomendações para lidar com o problema de práticas discriminatórias pelos compradores. Todavia, esta disposição aduzia uma não ignorável armadilha institucional, pois concedera um circunscrito campo de agir à Alta Autoridade: esta poderia atuar apenas no interior do círculo por ele delimitado, isto é, no da produção normativa das recomendações.

Ao estabelecer que, nos casos de prática sistemática de discriminações por parte dos compradores, a supranacionalidade apenas poderia responder por meio do uso de um instrumental linguístico jurídico-normativo, o Tratado da CECA aprisionara esta escala de existência dentro no cercado do uso da palavra - isto é, limitava as opções de ação desta ao âmbito do recurso à não-violência. A atribuição deste Poder normativo limitado pode ser entendida assim como deliberada negação de concessão de instrumentos localizados além do domínio do discurso nomogenético, ou ainda, mais explicitamente, como recusa da concessão do uso da força a um órgão comunitário.

Nesse sentido, ao se negar a introdução do elemento coercitivo dentre o rol de ações possíveis da Alta Autoridade para o constrangimento do agir dos compradores, o Tratado da CECA se mostrava ainda uma vez contra a formação de uma organização jurídico-política na Europa nos moldes de um Estado Europeu - pois os órgãos da Comunidade estaria desprovidos da possibilidade de mesmo exercer de qualquer maneira a força durante a vida em comum. O uso da violência permaneceria como opção centralizada apenas no interior dos Estados-Membros ${ }^{956}$.

\footnotetext{
${ }^{956}$ Este aspecto foi rapidamente suscitado neste momento da argumentação apenas para reforçar a percepção da constante preocupação do Tratado da CECA de, em diferentes momentos, negar a condição estatal à
} 
No mesmo sentido, ainda que de maneira distinta, a parcela final do parágrafo segundo do mesmo artigo 63 institucionalizava mais uma oposição escalar no interior da vida em comum. Com efeito, nas hipóteses em que um comprador não cumprisse com suas obrigações contratadas com as empresas vendedoras que haviam estabelecido as condições de venda de seus produtos, a Alta Autoridade poderia, ou limitar os direitos de as empresas da Comunidade contratarem com esses compradores, ou mesmo proibir temporariamente o exercício de tal direito. Em tais hipóteses, tais compradores poderiam recorrer de tais decisões perante a Corte da CECA.

Certamente, não se pode deixar de notar que o Tratado da CECA concedera à Alta Autoridade um mecanismo de ação bastante singular e efetivo: a tal entidade seria possível efetuar um controle indireto da ação de empresas compradoras (localizadas no interior ou no exterior da Comunidade) por meio da restrição direta e imediata dos direitos de tratativas das empresas exploradoras do setor econômico do carvão e do aço submetidas à competência temática da Comunidade.

Fora concedido pelo Tratado da CECA, por meio deste dispositivo, enérgico Poder à Alta Autoridade: a supranacionalidade deteria uma capacidade de agir efetivamente intensa e direta sobre os agentes econômicos localizados nos territórios dos EstadosMembros, sem a intermediação destes últimos. Diante de uma hipótese de extrema ameaça, o Tratado da CECA assegurou institucionalmente à supranacionalidade da Alta Autoridade a possibilidade de controlar de maneira extrema a ação dos agentes econômicos.

Contudo, não se pode deixar de notar que este dispositivo se preocupara com o esvaziamento de tal Poder. A engenharia institucional desse dispositivo revelava a reiteração da problemática de promover a atribuição de um Poder em si mesmo limitado às diferentes escalas de existência da Europa Politicamente Unida, de maneira a que estas exercessem a final um Poder cujo próprio exercício erigisse barreiras contra si mesmo e contra aquele que o exercia - de tal modo que ele estivesse impedido de proferir a última palavra sobre um possível sentido normativo comum.

De fato, por um lado a Alta Autoridade recebera a autorização para agir no sentido de determinar direta e imediatamente um controle direto sobre as empresas que atuavam no interior do mercado comum. Por outro lado, o exercício de tal restrição não era

CECA. Não se desenvolveu essa reflexão de maneira detalhada neste momento, pois este item 7.3.1. está preocupado em sua integralidade com a dissecação das normas de oposições escalares e de suas respectivas lógicas de funcionamento, e não com a apresentação reiterada e profunda desta rejeição do elemento coercitivo. Este aspecto foi mais bem explorado, não apenas no Sexto Capítulo desta Tese, como também no item 7.2.4., ambos supra, aos quais remetemos o leitor. 
desarrazoado, arbitrário ou sem critérios. Se a resposta à situação de excepcional ameaça era ela própria excepcional, as restrições apresentadas a seu exercício eram também excepcionais. Tratava-se efetivamente de uma estranha combinação de excepcionalidades que anularia tal exponencialização das exceções e reintroduziria no interior da vida em comum o vazio no lugar do Direito e do Poder.

Em primeiro lugar, da mesma maneira como salientado há pouco, algumas linhas acima, o instrumento de controle atribuído à Alta Autoridade se reduzia mais uma vez ao âmbito da Linguagem. Ainda que a Alta Autoridade pudesse agir sobre agentes econômicos sem qualquer intermediação por parte dos Estados-Membros, ela não poderia pretender jamais substituir as estatalidades, na medida em que apenas no interior da dimensão do discurso jurídico ela poderia atuar. Mais uma vez, o Tratado declarara recusar a possibilidade de se conceder um elemento coercitivo a uma entidade comunitária precisamente porque não se tratava de um Estado Europeu ${ }^{957}$.

Mas não apenas por meio desta veemente negação do elemento coercitivo à Alta Autoridade se conservava a dinâmica Política na Comunidade. O Tratado introduzia neste parágrafo segundo do artigo 63 série de condicionamentos que progressivamente esvaziavam os Poderes e contra-Poderes atribuídos às diferentes escalas de existência implicadas na vida em comum.

A parcela final do parágrafo segundo do artigo 63 afirmava que, nas hipóteses de infração cometida por um comprador, a Alta Autoridade apenas poderia ou limitar temporariamente o direito de livre iniciativa negocial com este infrator por parte das empresas que exercessem atividades no interior da Comunidade, ou, nos casos de reincidência de infração, a Alta Autoridade poderia efetuar a proibição integral, mas também temporária, do referido direito.

Em outras palavras, ainda que não estabelecesse o período de máximo de duração, não somente o Tratado determinava que a restrição deveria ser temporalmente limitada, como também estabelecia uma opção estritamente binária de ação. Não haveria possibilidade de ela escolher uma forma de controle que não fosse ou a limitação das possibilidades de negociação, ou a interdição deste direito. O rol de opções de controle da ação dos agentes econômicos estaria limitado a essas duas variáveis, sem que se mostrasse possível o recurso a outra maneira mais ou menos enfática, mais ou menos imediata, de

\footnotetext{
${ }^{957}$ Reiteram-se aqui os comentários feitos na nota de rodapé imediatamente anterior a esta, sobre a ausência da preocupação em analisar minuciosamente a lógica de recusa à concessão de coerção à Alta Autoridade como modo de afirmar o caráter não-estatal da CECA.
} 
restrição. A atuação restritora da Alta Autoridade estaria ela própria restrita a dois únicos caminhos, sem se admitir a opção por uma terceira via distinta das oferecidas pelo regime jurídico do Tratado da CECA.

Ademais, o controle exercido pela Alta Autoridade era mais uma vez limitado nele próprio pelo simples fato de que este órgão comunitário jamais poderia interditar discricionária e incondicionalmente a possibilidade de negociar com o comprador que tivesse violado as normas das condições de venda: mostrava-se necessária a repetição de uma prática de descumprimento de tais mandamentos.

Assim, mesmo a opção por uma ou outra via decisória estava juridicamente bloqueada e orientada pelos termos do Tratado: a Alta Autoridade apenas poderia proibir as negociações nas hipóteses de reincidência, vale dizer, não seria a interdição a primeira escolha possível por este órgão comunitário se a livre iniciativa de contratação com este comprador não tivesse sido anteriormente restringida por meio de uma decisão anterior que determinasse uma limitação temporária deste direito.

Não se pode ignorar ainda outro aspecto passível de ser suscitado a partir da leitura desses critérios orientadores da atividade de controle da Alta Autoridade: qualquer que fosse sua decisão, nenhuma delas poderia se estender indefinidamente no tempo. A preocupação do Tratado da CECA consiste precisamente em impedir a permanência intemporal e perpétua de uma situação jurídica restritora insensível à mutação das condições espontâneas das relações entre os agentes econômicos.

Nesse sentido, perceba-se que os condicionamentos trazidos pelo presente dispositivo ao exercício do Poder de controle pela Alta Autoriade evitava que esta e sua respectiva forma de habitar o mundo encontrassem caminhos que pudessem legitimar levianamente um discurso de pretensa totalização da dimensão supranacional no lugar de formação do sentido do Direito e do Poder na Comunidade.

Por fim, também não se pode ignorar que o mesmo dispositivo estabelecia ainda um último nicho de contenção da atividade da Alta Autoridade, por meio de explícita oposição escalar no seio dos órgãos comunitários. Além dos limites acima descritos, o contrapeso institucional fundamental era prontamente ativado ao final do dispositivo: a atuação da Alta Autoridade poderia ser controlada pela Corte. Afinal, nos casos em que a resposta da Alta Autoridade consistisse em uma interdição - sempre temporária - dos direitos de negociação com este ofensor, abria-se a possibilidade de o comprador contestar a referida decisão por meio de recurso à Corte. 
Instaurava-se com isso uma plena oposição escalar no interior da Comunidade. É facilmente perceptível aqui a instituição de uma maneira de opor duas formas de experienciar o mundo no interior da Europa Unida, a saber, a supranacionalidade da Alta Autoridade e a supranacionalidade da Corte. Se, como bem lembrara o mesmo dispositivo, jamais era prejudicada a possibilidade de um controle da validade dos atos da Alta Autoridade pela Corte ${ }^{958}$, esta previsão reforçava a dinâmica de freios e contrapesos entre escalas de existência.

Entenda-se que a presença da supranacionalidade da Corte relembrava à supranacionalidade da Alta Autoridade a impossibilidade de poder construir sobre si mesma uma auto-compreensão que a autorizasse supor como estando sozinha no centro nomogenético da Europa Unida: sua atividade estaria sob constante possibilidade de vigilância e revisão por parte da supranacionalidade da Corte, pois o controle de validade de atos da Alta Autoridade do artigo 33 se mostrava sempre passível de ser realizado, de acordo com as limitações deste dispositivo em especial ${ }^{959}$.

Ao mesmo tempo, não se pode ignorar que o Tratado da CECA estabelecia um contrapeso à própria faculdade de bloqueio atribuída à Corte, de maneira a também negar a esta a construção de uma auto-percepção que a autorizasse supor estar ela própria no lugar do Direito e do Poder. Ainda uma vez, a engenharia institucional se mostrava aqui preocupada com a preservação do embate multiescalar, pois nada, nem ninguém, poderia se supor ou ser suposto como o centro produtor da última e absoluta palavra sobre do Direito e Poder na Europa Politicamente Unida.

Note-se, nesse sentido, que se o controle de validade de atos da Alta Autoridade do artigo 33 era sempre passível de ser realizado. Mas tal controle referido neste artigo 63 encontrava duas restrições, a saber: (i) decisão da Alta Autoridade de proibir negociações com um comprador - isto é, não poderia se tratar de uma simples limitação; e (ii) provocação por parte de um comprador afetado pela decisão da Alta Autoridade.

Perceba-se aqui um primeiro freio de oposição escalar no interior da Comunidade voltado ao esvaziamento de Poderes: ao mesmo tempo em que conferia à Corte a possibilidade de controlar as decisões da Alta Autoridade, o Tratado estabelecia um contrapeso a esta capacidade de bloqueio jurisdicional por meio de um condicionamento

\footnotetext{
${ }^{958}$ Nesse sentido, indicamos a leitura dos comentários feitos neste trabalho no item 7.2.2.1., supra, acerca do artigo 33 do Tratado da CECA, onde se apontara a preocupação reiterada em se assegurar na solução de controvérsias no interior da Comunidade a plena horizontalidade relacional entre escalas de existência.

${ }_{959}$ Mais uma vez, remetemos o leitor aos comentários feitos neste trabalho no item 7.2.2.1., supra, acerca do artigo 33 do Tratado da CECA.
} 
dado à delimitação hipotética de seu âmbito de atuação: a Corte estava autorizada a atuar somente nos casos de absoluta interdição de negociação com o comprador para que a Corte saísse de sua inércia original.

Todavia, o esvaziamento do contra-Poder atribuído à Corte se revelava de maneira mais clara quando da análise do segundo requisito aposto pelo mesmo dispositivo em exame, a saber, a necessidade de provocação por parte de um comprador afetado pela decisão da Alta Autoridade. A presença dessa previsão normativa implica reconhecer que o Tratado da CECA estabelecia de imediato a exclusão da possibilidade de uma ação de ofício por parte da Corte sobre a atividade da Alta Autoridade: haveria que se aguardar eventual provocação por parte de um comprador afetado pela decisão de interdição de negociação.

A importância desse dispositivo para a manutenção de um vazio de Poder na Europa Unida deve ser adequadamente percebida. Se à supranacionalidade da Corte se assegurava a possibilidade de se opor à supranacionalidade da Alta Autoridade, ao mesmo tempo, buscava-se impedir a ocupação isolada e totalizante do lugar do Direito e do Poder na União Política da Europa. Não apenas a Alta Autoridade não se encontrava isolada na definição do sentido normativo (devendo e podendo ter sua atuação freada), como também não havia a possibilidade de a Corte se julgar pairando sobre as demais formas de habitar o mundo (não poderia atuar se não observadas as condições acima mencionadas e, principalmente, não poderia agir ex officio).

Por esse motivo, há que se compreender que o objetivo dessa segunda restrição à atividade de controle jurisdicional se apresentava precisamente com o objetivo de demarcar o campo vazio no lugar do Direito e do Poder na Europa Unida: mais uma vez, ao mesmo tempo em que se atribuíra a uma entidade comunitária um Poder de atuação para que sua escala de existência bloqueasse uma pretensão de destacamento por parte de outra dimensão existencial, o Tratado imediatamente apusera uma fórmula institucional de contenção desse próprio (contra-)Poder de limitação, a fim de opor um contrapeso também ao freio.

7.3.1.1.3.4. O Artigo 64 e o não-Estado Europeu da CECA: Breve Apontamento da Reiteração da Recusa ao Uso da Força pela Alta Autoridade

O artigo 64 do Tratado da CECA determinava que, na hipótese de empresas violarem as disposições constantes do Capítulo $\mathrm{V}$ do Tratado da CECA, ou as decisões 
tomadas para a aplicação deste mesmo Capítulo, a Alta Autoridade poderia lhes aplicar multas que não excedessem o dobro do valor das vendas irregulares - isto é, das vendas realizadas em desconformidade com as disposições jurídico-normativas constantes do Capítulo V e das decisões que visassem a aplicá-lo. Nas hipóteses de reincidência, o valor máximo seria elevado para o dobro.

O referido dispositivo surgira como instrumento voltado a conferir à Alta Autoridade mecanismos de garantia de observância das normas comunitárias derivadas por parte das empresas exploradoras de atividades econômicas relacionadas ao setor do carvão e do aço. Em outras palavras, o Tratado da CECA direcionava à Alta Autoridade a capacidade de dispor de um instrumento jurídico-econômico sancionador (possibilidade de aplicação de multas) voltado a aumentar a probabilidade de cumprimento pelos agentes econômicos das normas estipuladas.

Sem descuidar da inegável presença de um conteúdo econômico no interior desta norma jurídica, há que se enfatizar a possibilidade de dela se aproximar de acordo com outra perspectiva de leitura. Se se propuser o desvelamento da materialidade deste significante linguístico jurídico-econômico, será possível entreabrir campos de alteridades significativas com relação a esta única e mesma disposição textual, de maneira a evidenciar seu sentido jurídico-Político específico.

O Tratado da CECA efetivamente buscara atribuir à Alta Autoridade a faculdade de dispor de instrumentos para garantir que agentes econômicos fossem estimulados a conformar determinadas condutas racionais por ela esperadas. A possibilidade de aplicação da multa por parte da Alta Autoridade se apresentava em um primeiro momento como dispositivo jurídico-econômico voltado a fomentar um determinado agir por parte das empresas do setor.

Porém, ao mesmo tempo em que este dispositivo conferira instrumentos jurídicoseconômicos à Alta Autoridade, não se pode deixar de ignorar que o Tratado da CECA reduzia a possibilidade de ação deste órgão comunitário a esta única dimensão: a realização de um controle apenas adstrito à Linguagem Normativa de conteúdo econômico. Por meio dessa disposição se concedia à Alta Autoridade a capacidade para agir e para interferir sobre as empresas, mas o Tratado da CECA ao mesmo tempo retirava dela a possibilidade de agir sobre outros campos, a fim de lhe recusar uma qualidade interventiva mais incisiva.

Em outras palavras, a única possibilidade de controle direto por parte da Alta Autoridade das atividades das empresas localizadas no interior dos Estados-Membros se 
reduzia à aplicação de sanções econômicas, isto é, à estipulação de multas pesadas, porém limitadas, e jamais coercitivas. Ainda uma vez o uso da força a partir de uma origem comunitária (não-estatal) se revelava opção continuamente afastada pela organização jurídico-Política da CECA: em todo o momento em que a oportunidade poderia ter sido esboçada, tal possibilidade foi sumária e imediatamente rejeitada pelo Tratado.

Deste modo, este dispositivo pode ser entendido assim como mais uma manifestação da grande recusa institucional à constituição de uma organização jurídicopolítica na Europa Unida pela CECA detentora de elemento coercitivo. Dito de outro modo, mais uma vez se buscou afastar da Europa Politicamente Unida os contornos típicos do de um Estado, precisamente por não se tratar de um empreendimento que visava à constituição de um Estado Europeu ${ }^{960}$.

\subsubsection{Os Capítulos VI e VII do Título Terceiro do Tratado da CECA: A} Disciplina Jurídico-Política da Concorrência na Comunidade

Antes de principiar a análise detida das disposições jurídico-normativas selecionadas para este item 7.3.1.2., há que se relembrar o leitor sobre a organização estrutural deste trabalho. O objetivo desta observação consiste em facilitar a compreensão mais ordenada do movimento reflexivo empreendido neste item.

No item 7.3.1.1., supra, foram analisados artigos contendo normas jurídicas de conteúdo econômico voltadas a efetuar, mediante um manejo jurídico-Político das instituições, uma regulação jurídico-econômica da produção e do consumo do carvão e do aço. O objetivo deste item 7.3.1.2. consiste em examinar o significado jurídico-Político de normas jurídico-econômicas de outro tipo, isto é, normas jurídicas de conteúdo econômico preocupadas com a promoção e a com manutenção jurídico-Política de condições de mercado concorrenciais ${ }^{961}$. Com efeito, o objetivo deste próximo item consiste em

${ }^{960}$ A reflexão deste item dialoga bastante com as observações feitas ao longo de todo este trabalho sobre a construção histórica da CECA como experiência de organização jurídico-Política não-coercitiva de países europeus, a qual recusara a formatação em torno de termos semelhantes ao de um Estado.

Tendo em vista que esse aspecto foi diversas vezes mencionado por este trabalho, optou-se por não desenvolver mais este argumento neste item, restringindo-se aqui à mera menção dessa possibilidade de interpretação também neste dispositivo. Com isso, reforça-se o argumento geral de ser possível perceber não ter sido o Projeto de uma Europa Politicamente Unida em um Estado Europeu aquele que foi seguido pelos construtores da CECA.

Remetemos o leitor ao Sexto Capítulo, bem como ao item 7.2.4., ambos supra, para tomar contato com a argumentação outrora desenvolvida por este trabalho nesse mesmo sentido.

${ }^{961}$ A divisão estrutural dos itens deste Sétimo Capítulo segue implicitamente a divisão do Direito Econômico em Direito Econômico Regulatório e em Direito Econômico Concorrencial. 
Com efeito, o item 7.3.1.1., supra, ficou responsável pela apresentação do significado jurídicoPolítico das normas jurídicas que regulavam a exploração e o consumo da atividade econômica do setor do carvão e do aço (Direito Econômico Regulatório), ao passo que o presente item 7.3.1.2. se dirige a compreender o significado jurídico-Político das normas jurídicas de conteúdo econômico que disciplinavam especificamente a permanência da dinâmica concorrencial do mercado de carvão e do aço na Comunidade (Direito Econômico Concorrencial).

Não cabe aqui retomar todos os aspectos dessa distinção, nem a integralidade das discussões em torno dela. Afinal, há que se frisar que o compromisso desta Tese consiste em contribuir para a comunidade epistêmica jurídica brasileira em Direito Internacional, e não para a ocupada cientificamente com estudos em Direito Econômico.

Nesse sentido, esta nota de rodapé tem por objetivo apenas referir em poucas linhas os elementos fundamentais daquela distinção entre Direito Econômico Regulatório e Direito Econômico Concorrencial, a fim de esclarecer ao leitor as razões pelas quais foi feita a presente separação analítico-estrutural entre tais artigos neste texto neste item 7.3.1. a partir de elementos dados pela literatura jurídica nacional de base sobre o tema. Esta nota de rodapé visa tão somente a facilitar a compreensão pelo leitor da organização estrutural deste trabalho, sem que seja prejudicada a organicidade do trabalho.

Partira-se da ideia de que Direito Econômico Regulatório e Direito Econômico Concorrencial pertencem ao campo da Regulação (Jurídica) da Atividade Econômica, também conhecida como Direito Econômico.

Para Calixto SALOMÃO FILHO (2008, p. 21) seria "incorreto formular uma teoria [da regulação econômica] que não analis[ass]e ou abar[cass]e ambas as formas de regulação [antitruste e regulação]"; para ele, Direito Econômico Regulatório e Direito Econômico Concorrencial fariam parte de uma lógica de Regulação Jurídica da Atividade Econômica, isto é, de toda forma de organização juridicamente procedimentalizada da atividade econômica por meio de um Poder Público (SALOMÃO FILHO, 2008, p. 35 e 38).

Armando Castelar PINHEIRO; Jairo SADDI (2005, p. 255) entendem que a Regulação Econômica é o "conjunto de normas, regulamentos e procedimentos, em geral oriundos do Poder Executivo, por meio das instituições responsáveis pela sua aplicação, a que o Estado recorre para alterar os incentivos e restrições com que operam os agentes econômicos, buscando corrigir as ineficiências geradas por falhas de mercado", ou ainda, mais adiante, na mesma página "[p]ara o direito [...] a regulação é o resultado de restrições legais ao comportamento dos agentes, cuja origem, hierarquia e consistência interna são o resultado de processos por vezes completamente dissociados da lógica econômica.".

Por outro lado, mencione-se Mario Gomes SCHAPIRO (2008, 2009a), para quem Direito Econômico Regulatório e Direito Econômico Concorrencial comporiam conjuntamente o Direito Econômico. Este - por se inserir em uma racionalidade de intervenção de um Poder Público no domínio econômico - deve ser entendido como "organização pública das relações econômicas" expressa por uma dupla orientação de "preservação do ambiente econômico" mediante o Direito Econômico Regulatório e de modificação dos tradicionais "atributos individuais dos absolutos contratos e propriedade" mediante o Direito Econômico Concorrencial.

A distinção entre o Direito Econômico Regulatório e o Direito Econômico Concorrencial seria tênue, mas possível: "há um paralelo inegável entre o objetivo da tutela concorrencial e a regulação de mercado[, a]inda que a operacionalização e a intensidade das duas tutelas sejam absolutamente distintas [...]." (SALOMÃO FILHO, 2008, p. 37). Afinal, o Poder Público "introduz, pelo menos em certas áreas, uma forma de organização das relações econômicas que não se rege pela lógica concorrencial." (SALOMÃO FILHO, 2002, p. 21).

Para Mario Gomes SCHAPIRO (2009a), o Direito Econômico Regulatório seria caracterizado por ser uma intervenção indireta do Poder Público sobre o domínio econômico, mediante normas jurídicas que estimulem ou desestimulem condutas entre agentes econômicos, ao passo que o Direito Econômico Concorrencial seria marcado por promover uma intervenção mais direta do Poder Público sobre o domínio econômico, mediante atuação reativa (poder de polícia) a práticas que atentem contra a concorrência, inclusive mediante sanções econômicas.

Em sentido próximo, mas não igual, pode ser mencionado novamente Calixto SALOMÃO FILHO (2008, p. 37, grifos do autor): "[e]m termos bem simples, a diferença entre direito antitruste e regulação está basicamente na forma de intervenção. A atuação do direito antitruste é essencialmente passiva, controlando formação de estruturas e sancionando condutas. Trata-se do que a doutrina administrativa costuma chamar de atos de controle e de fiscalização, através dos quais o Estado não cria utilidade pública, limitando-se a fiscalizá-la ou controlá-la. Já a regulação não pode se limitar a tal função. É preciso uma intervenção ativa, que não se restringe ao controle, mas à verdade criação da utilidade pública através da regulação.”. Em texto de 2002, Calixto SALOMÃO FILHO (2002, p. 21) indicava que o Direito Econômico 
Regulatório era "o setor regulamentado pelo Estado", ao passo que o Direito Econômico Concorrencial correspondia ao setor "auto-regulamentado pelo mercado, onde o Estado deve, teoricamente, apenas assegurar o correto funcionamento do sistema e impedir abusos".

Por fim, mencionem-se Armando Castelar PINHEIRO; Jairo SADDI (2005, p. 357), para quem o Direito Econômico Regulatório - ou simplesmente regulação econômica - é produto de uma "política" na qual "a competição é um instrumento auxiliar, mas não o foco principal do trabalho do regulador", ao passo que o Direito Econômico Concorrencial é produto de uma "política [...] reativ[a], voltad[a] principalmente para impedir que os agentes econômicos dificultem o natural surgimento da competição".

Não se trata, aqui, de assumir posição sobre a discussão acima apresentada, pois isso fugiria ao escopo investigativo deste estudo. Apenas se pretende esclarecer ao leitor que a diferenciação estrutural da análise nos dois itens acima mencionados segue ao menos um ponto consensual no interior deste debate: há uma possibilidade de se estudar separadamente normas de Direito Econômico Regulatório e normas de Direito Econômico Concorrencial, sendo que ambas possuem em comum a preocupação de organização jurídica da Economia a partir de uma orientação dada por um Poder Público (Direito Econômico). Esta divisão é quem orientou - apenas em caráter formal - a divisão ordenada dos subitens que compõem este item 7.3.1.

Deste modo, as normas do Tratado da CECA que não se ocuparam diretamente da tutela da concorrência foram analisadas no item 7.3.1.1., supra, enquanto que as especificamente destinadas a disciplinar a concorrência serão analisadas neste item 7.3.1.2, infra. A consideração conjunta dos dois grandes grupos de comentários permitirá perceber que a organização jurídica do setor econômico do carvão e do aço na Europa Unida pela CECA foi dada por um Poder Público de caráter comunitário, institucionalmente viabilizado por normas jurídicas originárias do Tratado da CECA que se regeram por uma perspectiva Política (oposições escalares, multiescalaridade, vazio no lugar do Direito e do Poder). Em outras palavras, que a regulação jurídico-econômica da CECA recebera originariamente uma orientação institucional de caráter jurídico-Político.

Nesse sentido, lembre-se de que o objetivo deste estudo é ressaltar a posibilidade de se formular uma leitura jurídico-Política da História e das normas jurídicas originárias da CECA, para encontrar para além da materialidade do significante jurídico positivo (econômico ou não) uma camada de leitura de caráter jurídico-Político. Se a literatura nacional de Direito Econômico foi mencionada aqui em notas de rodapé, foi apenas para esclarecer ao leitor as razões de divisão estrutural deste texto. No entanto, perceba-se que não se incorpora na argumentação do texto principal deste trabalho qualquer variável analítica de Direito Econômico - pois a interpretação aqui desenvolvida é jurídico-Política, e não jurídico-econômica.

Assim, perceba-se que a menção a tal literatura não prejudica a integridade dos objetivos deste estudo, pois ela não é utilizada aqui para guiar a interpretação do arcabouço jurídico-normativo do Tratado da CECA, mas, sim, apenas para estruturar a exposição do texto ao leitor. Em outras palavras, as normas jurídicas analisadas em todo este Sétimo Capítulo são lidas contínua e incansavelmente apenas e tão somente a partir de uma chave interpretativa jurídico-Política - tendo sido relegada a literatura nacional de Direito Econômico apenas à margem textual de rodapé deste trabalho.

Note-se, inclusive, ter sido possível ao longo de todo este Sétimo Capítulo (itens 7.1, 7.2. e 7.3.1.1., supra) desenvolver reflexões jurídico-Políticas em torno do Tratado da CECA sem ter sido necessária qualquer menção aos estudos de Direito Econômico para interpretar o texto de Direito Positivo: bastou apenas recorrer à chave de leitura construída no Terceiro Capítulo. O mesmo ocorrerá, como se poderá ver, nos itens 7.3.1.2. e 7.3.2., infra: será plenamente possível compreender tais normas jurídicas a partir do uso exclusivo do referencial interpretativo jurídico-Político.

Não é demais observar que apenas neste diminuto campo do iten 7.3.1. é que se analisam normas jurídicas de Direito Econômico do Tratado da CECA: nos demais momentos deste Sétimo Capítulo, normas jurídicas que não detinham conteúdo econômico puderam ser analisadas também a partir de uma lente analítica jurídico-Política. Se até o presente momento não foi necessário recorrer à chave explicativa tradicional da literatura de Direito Econômico para interpretar o Tratado da CECA, mostra-se possível prosseguir a leitura deste documento jurídico-normativo sem necessidade de voltar a recorrer à chave explicativa jurídico-econômica. $O$ que permite perceber a possibilidade de se desenvolver uma leitura jurídico-Política do Tratado da CECA de maneira independente, auto-sustentada e autosustentável.

Assim, apenas para evitar indagações levianas sobre as razões pelas quais se dividiu estruturalmente a análise deste específico trecho do Sétimo Capítulo - apenas o item 7.3.1. - é que se esclareceu, pontualmente, que se socorreu apenas estruturalmente da distinção entre Direito Econômico Regulatório e Direito Econômico Concorrencial, somente para ordenar mais lógica e didaticamente a divisão da exposição do texto deste item 7.3.1. O que não deve ser compreendido como comprometendo a higidez argumentativa desta Tese, pois toda reflexão desenvolvida no texto principal deste trabalho 
interpretar as normas constantes do (i) Capítulo VI - Acordos e Concentrações (artigos 65 e 66); e (ii) Capítulo VII - Violações das Condições de Concorrência (artigo 67).

Estes três artigos detinham um lastro inegável de preocupações típicas de Direito Econômico Concorrencial: tais normas do Tratado se revelavam como um bloco de instrumentos jurídicos voltados à preservação de um ambiente econômico de mercado concorrencial. Em outros termos, a camada significativa fornecida pelo texto dito do Tratado da CECA revelava uma preocupação em regular juridicamente a preservação da lógica concorrencial na Europa Unida no setor econômico do carvão e do aço ${ }^{962}$.

É possível agrupar tais previsões normativas em função do objeto do controle a ser efetuado com o escopo de manter o funcionamento jurídico-Politicamente orientado da dinâmica de concorrência no setor do carvão e do aço na Europa Unida pela CECA. Neles é possível identificar mecanismos de controle (i) de condutas anticoncorrenciais em um mercado concorrencial (artigo 65 do Tratado da CECA), (ii) de atos voltados à degeneração das estruturas jurídico-econômicas de mercado concorrencial em direção ambiente não-concorrencial (artigo 66 do Tratado da CECA) ${ }^{963}$, e (iii) da

seguiu apenas e tão somente a chave interpretativa jurídico-Política, mostrando a viabilidade do intento acadêmico fundamental deste estudo. Do mesmo modo, a nota de rodapé 963, infra.

962 Como reconhece, na literatura jurídica nacional, Calixto SALOMÃO FILHO (2007, p. 50, grifos do autor): "a concorrência - e não o mercado - é o valor a ser protegido pelo direito concorrencial".

963 Apesar de não se tratar de preocupação principal deste trabalho, há que se compreender em termos gerais as estrutura básica de compreensão da atuação de um Poder Público sobre um mercado concorrencial com base em disposições de Direito Econômico Concorrencial. Em outras palavras, há que se compreender em linhas gerais a distinção entre controle de condutas e controle de estruturas, a fim de se entender a estruturação da interpretação dos artigos 65 a 67 nos itens a seguir.

Saliente-se desde já, ainda uma vez, que o compromisso deste trabalho consiste em contribuir ao pensamento jurídico científico brasileiro em Direito Internacional, e não com o voltado a compreender o Direito Econômico Concorrencial. Nesse sentido, serão apontadas aqui apenas algumas noções gerais sobre o controle de condutas e o controle de estruturas, a fim de situar o leitor no campo significativo desses dois termos, de maneira a compreender a razão pela qual se organizou a análise deste item 7.3.1.2. em dois subitens (7.3.1.2.1., 7.3.1.2.2. e 7.3.1.2.3.), cada um responsável pela interpretação jurídico-Política de normas jurídico-econômicas concorrenciais presentes no Tratado da CECA.

Assim, não há aqui também qualquer objetivo de se aprofundar nas questões e nas divisões em torno dessa classificação, nem mesmo em tomar posição com relação a linhas de pensamento ou autores determinados. Trata-se apenas de um ponto de parada reflexivo e organizador da condução do intelecto na leitura dos próximos itens.

A distinção entre condutas e estrutura deriva do modelo "estrutura-conduta-desempenho", cuja "suposição básica é que esse desempenho depende diretamente do comportamento ou conduta das empresas. A conduta dos participantes em um mercado (esforço, políticas de preço, propaganda, etc.), por sua vez, é influenciada por sua estrutura (número de empresas, barreiras à entrada, etc.). Dessa perspectiva, o papel das agências de defesa da concorrência é impedir que a estrutura do mercado e/ou a conduta das empresas comprometam o desempenho do mercado [...]." (PINHEIRO; SADDI, 2005, p. 361).

Para Calixto SALOMÃO FILHO (2007, p. 18 e 19), há uma verdadeira simbiose na tutela da concorrência por meio do controle de condutas e de estruturas: "[é] através da aplicação simultânea e conjunta de ambos os subsistemas (controles estrutural e comportamental) que a proteção concorrencial ganha eficácia", ou ainda, "[e]ssa simbiose manifesta-se de formas diversas[, havendo, por exemplo,] a convicção de que o controle dos comportamento é o complemento necessário para o controle das estruturas[, ao mesmo tempo em que se percebera que] a exagerada ênfase no controle estrutural pode ter conseqüências 
extremamente negativas [...].”. No mesmo sentido, Calixto SALOMÃO FILHO (2002, p. 359), em que o autor aponta também a complementaridade entre o controle de condutas e o controle de estruturas, ainda que seja possível perceber uma possibilidade de relativizar uma tal separação categorial.

A noção de condutas aponta para "os comportamentos empresariais", ao passo que a de estruturas aponta para "formações empresariais definitivas estabelecidas pelo mercado" (SCHAPIRO, 2009b). Mais especificamente, "[o]s principais determinantes da estrutura de um mercado são o seu grau de concentração e as condições de entrada, que são, por sua vez, o resultado da tecnologia, do grau de integração vertical das empresas, do grau de heterogeneidade dos produtos comercializados e do nível das barreiras à entrada. Entende-se por conduta das empresas as suas práticas e decisões quanto às políticas de fixação de preços, os gastos com propaganda, os investimentos e a taxa de utilização da sua capacidade instalada, as atividades de pesquisa e desenvolvimento (P\&D), e as formas de cooperação ou competição com seus fornecedores, clientes e concorrentes." (PINHEIRO; SADDI, 2005, p. 361-2).

Nesse sentido, o Direito Econômico Concorrencial se orienta para a defesa da concorrência por meio do controle (i) de estruturas, isto é, mediante a aposição de freios a atos que levem à concentração de um mercado, ou (ii) de condutas, isto é, mediante a contenção de comportamentos empresariais anticompetitivos (PINHEIRO; SADDI, 2005, p. 356 e 362).

$\mathrm{O}$ controle de condutas anticoncorrenciais visa assim ao combate de condutas desempenhadas por agentes econômicos em uma dada estrutura jurídico-econômica de mercado concorrencial. As infrações do ambiente concorrencial por meio de condutas anticoncorrenciais operam, não visando a uma modificação de tal estrutura, mas à mitigação da lógica de mercado em um ambiente concorrencial que, com isso, produz uma artificial alteração das condições do mercado.

Deste modo, o controle de condutas tem por foco apenas os "atos tendentes à dominação dos mercados" (SALOMÃO FILHO, 2007, p. 156), isto é, somente os comportamentos estratégicos no interior de um mercado concorrencial que visem à eliminação dos concorrentes (SALOMÃO FILHO, 2008, p. 62). Em outras palavras, "as condutas regulares de disputa do mercado, por mais agressivas que possam ser, não se voltam a aniquilar a concorrência", sendo apenas combatidas pelo Direito Econômico Concorrencial as condutas que implicarem um "desvio de finalidade do Poder Econômico", isto é, que possam ser entendidas como "abuso do poder econômico" por lesarem a concorrência sem produzir benefícios que superem os custos concorrenciais (SCHAPIRO, 2009d).

Nesse sentido, o controle de condutas pode ser entendido como forma de "pro[i]b[ir] certas condutas empresariais, tanto para impedir que um grupo de empresas aja de forma concertada para manipular as condições de oferta, como ainda para impedir que uma empresa dominante abuse de sua posição para prejudicar concorrentes menores" (PINHEIRO; SADDI, 2005, p. 356, grifos dos autores). Note-se que as "condutas anticompetitivas dividem-se em horizontais e verticais, conforme sejam voltadas para reduzir a rivalidade entre as empresas já instaladas ou alterar a estrutura do mercado, expulsando empresas já existentes ou dificultando novas entradas." (PINHEIRO; SADDI, 2005, p. 373).

Por outro lado, o controle de estruturas visa ao combate de ações entre empresas ou entre grupo de empresas que efetuem, em um determinado mercado concorrencial, uma modificação das próprias condições da estrutura deste mercado, isto é, que efetuem uma concentração econômica na estrutura. Esta infração é mais grave do que a anterior, pois implica efetiva reformatação da estrutura deste sistema em um novo mercado, de caráter não-concorrencial. O foco do controle de estruturas é conter os atos de concentração entre empresas, de maneira a impedir o surgimento de monopólios ou de empresas dominantes (PINHEIRO; SADDI, 2005, p. 356).

O controle de estruturas envolve assim a preocupação em "garanti[r] as condições estruturais da concorrência, isto é, as condições de acesso e de permanência no mercado dos agentes" (SALOMÃO FILHO, 2002, p. 45), ou ainda, implica uma atuação sobre as estruturas do mercado, de maneira a constituir condições institucionais que impeçam comportamentos estratégicos (SALOMÃO FILHO, 2008, p. 62). Afinal, as estruturas são controladas precisamente "pelo potencial de risco que oferecem a um funcionamento do mercado de forma concorrencial" (SCHAPIRO, 2009c).

Nesse sentido, o controle das estruturas tem por foco as empresas que tenham ou que possam conquistar poder de mercado (PINHEIRO; SADDI, 2005, p. 364), sendo que "[h]á diversas formas de se realizar [...] um ato de concentração, em especial a fusão, a aquisição, a conglomeração, e as joint-ventures. As fusões podem ser horizontais, quando envolverem empresas no mesmo mercado, ou verticais, quando disserem respeito a empresas que têm uma relação do tipo fornecedor-cliente ou produtor-distribuidor. Uma aquisição ou incorporação tem o mesmo efeito que uma fusão, com a diferença de que uma das empresas envolvidas mantém a sua personalidade jurídica [...]. Uma conglomeração é uma fusão entre empresas que não têm relação direta, seja horizonta ou vertical. [...]. Uma joint-venture é uma forma de associação mais 'leve' entre empresas, já que mantém sócios distintos ligados apenas por um certo objetivo comum, mas que 
atividade interventiva dos Estados-Membros sobre a Economia que pudesse impactar a concorrência.

Diante desta possibilidade de agrupar os artigos acima mencionados no interior de uma chave de leitura dada pela distinção típica do Direito Econômico Concorrencial (controle de condutas, controle de estruturas, controle da intervenção normativa estatal), torna-se mais fácil compreender o objetivo comum de cada um deles a partir de uma consideração conjunta de todos dentro de sua divisão específica. Os próximos itens comentarão separadamente as disposições normativas instituídas com o objetivo de introduzir mecanismos de controle de condutas (artigo 65 do Tratado da CECA), de controle de estruturas (artigo 66 do Tratado da CECA) ${ }^{964}$ e de controle da atividade interventiva estatal sobre a Economia (artigo 67 do Tratado da CECA) .

A preocupação em lidar jurídico-economicamente com (i) condutas que mitigassem as condições de concorrência por meio de estipulação de acordos (item 7.3.1.2.1, referente ao artigo 65); (ii) atos de concentração das estruturas do mercado da CECA (item

pode ou não se constituir em um ato de concentração, dependendo do seu foco." (PINHEIRO; SADDI, 2005, p. 371-2, grifos dos autores).

Deste modo, "[t]endo em mente o modelo estrutura-conduta-desempenho, as agências de defesa da concorrência usualmente atuam em duas frentes. Em uma, procuram manter as estruturas de mercado competitivas o suficiente para impedir o exercício de poder de mercado pelas empresas. Na outra, punem as condutas empresariais voltadas para impedir a competição e obter poder de mercado de formas outras que não a sua maior eficiência e criatividade" (PINHEIRO; SADDI, 2005, p. 389).

Ressalte-se, porém, que o interesse deste trabalho não consiste em examinar o Sistema de Defesa da Concorrência constante do processo de integração europeu. Neste item, como reiterado por diversas vezes neste texto, a análise procurará igualmente identificar no interior da articulação das disposições de Direito Econômico Concorrencial a presença de uma preocupação em se manter uma dinâmica jurídico-Política nesta arquitetura institucional.

Por esse motivo, há que se frisar que o uso da chave de leitura fornecida pelo conhecimento jurídico em torno do Direito Econômico Concorrencial nesta nota de rodapé não implica a incorporação súbita e derradeira de todo o complexo significativo do cosmos deste campo do conhecimento, nem mesmo se trata de um reconhecimento último de que o objetivo da integração europeia do pós-Segunda Guerra Mundial consistiu em instituir promover uma integração exclusivamente econômica, desprovida de orientação política - tal qual, no pensamento jurídico nacional sobre Direito Econômico Concorrencial, pensa Calixto SALOMÃO FILHO (2002, p. 44), ao afirmar que, para os países europeus no pós-Segunda Guerra Mundial, "o elemento agregador [era] o econômico e não o político". Como se pode perceber após a leitura do trabalho até este momento, não se pode concordar com esa afirmação.

De todo modo, por o Tratado da CECA conter inegavelmente disposições de Direito Econômico Concorrencial, não há como se recusar e rejeitar de antemão a análise de tais disposições - sob pena de obstinada e insincera cegueira. Antes, devem elas ser adequadamente compreendidas enquanto insertas no conjunto da arquitetura institucional Politicamente orientada da Europa Unida pela CECA.

Trata-se, como anunciado em diversos momentos neste estudo, de ampliar as possibilidades de leitura sobre um e mesmo fenômeno: será possível perceber que em tais disposições percebidas de Direito Econômico Concorrencial há uma articulação lógica anterior não-percebida de um vetor jurídico-Político. Em outros termos, mais uma vez neste item será possível perceber que o recurso aos instrumentos jurídicos de conteúdo econômico pelo processo de construção histórica da Europa Unida tinha por objetivo constituir um meio institucional para assegurar a conservação de uma dinâmica multiescalar tipicamente Política nas relações entre as diferentes medidas de existência.

${ }^{964}$ Todavia, há que se frisar que foram excluídos da análise interpretativa deste item os dispositivos que escapavam ao recorte metodológico estipulado pelo presente trabalho, ou seja, que não estabeleciam normas de oposições escalares. 
7.3.1.2.2., referente ao artigo 66); e (iii) intervenções estatais sobre a concorrência no setor do carvão e do aço (item 7.3.1.2.3., referente ao artigo 67), não estava orientada apenas à manutenção de um mercado concorrencial no setor do carvão e do aço. A análise do arranjo institucional desta parcela do Tratado da CECA permite perceber que se preocupava continuamente em abrir um conjunto de oportunidades de realização de oposições escalares e de esvaziamento do lugar de definição do sentido do Direito e do Poder na Europa Unida, de maneira a manter uma dinâmica propriamente Política na Comunidade.

Nesse sentido, será possível verificar que as normas de Direito Econômico Concorrencial traduziram elas também o intento de promover e de instaurar um sistema de convivência entre diferentes escalas de existência no interior da Europa Unida pela CECA, a fim de que todas elas pudessem formar em conjunto, ainda uma vez, o sentido normativo sobre questão concreta sensível comum. Este item não compreenderá assim a disciplina concorrencial que estruturava juridicamente o mercado de carvão e aço CECA, mas sim a organização jurídico-Política em que ela se inseria, de modo que se possa evidenciar com toda a clareza a presença de uma organização jurídico-Política também na regulamentação jurídico-econômica concorrencial.

Deste modo, efetuar-se-á nos itens a seguir um exame sobre a maneira por meio da qual se instaurara institucionalmente o esvaziamento do lugar do Direito e do Poder no interior da Europa Politicamente Unida pela CECA - e a consequente oposição multiescalar - por meio do manejo e da aplicação dos instrumentos de controle de condutas anticoncorrenciais e de ações degenerativas das estruturas concorrenciais - isto é, por meio do manejo Politicamente orientado das ferramentas do Direito Econômico Concorrencial do Tratado da CECA.

7.3.1.2.1. O Artigo 65 do Tratado da CECA e os Acordos entre Empresas: O Significado Jurídico-Político do Controle Concorrencial de Condutas na CECA

O parágrafo primeiro do artigo 65 do Tratado da CECA previa o combate de acordos entre empresas que lhes permitissem, por meio de práticas concertadas entre si, de maneira direta ou indireta, impedir, restringir ou falsear as condições de um mercado concorrencial no interior da CECA. As três alíneas do mesmo parágrafo sinalizavam que os principais - mas não exclusivos - focos de atenção desta previsão normativa eram acordos entre empresas voltados a: (i) fixar ou determinar os preços; (ii) restringir ou 
controlar a produção, o desenvolvimento técnico ou os investimentos; e (iii) repartir os mercados, os produtos, os clientes ou as fontes de provisão.

O parágrafo quarto do mesmo artigo 65 estabelecia que todos os acordos mencionados acima, de maneira genérica ou específica, eram nulos de pleno direito e que eles não poderiam ser invocados perante qualquer órgão jurisdicional dos EstadosMembros. Com o objetivo de dar operacionalidade a esta previsão, a parcela final do mesmo parágrafo quarto definia que competia à Alta Autoridade a exclusividade de se pronunciar sobre a conformidade dos eventuais acordos celebrados entre as empresas que exploravam a atividade econômica do carvão e do aço com as disposições deste artigo. $\mathrm{O}$ mesmo dispositivo previa ainda a possibilidade de apresentar um recurso perante a Corte para contestar o pronunciamento da Alta Autoridade.

A análise completa deste parágrafo quarto é bastante complexa e exige um exame acurado de cada um de seus mandamentos normativos. Apenas por este exame atento e minucioso se poderá compreender de maneira detalhada de que modo mais uma vez a oposição escalar fora institucionalmente instaurada no interior da Comunidade por meio dessa disposição normativa.

Está presente neste dispositivo a reiteração da preocupação em instaurar mais uma arena de oposição escalar no interior da Europa Unida, a qual deveria assegurar, por freios e contrapesos mútuos entre escalas de existência, o vazio no lugar do Direito e do Poder na Europa Unida e a correlata multiescalaridade na produção de mais um sentido normativo sobre questão concreta sensível envolvendo o carvão e o aço.

O caput do parágrafo quarto do artigo 65 estabelecia que os referidos acordos eram nulos de pleno direito e impassíveis de invocação perante qualquer órgão jurisdicional dos Estados-Membros. E, com o objetivo de dar operacionalidade a esta previsão, o mesmo parágrafo quarto definia que competia à Alta Autoridade a exclusividade de se pronunciar sobre a conformidade dos eventuais acordos celebrados entre as empresas com as disposições deste artigo.

É importante se deter no caput deste parágrafo quarto: não apenas os acordos seriam nulos de pleno direito, como também eles seriam impassíveis de serem invocados perante qualquer jurisdição dos Estados-Membros da CECA. Essa declaração normativa é relevante, na medida em que buscava afastar da esfera de possibilidades de ação da estatalidade isolada uma margem decisória potencialmente subversiva em torno da juridicidade do conteúdo destes acordos: a estatalidade isolada estava impedida de se 
pronunciar sobre a juridicidade de um acordo potencialmente em desconformidade com o Direito Comunitário Originário.

Não se tratava de uma exclusão pura e simples da escala de existência estatal. O impedimento de invocar tais acordos potencialmente disruptores perante Tribunal nacional de qualquer dos Estados-Membros visava antes a ciosamente evitar que estes órgãos estatais pudessem produzir em paralelo convicções de juridicidade próprias em torno das instituições da Comunidade.

Em outras palavras, a ideia deste dispositivo era precisamente evitar que as estatalidades isoladas pudessem por vias transversas construir marginalmente convicções de juridicidade paralelas sobre questões comuns: sua medida, como as demais, não poderia por si só e unilateralmente decidir sobre a juridicidade na vida em comum. Mais simplesmente, não se autorizava que qualquer órgão interno de um Estado-Membro pudesse buscar determinar o sentido normativo comunitário: afinal, isso poderia implicar a concessão sorrateira do lugar do Direito e do Poder às estatalidades isoladas.

Não se tratava aqui de uma inocente e modesta exclusão da presença dos EstadosMembros. O afastamento da estatalidade isolada não se mostrava como uma técnica institucional que somente pretendia manter essa dimensão existencial à distância: este preciso ato de apartar esta escala existencial concentrava toda uma rede de oposições escalares pressupostas ao longo de todo o texto do Tratado que, por sua vez, deve ser explicitada. Não há o favorecimento de qualquer forma de experienciar o mundo, mas simplesmente a conservação da organização jurídico-Política do social da Europa unida e de seu vácuo de Poder.

Quando da elaboração do texto do Tratado da CECA, a competência jurídicoeconômica regulatória do mercado do carvão e do aço foi atribuída pelas estatalidades isoladas e intergovernamentais à Comunidade, ou melhor, a construção do sentido normativo fora atribuída à dinâmica Política da vida em comum. Nestes termos, as estatalidades efetuaram uma auto-exclusão no que se refere à possibilidade de elas construírem o arcabouço jurídico comunitário derivado de conteúdo econômico da Europa Politicamente Unida: formalizadas pela supranacionalidade, as normas exigiriam sempre a presença de multiescalaridade para imprimir o sentido normativo comum sobre questões concretas sensíveis.

Assim, ao se retirarem do lugar do Direito e do Poder na Europa Unida, as estatalidades não se fizeram substituir pela Alta Autoridade, isto é, não se tratou de uma delegação ou de uma transferência de Poderes provida ou desprovida de reserva de 
Poderes. Instituíram-se entidades supranacionais (Alta Autoridade e Corte) para que estas pudessem criar um eixo de formação de novas escalas destinadas a se contrapor às diferentes dimensões estatais, para que estas não pudessem determinar unilateralmente o sentido normativo sobre questões sensíveis (carvão e aço) que deveriam ser solucionadas a partir de uma perspectiva não-mais exclusivamente estatal, mas comunitária.

Em outras palavras, a auto-exclusão estatal e a instituição das supranacionalidades devem ser entendidas antes como uma forma de direitificar um sistema de convivência entre diferentes escalas de existência, e não como forma de privilegiar uma determinada dimensão existencial. O sistema de convivência entre supranacionalidade e estatalidade direitificado por meio do Tratado da CECA deveria ser continuamente marcado pelo vazio no centro nomogenético comum - e não pela eleição de Um em detrimento dos demais.

Dito de outro modo, a auto-exclusão estatal do lugar do Direito e do Poder na Comunidade deve ser entendida como fruto de uma preocupação em ciosamente constituir um sistema institucional preocupado com a manutenção daquele vazio, de maneira a estimular a produção conjunta do sentido normativo comum. A ideia era precisamente assegurar a presença mista de diferentes formas de habitar o mundo por meio dos diferentes estímulos institucionais, de maneira a evitar a regência da vida comum por uma escala de existência totalizada.

Se a estatalidade não poderia ocupar o lugar de produção do sentido das decisões normativas e de Poder na Europa Unida, igualmente a supranacionalidade estava impedida de se considerar como podendo ocupar de maneira privilegiada o centro produtor de normas e de decisões de Poder na Europa Unida - o que por diversos momentos foi assinalado neste trabalho. E é no interior dessa chave de leitura que se deve compreender a auto-exclusão dos Estados-Membros efetuada pelo caput do parágrafo quarto do artigo 65: estimular institucionalmente a produção de repulsões multilaterais e multiescalares para conservar um vazio de Poder na União Política da Europa.

Diferentemente do que poderia parecer por meio de uma leitura apressada, a manutenção à distância da estatalidade isolada não era efetuada em detrimento desta e em favor da supranacionalidade - quer fosse da Alta Autoridade, quer fosse da Corte. O distanciamento promovido institucionalmente da estatalidade isolada derivava da preocupação constante de todo o Tratado em evitar a ascensão de qualquer escala existencial sobre as demais, de maneira a assegurar a preservação do vazio de Poder na Europa Unida. Era mais uma manifestação da constante inquietação deste Tratado com o afastamento de toda e qualquer possibilidade de unidimensionalização totalizante do lugar 
do Direito e do Poder na Europa Unida. Esta repulsa prejudicava a cada uma das escalas isoladamente e favorecia a todas elas em conjunto, enquanto agentes públicos de um sistema de convivência. Afastavam-se todas e favorecia-se apenas o vácuo de Poder.

Por isso mesmo, este dispositivo deve ser entendido como um dos inúmeros coroamentos institucionais da lógica comunitárias enquanto portadoras de uma determinada escala de existência: a regulamentação jurídico-econômica derivada do ambiente de mercado concorrencial da Europa Unida seria produzida Politicamente. Isso significava que a produção do Direito Econômico Concorrencial se daria sempre a partir de uma situação de vácuo de Poder, isto é, segundo a dinâmica no interior da qual ninguém deteria intemporalmente a última palavra sobre o sentido da nomogênese comunitária.

Nesse sentido, se, por um lado, o Tratado da CECA atribuía a acordos entre agentes econômicos a qualidade de serem nulos de pleno Direito caso perturbassem o ambiente concorrencial Politicamente orientado da Europa Unida, por outro lado, se se mantivesse a possibilidade de as jurisdições dos Estados-Membros controlarem a juridicidade de tais convenções entre agentes econômicos, todo o sistema de convivência ordenado segundo a lógica do vazio de Poder seria desconstruído. Afinal, se as Cortes nacionais pudessem se pronunciar sobre a adequação ou inadequação de tais acordos com relação ao Direito Comunitário, estar-sei-a concedendo, por vias transversas, a possibilidade de as diferentes estatalidades isoladas se pronunciarem sobre o sentido normativo comum.

Assim, na hipótese de não ser impedida expressamente a atuação dos EstadosMembros, seria aberta uma eclusa para a introdução de uma manifestação unilateral da escala estatal isolada e, consequentemente, para o preenchimento do lugar do Direito e do Poder segundo exclusivamente sua específica medida de existência: um órgão jurisdicional de um Estado-Membro deteria a última palavra sobre o sentido da nomogênese de toda a União Política da Europa.

Em outras palavras, haveria uma inadvertida elevação da estatalidade isolada sobre as demais escalas de existência que, progressivamente, poderia deturpar o equilíbrio do sistema de convivência até então arquitetado institucionalmente. Sub-repticiamente, algum Estado-Membro poderia buscar se alçar a Uma posição de destaque e eliminar vazio do lugar do Direito e do Poder - o que extinguiria a correlata multiescalaridade na formação do sentido normativo comum.

Assim, caso não houvesse este afastamento do controle jurisdicional estatal da juridicidade de tais acordos, o vácuo de Poder deixado pela oposição fundamental e fundante do Tratado entre supranacionalidade e estatalidade seria suprimido, tendo em 
vista que se teria mantido aberta a possibilidade de preenchimento deste espaço pela estatalidade isolada. Mas de maneira alguma poderia a estatalidade isolada pretender encontrar alguma escusa apta a legitimar sua presença única e total no centro nomogenético e decisório da vida comum na Europa.

Deste modo, de maneira a evitar que o vazio de Poder fosse eliminado por uma desautorizada e súbita ocupação por parte dos Estados-Membros, o dispositivo ora em análise apontava precisamente a necessidade de se afastar a possibilidade de um exame jurisdicional pelas estatalidades isoladas. Impassíveis de serem invocadas perante qualquer órgão jurisdicional estatal, não surgiria o risco de uma parcial escala de existência (um órgão jurisdicional de um Estado-Membro) ditar a partir de sua particularidade a ordem jurídica comunitária, isto é, de ela ocupar o lugar do Direito e do Poder na Europa Unida.

A contraposição dimensional fora assim reatada pelo Tratado, retirando-se - por meio da rejeição da possibilidade invocação dos acordos perante jurisdições dos EstadosMembros - também a estatalidade isolada ao lugar do Direito e do Poder. Agregara-se com este dispositivo mais uma fórmula de frenagem ao sistema de refreamento inaugural do Tratado. Estados-Membros excluídos porque (e da mesma maneira que) excluídas foram as demais formas de habitar o mundo.

Ao lado desta previsão, não se pode ignorar a da parcela final do mesmo parágrafo quarto do mesmo artigo 65. Neste dispositivo, estabelecera-se um mecanismo destinado à solução de dúvidas em torno da validade destas convenções entre agentes econômicos onde, mais uma vez, é possível perceber a reiteração da preocupação em instituir arenas de oposições escalares no interior da União Política da Europa.

Com o objetivo de dar operacionalidade ao conjunto do artigo 65, este parágrafo quarto definia que competia à Alta Autoridade a exclusividade de se pronunciar sobre a conformidade dos eventuais acordos celebrados entre as empresas com as disposições deste artigo. Além disso, o mesmo texto normativo garantia a possibilidade de se contestar perante a Corte da CECA tal pronunciamento da Alta Autoridade.

Note-se aqui uma oposição escalar explícita, derivada da contraposição entre as diferentes supranacionalidades comunitárias, a qual era operada segundo regras específicas de bloqueios e de contenções recíprocos. A inter-relação de negatividade mútua entre Alta Autoridade e a Corte da CECA fora ainda uma vez nesta parcela do Tratado aberta, com o objetivo de instaurar novamente um vácuo de Poder na Europa.

Aparentemente à Alta Autoridade teria sido concedida uma faculdade de ação bastante enérgica: apenas a esta entidade caberia a possibilidade de se pronunciar sobre a 
juridicidade ou a não-juridicidade das condutas constantes dos referidos acordos entre agentes econômicos. De acordo com essa interpretação, em última instância residiria na supranacionalidade exclusiva deste órgão comunitário a capacidade de proferir a última palavra sobre o sentido do Direito e do Poder na Comunidade - pois seria exclusivamente ela quem apontaria as condutas conformes ou desviantes com relação ao ordenamento jurídico-Político comunitário e sua expressão jurídico-econômica. Esta perspectiva compreenderia a Alta Autoridade como a tradição compreende: ela deteria a Única voz normativa possível, pois ocuparia o centro nomogenético na Europa Unida.

Todavia, ao mesmo tempo em que o Tratado parecia atribuir a exclusividade a esta entidade comunitária, imediatamente após esta previsão o artigo textualmente estabelecera a possibilidade de controle de tais pronunciamentos por parte da Corte da CECA. O Tratado apunha de maneira sucessiva à concessão do Poder, um contra-Poder, ou melhor, um contrapeso à margem de ação estabelecida à Alta Autoridade: se a esta forma de supranacionalidade fora prevista uma possibilidade de afirmar, à outra maneira de expressar a supranacionalidade fora concedida uma faculdade de negar tal afirmação.

Ao peso concedido à Alta Autoridade, o Tratado da CECA antepusera um contrapeso a partir da Corte: consciente da possibilidade de revisão de seu pronunciamento, a Alta Autoridade não cometeria abusos, isto é, não encontraria estímulo institucional suficiente para romper com a disposição Política da Europa. Dessa forma, há que se notar que se buscou minar a possibilidade de a Alta Autoridade construir sobre si própria uma auto-compreensão jurídico-política que lhe permitisse se destacar sobre os demais - afinal, residiria à espreita um mecanismo de desconstrução do patamar de ação a ela e por ela erigido.

Perceba-se que desta maneira havia uma constante inserção em situação de risco que buscaria preservar o vácuo de Poder: ao receber a possibilidade de agir no sentido de se pronunciar sobre o sentido e o não-sentido jurídico das condutas constantes dos referidos acordos, a Alta Autoridade deveria agir no sentido de preservar a Política permanecendo sempre alerta e cônscia sobre a possibilidade de ter suas pretensões de destacamento imediatamente bloqueadas pelo contra-Poder detido pela Corte.

Sob essa perspectiva, assim, a oposição escalar assegurara o esvaziamento de um Poder atribuído a uma dimensão de existência, impedindo sua escalada em direção ao topo em detrimento das demais. A Alta Autoridade se encontrava detentora, em suma, de mais um Poder "sem Poder", pois a qualquer momento poderia ter contestada sua decisão sobre 
a juridicidade ou não dos acordos. Não se encontrava assim sozinha no lugar do Direito e do Poder - pois, afinal, ela não o detinha com exclusividade, nem com ele se identificava.

A nenhuma outra escala de existência atribuíra-se o mesmo Poder da Alta Autoridade; todavia, dirigira-se a outra escala outro Poder, vale dizer, um contra-Poder, ou ainda, um Poder negativo: não sendo o mesmo Poder, a Corte poderia opor à Alta Autoridade a possibilidade de desconstrução daquilo que, por ela, teria sido afirmado. A regência jurídico-Política da Europa Unida operava aqui por meio de uma convivência entre escalas de existência mediante entrechoque entre Poderes, os quais atuavam mutuamente como freios ao destacamento de Um sobre os demais - freios estes que também são anulados por contrapesos a eles apostos.

Com efeito, ao lado da concessão de uma competência exclusiva à Alta Autoridade, o Tratado da CECA imediatamente opusera um contra-Poder atribuído a outra entidade comunitária supranacional - a Corte. Esta deveria, por meio de seu Poder de controle, assegurar ser impossível e impensável por parte da Alta Autoridade buscar elevar sua medida de existência sobre as demais. Ao mesmo tempo, além do contrapeso aposto com relação à supranacionalidade da Alta Autoridade, o Tratado da CECA procurara conter este próprio contra-Poder da Corte. Esta não poderia ser entendida assim como instância privilegiada portadora de escala de existência eleita.

Isso porque não apenas com relação à Alta Autoridade o Tratado da CECA promovera um esvaziamento do Poder. A própria atividade de controle da Corte fora ela própria controlada. Reiterava-se aqui também a contínua e progressiva limitação de Poderes concedidos a dimensões existenciais que tanto caracterizara o Tratado até o presente momento: um sempre poderia exercer um Poder bloqueador do desejo de mando eventualmente gestado no interior de outro.

O Tratado buscara impedir com relação à supranacionalidade da Corte o surgimento de uma pretensão de unidimensionalizar totalmente o lugar do Direito e do Poder conforme sua específica maneira: o contrapeso aposto de maneira originária ao Poder de freio detido pela Corte consistia na previsão da necessidade de este órgão jurisdicional ser provocado. Condição sem a qual a Corte não poderia atuar, a proibição de ação de ofício se tratava de requisito insuperável que garantia a impossibilidade de atuação autônoma, livre e desimpedida da Corte.

$\mathrm{O}$ artigo 65, parágrafo quarto, in fine, determinava que a Corte poderia ser provocada, mediante recurso interposto por um agente econômico cuja esfera de interesse houvesse sido tocada de maneira prejudicial em virtude do pronunciamento da Alta 
Autoridade sobre os referidos acordos, a fim de que a Corte pudesse decidir sobre a nulidade ou não da referida decisão da Alta Autoridade.

Assim, apesar de o Tratado da CECA ter se preocupado com o controle da atuação decisória da Alta Autoridade, ao mesmo tempo não descuidou da preservação da lógica de ser igualmente indispensável a aposição de um limite à própria atividade de bloqueio. Não apenas a Alta Autoridade deveria ser impedida de se considerar como detentora do lugar do Direito e do Poder, em virtude da presença de um freio aposto pela possibilidade de controle pelo Corte, mas, de maneira similar, a Corte não poderia se compreender enquanto detentora dos instrumentos de controle Alta Autoridade, como portadora da última palavra sobre o sentido normativo na Comunidade.

Não poder agir automaticamente sobre toda e qualquer decisão da Alta Autoridade concernente à juridicidade de acordos se mostrava como vigorosa barreira institucional introduzida com o objetivo de impedir um agir onipresente e onipotente por parte da Corte: este órgão comunitário estaria absolutamente desautorizado a responder por si só, de ofício, às decisões proferidas pela Alta Autoridade. Pelo contrário, deveria ele ser sempre provocado mediante a interposição de um recurso por parte de um interessado.

Para além destes limites, o contra-Poder da Corte não poderia ser exercido, sendo incapaz de conter a Alta Autoridade se e quando não fosse provocada. Imediatamente após a concessão à supranacionalidade da Corte de um Poder de contenção da supranacionalidade da Alta Autoridade, por meio da previsão desta necessidade de provocação do órgão jurisdicional comunitário se previra igualmente um instrumento de limitação deste Poder. O próprio Poder de negação era assim limitado por suas próprias condições internas - fragilizando sua margem de atuação. Essa repulsão simultânea das duas escalas nada mais produzia do que um vácuo de Poder, pois nenhuma das duas poderia ocupar o lugar do Direito e do Poder na Europa Unida.

Mais uma vez, o Tratado da CECA operara institucionalmente de acordo com a lógica de prever a concessão de um Poder desprovido de Poder a seus órgãos comunitários, sempre com o objetivo de lhes impedir a totalização unidimensional. A manutenção de uma regência da organização jurídico-Politica da Europa do pós-Segunda Guerra Mundial segundo o reiterado enigma do Poder "sem Poder" se mostrara aqui ainda uma vez como o centro de preocupações do edifício institucional veiculado por este documento jurídiconormativo internacional.

Por fim, há que se ressaltar ainda a previsão do artigo 65, parágrafo quinto, do Tratado da CECA. Esta teria sido construída para voltar a reafirmar no texto do Tratado a 
opção pelos fundadores da Comunidade por um determinado tipo de organização jurídicoPolítica da Europa: uma organização jurídico-Política não coercitiva, fruto da rejeição do Projeto de construir um Estado Europeu. Nesse sentido, o referido dispositivo determinava que, na hipótese de a Alta Autoridade ter constatado a existência de acordos que se mostravam em desconformidade com as disposições do artigo, ela poderia aplicar sanções econômicas sobre tais empresas.

Frise-se desde já que a rejeição da um Estado Europa foi questão analisada mais diretamente em outras oportunidades deste texto ${ }^{965}$, motivo pelo qual não será o argumento desenvolvido completamente neste item. Este breve apontamento pretende apenas sinalizar como o Tratado conscientemente optou em diferentes momentos normativos por uma rejeição institucional da possibilidade de se conceder por vias transversas a centralização do uso da força na Europa Politicamente Unida pela CECA - isto é, por uma rejeição de uma organização jurídico-Política estatal da Europa.

O Tratado da CECA reduzira a possibilidade de ação da Alta Autoridade a uma única consequência possível a partir de sua decisão: a aplicação de uma medida punitiva desprovida de elemento coercitivo sobre os agentes econômicos que aplicaram ou pretendiam aplicar uma tal convenção. Ao retirar da Alta Autoridade a possibilidade de, após se pronunciar sobre a juridicidade ou a não-juridicidade dos acordos (artigo 65, parágrafo quarto, in fine, do Tratado da CECA), ameaçar recorrer ao uso da força (artigo 65, parágrafo quinto, do Tratado da CECA), a engenharia institucional constante deste documento jurídico-normativo internacional revelava sinais da reafirmação de sua orientação no sentido manter uma Europa Politicamente Unida sem força.

A combinação da previsão dos dois últimos parágrafos do artigo 65 efetuava, dessa forma, a reiteração da lógica de promoção de um Poder "sem Poder", presente ao longo de todo o Tratado da CECA. Se o artigo 65, parágrafo quarto, in fine, determinava que à Alta Autoridade caberia a exclusividade de se pronunciar sobre a juridicidade dos referidos acordos, imediatamente o Tratado remetia à consequência de tal previsão, no parágrafo seguinte: a apresentação de uma resposta punitiva de caráter econômico.

Não haveria deste modo razão alguma para se temer um eventual movimento de ascensão da escala supranacional sobre as demais no que se refere à ocupação do lugar do Direito e do Poder na Europa Unida: a máxima consequência que poderia derivar dessa concentração das possibilidades de definição de juridicidade no âmbito da

${ }^{965}$ Como mencionado diversas vezes neste texto, o Sexto Capítulo, e o item 7.2.4., ambos supra. 
supranacionalidade da Alta Autoridade seria apenas e tão-somente uma limitada repercussão na esfera patrimonial dos agentes econômicos.

As referidas sanções econômicas poderiam ser multas ou adstrições (ou astreintes, multas diárias), ambas limitadas a um valor máximo equivalente ao dobro do volume de negócios realizado com os produtos que constituíram o objeto do acordo, da decisão ou da prática contrários às disposições deste artigo 65. Especial atenção deve ser dada ao fato de que, nas hipóteses de o objetivo do acordo, da decisão ou da prática consistir na restrição da produção, do desenvolvimento técnico ou dos investimentos, este valor máximo poderia ser aumentado: (i) nos casos das multas, em até $10 \%$ do volume de negócios anual das empresas em causa; e (ii) nos casos das adstrições, em até $20 \%$ do volume diário de negócios.

Para os fins deste trabalho, mais importante do que compreender as minúcias da racionalidade típica de Direito Econômico Concorrencial que informara a construção dessa disposição normativa, ou mesmo a natureza jurídica dos institutos jurídicos nele mencionados ${ }^{966}$, há que se deter sobre o aspecto que revela normativamente a orientação da institucional da organização jurídico-Política da CECA: afirmar e realizar a assunção de uma organização jurídico-Política não-coercitiva do sistema de convivência inaugurado pela CECA.

Ao conceder um campo de atuação exclusivo à Alta Autoridade para se pronunciar sobre o caráter jurídico ou não-jurídico, o Tratado da CECA concedera uma forma de Poder que jamais poderia significar a centralização do uso da força em uma organização semelhante à estatal. O Poder de definição do sentido ou do não-sentido jurídico do acordo era acompanhado por um instrumento desprovido de mecanismos similares aos das estatalidades isoladas (força).

Deste modo, os Estados-Membros não teriam ameaçados seus respectivos monopólios de uso centralizado da violência, ainda que à Alta Autoridade houvesse sido atribuído um Poder punitivo sobre agentes econômicos localizados em seu território. Tal atuação punitiva detinha um caráter meramente econômico, e jamais assumiria contornos coercitivos. E mais uma vez o Tratado manifestara normativamente a necessidade de se afastar institucionalmente a possibilidade de se considerar a organização jurídico-Política da vida em comum da CECA como um princípio de um Estado Europeu:

\footnotetext{
966 Tema que, por estar fora do recorte metodológico estipulado para este trabalho, não será aqui examinado.
} 
a Comunidade não deteria quaisquer instrumentos aptos a lhe conceder a centralização do uso da força na Europa.

7.3.1.2.2. O Artigo 66 do Tratado da CECA e os Atos de Concentração: O Significado Jurídico-Político do Controle Concorrencial das Estruturas na CECA

Como mencionado no início do item 7.3.1.2., supra, o Tratado da CECA apresentava um único artigo destinado ao controle e à preservação das estruturas concorrenciais do ambiente econômico regulatoriamente produzido pela Europa Politicamente Unida: o artigo 66. Este artigo estava localizado no Capítulo VI do Título Terceiro do Tratado ${ }^{967}$ e tinha por objetivo, em uma primeira análise, disciplinar a aceitabilidade de atos de concentração entre as empresas do setor econômico do carvão e do aço no interior da CECA. Todavia, há que se examinar mais detidamente o referido dispositivo normativo, a fim de revelar em suas disposições uma articulação institucional jurídico-Politicamente motivada.

Com efeito, de acordo com a delimitação metodológica deste estudo, mais importante do que compreender as minúcias da racionalidade típica de Direito Econômico Concorrencial que informara a construção desse dispositivo, ou mesmo a natureza jurídica dos institutos jurídicos nele mencionados ${ }^{968}$, há que se deter sobre aspectos deste dispositivo que permitam revelar a preocupação em instituir oposições escalares voltadas à conservação de uma União Política na Europa da CECA.

A fim de evitar a desnecessariamente fastidiosa citação do longo texto normativo deste artigo 66, o presente texto analisará a seguir de cada um de seus sete parágrafos, de acordo com uma ordem diversa da apresentada pela redação original. O objetivo dessa reordenação expositiva consiste em explicitar mais claramente, não o sentido normativo dado de Direito Econômico Concorrencial, mas principalmente o sentido jurídico-Político não-dado e não-sentido deste mandamento normativo.

$\mathrm{O}$ artigo 66 do Tratado da CECA articulava o conjunto de seu mandamento normativo por meio de pelo menos cinco movimentos lógicos distintos de imputação normativa, dentre os quais é possível agrupar ao menos um parágrafo deste dispositivo. A despeito de esses movimentos lógicos se comunicarem entre si explícita e implicitamente,

967 O outro artigo que compunha este Capítulo VI - o artigo 65 - foi examinado no item 7.3.1.2.1., supra, de acordo com a organização estrutural anunciada no início do item 7.3.1.2., também supra. Remetemos o leitor aos dois itens, para maiores esclarecimentos sobre a organização estrutural do trabalho.

${ }_{968}$ Tema que, por estar fora do recorte metodológico estipulado para este trabalho, não será aqui examinado. 
é possível efetuar um exame de cada um deles separadamente, mostrando-se viável uma exposição didática e lógica de cinco grande espécies normativas distintas - porém interrelacionadas. Cada uma delas procurara assegurar, para além da materialidade do significante de Direito Econômico Concorrencial de controle das estruturas, a preservação diretificada das Leis Políticas da Europa.

Em primeiro lugar, há que se perceber uma íntima relação entre os parágrafos primeiro, terceiro e quarto do artigo 66: o conjunto deles estabelecia o cerne da matriz do instrumento jurídico-econômico delineado neste dispositivo. Mas nele não apenas se definira em termos genéricos o objeto de Direito Econômico Concorrencial em torno do qual se erigiria a atuação combativa da Alta Autoridade - a concentração das estruturas do mercado de carvão e do aço na Europa Unida da CECA, mas também foram estabelecidos os condicionamentos gerais da atuação da Alta Autoridade.

Em segundo lugar, o parágrafo segundo deste mesmo artigo determinava um modelo de atuação preventivo (isto é, a priori) da Alta Autoridade voltado à preservação das condições de mercado concorrencial. Para evitar a transformação da estrutura jurídicoeconômica em um ambiente não-concorrencial, o Tratado explicitara série de objetivos e condições específicos para a autorização de concentrações do mercado, desde que estas não tendessem à aniquilação da qualidade concorrencial do mercado. Tratavam-se de limites e possibilidades de ação ex ante da Alta Autoridade.

Em terceiro lugar, o parágrafo quinto do artigo 66 apresentava uma regulamentação da ação repressiva (isto é, a posteriori) da Alta Autoridade. A preocupação deste dispositivo consistira em especificar objetivos e condições para a ação sancionadora da Alta Autoridade voltada ao combate de atos de concentração após a realização destes. Por meio desta disposição, buscava-se dissolver os atos de concentração para readequar as estruturas jurídico-econômicas de mercado conforme mandamentos de um ambiente concorrencial. E, para tanto, o Tratado estabelecera limites e possibilidades da tutela ex post da Alta Autoridade.

Em quarto lugar, o parágrafo sétimo do artigo 66 estabelecera linhas gerais para uma ação da Alta Autoridade em uma situação bastante particular: eventual abuso de posição dominante por uma empresa pública ou privada exploradora do setor econômico do carvão e do aço. Tratava-se de uma regulamentação voltada para as situações em que 
uma conduta era desempenhada em um ambiente econômico não-concorrencial, ou que inesperadamente perdera a estrutura concorrencial ${ }^{969}$.

Em quinto e último lugar, o parágrafo sexto do mesmo artigo 66 pode ser percebido como buscando efetuar um movimento final de retomada afirmativa do processo de negação multilateral da possibilidade de uma apropriação uniescalar do lugar do Direito e do Poder na Europa Unida. Esta negação teria sido sinalizada mais uma vez por meio da regulamentação - limitadora - da atividade sancionadora da Alta Autoridade em sua tutela dos atos de concentração operados no interior da CECA.

Como afirmado acima inúmeras vezes, a preocupação deste trabalho não consiste tanto em explicitar as minúcias das instituições e das racionalidades de Direito Econômico Concorrencial que permeavam essas disposições normativas. Reitera-se aqui se compreender que também no caso de tais regras de controle concorrencial de estruturas do Tratado da CECA é possível notar a presença de uma preocupação em afirmar um determinado sistema de convivência entre diferentes na União da Europa, sistema orientado para a organização jurídico-Política de uma vida comum.

Assim, a apresentação a seguir de tais normas de Direito Econômico Concorrencial será feita para sublinhar os elementos necessários a partir dos quais podem ser encontrados indícios que permitam depreender do dito jurídico-econômico o não-dito do jurídicoPolítico.

\footnotetext{
${ }^{969}$ Não se pode deixar de notar que, a rigor, a previsão normativa constante deste parágrafo sétimo do artigo 66 deveria ter sido analisada no item 7.3.1.2.1., supra, destinado ao exame minucioso do controle de concorrencial condutas. Todavia, a inserção do comentário no presente item 7.3.1.2.2. se justifica pelo fato de que esse dispositivo específico se inseria no interior do campo normativo abrangido pelo artigo 66, especificamente examinado neste item.

Com efeito, ao tratar especificamente da possibilidade do controle da conduta de abuso do Poder Econômico adquirido por uma modificação das condições de mercado concorrencial, apesar de o artigo 66 se referir a uma conduta em especial (abuso do Poder Econômico), ele visa a regulamentar uma conduta que se desenvolveria em momento posterior à modificação do caráter concorrencial do mercado do carvão e do aço na Europa Unida. Mais simplesmente, trata-se de uma previsão de controle de um tipo de conduta que se desenvolveria em uma estrutura que deixara de ser concorrencial - apesar da regulação jurídico-econômica originalmente estabelecida pela ordem jurídica comunitária. Nestes termos, a previsão normativa desta parcela final do artigo 66 está vinculada lógica e cronologicamente ao controle de estruturas holisticamente objetivado por este dispositivo em seu conjunto.

Dito de outro modo, a despeito de tratar de condutas a serem controladas, $\mathrm{o}$ artigo 66 se refere antes a condutas desenvolvidas em uma estrutura de mercado que perdera sua qualidade concorrencial. Nota-se com isso a perseverança da preocupação com as estruturas deste mercado na Europa Unida. Essa condição de persistência da preocupação com as estruturas permite que se efetue neste ponto do trabalho - destinado à compreensão jurídico-Política dos instrumentos de controle de estruturas concorrenciais do Tratado da CECA - a análise de um mecanismo de controle de condutas. O que será feito linhas a seguir.
} 
7.3.1.2.2.1. Os Parágrafos Primeiro, Terceiro e Quarto do Artigo 66: Concentração das Estruturas e Condicionamento da Tutela da Alta Autoridade

O primeiro parágrafo do artigo 66 estabelecia estar submetida a uma autorização prévia por parte da Alta Autoridade toda operação realizada nos territórios dos EstadosMembros da CECA que produzisse direta ou indiretamente, em consequência da ação de uma pessoa ou empresa, ou de um grupo de pessoas ou de empresas, uma concentração de empresas de produção e de distribuição de carvão e/ou de aço (artigo 66, parágrafo primeiro, conjugado com os artigos 79 e 80 do mesmo Tratado da CECA).

O primeiro objetivo dessa previsão consistia em assegurar genericamente o controle da Alta Autoridade sobre toda e qualquer ação que implicasse uma modificação da estrutura de divisão do mercado entre as empresas que pudesse determinar uma mutação de sua qualidade concorrencial. O objetivo desse dispositivo era controlar eventuais concentrações das parcelas percentuais do mercado do carvão e do aço na Europa Unida em uma ou em poucas empresas.

Nesse sentido, o primeiro parágrafo do artigo 66 estabelecia um amplo campo de atuação de controle por parte da Alta Autoridade: toda e qualquer ação de concentração realizada por meio de fusão, de aquisição de ações ou de elementos do ativo, de empréstimo, de contrato ou de qualquer outro meio que pudesse estabelecer a transferência do poder de controle sobre uma empresa a uma outra ${ }^{970}$ que, por isso mesmo, pudesse efetuar a concentração da estrutura atributiva de capacidade decisória sobre o nível de preços, de produção, de qualidade, de distribuição, entre outros, de um único produto ou de produtos diferentes, em uma empresa ou grupo de empresas, ou a poucas empresas ou poucos grupos de empresas.

Perceba-se, deste modo, que por meio dessa primeira parcela do dispositivo, o Tratado da CECA desenhara um quadro bastante amplo de possibilidade de atuação da Alta Autoridade: a ela seria concedida uma capacidade de agir no sentido de controlar

\footnotetext{
${ }^{970}$ Apesar de se encontrar fora do arco de questões buscadas pelo presente trabalho, há que se notar que o tema da transferência do Poder de controle de empresas encontrou grande solo fértil para debate na literatura jurídica nacional em Direito Comercial.

A título meramente exemplificativo, remetemos o leitor eventualmente interessado neste tema específico ao clássico Fábio Konder COMPARATO. O Poder de Controle na Sociedade Anônima. São Paulo: Forense, 1983, e também a Eduardo Secchi MUNHOZ. Empresa Contemporânea e Direito Societário - Poder de Controle e Grupos de Sociedades. São Paulo: Juarez de Oliveira, 2002 e, deste último autor, Transferência de Controle nas Companhias sem Controlador Majoritário. In: Rodrigo Monteiro CASTRO; Luis André AZEVEDO (Orgs.). Poder de Controle e Outros Temas de Direito Societário e Mercado de Capitais. São Paulo: Quartier Latin, p. 285-323, 2010.
} 
qualquer forma de concentração direta ou indireta, mais ou menos formal ou informal, do mercado de carvão e de aço na Europa Unida. Concedera-se à Alta Autoridade uma capacidade de agir bastante efetiva, enérgica medida de preservação de um determinado ambiente jurídico-econômico. Mas isso deve ser mais bem compreendido, para evitar desvios interpretativos.

Isso porque, apesar de se ter alçado a Alta Autoridade, aqui, a uma posição de destaque, há que se notar que não se tratava de uma posição de destacamento escalar sobre as demais dimensões existenciais. Em momento algum por meio deste dispositivo o Tratado alçara a supranacionalidade a Um absoluto superior aos demais. Do contrário, teria havido uma inadvertida ruptura com a lógica reiteradamente perseguida pelo Tratado da CECA em diferentes dispositivos já comentados.

Com efeito, o artigo 66 atribuíra à CECA uma importante atividade de vigilância e de inspeção que, todavia, não atuava no sentido de moderar todas as demais escalas de existência. A Alta Autoridade não detinha a chave de toda a organização jurídico-política da Europa Unida - orientada pela permanente organização jurídico-Política originária. A capacidade de neutralização da Alta Autoridade deve ser entendida como a disponibilização de uma possibilidade de controle vigoroso dos possíveis abusos (econômicos) de uma escala de existência específica não-Pública (privada). Todavia, de forma alguma poderia ser compreendida tal previsão como mecanismo sorrateiro de afastamento absoluto das demais escalas de existência participantes da vida em comum.

O Poder concedido à Alta Autoridade não poderia ser entendido como um Poder privilegiado e incondicionado, pois não se buscara desavisadamente dar a esta um papel de atuação destacado. Na verdade, havia no interior do Tratado um movimento de intensa e progressiva limitação deste Poder, com o objetivo de o esvaziar e de manter vazio o lugar do Direito e do Poder na Comunidade. Caso inexistisse a série de contenções deste Poder da Alta Autoridade - a ser examinada a seguir, talvez fosse possível cogitar a existência de uma desavisada fissura institucional permissiva da introdução velada de um móvel Teológico-Político na Europa Unida favorecedor da supranacionalidade. Não era este o caso, como se poderá ver a seguir.

O restante do parágrafo primeiro deste artigo 66, em conjunto com os parágrafos terceiro e quarto do mesmo dispositivo, apontava para um cuidado do Tratado da CECA de sucessivamente apor instrumentos de bloqueio à Alta Autoridade. Ao mesmo tempo em que a supranacionalidade detinha um enérgico Poder, a contenção desta se daria por meio de uma armadilha do Poder, cujo caráter ardiloso pode ser entendido na seguinte cláusula: 
o exercício deste Poder implicava necessariamente a imediata perda de capacidade de influência unilateral sobre o sentido normativo. Tratava-se de efetiva auto-sabotagem lúcida e ciente das consequências, pois o Tratado introduzira dispositivos de drenagem do conteúdo de seu Poder, de maneira a esvaziar a capacidade de agir da supranacionalidade.

A imposição da necessidade de prévia autorização de atos de concentração por parte da Alta Autoridade não significava que o Tratado da CECA lhe concedera a possibilidade de ocupar o lugar do Direito e do Poder da organização jurídico-Política na Europa Unida. Este Poder se encontrava internamente limitado, e essa autocontenção derivava das próprias condições de exercício deste Poder por parte da Alta Autoridade.

Com efeito, a própria engenharia institucional de atribuição do Tratado da CECA limitava a atuação da Alta Autoridade: se a ela caberia a definição das concentrações autorizadas ou não autorizadas, não residiria nela a definição absoluta das condições segundo as quais deveria haver a concessão ou a rejeição da autorização - as quais deveriam ser definidas após necessária consulta prévia ao Conselho (artigo 66, parágrafo primeiro, in fine, do Tratado da CECA).

Em outras palavras, em relação às demais formas de habitar o mundo, a supranacionalidade se encontrava em posição de igualdade, pois não poderia determinar por si só o padrão normativo único a ser seguido na Comunidade. Abria-se assim novamente uma cadeia de capacidades de agir inter-relacionadas entre si e multiescalarmente implicadas que condicionavam esse a autorização ou rejeição dos atos de concentração.

$\mathrm{O}$ exame atento do final do parágrafo primeiro, em conjunto com o parágrafo terceiro, ambos do mesmo artigo 66 do Tratado da CECA, permite visualizar mais proximamente esta preocupação de forçar a convivência entre diferentes dimensões existenciais - para que, por meio da promoção de uma oposição escalar, não fosse produzido um sentido normativo jurídico e de Poder que não fosse multidimensional, mesmo na regulamentação jurídico-econômica das condições de aceitação ou de rejeição de atos de concentração. Para além do explícito texto de Direito Econômico Concorrencial, subentende-se a regência de um discurso não-dito de ordem jurídico-Política.

Em contraposição ao Poder de autorizar ou de rejeitar previamente atos de concentração dado pela parcela inicial do parágrafo primeiro, a primeira parte do parágrafo terceiro estipulava a possibilidade de determinadas operações de concentração estarem isentas de tal obrigação de autorização prévia por parte da Alta Autoridade. Essa isenção deveria ser regulamentada pela Alta Autoridade e aprovada pelo Conselho, e deveria ser 
possível nas hipóteses em que, pela importância dos elementos do ativo que envolvessem ou das empresas a que se referissem, e em virtude da consideração da natureza da concentração que que realizavam, tais operações poderiam ser consideradas como não visando à determinação dos preços ou ao afastamento das regras de concorrência derivadas da aplicação do Tratado.

Perceba-se que o final de cada um dos parágrafos supramencionados estabelecia interessante mecanismo de atribuição-contenção, na medida em que delineia diversos elementos definidores de limites e de possibilidades de ação a mais de uma escala existencial. A orientação desses dois dispositivos era multiescalar, pois ao mesmo tempo que alcançavam a Alta Autoridade e o Conselho, implicavam uma dupla pavimentação de caminhos que se encontravam, mas que não se cruzavam. Eles antes se chocavam.

O último período do parágrafo primeiro do artigo 66 determinava o estabelecimento prévio de uma regulamentação sobre o que consistiria o controle de uma empresa, a fím de estabelecer critérios para o controle prévio dos atos de concentração por parte da Alta Autoridade. Ao mesmo tempo, a parcela final do parágrafo terceiro do mesmo artigo determinava de maneira semelhante que um regulamento deveria ser estabelecido para determinar as condições de isenção de autorização prévia.

Os dois dispositivos ora em comento operavam de acordo com a seguinte lógica: à Alta Autoridade caberia, sem dúvida, a possibilidade de conceder ou não a autorização prévia à realização de um ato de concentração entre agentes econômicos exploradores do setor de carvão e do aço (parágrafo primeiro do artigo 66 do Tratado da CECA), do mesmo modo que a ela igualmente caberia o Poder de isentar determinada concentração de empresas de requerer a referida autorização prévia (parágrafo terceiro do artigo 66 do Tratado da CECA). Esta seria uma esfera de competência atribuída com clareza a este órgão comunitário.

Todavia, este amplo espectro de ação à Alta Autoridade não era desacompanhado de sua imediata contenção: a atuação da supranacionalidade não poderia ser desenvolvida sem a presença de balizas que interrompessem qualquer pretensão de usurpação do lugar do Direito e do Poder. Isso equivale dizer que não apenas a concessão ou não de autorização prévia à realização desses atos deveria ser realizada conforme critérios prédeterminados juridicamente, como também o próprio reconhecimento da isenção da obrigação de solicitar esta autorização prévia não poderia se pautar por preferências casuísticas e/ou arbitrárias. 
De imediato, o Poder de controle concedido à Alta Autoridade estaria por si só contido, não restando ao dispor de seu bel-prazer ou de caprichos levianos - precisamente por não ser um Poder de propriedade da supranacionalidade, mas a ela concedido para operar no interior da racionalidade Pública comunitária de perseverar o ser de uma União Política da Europa.

Detentora do Poder de autorizar ou de proibir concentrações, ou mesmo de isentar tais práticas de requerer uma avaliação prévia, a Alta Autoridade poderia aparentar deter um enorme Poder. Contudo, o Tratado da CECA imediatamente retirara desta Alta Autoridade a possibilidade de se compreender como a única referência dimensional destinada a habitar o centro produtor dos critérios de definição de sua própria atuação. Suas decisões deveriam seguir condições de exercício previamente determinadas, não podendo ser reinventadas a cada oportunidade que fosse chamada a atuar - pois, afinal, não seria a Alta Autoridade proprietária exclusiva do espaço produtor do sentido normativo na Europa Politicamente Unida. Suas decisões deveriam se orientar por normas jurídicas préexistentes, normas estas não produtos totalizados de sua própria escala de existência.

É nesse sentido, inclusive, que se deve compreender o restante da parcela final de cada um dos parágrafos até agora examinados: nos dois casos, o Tratado da CECA determinava que o Conselho deveria ser consultado previamente para que, na hipótese da manifestação de sua concordância, pudesse o regulamento ser considerado como válido. Há aqui a manifestação de mais uma interessante oposição escalar no interior dessa precisa dinâmica, oposição esta que merece ser explicitada de forma mais clara.

Nota-se com facilidade o surgimento de um primeiro movimento de contenção escalar: não apenas a atividade de controle de atos de concentração exercida pela Alta Autoridade seria condicionada pela existência prévia de um regulamento, como também este não teria como fundamento exclusivo o modo de experienciar o mundo supranacional portado por esta entidade comunitária. A manifestação conforme da estatalidade intergovernamental do Conselho seria imprescindível para determinar o conteúdo das normas jurídicas a serem observadas pela Alta Autoridade.

A supranacionalidade se encontrava dessa forma desprovida de meios de ação que lhe permitissem a tomada do lugar do Direito e do Poder. Dessa forma, a enérgica competência a ela atribuída de controlar e de isentar atos de concentração praticados nos territórios dos Estados-membros da CECA estaria limitada não apenas por um regulamento prévio - o que, por si só, afastava a possibilidade de uma ação desprovida de critérios 
publicamente conhecidos, mas principalmente em virtude de este regulamento não ter sido produzido a própria sua imagem e semelhança.

O destacamento da Alta Autoridade sobre os demais partícipes da Europa Politicamente Unida encontrava-se impedido por meio desta exigência de participação do Conselho na definição das normas jurídicas a serem seguidas pela Alta Autoridade quando do exercício de sua atividade de controle de atos de concentração. A invocação da presença do Conselho neste preciso momento do Tratado operava como forma de apor um contrapeso à atividade da Alta Autoridade, com o objetivo de que a oposição entre estatalidade intergovernamental e supranacionalidade impedisse por parte desta a realização de um rompimento do vazio no lugar do Direito e do Poder da CECA.

Todavia, há que se perceber ambiguidade - ou melhor, a multilateralidade - desta disposição normativa. A oposição escalar instaurada institucionalmente seguia de perto a organização jurídico-Política da Europa Unida da CECA: se o Conselho fora convocado para limitar uma eventual transcendentalização da Alta Autoridade, a própria atividade de contenção efetuada pela estatalidade intergovernamental era contida para preservar a multiescalaridade na formação do sentido normativo.

A recusa a uma possível transcendentalização da intergovernamentalidade nestes parágrafos era perceptível a partir da compreensão de que a função desempenhada por esta entidade comunitária se reduzia à concessão ou não de um parecer conforme ao regulamento. Nesse sentido, entenda-se que o regulamento deveria ser inicialmente proposto pela Alta Autoridade para que ela própria pudesse agir posteriormente ${ }^{971}$; todavia, deveria ser ele igualmente aceito pelo Conselho para que ela pudesse agir, mas o Conselho ele próprio não poderia efetuar alterações ao texto proposto. A atividade deste se reduzia a aprovar ou a rejeitar o regulamento proposto.

Note-se aqui mais uma vez uma arquitetura institucional voltada a progressivamente enfatizar a dimensão do conflito nas relações entre as escalas de existência que compunham a Europa Unida, sem atribuir a qualquer delas nem mesmo alguma proeminência. Tratava-se de exemplar indicação da necessidade de interação opositora entre modos distintos de habitar o mundo para que, sabendo conviver em conjunto com o diferente, pudessem preservar esse sistema de convivência multiescalar para formular decisões normativas. O produto dessa interação não poderia se identificar

\footnotetext{
${ }^{971}$ Haja vista que, na ausência deste regulamento, não poderia ela exercer sua atividade de controle dos atos de concentração eventualmente praticados no interior da Comunidade.
} 
com qualquer delas, mas sim se revelar com resultante de tais tensões dimensionais, sem em qualquer maneira implicar o favorecimento ou o desfavorecimento de uma ou de outra.

Nesse sentido, o regulamento proposto pela Alta Autoridade jamais poderia significar a elevação desta sobre os demais participantes da vida em comum, sob pena de não ser este texto aprovado; ao mesmo tempo, ela dependeria deste documento jurídico para exercer o vigoroso - e também limitado - Poder a ela concedido pelo Tratado, a fim de controlar os atos de concentração praticados na Comunidade. No mesmo sentido o papel exercido pelo Conselho: se, por um lado, ele poderia conter a atividade normativa da Alta Autoridade por meio da aprovação ou não do texto do regulamento proposto, este contraPoder de contenção não se revelava de forma alguma absoluto, pois em nada poderia ele alterar o texto.

A função exercida pelo Conselho não era prevista em seu favor, mas em favor da Comunidade, não restando assim no âmbito de sua discricionariedade exercê-lo ou não. Antes mesmo, tratava-se de verdadeiro Poder-dever. Ao mesmo tempo, não poderia o Conselho aprovar todo e qualquer regulamento proposto pela Alta Autoridade, pois eventual descuido de sua parte poderia significar uma autorização velada ao progressivo destacamento da supranacionalidade sobre as demais escalas de existência.

Por esse motivo, de maneira a garantir um controle multiescalar dos atos de concentração praticados no interior da Comunidade, a estatalidade intergovernamental oporia um poder de resistência a qualquer texto normativo proposto pela Alta Autoridade que pudesse significar uma tendência de destacamento da medida de existência desta sobre as demais.

Opuseram-se assim essas duas escalas de existência com o objetivo de negar simultaneamente a todas elas a possibilidade de dar o sentido normativo último na Comunidade. A reafirmação da permanência de um vazio no lugar do Direito e do Poder era o único modo de assegurar a negação a todas e a cada uma das medidas de existência a auto-assunção do papel de fundamento e garante último das Leis e do Direito na Europa Unida.

Todavia, há ainda outros indícios de uma orientação Política do regime jurídicoconcorrencial de controle de atos de concentração do Tratado da CECA, os quais se evidenciam a partir do exame do parágrafo quarto do artigo 66. Este surgira no Tratado com o objetivo de prever mais um mecanismo para reforçar o enfraquecimento da Alta Autoridade. Afinal, se se atribuíra à Alta Autoridade a possibilidade de efetuar um controle prévio ou posterior de atos de concentração praticados entre empresas exploradoras do 
setor econômico do carvão e do aço, este controle deveria ainda uma vez ser contido por este dispositivo.

Perceba-se que o parágrafo quarto do artigo 66 do Tratado da CECA estipulava conscientemente uma forte capacidade de impacto sobre os territórios nacionais (ou seja, o território das estatalidades isoladas) à Alta Autoridade. A despeito da existência dos Estados-Membros e de suas respectivas Soberanias nacionais, teria sido concedida à supranacionalidade a possibilidade de obter as informações que julgasse necessárias diretamente de pessoas físicas ou jurídicas que tivessem adquirido ou reagrupado, ou que iriam adquirir ou reagrupar, ativos ou direitos de uma ou mais empresas, a fim de verificar a possibilidade de aplicação do Poder de controle de atos de concentração na Comunidade.

A racionalidade desta previsão inicial residia na assunção de que a Alta Autoridade deveria dispor de elementos suficientes sobre determinados atos de concentração para poder avaliar se tais práticas configurariam uma concentração de empresas por fusão, por aquisição de ações ou de ativos, por empréstimo, por contrato ou por qualquer outra forma de obtenção de Poder de controle. É inegável assim que este parágrafo quarto atribuía à Alta Autoridade um campo de ação inusitado, tendo em vista que independentemente da presença ou da mediação das estatalidades isoladas, ela poderia obter todas as informações necessárias para a formação de sua convicção.

O potencial de impacto de outro centro de Poder no interior de um Estado é aqui manifesto de maneira profunda, na medida em que a Alta Autoridade estaria autorizada de antemão a efetuar o contato direto necessário para a formação de sua convicção. Em um primeiro momento, portanto, a supranacionalidade pareceria ter sido agraciada com um Poder de elevada efetividade: outrora impensável, esta previsão inseriria ao lado da autoridade nacional uma outra, de caráter supranacional. Esta situação poderia suscitar uma desautorizada compreensão de que a Alta Autoridade poderia ser percebida como acima das demais escalas de existência.

Todavia, a articulação operada pela arquitetura institucional deste documento jurídico-normativo internacional evitava a realização efetiva deste destacamento escalar pois a todo momento o Tratado da CECA se mantinha comprometido com a conservação da multiescalaridade. Diante dessa possível proeminência por parte da Alta Autoridade, o Tratado se ocupara imediatamente deste indesejado alçar-se sobre os demais mediante nova instalação de uma arena de embates escalares, no interior da qual uma dimensão existencial oporia um freio imediatamente correlato a um contrapeso. 
A atuação da Alta Autoridade deveria ocorrer de acordo com diretrizes estabelecidas por balizas regulatórias. Neste primeiro movimento reflexivo, é inegável a presença de um primeiro elemento de contenção de um possível destacamento por parte da supranacionalidade, qual seja, a impossibilidade de essa sua ação ser desempenhada sem regras. Em outros termos, enquanto detentora de Poder, a Alta Autoridade não estava desincumbida ela mesma de observar as limitações impostas pelo Direito Comunitário: seu poder não era incondicionado.

Antes mesmo de analisar especificamente as duas modalidades de obtenção de informações por intermédio do referido regulamento da maneira como foram delineadas pelo texto do Tratado, é relevante prestar atenção ao menos em um aspecto singular: o regulamento não apenas deveria qualificar juridicamente as operações que seriam objeto de controle por parte da Alta Autoridade, como também, principalmente, deveriam ser tais regimes jurídicos estabelecidos após consulta formulada ao Conselho.

Neste ponto preciso, é possível entrever a previsão de duas formas distintas de contenção do Poder concedido à supranacionalidade, com o objetivo de esvaziar pouco a pouco sua capacidade de impacto no interior do território de um Estado-Membro. Tratavam-se de dois vetores vigorosos de contenção da atividade da Alta Autoridade apostos contra o Poder desta para evitar o desequilíbrio e a verticalização entre as escalas de existência partícipes do processo de União Política da Europa. Com o estabelecimento dessas duas limitações, o Tratado buscava recusar de maneira imediata a concessão integral do lugar do Poder e do Direito à supranacionalidade.

A fim de que o fino balanço destinado a garantir um centro vazio de Poder fosse preservado, em primeiro lugar o Tratado da CECA determinara que o regulamento deveria definir juridicamente as operações a serem controladas pela atuação da Alta Autoridade. Essa disposição normativa teria por objetivo retirar da Alta Autoridade a possibilidade de determinar de maneira casuística, arbitrária, ou simplesmente incondicionada as situações sobre as quais ela deveria ou não exercer seu Poder de controle.

O Tratado delimitava assim o espaço de ação da supranacionalidade, seja para evitar a não-ação nas hipóteses em que o controle seria cabível, seja para impedir perseguições desarrazoadas em que o controle se precipitaria sobre situações fora do espectro normativo abarcado pelo artigo. Em outros termos, este artigo continha a atividade da Alta Autoridade por meio do impedimento do arbítrio: a Alta Autoridade apenas poderia tocar diretamente os nacionais, residentes ou pessoas jurídicas estabelecidos no território de um Estado-membro para obter informações sobre atos de 
concentração praticados se, e somente se, a concentração promovida coincidisse com a situação do regulamento.

A previsão ainda no mesmo parágrafo de outro mecanismo de contrapeso ao Poder concedido à Alta Autoridade reforçava ainda mais a percepção de que o texto do Tratado teria neste artigo se preocupado com o cerco contínuo do potencial assalto ao lugar do Direito e do Poder. Não bastaria estabelecer a indispensabilidade de um regulamento condicionante do exercício da atividade de controle pela Alta Autoridade se, por sua vez, este regulamento não fosse produto ele mesmo da multiescalaridade. Em termos mais simples, o instrumento destinado a evitar a unidimensionalidade (supranacional) no exercício do controle dos atos de concentração por parte da Alta Autoridade deveria estar, ele próprio, desprovido de uma unidimensionalidade constitutiva (supranacional ou estatal).

A elaboração do regulamento em questão não poderia ser resultado de uma ou de outra escala de existência na Europa Unida, pois isso poderia significar a completa anulação do sentido da contenção prevista no parágrafo quarto, ou mesmo da própria atribuição do Poder de controle à Alta Autoridade - seja por privilegiar o modo de habitar o mundo supranacional, seja por dar preferência à dimensão da estatalidade (isolada ou intergovernamental). $\mathrm{O}$ regime jurídico estabelecido pelo regulamento não poderia ser nem mero rito formal de passagem, nem uma formalidade insuperável, vale dizer, nem uma fachada eclipsadora de maquinações supranacionais, nem um escudo protetor da perspectiva estatal.

É por esse motivo que o próprio parágrafo quarto estabelecera que o regulamento seria estabelecido após consulta formulada ao Conselho. Isso implica reconhecer que, se a Alta Autoridade deteria a incumbência de dar a forma jurídica final para o regime jurídico a ser estabelecido pelo regulamento, ao mesmo tempo, a ela não caberia com exclusividade a definição do conteúdo deste instrumento normativo (a qualificação jurídica das operações abarcadas pelo parágrafo quarto).

Do mesmo modo, se os Estados-Membros estavam alijados da possibilidade de determinar isoladamente o conteúdo do regulamento, estes poderiam vocalizar seus modos de habitar o mundo apenas em conjunto, mediante ativa interação de cada um deles no Conselho, com o objetivo de formar a convicção deste sobre o conteúdo do regulamento.

No mesmo sentido deve ser entendida a situação do Conselho: se não era capaz de formar por si só uma convicção sobre o conteúdo do regulamento, e se estava impedido de dar a forma final ao instrumento introdutor do regime jurídico do regulamento, a ele 
caberia fazer confluir as percepções estatais isoladas em um âmbito intergovernamental, de maneira a impedir uma possível avalanche regulatória originada do interior da Alta Autoridade.

Nesse sentido, é possível notar que série de mecanismos de mútua e recíproca anulação cruzada de Poderes restavam implícitos na singela previsão deste artigo 66, com o objetivo de assegurar um contra-Poder de contenção de outro Poder. Freios e contrapesos se contrabalançavam ainda uma vez nesta disposição do Tratado da CECA, não apenas para interromper eventual tomada de assalto do lugar do Direito e do Poder pela Alta Autoridade, mas também para garantir que a limitação desta fosse também limitada, vale dizer, para que o ato de bloqueio da supranacionalidade não viabilizasse o ressurgimento de uma pretensão totalizante por parte das estatalidades isoladas ou intergovernamentais. $\mathrm{O}$ jogo de Poder produziria deste modo um vácuo desprovido de centro unidimensional: todos e nem-Um definiriam o sentido normativo e de Poder na Europa Unida.

A análise conjunta dos três parágrafos do artigo 66 acima mencionados permitiu evidenciar mais uma vez que constantemente o Tratado da CECA visara a construir todo um arsenal institucional no sentido de preservar a Política na Europa Unida por meio do mútuo e recíproco afastamento entre escalas de existência. À concessão de um Poder, seguira-se sua imediata insignificação, seja pela existência de elementos internos que condicionavam seu exercício, seja pela presença de um contra-Poder atribuído a outra escala de existência. A permanência reiterada dessa inteligência de arquitetura institucional deve estar em mente para que se compreendam mais facilmente os comentários a seguir, em torno dos parágrafos restantes do artigo 66.

7.3.1.2.2.2. O Parágrafo Segundo do Artigo 66: As Condições à Autorização de Atos de Concentração pela Alta Autoridade

O parágrafo segundo do artigo 66 do Tratado da CECA estabelecia as condições pelas quais poderia a Alta Autoridade conceder a autorização a atos de concentração entre empresas no interior da Comunidade. O conjunto de suas alíneas designava os limites de atuação desta entidade comunitária, pois determinava genericamente os critérios segundo os quais a decisão da Alta Autoridade sobre a autorização ou não autorização de atos de concentração deveria ser proferida.

Inicialmente, é importante salientar que o terceiro inciso deste parágrafo segundo concedia à Alta Autoridade a possibilidade de subordinar a tal autorização a todas as 
condições que ela julgasse pertinentes. A margem de atuação da Alta Autoridade fora aqui delimitada de maneira bastante ampla, de maneira a lhe conferir uma capacidade enérgica de produção de efeitos sobre atos de concentração praticados nos territórios de Estadosmembros.

Em uma primeira leitura, a construção acima poderia ensejar uma errônea conclusão de deturpado empoderamento da Alta Autoridade por vias transversas, imoderado empoderamento apto a lhe conceder um relativo destaque em suas relações com outras escalas de existência. Há que se examinar essa construção normativa de maneira mais detalhada, para evitar maiores desentendimentos.

Apesar de parecer haver aqui um imoderado depósito de confiança sobre a Alta Autoridade, haveria que se perceber neste mesmo parágrafo segundo série de mecanismos voltados à contenção deste vigoroso Poder conferido à supranacionalidade, de maneira a evitar a unidimensionalização totalizante desta singular forma de experienciar o mundo. Por outros caminhos o Poder concedido por este parágrafo segundo foi progressivamente esvaziado mediante negação contínua deste supostamente enorme Poder concedido à Alta Autoridade.

Note-se que a Alta Autoridade apenas autorizaria atos de concentração entre empresas desde que tal prática não produzisse uma das duas situações reconhecidas explicitamente pelo Tratado como potenciais transformadoras do ambiente de mercado: a concessão a pessoa ou empresa do de Poder de (i) determinar os preços, controlar ou restringir a produção ou a distribuição, ou fazer obstáculo à manutenção de um regime efetivo de concorrência no mercado dos referidos produtos; e (ii) escapar às regras de concorrência derivadas da aplicação do Tratado da CECA, principalmente em virtude do estabelecimento de uma posição privilegiada artificial e que implicasse uma vantagem substancial no acesso aos suprimentos e aos mercados (artigo 66, parágrafo segundo, inciso primeiro, do Tratado da CECA).

Em outras palavras, a autorização à operação seria concedida apenas se a Alta Autoridade concluísse que o ato de concentração não iria conceder a qualquer pessoa ou empresa do setor do carvão e do aço na Comunidade a capacidade de impactar a estrutura do mercado concorrencial.

Nesse sentido, o primeiro inciso do parágrafo segundo do artigo 66 sinalizava uma forma específica de preservar o esvaziamento da capacidade de produção de efeitos nos territórios nacionais detida pela perspectiva tipicamente supranacional. Essa precisa racionalidade que informava a organização jurídico-Política institucional da Comunidade 
se mantinha, a despeito de se verificar a presença de uma potencial temível autorização à Alta Autoridade para exigir a satisfação das condições que julgasse necessárias para a concessão ou não da autorização a determinados atos de concentração.

Com efeito, a atividade de controle da Alta Autoridade não estava desprovida de critérios que orientassem sua ação: o artigo 66, parágrafo segundo, estabelecera condições específicas e, com isso, delimitara o espaço dentro do qual o agir da supranacionalidade seria admitido, de maneira a drenar pouco a pouco o Poder atribuído à Alta Autoridade. Tratavam-se de hipóteses de ação da Alta Autoridade clara e precisamente estabelecidas pelo Tratado da CECA: apesar de competir apenas a esta entidade comunitária a possibilidade de conceder ou de não conceder uma autorização, esta decisão não poderia em hipótese alguma partir de elementos fundamentais outros que não estes expressamente estabelecidos de maneira escrita e explícita no Tratado. Consistiam tais orientações critérios incontornáveis e insuperáveis, dos quais não poderia prescindir qualquer decisão da Alta Autoridade sobre esta temática.

Por isso mesmo, por mais que pudesse a Alta Autoridade estabelecer critérios outros para proferir sua decisão sobre a autorização ou não autorização do ato de concentração praticado no interior da Comunidade, em momento algum poderia ela descuidar da avaliação deste elemento central. Em outras palavras, quaisquer que fossem os elementos adicionais por ela sugeridos, a apreciação feita pela Alta Autoridade jamais poderia desconsiderar a necessidade de estimar se o ato de concentração submetido a seu exame se encontrava apto ou inapto a conceder a uma pessoa física e/ou jurídica o Poder de impactar na estrutura concorrencial do mercado da Comunidade.

O texto ora em análise operava como um construtor preciso do necessário caminho a ser seguido pela supranacionalidade no exercício de seu controle sobre atos de concentração: ela não admitia qualquer desvio de rota, atalho ou bifurcação durante sua execução. Por mais que pudessem ser incluídos aditivos que pudessem aumentar o desempenho da Alta Autoridade, momento algum ela poderia superar a série de cancelas que este parágrafo em especial estabelecera com relação a sua atividade.

Deste modo, a concessão ou a não concessão pela Alta Autoridade da autorização a um ato de concentração praticado no interior da Comunidade se encontrava submetida à necessária percepção, respectivamente, da não produção ou da produção de condições concedessem a pessoa física e/ou jurídica capacidade suficiente de impactar unilateralmente na própria estrutura de formação do mercado concorrencial, conforme sua própria concepção de como este deveria operar em seu favor. 
Mais simplesmente, tanto a autorização quanto a não autorização deveriam se pautar por critérios claros e bem estabelecidos, não havendo assim um depósito exagerado de confiança na escala de existência supranacional. Afinal, não caberia a ela com exclusividade a opção desarrazoada por autorizar ou não uma concentração, precisamente porque a Alta Autoridade não estava autorizada a determinar por si só, uniescalarmente, o sentido normativo a ser impresso na Comunidade sobre questões concretas sensíveis comuns.

É por esse motivo que se pode afirmar que esta previsão operava também uma contenção do Poder concedido à Alta Autoridade: ao esclarecer especificamente os limites de sua atuação, o Tratado da CECA impedia que a dimensão de existência desta se espraiasse sobre as demais no forjar das variáveis a serem utilizadas para construir suas decisões. A Alta Autoridade estaria impedida assim de estabelecer vertical e aleatoriamente um novo padrão para admitir ou não atos de concentração, isto é, não poderia ela mesma fabricar sentidos unicamente seus de produzir e de trabalhar o Direito e o Poder na Europa Politicamente Unida pela CECA.

No limite, o objetivo da previsão de tais critérios sobre os quais deveria atuar a Alta Autoridade consistia precisamente em assegurar a multiescalaridade típica do vazio de Poder no interior da Europa Politicamente Unida, na medida em que buscava preservar afastado um modo de habitar o mundo - o supranacional da Alta Autoridade - do centro doador de sentido normativo na Comunidade. O Tratado relembrava assim a necessidade de se manter a multiescalaridade na determinação do sentido do Direito e do Poder na Comunidade, recusando qualquer tendência à unidimensionalização totalizante de uma ou de outra medida de existência - mesmo daquela destinada a exercer um específico e enérgico Poder.

Ao introduzir um critério pré-estabelecido comunitariamente para a tomada de decisão, o Tratado pretendeu retirar do interior do rol de ações possíveis da Alta Autoridade a definição de tais critérios. O Tratado ainda uma vez mostrou se organizar jurídico-Politicamente no sentido de esvaziar progressivamente um determinado Poder cujo exercício fora conferido a uma singular escala de existência. Detentora de um Poder “sem Poder", nada além dos demais poderia pretender a Alta Autoridade com relação ao lugar do Direito e do Poder, salvo no que se refere a um aspecto: como todos, apenas deveria obedecer ao mandamento da construção multiescalar do sentido normativo comunitário originário. 
7.3.1.2.2.3. O Parágrafo Quinto do Artigo 66: A Disciplina Limitadora e Multiescalar do Controle Repressivo de Atos de Concentração pela Alta Autoridade

O parágrafo quinto do artigo 66 apresentava uma regulamentação do controle repressivo de atos de concentração pela Alta Autoridade. O objetivo deste dispositivo consistia em dissolver os atos de concentração para readequar as estruturas jurídicoeconômicas de mercado conforme mandamentos de um ambiente concorrencial. Todavia, a regulamentação jurídica de conteúdo econômico deste dispositivo não carecia de uma orientação jurídico-Política.

Com efeito, por meio deste parágrafo quinto, a Alta Autoridade teria recebido um Poder singularmente enérgico - possibilidade de punir agentes econômicos que teriam praticado atos de concentração. Todavia, este Poder foi imediatamente esvaziado pelo próprio Tratado, a fim de evitar que ela pudesse compreender que, estando autorizada a punir empresas, ela teria recebido alguma autorização velada a ocupar isoladamente o lugar do Direito e do Poder na Europa Politicamente Unida pela CECA.

Este parágrafo quinto foi dividido pelo Tratado da CECA em sete alíneas. Como ressaltado anteriormente ${ }^{972}$, este trabalho não seguirá a ordem de exposição topograficamente determinada pelo texto originário para desenvolver os comentários. As referidas alíneas podem ser interpretadas como se agrupando em ao menos três grandes movimentos lógicos: (i) disciplina da punição de atos de concentração ilícitos (segunda e terceira alíneas); (ii) disciplina da punição de atos de concentração lícitos, porém nãoautorizados (primeira alínea); e (iii) disciplina da execução da punição e das medidas destinadas a fazer cumprir a punição (quarta, quinta, sexta e sétima alíneas).

A disciplina da punição de atos de concentração ilícitos (segunda e terceira alíneas) pode ser considerada como o centro normativo deste parágrafo quinto. São essas duas alíneas que estabeleciam a referência seguida pelo mandamento normativo estabelecido na primeira alínea (segundo movimento lógico) ${ }^{973}$ e, ao mesmo tempo, tinham sua regulamentação completadas pelas quatro alíneas que compunham o terceiro movimento lógico ${ }^{974}$ deste dispositivo. Além deste encadeamento normativo-estrutural, não se pode deixar de notar a presença de uma orientação jurídico-Política quando de sua operacionalização prática.

\footnotetext{
972 Início do item 7.3.1., supra.

973 A ser analisado algumas linhas a seguir.

974 Também examinado algumas linhas adiante.
} 
A segunda alínea do parágrafo quinto do artigo 66 do Tratado da CECA determinava que quando fosse realizado um ato de concentração ao qual seria impossível conceder autorização prévia, a Alta Autoridade deveria constatar seu caráter ilícito, por meio de decisão motivada. Após a oitiva dos interessados, ela poderia ordenar (i) a separação das empresas ou dos ativos indevidamente reunidos, (ii) a cessação do controle comum, e (iii) toda outra medida que julgasse apropriada para reestabelecer a exploração independente do setor econômico do carvão e do aço, de maneira a restaurar as condições concorrenciais deste mercado.

Em um primeiro momento, parece que o presente dispositivo concedera à Alta Autoridade um Poder bastante enérgico: diante de um ato de concentração ilícito realizado entre empresas localizadas no território dos Estados-Membros da CECA, a Alta Autoridade poderia determinar, por meio de decisão, medidas que julgasse apropriadas para reestabelecer as condições concorrenciais do mercado do carvão e do aço, dentre as quais a alínea exemplificativamente enumerara: (i) a separação das empresas ou dos ativos indevidamente reunidos, e (ii) a cessação do controle comum.

Em outras palavras, por meio deste dispositivo, o Tratado da CECA autorizara a Alta Autoridade a decidir juridicamente - isto é, por meio de normas jurídicas vinculantes e obrigatórias - a realização de determinadas condutas em relação a empresas localizadas no interior do território de Estados-Membros. Nesse sentido, não se pode ignorar que, diante da possível ruptura do sistema concorrencial, a Alta Autoridade teria recebido a autorização de interferir diretamente sobre pessoas e bens submetidos usualmente à Soberania e à jurisdição de um Estado.

Simplesmente a partir da leitura deste dispositivo, poder-se-ia imaginar que a Alta Autoridade teria recebido condições para tomar unilateralmente o lugar do Direito e do Poder na Comunidade: a final, segundo essa interpretação, a Alta Autoridade poderia desconsiderar por si só os limites estabelecidos pelas Soberanias estatais e impactar diretamente a vida econômico-empresarial desenvolvida no territórios dos EstadosMembros da Comunidade.

Entretanto, por mais tentadora que seja essa linha argumentativa, há que se deter em torno de determinados aspectos do mesmo dispositivo, a fim de se extrair deste documento elementos que indicavam a persistência da preocupação do Tratado da CECA em, imediatamente após conceder de uma faculdade de ação efetivamente impactante, prever série de restrições ao seu exercício visando ao seu progressivo esvaziamento. Se até o presente momento, o Tratado da CECA seguira essa tendência, não seria diferente neste 
dispositivo: o equilíbrio entre escalas de existência também se daria por limitações internas ao próprio exercício do Poder.

Nesse sentido, não se pode ignorar a primeira exigência anteposta pelo Tratado da CECA: diante de ato de concentração realizado incapaz de ser autorizado pela Alta Autoridade, esta deveria, por meio de decisão motivada, constatar o caráter ilícito da operação. Dessa forma, é possível evidenciar um primeiro movimento de contenção interna da atividade da Alta Autoridade: ela apenas poderia decidir medidas para restabelecer as condições de concorrência (isto é, separação, cessação, etc.) se o caráter ilícito da operação fosse por ela constatado previamente por decisão motivada.

Isso implica reconhecer, dessa forma, que estava a Alta Autoridade de antemão proibida de determinar medidas visando a combater um ato de concentração antes de ter formulado uma decisão na qual, de maneira fundamentada, fosse constatada a ilicitude da operação. Sem este primeiro elemento normativo, não poderia a Alta Autoridade decidir posteriormente por medidas voltadas à desconcentração no mercado do carvão e do aço. Seria tal decisão que reconhecia o caráter ilícito da concentração o primeiro elo normativo, fundamental, da cadeia de decisões sucessivas possíveis para combater a concentração de estruturas na CECA.

Especial atenção deve ser dado ao fato que o Tratado da CECA determinava que a decisão a ser formulada pela Alta Autoridade deveria ser motivada. A inclusão de tal previsão é facilmente compreensível: diante da possibilidade de a Alta Autoridade poder determinar medidas que impactariam diretamente a vida econômico-empresarial de no mercado do carvão e do aço, não poderia tal decisão ser proferida sem qualquer baliza. Para que um ato de concentração pudesse ser considerado ilícito - e, por isso, passível de ser o alvo de sucessivas medidas voltadas ao seu desfazimento, era necessária a fundamentação de tal decisão, determinando de maneira precisa as razões pelas quais a Alta Autoridade reputava ser a concentração ilícita.

Nesse sentido, perceba-se que este dispositivo retirava da Alta Autoridade a possibilidade de ser arbitrária em suas decisões sobre a concentração praticada entre empresas no setor do carvão e do aço. Longe de se permitir uma atuação incondicionada e amplamente livre por parte da Alta Autoridade, o Tratado da CECA apunha um vigoroso elemento de contenção de sua ação.

Assim, por meio desta simples exigência de motivação da decisão, o Tratado da CECA relembrava à Alta Autoridade que estava institucionalmente voltado a garantir que nenhuma das escalas de existência participantes da vida em comum poderia tomar 
subitamente o lugar do Direito e do Poder. A possibilidade de determinar medidas de combate à concentração das estruturas não poderia implicar a unidimensionalização totalizante da supranacionalidade da Alta Autoridade e a supressão do vazio no centro nomogenético da vida em comum. Para poder encontrar condições para agir, a Alta Autoridade deveria motivar sua decisão de reconhecimento da ilicitude da operação, não estando livre para escolher aleatoriamente ou a se bel-prazer quais concentrações combater ou não, sem motivos que justificassem publicamente sua atuação para a vida em comum.

Não apenas essas duas exigências - decisão motivada, e decisão de reconhecimento da ilicitude da concentração - condicionavam neste dispositivo a atuação da Alta Autoridade. Há que se notar a presença de mais uma restrição bastante interessante no mesmo excerto analisado, a qual escancarava a preocupação do Tratado da CECA em assegurar a multiescalaridade na condução da vida comunitária.

De fato, cumpre observar que, antes de decidir (i) pela separação de empresas ou ativos, (ii) pela cessação do controle comum, e (iii) por outra medida apropriada, a Alta Autoridade deveria ouvir as observações dos interessados sobre a questão. A expressão utilizada pelo Tratado da CECA é efetivamente genérica: “após ter colocado os interessados em condições de apresentar suas observações"975.

Não há aqui restrição. O Tratado se referia aos interessados, podendo-se interpretar como sendo abrangidos por esse dispositivo não apenas as empresas envolvidas, mas certamente, ao menos, as escalas de existência diretamente implicadas nos atos de concentração: as estatalidades isoladas no interior das quais teria sido praticada a concentração. O Tratado da CECA mostrava se preocupar em abrir um espaço de interação opositiva entre escalas de existência, a fim de que não se compreendesse que apenas uma dimensão existencial poderia determinar unilateralmente o sentido normativo para questões concretas sensíveis tornadas comuns.

Por fim, ainda no que se refere ao mesmo trecho em análise, há que se notar mais um elemento voltado ao esvaziamento do Poder de ação concedido à Alta Autoridade: ainda uma vez, o Tratado da CECA estipulara de forma consciente uma restrição da atividade da Alta Autoridade ao círculo da Linguagem normativa, isto é, ao cerco da não-violência. Apesar de poder determinar (i) a separação de empresas ou ativos, (ii) a cessação do controle comum, e (iii) outra medida apropriada, a Alta Autoridade não

\footnotetext{
975 Em francês, no original “après avoir mis les intéressés en mesure de présenter leurs observations”.
} 
dispunha, nos termos deste artigo, de instrumentos - que não a simples Linguagem da norma jurídica - que pudessem tornar concreta e efetiva sua decisão.

Em outras palavras, o Tratado da CECA também neste dispositivo reiterava a recusa à CECA a concessão de mecanismos de efetivação de decisões similares aos usualmente atribuídos aos Estados. Se à Alta Autoridade competia a tomada de decisão sobre medidas para restaurar a concorrência no mercado do carvão e do aço, não seria a ela quem caberia a execução de tais decisões, mas aos Estados-Membros - os únicos detentores efetivos de instrumentos coercitivos na Europa Politicamente Unida da CECA. Deste modo, mais uma vez, o Tratado da CECA sinalizava não pretender romper com a lógica de centralização do uso do força nos Estados.

Assim, não dispondo de meios coercitivos para executar suas decisões, a Alta Autoridade tinha imediata e vigorosamente esvaziado seu grande Poder sobre as empresas localizadas nos territórios dos Estados-Membros: ela seria incapaz de agir ou melhor, não deteria competência para agir - além do estrito campo normativo. Afinal, como visto por diversas vezes neste trabalho ${ }^{976}$, a organização jurídico-Política da CECA não era percebida como um Projeto de Estado Europeu, e, por essa razão, as instituições deste Tratado não lhe atribuíram instrumentos coercitivos, pois precisamente não pretenderam romper com a centralização do uso da força em torno apenas de Estados nacionais.

Dessa forma, esse dispositivo contribuía para a conclusão de que a organização jurídico-Política da Europa pela CECA não se revelava como um Projeto Embrionário de Estado Europeu: nenhum dos órgãos comunitários deteria a sua disposição a possibilidade de recorrer ao uso da força. Esta seria ainda o recurso unicamente atribuível aos Estados. E, deste modo, o enérgico Poder atribuído à Alta Autoridade por esta alínea já mostrava sinais de paulatino esvaziamento, fruto da preocupação em se evitar que sua escala de existência pudesse visar à tomada unilateral e totalizante do centro nomogenético da vida comum - ou ainda, à supressão do vazio que caracterizava o lugar do Direito e do Poder na CECA.

Após essa disciplina que já sinalizava a tendência ao esvaziamento do robusto Poder de ação à Alta Autoridade, há que se seguir a leitura da mesma segunda alínea. Ela seguia a preocupação em reiteradamente diminuir a capacidade de ação da Alta Autoridade - aqui, por meio da atribuição expressa de capacidade de oposição aos demais participantes

\footnotetext{
${ }^{976}$ Especial, mas não exclusivamente, no Sexto Capítulo, e no item 7.2.4., ambos supra.
} 
da vida em comum - principal, mas não exclusivamente, à Corte, por meio de igualmente vigoroso contra-Poder.

Toda pessoa ${ }^{977}$ diretamente interessada poderia recorrer da decisão da Alta Autoridade perante a Corte da Comunidade, com base nas previsões do artigo 33 do Tratado da CECA. E a tutela jurisdicional da Corte da Comunidade não se esgotava aos estritos limites estabelecidos no artigo 33: a mesma alínea segunda do mesmo parágrafo quinto do artigo 66 do Tratado da CECA determinava que a Corte detinha plena competência para apreciar se, contrariamente ao que decidira a Alta Autoridade, a operação poderia ter sido autorizada pela Alta Autoridade. O recurso interposto nessas condições teria efeito suspensivo.

Em uma visão mais geral, pode-se notar um primeiro mecanismo de contenção da atividade da Alta Autoridade por meio da aposição de possibilidade de oposição operada a partir de uma escala de existência não-supranacional.

Com efeito, lembre-se de que a expressão no documento original em francês é efetivamente genérica, atribuindo o direito de ação a "toda pessoa diretamente interessada"978. A opção do Tratado da CECA por conceder tal direito a "toda pessoa" implica reconhecer que este (i) abrangia não apenas pessoas físicas, mas também jurídicas, (ii) não se limitava às pessoas jurídicas de Direito Privado diretamente envolvidas (empresas), podendo ser extensível às pessoas jurídicas de Direito Público igualmente comprometidas com a concentração das estruturas de mercado - isto é, ao menos os Estados-Membros isoladamente considerados ${ }^{979}$.

Em um primeiro movimento interpretativo, o Tratado da CECA reservara a possibilidade a Estados-Membros recorrerem perante a Corte da Comunidade caso não concordassem com a decisão da Alta Autoridade de declarar como ilícita a operação e de determinar (i) a separação de empresas ou ativos, (ii) a cessação do controle comum, ou (iii) outra medida apropriada. E, deste modo, a Alta Autoridade encontrava uma primeira barreira de oposição escalar a sua potencial tentativa de ocupação unidimensionalizante do lugar do Direito e do Poder na CECA.

\footnotetext{
${ }^{977}$ No original, em francês, a expressão é exatamente essa "[t]oute personne directement intéressée". A importância desta ressalva se revelará nas linhas a seguir.

978 V. nota de rodapé 977 , supra.

979 Por essa razão, as próximas linhas desta análise se referirão apenas aos Estados-Membros isoladamente considerados, apesar de se reconhecer que este dispositivo provavelmente se aplicaria a outras pessoas jurídicas que não os Estados-Membros - por exemplo, as empresas. Nada mais coerente com a proposta deste trabalho: afinal, o presente estudo se centra na relação tensa entre entidades dotadas de capacidade de influenciar no sentido normativo comum: Alta Autoridade, Conselho de Ministros, Corte, Estados-Membros e populidade. V., assim, o item 3.3.3.3. e a nota de rodapé 820, ambos supra.
} 
Por meio da abertura da possibilidade de recorrer perante a Corte, o Tratado da CECA antepunha ao enérgico Poder outrora atribuído à Alta Autoridade um vigoroso mecanismo de contenção a ser exercido a partir dos Estados-Membros. Nesse sentido, as próprias instituições da Comunidade poderiam dar vazão às oposições escalares possíveis no interior da vida em comum: sendo possível se contrapor juridicamente a decisões contra as quais se indispunham, não seria necessário aos Estados-Membros buscar outros meios potencialmente mais agressivos - para opor sua insatisfação à atuação da Alta Autoridade. A convivência conflitiva entre diferentes modos de habitar o mundo se mostrava mais uma vez direitificada para promover, por meio das próprias instituições - isto é, de maneira não disruptora, as tensões escalares.

Outro elemento previsto pelo Tratado da CECA que fora instituído para reforçar a oposição escalar há pouco destacada entre Estados-Membros e Alta Autoridade era a atribuição de antemão de efeito suspensivo ao recurso. O Tratado da CECA reconhecia assim que, uma vez interposto o recurso perante a Corte, a parte que o propusera teria garantido que seriam imediatamente suspensos todos os efeitos passíveis de serem produzidos a partir da decisão da Alta Autoridade - isto é, não seria executada a decisão que determinava (i) a separação de empresas ou ativos, (ii) a cessação do controle comum, ou (iii) outra medida apropriada.

Deste modo, além da possibilidade de recorrer da decisão formulada pela Corte, a estatalidade isolada tinha a seu dispor mais um mecanismo voltado a refrear a potencialmente enérgica ação da Alta Autoridade sobre pessoas e bens localizados em seus territórios: antes do julgamento do recurso interposto, o Estado não teria que se preocupar com a execução de normas jurídicas comunitárias derivadas potencialmente marcadas pela uniescalaridade supranacional da Alta Autoridade - isto é, de normas jurídicas não produzidas nacionalmente e possivelmente totalizantes. E, deste modo, por intermédio de mais um mecanismo, o Poder de intervenção da Alta Autoridade era contido pelas instituições do Tratado da CECA.

Ademais, o mesmo dispositivo previa a paralisia da ação da Alta Autoridade e, ao mesmo tempo, o refreamento da oposição aposta pelos Estados-Membros em relação à Alta autoridade, mediante a previsão de contra-Poder atribuído à Corte da CECA. Por referência expressa desta alínea segunda do parágrafo quinto do artigo 66 do Tratado da CECA, tanto a propositura do recurso, como os limites de ação das supranacionalidades (Alta Autoridade e Corte) e das estatalidades (isolada e intergovernamental), deveriam se pautar pelos limites estabelecidos pelo artigo 33 do Tratado da CECA. Como visto 
anteriormente, no item 7.2.2.1., supra, o regime jurídico instaurado por este dispositivo era marcado fortemente por uma orientação Política ${ }^{980}$.

Além dos exames de legalidade e de legitimidade regulamentados pelo artigo 33 do Tratado da $\mathrm{CECA}^{981}$, estava a Corte especialmente autorizada a apreciar se, contrariamente ao que decidira a Alta Autoridade, a operação poderia ter sido autorizada pela Alta Autoridade.

Em outras palavras, o dispositivo ora em análise não apenas facultava de maneira expressa a possibilidade de minucioso controle da atividade da Alta Autoridade por parte da Corte, nos termos do artigo 33 do Tratado da CECA, mas também a possibilidade de o órgão jurisdicional se contrapor direta e abertamente à Alta Autoridade sobre a questão central do próprio artigo 66 do Tratado da CECA: o caráter lícito ou ilícito do ato de concentração.

Neste momento, revela-se com toda a força a reiterada presença da preocupação com a preservação da multiescalaridade na produção do sentido normativo sobre questões comuns sensíveis: se a Alta Autoridade poderia decidir sobre o caráter ilícito da operação e determinar medidas para combater a concentração das estruturas de mercado, os EstadosMembros poderiam recorrer de tais decisões e impedir, por meio da simples interposição do recurso. Ao mesmo tempo, a Corte poderia até mesmo questionar as próprias decisões da Alta Autoridade e reverter o próprio fundamento da decisão desta, mediante reconhecimento do caráter lícito da concentração.

Deste modo, revela-se de maneira muito clara a presença continuada da busca em se fazer conservar a multiescalaridade e o correlato vazio no lugar do Direito e do Poder na Comunidade: nenhuma das escalas de existências implicadas sobre questões concretas sensíveis comuns poderia determinar, por si só, o sentido normativo a ser sobre elas impresso - nem estatalidade isolada, nem qualquer das supranacionalidades. Poder se contrapunha a contra-Poder, escalas de existência se friccionavam continuamente, a fim de que, por meio de ininterrupta tensão, fosse possível impedir que qualquer delas pudesse se identificar unilateral e totalizantemente com o lugar do Direito e do Poder na vida comum.

Por essa mesma razão, o final da mesma alínea segunda do parágrafo quinto do artigo 66 do Tratado da CECA apresentava duas restrições à possibilidade de iniciar a

\footnotetext{
${ }^{980}$ Não cabe aqui retomar os argumentos outrora desenvolvidos, sob pena de estender ainda mais os limites materiais deste trabalho. Neste item em especial, será enfatizada apenas uma questão trazida pela própria alínea segunda do parágrafo quinto do artigo 66 do Tratado da CECA. Por essa razão, remetemos o leitor para o item supramencionado, para maiores esclarecimentos sobre o artigo 33 do Tratado da CECA

${ }_{981} \mathrm{E}$ descritos no item 7.2.2.1.4.1., supra, ao qual remetemos o leitor para maiores esclarecimentos sobre essa distinção e suas repercussões para a oposição escalar no interior da CECA.
} 
tutela jurisdicional. Esses dois mecanismos de refreamento devem ser entendidos como instrumentos de paralisia de eventual intento por parte das estatalidades isoladas e da supranacionalidade da Corte de suprimir o vazio no lugar do Direito e do Poder.

Em primeiro lugar, há que se relembrar que a atuação da Corte não era de ofício: o julgamento sobre a decisão da Alta Autoridade não poderia ser formulado espontaneamente pela Corte. Esta deveria certamente aguardar a provocação da parte interessada, a fim de que, mediante interposição de recurso, pudesse julgar a questão a ele submetida. Deste modo, impedido de sair de sua inércia, a Corte apenas poderia atuar da maneira incisiva acima descrita se, e somente se, fosse provocado por qualquer "pessoa diretamente interessada".

Em segundo lugar, não se pode deixar de observar que este recurso apenas poderia ser formulado pela parte interessada uma vez que as medidas tivessem sido ordenadas pela Alta Autoridade, vale dizer, não seria possível interpor um recurso antes - salvo expressa concordância por parte da Alta Autoridade - da definição das medidas específicas a serem tomadas para combater a concentração das estruturas do mercado de carvão e aço na CECA. Assim, a "pessoa diretamente interessada" não poderia interpor um recurso especificamente direcionado contra a declaração do caráter ilícito da operação, salvo autorização expressa por parte da Alta Autoridade.

No que se refere a este último aspecto, perceba-se que o Tratado da CECA estipulara ser a regra a presunção - relativa, certamente, pois passível de questionamento e reversão por parte da Corte, como visto acima - de que o reconhecimento feito pela Alta Autoridade da ilicitude da operação teria sido adequadamente avaliado. A "pessoa diretamente interessada" não poderia questionar especificamente apenas essa declaração em seu recurso - salvo se autorizado pela Alta Autoridade.

Não se poderia concluir, com isso, que a Alta Autoridade detinha o monopólio da declaração do caráter ilícito da operação. Caso não autorizasse tal questionamento por parte dos Estados-Membros, o Tratado da CECA assegurava à Corte a possibilidade de reverter tal qualificação, como visto linhas acima.

A contraposição entre Poderes na Comunidade continuava na terceira alínea do parágrafo quinto do artigo 66 do Tratado da CECA, a qual estava voltada a reforçar a garantia de que a atuação de cada uma das escalas de existência sobre questões concretas sensíveis comuns não implicaria a tomada do lugar do Direito e do Poder por qualquer delas. O dispositivo determinava que a Alta Autoridade estava autorizada a, a qualquer momento, tomar ou provocar as medidas cautelares necessárias para (i) salvaguardar os 
interesses das empresas concorrentes e de terceiros não participantes do ato de concentração ilícito, e (ii) prevenir toda ação que pudesse obstar a execução de suas decisões. Nestes casos, ainda que houvesse sido interposto um recurso perante a Corte, tais medidas cautelares não seriam passíveis de suspensão.

Em uma primeira leitura, pode-se perceber claramente um intento do Tratado de fomentar uma contraposição entre Alta Autoridade e Corte, e entre Alta Autoridade e Estados-Membros, no sentido de atribuir possibilidades de atuação concreta à Alta Autoridade: esta poderia, a qualquer momento, tomar ou provocar medidas cautelares que produziriam efeitos diretamente nos territórios dos Estados-Membros, e que não poderiam ser suspensas, ainda que fossem objeto de recurso perante a Corte. A ideia era precisamente preservar condições de ação à supranacionalidade da Alta Autoridade para garantir a efetivação de uma tutela de ambiente concorrencial - mesmo nos casos em que sua atuação pudesse ser ou estivesse sendo questionada perante a Corte.

Dessa forma, em contraposição ao paulatino esvaziamento ao Poder atribuído à Alta Autoridade pela alínea segunda, esta alínea terceira surgia para apresentar a previsão que, apesar de toda consecutiva diminuição da possibilidade de atuação da Alta Autoridade, esta não teria sido reduzida a uma posição inferior com relação aos demais participantes da vida em comum. Muito pelo contrário: estava ela autorizada a lançar mão de medidas cautelares para assegurar parcela de sua atuação no sentido de preservar o ambiente concorrencial no setor do carvão e do aço. Surgia assim outro elemento institucional, voltado a mostrar que a vida em comum da CECA era marcada pelo equilíbrio multiescalar, jamais desconectado da preocupação em manter o vazio no centro nomogenético.

Entretanto, a leitura destas últimas linhas poderia engendrar a convicção de que, neste momento, teria sido imoderada a faculdade atribuída à Alta autoridade de conter o próprio contra-Poder da Corte: de que valeria o julgamento desta se a Alta Autoridade poderia determinar ações que não seriam suspensas pelo processamento do recurso perante a Corte? Imperceptivelmente, teria sido o lugar do Direito e do Poder na Comunidade atribuído, neste jogo entre Corte e a Alta Autoridade, à Alta Autoridade?

Uma leitura mais atenta e integral da alínea terceira do mesmo parágrafo quinto permite dissipar as últimas névoas sobre uma potencialmente desavisada tomada do centro nomogenético pela Alta Autoridade e, com isso, perceber a reiteração contínua do Tratado da CECA em apostar em uma vida comum construída de maneira renovada em torno da multiescalaridade e do correlato vazio no lugar do Direito e do Poder. 
Nesse sentido, nos termos da própria alínea terceira do mesmo parágrafo quinto, a possibilidade de a Alta Autoridade tomar ou provocar tais medidas cautelares apenas surgiria se, e somente se, a Corte não houvesse tomado tais medidas anteriormente. Isso significa que, uma vez praticados tais atos pela Corte, estava a Alta Autoridade impossibilitada de tomar outras medidas cautelares. A competência aqui atribuída à Corte surgira para controlar eventual intento desarrazoado e imoderado por parte da Alta Autoridade de se fazer substituir ao procedimento multiescalar de solução de conflitos pela via jurisdicional $^{982}$.

Ademais, ainda que a Corte não tivesse tomado tais medidas cautelares, não se pode deixar de notar que não era absoluta a restrição à possibilidade de se conceder efeito suspensivo - com relação às medidas cautelares tomadas ou provocadas pela Alta Autoridade - ao recurso interposto por qualquer interessado perante a Corte. $O$ final da mesma alínea terceira previa que a Corte poderia tomar uma decisão contrária, ou seja, que ela poderia atribuir ao recurso também efeito suspensivo oponível em relação às medidas cautelares tomadas ou provocas pela Alta Autoridade.

Deste modo, a Corte se encontrava dotada de Poder que lhe assegurava paridade de armas em relação à Alta Autoridade: podendo se antecipar a esta em relação à tomada de medidas cautelares, ou mesmo podendo determinar em cada recurso a suspensão das medidas cautelares tomadas ou provocadas pela Alta Autoridade, a Corte se revelava mais uma vez igualmente autorizada pelo Tratado da CECA a impedir qualquer intento de unidimensionalização escalar por parte da Alta Autoridade. Ainda uma vez, Poder se contrapunha a Poder, e escalas de existência se colocavam em conflito, a fim de que a tensão constante entre elas as repelisse vigorosamente do interior do centro nomogenético e, com isso, fossem preservados a multiescalaridade e o correlato vazio no lugar do Direito e do Poder.

Por sua vez, a disciplina da punição de atos de concentração lícitos, porém não previamente autorizados pela Alta Autoridade (primeira alínea), poderia ser compreendida como estando em função da disciplina estabelecida pelo primeiro movimento lógico do dispositivo (segunda e terceira alíneas) ${ }^{983}$, tendo também sua regulamentação completada pelas quatro alíneas que compunham o terceiro movimento lógico-normativo do parágrafo quinto do artigo $66^{984}$. Também neste caso, além deste

\footnotetext{
${ }^{982}$ Descrito no item 7.2., supra.

${ }^{983}$ Examinado algumas linhas acima.

${ }^{984}$ A ser analisado algumas linhas a seguir.
} 
encadeamento normativo-estrutural, não se pode deixar de notar a presença de uma orientação jurídico-Política quando de sua operacionalização prática.

A primeira alínea do parágrafo quinto do artigo 66 estabelecia que, nas hipóteses de (i) ter sido realizado um ato de concentração sem autorização prévia por parte da Alta Autoridade (parágrafo primeiro do artigo 66), mas que (ii) não implicasse concessão a pessoa ou empresa do Poder de (a) determinar os preços, controlar ou restringir a produção ou a distribuição, ou fazer obstáculo à manutenção de um regime efetivo de concorrência no mercado dos referidos produtos ou de (b) escapar às regras de concorrência (parágrafo segundo do artigo 66), poderia a Alta Autoridade considerar essa operação como não ilícita.

Com efeito, diante de tais condições estipuladas pelo Tratado da CECA, o ato de concentração não seria ilícito, mas simplesmente seria considerado como não tendo sido autorizado. Em outras palavras, ele não era considerado ilícito porque, apesar de não ter sido autorizado previamente pela Alta Autoridade, ele seria autorizável.

Deste modo, a hipótese trazida pela alínea primeira não poderia ser igualada de imediato à das alíneas segunda e terceira, há pouco examinadas. Seria simplesmente uma concentração que, apesar de não ter sido autorizada, o seria, pois não atentaria contra as condições concorrenciais do mercado de carvão e do aço na CECA. E, por isso, mesmo, para que essa operação se tornasse plenamente regular, o Tratado da CECA determinou que a Alta Autoridade deveria conceder uma autorização a posteriori da concentração uma vez que ela não modificaria as estruturas do mercado.

Para tanto, a concessão de tal autorização posterior estava condicionada à transferência, por parte das pessoas que tivessem adquirido ou reagrupado os direitos ou os ativos em causa, de valor equivalente ao da multa prevista no parágrafo sexto, alínea segunda, do artigo 66 do Tratado da $\mathrm{CECA}^{985}$. Este valor não poderia ser inferior à metade do máximo previsto naquela alínea, nos casos em que fosse manifesta a necessidade de apresentação do pedido de autorização à Alta Autoridade.

Na hipótese de não haver a transferência daquele valor, a Alta Autoridade deveria aplicar as medidas previstas nas alíneas segunda e terceira do parágrafo quinto do artigo 66 do Tratado da CECA - examinadas há pouco, referentes aos atos de concentração

\footnotetext{
${ }^{985}$ Comentado no item 7.3.1.2.2.5., infra: "quinze por cento do total dos ativos adquiridos ou reagrupados, nos casos em que uma pessoa física ou jurídica não comunicar previamente à Alta Autoridade a intenção de efetuar um ato de concentração entre determinadas empresas no interior da CECA; este montante seria acrescido de uma multa mensal de um vinte e quatro avos, cuja contagem se iniciaria a partir do décimosegundo mês da realização da operação e deteria por termo final a constatação da infração pela Alta Autoridade".
} 
considerados ilícitos. Assim, diante da renitente recusa a cumprir com este dever instrumental, a Alta Autoridade poderia dar tratamento equivalente para aqueles que, não ilícitos, nem mesmo se preocuparam descaradamente em receber a autorização da Alta Autoridade.

A orientação jurídico-Política desta alínea surge a partir da consideração de dois aspectos principais.

O primeiro deles apresenta a preocupação em se seguir uma orientação jurídicoPolítica precisamente pelo fato de o final da alínea primeira fazer referência à regulamentação estabelecida nas alíneas segunda e terceira - já analisadas acima como detendo uma orientação jurídico-Política. Em outras palavras, esta remissão a outro texto normativo tinha o objetivo de tornar mais completa a orientação jurídico-Política da alínea primeira por meio de vinculação direta e expressa a uma disposição normativa caracterizada fundamentalmente por um vetor constitutivo jurídico-Político.

Nesse sentido, no caso de um ato de concentração não-autorizado previamente pela Alta Autoridade, porém lícito - porque autorizável, a Alta Autoridade apenas poderia iniciar alguma ação de punição se, e somente se, não houvesse a transferência do valor acima mencionado. Nestes casos, a atuação da Alta Autoridade não seria livre e incondicionada: os parâmetros de sua atuação estavam balizados pelos limites jurídiconormativos institucionais das alíneas segunda e terceira - analisadas acima, os quais estavam pautados - como visto - por uma preocupação jurídico-Política.

Ao estabelecer que os mesmo trilhos deveriam ser seguidos em ambas as situações - multiescalaridade e o correlato vazio no lugar do Direito e do Poder, derivados ambos de clara oposição escalar entre supranacionalidades (Alta Autoridade e Corte), o Tratado da CECA buscara definir que a atuação Alta Autoridade jamais poderia descuidar da manutenção da Política. O percurso detalhado acima seria o mesmo, pois mesma deveria ser a dinâmica regente da vida em comum.

O segundo aspecto que revelava a presença de uma preocupação com uma persistente orientação jurídico-Política na Comunidade residia no interior da própria previsão normativa da alínea primeira do parágrafo quinto do artigo 66 do Tratado da CECA. Tratava-se de mais uma reiteração institucional da qualidade da organização jurídico-Política que a Comunidade teria instaurado na Europa: uma que recusasse a formação de um Estado Europeu.

Nesse sentido, é importante destacar que este dispositivo limitava vigorosamente a capacidade de ação de Alta Autoridade: não poderia ela punir atos de concentração que, 
embora não previamente autorizados por ela, seriam autorizáveis. Apenas e tão-somente se elas não transferissem o montante estipulado, poderia ser iniciado um procedimento punitivo - o qual seria regido pelos vetores jurídico-Políticos das alíneas segunda e terceira. E, de todo modo, se a imposição do dever de transferir determinado montante pecuniário - enquanto consequência do descumprimento do dever instrumental de solicitar a prévia autorização à Alta Autoridade para a realização do ato de concentração, puder ser interpretada também como punição, não se pode deixar de notar que esta não seria nada mais do que a previsão da possibilidade de aplicação de uma sanção econômica.

Nesse sentido, ao prever que a resposta da Alta Autoridade ao descumprimento do dever instrumental de previamente lhe solicitar autorização para realizar o ato de concentração apenas poderia ser a determinação de uma transferência de valores - ou ainda, de uma sanção econômica, é possível perceber que ainda uma vez o Tratado da CECA de maneira expressa, consciente e explícita recusara a tal entidade comunitária a possibilidade de lançar mão de recurso punitivo de caráter coercitivo - tal qual usualmente se atribui apenas a Estados.

Deste modo, sem poder centralizar de forma alguma o uso da violência na vida em comum - por não ter recebido qualquer competência para executar atos punitivos marcados pela força, ou mesmo sem poder interferir na dinâmica de centralização do uso da coerção nas mãos dos Estados-Membros da Comunidade, a Alta Autoridade estava impossibilitada - como qualquer outro órgão comunitário - de adquirir feições próximas ou embrionárias de Estado. E esta opção de recusa à concessão do uso da força à Alta Autoridade, ou mesmo à vida comum, dever ser compreendida especificamente como expressão do intento de constituir uma organização jurídico-Política na Europa que não fosse um Estado Europeu $^{986}$.

Por fim, a disciplina da execução da punição e das medidas destinadas a fazer cumprir a punição. Aqui também é necessário reordenar as quatro alíneas envolvidas (quarta, quinta, sexta e sétima) para compreender de forma um pouco mais sistemática o sentido normativo e a respectiva orientação jurídico-Política subjacente.

De um lado, a sexta alínea pode ser entendida como o centro doador de sentido para o conjunto deste terceiro movimento lógico, determinando a linha de compreensão das quarta e quinta alíneas. De outro lado, apesar de relacionada a esta temática, a sétima alínea não será objeto de comentário por este trabalho, na medida em que não trazia

${ }^{986}$ Como visto inúmeras vezes neste trabalho, principalmente no Sexto Capítulo e no item 7.2.4., ambos supra. 
consigo uma preocupação em estabelecer por si só oposições escalares. Deste modo, serão comentados neste último movimento lógico apenas as quarta, quinta e sexta alíneas, tendo por núcleo gravitacional a sexta alínea.

A sexta alínea do parágrafo sétimo do artigo 66 estipulava que a Alta Autoridade estava habilitada a dirigir aos Estados-Membros interessados as recomendações necessárias para obter, por meio das legislações nacionais, a execução das medidas previstas nas alíneas a ela precedentes (quarta e quinta alíneas).

A quarta alínea previa que a Alta Autoridade deveria abrir um prazo razoável à empresa que adquirira posição dominante para que ela cumprisse as decisões previstas nas alíneas segunda e terceira e, em caso de descumprimento, a Alta Autoridade poderia impor multas diárias à empresa, no montante de até um milésimo o valor dos direitos ou dos ativos em questão.

Na hipótese de ausência de cumprimento das decisões por parte de tais empresas ainda que diante das multas diárias, a quinta alínea previa que a Alta Autoridade estava autorizada a tomar ela própria medidas de execução, tais como (i) suspender o exercício dos direitos vinculados aos ativos irregularmente adquiridos, (ii) provocar a nomeação, por autoridade judicial, de um administrador judicial de tais ativos, (iii) organizar a venda forçada de tais bens, preservando os interesses legítimos de seus proprietários, e (iv) anular, por força da operação ilícita, com relação às pessoas físicas ou jurídicas que teriam adquirido os direitos ou ativos em causa, os atos, as decisões, as resoluções ou deliberações dos órgãos dirigentes das empresa.

Mais do que pretender compreender a particularidade de cada um dos institutos jurídicos presentes neste conjunto de dispositivo (multas diárias, suspensão de direitos, administração judicial de ativos, entre outros), ou tentar detalhar a racionalidade jurídicoeconômica subjacente a tal dispositivo, este trabalho tem por objetivo evidenciar a orientação jurídico-Política deste conjunto normativo.

Uma leitura rápida deste conjunto de normas poderia ensejar a interpretação de que à Alta Autoridade teria sido conferido um Poder vigoroso: além de produzir recomendações aos Estados-Membros, ela poderia praticar série de atos que concretamente afetariam a vida cotidiana das atividades empresariais: aplicação de multas diárias, suspensão do exercício de direitos, nomeação de administrador judicial, organização de venda forçada, anulação de atos, entre outros. Todavia, um exame mais acurado permite afastar ao menos a percepção de que a Alta Autoridade detinha um Poder efetivamente tão robusto. 
É inegável que a Alta Autoridade estava autorizada pelo Tratado a praticar um grande número de atos normativos e concretos que produziriam um impacto muito forte nas empresas localizadas no território dos Estados-Membros. Contudo, é importante notar como a conjunção das previsões normativas deste artigo 66 asseguravam uma dinâmica institucional que pouco a pouco esvaziava o Poder concedido a este órgão comunitário, a ponto de o tornar um Poder "sem Poder".

É importante observar o tipo de atividade que era assegurada à Alta Autoridade: sua atuação era imediatamente contida por meio da imposição de uma ação inicialmente adstrita ao campo normativo, isto é, pela previsão de necessidade de elaboração de recomendações dirigidas aos Estados-Membros.

Em outras palavras, para encontrar condições suficientes para executar suas decisões em hipótese de descumprimento (imposição de multas diárias), ou de descumprimento reiterado de suas decisões (suspensão do exercício de direitos, nomeação de administrador judicial, organização de venda forçada, anulação de atos), não poderia a Alta Autoridade lançar mão de meios outros que não recomendações aos EstadosMembros.

Nesse sentido, note-se que a Alta Autoridade não poderia diretamente, por si só, pretender alcançar as empresas localizadas no território dos Estados-Membros que tivessem adquirido posição dominante. Antes, a Alta Autoridade dependeria da intermediação feita pelos Estados-Membros, mediante previsões específicas feitas por legislações nacionais. A entidade comunitária não deteria condições de dominar os processos nacionais de produção normativa, os quais seguiriam as tradições e os costumes jurídicos e legais de cada Estado-Membro.

Poder se opõe a contra-Poder. Se Alta Autoridade poderia se dirigir às empresas, jamais poderia ela pretender direcionar unilateralmente as atividades destas, na medida em que os Estados-Membros poderiam e deveriam contrapor a tais pretensões mecanismos próprios de realização desta pretensão da Alta Autoridade. A escala supranacional era assim refreada em seu potencial intento de determinação normativa do sentido da vida comum, na medida em que sua recomendação jazia à espera da canalização normativa dada pelo Estado-Membro. Ao mesmo tempo, o Estado-Membro não poderia se opor à viabilização normativo-prática da execução da Alta Autoridade, mas tinha assegurado que esta não introduziria em seu território um regime jurídico-normativo de execução forçada estranho a suas próprias tradições jurídicas. 
Dessa forma, apesar de a atuação da Alta Autoridade prevista neste conjunto de alíneas ser efetivamente considerável, não se pode deixar de notar que o Tratado da CECA não disponibilizara um acesso direto da Alta Autoridade às empresas localizadas nos territórios dos Estados-Membros. Sempre seria necessária, a final, a presença dos instrumentos jurídico-normativos nacionais para permitir a efetivação dessa determinação da vida empresarial por parte da Alta Autoridade.

Sem dominar o processo legislativo nacional, a Alta Autoridade apenas poderia determinar o fim a ser atingido, mas não os mecanismos normativos que serviriam como instrumento a tal execução. Estes, por sua vez, tendo em vista os fins supranacionais, não teriam descaracterizadas suas marcadas propriamente estatais. Supranacionalidade e cada uma das estatalidades isoladas se contrapunham, assim, mais uma vez no conjunto normativo do Tratado.

Ademais, há que se considerar especificamente a espécie de ação facultada à Alta Autoridade pelo Tratado da CECA, mesmo nos casos de descumprimento reiterado e obstinado de suas decisões. Ela se situa em dois campos: atuação normativa (elaboração de recomendações) e imposição de sanções de caráter econômico ou de restrição de direitos (suspensão do exercício de direitos, nomeação de administrador judicial, organização de venda forçada, anulação de atos) de empresas.

Isso implica reconhecer que o Tratado da CECA previa a possibilidade de a Alta Autoridade responder juridicamente às desconsiderações das decisões por parte de empresas. Em outras palavras, estava a Alta Autoridade autorizada a reagir à nãoobservância das normas jurídicas comunitárias derivadas. Contudo, tal reação da supranacionalidade, mesmo nos casos de recusa inflexível ao cumprimento das decisões, jamais poderia ultrapassar o campo da atuação normativa, de sanções econômicas ou de restrições de direitos.

Isso porque o Tratado da CECA não facultava à Alta Autoridade a possibilidade de recorrer a meios outros, distintos destes mencionados. Na hipótese de pretender ver executadas as decisões, a Alta Autoridade apenas poderia atuar normativamente para, então, esperar a decisão legislativa nacional dos Estados-Membros que lhe permitiriam cobras multas diárias ou suspender, nomear, vender, anular, entre outros. E nada mais.

Dito de outro modo: mesmo se e quando constatada a inobservância de normas comunitárias, a Alta Autoridade não poderia nada mais do que atuar normativamente, isto é, não poderia recorrer ao uso de instrumentos de efetivação coercitivos, tais quais os dos 
Estados-Membros. Afinal, como visto anteriormente ${ }^{987}$, a Alta Autoridade não poderia ser entendida como instrumento de introdução desavisada de um princípio de organização jurídico-política estatal, precisamente porque a vida em comum da Europa Politicamente Unida pela CECA não visava a constituir um Estado Europeu.

Assim, restrita à atuação normativa, à imposição de sanções econômicas ou de restrições de direitos, tinha a Alta Autoridade mais uma vez contida sua atuação no campo da Linguagem da não-violência, isto é, no campo do não rompimento da centralização do uso da força por parte dos Estado-Membros.

7.3.1.2.2.4. O Parágrafo Sétimo do Artigo 66: Condições para o Controle de Concentração Inesperada pela Alta Autoridade

O parágrafo sétimo do artigo 66 do Tratado da CECA continha disposição bastante particular, voltada a mitigar os eventuais efeitos deletérios de uma dada concentração inesperadamente formada. Tratava-se de uma regulamentação jurídica específica que estabelecia critérios para a ação da Alta Autoridade sobre situações em que legitimamente teria havido uma concentração das estruturas do mercado concorrencial - isto é, uma concentração inesperada, porque e não-resultante da prática de um ato de concentração, mas do jogo normal das competições entre empresas em determinado setor econômico.

Por consistir em uma situação diversa das até então analisadas, tendo em vista ter sido formada espontaneamente, a partir da própria dinâmica da concorrência, a rigor, esta disposição não visa a tutelar a prática de atos de concentração ${ }^{988}$, mas a situações em que a concentração das estruturas resultasse de performances eficientes de um agente econômico - no interior da lógica de mercado concorrencial - em detrimento de sucessivos e profundos desempenhos ineficientes dos demais agentes econômicos.

Por esse motivo, a princípio, tais situações não se encontrariam completamente submetidas ao regime jurídico até então examinado - necessidade de autorização prévia, o exame de eventual isenção com relação à obrigação de demandar a referida autorização, entre outras obrigações analisadas linhas acima. Esta distinção regulatória diferenciada neste parágrafo sétimo era fundamental para abarcar normativamente também tais

\footnotetext{
${ }^{987}$ No Sexto Capítulo e também no item 7.2.4., ambos supra.

${ }^{988}$ Usualmente realizados por meio de fusão ou aquisição de ativos, etc., da maneira como definida no artigo 66, parágrafo primeiro, do Tratado da CECA, analisado no item 7.3.1.2.2.1., supra.
} 
acontecimentos imprevisíveis - que, precisamente por essa razão, não deveriam ser considerados de antemão como passíveis de punição.

Se a Alta Autoridade reconhecesse em uma empresa pública ou privada a aquisição de fato ou de direito de posição dominante em determinado segmento de mercado localizado no interior do setor econômico submetido à jurisdição da CECA, de tal modo que ela pudesse (i) se subtrair ao cumprimento das regras de Direito Econômico Concorrencial da Comunidade, ou ainda (ii) se utilizar dessa posição dominante para fins contrários à disciplina concorrencial do Tratado da CECA, deveria a Alta Autoridade agir normativamente para desestimular o potencial uso abusivo da posição dominante adquirida.

Mais uma vez, frisa-se aqui que, para os fins deste trabalho, mais importante do que compreender as minúcias da racionalidade típica de Direito Econômico Concorrencial que informara a construção desse dispositivo, ou mesmo a natureza jurídica dos institutos jurídicos nele mencionados, há que se deter sobre aspectos deste dispositivo que permitam revelar a preocupação permanente de conservar institucionalmente uma União Política na Europa da CECA. E, nesse sentido, é importante perceber se reproduzir neste dispositivo a lógica de manutenção de um vazio no lugar do Direito e do Poder.

A simples aquisição de posição dominante não era considerada como prejudicial pelo Tratado. Ela se apresentava como motivo para a ação da Alta Autoridade apenas nas hipóteses em que pudesse significar uma aquisição de um Poder Econômico que lhe permitisse se subtrair sozinha, de acordo com sua própria percepção de como deveria ser o mercado na CECA, ao conjunto normativo concorrencial comunitário no setor do carvão e do aço.

Assim, apenas nos casos em que a posição dominante pudesse sinalizar à Alta Autoridade uma ameaça de descumprimento das normas comunitárias de Direito Econômico Concorrencial por uma empresa pública ou privada, a Alta Autoridade deveria permanecer em estado de alerta e agir de maneira preventiva. Nesse sentido, ao buscar combater de maneira preventiva o eventual abuso de posição dominante inesperadamente adquirida por um agente econômico no interior da Comunidade, o Tratado da CECA não buscava desestimular ganhos de eficiência. Não seria a conquista desta meritória posição no jogo de mercado o problema, mas, sim, a possibilidade de esta ensejar o descumprimento das normas concorrenciais comunitárias.

Dessa forma, o dispositivo em análise estabelecera série de condicionamentos à atividade de controle da Alta Autoridade: não poderia ela de antemão punir toda e qualquer 
concentração das estruturas de mercado. Antes, deveria ela verificar se ela derivara da prática de um ato de concentração, ou se decorrera da prática normal do jogo de concorrencial de mercado (ganhos de eficiência), de maneira a submeter cada situação a um regime jurídico comunitário específico. Apenas no caso de uma concentração derivada de prática deliberada de ato de concentração é que a ação da Alta Autoridade deveria seguir o regime descrito nos itens anteriores ${ }^{989}$.

No caso especificamente tratado por este parágrafo sétimo do artigo 66, segundo o qual a concentração derivaria de ganhos de eficiência legítimos, o Tratado estabelecera outro condicionamento: a atuação da Alta Autoridade apenas seria possível se, e somente se, fosse constatado que tal concentração espontaneamente formada implicasse a aquisição de posição dominante passível de ser potencialmente utilizada para subtrair a empresa ao regime concorrencial vigente na Comunidade.

Nesse sentido, além da necessidade de a Alta Autoridade dever (i) verificar se se tratava de aquisição de posição dominante legítima ou ilegitimamente, ela deveria igualmente (ii) identificar se a aquisição de posição dominante derivada de concentração legítima da estrutura do mercado teria a potencialidade de implicar o descumprimento do regime jurídico-econômico concorrencial comunitário pela empresa. Apenas se presentes essas duas condições é que a Alta Autoridade poderia atuar, nos termos deste parágrafo, no sentido de controlar o possível abuso de posição dominante.

Dessa forma, há que se perceber que o presente dispositivo buscava esvaziar o Poder de controle concedido à Alta Autoridade por meio da aposição dessas duas condições ao seu exercício. Em outras palavras, mais uma vez se revela aqui que a atuação esta entidade comunitária não era livre e desimpedida, isto é, desprovida de condicionamentos.

Ao estabelecer limites bastante precisos de ação à Alta Autoridade, o Tratado da CECA sinalizava também por meio deste dispositivo a conservação de sua preocupação Política de impedir que qualquer escala de existência pudesse forjar uma autopercepção que formasse progressivamente uma compreensão de que ela poderia imprimir unilateralmente sobre questões concretas sensíveis comuns sua própria maneira de habitar o mundo. Tais condições previam, em suma, um cerco à atuação da Alta Autoridade, lembrando-lhe de que não poderia efetuar o controle de acordo com sua própria dimensão existencial.

${ }^{989}$ Itens 7.3.1.2.2.1. a 7.3.1.2.2.3, supra. 
Todavia, há ainda outros aspectos neste mesmo parágrafo sétimo que reforçam a percepção da presença de um esforço institucional do Tratado voltado ao paulatino refreamento da atuação da Alta Autoridade. O que deve ser analisado, a fim de evidenciar a reiteração de um intento originário de preservação de um lugar vazio de produção normativa multiescalar na Comunidade.

A tutela de posição dominante adquirida potencialmente disruptora da estrutura concorrencial pela Alta Autoridade era limitada pelo Tratado em um aspecto específico: a entidade comunitária deveria elaborar recomendações especificamente dirigidas a este agente econômico. Na hipótese de após o decurso de um prazo razoável se verificar a ausência de um cumprimento satisfatório das recomendações, a Alta Autoridade poderia elaborar decisões, em conjunto com o Governo interessado, (i) fixando preços e condições de venda a serem praticados pelo agente econômico em questão; (ii) estabelecendo um regime de programas de produção a ser seguido pelo mesmo agente econômico; ou mesmo, (iii) estabelecendo um regime de programas de distribuição a ser cumprido também pelo mesmo agente econômico - sob pena de este incorrer, inclusive, nas sanções previstas nos artigos 58, 59 e 64 do mesmo Tratado ${ }^{990}$.

O que está fundamentalmente em jogo neste dispositivo é a questão da produção normativa, ou melhor, é o problema da definição, não tanto das normas jurídicas a serem emitidas, mas o da delimitação da maneira segundo a qual deveriam ser elas gestadas (uniescalar ou multiescalarmente).

Diante do problema de possível abuso de posição dominante, a primeira solução designada pelo Tratado consistiu em estabelecer que deveria a Alta Autoridade produzir normas jurídicas comunitárias por meio de recomendações, para que o agente econômico não prejudicasse o ambiente concorrencial da Comunidade. E, na hipótese, de contumaz descumprimento dos deveres contidos nas recomendações editadas para este fim, antes mesmo de se prever a aplicação de qualquer espécie de sanção, o Tratado da CECA determinara que a Alta Autoridade deveria recorrer a uma solução igualmente nomogenética. Apenas posteriormente a disposição normativa tratava da possibilidade de aplicação eventual de sanções.

A partir desses indícios é possível perceber que o conjunto de preocupações deste dispositivo orbitava em torno do problema da normatividade no interior da Europa

\footnotetext{
${ }^{990}$ Remete-se o leitor aos itens 7.3.1.1.2.2., 7.3.1.1.2.3. e 7.3.1.1.3.4., supra, a fim de relembrar tanto a disciplina jurídica de cada um desses artigos, como também os comentários aduzidos a cada um deles.
} 
Politicamente Unida. E é esta delimitação ao círculo nomogenético prevista neste dispositivo que promove um esvaziamento do Poder concedido à Alta Autoridade.

Se o agente econômico desconsiderava e superava as normas jurídicas constantes do arcabouço de Direito Econômico Concorrencial constantes do Tratado, ele sinalizava estar se orientando em direção à usurpação do lugar do Direito e do Poder: detentor de tamanho Poder Econômico, ele poderia se autocompreender como acima do Direito e das Leis, podendo ele próprio editar, a sua imagem e semelhança, suas próprias normas de condutas, em contraposição às formuladas comunitariamente.

Diante dessa súbita ameaça - não apenas ao mercado concorrencial, mas agora, também ao próprio lugar do Direito e do Poder por entidade privada!, a Alta Autoridade era convocada para produzir o maior número de normas jurídicas, a fim de lançar para fora bruscamente aquele que buscaria tomar de inopino o lugar do Direito e do Poder na Europa Politicamente Unida. Por meio dessa solução normatizadora, a Alta Autoridade resolveria energicamente a dúvida sobre quem poderia ocupar o lugar do Poder: nada, nem ninguém, vale dizer, nem as escalas de existência públicas (supranacionalidade, estatalidade intergovernamental e estatalidade isolada), nem as dimensões privadas.

Seria deste modo o Público na Comunidade, isto é, o centro vazio vigente no lugar do Direito e do Poder na CECA, que nortearia o processo de doação de sentido normativo definitivo a questões concretas sensíveis comuns na Europa Politicamente Unida. E seria a partir desta perspectiva Pública europeia que o agente econômico detentor de posição dominante abusiva deveria orientar a prática de preços e de condições de venda, ou até mesmo os regimes de produção e de distribuição de suas mercadorias - e não, portanto, a partir de uma perspectiva isolada sua.

Todavia, haveria que se notar que este parágrafo sétimo também afastava a supranacionalidade da Alta Autoridade do interior do lugar do Direito e do Poder na União Política da Europa. Efetivamente, a leitura dos comentários que acabaram de ser aduzidos poderia produzir a equivocada imagem de que, neste momento, teria o Tratado da CECA inadvertidamente aberto uma eclusa à livre atuação normativa exclusivamente centrada na dimensão existencial da Alta Autoridade, alçando esta a uma eventual posição de destaque com relação às demais escalas de existência.

Apesar de acurada essa preocupação, um exame mais detalhado - porém menos extenso - do mesmo parágrafo sétimo do artigo 66 pode revelar a ausência de qualquer sobrevalorização desta escala de existência da Alta Autoridade por meio desta específica disposição normativa. Com efeito, não apenas a Alta Autoridade (i) não estava autorizada a 
agir normativamente de maneira integralmente livre, como também (ii) sua atividade era limitada precisamente porque se desenvolvia em um campo normativo, o qual era sucessivamente regulamentado para garantir especificamente o esvaziamento do Poder atribuído à supranacionalidade da Alta Autoridade.

Se a Alta Autoridade reconhecesse em uma empresa pública ou privada a aquisição de fato ou de direito de posição dominante em determinado segmento de mercado localizado no interior do setor econômico submetido à jurisdição da CECA, de tal modo que ela pudesse (i) se subtrair ao cumprimento das regras de Direito Econômico Concorrencial da Comunidade, ou ainda (ii) se utilizar dessa posição dominante para fins contrários à disciplina concorrencial do Tratado da CECA, deveria a Alta Autoridade agir normativamente para desestimular o potencial uso abusivo da posição dominante adquirida.

Sobre este primeiro aspecto, há que se frisar a condição de que a Alta Autoridade apenas poderia atuar normativamente se verificadas as condições estipuladas por este artigo, a saber: (i) empresa pública ou privada adquirir de fato ou de direito de posição dominante em atividade relacionada à exploração econômica do carvão e do aço, de tal modo que ela pudesse, ou (ii) se subtrair ao cumprimento das regras de Direito Econômico Concorrencial da Comunidade, ou (iii) se utilizar dessa posição dominante para fins contrários à disciplina concorrencial do Tratado da CECA.

Em outras palavras, não estava a Alta Autoridade livre para atuar normativamente sobre este espectro de situações (tutela de concentrações inesperadas do mercado concorrencial), pois o Tratado apenas lhe facultava a possibilidade de agir se satisfeitas as condições (i) e (ii) ou (i) e (iii) mencionadas no parágrafo anterior. Fora destes casos, não estava a Alta Autoridade autorizada a formalizar normas jurídicas comunitárias derivadas.

Por esse motivo, pode-se concluir que, neste primeiro movimento lógico, as instituições do Tratado da CECA opunham mais condições normativas que refreavam a atividade da Alta Autoridade em direção à tomada unidimensional e totalizante do lugar do Direito e do Poder na Comunidade. Contudo, não se reduz a apenas estes aspectos o esforço institucional em esvaziar o Poder de atuação da Alta Autoridade.

Note-se ainda que, para controlar as situações de concentração inesperada, a Alta Autoridade deveria elaborar recomendações especificamente dirigidas ao agente econômico. Somente na hipótese de, após o decurso de um prazo razoável, se verificar a ausência de um cumprimento satisfatório das recomendações, poderia a Alta Autoridade elaborar decisões, em conjunto com o Governo interessado, (i) fixando preços e condições 
de venda a serem praticados pelo agente econômico em questão; (ii) estabelecendo um regime de programas de produção a ser seguido pelo mesmo agente econômico; ou mesmo, (iii) estabelecendo um regime de programas de distribuição a ser cumprido também pelo mesmo agente econômico - sob pena de este incorrer, inclusive, nas sanções previstas nos artigos 58, 59 e 64 do mesmo Tratado.

Neste segundo movimento, pode-se perceber um mais sutil, mas também mais complexo e mais vigoroso retrato da preocupação institucional em refrear energicamente o Poder de atuação da Alta Autoridade, de maneira a impedir seu ingresso no lugar do Direito e do Poder mediante oposições escalares preocupadas em assegurar a multiescalaridade.

Lembre-se, neste particular, de que o âmbito de atuação da Alta Autoridade se reduzia ao campo normativo. Apenas por este singular aspecto se pode perceber mais uma manifestação do esforço institucional em conter eventuais tentativas de ascensão ao lugar do Direito e do Poder na Comunidade: nas hipóteses de concentrações espontâneas, a Alta Autoridade estava impedida de lançar mão de outros meios que não o da Linguagem normativa, isto é, da não-violência.

Em outras palavras, a atuação da Alta Autoridade se dirigiria diretamente à empresa - pública ou privada - que adquirira posição dominante e residente no território de um Estado-Membro e vincularia obrigatoriamente - por ser norma jurídica - seus destinatários. Todavia, apesar de essa firme possibilidade de reger, a partir de âmbito externo ao de um Estado-Membro, empresas localizadas no território estatal estar prevista e garantida pelo Tratado da CECA, ao mesmo tempo as instituições deste instrumento jurídico-normativo recusavam com robustez à Alta Autoridade a possibilidade de esta recorrer a meios outros para fazer cumprir suas disposições.

Mais simplesmente, há que se notar que o Tratado da CECA mais uma vez previra normativamente um interessante instrumento de ação à Alta Autoridade "vazio": seu Poder de controlar concentrações espontâneas no interior da Comunidade era "sem Poder", pois adstrita ao cerco da Linguagem normativa. E nada mais além disso - pois ela, como todas as escalas de existência envolvidas na vida em comum, não poderia deter tão amplas faculdades de agir que lhe permitissem a plenificação unidimensional do lugar do Direito e do Poder.

A supranacionalidade estava assim impedida de se utilizar os meios coercitivos de implementação típicos dos Estados-Membros. Sua enérgica capacidade de influenciar normativamente empresas localizadas nos territórios dos Estados-Membros era 
imediatamente repreendida de forma igualmente vigorosa. Afinal, o controle não poderia significar a descaracterização do Estado como o único detentor da centralização do uso da violência - pois, precisamente, a Europa Politicamente Unida pela CECA não pretendia assumir os contornos de um Estado Europeu ${ }^{991}$.

Por meio desta singela restrição do campo de atuação da Alta Autoridade ao âmbito normativo não-coercitivo, o Tratado da CECA retirava da supranacionalidade a possibilidade de formar uma autopercepção que a legitimasse a se compreender como podendo romper violentamente a horizontalidade e suprimir por meio da força o vazio no lugar do Direito e do Poder na Europa Política da CECA. Contudo, uma análise mais acurada do dispositivo permite notar ainda outros mecanismos de contenção da potencial unidimensionalização da supranacionalidade da Alta Autoridade.

Ainda no que se refere à restrição da atividade de controle da Alta Autoridade ao âmbito normativo, há que se notar a Alta Autoridade deveria atuar normativamente mediante recomendações ${ }^{992}$. Estas caracterizavam-se, como visto anteriormente ${ }^{993}$, por serem obrigatórias quanto aos fins, mas facultavam aos destinatários a escolha dos meios para o cumprimento deste objetivo comum.

A atuação direta da Alta Autoridade sobre empresas localizadas nos territórios dos Estados-Membros da Comunidade se resumia a estipular que a empresa que inesperadamente adquirisse posição dominante não poderia (i) se subtrair ao cumprimento das regras de Direito Econômico Concorrencial da Comunidade, ou (ii) se utilizar dessa posição dominante para fins contrários à disciplina concorrencial do Tratado da CECA. Outros fins poderiam ser estipulados pelas recomendações, mas jamais poderiam deixar de visar a impedir o abuso do poder dominante pela empresa diretamente considerada.

Perceba-se assim que se retirava mais uma vez da Alta Autoridade a possibilidade de utilizar outros meios constritores da atividade exercida pela empresa que inesperadamente adquirira posição dominante, estando circunscrita a atuar somente no plano de determinação normativa dos fins a serem seguidos. A Alta Autoridade poderia inovar juridicamente e afetar diretamente empresas localizadas nos territórios dos EstadosMembros - mas sem poder determinar as condutas das empresas às quais suas normas se

\footnotetext{
${ }^{991}$ Aspecto apontado por diversas vezes no texto deste trabalho, principal, mas não exclusivamente, no Sexto Capítulo e no item 7.2.4., ambos supra.

992 Sobre o estatuto normativo jurídico-positivo das recomendações, v. a nota de rodapé 154, supra, sobre o artigo 14 do Tratado da CECA.

${ }^{993}$ V. nota de rodapé 154 , supra.
} 
dirigiriam, nem pretender que houvesse um cumprimento de seu regime jurídico compelido mediante o uso da força.

Repare que o esvaziamento operava aqui em três aspectos: (i) possibilidade de determinar normativamente apenas os fins a serem atingidos, mas não as condutas específicas para atingir os fins; (ii) impossibilidade de estipular fins outros que não correspondessem aos dois fins gerais estipulados pela letra do texto do Tratado da $\mathrm{CECA}^{994}$; e (iii) impossibilidade de recorrer a mecanismos coercitivos, reforçando a percepção de a Alta Autoridade não deveria ser considerada como o gérmen de um Estado Europeu rudimentar.

Dessa forma, também neste aspecto este dispositivo pode ser entendido como mecanismo institucional do Tratado da CECA voltado ao condicionamento da atividade da Alta Autoridade e à correlata contenção de eventual intento de tomada do lugar do Direito e do Poder. Não apenas seu círculo de ação era limitado a um aspecto normativo nãocoercitivo, como também o próprio âmbito de sua atuação normativa era restrito a fins estipulados previamente pelo próprio Tratado da CECA.

Não caberia assim à Alta Autoridade buscar ela própria meios mais efetivos de cumprimento de suas normas jurídicas, como também não era ela senhora dos parâmetros destinados a orientador a atividade normativa: eles estavam previamente determinados pelos autores do Tratado da CECA. Mais e mais se fechava o cerco institucional em torno da Alta Autoridade voltado à limitação do enérgico Poder a ela atribuído. Mas a contenção e o correlato esvaziamento deste se torna mais claro à medida que se completa a interpretação desse parágrafo sétimo do artigo 66.

A Alta Autoridade poderia atuar normativamente mediante recomendações especificamente dirigidas ao agente econômico. Somente na hipótese de, após o decurso de um prazo razoável, se verificar a ausência de um cumprimento satisfatório das recomendações, poderia a Alta Autoridade elaborar decisões.

Há que se observar, neste ponto, que o Tratado efetuara uma mutação do tipo normativo passível de ser utilizado pela Alta Autoridade. De fato, para tornar mais efetiva a atuação desta entidade comunitária, poderia a Alta Autoridade se socorrer não de normas jurídicas comunitárias derivadas introduzidas por recomendações, mas sim de normas de

\footnotetext{
${ }^{994}$ Isto é, impedir que a empresa que adquirira posição dominante (i) se subtraísse ao cumprimento das regras de Direito Econômico Concorrencial da Comunidade, ou (ii) se utilizasse dessa posição dominante para fins contrários à disciplina concorrencial do Tratado da CECA.
} 
Direito Comunitário Derivado estabelecidas por decisões. Essa diferença é interessante e permite compreender o que se pretendeu com a indicação desta mutação de tipo normativo.

Como visto anteriormente ${ }^{995}$, as recomendações eram tipos normativos caracterizados por serem obrigatórios quanto aos fins, mas que facultavam aos destinatários a escolha dos meios para o cumprimento deste objetivo comum. As decisões eram diferentes, por sua vez, por serem obrigatórias em todos os seus elementos.

No caso examinado neste dispositivo, diferentemente da situação há pouco analisada, nas hipóteses de descumprimento da recomendação inicialmente formalizada pela Alta Autoridade, esta poderia utilizar outro tipo normativo voltado a tornar mais efetiva sua influência sobre as empresas localizadas nos territórios dos Estados-Membros: não mais por meio de meras recomendações (normas jurídicas vinculantes quanto aos fins), mas por meio de decisões (normas jurídicas integralmente vinculantes, abrangendo meios e fins).

Perceba-se assim que se concedera neste momento a possibilidade de uma atuação normativa mais robusta à Alta Autoridade, na medida em que tais normas não-nacionais não apenas seriam obrigatórias no interior dos territórios dos Estados-Membros com relação aos fins, mas também no que se refere aos meios necessários ao atingimento dos fins por elas visados.

Todavia, diferentemente do que uma leitura rápida poderia concluir, a mutação do tipo normativo neste dispositivo também não implicara a concessão de possível destacamento da supranacionalidade da Alta Autoridade sobre outras escalas de existência. Mais uma vez, o Tratado da CECA voltara a conceder um Poder vigoroso à Alta Autoridade para, logo em seguida, o esvaziar vertiginosamente, de maneira a torná-lo um Poder "sem Poder".

O enfraquecimento operado por este dispositivo operava em três aspectos principais: contenção da atividade de controle da Alta Autoridade por meio de (i) condicionamentos fáticos e instrumentais à elaboração das decisões; (ii) reiteração da recusa à concessão da possibilidade do uso da força por entidade comunitária; e (iii) instituição de normas de oposições escalares.

O Tratado da CECA estipulara dois tipos de condicionamentos à ação da Alta Autoridade, ambos visando à contenção do uso desta faculdade a ela atribuída. O primeiro condicionamento era de caráter fático: a Alta Autoridade apenas poderia lançar mão de

${ }^{995}$ V. nota de rodapé 154 , supra. 
outro tipo normativo - decisões, em substituição das recomendações, se, e somente se, se verificasse a ausência de um cumprimento satisfatório das recomendações pela empresa que tivesse adquirido posição dominante. O segundo condicionamento era de caráter instrumental: a decisão deveria (i) fixar preços e condições de venda a serem praticados pelo agente econômico em questão; (ii) estabelecer um regime de programas de produção a ser seguido pelo mesmo agente econômico; ou (iii) estabelecer um regime de programas de distribuição a ser cumprido também pelo mesmo agente econômico.

Em outras palavras, a partir da consideração dos dois condicionamentos acima mencionados, é possível perceber que o Tratado da CECA buscava limitar a capacidade de atuação da Alta Autoridade no que se refere à capacidade de se utilizar de decisões - pois implicariam uma vinculação jurídica não apenas de fins, mas de meios, de seus destinatários. Para compensar este grande Poder de determinação de empresas localizadas nos territórios de Estados-Membros, o Tratado estabelecera essas duas condições: a Alta Autoridade não estaria livre e desimpedida, fosse para agir normativamente, fosse para estabelecer os parâmetros de sua ação normativa.

Deste modo, não era a Alta Autoridade senhora de sua própria decisão sobre quando agir - pois somente poderia agir se houvesse o descumprimento ou o nãocumprimento satisfatório de uma recomendação prévia - ou sobre como agir - pois não poderia definir as vias segundo os quais as empresas deveriam agir para evitar o potencial abuso de posição dominante, na medida em que não poderia escolher instrumentos distintos dos estipulados pelo Tratado: (i) fixar preços e condições de venda; (ii) estabelecer um regime de programas de produção; ou (iii) estabelecer um regime de programas de distribuição. E, por esse motivo, pode-se perceber que o enérgico Poder dado pelo Tratado à Alta Autoridade de recorrer a decisões fora imediatamente esvaziado.

Contudo, não apenas neste imediato enfraquecimento de Poder concedido à Alta Autoridade mediante contenções internas ao exercício deste que residia o processo de transformação desta faculdade em um Poder "sem Poder". Como afirmado acima, há que se notar que mais uma vez surge neste dispositivo a reiteração da recusa a conceder a este órgão comunitário a possibilidade de recorrer ao uso da força.

Nesse sentido, é importante observar que o Tratado da CECA foi bastante claro em sua previsão normativa: na hipótese de descumprimento de suas recomendações, ou de cumprimento não satisfatório destas, poderia a Alta Autoridade se socorrer de outra espécie normativa - as decisões, e não de outros instrumentos residentes além do cerco não-violenta da Linguagem normativa. Em outras palavras, mesmo em uma situação limite 
de não cumprimento de normas jurídicas comunitárias, a Alta Autoridade não estava autorizada a manejar outro instrumento de estímulo ao não abuso de posição dominante que não fosse a formalização de outra norma jurídica comunitária derivada - as decisões.

Por esse motivo, mais uma vez se pode perceber deliberada opção de recusa à concessão do uso da violência a uma entidade supranacional, precisamente porque o Tratado da CECA não reconhecia seu Projeto de Europa Politicamente Unida como estando próximo ao de um Estado Europeu. Não havendo a quebra da centralização do uso da força nos Estados-Membros, não poderiam a CECA e suas entidades comunitárias pretender se socorrer de instrumentos coercitivos para fazer cumprir as normas jurídicas comunitárias. O máximo que poderia fazer seria recorrer a um reforço normativo decisões - de norma anterior - recomendações - descumpridas. E nada mais além disso.

Ademais, é importante observar mais um aspecto que permite vislumbrar a reiteração consciente da disposição institucional voltada ao paulatino enfraquecimento de um aparentemente robusto Poder concedido à Alta Autoridade. Tratou-se especificamente da introdução de uma oposição escalar no interior do processo de formação do sentido normativo a ser impresso sobre o descumprimento da recomendação. De fato, a Alta Autoridade poderia certamente elaborar norma jurídica comunitária derivada conhecida como decisão; contudo, tais decisões não poderiam ser tomadas senão em conjunto com o Governo interessado.

Isso implica reconhecer que o Tratado da CECA fora mais uma vez cuidadoso na disciplina do procedimento de produção normativa comunitária derivada: sem dúvida alguma poderia a Alta Autoridade se socorrer de um novo tipo normativo, mais vinculante do que o anterior. Todavia, não poderia sua escala de existência pretender orientar por si só, e de maneira isolada, o sentido normativo a ser dado sobre essa questão em especial. Ela deveria necessariamente levar em consideração a estatalidade isolada implicada no potencial abuso de poder dominante exercível pela empresa destinatária da norma.

Nesse sentido, pode-se perceber que mais uma vez o Tratado da CECA se preocupara em regulamentar de maneira bastante vigorosa um contra-Poder voltado a refrear o Poder concedido a outra escala de existência. Uma estatalidade isolada poderia e deveria - opor seu próprio sistema métrico em relação ao da supranacionalidade da Alta Autoridade. Tratou-se de mecanismo institucional voltado mais uma vez a pôr frente a frente diferentes dimensões existenciais para que nenhuma delas pudesse por si só determinar unilateral e uniescalarmente o sentido a ser dado sobre o Direito Comunitário Derivado por meio de decisões. 
Há ainda um último aspecto a ser ressaltado neste parágrafo sétimo do artigo 66 que reafirmava a preocupação dos autores do Tratado em tornar completamente vazio o Poder concedido à Alta Autoridade: tratava-se da reiteração da negativa em conceder à Alta Autoridade a possibilidade de utilizar o uso da força para estimular o cumprimento de normas comunitárias. Ao elaborar as decisões em conjunto com o Estado-Membro interessado, a Alta Autoridade poderia determinar que, caso a empresa à qual a decisão se destinava não cumprisse a disciplina normativa comunitária, ela incorreria nas sanções previstas nos artigos 58, 59 e 64 do mesmo Tratado.

Não cabe aqui detalhar novamente cada uma das sanções previstas nos artigos mencionados, na medida em que eles foram objeto de comentários em itens anteriores ${ }^{996}$. De todo modo, como visto anteriormente ${ }^{997}$, cabe apenas salientar que as sanções previstas nestes dispositivos eram econômicas, representando uma consciente opção normativa de recusa institucional ao uso da força pela Alta Autoridade.

Dessa forma, este dispositivo ora em análise mais uma vez mostrava a preocupação do Tratado em negar à vida em comum instaurada pela CECA a condição de um Estado Europeu: a organização jurídico-Política da Europa Unida jamais se aproximaria da de uma formação estatal, na medida em que estaria fora de seu horizonte a assunção da possibilidade de uso da força para o cumprimento de suas normas jurídicas comunitárias derivadas. Mesmo nos casos em que houvesse uma reiterada e obstinada recusa ao cumprimento de tais normas - primeiramente, de recomendações e, posteriormente, de decisões, nada além deste estrito campo de punição econômica - mas não violenta poderia a Alta Autoridade fazer.

Assim, mais uma vez o Tratado mostrava ter se orientado no sentido de evitar compreender a Comunidade como um Projeto "embrionário" de Estado Europeu, precisamente porque seu arcabouço institucional teria reiterado, mesmo em diversos momentos críticos de descumprimento renitente de normas jurídicas comunitárias, a opção pela recusa de conceder a um órgão comunitário a possibilidade de recorrer a instrumentos coercitivos. Havia, assim, a reiteração da preocupação em tornar mais e mais vazio do Poder concedido à Alta Autoridade, de maneira a transformá-lo em um Poder "sem Poder". Aspecto inclusive reforçado pela previsão normativa comentada no item a seguir.

\footnotetext{
${ }^{996}$ Com efeito, o artigo 58 do Tratado da CECA foi comentado no item 7.3.1.1.2.2., supra, ao passo que o artigo 59 foi comentado no item 7.3.1.1.2.3., também supra. O artigo 64 foi comentado, por sua vez, no item 7.3.1.1.3.4., igualmente supra.

${ }^{997}$ Itens 7.3.1.1.2.2.2., 7.3.1.1.2.3.2., e 7.3.1.1.3.4., todos supra,
} 
7.3.1.2.2.5. O Parágrafo Sexto do Artigo 66: Imposição de Multas pela Alta Autoridade e Controle pela Corte - Multiescalaridade e Recusa ao Uso da Força

A regulamentação das condições do exercício da atividade sancionadora detida pela Alta Autoridade na tutela dos atos de concentração praticados por empresas no interior da CECA dada pelo parágrafo sexto do artigo 66 coroava o processo de afastamento da Alta Autoridade, da Corte, do Conselho e dos Estados-Membros do centro produtor de sentido normativo da Europa Unid pela CECA.

O regime jurídico-econômico deste dispositivo previa a possibilidade de aplicação de multas pela Alta Autoridade. Contudo tal previsão normativa assumira interessantes contornos jurídico-Políticos: ao mesmo tempo em que limitava a possibilidade de punição a uma sanção econômica (recusa ao uso da força na Comunidade), afastava simultaneamente a possibilidade de a supranacionalidade, a intergovernamentalidade e a estatalidade isolada usurparem o lugar do Direito e do Poder na vida comum.

O parágrafo sexto do artigo 66 do Tratado da CECA estabelecia o regime jurídico sancionador da Alta Autoridade e operava como ponto de confluência da normatização anterior do artigo 66. Além da previsão de capacidade sancionadora à Alta Autoridade, o parágrafo sexto procurou estabelecer detalhadamente série de saídas que fechassem significativamente os diferentes discursos normativos suscitados por cada uma das parcelas anteriores do artigo.

Nesse sentido, (i) primeira alínea estabelecera critérios para a Alta Autoridade aplicar sanções para situações especificamente tratadas no parágrafo quarto do artigo 66; (ii) a segunda alínea fornecera condições para a atividade punitiva da Alta Autoridade combater hipóteses mencionadas no parágrafo primeiro do mesmo artigo 66; e (iii) a terceira alínea se ocupara com a definição da variável quantitativa que delimitaria a abrangência da atividade sancionadora da Alta Autoridade na eventual ocorrência de fatos sugeridos pelo parágrafo segundo do artigo 66.

Nestes termos, de acordo com cada uma das previsões normativas específicas, a Alta Autoridade estava autorizada a aplicar diferentes espécies de multas:

(i) três por cento do total de ativos adquiridos ou reagrupados, ou que seriam adquiridos ou reagrupados, nas hipóteses de uma pessoa física ou jurídica não cumprir a obrigação de fornecer à Alta Autoridade - a pedido desta - as informações necessárias sobre eventual concentração de empresas; 
(ii) quinze por cento do total dos ativos adquiridos ou reagrupados, nos casos em que uma pessoa física ou jurídica não comunicar previamente à Alta Autoridade a intenção de efetuar um ato de concentração entre determinadas empresas no interior da CECA; este montante seria acrescido de uma multa mensal de um vinte e quatro avos, cuja contagem se iniciaria a partir do décimo-segundo mês da realização da operação e deteria por termo final a constatação da infração pela Alta Autoridade; e

(iii) dez por cento dos ativos adquiridos ou reagrupados, ou que seriam adquiridos ou reagrupados, nas situações em que uma pessoa física ou jurídica tenha obtido ou tentado obter a isenção de autorização prévio pela Alta Autoridade para a realização de um ato de concentração entre empresas por meio do fornecimento de informações falsas ou deturpadas.

Ao mesmo tempo, em todos os casos acima brevemente mencionados, o parágrafo sexto previa ainda a possibilidade de as empresas eventualmente prejudicadas pelas sanções aplicadas pela Alta Autoridade recorrerem à tutela jurisdicional da Corte da CECA, nos termos estabelecidos pelo artigo 36 do mesmo Tratado.

Como inúmeras vezes mencionado neste estudo, mais importante do que se preocupar com o detalhamento da racionalidade de Direito Econômico Concorrencial subjacente à previsão normativa, há que se preocupar, para os fins deste trabalho, na explicitação da dimensão jurídico-Política constitutiva deste texto normativo. A intencionalidade desta análise se orienta para iluminar a opção institucional pela conservação de uma orientação Política da vida comum na Europa da CECA, seja por meio de organização jurídico-Política não-estatal, seja por meio da reiteração da dinâmica de oposição escalar no Tratado Internacional.

Em um primeiro momento, a leitura superficial destes significantes econômicos poderia ensejar a rápida conclusão de que o Tratado da CECA teria concedido um enorme Poder à Alta Autoridade. Com efeito, é inegável a presença de uma previsão normativa que atribuía diretamente à supranacionalidade a possibilidade de desconsiderar os clássicos limites estabelecidos pela Soberania das estatalidades para aplicar sanções em relação a pessoas físicas e/ou jurídicas localizadas no território submetido à Soberania de um de seus Estados-membros. 
A partir desta perspectiva, esta disposição do Tratado teria habilitado a Alta Autoridade a simplesmente desconsiderar, ignorar, superar, ou mesmo a ultrapassar os Estados-nacionais para, supra-nacionalmente, aplicar multas sobre residentes ou empresas estabelecidas em seus territórios. Em termos mais diretos, ainda de acordo com esta interpretação apressada, teria havido uma sobrevalorização da supranacionalidade, isto é, um centramento emissor do Direito e do Poder na Europa Unida na Alta Autoridade - um suposto privilégio a priori da supranacionalidade em relação às demais entidades comunitárias.

Entretanto, antes de seguir essas conclusões epidérmicas, haveria que se deter sobre outros aspectos deste parágrafo, os quais podem salientar a qualidade jurídico-Política da previsão deste dispositivo. Mais do que uma maneira de fortalecer e/ou de ampliar as capacidades de ação da supranacionalidade sobre as demais, haveria que se compreender de maneira diversa esse instituto: seria repetição do movimento de esvaziamento dos Poderes atribuídos à Alta Autoridade - o retorno da dinâmica de atribuição de um Poder "sem Poder", voltado a manter e a reproduzir o sistema de convivência multiescalar da Europa Politicamente Unida pela CECA.

É no interior desse encadeamento reflexivo que se deve, em primeiro lugar, compreender a presença desta disposição normativa: ela transmite uma mensagem bastante precisa a todas as escalas de existência partícipes do processo de integração da Europa Unida: não haveria na vida em comum qualquer preferência institucional a priori por uma escala de existência em detrimento das demais.

Sem dúvida alguma, caberia à Alta Autoridade a possibilidade de punir pessoas físicas e/ou jurídicas localizadas no território de Estados-membros do Tratado da CECA pela prática de atos de concentração no interior da Comunidade e em prejuízo desta. Todavia, o exercício desta atividade sancionadora jamais poderia estar desprovida de critérios orientadores - jamais seria desarrazoado, pois o próprio texto do Tratado da CECA estabelecera os critérios segundo os quais a Alta Autoridade poderia aplicar suas punições. Neste primeiro momento, revela-se o primeiro movimento de refreamento da atividade da supranacionalidade.

De fato, de forma a evitar perseguições e privilégios, o Tratado teria previsto condições únicas de contenção da atividade punitiva da Alta Autoridade: autorizada a sancionar economicamente atos de concentração, ela não poderia em hipótese alguma estabelecer casuística ou aleatoriamente a punição ou os critérios para tanto. Muito pelo contrário, ela deveria se pautar pelos critérios fixados pelo texto normativo comunitário 
originário constante do Tratado da CECA (hipótese de atuação e consequência normativa), sem poder extrapolar os limites por eles estabelecidos.

Assim, em um primeiro momento, as disposições deste parágrafo sexto do artigo 66 estabeleceram os limites normativos do campo de atuação da Alta Autoridade da CECA no que se refere ao exercício de sua atividade punitiva. Nestes termos, identifica-se um primeiro nível de esvaziamento do Poder atribuído à supranacionalidade por meio de condições inerentes a esta previsão atributiva de capacidade de agir. Ao punir, a Alta Autoridade não forjaria critérios aleatórios, formados a partir de sua própria dimensão existencial; antes, ela apenas poderia aplicar punições de acordo com o estrito caminho normativo estipulado pelo Tratado, devendo cumpri-los fielmente.

Havia, no entanto, outra contenção da atividade de tutela de atos de concentração da Alta Autoridade, de caráter geral, a qual fora prevista na parcela final do mesmo parágrafo sexto: a possibilidade de sua decisão de aplicação das multas ser questionada perante a Corte da Comunidade. E, nesse sentido, é importante observar que o Tratado da CECA estabelecera essa previsão, não tanto em favor dos eventuais prejudicados, mas principalmente com o objetivo de assegurar a permanência de um vazio no centro de definição do sentido do Direito e do Poder na Comunidade - e sua correlata multiescalaridade.

Identifica-se neste momento a presença de outro ato de esvaziamento do Poder atribuído à Alta Autoridade no artigo: diante de tamanha capacidade de ação e de interferência nas órbitas estatais nacionais atribuída à supranacionalidade da Alta Autoridade, não teria bastado o refreamento até então delineado pelo artigo 66. Haveria que se determinar mecanismo adicional que completaria a prática de progressivo enfraquecimento desta entidade comunitária, de maneira a se deixar absolutamente claro como a luz do Sol do meio-dia o singelo fato de que sua escala de existência - como qualquer outra - não deteria o lugar do Direito e do Poder na Europa Politicamente Unida pela CECA.

Nesse sentido, não apenas sua atividade de controle e de punição dos atos de concentração entre empresas no interior da Comunidade fora minuciosamente regulamentada com o objetivo de precisar os exatos limites de seu campo de atuação ${ }^{998}$. Suas atividades poderiam também ser controladas por outra entidade comunitária até o momento não mencionada em toda disciplina jurídica dos atos de concentração do Tratado

${ }^{998}$ Como visto em todo o conjunto das observações acima feitas sobre o artigo 66, neste item 7.3.1.2.2. 
- a Corte. A escala de existência desta estaria apta a efetuar, mediante provocação de eventual interessado, um controle final da atuação da Alta Autoridade, podendo rediscutir os termos da decisão punitiva desta.

O movimento de sucessiva negação do Poder da Alta Autoridade se mostrava assim completo, privilegiando a manutenção da uma situação em que esta, como todas as outras escalas de existência, se encontrava absolutamente incapaz de se apropriar do lugar do Direito e do Poder na Europa Politicamente Unida. Não apenas sua atuação jamais seria desarrazoada ou imbuída de princípio arbitrário, como também jamais escaparia de um controle realizado por diferentes formas de habitar o mundo que participavam do mesmo Projeto.

Todavia, não se pode ignorar que a limitação da Alta Autoridade pela Corte último reduto de controle das atividades da Alta Autoridade relacionadas à tutela de atos de concentração na CECA - em momento algum visou ao destacamento de sua escala de existência na vida em comum. Nesse sentido, o próprio contra-Poder atribuído à supranacionalidade da Corte era ele mesmo controlado, visando ao afastamento deste modo de experienciar o mundo de uma pretensa posição de destaque.

Com efeito, não apenas a previsão normativa do parágrafo sexto do artigo 66 condicionava a contenção da Alta Autoridade pela Corte à prévia provocação do órgão jurisdicional por iniciativa do interessado, como também o próprio dispositivo fazia referência expressa ao artigo 36 do Tratado da CECA, determinando que as condições de atuação previstas naquele artigo deveriam ser observadas pela Corte.

O artigo 36 não foi objeto de comentários por este trabalho no item 7.2., supra, por não se referir a normas de oposições escalares, mas a contenções das atividades da Alta Autoridade e da Corte em relação à atuação delas em relação às entidades privadas que exploravam atividade econômica do carvão e do aço. O artigo 36 do Tratado da CECA permite delinear um rápido arcabouço institucional limitador da atividade de controle da Corte, pois seu parágrafo terceiro remetia à disciplina de contenções da atividade da Corte prevista no parágrafo primeiro do artigo 33 do Tratado da CECA. Neste outro dispositivonormativo há série de refreamentos à atividade da Corte, examinados outrora neste trabalho no item 7.2.2.1.4., ao qual remetemos o leitor.

Dessa forma, note-se que nem mesmo o último instrumento de controle da Alta Autoridade poderia se julgar acima das Leis e do Direito na União Política da Europa: jamais a própria Corte da Comunidade deteria unilateralmente a capacidade de ditar uniescalarmente o sentido final do Direito e do Poder no interior da CECA. Haveria que se 
primar pela preservação do vazio no centro nomogenético comunitário e pela correlata multiescalaridade.

Deste modo, perceba-se que a regulamentação da atividade de controle da Alta Autoridade estabelecida no artigo 66, parágrafo sexto, do Tratado da CECA retirava de sua escala de existência a possibilidade de tomar de assalto o lugar do Direito e do Poder na Europa Politicamente Unida. Ao mesmo tempo, a conjunção explícita desta previsão com a do artigo 33 (por meio do artigo 36, parágrafo terceiro, também do Tratado da CECA) salientava ainda uma vez que nenhuma escala de existência poderia jamais se autocompreender como tendo sido eleita a uma suposta posição de destaque sobre as demais.

Poder se contrapunha a Poder: tratava-se de anulação mútua e recíproca voltada a assegurar a permanência de um vazio no lugar do Direito e do Poder na Europa Politicamente Unida mediante a aposição de sucessivas amarras de contenção de uma e de todas as escalas de existência. Longe de se escolher providencialmente (alg-)Um para restar acima das Leis e do Direito, todos eram continuamente moderados e reinvestidos em suas posições iniciais de desprovidos de Poder maior do que os dos demais - isto é, de iguais em plena relação de horizontalidade. Temperava-se de maneira equilibrada cada uma das fontes de possível dominação uniescalar, para que a harmonia da multiescalaridade produzisse o vigor da união dos partícipes comunitários por meio da fraqueza institucional de cada uma deles com relação a eles mesmos.

Nesse sentido de enfraquecimento dos participantes comunitários, não se deve ignorar ainda um último aspecto deste artigo 66, parágrafo sexto, o qual permite visualizar com ainda mais precisão o esvaziamento do papel atribuído à Alta Autoridade na vida em comum e com relação aos próprios Estados-Membros: a redução da atividade punitiva da Alta Autoridade à singela dimensão econômica.

O parágrafo sexto deste artigo estabelecera um interessante mecanismo de anulação do Poder concedido à Alta Autoridade, precisamente por meio do exercício deste Poder. A armadilha do Poder retorna neste momento do Tratado com todo seu vigor: ao mesmo tempo em que conferia à supranacionalidade a possibilidade de atuar sobre pessoas físicas e/ou jurídicas localizadas no território dos Estados-membros Soberanos partícipes da CECA, o dispositivo delimitava essa capacidade de ação ao exclusivo campo econômico.

Nesse sentido, mais uma vez o Tratado reafirmara sua recusa constante de conceder à supranacionalidade a possibilidade de recorrer ao uso da força dentre seu leque de opções de ação. Ainda uma vez passara bastante longe a hipótese de tentar tornar organização jurídico-Política da CECA imagem e semelhança da dada pelo fenômeno 
estatal. Muito pelo contrário: sucessivamente o Tratado buscara preservar nas mãos das estatalidades isoladas a centralização legal do exercício da violência, sem pretender abalar de forma alguma esta sua característica.

Assim, se por um lado o Tratado da CECA concedera à Alta Autoridade elevada capacidade de influência sobre os territórios dos Estados-membros, por outro lado, em momento algum pretendera conceder por meio dessa previsão qualquer supremacia à supranacionalidade. O supostamente "todo poderoso" Poder da Alta Autoridade teria se reduzido à esfera econômica, jamais podendo ultrapassar o domínio da linguagem da não-violência - pois não poderia significar o uso da força.

A Alta Autoridade era por meio deste mecanismo relembrada outra vez que este Poder a ela concedido pelo Tratado - como qualquer outro - apenas lhe fora dado para a manter plenamente consciente das limitações de seu lugar - como ocorrera com todas as escalas de existência. Ao ter facultada a possibilidade de exercício deste Poder, este era imediatamente esvaziado, assegurando à supranacionalidade a consciência de seu caráter efetivamente vazio, inócuo e inofensivo no que se refere à possibilidade de assumir o papel de princípio embrionário de um Estado Europeu ${ }^{999}$.

7.3.1.2.3. O Artigo 67 e as Violações das Condições de Concorrência pelos Estados-Membros: O Significado Jurídico-Político do Controle da Intervenção dos Estados sobre o Ambiente Concorrencial

Os itens 7.3.1.2.1. e 7.3.1.2.2. acima analisaram artigos que tinham em comum o objetivo de estabelecer um regime jurídico-Político comunitário de controle de decisões empresariais que, mediante condutas ou atos de concentração de estruturas, poderiam impactar a dinâmica de funcionamento concorrencial do mercado do setor econômico do carvão e do aço. Por outro lado, o presente item 7.3.1.2.3. tem por objeto o único artigo do Capítulo VII do Título Terceiro do Tratado da CECA: o artigo 67.

Apesar de este artigo também se dirigir à disciplina do regime de concorrência na Comunidade, seu foco de atenção é outro: não se tratava de estabelecer um regime jurídico-Político comunitário de controle de decisões empresariais que atentariam contra a concorrência. O artigo 67 do Tratado da CECA visa antes a estabelecer por meio deste

\footnotetext{
999 Aspecto apontado por diversas vezes no texto deste trabalho, principal, mas não exclusivamente, no Sexto Capítulo e no item 7.2.4., ambos supra.
} 
dispositivo um regime igualmente jurídico-Político de controle de decisões estatais que pudessem atentar contra a concorrência.

Nesse sentido, o objetivo da atuação da Comunidade disciplinada por este artigo 67 era especificamente estabelecer uma forma de controle da vida em comum sobre as decisões tomadas em nível estatal isolado que impactassem as diferentes Economias implicadas na CECA. Em outras palavras, a tônica regente de todo este dispositivo era precisamente a de estabelecer oposições escalares em relação às decisões tomadas pelos Estados-Membros que pudessem impactar a dinâmica concorrencial do mercado de carvão e do aço, de maneira a impedir que tais decisões pudessem unilateralmente pautar o sentido normativo a ser impresso sobre questões concretas sensíveis comuns.

Como se poderá perceber a seguir, além da preocupação em manter um ambiente jurídico-econômico pautado pela dinâmica típica da concorrência, o dispositivo tinha por preocupação estabelecer um mecanismo de interação tensa e tensiva entre escalas de existência - em relação principalmente à estatalidade isolada, para que a própria manutenção do ambiente concorrencial pudesse ser fruto de escolha consciente e reiteradamente construída sob uma perspectiva comunitária. Em outras palavras, será possível perceber mais uma vez o cuidado em estabelecer uma organização jurídicoPolítica do controle das atividades estatais de intervenção na Economia que violassem as condições de concorrência.

Pois bem. O primeiro parágrafo do artigo 67 estipulava que toda ação de um Estado-Membro que pudesse impactar sensivelmente as condições de concorrência na Comunidade deveria ser imediatamente comunicada à Alta Autoridade pelo respectivo Governo. Na esteira desta previsão, os parágrafos segundo e terceiro do mesmo artigo regulamentavam dois tipos distintos de situação: o parágrafo segundo versava sobre as ações que poderiam aumentar as diferenças nos custos de produção, ao passo que o parágrafo terceiro tratava das ações que poderiam reduzir as diferenças nos custos de produção. Cada um dos casos envolve uma solução distinta.

Antes de prosseguir na interpretação detalhada dos parágrafos segundo e terceiro do artigo 67, é importante se deter na análise de alguns elementos do primeiro parágrafo: o Estado-Membro deveria comunicar à Alta Autoridade toda ação interventiva sobre o domínio econômico que pudesse alterar sensivelmente as condições de concorrência no mercado do carvão e do aço na Comunidade.

Esta primeira parte do dispositivo porta consigo uma importante constatação: o Tratado da CECA estabelecera como regra a intangibilidade da intervenção dos Estados- 
Membros sobre o domínio econômico. A princípio, a Comunidade não estaria autorizada a regular ou a modificar as decisões estatais isoladas sobre como intervir no domínio econômico: este campo de ação ainda seria reservado aos Estados-Membros. Apenas um órgão comunitário - a Alta Autoridade - deveria ser notificado sobre a tomada de uma decisão de intervenção sobre o domínio econômico se ela versasse sobre o setor do carvão e do aço e, além disso, se impactasse sensivelmente as condições de concorrência na vida em comum.

Dessa forma, a obrigação de comunicar a Alta Autoridade sobre a decisão do Estado-Membro apenas surgiria em casos específicos - impacto sensível sobre as condições de concorrência na CECA. Mas, mais do que isso, a própria comunicação feita pelo Estado-Membro não seria motivo suficiente para ensejar por si só qualquer reação por parte da Alta Autoridade ou dos demais participantes da vida em comum. Muito pelo contrário: o Estado-Membro apenas teria o dever de comunicar a ação a ser tomada para intervir no domínio econômico, mas a mera existência de uma ação comunicada não engendraria qualquer faculdade de reação por parte da vida em comum.

Por esse motivo, há que se perceber que o primeiro parágrafo do artigo 67 surge como mecanismo de salvaguarda do campo de atuação reservado aos Estados-Membros de, no exercício de sua Soberania interna, decidir suas vias de intervenção sobre o domínio econômico. De antemão, ele não estava impedido de atuar, devendo apenas comunicar a Alta Autoridade se e quando sua decisão implicasse alteração sensível das condições da concorrência. Mas a Alta Autoridade não tinha qualquer previsão para imediatamente atuar com relação à medida tomada pelo Estado-Membro: se não se tratassem das hipóteses disciplinadas nos parágrafos segundo e terceiro ${ }^{1000}$, a Alta Autoridade teria o dever de permanecer inerte em sua posição. Pois, afinal, a regra seria preservar a possibilidade de apenas os Estados-Membros deliberarem sobre sua atuação no domínio econômico referente ao território a eles vinculado.

Todavia, a preservação do campo de atuação do Estado-Membro não era plena: se a regra era de antemão garantir a livre atuação da estatalidade isolada na definição de seus modos e meios de intervir em sua Economia, não se pode deixar de notar que, a partir do momento que essa decisão impactasse de maneira decisiva a condução da vida em comum na CECA, este domínio de atuação reservado da estataldade isolada era rompido para permitir a introdução da lógica comunitária.

${ }^{1000}$ Acima brevemente mencionadas, e descritas mais detidamente linhas abaixo. 
Em outras palavras, no preciso momento em que a decisão unilateralmente tomada por parte de um Estado-Membro ameaçasse pretender definir por si só o sentido normativo sobre questões concretas sensíveis comuns, o Tratado da CECA assegurava institucionalmente a abertura de fissuras para viabilizar o ingresso de uma perspectiva

multiescalar que, por sua vez, afastaria o movimento de supressão do vazio no lugar do Direito e do Poder na Comunidade.

Assim, no momento em que a decisão da estatalidade isolada tendesse a unidimensionalizar totalizantemente a medida desta sobre as demais, o Tratado da CECA apunha um vigoroso instrumento de oposição escalar, de maneira a fazer operar, ainda uma vez, a lógica da vida em comum. Deste modo, estaria mantida à distância a pretensão de a estatalidade isolada sub-repticiamente fazer introduzir unilateralmente sua dimensão existencial no centro nomogenético da CECA.

Com efeito, há que se voltar ao parágrafo segundo do artigo 67, mas de uma maneira mais detida. Como dito acima, este parágrafo versava sobre as ações dos EstadosMembros que poderiam alargar as diferenças nos custos de produção do carvão e do aço, de maneira a provocar um grave desequilíbrio na concorrência neste setor econômico. Nestas situações, a Alta Autoridade poderia adotar duas medidas distintas, conforme a situação. Em qualquer delas, a decisão da Alta Autoridade só poderia ser formulada a partir de prévia consulta ao Comitê Consultivo ${ }^{1001}$ e ao Conselho.

Se a ação do Estado produzisse efeitos danosos a empresas de carvão e aço dentro de seu território, a Alta Autoridade poderia autorizar a concessão de auxílio financeiro, cujos montante, condições e duração seriam fixados por sua decisão (artigo 67, parágrafo segundo, alínea primeira, do Tratado da CECA) ${ }^{1002}$. Por outro lado, se a ação do Estado produzisse efeitos danosos a empresas de carvão e aço localizadas nos territórios dos outros Estados-Membros, a Alta Autoridade poderia dirigir ao Estado-Membro uma recomendação para definir medidas compatíveis com o equilíbrio econômico deste Estado (artigo 67, parágrafo segundo, alínea terceira, do Tratado da CECA).

\footnotetext{
${ }^{1001}$ O qual, como mencionado inúmeras vezes neste trabalho, não é o foco de estudo deste texto; v., nesse sentido, justificativa constante da nota de rodapé 820, supra.

${ }^{1002}$ Esta alínea prevê, de maneira interessante, que a Alta Autoridade também poderia aprovar auxílio financeiro a empresas localizadas no território de um Estado-Membro em virtude de variação de salários e de condições de trabalho que pudessem produzir os mesmos efeitos danosos, ainda que tal variação não resultasse de uma ação do Estado-Membro.

Não cabe analisar aqui a presente ressalva deste artigo, tendo em vista que não houve uma previsão imediata de oposições escalares. Mas a menção a esta parcela é interessante, pois talvez fosse possível encontrar aqui um esboço dos futuros auxílio financeiros das Comunidades Europeias. Fica registrado o convite para futuras pesquisas conjuntas sobre o tema.
} 
Aqui também deve ser feita a ressalva, inúmeras vezes reiterada neste estudo, de que o objetivo deste comentário não consiste em tentar compreender a racionalidade jurídico-econômica que acompanhou a construção deste parágrafo segundo, mas, sim, evidenciar como esse texto normativo responde institucionalmente a uma preocupação de constantemente seguir uma orientação jurídico-Política para organizar as decisões da vida comum sobre questões concretas sensíveis.

Em ambos os casos regulados por este parágrafo segundo, a Alta Autoridade poderia tomar uma medida distinta, em função do âmbito territorial impactado. Se a ação do Estado-Membro impactasse negativamente somente empresas de seu território, a Alta Autoridade poderia apenas conceder um auxílio financeiro, ao passo que, caso a ação impactasse negativamente empresas localizadas nos territórios de outros EstadosMembros, a Alta Autoridade poderia editar recomendações para o Estado-Membro que dera causa ao alargamento da diferença nos custos de produção de carvão e aço.

Um primeiro indício da presença neste dispositivo de uma preocupação jurídicoPolítica consiste precisamente na espécie de resposta facultada pelo Tratado da CECA à Alta Autoridade à ação desempenhada por um Estado-Membro: em um caso, a Alta Autoridade apenas poderia agir no interior de um campo de auxílio econômico, enquanto que, em outro, a Alta Autoridade apenas poderia agir no interior de um campo estritamente normativo.

A diferença entre um e outro derivaria especificamente da gravidade da ação estatal isolada: se prejudicasse apenas as empresas de seu território, a atuação da Alta Autoridade consistiria apenas no auxílio econômico, mas, se prejudicasse empresas de território de outros Estados-Membros da Comunidade, a ação da Alta Autoridade seria normativa. No primeiro caso, por o raio de influência da ação estatal isolada ser apenas o seu próprio território, a Alta Autoridade equilibraria o nível geral dos custos de produção na Comunidade por meio de auxílio econômico para a empresa do Estado-Membro que tomara a ação. No segundo caso, por o raio de influência da ação estatal isolada ser outros territórios, a atuação da Alta Autoridade deveria ser mais incisiva: ela deveria atuar normativamente para evitar que a ação deste Estado-Membro prejudicasse diretamente a Comunidade como um todo.

A orientação jurídico-Política desta disciplina é bastante clara: nos dois casos, o Tratado da CECA mais uma vez mostrara recusar à Alta Autoridade a possibilidade de dispor de instrumentos coercitivos para responder à ação estatal isolada. Em outras palavras, até nos casos mais graves, nos quais a atuação do Estado-Membro pudesse 
implicar o alargamento da diferença dos custos de produção de carvão e do aço na Comunidade, o máximo que poderia fazer a Alta Autoridade era disciplinar normativamente, mediante recomendações, a atividade de intervenção do Estado-Membro - e nada mais do que isso. Esse era o instrumento máximo que dispunha a Alta Autoridade para conter uma intervenção estatal na Economia que pudesse impactar negativamente o ambiente concorrencial no setor do carvão e do aço.

Dessa forma, há que se perceber que este primeiro indício do parágrafo segundo revelava mais uma vez a preocupação do Tratado da CECA de impedir que a espécie de resposta que poderia a Alta Autoridade dar em relação a um Estado-Membro que impactasse o ambiente concorrencial fosse parecida com a usualmente atribuída ao fenômeno estatal. Ou melhor, ao restringir o campo de atuação da Alta Autoridade ao do auxílio econômico ou ao da atuação normativa, o Tratado da CECA nada mais fez do que reiterar sua preocupação em retirar da vida em comum a possibilidade de ser compreendida como um princípio de Estado Europeu.

Com efeito, ao negar a possibilidade de que decisões formadas pela Comunidade se revestissem de caráter coercitivo, o Tratado da CECA não permitia que houvesse qualquer elemento que pudesse sinalizar um movimento de início de centralização do uso da força em âmbito comunitário. Em outras palavras, em um primeiro movimento analítico, pode-se perceber que o Tratado da CECA ainda uma vez afirmou que a Europa Politicamente Unida pela CECA não poderia ser compreendida como uma organização jurídico-Política estatal embrionária $^{1003}$.

Contudo, não apenas nesta rejeição do elemento da força à Comunidade reside a orientação jurídico-Política neste parágrafo segundo do artigo 67 do Tratado da CECA. Além deste ponto ressaltado, há que se notar que a própria dinâmica de tomada de decisão sobre a medida a ser desempenhada pela Alta Autoridade reapresentava o cuidado de tecer um caminho jurídico-Político para se decidir o sentido normativo a ser impresso sobre questões concretas sensíveis comuns.

De fato, fosse no caso do auxílio econômico, fosse na hipótese de edição de recomendações, a Alta Autoridade não poderia por si só escolher a medida a ser tomada. $\mathrm{O}$ embate escalar entre supranacionalidade da Alta Autoridade e a estatalidade isolada era necessariamente antecedido por outra oposição escalar normativamente institucionalizada

1003 Tal qual afirmado por diversas vezes neste trabalho, como visto no Sexto Capítulo e no item 7.2.4., ambos supra. 
pelo próprio Tratado: o conflito direitificado entre Alta Autoridade e Conselho de Ministros.

Mais uma vez, o Tratado da CECA determinara que a formulação da decisão auxílio econômico ou recomendações - destinada a conter eventual ação estatal danosa para o ambiente concorrencial deveria ser pautada pela multiescalaridade e pelo correlato vazio de Poder: a Alta Autoridade estava impedida de, por si só, imprimir o sentido a ser dado para uma questão concreta sensível comum. Antes, ela deveria necessariamente consultar a estatalidade intergovernamental para, então, poder tomar sua decisão. A prévia oitiva era fundamental e não poderia ser ignorada pela Alta Autoridade, sob pena de não poder agir.

Assim, o Tratado da CECA reafirmava a necessidade de haver um tenso embate entre escalas de existência: Poder se contrapunha a outro Poder, de maneira que jamais a supranacionalidade pudesse decidir unilateral e totalizantemente como se deveria orientar a atividade estatal, do mesmo modo que a estatalidade intergovernamental não poderia deixar de estar presente e de apor sua medida de existência contra a supranacional, para contribuir à formação da decisão. Do mesmo modo que a estatalidade isolada não poderia deixar de se submeter à decisão formada a partir de uma perspectiva comum, contraposta a sua própria medida de existência que prejudicara a vida em comum.

Deste modo, ainda uma vez o Tratado da CECA apresentara um desenho institucional preocupado em conservar uma orientação multiescalar na formação de decisões comuns sobre questões concretas sensíveis. E, para tanto, ao opor escalas de existência entre si, mais uma vez sinalizou seu intento em preservar um vazio no lugar do Direito e do Poder na Comunidade, de tal modo que ninguém poderia por si só determinar o sentido comum.

O parágrafo terceiro do artigo 67 tratava das ações estatais que - por meio de tratamento preferencial positivo (vantagem especial) ou negativo (encargos especiais) poderiam reduzir as diferenças no custo de produção de carvão e aço em relação às demais indústrias do mesmo país. Nestas situações, a Alta Autoridade estaria habilitada a dirigir ao Estado-Membro as recomendações necessárias, desde que previamente consultados o Comitê Consultivo ${ }^{1004}$ e o Conselho.

Como por diversas vezes afirmado neste trabalho, o foco da interpretação deste parágrafo terceiro não é compreender a racionalidade jurídico-econômica subjacente a este

${ }^{1004} \mathrm{O}$ qual, como mencionado inúmeras vezes neste trabalho, não é o foco de estudo deste texto; v., nesse sentido, justificativa constante da nota de rodapé 820 , supra. 
dispositivo, mas, sim, explicitar a orientação jurídico-Política que pode ser retirada dessa previsão normativa voltada a definir critérios de ação da vida em comum sobre questões concretas sensíveis.

Do mesmo modo como ocorrera na análise do parágrafo segundo do artigo 67 do Tratado da CECA, há que se perceber que este parágrafo terceiro revelava duplamente uma preocupação jurídico-Política.

Em um primeiro aspecto, mais uma vez é negado o caráter estatal da Europa Politicamente Unida pela CECA, na medida em que, diante de uma ação estatal isolada que reduzisse as diferenças no custo de produção de carvão e aço em relação às demais indústrias do mesmo país, a Alta Autoridade apenas poderia direcionar a tal EstadoMembro recomendações.

Em outras palavras, também neste caso, a Alta Autoridade estava autorizada a no máximo editar normas jurídicas para orientar a intervenção deste Estado em particular na Economia. Isso implica reconhecer que, como no parágrafo segundo, o Tratado da CECA sinalizava que a resposta da Alta Autoridade a uma ação estatal que detivesse potencial de impactar a vida em comum não poderia jamais se assemelhar a uma resposta tipicamente estatal, na medida em que não poderia se aproximar de um princípio de centralização do uso da força. Mais simplesmente, o Tratado da CECA reiterava também neste dispositivo seu intento de deixar de reconhecer na organização jurídico-Política da Europa uma organização estatal, precisamente por não se tratar de um Projeto de um proto-Estado Europeu rudimentar.

Em um segundo aspecto, da mesma maneira que ocorrera no parágrafo segundo deste mesmo artigo, o Tratado da CECA determinara que a decisão normativa destinada a orientar a intervenção do Estado na Economia - de maneira a que esta não impactasse negativamente o ambiente concorrencial da Comunidade - não poderia ser tomada isoladamente pela Alta Autoridade. Ainda uma vez, o foi imposta institucionalmente a necessidade de a Alta Autoridade consultar o Conselho de Ministros.

Deste modo, ao determinar que a escala de existência supranacional da Alta Autoridade deveria se encontrar com a estatalidade intergovernamental para, então, conter eventuais prejuízos de uma decisão da estatalidade isolada, o Tratado da CECA instituíra normativamente mais um ambiente de oposição escalar para definir o sentido a ser dado a uma questão concreta sensível comum.

Poder se contrapondo a Poder, dimensões existenciais se chocando entre si: aqui também era manifesto o cuidadoso intento do Tratado da CECA em conservar uma 
formação multiescalar do sentido normativo comum a ser impresso sobre uma situação concreta sensível, sem autorizar que qualquer escala de existência pudesse se considerar como ocupando de antemão e intemporalmente o lugar do Direito e do Poder na Comunidade. Ninguém poderia por si só determinar o sentido normativo comum - apenas todos, em conjunto.

\subsubsection{O Papel Fundante da Populidade}

Depois de descrever extensiva e detalhadamente cada um dos Poderes atribuídos às diferentes escalas de existência participantes da determinação do sentido normativo derivado último das questões concretas sensíveis da vida comum inaugurada pela CECA, haveria que se perguntar ainda sobre o papel exercido pela populidade nas contraposições escalares estabelecidas normativamente pelo texto do Tratado.

De fato, se a análise até agora efetuada das atribuições de Poder entre estatalidades e supranacionalidades deixa clara a existência de uma cuidadosa preocupação com uma construção institucional jurídico-política que proporcionasse uma organização que instaurasse e conservasse um vazio no lugar do Direito e do Poder na vida em comum, talvez se pudesse cogitar sobre uma eventual insignificância atribuída normativamente pelo Tratado da CECA ao Poder popular.

Não há aqui uma cegueira analítica. Dois artigos localizados ao final do Tratado da CECA apunham uma função de grande relevância à populidade. Como se poderá ver a seguir, os artigos 96 e 99 do Tratado atribuem à populidade um Poder de grande peso na vida em comum. Com efeito, ela seria responsável não apenas pela instauração da vida em comum, mas também pela manutenção dos elementos que a compunham como um complexo jurídico-Político agregado.

Entender a articulação institucional dada à populidade no final do Tratado da CECA no interior de uma chave de leitura jurídico-política permitirá compreender que residia precisamente na populidade um papel efetivamente distinto e notável, ou ainda, um papel primeiro: o de fundação e de refundação da comunidade Política da Europa que fora Politicamente Unida por meio das instituições constantes do Tratado da CECA. 


\subsubsection{Aprovação de Modificações Jurídico-Normativas do Tratado da CECA}

O artigo 96 do Tratado da CECA estipulava que, após o período de transição ${ }^{1005}$, seria possível propor emendas ao texto do Tratado. Para tanto, o dispositivo atribuía a iniciativa da proposição ao Governo de cada Estado-Membro ou à Alta Autoridade da CECA. Independentemente da origem da proposta, ela deveria ser encaminhada ao Conselho. Este não deveria se manifestar sobre a proposta a ele submetida, pois o artigo 96 o incumbia de deliberar sobre outra questão, de caráter formal.

Com efeito, para dar seguimento ao procedimento de análise das emendas propostas, o Conselho deveria emitir um parecer favorável - aprovado por dois terços de seus membros, sobre a realização de uma Conferência de Representantes dos EstadosMembros da Comunidade. Seria esta Conferência - e não o Conselho de Ministros da CECA - que deveria examinar as propostas de emenda ao Tratado de Paris e decidir sobre as modificações de conteúdo das instituições deste.

Uma vez aprovadas as alterações propostas, as emendas entrariam em vigor apenas se ratificadas por todos os Estados-Membros da CECA, de acordo com suas respectivas regras constitucionais nacionais.

O papel exercido pela populidade neste artigo surgia precisamente no final de sua previsão normativa, isto é, quando se estabelecera a necessidade de aprovação das emendas ao Tratado da CECA mediante ratificação a ser realizada pelas regras constitucionais nacionais de cada Estado-Membro.

A História da CECA analisada anteriormente ${ }^{1006}$ permite perceber que o procedimento de ratificação adotado por cada Estado-signatário da CECA consistia em exigir que o documento jurídico-normativo internacional deveria ser aprovado pela maioria de ao menos uma das Casas dos Parlamentos nacionais.

\footnotetext{
${ }^{1005}$ A Convenção relativa às Disposições Transitórias do Tratado da CECA define, em seu $§ 1$, alíneas 2, 3 e 4, o que seria esse período transitório. Como afirmado na nota de rodapé 785, supra, o texto desta Convenção em especial não é objeto de comentários deste trabalho. Todavia, a fim de permitir ao leitor uma melhor compreensão desta disposição normativa em especial, cumpre efetuar, ao menos nesta nota de rodapé, uma breve explicação sobre o termo "período de transição" utilizado pelo artigo 96 do Tratado da CECA e que fora definido pelas disposições iniciais desta Convenção.

Segundo o §1, alínea 2, da Convenção, a execução do Tratado seria desenvolvida em dois períodos, a saber, o período preparatório (definido no $\$ 1$, alínea 3) e o período de transição (definido no $§ 1$, alínea 4). O período preparatório consistiria naquele lapso temporal compreendido entre a data de entrada em vigor do Tratado e a data de estabelecimento do mercado comum. Por sua vez, o período de transição iniciaria com o estabelecimento do mercado comum (isto é, com o fim do período preparatório) e terminaria após cinco anos, contados a partir da instituição do mercado comum para o carvão.

${ }^{1006}$ V. final do Sexto Capítulo, item 6.3.4., supra.
} 
A populidade era introduzida assim pelo Tratado de Paris de 1951 mediante a remissão aos órgãos nacionais oficiais de representação popular de cada um dos Estadossignatários. Em outras palavras, era no interior dos limites estabelecidos pelas diferentes formas constitucionais nacionais de reconhecimento de participação popular em cada um dos Estados-Membros da CECA que se assegurara a presença da escala de existência aqui designada como populidade perante as demais participantes da vida em comum, a fim de que contra elas exercesse seu contrapeso fundamental.

Em primeiro lugar, é importante perceber no interior desta previsão normativa que nenhuma das principais escalas de existência que compõem o jogo de Poder na Comunidade detinha a exclusividade de iniciar a proposição alteração do Tratado da CECA mediante emendas. Tanto a estatalide, quanto a supranacionalidade, dispunham de autorização expressa para pensar e para formular suas respectivas propostas de alteração de quaisquer normas do Tratado de Paris de 1951, a qualquer tempo ${ }^{1007}$.

Não havia qualquer restrição temática à atividade reformadora a ser eventualmente iniciada por uma ou por outra escala de existência, podendo abranger inclusive a própria redistribuição de Poderes prevista na arquitetura institucional fundamental da vida em comum. Deste modo, qualquer espécie de modificação dos termos normativos do Tratado estava autorizada por esse dispositivo, ainda que visasse a abranger o delicado equilíbrio de Poderes instituído pela cuidadosa engenharia de freios e contrapesos analisada extensivamente nos itens anteriores ${ }^{1008}$.

Todavia, ao não assegurar a nenhuma das escalas de existência fundamentais da vida em comum da CECA (estatalidade ou supranacionalidade) o privilégio de ser detentor exclusivo da iniciativa de proposições, a presente disposição do Tratado da CECA permitia que as sugestões de reforma das normas constantes do Tratado - inclusive a das estruturas elementares do ambiente institucional que assegurava o equilíbrio entre as diferentes escalas de existência - não tivessem como origem apenas uma ou outra dimensão existencial.

Deste modo, as possíveis transformações de quaisquer disposições jurídiconormativas do Tratado poderiam estar informadas tanto por uma racionalidade estatal, quanto por uma dinâmica supranacional, sem se poder afirmar a presença de qualquer traço que indicasse uma preferência prévia por uma ou por outra.

\footnotetext{
${ }^{1007}$ Salvo no que se refere à necessidade de término do período de transição, como visto na nota de rodapé 1005, supra.

${ }^{1008}$ Especialmente nos itens 7.2. e 7.3.1., supra.
} 
O que deve ser especialmente notado nesta primeira parte do processo de proposição de emendas ao Tratado é a previsão de que a proposta de alteração deveria necessariamente ser encaminhada ao Conselho de Ministros da CECA - o órgão intergovernamental por excelência da Comunidade. Se a iniciativa restava com qualquer das estatalidades isoladas da vida em comum ou com a supranacionalidade da Alta Autoridade, estas por si só não poderiam por si mesmas determinar unilateralmente o sentido da modificação das disposições do Tratado.

Perceba-se assim, que, ao atribuir o Poder de iniciativa a estas duas escalas de existência, o mesmo Tratado de Paris de 1951 simultaneamente retirava delas a possibilidade de adentrar no lugar do Direito e do Poder. A estatalidade isolada ou a supranacionalidade da Alta Autoridade não poderiam, por si só, introduzir unidimensional e totalizantemente suas respectivas escalas de existência como o padrão normativo destinado a transformar (unidimensionalmente) a orientação geral da articulação jurídicoinstitucional prevista no Tratado.

Em outras palavras, a disposição do artigo 96 do Tratado da CECA, imediatamente após a concessão de relevante Poder, esvaziara tal atribuição de maneira a negar concomitantemente a possibilidade à estatalidade isolada e à supranacionalidade da Alta Autoridade de ocupar o lugar do Direito e do Poder. Se estas poderiam suscitar modificações ao Tratado, jamais poderiam pretender que seus modos de habitar o mundo imprimissem unilateralmente o sentido normativo último das alterações ao Direito Comunitário Originário da CECA.

A necessidade da presença do Conselho de Ministros surge assim como um convite a que estatalidades isoladas e supranacionalidade da Alta Autoridade inaugurassem o procedimento de reforma das disposições sem que, com isso, tomassem as rédeas dele. Este convite operava como efetiva armadilha institucional ao compartilhamento da possibilidade de reorientação normativa do ambiente institucional com as demais as escalas participantes da vida em comum.

Nesse sentido, note-se que a atividade de cada uma dessas dimensões existenciais se limitava estritamente à proposição de modificação de normas do Tratado. A partir deste momento de deflagração do processo, não mais estavam autorizadas pela disposição normativa a em nada mais interferir no procedimento reformador. Na verdade, após essa parte inicial do artigo 96 do Tratado da CECA, as estatalidades isoladas e a supranacionalidade da Alta Autoridade desapareciam do dispositivo para dar lugar à atuação das demais dimensões existenciais participantes da vida em comum - ou seja, 
quem iniciara o movimento de modificação normativa originária da Comunidade não mais detinha controle sobre os destinos dele.

Deste modo, pode-se perceber que esta construção normativa detinha uma profunda significação Política: atribuir um grande Poder para, em seguida, esvaziá-lo, era a medida de segurança encontrada pelo Tratado para preservar o vazio no lugar do Direito e do Poder com relação às estatalidades isoladas e à supranacionalidade da Alta Autoridade. Estas restavam conscientes de que, depois de suas respectivas proposições, em nada mais estariam autorizadas a contribuir para as fases posteriores de alteração do texto do Tratado. A previsão do Poder transformador carregava em si mesma uma autocontenção de tal Poder por ele mesmo - e, por isso mesmo, deveria ser uma decisão bem refletida, à luz de uma preocupação atenta a uma perspectiva comunitária.

Não se pode ignorar, contudo, a especial condição na qual é introduzida a contribuição do Conselho de Ministros neste processo. Apesar de a proposta de alteração do Tratado dever necessariamente ser a ele encaminhada, enquanto portador da estatalidade intergovernamentalmente considerada, este órgão em praticamente quase nada poderia influenciar as propostas de alteração feitas por um dos Estados-Membros ou pela Alta Autoridade.

Nesse sentido, não se pode deixar de notar que o Conselho de Ministros não deveria se manifestar sobre a proposta a ele submetida. Antes, ele deveria apenas assegurar o seguimento formal do procedimento de análise das propostas. Sua deliberação consistia simplesmente em aprovar ou não a posterior organização e uma Conferência de Representantes dos Estados-Membros da CECA. Era precisamente esta Conferência extracomunitária - e não o Conselho de Ministros da CECA em si mesmo - que recebera a competência para examinar substancialmente as propostas de emenda ao Tratado de Paris e decidir sobre as modificações institucionais deste.

O exame atento deste dispositivo permite perceber que este não excluíra a possibilidade de a estatalidade intergovernamental avaliar as propostas formuladas pela estatalidade isolada ou pela supranacionalidade da Alta Autoridade. Muito pelo contrário, o Tratado da CECA cuidou em assegurar que neste procedimento de alteração de suas disposições jurídico-normativas institucionais fosse mantida a multiescalaridade e a correlata condição vazia do lugar do Direito e do Poder.

Em um primeiro momento, certamente houve uma profunda restrição da possibilidade de atuação da estatalidade intergovernamental - enquanto manifesta pelo Conselho de Ministros. Se a este órgão deveriam ser remetidas as propostas de 
modificação do Tratado da CECA, a própria previsão normativa restringiu o âmbito de atuação deste: a ele caberia a simples avaliação formal - não sobre as propostas, mas sobre ser ou não favorável à organização daquela Conferência de Representantes.

Perceba-se que, por meio da previsão desse sistema de envio necessário, o Tratado conferira um Poder vigoroso ao Conselho de Ministros: estava excluída a possibilidade de apenas um Estado-Membro da Comunidade, ou mesmo de apenas a Alta Autoridade, estabelecer a escala de existência destinada a ser o padrão normativo que regeria a modificação da arquitetura institucional originária do Tratado.

O grande Poder atribuído ao Conselho de Ministros era, ao mesmo tempo, limitado imediatamente pelo próprio dispositivo que o previra: ele excluía deste órgão comunitário a possibilidade mesma de buscar imprimir sua perspectiva estatal intergovernamental sobre as propostas outrora formuladas pelos outros dois partícipes da vida comum. O Poder de controle do Conselho era limitado a apenas uma questão de caráter formal, não envolvendo de qualquer maneira um juízo sobre as propostas. Seu Poder de controle era deste modo controlado, pois imediatamente esvaziado pela própria previsão normativa do Tratado da CECA.

Assim, restringindo o âmbito de atuação do Conselho a um mero "rito de passagem" formal em direção à Conferência de Representantes, o Tratado simultaneamente retirara da esfera da estatalidade isolada, da supranacionalidade e mesmo da estatalidade intergovernamental do Conselho a possibilidade de dar um sentido unidimensional às decisões sobre as possíveis modificações do ambiente institucional comunitário vigente. Mesmo o Poder de constrição era constrito, e essa condição de repulsa multilateral do centro de doação de sentido normativo assegurava a persistência da condição de um lugar de formulação do Direito e do Poder permanentemente vazio.

Todavia, em um segundo momento, o Tratado revelava sua preocupação em garantir a presença da conjunção intergovernamental na formulação das modificações de seu arcabouço institucional originário. De fato, a Conferência de Representantes dos Estados-Membros - pautada por uma dinâmica relacional intergovernamental tendo em vista a preservação da vida em comum - seria a responsável pela decisão das emendas ao Tratado que seriam admissíveis. E, também neste momento fundamental, não pode deixar de ser percebida a permanência de uma preocupação do Tratado da CECA em conservar institucionalmente o vazio tipicamente Político na condução da vida comum da CECA, mesmo neste momento de avaliação das propostas de alteração do Direito Comunitário Originário. 
Com efeito, as sugestões de modificação do Tratado tinham origem em iniciativa estatal isolada ou supranacional da Alta Autoridade e deveriam passar intocadas pelo Conselho de Ministros. Tais proposições deveriam chegar sem interferências naquela Conferência de Representantes, a qual seria - enquanto estatalidade intergovernamental localizada fora dos órgãos da Comunidade - a responsável pela aprovação das propostas $^{1009}$. Esse caminho institucionalmente desenhado abria assim um complexo entrechoque escalar que garantia a permanência do vazio.

De um lado, as estatalidades isoladas e a supranacionalidade da Alta Autoridade deteriam o Poder de propor modificações ao Tratado da CECA, mas não poderiam esperar impor unilateral e unidimensionalmente a transformação da ordem normativa do Tratado de Paris unicamente a partir suas próprias escalas de existência. Seu Poder propositivo era imediatamente contrabalançado pelo Poder impeditivo atribuído à Conferência de Representantes dos Estados-Membros.

Nesse sentido, tendo em mente o futuro crivo a ser exercido pela estatalidade intergovernamental, em momento algum suas propostas poderiam visar à simples moldagem da estrutura institucional da CECA à imagem e semelhança delas. Ambas não poderiam descuidar em suas propostas da preocupação Política originária da CECA de assegurar a multiescalaridade por meio do jogo de Poder institucional cuidadosamente confeccionado pelos autores do Tratado. Em outras palavras, ambas deveriam ter em mente a preservação da vida comum em seu ser propriamente Político - sob pena de possível veto por parte da estatalidade intergovernamental.

De outro lado, a Conferência de Representantes dos Estados-Membros não poderia ser vista como detentora da última palavra sobre o padrão normativo destinado a orientar as futuras articulações do Tratado da CECA. Se esta era dotada de um Poder impeditivo, sua capacidade de atuação era controlada por meio de uma limitação prevista pelo mesmo dispositivo jurídico. Tratava-se de um esvaziamento dos Poderes atribuídos à estatalidade intergovernamental mediante extrema redução de seu círculo de atuação.

Sobre este aspecto, basta notar que a ação da Conferência de Representantes se cingia à recepção das emendas e à decisão sobre quais delas deveriam ser adotadas para modificar o Tratado. Em outras palavras, a deliberação desta instância não deveria visar à

\footnotetext{
${ }^{1009}$ Poder-se-ia indagar sobre o significado deste deslocamento do centro de atividades da escala estatal intergovernamental, mas esta questão não diz respeito aos objetivos metodológicos delineados para este trabalho (interpretação jurídico-política do texto de Direito Positivo Comunitário Originário do Tratado da CECA). Para evitar conjecturas levianas e desprovidas de séria fundamentação científica, deixa-se este exame para trabalhos posteriores. Fica registrado aqui o convite para futuras investigações conjuntas sobre o tema.
} 
reformulação das propostas ou à apresentação de outras. Antes, seu campo de atuação era restrito pela previsão normativa do Tratado à mera aprovação ou não das propostas apresentadas, sendo-lhe vedada a faculdade de buscar imprimir sua própria estatalidade intergovernamental por sobre as sugestões da estatalidade isolada ou da supranacionalidade da Alta Autoridade.

Dessa maneira, aos Estados-Membros da CECA e à Alta Autoridade da CECA competia a possibilidade de formular propostas de alteração do texto do Tratado, mas a estes tinha sido negado simultaneamente o Poder de aprovar suas próprias sugestões de modificação. Ao mesmo tempo, à Conferência de Representantes dos Estados-Membros era facultada a possibilidade de aprovar ou de rejeitar proposições que receberia, sem que com isso pudesse ela própria apor suas próprias propostas de modificação do Tratado.

Em todos os casos foi previsto um vigoroso Poder (propositivo ou impositivo), o qual era imediatamente contrabalançado por outro Poder (respectivamente, impeditivo ou de autocontenção). A nenhuma escala de existência fora dada a faculdade de dar nova forma à articulação institucional originária do Tratado a partir de suas próprias formas de habitar o mundo. Se uma detinha um Poder a princípio invejável, não era ele incontrastável, na medida em que um mecanismo de contenção era imediatamente previsto para tornar quase nada o Poder outrora atribuído.

Assim, por meio dessa engenhosa preocupação, buscava-se preservar assim o vazio no lugar do Direito e do Poder na vida comum mediante o multilateral afastamento de todas do centro normativo.

De todo modo, é precisamente após as decisões daquela Conferência de Representantes dos Estados-Membros da CECA que aparece a opção por se preocupar normativamente com a atuação da populidade. Uma vez aprovadas as alterações propostas, as emendas entrariam em vigor apenas se ratificadas por todos os Estados-Membros da CECA, de acordo com suas respectivas regras constitucionais nacionais.

Enquanto órgãos estatais nacionais de representação popular, os Parlamentos nacionais são convidados a manifestar sua concordância com as alterações propostas e aprovadas, a fim de dar seu assentimento final às iniciativas. E, por este motivo, é importante examinar cuidadosamente esta previsão normativa para se compreender que esta margem de ação prevista pelo Tratado da CECA não implicava de forma alguma a supressão da condição de um lugar vazio de Direito e de Poder na vida comunitária.

Poder-se-ia pensar que a atuação da populidade era simplesmente semelhante à da estatalidade intergovernamental extracomunitária: receber a proposta por outros elaborada 
e aprová-la ou não - com implicações similares à ressaltada pela análise feita linhas acima. Apesar de aparentemente se reduzir a esta dimensão prática, a ação da populidade adquiria significação jurídico-política relevante neste momento do processo de alteração do Tratado da CECA.

Não se pode ignorar certamente que a atuação da populidade poderia parecer bastante limitada: segundo filtro no procedimento de alteração das normas do Tratado, ela receberia somente o resto da atuação multiescalar das fases anteriores, resumindo sua atuação a uma simples condição de "homologação ou não" das emendas propostas. A interferência de sua escala de existência seria hipótese afastada normativamente pelo Tratado, pois sequer poderia modificar o conteúdo das propostas recebidas.

Esses aspectos estão efetivamente presentes, mas são eles mesmos que concedem especial significado ao papel exercido pela populidade: refundação da Comunidade Política da Europa Unida pela CECA. A exigência de ratificação das emendas propostas pelas outras escalas de existência detém um significado jurídico-político que ultrapassa a dimensão de uma "simples certificação"; trata-se antes de abertura de oportunidade única para a manifestação da populidade sobre a condução da vida comum inaugurada pela CECA.

Lembre-se de que na série de dispositivos normativos do Tratado comentados anteriormente $^{1010}$, a populidade fora mantida afastada da decisão normativa sobre questões envolvendo a solução de conflitos entre as demais escalas de existência participantes da vida em comum ou sobre o uso e a administração do carvão e do aço. Contudo, como contrapartida a tal exclusão, preservara-se a populidade para atuar no momento mais crucial de todos: o de conservar o caráter Político da União da Europa mediante a manutenção da agregação Política entre as diferentes escalas de existência quando da ameaça de possível desfiguração da dinâmica de preservação do vazio no lugar do Direito e do Poder.

Nestes momentos singulares em que as Leis Políticas vigentes poderiam ser suspensas mediante sorrateira introdução jurídico-normativa de dinâmica institucional Teológico-Politicamente orientada, a populidade era invocada como o recurso destinado a certificar que as emendas propostas não produziriam uma indesejada metamorfose da estrutura da organização jurídico-Política da União da Europa. Se o Direito Comunitário Originário poderia ser alterado, tais modificações não poderiam

${ }^{1010}$ Examinados nos itens 7.2. e 7.3.1., supra. 
implicar a alteração da dinâmica política direitificada originariamente no imediato pósSegunda Guerra Mundial. A populidade de cada Estado-Membro seria a final invocada para assegurar a conservação de uma fundação Política da vida comum diante de inciativas que pudessem inadvertidamente modificar as Leis da Comunidade.

Observe-se que a eventual proposta de alteração das normas jurídicas do Tratado da CECA era autorizada para ser suscitada apenas após o decurso de alguns anos de experiência concreta da vivência da vida em comum ${ }^{1011}$. Se originariamente a União política da Europa pela CECA estava estruturada por determinado ambiente institucional apto a assegurar a vigência de Leis Políticas, não se poderia desconsiderar a possibilidade de serem provadas posteriormente tentativas de subverter tal ordenação jurídico-Política por propostas de redesenho institucional oriundas de escalas de existência participantes da vida comunitária.

Se as instituições preservavam o vazio no lugar do Direito e do Poder, as estatalidades ou a supranacionalidade da Alta Autoridade poderiam almejar, isolada ou conjuntamente, à superação das limitações impostas institucionalmente mediante uma completa transformação das estruturas elementares que fundavam jurídico-normativamente a vida em comum. Ao se poder desfigurar o complexo e engenhoso mecanismo institucional de contenção plurilateral, poder-se-ia desautorizadamente dar preferência à imissão totalizante de uma única escala de existência em detrimento das demais e, com isso, romper com o tenso equilíbrio pluriescalar tipicamente Político ${ }^{1012}$.

Nesse sentido, se as disposições institucionais originárias da CECA poderiam ser alteradas, os participantes deveriam ter suas atuações parcialmente limitadas. Isso permitiria que nenhum desses poderia imprimir - de maneira isolada ou concertada - um único padrão normativo na organização jurídico-política da vida comum. Apenas as estatalidades isoladas ou a supranacionalidade da Alta Autoridade poderiam propor, sem pretender aprovar de pronto suas próprias sugestões; ao mesmo tempo, a estatalidade intergovernamental extracomunitária seria quem decidiria pela aprovação das alterações, sem pretender propor ela própria modificações adicionais às anteriormente sugeridas pelas escalas de existência detentoras do Poder de iniciativa.

\footnotetext{
1011 V. nota de rodapé 1005, supra, sobre o período de transição.

1012 Como poderia ocorrer com a introdução posterior e sorrateira, por exemplo, de uma ordenação institucional afeita ao discurso jurídico-Teológico-Político do Federalismo Europeu. Como visto no item 3.4.3., supra, há sempre a possibilidade de haver um deslize de um regime Político para um regime Teológico-Político. Sobre o Federalismo Europeu, v. a integralidade do item 5.2.2., supra.
} 
Tamanha era a ameaça de completa transfiguração das Leis regentes da Europa Politicamente Unida pela CECA - mediante a alteração da articulação institucional direitificada - que o Tratado entendera por bem invocar mais uma escala de existência para participar deste processo: a populidade. Esta deveria, após a interferência limitada das demais, ela própria exercer seu controle limitado.

Nesse sentido, se não poderia propor as alterações que suas escalas de existências julgassem as mais apropriadas para a vida em comum ${ }^{1013}$, seria a populidade o elemento destinado a certificar que a nova engenharia institucional proposta não seria responsável pelo rompimento do delicado amálgama jurídico-Político estabelecido pela CECA desde sua origem.

Deste modo, ainda que houvesse uma imperceptível concertação entre as diferentes dimensões existenciais participantes da vida em comum ${ }^{1014}$, a populidade decidiria por ratificar tais emendas se estas não fossem percebidas como atentados em potencial à agregação multiescalar estabelecida no início da vida comunitária da CECA. Em outras

1013 Do contrário, representaria um possível desequilíbrio da cuidadosa organização jurídico-Política arquitetada ao longo de todo o Tratado, como visto neste item e nos itens anteriores (especialmente itens 7.2. e 7.3.1., supra).

Com efeito, se se desse à populidade da faculdade de exercer a última palavra sobre o sentido normativo a ser impresso nas disposições institucionais originárias estruturantes da vida comum, estar-se-ia denominando o Regime das Leis da Europa de "Democracia", e não de Regime Político. Se em diversas oportunidades o Tratado se preocupara em não permitir que o Regime fosse classificado como de uma única escala de existência ("Realeza" ou "Tirania"), de poucas delas ("Aristocracia ou Oligarquia") ou do maior número delas ("Democracia" ou "Oclocracia"), não seria neste momento final de sua minuciosa regulamentação jurídico-normativa originária que viria ele a romper com a condição mista do Regime jurídico-Político por ele organizado.

A conclusão acima permite compreender a razão pela qual se pôde afirmar por diversas vezes nos seis Capítulos anteriores deste trabalho que não se poderia concluir que o Tratado da CECA teria optado pela proteção e pela promoção da Democracia na Europa Politicamente Unida. Sem rejeitar a importância da participação popular, esta ficaria restrita aos momentos cruciais de possível rompimento da lógica Política, mediante os limites estabelecidos pelo Tratado e pelas regras constitucionais nacionais.

Assim, a presença da populidade de modo algum significaria a defesa pela introdução de um Regime Democrático Europeu, na Europa e para além dela - tal qual defendido pelo Federalismo Europeu. Sua atuação estaria resumida na necessária conservação do vazio no lugar do Direito e do Poder, sem pretender se incluir ela própria neste centro. A repulsa das demais escalas de existência significava também a própria repulsa, para não suprimir o caráter misto da organização jurídico-Política da Europa Unida pelas instituições da CECA.

A populidade estaria presente apenas para ajudar a conservar a politicidade da vida Comunitária da CECA quando da refundação do desenho institucional que articularia originalmente a dinâmica relacional entre as escalas de existência - mas jamais para poder se imprimir sobre as demais. Caso ela não aceitasse as modificações propostas, o sistema institucional de convivência seria preservado como o que fora até agora comentado: multiescalar, tenso, imanente e marcado pelo vazio de Poder - ou seja, Político.

Ademais, sobre a classificação das formas de Governo acima mencionadas, remetemos o leitor ao item 3.3.3.2.2., supra, onde se adota a divisão de POLÍBIO em oito formas. A coerência metodológica deste trabalho exige que se utilize a nomenclatura utilizada por este pensador grego, na medida em que ele é um dos pontos de partida fundamental da Tese.

${ }^{1014}$ Por exemplo, a adoção uníssona da uma nova dinâmica institucional afeita ao discurso Teológico-Político do Federalismo Europeu por força de atuação ideológica bem-sucedida de centros de defesa epistêmica e de difusão deste ideário entre os quadros burocráticos nacionais e comunitários... Nesse sentido, v. item 5.4.1., supra. 
palavras, tratava-se o recurso à populidade de um último mecanismo de controle previsto pelo Tratado da CECA, o qual estaria voltado à preservação do vazio no lugar do Direito e do Poder na vida comunitária: sem interferir nas propostas, a populidade atuaria para a permanência de uma Europa Unida em torno de um centro normativo multiescalar e jamais ocupado.

Para serem bem-sucedidas, as tentativas de usurpação deste centro ${ }^{1015}$ deveriam superar no fim as resistências populares nacionais à pacificação unidimensional da vida comum na Europa em torno de um discurso transcendente ou transcendentalizado fundado em um padrão normativo dado por escala de existência que preencheria de antemão e em caráter incondicional o lugar do Direito e do Poder na Europa Unida.

Ao mesmo tempo, para as propostas de alteração do Tratado de Paris de 1951 serem adotadas, deveriam elas não ameaçar a tensa estabilidade multiescalar da vida comum Política da Europa Unida pela CECA. A populidade deveria assegurar que esta não seria esquecida por qualquer iniciativa futura de modificação das instituições. Por isso mesmo, pode-se dizer que a previsão normativa do artigo 96 do Tratado da CECA atribuíra à populidade o papel de refundar de maneira contínua as Leis da CECA.

Assim, a atuação ratificadora da populidade representaria o último nicho de resistência Política à introdução do Teológico-Político durante a vivência da CECA. Ou ainda, a convocação para a atuação da populidade no procedimento de alteração das disposições institucionais da CECA operaria como engenhoso expediente institucional voltado a assegurar, enfim, que as tentativas imoderadas de preenchimento uniescalar do lugar do Direito e do Poder na vida em comum ao menos não encontrariam caminho livre para sua imediata e desenfreada totalização. A resistência poderia até não ser bem-sucedidade, mas fora, de todo modo, institucionalmente prevista.

\subsubsection{Aprovação da União Política da Europa Constituída pelo Tratado de Paris} $\underline{\text { de } 1951}$

O primeiro parágrafo do artigo 99 do Tratado da CECA determinava que o Tratado deveria ser ratificado por todos os Estados-Membros ${ }^{1016}$, de acordo com as respectivas regras constitucionais nacionais, e que os instrumentos de ratificação deveriam ser

\footnotetext{
1015 Oriundas das demais escalas de existência participantes da vida em comum da CECA.

1016 É precisamente este termo utilizado pelo Tratado da CECA: "Estados-Membros", e não "Estadossignatários", em seu artigo 99, primeiro parágrafo. Todavia, este último termo é empregado pelo mesmo artigo, no parágrafo seguinte, como se verá algumas linhas a seguir.
} 
depositados perante o Governo da República Francesa. O mesmo dispositivo previa em seu segundo parágrafo que o Tratado entraria em vigor no dia em que houvesse o depósito do instrumento de ratificação por parte do último Estado-signatário que cumprisse essa formalidade.

Por fim, o último parágrafo do mesmo artigo 99 estabelecia que, caso todos os instrumentos de ratificação não tivessem sido ainda depositados em seis meses contados da assinatura do Tratado ${ }^{1017}$, os Governos dos Estados-Membros que já houvessem depositado seus instrumentos de ratificação poderiam se concertar para discutir as medidas a serem tomadas.

Como visto no item anterior ${ }^{1018}$, a História da CECA permite perceber que o procedimento de ratificação adotado por cada Estado-signatário da CECA consistia em exigir que o documento jurídico-normativo internacional fosse aprovado pela maioria de ao menos uma das Casas dos Parlamentos nacionais. Era no interior das diferentes formas constitucionais nacionais de reconhecimento de participação popular dos EstadosMembros da CECA que se assegurara a presença da populidade na vida em comum, a fim de exercer seu contrapeso fundamental.

Ademais, é importante salientar que no comentário a este dispositivo em especial, a ênfase a ser dada na análise que segue reside precisamente na oposições escalar normativamente previstas pelo artigo 99 com relação à atuação da populidade.

Por essa razão, entenda-se que não será dada a atenção à regulamentação sobre o procedimento de ratificação (depósito do instrumento perante o Governo da França), à disciplina do momento em que o Tratado entraria em vigor (data do depósito do último instrumento de ratificação), e nem à concertação entre os Estados-Membros na hipótese de nem todos os Estados-signatários terem ratificado o Tratado da $\mathrm{CECA}^{1019}$.

A análise da atuação da populidade neste item é bastante semelhante à desenvolvida no item anterior ${ }^{1020}$, na medida em que se trata de igual invocação desta escala de existência ao longo de todo o Tratado afastada para agir de maneira contundente em

\footnotetext{
${ }^{1017}$ Como visto no final do Sexto Capítulo, supra, a assinatura do Tratado que Instituiu a CECA ocorreu em Paris, em 18.4.1951.

${ }^{1018}$ Item 7.3.2.1., supra.

${ }^{1019}$ Até porque, no que se refere a esta última exclusão, há que se notar que historicamente se provou que todos os Estados-signatários ratificaram o Tratado da CECA. Nenhum deles o fez no prazo de 6 (seis) meses previsto no artigo, é bem verdade (v., nesse sentido, a nota de rodapé 770 , supra). De todo modo, o comentário a esta disposição normativa não utilizada historicamente apenas estenderia inutilmente o presente estudo, razão pela qual não será comentada a articulação normativa referente ao último parágrafo do artigo 99 do Tratado da CECA.

${ }^{1020}$ Item 7.3.2.1., supra.
} 
momento crucial para a vida comum da CECA. Por esse motivo, para uma compreensão mais completa da complexidade do argumento, remetemos o leitor ao item anterior, com a ressalva de que deve estar atento de que se trata, aqui, de momento importante de outra natureza: o de fundação da Comunidade Política.

O artigo 99 do Tratado da CECA era o penúltimo dispositivo daquele documento jurídico-normativo internacional. Efetivo artigo de fechamento da série de disposições normativas do Tratado preocupadas com as oposições escalares ${ }^{1021}$, seu parágrafo primeiro introduzia aqui a lembrança de que, por mais que tivesse havido uma concertação intergovernamental visando a uma vida em comum durante as discussões que culminaram na redação e na assinatura do Tratado da Paris de 1951, seria indispensável a ratificação deste documento jurídico-normativo internacional por parte dos Parlamentos nacionais de cada um dos Estados-Membros.

Mais do que mero cumprimento de requisito jurídico-formal de entrada em vigor de um Tratado Internacional, a presente previsão de necessária ratificação adquiria no interior deste trabalho profunda significação jurídico-política.

Lembre-se de que, durante as discussões em Paris, em 1950, as estatalidades intergovernamentalmente articuladas haviam se comprometido ${ }^{1022}$ em adotar um método pluriescalar voltado à formação de instituições multidimensionais a serem plasmadas no Tratado. Elas deveriam se ocupar da produção pluriescalar de um centro normativo comum vazio e descentralizado, a fim de instaurar Leis Políticas entre os participantes da vida em comum da CECA.

Ao recusar a lógica da barganha e da negociação, os países haviam sinalizado efetiva opção por pensar "europeiamente" os problemas concretos sensíveis comuns. E, por esse motivo, o Tratado invocara a presença da populidade para que precisamente sobre este ponto atuasse, a fim de que conferisse o necessário lastro popular que reconhecesse o cumprimento de tais determinações sem qualquer ofensa uniescalar de suas próprias escalas de existência parciais.

Em outras palavras, a ação normativamente prevista para a populidade consistia em encontrar nesta dimensão existencial não comprometida em momento algum com a

1021 O artigo 100 do Tratado da CECA apenas afirmava que o Tratado havia sido redigido em uma única versão, a qual seria depositada nos arquivos do Governo da República Francesa. O mesmo artigo determinava ainda que o Governo Francês enviaria uma cópia certificada a cada um dos Governos dos Estados-signatários. Dessa forma, percebe-se que o artigo 99 do Tratado da CECA é o último em que aparece efetivamente uma regulamentação normativa preocupada com as oposições escalares constitutivas da vida em comum da CECA. Por essa razão, pode-se dizer que este dispositivo é o fechamento das disposições jurídiconormativas preocupadas com as oposições escalares na Comunidade.

${ }^{1022}$ V. item 6.3.3., supra. 
redação do Tratado, nem mesmo com a disciplina normativa futura do uso e da administração do carvão e do aço ${ }^{1023}$, a âncora que certificaria o sucesso jurídiconormativo institucional de instauração de Leis Políticas na Europa.

Tendo frescos em sua memória os horrores da Segunda Guerra Mundial - a qual derivara exatamente da pretensão de unidimensionalização totalizante da vida na Europa a partir da medida estabelecida por uma estatalidade isolada, a populidade atuaria neste preciso momento final para não aprovar um modo de relações constituído por desenho institucional que pudesse deixar passar (i) possíveis brechas à repetição de tentativas de unidimensionalização totalizante por parte de uma das estatalidades isoladas participantes (Estados-Membros); (ii) possíveis brechas à unificação unidimensional originada de uma perspectiva supranacional (Alta Autoridade ou Corte); e (iii) a repetição institucional de um simples e insatisfatório mecanismo de cooperação política intergovernamental (Conselho).

Assim, tratava-se de atribuição normativa de efetiva tarefa de fundação da Comunidade Política na Europa Unida pela CECA, pois a populidade apenas admitiria mediante ratificação - a instauração dessa vida em comum se ela se preservasse desde o princípio como desprovida de padrão normativo uniescalar prévio ou de qualquer tendência a assumir absolutamente um único modo de habitar o mundo.

Em outras palavras, a populidade atuaria nesse sentido para assegurar que o novo modo de relações entre países europeus não seria pautado por uma ocupação prévia e incondicional do lugar do Direito e do Poder. Ela somente reconheceria ter sido efetivamente adotado um novo modo de relações - de caráter Político - se nenhuma escala de existência - nem ela própria - pudesse pretender por meio das instituições previstas no Tratado ocupar unidimensionalmente o centro normativo compartilhado entre os diferentes participantes da vida em comum. Estaria fundada assim, em caráter originário, uma Comunidade Política na Europa instituída pela CECA.

7.3.2.3. O Significado Jurídico-Político da Populidade: Fundação e Refundação da Comunidade Política da Europa Unida pela CECA

Após a leitura dos dois itens imediatamente anteriores ${ }^{1024}$, torna-se mais clara a compreensão do significado jurídico-político da tarefa atribuída à populidade na 
construção da vida comum da CECA. Sua contribuição à manutenção do vazio no lugar do Direito e do Poder na Comunidade não se encontrava precisamente no dia-a-dia da atividade normativa sobre o uso e a administração do carvão e do aço, mas nos momentos mais importantes da vida comum: no de sua fundação, ou no de sua refundação, quando da definição da arquitetura institucional direitificada de uma União Política entre países europeus.

Note-se que, exercida mediante os respectivos Parlamentos nacionais de cada um dos Estados-Membros da $\mathrm{CECA}^{1025}$, a populidade atuava ao final de dois processos fundamentais - porque fundantes - para a construção política da vida comunitária, a saber: o de sua constituição inicial enquanto Comunidade Política na Europa, bem como o de sua conservação enquanto tal, ainda que com a reforma de suas instituições ${ }^{1026}$.

A restrição de sua atividade a essas duas ocasiões de modo algum diminuía sua contribuição à efetiva preservação do vazio do lugar do Direito e do Poder na Comunidade. Muito pelo contrário, sua atuação nestes dois momentos se reveste de profunda significação para a própria instauração deste centro permanentemente desocupado de produção de sentido normativo sobre as questões comuns. Em outras palavras, sem a ação da populidade nestes dois momentos cruciais, não haveria qualquer possibilidade, seja de inaugurar da União Política da Europa, seja de a preservar em seu ser Político.

Dito de outro modo, cabia à populidade nestes dois instantes a simplesmente fundamental tarefa de verificar, instituir e manter a agregação propriamente Política entre todas as outras escalas de existência na Europa Unida, de maneira a tornar real e concreta as pretensões de inaugurar um modo de relações absolutamente inaudito na História do continente europeu.

Tratava-se de tarefa de grande peso na concertação da vida em comum. Mesmo com a atuação de cada uma das demais dimensões existenciais implicadas na vida comunitária a ser constituída ${ }^{1027}$, se não houvesse a complementação dada pela atividade

${ }^{1025} \mathrm{O}$ que definia a limitação da atuação da populidade à regulamentação jurídico-constitucional nacional de cada um dos Estados que compunham a CECA.

A análise desta dimensão, apesar de interessante, escapa aos objetivos de exame por parte deste trabalho. Conforme delimitado no item 2.1.2., supra, apenas será examinado por este estudo - inserto em eixo de preocupações acadêmicas com o Direito Internacional - o Direito Originário da CECA - que, enquanto Direito Comunitário, é Direito Internacional, como visto no Segundo Capítulo, supra, e como se mencionou ao longo de todo este trabalho.

Registra-se aqui, todavia, o convite a futuras reflexões sobre o tema. Sobre os índices de aprovação do Tratado da CECA pelos Parlamentos nacionais, remetemos à nota de rodapé 770, supra.

${ }^{1026}$ Examinados respectivamente nos itens 7.3.2.2. e 7.3.2.1., supra.

1027 Isto é, (i) das estatalidades isoladas e intergovernamental concertadas em vista da futura vida comum quando da assinatura do Tratado da CECA (item 7.3.2.2., supra), bem como (ii) das estatalidades (isoladas e 
da populidade, o espaço comum no interior do qual a formação compartilhada do sentido normativo último sobre o uso e a administração do carvão e do aço não poderia ser considerado como tendo sido constituído e preservado enquanto arena de oposições escalares institucionalmente estimuladas. A populidade estaria presente para certificar que a preocupação com uma vida Política na Europa teria sido adequadamente traduzida para o Direito Comunitário Originário (fundação institucional) e conservada quando de sua eventual modificação (refundação institucional).

A ação da populidade era assim a única apta a produzir o necessário efeito de agregação multidimensional das diferentes escalas de existência no interior de uma dinâmica relacional voltada a organizar jurídico-Politicamente a vida na Europa continental. Ancorada na lembrança dos terrores derivados de uma ausência de Leis na Europa continental, a imagem da pesada e traumática História da Europa vivida por cada uma das populidades assegurava a persistência renovada de uma percepção voltada a saber lidar de maneira inaudita com as tradicionais oposições escalares da Europa.

Deste modo, desde o princípio da Europa Politicamente Unida da CECA a populidade deveria atuar para chancelar que teria havido uma direitificação atenta à construção institucional de um espaço comum no interior do qual se impediriam e se represariam pretensões unidimensionais totalizantes nas atividades da CECA que pudessem a corromper e reinstaurar as experiências desastrosas da Segunda Guerra Mundial. Ao mesmo tempo, a populidade se ocuparia também da incumbência fundamental de assegurar que, nas eventuais tentativas futuras de reforma institucional da CECA, esse equilíbrio Político não seria rompido. Desta maneira, ela também atuaria vigilantemente para que as oposições escalares não produzissem alterações que permitisse reintroduzir a variável da solução armada no interior da Europa.

Em outras palavras, era a populidade responsável pela produção do indispensável lastro que pudesse assegurar desde o início da Comunidade e durante sua vivência multiescalar que o barco comum estivesse corretamente direcionado visando à preservação originária e continuada de Leis Políticas na Europa marcadas pelos contínuos ajustamento e equilíbrio mútuos entre as diferentes dimensões existenciais da vida comum.

A populidade era assim portadora de um Poder de reenvio originário e continuado da vida comunitária a ela mesma, isto é, de um Poder que relembraria à Comunidade Política ela mesma a necessidade de se fundar e de se refundar continuamente em torno do 
constituído e constitutivo vazio do lugar do Direito e do Poder. Se fora excluída da decisão sobre o sentido normativo comunitário derivado sobre a administração e o uso do carvão e do aço, a atuação da populidade era fundamentalmente indispensável para a constituição e para a permanência de uma Europa Unida em torno de um centro normativo multiescalar e jamais ocupado. Era a populidade assim o necessário suporte de estabilidade para a vida da Comunidade Política da CECA. Fundamental, porque fundante e refundante. 


\title{
CONCLUSÕES PARCIAIS
}

\begin{abstract}
esperemos que a capacidade de criação e de formulação de interpretações não seja soterrada ante as ruidosas manifestações de certezas, com a intransigência fundamentalista de quem se recusa a aceitar perguntas, talvez por duvidar das respostas - mais que temer a dúvida, cabe compreender o papel desta na história humana: na medida em que se puseram dúvidas, os seres humanos puderam buscar respostas para as perguntas; se as perguntas são proibidas ou são restringidas ao 'politicamente correto', ao ortodoxamente estipulado, não se poderá criar nada novo e o mundo se imobilizaria? ante tal possibilidade cabe clamar, em defesa do espírito crítico - todos nós precisamos preservar o direito de fazer perguntas, e de poder receber respostas, e ter o instrumental analítico para o exercício da crítica, de forma construtiva. (CASELLA, 2007a, p. 17).
\end{abstract}

\begin{abstract}
[N]enhum homem é tão louvado em alguma ação sua quanto aqueles que, com leis e com instituições, reformam repúblicas e reinos. Estes são, depois daqueles que fundaram religiões, os primeiros louvados. Como foram poucos os que tiveram ocasião de fazê-lo e pouquíssimos aqueles que souberam fazer, é pequeno o número daqueles que o fizeram. Essa glória é tão estimada pelos homens que eles nunca esperaram outra coisa senão alcançá-la, tanto que, não tendo podido fazer uma república de fato, alguns a fizeram por escrito, como Aristóteles, Platão e muitos outros, os quais quiseram mostrar ao mundo que, se não puderam fundar uma vida civil como Sólon e Licurgo, não foi por ignorância, mas pela impotência de colocá-la em ato. (MAQUIAVEL, 2010, p. 76 , grifos do autor).
\end{abstract}

A Parte Segunda deste trabalho procurou tratar conceitualmente da História e do Tratado da CECA, com o objetivo de interpretar tal Comunidade como experiência histórica particular do pós-Segunda Guerra Mundial que se manifestou como locus histórico de realização prática (institucional) de um novo modo de relações na Europa: o modo jurídico-Político não-estatal. A CECA deve ser compreendida duplamente como um exemplo inaudito de afirmação histórica e institucional deste novo modo de relações.

Os três Capítulos históricos acima apresentados tiveram por objetivo inserir a construção da CECA na cadeia histórica de eventos da qual fez parte, a fim de evidenciar esta Organização Internacional como índice simultâneo de uma preocupação de organizar jurídico-politicamente as relações na Europa no pós-Segunda Guerra Mundial tendo em vista a afirmação de Leis Políticas e o correlato repúdio constante à realização bemsuceidada de orientações Teológico-Políticas.

O estudo da História da adoção da OECE e do Pacto de Bruxelas como exemplos de cooperação intergovernamental - respectivamente, econômica e militar - entre países europeus apontou que a adoção destas duas Organizações Internacionais foi realizada com o objetivo de manter à distância da Europa Leis não-propriamente europeias. Frutos da oposição EUA versus URSS, a OECE e o Pacto de Bruxelas tiveram sua origem em 
pressões estadunidenses para uma progressiva incorporação de uma escala de existência não europeia na Europa.

Como visto anteriormente, a cooperação intergovernamental entre países europeus nestes dois casos foi opção institucional consciente: reconhecendo as limitações inerentes à cooperação intergovernamental (econômica e militar), os países europeus a adotaram para assegurar a limitada e distante interferência das oposições escalares extraeuropeias, de modo a que a ameaça do jurídico-Teológico-Político - representada pela dimensão existencial estadunidense - não encontrasse condições institucionais para compor as Leis da Europa do pós-Segunda Guerra Mundial.

Ao mesmo tempo, o exame da construção da cooperação política europeia do $\mathrm{CdE}$ permitiu perceber esta opção institucional como fruto de experiência histórica de contenção do Teológico-Político na primeira tentativa de organização jurídico-política da Europa. Fruto do ideário europeísta federal, o Projeto original de uma União Política da Europa que engendrou o CdE visava a uma efetiva unificação da Europa em torno do discurso uniformizante dos Direitos Humanos e da Democracia, no interior de um Estado Federal Europeu que suprimiria os diferentes Estados-nacionais europeus.

Da mesma forma, como visto anteriormente, a edificação do CdE enquanto mecanismo de cooperação intergovernamental teve por objetivo impedir a realização deste Projeto de se constituir um Estado Federal Europeu. A realização institucional prática do CdE frustrou o intento original dos defensores do Projeto Federalista, pois a deliberada ausência de mecanismos institucionais similares ao de um Estado - isto é, de mecanismos coercitivos - impediu o controle totalizante e homogeneizante da diversidade em nome de uma suposta unidade jurídico-política e cultural comum abstrata e transcendente da Europa.

Nos três casos acima mencionados, a cooperação intergovernamental foi assim a solução institucional para impedir a introdução de Leis Teológico-Políticas na nova organização jurídico-política da vida entre diferentes na Europa, fosse porque as Leis teriam origem em um ambiente extraeuropeu, fosse porque as Leis poderiam ensejar uma uniformização cultural da Europa a partir de uma medida única tornada transcendente, única e absoluta.

O percurso histórico seguido para a construção da CECA foi distinto dos três anteriores: a organização de um novo modo de relações entre os países europeus envolvidos na vida comum não se restringiu a uma simples reprodução do modelo de cooperação intergovernamental, mas também não visou à consecução de um Estado 
Federal Europeu. Se o objetivo era fazer funcionar a Política - e não simplesmente colocar em comum a produção de carvão e aço entre os países europeus, de maneira a impedir o recometimento de novas Guerras, este deveria ser atingido mediante um aparato institucional completamente novo - insatisfeito com as limitações da simples cooperação intergovernamental e receoso das uniformizações prometidas por um discurso Federalista.

Foram as normas jurídico-positivas de Direito Internacional constantes originariamente do Tratado da CECA o instrumento prático responsável pela invenção institucional de uma organização jurídico-Política (mais do que uma cooperação intergovernamental) não-estatal não-federal (menos do que um Estado Federal). Diferentes escalas de existência europeias deveriam conviver mediante um arcabouço institucional responsável pela contínua co-presença na determinação do destino comum.

A eleição do carvão e do aço enquanto elemento concreto apenas visou a estabelecer um objeto em torno do qual a vida em comum deveria se desenvolver entre os diferentes: deveriam ser instituídas Leis (mais do que uma cooperação intergovernamental), mas estas não deveriam unificar a pluralidade (menos do que Federalismo Europeu). O fator de União Política não deveria ser uma medida abstrata, mas um ponto de partida concreto, sensível e caro a todos, sobre o qual todos deveriam conjuntamente se debruçar continuamente para decidir em conjunto o sentido a ser impresso para construir e para manter uma vida em comum.

Os instrumentos jurídico-normativos do Tratado de Paris espelharam essa preocupação. Eles não apenas afastaram a possibilidade de recometimento de Guerras regionais, como também paralisaram pretensões de deslizes em direção ao TeológicoPolítico. A imunização da Europa contra a unificação transcendente fora assegurada (i) pelas interações escalares entre as dimensões participantes da vida comunitária da CECA e (ii) pela rejeição da possibilidade de sujeição das decisões da Comunidade a perspectivas de entidade a ela externa - em outras palavras, pela independência mantida pela CECA com relação aos demais Projetos de Europa Unida do período, sobretudo com relação à OECE e ao CdE.

A análise dos artigos selecionados do Tratado da CECA permitiu compreender o engenho jurídico-normativo da inteligência política prática que informou a arquitetura das instituições da CECA. Havia neste Tratado uma racionalidade arquitetônica bastante peculiar no desenho institucional da Comunidade, pois não se tratava de neutra e leviana divisão de funções, mas de verdadeiro arranjo técnico jurídico voltado a promover e a estabelecer um modo de vida novo de convivência entre diferentes escalas de existência. 
Foi possível perceber uma preocupação reiterada em promover embates entre diferentes tipos de escalas de existência no Tratado, seja por meio de distribuição de competências normativas (isto é, de participação na formação do sentido normativo da normas jurídica comunitária derivada), seja por meio de contenção de escalas de existência estranhas à organização jurídico-Política da CECA.

No que se refere às normas de oposições escalares derivadas de distribuição de competências normativas, é importante notar que o Tratado da CECA não distribuíra faculdades de participação do processo nomogenético apenas aos órgãos comunitários (Alta Autoridade, Conselho de Ministros e Corte), e não excluíra a participação dos Estados-Membros desse processo. A CECA não visara à consolidação e à segurança exclusiva de um ou de outro, pois suas normas jurídicas jamais deixaram de forçar continuamente a convivência entre cada um deles.

Em outras palavras, foi possível notar uma preocupação em utilizar normas jurídicas que estabelecessem freios e contrapesos (oposições) entre cada um dos participantes da vida comunitária: (i) entre os Estados-Membros, sem dúvida alguma, mas também (ii) entre estes e os órgãos comunitários (Alta Autoridade, Conselho de Ministros e Corte), da mesma maneira em que estabelecera (iii) entre os próprios órgãos comunitários entre si (Alta Autoridade, Conselho de Ministros e Corte).

Identificara-se ainda a presença de função de vigoroso peso atribuída aos povos de cada um dos Estados-Membros no final do Tratado: por meio dos Parlamentos nacionais, eles seriam responsáveis pela instauração da Comunidade (aprovação do Tratado como fundação institucional consciente de uma vida Política) e pela preservação dela diante de propostas de Reformas (aprovação de modificações no texto do Tratado como refundação institucional consciente de uma vida Política).

Assim, Alta Autoridade, Conselho de Ministros, Corte, Estados-Membros e povos dos Estados-Membros teriam sido apontados como participantes da vida nomogenética comunitária da CECA - cada um à sua específica maneira de perceber como deveria ser seguida a vida em comum. E, por esse motivo, o Tratado da CECA estabelecera um cuidadoso sistema de freios e de contrapesos mútuos (oposições) entre eles para assegurar que nenhuma dessas perspectivas orientasse por si só o sentido normativo comunitário a ser impresso sobre questões concretas sensíveis - referentes ao carvão e ao aço - tornadas comuns.

Nesse sentido, o Tratado da CECA não apenas atribuíra competências normativas aos órgãos comunitários, excluindo a participação dos Estados-Membros ou os povos 
europeus do processo nomogenético comunitário. Antes, o Tratado convidara cada um deles a participar continuamente e de forma ativa do processo de formação das principais decisões sobre o sentido normativo do Direito Comunitário Originário e Derivado. A CECA teria promovido um efetivo sistema político de contraposição contínua entre diferentes para construir normas jurídicas, ordenando um regime estável por meio da congregação de todas as partes.

No que se refere às normas de oposições escalares derivadas de contenção de escalas de existência estranhas à organização jurídico-Política da CECA, é importante frisar que foi observada uma preocupação explícita do Tratado em firmar uma independência de atuação bastante forte em relação a outros processos de aproximação de países europeus que se organizaram no período do pós-Segunda Guerra Mundial.

Se a CECA se dispunha normativamente a colaborar com Organizações Internacionais europeias de cooperação econômica (OECE) e política (CdE), essa relação não deveria ultrapassar esse estrito campo de colaboração, isto é, não se poderia compreender que essa relação permitiria instituir qualquer vínculo de subordinação do Projeto de Europa Politicamente Unida da CECA ao da OECE (cooperação econômica intergovernamental) ou ao do CdE (cooperação política intergovernamental).

Essa recusa de submissão dos objetivos da CECA aos da OECE e do CdE permite vislumbrar o quanto o Projeto de Europa Unida se mantinha distante de um Projeto simplesmente econômico cooperativo (OECE) e de um Projeto político voltado à constituição de um Estado Federal Europeu (CdE).

A instituição da CECA pode ser entendida assim como afirmação histórica da opção por uma organização jurídico-Política das relações entre alguns dos povos europeus no pós-Segunda Guerra Mundial. Esta opção pela CECA engendrara entre 1945 e 1951 a paulatina recusa de outras formas propostas de relações (Teológico-Políticas) no continente europeu mediante a instituição de singelos mecanismos jurídicos de cooperação intergovernamental (i) desprovidos de Leis (Pacto de Bruxelas e OECE), ou (ii) formados a partir de pretensão de instituir Leis unificadoras (CdE ideal), mas que institucionalmente foram impedidos de as realizar (CdE real).

Dessa maneira, a CECA pode ser compreendida como manifestação histórica da preferência por um sistema de convivência entre diferentes, a ser instituído e promovido, mas que deveria principalmente ser preservado. O Tratado da CECA foi o instrumento jurídico-normativo responsável para constituir e para conservar a opção institucional distinta das até então intentadas no imediato pós-Segunda Guerra Mundial. 
A CECA e seu Tratado Constitutivo se revelaram como uma engenhosa construção institucional expressa em normas jurídicas de Direito Internacional cuidadosamente refletidas. Eles se apresentaram como uma criação institucional consciente e minuciosamente calculada em suas estruturas normativas, a fim de impedir o ingresso do Teológico-Político na vida em comum recém-instaurada e de assegurar a preservação da dinâmica Política.

Após este primeiro movimento reflexivo de condensamento das principais conclusões que os quatro Capítulos desta Parte Segunda aportaram sobre o tema especificamente estudado, há que se esclarecer rapidamente como o presente estudo pôde contribuir originalmente ao pensamento jurídico acadêmico brasileiro em Direito Internacional. O novelo de informações - fruto do pensamento único ${ }^{1028}$ - deve ser aqui minimamente desemaranhado, a fim de salientar algumas das principais contribuições desta extensa análise de Zetética Jurídica da CECA.

A partir do minucioso estudo da construção histórica da CECA, entendida como manifestação jurídico-Política do fenômeno da integração, o presente trabalho pretende ter contribuído ao pensamento jurídico brasileiro em Direito Internacional em dois aspectos: metodológico e substancial.

No que se refere às contribuições de caráter metodológico, é importante enumerar os seguintes aspectos.

Como afirmado na Introdução Geral deste texto, o primeiro aspecto que deve ser considerado é precisamente o de se ter colocado em suspenso uma leitura jurídicoeconômica do processo da integração, para evidenciar seu aspecto jurídico-político - sem pretender anular ou desqualificar a leitura jurídico-econômica. Tratou-se apenas de apresentar uma leitura alternativa de um e mesmo fenômeno que é de especial interesse para os estudos contemporâneos de Direito Internacional, evidenciando possibilidades de interpretação de acordo com um referencial hermenêutico distinto do usual.

Assim, deixar de simplesmente se referir à CECA como (i) resquício do movimento de liberalização multilateral do comércio internacional inaugurado pela Conferência de Bretton Woods (1944); e, por isso mesmo, (ii) inserta na lógica geral do Acordo Geral de Tarifas e Comércio (GATT, sigla em inglês); ou mesmo, (iii) motor de promoção de Desenvolvimento Econômico regional, permite entreabrir outro leque de questões: como compreender alternativamente um mesmo fenômeno jurídico? Novas formas de

${ }^{1028}$ Tal qual salientado na nota de rodapé 136, supra. 
interpretação permitem alavancar não apenas novas respostas, como também novas perguntas.

Ainda no que se refere às contribuições metodológicas, há que se notar que o presente trabalho parte de uma chave de leitura jurídico-política original para os estudos brasileiros em Direito Internacional. Com efeito, a chave hermenêutica empregada ao longo de todo o trabalho resulta de síntese autonomamente efetuada do pensamento de importante pensador de Filosofia Política Antiga (POLÍBIO) com as contribuições intelectuais de importante pensador de Filosofia Política Contemporânea (Claude LEFORT).

Com isso, foi possível depreender a importância de determinado tipo normativo - as normas jurídicas de oposições escalares - para contruir institucionalmente um ambiente de convivência entre diferentes. Por meio de normas de oposições escalares, o Direito deteria importância fundamental para construir um ambiente institucional apto a promover tensões entre diferentes escalas de existência e, nesse sentido, para formar um regime Político ou Teológico-Político quando da direitificação de relações entre diferentes permanentemente em conflito.

Ademais, ainda no que se refere às contribuições metodológicas, não se pode ignorar que, em virtude de período de Pesquisas realizado durante o período de um ano junto ao Institut d'Histoire du Droit (IHD) da Université Panthéon-Assas (Paris II), o presente estudo teve plenas condições para encontrar, acessar e incluir neste texto informações extraídas a partir de documentos históricos exclusivos produzidos no período selecionado (1945 a 1951), onde se manifestaram as intensas discussões da época em torno dos Projetos de Europa Unida do pós-Segunda Guerra Mundial. Também foi possível trabalhar neste texto informações produzidas pela historiografia europeia recente sobre a História da Europa.

Deste modo, este trabalho pôde trazer ao conhecimento jurídico brasileiro informações mais completas sobre a História da CECA, de maneira que o pensamento jurídico nacional possa se beneficiar de fontes primárias e secundárias até então ou desconhecidas, ou não completamente trabalhadas.

A interpretação do material histórico exclusivo e do material historiográfico novo a partir da definição de uma chave de hermenêutica nova - leitura jurídico-política, a partir de conjunção de contribuições de POLÍBIO e de Claude LEFORT, bem como do próprio Tratado Constitutivo da CECA é uma escolha metodológica inovadora para os estudos 
brasileiros em Direito Internacional. De fato, tanto a História da CCA como seu Tratado foram aqui interpretados a partir de uma chave de leitura até então não utilizada.

A conjunção original do aparato interpretativo conceitual novo com elementos da experiência histórica e jurídico-positiva da CECA por si só deve ser considerada como contribuição relevante para a comunidade epistêmica jurídica nacional em Direito Internacional. De fato, a inserção de elementos da experiência já conhecidos - ou mesmo de elementos desconhecidos - em campo significativo distinto é, por si só, um esforço analítico original que deve ser academicamente reconhecido como tentativa de construir um conhecimento jurídico novo.

Felizmente, além dessa contribuição metodológica, o presente estudo foi capaz de aportar substantivamente um conhecimento jurídico novo - isto é, dentro de um novo campo significativo de interpretação - para os estudos brasileiros em Direito Internacional. E isso deriva precisamente da conjunção da chave de leitura com o estudo da História dos Projetos de Europa Unida paralelos ao da CECA, com o da História da CECA, e com o do Tratado da CECA. Diferentes aspectos poderiam ser aqui suscitados, mas serão aqui apontados apenas os principais.

A escolha por uma leitura jurídico-política da integração permitiu evidenciar aspectos outros do fenômeno a partir de uma nova chave de significação. Alguns conceitos usualmente utilizados para compreender o processo de integração realizado entre os países europeus dentro de uma perspectiva econômica sofreram intenso deslocamento significativo em virtude da eleição de outro centro doador de sentido - de modo que novas conclusões puderam ser extraídas.

Dizer que a integração pode ser compreendida a partir de uma perspectiva jurídicopolítica implica rejeitar a ideia usualmente aceita (BERL, 1961, p. 4; HABERMAS, 2011a; POZO, 2011a, p. 63; QUADROS, 1984, p. 121-4; RAMOS, 2005, p. 648-9 e 657; VEÇOSO, 2006, p. 32-3) de que integração política da Europa apenas teria advindo após o sucesso da integração econômica. Antes, (i) a integração política da Europa não fora planejada como uma mera e eventual consequência da integração econômica, isto é, (ii) estava também presente a preocupação com o fomento de uma integração política da Europa por meio da CECA. Tratou-se de uma recusa à postergação da realização de uma integração política - ainda que o político tenha adquirido um sentido peculiar.

Compreender jurídico-politicamente o princípio da integração europeia (CECA) adquire neste trabalho um sentido bastante específico. Não se trata de uma leviana afirmação de que a CECA era integração jurídico-política por ter sido regulamentação 
jurídica oriunda de barganhas políticas entre seus seis Estados-Membros (RAMOS, 1996, p. 647). O Direito não era simples técnica pura resultante de jogos políticos fundados nas egoísticas vontades estatais negociadas, mas uma ferramenta conscientemente promotora de um modo de vida político. E isso não significa afirmar que a CECA era política por ter sido o primeiro passo em direção à construção de um futuro Estado Federal Europeu fundado nos Direitos Humanos e na Democracia: a CECA foi precisamente a opção tomada em 1951 para impedir o sucesso do Projeto Federalista Europeu que rondava os discursos políticos de alguns intelectuais desde o período entre guerras.

Lembre-se de que, precisamente para este fim de instaurar uma Federação Europeia por meio da promoção de Direitos Humanos e da Democracia, fora fundado em 1949 o Conselho da Europa (CdE), por meio do Tratado de Londres - ainda que tal iniciativa tenha fracassado e tenha sido reduzida, naquele momento, a um mecanismo político intergovernamental. Ao mesmo tempo, não se pode ignorar que os termos "Direitos Humanos" e "Democracia" não constavam do texto do Tratado da CECA.

Por esse motivo, não se pode derivar a condição de fenômeno jurídico-político da CECA de uma suposta afirmação dos Direitos Humanos, da Democracia ou de um Estado Federal Europeu. Tais preocupações não estavam presentes em seu Tratado Constitutivo. Mais uma vez, evidencia-se aqui a ideia de que a noção de político neste trabalho detém um significado mais circunscrito.

Ademais, afirmar que a CECA introduzira uma organização jurídico-Política da vida na Europa não poderia significar que se visava à formação de um Estado Europeu, pois as instituições foram arquitetadas para formar algo distinto de um Estado. Ao longo de todo o Tratado da CECA, pode-se perceber um movimento contínuo de recusa a qualquer órgão comunitário (Alta Autoridade, Conselho ou Corte) a possibilidade de pretender centralizar o uso da força: o monopólio legal da violência haveria que residir apenas entre os Estados-Membros. A vida em comum deteria um Poder jurídico-Politicamente constituído, mas não disporia de instrumentos coercitivos que pudessem acompanhar o sentido normativo por ela impresso.

Assim, além de colocar em suspenso as explicações econômicas usualmente dadas para compreender a História da CECA, este trabalho também negou a possibilidade de se atribuir a esta Organização Internacional o caráter de ser fenômeno jurídico-político (i) por ser produto de negociação diplomática; (ii) por ter sido manifestação originária de uma pretensão de construir um Estado Federal Europeu sustentado nos Direitos Humanos e 
na Democracia; ou (iii) por ter visado a regulamentar o uso da força (militar) na Europa. $\mathrm{O}$ trabalho mostra que a condição jurídico-política da CECA derivava de outro aspecto.

A noção de jurídico-político neste trabalho detém contornos específicos e remete à distinção acima entre coexistência, cooperação e convivência nas relações entre os Estados $^{1029}$. A CECA pode ser entendida como um fenômeno jurídico-político simplesmente em virtude de ela ter viabilizado, por meio das instituições internacionais de seu Tratado, um sistema de convivência entre diferentes tradicionalmente opostos entre si em termos bélicos.

Até o final da Segunda Guerra Mundial, as relações entre os países era pautada pelo paradigma da coexistência, isto é, pela persistência de um discurso de Direito Internacional exclusivamente moldado para e pelos os Estados. Sua lógica era a do bilateralismo, da coordenação ou de uma sociedade relacional. Este foi o fundamento do Direito Internacional em suas origens (séculos XVI e XVII) e entendia a relação entre países como relações entre entidades políticas independentes, centros de poder não subordinados a uma autoridade superior, salvo mediante consentimento, usualmente expresso por meio de Tratados Internacionais. Fundado em normas de obrigação negativa (mútua abstenção), era o Direito Internacional estritamente diplomático.

Com o final da Segunda Guerra Mundial, tende-se a afirmar que as relações entre os países passou a se desenvolver a partir de uma racionalidade de cooperação, isto é, uma nova estrutura de Direito Internacional que partiria de sujeitos de Direito Internacional adicionais, como as Organizações Internacionais. Os Estados seriam convidados a se concertar organizada e ativamente dentro destas, o que qualificaria sua racionalidade como sendo a do multilateralismo ou a da sociedade institucional. Foram assim introduzidas normas jurídicas internacionais voltadas a satisfazer interesses e necessidades comuns por meio de instituições comuns. Nesse sentido, a cooperação sempre seria manifesta por meio de instituições (cooperação institucionalizada), abandonando a perspectiva de que as relações entre Estados se dariam exclusivamente mediante relações diplomáticas.

O estudo da História dos Projetos de aproximação dos países da Europa iniciados imediatamente após o final da Segunda Guerra Mundial permite os compreender como compartilhando do intento de se afastar do paradigma da coexistência. A OECE, a Organização do Pacto de Bruxelas e o CdE se pautaram pelo paradigma da cooperação, cada qual objetivando instituir a cooperação no interior de áreas distintas, a saber,

${ }^{1029}$ V. nesse sentido nota de rodapé 2 e item 2.1., ambos supra. 
respectivamente, a cooperação na área econômica, a cooperação na área militar e a cooperação na área política.

O estudo da História da CECA segue, por seu turno, um caminho diferenciado. Se, por um lado, ela compartilha o intento de se afastar do paradigma da coexistência, por outro lado, ela também não pode ser reduzida à mera condição de cooperação intergovernamental técnica no setor econômico do carvão e do aço.

Entendida como um processo de integração, a CECA deve ser considerada como mecanismo institucional que "inovou a inovação", na medida em que também não se contentou com a simples condição de cooperação. Sendo algo "um pouco a mais" do que a cooperação - e, ao mesmo tempo, "algo a menos" que um Estado, a CECA foi exemplo histórico que inaugurara um efetivo novo modo de relações entre países europeus no pósSegunda Guerra Mundial, precisamente por não se basear nem no paradigma da coexistência, nem no da cooperação, nem no estatal.

Em vez de persistir no uso do termo "integração" para designar a CECA - pois o uso desta expressão está fortemente vinculado na tradição brasileira para indicar o aspecto simplesmente econômico da CECA, isto é, por ser associado imediatamente à ideia de "integração econômica", o trabalho optou por recorrer a outro termo para qualificar esse adensamento jurídico-institucional das relações entre os países europeus.

A fim de evidenciar o caráter jurídico-político envolvido na construção da CECA e de manter à distância explicações econômicas, escolheu-se o termo "convivência", para enfatizar a preocupação de fazer conviver diferentes no interior de um sistema institucional especialmente desenhado para instaurar uma vida em comum entre eles - vale dizer, uma organização jurídico-política de suas relações.

Coexistência, cooperação e convivência são termos que buscam designar maneiras distintas de estabelecer juridicamente as relações entre os países europeus no pós-Segunda Guerra Mundial, sem que se possa dizer que, desde então, um modelo tenha "prevalecido historicamente" sobre outro- pois há até hoje elementos jurídicos que caracterizam todos eles. O que diferencia cada um deles é precisamente o modo qualitativo de organização jurídica das relações.

Se em um paradigma não existe uma preocupação com a construção de instituições comuns (coexistência), em outro, as instituições são conformadas por normas jurídicas para estimular a simples barganha intergovernamental de posições (cooperação). A tabela a seguir ajuda a esclarecer a diferença entre cada uma delas. 


\begin{tabular}{|c|c|c|c|}
\hline Modelo & Direito & $\begin{array}{c}\text { Escala de Existência } \\
\text { Institucionalizada }\end{array}$ & Espécie Normativa \\
\hline Coexistência & $\begin{array}{c}\text { Direito Internacional } \\
\text { Clássico }\end{array}$ & Nacional & $\begin{array}{c}\text { Abstenção } \\
\text { (obrigação negativa) }\end{array}$ \\
\hline Cooperação & $\begin{array}{c}\text { Direito das Organizações } \\
\text { Internacionais }\end{array}$ & Intergovernamental & $\begin{array}{c}\text { Ação } \\
\text { (obrigação positiva) }\end{array}$ \\
\hline Convivência & Direito Comunitário & $\begin{array}{c}\text { Nacional, } \\
\text { Intergovernamental e } \\
\text { Supranacional }\end{array}$ & $\begin{array}{c}\text { Oposição } \\
\text { (contenção escalar) }\end{array}$ \\
\hline
\end{tabular}

Tabela Única: Resumo das Características dos Modelos de Direito Internacional.

Diferencia-se a cooperação da convivência (integração) apenas em virtude da qualidade das instituições: a cooperação seria responsável por Organização Internacional de caráter intergovernamental, enquanto que a convivência seria responsável por uma Organização Internacional de caráter supranacional. Nesta última se aponta tradicionalmente como característica a supranacionalidade pelo fato de que as decisões não são tomadas por unanimidade (consenso no resultado das negociações), mas por maioria (visando à preservação do interesse comunitário, ainda que contrariamente à perspectiva de um ou mais Estados) $)^{1030}$.

Este trabalho enfatiza, todavia, uma diferença ainda mais precisa entre a cooperação e a convivência: a qualidade da norma jurídica utilizada para fomentar a aproximação entre países europeus.

Se na cooperação se pode perceber uma preocupação em assegurar a satisfação de interesses e de necessidades comuns mediante processo de negociação ativa entre os Estados, o exemplo institucional analisado da CECA revela que a convivência se estrutura segundo a preocupação de utilizar normas jurídicas que estabeleçam principalmente contenções escalares mediante freios e contrapesos entre cada um dos participantes da vida comunitária: (i) entre os Estados, sem dúvida alguma, mas também (ii) entre estes e os órgãos comunitários (Alta Autoridade, Corte e Conselho de Ministros), da mesma maneira em que estabelecera (iii) entre os próprios órgãos comunitários entre si (Alta Autoridade, Corte e Conselho de Ministros). Identificara-se ainda a presença de robusta função atribuída aos povos de cada um dos Estados-Membros no final do Tratado: por meio dos Parlamentos nacionais, eles seriam responsáveis por importantes decisões relativas à vida em comum.

${ }^{1030}$ Sobre supranacionalidade, v. nota de rodapé 410, supra. 
Estão assim presentes, em um regime de convivência, não apenas escalas de existência estatais, intergovernamentais, supranacionais ou populares, mas todas ao mesmo tempo, em conjunto, convivendo umas com as outras no interior de um sistema de vida direitificado caracterizado pela permanência da tensão escalar - isto é, no interior de um sistema de vida constituído normativamente por meio de instituições jurídicas positivadas em um Tratado Internacional. Se na cooperação não existe uma preocupação em estabelecer um regime de convivência entre diferentes (não se procura instaurar Leis), na convivência o objetivo de organizar jurídico-politicamente as relações se mostra de maneira mais evidente (Leis).

Neste aspecto, lembre-se ainda de que as leituras tradicionais em torno da Europa Unida costumam ressaltar impensadamente o mantra de que a todo o corpo normativo da CECA girava em torno da Alta Autoridade como o centro de Poder e de produção normativa da Europa Unida ${ }^{1031}$.

Todavia, o estudo minucioso de cada passo normativo do Tratado da CECA revelou que não apenas a Alta Autoridade não estava inserida isoladamente no centro nomogenético comunitário, como também que a configuração institucional da Europa Unida sucessivamente desmentia, por meio do Tratado de Paris de 1951, a escolha pela permanência de qualquer escala de existência para imprimir total e unidimensionalmente um modo de habitar o mundo sobre os demais.

Com efeito, em todo o Tratado foi possível identificar um contínuo esforço da engenharia institucional de negar ininterruptamente a todos e a cada um a possibilidade de definir unilateral e unidimensionalmente o sentido normativo sobre as questões concretas sensíveis comuns. Tal decisão derivaria, não de Um ou de poucos modos de habitar o mundo, mas a partir do meio do círculo vazio, sempre aberto a inumeráveis e incontroláveis possibilidades resultantes normativas da conjunção interativa multiescalar entre cada modo de experienciar o mundo.

Ressalte-se aqui, sobre este aspecto em particular, que se pode sugerir, ainda, uma compreensão mais precisa do Direito Comunitário produzido pela vida comum (Direito Comunitário Derivado): produto de interações escalares, ele não poderia ser considerado um Direito nacional - por não ser produto exclusivo de uma estatalidade isolada, nem um Direito intergovernamental - por não ser fruto apenas das estatalidades

${ }^{1031}$ Como indicado na nota de rodapé 202, supra. 
intergovernamentais, muito menos Direito supranacional - por não ter sido produzido apenas a partir da escala de existência supranacional.

Como visto anteriormente ${ }^{1032}$, o ambiente institucional do Tratado da CECA não incumbira seus órgãos comunitários a produzir normas jurídicas em nome da Comunidade, a partir de seu próprio modo de habitar o mundo (supranacional). A arquitetura institucional do Tratado da CECA estava cuidadosamente voltada à preservação da multidimensionalidade permanentemente tensa na formação do sentido normativo sobre questões concretas comuns sensíveis (carvão e aço) e, por isso, diferentemente do que o discurso monolítico da tradição jurídica afirma, o Tratado da CECA não atribuíra a nenhuma das supranacionalidades vigentes em seus dois órgãos comunitários (Alta Autoridade e Corte) um papel central de destaque na produção normativa. Estes não dariam a palavra última sobre as normas jurídicas, pois deveriam levar em consideração as medidas de existência apresentadas pelos demais partícipes da vida em comum.

O Direito assim produzido deveria ser compreendido como Direito efetivamente Comunitário, na medida em que seria produto da dinâmica propriamente Política de compartilhamento do processo de formação da decisão sobre o sentido normativo sobre questões comuns. Mais simplesmente, ele seria um arcabouço jurídico-normativo de uma organização jurídico-Política de convivência entre diferentes no interior de uma vida comum, ou melhor, de uma vida tornada comum, de uma vida comunitária. Nem nacional, nem intergovernamental, nem supranacional, mas o produto do encontro de cada uma das respectivas escalas de existência - sob a atenta vigilância da populidade.

Por fim, ao inserir o estudo histórico da CECA no interior de um campo hermenêutico jurídico-político, o presente trabalho pôde operar um deslocamento significativo da noção de Funcionalismo - termo usualmente utilizado para classificar a CECA como uma via de União da Europa distinta ao mesmo tempo de uma lógica estritamente Unionista (CdE real) ou Federalista (Projeto Original do CdE).

Como visto anteriormente ${ }^{1033}$, não se contentando com as limitações do Unionismo Europeu, nem pretendendo apostar absolutamente na ousadia imoderada do Federalismo Europeu, a proposta de integração europeia setorial de Robert SCHUMAN detinha efetivo cunho prático, pois estava comprometida com o fazer funcionar a Política no continente europeu.

\footnotetext{
${ }^{1032}$ Nota de rodapé 862, supra.

${ }^{1033}$ V., nesse sentido, os Capítulos Quinto e Sexto deste trabalho, principalmente os itens 5.2. e 6.2.2.5., bem como a nota de rodapé 734, todos supra. Aqui se remete rapidamente ao teor geral da discussão.
} 
Usualmente se compreende, a partir de uma leitura jurídico-econômica da CECA, que o Funcionalismo não era necessariamente oposto ao Federalismo, afirmando-se ainda ser uma opção funcional por ter visado ao simples estabelecimento de uma rede de cooperação funcional entre setores da atividade econômica de diferentes Estados para tornar impossível ou menos provável a Guerra entre estes. Essa mudança de atitude derivaria, segundo essa perspectiva, do simples fato de que o pacto selado por meio do Tratado da CECA teria imposto pesados custos econômicos que desestimulariam o rompimento das relações e o descumprimento de obrigações.

Este estudo propõe assim uma ressignificação do termo Funcionalismo, de maneira a associá-lo à proposição de Europa Unida forjada a partir da opção pela imanência típica da Política.

O Funcionalismo seria uma efetiva terceira via jurídico-política institucional de fomento de uma organização jurídico-Política das relações entre os países europeus no interior de um sistema de convivência entre diferentes permanentes. Esta via em particular residiria, por assim dizer, no meio entre os dois extremos de (i) convivência política unificadora (Federalismo) ou (ii) cooperação política intergovernamental (Unionismo). Por nem a um, nem a outro, conceder intemporalmente o lugar do Direito e do Poder, manteria ser a condição permanente da integração política a de um necessário vácuo de Poder.

A CECA representaria a via Funcionalista, assim, por ter se preocupado simplesmente em assegurar por meio de suas instituições o funcionamento de uma vida em comum entre diferentes, os quais permaneceriam em suas condições de diferentes. O Direito Comunitário Originário da CECA expressaria na conformação de sua engenharia institucional o próprio intento de realizar progressiva e continuamente, aqui e agora, esta convivência em si mesma, à medida que os problemas do viver em comum se apresentassem para o conjunto e exigissem, em cada momento, de todos, uma nova solução sobre questões comuns concretas sensíveis.

A partir dos aspectos acima salientados, é possível compreender que determinadas parcelas do conhecimento jurídico brasileiro em Direito Internacional sobre o processo de integração europeu iniciado pela CECA puderam sofrer alguns deslocamentos significativos importantes. Estes poderão servir como ponto de partida de futuras Pesquisas sobre o tema, bem como para fundamentar uma Nova Agenda de Pesquisa em Direito Internacional sobre a CECA, sobre a EU e, talvez, sobre outros processos de integração contemporâneos. 
Com isto, torna-se finalmente viável indicar a possibilidade de responder completamente a pergunta formulada ao início deste trabalho: quando, como e por meio de quais instituições, países europeus tradicionalmente opostos em termos bélicos conseguiram estabelecer entre si um novo modo de relações, o qual tornou impossível e impensável a deflagração de uma nova Guerra regional na Europa.

Quando: certamente a partir da Segunda Guerra Mundial (1945), mas, diante das demais experiências históricas de Projeto de Europa Unida (OECE, Pacto de Bruxelas e $\mathrm{CdE}$ ), pode-se dizer que o novo modo de relações visado por este trabalho surgira apenas em 1951, com a assinatura do Tratado de Paris, o qual constituiu a CECA.

Como: mediante a opção pelo estabelecimento de Leis, isto é, de uma organização jurídico-política das relações entre diferentes tradicionalmente opostos (direitificação). Isso significa dizer que se reconheceu a insuficiência de um modelo de Direito Internacional de mera coexistência, e que seria limitado o estabelecimento de uma simples cooperação (OECE, Pacto de Bruxelas e CdE real). Mais do que isso, percebeu-se ser necessário estabelecer juridicamente uma vida comum entre todos os países envolvidos, de modo a que todos pudessem dirigir em conjunto uma vida tornada entre todos pública (Projeto Original CdE e CECA).

Por meio de quais instituições: o Direito Internacional Público seria o instrumento jurídico-normativo positivo responsável para instituir o novo modo de relações (convivência, ou ainda, segundo Leis), isto é, seria ele o mecanismo apto a elaborar as instituições responsáveis pela edificação e pela conservação Originária e Derivada daquela vida em comum.

Para tanto, foi escolhido para a CECA um tipo normativo novo: não normas de abstenção (coexistência), nem normas de ação (cooperação), mas normas de oposição (convivência) entre diferentes escalas de existência, de maneira a que uma pudesse refrear tentativas de regência unilateral, unidimensional e totalizante do sentido normativo a ser impresso sobre a vida em comum.

A convivência seria assim instaurada normativamente mediante instituições responsáveis pela direitificação das relações entre as escalas de existência, vale dizer, por meio de normas jurídicas que colocariam em tensão contínua as diferentes dimensões existenciais envolvidas, de tal modo que nenhuma delas poderia nem mesmo pretender tomar o lugar do Direito e do Poder na definição do destino comum. As Leis a serem instauradas (como) seguiriam uma orientação material específica: não a unificação da 
pluralidade escalar (Projeto Original CdE), mas de preservação permanente da pluralidade dimensional (CECA).

É deste modo que se pode dizer, enfim, que a integração europeia iniciada pela CECA pode ser entendida como um fenômeno jurídico-Político: a organização jurídicoPolítica da vida na Europa entre os seis países europeus fundadores da CECA foi viabilizada por meio de um regime misto de produção normativa cuidadosamente regulamentado pelas instituições do Direito Comunitário Originário da CECA - o Tratado da CECA, fundado em normas de oposições escalares que contrapuseram continuamente as diferentes dimensões existenciais.

De fato, a União Política da Europa pela CECA, fundada em normas de oposições escalares, buscou (i) assegurar a imanência no fundamento do Poder, por meio da (a) recusa da transcencência escalar intraeuropeia federalista e extraeuropeia estadunidense, (b) construção de barreiras institucionais jurídico-normativas à transcedentalização de escalas de existências participantes da vida em comum (estatalidades, supranacionalidades e populidade). Neste último aspecto, aliás, por meio da (ii) promoção contínua de tensões entre cada uma das medidas de existência que participavam da vida comunitária, as normas jurídicas do Tratado da CECA preservaram (iii) a multidimensionalidade no processo de formação do sentido normativo a ser impresso sobre as questões concretas sensíveis comuns (carvão e aço), e (iv) o correlato vazio no lugar do Direito e do Poder - pois ninguém poderia determinar por si só sentido a ser produzido no interior do centro nomogenético da Comunidade.

Nenhum estudo histórico deve buscar reconstruir literariamente uma realidade por meio de livre exercício narrativo. Trata-se antes de um exercício intelectual voltado a apresentar uma narrativa sobre o passado, sempre tendo em vista um diálogo mais ou menos explícito com a sociedade presente. Ele nada mais é sempre fabricação no presente, não um mero "testemunho fiel do passado".

O estudo do passado não se apresenta como fonte pura e ilusória de deleite, de comoção, ou simplesmente de emoções. Muito pelo contrário. O passado é produto de experiência vivida, e seu conhecimento mais detalhado deve dialogar com problemáticas atuais. Apenas deste modo será possível produzir respostas capazes de mudar percepções e revalorizar aspectos até então ignorados (CASELLA, 2012, p. 25; KHOURY, 2012, p. 89; LEFORT, 1992a p. 142; PÉDECH, 1964, p. 34; POLYBE, 2003, p. 228 e 548; SEBASTIANI, 2006a, p. 75, 2007a, p. 71-5). 
Conhecer a História não é um passatempo, nem uma exposição supérflua ou irrefletida, mas uma escolha deliberada pelo aprendizado virtuoso diante de exemplos passados para extrair uma utilidade para o presente mediante a aquisição da "intelligence, tant sur la connaissance des faits présents que des faits passés.” (LEFORT, 1992a, p. 142) para que hoje se possa pensar diferentemente a temática da integração europeia. $\mathrm{O}$ encadeamento dos eventos é feito com a finalidade didática de evidenciar ensinamentos do passado e extraí-los para aprimorar as opções jurídico-Políticas do presente, visando ao futuro (CASELLA, 2012, p. 25 e 39; KHOURY, 2012, p. 89; LEFORT, 1992a, p. 141-2; PÉDECH, 1964, p. 50; POLYBE, 2003, p. 664; SEBASTIANI, 2006a, p. 65 e 74, 2010, p. 74).

Depois de 62 (sessenta e dois) anos da instituição do regime jurídico-Político virtuoso da CECA, hoje se argumenta que a UE - a expressão atual da integração europeia iniciada pela CECA - enfrenta uma situação de profunda crise. Compreender histórica e jurídico-políticamente o início da UE sinaliza que, por meio da medida comparativa histórica do sucesso da CECA, se pode compreender que a crise da UE pode ser entendida não apenas como uma simples crise econômica ou financeira, mas uma crise institucional e, sobretudo, uma crise jurídico-política - isto é, de determinada qualidade de Leis assumidas historicamente após constituição da CECA.

Com efeito, desde a CECA até a atual UE, o ambiente institucional se alterou profundamente: novas Organizações Internacionais foram inseridas (CEEA e CEE), estas foram unificadas, novos países ingressaram na vida comum, novos órgãos comunitários foram criados. As modificações institucionais da UE posteriores à CECA foram realizadas para tentar responder a tais transformações da vida comunitária, abarcando novos participantes e novas racionalidades que certamente ingressaram na dinâmica do regime de convivência europeu.

Em outras palavras, pode-se sugerir, aqui, que a crise pela qual passa a atual UE deriva, precisamente, de um possível desvio de rota com relação à engenharia da organização jurídico-Política inicialmente estabelecida com a CECA. Faz-se assim necessário o estudo da História dos Projetos de Europa Unida posteriores à instituição da CECA, acompanhado da respectiva análise institucional dos sucessivos Tratados Constitutivos e Modificativos da integração europeia, a fim de que se possa avaliar e aferir precisamente quando, como e por meio de quais instituições, a Europa Unida pela CECA talvez tenha deslizado de uma organização jurídico-Política (Leis Políticas) para uma organização qualitativamente distinta da anterior. Poder-se-ia afirmar ter ela se tornado 
uma organização jurídico-Teológico-Política (Leis Teológico-Políticas), tal qual o Projeto Original do CdE?

Essas questões fogem ao escopo deste trabalho, uma vez que se encontram fora do recorte metodológico temporal estabelecido no início deste trabalho, devendo ser analisadas, assim, em trabalhos posteriores a esta Tese de Doutorado. Apenas se pode lembrar, nas limitações deste trabalho ${ }^{1034}$, de que toda construção humana está inserta na História, vale dizer, que todo produto cultural - inclusive regimes jurídico-politicamente organizados, mesmo o misto - necessariamente atravessa os períodos de surgimento, ascensão e apogeu para, em seguida, rumar em direção aos necessários envelhecimento e perecimento (PÉDECH, 1964, p. 309, 312 e 316).

Assim, diante da excelência do exemplo da arquitetura institucional do passado (CECA), e à luz da profunda crise pela qual perpassa a atual UE, apenas podem ser lembradas, neste trabalho, diante das limitações metodológicas assumidas desde o início do texto, as palavras registradas por POLÍBIO (POLYBE, 2003, p. 1339, grifos nossos):

\footnotetext{
Scipion se retourna alors vers moi et dit, en me saisissant la main: «C'est un beau jour, Polybe, mais j'éprouve, je ne sais pourquoi, quelque inquiétude et j'appréhende le moment à venir où un autre porrait nous adresser pareil avertissement au sujet de notre propre patrie.» Il serait difficile de faire une réflexion plus digne d'un homme d'État et plus profonde que celle-là. 2. être capable, à l'heure du plus grand triomphe, 3. quand l'ennemi est au fond du malheur, de réfléchir à sa propre situation et à la possibilité d'un renversement du sort, de ne pas oublier, dans le succès, que la Fortune est changeante, voilà le fait d'un grand homme, qui atteint à la perfection; d'un homme, en un mot, qui mérite de ne pas être oublié... (Un passage d'Appien, Punica, 132, permet de complèter un peu le texte de Polybe).

22. En voyant la ville de Carthage ainsi détruite de fond en comble, Scipion, diton, versa des larmes et l'on vit qu'il pleurait sur le sort de l'ennemi. Après être resté un longtemps perdu dans so méditation, songeant que les cités, les nations et les empires sont tous, comme les hommes, voués au déclin par la divinité, que tel avait été le sort d'Illion, cité jadis prospère, celui des empires assyrien, mède et perse, qui furent, en leur temps, les plus vastes du monde, celui, en dernier lieu, de la Macédonie, qui brilla d'un si vif éclat, il cita, intentionellement ou comme sans le vouloir, les vers que voici:

Un jour viendra où elle périra, la sainte Illion, et avec elle, Priam et le peuple de Priam à la bonne lance.

Polybe, qui avait été son maître, lui demanda sans détour à quoi il pensait. Scipion répondit alors, sans essayer de le cacher, qu'il pensait à sa patrie, pour laquelle il éprouvait des craintes, en voyant comment vont les choses humaines. Polybe rapporte ces mots qu'il entendit lui-même.
}

${ }^{1034}$ Conforme salientado ao final do item 3.3.3.2.2., supra. 


\title{
CONCLUSÕES GERAIS
}

\begin{abstract}
Os antigos políticos falavam constantemente de costumes e de virtudes, os nossos só falam de comércio e de dinheiro. Um vos dirá que um homem numa determinada região vale a soma pela qual o venderiam na Argélia; outro, seguindo esse cálculo, encontrará regiões nas quais um homem nada vale, e outras em que ele vale menos do que nada. Avaliam os homens como gado. (ROUSSEAU, 1980, p. 344).
\end{abstract}

Aproveitem, portanto, o bem e o mal que Vossas Senhorias mesmas procuraram. E se chegarem a aceitar com benevolência os meus comentários, esforçar-me-ei por continuar esta história, cumprindo assim a promessa que fiz ao começar a escrevê-la. (MAQUIAVEL, 2008, p. 13).

O presente trabalho iniciou com a seguinte provocação intelectual: a partir do relato feito sobre os comentários de Maurice MERLEAU-PONTY (2004, p. 39-40) a uma gravura japonesa sobre um elefante ${ }^{1035}$, sugeriu-se que um mesmo fenômeno poderia estar sujeito a um número infindável de possibilidades de leitura, sem que jamais se pudesse deter uma decisão definitiva sobre qual delas seria a mais completa, melhor, ou simplesmente, "mais verdadeira".

É importante ter em mente este aspecto quando se estuda o Direito historicamente: a cada momento que se rememora o passado, novos elementos são introduzidos e o encadeamento dos eventos é feito segundo significações novas. Em outras palavras, há uma ressignificação daquilo que já ocorreu, sempre tendo por base uma raiz explicativa alternativa - conscientemente ou não, o que não invalida o ato de resgate histórico. A interpretação histórica das instituições jurídicas é assim continuamente feita e refeita, a partir de novas perspectivas assumidas no presente com relação ao mesmo fenômeno jurídico-normativo historicamente positivado e alterado (CASELLA, 2012, p. xiii; KHOURY, 2012, p. 85 e 89; LEFORT, 1979, p. 356, 1992c, p. 13; PÉDECH, 1964, p. 34; POLYBE, 2003, p. 228 e 548; SEBASTIANI, 2006a, p. 75, 2007a, p. 71-5).

Esse aspecto se evidencia de maneira ainda mais clara, talvez, particularmente quando se debruça sobre a História da Europa, a fim de compreender a História dos Projetos de Europa Unida do pós-Segunda Guerra Mundial.

Com efeito, como salientado na Introdução Geral deste trabalho, puderam ser encontrados mitos religiosos antigos e medievais sobre a origem comum dos países e dos povos europeus. A leitura impressa sobre o passado da Europa naqueles textos tinha por raiz explicativa um determinado objetivo de promover uma unidade dos povos europeus

${ }^{1035}$ V., nesse sentido, a Introdução Geral deste trabalho. 
em torno de caracteres comuns. Não foi o objetivo deste trabalho explicitar tais objetivos, mas se pode compreender que tiveram por função diferenciar determinados povos de outros $^{1036}$.

De todo modo, na literatura jurídica brasileira e estrangeira contemporânea de Direito Internacional Público sobre a construção da atual Europa Unida percebe o princípio deste processo - a CECA - de acordo com um ponto de partida específico: uma leitura jurídico-econômica. Usualmente percebida como "Bloco Econômico", a CECA parece ser percebida como (i) resquício do movimento de liberalização multilateral do comércio internacional inaugurado pela Conferência de Bretton Woods (1944); e, por isso mesmo, (ii) inserta na lógica geral do Acordo Geral de Tarifas e Comércio (GATT, sigla em inglês); ou mesmo, (iii) princípio motor de promoção de Desenvolvimento Econômico regional na Europa.

Tal matriz explicativa dada pela leitura jurídico-econômica justifica estudos em Direito que avaliam historicamente a estrutura institucional da CECA e da UE como portadora exclusivamente de normas de Direito Econômico Internacional voltadas simplesmente ao estabelecimento de um mercado comum. Para esta concepção, a integração promovida na Europa seria o exemplo perfeito da sucessão entre fases necessárias de integração econômica: Zona de Livre Comércio, União Aduaneira, Mercado Comum, União simplesmente Econômica, União Econômica e Monetária.

Sem pretender invalidar ou desqualificar essa possibilidade de leitura, o presente trabalho pretendeu partir de uma perspectiva distinta: suspender a chave de interpretação dada pela literatura jurídico-econômica e salientar uma possível leitura jurídico-política da História e das instituições jurídico-normativas positivas da CECA. A ideia era fornecer outra fonte explicativa deste fenômeno.

É uma empresa difícil que espero, contudo, conduzir longe o bastante para que fique faltando pouco caminho a quem queira levá-la a termo. (MAQUIAVEL, 2008, p. 18).

A leitura jurídico-política da História e das instituições do Tratado da CECA foi guiada pela pergunta: quando, como e por meio de quais instituições, países europeus

\footnotetext{
${ }^{1036}$ A lista de Projetos de Europa Unida mencionada no item 1.1., supra, permite perceber uma constante, ao menos durante o período medieval: contrapor uma suposta comunidade cristã europeia a comunidades nãocristãs. Mas o aprofundamento deste tipo de investigação não diz respeito a este trabaho, razão pela qual não se dedicou e nem se dedica a um maior detalhamento desta questão.
} 
tradicionalmente opostos em termos bélicos conseguiram estabelecer entre si um novo modo de relações, tornando impossível e impensável uma nova Guerra regional.

A pergunta direcionou para outra raiz explicativa não-exclusiva do fenômeno. $\mathrm{Na}$ Parte Primeira deste trabalho foram esclarecidos os limites metodológicos da pergunta, o campo significativo dos elementos que a compunham e dos critérios de análise a serem utilizados como chave de leitura conceitual do fenômeno. Na Parte Segunda foram apresentados os elementos da experiência histórica e normativa da CECA a serem interpretados pelo aparato conceitual formulado.

Por meio desse empreendimento investigativo de conjunção da razão com a experiência, foi possível produzir um conhecimento jurídico de Direito Internacional apto a salientar ao menos três aspectos: (i) firme convicção histórica da necessidade de instituição de Leis - isto é, de uma organização jurídico-política das relações entre os países europeus, principalmente entre Alemanha e França; (ii) inteligente engenharia institucional, fundada em normas de oposições escalares, as quais foram sistematicamente apostas para contrapor as diferentes escalas de existência participantes da vida em comum; e (iii) constante preocupação em (a) impedir a ascensão destacada de uma escala de existência extra ou intraeuropeia em direção à ocupação de uma posição central e exclusiva na determinação do sentido normativo a ser impresso sobre questões concretas sensíveis comuns, de maneira a assegurar a continuidade de um sistema de convivência plural (multiescalar) permanente, e (b) negar a um Projeto de Europa Politicamente Unida disposições institucionais que o aproximassem de um Estado Europeu embrionário.

Em termos jurídico-positivos, a possibilidade de leitura jurídico-Política do texto normativo do Tratado da CECA se revelara como factível para o trabalho. A seleção de normas de oposições escalares do texto do Tratado permitiu visualizar em cada uma delas mesmo no que se refere às normas de Direito Econômico - a possibilidade de se perceber um cuidadoso manejo institucional voltado a assegurar que a produção de normas jurídicas comunitárias - mesmo as que detivessem conteúdo econômico - fosse produto de tensa e intensa oposição entre os diferentes modos de participar da vida comum da CECA.

Espera-se de uma Tese de Doutorado uma contribuição original a sua comunidade epistêmica. Ao pretender contribuir ao conhecimento jurídico brasileiro em Direito Internacional sobre o processo de integração europeu sob uma perspectiva jurídicopolítica, esta Tese de Doutorado optou pela perturbação do discurso jurídico comum sobre este fenômeno - afastando a repetição da leitura jurídico-econômica e assumindo uma robusta chave de leitura jurídico-política específica. 
A assunção de um ponto de partida para uma interpretação alternativa de um e mesmo fenômeno é, inclusive, sinal de abertura a uma experiência Política (LEFORT, 1986, p. 306) - o que revela mais um aspecto da leitura jurídico-política deste trabalho. Provocar perturbações discursivas sobre as interpretações em torno da CECA tinha por objetivo tornar incômoda, ou ainda, incerta, a pacificidade absoluta assumida pelo discurso da literatura jurídica tradicional brasileira e estrangeira sobre o tema.

Lembre-se de que "la plus grande tentation de l'interprète est d'occuper la position du pouvoir absolu: elle signale dans l'accomplissement d'un projet grâce auquel [...] il peut mettre un terme à l'histoire des interprétations" (LEFORT, 1986, p. 308). Assumir “l'impossibilité [de] l'interprète d'occuper cette position" (LEFORT, 1986, p. 308)" é precisamente assumir uma postura política de contestação do marasmo e da quietude da fácil inclinação a se submeter automaticamente às interpretações correntes sobre o um e mesmo fenômeno.

Em outras palavras, trata-se de uma forma de também buscar instaurar um vazio no lugar do Saber sobre a História da Europa Unida e sobre o conhecimento jurídico produzido a partir dela, recusando-se a se seguir impensadamente as leituras da tradição jurídica brasileira. Tais autores que escreveram anteriormente sobre a História da Europa Unida em Direito Internacional não podem ser considerados como o único centro doador de sentido sobre este fenômeno histórico.

Há outras formas de interpretar as origens históricas da UE, e apenas mediante um pensamento alternativo sobre a História e as instituições da CECA é que se poderá pensar em formas novas de se compreender juridicamente o desenvolvimento progressivo da UE em direção à presente situação de crise - também jurídico-Política.

Nesse sentido, note-se que "[o]n ne se étonnera donc pas que tous ceux qui veulent préserver les droits absolus de l'individu ou s'en remettre à une raison cachée qui garantisse leurs intérêts ou sauve leurs illusions, ferment les yeux sur ces transformations [...] et soient pressés d'annoncer le déclin" (LEFORT, 2007a, p. 125), pois nenhum pretendente a ocupar o lugar do Saber - como todo aquele que ocupa o lugar do Poder aceita sem retaliações um conhecimento produzido criticamente contra a tranquila fonte unidimensional e totalizante de explicações de um fenômeno. E é contra este pacifismo sepulcral que se levanta a vitalidade da presente interpretação alternativa sobre a CECA Política na forma, Política no conteúdo.

Certamente, há que se notar que nenhuma interpretação é definitiva, isto é, nenhuma delas ocupa intermporalmente o lugar do Saber em torno de um e mesmo 
fenômeno. Nesse sentido, não basta o exclusivismo de uma leitura jurídico-econômica da Europa, da mesma maneira que não basta o estreitismo de uma leitura jurídico-política determinada. Nem a leitura da tradição, nem a presente, são suficientes para poder responder ou esgotar como se compreender a História da Europa.

$\mathrm{Na}$ verdade, apenas mediante a confluência aberta, consciente e reiterada de todas as perspectivas é que se poderá compreender mais completamente - mas jamais exaustivamente - o um e mesmo fenômeno: as origens do Projeto de Europa Unida. A assunção de uma postura Política nas leituras acadêmicas sobre a Europa é condição para que novas formas de compreendê-la historicamente surjam de maneira virtuosamente útil para que possam aflorar multidimensionalmente novas formas de encaminhamento jurídico-institucional do futuro comum europeu atual.

Este trabalho aponta assim que também se deve (Politicamente) se indispor contra uma possível formação de cultura padronizada de leituras sobre a História e sobre as instituições da CECA, de maneira a reforçar que mesmo o lugar do Saber deve estar aberto a exceções interpretativas - pois apenas a convivência tensa da variabilidade de formas de compreender e de apreender o mundo torna possível fazer aflorar soluções comuns atentas à satisfação, não apenas de Um, mas de todos, sem implicar a ruptura abrupta ou violenta das relações entre as diferentes escalas de existência.

O temor assinalado no início do trabalho - por um mesmo meio (originalidade de uma Tese), atingem-se distintos fins (boa ou má recepção pela Comunidade Acadêmica) pôde ao menos assegurar o cuidado minucioso de conduzir a Pesquisa e o presente registro de modo coerente metodológica, terminológica e conteudísticamente. Foi ele quem alertou constantemente para as precauções a serem tomadas com a propositura da presente exceção no discurso jurídico sobre o início da UE. E, graças às seguranças tomadas por força dele, não há que se temer uma incerteza científica com relação à posição abertamente assumida por este trabalho.

En un sens, voyez-vous, la peur est tout de même la fille de Dieu. Rachetée la nuit du vendredi saint, elle n'est pas belle à voir non, tantôt raillée, tantôt maudite, renoncée par tous.

Et cependant ne vous y trompez pas, elle est au chevet de chaque agonie. Elle intercède pour l'homme. Car il $\mathrm{y}$ a la règle et il y a l'exception. Il y a la culture qui est de la règle. Il y a l'exception qui est de l'art. Tous disent la règle: cigarette, ordinateur, t-shirt, télévision, tourisme, guerre. Personne ne dit l'exception. Cela ne se dit pas, cela s'écrit : Flaubert, Dostoievski ; cela se compose : Gershwin, Mozart ; cela se peint : Cézanne, Vermeer ; cela s'enregistre : Antonioni, Vigo. Ou cela se vit, et c'est alors l'art de vivre : Srebrenica, Mostar, Sarajevo. Il est de la règle que vouloir la mort de l'exception. 
Il sera donc de la règle de l'Europe de la culture d'organiser la mort de l'art de vivre qui fleurit encore à nos pieds.

Quand il faudra fermer le livre, ce sera sans regretter rien : j'ai vu tant de gens si mal vivre, et tant de gens, mourir si bien. (GODARD, 2006). 


\section{REFERÊNCIAS}

\section{Fontes Primárias}

ACHESON, Dean. Telegram to the US Embassy in Paris (19 Oct. 1949). In: Foreign Relations of the United States, 1949. v. IV. Washington: Department of State, 1975. Disponível em: <http://www.cvce.eu/obj/Telegram_from_Dean_Acheson_to_the_US_Embassy_in_Paris_ Washington_19_October_1949-en-ef456d4c-b0cc-4a98-a496-586b8ccb19b5.html>. Acesso em: 25.2.2013.

ADENAUER, Konrad. Discours à l'Occasion de la Première Séance du Conseil des Ministres de la Communauté Européenne du Charbon et de l'Acier (8 septembre 1952). In : LEFORT, Bernard (Org.). Une Europe Inédite - Documents des Archives Jean Monnet. Villeneuve d'Ascq : Presses Universitaires du Septentrion, p. 171-4, 2001.

BLUM, Léon. Message sur l'Importance de l'Intégration Européenne (Fév. 1950). London: The National Archives of the United Kingdom, 1950. Disponível em: <http://www.cvce.eu/obj/Message_de_Leon_Blum_sur_1_importance_de_1_integration_eu ropeenne_Fevrier_1950-fr-b461a41d-7e3b-4137-b65d-bf9d1a529a89.html>. Acesso em: 25.2.2013.

BRIAND, Aristide. Discours pour l'Union Européenne, 1929. In: ELISHA, Achille. Aristide Briand - La Paix Mondiale et l'Union Européenne. 2 ed. Louvain-la-Neuve : Bruylant Academia, p. 259-68, 2000.

BRIAND, Aristide; LEGER, Alexis. Memorandum sur l'Organisation d'Un Régime Fédérale Européenne, 1930. In : FLEURY, Antoine ; JÍLEK, Lubor (Ed.). Le Plan Briand d'Union Fédéral Européenne - Perspectives Nationales et Transnationales, avec Documents. Bern/Berlin/Frankfurt/New York/Paris/Wien : Peter Lang, p. 569-82, 1998.

BRUGMANS, Hendrik. Discours d'Ouverture du Congrès de la Haye (7 Mai 1948. Genève : UEF, 1948. Disponível em : <http://www.cvce.eu/obj/Discours_d_Henri_Brugmans_La_Haye_7_mai_1948-fr3b6cf228-5aa8-4dae-8363-8661724b30d0.html>. Acesso em : 25.2.2013.

BUNDESREPUBLIK DEUTSCHLAND. Auswärtiges Amt. Kurtzprotokoll der ersten Verhandlung über den Schuman-Plan (12 Juni. 1950). Berlin: Politiches Archivs des Auswärtiges Amt, $1950 . \quad$ Disponível em: <http://www.cvce.eu/obj/Kurzprotokoll_der_ersten_Verhandlungsrunde_uber_den_Schum an_Plan_Paris_21_Juni_1950-de-c1a0ca0a-0b0f-43b8-80e3-a56ddabba3c1.html >. Acesso em 25.2.2013. (B15. Abteilung 2. Sekretariat für Fragen des Schuman-Plans Bd. 56.).

CHURCHILL, Winston. Discours d'Ouverture du Congrès de la Haye (7 Mai 1948).

Vabre: Arquivos privados de Guy de ROUVILLE, 1948. Disponível em: 
<http://www.cvce.eu/obj/Discours_de_Winston_Churchill_au_congres_europeen_de_La_ Haye_7_mai_1948-fr-58118da1-af22-48c0-bc88-93cda974f42c.html>. Acesso em : 25.2.2013.

A Speech at Zurich University. In: BRUGMANS, Henri. L'Idée Européenne (1918-1965). 12 ed. Bruges : Tempelhof, p. 263-6, 1966.

CLAPPIER, Bernard. Interview (Extraits) sur les Origines du Plan Schuman et le Rôle de Jean Monnet (11 Nov. 1980). In: L'Europe une Longue Marche. Lausanne : Fondation Jean Monnet pour l'Europe/Centre de Recherches Européennes, 1985. Disponível em : <http://www.cvce.eu/obj/Interview_de_Bernard_Clappier_extraits_sur_les_origines_du_pl an_Schuman_et_le_role_de_Jean_Monnet_11_novembre_1980-fr-278699a3-a23a-46888fe2-c4a83186c762.html>. Acesso em: 25.2.2013.

COMMUNAUTÉ EUROPÉENNE DU CHARBON ET DE L'ACIER (CECA). Haute Autorité. Décision n. 30-53. Presidente: Jean MONNET. Luxembourg. D. em: 2.5.1953. Disponível em : $<$ http://eurlex.europa.eu/LexUriServ/LexUriServ.do?uri=OJ:A:1953:006:0109:0110:FR:PDF>. Acesso em: 25.2.2013.

Décision n. 1-54. Presidente: Jean MONNET. Luxembourg. D. em: 7.1.1954. Disponível em : $<$ http://eurlex.europa.eu/LexUriServ/LexUriServ.do?uri=OJ:A:1954:001:0217:0217:FR:PDF>. Acesso em: 25.2.2013.

CONGRÈS DE LA HAYE (CGH). Résolution Politique (10 Mai 1948). In: ROLLAND, Patrice (Org.). L'Unité Politique de l'Europe - Histoire d'une Idée. Bruxelles: Bruylant, p. 531-3, 2006a. (Collection Droit de l'Union Européenne).

Résolution Culturelle (10 Mai 1948). In: ROLLAND, Patrice (Org.). L'Unité Politique de l'Europe - Histoire d'une Idée. Bruxelles : Bruylant, p. 538-40, 2006b. (Collection Droit de l’Union Européenne).

COUNCIL OF EUROPE. Committe of Ministers. Resolution adopted at the Eighth Session on Specialized Authorities (3 May 1951). Committe of Ministers: Strasbourg, 1951. Disponível em: <https://wcd.coe.int/com.instranet.InstraServlet?command=com.instranet.CmdBlobGet\&In stranetImage $=1729573 \&$ SecMode $=1 \&$ DocId $=1673422 \&$ Usage $=2>. \quad$ Acesso $\quad \mathrm{em}$ : 25.2.2013. $(\operatorname{Res}(51) 30 \mathrm{E} / 03$ May 1951).

GERBET, Pierre. Interview sur La Méthode Jean Monnet [23 Jan. 2004]. Entrevistador: Étienne Deschamps. Paris: CVCE, 2004. Disponível em : <http://www.cvce.eu/viewer/-/content/232ed0b4-3bfa-43ab-a44d-313de4e04e21/6afc 76382857-4420-9b6a-37450490ab04/fr> . Acesso em : 25.2.2013. 
GOUZY, Jean-Pierre. Interview sur l'Atmosphère du Congrès de l'Europe à la Haye [19 oct. 2007]. Entrevistador : Étienne Deschamps. Paris : CVCE, 2007a. Disponível em : <http://www.cvce.eu/viewer/-/content/20eef6ef-c984-4f0e-943e-b42d560635f4/6d53d89c9f43-40e7-87ab-b2b171ae3f54/fr>. Acesso em : 25.2.2013.

Interview sur les Temps Forts du Congrès de La Haye [19 Oct. 2007]. Entrevistador: Jean-Michel Guieu. Paris: CVCE, 2007b. Disponível em : <http://www.cvce.eu/viewer/-/content/20eef6ef-c984-4f0e-943e-b42d560635f4/9c05fb4bb04a-42cb-bdeb-5784d295755e/fr>. Acesso em : 25.2.2013.

HOFFMAN, Paul G. Statement on the OEEC's Role with regard to European Economic Integration (1 Feb. 1950). London: The National Archives of the United Kingdom, $1950 . \quad$ Disponível em: <http://www.cvce.eu/obj/Statement_by_Paul_Hoffman_on_the_OEEC_s_role_with_regar d_to_European_economic_integration_Paris_1_February_1950-en-2a0fb584-af9f-44dc8489-368684aa9fa3.html>. Acesso em: 25.2.2013.

LEFORT, Claude. Entretien avec l'Anti-Mythes. In : LEFORT, Claude. Le Temps Présent - Écrits 1945-2005. Paris : Belin, p. 223-60, 2007c.

. Aperçu d'un Itinéraire - Entretien avec Pierre Rosanvallon et Patrick Viveret. In :

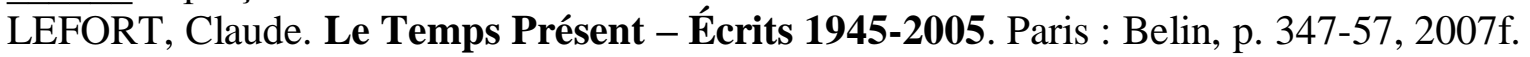

. Repenser le Politique - Entretien avec E. A. El Maleh. In : LEFORT, Claude. Le Temps Présent - Écrits 1945-2005. Paris : Belin, p. 359-67, 2007g.

MARSHALL, George. A Speech by Mr. George Marshall, Harvard University. In: BRUGMANS, Henri. L'Idée Européenne (1918-1965). 12 ed. Bruges: Tempelhof, p. 268-71, 1966.

MONNET, Jean. Note sur la Situation Internationale $\left(1^{\text {er }}\right.$ ou 2 Mai 1950). Lausanne : Fondation Jean Monnet pour l'Europe, 1950. Disponível em: <http://www.cvce.eu/obj/Note_de_Jean_Monnet_sur_la_situation_internationale_1er_ou_ 2_mai_1950-frfc5102d5-f524-4ab7-82fb-c8a3c0607b85.html>. Acesso em: 25.2.2013. (Archives Jean Monnet. Fonds AMI. 4/1/2).

Discours lors de la Séance de Paraphe du Traité CECA (19 Mars 1951). Laussanne: Fondation Jean Monnet pour l'Europe, 1951. Disponível em : <http://www.cvce.eu/obj/Discours_de_Jean_Monnet_lors_de_la_seance_de_paraphe_du_t raite_CECA_Paris_19_mars_1951-fr-5752bf8f-4cfa-4553-bcbf-0cc14fcfa37b.html>. Acesso em : 25.2.2013. (Fonds AMG. 14/2/1.).

. Le « Mémorandum Monnet» du 3 Mai 1950, Le Monde, Paris, a. 27, n. 7874, p. 6, 9 mai 1970. (Le Vingtième Anniversaire du « Mémorandum Monnet »). 
Interview sur les Origines du Plan Schuman [22 Jan. 1972]. Paris : RTL, 1972. Disponível em : <http://www.cvce.eu/viewer/-/content/232ed0b4-3bfa-43ab-a44d313de4e04e21/f0a4bb4b-9660-4754-a129-9ca64edfff4d/fr>. Acesso em : 25.2.2013.

. Lettre à Robert Schuman sur les Négociations du Pool Charbon-Acier (14 Oct. 1950). In : MONNET, Jean; SCHUMAN, Robert. Correspondance 1947-1953. Lausanne : Fondation Jean Monnet pour l'Europe/Centre de Recherches Européennes, 1986a. Disponível em : <http://www.cvce.eu/obj/Lettre_de_Jean_Monnet_a_Robert_Schuman_Paris_14_octobre_ 1950-fr-4a8f88b1-d145- 4926-8d53-f7d3154b5f6a.html>. Acesso em : 25.2.2013. (Cahiers Rouges. Copie dactylographiée. AMI 4/6/1.).

. Mémorandum à Robert Schuman sur l'Avancement des Négaciations sur le Plan Schuman In: MONNET, Jean ; SCHUMAN, Robert. Correspondance 1947-1953. Lausanne: Fondation Jean Monnet pour l'Europe/Centre de Recherches Européennes, 1986b. Disponivel em : <http://www.cvce.eu/obj/Memorandum_de_Jean_Monnet_a_Robert_Schuman_Paris_30_ novembre_1950-fra313e93f-cbcf-4471-b473-428a8ab852fa.html>. Acesso em : 25.2.2013. (Cahiers Rouges).

. Réponse au Discours du Chancelier Konrad Adenauer à l'Occasion de la Première Séance du Conseil des Ministres de la Communauté Européenne du Charbon et de l'Acier (8 septembre 1952). In : LEFORT, Bernard (Org.). Une Europe Inédite - Documents des Archives Jean Monnet. Villeneuve d'Ascq: Presses Universitaires du Septentrion, p. 175-6, 2001a.

L'Europe se Fait (30 juin 1953). In : LEFORT, Bernard (Org.). Une Europe Inédite - Documents des Archives Jean Monnet. Villeneuve d'Ascq: Presses Universitaires du Septentrion, p. 176-94, 2001b. (Discours à la Société d'Économie Politique, à Bruxelles).

. Où en est l'Europe ? Les Prochains Pas (15 avril 1960). In : LEFORT, Bernard (Org.). Une Europe Inédite - Documents des Archives Jean Monnet. Villeneuve d'Ascq : Presses Universitaires du Septentrion, p. 259-61, 2001c. (Texte-bilan de Jean Monnet).

L'Europe en s'Unissant, Change l'Occident (avril-juin 1962). In : LEFORT, Bernard (Org.). Une Europe Inédite - Documents des Archives Jean Monnet. Villeneuve d'Ascq : Presses Universitaires du Septentrion, p. 274-7, 2001d. (Texte publié dans la Revue La Nef).

MOUVEMENT EUROPÉEN (ME). Comité Exécutif. Memorandum (23 Novembre 1948). In: ROLLAND, Patrice (Org.). L'Unité Politique de l'Europe - Histoire d'une Idée. Bruxelles : Bruylant, p. 575-83, 2006. (Collection Droit de l'Union Européenne). 
PARLEMENT EUROPÉEN, Résolution sur une Dénomination Unique pour la Communauté du 16 février 1978, Journal Officiel des Communautés Européennes, Luxembourg, n. C 63, p. 36, 13 mars 1978. Disponível em: <http://eurlex.europa.eu/LexUriServ/LexUriServ.do?uri=OJ:C:1978:063:0024:0043:FR:PDF>.

Acesso em: 25.2.2013.

RABIER, Jacques-René. Interview sur la Méthode de Travail de Jean Monnet [8 Fév. 2002]. Entrevistador : Étienne Deschamps. Luxembourg : CVCE, 2002a. Disponível em: <http://www.cvce.eu/viewer/-/content/232ed0b4-3bfa-43ab-a44d-313de4e04e21/fd5ea5e47820-47d3-8227-9aa13eb029f7/fr>. Acesso em: 25.2.2013.

Interview sur l'Origine des Convictions de Jean Monnet pour la Construction Européenne [8 Fév. 2002]. Entrevistador: Étienne Deschamps. Luxembourg : CVCE, 2002b. Disponível em: <http://www.cvce.eu/viewer/-/content/232ed0b4-3bfa-43ab-a44d313de4e04e21/b8b5ea1b-1977-435c-a493-1373fa6b6812/fr>. Acesso em : 25.2.2013.

Interview sur la Genèse de la Déclaration Schuman [8 Fév. 2002]. Entrevistador: Étienne Deschamps. Luxembourg: CVCE, 2002c. Disponível em : <http://www.cvce.eu/viewer/-/content/232ed0b4-3bfa-43ab-a44d-

313de4e04e21/7896515b-4e93-454a-9faf-603d5548ece4/fr>. Acesso em : 25.2.2013.

RÉPUBLIQUE FÉDÉRALE D’ALLEMAGNE; ROYAUME DE BELGIQUE; RÉPUBLIQUE FRANÇAISE ; RÉPUBLIQUE ITALIENNE; GRAND-DUCALE DE LUXEMBOURG; ROYAUME DES PAYS-BAS. Communiqué Commun des Gouvernements (3 Juin 1950). Florence : Archives Historiques de l'Union Européenne, 1950.

Disponível em: <http://www.cvce.eu/obj/Communique_commun_des_gouvernements_francais_allemand_ belge_italien_luxembourgeois_et_neerlandais_sur_le_plan_Schuman_3_juin_1950-frba5aa8bc-1519-4fc8-979a-04cc677d447a.html>. Acesso em : 25.2.2013. (Villa Il Poggiolo. Fonds des institutions communautaires européennes, EC. Commission européenne-Haute Autorité CECA, CEAB. Plan Schuman: déclaration de Robert Schuman du 9 mai 1950 et réactions, CEAB 2-14.)

$\begin{aligned} & \text { Traité Instituant la Communauté Européenne du Charbon et de l'Acier. } \\ & \text { Paris, }\end{aligned} \begin{aligned} & \text { 1951. } \\ & \text { lex.europa.eu/LexUriServ/LexUriServ.do?uri=CELEX:11951K/TXT:FR:PDF>. }\end{aligned}$
$\begin{aligned} & \text { emttp://eur- } \\ & \text { em: 25.2.2013. }\end{aligned}$

La Déclaration Commune de Ministres Signataires (18 Avril 1951), Bulletin d'Information du Service Information et Presse du Ministère d'État, Luxembourg, a. 8, n. 10, oct. 1952. Disponível em : <http://www.cvce.eu/obj/La_declaration_commune_des_ministres_signataires_18_avril_1 951-fr-a5bee6ca-6506-48bb-9bd5-c1aa8487bdfd.html>.Acesso em : 25.2.2013.

ROUGEMONT, Denis de. Message aux Européens (Congrès de la Haye). In: BRUGMANS, Henri. L'Idée Européenne (1918-1965). 12 ed. Bruges: Tempelhof, p. 271-2, 1966. 
ROYAUME DES PAYS-BAS ; ROYAUME DE BELGIQUE; GRAND-DUCALE DE LUXEMBOURG. Compte Rendu de la Réunion entre Fonctionnaires en Vue de Préparer les Négociations concernant la Création d'un Pool International du Charbon et de l'Acier (8 Juin 1950). Luxembourg: Archives Nationales du Luxembourg/Ministère des Affaires Étrangères, 1950. Disponível em : <http://www.cvce.eu/obj/Compte_rendu_de_la_reunion_entre_fonctionnaires_neerlandais _belge_et_luxembourgeois_Bruxelles_8_juin_1950-fr-93f5ef2a-0dfc-46e4-9c45-

1051da6ec167.html>. Acesso em: 25.2.2013. (Traités. Traités - Economiques et Financiers. Plan Schuman - Négociations - La déclaration Schuman du 9 mai 1950 et les premières réactions - 1950, AE 11346.).

RUTTEN, Charles. Interview sur Les Nouvelles Équipes Internationales [29 nov. 2006]. Entrevistador: Étienne Deschamps. La Haye : CVCE, 2006a. Disponível em : <http://www.cvce.eu/viewer/-/content/392d80e2-722f-4f43-a6e1-58971909d2f1/7df6a4830578-489a-b645-f8f9241af6e7/fr >. Acesso em: 25.2.2013.

Interview sur le Congrès de La Haye [29 nov. 2006]. Entrevistador : Étienne Deschamps. La Haye : CVCE, 2006b. Disponível em: <http://www.cvce.eu/viewer//content/20eef6ef-c984-4f0e-943e-b42d560635f4/5f49c7d8-2ffd-4a61-87c7-

a4090d299976/fr>. Acesso em : 25.2.2013.

SANDYS, Duncan. Memorandum on the Hague Congress (1948). Florence: Historical Archives of the European Union/European University Institute (EUI), 1948. Disponível em

<http://www.cvce.eu/obj/Memorandum_by_Duncan_Sandys_on_the_Hague_Congress_19 48-en-f15ddb58-c635-45f2-9d60-cfea73e52707.html>. Acesso em : 25.2.2013. (Villa il Poggiolo/EUI. DEP. Mouvement Européen, ME 1183).

SCHUMAN, Robert. Discours en Ouverture de la Conférence sur le Plan Schuman (20 Juin 1950). Lausanne : Fondation Jean Monnet pour l'Europe, 1950. Disponível em : $<$ http://www.cvce.eu/obj/Discours_de_Robert_Schuman_en_ouverture_de_la_conference_ sur_le_plan_Schuman_Paris_20_juin_1950-fr-411d38eb-3475-4a98-b0b3-

aecce8ca60a7.html>. Acesso em 25.2.2013. (Fonds AMG. 3/1/2.).

Discours sur les Origines et sur l'Élaboration de la CECA (22-23 Oct. 1953),

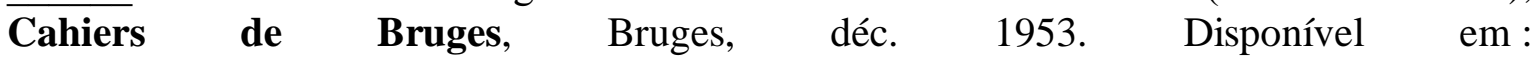
<http://www.cvce.eu/obj/Discours_de_Robert_Schuman_sur_les_origines_et_sur_1_elabor ation_de_la_CECA_Bruges_22_23_octobre_1953-fr-91c347fc-ab32-4e8d-a31f-

f8e244362705.html>. Acesso em: 25.2.2013. (Conférence au Collège d'Europe. Leçons d'Introduction à la Chaire Robert Schuman du Collège d'Europe).

Discours à Strasbourg (10 Mai 1955). Lausanne : Fondation Jean Monnet pour l'Europe, $1955 . \quad$ Disponível em : <http://www.cvce.eu/obj/Discours_de_Robert_Schuman_a_Strasbourg_Strasbourg_10_ma i_1955-fr-70e3bd90-8d74-4cb5-83aa-2178d46f261f.html>. Acesso em : 25.2.2013. (Fonds Robert Schuman. 1/2/12). 
. Déclaration du 9 Mai 1950. In: SCHUMAN, Robert. Pour l'Europe. Paris : Nagel, p. 197-209, 1963. (Écrits Politiques).

Déclaration du 9 Mai 1950. In: RIEBEN, Henri; NATHUSIUS, Martin; NICOD, Françoise; CAMPERIO-TIXIER, Claire. Un Changement d'Espérance. Lausanne : Fondation Jean Monnet pour l'Europe/Centre de Recherches Européennes, 2000. Disponível em: <http://www.cvce.eu/viewer/-/content/4909847d-df12-4c67-83d28e0978da025b/fr>. Acesso em : 25.2.2013. (Versão definitiva da Declaração. Redação: 6 Maio 1950).

Déclaration du 9 Mai 1950. In: ROLLAND, Patrice (Org.). L'Unité Politique de l'Europe - Histoire d'une Idée. Bruxelles : Bruylant, p. 585-6, 2006. (Collection Droit de l’Union Européenne).

SFORZA, Carlos. Messagio sul Processo d'Integrazione Europea (Feb. 1950). London: The National Archives of the United Kingdom, 1950. Disponível em: <http://www.cvce.eu/obj/Messagio_di_Carlo_Sforza_sul_processo_d_integrazione_europe a_Febbraio_1950-it-14f480d7-af9e-4cd9-ba98-1050f44cae72.html>. Acesso em: 25.2.2013.

SPAAK, Paul-Henri. Déclaration sur les Difficultés de l'Intégration Européenne (Fév. 1950). London: The National Archives of the United Kingdom, 1950. Disponível em:<http://www.cvce.eu/obj/Declaration_de_Paul_Henri_Spaak_sur_les_difficultes_de_l_ integration_europeenne_Fevrier_1950-fr-9126fb3d-a9bf-4e0a-ba80-dd87a13fa892.html〉. Acesso em: 25.2.2013.

UNION EUROPÉENNE DES FÉDÉRALISTES (UEF). Programme d'Hertenstein (Septembre 1946). In: ROLLAND, Patrice (Org.). L'Unité Politique de l'Europe Histoire d'une Idée. Bruxelles : Bruylant, p. 488-9, 2006a. (Collection Droit de 1'Union Européenne).

Programme de Montreux (Août 1947). In: ROLLAND, Patrice (Org.). L'Unité Politique de l'Europe - Histoire d'une Idée. Bruxelles : Bruylant, p. 489-99, 2006b. (Collection Droit de l'Union Européenne).

Résolutions et Avant-Projet sur la Constitution Européenne (Congrès de Rome, Novembre 1948). In: ROLLAND, Patrice (Org.). L'Unité Politique de l'Europe Histoire d'une Idée. Bruxelles : Bruylant, p. 558-75, 2006c. (Collection Droit de l'Union Européenne).

UNITED NATIONS. Charter of the United Nations and the Statute of the International Court of Justice. United Nations: San Francisco, 1945. Disponível em: $\langle$ http://treaties.un.org/doc/Publication/CTC/uncharter-all-lang.pdf $>$ Acesso em: 25.2.2013. 


\section{Fontes Secundárias}

ABRÃO, Bernadette Siqueira. História da Filosofia. São Paulo: Nova Cultural, 1999.

ACCIOLY, Elizabeth. Mercosul e União Européia: Estrutura Jurídico-Institucional. 3 ed. Curitiba: Juruá, 2003.

ACCIOLY, Hildebrando; NASCIMENTO E SILVA, Geraldo Eulálio do; CASELLA, Paulo Borba. Manual de Direito Internacional Público. 17 ed. São Paulo: Saraiva, 2009.

ADENAUER, Konrad. Begegnung mit Robert Schuman in Bonn im Januar 1950. In: ADENAUER, Konrad. Erinnerungen (1945-1953). 4 ed. Stuttgart: DVA, p. 295-302, 1980a.

. Die „Saarkonventionen“ vom 3. März 1950. In: ADENAUER, Konrad. Erinnerungen (1945-1953). 4 ed. Stuttgart : DVA, p. 304-11, 1980 b.

. Mein Vorschlag über die Bildung einer europäischen politischen Union vom März 1950. In: ADENAUER, Konrad. Erinnerungen (1945-1953). 4 ed. Stuttgart: DVA, p. 311-6, 1980c.

Beitritt zum Europarat? In: ADENAUER, Konrad. Erinnerungen (1945-1953). 4 ed. Stuttgart : DVA, p. 317-26, 1980d.

Der Schuman-Plan. In: ADENAUER, Konrad. Erinnerungen (1945-1953). 4 ed. Stuttgart : DVA, p. 327-31, 1980e.

. Fortschritte durch die Londoner Außenministerkonferenz vom Mai 1950. In: ADENAUER, Konrad. Erinnerungen (1945-1953). 4 ed. Stuttgart: DVA, p. 332-5, 1980f.

. Treffen mit Jean Monnet. In: ADENAUER, Konrad. Erinnerungen (1945-1953). 4 ed. Stuttgart : DVA, p. 336-7, 1980g.

Bundestagsentscheidung über den Beitritt zum Europarat. In: ADENAUER, Konrad. Erinnerungen (1945-1953). 4 ed. Stuttgart : DVA, p. 337-40, 1980h.

ALVES, Alaôr Caffé. Lógica - Pensamento Formal e Argumentação. 3 ed. São Paulo: Quartier Latin, 2003.

ANDERSON, Benedict. Comunidades Imaginadas - Reflexões sobre a Origem e a Difusão do Nacionalismo. São Paulo: Companhia das Letras, 2009. 
ANZILOTTI, Dionisio. Corso di Diritto Internazionale. Roma: Athenaeum, 1923.

ARATO, Andrew. Lefort, Philosopher of 1989. In: ÉCOLE DES HAUTES ÉTUDES EN SCIENCES SOCIALES (EHESS). Claude Lefort et la Pensée du Politique. Paris : EHESS, 2012. (Anotações da Palestra, realizada em 8.3.2012).

ARISTÓTELES. A Política. 2 ed. São Paulo: Martins Fontes, 1998.

Analíticos Posteriores. In: ARISTÓTELES. Órganon. São Paulo: Edipro, p. 251345, 2005.

ASSIS, Luis Fabiano de. Ativismo Judicial na Justiça do Trabalho. Tese (Doutorado em Direito). São Paulo: Faculdade de Direito, Universidade de São Paulo, 2011.

AZEVEDO, Araminta Mercadante. Os Aspectos Institucionais da Integração LatinoAmericana, Revista de Informação Legislativa, a. 8, v. 30, p. 73-92, abr./jun. 1971.

BARJOT, Dominique. Introduction Générale. In: BARJOT, Dominique (Dir.). Penser et Construire l'Europe (1919-1992). Paris/Chasseneuil: SEDES/CNED, p. 1-48, 2008.

BARNAVI, Elie; POMIAN, Krzysztof. La Révolution Européenne (1945-2007). Paris : Perrin, 2008.

BASSO, Larissa de Santis. A Eficácia do Regionalismo no Desenvolvimento Reflexões para a América Latina. Dissertação (Mestrado em Direito). São Paulo: Faculdade de Direito, Universidade de São Paulo, 2008.

BASSO, Maristela. Apresentação da Segunda Edição. In: BASSO, Maristela (Org.). Mercosul - Seus Efeitos Jurídicos, Econômicos e Políticos nos Estados-Membros. 2 ed. Porto Alegre: Livraria do Advogado, p. 15-29, 1997.

. As Experiências do Mercosul e da União Européia, Revista CEJ, v. 2, n. 4, p. 73 83, abr. 1998a.

O Mercosul e a União Européia, Revista de Direito do Mercosul/Revista de Derecho del Mercosur, v. 2, n. 2, p. 21-35, abr.1998b.

BASTOS, Celso Ribeiro. Curso de Direito Constitucional. 22 ed. São Paulo : Saraiva, 2001.

BATAILLON, Gilles. Présentation du Colloque. In: ÉCOLE DES HAUTES ÉTUDES EN SCIENCES SOCIALES (EHESS). Claude Lefort et la Pensée du Politique. Paris : EHESS, 2012a. (Anotações da Palestra, realizada em 7.3.2012). 
Un Penseur de la Désincorporation. In: ÉCOLE DES HAUTES ÉTUDES EN SCIENCES SOCIALES (EHESS). Claude Lefort et la Pensée du Politique. Paris : EHESS, 2012b. (Anotações da Palestra, realizada em 7.3.2012).

BAUMAN, Zygmunt. O Mal-Estar da Pós-Modernidade. Rio de Janeiro: Jorge Zahar, 1998.

Europa - Uma Aventura Inacabada. Rio de Janeiro: Jorge Zahar, 2006.

BENETTI, Liliane. O Fundamento de Legitimidade do Direito na Teoria de Jürgen Habermas. Dissertação (Mestrado em Direito). São Paulo: Faculdade de Direito, Universidade de São Paulo, 2002.

BERL, Emmanuel. Évolution du Projet Européen, Bulletin SEDEIS, Paris, n. 789, p. 3-15, juin 1961.

BERNHARDT, Rudolf. Einführung. In: MOSLER, Hermann ; BERNHARDT, Rudolf; HILF, Meinhard. (Hg.). Grundrechtsschutz in Europa. Berlin/Heidelberg/New York: Springer, p. 3-6, 1977. (Internationales Kolloquium veranstaltet von Max-Planck-Institut für ausländisches öffentliches REcht und Völkerrecht - Heidelberg 1976).

. Europäische Menschenrechtskonvention - Entwicklung und gegenwärtiger Stand. In: MERTEN, Detlef; PAPIER, Hans-Jürgen (Hg.). Handbuch der Grundrechte in Deutschland und Europa. Heidelberg/München/Landsberg/Frechen/Hamburg: C. F. Müller, p. 45-75, 2010. (Band VI/1 - Europäische Grundrechte I).

BERSTEIN, Serge; MILZA, Pierre. Histoire de l'Europe Contemporaine - De l'Héritage de XIXe Siècle à l'Europe d'Aujourd'hui. Paris: Hatier, 2002.

BIGNOTTO, Newton. Un Lecteur de Machiavel. In: ÉCOLE DES HAUTES ÉTUDES EN SCIENCES SOCIALES (EHESS). Claude Lefort et la Pensée du Politique. Paris : EHESS, 2012. (Anotações da Palestra, realizada em 7.3.2012).

BITAR, Hildeberto. Prefácio. In : PLATÃO. Diálogos - Leis e Epínomis. V. XII-XIII. Belém: Universidade Federal do Pará, p. 5-16, 1980.

BITSCH, Marie-Thérèse. Histoire de la Construction Européenne - De 1945 à nos Jours. Bruxelles : Complexe, 2006. (Questions à 1'Histoire).

BITTAR, Eduardo Carlos Bianca. Curso de Filosofia Aristotélica. Barueri: Manole, 2003.

O Direito na Pós-Modernidade. São Paulo: Forense Universitária, 2005. 
BITTAR, Eduardo Carlos Bianca; ALMEIDA, Guilherme Assis de. Curso de Filosofia do Direito. 4 ed. São Paulo: Atlas, 2006.

BLOTTA, Vitor Souza Lima. O Direito da Comunicação: Reconstrução dos Princípios Normativos da Esfera Pública Política a partir do Pensamento de Jürgen Habermas. Tese (Doutorado em Direito). São Paulo: Faculdade de Direito, Universidade de São Paulo, 2012.

BOBBITT, Philip. The Shield of Achilles - War, Peace and the Course of History. London/New York/Toronto/Dublin: Penguin, 2003.

The Idea of War on Terror. In: TEIXEIRA, Nuno Severiano (Coord.). Global Security Challenges for Europe. Firenze: European University Institute (EUI)/Robert Schuman Centre for Advanced Studies (RSCAS), 2011. (Anotações da Palestra, realizada em 21.10.2011).

BOGDANDY, Armin von. La Fusion des Communautés dans l'Union Européenne - Un Modèle Juridique de Pluralisme Institutionnel dans un Cadre Institutionnel Unique, RDUE, v. 3, p. 617-54, 2001.

. The European Union as Situation, Executive, and Promoter of the International Law of Cultural Diversity, EJIL, v. 19, n. 2, p. 241-75, 2008.

BOSSUAT, Gérard. Les Fondateurs de l'Europe. Paris : Belin, 1994. (Histoire).

Sarre. In: GERBET, Pierre ; BOSSUAT, Gérard ; GROSBOIS, Thierry (Dir.). Dictionnaire Historique de l'Europe Unie. Bruxelles: André Versaille, p. 913-5, 2009.

BRASIL. Ministério das Relações Exteriores. Integração da América do Sul. Brasília: FUNAG, 2010.

BRONDEL, Georges. L’Élargissement à la Lumière des Expériences du Passé. In : RÉAU, Élisabeth du (Dir.). L'Élargissement de l'Union Européenne - Quels Enjeux ? Quels Défis ? Paris : Sorbonne Nouvelle, p. 79-83, 2001.

BRUGMANS, Hendrik. Le Fédéralisme Européen, Synthèses, Bruxelles, n. 9, sep. 1947. Disponível em: <http://www.cvce.eu/obj/Opinion_d_Henri_Brugmans_sur_le_federalisme_europeen_Sept embre_1947-frd141503e-61d0-456b-8245-72c1f7998f00.html >. Acesso em : 25.2.2013.

Le Congrès de la Haye - Avant, Pendant et Après. In: CONSEIL D'EUROPE. Annuaire Européen/European Yearbook. v. XV. La Haye/The Hague: Martinus Nijhoff, $1969 . \quad$ Disponível em : <http://www.cvce.eu/obj/Hendrik_Brugmans_Le_congres_de_La_Haye_avant_pendant_et _apres_1969-fr-887e4ebc-8a63-4947-b6ec-ed8e1a9c3dc3.html>. Acesso em : 25.2.2013. 
CAHEN, Alfred. L'Union de l'Europe Occidentale (UEO) et la Mise en Euvre de la Future Défense Commune de l'Union Européenne, Revue du Marché Commun et de l'Union Européenne, Paris, n. 394, p. 21-35, jan. 1996.

CAMPENHAUSEN, Alexander Freiherr von. Grundrechte als europäische Leitidee. In: MERTEN, Detlef; PAPIER, Hans-Jürgen (Hg.). Handbuch der Grundrechte in Deutschland und Europa. Heidelberg/München/Landsberg/Frechen/Hamburg: C. F. Müller, p. 3-43, 2010. (Band VI/1 - Europäische Grundrechte I).

CANSACCHI, Giorgio. U.E.O. (Unione Europea Occidentale). In: AZARA, Antonio; EULA, Ernesto (Dir.). Novissimo Digesto Italiano. v. XIX. Torino: UTET, p. 1013-14, 1973.

CARBONELL, Charles-Olivier. L'Europe. Une Histoire de ses Histoires. In : CARBONELL, Charles-Olivier (Dir.). De l'Europe - Identités et Identité, Mémoires et Mémoire. Toulouse : Université des Sciences Sociales de Toulouse, p. 235-54, 1996 .

. L'Europe sans Histoire? A Propos de Quelques Récentes Histoires de l'Europe. In : CARBONELL, Charles-Olivier (Dir.). De l'Europe - Identités et Identité, Mémoires et Mémoire. Toulouse : Université des Sciences Sociales de Toulouse, p. 25564, 1996b.

. Pour une Histoire Européenne de l'Europe. In : CARBONELL, Charles-Olivier (Dir.). De l'Europe - Identités et Identité, Mémoires et Mémoire. Toulouse : Université des Sciences Sociales de Toulouse, p. 265-72, 1996c.

CARBONELL, Charles-Olivier; BILOGHI, Dominique; LIMOUZIN, Jacques; ROUSSEAU, Fredéric; SCHULTZ; Joseph. Une Histoire Européenne de I Europe Mythes et Fondements (Des Origines au XV ${ }^{\mathrm{e}}$ Siècle). Toulouse: Privat, 1999a.

Une Histoire Européenne de I'Europe - D'Une Renaissance à l'Autre (XV ${ }^{\mathrm{e}}$ XX $^{\mathrm{e}}$ Siècle). Toulouse: Privat, 1999b.

CARDOSO, Sérgio. Que República? Notas sobre a Tradição do "Governo Misto". In: BIGNOTTO, Newton (Org.). Pensar a República. Belo Horizonte: Universidade Federal de Minas Gerais, p. 27-48, 2002.

Por que República? Notas sobre o Ideário Democrático e Republicano. In: CARDOSO, Sérgio (Org.). Retorno ao Republicanismo. Belo Horizonte: Universidade Federal de Minas Gerais, p. 45-66, 2004.

Republicanismo: Notas sobre a Presença de Artistóteles, Políbio e Cícero no Pensamento Político Italiano do Início do Século XVI. In: VALLS, Alvaro Luiz Montenegro; MARTINS, Jasson da Silva; AQUINO, Marcelo Fernandes de (Eds.). Atas 
do XIII Encontro Nacional da Filosofia (ANPOF). Campinas/Porto Alegre: ANPOF;Unisinos, p. 634-5, 2005.

- Claude Lefort: Uma História de Vida Política. In: FACULDADE DE FILOSOFIA, LETRAS E CIÊNCIAS HUMANAS DA UNIVERSIDADE DE SÃO PAULO. Homenagem ao Prof. Claude Lefort. São Paulo: Faculdade de Filosofia, Letras e Ciências Humanas da Universidade de São Paulo, 2011. (Anotação da Palestra, realizada em 28.4.2011).

Matrizes do Republicanismo Romano. São Paulo: s.n., 2012. (Mimeografado).

CARRILlo SAlCEDO, Juan António. El Derecho Internacional en un Mundo en Cambio. Madrid: Tecnos, 1985.

CASELLA, Paulo Borba. Comunidade Européia e seu Ordenamento Jurídico. São Paulo: LTr, 1994a.

Dimensão Constitucional da Integração Econômica, Revista de Informação Legislativa, a. 31, n. 122, p. 243-53, abr./jun. 1994b.

. Direito da Concorrência na C. E. e no MERCOSUL. In: BAPTISTA, Luiz Olavo; MERCADANTE, Araminta de Azevedo; CASELLA, Paulo Borba. Mercosul - Das Negociações à Implantação. São Paulo: LTr, p. 208-61, 1994c.

Mercosul - Exigências e Perspectivas. São Paulo: LTR, 1996a.

Introdução - Dimensão Jurídica da Integração Econômica. In: CASELLA, Paulo Borba (Coord.). Contratos Internacionais e Direito Econômico no MERCOSUL. São Paulo: LTr, p. 17-30, 1996 b.

Pax Perpetua - A Review of the Concept from the Perspective of Economic Integration. In: CASELLA, Paulo Borba. (Org.). Dimensão Internacional do Direito Estudos em Homenagem a G. E. Nascimento e Silva. São Paulo: LTr, p. 69-88, 2000a.

Síntese, 2000b.

Direito Internacional: Vertente Jurídica da Globalização. Porto Alegre: 2002.

União Europeia: Instituições e Ordenamento Jurídico. 2 ed. São Paulo: LTr, Impacto Interno e Internacional da Ampliação da União Européia, Revista da Faculdade de Direito da Universidade de São Paulo, v. 99, p. 523-37, jan./dez. 2004. 
Mercosul entre União Européia e Alca: Opção ou Sobrevivência na Selva? In: CASELLA, Paulo Borba; SANCHEZ, Rodrigo Elian. Quem tem medo da ALCA?. Belo Horizonte: Del Rey, p. 87-128, 2005.

Livro dos Ancestrais Imaginados e Outros Ensaios Pós-Modernos. Madrid: Amaral Gurgel, 2007a.

- Tratado de Versalhes na História do Direito Internacional. São Paulo: Quartier Latin, 2007b.

Latin, 2008.

Fundamentos do Direito Internacional Pós-Moderno. São Paulo: Quartier

. ABZ - Ensaios Didáticos. São Paulo: Imprensa Oficial do Estado, 2009a.

Direito Internacional dos Espaços. São Paulo: Atlas, 2009 b.

Direito Internacional do Desenvolvimento, Direito ao Desenvolvimento e a

Crise da Pós-Modernidade. São Paulo: s. n., 2009c. Mimeografado.

. Direito Internacional e Dignidade Humana. In: CASELLA, Paulo Borba; RAMOS, André de Carvalho. Direito Internacional: Homenagem a Adherbal Meira Mattos. São Paulo: Quartier Latin/FUNAG, 2009d.

Repensar a Integração Regional. In: BRASIL. Ministério das Relações Exteriores. Integração da América do Sul. Brasília: FUNAG, p. 169-92, 2010.

Prefácio. In: SETTE-CAMARA, José. Poluição de Rios Internacionais. São Paulo/Brasília: Quartier Latin/FUNAG, p. 11-9, 2011.

. Direito Internacional no Tempo Antigo. São Paulo: Atlas, 2012.

CELLI JR., Umberto. A Integração Latino-Americana: Do Discurso à Ação. Dissertação (Mestrado em Direito). São Paulo: Faculdade de Direito, Universidade de São Paulo, 1990.

- Teoria Geral da Integração: Em Busca de um Modelo Alternativo. In: MERCADANTE, Araminta Azevedo; CELLI JUNIOR, Umberto; ARAÚJO, Leandro Rocha (Orgs.). Blocos Econômicos e Integração na América Latina, África e Ásia. Curitiba: Juruá, p. 19-37, 2006.

CENTRE VIRTUEL DE CONNAISSANCE SUR L'EUROPE (CVCE). Les Négociations du Traité CECA. Sanem: CVCE, 2011. Disponível em : 
<http://www.cvce.eu/obj/Les_negociations_du_traite_CECA-fr-dde9a336-6df6-40f5-902a417ecda702e0.html>. Acesso em: 25.2.2013.

CHAUÍ, Marilena. Introdução à História da Filosofia: Dos Pré-Socráticos. 2 ed. São Paulo: Schwarcz, 2008.

CLERGERIE ; Jean-Louis ; GRUBER, Annie; RAMBAUD, Patrick. L'Union Européenne. 8 ed. Paris: Dalloz, 2010.

CLOSA, Carlos. ... 'E pur si muove': Teorías sobre la Integración Europea, Revista de Estudios Políticos (Nueva Epoca), n. 85, p. 339-64, jul./sep. 1994.

. La Ampliación de la Unión Europea y sus Efectos sobre el Proceso de Integración, Revista de Estudios Políticos (Nueva Epoca), n. 90, p. 147-71, oct./dic. 1995.

COMMUNAUTÉ EUROPÉENNE DU CHARBON ET DE L'ACIER (CECA). Assemblée Commune. Le Traité CECA devant les Parlements Nationaux. Luxembourg: Assemblée Commune CECA - Division Études, Information et Documentation, $1958 . \quad$ Disponível em : <http://www.cvce.eu/obj/Tableau_comparatif_des_votes_lors_de_la_ratification_du_traite _CECA-fr-16cb9e70-62ca-4d14-bed7-ba3dfc60cfb4.html>. Acesso em : 25.2.2013.

CONCI, Luis Guilherme Arcaro. Las Sentencias de los Tribunales Internacionales de Derechos Humanos y los Tribunales Supremos Nacionales: El Caso de Brasil. In: POZO, Carlos Molina del; PIZZOLO, Calogero (Orgs.). Seminario Internacional - Derecho Constitucional Transnacional. Madrid: Facultad de Derecho de la Universidad de Alcalá de Henares, 2012. (Anotações da Palestra, realizada em 22.2.2012).

COSTA, José Augusto Fontoura. Globalização e Integração Jurídica. In: PIMENTEL, Luiz Otávio (Org.). Mercosul, ALCA e Integração Euro-Latino-Americana. v. II. Curitiba: Juruá, p. 39-48, 2001.

CUNHA, Ricardo Thomazinho da. O Direito de Defesa Concorrencial no Mercosul: um Estudo Comparativo com a União Européia. Tese (Doutorado em Direito). São Paulo: Faculdade de Direito, Universidade de São Paulo, 2000.

DALLARI, Dalmo de Abreu. Elementos de Teoria Geral do Estado. 22 ed. São Paulo: Saraiva, 2001.

DANIELE, Luigi. Il Diritto Materiale della Comunità Economica Europea Introduzione allo Studio delle Libertà di Circolazione e delle Politiche Comunitarie. Milano: Giuffrè, 1991. 
DAVID, François. Reconstruire l'Europe: Plan Marshall et Politique de Containment. In: BARJOT, Dominique (Dir.). Penser et Construire l'Europe (1919-1992). Paris/Chasseneuil: SEDES/CNED, p. 129-43, 2008.

DEHOUSSE, Renaud. The 'Community Method' at Sixty. In: DEHOUSSE, Renaud (Ed.). The 'Community Method' - Obstinate or Obsolete? Basingstoke/New York: Palgrave Macmillan, p. 3-15, 2011. (Palgrave Studies in European Union Politics).

DELANTY, Gerard. The European Heritage from a Critical Cosmopolitan Perspective, s.1., London School of Economics and Political Science, feb. 2010. (LSE 'Europe in Question' Discussion Paper Series).

DELMAS-MARTY, Mireille. Por um Direito Comum. São Paulo: Martins Fontes, 2004. (Justiça e Direito).

DESCAMPS, Olivier. Histoire de la Construction Européenne. Paris : Université Panthéon-Assas (Paris II) - Institut de Droit Comparé (IDC), 2011a. (Anotações da Primeira Aula da Disciplina Histoire de la Construction Européenne, do Curso Master 2 Recherche - Droit de l'Union Européenne).

Histoire de la Construction Européenne. Paris : Université Panthéon-Assas (Paris II) - Institut de Droit Comparé (IDC), 2011b. (Anotações da Segunda Aula da Disciplina Histoire de la Construction Européenne, do Curso Master 2 Recherche - Droit de l'Union Européenne).

Histoire de la Construction Européenne. Paris : Université Panthéon-Assas (Paris II) - Institut de Droit Comparé (IDC), 2011c. (Anotações da Terceira Aula da Disciplina Histoire de la Construction Européenne, do Curso Master 2 Recherche - Droit de l’Union Européenne).

Histoire de la Construction Européenne. Paris : Université Panthéon-Assas (Paris II) - Institut de Droit Comparé (IDC), 2011d. (Anotações da Quarta Aula da Disciplina Histoire de la Construction Européenne, do Curso Master 2 Recherche - Droit de l’Union Européenne).

Histoire de la Construction Européenne. Paris : Université Panthéon-Assas (Paris II) - Institut de Droit Comparé (IDC), 2011e. (Anotações da Quinta Aula da Disciplina Histoire de la Construction Européenne, do Curso Master 2 Recherche - Droit de l'Union Européenne).

Histoire de la Construction Européenne. Paris : Université Panthéon-Assas (Paris II) - Institut de Droit Comparé (IDC), 2011f. (Anotações da Sexta Aula da Disciplina Histoire de la Construction Européenne, do Curso Master 2 Recherche - Droit de l'Union Européenne). 
Histoire de la Construction Européenne. Paris : Université Panthéon-Assas (Paris II) - Institut de Droit Comparé (IDC), 2011g. (Anotações da Sétima Aula da Disciplina Histoire de la Construction Européenne, do Curso Master 2 Recherche - Droit de l'Union Européenne).

Histoire de la Construction Européenne. Paris : Université Panthéon-Assas (Paris II) - Institut de Droit Comparé (IDC), 2011h. (Anotações da Oitava Aula da Disciplina Histoire de la Construction Européenne, do Curso Master 2 Recherche - Droit de l'Union Européenne).

Histoire de la Construction Européenne. Paris : Université Panthéon-Assas (Paris II) - Institut de Droit Comparé (IDC), 2011i. (Anotações da Nona Aula da Disciplina Histoire de la Construction Européenne, do Curso Master 2 Recherche - Droit de l'Union Européenne).

Histoire de la Construction Européenne. Paris : Université Panthéon-Assas (Paris II) - Institut de Droit Comparé (IDC), 2011j. (Anotações da Décima Aula da Disciplina Histoire de la Construction Européenne, do Curso Master 2 Recherche - Droit de l’Union Européenne).

Histoire de la Construction Européenne. Paris : Université Panthéon-Assas (Paris II) - Institut de Droit Comparé (IDC), 2011k. (Anotações da Décima Primeira Aula da Disciplina Histoire de la Construction Européenne, do Curso Master 2 Recherche Droit de l'Union Européenne).

Histoire de la Construction Européenne. Paris : Université Panthéon-Assas (Paris II) - Institut de Droit Comparé (IDC), 20111. (Anotações da Décima Segunda Aula da Disciplina Histoire de la Construction Européenne, do Curso Master 2 Recherche Droit de l'Union Européenne).

DESCARTES, René. Regras para a Direcção do Espírito. Lisboa: 70, 1985.

Discurso do Método. 2 ed. São Paulo: Martins Fontes, 2001.

DESCHAMPS, Étienne. Campagne Européenne de la Jeunesse. In: GERBET, Pierre ; BOSSUAT, Gérard; GROSBOIS, Thierry (Dir.). Dictionnaire Historique de l'Europe Unie. Bruxelles: André Versaille, p. 160-4, 2009a.

. Centre Européen de la Culture. In: GERBET, Pierre; BOSSUAT, Gérard; GROSBOIS, Thierry (Dir.). Dictionnaire Historique de l'Europe Unie. Bruxelles: André Versaille, p. 175-7, 2009b.

Collège d'Europe. In: GERBET, Pierre ; BOSSUAT, Gérard ; GROSBOIS, Thierry (Dir.). Dictionnaire Historique de l'Europe Unie. Bruxelles: André Versaille, p. 201-3, 2009c. 
DREYFUS, Emmanuel. Vers une Europe Économique. In: BARJOT, Dominique (Dir.). Penser et Construire l'Europe (1919-1992). Paris/Chasseneuil: SEDES/CNED, p. 14457, 2008.

FARIA, José Eduardo. A Inflação Legislativa e a Crise do Estado no Brasil, Direito, Estado e Sociedade, n. 5, p. 49-60, ago./dez. 1994.

O Direito num Cenário em Transformação, Revista do Tribunal Regional do Trabalho da Nona Região, v. 21, n. 1, p. 77-83, jan./jul. 1996.

O Direito na Economia Globalizada. São Paulo: Malheiros, 1999.

Direito e Conjuntura. São Paulo: Saraiva, 2008. (Série GVlaw).

O Novo Modelo de Sistema Legal. São Paulo: Faculdade de Direito da Universidade de São Paulo - Largo São Francisco (FADUSP), 2009. (Anotações da Décima Segunda Aula da Disciplina Metodologia do Ensino Jurídico, do Curso de PósGraduação em Direito).

FERRAJOLI, Luigi. Sobre los Derechos Fundamentales, Cuestiones Constitucionales: Revista Mexicana de Derecho Constitucional, México D.F., n. 15, p. 113-36, jul./dic. 2006.

FERRAZ JR., Tercio Sampaio. Conceito de Sistema no Direito. São Paulo: Revista dos Tribunais/Universidade de São Paulo, 1976.

Introdução ao Estudo do Direito - Técnica, Decisão, Dominação. 3 ed. São Paulo: Atlas, 2001.

Estudos de Filosofia do Direito - Reflexões sobre o Poder, a Liberdade, a Justiça e o Direito. 2 ed. São Paulo: Atlas, 2003.

FIGUEIREDO, Marcelo. América Latina y la Defensa y Promoción de los Derechos Humanos: Las Constituciones y El Derecho Internacional de los Derechos Humanos en la Región. In: POZO, Carlos Molina del; PIZZOLO, Calogero (Orgs.). Seminario Internacional - Derecho Constitucional Transnacional. Madrid: Facultad de Derecho de la Universidad de Alcalá de Henares, 2012. (Anotações da Palestra, realizada em 22.2.2012).

FITZMAURICE, Gerald. Some Reflections on the European Convention on Human Rights - and on Human Rights. In: BERNHARDT, Rudolf; GECK, Wilhelm Karl; JAENICKE, Günther; STEINBERGER, Helmut. (Hg.). Völkerrecht als Rechtordnung - 
Internationale Gerichtsbarkeit Menschenrechte. Berlin/Heidelberg/New York: Springer, p. 203-19, 1983.

FLANDIN, Pierre-Étienne. Le Plan Schuman - Aspects Politiques, Nouvelle Revue de l'Économie Contemporaine, Paris, n. 16-17, 1951. Disponível em : <http://www.cvce.eu/obj/Pierre_Etienne_Flandin_Le_plan_Schuman_Aspects_politiques_ 1951-fr-140c8759-4260-43b2-aafd-c5f293e8274e.html>. Acesso em : 25.2.2013. (Numéro Spécial: Le Plan Schuman).

FLORIO, Líbia Cristiane Corrêa de Andrade e. O Conceito Jurídico de Consumidor e Fornecedor no Mercosul e na União Européia. Dissertação (Mestrado em Direito). São Paulo: Faculdade de Direito, Universidade de São Paulo, 2002.

FOUCAULT, Michel. Qu'est-ce qu'un Auteur? In : FOUCAULT, Michel. Dits et Écrits: 1954-1969. t. I. Paris: Gallimard, p. 789-821, 1994.

FRANCE. Cour de Cassation. La Nouvelle Architecture Institutionnelle et les Compétences de l'Union Européenne après le Traité de Lisbonne. In : KESSEDJIAN, Catherine (Org.). Cycle Droit de l'Union Européenne. Paris : Cour de Cassation, 2011a. (Anotações da Palestra, realizada em 29.9.2011).

La Charte des Droits Fondamentaux de l'Union Européenne et l'Office du Juge National. In : KESSEDJIAN, Catherine (Org.). Cycle Droit de l'Union Européenne. Paris : Cour de Cassation, 2011b. (Anotações da Palestra, realizada em 24.11.2011).

Les Nouveaux Droits Conférés par la Citoyenneté Européenne. In : KESSEDJIAN, Catherine (Org.). Cycle Droit de l'Union Européenne. Paris : Cour de Cassation, 2011c. (Anotações da Palestra, realizada em 15.12.2011).

FREY, Bruno S. A New Concept of European Federalism, s.1., London School of Economics and Political Science, may 2009. (LSE 'Europe in Question' Discussion Paper Series).

FRIEDMANN, Wolfgang. The Changing Structure of International Law. New York: Columbia University, 1964.

GAUTRON, Jean-Claude. Um Ordre Juridique Autonome et Hiérarchisé. In : RIDEAU, Joël (Dir.). De la Communauté de Droit à l'Union de Droit - Continuités et Avatars Européens. Paris : L.G.D.J., p. 25-26, 2000.

GERBET, Pierre. Acte Unique Européen. In: GERBET, Pierre ; BOSSUAT, Gérard ; GROSBOIS, Thierry (Dir.). Dictionnaire Historique de l'Europe Unie. Bruxelles: André Versaille, p. 17-9, 2009a. 
Conseil Européen. In: GERBET, Pierre ; BOSSUAT, Gérard ; GROSBOIS, Thierry (Dir.). Dictionnaire Historique de l'Europe Unie. Bruxelles: André Versaille, p. 300-6, 2009b.

Fonctionnalisme. In: GERBET, Pierre ; BOSSUAT, Gérard ; GROSBOIS, Thierry (Dir.). Dictionnaire Historique de l'Europe Unie. Bruxelles: André Versaille, p. 481-4, 2009c.

Allemagne. In: GERBET, Pierre ; BOSSUAT, Gérard ; GROSBOIS, Thierry (Dir.). Dictionnaire Historique de l'Europe Unie. Bruxelles: André Versaille, p. 45-52, 2009d.

GIANNATTASIO, Arthur Roberto Capella. A Opinio Iuris Sive Necessitatis: Do Elemento Subjetivo Consuetudinário à Intersubjetividade Jurídica. In: CASELLA, Paulo Borba; RAMOS, André de Carvalho. Direito Internacional: Homenagem a Adherbal Meira Mattos. São Paulo: Quartier Latin/FUNAG, p. 575-617, 2009a.

Ensino e Recusa dos Direitos Humanos no Brasil: A Ambivalência das Origens, dos Fundamentos e da Eficácia dos Direitos Humanos. XVIII CONGRESSO NACIONAL DO CONSELHO NACIONAL DE PESQUISA DE PÓS-GRADUAÇÃO EM DIREITO. 2009. São Paulo. Anais... Florianópolis: CONPEDI/Fundação Boiteux, p. 8565-87, 2009b.

A Função Simbólica da Liberdade Sindical. Monografia (Especialização em Direito do Trabalho). São Paulo: Faculdade de Direito, Universidade de São Paulo, 2009c.

Problemas sobre a Pesquisa em Direito no Brasil: Uma Perspectiva. XIX CONGRESSO NACIONAL DO CONSELHO NACIONAL DE PESQUISA DE PÓSGRADUAÇÃO EM DIREITO. 2010. Florianópolis. Anais... Florianópolis: CONPEDI/Fundação Boiteux, p. 8018-36, 2010a.

O Direito Internacional entre Dois Pós-Modernismos: A Ressignificação das Relações entre Direito Internacional e Direito Interno, Revista Eletrônica do CEDIN, v. 6, p. 42-90, 2010b.

Globalização Jurídico-Econômica e Irritações Legais Locais: A Racionalidade de Incorporação do Law \& Economics pelo Pensamento Jurídico Brasileiro. XIX CONGRESSO NACIONAL DO CONSELHO NACIONAL DE PESQUISA DE PÓS-GRADUAÇÃO EM DIREITO. 2010. Florianópolis. Anais... Florianópolis: CONPEDI/Fundação Boiteux, p. 707-32, 2010c.

International Law between Two Postmodernisms: Reframing the Relationship between International Law and Domestic Law. In: FORST, Rainer; ROSA, Hartmut (Orgs.). Philosophy and the Social Sciences. Prague: Johann Wolfgang Goethe Universität Frankfurt am Main/Friedrich Schiller - Universität Jena an der Saale/Academy 
of Sciences of the Czech Republic/Charles University, 2011a. (Conferência realizada entre 11-5.5.2011).

International Human Rights: A Dystopian Utopia. In: MANCHESTER CENTRE FOR POLITICAL THEORY (MANCEPT). MANCEPT's Workshops - Eighth Annual Conference. Manchester: University of Manchester, 2011b. (Conferência realizada entre 31.8.2011-2.9.2011).

GIANNATTASIO, Arthur Roberto Capella; PREBIANCA, Letícia. A Responsabilidade Civil pelo Assédio Moral - Limites e Possibilidades, Revista LTr, v. 74, p. 233-41, 2010.

A Responsabilidade Civil em razão do Assédio Moral: A Função Social da Empresa como Opção Normativa Regular acerca da Colisão dos Princípios da Liberdade e da Igualdade. In: FREITAS JR., Antônio Rodrigues; BOUCINHAS FILHO, Jorge Cavalcanti; BASTAZINE, Cleber Alves (Org.). Responsabilidade Civil nas Relações de Trabalho: Questões Atuais e Controvertidas. São Paulo: LTr, p. 80-95, 2011.

GIANNATTASIO, Arthur Roberto Capella; SCUDELlER, Pedro de Assis Pereira. Cidadania na Comparação Internacional. In: RICHTER, Thomas; SCHMIDT, Rainer (Org.). Integração e Cidadania Europeia. São Paulo: Saraiva, p. 164-208, 2011.

GLAESNER, Hans-Joachim. Les Objectifs de la Communauté Économique Européenne Origine et Développements. In : L'Europe et le Droit - Mélanges en Hommage à Jean BOULOUIS. Paris : Dalloz, p. 285-95, 1991.

GODARD, Jean-Luc. Je vous salue, Sarajevo. (2 min), France: Périphéria/ECM, 2006. (son., color.).

GOLDSCHMIDT, Vitor. A Religião de Platão. São Paulo: Difel, 1963.

HABERMAS, Jürgen. O Ocidente Dividido. Rio de Janeiro: Tempo Brasileiro, 2006.

Die Zukunft der Europäischen Union. In: GOETHE-INSTITUT PARIS. Entretien avec Jürgen Habermas - Hommage à la Vie et à l'Guvre . Paris : GoetheInstitut Paris, 2011a. (Anotações da Palestra, realizada em 12.11.2011).

. La Crise de l'Union Européenne à la Lumière d'une Constitionalisation du Droit International. In: UNIVERSITÉ PARIS-DESCARTES (PARIS V). Colloque International - Comment surmonter les Crises du Présent : Quel Avenir pour l'Europe ?, Paris, 2011b. (Anotações da Palestra, realizada em 10.11.2011).

The Crisis of the European Union in the Light of a Constitutionalization of International Law, EJIL, v. 23, n. 2, p. 335-348, may 2012. 
HALL, Stuart. A Identidade Cultural na Pós-Modernidade. 11 ed. Rio de Janeiro, DP\&A, 2006.

HARST, Jan van der. Introduction - History and Theory, RHIE, v. 14, n. 1, p. 5-8, 2008.

HARTOG, François. Préface. In: POLYBE. Histoire. Paris: Gallimard, p. 9-29, 2003. (Quarto Gallimard).

HOBOLTH, Mogens. European Visa Cooperation: Interest Politics and Regional Imagined Communities, s.l., London School of Economics and Political Science, may 2011. (LSE 'Europe in Question’ Discussion Paper Series).

HOBSBAWM, Eric. O Novo Século. São Paulo: Schwarcz, 2000.

HOMERO. Odisséia. 5 ed. Rio de Janeiro: Ediouro, 2002.

HUDEMANN, Rainer. Couple Franco-Allemand. In: BERTONCINI, Yves; CHOPIN, Thierry; DULPHY, Anne; KAHN, Sylvain; MANIGAND, Christine. Dictionnaire Critique de l'Union Européenne. Paris: Armand Colin, p. 93-6, 2008.

HUSSERL, Edmund. Investigações Lógicas - Sexta Investigação (Elementos de uma Elucidação Fenomenológica do Conhecimento). In: HUSSERL, Edmund. Husserl. São Paulo: Abril Cultural, 1980. (Col. Os Pensadores).

Ideias para uma Fenomenologia Pura e para uma Filosofia Fenomenológica. 3 ed. Aparecida: Idéias \& Letras, 2006.

HUSSON, Édouard. Idée Européenne, Europe Allemande, Ordre Nouveau Nazi. In: BARJOT, Dominique (Dir.). Penser et Construire l'Europe (1919-1992). Paris/Chasseneuil: SEDES/CNED, p. 109-25, 2008.

JAMESON, Fredric. Pós-modernidade e Sociedade de Consumo, Novos Estudos CEBRAP, n. 12, p.16-26, jun. 1985.

JAMET, Jean-François. L'Europe Peut-Elle se Passer d'Un Gouvernement Économique? Paris : La Documentation Française, 2011. (SciencesPo/Réflexe Europe).

JOERGERS, Christian. Unity in Diversity as Europe's Vocation and Conflict Law as Europe's Constitutional Form. s.l., London School of Economics and Political Science, dec. 2010. (LSE ‘Europe in Question’ Discussion Paper Series).

JUDT, Tony. Pós-Guerra: Uma História da Europa desde 1945. Rio de Janeiro: Objetiva, 2008. 
KANT, Immanuel. Prolegômenos. In: Kant. v. II. São Paulo: Abril Cultural, 1980. (Col. Os Pensadores).

Crítica da Razão Pura. Petrópolis/Bragança Paulista: Vozes/Universitária São Francisco, 2012. (Col. Pensamento Humano).

KARAGIANNIS, Syméon. Le Protocole de 1997 sur les Institutions dans la Perspective de l'Élargissement de l’Union Européenne, RDUE, v. 2, p. 337-59, 2000.

KELSEN, Hans. Teoria Pura do Direito. 6 ed. São Paulo: Martins Fontes, 2000.

. A Paz pelo Direito. São Paulo: WMF Martins Fontes, 2011.

KESSEDJIAN, Catherine. Choice of Court. São Paulo: Universidade de São Paulo Faculdade de Direito do Largo São Franscisco (FADUSP), 2010. (Anotações da Segunda Aula da Disciplina Contencioso Internacional nos Tribunais Nacionais e Internacionais, do Curso de Pós-Graduação em Direito da FADUSP).

KHOURY, Aline. Le Patrimoine Immatériel dans le Développement Social : Sa Sauvegarde, Ses Controverses et ses Manipulations Illustrées à San Basílio de Palenque. Mémoire (Master en Sciences de la Société). Paris : Sciences Humaines et Sociales Sorbonne, Université Paris Descartes (Paris V), 2012.

KYMLICKA, Will. Multicultural Odysseys: Navigating the New International Politics of Diversity. Oxford: Oxford University, 2007.

LA BOÉTIE, Etienne de. Discurso da Servidão Voluntária ou o Contra Um. In: CLASTRES, Pierre; LEFORT, Claude; CHAUÍ, Marilena. Discurso da Servidão Voluntária. São Paulo: Brasiliense, p. 11- 37, 1999.

LAFER, Celso. A OMC face à Globalização e à Regionalização, Política Externa, v. 6, n. 2, p. 84-93, set./nov. 1997.

A OMC e a Regulamentação do Comércio Internacional - Uma Visão Brasileira. Porto Alegre: Livraria do Advogado, 1998.

LALANDE, André. Invenção. In: LALANDE, André. Vocabulário Técnico e Crítico da Filosofia. 3 ed. São Paulo: Martins Fontes, p. 597, 1999.

LAMBERTI, Lucia Baungartner. Reestruturação do Direito Internacional: Reflexões sobre o Papel do Direito numa Ordem Mundial em Transformação. Dissertação (Mestrado em Direito). São Paulo: Faculdade de Direito, Universidade de São Paulo, 1991. 
LAUMONIER, Paul. La Pensée de Montaigne. In: IV $^{\mathrm{e}}$ Centenaire de la Naissance de Montaigne 1533-1933. Genève: Slatkine, p. 163-81, 1969.

LEBRUN, Gérard. Sobre Kant. São Paulo: Iluminuras/Universidade de São Paulo, 1993.

LECOURT, Robert. Quel eut Été le Droit des Communautés sans les Arrêts de 1963 et 1964 ? In : L'Europe et le Droit - Mélanges en Hommage à Jean BOULOUIS. Paris : Dalloz, p. 349-61, 1991.

LEFORT, Claude. Éléments d'une Critique de la Bureaucratie. Paris : Gallimard, 1979. (Collection Tel).

Le Travail de l'Euvre Machiavel. Paris : Gallimard, 1986. (Collection Tel).

. Permanência do Teológico-Político? In: LEFORT, Claude. Pensando o Político Ensaios sobre Democracia, Revolução e Liberdade. São Paulo/Rio de Janeiro: Paz e Terra, 1991.

Machiavel et la veritá effetuale. In: LEFORT, Claude. Écrire - À l'Épreuve du Politique. Paris : Calmann-Lévy, p. 141-79, 1992a.

Foyers du Républicanisme. In: LEFORT, Claude. Écrire - À l'Épreuve du Politique. Paris : Calmann-Lévy, p. 181-209, 1992b.

Préface. In: LEFORT, Claude. Écrire - À l'Épreuve du Politique. Paris : Calmann-Lévy, p. 9-13, 1992c.

O Nome de Um. In: CLASTRES, Pierre; LEFORT, Claude; CHAUÍ, Marilena. Discurso da Servidão Voluntária. São Paulo: Brasiliense, p. 125-71, 1999.

. La Littérature Moderne comme Expression de l'Homme. In : LEFORT, Claude. Le Temps Présent - Écrits 1945-2005. Paris : Belin, p. 109-26, 2007a.

Avertissement. In : LEFORT, Claude. Le Temps Présent - Écrits 1945-2005. Paris : Belin, p. 29, $2007 \mathrm{~b}$.

Sur Penser la Guerre, Clausewitz de Raymond Aron. In : LEFORT, Claude. Le Temps Présent - Écrits 1945-2005. Paris : Belin, p. 321-40, 2007d.

Repenser la Démocratie. In : LEFORT, Claude. Le Temps Présent - Écrits 1945-2005. Paris : Belin, p. 341-6, 2007e. 
. L'Europe: Civilisation Urbaine. In : LEFORT, Claude. Le Temps Présent Écrits 1945-2005. Paris : Belin, p. 1001-18, 2007h.

LEMBO, Carolina Maria. Federalismo e suas Variantes - Do Modelo Norte-Americano à União Europeia. Dissertação (Mestrado em Direito). São Paulo: Faculdade de Direito, Universidade de São Paulo, 2010.

LEOPOLDO E SILVA, Franklin. Fenomenologia e Existencialismo. In: Fundadores do Pensamento. Campinas: TV Cultura/Espaço cultural CPFL, 2006. 54:02. (Série Balanço do Século XX - Paradigmas do Século XXI).

LIMA, Maria Lúcia M. Pádua; GOLDBAUM, Sérgio; ARASHIRO, Zuleika; PEDROSSIAN NETO, Pedro; LIMA, Ieda Miyuki Koshi Dias de. Acordos Regionais de Comércio. In: THORSTENSEN, Vera; JANK, Marcos S. (Coord.). O Brasil e os Grandes Temas do Comércio Internacional. São Paulo: Lex/Aduaneiras, p. 209-39, 2005.

LOTH, Wilfried. Explaining European Integration: The Contribution from Historians, RHIE, v. 14, n. 1, p. 9-26, 2008.

LUCATELLO, Guido. Consiglio d'Europa. In: AZARA, Antonio; EULA, Ernesto (Dir.). Novissimo Digesto Italiano. v. IV. Torino: UTET, p. 131-6, 1959.

MACEDO JR., Ronaldo Porto. O Método de Leitura Estrutural, Cadernos DireitoGV, São Paulo, v. 4, n. 2, mar. 2007.

MACEK, Lukáš. L’Élargissement Met-Il en Péril le Projet Européen ? Paris : La Documentation Française, 2011. (SciencesPo/Réflexe Europe).

MAgalHÃeS, José Carlos de. Direito Econômico Internacional - Tendências e Perspectivas. Curitiba: Juruá, 2005.

MagnetTe, Paul. Au Nom de Peuples - Le Malentendu Constitutionnel Européen. Paris: Cerf, 2006. (Humanités).

MAQUIAVEL, Nicolau. O Príncipe. 3 ed. São Paulo: Martins Fontes, 2004.

. Comentários sobre a Primeira Década de Tito Lívio. 5 ed. Brasília: Universidade de Brasília, 2008.

Discurso sobre as Formas de Governo de Florença após a Morte do Jovem Lorenzo de Medici. In: ADVERSE, Helton (Org.). Maquiavel: Diálogo sobre Nossa Língua e Discurso sobre as Formas de Governo de Florença. Belo Horizonte: Universidade Federal de Minas Gerais (UFMG), p. 59-78, 2010. 
MARC, Alexandre. L'Europe assume son Destin, Cahiers du Monde Nouveau, Paris, a. 4, n. 5, Mai 1948. Disponível em : <http://www.cvce.eu/obj/Alexandre_Marc_L_Europe_assume_son_destin_dans_Cahiers_d u_Monde_nouveau_Mai_1948

-fr-f9936724-9ca5-4c9a-9605-6287953be9f4.html>. Acesso em : 25.2.2013.

MARCOTTE-CHENARD, Sophie. La Question de l'Eeuvre et le Statut de la Parole Interprétative. In: ÉCOLE DES HAUTES ÉTUDES EN SCIENCES SOCIALES (EHESS). Claude Lefort et la Pensée du Politique. Paris : EHESS, 2012. (Anotações da Palestra, realizada em 7.3.2012).

MARTINICO, Giuseppe. Is the European Convention Going to Be 'Supreme'? A Comparative-Constitutional Overview of ECHR and EU Law before National Courts, EJIL, v. 23, n. 2, p. 401-24, 2012.

MATTERA, Alfonso. De la Deuxième Guerre Mondiale au «Projet Européen » de Jean Monnet, RDUE, n. 1, p. 5-33, 2002.

MAZOWER, Mark. Dark Continent - Europe's Twentieth Century. London/New York/Toronto/Dublin: Penguin, 1998.

MENEZES, Wagner. Lineamentos para a Sistematização do Estudo do Direito da Integração, Revista dos Tribunais, a. 89, v. 773, p. 52-73, mar. 2000a.

. Direito Comunitário, Revista dos Tribunais, a. 89, v. 778, p. 733-52, ago. 2000 b.

MERLEAU-PONTY, Maurice. Signes. Paris : Gallimard, 1960. (Folio essais).

. Sens et Non-Sens. Paris : Gallimard, 1996. (Bibliothèque de Philosophie).

Conversas - 1948. São Paulo: Martins Fontes, 2004.

MEZZETTI, Luca. La Protección de los Derechos Humanos en la UE después del Tratado de Lisboa: La Futura Adhésion al Convenio Europea, la Carta de Derechos Fundamentales de la UE. Madrid: Universidad Alcalá de Henares - Facultad de Derecho, 2012. (Anotações da Aula do II Curso de Actualización en Teoría y Práctica de la Integración Regional).

MINIUCI, Geraldo. O Direito Internacional, o Projeto de Integração Europeia e a Crise na Zona do Euro: E Agora?, Revista Consulex, n. 374, 2012. (Mimeografado).

MIRAGEM, Bruno. Conteúdo da Ordem Pública e os Direitos Humanos. Elementos para um Direito Internacional Pós-Moderno. In: MARQUES, Claudia Lima; ARAUJO, Nadia 
de. O Novo Direito Internacional - Estudos em Homenagem a Erik Jayme. Rio de Janeiro/São Paulo/Recife: Renovar, 2005.

MONACO, Gustavo Ferraz de Campos. A União Européia, os Estados e as Regiões: Em Busca da Coesão Econômica e Social por meio de uma Política Regional - Aspectos Jurídicos, Revista Instituto de Pesquisas e Estudos, n. 39, p. 211-30, jan./abr. 2004.

MONACO, Riccardo. Comunità Economica Europea. In: Enciclopedia del Diritto. t. VIII. Milano: Giuffrè, p. 319-37, 1961a. (Compe-Cong).

Comunità Europea del Carbone e dell'Acciaio. In: Enciclopedia del Diritto. t. VIII. Milano: Giuffrè, p. 337-47, 1961b. (Compe-Cong).

. Consiglio d'Europa. In: Enciclopedia del Diritto. t. IX. Milano: Giuffrè, p. 20919, 1961c. (Coni-Contratto).

MONTAIGNE, Michel de. Ensaios. 2 ed. São Paulo: Abril Cultural, 1980. (Col. Os Pensadores).

MORA, José Ferrater. Ceticismo, Céticos. In: MORA, José Ferrater. Dicionário de Filosofia (A-D). t. I, São Paulo: Loyola, p. 436-440, 2000.

MORAVCSIK, Andrew. The Choice for Europe: Social Purpose \& State Power from Messina to Maastricht. London/New York: Routledge, 2005.

MOSLER, Hermann; BERNHARDT, Rudolf. Ergebnisse und Perspektiven des Kolloquiums über Grundrechtsschutz in Europa. In: MOSLER, Hermann ; BERNHARDT, Rudolf; HILF, Meinhard. (Hg.). Grundrechtsschutz in Europa. Berlin/Heidelberg/New York: Springer, p. 205-23, 1977. (Internationales Kolloquium veranstaltet von MaxPlanck-Institut für ausländisches öffentliches REcht und Völkerrecht - Heidelberg 1976).

MOURA, Carlos Alberto Ribeiro. Prefácio. In: HUSSERL, Edmund. Ideias para uma Fenomenologia Pura e para uma Filosofia Fenomenológica. 3 ed. Aparecida: Idéias \& Letras, p. , 15-23, 2006a.

Husserl: Significação e Fenômeno, Dois Pontos, v. 3, n. 1, p. 37-61, abr. 2006b.

NAPOLETANO, Guido; MOLINARO, Enrico. Unione dell'Europa Occidentale. In: Enciclopedia del Diritto. t. XLV. Milano: Giuffrè, p. 734-40, 1992. (Tribunale Utilitarismo).

NASCIMENTO, Milton Meira do. Rousseau, a Revolução e os Nossos Fantasmas, Discurso, São Paulo, v. 13, p. 169-85, 1983. 
119-29, 1988.

O Contrato Social - Entre a Escala e o Programa, Discurso, São Paulo, v. 17, p. Opinião Pública e Revolução. São Paulo: USP/Nova Stella, 1989.

A Transparência dos Corações, Jornal de Resenhas, São Paulo, n. 12, p. 371-2, mar. 1996.

A Recepção do Contrato Social durante a Revolução. São Paulo: Universidade de São Paulo - Faculdade de Filosofia, Letras e Ciências Humanas (FFLCH/USP), 2010. (Anotações da Sétima Aula da Disciplina Ética e Filosofia Política - Opinião Pública e Revolução, do Curso de Pós-Graduação em Filosofia da FFLCH/USP).

NASCIMENTO E SILVA, Geraldo Eulálio do; ACCIOLY, Hildebrando. Manual de Direito Internacional Público. 15 ed. São Paulo: Saraiva, 2002.

NIETZSCHE, Friedrich. Aurora. Petrópolis: Vozes, 2008.

NOËL, Gilbert; JEANNESSON, Stanislas; ULRICH-PIER, Raphaële; BRICE, Catherine; FABRE, Rémi. Penser et Construire l'Europe (1919-1992). Neuilly: Atlande, 2008. (Histoire Contemporaine).

OLDROYD, David. The Arch of Knowledge: An Introductory Study of the History of the Philosophy and Methodology of Science. New York/London: Methuen, 1986.

OLIVI, Bino; GIACONE, Alessandro. L'Europe Difficile - La Construction Européenne. Paris : Gallimard, 2007. (Folio Histoire).

PACHET, Pierre. Un Lecteur aux Aguets. In: ÉCOLE DES HAUTES ÉTUDES EN SCIENCES SOCIALES (EHESS). Claude Lefort et la Pensée du Politique. Paris : EHESS, 2012. (Anotações da Palestra, realizada em 8.3.2012).

PÉDECH, Paul. La Méthode Historique de Polybe. Paris : Les Belles Lettres, 1964.

PERTEK, Jacques. Droit des Institutions de l'Union Européenne. 3 ed. Paris : Presses Universitaires de France, 2011. (Col. Thémis).

PILOTTI, Massimo. C.E.C.A. (Communità Europea del Carbone e dell'Acciaio. In: AZARA, Antonio; EULA, Ernesto (Dir.). Novissimo Digesto Italiano. v. III. Torino: UTET, p. 75-87, 1959.

PINHEIRO, Armando Castelar; SADDI, Jairo. Direito, Economia e Mercados. Rio de Janeiro: Campus/Elsevier, 2005. 
PIOVESAN, Flávia. Temas de Direitos Humanos. 2 ed. São Paulo: Max Limonad, 2003.

Direitos Humanos e Justiça Internacional. São Paulo: Saraiva, 2007.

PITTA E CUNHA, Paulo de. Direito Institucional da União Européia. Coimbra: Almedina, 2004.

PIZZOLO, Calogero. La Fase Descendente del Derecho Constitucional Transnacional: Explicación y Alcance. In: POZO, Carlos Molina del; PIZZOLO, Calogero (Orgs.). Seminario Internacional - Derecho Constitucional Transnacional. Madrid: Facultad de Derecho de la Universidad de Alcalá de Henares, 2012a. (Anotações da Palestra, realizada em 22.2.2012).

Comunidad Andina de Naciones (CAN). Madrid: Universidad Alcalá de Henares - Facultad de Derecho, 2012b. (Anotações da Aula do II Curso de Actualización en Teoría y Práctica de la Integración Regional).

PLATÃO. Teeteto ou Da Ciência. Lisboa: Inquérito, 19??a. 44-74, 19??b.

Mênon. In: Diálogos I - Mênon, Banquete, Fedro. Rio de Janeiro: Ediouro, p. Diálogos - Leis e Epínomis. V. XII-XIII. Belém: Universidade Federal do Pará, 1980.

A República. São Paulo: Martins Fontes, 2006.

PLIAKOS, Astéris D. La Nature Juridique de l'Union Européenne, Revue Trimestrielle de Droit Européen, a. 29, n. 2, p. 187-224, avril/juin 1993.

POCAR, Fausto. Diritto dell'Unione e delle Comunità Europee. 10 ed. Milano: Giuffrè, 2006.

POLYBE. Histoire. Paris: Gallimard, 2003. (Quarto Gallimard).

POZO, Carlos Francisco Molina del. Manual de Derecho de la Comunidad Europea. Madrid: DIJUSA, 2002.

Derecho Comunitario. Barcelona: Cálamo, 2004.

. Las Instituciones en el Tratado de Lisboa. In: POZO, Carlos Francisco Molina del

(Coord.). Treinta Años de Integración Europea. Curitiba: Juruá, p. 153-67, 2009. 
Derecho de la Unión Europea. Madrid: Reus, 2011a.

. (Dir.). Evolución Histórica y Jurídica de los Procesos de Integración en la Unión Europea y en el Mercosur - Liber Amicorum Miguel Ángel Ciuro Caldani. Buenos Aires: Eudeba, 2011b.

El Derecho de la Unión Europea y su Naturaleza Supranacional. Alcalá de Henares: Facultad de Derecho de la Universidad de Alcalá de Henares, 2012. (Anotações do Seminário Internacional Derecho Constitucional Transnacional).

PRADO JR., Bento. Metamorfoses do Enunciado de Ficção (Nota sobre a Assinatura da Nouvelle Héloise), Almanaque - Cadernos de Literatura, São Paulo, v. 5, p. 38-43, 1977.

PRIOLLAUD, François-Xavier. Conseil Européen. In: BERTONCINI, Yves; CHOPIN, Thierry; DULPHY, Anne; KAHN, Sylvain; MANIGAND, Christine. Dictionnaire Critique de l'Union Européenne. Paris: Armand Colin, p. 82-4, 2008.

PRIOLLAUD, François-Xavier; SIRITZKY, David. Que Reste-t-il de l'Influence Française en Europe? Paris : La Documentation Française, 2011. (SciencesPo/Réflexe Europe).

PUPO, Rodrigo Luís. Regionalismo e Multilateralismo. In: CASELLA, Paulo Borba; LIQUIDATO, Vera Lúcia Viegas (Coord.). Direito da Integração. São Paulo: Quartier Latin, p. 157-77, 2006.

PUISSOCHET, Jean-Pierre. L'Affirmation de la Personnalité Internationale des Communautés Européennes. In : L'Europe et le Droit - Mélanges en Hommage à Jean BOULOUIS. Paris : Dalloz, p. 437-50, 1991.

QUADROS, Fausto de. Direito das Comunidades Europeias - Contributo para o Estudo da Natureza Jurídica do Direito Comunitário Europeu. Lisboa: Almedina, 1984. (Coleção Teses).

QUERMONNE, Jean-Louis. Fonctionnalisme. In: BERTONCINI, Yves; CHOPIN, Thierry; DULPHY, Anne; KAHN, Sylvain; MANIGAND, Christine. Dictionnaire Critique de l'Union Européenne. Paris: Armand Colin, p. 186-7, 2008a.

L'Union Européenne dans le Temps Long. Paris : SciencesPo, 2008b. (La Bibliothèque du Citoyen).

. Le Système Politique de l’Union Européenne. 8 ed. Paris : Montchrestien, 2010. (Clefs - Politique). 
RAMOS, André de Carvalho. A Integração Política Européia. In: CASELLA, Paulo Borba (Coord.). Contratos Internacionais e Direito Econômico no MERCOSUL. São Paulo: LTr, p. 646-59, 1996.

Direitos Humanos na Integração Econômica - Análise Comparativa da Proteção de Direitos Humanos e Conflitos Jurisdicionais na União Européia e Mercosul. Tese (Livre-Docência em Direito). São Paulo: Faculdade de Direito, Universidade de São Paulo, 2005.

Organizações Internacionais. In: DIMOULIS, Dimitri (Coord.). Dicionário Brasileiro de Direito Constitucional. São Paulo: Saraiva, p. 253-4, 2007.

REALE, Miguel. Lições Preliminares de Direito. 25 ed. São Paulo : Saraiva, 2001.

REALE, Giovanni; ANTISERI, Dario. História da Filosofia - Antigüidade e Idade Média. 4 ed. v. I. São Paulo : Paulus, 1990.

RÉAU, Élisabeth du. Les Enjeux de la Construction Européenne pendant les Temps de Guerre Froide. In : RÉAU, Élisabeth (Dir.). L'Europe en Construction - Le Second XX $\mathbf{X}^{\mathbf{e}}$ Siècle. 2 ed. Paris : Hachette, p. 5-23, 2007.

. L'Idée d'Europe au $\mathbf{X X}^{\text {ème }}$ Siècle - Des Mythes aux Réalités. Bruxelles : Complexe, 2008.

REFALO, Elizabeth de Almeida Meirelles. A Convenção Européia dos Direitos Humanos. Dissertação (Mestrado em Direito). São Paulo: Faculdade de Direito, Universidade de São Paulo, 1980.

REUTER, Paul. Organisations Européennes. Paris: Presses Universitaires de France, 1965. (Col. Thémis).

. L'Origine du Projet de Communauté Européenne de Défense : Souvenirs et Réflexions. In : Humanité et Droit International - Mélanges René-Jean DUPUY. Paris : Pedone, p. 241-8, 1991.

RICHTER, Thomas; SCHMIDT, Rainer. Introdução. In: RICHTER, Thomas; SCHMIDT, Rainer (Orgs.). Integração e Cidadania Europeia. São Paulo: Saraiva, 2011.

ROCHA, Jean Paul Cabral Veiga da. A Capacidade Normativa de Conjuntura no Direito Econômico: O Déficit Democrático da Regulação Financeira. Tese (Doutorado em Direito). São Paulo: Faculdade de Direito, Universidade de São Paulo, 2004. 
ROESLER, Cláudia Rosane. Saber Jurídico, Retórica, Ciência: Uma Análise da Obra de Theodor Viehweg. Tese (Doutorado em Direito). São Paulo: Faculdade de Direito, Universidade de São Paulo, 2002.

ROLLAND, Patrice. Montesquieu et l'Europe. In : GANZIN, M. (Dir.). L'Europe entre Deux Tempéraments Politiques: Idéal d'Unité et Particularismes Régionaux - Études d'Histoire des Idées Politiques. Aix-en-Provence: Presses Universitaires d'AixMarseille, p. 41-60, 1994.

L'Unité Politique de l'Europe - Histoire d'une Idée. Bruxelles : Bruylant, 2006. (Collection Droit de l'Union Européenne).

ROUGEMONT, Denis de. Vingt-Huit Siècles d'Europe: La Conscience Européenne à Travers les Textes - D`Hésiode à Nos Jours. Paris: Payot, 1961.

—. Souvenirs sur le Congrès de la Haye, Communauté Européenne, Paris, n. 118, mai $1968 . \quad$ Disponível em : <http://www.cvce.eu/obj/Souvenirs_de_Denis_de_Rougemont_sur_le_congres_de_La_Ha ye_Geneve_mai_1968-

fr-7eb6991f-2c62-42e4-8e81-2b3801aeb548.html>. Acesso em 25.2.2013.

ROUSSEAU, Jean-Jacques. Discurso que Alcançou o Prêmio da Academia de Dijon, em 1750, sobre a Seguinte Questão, Proposta pela Mesma Academia: o Restabelecimento das Ciências e das Artes terá Contribuído para Aprimorar os Costumes? In: ROUSSEAU, Jean-Jacques. Rousseau. São Paulo: Abril Cultural, p. 329-52, 1980. (Col. Os Pensadores).

. Júlia ou a Nova Heloísa. São Paulo/Campinas: Hucitec/UNICAMP, 1994.

Do Contrato Social - Princípios do Direito Político. Bauru: EDIPRO, 2000.

ROUSSEL, Denis. Introduction. In: POLYBE. Histoire. Paris: Gallimard, p. 31-52, 2003. (Quarto Gallimard).

SAINT-MARTIN, Élisabeth Claverie. El Papel de Francia em la Integración Europea. Madrid: Universidad Alcalá de Henares - Facultad de Derecho, 2012. (Anotações da Aula do II Curso de Actualización en Teoría y Práctica de la Integración Regional).

SALA, José Blanes. Regime Jurídico dos Empregados Extracomunitários na União Européia. Tese (Doutorado em Direito). São Paulo: Faculdade de Direito, Universidade de São Paulo, 2002.

SALERNO, Francesco. Organizzazione per la Cooperazione e lo Sviluppo Economici (OCSE). In: Enciclopedia del Diritto. t. XXXI. Milano: Giuffrè, p. 382-402, 1981. (Ordine-Parte). 
SAlOMÃo FILHO, Calixto. Direito Concorrencial - As Estruturas. 2 ed. São Paulo: Malheiros, 2002.

Direito Concorrencial - As Condutas. São Paulo: Malheiros, 2007.

Regulação da Atividade Econômica - Princípios e Fundamentos Jurídicos. 2 ed. São Paulo: Malheiros, 2008.

SANTOS, Boaventura de Sousa. Um Discurso sobre as Ciências na Transição para uma Ciência Pós-Moderna, Revista Estudos Avançados, a. 7, v. 2, n. 2, p. 46-71, 1988.

SARTRE, Jean-Paul. Uma Idéia Fundamental da Fenomenologia de Husserl: A Intencionalidade. In: SARTRE, Jean-Paul. Situações I - Crítica Literária. São Paulo: Cosacnaify, p. 55-7, 2005.

SCHAPIRO, Mario Gomes. Direito Econômico e Setores Regulados. São Paulo: Escola de Direito de São Paulo da Fundação Getulio Vargas - DireitoGV, 2008. (Anotações da Primeira Aula da Disciplina Direito Econômico e Setores Regulados, do Curso de Especialização em Direito Econômico).

. Direito Econômico e Direito Concorrencial. São Paulo: Escola de Direito de São Paulo da Fundação Getulio Vargas - DireitoGV, 2009a. (Anotações da Segunda Aula da Disciplina Direito Econômico Concorrencial do Curso de Especialização em Direito Econômico).

. Escolas e Paradigmas de Defesa da Concorrência. São Paulo: Escola de Direito de São Paulo da Fundação Getulia Vargas - DireitoGV, 2009b. (Anotações da Terceira Aula da Disciplina Direito Econômico Concorrencial do Curso de Especialização em Direito Econômico).

O Controle das Estruturas. São Paulo: Escola de Direito de São Paulo da Fundação Getulio Vargas - DireitoGV, 2009c. (Anotações da Sétima Aula da Disciplina Direito Econômico Concorrencial do Curso de Especialização em Direito Econômico).

O Controle das Condutas. São Paulo: Escola de Direito de São Paulo da Fundação Getulio Vargas - DireitoGV, 2009d. (Anotações da Nona Aula da Disciplina Direito Econômico Concorrencial do Curso de Especialização em Direito Econômico).

. Amarrando as Próprias Botas do Desenvolvimento: A Nova Economia Global e a Relevância de um Desenho Jurídico-Institucional Nacionalmente Adequado, Revista DireitoGV, a. 7, n. 1, p. 341-52, jan./jun. 2011.

SCHMIDT, Teresa Molina. Política de Mediamabiente en la UE. Madrid: Universidad Alcalá de Henares - Facultad de Derecho, 2012. (Anotações da Aula do II Curso de Actualización en Teoría y Práctica de la Integración Regional). 
SCHOPENHAUER, Arthur. O Mundo como Vontade e Representação. t. I. São Paulo: UNESP, 2005.

Sobre a Filosofia e seu Método. In: SCHOPENHAUER, Arthur. Sobre a Filosofia e seu Método. São Paulo: Hedra, p. 29-50, 2010.

SEBASTIANI, Breno Battistin. Políbio e o Imperialismo Romano, Projeto História, n. 30, p. 197-209, jan./jun. 2005.

Políbio como Modelo Epistemológico de Konstantinos Paparrigópoulos, Byzantion Nea Hellás, Santiago, v. 25, p. 55-78, 2006 a.

Bélica Lição Polibiana. Tese (Doutorado em História). Faculdade de Filosofia, Letras e Ciências Humanas. São Paulo: Universidade de São Paulo, 2006 b.

. Políbio contra Filarco, ou Crítica à Historiografia Trágica, Hypnos, a. 13, n. 19, p. 68-84, jul./dez. $2007 \mathrm{a}$.

O Odisseu de Políbio: Leituras da Odisséia na Roma Cipiônica, Calíope, Rio de Janeiro, n. 17, p. 24-37, 2007 b.

Políbio e as Causas de uma Guerra sem Responsabilidade, Revista Eletrônica Antiguidade Clássica, São Paulo, p. 39-51, 2008.

. Três Fragmentos de Políbio. In: OLIVA NETO, João Angelo (Org.). I Semana de Estudos Helenísticos. São Paulo: Humanitas, p. 69-103, 2010. abr. 2011

Políbio por Paparrigópoulos, Língua e Literatura, São Paulo, n. 28, p. 113-24, Políbio (200 a.C.-118 a.C.). In: PARADA, Maurício (Org.). Os Historiadores Clássicos da História. v. I. Petrópolis: Vozes/PUC-Rio, p. 51-67, 2012.

SEIGNOBOS, Charles. Histoire de l'Europe. Paris : Cluny, 1934.

Essai d'une Histoire Comparée des Peuples de l'Europe. 3 ed. Paris : Presses Universitaires de France, 1947.

SERRANO, Miryam Rodríguez-Izquierdo. Primacía y Subsidiariedad de la Unión Europea. Madrid: Centro de Estudios Políticos y Constitucionales, 2011. 
SILVA, José Afonso da. Curso de Direito Constitucional Positivo. 25 ed. São Paulo: Malheiros, 2005.

SPENGLER, Oswald. Le Déclin de l'Occident: Esquisse d'une Morphologie de l'Histoire Universelle - Forme et Réalité. t. I. Paris : Gallimard, 1976a. (Bibliothèque des Idées).

- Le Déclin de l'Occident: Esquisse d'une Morphologie de l'Histoire Universelle - Perspectives de l'Histoire Universelle. t. II. Paris : Gallimard, 1976b. (Bibliothèque des Idées).

TEUBNER, Gunther. Substantive and Reflexive Elements in Modern Law, Law \& Society Review, v. 17, n. 2, p. 239-85, 1983.

. Verrechtlichung - Begriffe, Merkmale, Grenzen, Auswege. In: ZACHER, Hans; SIMITIS, Spiros; KÜBLER, Friedrich; HOPT, Klaus; TEUBNER, Gunther. Verrechtlichung von Wirtschaft, Arbeit und sozialer Solidarität - Vergleichend Analysen. Baden-Baden/Frankfurt: Nomos/Suhrkamp, p. 289-344, 1984.

. „Man schritt auf allen Gebieten zur Verrechtlichung“: Rechtssoziologische Theorie im Werk Otto Kirchheimers. In: LUTTER, Marcus; STIEFEL, Ernst C.; HOEFLICH, Michael (Hrsg.). Der Einfluss deutschsprachiger Emigranten auf die Rechtentwicklung in den USA und in Deutschland. Tübingen: Mohr Siebeck, p. 505-20, 1993.

TORRES FILHO, Rubens Rodrigues. Dogmatismo e Antidogmatismo: Kant na Sala de Aula. In: TORRES FILHO, Rubens Rodrigues. Ensaios de Filosofia ilustrada. 2 ed. São Paulo: Iluminuras, p. 137-57, 2004.

TOURNON, André. Montaigne. São Paulo: Discurso, 2004.

UNGER, Roberto Mangabeira. Como Ensinar o Direito Hoje? s.l.: s.n., s.d.. (Mimeografado).

. Uma Nova Faculdade de Direito para o Brasil. s.1.: s.n., 2001. (Mimeografado).

O Direito e o Futuro da Democracia. São Paulo: Boitempo, 2004.

VALÉRY, Paul. La Crise de l'Esprit. In: VALÉRY, Paul. Variété I et II. Paris: Gallimard, p. 13-51, 1924. (Folio Essais).

Préface. In: CORNÉJO, Mariano H. La Lutte pour la Paix. Paris : Félix Alcan, p. IX-XI, 1934. 
VASCONCELOS, Raphael Carvalho de. Direito Internacional entre Unidade e Fragmentação: MERCOSUL e o Multilateralismo. Dissertação (Mestrado em Direito). São Paulo: Faculdade de Direito, Universidade de São Paulo, 2010.

VEÇOSO, Fabia Fernandes Carvalho. A Tutela dos Direitos Fundamentais na União Européia. Dissertação (Mestrado em Direito). São Paulo: Faculdade de Direito, Universidade de São Paulo, 2006.

VERnANT, Jean-Pierre. As Origens do Pensamento Grego. 3 ed. São Paulo: Difel, 1981.

VÉRON, Nicolas. L'Europe a Besoin d'Imagination Institutionnelle, La Tribune, Paris, $2011 . \quad$ Disponível em : <http://www.latribune.fr/opinions/tribunes/20111123trib000666168/1-europe-a-besoin-dimagination-institutionnelle.html>. Acesso em: 25.2.2013.

VIEHWEG, Theodor. Tópica e Jurisprudência - Uma Contribuição à Investigação dos Fundamentos Jurídico-Científicos. Porto Alegre: Sergio Antonio Fabris, 2008.

VIEIRA, José Luiz Conrado. As Bases Conceituais da Integração Econômica e do Investimento Internacional no Mercosul: Fundamentos para uma Revisão. Tese (Doutorado em Direito). São Paulo: Faculdade de Direito, Universidade de São Paulo, 1999.

VIEIRA, José Ribas. A Relevância dos Fundamentos da Teoria do Direito Contemporâneo e do Direito Internacional Público de Base Conflitiva para os Direitos Humanos. In: NALINI, José Renato; CARLINI, Angélica (Coords.). Direitos Humanos e Formação Jurídica. Rio de Janeiro: Forense, p. 312-22, 2010.

VOYENNE, Bernard. Les Fédéralistes au Congrès de l'Europe, Cahiers du Monde Nouveau, Paris, a. 4, n. 6, Juin-Juil. 1948. Disponível em : <http://www.cvce.eu/obj/Les_federalistes_au_congres_de_1_Europe_dans_Cahiers_du_M onde_nouveau_Juin_1948-fref5541a2-e1f9-4574-bfce-b3dbd3981616.html>. Acesso em: 25.2.2013.

WÆVER, Ole. Insecurity, Security, and Asecurity in the West European non-War Community. In: ADLER; Emanuel; BARNETT, Michael. Security Communities. Cambridge: Cambridge University, p. 69-118, 1998. (Cambridge Studies in International Relations).

WEBER, Max. A “Objetividade” do Conhecimento nas Ciências Sociais. São Paulo: Ática, 2006. 
WEIL, François. Ouverture du Colloque. In: ÉCOLE DES HAUTES ÉTUDES EN SCIENCES SOCIALES (EHESS). Claude Lefort et la Pensée du Politique. Paris : EHESS, 2012. (Anotações da Palestra, realizada em 7.3.2012).

WEILER, Joseph H. H. The Constitution of Europe - "Do the New Clothes have an Emperor?" and Other Essays on European Integration. Cambridge/New Yok/Melbourne/Madrid/Cape Town/Singapore/São Paulo: Cambridge University, 2005.

European Integration Legitimacy and Mobilizing Force - An Appraisal. In: UNIVERSTIÉ PANTHÉON-ASSAS (PARIS II)/INSTITUT DE DROIT COMPARÉ (IDC), Paris, 2011. (Anotações da Palestra, realizada em 14.11.2011).

WILKENS, Andreas. Allemagne. In: BERTONCINI, Yves; CHOPIN, Thierry; DULPHY, Anne; KAHN, Sylvain; MANIGAND, Christine. Dictionnaire Critique de l'Union Européenne. Paris: Armand Colin, p. 9-13, 2008.

WINKLER, Heinrich August. Greatness and Limits of the West - The History of an Unfinished Project. s.l., London School of Economics and Political Science, feb. 2011. (LSE 'Europe in Question’ Discussion Paper Series).

WOLFF, Francis. Aristóteles e a Política. São Paulo: Discurso, 1999.

ZORGBIBE, Charles. Histoire de la Construction Européenne. 2 ed. Paris : Presses Universitaires de France, 1997. 


\section{ANEXO I - Artigos do Tratado da CECA Comentados por este Trabalho}

Traité instituant la Communauté Européenne du Charbon et de l'Acier

TITRE PREMIER - De la Communauté Européenne du Charbon et de l'Acier

\section{Article 6}

La Communauté a la personnalité juridique.

Dans les relations internationales, la Communauté jouit de la capacité juridique nécessaire pour exercer ses fonctions et atteindre ses buts. [...]

La Communauté est représentée par ses institutions, chacune dans le cadre de ses attributions.

\section{TITRE DEUXIÈME - Des institutions de la Communauté}

\section{Article 7}

Les institutions de la Communauté sont :

- une Haute Autorité, assistée d'un Comité Consultatif;

- une Assemblée Commune, ci-après dénommée «l'Assemblée»;

- un Conseil Spécial de Ministres, ci-après dénommé « le Conseil »;

- une Cour de Justice, ci-après dénommée « la Cour » .

Article $9[\ldots]$

Les membres de la Haute Autorité exercent leurs fonctions en pleine indépendance, dans l'intérêt général de la Communauté. Dans l'accomplissement de leurs devoirs, ils ne sollicitent ni n'acceptent d'instructions d'aucun gouvernement ni d'aucun organisme. Ili s'abstiennent de tout acte incompatible avec le caractère supranational de leurs fonctions. Chaque Etat membre s'engage à respecter ce caractère supranational et à ne pas chercher à influencer les membres de la Haute Autorité dans l'exécution de leur tâche.

\section{Article 14}

Pour l'exécution des missions qui lui sont confiées et dans lis conditions prévues au présent Traité, la Haute Autorité prend des décisions, formule des recommandations ou émet des avis. 
Le- dérivons sont obligatoires en tous leurs éléments.

Les recommandations comportent obligation dans les buts qu'elles assignent, mais laissent à ceux qui en sont l'objet le choix des moyens propres à atteindre ces buts.

Les avis ne lient pas.

Lorsque la Haute Autorité est habilitée à prendre une décision, elle peut se borner à formuler une recommandation.

\section{Article 27}

Le Conseil est formé par les représentants des Etats membres. Chaque Etat y délègue un membre de son gouvernement. [...]

\section{Article 31}

La Cour assure le respect du droit dans l'interprétation et l'application du présent Traité et des règlements d'exécution.

Artide 33

La Cour est compétente pour se prononcer sur les recours en annulation pour incompétence, violation des formes substantielles, violation du Traité ou de toute règle de droit relative à son application, ou détournement de pouvoir, formés contre les décisions et recommandations de la Haute Autorité par un des Etats membres ou par le Conseil. Toutefois, l'examen de la Cour ne peut porter sur l'appréciation de la situation découlant des faits ou circonstances économiques au vu de laquelle sont intervenues lesdites décisions ou recommandations, sauf s'il est fait grief à la Haute Autorité d'avoir commis un détournement de pouvoir ou d'avoir méconnu d'une manière patente les dispositions du Traité ou toute règle de droit relative à son application. [...]

Les recours prévus aux deux premiers alinéas du présent article doivent être formés dans le délai d'un mois à compter, suivant le cas, de la notification ou de la publication de la décision ou recommandation.

Article 34

En cas d'annulation, la Cour renvoie l'affaire devant la Haute Autorité. Celle-ci est tenue de prendre les mesures que comporte l'exécution de la décision d'annulation. En cas de préjudice direct et spécial subi par une entreprise ou un groupe d'entreprises du fait d'une décision ou d'une recommandation reconnue par la Cour entachée d'une faute de nature à 
engager la responsabilité de la Communauté la Haute Autorité est tenue de prendre, en usant des pouvoirs qui lui sont reconnus par les dispositions du présent Traité, les mesures propres à assurer une équitable réparation du préjudice résultant directement, de la décision ou de la recommandation annulée et d'accorder, en tant que de besoin, une juste indemnité.

Si la Haute Autorité s'abstient do prendre dans un délai raisonnable les mesures que comporte l'exécution d'une décision d'annulation, un recours en indemnité est ouvert devant la Cour.

\section{Article 35}

Dans le cas où la Haute Autorité, tenue par une disposition du présent Traité ou des règlements d'application de prendre une décision ou de formuler une recommandation, ne se conforme pas à cette obligation, il appartient selon le cas, aux Etats, au Conseil ou aux entreprises et associations de la saisir.

Il en est de même dans le cas où la Haute Autorité habilitée par une disposition du présent Traité ou des règlements d'application à prendre une décision ou à formuler une recommandation, s'en abstient et où cette abstention constitue un détournement de pouvoir. Si, à l'expiration d'un délai de deux mois, la Haute Autorité n'a pris aucune décision ou formulé aucune recommandation, un recours peut être formé devant la Cour dans un délai d'un mois contre la décision implicite de refus qui est réputée résulter de ce silence.

\section{Article $36[\ldots]$}

Les requérants peuvent se prévaloir, à l'appui de ce recours, dans les conditions prévues au premier alinéa de l'article 33 du présent Traité, de l'irrégularité des décisions et recommandations dont la méconnaissance leur est reprochée.

\section{Article 37}

Lorsqu'un Etat membre estime que, dans un cas déterminé, une action ou un défaut d'action de la Haute Autorité est de nature à provoquer clans son économie des troubles fondamentaux et persistants, il peut saisir la Haute Autorité.

Celle-ci, après consultation du Conseil, reconnaît, s'il y a lieu, l'existence d'une telle situation et décide des mesures à prendre, dans les conditions prévues au présent Traité, pour mettre fin à cette situation tout en sauvegardant les intérêts essentiels de la Communauté. 
Lorsque la Cour est saisie d'un recours fondé sur les dispositions du présent article contre cette décision ou contre la décision explicite ou implicite refusant de reconnaître l'existence de la situation ci-dessus visée, il lui appartient d'en apprécier le bien-fondé.

En cas d'annulation, la Haute Autorité est tenue de décider, dans le cadre de l'arrêt de la Cour, (les mesures à prendre aux lins prévues au deuxième alinéa du présent article.

Article 38

La Cour peut annuler, à la requête d'un des Etats membres ou de la Haute Autorité, les délibérations de l'Assemblée ou du Conseil.

La requête doit être formée dans le délai d'un mois à compter de la publication de la délibération de l'Assemblée ou de la communication de la délibération du Conseil aux Etats membres ou à la Haute Autorité.

Seuls les moyens tirés de l'incompétence ou de la violation des formes substantielles peuvent être invoqués à l'appui d'un tel recours.

Article 39

Les recours formés devant la Cour n'ont pas d'effet suspensif.

Toutefois, la Cour peut, si elle estime que les circonstances l'exigent, ordonner le sursis à l'exécution de la décision ou de la recommandation attaquée.

Elle peut prescrire toutes autres mesures provisoires nécessaires.

Article 41

La Cour est seule compétente pour statuer, à titre préjudiciel, sur la validité des délibérations de la Haute Autorité et du Conseil, dans le cas où un litige porté devant un tribunal national mettrait en cause cette validité.

Article 44

Les arrêts de la Cour ont force exécutoire sur le territoire des Etats membres, dans les conditions fixées à l'article 92 ci-après. 
TITRE TROISIÈME - Dispositions Économiques et Sociales

\section{Article 67}

Dans le domaine de la production, la Haute Autorité recourt de préférence aux modes d'action indirects qui sont à sa disposition, tels que :

- la coopération avec les gouvernements pour régulariser ou influencer la consommation générale, en particulier celle des services publics ;

- les interventions en matière de prix et de politique commerciale prévues par le présent Traité.

Article 58

1. En cas de réduction de la demande, si la Haute Autorité estime que la Communauté se trouve en présence d'une période de crise manifeste et que les moyens d'action prévus à l'article 57 ne permettent pas d'y faire face, elle doit, après consultation du Comité Consultatif et sur avis conforme du Conseil, instaurer un régime de quotas de production accompagné, en tant que de besoin, des mesures prévues à l'article 74.

A défaut d'initiative de la Haute Autorité, l'un des Etats membres peut saisir le Conseil qui, statuant à l'unanimité, peut prescrire à la Haute Autorité l'instauration d'un régime de quotas. [...]

3. Le régime des quotas prend fin sur proposition adressée au Conseil par la Haute Autorité, après consultation du Comité Consultatif, ou par le gouvernement d'un des Etats membres, sauf décision contraire du Conseil à l'unanimité si la proposition émane de la Haute Autorité et à la majorité simple si elle émane d'un gouvernement. La fin du régime des quotas fait l'objet d'une publication par les soins de la Haute Autorité.

4. La Haute Autorité peut prononcer, à rencontre des entreprises qui violeraient les décisions prises par elle en application du présent article, des amendes dont le montant est égal au maximum à la valeur des productions irrégulières.

\section{Article 59}

1. Si la Haute Autorité constate, après consultation du Comité Consultatif, que la Communauté se trouve en présence d'une pénurie sérieuse de certains ou de l'ensemble des produits soumis à sa juridiction, et que les moyens d'action prévus à l'article 57 ne permettent pas d'y faire face, elle doit saisir le Conseil de cette situation et, sauf décision contraire de celui-ci statuant à l'unanimité, lui proposer les mesures nécessaires. 
A défaut d'initiative de la Haute Autorité, le Conseil peut être saisi par l'un des Etats membres et, par une décision prise à l'unanimité, reconnaître l'existence de la situation prévue ci-dessus.

2. Le Conseil statuant à l'unanimité, décide, sur proposition de la Haute Autorité, et en consultation avec elle, d'une part, des priorités d'utilisation, et, d'autre part, de la répartition des ressources de la Communauté en charbon et en acier entre les industries soumises à sa juridiction, l'exportation et les autres consommations.

En fonction des priorités d'utilisation ainsi décidées, la Haute Autorité établit, après consultation des entreprises intéressées, les programmes de fabrication que les entreprises sont tenues d'exécuter.

3. A défaut d'une décision unanime du Conseil sur les mesures visées au paragraphe 2, la Haute Autorité procède elle-même, en fonction des consommations et des exportations et indépendamment de la localisation des productions, à la répartition des ressources de la Communauté entre les États membres.

Dans chacun des États membres, la répartition des ressources attribuées par la Haute Autorité est faite sous la responsabilité du gouvernement, sans qu'elle puisse affecter les livraisons prévues à d'autres Etats membres, et sous réserve de consultations avec la Haute Autorité en ce qui concerne les parts affectées à l'exportation et à la marche des industries du charbon et de l'acier.

Si la part affectée à l'exportation par un gouvernement est réduite par rapport aux bases retenues dans l'attribution totale faite à l'Etat membre en cause, la Haute Autorité, lors du renouvellement des opérations de répartition, redistribuera, en tant que de besoin, entre les Etats membres les ressources ainsi dégagées pour la consommation.

Si une réduction relative dans la part affectée par un gouvernement à la marche des industries du charbon ou de l'acier a pour conséquence une réduction dans une production de la Communauté, l'attribution des produits correspondants faite à l'Etat membre en cause lors du renouvellement des opérations de répartition sera réduite à concurrence de la réduction de production qui lui est imputable.

4. Dans tous les cas, la Haute Autorité a la charge de répartir entre les entreprises, sur une base équitable, les quantités attribuées aux industries de sa juridiction, sur la base d'études faites en liaison avec les entreprises et les associations d'entreprises.

5. Dans la situation prévue au paragraphe $1 \mathrm{du}$ présent article, l'établissement, dans l'ensemble des Etats membres, de restrictions aux exportations à destination des pays tiers peut être décidé par la Haute Autorité, conformément aux dispositions de l'article 57, après 
consultation du Comité Consultatif et sur avis conforme du Conseil, ou, à défaut d'initiative de la Haute Autorité, par le Conseil statuant à l'unanimité sur proposition d'un gouvernement.

6. La Haute Autorité peut mettre fin au régime institué en conformité du présent article après consultation du Comité Consultatif et du Conseil. Elle ne peut passer outre à un avis défavorable du Conseil, si cet avis a été pris à l'unanimité.

A défaut d'initiative de la Haute Autorité, le Conseil statuant à l'unanimité peut mettre fin à ce régime.

7. La Haute Autorité peut prononcer à rencontre des entreprises qui violeraient les décisions prises en application du présent article des amendes dont le montant ne peut excéder le double de la valeur des fabrications ou des livraisons prescrites et non exécutées ou détournées de leur emploi régulier.

\section{Article 60}

1. Sont interdites en matière de prix les pratiques contraires aux articles 2,3 et 4 et notamment :

- les pratiques déloyales de concurrence, en particulier les baisses de prix purement temporaires ou purement locales tendant, à l'intérieur du marché commun, à l'acquisition d'une position de monopole ;

- les pratiques discriminatoires comportant, dans le marché commun, l'application par un vendeur de conditions inégales à des transactions comparables, notamment suivant la nationalité des acheteurs.

La Haute Autorité pourra définir, par décisions prises après consultation du Comité Consultatif et du Conseil, les pratiques visées par cette interdiction.

2. Aux fins énoncées ci-dessus :

a) les barèmes des prix et conditions de vente appliqués sur le marché commun par les entreprises doivent être rendus publics, dans la mesure et dans les formes prescrites par la Haute Autorité, après consultation du Comité Consultatif ; si la Haute Autorité reconnait que le choix, par une entreprise, du point sur la base duquel elle établit son barème présente un caractère anormal et permet notamment d'éluder les dispositions du b cidessous, elle adresse à cette entreprise les recommandations appropriées ;

b) les modes de cotation appliqués ne doivent pas avoir pour effet d'introduire dans les prix pratiqués par une entreprise sur le marché commun, ramenés à leur équivalent au départ du point choisi pour l'établissement de son barème : 
- des majorations par rapport au prix prévu par ledit barème pour une transaction comparable ;

- ou des rabais sur ce prix dont le montant excède :

- soit la mesure permettant d'aligner l'offre faite sur le barème, établi sur la base d'un autre point, qui procure à l'acheteur les conditions les plus avantageuses au lieu de livraison ;

- soit les limites fixées pour chaque catégorie de produits, en tenant compte éventuellement de leur origine et de leur destination, par décisions de la Haute Autorité prises après avis du Comité Consultatif.

Ces décisions interviennent quand leur nécessité apparaît, pour éviter des perturbations dans l'ensemble ou dans une partie du marché commun, ou des déséquilibres qui résulteraient d'une divergence entre les modes de cotation utilisés pour un produit et pour les matières qui entrent dans sa fabrication. Elles ne font pas obstacle à ce que les entreprises alignent leurs offres sur les conditions offertes par des entreprises extérieures à la Communauté, à condition que ces transactions soient notifiées à la Haute Autorité qui peut, en cas d'abus, limiter ou supprimer, à l'égard des entreprises en cause, le bénéfice de cette dérogation.

\section{Article 61}

Sur la base d'études faites en liaison avec les entreprises et les associations d'entreprises, conformément aux dispositions de l'article 46, alinéa 1 , et de l'article 48 , alinéa 3 , et après consultation du Comité Consultatif et du Conseil, tant sur l'opportunité de ces mesures que sur le niveau de prix qu'elles déterminent, la Haute Autorité peut fixer, pour un ou plusieurs produits soumis à sa juridiction :

a) des prix maxima à l'intérieur du marché commun, si elle reconnaît qu'une telle décision est nécessaire pour atteindre les objectifs définis à l'article 3, notamment en son alinéa c ;

b) des prix minima à l'intérieur du marché commun, si elle reconnaît l'existence ou l'imminence d'une crise manifeste et la nécessité d'une telle décision pour atteindre les objectifs définis à l'article 3 ;

c) après consultation des associations des entreprises intéressées ou de ces entreprises elles-mêmes, et suivant des modalités adaptées à la nature des marchés extérieurs, des prix minima ou maxima à l'exportation, si une telle action est susceptible d'un contrôle efficace et apparaît nécessaire, tant en raison des dangers résultant pour les entreprises de la situation du marché que pour faire prévaloir dans les relations économiques internationales 
l'objectif défini à l'article 3, alinéa $\mathrm{f}$, et sans préjudice, en cas de fixation de prix minima, de l'application des dispositions prévues à l'article $60, \S 2$, dernier alinéa.

Dans la fixation des prix, la Haute Autorité doit tenir compte de la nécessité d'assurer la capacité concurrentielle tant des industries du charbon ou de l'acier que des industries utilisatrices, suivant les principes définis à l'article 3, alinéa c.

A défaut d'initiative de la Haute Autorité, dans les circonstances prévues ci-dessus, le gouvernement d'un des Etats membres peut saisir le Conseil qui, par décision prise à l'unanimité, peut inviter la Haute Autorité à fixer de tels maxima ou minima.

\section{Article 63}

1. Si la Haute Autorité constate que dos discriminations sont systématiquement exercées par des acheteurs, notamment en vertu de clauses régissant les marchés passés par des organismes dépendant des pouvoirs publics, elle adresse aux gouvernements intéressés les recommandations nécessaires.

2. Dans la mesure où elle l'estime nécessaire, la Haute Autorité peut décider que :

a) les entreprises devront établir leurs conditions de vente de telle sorte que leurs acheteurs et leurs commissionnaires s'obligent à se conformer aux règles posées par la Haute Autorité en application des dispositions du présent chapitre ;

b) les entreprises seront rendues responsables des infractions aux obligations ainsi contractées commises par leurs agents directs ou les commissionnaires traitant pour le compte desdites entreprises.

Elle pourra, en cas d'infraction commise par un acheteur aux obligations ainsi contractées, limiter, dans une mesure qui pourra, en cas de récidive, comporter une interdiction temporaire, le droit des entreprises de la Communauté de traiter avec ledit acheteur. Dans ce cas, et sans préjudice des dispositions de l'article 33, un recours sera ouvert à l'acheteur devant la Cour.

3. En outre, la Haute Autorité ost habilitée à adresser aux Etats membres intéressés toutes recommandations appropriées en vue d'assurer le respect des règles posées en application des dispositions de l'article $60, \S 1$, par toute entreprise ou organisme exerçant une activité de distribution dans le domaine du charbon ou de l'acier.

\section{Article 64}

La Haute Autorité peut prononcer à rencontre des entreprises qui violeraient les dispositions du présent chapitre ou les décisions prises pour son application des amendes à 
concurrence du double de la valeur des ventes irrégulières. En cas de récidive, le maximum ci-dessus est doublé.

\section{Article 65}

1. Sont interdits tous accords entre entreprises, toutes décisions d'associations d'entreprises et toutes pratiques concertées qui tendraient, sur le marché commun, directement ou indirectement, à empêcher, restreindre ou fausser le jeu normal do la concurrence et en particulier :

a) à fixer ou déterminer les prix ;

b) à restreindre ou à contrôler la production, le développement technique ou les investissements ;

c) à répartir les marchés, produits, clients ou sources d'approvisionnement. [...]

4. Les accords ou décisions interdits en vertu du paragraphe 1 du présent article sont nuls de plein droit et ne peuvent être invoqués devant aucune juridiction des Etats membres.

La Haute Autorité a compétence exclusive, sous réserve des recours devant la Cour, pour se prononcer sur la conformité avec les dispositions du présent article desdits accords ou décisions.

5. La Haute Autorité peut prononcer contre les entreprises qui auraient conclu un accord nul de plein droit, appliqué ou tenté d'appliquer, par voie d'arbitrage, dédit, boycott, ou tout autre moyen, un accord ou une décision nuls de plein droit ou un accord dont l'approbation a été refusée ou révoquée, ou qui obtiendraient le bénéfice d'une autorisation au moyen d'informations sciemment fausses ou déformées, ou qui se livreraient à des pratiques contraires aux dispositions du paragraphe 1, des amendes et astreintes au maximum égales au double du chiffre d'affaires réalisé sur les produits ayant fait l'objet de l'accord, de la décision ou de la pratique contraires aux dispositions du présent article, sans préjudice, si cet objet est de restreindre la production, le développement technique ou les investissements, d'un relèvement du maximum ainsi déterminé à concurrence de 10 p. 100 du chiffre d'affaires annuel des entreprises en cause, en ce qui concerne l'amende, et de 20 p. 100 du chiffre d'affaires journalier, en ce qui concerne les astreintes.

\section{Article 66}

1. Est soumise à autorisation préalable de la Haute Autorité, sous réserve des dispositions du paragraphe 3, toute opération ayant par elle-même pour effet direct ou indirect, à l'intérieur des territoires visés à l'alinéa 1 de l'article 79, et du fait d'une personne ou d'une 
entreprise, d'un groupe de personnes ou d'entreprises, une concentration entre entreprises dont l'une au moins relève de l'application de l'article 80, que l'opération soit relative à un même produit ou à des produits différents, qu'elle soit effectuée par fusion, acquisition d'actions ou d'éléments d'actifs, prêt, contrat, ou tout autre moyen de contrôle. Pour l'application des dispositions ci-dessus, la Haute Autorité définit par un règlement, établi après consultation du Conseil, les éléments qui constituent le contrôle d'une entreprise.

2. La Haute Autorité accorde l'autorisation visée au paragraphe précédent, si elle reconnaît que l'opération envisagée ne donnera pas aux personnes ou aux entreprises intéressées, en ce qui concerne celui ou ceux des produits en cause qui relèvent de sa juridiction, le pouvoir :

- do déterminer les prix, contrôler ou restreindre la production ou la distribution, ou faire obstacle au maintien d'une concurrence effective, sur une partie importante du marché desdits produits ;

- ou d'échapper, notamment en établissant une position artificiellement privilégiée et comportant un avantage substantiel dans l'accès aux approvisionnements ou aux débouchés, aux règles de concurrence résultant de l'application du présent Traité.

Dans cette appréciation, et conformément au principe de non-discrimination énoncé à l'article 4, alinéa b, la Haute Autorité tient compte de l'importance des entreprises de même nature existant dans la Communauté, dans la mesure qu'elle estime justifiée pour éviter ou corriger les désavantages résultant d'une inégalité dans les conditions de concurrence.

La Haute Autorité peut subordonner l'autorisation à toutes conditions qu'elle estime appropriées aux fins du présent paragraphe.

Avant de se prononcer sur une opération affectant des entreprises dont l'une au moins échappe à l'application de l'article 80, la Haute Autorité recueille les observations du gouvernement intéressé.

3. La Haute. Autorité exempte de l'obligation d'autorisation préalable les catégories d'opérations dont elle reconnaît que, par l'importance des actifs ou entreprises qu'elles affectent, considérée en liaison avec la nature de la concentration qu'elles réalisent, elles doivent être réputées conformes aux conditions requises par le paragraphe 2. Le règlement, établi à cet effet après avis conforme du Conseil, fixe également les conditions auxquelles cette exemption est soumise.

4. Sans préjudice de l'application de l'article 47 à l'égard des entreprises relevant de sa juridiction, la Haute Autorité peut, soit par un règlement établi après consultation du Conseil et définissant la nature des opérations qui ont à lui être communiquées, soit par 
demande spéciale adressée aux intéressés dans le cadre de ce règlement, obtenir des personnes physiques ou morales ayant acquis ou regroupé, ou devant acquérir ou regrouper les droits ou actifs on cause, toutes informations nécessaires à l'application du présent article sur les opérations susceptibles de produire l'effet visé au paragraphe 1.

5. Si une concentration vient à être réalisée, dont la Haute Autorité reconnaît qu'elle a été effectuée en infraction aux dispositions du paragraphe 1 et satisfait néanmoins aux conditions prévues par le paragraphe 2, elle subordonne l'approbation de cette concentration au versement, par les personnes ayant acquis ou regroupé les droits ou actifs en cause, de l'amende prévue au paragraphe 6 , deuxième alinéa, sans que le montant puisse être inférieur à la moitié du maximum prévu audit alinéa dans les cas où il apparaît clairement que l'autorisation devait être demandée. A défaut de ce versement, la Haute Autorité applique les mesures prévues ci-après en ce qui concerne les concentrations reconnues illicites.

Si une concentration vient à être réalisée, dont la Haute Autorité reconnaît qu'elle ne peut satisfaire aux conditions générales ou particulières auxquelles une autorisation au titre du paragraphe 2 serait subordonnée, elle constate par décision motivée le caractère illicite de cette concentration et, après avoir mis les intéressés on mesure de présenter leurs observations, ordonne la séparation des entreprises ou des actifs indûment réunis ou la cessation du contrôle commun, ou toute autre action qu'elle estime appropriée pour rétablir l'exploitation indépendante des entreprises ou des actifs en cause et restaurer des conditions normales de concurrence. Toute personne directement intéressée peut former contre ces décisions un recours dans les conditions prévues à l'article 33. Par dérogation audit article, la Cour a pleine compétence pour apprécier si l'opération réalisée a le caractère d'une concentration au sens du paragraphe $1 \mathrm{du}$ présent article et des règlements pris on application du même paragraphe. Ce recours est suspensif. Il ne peut être formé qu'une fois ordonnées les mesures ci-dessus prévues, sauf accord donné par la Haute Autorité à l'introduction d'un recours distinct contre la décision déclarant l'opération illicite.

La Haute Autorité peut, à tout moment, et sauf application éventuelle des dispositions de l'article 39, alinéa 3, prendre ou provoquer les mesures conservatoires qu'elle estime nécessaires pour sauvegarder les intérêts des entreprises concurrentes et des tiers, et à prévenir toute action susceptible de faire obstacle à l'exécution de ses décisions.

Sauf décision contraire de la Cour, les recours ne suspendent pas l'application des mesures conservatoires ainsi arrêtées. 
La Haute Autorité accorde aux intéressés, pour exécuter ses décisions, un délai raisonnable au-delà duquel elle peut imposer des astreintes journalières à concurrence de un pour mille de la valeur des droits ou actifs en cause.

En outre, à défaut par les intéressés de remplir leurs obligations, la Haute Autorité prend elle-même des mesures d'exécution et peut notamment suspendre l'exercice, dans les entreprises relevant de sa juridiction, des droits attachés aux actifs irrégulièrement acquis, provoquer la nomination par autorité de justice d'un administrateur séquestre pour ces actifs, en organiser la vente forcée dans des conditions préservant les intérêts légitimes do leurs propriétaires, annuler, à l'égard des personnes physiques ou morales ayant, acquis, par l'effet de l'opération illicite, les droits ou actifs en cause, les actes, décisions, résolutions ou délibérations des organes dirigeants des entreprises soumises à un contrôle irrégulièrement établi.

La Haute Autorité est, en outre, habilitée à adresser aux Etats membres intéressés les recommandations nécessaires pour obtenir, dans le cadre des législations nationales, l'exécution des mesures prévues aux alinéas précédents.

Dans l'exercice de ses pouvoirs, la Haute Autorité tient compte des droits des tiers acquis de bonne foi.

6. La Haute Autorité peut imposer des amendes à concurrence de :

- 3 p. 100 de la valeur des actifs acquis ou regroupés, ou devant être acquis ou regroupés, aux personnes physiques ou morales qui se seraient soustraites aux obligations prévues par le paragraphe 4 ;

- 15 p. 100 de la valeur des actifs acquis ou regroupés, aux personnes physiques ou morales qui se seraient soustraites aux obligations prévues par le paragraphe 1, ce maximum étant relevé, au-delà du douzième mois qui suit la réalisation do l'opération, d'un vingtquatrième par mois supplémentaire écoulé jusqu'à la constatation de l'infraction par la Haute Autorité ;

- 10 p. 100 de la valeur dos actifs acquis ou regroupés, ou devant être acquis ou regroupés, aux personnes physiques ou morales qui auraient obtenu ou tenté d'obtenir le bénéfice des dispositions prévues au paragraphe 2 au moyen d'informations fausses ou déformées ; Un recours est ouvert devant la Cour, dans les conditions de l'article 30, au profit des personnes qui sont l'objet des sanctions prévues au présent paragraphe.

7. Si la Haute Autorité reconnaît que les entreprises publiques ou privées qui, en droit ou en fait, ont ou acquièrent, sur le marché d'un des produits relevant de sa juridiction, 
une position dominante qui les soustrait à une concurrence effective dans une partie importante du marché commun, utilisent cette position à des tins contraires aux objectifs du présent Traité, elle leur adresse toutes recommandations propres à obtenir que cette position ne soit pas utilisée à ces fins. A défaut, d'exécution satisfaisante desdites recommandations dans un délai raisonnable, la Haute Autorité, par décisions prises en consultation avec le gouvernement intéressé, et sous les sanctions prévues respectivement aux articles 58, 59 et 64, fixe les prix et conditions de vente à appliquer par l'entreprise en cause, ou établit des programmes de fabrication ou dos programmes de livraison à exécuter par elle.

\section{Article 67}

1. Toute action d'un Etat membre susceptible d'exercer une répercussion sensible sur les conditions de la concurrence dans les industries du charbon ou de l'acier doit être portée à la connaissance de la Haute Autorité par le gouvernement intéressé.

2. Si une telle action est de nature, en élargissant substantiellement, autrement (pie par variation des rendements, les différences de coûts de production, à provoquer un déséquilibre grave, la Haute Autorité, après consultation du Comité Consultatif et du Conseil, peut prendre les mesures suivantes :

Si l'action de cet Etat comporte dos effets dommageables pour les entreprises de charbon ou d'acier relevant de la juridiction dudit État, la Haute Autorité peut l'autoriser

à leur octroyer une aide dont le montant, les conditions et la durée sont fixés en accord avec elle. Les mêmes dispositions s'appliquent en cas de variation des salaires et des conditions de travail qui auraient les mêmes effets, même si elles ne résultent pas d'une action de l'Etat.

Si l'action de cet Etat comporte des effets dommageables pour les entreprises de charbon ou d'acier relevant de la juridiction dos autres Etats membres, la Haute Autorité lui adresse une recommandation en vue d'y remédier par les mesures qu'il estimera les plus compatibles avec son propre équilibre économique.

3. Si l'action de cet Etat réduit les différences de coût de production on apportant un avantage spécial, ou en imposant des charges spéciales, aux entreprises de charbon ou d'acier relevant de sa juridiction par comparaison avec les autres industries du même pays, la Haute Autorité est habilitée, après consultation du Comité Consultatif et du Conseil à adresser à cet Etat les recommandations nécessaires. 


\section{TITRE QUATRIÈME - Dispositions générales}

Article 86

Les États membres s'engagent à prendre toutes mesures générales ou particulières propres à assurer l'exécution des obligations résultant des décisions et recommandations des institutions do la Communauté et à faciliter à celle-ci l'accomplissement de sa mission. $[\ldots]$

Les agents de la Haute Autorité chargés par elle de missions de contrôle disposent, sur le territoire des États membres et dans toute la mesure nécessaire à l'accomplissement de leur mission, des droits et pouvoirs dévolus par les législations de ces Etats aux agents des administrations fiscales. Les missions de contrôle et la qualité des agents chargés de cellesci sont dûment notifiées à l'Etat intéressé. Des agents de cet Etat peuvent, à la demande de celui-ci ou de la Haute Autorité, assister les agents de la Haute Autorité dans l'accomplissement de leur mission.

\section{Article 87}

Les Hautes Parties Contractantes s'engagent à ne pas se prévaloir des traités, conventions ou déclarations existant entre Elles en vue de soumettre un différend relatif à l'interprétation ou à l'application du présent Traité à un mode de règlement autre que ceux prévus par celui-ci.

Article 88

Si la Haute Autorité estime qu'un Etat a manqué à une des obligations qui lui incombent en vertu du présent Traité, elle constate ledit manquement par une décision motivée, après avoir mis cet Etat en mesure de présenter ses observations. Elle impartit à l'Etat en cause un délai pour pourvoir à l'exécution de son obligation.

Un recours de pleine juridiction est ouvert à cet Etat devant la Cour dans un délai de doux mois à compter de la notification de la décision.

Si l'Etat n'a pas pourvu à l'exécution de son obligation dans le délai fixé par la Haute Autorité ou, en cas de recours, si celui-ci a été rejeté, la Haute Autorité peut, sur avis conforme du Conseil statuant à la majorité des deux tiers :

a) suspendre le versement des sommes dont elle serait redevable pour le compte de l'Etat en question en vertu du présent Traité; 
b) prendre ou autoriser les autres Etats membres à prendre des mesures dérogatoires aux dispositions de l'article 4 en vue de corriger les effets du manquement constaté.

Un recours de pleine juridiction est ouvert, dans un délai de doux mois à compter de leur notification, contre les décisions prises on application des alinéas a et $b$.

Si les mesures ci-dessus prévues s'avèrent inopérantes, la Haute Autorité en réfêre au Conseil.

Article 89

Tout différend entre Etats membres au sujet de l'application du présent Traité, qui n'est pas susceptible d'être réglé par une autre procédure prévue au présent Traité, peut être soumis à la Cour, à la requête de l'un des Etats parties au différend.

La Cour est également compétente pour statuer sur tout différend entre Etats membres en connexité avec l'objet du présent Traité, si ce différend lui est soumis en vertu d'un compromis.

Article 92

Les décisions de la Haute Autorité comportant des obligations pécuniaires forment titre exécutoire.

L'exécution forcée sur le territoire dos Etats membres est poursuivie suivant les voies de droit en vigueur dans chacun de ces Etats et après qu'aura été apposée, sans autre contrôle que celui de la vérification de l'authenticité de ces décisions, la formule exécutoire usitée dans l'Etat sur le territoire duquel la décision doit être exécutée. Il est pourvu à cette formalité à la diligence d'un ministre désigné à cet effet par chacun des gouvernements. L'exécution forcée ne peut être suspendue qu'en vertu d'une décision de la Cour.

Article 93

La Haute Autorité assure avec les Nations Unies et avec l'Organisation Européenne de Coopération Economique toutes liaisons utiles et les tient régulièrement informées de l'activité de la Communauté.

Article 94

La liaison entre les institutions de la Communauté et le Conseil de l'Europe est assurée dans les conditions prévues par un Protocole annexe. 
Article 96

Après l'expiration de la période de transition, le gouvernement de chaque État membre et la Haute Autorité pourront proposer dos amendements au présent Traité. Cette proposition sera soumise au Conseil. Si celui-ci émet, à la majorité des deux tiers, un avis favorable à la réunion d'une conférence des représentants des gouvernements des Etats membres, celleci est immédiatement convoquée par le président du Conseil, on vue d'arrêter d'un commun accord les modifications à apporter aux dispositions du Traité.

Ces amendements entreront en vigueur après avoir été ratifiés par tous les Etats membres en conformité de leurs règles constitutionnelles respectives.

Article 99

Le présent Traité sera ratifié par tous les Etats membres, en conformité do leurs règles constitutionnelles respectives; les instruments de ratification seront déposés auprès du Gouvernement de la République Française.

Il entrera en vigueur le jour du dépôt de l'instrument de ratification do l'Etat signataire qui procédera le dernier à cette formalité.

$\mathrm{Au}$ cas où tous les instruments de ratification n'auraient pas été déposés dans un délai de six mois à dater de la signature du présent Traité, les gouvernements des Etats ayant effectué le dépôt se concerteraient sur les mesures à prendre. 


\section{ANEXO II - Artigos do Protocolo sobre as Relações da CECA com o CdE Comentados por este Trabalho}

Protocole sur les relations avec le Conseil de l'Europe

\section{Article 1}

Les gouvernements des Etats membres sont invités à recommander à leurs Parlements respectifs que les membres de l'Assemblée, qu'ils sont appelés à désigner, soient choisis de préférence parmi les représentants à l'Assemblée Consultative du Conseil de l'Europe.

\section{Article 2}

L'Assemblée de la Communauté présente chaque année à l'Assemblée Consultative du Conseil de l'Europe un rapport sur son activité.

\section{Article 3}

La Haute Autorité communique chaque année au Comité des Ministres et à l'Assemblée Consultative du Conseil de l'Europe le rapport général prévu à l'article 17 du Traité.

\section{Article 4}

La Haute Autorité fait connaître au Conseil de l'Europe la suite qu'elle a pu donner aux recommandations qui lui auraient été adressées par le Comité des Ministres du Conseil de l'Europe, en vertu de l'article 15 (b) du Statut du Conseil de l'Europe.

\section{Article 5}

Le présent Traité instituant la Communauté Européenne du Charbon et de l'Acier et ses annexes seront enregistrés au Secrétariat Général du Conseil de l'Europe.

\section{Article 6}

Des accords entre la Communauté et le Conseil de l'Europe pourront, entre autres, prévoir toute autre forme d'assistance mutuelle et de collaboration entre les deux organisations et, éventuellement, des formes appropriées de l'une ou de l'autre. 